
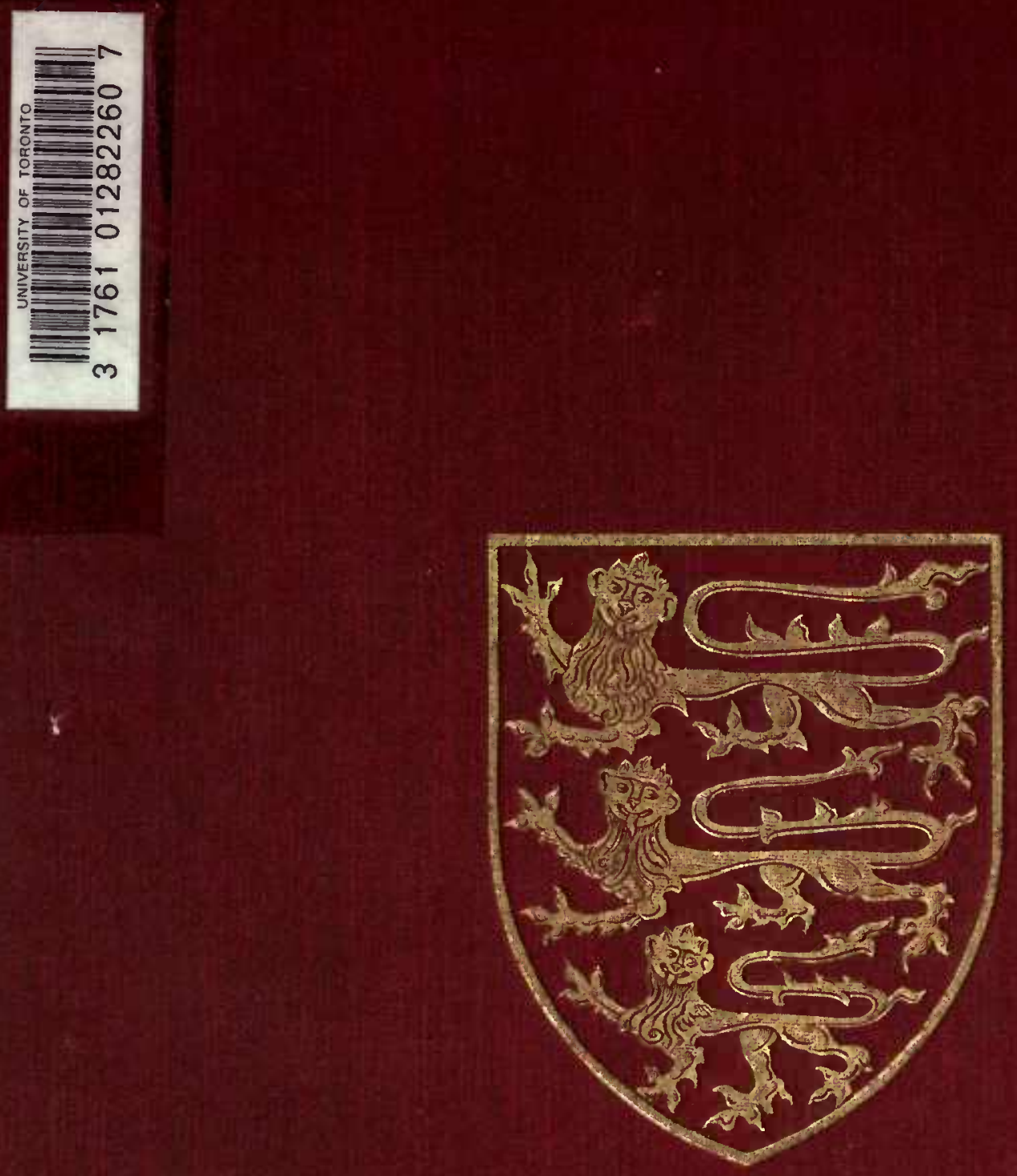


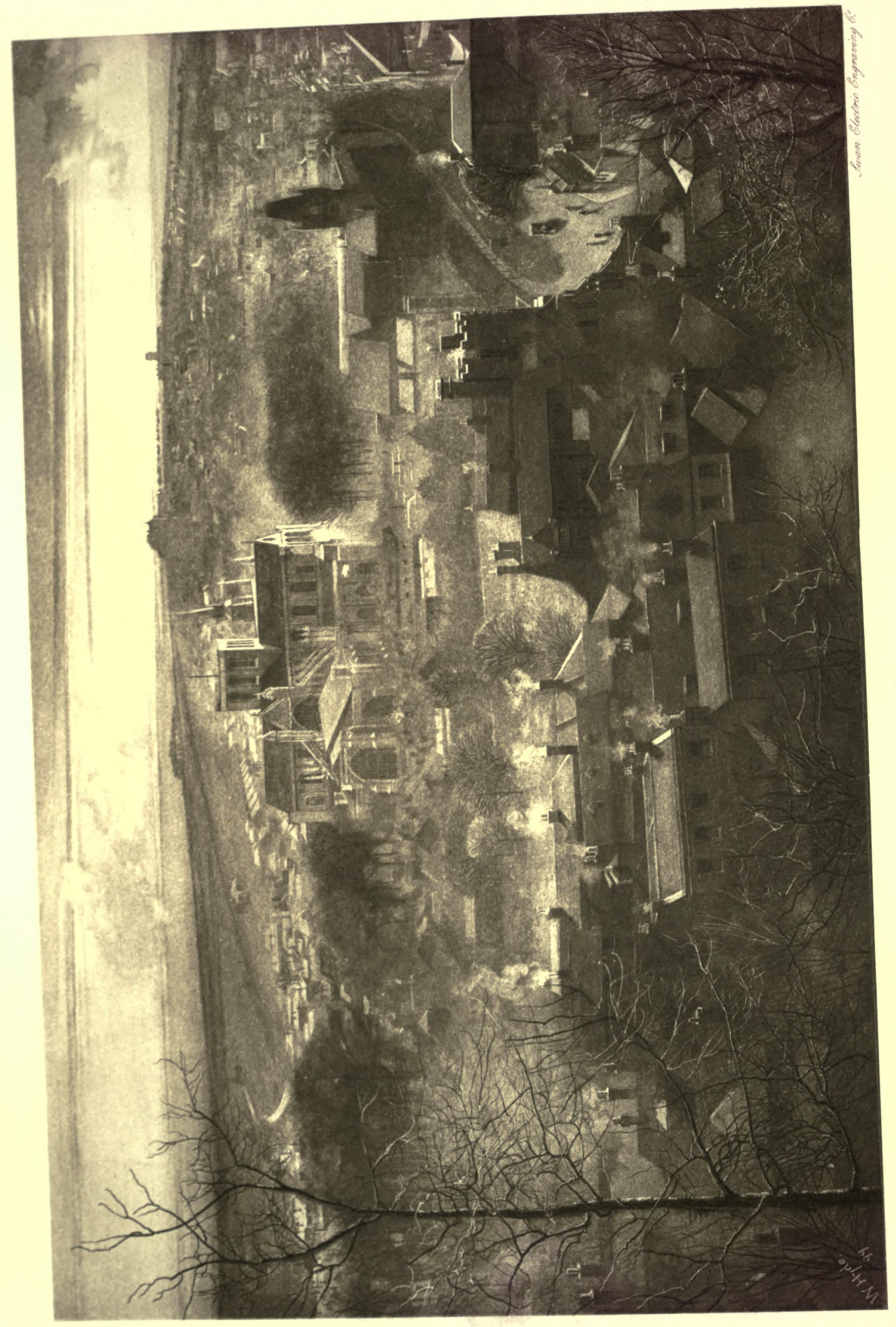




\section{THE}

VICTORIA HISTORY

OF THE COUNTIES

OF ENGLAND

HAMPSHIRE AND

THE ISLE OF WIGHT

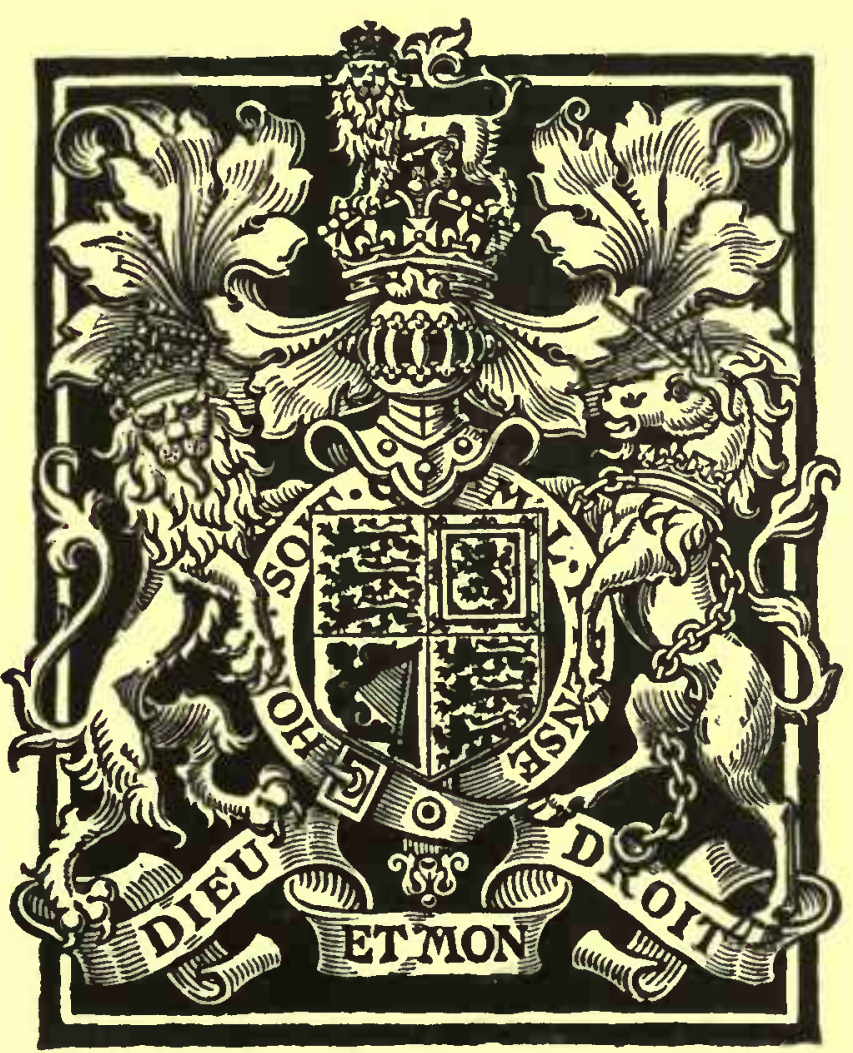

WESTMINSTER

ARCHIBALD CONSTABLE

AND COMPANY LIMITED 
This History is issued to Subscribers only By Archibald Constable E Company Limited and printed by Butler छ Tanner of Frome and London 


\section{IN S C R I B E D}

TO THE MEMORY OF

HER LATE MAJESTY

\section{QUEEN VICTORIA}

WHO GRACIOUSL G A VE

THE TITLE TO AND

A C C E P T E D T H E

DEDICATION OF

THIS HISTORY 



\section{A HISTORY OF \\ H A M P S H I R E AND THE ISLE \\ OF WIGHT \\ VOLUME TWO}

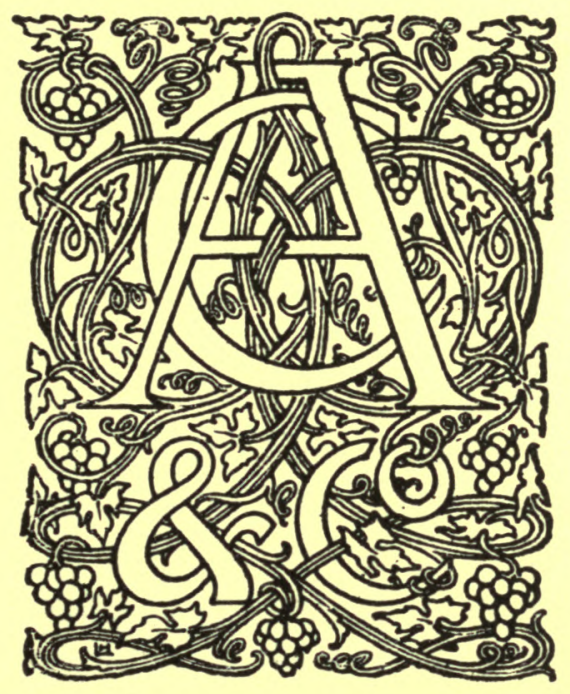

WEST MINSTER

2 WHITEHALL GARDENS

I903 


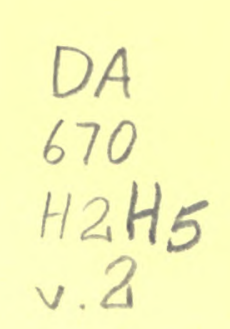




\section{CONTENTS OF VOLUME TWO}

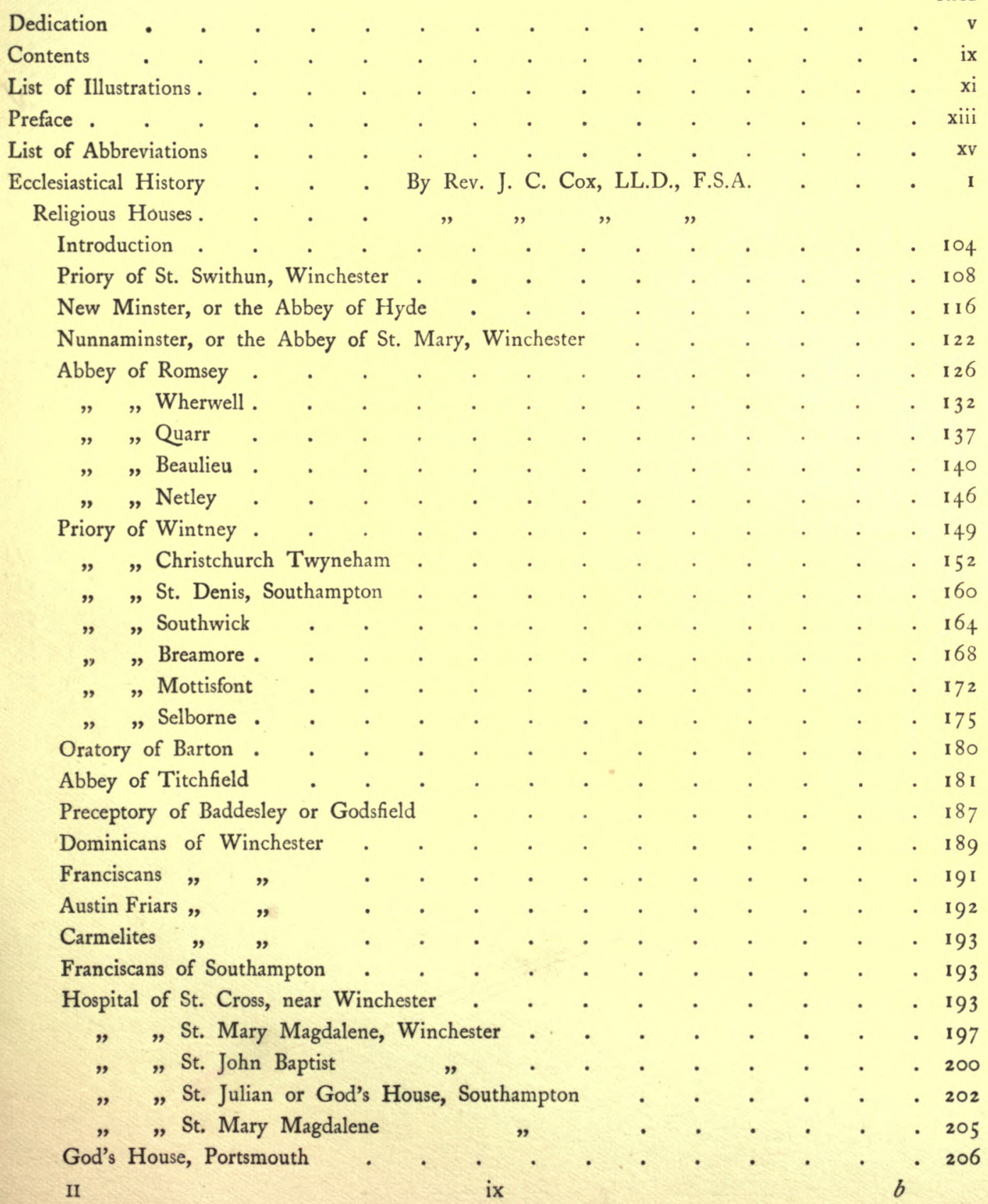




\section{CONTENTS OF VOLUME TWO}

Religious Houses (continued)

Hospital of St. John Baptist, Basingstoke . . . . . . . . . 208

" , Fordingbridge

College of Marwell .

" "St. Elizabeth, Winchester

Chapel and Gild of the Holy Ghost, Basingstoke

Priory of St. Helen

, , Hayling

, "Hamble

, , Andwell

„ „ St. Cross, I. of Wight

" , Monk Sherborne

" , Ellingham

" "Carisbrooke

" , Appledurcombe

Early Christian Art and Inscriptions.

History of Schools .

By J. Romily Aurv, F.S.

Forestry and the New Forest. . By J. Nisbet, D.Oec. and The Hon. Gerald W.

LASCELLES

Topography : Alton Hundred. Compiled by W. J. Hardy, F.S.A.

Binsted

Bramshott

Chawton

$$
" \quad,
$$

" " 483

" "

,

C. R. PEERS, M.A., F.S.A. • 491

Froyle

Greatham

Hartley Mauditt

Holybourne and

\section{Neatham}

Kingsley

East Worldham

West

Index of Parishes in Topographical Maps

" Manor House, by C. R. Peers, M.A., F.S.A. 496

"Church, by W. H. ST. John Hope, M.A. 501

C. R. Peers, M.A., F.S.A. - 506 W. H. St. John Hope, M.A. 508

C. R. Peers, M.A., F.S.A. . 511 W. H. St. Јонn Hope, M.A. 515

"

518

$52 \mathrm{I}$ 


\section{LIST OF ILLUSTRATIONS}

PAGE

Winchester. By WILLIAM HYde

- frontispiece

Cardinal Beaufort

Bishop Waynflete

Marprelate Tract

Episcopal Seals

Seals of Religious Houses

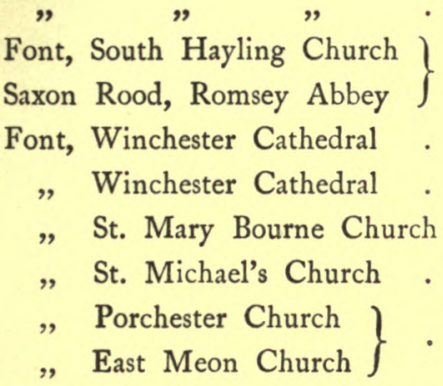

William of Wykeham

Archbishop Chicheley

Winchester College Statutes Title-page

John Kent

Winchester College in 1460 .

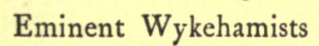

Prince Arthur with Catherine of Aragon

Archbishop Warham

Bishop Ken .

Joseph Warton

Sydney Smith .

Dr. Goddard .

Lord Chancellor Hatherley

Archbishop Howley.

Chief Justice Erle .

Lord Chancellor Cranworth

Viscount Cardwell .

Roundell Palmer, Earl of Selborne .

Robert Lowe, Viscount Sherbrooke .

James Edwards Sewell

General View of Alton

Corner of the Market-Place, Alton

Plan of Alton Church

Arches of the Old Central Tower, Alton Church

Interior of Alton Church looking West

Interior of Alton Church looking East

Binsted Wyck 


\section{LIST OF ILLUSTRATIONS}

Binsted Church from the South-East . . . . . . . 487

Interior of Church .

Monument of Richard de Westcote

Arches in Binsted Church

Glass in Lancet Window of the Baptistery at Binsted

Bramshott Place

Royal Anchor Hotel, Liphook.

Chancel of Bramshott Church from South Transept . . . . . . . . 494

Chawton House (from an old picture) . . . . . . . . . . . 497

Chawton House . . . . . . . . . . . . 499

„Entrance Doorway to Stables . . . . . . . . . 500

Church of St. Nicholas of Chawton . . . . . . . . . . $50 \mathbf{I}$

An Old Timbered Cotiage at Froyle . . . . . . . . . . . . 502

Coldrey House . . . . . . . . . . . . . . 503

Church and Manor House at Froyle . . . . . . . . . . 504

Window in Froyle Church . . . . . . . . full-page plate facing 504

Ruins of the Old Church, Greatham . . . . . . . . . . 507

South Doorway of Hartley Mauditt Church . . . . . full-page plate facing 508

The Round House, Hartley Mauditt . . . . . . . . . . 509

Bell Turret on Hartley Mauditt Church . . . . . . full-page plate facing 510

Holybourne Village. . . . . . . . . . . . . . 51

Source of the Holybourne . . . . . . . . . . . . . . 512

The Mill, Neatham . . . . . . . . . . . . . 5 I3

Lode Farm, Kingsley . . . . . . . . . . . . . . 517

Old Church of St. Nicholas of Kingsley . . . . . . . . . . 517

Chancel of Church, East Worldham. . . . . . . . . . . 520

Doorway in East Worldham Church . . . . . . full-page plate facing 520

Hammond's Farm, West Worldham . . . . . . . . . . . 522

St. Nicholas' Church, West Worldham . . . . . . . . . . 522

\section{LIST OF MAPS}

Ecclesiastical Map of Hampshire

facing $\mathbf{r} 0 \mathbf{1}$

Index Map to the Hundreds of Hampshire . . . . . . . " " 471

Index Map to the Hundred of Alton . . . . . . . . . . . 472

Index Map to Sections of the Topographical Map . . . . . . . . . $\quad$. 527

Topographical Map of Hampshire in six sections . . . . . . at end of volume

[The Sbields of Arms have been drawn by Mr. 7 . Forbes Nixon, under the direction of Mr. Oswald Barron, F.S.A.] 


\section{PREFACE}

I

$\mathrm{N}$ placing the second volume of the History of Hampsbire and the Isle of Wight before their readers the editors feel that an apology is due from them for the long interval which has been allowed to elapse since the publication of the first volume.

As the history of this county was the first in the series of which it forms a part the scheme for the whole undertaking has had to be developed in the course of the preparation of the present volume. The small amount of original research which has hitherto been made for Hampshire was in itself a serious obstacle to rapid progress; but in the course of the work it was found necessary to revise very largely the system of dealing with original research for the Victoria History Series as a whole. Experience proved that many classes of records would have to be exhausted for all the counties in order to obtain the information needed for the compilation of the articles contained herein. Further difficulties have arisen owing to changes in editorship. With the exception of a few local investigations the present volume does not contain any contributions by the Rev. G. H. Gotley, who was originally appointed joint topographical editor with Mr. W. J. Hardy. Mr. Gotley's connection with the Victoria History was severed before any portion of the topography of Alton Hundred was completed.

In the course of a work which deals on a great scale with English armory, and more particularly with its ancient forms, the difficulty must be met at the outset of reconciling the conflicting methods of blazonry offered by the many handbooks of modern armorial writers. The editors have therefore decided to adopt throughout the work the simple and easily understood blazon used in mediæval times, following as far as is possible the neglected and historic English form of phrases.

The succeeding volumes will continue, until it be completed, the topographical and municipal history of the county, and thereafter will follow articles on maritime, political, social and economic history, sport and biographies.

For permission to reproduce certain of the illustrations in this volume the editors beg to thank the Viscount Dillon, Mrs. Wickham, 


\section{PREFACE}

Messrs. C. Butler, William Curtis, Montagu G. Knight, the Wardens of New College and All Souls College, Oxford, and the Society of Antiquaries. The editors are also under special obligations to Mr. Montagu G. Knight for presenting a drawing of Chawton House, and to $\mathrm{Mr}$. Knight, Sir J. C. Hubert Miller, Mr. Henry J. Dutton, Mr. Henry Wheeler, and the clergy and numerous individuals throughout the hundred for affording help in the manorial history of several parishes.

Finally, the editors wish to acknowledge gratefully the contributions on architecture voluntarily made by Mr. C. R. Peers and Mr. W. H. St. John Hope. 


\section{TABLE OF ABBREVIATIONS}

Abbrev. Plac. (Rec. Abbreviatio Placitorum (ReCom.)

P.C. - . Acts of Privy Council

Add.. . . . . Additional

Add. Chart. . . Additional Charters

Admir. . . . Admiralty

Agarde . . . Agarde's Indices

Anct. Corresp. . . Ancient Corrcspondence

Anct. D. (P.R.O.) Ancient Deeds (Public Record

$$
\text { A } 2420
$$

Antiq. . . . Antiquarian or Antiquarics

App. . . . . . Appendix

Arch. . . . Archæologia or Archæological

Arch. Cant. . . Archæologia Cantiana

Archd. Rec. . . Archdeacon's Records

Archit. . . . Architectural

Assize R. . . . Assize Rolls

Aud. Off. . . . Audit Office

Aug. Off. . . . Augmentation Office

Ayloffe . . . Ayloffe's Calendars

Bed. . . . . . Bedford

Beds . . . . . Bedfordshire

Berks . . . Berkshire

Bdle. . . . Bundle

B.M. . . . British Muscum

Bodl. Lib. . . . Bodley's Library

Boro. . . . Borough

Brev. Reg. . . . Brevia Regia

Brit. . . . Britain, British, Britannia, etc.

Buck. . . . . Buckingham

Bucks . . . Buckinghamshire

Cal. . . . Calendar

Camb. . . . Cambridgeshire or Cambridge

Cambr. . . . Cambria, Cambrian, Cambrensis, etc.

Cant. . . . Canterbury

Cap. . . . Chapter

Carl. . . . Carlisle

Cart. Antiq. R. - Cartæ Antiquæ Rolls

C.C.C. Camb. . . Corpus Christi College, Cambridge

Certiorari Bdles. Certiorari Bundles (Rolls (Rolls Chap.)

Chan. Enr. Decree $\mathrm{R}$.

Chan. Proc. Chapel)

Chancery Enrolled Decree Rolls

Chant. Cert. . . Chantry Certificates (or Certificates of Colleges and Chantries)

Chap. Ho. . . . Chapter House

Charity Inq. . Charity Inquisitions

Chart. R. zo Hen. Charter Roll, zo Henry III.

III. pt. i. No. IO

Chartul. part i. Number 10

Chartulary
Chas. . . . Charles

Ches. . . . Cheshire

Chest. . . Chester

Ch. Gds. (Exch. Church Goods (Exchequer K.R.)

Chich. . . . Chichester

Chron. . . . Chronicle, Chronica, etc.

Close. . . . . Close Roll

Co. . . . . . County

Colch. . . . Colchester

Coll. . . . Collections

Com. . . Commission

Com. Pleas. - Common Pleas

Conf. R. . . Confirmation Rolls

Co. Plac. . . . County Placita

Cornw. . . . Cornwall

Corp. . . . Corporation

Cott. . . . Cotton or Cottonian

Ct. R. . . . Court Rolls

Ct. of Wards . . Court of Wards

Cumb. . . . Cumberland

Cur. Reg. . . Curia Regis

D. and C. . . . Dcan and Chapter

De Banc. R. . . De Banco Rolls

Dec. and Ord. . Decrecs and Orders

Dep. Kecper's Rep. Deputy Keeper's Reports

Derb. . . . . Derbyshire or Derby

Devon . . . Devonshirc

Doc. . . . Documents

Dods. MSS. . . Dodsworth MSS.

Dom. Bk. . . . Domesday Book

Dors. . . . . Dorsetshire

Duchy of Lanc. . Duchy of Lancaster

Dur. . . . Durham

East. . . . Easter Term

Eccl. . . . Ecclesiastical

Eccl. Com. . Ecclesiastical Commission

Edw. . . . Edward

Eliz. . . . Elizabeth

Engl. . . . England or English

Engl. Hist. Rev. . English Historical Review

Epis. Reg. . . Episcopal Registers

Esch. Enr. Accts. . Escheators Enrolled Accounts

Excerptae Rot. Fin. Excerpta e Rotulis Finium

(Rec. Com.) (Record Commission)

Exch. Dep. . Exchequer Depositions

Exch. K.B. . . Exchequer King's Bench

Exch. K.R. . . Exchequer King's Remembrancer

Exch. L.T.R. . . Exchequer Lord Treasurer's Rcmembrancer

Exch. of Pleas, Plea Exchequer of Pleas, Plea Roll $\mathrm{R}$.

Exch. of Receipt . Exchequer of Receipt 


\section{TABLE OF ABBREVIATIONS}

Exch. Spec. Com. Exchequer Special Commis- Misc. Bks. (Exch. sions

Feet of F. . . Feet of Fines

Feod. Accts. (Ct. Feodaries Accounts (Court of of Wards)

Feod. Surv. (Ct. of Wards) Wards)

Feud. Aids . . Feudal Aids

fol. . . . Folio

Foreign R. . . Foreign Rolls

Forest Proc. . . Forest Proceedings

Gen. . . . Genealogical, Genealogica, etc.

Geo. . . . George

Glouc. . . Gloucestershire or Gloucester

Guild Certif. Guild Certificates (Chancery) (Chan.) Ric. II. Richard II.

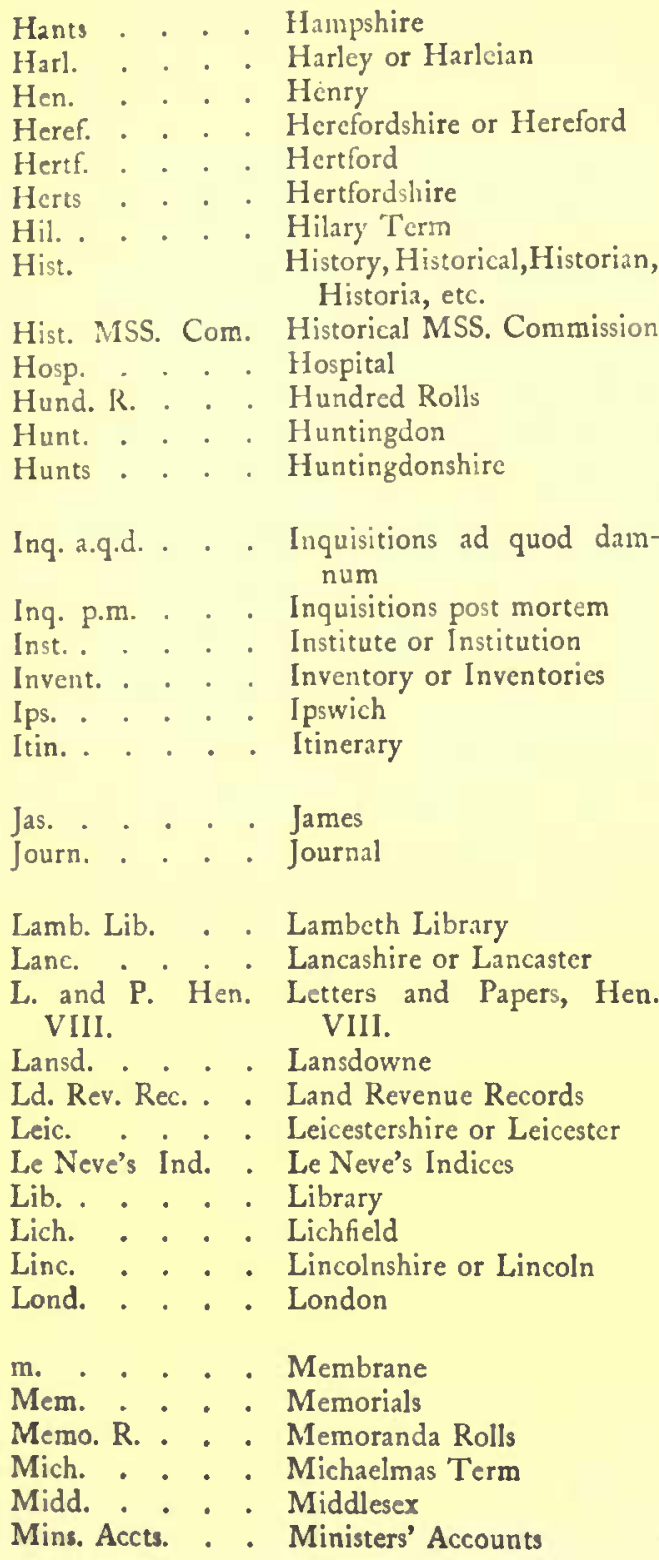

K.R., Exch. T.R. or Aug. Off.)

Mon.

Monm. . . Monmouth

Mun. . . . Muniments or Munimenta

Mus. . . . Museum

N. and Q. . . Notes and Queries

Norf. . . . Norfolk

Northampt. . . Northampton

Northants . . Northamptonshire

Northumb. . . Northumberland

Norw. . . . Norwich

Nott. . . . Nottinghasnshire or Notting-

N.S. . . . New Style

Off. . . . Office

Orig. R. . . . Originalia Rolls

Oxf. . . . . Oxfordshire or Oxford

p. . . . . Page

Palmer's Ind. . . Palmer's Indices

Pal. of Chest. . . Palatinate of Chester

Pal. of Dur. . . Palatinate of Durham

Pal. of Lanc. - . Palatinate of Lancaster

Par. . . . Parish, Parochial, etc.

Parl.. . . . Parliament or Parliamentary

Parl. R. . . . Parliament Rolls

Parl. Surv. . . . Parliamentary Surveys

Partic. for Gts. . Particulars for Grants

Pat. . . . . Patent Roll or Letters Patent

P.C.C. . . . Prerogative Court of Canterbury

Peterb. . . . Peterborough

Phil. . . . Philip

Pipe R. . . . Pipe Roll

Plea R. . . . . Plea Rolls

Pope Nich. Tax. Pope Nicholas' Taxation (Re (Rec. Com.) cord Commission)

P.R.O. . . . Public Record Office

Proc. . . . Procecdings

Proc. Soc. Antiq. . Proceedings of the Society of

pt. . . . . Part Antiquaries

Pub. . . . . Publications

R. . . . . Roll

Rec. . . . Records

Recov. R. . . Recovery Rolls

Kentals and Surv. . Rentals and Surveys

Rep. . . . . . Report

Rev. . . . . Review

Ric. . . . . Richard

Roff. . . . Rochester diocese

Rot. Cur. Reg. . Rotuli Curiæ Regis

Rut. . . . . Rutland

Sarum . . . Salisbury diocese

Ser. . . . . Series

Sess. R. . . . Sessions Rolls

Shrews. . . . Shrewsbury 


\section{TABLE OF ABBREVIATIONS}

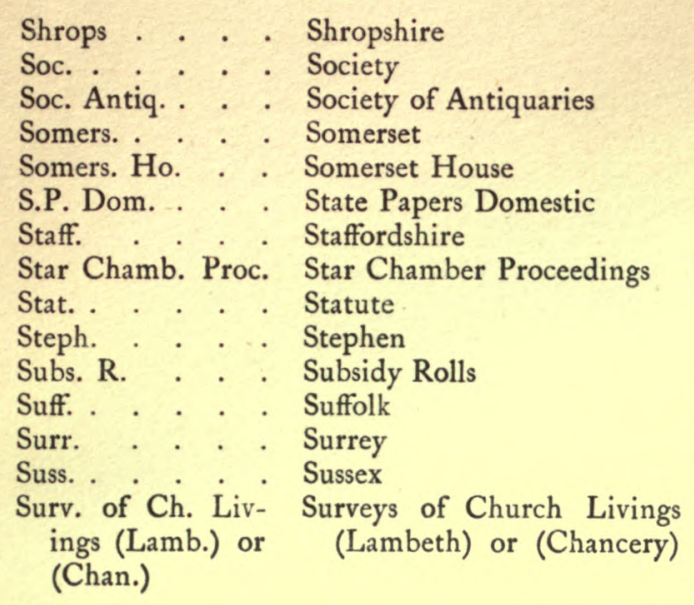

Topog. . . . . Topography or Topographical

Trans. . . . . Transactions
Transl. . . . Translation

Treas. . . . . Treasury or Treasurer

Trin. . . . Trinity Term

Univ. . . . University

Valor Eccl. (Rec. Valor Ecclesiasticus (Record Com.) Commission)

Vet. Mon. . . . Vetusta Monumenta

V.C.H. . . . Victoria County History

Vic. . . . . Victoria

vol. . . . . Volume

Warw. . . . Warwickshire or Warwick

Westm. . . Westminster

Will. . . . William

Wilts . . . Wiltshire

Winton. . Winchester diocese

Worc. . . . Worcestershire or Worcester

Yorks . . . Yorkshire 



\section{ECCLESIASTICAL HISTORY}

$\mathrm{H}$

AMPSHIRE possesses the most interesting relic of the Romano-British church that has as yet been found in England. The foundations of the little fourth century Christian church within the walls of Silchester, uncovered in $1893,{ }^{1}$ together with the gold ring bearing a Christian inscription, ${ }^{2}$ and the leaden seal stamped with the Chi-Rho monogram, ${ }^{3}$ have been already described and illustrated.

Though archæology is thus definite in its evidence as to early Christianity in the shire, history has nothing to say, for the tales of King Lucius and of Constantine's college at Winchester are but pious inventions of the fifteenth century.

Of the archæology of the Anglo-Saxon Church, from the seventh century downwards, Hampshire has abundant evidence in the structure and stones of many of her churches, as will be elsewhere shown; but for this period history speaks plainly.

The story of the conversion of Wessex and the establishment of the bishopric in Hampshire is easier to follow and much less involved than the like tale in many other English shires, particularly in those of the outlying parts of Mercia. This arises to some extent from Wessex becoming the most important of all the petty kingdoms, which naturally brought about a greater care and fulness in its chronicles.

Wessex, or the kingdom of the West Saxons, was founded by Cerdic about 5 I 9 ; but it was not until 634 that the missionary bishop Birinus, with a little band of evangelists, is said to have begun the work of converting the south and west of England. The remnants of that Celtic church, which once had foothold in Hampshire, had long ago been driven elsewhere, mainly to the extreme west. Reports as to the outer darkness of most of this country appealed to the missionary instincts of Birinus, and offering himself to Pope Honorius he was consecrated bishop at Genoa and sent forth, as Bede expresses it, 'to sow the seeds of the holy faith in the innermost parts of pagan Britain.' Landing on the coast of Wessex (probably at Porchester), Birinus at first intended to push on into Mercia where there was as yet no bishopric; but finding heathendom absolutely dominant among the Gewissas he deemed it best to tarry at the court of King Cynegils. He preached the

$$
\text { Supra, i. 278, 364-5. } \quad \text { Ibid. i. } 223 . \quad 3 \text { Ibid. i. } 284 .
$$




\section{A HISTORY OF HAMPSHIRE}

faith with such earnestness at Winchester that in the following year the king, with his son Cenwalh and many of the chiefs, was baptized. At this function the duty of chief sponsor, who gave the newly baptized Christian his hand as he left the water, was undertaken by Oswald, the famous king of Northumbria, the devoted adherent of the Scottish church. Thus was brought about at this historic baptism a most happy blending of the Christian influences of Celtic and Italian origin, each of which had their share in the enlightenment of Wessex. It may be suggested, without in the least impugning the reality of Cynegils' acceptance of the truth, that state policy possibly showed the advantage of a Christian alliance. The baptism was shortly followed by the marriage of Oswald with the king's daughter.

Winchester was not however made the first seat of the West Saxon bishopric. Cynegils, in conjunction with his royal son-in-law, decided that the bishop's stool should be placed at Dorchester-on-theThames. It seems at first sight curious that the centre of the see should be placed on the verge of the kingdom, but anticipations as to the future development of their respective kingdoms, which were not afterwards fulfilled, afford the probable solution of this decision of the two friendly kings. Bede tells us how zealously Birinus laboured, building and dedicating churches, and winning much people to the faith. He died in 650 and was buried at Dorchester.

Although Winchester was not as yet the ecclesiastical capital of the kingdom, Cenwalh built there a great church dedicated to Saints Peter and Paul, the parent of the future cathedral church, and established a monastery whence Christianity radiated into parts that could but rarely be visited by Birinus.

Into the diocesan divisions connected with the short episcopates of Agilbert, Wini and Leutherius there is no occasion to enter; suffice it here to say that in 676 Bishop Haedde transferred the episcopal seat from Dorchester to Winchester, and translated the body of Birinus to the cathedral church of the city that had witnessed the royal baptisms of 634. Haedde's great piety secured for him the honour of canonization, and Bede records many miracles at his tomb. On his death in 705 the growing diocese was divided; Hampshire with the Isle of Wight, Surrey and Sussex forming the diocese of Winchester, whilst the more recently converted parts further west were placed in the charge of a bishop established at Sherborne.

With regard to the Isle of Wight, it may be remarked that as it lay opposite the division between the two kingdoms of Wessex and Sussex there was much dispute as to its ownership, it being at one time considered part of Wessex and at another of Sussex. Bishop Daniel (705-44) was the first person to exercise episcopal authority in the island. Bede's language implies that up to that period it had not received Christianity. ' From that date onwards it has always remained a part of the diocese of Winchester. 


\section{ECCLESIASTICAL HISTORY}

The Isle of Wight, conquered by the Jutes, received its Christianity from another source. In the strange vicissitudes and wanderings of St. Wilfrid, that bishop sought shelter in 687 in the kingdom of Sussex under the Christian king Ethelwald. Here he laboured successfully for some years and befriended Cedwalla, an exiled member of the royal house of Wessex. When Cedwalla came to the throne of the West Saxons in 686 he gave to Wilfrid for the church a fourth part of the Isle of Wight, which had been the last stronghold of paganism. At this time Wilfrid was returning to the north of England, and he committed the charge of this property and the spiritual necessities of the island to Bernwin, one of his clerks, and to a priest named Hiddila. ${ }^{1}$

The kingdom of Sussex, or the South Saxons, not only for some time possessed the Isle of Wight, but also the Jutish settlement of the Meonwaras on the mainland. When the Jutes arrived simultaneously with the West Saxons, one of their tribes made their way up the Meon, a tributary of Southampton Water. Along the borders of that stream they established little colonies or settlements, and became known as the Meonwara or men of Meon. They held themselves rigidly aloof from their neighbours, and had not been touched by the Christian teaching of Birinus and his successors. Here, at the end of the seventh century, Wilfrid also laboured with conspicuous success, founding several churches and christianizing this wedge of Jutish territory which had long before been driven into the heart of Hampshire. The archæologist finds many traces of pre-Norman church fabrics along the banks of the Meon. At Warnford a most interesting double inscription on the church, of a date a generation or two after the Norman Conquest, still testifies to the missionary zeal of St. Wilfrid, telling of the rebuilding of this seventh century church by a great Hampshire landowner, Adam de Port, in the time of Henry II. The inscriptions run as follows, the first on the porch and the second on the north wall :-

(I) Fratres orate PRECE vestra sanctificate

TEMPLI FACTORES SENIORES AC JUNIORES

Privavit Wilfrit fundavit bonUs Adam modo Reno[vavit].

(2) Adam hic de Portu solis benedicat ab ortu Gens cruce isignata PER QUEM SUM SIC RENOVATA.

Returning to the episcopate of the West Saxons, it should be noted that Bishop Daniel, within a few years of his consecration, was the better able to administer his diocese by the formation (in 7II) of the new diocese of Sussex, leaving only Hampshire, with the Isle of Wight and Surrey, in his charge. This, with some slight modifications, has ever since remained the extent of Winchester diocese. Daniel was the contemporary and friend of Bede, and of much assistance to him in those parts of his history that relate to Wessex and Sussex. He was a man of much learning and devotion and of many gifts. ${ }^{2}$ He was also able to

1 Bede (Eng. Hist. Soc.), iv. I 6.

2 The author of the life of St. Aldhelm, the contemporary Bishop of Sherborne, writes of Daniel as vir in multis strenuisissimus. 


\section{A HISTORY OF HAMPSHIRE}

give much advice and counsel to Winfrid of Crediton, who had been educated in the Hampshire monastery of Nursling, and who afterwards became so well known, under the name of Saint Boniface, as the great Christian missionary to the heathen tribes of Germany. After ruling his diocese for forty-two years, Daniel's health and eyesight failed; he resigned his see and spent the last months of his life in retirement at the monastery of Malmesbury, of which house he had originally been a monk.

There is nothing noteworthy pertaining to the ecclesiastical history of Hampshire or the bishops of Winchester during the last half of the eighth century, but the cathedral city and hence the county rose to great importance when Egbert came to the throne in 802 . His reign is a distinct epoch in English history, for it was then that the sceptre of English rule departed from Northumbria and Mercia and settled for a considerable period in Wessex. By 829 Egbert was practically king of England, with his capital at Winchester: though other subject rulers kept for a time their titles of kings they all accepted Egbert as their over-lord. Egbert made numerous grants of land to the great minster of St. Peter and St. Paul at Winchester, the chief Hampshire gifts being at Droxford and Worthy, as well as at Calbourne in the Isle of Wight. ${ }^{1}$

In 835 the peace of his kingdom was disturbed by a great invasion of Scandinavian pirates, who landed from thirty-five ships at Charmouth in Dorset. Egbert gave them battle and there was a great slaughter. The English chronicle states that the Danes held the field, and 'Herefrith and Wigthun two bishops died.' It is supposed that both these ecclesiastics were bishops of Wessex, and that one was the suffragan of the other.

In 838 Helmstan, a monk of Winchester and tutor of Egbert's younger son Ethelwulf, was consecrated bishop. Another ecclesiastic, Swithun, was associated with Helmstan in the tutelage of Ethelwulf. His clerical tutors had such influence over the prince that he received orders, but by the time he had advanced to the sub-deaconship his elder brother and father both died. A papal dispensation was obtained, and in 837 Ethelwulf was called to the throne. On the death of Bishop Helmstan in 852 the king summoned his old tutor Swithun to succeed him. The ten years of St. Swithun's episcopate were remarkable for vigour of administration. William of Malmesbury delights to do this prelate honour, and much of the glory of Alfred's subsequent reign was attributed to the bishop's wise counsel. He is described as a diligent builder of churches in the diocese and a repairer of those that had been ruined, ${ }^{2}$ and as so humble that he always went on foot in his visitations, and preferred travelling by night so as to attract less attention. The celebrated and oft disputed charter, popularly supposed to be for the general establishment of tithes, attested by the king and his two vassal kings of Mercia and the East Angles in 854 and placed

1 Kemble's Codex Diplomaticus, v. 73-87.

2 About fifty old churches are dedicated to St. Swithun, seven of which are in his old diocese. 


\section{ECCLESIASTICAL HISTORY}

on the high altar in the cathedral church of Winchester, is the most memorable event during Swithun's episcopacy.'

In 857 Ethelwulf was succeeded by his son Ethelbald, and it was Swithun who persuaded the latter to fortify the church and monastery of Winchester in readiness for any sudden attack on the part of the Danes. The advantage of this timely act was realized in the reign of his brother Ethelbert, for in 860 a great army of Norsemen landed at Southampton and made an onslaught upon Winchester. Most of the city was plundered and burnt, but the new defence works saved the minster and the cloister, together with all the citizens who had fled there for safety. In 862 the good bishop died, and is said to have been buried in the churchyard that the rain of heaven might fall upon him.

Wessex was now the only kingdom strong enough to resist the Danes. Ethelred, the third son of Ethelwulf, came to the throne in 866, and with the powerful assistance of his youngest brother Alfred fought gallantly and continuously against the foe and their treacherous allies. In the hottest of the strife in $87 \mathrm{I}$, Ethelred was slain, and the charge of the almost ruined kingdom devolved upon the heroic Alfred. To eight years of war succeeded eighteen years of peace, during which the Church flourished, chiefly through the education of her clergy, to which Alfred gave special attention.

Amongst other continental men of learning, the king invited to Winchester St. Grimbald, purposing to found for him a new monastery (New Minster) in the cemetery to the north of the cathedral church.? He had already founded at Winchester the abbey of St. Mary for Benedictine nuns, commonly known as the Nunnaminster. This grand group of three great minsters with their conventual buildings, which filled up the south-eastern angle of the city of Winchester, must have formed for many a generation one of the finest architectural spectacles of all Christendom.

On the death of Alfred in $899,{ }^{3}$ one of the first acts of Edward the Elder was to carry out his father's promises and complete the New Minster, which was shortly afterwards dedicated by Archbishop Plegmund of Canterbury. Edward also completed the Nunnaminster, to which his mother Ealhswith betook herself, following the religious life with such ardour that she was afterwards canonized.

There was a considerable re-division and extension of dioceses at the beginning of the tenth century, when it is said that seven bishops were consecrated at the same time. Though the dioceses of the west

1 The phrase of the chronicle is, ' He booked (gebocade) the tenth part of his lands to God's praise and his own eternal welfare'. The gift therefore was expressly limited to the king's lands. Professor Maitland thinks it may have been a case of 'beneficial hidation.' Cf. Earle's Land Charters, p. Ixxiii. n, and Lord Selborne's Facts and Fictions concerning Tithes.

2 The name New Minster distinguished it from the cathedral church or 'Old Minster,' but in the time of Henry I. it was removed to Hyde Meadow and was subsequently known for the most part as Hyde Abbey.

3 Eng. Hist. Rev. xii. 71. Bishop Stubbs accepted the argument set forth by Mr. Stevenson in this article as conclusively establishing the real date of Alfred's death. 


\section{A HISTORY OF HAMPSHIRE}

of England and in the south of Mercia were much altered about this period, the limit of Winchester remained as before. Frithstan, a monk of much piety who had been a scholar of St. Grimbald, was at this time appointed to the bishopric of Winchester. Having ruled his diocese with faithfulness for twenty years, like his predecessor Daniel, he resigned the see in 931 to end his days in devotion, and died the following year. The splendid stole and fanon of this good bishop, with numerous figures of Old and New Testament saints and inscriptions embroidered in gold, crimson, blue and green, are in the capitular library at Durham; an inscription on both stole and fanon says that '死lfæd caused it to be made for the pious Bishop Frithstan.' They were discovered in 1827 , when the coffins of St. Cuthbert were ransacked. Elflæd or Ethelfled, who died in 9 I6, was queen of Edward the Elder. It seems likely that these vestments were the gift of Athelstan, illegitimate son of Edward the Elder, to the shrine of the saint on the occasion of his visit to Chester-le-Street in 934. ${ }^{1}$ Frithstan nominated Beornstan as his successor, who had been his brother monk of the New Minster; Beornstan left behind him a blessed reputation for charity to the poor and earnestness in prayer. William of Malmesbury pictures him as walking about daily through the churchyards of the city praying for the dead that he had known, whose lives had been such as grieved him.

Alphege the Bald, a monk of Glastonbury, best known as being an uncle of Dunstan, was the next bishop. On his death Dunstan was offered the see, but refused. After two short and insignificant episcopates came Athelwold $(963-84)$, afterwards canonized, a monk of Glastonbury and the son of a wealthy citizen of Winchester. His industry in church building equalled his piety, learning and zeal as a preacher. It was through his personal exertions and superintendence that the great churches so cruelly used by the Danes up and down the country were renovated, as at Abingdon, Chertsey, Ely, St. Neots, Peterborough, and Thorney. He rebuilt his cathedral church at Winchester, removing the bones of St. Swithun from the churchyard to a shrine in the church on 15 July, 97 1 . The terrific thunderstorm and downpour of rain that gave rise to a weather tradition which seems to be imperishable are inventions of a comparatively late date. The monk Wulfstan, who had watched the growth of this great and then wondrous pile of buildings, celebrated it in rough elegaic verse. He describes the chapels, aisles and columns as being so numerous that a man might easily be lost in their maze, and tells how it was crowned with a mighty tower having pinnacles and balls of burnished gold, the whole surmounted by a glistening weathercock which, when it caught the morning sun, filled the traveller descending to the city with amazement. The Benedictional of St. Etbelwold, that priceless gem of the Chatsworth library, yields in the background of one of the illu-

1 Romilly Allen's Monumental History of the British Church, pp. 240-3; see also Thorpe's Diplomatarixm, pp. $321-4$, for an account of the visit to Durham of Eadwine, a monk of New Minster, Winchester, for the investiture of the body of St. Cuthbert. 


\section{ECCLESIASTICAL HISTORY}

minations a contemporary drawing of this noble tower, with the golden weathercock above the swinging bells. ${ }^{1}$

Ethelwold also rebuilt the Nunnaminster and assisted King Edgar in the renovating and extending of Romsey Abbey, which had been founded by Edward the Elder.

In Ethelwold, Dunstan, then primate, found an energetic lieutenant for that monastic revival which was the special characteristic of the last half of the tenth century. After making every allowance for the exaggerations and prejudices of the monkish chronicles, there can be no doubt that the condition of the leading secular clergy of those days was often disreputable. The clergy of the cathedral church of Winchester were secular canons, and the bishop, with the support of King Edgar, resolved to replace them by Benedictine monks. On the first Saturday in Lent, 964, Ethelwold went into the quire of his cathedral church accompanied by one bearing a number of Benedictine cowls. After an exhortation to holiness of life, the bishop urged the canons at once to adopt the cowls as pledges of a change of life. Only three assented; the remainder were dispossessed of their benefices, monks from the abbey of Abingdon (whence Ethelwold had come to Winchester) being put in their place. An embittered strife, of some duration, ensued between the regulars and seculars and their friends throughout the kingdom.

An interesting memorial of this eminent tenth century bishop was his cup, which was greatly esteemed in the house of St. Swithun down to the dissolution. It was the use of the monastery, on the day of the deposition of that saint, for the keeper of the refectory to carry into the frater St. Ethelwold's cup at dinner time with a pitcher of wine. After it had been kissed by all the brethren there assembled, the cup was carried to be kissed by every one at the tables of the farmery, and then to the prior's hall for a like salutation from the prior and his guests. ${ }^{2}$

On the death of Ethelwold in 984 the dispossessed canons tried their best to recover their position, but Dunstan secured the episcopal throne of Winchester for Alphege II., a keen supporter of the monastic rule. Some of the most stirring events in the life of this saintly prelate occurred during the twenty years that he presided over the see of Winchester. In 994, when Ethelred (the degenerate successor of Edgar and the short-lived Edward the Martyr) reigned, Olaf of Norway and Sweyn of Denmark, after ravaging the western districts, wintered at Southampton. Ethelred decided to make terms, and sent Bishop Alphege to offer tribute and friendship. Olaf had already received baptism at the hands of English missionaries in his own land. The exhortation of the bishop greatly impressed the Norwegian king, who not only submitted to the rite of confirmation but promised that he would never make another raid on England. But Sweyn, an apostate and fiercely opposed to Christianity, refused to join in any pledges, and on the death of Olaf in the year 1000 he returned to the English coasts and ravaged Hamp-

1 Archaologia, xxiv. pl. 32.

2 A Consuetudinary of the Fourteenth Centary, edited by Dean Kitchin in 1889, pp. 11, 20. 


\section{A HISTORY OF HAMPSHIRE}

shire right up to the walls of the city of Winchester. Then came the wickedness of the massacre of St. Brice's Day (13 November, 1002), when, after all allowance for exaggeration, the murder of a great number of Danes throughout the kingdom was accomplished. The cruel work began at Winchester, whence the order emanated. Prompt and bitter was the vengeance. The next year brought Sweyn, with the young Cnut his son, back to England to avenge their kindred. For four years Sweyn marched backwards and forwards through southern and eastern England in a continuous march of pillage and slaughter. Southampton was sacked; the abbey of Romsey was pillaged, the abbess and her nuns escaping to Winchester. Waltham was burnt, and most of the churches of the county were rased to the ground. In 1006 the Danes had mastered all central England and made the Isle of Wight their permanent winter quarters. They were bought off from time to time by immense sums, but only to be succeeded by fresh bands. In Io1 4 Canterbury was sacked and burnt; and St. Alphege, who had been translated from Winchester to Canterbury in 1005 , was murdered. In the following year, 1015, Winchester had to ransom herself and give hostages.

To this terrible gloom, which had settled down more darkly over Hampshire than over any other part of the country, there now came unexpected relief. Sweyn died in ror 4, and the feeble Ethelred returned from Normandy with his heroic son Edmund Ironside. Cnut's main strength was in Wessex, and he established his capital at Winchester. On Ethelred's death in 1016, the Witan at Southampton accepted Cnut as their king, whilst the burghers of London stood by Edmund. After some months of fierce fighting between the rivals the two kings agreed to divide the kingdom, with Winchester as the capital of the Dane's dominion; but immediately afterwards Edmund died, and Cnut became the sole king of England. The Christianity of the young king seems to have been genuine. As an act of reparation for the murder of Saint Alphege by his countrymen, he caused the remains to be enshrined at Canterbury and took an important part in the ceremonial. Winchester, as the seat of his government, became the place of the greatest importance in the kingdom. Cnut was lavish in his gifts both to the Old and New Minsters, and on his death at Shaftesbury in 1035, at the early age of forty, his remains were brought back for burial in the Old Minster. ${ }^{1}$

Cnut had taken to wife Emma, daughter of the Duke of Normandy and widow of Ethelred, and after the succession and death of their sons Harold and Harthacnut (the last of the Danish race of kings), England joyfully called to the throne the surviving son of Ethelred and Emma. This son, best known as Edward the Confessor, was crowned at Winchester on Easter Day, 1043, by the Archbishops of Canterbury and York and a host of suffragans. Alwine, a Norman by birth and related to Queen Emma, was at this time Bishop of Winchester. The

1 His bones, with those of Emma his queen, are in one of the coffers on the screen of the cathedral church. 


\section{ECCLESIASTICAL HISTORY}

scandals once generally accredited, as to Emma and Alwine, and the story of the ordeal of the red-hot ploughshares in the nave of the Old Minster are now regarded by all scholars as mere myths.

Bishop Alwine died in 1047, and Stigand, Bishop of Elmham, was translated to Winchester. His appointment was a victory for the antiNorman party at the court achieved by Earl Godwin. All the Norman bishops but one were banished, and five years later Stigand, though still retaining Winchester, was appointed Archbishop of Canterbury. The appointment was however uncanonical, Robert of Jumiéges being illegally dispossessed of the archbishopric, and Stigand's claims were opposed by successive popes. He was covetous and unscrupulous, and even his friend Harold, nominated by Edward the Confessor as his successor in 1066, refused to accept coronation at his hands. After the defeat and death of Harold, Stigand took part in the selection of Edgar Atheling; but meeting the Conqueror at Wallingford submitted to him. When at William's request the papal legates visited England in 1070, Stigand was cited before them. He was condemned on three counts-for usurping the archbishopric in Robert's lifetime and using his pall ; for receiving his pall from a schismatical pope; and for holding the see of Winchester in plurality. He was deprived of both sees and placed by the king in custody at Winchester, where he remained till his death in 1072.

In connection with Winchester and the critical battle of Hastings, there is a picturesque story of the abbot of New Minster fighting with twelve of his monks in coats of mail over their monastic frocks, but Mr. Round has shown that it rests on slight foundation. ${ }^{3}$ The Conqueror naturally hastened to Winchester, so long the imperial city, and there he met with no resistance. Two years after his crowning at Westminster, the coronation of William and his wife Maud was repeated in the cathedral church of Winchester.

Under the Normans the imperial importance of Winchester as a city began to wane; though its state importance was duly acknowledged by the earlier Norman kings, London and Winchester divided the honours between them. But from that day to the present the bishopric of Winchester has continued to be considered one of the first in all England. On the deposition of Stigand, Walkelin, a Norman, a zealous adherent of the Conqueror and said to have been his kinsman, was consecrated in his place as Bishop of Winchester. In 1079 he began to re-build his cathedral church on a stately and majestic plan of which much yet remains. The bishop was also energetic in parochial church building, renovating or rebuilding the various churches on his Hampshire manors. At East Meon he built himself a palace which became his favourite residence.

As to Domesday Survey nothing need be here stated, save that no fewer than 132 churches are named on the 300 manors; but it must always be remembered that no mention of a church is not proof of

1 Vol. i. p. 417. 


\section{A HISTORY OF HAMPSHIRE}

its non-existence. About two-fifths of the total rental of the county then belonged to the Church.

It was not until 1093 that the new cathedral church, with its accompanying conventual buildings, was sufficiently completed for consecration in the presence of nearly all the bishops and abbots of the kingdom. Walkelin was present at the consecration of Battle Abbey in the following year, when the Red King granted him St. Giles fair and all the royal rents in Winchester. But though Walkelin was a great bishop as a builder, and in some respects as a diocesan, his intimacy with Rufus made him a zealous supporter of the royal caprice and a staunch opponent of the saintly Anselm. At the council held at Winchester on 15 October, 1097, Walkelin was vehement against the archbishop and his proposed appeal to Rome. 'Walkelin,' says Dean Kitchin, 'does not come out well by the side of this strong hero of the church. Anselm lost all of what was right, and, as his protest against the scandals for the reign, Walkelin was made joint regent with Ranulph Flambard,

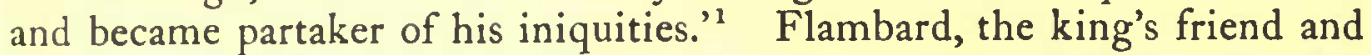
evil genius, had long made Winchester his home, where he presided over the royal treasury. He was the chief abettor of the king's favourite plans of keeping the preferments of the church vacant and taking the revenue, or else of selling them unblushingly to the highest bidder. When Walkelin died, in 1098 , this wealthy and most important see remained unfilled till after the death of Rufus in I IOO, whilst the unprincipled Flambard was made Bishop of Durham (I099-I I 33).

When Henry heard of the death of Rufus he hurried to Winchester, and was elected king by the Witan on the very day of his brother's unhonoured burial. His first act as king-elect was to fill up the vacant see of Winchester by the appointment of William Giffard, a Norman of noble birth, well versed in the court life and statecraft of the day. Giffard was the first Bishop of Winchester who was also chancellor of the kingdom, an office that was filled by nine of his successors, this diocese being the most prolific in supplying statesmen of the first rank from among its prelates.

The king's next step was to recall Anselm. The first important act of the archbishop on his return was closely connected with Hampshire. Edith (who afterwards took the name of Maud), the greatgranddaughter of Edmund Ironsides, was living in the abbey of Romsey, over which her aunt Christine presided. The king desired to marry Edith, urged thereto by reasons of policy as well as of affection. The abbess warmly protested, asserting that the girl had made her profession as a nun ; this was as warmly denied by Edith, who said that she only occasionally wore a religious habit to pacify her aunt, but when the abbess had left her she would throw it on the ground and trample on it. The matter was referred to Anselm, who frankly accepted the girl's story, and married the royal couple on St. Martin's Day, I Ioo, thus uniting the houses of Rolf and Cerdic. 


\section{ECCLESIASTICAL HISTORY}

A considerable difficulty, however, arose about the consecration of Giffard which redounds greatly to the credit of that prelate. The important dispute as to lay investiture was now at its height. A Lateran Council of 1099, when Anselm was present, had declared any bishop excommunicate who should accept investiture from a king. Anselm was ordered by Henry to consecrate Giffard and two others nominated respectively to the sees of Salisbury and Hereford. The archbishop refused, save in the case of Giffard, who had declined to accept the ring and crosier at the king's hands. Henry thereupon commanded the Archbishop of York to consecrate the three bishops-elect, to which Gerard consented. But the bishop-elect of Hereford declined, returning to the king both ring and staff, the recognized symbols of spiritual power. The king ordered Gerard to proceed with the consecration of the bishops of Winchester and Salisbury; but in the very midst of the ceremony Giffard's conscience asserted itself, and suddenly interrupting the service he declared his agreement with his brother of Hereford, and that he could not do this indignity to Anslem by accepting consecration from Gerard of York. Giffard was then banished from court, and his property seized by the Crown. The dispute was not settled until I 107, when on I I August, at Canterbury, Giffard was at last consecrated by Anselm, assisted by Gerard and divers other bishops.

For twenty-eight years Giffard now ruled the diocese with much zeal. In the episcopal city the bishop made a considerable change by removing the New Minster from its position-so closely adjacent to the Old Minster that the two interrupted each other's plain song-to Hyde Meadow, leaving a fine open space that still remains to the north of the cathedral church. At the close of his episcopate, in 1129, Bishop Giffard conferred a great blessing on his diocese by being the first English bishop to recognize the spirit of religious revival and devotion as shown forth in the Cistercian order, which did something to redeem the bitterness of the coming days of anarchy and bloodshed. The bishop in that year founded the first English monastery of Cistercians at Waverley, close to the borders of Hampshire, in the northern part of the great forest of Andred. Three years later the second English house of this order was founded in the Winchester diocese, for in I 132 a Cistercian abbey was established at Quarr, Isle of Wight. Some seventy years later the great abbey of Beaulieu was founded, and from thence, in I 239, went a colony to establish Netley on the other side of the Southampton Water, so that Hampshire had three Cistercian abbeys within its borders as well as one on its immediate confines. By the end of the century this reformed order of earnest Benedictines had I 20 houses in Great Britain.

The episcopate of Henry of Blois, the son of the Conqueror's daughter Adela, and the king's brother, extending from I I 29 to I I 7 , is one of the most striking in the annals of the see. There was far more of the princely baron about Henry of Blois than of the Christian bishop. He spent most of his great income in the building of castles, 


\section{A HISTORY OF HAMPSHIRE}

particularly on his Hampshire manors of Farnham, Merdon (Hursley) and Waltham, and converted the episcopal residence of his predecessors in the city of Winchester into the strongly fortified castle of Wolvesey.

This proved to be most disastrous, so far as Hampshire was concerned, in the prolonged and awful civil strife between the forces of Stephen and Maud. If it had not been for these castles the soil of Hampshire would have been spared much bloodshed, for not a little of the struggle naturally centred round strongholds held by so influential a personage of the royal line. The bishop was to be found now on one side and now on the other, a line of conduct that was eminently disastrous to the peace of his diocese. Having solemnly sworn fealty and obedience to Maud, in the name of the Church and as papal legate at a synod of his assembling at Winchester in I I $4 \mathrm{I}$, he very soon became an equally energetic partisan of Stephen. This brought about a sickening warfare of seven weeks' duration in the very heart of the city of Winchester. The bishop held Wolvesey Castle and the cathedral precincts for the king, and with fireballs deliberately burnt down the recently erected New Minster at Hyde, the abbey of St. Mary and twenty churches, as well as the royal palace and a great number of houses.

There is one redeeming feature in the warlike career of this militant bishop that does him no small credit. He held a council as papal legate at London in the presence of the king in 1142 , at which it was resolved that ploughmen and ploughs should during the war be held as sacred as clergy and churches, and solemn excommunication was pronounced upon all who should attack or injure those engaged in agriculture, who were to be esteemed as much in sanctuary in their fields as if they were in churchyards. ${ }^{1}$

Through pride in his legatine authority Bishop Henry was led to endeavour to make Winchester an archbishopric, as the metropolitical see of the old kingdom of Wessex. His prayer was however rejected by Pope Innocent II., and on that pontiff's death in I I 43 Henry ceased to be legate and the honour was more appropriately conferred on Archbishop Theobald. On the accession of Henry II. the bishop fled to the continent, and the king dismantled three of his four Hampshire castles, namely those of Wolvesey, Merdon, and Waltham. However a speedy reconciliation ensued, but the bishop's overweening influence in state affairs had departed. He was the consecrator of St. Thomas of Canterbury, and in the great controversy between the king and the archbishop Henry of Blois always supported the latter. During his episcopate the Austin priory of St. Denis was founded at Southampton; but the best memorial of the soldier-bishop is the noble foundation of the beautiful hospital of St. Cross.

Henry II., in violation of the solemn pledge given at his enthronement, kept the see of Winchester vacant for two years, appropriating

1 Rog. de Wendover, Flores Historiarum (Engl. Hist. Soc.), ii. 232 ; Matt. Paris, Hist. Angl. (Rolls 


\section{ECCLESIASTICAL HISTORY}

its revenues. At last in May, II73, he gave leave to the monks of St. Swithun's to proceed to an election, and their choice fell upon Richard of Ilchester, a native of Winchester, and at that time Archdeacon of Poictiers; but his consecration was not effected until 6 October, I I74, at Canterbury, when the sees of Ely, Hereford, and Chichester were also filled. Bishop Richard had formerly been a headstrong opponent of the archbishop, but after the canonization of St. Thomas he showed his penitence by causing the newly erected churches of his diocese to be dedicated in honour of St. Thomas of Canterbury. ${ }^{1}$ It has also been supposed that he founded the hospital of St. Mary Magdalene for the sick and infirm at Winchester in further expiation of this offence. These were bad days for the successful working of the diocese, even if much was done by proxy. To a soldier-bishop had succeeded a lawyer-bishop, and the inner working of the Church's life must have suffered grievously. Bishop Richard was appointed justiciar of Normandy in 1176 , justice itinerant for Hampshire and other counties in I 179, and eventually justiciar of England. The bishop died in I 189, the same year as his master, Henry II.

To the lawyer-bishop succeeded Godfrey de Lucy (II89-1205), himself the son of a chief justice. The most memorable event of this episcopacy was the establishing, in 1202 , of a gild or fraternity for the renovation of the cathedral church, which was to exist for only five years for the purpose of collecting alms. To this gild is probably due much of the present beautiful east portion of St. Swithun's. To the same period belongs the Cistercian abbey of Beaulieu, founded and enriched by King John in 1204 during an abnormal fit of penitence for his iniquities.

In 1207 , two years after Bishop Godfrey's death, John paid his first visit to Winchester, where he tarried for a twelvemonth, and there was born the son who succeeded him. When the contest between John and the Church was at last settled and the exiled bishops returned to England they went straightway to Winchester. The miserable king met the archbishop and his suffragans outside the walls, and falling on his knees before them shed an abundance of tears. To the minor strains of the Psalm of royal penitence the procession passed into the chapter house, where John received absolution and swore to revive the laws of the Confessor. Then Stephen Langton led the king into the great church and sang mass, and John presented a mark of gold. The more solemn the vows, the more did the faithless king delight to break them, and no sooner was the ceremony over than John renewed his schemes against both Church and barons. In their despair at this renewed treachery, the barons invited the young Prince Louis of France to come to their aid. John retreated to Winchester, but the city thrust him out and welcomed Louis, who soon established himself in the castle of Wolvesey.

1 Several of the churches in this diocese usually assigned (as in the Diocesan Calendar) to St. Thomas the Apostle are really dedicated to St. Thomas of Canterbury. This is the case with at least two of the Hampshire churches, Bedhampton and Portsmouth. 


\section{A HISTORY OF HAMPSHIRE}

The bishop who followed Godfrey was Peter des Roches, a Poitevin, sometimes termed Peter de Rupibus. To Winchester diocese belongs the disgrace of having the only bishop who abetted the king in his evil ways, and who as a foreigner counselled John to resist the national will. But Peter of Winchester, though the king's justiciar, proved no match for Stephen of Canterbury; and John, finding himself at last in Odiham castle with a miserable following of only seven knights, was compelled to give a reluctant assent to the Great Charter.

On the death of John there was a miserable beginning to the reign of his successor. Henry III. (usually termed Henry of Winchester from the place of his birth), a lad of nine, was crowned at Gloucester in October, I 216 , by Bishop Peter des Roches. Archbishop Langton was at Rome, whilst London and Winchester were both in the hands of the French. The Bishop of Winchester proved as evil a councillor to the youthful Henry as to his father, and was alternately in favour or disgrace. He died at Farnham Castle in 1238.

It is pleasant to be able to add that Bishop Peter's gross neglect of his spiritual obligations brought upon him, even in those lax days, not only the stern rebuke of his metropolitan, but a singularly severe censure from the Roman pontiff. A bull of Innocent III. upbraids the Bishop of Winchester in such vehement terms of rebuke that it seems best to give its exact terms, particularly as it has hitherto escaped attention:-

Innocencius papa III. Episcopo Wintoniensi. Si uera sunt que de te nobis nunciantur non est timor dei ante oculos tuos set abiecisti cum illo proprie forme curam pariter et Salutis. Nostramque de te fiduciam et expectacionem penitus fefellisti. Expectauimus enim vt ad regimen assumptus feruenti studio ecclesie sua uira et ecclesiasticam non solum impenderes verum eciam defenderes libertatem debito ad id pontificalis officii inductus nostre quoque gracie beneficio intitulatus. Tu autem ut dicitur conuersus es in artum prauum et in sensum reprobum datus, eam crudelitate tirannica opprimis et affligio ac in pessimam conaris reducere seruitutem eandem libertantem (sic) conculcando: easquc suscitando questiones consuetudinum contra ipsam que non modum sopite verum eciam sicut dignum erat prorsus abolite sperabantur. Ac uelud in corde tuo dixeris non est deus eo quod circa ecclesiam euis presumis attemptare que ipsi quoque laici detestantur, et pro quibus euertendis ab ea deberes si opus esset uitam tuam exponere : machinaris inducere super eam deo displicere non metuens dum valeas homini complacere sicut ad nos certa relacoine pervenit et cedula presentibus inclusa poterit edocere. Quam idcerco tibi duximus transmittendam vt hoc speculo considerans uultum tuum de tue mentis tribunali indices te ipsum. Paruis tibi profecto est labor noster quam toleratum tot annis pro libertate et statu anglicane ecclesie tu evacuare moliris tam facile tamque cito efficere, ut in pace tot desiderata suspiriis totque procurata laboribus amaritudinem suam amarrissimam conqueratur. Hies igitur tacti doloribus cordis intrinsecus et circa tue presumptionis audaciam non iniuste commoti et obtentu gracie immo sub pena indignacionis nostre et precipiendo mandamus et mandando precipimus quatinus et excessus in presenti cedula comprehensos quantum que ualuens studeas emendare et attemptare similes decetero non presumas pro certo sciturus quod nisi a talibus omnino duxeris desistendum nos tue temeritatis insolenciam taliter curabimus castigare. Quod pena tua erit aliis in exemplum. ${ }^{1}$

Though neglecting so much the spiritual affairs of his diocese, the memory of Bishop Peter is associated with the momentous introduction of the friars into his diocese. He was the founder of a house of

1 British Museum Add. MS. 34254, f. 97 b. 


\section{ECCLESIASTICAL HISTORY}

Dominican or Black friars, who planted themselves within the walls of Winchester, on the north side of the city, about 1230 . Winchester was one of the twelve places in the kingdom that had all the four chief orders of these town missionaries established in its midst. The Franciscans or Grey friars were placed here, near the east gate, by Henry III. about the same period. The Carmelites or White friars had a house found for them in 1278 opposite the church of St. Michael by Peter, the parish priest of St. Helen's, Winchester. The Austin friars also had a house near the south gate, founded in the time of Edward I. Hampshire possessed one other friary, namely a house of Franciscans, founded at Southampton in 1240.

It may be well here to give a few further particulars relative to the friars of Hampshire gleaned from subsequent episcopal registers. The common notion prevalent as to the friars is that they were one and all armed with power to oust the secular beneficed priest from his pulpit and to hear confessions just as they listed. But the Winchester registers, as well as like episcopal records show that they were often under the direct control of the diocesan. In the register of Bishop Pontoise (I 282-1 304), towards the end of the book, is an undated entry, but apparently pertaining to the beginning of his episcopacy, which gives the names of fifteen Dominican friars licensed to preach in the diocese. ${ }^{1}$

On $8 \mathrm{March}$, I 3 I 8, Bishop Sandale directed his mandate to Robert de Wamberge, commissary of the bishop's official, to license the warden of the Franciscans of Winchester and eight other of the friars, together with six Franciscan friars of the Southampton convent to preach and hear confessions, who had been duly presented by their wardens; but as the three friars last named on the list, from the Winchester convent, were unable through age and infirmity to go outside the doors of their house, they were licensed to preach and hear confessions within the priory precincts. ${ }^{2}$

In May, I 3 I 8 , the bishop gave leave to the prior and convent of the Austin friars at Winchester for the consecration of the site, upon which their church was to be built, by any bishop of the Catholic Church. Immediately after its consecration, and before the church could possibly have been built, the friars began to use the ground for burial. As the site was adjacent to the most crowded and poorest part of the city, this action would doubtless interfere with the burial fees of the secular clergy of the adjacent parishes. On remonstrance, the bishop directed his official to inhibit the Austin friars from using this cemetery, contrary to his intention, as a common burial-place for those who wished to be there interred. The bishop directed that the ground was only to be used for the burial of friars and their servants. A month, however, had only elapsed when the bishop found himself obliged to remove the interdict

1 Winton. Epis. Reg., John of Pontoise, f. 206b. The names are Robert de Bromhierd, Stephen de Winton, Robert de Forton, John de Hursley, Henry de Weston, Adam de Winton, Robert de Nomes, Walter de Overton, William de Woxebrigg, Henry Trenchard, Reginald de Stackton, Richard de Basing, John de Chireton, and Thomas de Basing. 2 Winton. Epis. Reg., Sandale, f. 26. 


\section{A HISTORY OF HAMPSHIRE}

on the friars' cemetery, it having been proved that such action was contrary to the papal privileges granted to this order. ${ }^{1}$

During the short episcopate of Bishop Asserio (1 320-3), who was so constantly absent from England, the affairs of the diocese were chiefly administered by Peter, Bishop of Corbavia. This bishop was a Franciscan who had been consecrated to act as suffragan in the diocese of London, but also fulfilled many episcopal duties in the dioceses of Winchester, Rochester, and Canterbury. The fact of this active suffragan being a Franciscan naturally gave considerable prominence to the friars.

In August, I 32I, license was granted to the Carmelite friars to preach in the cathedral church every third turn in conjunction with the Dominicans and the Franciscans. They were also authorized by the same license to preach the Word of God, 'verbum Dei,' in the parish churches throughout Hampshire and the rest of the diocese. As this license however stipulated that the friars were not to preach in the cathedral church if one of the monks of St. Swithun desired to do so, it may naturally be concluded that the same rule applied to the parish churches, and that Hampshire incumbents (provided they were themselves licensed preachers) were not obliged to yield their pulpits to the friars if they desired personally to occupy them. ${ }^{2}$ A fortnight later in the same month, a further license was granted to those of the Carmelite friars whom the provincial chapter might select for the purpose of hearing confessions within the diocese, with the usual exception of reserved cases, and with an indulgence of thirty days of all who availed themselves of their ministrations. On 13 September, I 321 , Nicholas de Morton, an Austin friar, was appointed penitentiary for the diocese till fifteen days after the ensuing Easter.

In November, I 322 , license was granted to William de Corfe, a Franciscan, to hear the confessions of Sir James de Norton, Sir Nicholas de Spurshot and Sir Robert de Harnhull, as well as those of nine other manorial lords and their wives who were all of first rank among the county families. Sir James de Norton, who was lord of the manors of Norton, Nutley, and East Tisted, was sheriff of the county on two separate occasions. Sir Nicholas de Spurshot was one of the knights of the shire from $1309-13$, and was also steward of the abbey of Hyde. The license also authorized the Franciscan to hear the confessions of the rectors of Amport, Abbots Anne and Compton.

A similar license was granted on the same day to Adam de Stokes, a Dominican, to hear the confessions of Sir John de Insula, his wife and children. Sir John was one of the barons of the Exchequer and governor of the Isle of Wight, and he had been sheriff of the county.

In 1325 Bishop Stratford formally authorized certain friars of each of the four orders in his diocese to preach and hear confessions, and instructed the parochial clergy to grant them the necessary facilities.

1 Winton. Epis. Reg., Sandale, ff. 30b, 31, 3 Ib. 


\section{ECCLESIASTICAL HISTORY}

This license was extended to William de Horseleye, prior of the Dominicans of Winchester, and nine of his brethren, one of them being Nicholas de Stratton, doctor of theology ; to William de Sutton, warden of the Franciscans of Winchester, and six of the friars; to five of the Franciscans of Southampton; to Simon de Scaleby, prior of the Austin friars of Winchester, and six others of that convent ; and to Thomas de Gnosham, prior of the Carmelites of Winchester, and six of his convent. As a proof that this was no rash licensing of every friar as a matter of course, it may be noted that in this register several of the names have been erased and others interpolated at a later date in Bishop Stratford's episcopate.

The bishop issued a monition just before Lent, I 325 , to the dean (rural) of Winchester, enjoining that all the parishioners of the city should be urged to attend the preaching of the friars on Ash Wednesday in the cathedral church. ${ }^{1}$

William of Wykeham, amidst all his other duties, found time to hold the office of conservator of both the Dominican and Franciscan friars throughout England and Wales. Although he was not called upon to exercise the duties of this position in his own diocese, it was by no means a sinecure. His registers afford proof that on various occasions he had to interfere for the protection of friars and their interests in other dioceses. $^{2}$ The custom of using friars as the chief diocesan confessors had waned in most English dioceses in Wykeham's times. In $\mathrm{r} 393$ the bishop appointed John Cole, a Dominican, to hear confessions throughout the diocese and to act even in reserved cases, but with him he associated Thomas Nevyle, a monk of St. Swithun's who was afterwards prior. ${ }^{3}$ Their treatment at the dissolution obtains later mention.

To return to the episcopal history. On the death of Peter, Henry III., who had recently wedded Eleanor of Provence, tried to secure the rich bishopric of Winchester for his wife's uncle, William of Valence. The monks of St. Swithun stoutly resisted the king; they did not desire to have another soldier-bishop and termed William of Valence a man of blood. Their choice fell upon William of Raleigh, Bishop of Norwich, and afterwards on Ralph Nevill, Bishop of Chichester, both of whom were favourite royal chaplains. The king resisted, and the diocese was bishopless for five years. At last William of Valence died, and the monks re-elected Raleigh, notwithstanding the outrageous and continued violence of the king, who actually on one occasion manacled the monks of Raleigh's party in pairs and imprisoned them in a squalid den outside the city. The monks of St. Swithun, on appealing to Rome, obtained from the pope a confirmation of their right of free election; they were not at the king's bidding to elect any foreigner or person odious to England, but to choose freely for bishop the man they deemed best for the post.

1 Winton. Epis. Reg., Stratford, f. I 5.

2 Wykeham's Registers (Hants Record Society), pt. iii. pp. 266, 271, $318,347,384,534$.

I Ibid. pt. i. f. 157. 


\section{A HISTORY OF HAMPSHIRE}

Raleigh having his election thus ratified by Innocent III. came down to Winchester to take possession, but the king insisted on the mayor closing the city gates and refusing him admission. The bishop retaliated by laying an interdict on the cathedral and other churches, and excommunicated all the officials, lay and cleric, who had any part in denying him access to the city. The king rejoined by sending letters to the clergy threatening them with the loss of their benefices if they obeyed their diocesan. They listened however to the spiritual rather than the temporal power, left the city and closed the churches. The bishop crossed the seas; but in 1244 the king relented, William of Raleigh returned, all his opponents submitted, the interdict was removed, and Henry, in token of reconciliation, dined at the bishop's table.

On William's death in 1250 , the rapacious Henry put forward another Poitevin, his half-brother Aymer of Valence, for election. Aymer, who was a younger son of Isabel, King John's widow, by her second husband Hugh le Brun, Count of La Marche, already possessed through the king's pressure the income of four rich livings, as well as innumerable pensions from other benefices. He was only in acolyte's orders, was not of canonical age for consecration, possessed neither learning nor character, and knew not the English tongue. At first the monks of St. Swithun resisted, but the king appeared in person in their chapter house, thrust himself into the abbot's or bishop's seat, and thence addressed them with stern threats intermingled with blandishments. The unhappy monks at last gave way, subject to papal dispensation. The dispensation was soon granted, and not only so, but the pope permitted this high-born intruder to retain all the revenues he had drained from the Church of England prior to his election as bishop. Matthew Paris said : 'It is believed that there was not one great church in England from the breasts of which he did not suck the milk.' These were sorry days for the Church in Hampshire. The timorous monks had betrayed their trust by being cajoled into electing a youthful prodigal as nominal bishop, the only redeeming point being that the blasphemy of a consecration of Aymer was never performed in England. They suffered severely for their cowardice, as Aymer greatly oppressed the monks from time to time, subjecting them to inconceivable indignities, and filling their house with the riff-raff of the continent. Winchester's miserable plight was reflected in many other parts of the country, and at last in I $25^{8}$ came the Parliament of Oxford, which made short work with the foreign intruder. Aymer's brother fled to his castle of Wolvesey, dreading the wrath of Earl Simon. The barons attacked the castle and drove Aymer from the kingdom, stripping him of his possessions. A worse and more deservedly hated man never left the walls of Winchester. Expelled from France, Aymer reached Rome and actually obtained consecration at the hands of Pope Alexander IV. in May, I26o. Setting out to return to this country he was taken ill at Paris, where he died on December 4 to the unmistakable joy and relief of the English. 


\section{ECCLESIASTICAL HISTORY}

When the question of a successor to Aymer came before the chapter of the monks of St. Swithun, fifty-four votes were recorded for their old and misused prior, William of Taunton, whilst seven voted for Andrew of London, who was nominated by the remnant of the foreign party. The pope refused to ratify the election of either, and consecrated John Gervais, Chancellor of York, who was then at Rome. On reaching Winchester, Bishop John ejected the rival Prior Andrew of London, and placed him in confinement in the abbey of Hyde. Thence he escaped, and put about the tale that he had been miraculously delivered by St. Thomas of Canterbury. He hung up his fetters by the shrine at Canterbury, where they remained duly inscribed for many a generation, but the Winton annalist states that they were kept there in sport as no one believed a word of his tale. Meanwhile Winchester, and consequently the diocese, was in a miserable plight through the civil strife, the bishop being the warm partisan of Simon de Montfort the younger. In September, I 265, soon after the battle of Evesham, the king came in triumph to Winchester, and there summoned a parliament. The cathedral church and eventually the city were laid under an interdict, and Ottoboni, the papal legate, suspended Bishop John on account of his popular sympathies, together with his brother prelates of London and Chichester. The three bishops crossed the sea to appeal to Rome. The Bishop of Winchester died at Viterbo in January, 1268, and the pope, as he had died at the court of Rome, claimed the canonical right to appoint his successor.

Setting aside the election by the chapter, Clement's choice fell upon Nicholas of Ely, Bishop of Worcester, who had been Chancellor of England in I 260 and in I263. Nicholas, though an avowed sympathizer with the barons, was a man of moderation and peace, and was one of the six selected by the king at Kenilworth, in I 266, to arrange terms with the disinherited nobles. At last Hampshire and the rest of the diocese enjoyed a certain time of peace, and Nicholas in the second week of Lent, I 27 I, began a complete and sorely needed visitation of his spiritual inheritance. On Monday he visited the cathedral church and priory of St. Swithun, on Tuesday the abbey of Hyde, and on Wednesday the nunnery of St. Mary. On the following day the parochial visitation of the archdeaconry of Winchester was begun. When Henry died Nicholas was one of the magnates who wrote to Edward to tell him of his peaceful succession, and in the following year he went with the Bishop of Exeter to meet Edward I. at Paris on his return from the Holy Land. His episcopate was however much marred by a long and obstinate dispute with the chapter of St. Swithun.

Bishop Nicholas died in I 279, and the pope again, after much strife with the chapter, contrived to secure the appointment. The papal choice was however a good one, John of Pontoise, who had been Chancellor of Oxford and was at that time Professor of Civil Law at Modena, being consecrated Bishop of Winchester at Orvieto on I 4 June, 1282. He made a good beginning when he reached his diocese by 


\section{A HISTORY OF HAMPSHIRE}

coming to terms with the monks of his cathedral church. In 1284 the bishop yielded to the prior the right of appointing and removing the officials of the monastery. In return the priory surrendered to the bishop the manors of Droxford, Alverstoke and Havant.

The glories and the troubles of Winchester now came for the most part to an end. The city ceased to be a favourite royal residence. The chief events of the church history of Hampshire are no longer to be gleaned from among the bloodstained annals of royal struggles, but are henceforth to be found in the quiet volumes of episcopal registers, stored in unbroken succession from 1282 down to the present day on the shelves of the diocesan registry.

John of Pontoise's beautifully kept and detailed register gives a considerable insight into the working of the diocese, and shows that there was a most genuine oversight throughout the twenty-two years of his episcopate.

The first entry records the institution, in 1 282, of Thomas de Anne to the vicarage of Amport, on the presentation of the Dean and Chapter of Chichester. Various other Hampshire vicarages had been founded before this episcopate to which there are institutions or collations in this register. Such are the vicarages of Chilworth, the rectory being appropriated by the priory of St. Denis of Southampton; of Crondall and Twyford, appropriated by the hospital of St. Cross; of Eastmeon, by the abbey of St. Swithun; of Eling and Somborne, by the priory of Mottisfont ; of Hayling, by the abbey of Jumiéges ; and of Porchester, by the priory of Southwick.

It is not possible in this diocese, as is the case with the great diocese of Lincoln, ${ }^{1}$ to give definite particulars and dates as to the earlier vicarages, as the older registers or rolls are missing. A considerable proportion of the churches of England were in the hands of the monasteries in the twelfth century. Where the living was a good one, the monks or canons who had control of the revenue of the benefice usually hired a clerk or chaplain to serve the cure on the best terms that they could arrange for the interests of their own house. These parochial chaplains were mere servants of the convent and dismissible at will. This custom practically withdrew such parishes from episcopal control, in addition to other evils, and hence was resisted by the bishops. The custom of ordaining vicarages-that is, making the appointment perpetual and subject to episcopal institution, and assigning a definite income to the vicar-began to come into force here and there in the latter half of the twelfth century, ${ }^{2}$ and was enjoined by the third Lateran Council of I 179 .

The more powerful monasteries throughout England resisted however all attempts to control their action in such cases, notwithstanding the

1 The extant Liber Antiquus Hugonis Wells (1 209-35) deals solely with vicarages.

2 The earliest instance we have met with is that of Blakesley, Northamptonshire, the vicarage of which was formally ordained in 1156. 


\section{ECCLESIASTICAL HISTORY}

yet more definite pronouncement on the subject by the fourth Lateran Council of I 2 I 5. But no sooner had that energetic Bishop of Lincoln, Hugh Wells, become firmly established in his important see than he determined to bring the matter to a definite issue. He boldly attacked the powerful Austin house of Dunstable, taking the instance of their treatment of the church of Luton as a test case. The pope appointed a commission of inquiry and judgment, who gave a decision in 1219 entirely in the bishop's favour. Four years later this decision was still further strengthened by the Council of Oxford, and henceforth the English episcopate insisted on definitely ordained vicarages for appropriated churches.

In forming an estimate of the respective conditions of a parish in mediæval days, where the parish priest was a rector or a vicar, it should always be remembered that vicarages were only allowed where the total income of the benefice was large, that not a few of the smaller rectories were of less value than vicarages, and that the rectories themselves were often, through plurality and non-residence, in the hands of a poorly paid and removable chaplain or curate, and were therefore worse off, from the parochial point of view, than those appropriated to the monasteries.

Notwithstanding the number of her religious houses, Hampshire never had as large a proportion of vicarages as other shires. They slowly but steadily increased throughout the fourteenth century, as will be noted. In the midst of John of Pontoise's episcopate came the important Taxatio of Pope Nicholas IV. In 1288 the pope gave up his annual tax of one-tenth of the Church benefices to Edward I. for six years for crusading purposes. To insure accuracy a new assessment basis or valor was drawn up, which was completed for the province of Canterbury in $\mathrm{I} 29 \mathrm{I}$. This taxation continued to be the basis of all church assessments down to 1535 , when a new valor took its place. From this return we find that there were then thirty-seven vicarages in Hampshire and the Isle of Wight out of 233 churches. These were distributed as follows: In the deanery of Alresford, Easton and Bishop's Sutton; in the deanery of Alton, Alton; in the deanery of Andover, Andover, Nether Wallop, Shipton, Hurstbourne Priors, and Combe ; in the deanery of Basingstoke, Basingstoke, Bromley, Herriard, Crondall, Heckfield and Odiham; in the deanery of Droxford, Hayling, Warblington, Porchester, Wymering, Fareham, Hambledon, Eastmeon, and Portsea; in the deanery of Fordingbridge, Fordingbridge, Sopley, Milford and Boldre ; in the deanery of Somborne, Somborne, Micheldever, Longstock and Wellow ; in the deanery of Southampton, Eling; in the deanery of the Isle of Wight, Shalfleet, Carisbrook, Brading and Arreton; and in the deanery of Winchester, Sparsholt and Twyford. ${ }^{1}$

1 The proportion for the whole diocese of Winchester was 53 vicarages out of 338 churches. In the adjacent dioceses the proportion of vicarages was considerably larger : in Salisbury 104 out of 493 , in Chichester II 2 out of 286 , and in Rochester 31 out of 108. 


\section{A HISTORY OF HAMPSHIRE}

Some of these appropriated Hampshire benefices were very valuable, and their vicarages much out of proportion.

Here are some instances:-

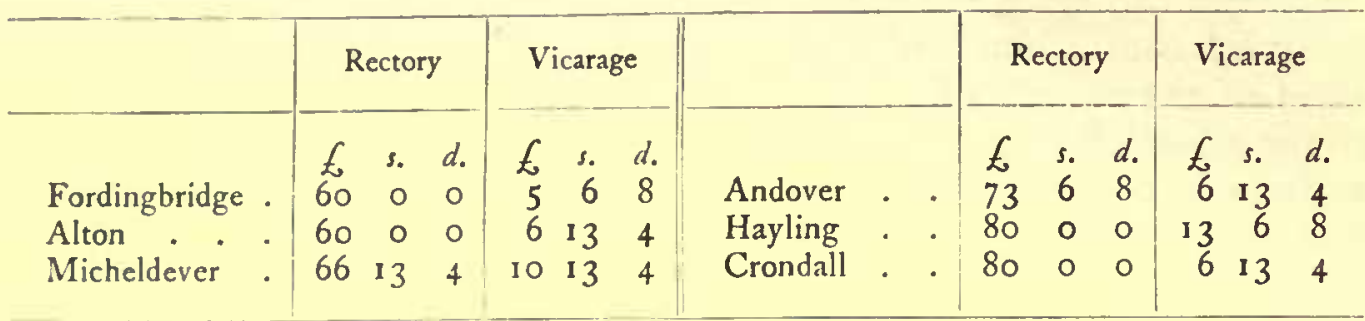

In addition to the appropriated rectories the religious houses drew small pensions from certain of the Hampshire rectories. These varied in I 29 I from $f_{1} 16 s .8 d$. down to a single shilling.

By the time that the revised Valor Ecclesiasticus of Henry VIII. was drawn up, the vicarages of the ten Hampshire deaneries had increased from thirty-seven to seventy-one.

Now and again in most dioceses it is found that vicarages of early foundation were re-arranged at a later date, the income assigned to the vicar being found to be insufficient. Brading in the Isle of Wight is an instance of this; although entered as a vicarage in the Valor of I291, the rectory was re-appropriated to the priory of Breamore in I 301 , and the vicarage formally reconstituted in $\mathrm{I} 304 .^{.}$At the latter date there were assigned to Thomas Sutton, as vicar, with much detail, all altar oblations and obventions, the tithes of lambs, calves, cheese, milk, geese, pigs, pigeons, fowls, apples, eggs, honey, beet, flax, hemp, gardens and crofts tilled by spade husbandry, also of fish and mills, and of the hay of certain meadows. The vicar was also to have three acres of land near the church for his house and appurtenances, which he was to build at his own expense.

In I 301 , Bishop Pontoise founded at Winchester a great chapel or college, in honour of St. Elizabeth of Hungary, for a provost, six chaplains, six clerks, and six choristers. This was a chantry on a great scale, and was an endowment for masses for the souls of the Bishops of Winchester and the faithful in general. There were to be three sung and three plain masses daily. ${ }^{2}$ This foundation led to the ordination of two more vicarages, the rectories of which were given by the bishop to the chapel of St. Elizabeth. These were Amport and Hursley. ${ }^{3}$

Under Bishop Pontoise begins the licensing of oratories for manor houses, which increased considerably under subsequent bishops. One of the earliest mentioned is that for the manor of Tichborne." These

1 Winton. Epis. Reg., Pontoise, ff. $31,44 \mathrm{~b}$.

2 John of Pontoise's Register, f. 32. There was not much distinction between the larger chantries and some of the later collegiate churches or colleges. Hence the chapel of St. Elizabeth was in the fifteenth and sixteenth centuries sometimes called the college of St. Elizabeth. The name has thus deceived some writers as to the intention of the founder. The Diocesan History of Winchester (p. I I6) says that the bishop founded it 'for the purpose of promoting learning amongst his clergy.'

Ibid. ff. $32 \mathrm{~b}, 35$. Ibid. f. 88 . 


\section{ECCLESIASTICAL HISTORY}

oratories, notwithstanding the abundant supply of churches and chapels in proportion to the population, are interesting proofs of the reality of the faith of the laity of the times.

Henry Woodlock, prior of St. Swithun's, was raised to the episcopate of Winchester in 1305 , just about the time when the quarrel between the king and Archbishop Robert of Winchelsey was at its height. Espousing the cause of the archbishop, who had been his consecrator at Canterbury, Woodlock was outlawed with the primate. On the death of Edward I. in 1307 the two prelates were recalled by the young king. The archbishop was too ill to hasten home for the coronation, and issued a commission authorizing any one of three of his suffragans to act in his behalf. Of the three named, Edward II. selected the Bishop of Winchester, and Henry Woodlock had the honour of crowning Edward and Isabel at the magnificent ceremonial at Westminster, when the favourite Gaveston carried the crown of England before the monarch. Woodlock, on his return to Winchester, caused his registrar to enter various documents pertaining to the coronation in his register, including the copy of the bishop's formal protest that no prejudice is intended to the church of Canterbury by his officiating on that occasion. ${ }^{1}$

Woodlock's register presents several points of interest. His careful rule over the religious houses under his sway is shown in their subsequent outline history. In the first year of his episcopate there is the confirmation and strengthening of a former ordination of the vicarage of Andover, which was granted by Bishop Ralegh in I 246, and which is, we believe, the earliest ordering of a vicarage of this diocese now extant. ${ }^{2}$ There was also an ordination of the vicarage of Alton in I 3 I 2. In I 3 Io the rural dean of Basingstoke was ordered to cite the parishioners and vicar of Basing to appear, on the third day after the feast of St. James, about a dispute between them as to two chalices and a pyx of silver. $^{3}$

The register of this episcopate affords proof of considerable laxity of patronage in various directions. Pope Clement, in I3 I3, granted the bishop a dispensation for appointing six clerks under the canonical age to benefices, a power that Woodlock made haste to exercise in favour of youthful relatives. ${ }^{4}$

It was for a long time the custom of the Bishops of Winchester to hold their ordinations at various centres, frequently in the chapels of their numerous castles and manor houses. During his episcopate Woodlock held ordinations in Hampshire at his manors of Marwell (his birthplace), Waltham, Esher, Highclere, Hursley, and Bishop's Sutton, as well as in the conventual church of Breamore, in the chapel of St. Cross, Winchester, and in the parish churches of Bitterne, Micheldever, Alresford, Basingstoke, and St. Mary's, Southampton.

The short episcopate of John Sandale ( $13 \mathrm{I} 6-20$ ) is not memorable so far as Hampshire or his diocese was concerned. His career,

1 Winton. Epis. Reg., Woodlock, ff. 77-9.

3 Ibid. f. 88 .
2 Ibid. ff. $38 \mathrm{~b}, 39$.

4 Ibid. f. 167 . 


\section{A HISTORY OF HAMPSHIRE}

however, affords a favourable example of a zealous civil servant of the crown, whose large stipend was mainly drawn from ecclesiastical benefices, an absolute perversion of the tithe system. Clerks in the king's service, by 'ancient prescription,' a vague term usually employed to cloak an abuse, were permitted to hold almost any number of benefices in plurality, and were exempt from residence or service provided they appointed substitutes to do their duty. The worst of this scandal was that the proxies in these benefices were not duly appointed perpetual vicars with stipulated salaries, but were mere clerical hacks or chaplains removable at will. In September, 1314, when the king made Sandale chancellor of the kingdom, he held 'no fewer than two dignities, eight prebendal stalls and ten rectories, the taxed annual value of which amounted in the aggregate to close upon $£ 85^{\circ}$.' excuse of this high office being unsalaried, as the salary of the chancellor was $\oint_{0} 00$, so that Sandale's income at the then value of money was enormous.

When the vacancy occurred at Winchester the monks at once obtained the royal congé d'élire, but the king's persuasions frequently prevailed in such elections. On this occasion Edward II. was determined to win. He wrote, though not in the dictatorial shape of a modern 'letter missive,' to the chapter, entreating them to elect his chancellor, and persuaded the queen and other magnates of the realm to write in a similar sense. Edward also wrote two letters to his cousin Aymer de Valence, Earl of Pembroke, urging him to proceed at once to Winchester, and to use his utmost exertions with the monks to secure Sandale's appointment. The chapter of St. Swithun's complied with these earnest solicitations and elected the chancellor. He was consecrated at Canterbury by the archbishop on 31 October, I316. Notwithstanding the other calls upon his time he was exceptionally diligent in the work of his diocese, employing no suffragan, and holding all his ordinations personally. ${ }^{2} \quad$ Although he did not make use of the services of a suffragan, an interesting case occurred of another bishop officiating in his diocese. On 4 February, ${ }_{13}$ I 7 , Bishop Sandale granted a special license to John Drokensford, Bishop of Bath and Wells, to consecrate the high altar and other altars of the parish church of Droxford (which had been removed and re-erected on the reconstruction of the church), in consequence of the latter bishop's particular affection for the church in which he had been baptized. ${ }^{3}$ In the following April, Sandale granted his brother bishop letters dimissory for ordination on behalf of five of his relatives, Philip, Andrew, Nicholas, Richard and Thomas de Droxford, who were all subjects of the diocese of Winchester." The

1 Baigent's Introduction to Sandale's Register, p. xxxii. These benefices were : the chancellorship of St. Patrick's, Dublin ; the treasurership of Lichfield; prebends at Dublin, Wells, Beverley, Lincoln, London, York, Glasgow and another ; and the rectories of Chalk, Dunbar, North Creake, Ratcliffeon-Soar, Simonburn, Solihull, Stillingfleet, Stoke-upon-'Trent, and Wimbledon.

2 The Diocesan History of Winchester, p. 119 , gives a very brief and strangely wrong notice of Sandale's episcopate, stating 'that there is hardly anything recorded except that he neglected his diocese.'

Winton. Epis. Reg., Sandale, f. 7 b. 4 Ibid. f. 54 . 


\section{ECCLESIASTICAL HISTORY}

licenses for non-residents were unusually numerous during this short episcopate. For the most part these licenses were for a year or two years for study, and were granted to enable those in minor orders to prepare the better for their priesthood. Among those granted for exceptional reasons may be mentioned leave of absence for a year to the rector of the churches of Nutshelling (Nursling) and West Tytherley, that he might accompany the Archdeacon of Winchester to the Roman court; to the rector of Crux Easton, that he might go on pilgrimage to divers religious places beyond the seas; to the rector of St. Michael's, Southampton, that he might be in attendance on the Lady Mary (daughter of Edward I.), who was a Benedictine nun at Amesbury ; to the rector of Minstead, to be in attendance on Dame Sibil, Abbess of Romsey; and to Gerard de Seysiniaco, to be in attendance on the Archbishop of Lyons.

It was rather awkward for Sandale, who had himself been so great a pluralist, that Pope John XXII., moved by a spirit of righteous reformation, suddenly withdrew the numerous dispensations of plurality granted by his predecessors, and commanded the immediate surrender of all benefices with cure of souls save the one where the incumbent was resident. Moreover each bishop was enjoined to make a return of the names and value of such livings, together with the names of the incumbents and the churches which they had resigned or from which they had been dismissed. Whatever might have been his views Sandale yielded prompt obedience to the pontiff. On 3i March, I318, he directed the Archdeacon of Winchester to certify the names of all pluralists and their benefices, and on 29 May he forwarded a letter to the pope certifying that his new constitution against pluralists had been carried out, and enclosing a schedule giving the required particulars. The benefices thus vacated in the county of Hampshire through this righteous ordinance were those of West Tytherley, Farley, Warnford, Bedhampton, Itchenstoke, Freshwater, Atherton, Michelmarsh and Church Oakley. ${ }^{1}$ Sandale joined with the Archbishop of Canterbury and the rest of the prelates of the southern province in a letter which was sent to the pope on 30 May, thanking him for this reform, but stating that, in consequence of his reservation of the churches thus left vacant, many were without pastors. They asked for facilities to enable them to fill up these benefices, or else that the pope would himself confer such benefices on one or other of the clerks named in separate schedules which were forwarded to him by the respective bishops. This action of the pope seems to have stirred the bishop to look generally into the question of non-residence, and early in March, I $_{3} 18$, he directed his archdeacons to admonish in high-toned scriptural language non-resident incumbents (apart from plurality) to return within three months and to take up continued residence, so as to sustain hospitality and the other burdens of their cure. The archdeacons were to furnish him with the names of non-resident rectors before Easter. In 


\section{A HISTORY OF HAMPSHIRE}

the following October he appointed a special commission to take proceedings against non-resident incumbents. ${ }^{1}$

Bishop Sandale evidently looked closely after the efficiency of his clergy. In November, I 3 I6, the bishop addressed the king's justices, informing them that he had pronounced sentence of excommunication against the prior of St. Helen's, Isle of Wight, for various offences and contumacy. There seems to have been some serious objection to the bishop's authority in that part of his diocese, for two years later he directs a letter to the king for the arrest of certain rectors and vicars of his diocese who had been under sentence of the greater excommunication, and contumacious for forty days and more. These were chiefly incumbents in the Isle of Wight, and included the prior and warden of St. Helen's, the rectors of Motteston, Shorewell and Newchurch, and the vicars of Shalfleet and Brading. ${ }^{2}$

A dispute having arisen between the parishioners of the chapel of Northwood and the vicar of Hayling as to neglect of services, the bishop intervened, and ordered the vicar to fulfil his obligations at Northwood, whereby he was to provide full services in the weeks of Christmas, Easter and Whitsuntide, and on all double feasts, as well as on every Sunday, namely, mattins, mass, evensong and compline, together with mass on every Monday, Wednesday and Friday throughout the year. ${ }^{3}$

On two occasions he directed his Hampshire rural deans, taking with them a sufficiency of rectors and vicars of the deanery, to hold local inquests as to age and infirmities of incumbents, and whether they were competent to discharge the functions of their sacred calling. One of these related to the vicar of Whitchurch in Andover deanery, and the other to the rector of Eastrop, in the deanery of Basingstoke. ${ }^{4}$

The only ordination of a Hampshire vicarage during this episcopate was that of Eastmeon, the rectory of which pertained to the Bishop of Winchester. Richard de Wardington, the vicar, complained that the late bishop (Henry de Woodlock) had made certain provisions for the vicarage, but these had proved far too slender and the bishop was about to augment them when death intervened. Bishop Sandale made certain arrangements for the augmentation in February, 1318 , and issued a formal instrument of ordination in June of the same year. By this it was provided that the vicar and his successors should receive all the tithes, great and small, of the hamlet of Froxfield and the chapel of Westbury, and all the oblations of the church of Eastmeon and its three chapels of Froxfield, Steep and Our-Lady-in-the-Fields; also that every tenant of the parishes should pay five eggs at Easter; also that five quarters of corn and ten acres of arable land should be assigned to the vicar from the episcopal granges. Thus far was the old vicarage endowment; to this Bishop Sandale added, in augmentation, the small tithes of the whole parish and chapelries, namely those of milk, cheese, calves, fowls, pigs, geese, eggs, milk, honey, hay, pigeons, flax, hemp, gardens,

$$
1 \text { Winton. Epis. Reg., Sandale, ff. } 26 \text { b, 31. } \quad 2 \text { Ibid. ff. 5, } 27 . \quad 3 \text { Ibid. f. } 21 .
$$




\section{ECCLESIASTICAL HISTORY}

and everything else tithable of right or according to the custom of the parish; but the tithes of wool, lambs and apples were reserved for the bishop and his successors, save the tithes of wool of the chapelry of Westbury, which pertained to the vicar. ${ }^{1}$

The bishop, as visitor, also found time to supervise with boldness the religious as well as the secular clergy of Hampshire. On 29 March, I 3 I 8 , he wrote a formal letter to the Abbot of Hyde, complaining in strong but dignified language of his negligence in the rule of his monastery, and of the frequent breaches of the rule committed by the monks. The bishop did not hesitate to say that the continuous insubordination of the monks was chiefly owing to their superior's lukewarmness ( $a b$ tepiditatem vestri regiminis), and warned him that if matters were not remedied severe proceedings would be taken. ${ }^{2}$ On $20 \mathrm{July}$, I 3 I 9 , the bishop sent a letter of citation to the prior and convent of St. Swithun, announcing his intention to hold a visitation of their monastery on 30 August, requesting that all who were absent should be recalled, so as to be present in chapter on that day. Similar citations for visitations to be held in the month of August were also dispatched to the priories of Christchurch and Breamore, and to the abbey of Wherwell; but these visitations had to be postponed through the bishop's ill-health. ${ }^{3}$ The last act noted in Sandale's register is a letter of October to the prior and convent of Christchurch, requiring them, on the authority of a bull of the previous December, to receive into their community as a clerk Stephen de Stapelbrugge, brother of the late order of Knights Templars, who had only received the first tonsure."

On 2 November Bishop Sandale, who, much indisposed during the previous two months, had been sojourning at Wolvesey, Farnham and Esher, died at Southwark. On the day of his burial at the conventual church of St. Mary, Southwark, there was an immense concourse. The household expenses (in addition to the great dole to the poor) included the cost of 14 carcasses of beef, 78 sheep, 24 pigs, 22 calves, 8 swans, 140 geese, 240 fowls, I 9 partridges, 206 pigeons, I, 300 eggs, and large quantities of pike, conger eels and herrings. The drink included 320 gallons of wine, 695 gallons of ale at $\mathrm{I} \frac{\mathrm{I}}{2} d$. and 448 gallons at $\mathrm{i} d$.

It may seem that more space has here been assigned to the acts of Bishop Sandale than is justified by so short an episcopate, but his register gives in a brief compass a remarkable and exceptional insight into the working of an English mediæval diocese by a zealous prelate. ${ }^{b}$

I Winton. Epis. Reg., Sandale, ff. 25 b, 3 I.

2 Ibid. f. 27. This was Abbot William de Odiham; he had only been appointed abbot in 1317 and he died in 1319 .

3 Ibid. ff. 33 b, 34 .

4 Ibid. f. 34 b. This is followed by a copy of the bull of John XXII. (17 December, 1318 ) addressed to the bishops to prevent the scandal of brothers of the suppressed order going back into the world and behaving like laymen, enjoining them to place them in religious houses, the house to receive the pension that had been assigned.

The writer of this section knows well all the episcopal registers of Lichfield and York, and has a fair knowledge of those of Lincoln and Canterbury. He has no hesitation in saying that he is not aware of any other two or three years of an English pre-Reformation episcopate that can compare in 


\section{A HISTORY OF HAMPSHIRE}

The bishop resigned the great seal in June, 1318 , having held it for about eighteen months after his consecration. This he did to secure more time for his diocesan work; but the king refused to spare him altogether from affairs of state, and for the last year of his life he held the office of treasurer. In this position he was of great service in the grave financial difficulties connected with the war with Scotland; nevertheless his episcopal supervision over Hampshire and Surrey was remarkably thorough, earnest and minute. As he went through the streets of his cathedral city his attention was drawn to a young cleric walking about in a parti-coloured dress (vestem publice deferens stragulatam), and learning that his name was John Ashley, subdeacon of the abbey church of St. Mary, he at once issued a formal mandate to the abbess and convent, drawing their attention to this scandal to their convent. Nor was it mere trifling that caused him to order his registrar to enrol this mandate in his act book, but rather as a token that he expected all his clergy to be sober in their habits. At another time we find Sandale issuing his mandate to the Archdeacon of Winchester to order special prayers to be said in every church on Sundays and festivals that God, of His divine mercy, may direct and prosper the king and his army, and restore peace to the realm; and this in no mere formal or perfunctory manner, but requesting in beautiful language that the people may be instructed to be assiduous at mass and in prayer, and also in almsgiving, fasting and other works of charity, without which they could expect no heavenly blessing.'

On the death of Sandale a prolonged dispute between the monks and the king resulted in the pope nominating Rigaud de Asserio, an Italian who knew this country well, having been papal nuncio for some years to England, Scotland, Ireland and Wales. He was not consecrated until November, I 320 , and was enthroned at Winchester on Whitsunday, I 321. Early in December of the latter year, when the young bishop had only had seven months' experience of his important diocese, he was dispatched by the king on affairs of state to the Roman court. Asserio tarried in the south of France till his death in April, I 323 . Just before leaving England, the bishop issued a special commission to Peter of Bologna, Bishop of Corbavia, who already acted as suffragan bishop of London and Canterbury, to discharge the necessary episcopal functions during his absence.

As Asserio died at the papal court, the pope claimed the right of appointing his successor, and nominated John Stratford, a distinguished lawyer, who had been made Dean of Arches by Archbishop Reynolds in I 32I. Stratford played an important part in the revolution of 1327 , and was one of the twelve special councillors of the young king Edward III.

chronicled efficiency with that of Sandale. It has been admirably reproduced and edited by Mr. Baigent in the Hants Record Series. There is another remarkable example of episcopal energy in Thomas's account of the contemporary Bishop of Worcester, Walter Maidstone, $1313-7$.

1 There are three of these mandates for diocesan prayer for the year 1317 , viz. June 9, August 12
November 3 . and November 3. 


\section{ECCLESIASTICAL HISTORY}

Incurring however the wrath of Isabel and Mortimer, the bishop fled to his Hampshire manor house of Waltham, and there sought security in the neighbouring forest, where it is said that Stratford caused his chaplains to chant the daily offices under the greenwood tree. On the fall of Mortimer he was restored to honour, and received the great seal as chancellor in November, I330. In Stratford the statesman predominated over the ecclesiastic, and it would be foreign to our present purpose to follow, even in meagre outline, the incidents of his distinguished life. There are two matters however which cannot be passed over. England owes some share of her national liberties to this Bishop of Winchester. It was not until I 332, through the direct action of Stratford, that the elected knights and burgesses were permitted to form a separate and independent house during the sitting of parliament. It was too on Stratford's advice that a proclamation was issued before the assembling of the parliament of 1332 , prohibiting the wearing of arms or armour throughout London and Westminster during its session. It henceforth became customary to issue a like proclamation before the meeting of each parliament. Another considerable and useful change that Stratford effected was the making the Court of Chancery stationary at Westminster ; this court had hitherto been vaguely itinerant, for the chancellor sat wherever the king might be holding his court.

During the ten years of his Winchester episcopate Stratford, in addition to his other state duties, was frequently absent from the kingdom on embassies to France and other powers. The episcopal functions in Hampshire and Surrey were for the most part discharged by that useful suffragan Peter, Bishop of Corbavia, and after his death in June, I 332, by Benedict, Bishop of Sardica, prior of the Austin friars of Norwich, and suffragan bishop of both Winchester and Norwich up to his death in I 346 . At the same time Stratford's beautifully kept and comprehensive register at Winchester shows that he took a larger share in diocesan administration than could have been expected, and that the routine work was by no means neglected by his various officials or deputies. In 1327 the bishop held a visitation of the clergy and people of the deanery of Southampton; the rural dean received with the citation a schedule to forward to each parish, giving the names of those who were personally cited. The visitation was held in the parish church of Waltham. ${ }^{1}$ In 1329 the bishop gave a special commission to John de Leah, his official, to hold visitations in his name throughout the whole of the archdeaconry of Winchester. ${ }^{2}$

Among the more exceptional licenses for non-residence in this register two may be mentioned. In 1326 Walter, vicar of Portsmouth, was granted leave of absence for a year because the sea air did not suit his health. ${ }^{3} \quad$ In 1332 William Knight, vicar of Micheldever, was permitted to leave his benefice to visit the apostolical court on account of the irregularity of a marriage that he had celebrated. ${ }^{4}$

\footnotetext{
1 Winton. Epis. Reg., Stratford, f. 33.

3 Ibid. f. $18 \mathrm{~b}$ : propter aeris intemperiem juxta mare. 


\section{A HISTORY OF HAMPSHIRE}

In 1330 there were considerable disturbances in the parish of Alton, and the bishop promptly interfered in the interests of reverence and order. From the long documents relative to this case it would appear that the image of St. Lawrence ${ }^{1}$ (the saint in whose honour the church was dedicated) was moved from its position by the high altar just before the annual parochial feast of 10 August. The bishop therefore ordered the official of the archdeaconry of Winchester to publish at once in the church of Alton a monition of censure on the offenders, warning them against any repetition of the offence. This action seems to have been taken in consequence of the clergy striving to suppress the grossly irreverent custom of holding a fair at this season in church or churchyard, and other grave disorders which ensued. ${ }^{2}$ On Sunday, I 9 August, immediately after the octave of St. Lawrence, Bishop Stratford, in all episcopal pomp, having with him the prior of St. Swithun, the abbot of Hyde, the prior of Selborne, and the rural deans of Alton and Basing, pronounced in the parish church of Alton solemn excommunication against John de Aulton and John his son, John de But, Nicholas Upchepyng, Alan Bat and many other 'satellites of Satan' whose names were unknown, for infringing the liberties of the church by their gross and violent behaviour. This was followed by an inhibition of all fairs or any sale of merchandise in the church or churchyard of Alton, or in any church or churchyard throughout the whole diocese of Winchester. This once prevalent custom had been long ago stamped out in most English dioceses, though now and again it sprung up anew in certain places at a much later date. It was stringently forbidden in the time of King John throughout the Lincoln diocese. On the death of Archbishop Meopham in 1333, Bishop Stratford was translated to Canterbury.

The unhappy and pitiable ending of the kingship of Edward II. is the saddest dramatic episode in England's history during the fourteenth century. In that scene Stratford's successor in the bishopric, Adam Orlton, then Bishop of Hereford, played the most important part. The commission appointed by parliament to depose the king consisted of three bishops, two earls, four barons, two abbots and two justices, with a certain number of citizens and burgesses. Of this commission Orlton (the oldest by consecration of the three prelates) was appointed prolocutor. On 25 January, I 327 , the commission arrived at Kenilworth, where the king was a prisoner. Edward, unattended, in ordinary civil dress, entered the chamber round which the silent commissioners were placed. Orlton stepped forward to address him, and when the king saw that their mouthpiece was his implacable enemy, his heart failed him and he fell to the ground in a dead faint. The queen and her paramour Mortimer showed their gratitude to him, whom Dean Hook

1 The patronal image of a church was always placed in the chancel, usually on the north side of the high altar. It is here expressed that the image had been removed a loco summi altaris ubi de consuetudine approbata esse deberet.

Winton. Epis. Reg., Stratford, ff. $51 \mathrm{~b}, 52$. 
rightly describes as 'their agent, the unprincipled Orlton,' moting him to Worcester in 1327 , and through papal favour he was translated to Winchester in $\mathrm{I} 333$.

A most striking incident happened on 2 April, I333, in the cathedral church of St. Swithun, when a solemn protest was made against Orlton's translation, coram populo, and in Orlton's own presence, by one John Pritchare. The bishop was charged by his accuser with implication in the murders (in 1326) of Walter Stapleton, Bishop of Exeter, and of Robert Baldock, the chancellor, whom it was also alleged he had imprisoned and tortured. He was further charged with treason to the late king, inasmuch as he had preached to Oxford University that Edward II. was an immoral tyrant, and that he carried a dagger in one of his boots to kill Queen Isabel, and had said that if he had nothing else he would kill her with his teeth (dentibus strangularet). The bishop answered that Baldock was a traitor, and after being condemned by a secular judge had been handed over to his custody as a criminous clerk, but that the people of London broke open his prison and put him in the city gaol ; that he had called Despencer immoral, and not Edward II. ; and that what he had said about the late king and his queen was by order of Edward III. and his mother and at the request of the council. Edward III. had, on 23 March, instructed the sheriff of Hampshire, Sir John de Scures, that Orlton having obtained the bishopric by papal provision was to be proceeded against, and meanwhile was not to be obeyed as bishop. The bishop had to set out for Rome, whence he wrote to the Prior of St. Swithun to implore his aid. It was not until late in I 334 that the temporalities were restored, and the bishop made his peace with his predecessor in the see of Winchester, the Archbishop of Canterbury. ${ }^{2}$

Orlton's was an uneventful episcopate of twelve years. His registers have no very special interest. They contain however a copy of the ordination of Maldon vicarage in 1279 by Bishop Ely, which is of value, as the earliest extant registers do not begin till i 282 . Soon after his appointment to Winchester, namely in November, I 334, the bishop visited all the religious houses of Hampshire which were subject to his jurisdiction, and the text of the sermon that he preached to the inmates in each chapter house is entered in the first of his registers.

Bishop Orlton suffered from blindness during the latter part of his life. He died on 18 July, I 345, and Edward III. at last succeeded in overcoming opposition to his appointment to the bishopric of William Edendon his treasurer, who was at that time master of St. Cross. Bishop Edendon was not consecrated till I 4 May, I 346. His well deserved fame as a great and generous church builder is elsewhere described. The age of demonstrative chivalry had reached its zenith just at the time of the new bishop's consecration. Edward III., in instituting the Order of the Garter, showed his regard for Edendon by appointing him

1 Hook's Arcbbishops of Canterbury, x. 9.

2 Chartulary of St. Swithun's, Nos. 233-44, 260. 


\section{A HISTORY OF HAMPSHIRE}

chancellor of the new order. It was also ordained that this honour should be passed on to his successors in the see of Winchester for ever ; and to this day the Bishop of Winchester is prelate of the order.

Edendon seems to have been not indisposed to take his full share in the pageantry of the times. The utter defeat of France at Cressy in $\mathrm{I} 346$, and the taking of Calais in the following year, had intoxicated England and England's king with a fervour of extravagant patriotism. When the triumphant Edward landed at Sandwich on 14 October, I 347, the country went wild with joy. Of this national excitement Hampshire had by far the largest share. The king and queen, instead of proceeding to London, made a triumphal progress through the county, visiting the castles of Porchester, Southampton and Winchester.

Chroniclers tell us that at this time there was hardly an English household of the upper or trading classes to be found which was not decked with the costly spoils of Caen, Calais and other French towns from across the seas. Hampshire and the Isle of Wight, with their wide seaboard, felt the effects of this incursion of riches far more than most parts of the kingdom. It was the same wide seaboard that rendered them specially liable to the attacks of the seeds of pestilence that now swept over the same waters. Close upon the heels of this outbreak of martial magnificence and extravagant pomp came an awful avenger, which was nowhere more direful in its devastating force than within the limits of Hampshire.

Towards the end of August, 1348 , this terrible visitor reached our shores, first effecting a landing at the port of Melcombe Regis (Weymouth). It soon began to spread throughout the west and south of England. On 24 October Bishop Edendon issued from Southwark Mandatum ad orandum pro Pestilentia to the prior and chapter of Winchester, speedily followed by others to the archdeacon of Winchester and to the archdeacon of Surrey. ${ }^{1}$ This mandate to his clergy, made through the archdeacons, is no mere official direction, but the exceptional and pathetic vigour of its language shows that the terrible news of the havoc wrought by the Black Death on the continent had stamped itself on the bishop's mind.

The mandate for the archdeaconry of Winchester is addressed to the whole of the abbots, priors, chaplains of chantries and colleges, rectors of parishes, vicars and parochial chaplains. The bishop charges them to see that all are exhorted to frequent the sacrament of penance, and on all Sundays, Wednesdays and Fridays to join in the saying of the seven penitential psalms and the fifteen gradual psalms devoutly kneeling, and also to take part, barefoot, in procession, reciting the greater litany in towns through the market places, and in villages in the churchyards round about the churches.

As the plague crept nearer and nearer to his diocese, Bishop Edendon made further spiritual provision against its approach. On 17 November the bishop, who was then at Esher, granted facilities to 


\section{ECCLESIASTICAL HISTORY}

absolve in all reserved cases, and the people were to be reminded of 'the approved teaching of the Holy Fathers, that sickness and premature death often come from sin, and that by the healing of souls this kind of sickness is known to cease.'

At the same time the superiors of all convents were authorized to appoint two or three suitable priests to hear the nuns' confessions in case of the sudden death of their authorized chaplain. By Christmastide the plague was in the county of Southampton. On 19 January, $1348-9$, the bishop announced that the pope, in response to his request, had granted to all those of his diocese, religious or secular, ecclesiastics or laymen, who should confess their sins with true repentance to any priest of their choice, a plenary indulgence at the hour of death if they departed in the true faith. The indulgence was to last till Easter, but, as the plague did not abate, the bishop announced that the pope had granted its extension till Michaelmas.

The deaths in January in the city of Winchester were so numerous that great difficulty arose as to burials. The clergy were anxious to restrict the interments within consecrated churchyards, but to this some of the citizens objected (probably with a wise regard for sanitation), and to enforce their objections a party of unruly townsfolk set upon and wounded a monk of St. Swithun's who was engaged in the burial rites in the central churchyard of the city. The bishop promptly excommunicated those engaged in the affray, and ordered the prior of Winchester and the abbot of Hyde to have sermons preached on the doctrine of the resurrection of the body, evidently fearing that the grievous times might bring about some open repudiation of the Church's faith, as had already been the case in certain continental towns. At the same time the bishop gave special facilities for the enlarging of graveyards and the dedication of new ones, so 'that the people of the various parishes may have every opportunity for speedy burial.'

In this diocese, as elsewhere, an examination of the institutions in the episcopal registers at this dread season tends to show that the statements of the chroniclers as to the terrible death-roll in England are not one whit exaggerated. In Hampshire, including the Isle of Wight, the average annual number of appointments to benefices recorded in the act books for twelve years prior to the pestilence was twenty; but in the fateful year of 1340 this number was increased more than tenfold, the institutions that were registered mounting up to 228 . Judging from the institutions, the plague came into the diocese from Wiltshire as well as from the seaboard, for it was on the western side of the county that several vacant livings had to be filled up in the month of February. The deanery of Basing, in the north of Hampshire, suffered most severely; by far the greater part of the benefices falling vacant in March and April. The southern coast of the county round Portsmouth, Hayling and the Isle of Wight suffered chiefly in the same months. In this dire distress the bishop did not hesitate to collate speedily to livings not in his own gift, in order to save time in providing for II 


\section{A HISTORY OF HAMPSHIRE}

spiritual necessities. The bishop specifically alleged this as the reason for his appointing on I 4 January, 1 349, to the vicarage of Wandsworth, which was appropriated to the abbey of Westminster.

In short, almost every catholic usage and canonical rule had to be set aside owing to the stress of circumstances. This was specially the case with regard to ordinations. The 2uatuor Tempora of the Ember seasons had to be quite disregarded. Bishop Edendon held six large ordinations in 1349 , and the like number in 1350 . In addition there were many quasi-private ordinations of one or two candidates without any papal or other dispensation, as well as numerous instances of cumulative ordinations on the same day. Thus on 5 March, I 349, a single candidate was ordained from first tonsure to the priesthood per saltum; on 6 March four were admitted to the first tonsure, and two were ordained sub-deacons; on Io March a sub-deacon was ordained deacon and priest, and the same was repeated for another candidate on 20 March.

The numbers at the usual ordinations leapt up after an astonishing fashion. The following are the figures that Bishop Edendon's registers supply for his March ordinations in I 347, I 348 and I 349 , and they may serve as a sample of the contrasts:-

\begin{tabular}{|c|c|c|c|c|c|c|c|}
\hline & Year & & Acolytes & Sub-deacons & Deacons & Priests & Total \\
\hline March, & 1347 & . & 8 & 17 & 14 & 18 & 57 \\
\hline$"$ & 1348 & . & 9 & 22 & 22 & 22 & 75 \\
\hline$"$ & 1349 & . & $4^{8}$ & 62 & 25 & 23 & 158 \\
\hline
\end{tabular}

With regard to the religious houses of Hampshire much may be gleaned from the episcopal registers as to the effect of the great pestilence. In the city of Winchester the prior of St. Swithun's and the abbess of St. Mary's both died, and it is safe to assume that the deathrate in these communities would be very large. Up to I 349 the average number of the monks of the cathedral church of St. Swithun was sixty; after the great pestilence until the dissolution the average was about thirty-five. The monks of the neighbouring abbey of Hyde were reduced by the same cause from about thirty-five to twenty. The financial distress of the nuns of St. Mary's Abbey not only reduced their numbers by half, but threatened the destruction of the convent. Bishop Edendon came so generously to their rescue that they described him as their second founder. The appointed rents of their slender endowments remained unpaid or were considerably diminished through the dearth of tenants owing to this unheard-of and unwonted pestilence. ${ }^{\mathrm{I}}$ The bishop rendered like assistance to the nuns of Romsey in July, I 35 I, saving them also from collapse. ${ }^{2}$ At the election in the year 1333 of the abbess of Romsey (who fell a victim to the plague in May, I 349) there were ninety nuns present to record their votes, but from the date

\footnotetext{
1 Insolita et inaudisa pestilentia, Close, 28 Edw. III. m. 3.

2 Ibid. m. 6.
} 


\section{ECCLESIASTICAL HISTORY}

of the pestilence up to the suppression their numbers never rose above twenty-five.

The friars, who lived in the main on the alms of the faithful, were materially affected by this staggering blow, and nowhere more so than in Hampshire. Between September, 1 346, and June, 1 348, the Austin friars of Winchester had presented four of their number for ordination to the priesthood ; from that date until Bishop Edendon's death in I 366 only two more were ordained, both of them in 1358 . For the two Franciscan houses of Winchester and Southampton three priests were ordained in 1347 and 1348 , but only two more received orders during Edendon's episcopate, both of those in I359. It was the same with both the other orders of friars. The Dominican house at Winchester could only find a single subject to present to the bishop for ordination in the ten years following the plague. The Carmelites of the same city presented eleven of their number to Bishop Edendon from I 346 to I 348 , but there were only three more Carmelites ordained during the remainder of his episcopate.

Bishop Edendon in January, I 353, appointed commissioners to inquire into the condition of things in the monastery of St. Swithun and the priory of Christchurch, both houses having become involved in debt and lax in fulfilment of their obligations as the result of the grievous pestilence. ${ }^{1}$

Although in Hampshire, as elsewhere, the majority of the clergy, both secular and religious, doubtless distinguished themselves by devotion to their duties, as seems proved by the special severity of their deathrate, still there were those who, in their alarm for their own persons, fled from their cures. In April, I 350, when the scourge had abated, the bishop issued a general admonition to his clergy as to residence in their parishes. Reports, he says, had reached him of some priests shamefully absenting themselves from their cures to the danger of many souls, so that even the holy sacrifice for which the churches had been built and adorned had not been celebrated. He complained further that in some cases the churches had been left to birds and beasts and were becoming ruinous, and ordered all absentees to return within a month. ${ }^{2}$

In July of the same year the bishop issued a joint letter of the archbishop and bishops of the southern province ordering priests to serve the churches at their previous stipends, and that no parish church must have more than one chaplain so long as any remain unserved. ${ }^{3}$

The Close and Patent Rolls afford abundant and painful testimony to the exceptional extent of the suffering through the Black Death in Hampshire among other than clerical communities, especially round

1 Winton. Epis. Reg., Edingdon, ii. ff. $27,28$.

2 Ibid. ii. f. 22 b.

3 Ibid. f. 23 b. The numerous plague entries in Bishop Edendon's registers are quoted fully and after a most interesting fashion in Abbot Gasquet's The Great Pestilence (1898). Though the original registers have been consulted, we desire to express our great indebtedness to that work. In the tables of institutions in the notes to pp. 112,113 'Hants' has been substituted for 'Surrey,' and vice versa. Edendon set a good example to his clergy during those fearsome times. He held his ordinations during the period of the visitation up and down the diocese, two of them (Waltham and Highclere) being in Hampshire. 


\section{A HISTORY OF HAMPSHIRE}

Southampton, Portsmouth and the Isle of Wight. From the extant documents of both Church and State it is safe to assert that half the population of England was swept away by the plague within a twelvemonth. In parts of Hampshire there seems no doubt that the death-rate was still more awful. Of Hayling Island it was definitely shown that 'the greatest part of the population died whilst the plague was raging."

In 135 I an important step was taken in defence of the rights of the Church of England against papal encroachment by the passing of the first Statute of Provisors, which made the obtaining of a benefice by reservation or provision from the pope, in derogation of the rights of the true patron, an offence punishable by fine or imprisonment. Edendon, as the king's treasurer, gave this statute his hearty support, and his diocese reaped therefrom much benefit. When Islip, Archbishop of Canterbury, died in 1362 , Edendon was offered but declined the primacy. Four years later he died.

This is not the place for an attempt at an outline life of that distinguished prelate, William of Wykeham. ${ }^{2}$ Our reference to him is confined to his action as diocesan and in connection with the county, and has no concern with his important secular offices or influence in national affairs. It is however of initial interest to remember that he belonged to Hampshire, having been born in 1324 at Wickham, a small village between Bishop's Waltham and Fareham. About I 347 he passed into the king's service, and though not even in minor orders-in accordance with the grave abuses of the times-he was appointed a royal chaplain, and presented in 1349 to the rectory of Linstead, Suffolk. His business capacities led to his being appointed surveyor for the works at Windsor, and eventually of other royal castles at Leeds, Dover and Hadleigh. In 1360 , Wykeham became keeper of the privy seal and secretary to the king, and though he received an extra allowance of a pound a day on account of his great labours and expenses, it was thought fit to continue to reward him lavishly with church benefices, so that he became the greatest pluralist of the age. Being already a rector twice over, a prebendary and a dean, Wykeham was offered and accepted from the king no fewer than thirteen more prebends during $1361-2$, the plague of that date having caused many vacancies. At last he took orders, being ordained acolyte in December, $136 \mathrm{I}$, and priest in the following June.

When the see of Winchester became vacant in October, 1366 , the king found no difficulty in persuading the chapter of St. Swithun's to elect Wykeham. The pope for some time withheld his consent, so that his consecration did not take place till October, I 367 , and it was July, 1368 , before he was enthroned at Winchester. From that time until his death in 1404 Wykeham resided in his diocese almost continuously,

1 Originalia Rolls, 29 Edw. III. m. 8.

2 This can best be gleaned from the two volumes of Wykebam's Registers (Hants Record Society, 1896, 1899), edited, with introductions, by Mr. T. F. Kirby, F.S.A., in connection with Rev. G. H. Moberly's Life of William of Wykebam (1887), and Mr. Leach's History of Winchester College (1899). 


\section{ECCLESIASTICAL HISTORY}

tarrying in turn at his various Hampshire manors of Highclere, Marwell, Bishopstoke, Bishop's Sutton, Waltham and Wolvesey, but staying chiefly at Waltham during the latter part of his life. Waltham was his favourite Hampshire residence. ${ }^{1}$

Wykeham almost invariably conducted his diocesan ordinations until the last years of his life, when Henry Twillowe and John Britt, successive Bishops of Annadown (Ireland), and Thomas Merks, ex-Bishop of Carlisle, acted for him ; but even on these occasions the aged bishop was generally present. Earlier in his episcopate he had the assistance of suffragans, duly commissioned for a given period ; but their work was to be supplemental to his own. ${ }^{2}$ In February, 1382 , Wykeham commissioned Thomas, Bishop of Annadown, to act as his suffragan in the Isle of Wight and other exterior parts of his diocese ${ }^{3}$; and in March, I 386 , Simon, Bishop of Achonry, a Cistercian monk of Quarr Abbey, was commissioned to act as suffragan for the Isle of Wight and the deanery of Fordingbridge. ${ }^{4}$ This appointment was renewed in $\mathrm{I} 388$.

In the thirty-seven years of his episcopate, Wykeham ordained 1,334 acolytes, I, 382 sub-deacons, I, 360 deacons and I, 273 priests.

As a first proof of the unflagging zeal of his administration, the bishop immediately on his enthronement began the difficult and costly process of effecting a reformation in the fine foundation of the hospital of St. Cross, whose funds and property were being shamelessly plundered by a succession of masters, who denied his right to interfere. After six years' struggle Wykeham secured a complete victory by the final decision of the papal delegates.

In 1373 , in addition to visiting all the religious houses of his diocese, William of Wykeham cited all the secular clergy, beneficed and unbeneficed, to a visitation which was held in sequence in each rural deanery. He began with the deanery of Winchester, the clergy appearing before him in the cathedral church on the Thursday after the feast of the Holy Trinity. They were called upon to exhibit their letters of orders and their titles if beneficed. The rural dean had also to cite to the visitation six or four (according to its size) of the most trustworthy men of each parish to reply to interrogatories as to the due celebration of divine worship. At the same time notice was to be given for the children to be assembled for confirmation. ${ }^{5}$ In the following year the bishop sent a commission round the diocese, with powers to correct and reform the irregularities or abuses that had been detected during the visitation. This commission was wisely drawn exclusively from outside the diocese, and consisted of the Chancellor of Lichfield and three canons

1 Wykebam's Itinerary, Register, ii. 621-9.

2 Wykeham in his commissions to suffragans usually stated that he was much occupied with the affairs of the king and the kingdom, but this was evidently a form current in the diocese, and did not imply much absence even when chancellor. For instance, when Henry, Bishop of Annadown, was commissioned with this plea on 5 May, 1399, to act till November, Wykeham conducted his own ordinations during that period.

3 Winton. Epis. Reg., Wykeham, pt. i. f. $129 . \quad 4$ Ibid. pt. iii. ff. 222, 232. actualiter.

5 Ibid. pt. iil. f. 90 . The visitation is described as undertaken by the bishop personaliter et 


\section{A HISTORY OF HAMPSHIRE}

belonging respectively to the chapters of Sarum, Bangor and Lincoln. ${ }^{1}$ Like visitations were held in $13^{80}$ and ${ }_{1} 387$.

Wykeham did his best, after his consecration, to check the abuses of the day in connection with preferment, but he was powerless to prevent the appointment to benefices of those in minor orders. There are various entries in his registers excusing residence for the definite purpose of further instruction, and these licenses are of a more precise kind than thase to be found in some episcopal registers of the period.

In $13^{8} \mathrm{I}$ William Wichot, rector of the church of St. Peterwithout-Southgate, Winchester, was instituted to the church of Newnham on the presentation of the king; but he had to take his oath to the bishop that he would regularly attend a grammar school at the hours of reading and study, that he would use all diligence in acquiring enough grammar for his station and as much plain song as possible, and that during the interval of four years till priest's orders he would provide a sufficient chaplain to serve the church of Newnham, under the penalty of 100 s. a year for each year if he should make default. ${ }^{2}$

The bishop was constantly on the watch to insist on the residence of all who could not claim or had not obtained due leave of absence. In January, 1368, he required his archdeacons to cause three proclamations to be made on Sundays and festivals in the churches of the absentee clergy, ordering residence within two months. ${ }^{3}$ In November, I 379, a mandate was directed to the official of the archdeaconry of Winchester to admonish certain Hampshire beneficed absentees, whose names were annexed in a schedule, for continued absence notwithstanding previous warnings, the result being that divine worship was much lessened, hospitality was not exercised, the devotion of the people ceased, and church and parsonage fell into decay." On I March, 1400 , another mandate was issued to the non-resident clergy of Hampshire through the archdeacon. ${ }^{\circ}$ In November, 1403 , abuses of this description were more limited in the county, and the bishop contented himself with directing the rural dean of Droxford (who was at that time rector of Warnford) to admonish the vicars of Hambledon and Eastmeon to return into residence. ${ }^{6}$

Whatever may be the truth with regard to the early tripartite division of tithes in English dioceses, insistence on the duty of hospitality and care for the poor as a chief part of the obligations resting on the beneficed clergy is continually set forth by the mediæval bishops. This comes out with much emphasis in Wykeham's official instruments. When the bishop granted John Edendon, archdeacon of Surrey and rector of the Hampshire living of Ringwood and the Surrey living of Farnham, leave of absence for three years to go across the seas, he was not only ordered to find suitable priests for the spiritual needs of the two parishes, but it was expressly stipulated that the incomes of both benefices

\footnotetext{
1 Winton. Epis. Reg., Wykeham, f. II 2.

2 Ibid. pt. i. f. 118.

8 Ibid. pt. iii. f. 6.

- Ibid. pt. iil. f. $18 \mathrm{Ib}$. These defaulters are described as per nonnulla tempora se absentarunt per diversas mundi partes miserabiliter evagando.

6 Ib1d. pt. iii. f. $319 .{ }^{6}$ Ibid. pt. iii. f. 36 Ib.
} 


\section{ECCLESIASTICAL HISTORY}

were to be taxed according to the bishop's judgment for largess for the poor parishioners. ${ }^{1}$

Exchanges of benefices are a usual feature of mediæval registers, but they were remarkably frequent in Winchester diocese during the episcopate of Wykeham, particularly in Hampshire. One out of every five of his institutions in that archdeaconry was of the nature of an exchange. It has been conjectured that these changes were chiefly owing to a spirit of unrest that was then abroad and the absence of local ties among a celibate clergy. But such reasons would equally affect other dioceses and other periods, and we are inclined to think that $\mathrm{Mr}$. Moberly is right in attributing the chief cause to the bishop's great interest in his diocese, which led him to believe that five or six years in the same cure was sufficiently long for the average parochial priest. ${ }^{2}$ There are in Hampshire instances where the same church changed hands seven and even eight times during Wykeham's episcopate of thirty-seven years.

None of the superiors of the various religious houses of Hampshire (save the Premonstratensian abbot of Titchfield, who was exempt from ordinary episcopal or diocesan control, and the alien priories) could be appointed without the house having first obtained a congé d'élire from the bishop, and the formal submission of the superior elect to episcopal benediction. Such matters received special attention from Bishop Wykeham, and are set forth with much detail in his registers. Even the abbots of the Cistercian order, though exempt from diocesan visitation, made a qualified submission to the bishop on appointment and received his benediction.

On Sunday in Passion week, I 4 March, I 372 , brother Henry Inglesham, abbot-elect of the Cistercian house of Netley, made the vow of canonical obedience to William of Wykeham in the chapel of Waltham. The bishop, after mass, bestowed his episcopal benediction on Inglesham, giving him a book of the rule of St. Benedict, and placing a crosier in his hand. The abbot at the same time read out publicly his vow of obedience to the bishop and his successors, "salvo ordine meo,' affixing his signature and signing it with the sign of the cross. The forms of the petition from the monastery to the bishop for leave to elect, and the presentation of the abbot-elect to the bishop, are appended to the account of the ceremony of the benediction of Abbot Inglesham. ${ }^{3}$

On Saturday, 20 October, I 375, before Master John de Bukyngham,

1 Winton. Epis. Reg., Wykeham, pt. iii. f. 6. It would seem that the rule in all cases of licensed non-residence was for the bishop to assign some portion of the income to the poor, but that it depended much on the zeal or laxity of the particular bishop. According to Archbishop Peckham's Constitutions of 1279 , the share for the poor was to be pinguis portio, the exact amount of which was to be determined by four trustworthy parishioners. Wilkin's Concilia, ii. 33 ; Lyndwood, p. I 33.

2 Moberly's Life of Wykeham, p. 246. Of course, now and again, the exchange was made from self-interested motives. In Archbishop Courtney's denunciation of various abuses among the clergy, as to non-residence, etc., special mention is made of what he terms 'Choppe churches.' His injunction of 5 March, 1392, is copied into Wykeham's Registers, pt. iii. f. 254.

${ }^{3}$ Winton. Epis. Reg., Wykeham, pt. iii. f. 38. 


\section{A HISTORY OF HAMPSHIRE}

canon of York, the bishop's commissary, seated on the tribunal in the chapel of the parish church of Farnham at the hour when judges are wont to sit, came Sister Cecilia de Lavyngtone, abbess-elect of Wherwell, praying confirmation, which, on production of evidence of the election, was granted. On the following day the abbess presented herself at the episcopal chapel of Farnham, and having made and duly signed her vow of canonical obedience received the bishop's benediction immediately after the reading of the gospel during mass. The bishop afterwards directed letters of confirmation to the new abbess, letters enjoining obedience to the convent, letters to the archdeacon of Winchester to instal her, and letters to the king for restitution of the temporalities. ${ }^{1}$

Wykeham was rightly very stern in maintaining the sanctuary privileges of the Church which so materially alleviated the severity of the mediaval criminal law. One of the most curious cases recorded in his register refers to an incident in connection with the parish church of Overton. On a Sunday evening about Michaelmas, I 390, one John Bentley was attending evensong. He was known to be a stranger, and from his excitement was judged to be there for sanctuary purposes. He was asked if he was a thief or a robber, and he replied that he was neither, but had had the misfortune to kill a man. Bentley then went out into the churchyard, and whilst there was hailed by one, Robert Dingle, who was standing by the open south gate. Whilst speaking to Dingle, a shoemaker of Overton suddenly pushed him from behind out of the churchyard into the highway. Bentley struggled to re-enter, but some of the villagers dragged him away, put him in the stocks, and afterwards took him to Winchester gaol. The case was reported to the bishop, who issued a commission to his official, in conjunction with the prior of St. Swithun's and the abbot of Hyde, to punish the offenders and compel them to replace Bentley in sanctuary. At the same time the bishop petitioned the king for Bentley's discharge from gaol. The outcome of this case is not to be gathered from the register, but judging from a somewhat similar case in the diocese four years later the penance would be a severe one. The offenders in the Streatham case had to endure the following penance on three successive Sundays. They walked in the procession stripped to their shirts and drawers and carrying lighted tapers. One of the clergy, clad in a surplice, following and flagellating them with a rod, declared to the people at the same time the cause of the penance, after which the penitents knelt in the middle of the church at high mass, repeating the Magnificat in audible voices and praying forgiveness. The authorities of a church when sanctuary was claimed were expected to provide the offender with necessary food. In a case where this was neglected in I 377 , Wykeham did not hesitate to excommunicate those responsible for this grave breach of sanctuary law. ${ }^{2}$

1 Winton. Epis. Reg., Wykeham, pt. iii. f. 66.

2 Any one who had committed a felony and for the safeguard of his life fled to a church or churchyard could remain there in security from arrest for forty days. If within that period he confessed the felony before the coroner of the district and took an oath of perpetual exile into some foreign country, he could claim safe conduct to the port that was assigned to him, provided he kept to the highway and 


\section{ECCLESIASTICAL HISTORY}

The question of alien priories (which will receive further attention under the respective houses) somewhat particularly affected Hampshire, as the number of cells or small priories owing allegiance to foreign mother-houses was considerable in this county. Their revenues had from time to time been seized in the reigns of John, and Edward I. Edward III., during the long struggle with France, continually appointed to churches in their gift until the peace of $136 \mathrm{I}$. Although the complete suppression of these houses was not accomplished until the days of Wykeham's successor in I 4I 5 , nevertheless the matter was much agitated during this episcopacy. There can be no doubt which way Wykeham's strong national sympathies would run. In 9 March, I 370, the bishop directed a mandate to his archdeacons, asking for a return by Easter of the number of aliens, secular and religious, beneficed in their archdeaconries, with their names and the annual value of their benefices. ${ }^{1}$ A like mandate was issued in February, 1385 . The return to this latter mandate gave the following :-

Priory of Carisbrook: Thomas de Val Osoul, a monk of Lire, prior : 130 marks.

Priory of Apuldercombe : Peter de Mouster, a monk of St. Mary de Montebourg, Normandy, prior: $€ 45$.

Priory of Andover : Denys Chanon, a monk of St. Florent, Anjou, prior : 80 marks.

Church of Combe : Prior of Okeborne, an alien monk, rector : $£$ io.

Priory of West Shirborne : Inguerand de Dinno, a monk of St. Vigor's, diocese of Bayeux, prior: $£_{2}^{2} 33^{\text {s. }} 3^{d}$.

Priory of Andwell: In the hands of Thomas Driffelde and Elienora his wife: 20 marks.

Priory of Hayling : John de Ousqueto, a monk of Jumièges, Normandy, prior : $£$ 1 $100^{2}$

A writ for a return of all presentations to alien priories recorded in extant episcopal registers was issued in $140 \mathrm{I}$. The return from Winchester begins with Pontoise's registers, and records the presentation and institution during a little more than a century of the following priors of the alien houses of Hampshire : Andover, seven; Carisbrook, seven; Ellingham, five ; and Hamble, five. ${ }^{3}$

Though of a gentle disposition, Wykeham felt bound to join in the movement against the extravagances of Wycliffe and his followers. On 2 I May, 1382, the bishop directed his mandate to the vicar of Odiham and to all the chaplains ministering in the parish church or any of its chapels, inhibiting Nicholas Hereford, John Ashton, Robert Alynton, Lawrence Bedeman of Cornwall and others their accomplices and followers from preaching or teaching in the church of Odiham or elsewhere in the diocese, under pain of excommunication." Wykeham had been one of the ten bishops present at the council held at Blackfriars, London, only three days before (I 8 May), when, amidst an earthquake, considered ominous both by the Lollards and their opponents, ten of Wycliffe's

did not stop two nights in one place. On arrival at the port he was to seek diligently for passage, and if he could not obtain it he was to go daily into the sea up to his knees as though essaying to pass over. If within forty days he could not get passage he was then again to place himself in sanctuary in the nearest church. See Sanctuaries, by T. J. de Mazzinghi (1 887).

1 Winton. Epis. Reg., Wykeham, pt. iii. f. 32 a.

2 Ibid. pt. iii. f. $213 . \quad{ }^{3}$ Ibid. pt. iv. pp. 39, 40. 4 Ibid. pt. iii. f. 194 b. 


\section{A HISTORY OF HAMPSHIRE}

statements were pronounced heretical and fourteen more erroneous. The announcement of the formal condemnation of these views, with the threat of excommunication against any one teaching them or permitting them to be taught, was not drawn up by the archbishop and issued to the province until 30 May, so that Wykeham's action on 2i May showed great determination and vigour on his part. In his mandate to the vicar of Odiham the bishop stated that it was a matter of common notoriety that those named had been recently preaching in his church, so that it is evident that that corner of Hampshire had been selected by the Wycliffite leaders for some special effort. Hereford, Ashton and Bedeman were the Oxford leaders of the movement, and next in importance to Wycliffe himself; Hereford had preached before the university on I 6 May. Notwithstanding the patronage of the Chancellor of Oxford, the archbishop and bishops were strong enough to secure the suspension of Hereford, Ashton and Repingdon (who is not mentioned here), and their eventual condemnation as heretics by the end of June. ${ }^{1}$ They all recanted ; Repingdon became Bishop of Lincoln and a cardinal, and Hereford died a Carthusian monk. Bedeman gave way directly he was suspended, being formally restored to his functions in the following October, and ended his days as a Devonshire rector. ${ }^{2}$ If Robert Alynton is the same, which is probably the case, as Robert Alyngton of Queen's College, who was Chancellor of Oxford in I 394, he afterwards became a writer against Wycliffe. ${ }^{3}$

The mandate against John, vicar of Odiham, is followed in Wykeham's register by the entry in full, under date of 30 May, of the twenty-four doctrines condemned by the Blackfriars' synod and by the archbishop's circular denouncing excommunication against Hereford and Repingdon." Wykeham's conscientious determination of judgment is shown by his decision with regard to Bedeman, dated at Southwark, 22 October, 1382 , when he formally dismissed the charges of heresy. The bishop frankly admits that he had vehemently suspected Lawrence Bedeman, alias Stephen, of preaching in his diocese various heretical and erroneous doctrines contrary to the decision of the Church; but that when summoned before him and certain doctors of law and divinity as assessors, they found him a true Catholic. Bedeman swore that he had never held, taught, or preached the errors with which he was charged, wherefore the court granted him full absolution and discharge. ${ }^{6}$

The elaborate and carefully kept registers of Wykeham afford much information on the subject of special prayers. The parish priest of England of those days was frequently called upon by his diocesan to use spiritual intercession for the affairs of state. The bishop took action in three ways: most frequently he received a privy seal from the Crown directing his conduct; occasionally the order reached him from

1 Walden's Fasciculi Zizaniorum, pp. 273-5, 309-I 1.

2 Fox the martyrologist blunders in naming Bedeman as one who 'suffered a most cruel death.' Bedeman's name seems really to have been Stevine (Boase's Reg. of Exiter Coll. p. 17, ed. 1894).

3 Wood's Fasti, p. 34 ; Bale, cent. i. 519.

4 Winton. Epis. Reg., Wykeham, iii. ff. 196, 197.

b Ibid. 198b. 


\section{ECCLESIASTICAL HISTORY}

the archbishop, coming through the Bishop of London as dean of the province; and thirdly, the bishop had power to enjoin such prayers ipso motu on his own clergy.

The first instance in Wykeham's episcopate was the issuing of his own mandate on 20 September, ${ }_{3} 68$, for prayer for the soul of Blanche, Duchess of Lancaster. The mandate begins with a phrase from the Apocrypha that 'it was an holy and good thought to pray for the dead." In December of the same year a privy seal was issued for prayers for the soul of Lionel, Duke of Clarence. Queen Philippa died at Windsor on 15 August, 1369 , and Wykeham (without waiting for any orders) issued on the following day his mandate to the two archdeacons and to the prior of Winchester for solemn masses for her soul on the day of her burial and on the following day. The mandate is couched in terms of the greatest grief at her loss and of the most tender affection for his queen, of whom he writes with profound esteem, particularly for her humility and her personal devotion to the poor. In February, I 393, Wykeham, at the request of Archbishop Courtenay, ordered prayers for the soul of the Countess of Devon, the archbishop's mother. On 22 June, 1394 , the bishop ordered prayers for the soul of Queen Anne of Bohemia, reciting the privy seal of I 3 June to that effect, but giving utterance to no opinion of his own with regard to the first wife of Richard II.

The defeat and disaster which the English experienced between I 370 and 1375 in the French wars caused the issue of many commands for masses, litanies and other devout prayers for peace, and in favour of particular expeditions of the king and his sons. Six of these were issued in Winchester diocese. The most noteworthy was that sent forth by Wykeham on 30 May, I 375, "at a time of shame and suffering such as England had never known. ${ }^{2}$ The bishop recited the king's writ, but went at length into the matter, making special reference to the defeat off Rochelle, and to the nation's need of a spirit of humility and devotion. Solemn processions were ordered for Wednesdays and Fridays.

In connection with the accession of Richard II. special prayers were asked for his guidance and protection by writ of I July, I 377, and the Bishop of Winchester's mandate for the same was dated 6 July. On I 2 April, I 380 , prayers were ordered on Wednesdays and Fridays in connection with the king's expedition to France. When Richard II.'s queen came from Bohemia in January, $\mathrm{I}_{3} 82$, no sooner had she set foot on our shores than a fearful storm arose, and her ship, with many others, was dashed to pieces in the harbour.

From that time onward for some months the weather was most tempestuous, and the plague broke out. On 30 May the archbishop enjoined prayers on the whole province for fair weather, peace and preservation from pestilence. Three special collects were issued for use at mass, which are transcribed in Wykeham's register. When the king 


\section{A HISTORY OF HAMPSHIRE}

planned an expedition into Scotland in July, 1385 , the archbishop enjoined the use, on Wednesdays and Fridays, of special masses, sermons and litanies, which were duly ordered for the churches of Hampshire and Surrey.

The king's uncle, Thomas Duke of Gloucester, prepared an ill-fated expedition in the autumn of $\mathrm{I} 39 \mathrm{I}$, and Wykeham issued a mandate, dated 20 November, for prayers on his behalf, ad partes externas et remotas contra inimicos Christi pugnaturus ob devocionem pergrandem.

In August, I 39I, the bishop enjoined prayers on behalf of the king's coming expedition into Ireland, and in the following October a writ was issued by Edmund, Duke of York, as custos Anglia, for the king's success, which was circulated in Hampshire and Surrey on I I November.

In 1399 came the revolution that resulted in the deposition of Richard II. The course of prayers enjoined this year throughout Hampshire must have somewhat bewildered the simpler country folk. Richard was in Ireland, and on 4 July Henry of Lancaster landed at Ravenspur, Yorkshire, and was at once joined by the Earls of Northumberland and Westmorland. When the news of this serious outbreak reached William of Wykeham, then at Farnham Castle, he issued mandates to his archdeacons and to the prior of Winchester, dated I 9 July, for prayers (with forty days of indulgence) for the preservation of the king and his kingdom in safety, prosperity and tranquillity. Thousands, doubtless, of the good folk of Hampshire followed the guidance of the now aged prelate who had lived amongst them, universally respected, for so many years. Richard returned from Ireland, only to be imprisoned in the Tower, and formally deposed by parliament on $3 \circ$ September. ${ }^{1}$ Archbishop Arundel's mandate for prayers for Henry IV. was issued from Lambeth in October, couched in most extravagant language, and was duly entered in Wykeham's registers. It is, however, possible that the bishop issued no mandate for its promulgation. On 30 September Bishop Merks of Carlisle is said to have been the only one of sufficient faith and spirit to defend Richard and to deny the right of parliament either to depose him or to pass by the next prince of the blood, with the result of his deprivation and temporary imprisonment. The appointment shortly afterwards of Bishop Merks as suffragan of Winchester is significant.

The story of the founding and building of Winchester College by Wykeham will be told elsewhere, as well as the rebuilding of the Norman nave of St. Swithun's.

It only here remains to note that his extraordinary liberality brightened the worship of the churches throughout Hampshire. Irrespective of the numerous bequests of that character in his will, he gave during his lifetime one hundred and thirteen chalices and a hundred sets of vestments to the parish churches of his diocese and repaired a large

1 Moberly (Wykebam, p. 257) is mistaken in saying that Wykeham attended the parliament that deposed Richard; he was conspicuous by his absence. 


\section{ECCLESIASTICAL HISTORY}

number of the fabrics. As to charity, almost his first act as bishop was the excusing of his poorer manorial tenants of their customary payments to the amount of $£ 500$, while open house was kept for the poor throughout his long episcopate. His will was characteristic of his large-heartedness, for by it great minsters and humble village churches, collegiate foundations and mendicant orders, noble friends and household retainers, high-placed officials and poor prisoners alike profited.

At the end of Wykeham's episcopate, when his strength was failing, Bishop Merks, who was deprived of the see of Carlisle in I 400 , acted as suffragan. He died in 1409 . From 1407 to 1417 William, Bishop of Selymbria, was suffragan of Winchester, during most of which period he also acted as suffragan of Sarum. John, Bishop of Cyrene, was subsequently for a time responsible for Beaufort's episcopal duties. ${ }^{1}$

At the beginning of the fifteenth century the next to Archbishop Arundel in influence in the government of the country was Henry Beaufort, a child of John of Gaunt, born of his adultery with Catherine Swinford. The famed Lord Cardinal of Winchester became in rapid succession Dean of Wells (1 397), Bishop of Lincoln (1 398), Chancellor of England (1403), and, upon the death of Wykeham, Bishop of Winchester, though not yet thirty years of age. The kingdom saw far more of him than the diocese, and his long episcopate (1 404-47), a most sad contrast to that of Wykeham, requires here but brief notice. Consecrations and ordinations were for the most part discharged by suffragan bishops.

In 1407 Archbishop Arundel summoned a provincial council to meet at Oxford for the purpose of stemming the tide of Lollardism. Under that word were now comprehended not only a setting forth of strange doctrine, but a spirit of rampant revolution. This council met on 28 November, in the priory church of St. Frideswide, and agreed to a series of thirteen injunctions which were to be binding on all clerks within the province of Canterbury. These became at once known as the Constitutions of Arundel. It was thereby ordered, amongst other prohibitions, that no one was to preach in church or churchyard without the bishop's license; that no speculations on the subject of the sacraments or articles of faith were to be allowed; that no tract or treatise written by Wycliffe was to circulate in schools, halls or elsewhere, unless sanctioned by twelve doctors and masters appointed by each of the universities; and that the scriptures were not to be translated into English until an authorized version had been put forth by a provincial council. Oxford was at this time so permeated with freedom of thought that neither the time nor place were considered suitable for setting forth these decisions. Eventually they were promulgated in Convocation, when it met at St. Paul's on I 4 January, 1409. Copies were forwarded to the bishops to be made known throughout their dioceses in the following April. These Constitutions of Arundel are transcribed in full in Beaufort's register. ${ }^{2}$

1 Stubbs' Registr. Sacr. Anglic.

2 Winton. Epis. Reg., Beaufort, pp. 18-20. 


\section{A HISTORY OF HAMPSHIRE}

In the following year Sir John Oldcastle (Lord Cobham in right of his wife), as leader of the Lollards, introduced a bill into parliament for the confiscation to the nation of the Church's property, and identified himself with most of their extreme views. So long as Henry IV. lived he was under the king's special protection; but on the accession of his youthful successor, in 1413 , action was taken against him on mingled charges of heresy and treason. Sir John laughed excommunication to scorn, but was at last brought before Archbishop Arundel to answer for his own views, and charged besides with being the chief supporter and instigator of the Lollard preachers in the dioceses of London, Rochester and Hereford. With the archbishops were associated the Bishops of Winchester, London and Bangor. There was no choice for them but to condemn an offender, who during the trial warned the people that his judges were trying to lead them to hell. After sentence was pronounced and Sir John Oldcastle was handed over to the secular power, the archbishop pleaded for and obtained a respite of fifty days, during which time the condemned prisoner escaped from the Tower and raised a rebellion. His capture and execution did not occur until I 4 I 7 .

It has been more than once surmised or even alleged that Bishop Beaufort was averse to the sentence on Oldcastle, was almost compelled to acquiesce in it, and winked at his escape. But the evidence of his register is in direct contradiction to this idea. Under date of 23 October, $14 \mathrm{I} 3$, a mandate was issued to the diocese citing the judgment as one given by the authority of the archbishop and the Bishop of Winchester, and ordering the process against Sir John Oldcastle to be published in an intelligible voice by all curates in their churches throughout the city and diocese of Winchester when there was the largest congregation. In this mandate the constitutions of the council of Oxford contra detractores evangelicos are quoted.' If Cardinal Beaufort's sympathies had been in the other direction, it would have been comparatively simple for so powerful a prelate to have ignored any order for publication of the sentence in the diocese.

The chief mark that Beaufort afterwards made in his diocese was his refounding of the hospital of St. Cross on a more generous and extended basis. The end of his life was spent chiefly at Wolvesey, and was characterized by some notable acts of charity. Beaufort was doubtless a somewhat unscrupulous politician. The terrible character given him by Shakespeare is however drawn with far too dark a pencil. The dramatist represents his deathbed as one of black despair :-

\section{Lord Cardinal, if thou think'st on heaven's bliss, Hold up thy hand, make signal of thy hope- He dies, and makes no sign!}

This is contradicted by the thoughtful, considerate and pious tone of his will, to which he added a codicil with his own hand only two days before his death. In addition to bequests to the cathedral churches of sia Dei.

1 Winton. Epis. Reg., Beaufort, f. $44^{\mathrm{b}}$ : Mandatum contra Lollardos et seminatores zizaniorum in ecck- 


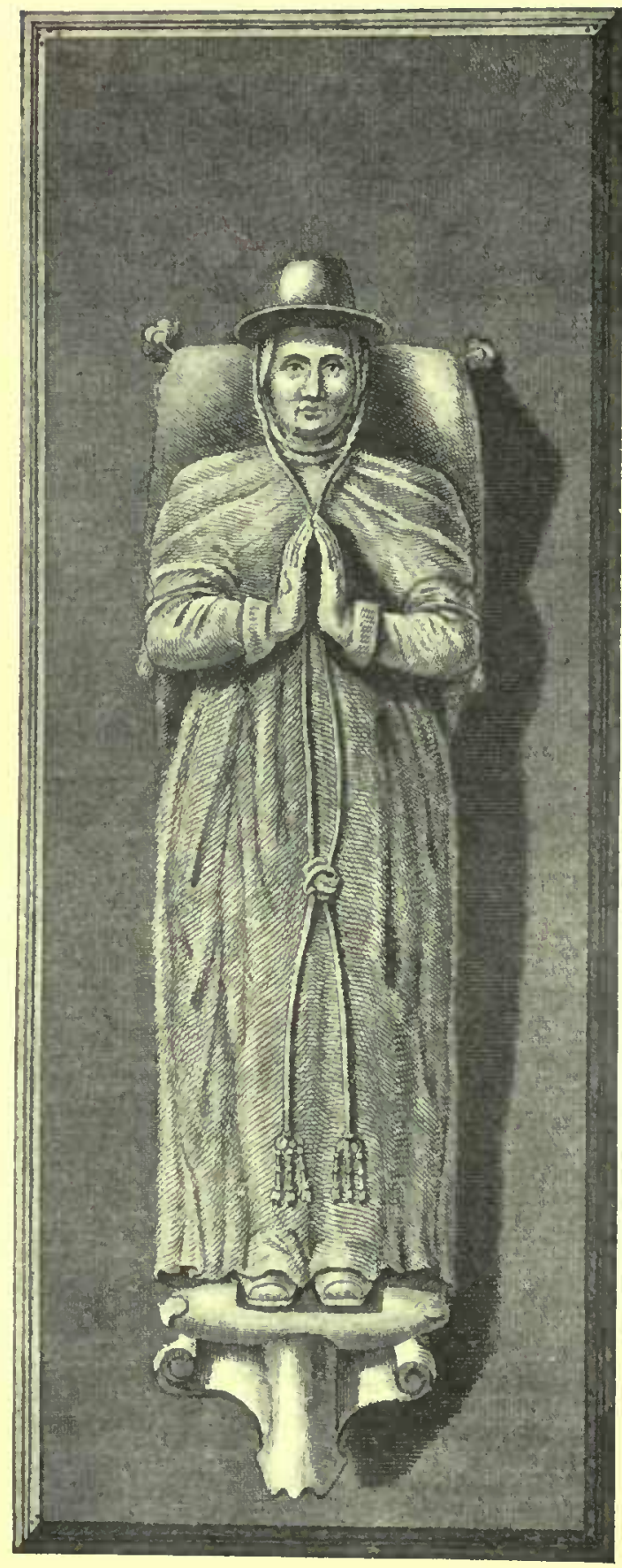

LfFigy ui Cintuinal, Bladugort.

(From ant oxt promt) 



\section{ECCLESIASTICAL HISTORY}

Winchester, Lincoln and Canterbury, he left $\oint_{0} 400$ to poor prisoners, 2,000 marks to his poor tenants (to be distributed by men of good conscience who were to be paid for their trouble), $\oint_{2}, 000$ to his servants, $f_{1} \circ 0$ and plate to his acknowledged daughter, Joan Stralkyng, and the residue to poor religious houses, to marriage portions for poor maidens, and for the general succour of the poor and needy.

To forty-three years of Beaufort's episcopate there followed forty years under his successor, Bishop William Waynflete (1447-87). Waynflete had been educated at Wykeham's colleges at Winchester and Oxford, and had been appointed headmaster of the former in 1479 . Afterwards he was successively master of St. Mary Magdalen's Hospital, Winchester, and headmaster and then provost of Eton. He was a staunch adherent of the House of Lancaster, but conducted himself so circumspectly as to win the favour of Edward IV.

Although, like his predecessor, Waynflete gave more time to the affairs of the State than to those of the Church, he held his own ordinations from time to time and personally visited the religious houses of his diocese. The canons of Selborne, who had been seriously rebuked by Wykeham and other of his predecessors for laxity, maintained their reputation for idleness; and after many vain remonstrances Waynflete at last secured, in I486, a papal bull conveying their revenues to the Oxford college of St. Mary Magdalen of which this bishop was the munificent founder. ${ }^{.}$It is most interesting to note that Waynflete placed his foundation of Magdalen College within his own diocese, wherein it still remains. The Bishop of Winchester is not only visitor but ordinary of the college.

It is much to the credit of Waynflete that he took active steps against non-residence and plurality. Several incumbents who failed to obey monitions or to answer citation were deprived. ${ }^{2}$

The custom of granting indulgences for various corporal works of mercy was considerably extended during this episcopate. They were granted in aid of one intending to make a pilgrimage to the Holy Land, for the relief of Sir Robert Molineux captured by the Saracens, for one whose goods were burnt, and for the repair of the important Hampshire bridges of Bedhampton and Stockbridge. ${ }^{3}$

In 1475, when Edward IV. made an important expedition into France, which resulted in the treaty of Pecquigny and the betrothal of his daughter Elizabeth to the dauphin, the bishop issued a mandate enjoining public prayers and litanies throughout his diocese for the good estate of the Church, for a happy issue to the king's expedition, for the tranquillity of the kingdom, for suitable weather, and for a blessing on the fruits of the earth and the flocks of the field."

1 Cbarters and Documents relative to Selborne Priory, 2 vols., 1891 and 1894 , by Rev. W. Dunn Macray, F.S.A., Hants Record Society.

2 Winton. Epis. Reg., Waynfiete, I., ff. 25b, 28, 90. 3 Ibid. passim.

4 Ibid. ii. 140 : Pro statu et fermitate ecclesie, prosp et felici expeditione Regis et tranquilitate Regni, aeris congrus temperie et serenitate, ac fructuum et pecorum ubertate increnten to et conservatione. 


\section{A HISTORY OF HAMPSHIRE}

After the battle of Bosworth Field, in 1485 , the aged bishop withdrew to his manor house at Waltham, where he ended his days on II August, 1486.

During the civil strife, the powerful family of Courtenay had been zealous against Richard III., and on the death of Waynflete, Henry VII. secured the bishopric of Winchester for Peter Courtenay (1487-92), who had been for nine years Bishop of Exeter.

His episcopate was uneventful, save for recrudescence of Lollardism. Richard Petefyne, alias Sawyer, of Woodhay, was charged with uttering heresy during the months of March, April, May, June and July, I 49I, against the sacraments of penance, matrimony, confirmation, extreme unction and orders, and for saying that no priest ought to have more than $2 d$. for the labour of saying mass. The bishop cited the witnesses to appear in the chapel of Fromond in the college of St. Mary, Winchester. Richard Sawyer thereupon confessed to having said that 'the blessed sacramente was but a pece of dowe bakyn and prentyd betwyxt Irones and that I cowde make $\mathrm{xxx}^{\text {ti }}$ of theym $\mathrm{w}^{\mathrm{t}}$ in a owyr if $\mathrm{I}$ hyd such prentyng Irones,' also to 'buying and conceilyng of Englyshe bokes,' and to various other charges. Eventually he solemnly abjured his errors and was absolved. ${ }^{1}$

Courtenay died in September, 1492, and was succeeded in the following year by Thomas Langton, who had been successively Bishop of St. David's and Sarum. He had been Provost of Queen's, Oxford, and was a thorough supporter of the new learning. Wood describes him as a Mæcenas of learning. He took a keen interest in the education of boys, and Winchester College has more occasion to remember him than the diocese at large. When Archbishop Morton died in 1500 , Thomas Langton was (on 22 January, 150I) elected as his successor in the primacy, but he died of the plague on 27 January, before his translation could be effected.

John Morton, the aged Archbishop of Canterbury, breathed his last on 12 October, I 500. His successor, Henry Dean, was not elected until 26 April, I 50r. During the vacancy, the prior of Christ Church, Canterbury, asserted his right to hold metropolitical visitations, and as Winchester was vacant at the same time, the assertion of such a right in that diocese was the less likely to meet with opposition. Master Thomas Hede, doctor of laws, was appointed to act as visitor by Prior Thomas of Canterbury.

All the Hampshire houses that were subject to episcopal visitation were taken in turn. Dr. Hede's first visit was paid to the cathedral church and priory of St. Swithun. The visitation began in the chapter house on 27 February, I 50 I, when the prior Thomas Sylkestede was first examined. He gave a good account of the order and discipline of his house, and stated that the statutory number of the monks was forty, and that their then number was thirty-five, there having been five recent deaths. His account was confirmed and elaborated by the 


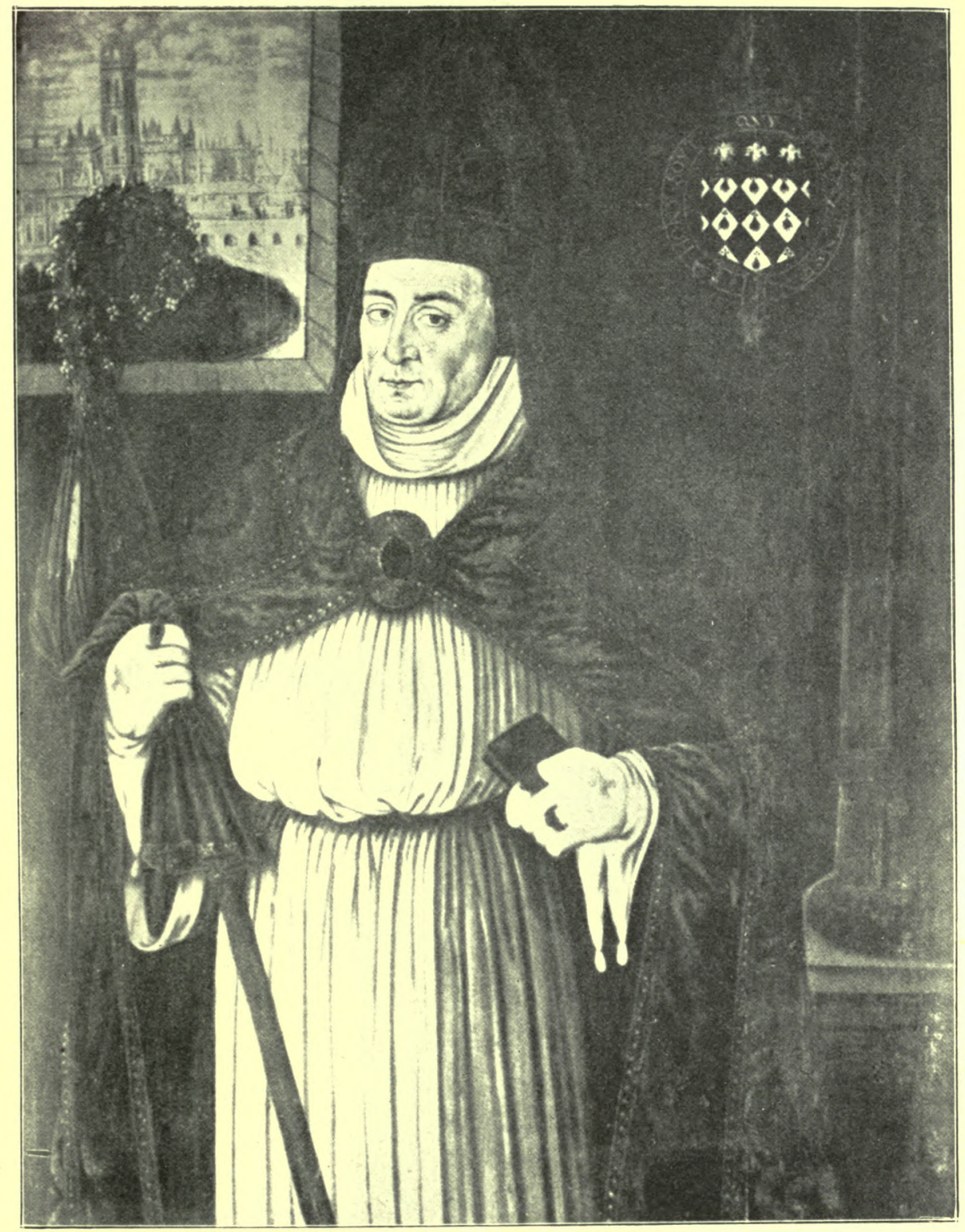

Bishop Waynflete. 



\section{ECCLESIASTICAL HISTORY}

sub-prior, and by various other officials such as the sacrist, treasurer, chamberlain, precentor, and almoner. Twenty-nine members of the convent underwent examination, and at the end, after some demur, Silkestede took an oath of canonical obedience to the prior and convent of Canterbury, during the vacancy of the archiepiscopal see.

On 2 March, the abbey of St. Mary, Winchester, was visited, when the abbess, Joan Legh, supported by the prioress, sacrist, precentrix, four cantrices, librarian, 'senior dogmatista,' and other of the nuns were able to give a good account of themselves. On the following day a visitation was held in the chapter house of the abbey of Hyde. Abbot Richard Hall put in his written replies to the visitation articles, on which they were afterwards examined. The replies of the different officials, such as prior, sub-prior, steward, and almoner, gave full satisfaction. Twentytwo members of the convent underwent this personal examination, of whom one was a deacon, two sub-deacons, one an acolyte, and three novices. Dr. Hede proceeded to the priory of Southwick on I 2 March, where a like full examination of the canons there was undertaken. On the $1^{\text {th }}$ he was at the priory of St. Denis, Southampton, where the examination of the canons proved equally satisfactory, the pawning of a piece of valuable silver called ' a spice plate' being assigned by the subprior to the fault of his predecessor.

The next visit was paid on $22 \mathrm{March}$, to the large and important priory of Christchurch. Prior John Draper and his colleagues were able to give satisfactory accounts of their house and its administration. Twenty members of this community underwent examination, of whom three were sub-deacons. On 24 March the priory of Breamore was visited. Five canons, in addition to John Chandler, of this comparatively small house gave evidence. On 27 March the large nunnery of Romsey was reached, and here the only scandal (a grievous one) of the whole visitation came to light and was suppressed. Everywhere else things appear to have been most creditably conducted; and we may be quite sure that a thorough visitation of this kind, undertaken by an outside and somewhat jealous authority, would have no reason, but the contrary, to gloss over faults. On $30 \mathrm{March}$ Dr. Hede proceeded to the priory of Mottisfont, when satisfactory statements were made by prior John Edmond and four of his colleagues. The nuns of Wherwell were visited on the following day. Nineteen nuns, in addition to Matilda Rouse the abbess, were questioned by the visitor, of whom six were novices. On 3 April the small priory of Wintney was visited, when Anna Thomas the prioress, and three of her sisters gave evidence.

In addition to these religious houses, the College of St. Elizabeth and the New College at Winchester were visited by Dr. Hede on the same occasion.

The expenses of this visitation are set forth with some detail. In the first place, Dr. Hede expended i $8 \mathrm{~s}$. ' for iij yards of brode cloth for a shorte gown for myself.' Three yards of lining for the same cost

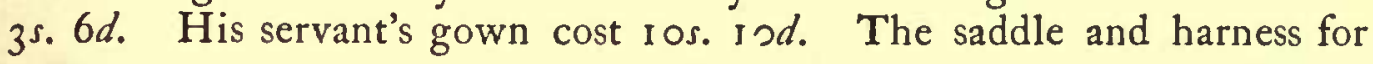




\section{A HISTORY OF HAMPSHIRE}

his own horse cost I2s., and the shoeing of his two horses before his journey to Winchester cost 16 pence. 'Mete and drynke for himself and servant, together with horse's mete" and other necessary expenses from London to Winchester, and tarrying there from 7 to I 2 February, and from thence homeward, is put down at $23 s .4 d$. This was Dr. Hede's expenditure when he went down to make preliminary preparations for the official visitation. Amongst the later entries may be mentioned: 'For fyre and candyll and brede and ale in my chamber in the Inne by cause I had no chamber in the Abbey of Saint Swithun's in the tyme of their visitation, ijs. vjd.'

Langton was followed by another much translated bishop. Richard Fox when a young man had done Henry VII. (as Earl of Richmond) many substantial services. On Courtenay's translation to Winchester in 1487, Fox succeeded him at Exeter; he was moved to Bath and Wells in 1492 and to Durham in 1494. The income of the bishopric of Winchester was at this time greater than that of Durham, and its nearness to London made it pleasanter for a confidential friend of the king, so Richard Fox came south and ruled over this diocese for nearly twentyeight years. When he had been Bishop of Winchester for nine years, Henry VIII. (whom he had baptized at his birth) came to the throne, but the bishop died before the upheavals that characterized the latter part of that reign. Fox was most staunchly orthodox, and had some sorry work to do with the heretics of his diocese. The burning of Thomas Denys in the midst of the market place of Kingston, on 5 March, $15^{12-3}$, is set forth with a great deal of circumstance and detail in his register. From the same source we learn that Thomas Watt and Anne his wife of Dogmersfield, and William Wikham and Alice his wife, and Robert Winter of Crondal, appeared before Bishop Fox in the parish church of Farnham on 30 September, 1 514 , on the charge of heresy, but having confessed and solemnly abjured their errors, penance was assigned them and they received absolution. ${ }^{2}$

Fox was most generous with his great income, but chiefly outside the diocese. He is remembered as the founder of Corpus Christi College, Oxford. For nearly the last ten years of his life the bishop was afflicted with blindness, and lived constantly at Wolvesey, but two or three years before this trial had begun the bishop had sickened of court life.

There is nothing more creditable to Fox than the latter part of his life, when he saw so clearly - in advance of his time-the inconsistency of attempting to serve zealously both State and Church. Both Wolsey and the king had great difficulty in keeping him to his seat at the council table. In a letter he wrote to Wolsey on 23 April, 1516 , he excused himself from coming to court, as he had the king's license to be

1 From transcripts of a Register Sede vacante at Canterbury, made by Mr. Leland L. Duncan, F.S.A.

Winton. Epis. Reg., Fox, iii. 69-76. It is not a little curious that the martyrdom of Denys and the whole of Bishop Fox's proceedings against heretics escaped Fox the martyrologist. A burning at Kingston-on-Thames would not fail to be notorious. 


\section{ECCLESIASTICAL HISTORY}

occupied in his cure, and to make satisfaction for twenty years of neglect. He feels sure that Wolsey would not have him serve the world to the damnation of his soul and other souls committed to him, and assures him that his absence is not to hunt nor hawk, nor even for quietness of mind, but to endeavour to do his duty to the flock committed to his charge. ${ }^{1}$

On 30 April, I 522, Fox wrote another touching letter to Wolsey on the same subject, saying that as an old priest of over seventy years of age he could no longer have anything to do with the war, that he had no little remorse of conscience as to the enormities of the war, that if he should live twenty years longer and do penance every day he could not make sufficient recompense for his share, that the king had licensed him to remain in his church, and that that was the least he could do, for he had been so negligent that of his four cathedral churches he had never even seen Exeter nor Wells. In the same letter he stated that he had much diocesan business on hand, both of correction and justice, and that he visited his cathedral and the monastery of Hyde once every fifteen days. ${ }^{2}$

The bishop seems to have found his diocese in a sadly neglected condition, for in a third letter to Wolsey, between the dates just cited, namely in January, $152 \mathrm{I}$, he writes with joy as to a projected scheme of Wolsey's for the reformation of the clergy, and says that he is endeavouring to do within his own small jurisdiction what the cardinal is proposing to effect throughout the two provinces. The bishop stated that he had given his whole mind to this subject for nearly three years, and had found the clergy, and particularly the monks, so corrupted by the license of the times, that he had almost despaired of effecting any perfect reformation. ${ }^{s}$

However, in January, 1528 , after a wider experience of his diocese, and after his careful visiting, he is able to write to his friend Wolsey from Winchester in a very different strain. He says that he had never had occasion to deprive any one in any of his dioceses, and that (except at Southwark, which is under the archdeacon's jurisdiction) there was as little known crime as within any diocese in the realm. In the same letter the interesting fact comes out that the various monasteries had been put to less cost during the twenty-six years of his episcopate than was usual, for during the whole of that period he had never taken procurations of them in all his visitations."

From I 520 the blind bishop, though frequently officiating in person, had the assistance, as suffragan, of William Barnett, Bishop of Kildare.

On the death of Fox, the see of Winchester was conferred on his friend Cardinal Wolsey, who held it in commendam from 6 April, I 529. Wolsey was merely nominal bishop. He never visited the cathedral

1 Letters and Papers, Henry VIII. (1515-16), No. 1814.

2 Cott. MSS. Faust, E. vii. I21. 3 Ibid. C. vii. 216.

4 Letrers and Papers, Henry VIII. (1 $526-8$ ), No. 3815 . 


\section{A HISTORY OF HAMPSHIRE}

church, and was installed by proxy. His fall was close at hand, and the beginning of his disgrace occasioned his residence for some months in Surrey. On I9 October, I529, he gave up the Great Seal, and retired by the king's orders to the episcopal manor house of Esher, suffering considerable privations and sickening with an attack of dropsy. He left Esher in the spring of 1530 , being ordered to withdraw to his northern diocese, and in November of the same year he died.

Just a year after the death of Wolsey, at the end of November, I 53 I, that shrewd and able statesman, Stephen Gardiner, for some time secretary to the cardinal, was consecrated to the see of Winchester. He was learned in civil and canon law, but owed his original advancement to the fact of being Cardinal Wolsey's private secretary. During his remarkable episcopate, the king's divorces and the general flux of the Reformation changes absorbed more of his talents and industry than the more prosaic affairs of diocesan administration. Nevertheless the diocese was by no means neglected, and we have the evidence of the Scotch scholar, Volusenus, that at the beginning of his episcopal career Gardiner was most assiduous in visiting and preaching throughout the parishes of Hampshire and Surrey. ${ }^{1}$ With the singular intermediate position that Gardiner took up on matters affecting the Reformation, and his remarkable treatise, De Vera Obedientia, repudiating Roman domination, we have here no concern; but mention should be made of his dispute with Cranmer as to a visitation of Winchester diocese, as this must have caused some considerable heartburning and no little bewilderment to many of the incumbents of Hampshire.

The archbishop insisted on his right to hold a provincial visitation, a course which had, perhaps naturally, been always unpopular with the suffragans of Canterbury, and which was peculiarly trying at this crisis. Irrespective of other reasons, the matter of fees made such a progress a heavy burden on all concerned, whilst materially enriching the archiepiscopal officials. Moreover it was only five years since Archbishop Wareham had made a metropolitical visitation of Winchester diocese, so if any diocese of the southern province ought to have been exempted or left to the last, Gardiner's was the one. Nevertheless Cranmer decided on beginning with Winchester, and this-to say the least-was a specially unfortunate selection, as there had already been bickerings and jealousy between the two prelates. Gardiner resolutely opposed the visitation, an action that was doubtless acceptable to his clergy. He urged against it the recent costly visitation of Wareham, and the new and heavy imposition of the tenths, but chiefly contended that, as the archbishop had abandoned the ancient title of legate of the apostolic see as being in contradiction to the royal prerogative, he had no right to the title of Primate of all England, by virtue of which the visitation was to be held. To all this Cranmer wrote a clever reply to

1 Volusenus dedicated his commentary on Psalm li, published in 1532, to Gardiner, and, for his energy, holds him up as an example to other bishops. 


\section{ECCLESIASTICAL HISTORY}

Cromwell, insisting on the title of Totius Anglie Primas, and persisted in the Winchester visitation. ${ }^{1}$

Meanwhile Gardiner was faithfully working at his share of the translation of the New Testament, on the scheme projected by Cranmer in 1533 , with which he was occupied chiefly at his quiet manor house of Bishops Waltham. On 1o June, 1535, he wrote to Cromwell, stating that he had just finished the translation of the Gospels of St. Luke and St. John, and being overwrought by his labours intended for a time to put aside all books and writing. ${ }^{2}$

Following on the divorce of Catherine in 1533 came the separation from Rome in 1534 and the proclaiming of Henry VIII. as the supreme head of the Church of England, accompanied by the Verbal Treason Act, by which any one questioning even by 'malicious silence' the right of the king to such a title was liable to execution as a traitor. The clergy, secular and religious, as well as members of parliament and officials, were ordered to swear allegiance to Anne (Boleyn) and her children, to acknowledge the supremacy of the Crown, and to deny that the pope had any more authority in England than any other bishop. To this stringent oath the now despotic Henry secured the subscription of almost the whole of the clergy, parochial and monastic. Fisher, Bishop of Rochester, Sir Thomas More, the late chancellor, and several Carthusian monks were executed under the Verbal Treason Act. Gardiner of Winchester hesitated for some time, but at last (on ro February, 1535$)^{3}$ he signed his repudiation of papal authority, and calling together his clergy at St. Swithun's induced the falterers to follow his example.

The foremost and plainest opponents of the king's divorce were the Friars Observants, who numbered amongst them the best preachers of the day, such as Peto, Elstow and Forest. The king, who but a few years previously had declared this order to be the most holy and faithful in his dominion, now resolved on its suppression. About 200 of the order were flung into prison without trial, where upwards of fifty died from the severity of their treatment, whilst their houses were handed over to the Augustinian friars. The Observants had their origin in a reformation of the relaxed Franciscan rule, begun in 1400 and confirmed by the council of Constance in 1414. The Southampton house of Franciscan friars was one of the seven English houses that adopted the reformed rule, and were henceforth Observant friars. On Passion Sunday, 1534, one, Robert Cooke of Rye, had to do penance for certain heresies about the sacrament of the altar, and to make public confession and abjuration in the cathedral church at Winchester. The preacher on that occasion was Friar Pecock, warden of the Observant convent at Southampton. He was bold enough to avail himself of the opportunity

1 Cott. MSS. Cleop. F. i. 260.

2 Letters and Papers, Henry VIII. No. 850. The four Gospels were assigned to the Bishops of Canterbury, Lincoln, Winchester and Ely, and it is a great tribute to Gardiner's learning that the two longest were eventually allotted to him as his share.

3 Wilkins, Concilia, iii. 780. 


\section{A HISTORY OF HAMPSHIRE}

of dealing with 'other dampned heresies,' and exhorted the people to be steadfast even unto death in their ancient faith and practices. ${ }^{1}$ He then made pointed reference to the story of St. Maurice, who refused obedience to his prince's command where contrary to the divine law, and concluded by arguing strongly in favour of the primacy of St. Peter. This plain preaching was reported to Cromwell. Orders were at once issued to John Perchard, the mayor of Southampton, to arrest Gabriel Pecock and bring him up to London. Accordingly on Wednesday in Easter week the mayor proceeded to the Observant friary at Southampton, but found that the warden was still absent on a preaching tour. A few days later he was apprehended and sent to Cromwell, but at the same time the mayor and his colleague wrote to the vicar-general in warm terms as to Pecock's very good behaviour ever since he had been in Southampton, and also of the good order of his convent. His popularity at Southampton probably procured his release, or he may to some extent have recanted; at all events Pecock, a few months later, was again at Southampton. ${ }^{2}$

During this year the visiting of religious houses by virtue of letters patent-the king considering himself for such purposes the superior of all the episcopate-was first put in practice. Selection was made of two renegade friars, Dr. Hilsey, a Dominican, and Dr. Brown, an Augustinian, as 'grand visitors and provincials' to all the friaries of the kingdom.' This action gave rise to imposition, in addition to royal harshness. More than one self-appointed 'visitor,' with forged letters, went about to different houses extorting bribes and payments. Friar Pecock, of the Southampton Observants, had one of these sham visitors on i 5 July. Dressed as a 'father Black friar' he entered the friary, took the keys from the porter, rang the bell and assembled the convent in the chapter house. He said he was visitor by the king's authority, and read a transcript of the royal letters patent to Hilsey and Brown, certified (as he pretended) under the seal of the Archbishop of Canterbury, and passed himself off as Hilsey. As however it was discovered by chance from one of his servants that he was not Hilsey and was not named in the commission, they refused to let him proceed. The 'visitor' threatened them with the king's and Cromwell's displeasure, whereupon Warden Pecock wrote on the morrow a full account of the whole occurrence and forwarded it to Cromwell."

In 1535 began the suppression of the monasteries. From one point

1 In 1533 Stokcsley was president of a commission that condemned and burned two Eucharistic herctics. In 1535 fourteen Anabaptists were condemned at St. Paul's, and burned in different parts of England so as to strike a terror throughout the kingdom. Others were burnt for like reasons in 1538 , 1540, 1541, 1543 and 1546. At least thirty persons were burned at the stake for their Protestant opinions in the reign of Henry VIII., and a far larger number escaped the stake, like Robert Cooke, by recantation. See Wakeman's History of the Church of England, pp. 255-6.

2. Lesers and Papers, Henry VIII. (1 534$), 448-50$.

3 Hilsey was rewarded by being made Bishop of Rochester, whilst Brown was raised to the archbishopric of Dublin.

4 Letters and Papers, Henry VIII. (1534), 982. In a list of the whereabouts of various leading friars drawn up in December, 1534, many having escaped over the seas, Gabriel Pecock is named as being at Lincoln (ibid. 1607). 


\section{ECCLESIASTICAL HISTORY}

of view this was no new idea. Rome itself had not been hostile to their occasional suppression in favour of some better scheme, as witness the bulls so recently obtained by Wolsey to find funds for the establishment of his colleges. Moreover no county in England, for its area, had had a wider and therefore better recollected experience of suppression in the previous century than Hampshire. But when parliament agreed to the suppression of the alien monasteries in 1415 , their revenues were assigned to other religious establishments. The twelve cases of suppression of that year in Hampshire and the Isle of Wight benefited such institutions as Winchester College or the hospitals of St. Cross and God's House, Southampton, as will be set out hereafter. In 1486 , Bishop Waynflete was allowed to transfer the possessions of the Hampshire priory of Selborne to Magdalen College, Oxford. Again, in 1494, Pope Alexander granted a bull, at the request of Henry VII., for the suppression of Mottisfont Priory and the annexation of its revenue to his foundation at Windsor, Mottisfont having then only three canons, a number insufficient for the fulfilment of its religious obligations. There was now however a totally different spirit abroad; the king and his courtiers took advantage of a certain genuine yearning for reform that was exercising the minds of some of the more devout and thoughtful, to enrich themselves. However diverse may be the opinions of men qualified to judge as to monasticism having played its part out, or as to the extent of its decadence, no man can approve of the way in which the dissolution of the religious houses was accomplished, and of the manner in which their revenues were used.

To give colour to the policy of confiscation, Thomas Cromwell, as the king's agent, appointed a commission of visitors to the monasteries. The first result was the suppression of the lesser houses whose revenues did not exceed $f_{0} 200$ a year, which were pronounced to be the more corrupt. The preamble to the act of ${ }_{15} 6$ stated that ' in the greater monasteries, thanks be to God, religion is right well observed and kept up.' Some of the condemned houses managed by bribes to stave off the evil day. The most celebrated Hampshire convent condemned under this act was the Winchester abbey of St. Mary, of early royal foundation-founded by Alfred, extinguished by Henry VIII. The abbess, Elizabeth Shelley, by paying a fine of $\oint_{03} 336 \mathrm{~s}$. 8d, and by resigning to Sir Edward Seymour, the king's brother-in-law, the manors of Urchfont and Allcanning, secured a reprieve, and a new charter was granted in 1536. The reports of the mixed commissioners of local gentry as to the lesser monasteries, of which there are but few full returns, certainly did not justify the suppression of these houses ${ }^{1}$; and the reports are the more remarkable, as the visitors were all servants of the Crown in different capacities. ${ }^{2}$

1 Details will be subsequently cited in the account of each religious house.

2 Sir James Worsley was governor of the Isle of Wight and captain of Carisbrook Castle, whilst the two Paulets (brothers of Sir William Paulet, treasurer of the household) and Berners were Irish commissioners and officials of the Augmentation Office. 


\section{A HISTORY OF HAMPSHIRE}

In the account presented on 30 May, 1536 , by Sir James Worsley, John Paulet, George Paulet and William Berners, not a single scandal is even hinted at in connection with the Hampshire houses. Of the Cistercian nuns of Wintney, they say that they are by report of good conversation and all desirous of continuing in religion; of the Benedictine nuns of Winchester, that the whole number are religious and in living virtuous; of the Austin canons of St. Denis, Southampton, that they are of good conversation; of the Cistercian monks of Netley, that they are of good religious conversation; of the Cistercian monks of Quarr, that they too are of good religious conversation; of the Austin canons of Breamore, that they are of good conversation.' Notwithstanding however the nature of these reports of the smaller houses, every one of them was suppressed before the close of the year. ${ }^{2}$

A peculiarly interesting and exceptional point of this return may here be noticed. The commissioners say of the abbey of Netley, which was close to the water's edge, that it afforded both to the king's subjects and to strangers travelling the seas 'great relief and comforte'; and of the abbey of Quarr, which was also close to the sea coast, it is reported that it is "a greate refuge and comforte to all the inhabitants of the Yle and to strangers travellinge the sees.' There can be but little doubt that these expressions refer to the fact that the monks of both Netley and Quarr kept a fire flaring or a lamp burning at nightfall for the guidance of ships. ${ }^{3}$

The Premonstratensian abbey of Titchfield, valued at the dissolution at $f_{0} 249$ I 6s. I $d$., surrendered on 28 December, I 537, John Salisbury, the abbot, being made suffragan bishop of Thetford." The superior of another Hampshire house, the priory of Breamore, was made suffragan bishop of Taunton.

It is stated in Milner's Winchester that one of the results of the I 535 act was to destroy the four houses of friars at Winchester; but this is an error. The friars throughout England (saving the extinguished Observants) had escaped because of their honourable condition of poverty. They had no fixed source of income to which the act could apply ; they were not even named in its clauses, and there can be little or no doubt that it was never drafted with any idea of including them. It seemed however to occur to the king and his agents that even friars had houses, that their sites were valuable, and that their very poverty would make their resistance feeble. An attack all along the line was therefore decided upon in the autumn of 1537 . It began in London in November, 1537, and it reached Winchester in May, 1538. An exfriar was made the chief instrument of this action in the west of England. Richard Ingworth, formerly prior of the Dominicans of King's

1 P. R. O. Augm. Office, Chantry and College Certificates, I I 2. Owing probably to wrong classification, this return has hitherto been overlooked.

2 Letters and Papers, Henry VIHI. I 536, passim.

3 Sce W. J. Hardy's Lighthouses : their History and Romance (1895).

- Letters and Papers, Henry VIII. (I 537 ), ii. 1274. 


\section{ECCLESIASTICAL HISTORY}

Langley, was consecrated suffragan bishop of Dover towards the end of 1537. Instead of doing episcopal work he at once sought and obtained a commission as visitor of religious houses, and determined to devote his chief attention to the extermination of friars. In May, 1538, he visited the Winchester houses of the Franciscan, Austin and Dominican friars, and asked directions as to what he was to do with the Carmelite house, as there were no friars. He reported to Cromwell that he had left all the stuff pertaining to the Black friars ' in a secular mannys handdes,' and gave license to the prior to say mass in the church till he heard from him again. Two months later he again visited Winchester, and received the formal surrender of the friars' houses on 2 I July, there being then twenty-five priests amongst them, all told.'

Within a letter from Richard, Bishop of Dover, to Cromwell in July, I $53^{8}$, recording his dealings with the friars in the west of England, was enclosed a schedule giving lists of friars concerning whom 'I beseche youre lordeschype to have dyscharge for theys fryers to change ther apparell.' The reason for this application was, as is explained by the bishop in other letters, that the friars were too poor to purchase even a coat in lieu of their religious frocks. The following are those named at Winchester :-

The Grey Fryers off Winchester: Fryer Thomas Parys; Fryer Wyllyam Kenett ; Fryer Rycharde Forde. The Austen Fryers off Wynchester : Fryer Johan Wyhte. The Blacke Fryers off Wynchester: Fryer Rycharde Chessam, doctor of dyvynyte, prior; Fryer Robarde Browne; Fryer Johan George; Fryer Nycholas Barker ; Fryer Johan Ynggylbye; Fryer Robarde Haymys. I want iii or iiii freeres names of the Austen and Wheyte Freers of Winchester, I left the boke at hom. If ye wold be so gode as to send me iii or iiii warranttes with a space for ther names, I wer bonde to you.

From this it would appear that the visitor had discovered some White or Carmelite friars. He goes on to say :

In all placys wher as yet I have ben I have made an inventory indenteid, and selyd up their common sealys so that thir shall sell or alienate no more of their jewellys nor other stuffe, wherefor I am suar that within a year the more parte shall be fayne to giffe up their housis for poverty. ${ }^{2}$

The Bishop of Dover was however too mild a man for Cromwell's purposes, and he soon lost favour and had to make way for rougher tools. ${ }^{3}$ In the suppression of the remainder of the friars the chief agent was the notorious Dr. London, ${ }^{4}$ who, with a posse of his coadjutors, visited Hampshire in September, $153^{8}$, and again in 1539.

In May, $153^{8}$, John Draper, the prior of Christchurch, who was one of the king's chaplains and friendly with several about the court, petitioned against the suppression of his house. He pleaded that the church was the parish church for the town and its hamlets, wherein

1 Letters and Papers, Henry VIII. passim.

3 Dixon's History of Cburch of England, ii. 37-40.

2 Cott. MSS. Cleop. E. iv. f. 250,25 I.

4 Dr. London was put to open penance for adultery, and died in prison for perjury (Narratives of Reformation [Camd. Soc.], p. 35 ; Strype's Eccl. Memorials, i. 175; Strype's Memorials of Cranmer, i. 158). Cranmer terms him 'a stout and filthy prebendary of Windsor.' Dr. London was not only canon of Windsor, but warden of New College, Oxford, and dean of Wallingford. 


\section{A HISTORY OF HAMPSHIRE}

were fifteen or sixteen hundred communicants; that the country round about was very barren, and that there was no other place of refuge for honest men within eight or nine miles, and in some directions sixteen or eighteen miles, that the poor of the country round were fed there day by day; that a school was kept and a master provided for the children; and that there was a daily lecture of divinity. ${ }^{1}$ This petition had the result of staving off the evil day for some eighteen months, and securing the most favourable terms for the prior. But Christchurch was a wealthy house of $£ 550$ a year and was bound to go. The surrender was effected on 28 November, 1 539, when London and his colleagues assigned the great pension of $\oint_{1} 336 s$. $8 d$. to Draper, as well as the mansion of the prior's lodgings. They reported to Cromwell that the prior was a very honest and comformable person, and described with gusto the great value of the gold and silver plate 'mete for the Kinges majestie is use.' In the same letter the visitors gloried in having defaced the beautiful chantry chapel but recently erected by the Countess of Salisbury for the burial of herself and her son, Cardinal Pole. ${ }^{2}$

On 2 April, 1 538, Thomas Stephens, the abbot of Beaulieu, and twenty of his monks were induced to sign a surrender. The site and possessions were speedily assigned to Sir Thomas Wriothesley, who was controller of the king's household, and subsequently created first Earl of Southampton. Its annual value was declared to be $£_{4} 4286 \mathrm{~s} .8 \frac{1}{4} d .^{3}$

On 7 April of the same year the Austin priory of Southwick, of the annual value of $\delta_{3}{ }^{1} 4$ i 7 s. Iod., was surrendered by the prior, William Norton, and twelve of the canons. This house too was originally assigned to Wriothesley.

These surrenders of houses over the value of $\oint_{0} 200$ were clearly illegal, but the action of the visitors was subsequently legalized by the act of 1539 .

With regard to Beaulieu, an interesting point occurred which shows how many awkward questions were involved in the suppression of these larger houses, and how much this monastic system tended to alleviate the sternness of the criminal law of the land. On the day after the visitors obtained the surrender of Beaulieu they wrote to Cromwell telling him that there were thirty-two sanctuary men within the bounds of the abbey who were there for debt, felony and murder, and to whom had been assigned houses where they lived with their wives and children. They declare that if sent to other sanctuaries they will be undone, and desire to stay there for the rest of their lives. On the sixteenth of the same month the ex-abbot Stephens wrote to Wriothesley begging him to be a good master to the poor men privileged in the sanctuary of Beaulieu for debt, and stating that they had been very honest whilst he was their governor. As a cogent

\footnotetext{
1 Letters and Papers, Henty VIII. (1538), xiii.(1) No. 1117.

I Ibid. (1 539), ii. 597 ; Cott. MSS. Cleop. E. iv. 267.

3 Letters and Papers, Henry VIII. (1 538), xiii.(1) 660.
} 


\section{ECCLESIASTICAL HISTORY}

argument with such a one as Wriothesley, he added that the houses these sanctuary men occupied were so poor that if they were turned out they would yield no rent. On the following day Dr. Crayford, an agent of Wriothesley, begs his master to obtain the king's protection for such of the Beaulieu sanctuary men as are debtors, an action which would much redound to his credit in the neighbourhood. From some of Cromwell's notes later in the year it is shown that this request in favour of the debtors was granted by the Crown. ${ }^{1}$

The letters of John Crayford and certain of Wriothesley's retainers sent down to look after his rich Hampshire spoils are distressing to read. Crayford (one of Cromwell's sub-commissioners) writes to the controller of Henry's household on 2 January, $153^{8}$, as to the extent of the fishponds (four of them a mile in length) and other details of the Titchfield monastery, only surrendered the previous week. The greed of the country side to gain some profit is a sorry sign of the times. On the Sunday following the fall of the house half a dozen neighbours from Eastmeon, fourteen miles off, came over to inspect, and promised to buy marble monuments, altars, etc., out of the monastic church. Crayford, himself in holy orders, tells his patron that 'Mrs. Wriothesley nor you neither be no meticulous ne scrupulous to make sale of such holy things, having the example of devout Bishop Alexander of Rome whose epitaph is :-

\section{Vendit Alexander cruces, altaria Christi ; \\ Vendere jure potest; emerat ille prius.}

He adds that plucking down the church is but a small matter, as he will build a chapel. Directly Beaulieu comes into Wriothesley's hands an army of masons, etc., are turned in to change it into a grand mansion for his residence. The choir and other parts of the church are employed, being useful to protect him from the sea wind; but all men of taste whom he consults decide against the tower of the church remaining. Southwick, which also fell into his clutches, was eventually assigned to one of his unscrupulous servants, John White. The only relief to this sorry business is that the church robbers fell out among themelves.

Sir Thomas Wriothesley not only obtained possession of the abbeys of Beaulieu and Titchfield on different sides of the Southampton Water, but also of the site and many of the manors of the abbey of Hyde, of which he was actually seneschal or steward. He sold the spoils of this abbey, and personally superintended the rapid extinction of its fabric. No wonder that his case is chronicled in Spelman's History of Sacrilege. His acts as a spoiler, particularly at Winchester, brought about the hostility of Bishop Gardiner, who was his wife's uncle, but Cromwell's patronage secured him against the bishop's displeasure.

On 21 September, 1 538, Wriothesley, with Pollard and Williams, two of the minor monastic visitors, made an end of the shrine of St.

1 Letters and Papers, Henry VIII. (1538), i. 668, 792, 796, 877. 


\section{A HISTORY OF HAMPSHIRE}

Swithun in the cathedral church of Winchester. Their joint letter to Cromwell says that their work was done 'aboutes thre of the clok this Saturdaye in the mornyng,' so we may conclude that cowardice or shame caused them to labour in the dark. They bemoan that there was no gold, and that the precious stones were counterfeits, but they thought that the mere silver from the shrine was worth 2,000 marks. They also obtained a cross of emeralds, a cross called Jerusalem, a cross of gold, two gold chalices and some silver plate. They add: 'We have also this mornyng going to our beddeswarde, viewed th' aulter, which we purpose to bring with us; it wol be worthe the taking downe." 'The visitors continue: 'We entende, both at Hide and St. Marye's, to swepe away all the roten bones that be called reliques; which we may not omitt, lest it shuld be thought we care more for the treasure thenne for avoiding of tha abomynation of ydolatry.' ${ }^{2}$

The acquiescence of the abbot of Hyde in the dissolution of that great historic abbey was secured by considerable promises, which were shortly fulfilled. He had been made Bishop of Bangor in 1534, and only held the abbey in commendam. Immediately after the surrender he was translated to Salisbury. The formal surrender was not signed till 30 April, I 539.

The nuns of St. Mary's, Winchester, held out till 15 November, I 539, when they too surrendered, Elizabeth Shelley, the abbess, securing a pension of $\oint_{2} 26$ i $3^{s .} 4 d$. The wealthy convents of Wherwell ( $\oint_{3} 398$ s. 7 d.) and Romsey $\left(\oint_{5} 28\right.$ ios. $\left.10 \frac{1}{2} d.\right)$ succumbed in the same year.

So far as the monastery of St. Swithun was concerned, William Kingsmill, the prior, became dean, and most of the canons and minor canons were taken from the old body. There seems to have been only one of the old house provided with a pension, the rest having posts found for them in the new establishment. ${ }^{3}$

$\mathrm{Had}$ the officially announced intention which was mainly alleged for the second act of dissolution of monasteries in 1539 been fulfilled, the diocese of Winchester would to some extent have profited, for Southampton, Guildford and the Isle of Wight were places named as sees of suffragan bishops. Out of the twenty-three promised bishoprics only six were founded.

St. Swithun's, Winchester, was one of those seven Benedictine monasteries having the charge of cathedral churches which were changed at the Reformation into a body of secular canons. ${ }^{4}$ Though the king cared not personally for education, it was the rising European

\footnotetext{
1 'The nether part of the high altar, plate of gold garnished with stones, the front above of broidering work and pearl, and above a table of images of silver and gilt garnished with stones' (Inventory of St. Swithun's, Harl. MSS. 358, f. $17 \mathrm{~b}$ ).

2 Letiers and Papers, Henyy VIII. (1 538 ), ii. 485

Winchester Catbedral Documents, $154 \mathrm{I}-7$, Hants Record Society.
'There had been nine, but Coventry was destroyed, and Bath never received a capitular establishment.
} 


\section{ECCLESIASTICAL HISTORY}

question, and could not be ignored in his schemes of reform. In the new statutes for Winchester it was expressly stated that the monastery of St. Swithun was dissolved in order that, inter alia, 'the youth of the realm may be educated in good letters to the advancement of the Christian faith and piety.' It was also Cranmer's desire and intention to make use of the cathedral establishments as theological colleges, with readers in divinity, Hebrew and Greek, and a body of students. This brave project, so far as Winchester was concerned, dwindled down to the ordering, in 1544, that twelve poor scholars in theology should be constantly maintained in the two universities, six at each, by the dean and chapter. The total outlay ordered would have amounted to about fioo. For the support of these students the king re-granted to the new body, from the great spoils of the monastery, the manors of Westmeon, Nursling, Milbrook, Avington and Hoddington. Speedily however repenting himself of this trifling fulfilment of his pledge to assist education made so solemnly in the statutes, the king in less than a twelvemonth insisted on the surrender by the dean and chapter of these very manors. With their surrender these shadowy students of divinity vanish into space, having never had aught but a birth on paper.

A few remarks may be here added as to the subsequent history of the religious houses of the county, though somewhat out of chronological order. Amongst the five or six religious houses re-established during Mary's reign was that of the Franciscan Observants at Southampton. Mr. Baigent has been able to prove this from bequests in wills of the year 1558 , which show that not only were there 'brethren of St. Francis' Rule' in the town, but that they were using their old church dedicated to St. Francis. ${ }^{1}$

It is interesting to note with regard to Dame Elizabeth Shelley, the last abbess of St. Mary's, Winchester, that it is one of the instances in which the head of a convent managed to gather together a few of the dispossessed nuns to live with her in a quasi-community life. The abbess died in 1547 , leaving twenty shillings to each of the seven nuns who were apparently living with her at the time of her death. Agnes Badgecroft, who had been sub-prioress of St. Mary's, died during the Marian reaction ( 1556 ). By her will she left ' my professed ring to the Blessed Sacrament to be sold, and to buy therewith a canopy for the Sacrament.' It would appear that the same thing occurred with the disbanded ladies of the convent of Wherwell : the last abbess, Morpheta Kingsmill, by her will of I 569 , left bequests to seven of her old community, who were probably living with her at the time of her death. ${ }^{2}$

The religious pension list was carefully revised in Mary's reign. The original results, arranged by counties, are in the British Museum. The following is an abstract for Hampshire: The monks or canons of the suppressed houses then receiving pensions were-Beaulieu, 8 ; St. Swithun, I ; Christchurch, I 4 ; Hyde, I I ; Breamore, I ; Southwick, 5.

1 Abbot Gasquet's Henty VIII. and the English Montasteries, ii. 483.

${ }^{2}$ Ibid. ii. $476-8$. 


\section{A HISTORY OF HAMPSHIRE}

The nuns were-Wherwell, $\mathrm{I}_{3}$ (including the abbess at $\mathrm{f}_{4} \mathrm{o}$ ), and St. Mary's, Winchester, I2. The chantry priests numbered 10; the stipendiary priests, 6 ; and the priests of free chapels, 7. This gives a total of 88 pensioners for the county.

The chantries named in this roll are those of-Andover, 'le Vyne' in the parish of Shirborne St. John, Newport, Bisterne, castle of Southampton, free chapel of Boldre, St. Mary in Southampton, Marwell, 'le Charnalhouse in Ebynton' and Godshill. The stipendiary priests were at Alton, Odiham, Shirborne Monachorum, Carisbrooke, and two at St. Cross in Southampton. The free chapels named were those of Boldre, St. Martin's Briddlesford, St. Mary Magdalen's Godshill, Froberry in the parish of Kingsclere, Esteflede, Christchurch, and Wilberton in the parish of Brading.

An interesting and exceptional manuscript gives a full list of the names of curates and other stipendiary priests, 324 in number, in the diocese of Winchester at Christmas, I54I. They are arranged under parishes in the several deaneries, together with the names of the rectors, vicars and others by whom their stipends were paid. ${ }^{1}$ There were twenty-five in the deanery of Winton-four for the church of St. Faith, paid by the master of St. Cross; five for the chapel of St. Elizabeth, paid by the provost of the chapel; one for the church of St. John, paid by the vicar; three for Twyford with the chapelry of Ouslebury; two paid by the vicar and one by the mayor of Winchester; the curate of Weke by the rector, of St. Bartholomew by the vicar, and of St. Lawrence by the rector; the two for Hursley by the vicar; the curates of Chilcombe, Compton and Headborne Worthy by their respective rectors; the curate of St. Nicholas by Mr. Nicholas Harpsfield; the curate of Hunton by the rector of Cronsley; and the curate of Littleton by the Dean of Winchester. In the deanery of Basingstoke there were thirty-five curates, of whom there were two for Basingstoke, three for Odiham and the rest singly for different parishes. In the deanery of Andover there were twenty-nine, three being for Andover and two for Hurstbourne Priors. In the deanery of Alton there were fifteen, two each for Alton and Colmer. In the deanery of Alresford were twentyone, two each for Medstead and Kilmeston. In the deanery of Fordingbridge there were seventeen, two each for Harbridge, Fordingbridge, Wilford and Lymington. In the deanery of Somborne there were seventeen, two for Romsey. In the deanery of Southampton there were seventeen, three for St. Cross, Southampton. In the deanery of Droxford there were thirty-three, two each for Havant and Waltham and three for Eastmeon. In the Isle of Wight there were twenty-one, two for Godshill. This gives 230 as the total of curates for Hampshire and the Isle of Wight.

In March and April, r 543, a visitation was held of Hampshire and the Isle of Wight by Nicholas Harpsfield, official of the arch1 Add.
and Tithes.

Add. MSS. 34, I 37. This return was made for the Chancellor of the Court of First-fruits 


\section{ECCLESIASTICAL HISTORY}

deacon of Winchester. ${ }^{1}$ The centres of the visitation were Basingstoke, Alton, Martyr Worthy, Andover, Romsey, St. Cross Southampton, Southwick, the chapel of Newport, Lymington and St. Mary Calender Winchester. To this visitation were summoned all impropriators, rectors, vicars, curates, chaplains and laymen (churchwardens) of the respective deaneries. Their names are all entered in the rough minutes of the visitation under their respective parishes. Several of the curates who had neglected to bring with them their letters of orders were warned to produce them at Winchester on a given day. The rector of St. Peter's Cheesehill (Winchester) being in default with his induction fees was threatened with the sequestration of his benefice. The wardens of Alverstoke, Niton, King's Somborne and Whitwell were ordered to repair their church windows; those of Holybourne, Froyle, Steventon and Fordingbridge to repair the churchyard walls; those of Carisbrooke the church walls; and those of Andover the roof of the church. The wardens of Bighton were warned to procure a font ; those of Hurstbourne Tarrant to procure a portifer or breviary; and those of Amport to provide by Whitsuntide a clerk (aqua-bajulus) at the cost of the parish, under pain of the church being interdicted. A particular day was named within which the work ordered was to be done, it being in most cases the nativity of St. John the Baptist.

At the funeral of Henry VIII. the Bishop of Winchester was the celebrant ; but with the accession of Edward VI. Gardiner was excluded from the council, and protested against having to accept a renewal of his episcopate at the boy king's hands. The Duke of Somerset as Protector was determined to push on a religious revolution, and paid no heed to Gardiner's protests. On 25 September, I 547, the council sent Stephen Gardiner, the ex-chancellor, as a prisoner to the Fleet, on the charge of having 'spoken impertinent thinges of the Kinges Majeste's Visitacion and refused to set forth and receyve the injunctions and Homelyes for that as he sayd they contayned thinges dissident with the Word of God.' On 8 January, I 548, the bishop was sent for from the Fleet prison, and was told by the council that he had remission of his offences under the general pardon of the previous month, "whereupon having minstred to him a good lesson and admonition, he was discharged of emprisonment.' He returned to his diocese, making Winchester his headquarters, but was not long permitted to exercise any episcopal functions in Hampshire. Somerset was determined to overthrow him, and adopted the not unusual but none the less ignoble expedient of summoning him to London in May (I 548) to preach before the council. His sermon on St. Peter's day at Paul's Cross naturally failed to satisfy his censors, and on the morrow he was summoned before Somerset, the archbishop, and three other of the privy council, and committed to the Tower. In the statement set forth in the council's act book it is alleged that on his return to his diocese in January the bishop 'began forthewith to sett foorth siche mattiers

$$
1 \text { Add. MSS. } 12,483 \text {. }
$$




\section{A HISTORY OF HAMPSHIRE}

as bred again more strife, variance, and contention in that one small cite and shyre than was almost in the holl realme.' They also charged him that when they sent down godly and learned men to preach God's Word at Winchester, in order to disappoint disgrace and hinder them, "he dyd occupye the pulpit himself."

Recognizing the gravity of such an act towards a well known statesman, the council on the next day ( $\mathrm{r}$ July) communicated with all the ambassadors of the foreign powers, setting forth in detail their reasons for sending the bishop to the Tower. ${ }^{2}$

After an imprisonment of two years the council on 8 June, r $55^{\circ}$, agreed that it was time to speak to the imprisoned bishop and promise him release if he would repent of his former obstinacy. Somerset and others were appointed to visit him. During the next six weeks several visits were paid to Gardiner in the Tower, and various declarations drawn up for him to sign; but so soon as he had signed certain statements others of a much more advanced nature were presented to him. ${ }^{3}$ It is quite clear that the action of the council at this time was only intended to conciliate the considerable weight of opinion against his long imprisonment. On 19 July sentence of sequestration from his bishopric was pronounced." Burnet admits that the bishop's treatment was now 'much censured as being contrary to the liberties of Englishmen and the forms of all legal proceedings.'

At last the council could no longer resist the remonstrances of Gardiner and his friends, and he was brought to trial at Lambeth before a special commission presided over by the archbishop. The trial began on I 5 December, I $55^{\circ}$, and ended on I 4 February, I $55^{\text {I }}$, the court having sat twenty-two days. ${ }^{5}$ A good deal of the evidence turned upon what the bishop had really said on certain controversial matters in his sermon at Paul's Cross, there being many conflicting statements. There was also a great body of evidence on behalf of the bishop from Hampshire, clergy, gentlemen and tradesmen (in addition to many of the bishop's servants) vying with each other in protestations as to Gardiner's peaceable conduct and endeavours to secure due obedience to constituted authority. The warden of Winchester College, the master of St. Cross and several of the cathedral clergy, as well as the verger, described the nature of the bishop's sermon at St. Swithun's on Palm Sunday. Much evidence was also given by people of all ranks, who had heard the bishop preach in the parish church of Farnham on St. Matthew's day, I 548 , when on his way to Winchester, after his release from the Fleet. William Locking (vicar of Farnham) deposed that the bishop tarried at the vicarage on St. Matthew's eve, and that he preached the following day on the virtue of obedience and submission, to quiet men's minds who had been much disturbed by the recent visitation of the king's

1 Acts of Privy Council, 1 547-50, pp. 131, 157, 208-10.

Dom. State Papers, Edward VI. vol. iv. No. 20.

s Acts of Privy Council, 1550-2, pp. 43, 44, 48, 65, 67, 69, 70, 72, 73, 76, 78.

1 Ibid. pp. 84-7; Dom. Siate Papers, Edward VI. vol. x. No. 14.

'The trial is set forth at length in Fox's Acts and Monuments, vi. 93-266 (Townshend's ed.). 


\section{ECCLESIASTICAL HISTORY}

officials and their action in the removal of images. Thomas Williams (vicar of Andover), who was at that time curate of Farnham, made a similar deposition. Evidence was also given as to the courtesy shown to the king's visitors by the bishop's officials. The bishop's chancellor, Dr. Steward, was further proved to be most zealous (at the bishop's instance) in urging obedience to the various injunctions. As an instance it was shown that the order prohibiting the carrying of candles on Candlemas day was so zealously obeyed that, though it only reached Winchester on Candlemas eve, it was circulated far and wide. At Southampton the order came on Candlemas day when the service had begun, and the priest stopped hallowing the candles and left them in the church. No evidence was produced at the trial that in any degree supported the previous contention of the Privy Council that Gardiner had made any disturbances at Winchester or in Hampshire, but the commissioners seem to have had no hesitation in pronouncing him guilty, and on I4 February, I5 1 , he was formally deprived of his bishopric. On the following day the council (including the Archbishop of Canterbury and the Bishop of Ely, two of his judges) were ungenerous enough, on the plea that he had called his judges 'hereticks and sacramentaries,' to decide that the aged bishop 'should be removed from the lodging be hathe nowe in the Tower to a meaner lodging and none to waite upon him but one by the Lieutenante's appoinctement, in suche sorte as by the reasorte of any man to him, he have not the meanes to sende oute to any man or to heare from any man; and likewise that his bookes and papers be taken from him and seen, and that from henseforthe he have neither penne, inke nor paper to write his detestable purposes, but be sequestred from all conference, and from all meanes that may serve him to practise anywaie.'

One of the articles that the council in vain tried to induce Gardiner to put his signature to in July, $155^{\circ}$, was to the effect that the king did upon just ground ' and reason suppress, abolish, and take away the chantries and such other livings as were used and occupied for maintenance of private masses, and masses satisfactory for the souls of them that are dead, or finding of obits, lights, or othere like things,' and further that it was a good thing to change them to other uses.

Hampshire did not feel the suppression of the chantries quite so keenly as some shires, for the number of the endowed chantries was small when compared with its area and the number of the parishes. ${ }^{2}$ Nevertheless it was a severe blow, and grossly unjust in the manner of its execution. It is true that the original idea of a chantry (which began in England about the close of the thirteenth century, Bishop John of Pontoise's great chantry of St. Elizabeth of I 30 I being a notable

1 Acts of the Privy Council, 1550-2, pp. 2 I 3, 214.

2 There were but two or three chantries, and those served by the monks, attached to the great cathedral church of Winchester, yet Lincoln Minster had 36 ; St. Paul's, London, 37 ; Chichester, I 2 ; and Sarum, $1 \mathrm{I}$. Chantries seem to have been discouraged in those minsters served by Benedictine monks (Cutts' Parish Priests and their People). 


\section{A HISTORY OF HAMPSHIRE}

example) was the offering up of prayers for the souls of the founder and his family, and for other Christian souls. This was the primary motive of the great majority of the founders of the fourteenth and fifteenth centuries. It was probably always understood, and in very many cases it can be proved, where the foundation charters exist, that the chantry priest had duties assigned to him which sometimes corresponded to those of an assistant curate of to-day, and sometimes involved the definite teaching of the children of the parish. Other chantries, as Dr. Cutts points out, were really chapels-of-ease to outlying districts, and were founded in that shape to avoid legal difficulties. ${ }^{1}$

In 1545 , an Act was passed empowering Henry VIII., for his life, to dissolve chantries and like foundations, but under it few of these were dissolved. A new Act was therefore passed in 1547, which swept away all chantries, collegiate churches, and obits which were temporary chantries, as well as stipendiary priests (within whose duty were masses for the departed) and lands left to a parish church on condition of certain lights being maintained. If there had been merely a desire for the suppression of practices termed superstitious, it would have been perfectly simple to check them, and to use the endowments otherwise; but that would not have filled the royal coffers.

The particulars given in the certificates of the suppression will be found set forth under the respective parishes.

John Ponet, who was translated from Rochester to Winchester on Gardiner's deprivation, was the first of the bishops consecrated under the reformed ordinal. ${ }^{2}$ He was a great scholar, and at Cranmer's right hand throughout the reign of Edward VI.; but Hampshire was probably never under the religious rule of a man so destitute of even decency of character. He obtained the see of Winchester $(8 \mathrm{March}$, I 55 I) by barefaced simony, the condition of his appointment being that he should give up to the crown the episcopal manors, and be content with a fixed income of 2,000 marks. ${ }^{3}$ The Protector having secured possession of such ancient Hampshire endowments of the see as the manors of Marwell, Highclere, Bitterne and Twyford, at once gave them to his brother, Sir Henry Seymour. Seymour took up his residence at Marwell palace, and seems to have well deserved the title of 'hideous ruffian' bestowed on him by Canon Benham." On one occasion, it is said, he rushed forth from Marwell into the church of Owslebury and dragged out the priest who was celebrating the Holy Communion. The priest, on being liberated, returned to the church and solemnly denounced the sacrilege, whereupon Sir Henry's servants, by his order, shot him dead.

Ponet in 1549 published $A$ Defence for Marriage of Priests by Scripture and Aunciente Writers. His own experiences of marriage were curious. When Bishop of Rochester he went through the form of

\footnotetext{
1 Cutts' Parish Priests and their People, p. 442. 3 Strype's Cranmer, pp. 274, 363.

3 Acts of Privy Council, 1550 and I $552, \mathrm{Pp} .231,358,359$.

4 Dioc. Hist. of Winchester, p. 169.
} 


\section{ECCLESIASTICAL HISTORY}

marriage with the wife of a butcher of Nottingham, but was divorced soon after his translation to Winchester. ${ }^{1}$ The divorce took place at the end of July, and in the following October he was married again to one, Maria Haymond, in the parish church of Croydon, in the presence of Archbishop Cranmer and a great concourse of people. ${ }^{2}$

It was really a happy thing for Gardiner that he was a prisoner in the sixth year of Edward VI., and could not be a witness of the way in which the Hampshire parish churches were stripped bare of the beautiful gifts of Bishop Wykeham and of other adornments. The council having had their appetites whetted by previous spoils resolved to complete their earlier work, which had in some parts been only superficially performed. On 3 March, 155I, they decreed 'That for as muche as the Kings Majestie had neede presently of a Masse of Mooney therefore Commissions should be addressed into all shires of Englande to take into the Kinges handes such churche plate as remaigneth to be emploied unto his Highness' use.' ${ }^{3}$ A body of the gentry of every shire and important town was named to take inventories of church and chapel goods, to compare them with those of the former visitation, and to commit to prison any who resisted them. The commissioners for Hampshire were the Lord Treasurer, Sir Richard Cotton, Sir Henry Seymour, Sir Richard Winxfeld, William Kelloway, Richard Worsley and John Kingsmill ; for Winchester, the bishop, the mayor, John Kingsmill, Thomas White and John Norton; and for Southampton, the mayor, Sir William Barkley, Sir Francis Fleming, Thomas Wells and Thomas Pacy. ${ }^{4}$

On 8 October, I 552, the Privy Council directed Bishop Ponet and John Kingsmill to certify what was the value of the 'embeselled Churche goodes,' and what they had recovered. ${ }^{5}$

'In this,' says Canon Dixon, 'we may justly rejoice, since private robbery was no more illegal than this infamous public abuse of power. The loss which the arts and crafts sustained in the destruction of so many exquisite vessels and fabrics of gold and silver, of cloth of gold and tissue of silver, of brass and iron, of stitched work, of Naples fustian and Arras tapestry and Bruges satin, a loss which was disregarded or unfelt by the vigour of that new barbarism, may be lamented and cannot be supplied by culture.'"

The original inventories of $6 \mathrm{Edward}$ VI. of almost the whole of the churches of Hampshire and the Isle of Wight are still extant at the

1 This scandal has been denied, but there is no doubt of its truth. Henry Machyn, in his diary, (p. 8), under 1551 , enters: 'The xxvii. day of July was the newe bishope of Winchester devorcyd from the bucher wyff with shame enogh.' The Grey Friars Chronicle (p. 70), says : 'On 27th July, 1551, Poynet, the bishop of Winchester, was divorced from his wife in Paul's, the whiche was a butchers wife of Nottingham, and gave her husband a certain sum of money a year during his life, as was judged by the law.'

- Collect. Top. et Geneal. iv. 91.

3 Acts of Privy Council, $1550-2$, p. 228.

4 Deputy Keeper's Reports vii. Appendix ii. p. 309.

5 Acts of Privy Council, 1552, 4, 139.

6 Dixon's History of Church of England, iii. 453-5. 


\section{A HISTORY OF HAMPSHIRE}

Record Office. ${ }^{1}$ These are for the most part fuller than in other counties. Hampshire was certainly what would now be termed a High Church county, and most of the parishes seem to have retained all they could up to that date. Two of these inventories are given as examples.

\section{ALVERSTOKE.}

Imprimis. In the steple iii belles and a santus bell. It' a beadmans bell and iii lytell belles. It' iii chalyces of Sylver $w^{t}$ patenes. It' a sylverne pec ${ }^{2}$ to drynke yn. It' broken sylver to ye Value of vid. It' iii Rynges of Sylver. It' a gyrdyll of grene Sylke $w^{t}$ buckell stud and pendant of Sylver. It' a Cope of purple velvett. It'a vestement of blew Satyn. It' a vestement of Whyt Cruell. 'It' iiii old vestementes of dornex. It' iii albes $w^{t}$ chesibles. It' ii tynycles of chang'ell sylke. It' ii hangynges of blew Chamlett, and tawny. It' a pawle of clothe of Crewell. It' a banner clothe of Sylke $w^{t}$ a pelow of Red Sylke. It' iiii table clothys $w^{t}$ a shete. It' viii Kerchiffes. It' a pyx of latyn. It' iiii candle-styckes of latyn. It' ii prycketts of latyn. It' a holy water pot of latyn'. It' ii hanginges of dornex. It' i crosse of lattyn. ' It' a sensor of lattyn $w^{\text {th }}$ a shyp of the same. It' a kaneype of Sylke. It' ii kanapes of nedell work to hang ye pyx yn. It' iii lynnyn stremores staynyd, wt. iii other staynyd clothys. It' iiii cofferes and ii payer of harness. ${ }^{3}$ It' iiii cruettes and ii Corporas casys. The residew of the goodes specyfyed in the old Invyntory ys stolen as playnly shall be declaryed. It' sold for reparacyon of the Churche xxx li of waxe and $x x$ li of olde yarn. ${ }^{4}$

EXTON.

Fyrst i pyx of copper and gylt stolen owte of the Churche. It' i chalys parcell gylt $w^{t .}$ a patten. It' i crosse of copper gylte. It' i payr of crewettes of tynne. It' $i$ oyle box of tynne. It' ii candlestyckes of latten. 'It' iii belles in the tower. It' $i$ lytle bell and $i$ sanctus bell and ii sacryng belles. It' i payer of vestment $w^{\text {t. }}$ strakyd velvet $w^{\text {t. }}$ albe and chyseble. It' i payr of vestment of red satten. It' i olde vestment of red velvet. It' i vestment of red Sylke. It' i vestment chaungeable sylke. It' $i$ cope of red satten of Bruges. It' iii corporas $w^{t}$ iii cases. It' $i$ banner of sylke chaungeable. It' $i$ aulter cloth of whyte fustian braunchyd. It' $i$ surples. It' iiii rotchets. It' $v$ aulter clothes of playn lynnen. It' iii towelles of lynnen and dyaper. It' ii font clothes of lynnen. It' i latten censer. It' i basyn of tynne. It' $\mathrm{j}$ holy water pot of latten. $\mathrm{It}^{\prime} \mathrm{i}$ pax of glasse. ${ }^{5}$

Amongst other churches that had been robbed by unknown thieves during the interval between the two inventories may be named Meonstoke, which lost a cope of black satin of Bruges, a green vestment of satin of Bruges, a tawny vestment embroidered with gold, and a white vestment of sarcenet; and Sopley, from whence were taken a set of blue damask vestments, a cope of baudekin, an altar cloth of satin of Bruges, and a set of white baudekin vestments. In some cases the parishioners or churchwardens had parted with some of the goods for other church purposes. At Warblington the parishioners had sold

1 There is now an excellent MS. index in two volumes to all these church goods inventories arranged under counties. Those for the Isle of Wight have been given in extenso in the appendix to Mr. Percy G. Stone's Architectural Antiquities of the Isle of Wight.

2 'This 'pec' or piece of old silver might be the calamus or pipe through which the communicants received the wine before the cup was denied to the laity. But a more probable explanation is that it was a cup used at bridals.

3 Parish armour for the two men they had to supply.

4 'The wardens often had large stores of wax and yarn for making the great tapers ("serges" or 'torches') for mortuary use, and for the big sacring tapers lighted at the mass. These were now forbidden.

5 The pax was generally of metal, occasionally silver, but more often latten. Glass is a most unusual material. Chicheley gave one of glass to his college of All Souls', Oxford. 


\section{ECCLESIASTICAL HISTORY}

two chalices worth $\oint_{5} 5$ ros. od., also a cross of wood covered with silver, a pax, and an altar cloth to the value of $\oint_{4} 4 \mathrm{ros}$. od. ; the money had been spent in church repairs. At North Hayling one of the two silver chalices had been sold by the churchwardens for $\oint_{3}$ (a sum which went towards the repair of the church), but without the consent of the parish.

With regard to colours there seems to have been an occasional love of strong contrasts. Southwick church possessed a vestment of yellow and red with St. Andrew's cross; whilst at Kingsyate the inventory thus describes the carpet and dossal of the altar :-

It' ii clothes of chamlett that dyd hang one benethe the aut. and a nother above red and yellow.

The Titchfield inventory mentions ' a chasuble of whyte fustyan for Lent.' At Fordingbridge, which was a well furnished church, mention is made of an organ. At South Hayling there were 'ii masers in the Church House for ale.'

The Isle of Wight had a separate commission. This is the heading of their report :

The Certificatt of the viewe of All Church Goodes plate jewells vestyments bells and other ornaments within the Isle of Wight takene by Richard Worsley Capteyn of the said Isle, John Mewce, George Wyllis, John Worsley, and Edward Lee Comyssyoners the first day of August in the sixth yeare of the reigne of ower Sovraine Lorde Edwarde the Sixthe. Churches xxiiii. Chappelles v.

These Isle of Wight returns are most carefully drawn up in book form, all in one hand. The stock of kine and sheep belonging to almost every parish church is duly recorded; occasionally a cow or a few sheep had been sold since I 549. The great majority of these parishes, apparently recognizing the object of the first inventory, and being desirous of utilizing the worth of the goods within their own limits, had sold silver plate and vestments since 3 Edward VI., and particularly their second chalice and censers and paxes. Carisbrooke had parted with chalice and pipe, pax and cross, and two bells for which they received f. 47 Ios. od. The wardens also sold ( I Edward VI.) a pair of censers and a ship of silver, 'wherewith they bowght xii half hakes and vii sheffes of arrowes.' The wardens of Godshill had sold two candlesticks, two cruets, a chalice, and a pyx for $\oint_{2} 37^{s}$. 7 d., and a cross and pax (all silver) for $f_{\mathrm{I}} \mathrm{I} 2 \mathrm{2s} .4 d$. Arreton had sold silver plate to the value of $£_{0} 326 s .6 d$., and brass ornaments for $36 s$. 8d. Brading possessed a valuable cross of silver and gilt, which was sold in I 549 to Ellen Pocock for $f_{2} 233^{s}$. $4 d$., and at the same time obtained $f_{1} 5$ from a London goldsmith for a pair of silver censers, a ship and a pax. But by far the largest sale in the island had been effected by the chapel wardens of Newport, which must have been exceptionally richly furnished. Silver was sold to the extent of $\oint_{047}$ is. $3^{d}$., whilst a great variety of vestments and altar linen realized a considerable sum, and two bells $f_{0} 19 \mathrm{r} 6 s$. od. Every item, with the name of the pur- 


\section{A HISTORY OF HAMPSHIRE}

chaser, is set out in detail down to 'iid. one olde clothe.' The most interesting of these is 'Item to Richard James the Good Friday's whit

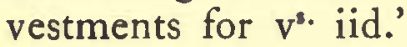

The churches of the island were exceptionally rich in vestments. The following may be named: "One olde cope of Redde velvet and a vestment of the same bordered $w^{\text {t. }}$ Imagery and powdered over $\mathrm{w}^{\mathrm{t} .}$ flowers and Angeles w' the Albe to the same' (Shorwell); 'One cope of Redde bawdkine bordered $\mathrm{w}^{\text {t. }}$ grene velvet powdrid ower $\mathrm{w}^{\text {th }}$ byrdes bestes and flowers' (Chale); and 'One sewt of grene sylke bordered and crossed $\mathrm{w}^{\text {t. }}$ embrothery of Tissewe and spangled abrode $\mathrm{w}^{\text {t. }}$ the same the Albe and everything to the same' (Carisbrook). The Arreton inventory includes ' iiii narrowe sepulker clothes of Arris worke the story of the passione.'

The following curious entry ends the Yarmouth inventory : 'One of their belles was takine owt of the styple by the parishe in $a n^{\circ}$ iiii E. VIth. to be solde and the solders of the Castell supposing hit shoulde be convayed ower the seas arrested it and so it remayneth upon their chardge.'

On 4 July, 1553 , the young king died, and whatever may have been the forebodings of many, there was much satisfaction among all the decent folk of Hampshire that this death at once relieved them of the presence of Ponet. The bishop joined in Wyat's attempted revolution, and on its failure fled across the seas to the house of Peter Martyr at Strasburg, with whom he tarried till his death in August, 1556 . In the year of his death he published, on the continent, $A$ Sborte Treatise of Politike Power, under the initials D.I.P., B.R.W., which stand for Doctor John Ponet, Bishop of Rochester and Winchester. In this treatise he advocated tyrannicide in the plainest and most direct terms, instancing the cases of Jezebel and Athalia as appropriate to that of Mary Tudor. It was evidently written as a popular appeal, for Ponet, though no mean astronomer for those days and the constructor of a curious dial for Henry VIII., did not disdain to instance recent frequent eclipses among the signs of heaven's wrath with England.'

On 3 August, I 553, Mary visited the Tower, and Gardiner was at once released after five years of captivity. Two days later the old man was 'sworne of the Queens Highnes Prevy Councel ${ }^{2}$ on the 8th he said mass for the king's soul before her ; and on the $23^{\text {rd }}$ was declared Chancellor of England. In the strange vicissitudes of his fortune, it

1 Hallam (Literature, ii. 39-42) has given this extraordinary booklet some fame by his praise of the vigour of its prose, though he adds that it is "not entirely free from the usual fault, vulgar and ribaldous invective.' 'This is very mild censure, for many parts are far too disgusting to bear quotation. It must have been very trying to Ponet in his exile to think of Stephen Gardiner having been again installed in the bishopric of Winchester ; but what manner of soul could a man have who would thus write of an opponent who had been dead for some years. 'See how nature had shaped the outwarde partes, to declare what was within. This doctour hade a swart colour, an hanging loke, frowning browes, cies an ynche within the head, a nose hooked like a bussarde, wyde nosetrilles like a horse, ever snuffing in to the wynde, a sparowe mouthe, great pawes like the devil, talauntes on his fete like a ryfre, two ynches longer than the naturale toes and so tyed to with sinowes, that he coulde not abyde to be touched, nor scarce suffre them to touche the stones.'

2 Acts of Priey Council, I $552-4$, p. 311. 


\section{ECCLESIASTICAL HISTORY}

also fell to Gardiner's lot on I October to crown the queen at Westminster, the archbishop having now taken his place in the Tower on the charge of high treason. As a statesman he took the patriotic view of the queen's marriage with a British subject, which he strongly urged upon her; but the circumstances of his diocese almost necessitated his taking the leading part in the queen's unhappy alliance with Spain. On 20 July, I 554, Philip landed at Southampton with I60 sail. Thence he proceeded to Winchester, and became the bishop's guest at Wolvesey. On the $25^{\text {th }}$ this ill-fated marriage was celebrated in the cathedral church of Winchester, the bishop officiating. There is much controversy as to Gardiner's share in the severity of the earlier part of Mary's reign; but at all events he did his best to save Cranmer's life, and prevented the committal of Peter Martyr to prison.

In I 556, under Philip and Mary, warrants were issued by the Crown for the restoration throughout Hampshire of the ornaments seized by Edward VI.'s commissioners, or the return to the churchwardens of their money value when the ornaments were not forthcoming. These returns prove that in some cases the church goods that had been sent up to London at the end of the young king's reign were not sold or melted down to provide ' the masse of money ' so much needed, but remained docketed with the name of the parish from which they had been purloined. Among the restorations in kind were : Alresford, two chalices and patens and a cross of silver; Alton, "one swete of vestment of blewe velvet'; Andover, a suit of vestments of white damask; Basingstoke, vestments and copes, valued at EI 2 I 3 s. od. ; Beaulieu, 'one oyle box of silver'; Christchurch, a pax of wood covered with silver; Fordingbridge, a cross, a pyx, a pair of censers and ship, a sacring bell, and a pax, all of silver; Milbrook, a silver cross; Nether Wallop, a pyx of silver and a suit of vestments of blue velvet; Newton, a pyx of silver; Ringwood, a cross, two candlesticks, a pyx, a pair of censers and ship, a sacring bell, two cruets and a pax, all of silver ; Romsey, a chrismatory and a little bottle and cup of silver; and Whitchurch, two chalices and patens, a pair of censers, a pair of cruets, and a pax, all of silver.

A far larger number of Hampshire churches, however, received the money value of the goods of which they had been spoiled, ranging from $f_{2} 268 \mathrm{~s}$. od., the sum paid to the wardens of Winchfield, down to 3 s. $4 d$., which was obtained by those of St. Bartholomew's, Winchester. The commissioners' charge for this work of partial restoration was $f_{0} 8 \mathrm{I}_{3}$ s. 4 d., which included the sum of $£_{3} 3 \mathrm{gs}$. od. for riding up to London to bring back the money.' Hampshire is the only county of which any trace of restored church goods remains at the Public Record Office. This restitution was not generally carried out throughout the country; the results in Hampshire were probably brought about through the influential position of Bishop Gardiner. He died of gout at Whitehall 


\section{A HISTORY OF HAMPSHIRE}

on I 7 November, I 555, and was spared the worst of the persecutions that throw such a gloom upon Mary's reign.

The successor of Gardiner in the bishopric of Winchester was John White, a native of Hampshire and warden of Winchester college. He was one of Gardiner's executors, he preached at the requiem mass and went with the funeral procession in February, I 556, that conveyed his predecessor's remains from Southwark to Winchester. He had been consecrated Bishop of Lincoln by Gardiner at St. Saviour's, Southwark, in I 554, and soon attained an evil name in the pursuit of heretics. He presided in September, I 555, at the trial of Ridley.

White was appointed to the bishopric of Winchester on 15 April, 1556 , and on the same day Cardinal Pole appointed Dr. Steward, Dean of Winchester, and Dr. Stympe, who succeeded White as warden of the college, to visit the diocese of Winchester. ${ }^{1}$ The bulls for his translation were however delayed, and the congé d'élire did not reach the chapter till 16 July. Hampshire rallied to the 'old religion' during the grievous and bitter years of Mary's reign, so that the county was happily almost entirely free from persecution. In the long list of martyrs arranged under counties during the four years of the burnings given in Strype's Memorials, Hampshire is not once named. Nevertheless there was one county burning during White's episcopate a few months before the Queen's death. Thomas Benbridge, a gentleman of position, after examination before the bishop, was condemned to the stake at Winchester on $29 \mathrm{July,}$ I 558 . When the fire reached him the pains caused him to recant, and the sheriff released him and sent him back to prison. On 4 August the Privy Council sent a letter of severe rebuke to Sir Richard Pexsall, the sheriff of Hampshire, for having released Benbridge without authority, and at the same time wrote to the bishop to insist on the execution of the sentence. Meanwhile Benbridge retracted his recantation, was once more led to the stake and martyred."

Though he suffered at Smithfield, and was examined by Bonner, John Philpot, ${ }^{3}$ Archdeacon of Winchester, may also be mentioned here as a Marian martyr. He was born at Compton, Hampshire, and was third son of Sir Peter Philpot. It is probably to his credit that he quarrelled with his diocesan, Bishop Ponet, but the Privy Council intervened and told him to pay his dues to the bishop, and not to trouble the people with a visitation during harvest. ${ }^{4}$ He was a voluminous writer of the reformed school, and was burned for his doctrines on 18 December, I 555 .

On I 3 December, I 558 , White preached the funeral sermon on Queen Mary. For certain slighting expressions that he was supposed to have used towards Elizabeth, he was commanded to keep his house ; but on I 9 January, I 559, he was called before the council, and 'after a good

\footnotetext{
4 Acts of Privy Council, 1552-4, p. 99.
} Book.

1 Strype, Eccl. Mem. iii. pt. 1, 481,487 .

2 Fox, viii. 490 ; Acts of Privy Council, 1556-8, p. 361.

3 Philpot was one of the three brave men who in the Marian Convocation defended the Prayer 


\section{ECCLESIASTICAL HISTORY}

admonition geven him, was sett at lyberty and discharged of the said commandement of keping his house."1

In March he voted in parliament against the Supremacy Bill, and at the end of the month took part in the Westminster Abbey conference between nine supporters of the late queen's policy and nine reformers. It was characteristic of the spirit of the day that at the end of the conference, which concluded on 3 April, the Bishop of Winchester, together with the Bishop of Lincoln, who were the most conspicuous disputants, were sent to the Tower and their goods sequestrated. ${ }^{2}$ On 26 June, White was formally deprived of his bishopric, but in consequence of ill-health was released from the Tower on 7 July, and suffered to live with his brother, an alderman of the city of London. Bishop White died in 1560 , and was buried in his cathedral church. ${ }^{3}$

For refusing the oath of supremacy Dean Steward of Winchester was also deprived, as well as Prebendaries Hill, Bilson, Harding, Langridge and Hyde, and Edmund Mervyn, Archdeacon of Surrey. The number of clergy throughout England who were ejected for declining to subscribe to Elizabeth's ecclesiastical supremacy was larger than is generally supposed. The number of Hampshire incumbents deprived in the early years of Elizabeth, in addition to the dignitaries, was twenty-four, serving the following parishes: Alresford, Ashley, Beaulieu, Compton, Crawley, Catherington, Cliddisden, Clanfield, Ewhurst, Freshwater, Farley, Hursley, King's Worthy, Nateley-Scures, North Stoneham, Portsea, Sutton, Sparsholt, Sherfield-English, St. Lawrence (Isle of Wight), Titchfield, Wonsington, Wootton (Isle of Wight), and Wootton St. Lawrence. ${ }^{4}$ To these must be added John Marschall, Fellow of New College, Oxford, who was second master at Winchester College. Prebendary Hyde, named above, was head master. This gives a total for the county of thirty-three.

The queen was no sooner settled on the throne than Cecil and other advisers urged a general royal visitation of the dioceses of England and Wales, on the lines of the one carried out when her boy-brother came to the kingship. The visitors were, in the main, leading Elizabethan statesmen ; but they were accompanied by certain of the clergy, who were chiefly named to act as preachers during the visitation circuit. Dr. Robert Horne was nominated as a preacher-visitor for the southern province in June, I 559, and he was also visitor for Cambridge University and Eton. Winchester was one of the two dioceses that escaped this general visitation. The reason was that it had been already decided to

1 Acts of Privy Council, 1558-70, p. 45. The sermon preached by White at Queen Mary's funeral is set forth in Brit. Mus. Sloane MSS. I 578 ; there is a careless copy of this in Strype's Memorials of 2ueen Mary, app. lxxxi. The proverbial comparison quoted by the preacher between 'a live dog and a dead lion' was twisted by some to refer to the two queenly sisters; but the whole sense and argument of the sermon is destroyed by any such strained interpretation. 2 Ibid. p. 78 .

${ }^{3}$ Cal. Spanish State Papers (1558-67), pp. 46-8 ; Cal. Venetian State Papers (1558-80), p. 65. There is no evidence to be found in support of the story that White threatened to excommunicate Elizabeth (Gee's Elizabethan Clergy, p. 32 ). error.

4 Ibid. pp. 285, 292. Chancellor Martin is generally named as deprived at this time, but it is an 


\section{A HISTORY OF HAMPSHIRE}

put Horne in White's place, and it was thought that he might well be left to do his own visiting.

Robert Horne, who had been Dean of Durham under Edward VI., was not however consecrated Bishop of Winchester by the archbishop until February, 156r. He held the see for almost twenty years. The power for good or evil that follows the possession of a vast income was now much changed so far as this bishopric was concerned. An act of parliament was passed to strip it of those possessions which had been alienated with the connivance of Ponet in the days of Edward VI., but recovered in those of Mary. ${ }^{1}$ Moreover, a general Act had become law by which the Crown, in the event of any see falling vacant, could issue a commission to survey its castles, manors or lands, and to take to itself whatsoever seemed good, giving in exchange impropriations or tithes to a like amount. The proviso of exchange was however a delusion, and readily made void; even Burnet styles this 'an act for robbing the Church without enriching the Crown.' At Durham, Horne had destroyed with his own hands not only what were technically 'superstitious monuments,' but much that was purely artistic, so that of him it was written by one of his own chapter that 'he could never abide any ancient monuments, acts, or deeds that gave any light of or to godly religion.' ${ }^{2}$ In his new diocese the destruction that he wrought, particularly with Wykeham's work at Winchester, was piteous. Much detail could be given from various contemporary writers and from letters, but it may suffice to sum it all up in the words of Wood: 'Bishop Horne was a most zealous and active Puritan, and one of the greatest enemies which the monuments of art and the ancient rites of religion found at the Reformation.' ${ }^{3}$

No sooner had Horne established himself in his diocese than he began a general visitation with the object of securing uniformity. Surrey was his first care. On 8 June, 1561 , the bishop wrote to Cecil stating that he had completed his visitation of Surrey and a great part of Hampshire, and was about to go forward to Southampton and the Isle of Wight. As to those who had appeared at his visitation, he had not found any 'repugning to the ordering of the realme concerning religion,' or any ministers declining to subscribe to the declaration. But he complains that many were absent, and many churches destitute of incumbents. He intended to have all absentees summoned before him when his visitation was complete." In August of the same year Horne wrote again at length to Cecil, expressing his bounden duty to report to the council, since the queen had entrusted him with a considerable amount of civil jurisdiction in Hampshire, as well as that which pertained to his spiritual office. The letters lately sent from the council had struck no small terror into men's minds, and were useful in forcing

1 I Eliz. c. 4.

2 Rites of Durbam (Surtees Soc.) pp. 59, 65.

3 Wood's Athena, i. 180. See also Warton's Life of Sir T. Pope, appendix 19, and Kitchin's Winchester, p. 180 .

4om. State Papers, Eliz. xvii. 23. The various references to the State Papers are to the originals; where only the printed calendars have been used it is so stated. 


\section{ECCLESIASTICAL HISTORY}

them to live in order; but their zeal must not be slackened. $\mathrm{He}$ thought the common sort of people could be easily brought to conform themselves, but the better sort required constant pressure, and the justices must be kept up to the mark. In conjunction with Sir Henry Seymour and Mr. Foster, he had called together the constables of the hundreds in their charge, and appointed days for their supplying lists on oath of recusants in each parish and tithing. Through this civil procedure he had gained far more knowledge of religious disorders than through the churchwardens at his visitation. By diligent action he had driven out of the hundreds in his charge many idle and evilly-disposed persons; but they merely moved to other hundreds where there was not such discipline. He complained that 'the great man that had rule the last yeer in this shere being resyaunt here ' was bitterly opposing him. ${ }^{1}$

In his next letter to Cecil, dated I 2 January, I 562 , from Waltham, he recites the great and diverse pains he had taken to reduce the inhabitants of Winchester to a good uniformity in religion. The churches had not been frequented as they ought for common prayer since 'the massing tyme,' and he had difficulty in finding ministers to preach sound doctrine. Many of the city livings were very small, and he had arranged with the mayor for certain churches to be united ('altho' the common sort be against it'), otherwise he could not get them well served. Some of these livings were in the queen's gift, and some in his; and so he craved assistance from the Crown in this amalgamation. As it was, some even of the cathedral priests were still inculcating popery and superstition. He complains that he finds the citizens of Winchester 'very stubborne, whose reformation wolde helpe the greatest part of the shere.' 2

In November, I 567 , a body of Walloons who had fled from the Low Countries to escape the horrors of the Inquisition petitioned the mayor of Southampton for leave to establish themselves in that town and to have a church assigned to them 'where to learn to reverence God and the Magistrates.' The mayor referred the latter question to the Bishop of Winchester, before whom the refugees stated they were willing to make a confession of their faith; but he raised certain difficulties with regard to their other requests, mainly with regard to servants and apprentices. On receipt of the mayor's detailed reply the Walloons forwarded it to Bishop Horne, and he at once wrote strongly in their favour to Cecil, with the result that the queen authorized the settling at Southampton of twenty families of Low Country aliens, with ten menservants for each household. ${ }^{3}$ The bishop assigned to them for worship, with the sanction of Queen's College, Oxford, the chapel of St. Julian or God's House. In I7I2 this congregation conformed to the Church of England, and still continues to use its liturgy.

1 Dom. State Papers, Elix. ix. 36.

3 Ibid. (addenda) xiii. 80-2, xliii. 16 and xliv. 8

2 Ibid. xxi. 7

4 The registers of this Walloon church, which began in December, 1567 , are peculiarly interesting. The first baptism suivant La Liturgie Anglicane was on 21 April, 1712. They were printed in extenso for the Huguenot Society in 1890 . 


\section{A HISTORY OF HAMPSHIRE}

Hampshire, from the number of recusants, who increased rather than diminished under the bishop's vigorous treatment, was more troubled than most shires by repeated tests of uniformity. In November, I 569 , the justices of Hampshire send to the council a formal certificate of their obedience to the Act of Uniformity, willingly subscribed to by ' the moste parte of us nowe presentlie in Commission.' They reported that Lord Chidiock Paulet objected to sign, as he did not agree with receiving the Sacrament; that Sir John Berkeley was absent, but wrote promising to subscribe ; that of those who were heretofore in the commission, Richard Dowse excused his coming through sickness, Thomas Shelley cannot be found by the constable, and 'Anthonie Cope (an excommunicate person) refuseth to subscribe most obstinately.' The document is signed by nine justices, the first two being Bishop Horne and Henry Seymour. ${ }^{1}$

A communication from the bishop to Cecil and the council, dated 24 October, 1577, shows what a considerable number of influential folk still clung to the Roman obedience in Hampshire. He forwarded a list of Hampshire recusants of substance, with the value of their property or goods, and promised shortly to send one of Surrey. The list of these recusants is headed with the name of the Earl of Southampton, but the bishop does not attempt any valuation of his property, as he says it will be so well known to the council. Forty-four names are given, without counting the wives of the recusants. At Warblington, George Cotton, Esq., and wife are mentioned, who had $f_{0} 300$ a year in lands, and Mrs. Bullaker, a widow, whose goods were worth $£_{5} 500$. Henry Shelley, gent., and wife, who had $f_{2} 200$ in goods and $f_{0} 100$ a year in lands, are enumerated under Buriton. Amongst others in this list are Lady Elizabeth Paulet of Crondal; Peter Tichborne, gent., and wife, of Porchester ; and Mrs. Tichborne, widow, of Westerton. ${ }^{2}$

Horne died in 1579 , and was succeeded in the same year by John Watson, who had taken an Oxford M.D. degree, and originally practised as a physician. Afterwards he was ordained, and being known as a reformer he was appointed a prebendary of Winchester. Watson seemed well able to adapt himself to changing circumstances, for he not only retained his prebend through Mary's reign, but was instituted to the Hampshire rectory of Winchfield, to another benefice, and to the chancellorship of St. Paul's. When Elizabeth succeeded her sister, Watson again managed to keep in favour and received further preferment. He was made Archdeacon of Surrey in I 559, rector of South Warnborough and master of St. Cross in 1568 , and Dean of Winchester in $157^{\circ}$. Watson held the bishopric for only a little over three years, for he died in January, $15^{84}$. It was scarcely to be expected that one who had changed his own religious views so frequently would be very stern with either ' papists or sectaries,' and it is generally supposed that he was lax in his administration of all episcopal duties. The Privy

1 Dom. State Papers, Eliz. lix. 46.

2 Ibid. crvii. Io, IOI (I). 


\section{ECCLESIASTICAL HISTORY}

Council were constantly reminding him of the work they expected him to do.

In August, I 580 , when Watson was only bishop elect, the council wrote to him concerning the examination of certain notorious papists lately apprehended in that county, and ordered that they should be committed to Winchester gaol and kept apart from others. He was urged to use his 'best indevours from tyme to time to boulte owte all such matters as he shall thinke may by anie good meanes be gotten at their handes.' In the following October the bishop hears again from the council that they are informed that many of the wives of those who had been reduced to conformity ' do not only contynue obstinate by refusing to come to the Churche to Common Prayer, but also do use at their ordinarie meetinges among themselfes verie unreverende speeches of the Relligion nowe established in this realme, defacing the same as much as in them lieth; he is therefore required not only to take bandes of every the husbandes of the said offenders that their wifes shall kepe themselves in their houses, and that no corrupte persons of Relligion shall have accesse unto them untill they shall be reduced to follow the example of their husbands in yelding due obedience to her Majesties lawes, but also for the speedy bringing them thereunto it is thought meete that they laye a convenient mulcte upon them from tyme to tyme, which may be imployed either for the setting fourthe of the House of Correction or some suche like charitable use.'

In November, I 580 , there was considerable excitement over the arrest in Hampshire of Elizabeth Sanders, ' a professed noone,' and sister of the celebrated Roman controversialist and historian, Dr. Nicholas Sanders. She refused to say where she had been harboured since she came to England, and the bishop was ordered to detain her in the House of Correction and examine her straitly as to the place of her residence when in London. Another of Dr. Sanders' sisters married Henry Pitts of Alton, Hants, a family constantly in trouble for recusancy. ${ }^{3}$

When however the bishop did do his best to please the council by showing zeal against recusancy, he did not always give satisfaction. In compliance with their order of October, I580, Bishop Watson committed one John Goldsmith of Exton, gentleman, to the common gaol, because his wife was 'obstinate in her Poperie' and would not come to church, whilst he refused to enter into bonds for her conformity. Goldsmith was sufficiently influential to get the ear of the council, and the result was that in February, $158 \mathrm{I}$, the bishop was ordered to release him for the following quaintly expressed reasons: 'their Lordships are credibly given to understande, that the said Goldsmithe is not hable to overule his wiefes pevish disposicion in that behaulf, he is required to give order presently for his enlargement, and that the correction of her obstanacie be layed uppon her owne carcas, in case she shall contynue willfull disposicion in refusing to come to the Churche.'

\footnotetext{
1 Acts of Privy Council, I $580-1$, p. 133.

I Ibid. p. 270 ; Dom. State Papers, Eliz. cxlvii. 74.

2 Ibid. p. 244.

4 Ibid. cxvii. 232.
} 


\section{A HISTORY OF HAMPSHIRE}

The council were better pleased with the bishop in the following September, when they wrote expressing their pleasure that he had reduced some recusants to conformity by conferences of learned and godly men, and instructing him to commit others to take their trial at Quarter Sessions. ${ }^{1}$

In a list drawn up in June, I 582 , of ' the notablest recusants yet remayninge prisoners in Winchester and elsewhere' occur the names of 'William Burley, gent, in Queene Maries tyme a justice of peace'; 'Nicholas Scroope, gent, Thomas Owen, gent, a bachelor of the Civile lawe; Symon Cuffolde, gent ; Gilbert Welles, gent,' who were all at that time in Winchester gaol. In a later hand to this list is added, 'Ticheburne gent prisoner in Bekonsfelde gent.'

On 8 August, I 582 , Bishop Watson wrote to Walsingham requesting instructions how to proceed with one, John Chapman, 'a Seminarie and Massing Priest.' He forwarded the little he had got him to confess, and wished to be directed whether he should still detain him or send him to the assizes at Andover. ' $\mathrm{He}$ is in the meane tyme comytted to a safe place in the Correction Howse. The Gaole hath many backward People, that we thought not goode to Comytt nether the Priest nor the Widdowe Mrs. Bullacre ${ }^{3}$ thither.'

The examination of John Chapman, taken before the Bishop of Winchester, and Francis Cotton and William Wright, esquires, testifies that he was ordained by the Bishop of Wells and held the living of Langton Herring, Dorset, which he served six years; that he left the ministry through doubts engendered by reading, without formal resignation; that he went to London and saw one, Blewet, a prisoner at the Marshalsea, and was directed to cross the seas to Rheims; that after a year's sojourn with the seminaries at Rheims he was ordained priest; that he landed in England about midsummer twelvemonth; and that after visiting various parts of the west of England he came to Mrs. Bullacre's of Warblington. He acknowledged taking an oath to the pope at his ordination, but only such as all catholic priests take, and that he is the queen's subject in all causes temporal." Hampshire knew more of these seminary priests than almost any shire, because of its extensive seaboard whereon they might stealthily land from small vessels, and because of the residence in the county of not a few of substance who were thankful for their ministrations.

In January, $15^{8} 3$, a sudden search was made by order of the council in the chambers of Winchester gaol occupied by Warnford, Howard, Slade, Body, Travers and Mercy Deane. The inventory

1 Dom. State Papers, Eliz. 1581-2, p. 203.

${ }^{2}$ Ibid. cliv. 38. The Tichbornes, as one of the leading Hampshire families, were perpetually harassed, fined and imprisoned throughout Elizabeth's reign for their recusancy. The Diocesan History, strangely enough, instances them as a loyal Roman Catholic family, who were allowed 'to exercise their religion at home unmolested.'

3 Ibid. clv. 8.

4 The college of Douay, afterwards transferred to Rheims, was founded in 1568 to supply secular English priests to secretly serve the English Catholics of the Roman obedience, as the old 'Queen Mary priests' were beginning to die out or had become infirm. 


\section{ECCLESIASTICAL HISTORY}

and goods that were seized were sent up to London, included a superaltar, a cope, five pieces of massing ornaments, a vestment, a stole, a set of beads, two great wax candles, and 'a greate masse booke in Latin.' They also took from the prisoners a variety of devotional and controversial works of theology, and one work of more serious import, Allen's Defence of English Catbolics, wherein the lawfulness of killing Elizabeth is maintained, though not in such plain or virulent terms as those used by Bishop Ponet for the killing of Mary.

The end of this episcopate was stained by two martyrdoms. John Slade, educated at Douay, followed the profession of a schoolmaster at Winchester. John Body, a Wykehamist and master of arts, was another Hampshire schoolmaster. After a long confinement in gaol they were condemned at the Winchester assizes for denying the queen's supremacy. Slade was butchered as a traitor at Winchester on 30 October, 1583 , and Body at Andover on 2 November of the same year. ${ }^{2}$ They were both laymen. ${ }^{3}$

But it was not only the perverse Romanists who were a trouble to Bishop Watson. An extreme and extravagant section of the Anabaptists, who became known as the Family of Love or the Familists, established themselves in England towards the end of Edward VI.'s reign. There seems no doubt that they often offended grossly against decency and order. On 3 October, I 580 , a proclamation was issued against 'the Sectaries of the Family of Love,' and a form of abjuration of their various heresies was issued by the council, to be administered to its members. A letter was sent to the Bishop of Winchester on 10 October, directing him to call to his assistance Sir William Moore, Sir Thomas Browne, and such other learned men as he thought meet for the suppressing and punishing of the "Familie of Love." ${ }^{4}$ The dioceses of Winchester, Ely and Norwich were the chief centres of the sect.

On the death of Watson a more distinguished man and considerable scholar succeeded to the bishopric of Winchester. Thomas Cooper, the son of a poor Oxford tailor, educated as a Magdalen College quire boy, eventually through his diligence became fellow and master of the school where he had been pupil. His greatest work was the Thesaurus, or Latin dictionary, first published in $\mathrm{I}_{5} 65$, which won Elizabeth's special esteem. He was also a considerable theologian and controversialist. Cooper was successively Dean of Christchurch and Gloucester and Bishop of Lincoln, and was translated to Winchester in 1584 , where he was noted for his learning and personal sanctity. When the famous series of Martin Marprelate tracts attacking the English prelacy in $1588-9$ were

1 Dom. State Papers, Eliz. clviii. 9.

2 Stow's Annals; Challoner's Martyrs (Law's ed.) i. 90-2.

3 One of the most astounding mistakes in Green's Sbort History (which fully acknowledges the cruelty and extent of the Elizabethan persecution fostered by the wicked bull of Pope Pius) is his statement that under the penal Act of 1581 'no layman was brought to the bar or to the block... the work of bloodshed was reserved wholly for priests.' The fact is that fifty-seven laymen and laywomen were done to death under its provisions in addition to upwards of 100 priests.

4 Acts of Priey Council, i $580-1$, p. 233. 


\section{A HISTORY OF HAMPSHIRE}

provoking rejoinders of a vulgar and coarse character, the Bishop of Winchester issued a scholarly and temperate rejoinder entitled $A n$ Admonition to the People of England, which was published under his initials. $^{1}$

The reply of Martin to this dignified rejoinder surpassed the scurrility of the previous six tracts issued from this itinerant press. The title page of 'Hay any worke for Cooper,' of which a facsimile is given, with its coarse wit affords a good sample of the contents of its forty-eight pages. There is a certain kind of humour in styling Cooper 'Tom Tubtrimmer of Winchester,' but it is mere virulence to write down this scholar as 'a beastly defender of corrupt church government and not only a traitor to God and his Word but an enemy to her majesty and the state.' The Bishop of Gloucester is termed ' that olde stealecounter massepriest John of Gloucester,' while the coarsest of personalities are indulged in as to the unmarried state of the Archbishop of Canterbury and the Bishop of Peterborough. The bishops collectively are termed wretches, sots, gross beasts, senseless and undutiful beasts, false apostles like Judas, incarnate devils, vicars of hell and bishops of the devil!

Although Bishop Cooper's name is chiefly identified with the Marprelate controversy, he had but little trouble with 'sectaries' in Hampshire or elsewhere in his diocese. He was a good administrator of his diocese in both spiritual and temporal matters, but made it a matter of conscience to keep down and continuously harass the numerous Romish recusants of Hampshire throughout his episcopate. The bishop was no doubt the greatest persecutor of the recusants during Elizabeth's reign, outside the council, but this was mainly owing to the presence of papists in such large numbers in the Hampshire part of his diocese.

In December, 1585 , Bishop Cooper wrote to Walsingham begging that no favour might be shown to Mrs. Pitts of Alton, who at his instigation had been sent up to London and committed by the council to the Clink. ${ }^{2}$ He wrote that she was a very obstinate person, and reminded their lordships that she was a sister of 'Nicholas Saunders the traitor.' He considered that her return to Winchester would do more harm than ten sermons would do good, and with regard to her husband, who had conformed, he laid down the ruling that no man whose wife is a recusant could possibly be himself sound. ${ }^{3}$

Early in the year I 586 Robert Anderton and William Marsden, two priests from Rheims, landed in the Isle of Wight. They were at once arrested, and acknowledged themselves priests. They were sent to Winchester gaol and tried at the Lent Assizes. The judge showed special sympathy, as they had neither of them spoken a word on English soil before their arrest, but had to condemn them to death under the Act

\footnotetext{
1 For a full account of this able and exhaustive treatise see Arber's reprint (1883), with an introduction from the Puritan standpoint.

2 The Clink was the prison that adjoined the Southwark palace of the Bishops of Winchester; it often went by the name of 'the hall of Winchester.'

3 Dom. State Papers, Eliz. clxxxv. 17.
} 


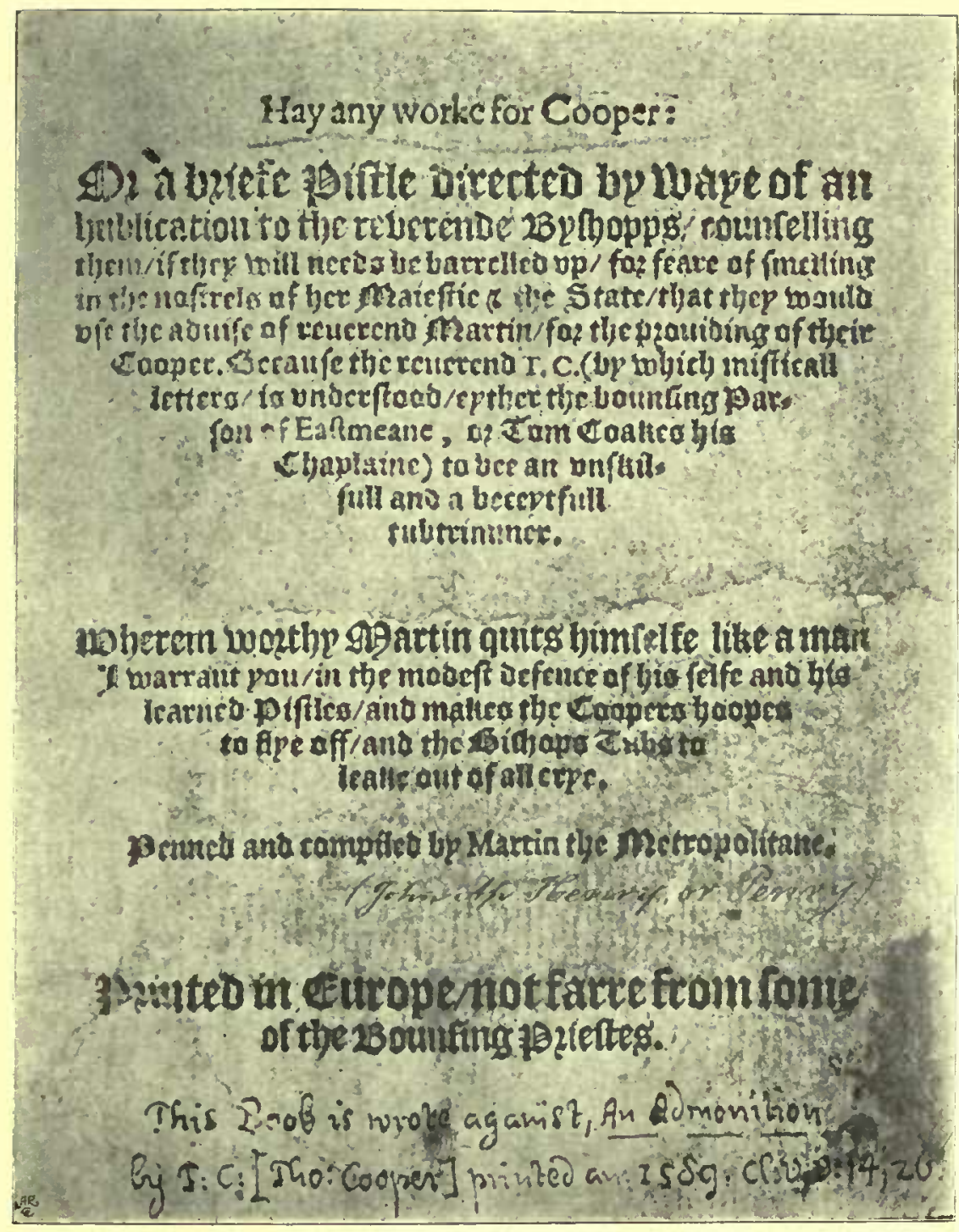

Title page of one of the Marprelate 'T'racts. 


\section{ECCLESIASTICAL HISTORY}

of $15^{8} \mathrm{I}$. A respite was obtained, and they were sent up to London to the council and examined. After some weeks in a London prison, the council on io April sent a letter to Sir George Carey, Governor of the Isle of Wight. In this letter it is stated that the council had decided, notwithstanding the respite, to proceed with the execution of Anderton and Marsden in the Isle, either at the place of their landing or some other fit place. The under-sheriff of the county was to confer with him as to the best site for the execution, and declarations giving the reasons why the queen was now moved to suffer the judgment of the law to take place were to be fixed in public places, in view of the people. On the I 7 th of the same month the council furnished Thomas Tailour, a servant of the knight marshall, with a 'placard' for aid and assistance in conveying the bodies of the two priests to Winchester. The execution took place at the sea coast on 25 April. ${ }^{1}$

In May, I 586, Bishop Cooper, as though anxious for more victims, forwarded to the council a petition 'for certaine Orders to represse the bouldness and waiewardnes of the recusants in the Countie of Southampton.' His petition or suggestions resolved themselves into four heads. In the first place he asked that there should be diligent supervision of the seaside and creeks 'for the coming in or passing foorth of ill-disposed persons.' The next suggestion was that the sheriff should once in a month or three weeks suddenly make a privy search in sundry places where it is suspected that Jesuits or seminary priests lurk. The third and most notorious of these requests was that 'an hundred or two of obstinate recusants lustie men well hable to labour, maie by some convenient Commission be taken up and sent into Flaunders as Pioners and labourers, whereby the Country shall be disburdened of a compaine of dangerous persons, and the residue $\mathrm{y}^{\mathrm{t}}$ remaine be put in some feare $y^{t}$ theie maie not so safe revolte as now they doe.' The fourth request was to the effect that those gentlemen who might gain their liberty by compounding, in accordance with recent orders, might not be suffered to remain in Hampshire, but in some other place, for they had 'stollen awaie the peoples hartes mightilie and dailie doe continue so to doe, for even this late Easter, upon some secret fact purposelie wrought 500 persons have refused to communicate more than before did, which bouldnes assuredlie will fall out to great inconvenience if it be not presentlie mett withal." ${ }^{2}$

The council listened to these suggestions, and actually wrote to the Earl of Leicester in the Netherlands, citing the bishop's letter and asking if he would find employment in his army for that number of Hampshire recusants as labourers. At the same time they also wrote to the sheriff and certain of the justices of the shire authorizing the suggested sudden

1 Acts of Privy Council, I 586-7, pp. 26, 57, 58 ; Challoner's Martyrs, i. 1 21, 275. 'Two other priests, Thomas Hemerford and John Adams, were both arrested in Hampshire about this date, but they were sent up to London, and were there condemned and disembowelled at Tyburn, solely for the sin of being Roman priests.

2 British Museum, Egerton MSS. I693, p. I 17.

11 


\section{A HISTORY OF HAMPSHIRE}

searches, and ordering them to follow the bishop's directions and information. ${ }^{1}$

In September, 1589 , we find the bishop again inciting the council on the question of recusancy. A gentleman of the county, Henry Carew of Tadlethorp, was cited to appear before the bishop to answer for nonattendance at church. Carew treated the summons with contempt, whereupon Cooper reported the matter to the council. Their lordships immediately ordered Carew to appear before them in London, committed him to the Marshalsea for a month, and then released him on his entering into bonds to duly appear before the Bishop of Winchester within twenty days. ${ }^{2}$

In the spring of I 590 the bishop again wrote to the council at length, sending in the names and worth of the Hampshire recusants, and begging that order might be taken for 'restraining the most dangerous personns and of greatest likelyhood.' In their reply of 7 April it seems possible to detect a little weariness with the bishop's persistence, and smiles must have passed over the faces of the Lord Chancellor, the Lord Treasurer and others as they dictated to the secretary the terms of their answer. Their lordships, writing jointly to the bishop and the Marquis of Winchester, recognized the gravity of the case, and whilst authorizing the detention in the common gaol of the worst characters, they continued: "We are to praie your Lordship the Bishop of Winchester seeing the matter doth concerne the cause of God and the estate of the realme that you will be contented to spare your house of Farnham Castle where those named in the enclosed scedule may be restrayned, with such others as your Lordships shall in your discretion thinke fit to be added unto them, to remayne under the charge of some discreete and well affected gentleman such as you shall make choice of for that purpose."

The bishop had to comply, and for some time Farnham Castle became the gaol of the quieter of the recusants. Before the end, however, of April, Cooper was yet again in communication with the council, this time accusing George Vaux, the under-sheriff of Hampshire, of too great laxity towards the recusants in his custody. Vaux was summoned to London, but on his promise to amend and to keep all recusants for the future close prisoners he was discharged with a warning. The bishop further complained that very many of the Hampshire recusants, to the number of 300 or upwards, were yet at liberty, and that 'by lurkinge in howses and in the confines and owtcorners of the shire' conveyed themselves out of his jurisdiction. Thereupon the complacent council issued letters to the lord lieutenants of the adjacent counties ordering them to yield all assistance, and to arrest those escaping out of

1 Acts of Privy Council, 1586-7, p. 125. The Rev. G. H. Cassan, in his Lives of the Bishops of Winchester, a poor compilation published in 1827 , shows that the spirit of religious persecution was not then dead ; for after citing Cooper's deportation proposals (ii. 47) and calling them admirable, Cassan adds: "What a pity that some such plan could not be adopted at the present time-I do not mean against the Catholics, but against the numerous Sectarian teachers, that now infest almost every town and village, and alienate the minds of the people from their legitimate spiritual guides.'

Ibid. $1589-90$, pp. $123,199$.

3 lbid. 1590 , P. 27. 


\section{ECCLESIASTICAL HISTORY}

Hampshire and to commit them, both men and women, to safe and close restraint, those of the best quality to Farnham Castle and the rest to the cammon gaol at Winchester. ${ }^{1}$

In January, I $59 \mathrm{I}$, the bishop caught one, Richard Johnson, a seminary priest, in the act of saying mass, and caused him and his congregation to be at once imprisoned. He immediately reported the good news to the council, and was ordered to send up Johnson and another to London."

On 7 July, I 59I, Roger Dickinson, a priest from Rheims, was executed at Winchester. The specially piteous thing about this execution was that a pious old labourer, Ralph Milner, was butchered at the same time for aiding and assisting the priest. He left behind a wife and seven children. ${ }^{3}$ Seven maiden ladies of Winchester and the neighbourhood, at whose houses Dickinson had been in the habit of celebrating mass, were also sentenced to death, but they were reprieved.

Bishop Cooper lived to see yet another religious execution in his cathedral city. This time it was a lad of nineteen, James Bird, the son of a gentleman citizen of Winchester. Becoming a convert to Romanism, he went abroad for his education to Rheims, as it could not be attained in England. On his return he was arrested, kept for some time in Winchester gaol, and on persisting in his refusal to go to church was executed on 25 March, I 593, and his head stuck on a pole over one of the city gates. ${ }^{4}$

Bishop Cooper, who died in the spring of 1594 , was followed by two successors of very short and uneventful reigns. In May, I 597, Thomas Bilson, who had been a prebendary of Winchester and warden of the college, was translated from Worcester to this bishopric. $\mathrm{He}$ was a considerable scholar, and had won the queen's gratitude by writing at her command a treatise entitled of the True Difference between Cbristian Subjection and Uncbristian Rebellion. Its aim was to justify the queen in taking up the cause of the Netherlanders who revolted against Philip. It served its purpose, but was afterwards much used, with fatal results, to justify the resistance to Charles I.

In September, I 599, Bishop Bilson secured the arrest of one, Edward Kenyon. The bishop, who was at Waltham, committed him to Winchester gaol, charging the keeper in writing to keep him closely as a traitor, for he had confessed to being a seminary priest, and was therefore guilty of high treason according to the Act of 27 Elizabeth. ${ }^{5}$

Shortly after this Kenyon escaped from Winchester gaol, and the bishop wrote to Cecil complaining of the gaoler's dissolute carelessness in the keeping and dismissing of recusant prisoners, and urged that he should be severely punished. He pointed out that the manor of Wood-

1 Acts of Privy Council, 1590 , pp. 105-6.

2 Ibid. I 590-I, p. 234 .

3 Challoner's Martyrs, i. $173-4,280-2$. Milner was offered his life if he would but promise to attend church.

4 Ibid. i. 193-4.

5 Dom. State Papers, Eliz. cclxxii. 11 I. 


\section{A HISTORY OF HAMPSHIRE}

cot, Hants, was given to the ancestor of one, Anthony Uvedale, lately dead, for the safe keeping of the gaol, and that he was a recusant. He bequeathed the inheritance of the gaol to his daughter's son, Anthony Brewning, a minor of seven years of age, both of whose parents were recusants. He suggests that as the child is a ward for this tenure, the manor and its duties can be administered by the Crown till the lad comes of age, even if the releasing of prisoners does not forfeit it to the queen's hands. The bishop stated that the conveyance of this manor could be readily found, as the maker and executor were two of his own officers. With this communication he enclosed a number of examinations and statements made before him as bishop or before Dr. Ridley as chancellor of the diocese. Thomas Canterton, alias Grove, alias Steven, alias Bale, stated he was a prisoner in Winchester gaol for religion, but was absent by leave of $\mathrm{Mr}$. W. Uvedale, returning every sessions and assizes. Richard Brewning, Esq., and William Uvedale admitted releasing certain poorer recusants to get their living, and prayed time to get them back. Richard Joy, of East Meon, had been a recusant for twenty years and most of that time a prisoner in Winchester gaol. Seven years ago he obtained leave from Mr. Uvedale, deputy keeper of the gaol, to go to his house at East Meon and has not since returned. Valentine Noyse, under gaol keeper, gave evidence as to the details of Kenyon's escape, stating that he never had any irons on him whilst in gaol. Andrew Valence, who was in gaol as a debtor, deposed that baked venison and fresh fish were often sent to Kenyon, and that he was allowed to see and converse with whom he pleased.' ${ }^{1}$ The whole of these long depositions show that there was a remarkable amount of sympathy with the recusants at Winchester among almost all classes, which twenty years of severe treatment had engendered rather than suppressed.

In 160I, Thomas Tichborne, of the well known Hampshire family, was arrested, sent to London and executed at Tyburn for being a Roman priest. In the same year his kinsman, Nicholas Tichborne, was also executed at Tyburn for attempting to release Thomas. There was scarcely a year of Elizabeth's reign that did not find one or another of this staunchly Roman family either in Winchester gaol or in one of the London prisons. Another Nicholas Tichborne, of Hartley Maudit, died in Winchester gaol after nine years' imprisonment, in $1589 .{ }^{2}$ This Nicholas describes himself as the younger son of a younger son. His father was Henry Tichborne of Owslebury, a younger brother of Nicholas Tichborne of Tichborne, the grandfather of the first baronet. Henry had at least ten children. Nicholas, who died in 1589 ; and Peter, his brother, also spent much of his life in gaol together with his son Chideoke. We believe that Thomas, the martyr priest, was one of the sons of Nicholas (ob. 1589 ). ${ }^{3}$

\footnotetext{
1 Dom. State Papers, cclxxiii. 23 to 23 viii. A nearly full abstract is given in the printed calendar.

2 Abbot Gasquet's Essays (1897), pp. 377-9.

3 The pedigree with this large number of sons is much complicated (Visitation of Hants in 1576 and Harl. MSS. 1139, f. 21).
} 


\section{ECCLESIASTICAL HISTORY}

It is not a little remarkable to note that the then head of the Tichborne family, Benjamin Tichborne, himself like the rest a recusant, was knighted by Queen Elizabeth on I4 September, I60I, the very year in which two of his immediate kinsmen of Hampshire were executed. This knighting took place when the queen was at Basing, and in a particularly good humour, during one of her last progresses. ${ }^{1}$ Now and again Elizabeth singled out specially distinguished and high placed recusants for favourable distinction after an illogical and a capricious fashion, but on this occasion no fewer than ten knights were made at once. Probably the queen was scarcely aware of his recusancy, and Sir Benjamin Tichborne of Tichborne was very possibly as astonished as any one at the dignity conferred upon him.

Elizabeth died on $24 \mathrm{March}, \mathrm{I} 603$. The news reached Winchester in a few hours, and Sir Benjamin Tichborne of Tichborne, who was then sheriff of the county, instantly hurried to Winchester and proclaimed James I. King of England without waiting for any direction from the council in London, who were then debating the question of the succession. There is no doubt that the Roman Catholics expected great things from his rule, and these expectations would have been realized had it not been for parliament. James was delighted with the conduct of the Hampshire sheriff, and when the stress of the plague speedily drove the court to Winchester he heaped favours on Sir Benjamin Tichborne, made him a baronet in $\mathrm{I} 62 \mathrm{I}$, and knighted all his four sons. ${ }^{2}$

Bishop Bilson took a prominent part in the Hampton Court Conference of 1604 , but Hampshire seems to have been exceptionally free from any overt display of puritanism. The bishop died in 1616 and was followed by James Montagu, who was translated from Bath and Wells and only held the see for two years.

As the number of recusants in the reigns of Elizabeth and James I. was far larger (in proportion to its area) and the value of their estates far higher in Hampshire than in any other shire, it will be well to here furnish some further particulars as to their treatment. ${ }^{3}$

The public executions and imprisonments were after all only a small part of the continuous persecution experienced by the recusants, as is made manifest in the impartial pages of Hallam. The legislation immediately after the accession of Elizabeth imposed a fine of $\mathrm{I} 2 d$. on all absentees from the parish church on Sundays and holy days. In I 581 this punishment was much intensified; it was actually laid down that a

1 Nichols' Progresses of Elizabeth, iii. 567.

2 'The king stayed at Tichborne in 1603, 1615, 1618 and 1623 (Milner's Winchesier and Nichols' Progresses of James 1 . i. 116 ).

3 In 1584 the clerk of the peace for Hampshire complained to the Privy Council that the number of recusants indicted at every session was so great ('seven score at the least') that not only had he and his deputy to employ much extra assistance to draw up and engross indictments, judgments and processes for days before and after the sessions, but that this work so occupied the justices that all other causes and grievances throughout the shire were being neglected (Dom. State Papers, Eliz. clxxxiii. 83). 


\section{A HISTORY OF HAMPSHIRE}

penalty of 620 a month was to be imposed on all absenting themselves from church, and such as could not pay the fine within three months of the judgment were to be imprisoned till they conformed. The Crown, by further legislation, had also the power of seizing two-thirds of the offender's land and all his goods in default of payment, nor were the penalties of these acts mere paper enactments. In Hampshire at all events they were from time to time most rigidly enforced. The Recusant Rolls at the Public Record Office begin in I 590; the roll for that year shows that the tenants of various properties in the county had paid two-thirds of their rents to Crown collectors because their owners were recusants and had not paid their fines. The case of Richard Warnford is an example. He was in arrears for his non-churchgoing fines to the extent of $f_{\mathrm{I}} \mathrm{I}, 540$. The property of Gilbert Wells of Bambridge, near Twyford, had been farmed for a like reason to a Crown-appointed tenant as far back as I $57 \mathrm{I}$. Other instances of the loss of two-thirds of their rental are Thomas Poundes (who spent nearly three years of his life in prison) of Beaumont, Farlington; Anthony Uvedale (the hereditary keeper of Winchester gaol) of Woodcote, near Alresford; Edward Bannister of the manors of Idsworth and Bannisters Court ; and Stephen Vachell of Heath House, Buriton.

The record of the same year (I 590) of those who paid the $f_{2} 20$ a month fine is a long one. The first is George Cotton of Warblington, who paid 6260 , at the rate it will be noted of lunar months. A large number paid $f_{1} 40$ for seven months' recusancy, and another group 580 for four months. When it is recollected what the purchasing power of a penny was at the end of Elizabeth's reign, it is marvellous that so many gentlemen and yeomen were able to pay it. The fines it is true, save in the two-third cases imposed on all big estates, were not collected regularly year by year, but somewhat fitfully. The recusant roll of the second year of James I. yields the names of 500 Hampshire offenders who owed $\oint_{0} \mathrm{r} 20$ for not appearing at church for six months. The list includes not only yeomen, but millers, tailors, husbandmen, shoemakers, blacksmiths, fishermen and labourers, as well as widows and spinsters. It is absolutely impossible that more than a small percentage of these could have paid so great a sum, but their being entered on the roll made them convicted recusants. The next step was for the Crown officials to distrain on their goods and chattels for the amount of their fines. These poor folk were then often sold up: farm or trade implements, hayricks, furniture, and their very houses. Even in cases where pity prevailed to some extent they had to continue their work or business under the depressing weight of knowing that their goods could be seized at any moment by the Crown officials or by the authorized farmers of the recusant fines. Sometimes the more wealthy managed to pay the enormous fine regularly year by year. Thus Abbot Gasquet, who has thoroughly analysed the Hampshire rolls, has shown that George Cotton of Warblington actually paid $\$ 260$ a year from 1587 to 1607 , handing over therefore to the Crown in twenty 


\section{ECCLESIASTICAL HISTORY}

years a sum that corresponded to about $f_{5}, 0,000$ of our money for the privilege of not attending his parish church. ${ }^{1}$

Although the sums that came to the Crown from recusant fines during the reigns of Elizabeth and James I. were so considerable that they formed a fiftieth part of the whole revenue, nevertheless the amount actually exacted was far larger. The evil system prevailed not only of occasionally farming out these fines in a given area for a fixed sum, leaving the farmer to make what profit he could, but of actually conferring what was termed ' the value of the recusancy' of particular Roman Catholics on court favourites or court officials. This was done to a great extent in Hampshire, particularly in the reign of James I. Two or three examples will suffice. In I609 Walter Toderick had the grant of the value of the recusancy of Widow Chamberlain of Titchfield conferred on him. ${ }^{2}$ John Corbet in the same year obtained the valuable grant of the recusancy of Richard Cotton of Warblington. ${ }^{3}$ In the following year Thomas Pinchey, Anthony Dodsworth and Jerome Metcalf, servants of the prince, obtained the benefit of the recusancy of Henry Shelley of Petersfield, Thomas Lane of Silksted, Elizabeth Hedger and Elizabeth Norton of Barden, and Thomas Likehorne of Boyatt."

We now turn back to the episcopal annals of Hampshire. Bishop Montagu died at Greenwich on 20 July, 16 I 8 , and the very same day the king nominated the saintly Launcelot Andrewes to the vacant bishopric. His translation from Ely to Winchester was soon accomplished. Of Andrewes it may be said that he belonged, more than any other bishop of the seventeenth century, to the whole Church of England rather than to the special dioceses which he successively held of Chichester, Ely and Winchester. ${ }^{5}$ Year after year, though in one sense no courtier, he preached sermons to the court on the verities of the faith on all the great festivals of the Church. Nevertheless he discharged his episcopal functions with dignity and assiduity, and Hampshire must have felt the blessings of his rule, more particularly as he refused at all hazards to institute to certain benefices priests whom he believed or suspected of having obtained presentations through simony. For this he had to suffer considerable loss in expensive law suits.

At the time of the Reformation, when the old office books were being revised, there was a singular omission with regard to a pontifical. The service now generally used at the consecration of churches and churchyards is based upon that drawn up by Bishop Andrewes when consecrating Jesus Chapel on Pear Tree Green near Southampton, on Sunday, I7 September, I620. Some bishops follow this form much

1 The above facts were taken fron Abbot Gasquet's The Old English Bible and other Essays (1 897), pp. 319-82, but have been verified by reference to the Rolls. The receipts from recusant fines throughout the country from 1583 to 1602 brought over $\{120,000$ to the Crown.

2 Dom. State Papers, Fames 1. xliii. 95.

3 Ibid. xlix. 45. 1 Ibid. pp. 54-80.

- In 1601 the lease of Alton Rectory, Hants, was assigned by the Crown to Sir Francis Walsingham, and he assigned it to Launcelot Andrewes, towards his better maintenance at the University (Pat. 23 Eliz. p. 2, m. 3). 


\section{A HISTORY OF HAMPSHIRE}

more closely than others. At eight in the morning the bishop, attended by his two chaplains, Matthew and Christopher Wren, came out from the chapel and greeted Captain Richard Smith, who gave to the registrar the instrument praying for the consecration. The following is an extract :-

I present unto you the state of the village of Weston and the hamlets of Itchin, Wolston, Ridgeway, and the part of Bittern mannor (being all of the Parish of S. Maries neer Southampton in the Diocese of Winton) as well in his own, as in the name of the Inhabitants of the said village, hamlets, etc., wherein are many Housholds, and much people of all sorts who not only dwell far from the Church, but are also divided from the same by the great River of Itchin, where the passage is very broad, and often dangerous; and very many times on the dayes appointed for Common Prayer and that service of God, so tempestuous, as the River cannot be passed; and so the people go not over at all; or if any do, yet they both go and return back in great danger, and sometimes not the same day. Besides, in the fairest weathers at their return from Church, they press so thick into the Boat for haste home, that often it proves dangerous, and even fearful, especially to women with childe, old, impotent, sickly people, and to young children; many times also they are forced to baptize their Children in private Houses, the water not being passable ; and when they lye sick, they are without comfort to their souls, and dye without any Ghostly advice or counsel; their own minister not being able to visit them, by reason of the roughness of the water, and other ministers being some miles off remote from them. ${ }^{1}$

After entering the chapel the bishop separately consecrated the font, pulpit, reading desk, altar, the place of matrimony, and the pavement with reference to bodies that might be interred beneath. In the afternoon the chapel yard was consecrated, the instrument presented by Captain Smith stating that through difficulty in crossing the water bodies had often to be buried in the open fields.

The Hampshire residence that Bishop Andrewes most frequented was Waltham, and it was here that he had a dangerous illness in I 624. It was here too that he had his beautifully appointed chapel adorned with what Prynne terms ' popish furniture.' Laud had inventories made of the fittings of Andrewes' chapels at Ely and in Winchester diocese, and reproduced them at Lambeth. These included silver candlesticks with tapers on the altar, censer and incense boat, cruets for water as well as wine, and 'a Bason and Ewer for the polluted Priests and Prelates to wash in before consecration.' ${ }^{2}$ The good bishop died in September, I 626, at Winchester House, Southwark. One of the earliest panegyrics on him says that he was "Doctor Andrewes in the schools, Bishop Andrewes in the diocese, and Saint Andrewes in the closet.' ${ }^{3}$

These were emphatically the days of bishops moving from one diocese to another, and Winchester, from its income and status, was peculiarly subject to translations. Richard Neile, the successor of Andrewes, who held this see for five years, was a striking example of

1 This form and particulars were printed in a small 24 mo book in 1659 . British Museum, press mark G. 2260. It was afterwards reprinted in Bishop Sparrow's Rationale.

2 See Prynne's Canterburies Doome (1646), pp. I $21-4$, with plan of the chapel and furniture.

${ }^{3}$ Isaacson's Life and Death of Andrewes, first printed in 1659; see also life by Rev. A. T. Russell, 1863. 


\section{ECCLESIASTICAL HISTORY}

this shifting policy. He successively filled six bishoprics, namely those of Rochester, Lichfield, Lincoln, Durham, Winchester and York. Neile is said to have been anxious to maintain the beauty and dignity of worship in the churches of Hampshire and Surrey that had been so much aimed at by Andrewes. He had the honour, when laymen began to sit in judgment on the doctrines and practices of bishops, of being bracketed with Laud (then Bishop of Bath and Wells) in a vote of censure passed by the House of Commons, as inclined to Arminianism and favouring popish doctrines and ceremonies.

On the translation of Neile to York, in 1631 , Walter Curle, who had only held two previous bishoprics, was moved from Bath and Wells to Winchester. He was in thorough sympathy with Archbishop Laud and heartily supported him in putting down the gross irreverence that had come about where the holy table was placed in the body of the church. In the royal chapels and in most of the cathedrals the altars had remained continuously in their old position. The rubric of the Prayer Books of 1552 , 1559 and 1603 had left the position apparently optional, and puritan feeling in many parish churches had removed it to the body of the church and had placed it east and west near the centre of the building, ' but it had been decided that the question of its position was to be left to the ordinary. Laud's contention was that Elizabeth's injunctions plainly ordered that the holy table in every church was to be set in the place where the altar stood, and he also pleaded the 8 and canon. We can find no case of Hampshire resistance to the ordering of the holy table being placed altarwise in the chancel and railed in, though in some parts of England this was fiercely contested. ${ }^{3}$ In Laud's metropolitical visitation of 1635 , the see of $\dot{W}$ inchester is reported as being 'well ordered.'

In 1639 , Bishop Curle held the last of his triennial visitations. There is a copy extant of 'The Articles to be enquired of by the Churchwardens and Sworn-men.' The queries are unusually elaborate and exhaustive. There are eleven articles touching the church; thirtythree as to the ministry, service and sacraments; two touching schoolmasters; five as to the parish clerk and sexton; twenty-six as to parishioners; and ten touching churchwardens and sworn-men."

In the days of the Civil War the great families of Hampshire were divided in their allegiance to the king or the parliament. Some of the most stirring incidents of the strife took place on Hampshire soil, notably the thrilling sieges of Basing House. The parish churches suffered

1 The rubric (which still stands) said : "The Table shall stand in the body of the churche or in the chauncell where mornyng prayour and evenyng prayour be apointed to be sayd.' It was held that this meant that if the chancel was disused (owing to the considerable diminution of assistant priests) and prayers said at the east end of the nave, the holy table should then be in the nave.

2 This is clearly the case (Wilkins' Concilia, iv. 138).

3 Laud's Works, iv. 121, 225-7, vi. 59-64. Bishop Davenant of Salisbury, of strong Calvinistic leanings, thoroughly supported Laud's view on this question. On the whole controversy see Hacket's Life of Williams and Heylin's Life of Laud.

4 They are of particular interest with regard to the liturgical and parochial customs of the day (British Museum, press mark 698, H. 20). The 'sworn-men' were the sidesmen. 


\section{A HISTORY OF HAMPSHIRE}

grievously in many districts, but chiefly through being held as strongholds by the one party or the other during the stress of war. On 12 December, 1642 , the parliamentary forces under Waller besieged Winchester, which soon yielded. The city compounded for $£ \mathrm{I}, 000$ to be saved from any general sack, but much violence was done to the cathedral church and its fittings. In March, 1643, Waller was again at Winchester, and levied $£_{6} 600$ from its inhabitants. Bishop Curle, Dr. Heylin and other distinguished churchmen remained in the county supporting the royalists. In October, I 645, Oliver Cromwell approached Winchester to effect its complete reduction. The castle was successfully assaulted, and the clergy of the close, together with the bishop and his chaplains, were suffered to depart. Bishop Curle retired to his sister's house at Soberton, where he died in 1647 .

On two occasions ( 1642 and 1646 ) the muniment room of the dean and chapter was ransacked by the soldiers, but the zeal of the chapter clerk, John Chase, recovered a considerable number of the documents. In I 649 the deanery and prebendal houses, which had been stripped of their lead, were given to various friends of the parliamentary party. In $165 \mathrm{I}$ a parliamentary committee advised that all cathedral churches, where there was sufficient other church accommodation, be surveyed, pulled down and sold for the use of the poor. Winchester in alarm petitioned, through their recorder, against this proposal, and nothing came of it. In 1654 there was a small collection made in the city towards the repair of its glorious minster, headed by some of the principal parliamentarians. ${ }^{1}$

The abolition of episcopacy by parliament in $164 \mathrm{I}$, the making even the private use of the Prayer Book penal, and the imposition of the Directory for Worship in 1644 , made little impression on a considerable portion of Hampshire where loyalty and Church principles were in the ascendant. But after the driving forth of the clergy from Winchester in I 645-6, the general ejection of all from their livings, save those who thoroughly abandoned episcopacy, was ruthlessly carried out. Their number and their sufferings were larger in Hampshire than in most counties, owing no doubt to the sustained resistance of the royalists in many parts of the county. ${ }^{2}$

In 1648 the dean and chapter estates throughout England were sold. From the general sum thus realized grants were made of $\oint_{1} 5^{\circ}$ each for nine months' service to Leonard Cooke and Humphrey Ellis, the two ministers appointed by parliament to serve the cathedral church of Winchester. ${ }^{3}$

\footnotetext{
1 Documents relating to the Hist. of Cath. Cburch of Winchester in Seventeenth Century (Hants Record Society, 1897).

2 See Walker's Sufferings of the Clergy, passim, and Dioc. Hist. ch. xv. Peter Heylyn, the historian, rector of Alresford, is the most interesting case. He had been so active a supporter of Laud that Waller, when the first parliamentary army entered the county, sent a troop of soldiers to arrest him, but he escaped and joined the king at Oxford. His house and library were stripped and he was reduced to destitution. Nominally the ejected clergymen and their families were entitled to a fifth of the living, but this rule worked very fitfully and had many exceptions.

's Shaw's Hist. of the English Church during the Commonwealth, ii. 543.
} 


\section{ECCLESIASTICAL HISTORY}

The elaborate Presbyterian system, with its classis organization, which existed on paper for the whole country, took firm hold for a time in certain shires. Hampshire was one of those counties that was the least affected by it. Evidence is forthcoming of ordination by presbyters at Newport, Isle of Wight, and at Bishopstoke, near Southampton, so there may have been a classis in the Isle of Wight and another on the mainland. ${ }^{1}$ Independency had the upper hand in Hampshire from 1646 to 1660 .

In 1650 an important survey of the whole of the benefices of England was undertaken by the Commonwealth, most of the returns being now at Lambeth Library. The report on Southampton was drawn up on 20 June, when evidence was given before the mayor (Christopher Walleston), aldermen and burgesses. The value of St. Mary (with St. Paul) was declared at $\oint_{0} 300$. Of this sum $\oint_{0} \mathrm{r} 70$ went out of the parish, Roger Turner of Jesus Chapel having $f_{4} 4$, the residue being equally divided among the ministers of the town 'for there paynes in preachinge by turne in the Parishe Church.' The balance went to Walter Bright, who is described as the parson of St. Mary. All Saints was returned as a rectory worth $f_{0} 22$, and without a minister; St. Lawrence, a vicarage, $\oint_{3} \mathrm{I}$, Nathaniel Robinson, minister ; St. Michael, a vicarage, $f_{1} 8$, John Toms; and St. John, a vicarage, $\oint_{7}$, and no minister. The chapel of God's House was used by the French congregation, who paid their minister, Daniel Savage. The commissioners recommended that St. Mary and All Saints, St. Cross and St. Lawrence, and St. Michael and St. John should be respectively united so as to form three parishes instead of six. ${ }^{2}$

Occasionally these returns present special points of interest, of which the following will serve as an example:-

The returne for the parishe of Yarmouth in the Isle of Wight concerning the inquiry to be made for preachinge ministers and mayntenance for them \&c. There is a small Parsonage here only belonginge to this Towne. The said Parsonage is not worth above twenty markes per annum, one yeare with another at utmost. There is one Master Richard Faulkener, a feeble old man who was onley a Reader here for neare thirtie yeares till he was putt out by order sixe or seaven yeares since for his debility and insufficiency and hath and doth receive the profittes of our Parsonage for his livelyhood, having noe other meanes to mayntain him. Wee have noe preaching minister here at all, neither have had a long tyme albeit there are about foure hundred soules in our Towne and all the howses compact neere together, and noe other Church within a myle of us, and that is a very small one twoe, and if the tide be up it is above twoe miles thither. Wee have onely one Church in our Towne which is large enough and well fitted for all our congregation, onely wee want a godlie preaching minister which is rare, and the Towne's humble desire may be speedily obtayned for the glory of God and the comfort of our poore soules. Thomas Byles. William Prickett. John Griar. William Hide.

The differences between Presbyterians and Independents brought about an agitation for the abolition of tithes, which came to a head in 1653 .

1 Shaw's Hist. of the English Church during the Commonwealth, ii. 30, 393.

2 Commonwealth Surveys, Lambeth, xv. 476-95. 


\section{A HISTORY OF HAMPSHIRE}

' The humble petition of the County of Southampton, subscribed at the late Assizes held at Winton, by the Grand Jury and neer 8000 of the Gentry, Freeholders, and other Inhabitants of the said County' set forth, in a wordy preamble, that a learned and godly ministry such as now for the most prevailed, though amid much opposition, was the greatest blessing that England enjoyed, and prayed definitely, under four heads, that (I) the universities with other schools and nurseries of religion and learning might be continued; that (2) tithes and other settled maintenance for ministers may be upheld; that (3) 'unsavory salt may be cast out, and such as know not the worth of souls and are only skilful to destroy them may be removed '; and that (4) there may be a settled order established for the admission to the ministry of those who are orthodox and fitly qualified. On Friday, 8 April, 16 53 , Major Hooker, Captain Terry and Captain Chase, who had been desired by the justices and grand jury and the other Hampshire petitioners to represent them, presented this county petition personally in the House of Commons. After the petitioners had withdrawn, the House resolved that the petitioners be recalled and that Mr. Speaker should give them the thanks of the parliament, and to let them know that some of the other matters contained in the petition were already under consideration and that the rest would be considered in due time. ${ }^{1}$

After an ineffectual attempt by the minority to abolish tithes, a committee was appointed on 10 July to consider the propriety and legality of their payment. It did not report until the following December, and meanwhile Hampshire again petitioned.

On 28 September, I6 53 , Mr. Hooker, the recorder of Winchester, with four other esquires of the county, presented a petition to the parliament from ' many of the well-affected of the County of Southampton and town and county thereof' in favour of the continuance of tithes. The recorder's speech and the petition itself both allege that they were moved to take this action because of a petition in the contrary sense lately presented from the county of Kent. They argued that tithes were of above 500 years' growth and had been confirmed by Magna Charta, and that their abolition would be grievous both to ministers of the gospel and to impropriators and to their respective families. The petitioners withdrew and after a short debate were again called in, and the Speaker made the following meaningless answer: 'That the House had commanded him to give them thanks for their good Affections; and that the particulars by them petitioned for were under debate, and the Parliament will proceed therein as God shall direct them.' ${ }^{2}$

It is a mistake to imagine that the Commonwealth was a period of toleration. The Presbyterians and the Independents found it necessary to conclude a truce, which also embraced the Baptists; but for Anglicans, Romanists, Quakers and Unitarians there was nothing but persecution. The Quakers suffered most severely, though their continuous interruption of the worship of others was most provocative.

1 Brit. Mus., King's Pamphlets, E. 693, iv.

2 Ibid. 714. 


\section{ECCLESIASTICAL HISTORY}

In 1655 ' the priest of Basingstoke,' in company with a justice of the peace, caused certain Quakers to have the oath of abjuration tendered them, and on their refusing they were committed to gaol for fifteen weeks. In 1656 Ambrose Rigg, " for uttering a Christian Exhortation to the people in the place of publick Worship at Southampton '-or, in other words, for interrupting authorized service-was sent to prison, where he was soon joined by others, including two women, for a like cause. In the same year other Quakers were imprisoned at Winchester for giving 'Christian Advice' in the steeple-houses at Southwick and Baughurst. Between 1658 and 1660 divers Quakers were imprisoned and ill-used for refusing to pay tithes or steeple-house rates, and for declining the oath of abjuration at Winchester, Southampton and Portsmouth.

Their treatment did not improve with the restoration. At the Winchester Sessions, January, 1663 , a pitiful petition was presented to the justices from six of the imprisoned Quakers at Portsmouth, complaining bitterly of their treatment, and of the foul places at Portsmouth where they were detained-' in Felton's Hole the waves of the sea have so beat in on one of us in winter seasons that he has stood in water up to his ankles, for the which things the Lord God hath and will visit them that were the actors therein.' In the next few years many were imprisoned, especially in the Southampton district, under the Conventicle Act, and usually provoked the magistrates by insisting on wearing their hats in the courts. The cattle of others were seized at Bramshott and Headley for refusing to pay towards the charge of the militia. In 1672 nine Quakers were released from prison in this county in accordance with the King's Declaration. Distresses for tithes and occasional imprisonments for attending meetings continued year by year in different parts of the county up to $1688 .^{1}$

When the restoration of monarchy and episcopacy came in 1660 , Bishop Curle was dead, as well as Dean Young, and just half of the whole cathedral staff. A considerable number of the old beneficed clergy were at once reinstated in their former livings, but upwards of one half of the parochial clergy of Hampshire had been appointed during the Commonwealth, many of them by the direct interference of parliament, who claimed to present to all the livings whose patrons were delinquents. Nine of the old bishops survived. Among them was the pious Brian Duppa, who had been successively Bishop of Chichester and Salisbury. $\mathrm{He}$ had lived in privacy during the Commonwealth at Richmond, Surrey, being chiefly engaged in the writing of doctrinal books, and in secretly preparing and ordaining young men for the ministry. At the restoration, he was translated to Winchester, but only held the see for two years.

His successor was George Morley, who went into exile during the Commonwealth, and acted as chaplain at the Hague to the Queen of 


\section{A HISTORY OF HAMPSHIRE}

Bohemia, sister to Charles $I$. At the restoration, he was first appointed Bishop of Worcester.

An elaborate series of articles of the primary visitation of his diocese were issued and printed by Bishop Morley in 1662. ${ }^{1}$ They go more into detail than some others of the same date. Inquiries are made whether the font is of stone and if it has a good cover, also if there is ' a Bier with a black Hearscloth for the Burial of the dead.' Inquiries were also made if the clerk or sexton kept the church 'clean from dust, cobwebs, and other annoyance,' and if the churchwardens saw that none ' sit, lean, or lay their hats upon the Communion-table,' and also permitted ' no minstrels, no morris-dancers, no dogs, hawks, or hounds to be brought or come in to your Church to the disturbance of the Congregation.'

After two years of grace the beneficed ministers were required, under pain of deprivation, " to declare their unfeigned assent and consent to all and everything contained in and prescribed by the Book of Common Prayer,' and those who had not received ordination were to submit themselves to the bishop. On St. Bartholomew's day, 1662, in Hampshire as elsewhere, a considerable number of beneficed ministers (though certainly a smaller number than the previously ejected episcopalians) had to withdraw from their cures. ${ }^{2}$ All honour to those, whether prelatists or nonconformists, who preferred freedom of conscience to the allurements of a settled income and a cosy parsonage. The men in those changeful times to be really pitied were those who clung to their benefices right through that period, easily changing their profession of faith in accordance with that of the dominant power.

Among those Hampshire incumbents to be honoured for their consistency in declining conformity was Nathaniel Robinson of All Saints, Southampton, who had been one of Cromwell's chaplains, and had arranged the marriage between Richard Cromwell and Dorothy Mayor of Hursley; John Warren of Romsey, who is said by Calamy to have refused two bishoprics; and Walter Marshall of Hursley, who was a fellow of New College and author of an appreciated book, The Gospel Mystery of Sanctification. These and many others speedily became the founders of Presbyterian or Independent congregations. Just at first these nonconformists were left alone and allowed to form themselves into congregations for worship, but Charles II.'s desire for toleration was soon overcome by the parliament, who dreaded the reintroduction of popery.

The Church was outwardly strengthened but inwardly and spiritually weakened by such legislation as the Five Mile Act, the Conventicle Act and the Sacramental Test Act. The severity of treatment accorded to the Quakers during this period, already mentioned, applied almost equally to other nonconformists of Hampshire, particularly about South-

1 There is a copy in the British Museum, press mark 5155, C. 52.

- Grcen's account of the causes for expelling parsons during the Civil War is another of the grave blots on his history. He must have known that the use of the Prayer Book in public or private was prohibited, and that no orderly minded ordained priest could possibly have retained his benefice under such conditions (Hist. of Eng. People, viii. ch. 1). 


\section{ECCLESIASTICAL HISTORY}

ampton, which was their stronghold. Isaac Watts, deacon of the Independent Meeting House of Upper Bar, ${ }^{1}$ Southampton, was in the gaol of Southampton for a religious offence at the time of the birth of his son Isaac in I674, as well as in the following year. It is to the young Isaac Watts, son of a Southampton clothier, born in the stress of a bigoted persecution, that the whole Church owes that noble rendering of Psalm xc., ' Our God, our help in ages past.' This inspired hymn of the Hampshire lad was first sung from manuscript, line by line, in the humble Southampton meeting house where his father was deacon. Surely it is a sign of more generous days that this truly catholic hymn was the one selected to be sung at the great commemorative service for Archbishop Laud in All Hallows Church, Barking, on 10 January, I 895 , before Bishop Creighton's sermon; and that on I J January, I 90I, it was again sung by archbishops and bishops, king's representatives and lord mayors, round the grave of Bishop Creighton in the cathedral church of St. Paul.

The licentious Charles was fond of Winchester, and Wren began for him here a magnificent residence on the lines of Versailles. Oft as the story has been told, it must here be chronicled how bringing with him, on one of his last visits to Winchester, Nell Gwynne, he requested Prebendary Ken to receive her as his guest, but Ken flatly refused. Soon afterwards (1684) Bishop Morley died, and Peter Mews was translated to Winchester. There were many applications for the see vacated by Mews. "Where is the little man who would not give poor Nelly a lodging,' said the king ; 'give it to him.' In this worthy way the saintly Ken became bishop of Bath and IVells.

The suspension, by the king's indulgence in I672, of the penal laws against worship other than that of the Church of England, which was however speedily set at nought by the parliament, brought to light the strength of nonconformity in Hampshire. Licenses had to be obtained from London for permission to assemble. The returns show that there were 39 licensed for Presbyterian worship or as residences of their ministers, 26 Congregational and 5 Anabaptists. ${ }^{2}$

The boldest application made for a license was for one in the centre of the cathedral city. Samuel Tomlins, Presbyterian minister of Upham, applied for a license to hold services in the house of Anne Complim, 'over the market house, Winchester.'

1 The records of the Independent chapel of Upper or Above Bar, Southampton (founded in 16 \$2), of which Cromwell's chaplain Robinson became the minister in 1662 , show that it was originally a curious amalgam of Presbyterianism and Independency, there being both elders and deacons at the same time (From information kindly supplied by Mr. Charles Cox, ser. deacon).

Presbyterian at Alton, Andover (2), Ashmansworth, Bredland, Brocklehurst, Clatford, Crondal (2), Christchurch (2), Easton (2), Emsworth, Eling, Farnborough, Fordingbridge, Godshill, Gosport, Havant, Hayling (2), Kingsclere, Lymington (2), Lower Clatford, Longstock (2), Longparish, Odiham, Portsmouth, Ringwood, Romsey (3), Sopley, Southampton and Winchester (2). Congregational at Andover, Binsted, Castlehold, Droxford, Fareham, Gosport, Hayling, Hythe, Lymington, Nether Wallop, Newport, Odiham, Romsey (2), Southampton (2), Sutton, Southwick (2), Titchfield, Wherwell, Weston, Westcourt (2), Upper Wallop and Yarmouth. Anabaptist : Broughton, St. Mary Bourne, Waltham (2), Whitchurch and Upper Wallop (Calendar of Stase Papers, Charles 11.88 b. 88 c. passim.).

3 Dom. State Papers, Charles 11. cccx. 72. 


\section{A HISTORY OF HAMPSHIRE}

In the Salt Library, Stafford, is an invaluable MS. return of the population of the province of Canterbury over sixteen years of age, for the year 1676, divided into three classes: "Conformists, Papists and Nonconformists.' It was drawn up by order of Henry Compton, Bishop of London, and was obtained from the clergy at the archidiaconal visitations. The following are the figures for the ten rural deaneries of Hampshire :-

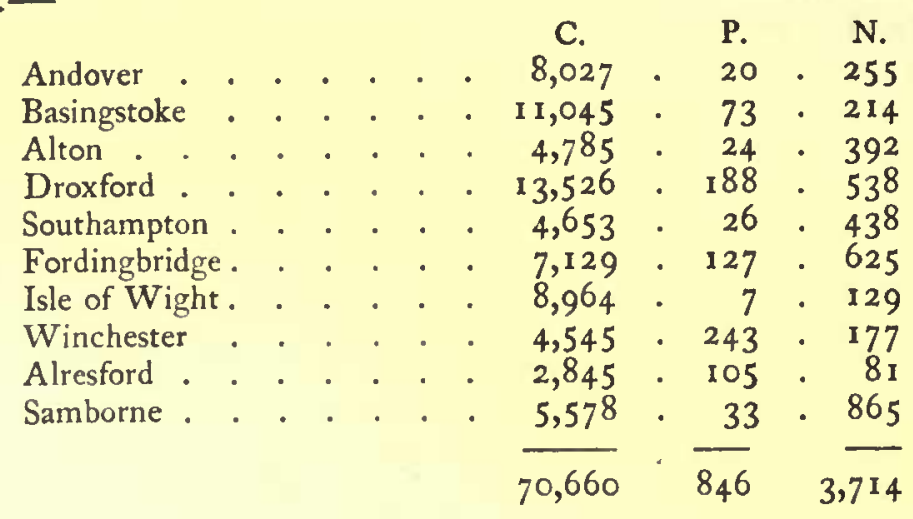

The proportion of Roman Catholics may not seem large, but it is nearly the largest of any county in England.' Although this little known and seldom cited return is probably not exactly correct, and most likely somewhat understates the numbers of both papists and nonconformists, it is found when tested by other returns to be approximately accurate. To form a general total of the whole population, when the numbers given are of those over sixteen years of age, it is necessary to add about forty to every hundred.

The parishes or chapelries where the proportion of Roman Catholics was the largest were: Bedhampton, where there were I 2 papists to 45 conformists and 2 nonconformists; Twyford, where there were 70 papists and 430 conformists; Tichbourne, where the papists numbered 24 to the conformists' 79 ; and Otterbourne, where the papists were 54 out of a total population (over sixteen) of 189 . The proportion of nonconformists was largest at Romsey, where they numbered 777 to 3 papists and 1070 churchfolk; and at Porchester, where they numbered 140 to 5 papists and 175 churchfolk.

Bishop Mews was a remarkable man. He was an Oxford graduate, and for a time president of St. John's College, who took service in the royalist force raised by the university in 1642 , obtaining the rank of captain and being one of the numerous prisoners taken at Naseby. He was an active messenger (being an adept in disguises) between the continent and England and Scotland in the royalist interest during the Commonwealth. The date of his ordination is not known. After the restoration he obtained rapid and abundant promotion. Soon after his translation to Winchester the militant bishop had an opportunity of displaying his

1 The papists of Derbyshire were somewhat higher in proportion; the figures for that county were: C. 47,151 ; P. 588 ; N. 918 . The diocese of London had 2,069 papists, but the conformists were 263,000; the diocese of Lincoln had 1,244 papists out of 215,000 conformists. 


\section{ECCLESIASTICAL HISTORY}

warlike proclivities. The Monmouth rebellion obtained considerable support in parts of Hampshire, the mayor of Lymington, Colonel Dore, proclaiming him king and raising a troop in his service. The Bishop of Winchester, though over seventy, at once took the field. At Sedgemoor it was the bishop's horses that drew the cannon and the bishop's hands that directed the decisive fire. Mews received at Sedgemoor a wound from which he suffered during the remainder of his life. It is pleasant to know that he afterwards interceded for the lives of the rebels, bearding even the ruffian Jeffreys. This rebellion led to perhaps the most infamous execution that has ever disgraced Winchester. Alice Lisle, of Ellingham, a widow of three score and ten, the second wife of John Lisle, ' a regicide,' but one of the most distinguished men in the Commonwealth service, gave shelter to John Hickes, a dissenting minister who had been an active supporter of Monmouth, but whom Lady Lisle believed to be escaping from a warrant for illegal preaching. She was arrested for harbouring a traitor, and Jeffreys, at the special commission at Winchester in August, I 685 , surpassed himself in brutal browbeating and bullied the jury into finding her guilty of this capital charge. On 28 August, Jeffreys sentenced her to be burnt alive the same afternoon. The bishop's pressure secured a respite of a few days, and an alteration in the sentence. The aged lady, daughter and heiress of Sir White Beckenshaw of Moyles Court, Ellingham, was beheaded in the market place on 2 September, 'the victim of a judicial murder.'

At the revolution of 1688 , Mews took the oaths to William and Mary. The nonjuring movement did not take much hold of the Hampshire clergy. The following were those who were then deprived : William Hanbury, rector of Botley; Edward Worsley (son of Sir Edward Worsley), rector of Gatcombe ; Charles Buchannan, vicar of Farnborough ; Mr. Flood, curate of Ringwood ; and Mr. Kilback. Of Mr. Buchannan it is said that he was 'first a Complier, then a Recanter, afterwards complied again."

Bishop Mews died in 1706, at the age of eighty-nine, and was followed by Sir Jonathan Trelawney, translated from Exeter. During the time that he held the see of Bristol, Trelawney was one of the seven bishops who were put on their trial for resistance to the indulgence of James II. But his opinions underwent strange changes. In his visitation charge on first entering Winchester diocese he announced that he was equally hostile both to papists and the 'furious sects of dissenters.' Trelawney finished the rebuilding of the palace of Wolvesey, which had been begun by his predecessor, and resided there when in Hampshire.

The most distinguished clergyman in Hampshire at this time was Joseph Bingham, author of that classical work, The Antiquities of the

1 Sidney Lee, Dict. of Nat. Biog.

8 Life of Kettlewell (1718), Appendix 6. The British Museum copy has MS. additions and alterations. Bowles' Life of Bishop Ken, ii. 18 z.

This charge and a sermon were privately printed in 1877. British Museum, press mark 4473, P. 4 .

II

97 


\section{A HISTORY OF HAMPSHIRE}

Cbristian Church, in ten volumes. He held the small living of Headbourne Worthy until Bishop Trelawney collated him in 17 I 2 to Havant.

On Trelawney's death in 172 I Bishop Charles Trimnell was translated from Norwich to Winchester, but only survived the change for two years. From the dedication that Bingham prefixed to the last two volumes of his Antiquities, it may be gathered that he was a zealous and conscientious administrator of his new diocese. He was a prolific writer of the Whig school, and held most pronounced latitudinarian views on the subordination of the Church to the State.

To the same school belonged Bishop Richard Willis, who had previously held the sees of Gloucester and Sarum. Benjamin Hoadly, who succeeded to Winchester in 1734 and who had been successively Bishop of Bangor, Hereford and Sarum, was far more of a vehement controversialist of the extreme latitudinarian and political school than a diocesan administrator. The value that he set upon the office that he held can be judged from the fact that during the six years he held the bishopric of Bangor and drew its emoluments the diocese never once saw him, and it is supposed to have been the same with Hereford. To him belongs the shame of being the cause of the suppression of Convocation for nearly a century and a half. Two years after his acceptance of Winchester he endeavoured, in a charge, to allay the feeling of his clergy against him by a laboured defence of his writings, particularly of the painful Plain Account of the Nature and End of the Sacrament of the Lord's Supper. The mere list of his printed pamphlets, sermons and controversial books occupies thirty columns of the British Museum catalogue. He much neglected his diocese, and died in $176 \mathrm{r}$ at the age of eighty-five.

Whilst the spiritual interests of Hampshire were being thus neglected in high places the warmth of the personal preaching of John Wesley naturally made itself specially felt. In 1753 this great itinerant preacher records his first impression of Portsmouth, where he preached on the Common on Sunday evening, 8 July. Wesley was favourably impressed, and describes the people as the most civil of any seaport in England. He does not give too good an account of the inhabitants of Newport, whom he visited on the following Tuesday. In October Wesley again visited the Isle of Wight, Portsmouth and Southampton. He was not here again till October, I 758, when he preached in Mr. Whitefield's tabernacle at Portsmouth. In 1767 his journal records another visit to Portsmouth in the month of October, and from that year down to 1790 Wesley hardly ever let a year go by without his annual October visit to the great seaport and the Isle of Wight. Winchester was also visited with some regularity between I 766 and 1789 . Wesley was at Winchester on Friday, 10 October, ${ }^{1} 783$, when he entered in his diary that 'a clergyman having offered me his church, I purposed beginning at five; but the key was not to be found; so I made a virtue of necessity, and preached near the Cross Street; probably to double the congregation which would have been in the church.' 


\section{ECCLESIASTICAL HISTORY}

The sad condition of things engendered by the lax administration and neglect of the Whig Bishops of Winchester throughout the eighteenth century was not improved by the translation to this see, on the death of Hoadly, of John Thomas, who had obtained his preferment through being tutor to George III., and who had already occupied the sees of Peterborough and Salisbury.

Brownlow North, who was successively Bishop of Lichfield, Worcester and Winchester ( $178 \mathrm{I}$ ), owed his promotion to being halfbrother of the premier, Lord North. The current tradition, cited in the Diocesan History, that Bishop North once examined certain candidates for ordination on the cricket field is as much a reflection on the laxity of the age as on that of the individual bishop. Nevertheless there was some real church life in the county under Bishop North, especially when the nineteenth century had opened. Between 1804 and his death in 1820 , the bishop consecrated new churches at Dogmersfield, Whippingham, East Stratton, Micheldever, Chilworth, Fareham, Wyke and Baddesley. It would be doing a wrong to Church history to be silent as to the flagrant nepotism of this episcopate. Long leases of Church property were granted by Bishop North to members of his family on nominal fines. He appointed a nephew and namesake (afterwards a well known lay preacher) to a lucrative patent office when a babe in arms. The mastership of St. Cross bestowed on his son Francis, afterwards Earl of Guildford, and the outrageous misuse of the hospital funds, became a public scandal. A public inquiry in 1853 resulted in the Master of the Rolls declaring the matter 'a manifest and probably wilful breach of trust' and that the distribution of the revenues was ' in direct opposition to the evidence and documents in their own custody.'

To the tutor of George III. and the brother of a prime minister succeeded the tutor of William Pitt. Sir George Pretyman Tomline was appointed to the bishopric of Lincoln and the deanery of St. Paul's in 1787 , and thence (after Pitt had failed in his efforts to promote him to Canterbury) translated to Winchester. He ruled the diocese for seven years with some zeal, but will be chiefly remembered for Sydney Smith's caustic attacks on his nepotism.

A far happier era began in 1827 , with the translation from Llandaff of Charles Richard Sumner, whose earnest episcopate lasted for forty years. ${ }^{1} \quad$ His very first act on his translation was an augury of the interest Bishop Sumner took in his work, for he was enthroned in his cathedral

1 His first clerical promotion gave rise to a cabinet crisis and nearly to a change of ministry. In May, 182I, Lady Conyngham, George IV.'s favourite, asked the king to give Mr. Sumner a vacant canonry at Windsor and the king assented. Lord Liverpool, when he heard of it, posted down to Brighton and said that if he was not allowed the distribution of patronage he should resign. The Duke of Wellington and all his colleagues joined in the remonstrance against the presentation of Mr. Sumner and it was cancelled. However in 1826 the king gave Mr. Sumner the bishopric of Llandaff and next year that of Winchester without consulting the premier or ministers of 2 weaker cabinet (The Greville Memoirs, i. 467, 117 ; Correspondence of Duke of Wellington, i. 195). It is however kindly and justly said by the editor of the Greville Memoirs that if C. R. Sumner 'owed his early advancement to questionable influence, no man ever filled the office with more unaffected piety, dignity and goodness.' 


\section{A HISTORY OF HAMPSHIRE}

church in person. By the middle of the century any other action would have been considered a scandal, but it is a fact that from the Reformation until 1827 every Bishop of Winchester had been enthroned by proxy. An earnest and conscientious evangelical, and confining his preferments to clergy of that school, Bishop Sumner was nevertheless respected and esteemed by the whole of his diocese. He held an exhaustive visitation of Hampshire and the rest of the see in $1828 .^{1}$

From that date until 1868 , when seized with paralysis he resigned the see, the good bishop's life was one of continued faithfulness and vigour. In a 'Conspectus' that he drew up in 1864 it was shown that up to that date Bishop Sumner had consecrated in Hampshire eight new churches as well as sixty-five which had been rebuilt.

During his time extensive changes were made in the arrangements of the see of Winchester. The Ecclesiastical Commissioners, appointed in 1836 , at the very threshold of their work ordered that $f_{3} 3,600$ a year should be paid by Winchester towards the augmentation of the smaller sees, and in $185 \mathrm{I}$ the bishop's income was fixed at the next avoidance at $f_{0} 7,000$. This was afterwards diminished to $f_{0} 6,500$ by Bishop Browne's assignment of $\oint_{0} 500$ to the new bishopric of St. Albans. In Victoria's reign the boundaries of the see have been altered at three different dates, but those changes have not affected Hampshire and the Isle of Wight.

Four grand and eminent examples of different schools of thought within the Church of England were closely connected with Hampshire during the nineteenth century. Legh Richmond (1772-1827), the pious evangelical divine, was ordained to the curacy of the parishes of Brading and Yaverland in the Isle of Wight; his narratives of $\mathcal{T}$ he Dairyman's Daughter and The roung Cottager were at one time the most popular religious works in England. John Keble (1797-1866), poet and divine, was rector of Hursley from $18{ }_{3} 6$ to the end of his life. Charles Kingsley (1819-75), Christian socialist and author, was rector of Eversley from 1844 to the time of his death. Richard Chevenix Trench (1807-86), poet and divine, held curacies in Hampshire from 1835 to 1844 when he was appointed to the rectory of Itchenstoke, which he resigned for the archbishopric of Dublin in 1863 .

Of the three last well known Bishops of Winchester, Samuel Wilberforce, Edward Harold Browne and Anthony Wilson Thorold, and of Randall Thomas Davidson, the present occupant of the see, it will suffice here to say that in their administration of a high office Hampshire and the diocese at large have been exceptionally favoured.

1 The life of the good bishop issued by his son in 1876 falls into several mistakes in his contrast of Sumner's energies with his predecessor's laxity. For instance it is stated as to visitations that 'no queries had been officially issued in the diocese since 1788.' This is quite wrong ; it is due to Bishop North to state that visitation articles were issued and printed in 1801 . 


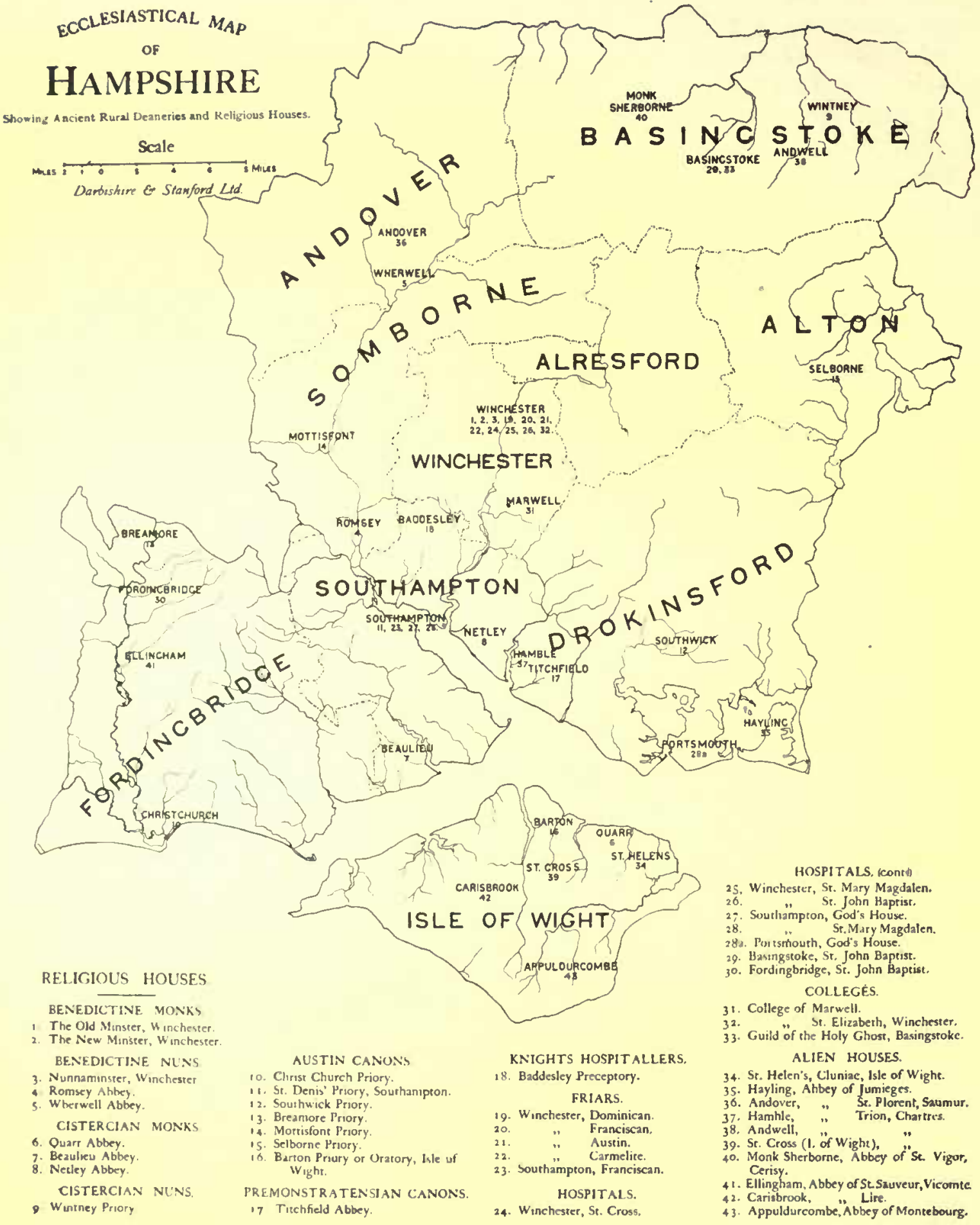

[The Victoria History of the Counties of England] 


\section{ECCLESIASTICAL HISTORY}

\section{APPENDIX NO. I \\ ECCLESIASTICAL DIVISIONS OF THE COUNTY}

The district now known as Hampshire was during the middle part of the seventh century in the diocese of Dorchester. In 676 Bishop Haedde moved the seat of his bishopric to Winchester, and in the diocese of Winchester this district has always been from that date, although the bishopric was in 705 divided into the dioceses of Winchester and Sherborne, ${ }^{1}$ and again in 709 the then existing bishopric of Winchester was divided into the dioceses of Selsey and Winchester."

From I 291, the date of Pope Nicholas' taxation, ${ }^{3}$ till the archdeaconry of the Isle of Wight comprising the whole of that island was formed in $187 \mathrm{I}$, the county was co-terminous with the archdeaconry of Winchester. The rural deaneries within this archdeaconry were, in I $29 \mathrm{I}$, ten in number, namely Alresford, Alton, Andover, Basingstoke, Drokinsford, Fordingbridge, the Isle of Wight, Sombourne, Southampton and Winchester. ${ }^{.}$According to the Valor Ecclesiasticus ${ }^{6}$ taken in I 535 they were at that date the same, except that the rural deanery of Alresford was included in that of Andover, but this is clearly a mistake caused by the omission of the heading of the former rural deanery, as all the parishes in Alresford deanery are taken together at the end of that of Andover. The rural deaneries remained practically unchanged till i 850 , when the Isle of Wight was divided into the rural deaneries of East Medina and West Medina." About 1856 the archdeaconry of Winchester was re-constituted and the rural deaneries were increased to twenty-four, namely Alresford, Alton East Division, Alton West Division, Andover North-East Division, Andover North-West Division, Andover South-West Division, Basingstoke South-West Division, Basingstoke North-East Division, Chilbolton, Droxford North-East Division, Droxford South-East Division, Droxford South-West Division, Droxford North-West Division, Fawley, Fordingbridge East Division, Fordingbridge West Division, Micheldever, Odiham, Somborne, Southampton, West Meon, Winchester, East Medina and West Medina in the Isle of Wight. Some further alterations were made about fifteen years later when the deaneries were reduced to twenty-one, namely Alresford, Alton, Alverstoke and Portsea, Andover North Division, Andover West Division, Andover South Division, Basing South-West Division, Basing NorthEast Division, Bishop's Waltham, Fawley, Fordingbridge East Division, Fordingbridge West Division, Havant, Odiham, Petersfield, Romsey, Southampton and Winchester. By order in council of I 8 April, I878, the rural deaneries of Surrey were reconstituted, and the parish of Bentley

1 Anglo-Saxon Cbron. (Rec. Com.), i. 68.

2 Bede, Hist. Eccl. (Mon. Hist. Brit.), v. 18, and Matth. Paris, Cbron. Maj. (Rec. Com.), i. 323.

3 Pope Nich. Tax. (Rec. Com.), 210.

(5ope Nich. Tax. (Rec. Com.), 210.

1 London Gazette, 22 Dec. $187 \mathrm{I}$.

7 Clergy List, 1851, p. 281 .

- Valor Eccles. (Rec. Com.), ii. 7, etc. 


\section{A HISTORY OF HAMPSHIRE}

in the rural deanery of Alton was transferred to the rural deanery of Farnham in Surrey. ${ }^{1}$ The rural deanery of Alverstoke was by order of 4 February, 1 879, divided into the rural deaneries of Alverstoke and Portsea Island. ${ }^{2}$

By an order in council of 9 May, 1892 , the whole of the rural deaneries of Hampshire within the archdeaconry of Winchester were reconstituted and made eighteen in number, namely, Aldershot, Alresford, Alton, Alverstoke, Andover, Basingstoke, Bishop's Waltham, Christchurch, Kingsclere, Landport, Lyndhurst, Petersfield, Portsmouth, Romsey, Silchester, Southampton, Stockbridge and Winchester, and the archdeaconry of the Isle of Wight was divided into two rural deaneries of East Wight and West Wight. ${ }^{3}$ On 7 August, 1900, the name of the rural deanery of Landport was changed to Havant and a few parishes were transferred from one deanery to another."

\section{APPENDIX NO. II}

\section{SOME TYPICAL SEALS OF THE BISHOPS OF WINCHESTER}

The fine pointed oval seal of Richard of Ilchester (1 I74-88) (plate I.) represents the bishop standing on a platform, with right hand lifted in benediction and crozier in the left hand. In the field on the left hand is a hand holding a crozier, and on the right a pentacle. Legend : RICARDUS : DEI : GRATIA : wiNTONIENSIS : EPISCOPUS.

The reverse (plate I.) is a small pointed oval counterseal, with full length small figures of Sts. Peter and Paul, each having one foot on an orb. Legend : + SUNT - MICHI - SINT - Q - BONI - PETRUS - PAUL9Q - PATRONI.

The oval seal of Peter des Roches (1 205-38) (plate I.) gives the bishop standing on a corbel with right hand raised in benediction, and left hand holding a crozier. Legend : PETRUS : DEI : GRATIA : WINTONIENSIS : EPISCOPUS.

The pointed oval seal of John of Pontoise (1282-I 304) (plate I.) gives a full length figure of the bishop in the usual attitude. In the field, on the left, is a fleur-de-lis, and on the right two small flowers. Legend: + s. IOHANNIS : DEI : GRA : WINTONIEN : EPISCOPI.

John Stratford's seal (I $323-33)$ (plate II.) is a somewhat rude representation of the bishop in the customary attitude. Legend: sigirLUM - jo ...

William of Wykeham's (I 367-I 404) circular priory seal (plate II.) shows excellent workmanship of its date. In the upper canopy are the Virgin and Child in a niche; below them are two other saints. Ir. larger niches on each side are figures of St. Peter and St. Paul. In base is a shield of arms, two chevrons between three roses. Legend: SECRETUM : WYLLELMI : DE : WYKEHAM : EPI : WYNTTON.

1 London Gazette, 7 May, 1878.
3 Ibid. 13 May, 1892.
2 Ibid. 14 Feb. 1879.

I Ibid. 14 Aug. 1900. 
HAMPSHIRE EPISCOPAL SEALS. I.

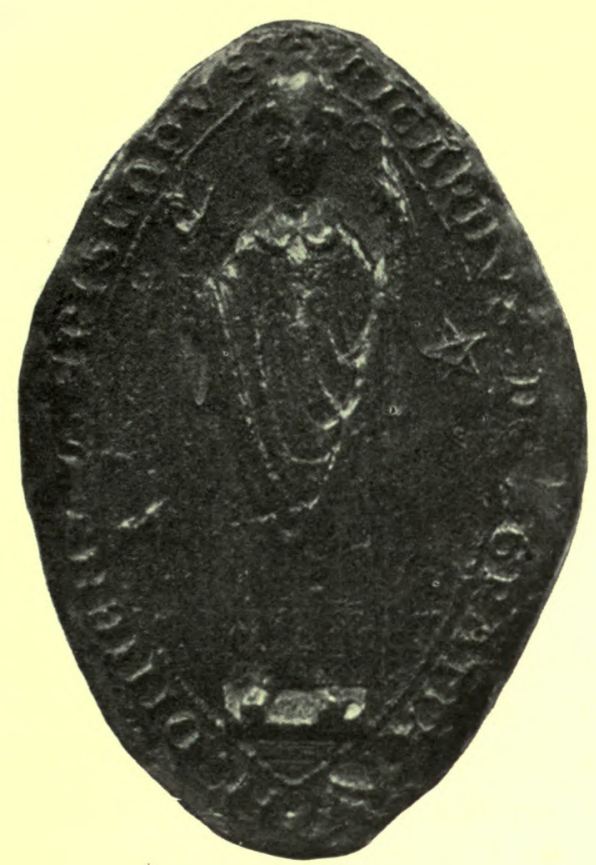

RICHARD OF ILCHESTER. (II74-I I 88.)

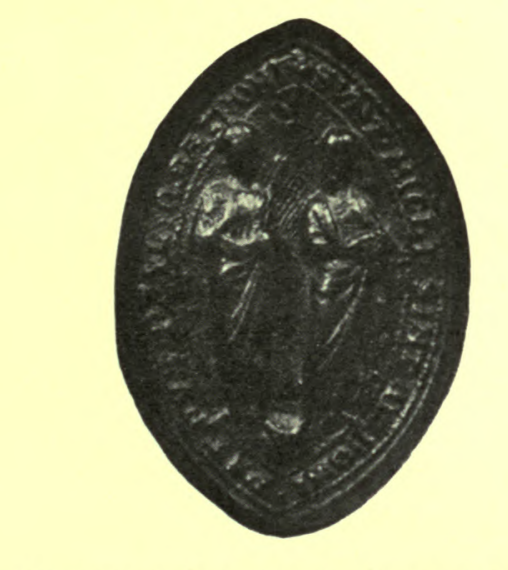

Richard of Ilchester. Counterseal.

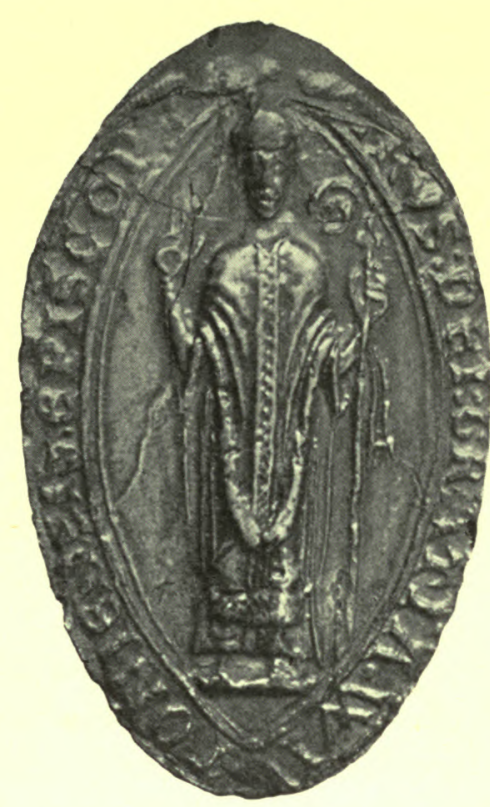

PETER DES Roches. (I 205-1238.)

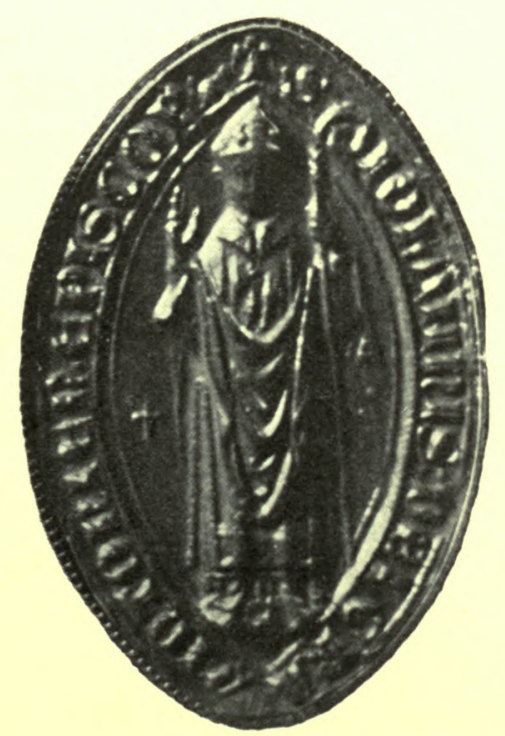

JOHN OF PONTOISE. (I282-1304.) 



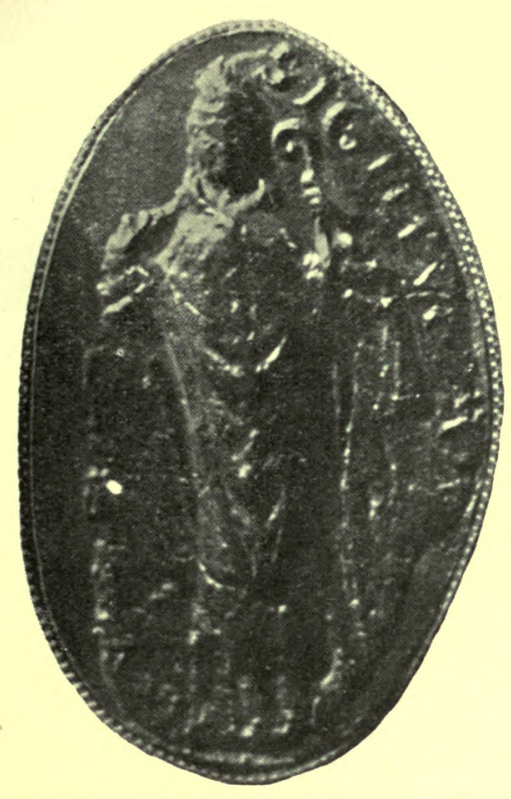

John Stratford. (1323-1333.)

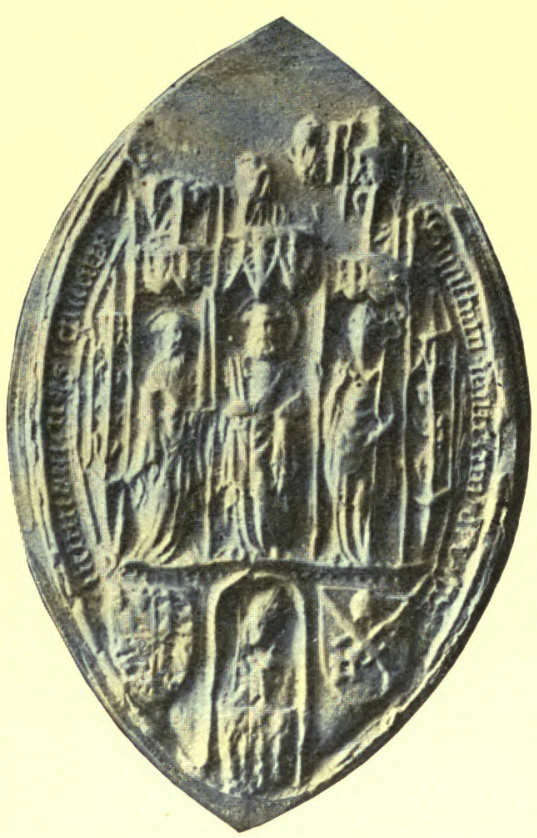

William Waynflete. (I447-I486.)

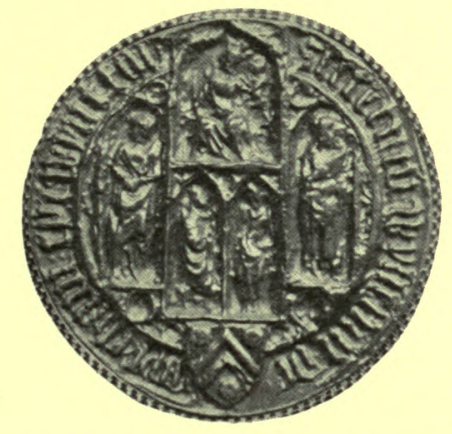

William of Wykeham. (1367-I404.)

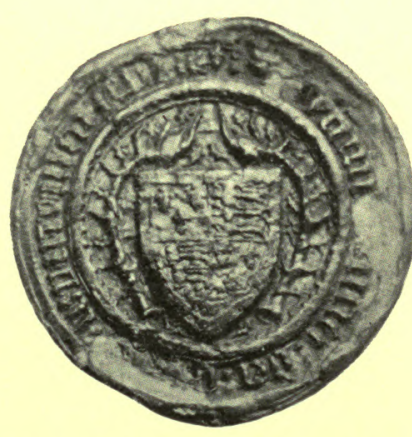

Henry Beaufort. (I405-1447.) 



\section{ECCLESIASTICAL HISTORY}

The circular privy seal of Henry Beaufort (1405-47) (plate II.) has quarterly the arms of France and England within a bordure compony. Legend : SECRETUM : HENRICI : DEI : GRATIA : WINTONIEN : EPI.

The large oval seal of William of Waynflete ( $1447-86)$ (plate II.) is an example of the overloaded and enriched seals of that date. In three elaborately canopied niches are figures of Sts. Paul, Peter and Swithun; in smaller niches on each side are two angels. In the base the bishop with crozier is kneeling, between the arms of the see of Winchester and of France and England. The group at the top of the seal is obliterated. Legend: SIGILLUM : WILLELMI : WYNTONIENSIS : EPISCOPI. 


\section{THE RELIGIOUS HOUSES OF HAMPSHIRE}

\section{INTRODUCTION}

So much interest is taken in the history of the various religious foundations which were suppressed in the days of Henry VIII. and Edward VI. that it is thought better to treat of them in a separate section, arranged according to the Order to which they belonged, apart from the topographical history." This arrangement will suit the convenience of readers who may be specially interested in the story of the religious houses generally, or of any particular branch; for there will be no necessity to look them up under a number of separate parishes scattered throughout the different hundreds. The account of the site or the condition of the remains and ruins will be given in the parochial history.

Hampshire, with Winchester as its centre, was so pre-eminent in the making of England and of England's Church, that it is not surprising to find that various large and influential Benedictine houses of royal foundation were established in its midst at an early date. Such were the Old Minster (643) and the New Minster (901) for Benedictine monks at Winchester, and the three large houses, with canonries attached, for Benedictine nuns at Nunnaminster, Winchester (circa 899), and at the abbeys of Romsey (circa 907) and Wherwell (circa 986).

The Cistercian or White monks had three houses in the county, namely Beaulieu (1 204) and her daughter Netley (1 239) on the mainland, and Quarr ( $\mathrm{I}$ I $3 \mathrm{I}$ ) in the Isle of Wight. There was also a convent of Cistercian nuns at Wintney (twelfth century).

The Austin canons had seven houses, namely the great priory of early foundation, termed Christ Church (eleventh century?), which was of such importance that it absorbed the name of Twyneham, where it was established; St. Denis, Southampton (circa II 24), founded by Henry I.; Southwick (I I 33) of like royal origin, but originally established at Porchester Church; the smaller houses of Breamore (close of reign of Henry I.), Mottisfont (circa I 200), and Selborne (1233), and the Oratory of Barton (I 275) in the Isle of Wight.

There was but one house of Premonstratensian or White Canons,

\footnotetext{
the map.

1 For convenience of reference the Houses are numbered in accordance with the numerals on
} 


\section{RELIGIOUS HOUSES}

namely that of Titchfield (1222), remarkable for its well-arranged library.

The military orders of both the Templars and the Hospitallers had property in the county, but it was only at North Baddesley (twelfth century) that there was a preceptory of the latter.

The four chief mendicant orders of itinerant friars had houses at Winchester (Dominicans, 123I-4; Franciscans, circa 1235; Austin Friars, temp. Edward I.; and Carmelites, I 278). The Franciscans were also established at Southampton about 1237.

The old hospitals of England were invariably closely connected with religion, and were not infrequently under the control of a master and brethren, or master brethren and sisters who followed the Austin rule; hence they were occasionally termed priories, and the master a prior. They were for the accommodation and relief of poor wayfarers and for the more permanent relief of the sick and infirm; hence they were found in or near towns, or, if for lepers, on the outskirts beyond the gates. Winchester had its three hospitals : the richly endowed St. Cross (I I 36), whose funds were often so grievously misused; St. Mary Magdalen (circa I 174-89); and St. John Baptist (1 275). Southampton had one of special interest in God's House (circa I I97), as well as the lazar house of St. Mary Magdalen (I 173-4). Portsmouth had another Maison Dieu (1 235-8) ; Walter de Merton turned the old hospital of Basingstoke ( $1230-40$ ) into a resting-place for aged and infirm priests; and there was another hospital at Fordingbridge (before 1282) of which but little is known.

Of colleges and collegiate churches Hampshire had but three examples, in addition to the great educational establishment of William of Wykeham. The usual college or collegiate church was in no sense a place of education, save that provision was occasionally made for the instruction of the quire boys. The college, though no two foundations were exactly alike, was a collection of secular priests, guided in their life by certain statutory rules which ensured a certain amount of common life, and whose chief occupation was the rendering of a continuous round of choral worship and the celebration of masses for the souls of the founders. Occasionally the chaplains or fellows had poor brethren living in the college or infirm and sick under their charge, but they were in the main large chantry foundations. The small country college of Marwell owed its origin to Bishop Henry de Blois (I I 29-7I), and the later and more important one of St. Elizabeth (I 30 I) at Winchester to Bishop Pontoise. To these must be added, in its later development, the Gild of the Holy Ghost at Basingstoke (before 1 244).

The chief feature however of the religious houses of the county was the number of alien priories. They were more numerous in Hampshire than in any other county, which was doubtless chiefly owing to the easy accessibility of so much of the shire, with its extensive seaboard, to visitors from Normandy.

The influence of these foreign monks from the great abbeys of II 


\section{A HISTORY OF HAMPSHIRE}

Normandy, ruling their large estate in the interest of parent communities that owed direct allegiance to a power with which England was so frequently at war, constituted at times a genuine national danger, and must have been a constant cause of local irritation.

There was probably a general feeling of satisfaction throughout Hampshire when these alien priories, that had been ruled with so much fickleness for more than a hundred years, were finally suppressed at the beginning of the fifteenth century; more especially as their revenues were merely transferred to other religious purposes.

The island of Hayling was owned by the powerful abbey of Jumièges, where the abbot established a priory probably in the twelfth century, the site of which is now beneath the sea; the abbey of St. Florent, Saumur, established a priory at Andover during the same period; St. Vigor, Cerisy, at Monk Sherborne (I I00-35); St. Sauveur Vicomte, at Ellingham (I 160); whilst the abbey of Tiron, Chartres, had three houses, namely at Andwell (early in twelfth century), Hamble (1098-1 128), and St. Cross (I 120) in the Isle of Wight. In the Isle of Wight the abbeys of Lire and Montebourg also respectively controlled the small priories of Carisbrook (circa i I 56) and Appuldurcombe (circa I I O0), whilst the house of St. Helen's (circa I 090) was of Cluniac foundation. Not one of these ten houses were conventual, that is, the inmates had no voice in the appointment of their superiors, who were sent across the seas by the Norman abbots and who could be withdrawn at pleasure.

The constitution of these alien priories has already been referred to in the ecclesiastical section, and their individual peculiarities are subsequently briefly discussed under their respective houses; but a word or two may here be permitted as to their treatment by the English Crown. It is easy to understand how they sprang up in England under the first kings of the Norman dynasty, but they soon became settlements of foreign monks, whose sympathies naturally centred in their homes across the seas, and whose main duties were the collecting and guarding of English rents and tithes that were sent year by year out of the kingdom to the parent house. King John was the first to seize the priories that were dependent on foreign houses, compelling them to pay into the royal treasury the sums or tribute-usually termed apport-which they had been in the habit of forwarding to the continent. In 1295, when Edward I. made war upon France to recover the province of Guienne, he had great difficulty in procuring the necessary funds for the campaign. He seized all the alien priories, numbering about a hundred, and used their revenues to fill his war chest. In order to prevent the foreign monks of the Isle of Wight and on the seaboard of Hampshire and elsewhere on the coast giving possible help to invaders, he deported many of them to other religious houses that were twenty or more miles from the coast. Edward II. subsequently followed this example, taking the alien priories into his own hands, but he not infrequently appointed their priors custodians for a consideration, obliging them to pay to the Crown 106 


\section{RELIGIOUS HOUSES}

the apport due to their superiors. If other custodians were appointed, reservation was however always made of a minimum sufficient to sustain the prior and the two or three monks who dwelt with him. When Edward III. came to the throne he restored many of the alien priories to their original owners and remitted the arrears of payments due to the Crown. But ten years later, when war broke out again with France, he reverted to the policy of his predecessors, and again seized the property of these French aliens. For twenty-three years these foreign houses remained in his hands; but with the peace of 1361 most of them were restored, only to be again sequestrated eight years later when the war was renewed. In the time of Richard II. the alien priories continued mostly in the hands of the Crown; they finally came to an end under Henry V. in 1414 , when those that had not been already assigned with the Pope's assent to other religious purposes, were suppressed and their estates vested in the Crown. The Crown however in the great majority of cases recognized its responsibilities and transferred the property to other monasteries, such as the Carthusian house of Sheen, or to colleges and schools for educational purposes. ${ }^{1}$

A large number of the religious houses of Hampshire were subject to diocesan visitation, but the three Cistercian monasteries, the house of White Canons, and the alien priories, as well as the priories of the mendicant orders and the preceptory of the Hospitallers, were exempt. It is a little remarkable to find that the Cistercian nunnery of Wintney was subject to the bishop. There were in the county, exclusive of the hospitals and colleges, thirteen houses visited by the Bishop of Winchester, whilst twenty were visited by commissaries of their own order.

The record of the visitations made by the commissary of the prior of Canterbury in 1501 is given under the respective houses for the first time, nor have the valuable reports of the 'mixed commission' of 1535 been hitherto printed. Numerous references to monastic visitations have also been obtained from the episcopal registers of Winchester. The lists of superiors have in several cases been materially extended from those supplied in the modern Monasticon. Information has been sought not only from the episcopal registers, but from original chartularies, and from the stores of the British Museum and Public Record Office. These sketches of the different religious houses make no pretence to be exhaustive in their treatment. Several of the Hampshire foundations well deserve monographs which have yet to be written.

1 There is a good summary of the history of the alien priories in Gasquet's Henry VIII. and the Monasteries, vol. i. ch. 2.

2 Kindly supplied by Mr. Leland S. Duncan, F.S.A. 


\section{A HISTORY OF HAMPSHIRE}

\section{HOUSES OF BENEDICTINE MONKS}

\section{THE PRIORY OF ST. SWITHUN, WINCHESTER}

The history of this monastery has been already so much dealt with in the Ecclesiastical History of the county that there is comparatively little to add. This monastery, is said to have been founded in honour of Sts. Peter and Paul, by Cenwalh, King of Wessex, according to the Anglo-Saxon Chronicle in $643,{ }^{1}$ and according to the Annals of Winchester in 639, and was known after the foundation of Newminster or Hyde as the Old Minster.

It was probably after the rebuilding of the cathedral church by Bishop Athelwold in $97 \mathrm{I}$ that the church and the monastery received the additional dedication in honour of St. Swithun by which it was afterwards known, though the joint dedication to Sts. Peter and Paul and St. Swithun lingered on for some time in official documents.

There was apparently no distinction in early times between the lands of the bishop and the lands of the monastery. Grants were made to the church generally, but the lands granted appear to have been under the control of the bishop. About the middle of the tenth century certain lands seem to have been allotted for the maintenance of the monastery, but they remained still under the management of the bishop. ${ }^{3}$ At the time of the Domesday Survey the lands allotted for the support of the monks were mostly held by the bishop, those in Hampshire being Chilcomb, Nursling, Chilbolton, Avington, Whitchurch, Freefolk, Witnal in Whitchurch, Hurstbourne Priors, Clere, Crondal, Droxford, Polhampton in Overton, Exton, Alverstoke, Worthy, Wonston, Brainsbury in Barton Stacy, South Stoneham, Milbrook, Hinton Ampner, Fawley, Itchingswell, Hannington and Hoddington in Upton Gray." The monks themselves held Boarhunt, Wootton St. Laurence, Hayling Island, Brockhampton and Havant. ${ }^{5}$ The lands of the bishop and prior formed a great fief for which the bishop owed, at the end of the twelfth century, the service of sixty knights. ${ }^{6}$

1 Anglo-Saxon Chron. (Rolls Series). i, 48, 49.

2 Annales Monastici (Rolls Series), ii. 5 .

See Athelstan's charter to Winchester A.D. 938, enrolled on Charter Roll, 12 Edw. II. No. $4^{8}$.

V.C.H. Hampsbire, i. $46_{3}$.

- Ibid. 468 .

- Red Book of the Exchequer (Rolls Series), i. 72, 91 , etc.
There are two chartularies in the British Museum of the priory of St. Swithun, both of which were unknown to the compilers of Dugdale's Monasticon.

The first of these, acquired in 1844 from the dean and chapter of Winchester, contains a large collection of royal and other charters in Anglo-Saxon and Latin, from the reign of Cenwalh of Wessex, 688, to the time of Edward the Confessor, with the addition of a few Norman charters granted by William I., Henry I. and Stephen. It is beautifully written and in good preservation in the original stamped binding; it is supposed to have been compiled between I I 30 and $11500^{7}$

The other chartulary, acquired in 1873 , opens with a brief history of the church to the year 967 , followed by a notice of the bishops up to Egbald, 793. This is followed by charters from the time of the Confessor to 1242. Among the other entries are agreements with the monasteries of Canterbury, Peterborough, Worcester, Gloucester, Reading, Tewkesbury, Chertsey, Burton, Ely, Abingdon, St. Albans, St. Pancras at Lewes, Glastonbury, Durham, Merton, Malmesbury, Bury St. Edmunds, Westminster, Wherwell, Romsey, Bec (Normandy) and Battle, as to mutual masses for the dead; a list of plate and vestments, the gifts of Bishop Henry de Blois; notices of the deaths and benefactions of Bishop William de Raleigh (1243) and Bishop John of Exeter (1262); copies of charters and agreements between priors and bishops, and as to pensions or oblations of parochial clergy from 1284 to 1334 ; together with the consuetudines elemosine and other customs of the church. The chartulary contains eighty-three folios, and was compiled in the thirteenth century, save that there are a few fifteenth century entries towards the end. ${ }^{8}$

The prior furnished Thomas Cromwell, on his appointment as general visitor, with a succinct account of the early history of their house from the year 604 , giving what they termed the annals of their first, second, third and fourth foundations. There is a copy of this in the Harley manuscripts. ${ }^{\circ}$

In September, 1243, the monks of St. Swithun obtained papal sanction to wear caps (pilleis) in quire on account of the cold, pro-

7 Add. MS. $15,350$.

8 Ibid. 29,436 .

- Harl. MS. 358 , fo. $60 \mathrm{~b}-64$. 


\section{RELIGIOUS HOUSES}

vided that due reverence was shown at the gospel and the elevation. ${ }^{1}$ In the same month Innocent IV. issued his mandate to the priors of Rochester and of Holy Trinity, London, in a matter affecting this priory. The convent of Winchester had complained that, on the voidance of the priory (I 239), Andrew, a monk, by secular force and by the assistance of the archdeacons of Winchester and Surrey, had obtruded himself into the office of prior. Andrew was therefore excommunicated by the Archbishop of Canterbury ; but of this he took no heed, and introducing an armed band into the cloister by night, ill-used, bound and imprisoned Richard de Triveri and many other monks. Further, at his instance, the archdeacon of Winchester issued sentences of excommunication and suspension against many members of the convent. The pope ordered the two priors to go to Winchester, to relax provisionally the archdeacon's sentences, and if, on examination, the facts justified it, to provide a prior by canonical election. At the same date a papal faculty was forwarded to the sub-prior and convent of Winchester to use their privileges, although they had not done so for a long time on account of their ignorance of the law, the disturbance of the realm, and the change of prelates of the see. This was accompanied by a general licence to the priory to administer their property, wherein is recited the particulars of their manors, advowsons, pensions and other rights. ${ }^{2}$

The monks paid dearly for yielding to the pressure exercised by the Crown in the matter of the election of Aymer to the bishopric. Soon after his election Aymer treated them with the utmost indignity and violence, driving the prior and his obedientaries from the house. In 1254 Prior William de Andrew visited Rome to lay his grievances before the papal court. Innocent IV. treated him with every consideration, and granted to him and his successors the use of mitre, ring, tunicle, dalmatic, gloves and sandals; the right of blessing chalices, altar palls and other church ornaments; the giving of the first tonsure; the conferring of the minor orders of doorkeeper and reader; and the giving of solemn benediction in divine offices and at table. ${ }^{3}$

The disturbed state of the unfortunate monastery at this period of its history is shown by a patent issued by Henry III. in July, 1255. It took the shape of a precept

1 Papal Registers, i. 200.

2 Ibid. 200, 20I. The licence or bull is set forth at length in the Monasticon, i. 21 1-2.

2 Papal Registers, i. 305 ; Ann. Winton. 95. to the abbots and priors throughout England, inhibiting them from receiving into their monasteries and houses any of the monks of Winchester, very many of whom of their own will and pleasure wander all over England in contempt and despite of monastic religion, and to the peril of their own souls, unless by letters of permission from the elect of Winchester or the prior of the same place.

It was not until 1256 that this quarrel between bishop and prior was temporarily settled. The right of the monks to elect their own prior was formally conceded in $125^{\circ},^{\circ}$ but this was again disputed in 1266 , and once more settled in their favour in $1273^{\circ}{ }^{\circ}$

On 4 May, 1264, the citizens of Winchester rose against the monks and burnt the priory gateway, the gate called Kingsgate, the upper part of the church (ecclesia) of St. Swithun, and all the houses near the wall that belonged to the convent. The annalists do not mention any cause for this popular tumult, which was sufficiently severe to cause the death of several of the prior's servants."

Considerable disputes again arose between the Bishop of Winchester and the prior of St. Swithun's at the beginning of the rule of Bishop Pontoise, as to the appointment of the obedientaries or officials of the monastery. In October, 1282, the bishop appointed Ralph Chaunterel, one of his attendants, to the important office of kitchener to the priory, stating in his register that it was on account of his faithful service to him. ${ }^{8}$ In the following year the bishop collated John de Nortwold to the still more important office of cellarer; this appointment is entered in his register among other collations and institutions to benefices. This last nomination gave rise to vigorous remonstrance on the part of the prior and convent. Eventually in July, 1284, the bishop covenanted to yield to the prior the liberty of appointing and removing obedientaries and secular servants; but the priory did not obtain this covenant in their favour without making a substantial concession. On the same day and year that this episcopal ordinance was issued the prior and convent conceded to the bishop the very valuable manors of Droxford, Alverstoke and Havant. ${ }^{10}$ As

4 Pat. 39 Hen. III. m. 9 d.

- Annales Monastici (Rolls Series), iv. 122.

- Ibid. ii. 122, 389 .

7 Ibid. ii. 101, iv. 450.

8 Winton. Epis. Reg., Pontoise, f. 100.

- Ibid. f. 2.

10 Ibid. 106-9, Maneria de Drokensford, Alvarestok cum Gosport, et Havante cum tencnibus corum de Heling et Hamelettam de Conoel. 


\section{A HISTORY OF HAMPSHIRE}

the Crown had on several occasions appointed obedientaries and sergeants for the monastery during the vacancy of the see, it was thought well to obtain royal sanction for this episcopal ordinance. Consequently Edward I., in September, 1284, granted letters patent confirming the episcopal covenant, and also granting to the prior the power of appointing to the sergeanties or other secular offices pertaining to the house. At the same time the chapter was granted the custody of the priory during voidance. ${ }^{1}$

About ten days after the sealing of the covenant between the bishop and priory, through the resignation of William de Basing, there was a vacancy in the office of prior, and the bishop, with the unanimous assent of his brethren, put the custody of the house into the hands of Nicholas de Merewell, the subprior. On the same day (I 3 July) the bishop issued a letter to the retiring prior and the obedientaries giving them absolution after certain scandals, the nature of which is not stated. On I 8 July the sub-prior and chapter asked leave of the bishop to elect a new prior; in the bishop's letter of sanction he referred to the resignation of Prior William, stating that it was not caused through any crime or conscious fault, but for the sake of humility and true religion. ${ }^{2}$

On 25 August, 1284, the bishop gave his assent to the election of William de Basing as prior, and issued the usual injunction to the sub-prior and convent to yield him due obedience. ${ }^{3}$ From this it would appear that the ex-prior was, with episcopal assent, reelected."

Bishop John of Pontoise was probably anxious to see if the re-election was satisfactory, for on 14 September he issued notice of a personal visitation of the cathedral priory to be held at the ensuing Michaelmas. As no injunctions were issued consequent on this visitation it may be assumed that everything was found to be satisfactory. ${ }^{5}$

By 1291 the possessions of the prior seem to have been definitely separated from those of the bishop, and the estates of the former had considerably increased. The total yearly value was $£ 701$ os. $7 d^{\circ}$ At the same time

1 Pat. 12 Edw. I. m. 3.

2 Winton. Epis. Reg., Pontoise, 70, $70 \mathrm{~b}$.

${ }^{3}$ Ibid. f. 73.

- The Monasticon and other printed lists of priors make out that there were two successive priors called W. de Basing; but this seems improbable if not incorrect.

5 Winton. Epis. Reg., Pontissera, 73.

- Pope Nicb. Tax. (Rec. Com.), 213. it will be noticed that as late as 1346 the bishop owed the service of five knights' fees for his own land and also for all the lands of the prior. ${ }^{7}$ From the aid for making Edward the Black Prince a knight in this year we find that the prior of St. Swithun's held with John Frilende half a knight's fee in 'Nywenton'; he held also with two others half a fee in Stoke in St. Mary Bourne (Crokerestok), and half a fee in Long Sutton. ${ }^{8}$

On the death of Prior William in May, 1295, leave to elect was applied for and granted by the bishop. The monks on this occasion elected by way of 'compromise.' The chapter appointed William de Hoo, Adam de Hyde, Roger de Entingham, Henry Bacun, Henry de Merwell, Nicholas de Tarente and William Wallup to act as electors. Their choice eventually fell upon Henry de Merwell alias Woodlock, and the bishop's assent was given on 7 June. The particulars as to this election are set forth in the episcopal register with much detail. 9

On 13 June, I 305 , Bishop Henry granted leave to fill up the vacancy in the priory, caused by his own elevation to the episcopate, and gave the custody during the vacancy to William de Somborne, John de Donketon and Ralph de Canne. On 31 July entry was made in the episcopal register of the process of election, and a week later the bishop's consent to the appointment of Nicholas de Tarente was signified, and he was duly installed. ${ }^{10}$ The bishop visited the priory in 1308 , and apparently found nothing to correct.

In 1297 mandate was issued by the Crown to the justice of the forest to permit the prior to grant and make stable-stands, according to the term of the king's charter to him and his successors, in the demesne lands and woods where they had chases in Hampshire, and to carry away venison, and to keep their dogs not expeditated, but on condition that they set or stretched no nets for taking such venison. ${ }^{11}$ John de Ford, monk of St. Swithun's, received a royal pardon in June, 1344 , for taking a doe and a sorel in the New Forest and carrying them away. At the same time Prior Alexander was pardoned for receiving the said doe and sorel. ${ }^{12}$

The various acta relative to the election of Richard de Eneford as prior are briefly

7 Feudal Aids, ii. 335.

8 Ibid. $325,330,333$.

- Winton. Epis. Reg., Pontoise, 16, 17.

10 Ibid. Woodlock, 9-11.

11 Pat. 25 Edw. I. pt. 2, m. 14.

12 Ibid. 18 Edw. III. pt. I, m. 1 . 


\section{RELIGIOUS HOUSES}

cited in Henry de Woodlock's register under the date of 8 September, $1309 .{ }^{1}$

An important visitation of the priory of St. Swithun's was held by the bishop in 1315 , which resulted in a considerable number of injunctions. The greater part of these are of the usual character, and partake more of enjoining a careful observance of the rule than of dealing with any particular delinquency. Such were orders to attend all the offices, night and day; frequent celebrating by the monks in priest's orders ; silence at the appointed time and places; never to break bounds without leave; to speak to no women, religious or secular, save in public; to wear nought save the statutory dress; and juniors to respect seniors. Others related to the due keeping of the cloister gate, to the custody of the seal, and to the annual rendering of accounts by obedientaries and bailiffs. Two or three are less usual, and probably refer to specific faults, such as directions against selling surplus food, and that parents or relatives visiting the inmates were to be invited to contribute according to their means. One order has a decidedly local touch, by which all the monks, save the sacrist and his servants, are forbidden to go out of the monastery by the gate called 'Redebreck': The bishop had the advantage in this visitation of full personal knowledge of the house during the ten years that he was prior.

In the second year of Bishop Stratford's rule (1 325$)$, a complete list of the monks of St. Swithun was drawn up. It begins with Prior Richard ; the second name, presumably the sub-prior, is Adam de Hyde, and then follow the names of sixty-two other monks. ${ }^{9}$

Bishop Stratford held two visitations of St. Swithun's during the ten years that he administered the see. In the last case penalties were imposed and then taken off. ${ }^{4}$

The priory was visited in February, 14 I O-I, by John Cattyk, chancellor of the diocese. $\mathrm{He}$ visited as the commissary of the diocesan, Bishop Henry Beaufort stating that he was not able personally to visit owing to the pressure of other arduous affairs. ${ }^{5}$

The earlier episcopal registers are for the

1 Winton. Epis. Reg., Woodlock, f. 1 \& 3 b.

2 Ibid. f. 23 (2d. numbers).

3 Ibid. Pontoise, f. 143. It is curious that this list should be entered on a blank leaf of an earlier register; it was probably an error of the scrivener who made the entry.

- Ibid. Stratford, ff. 1 3 b, 19b, $171 b-4$.

- Ibid. Beaumont, f. 32 (2d. numbers). most part somewhat sparing in their reference to the work and administration of the catliedral priory, but the entries are frequent in William of Wykeham's days.

The rectory of the church of Littleton was appropriated to the office of guest-master of the priory in the year II 7 I. In March, 1373, Bishop William of Wykeham licensed John Hyde, the monk guest-master, to hear confessions and to administer the Eucharist at Littleton during Lent and at Easter, for the depression of the times prevented the parishioners employing a parochial chaplain to assist the vicar. The licence was to expire at the end of the Easter octave. ${ }^{6}$ This temporary and useful licence was renewed to the guestmaster year by year up to 1379 .

Hugh Basing was prior when Wykeham was elected bishop. On his death in 1384 Dr. Robert Rudborne succeeded, and he was followed in 1394 by Dr. Thomas Neville. The friction between bishops and priors is illustrated by the action that took place during Wykeham's episcopate with regard to a comparatively trifling but very interesting custom dating back to time immemorial. According to this ancient custom whenever the diocesan visited Wolvesey, or any other residence in Winchester, the domicellus of the priory presented him with eight loaves of fine wheat flour and four gallons of wine, saying at the same time these words in French: 'Mounseigneur, Seint Pere et Seint Paule vous envoient.' Prior Hugh set the example of reducing the offering to a single loaf and one gallon of wine, and his example was followed by Prior Rudborne and by Prior Neville for the first four years of his office. But in 1398, other disputes having arisen, a covenant was made between Wykeham and Neville for the resumption of the full customary offering of bread and wine, and that the ancient words should be said in French, Latin or English. At the same time it was agreed that disputes between the tenants of their respective estates should be tried in the bishop's or prior's court and not in those of the king; that the priory should maintain the bridge over the Lockburn in College Street, and halve the expense with bishop of the bridge over the river; and that the priory should abstain from feeding sheep or taking rabbits in the episcopal chase and warren at Morestead.?

In June, 1 373, Wykeham visited the priory and was apparently content with its condition, as no injunctions were entered.

\footnotetext{
' Ibid. Wykeham, iii. f. 88b,

7 Ibid. f. 323.
} 


\section{A HISTORY OF HAMPSHIRE}

Another visitation of the cathedral priory was arranged by the bishop to be held in the autumn of 1386 , but in November a mandate was issued postponing it, in consequence of urgent business, to Io February. ${ }^{1}$ On 6 February, I $386-7$, W ykeham addressed a letter to the prior and convent on the serious reduction in their numbers, and two days later he directed his official and another to conduct the visitation on 10 February.? It was at this time that the bishop issued a code of directions or revised rule for the guidance of the monks, providing in various ways against laxity. ${ }^{3}$ The number of the monks was at that time reduced to forty-six. It still stood at that figure during a third visitation, 1393, and though Wykeham again specially insisted on the raising of their numbers, the roll had fallen to forty-two at the time of his death. ${ }^{4}$

Much of the administration of the priory can be learnt from some of the old account rolls that still survive. A fourteenth-century roll in the possession of the dean and chapter contains an interesting account of the obligations of the officers of the priory in connection with the frater. ${ }^{\circ}$ 'The prior was bound to provide the frater with bread, beer, wine, salt, cheese and butter; also with the necessary rush-woven mats and with straw litter for the floor. Cheese was to be served daily at dinner and supper from Easter Day to Quinquagesima Sunday, and butter on Wednesdays and Saturdays from I May to 14 September. New mats were to be furnished on the vigil of All Saints, and fresh straw seven times a year. The chamberlain provided a new cloth for the high table every Palm Sunday, and canvas cloths for the other tables as often as necessary; he had also to find old cloths for cleansing the silver and other vessels. The sacrist had to send the fraterer fifteen wax candles on the vigil of All Saints, to be renewed as often as needful down to Maundy Thursday. The precentor and his fellows, who on Sunday and other feasts at 12 o'clock (after nones) have said the Placebo, were to have a 'punchard' of good beer. The almoner was to give the fraterer a clapper (signum) on Maundy Thursday. The kitchener was to receive his food daily with the under-cooks, but was to sit at

1 Winton. Epis. Reg., Wykeham, iii. f. 225 b.

2 Ibid. f. 226.

${ }^{3}$ Moberly's Life of Wykeham, pp. 737-9, citing New College MSS.

"Winton. Epis. Reg., Wykeham, iii. f. 255b.

- A Consuetudinary for the Refectory of the House of S. Swithun, edited by Dean Kitchin. the high table and have a punchard. The gardener was to provide apples on Mondays Wednesdays and Fridays in Advent and Lent ; the sub-prior, third prior and fourth prior, the fraterer and other officers were to have ten apples each; if the prior was present he was to have fifteen. The same was to be done on St. James' Day, when there was the blessing of apples. At the east end of the frater, between the windows, stood a celebrated old cross or crucifix, from which, according to tradition, a voice proceeded, deciding the controversy between St. Dunstan and the ejected secular canons. The guardian of the altar of Our Lady and the keeper of the cloister garth had to provide tapers to burn before this cross on certain high days, and the fraterer to provide seven branches to burn in the like place daily during the second collation. The custom of carrying round the ancient cup of St. Athelwold to be kissed by all on his festival has been already described. ${ }^{6}$ The cellarer had his meals with the community; it was his duty to provide meat and drink and food of every kind, to produce and keep in repair all the necessary vessels for the cellar, kitchen and frater, to attend to the lighting of the chandelier and of the three flat lamps that hung before the cross. A curious entry further records that he was to have the care of all the animals acquired by different brethren. Pet animals were frequently found in religious houses: occasionally visitors ordered their expulsion, particularly squirrels and birds in cages, from nunneries. The curtarian looked after the due allowance of bread, and the corrodies or due provision for bishops, kings and other visitors. It was the porter's duty to clean out the frater against Easter, and to make the fire on the hearth in snowy weather.

The daily life of these Benedictine monks can be traced from point to point in the large number of Obedientary Rolls of the different officials of the house that still survive of the fourteenth, fifteenth and sixteenth centuries. ${ }^{7}$ The obedientaries were monks told off to fulfil certain duties, and to superintend particular parts of the administration of the convent and its property. Their duty at St. Swithun's was essentially connected with the exercise of hospitality; their priory lay in a chief city on one of the most important highways in England, and it was their well sustained boast to keep open house

- V.C.H. Hants, ii. 7 .

7 Compotus Rolls of the Obedientaries of St. Switbun's Priory, edited by Dean Kitchin (Hants Rec. Soc. 1892). 


\section{RELIGIOUS HOUSES}

for all comers. In this and in other respects the monks of the cathedral priory of the diocese maintained on the whole an excellent character. The ideal number of monks at which all the large Benedictine houses was supposed to aim was seventy; but this was seldom attained. In r 325 , as has been stated, the roll reached to sixty-four; but the priory never recovered from the staggering blow of the Black Death. The numbers, even under the stirring episcopate of Bishop Wykeham, did not exceed forty-six, and at his death were only forty-two. Only once did they subsequently rise, and that by a single figure, the total in 1533 being forty-three. The Obedientary Rolls show that the lowest level was in $1495-6$, when the numbers were only twenty-nine.

Dean Kitchin, in his introduction to the Obedientary Rolls, makes a helpful division of the monastic officials of St. Swithun's into four groups, a division which applies broadly speaking not only to other Benedictine houses, but to most of the other religious orders:-

(a) Round the Prior (the most dignified personage, the bishop acting as abbot) were grouped the Subprior, the third Prior, and the fourth Prior, who all had definite claustral duties to fulfil. This group was responsible for the general order of the house. With these may be associated the land Steward, who was not a monk, and who is usually described as the prior's steward.

(b) The second group was attached to the church, and included the Sacrist and Subsacrist who had charge of all material things pertaining to the services; the Chanter and Subchanter, who were responsible for the actual conduct of divine worship; the Anniversarian, who had charge of the obit days of benefactors; and the Warden of the Works, who looked after all repairs of the church and other buildings.

(c) The internal officers of the house were the Receiver, to whom were paid the rents of the several estates ; the Hordarian, who had charge of the material resources of the convent supplying the frater, etc., and also having charge of estates and income specially assigned for such purposes; the Refectorian who received all the eatables, passing them on to the Kitchener; the Chamberlain, who had charge of the furniture ; the Cellarer who looked after the beer and wine and took charge of all the outbuildings and stables; the Almoner who distributed to the poor in kind and money; and the infirmarer, or physician monk in charge of the farmery.

(d) The fourth was a little group of officers dealing with external affairs, as the Outer and Inner Porters, and the Guestmaster.

The extant Obedientary Rolls of St. Swithun's are most numerous in connection with the office of hordarian, of which there are fifteen, and of the almoner, of which there are thirty-two. The Diet Roll for 1492 describes precisely how the Winchester monks fed at their two meals, apart from beer and vegetables, which are not entered. On an ordinary day, such as the Monday before Christmas, they had on the table a dish of marrow and grated bread, eggs, venison, beef, mutton and calves' feet. On Christmas Day they had in addition onion broth, the total cost being 10s. $9 d$. against $8 s .4 d$. of the previous Monday. On a day of strict fast, such as Friday in Passion week, they had salt fish, figs and raisins, and rice. Another interesting item is that the monk gardener of St. Swithun's was bound to provide flowers to deck the church at certain festivals, as well as to find the apples for Advent and Lent consumption.

Bishop Fox visited St. Swithun's on 26 August, 1521, and subsequently (I February, $1521-2$ ) issued a variety of injunctions that tell of some disorder. The injunctions open with blaming the chanter and subchanter for lack of quire books, and that those in use were torn (rupta) and out of repair. The most interesting rebuke to the monks was that they neglected to choose scholars to send to the University of Oxford in accordance with the Benedictine constitutions. ${ }^{1}$

The election of Henry Brook as prior in the time of Bishop Fox is set forth with great circumstance in his registers. Application for licence to elect was made in December, I 524, but the new prior was not installed until 7 March, $1524-5 .^{2}$

Dr. Hede, commissary of the prior of Canterbury, during the vacancy of the sees of both Canterbury and Winchester, visited St. Swithun's on 27 February, 1500.

In addition to Thomas Silkstede, the prior, the following office holders were examined at the visitation : Thomas Manhouse, sub-prior; John Dorsett, third prior ; John Pury, gardener; Richard Aunstell, sacrist; Philip Yong, almoner; Thomas Gyan, hordarian; John Stonkton, master of the works; Walter Hyll, frmarius; John Beste, hostilar; John Cerne, depositarius; John Wodesun, warden of Our Lady ; Peter Marlow, chanter; Arnold Gylbert, chamberlain; John Westbury, curtarian; Henry Broke, fourth prior ; and Tympany Alt, depositarius. Twelve others were also examined, giving a total of twenty-nine who appeared before the visitor. Of these three were deacons, one a sub-deacon, and one an acolyte. Two are simply entered as professed of the order of St. Benedict, and were novices:

1 Winton, Epis. Reg., Fox, iv. ff. 67, 67b.

2 Ibid. Fox, v. ff. 74-83. 


\section{A HISTORY OF HAMPSHIRE}

Thomas Manydon, aged 16, who had been three weeks in the monastery, and Fulk Hampton, 18, who had been there for a like period; neither of them had as yet received the first tonsure. The evidence was wholly in favour of the order and administration of the house. The statutory number of the monks was at that time reduced to forty, and there were then only thirty-five, but the treasurer reminded the visitor that there had been five recent deaths. At the close of the evidence Dr. Hede's only injunction was as to the speedy filling up of the full number of the monks. The visitor called upon the prior to take an oath of canonical obedience to the prior and convent of Canterbury during the vacancy of the see, and to the Archbishop of Canterbury when the see was filled. Prior Silkestede however declined, unless the prior of Canterbury took an oath to observe the rights of the cathedral church in the same way as the Bishop of Winchester did at the time of his consecration. The question was adjourned till the following day, when Silkestede submitted. ${ }^{2}$

The story of the end of St. Swithun's as a monastery, and the desolation effected in the church in September, 1538 , has already been told in the Ecclesiastical History.

At the time of the dissolution the monastery held the manors of Nursling, Millbrook Morecourt, Hursley, 'Oxenbridge,' Avington, Exton, 'Hadington,' Bransbury, Upsomborne, 'Henton, Wymanston,' the city of Winchester and the soke, and lands and rents in Dean and Lovington in Hampshire; and the manors of 'Hynxton,' Overton with the rectory, Alton with the rectory, Stocketon, Patney, Westwood 'Langfischedide' next Endford, and Shipton Bellinger in Wiltshire; and the manor of Bleadon in Somersetshire, as well as pensions from divers churches. ${ }^{2}$

The steps by which the ancient Benedictine house of St. Swithun was turned into a dean and chapter in 1539-42 have been already mentioned in the Ecclesiastical History. A whole series of documents touching this changc, eleven in number, are extant at Winchester, and have been printed and edited by Dean Kitchin. ${ }^{3}$ The first letters patent formally establishing the new body are dated 28 March, 1542.

On I May, 1542, the newly-formed dean and chapter were endowed with the following

1 Sede Vacante Register, Christ Church, Canterbury.

${ }^{2}$ Dugdale, Monasticon, i. 217.

3 Documents relating to the Foundation of the Chapter of Winchester (Hants Record Soc. 1889). manors and lands, most of which had previously belonged to the prior and convent, viz. Avington, Berthon Priors, Bransbury, Chilbolton, Crondall, Exton,-Haddington, Hanton, 'Littleton,' Manydown, Millbrook, Moorecourt, Nursling, Silkstead, Sutton, Upsomborne, West Meon, Whitchurch and 'Wonsington' in Hampshire; and Alton, Ham, Hinton ' Langefysshehre' near Endford, Overton, Patney, Shipton Bellinger, Stockton, Westwood, 'Winnaston' and Wroughton in Wiltshire, and Bleadon in Somerset.

The possessions of the dean and chapter in 1682 consisted of the Hampshire manors of Barton and Newhouse, Sparsholt and Wyke, Compton, Sparkford and 'Fulfludd,' Chilcombe and Morstead, 'Wynall,' Ovington and 'Brixden,' Crondall, Sutton, Manydown, 'Boghurst,' Hannington, Whitchurch, Freefolk, Charlcott, 'Wonsington,' Bransbury, Chilbolton, Littleton, Upsomborne, 'Thurmunds,' Silkstead, Exton, Hinton Ampner, Shipton, Morecourt and Oxenbridge, Lovington, the city of Winchester, office of woodward and the liberty of the fair of St. Mary Magdalene; in the county of Wilts the manor of Hinton, Ham, 'Bechinstoke,' Botwell and Longstreet, Wroughton, Little Alton, Westwood, 'Elmestubb' and Eversley, and a large number of churches in both counties.

The manors of inheritance, which belonged to the dean and chapter and were handed over to the ecclesiastical commissioners in 1861 , were Crondall with Sutton, Warblington, and Hinton Ampner. ${ }^{6}$

\section{Priors of St. Swithun of Winchester}

Brithnoth, about 970 , made abbot of Ely

Brithwold, about Ioo6, became Bishop of Winchester

Elfric Puttoc, I023, made Archbishop of York

Wulfsig, died ro6 5

Simon or Simeon, 1065-82, brother to Bishop Walkelyn, made abbot of Ely $^{7}$

Godfrey, ${ }^{8}$ 1082-1107. A volume of his epigrams is among the Cott. MSS. Vit. A. xii.

Geoffrey, I I07-I I. He was deposed

Geoffrey II., ${ }^{10}$ I I I I-4, made abbot of Burton, Staffordshire

4 Dugdale, Monasticon, i. 70.

5 Documents relating to the Church of Winchester (Hants Record Society), ii. 182.

- Information supplied by Mr. Hugh de B. Porter, Deputy Steward.

7 Annales Monastici (Rolls Series), ii. 33.

8 Ibid. 43. 9 Ibid. 10 Ibid. 


\section{RELIGIOUS HOUSES}

Eustace, II I 4-20

Hugh, I 120

Geoffrey III., died in 1 I 26

Ingulph, made abbot of Abingdon in 1130

Robert, I I30-6, made Bishop of Bath and Wells

Robert II., ${ }^{1}$ I 73 , made abbot of Glastonbury

Walter, ${ }^{2}$ I $17 I-5$, made abbot of Westminster

John, ${ }^{3}$ died 1 I 87

Robert III., surnamed Fitzhenry, ${ }^{4}$ I 187 12 I 4, made abbot of Burton

Roger, I 214

Walter II., ${ }^{5}$ died 1239

Andrew, ${ }^{6} 1239$

Walter III., 1243 , resigned in 1247

John de Cauz, 1247-9, in latter year made abbot of Peterborough ${ }^{7}$

William Taunton, 1249-56, made abbot of Middleton in Dorsetshire, ${ }^{8}$ and afterwards elected Bishop of Winchester, but the election was invalidated

Andrew of London, ${ }^{9}$ I 258-6 I, resigned

Ralph Russel, ${ }^{10}$ 1 261-5

Valentine, ${ }^{11}$ I 265-76, deprived

John de Dureville, $1276^{12}-8^{13}$

Adam de Farnham, $1279,{ }^{14}$ excommunicated for disobedience July, $\mathbf{1 2 8 2}$, and absolved in the following month

William de Basynge, 1282 , resigned in I 284 , but was re-elected the same year ; finally resigned in $\mathbf{1} 295$

Henry Wodelock, alias Mereville, I 2951305, made Bishop of Winchester ${ }^{15}$

Nicholas de Tarente, ${ }^{18}$ 1 305-9

Richard de Enford, ${ }^{17}$ I 309 , 1326

Alexander Heriard, ${ }^{18}$ I 327 , died 1349

John Merlaw, ${ }^{19}$ I 349-56

Hugh Basyng, ${ }^{20}$ I $356-84$

Robert Rudborn, ${ }^{21}$ I 384-95

Thomas Nevil, ${ }^{22}$ I 395

Thomas Shyrebourn ${ }^{23}$

1 Annales Monastici (Rolls Series), ii. 6I.

Ibid. 3 Ibid. 63. Ibid.

Ibid. 323. ${ }^{8}$ Ibid. 7 Ibid. 9I.

8 Ibid. 96. Ibid. 99. 10 Ibid. 102

11 Ibid. I 23. ${ }^{12}$ Ibid. ${ }^{13}$ Ibid. iv. 475.

14 Ibid. 476.

16 Pat. 33 Edw. I. p. I, m. I7, and Winton.

Epis. Reg., Pontoise, 9.

1s Winton. Epis. Reg., Woodlock, I ib.

17 Ibid. I I 3 b. $\quad 18$ Ibid. Stratford, 107.

19 Ibid. 46 b, 5 I. 20 Ibid. I I 3-5.

21 Ibid. Wykeham, I 57-9. 22 Ibid.

23 His name occurs in the Obedientaries Rolls from 1413 to 1433 .
William Aulton, ${ }^{24}$ died 1450

Richard Marlborough, ${ }^{25}$ I 450-7

Robert Westgate, ${ }^{26}{ }_{1457-70}$

Thomas Hinton, ${ }^{27}$ 1470-98

Thomas Silkested, ${ }^{28} 1498-1524$

Henry Brook, ${ }^{29}$ 1 524-35

William Basyng, alias Kingsmill, ${ }^{30}$ 1535-9

DeAns OF InCHESTER $^{31}$

William Kingsmill, D.D., I 54 $1-8$

Sir John Mason, knt. (layman), I 549-53

Edmund Steward, LL.D., I 554-9

John Warner, M.D., I 559-64

Francis Newton, D.D., $1565-72$

John Watson, M.D., 1573-80

(Bishop of Winchester, 1580 )

Lawrence Humphrey, D.D., I 580-89

Martin Heton, D.D., I 589-99. (Bishop of Ely, 1599)

George Abbot, D.D., I 599-1600-9. (Bishop of Lichfield and Coventry, 1609; London, 1610; Archbishop of Canterbury, I6 I I)

Thomas Morton, D.D., 1610-16. (Bishop of Chester, I616)

John Young, D.D., 1616-dispossessed by the Commonwealth

Alexander Hyde, LL.D., I660-5. (Bishop of Salisbury, 1665)

William Clark, D.D., I666-79

Richard Meggott, D.D., I679-92

John Wickart, D.D., I693-I72I

William Trimnell, D.D., I 722-9

Charles Naylor, LL.D., I 729-39

Zachary Pearce, D.D., $1739-48$. (Bishop of Bangor, I 748 )

Thomas Cheyney, D.D., 1748-60

Jonathan Shipley, D.D., I 760-9. (Bishop of Llandaff, I769; St. Asaph, 1769)

Newton Ogle, D.D., I 769-1 804

Robert Holmes, $1804-5$

Thomas Rennell, D.D., I 805-40

Thomas Garnier, D.C.L., I $840-72$

John Bramston, D.D., 1 872-83

George William Kitchin, D.D., $188_{3}-$ 95

William Richard Wood Stephens, D.D., 1895-1902

24 His name occurs in the same, 1435 to 1447.

25 Winton. Epis. Reg., Wainflete, i. 29-34.

26 Ibid. 85.

${ }^{28}$ His name occurs in the Obedientaries Rolls from 1498 to 1517 .

29 Winton. Epis. Reg., Fox, v. 83.

30 $\mathrm{His}$ name occurs in the Obedientaries Rolls from 1536 to 1537 .

${ }_{31}$ List from Woodward's Hants, vol. i., collated with Dioc. Calendar and Dioc. History. 


\section{A HISTORY OF HAMPSHIRE}

\section{NEW MINSTER, OR THE ABBEY OF HYDE}

The abbey of the Holy Trinity, the Blessed Virgin Mary, and St. Peter of the New Minster $^{1}$ in Winchester was founded in $90 \mathrm{I}$ by Edward the Elder in accordance with the wishes of his father King Alfred. It would appear that towards the close of the ninth century Alfred, being anxious to promote the better education of the children of his nobles, summoned Grimbald, a learned priest and monk of St. Bertin at St. Omer in Flanders to assist him in-this work. Grimbald arrived in $893,{ }^{2}$ but it was not till the last year of his reign that Alfred told him of his intention to build a new monastery at his royal borough of Winchester. ${ }^{3}$ The king only lived long enough to purchase the site for the monastery in the opcn churchyard immediately to the north of the cathedral or the Old Minster from Bishop Denewulph and the canons of the Old Minster and others. ${ }^{4}$ It was left to Edward the Elder to carry out his father's intention to build the monastery and to place Grimbald $^{5}$ there as the first Abbot. The Church was consecrated in $903^{6}$ and in the same year Edward endowed the monastery with considerable possessions, including the land of Micheldever and lands of Stratton, 'Burcote,' Popham, Woodmancote, Candover, Cranborne, Drayton juxta Nunneton, Swarraton, Northingtone, Norton juxta Selborne, 'Slastede,' 'Tatchbury, Abbots Anne, 'Colengaburna,' 'Ceoseldene' and Durley." At this

1 According to Edward's first charter the dedication was to the honour of the Holy Trinity only, but in his second the dedication was as is given here (Liber de Hyda, Rolls Series, Introd. xxix.). At a later date the dedications to the honour of St. Saviour and St. Grimbald appear (see a table of the dedications at various periods in Newminster and $H y d e$ Abbey, Hampshire Rec. Soc. Pref. viii.).

- Liber de Hydo (Rolls Series), 36 ; see also Hist. of the Engl. Church, by W. Hunt, 275 ; and Dict. of Nat. Biog. under 'Grimbald.'

3 These facts and most of the particulars given in this sketch are taken from the Liber Vita or register and martyrology of the abbey, edited for the Hants Record Society by Dr. de Gray Birch, and the Liber de Hydn, edited by Mr. Edward Edwards for the Rolls Series.

4 There is some doubt whether Alfred or his son purchased the land for the site (Dict. of Nat. Biog. ' Grimbald').

6 Grimbald died in 903. He became a tutebry saint of the foundation attaining to a place in the English calendar in the next century (Plummer's Life of Alfred the Great, 1 37-9).

- Anglo-Saxon Chron. (Rolls Series), 181.

7 Cott. MS. Domit. A. xiv. 72 b. and Harl. MS. 1761, f. 47 . time also the church was enriched with the relics of St. Judoc or Josse the confessor, which were brought there by certain monks of Ponthieu who fled to England from Danish raiders.

Shortly after the dedication of the church the remains of Alfred were carried in solemn procession to the New Minster from their temporary resting-place in the church of St. Swithun or the Old Minster in Winchester and buried on the right side of the altar. In the same tomb were also interred Edward's mother, Queen Ealhswith, foundress of Nunnaminster, and afterwards the bodies of Edward and his two sons, Ethelward and Elfward, were buried in a tomb adjoining that of his parents. At a later date the New Minster became the burial place for several members of the Saxon royal house. ${ }^{8}$

The church was served by secular canons, who, as it is said by the later chroniclers that had no sympathy with the seculars and married priests, permitted great laxity of discipline and were the cause of scandal. About 963 Ethelwold, Bishop of Winchester, with the approval of King Edgar and St. Dunstan, as a part of his scheme for monastic reform in his diocese, insisted upon the adoption of the Benedictine rule by the inmates of New Minster under pain of expulsion, and King Edgar supplied a series of laws to be used by the monastery. ${ }^{\circ}$ The majority of the house refused to accept the new rules and were driven from the monastery, their places being taken by regular monks from Abingdon, over whom Ethelgar was placed as abbot. Ethelgar, like most of the Church reformers of this date, was a man of distinct individuality; he had received his monastic training under Ethelwold at Abingdon and upon his appointment to New Minster he took in hand the reform of the monastery with the zeal copied from his late master. Not only did he look to the rule of the house, but he carried out various works on the buildings including the erection of a tower, said to be of great height and beauty, and a richly carved ceiling. He became Bishop of Selsey in 980 and succeeded St. Dunstan as Archbishop of Canterbury in 988 .

King Cnut was a great benefactor to the Minster, not only in lands but by the gift of the golden cross richly adorned with precious stones with two great images of gold and silver and sundry relics of saints. Among other benefactions received by the monastery etc.

8 Nerominster (Hants Record Soc.), Pref. rvii.

- Printed in Dugdale's Monasticon, ii. 439. 


\section{RELIGIOUS HOUSES}

at about this time was the gift in I04I by Queen Emma, widow of Cnut, of the head of St. Valentine, which was cherished as one of the most valuable possessions of the house.

Alwyn, brother of Earl Godwin, became abbot in 1064. During his abbacy a disastrous fire destroyed a considerable part of the domestic buildings of the Minster on St. George's Day, 1066. This abbot naturally took the part of his nephew Harold in resisting the Norman invasion, and according to the register of the monastery he was slain in battle on the field of Hastings. Mr. Round has already dealt with the question of the supposed active part that the monks of New Minster took at the battle of Hastings, and has shown from the Domesday Survey how considerable are the exaggerations usually current with regard to the consequent confiscations of the Conqueror. ${ }^{1}$ At the time of the Survey the Abbey held in Hampshire, Brown Candover, Woodmancote, Fullerton in Wherwell, Leckford, Micheldever, Cranbourne, Drayton in Barton Stacey, West Stratton, East Popham, Abbot's Worthy, Alton, Worting, Bighton, Bedhampton, Lomer in Corhampton, Warnford, Lickpit in Basing, North Stoneham, Kingsclere, Tatchbury in Eling, Abbots Anne, and Laverstoke. ${ }^{2}$

Not long after the Conquest evil days fell upon the abbey. On the death of Rewalan the Red King made his 'infamous chancellor,' Ralph Flambard, abbot. By an openly simoniacal arrangement between the abbot-chancellor and the king, Herbert Losinga, Bishop of Norwich, bought the New Minster for his father, Robert Losinga, who was appointed abbot in rogr. On the death of Abbot Robert in 1093, the unhappy abbey again fell into the unscrupulous hands of Ralph Flambard. Relief however came to this scandal with the accession of Henry Beauclerk in I I O0, when Hugh, a monk of St. Swithun's, was appointed abbot.

The will of the next abbot, Geoffrey, was one of singular moment to the abbey; the register styles him Fundator Hide. In I I og the monks were enabled to leave their crowded site, the cause of many a serious inconvenience, and move to commodious quarters on the north side of Winchester, just beyond the city walls, known as Hyde Mead. Henceforth this important Benedictine house was known as Hyde Abbey. The old site was surrendered into the king's hands, and was shortly afterwards restored to the cathedral

1 V.C.H. Honts, i. 417.

2 Ibid. 469 . church of St. Swithun. To the monks of Hyde the king granted another charter, whereby, amongst other regulations, it was arranged that a joint procession of the monks of St. Swithun and Hyde was to be made year by year. ${ }^{3}$ Their new home was speedily ready for occupation, and in I I 10 the monks of New Minster carried with them to the Abbey of Hyde, in solemn procession, their sacred relics, the great gold cross of Cnut's benefaction, together with the illustrious remains of Alfred, his queen and his son. Henry I. made several grants to the abbey, among them the churches of Kingsclere and Alton and 5 hides in Alton which William I. had given in exchange for land in the city of Winchester." $\mathrm{He}$ also confirmed to them the right of soc and sac, thol and theam and other liberties. ${ }^{5}$

To Geoffrey succeeded Osbert in 1124. The length of his rule is somewhat uncertain, but it probably ended in II35. The new abbcy, however, only lasted for thirty years, for when the city was fired in I I 41 , in the midst of the fierce civil war between the adherents of Maud and Stephen, the Abbey of Hyde perished in the conflagration. "Then for several years there was continuous strife between the monks of Hyde and the high born and imperious Bishop Henry de Blois. By him, say the Hyde annalists, was the great cross of Cnut burnt, alluding to its loss in the great fire, when the bishop directed fireballs to be thrown from his castle of Wolvesey into that quarter of the city adjoining the abbey.

In I I 42 Hugh de Lens succeeded as abbot after a vacancy of six years. There was much internal dissension at this time, and in I I 49 a large deputation of the monks proceeded to Rome to complain of their abbot, as well as to renew their charges against their diocesan. Hugh was removed, and for two years the abbey was again vacant, whilst Bishop Henry endeavoured to persuade the Pope to convert his ancient see to an archiepiscopate, and to make Hyde Abbey the centre of one of his suffragan bishoprics. The scheme however failed, and Selid was elected abbot in 115I. In the seventeenth year of his abbacy, the continuous suits against the bishop were at last decided in favour of Hyde, and amongst other acts of restitution the bishop presented to the abbey as skilful a reproduction of Cnut's golden

3 Charter R. 16 Edw. IV. m. 9.

4 Ibid.

- Harl. MS. 176, f. $26 \mathrm{~b}$.

- Ann. Mon. (Rolls Series), ii. 52. 


\section{A HISTORY OF HAMPSHIRE}

cross as the art of the day could furnish. After its destruction by fire some parts of the abbey were rebuilt, but the work was very gradual. The thorough reconstruction of the great church was not even begun until i 182 .

Selid died in 1171, the same year as Bishop Henry, when there was again a vacancy for about five years. In 1177 Thomas, the Prior of Montacute, ${ }^{1}$ a Cluniac house in Somerset, became abbot; he resigned his office in $118 \mathrm{r}$. He was succeeded by John Suthill, during whose vigorous rule of nearly forty-two years the abbey prospered and enjoyed much internal peace. In 1 I 85 this abbot proceeded to Rome to bring back the pall for Baldwin, Archbishop-elect of Canterbury. In $1208 \mathrm{John}$ restored the temporalities which had been taken into his hands by reason of the interdict. ${ }^{2}$ The abbot at this time owed the service of twenty knights to the Crown for his lands. ${ }^{3}$

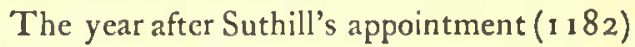
the annalists tell of a miraculous appearance of St. Barnabas at an altar dedicated to his honour, and it was this incident that gave an impetus to the church restoration. There were various other remarkable manifestations at this altar, which caused the faithful to flock to the abbey, and the saint became the object of a special cult at Hyde. Henceforth the monks were frequently described as monks of St. Barnabas.

In 1267 there was a serious affray in the abbey between the scrvants of the abbot and those of the pope's legate, Otho, who had come to Hyde to keep the festival of Christmas with a great retinue, and who observed the feast with too much conviviality. ${ }^{4}$

A curious faculty, which throws some light upon the condition of monastic life in the thirteenth century, was granted by Pope Nicholas IV. in 1288 to this abbey, by which permission was granted to the monks to wear caps of sheep or lamb skin at the divine offices and processions, the cold in those parts, it was said, having caused paralysis and other diseases to some of the monks. ${ }^{5}$

In 1302 royal licence was obtained for the appropriation (in accordance with a patent of 1292) of the church of Micheldever and

${ }^{1}$ Mr. Edwards is wrong in styling him, when editing the Liber de Hyda, Prior of Bermondsey. The Prior of Bermondsey was made Abbot of A bingdon about the same time (see $A n n$. de Wint., p. 6r).

2 Close Rolls, Fobn (Rec. Com.), p. 110.

${ }^{3}$ Red Book of the Exchequer (Rolls Series), i, 72, 91 , etc.

4 Ibid. 14 Hen. III. m. 5 d.

3 Cal. of Papal Letters, i. 492. its chapels, of the annual value of $£ 70$, to which the bishop had already assented, on condition that the revenue should be applied to the use of guests and of the poor and infirm persons who flocked to the abbey. ${ }^{5}$ Various impediments arose to this appropriation, but at last it was confirmed by Clement V. in 1309 , and papal mandates to that effect were sent to the Archdeacon of Winchester and to the Chapter of Salisbury; in the same year there was the like papal confirmation of the appropriation of the church of Alton. ${ }^{7}$

There were several visitations of the monastery during the first half the fourteenth century, and in 1312 Bishop Woodlock had occasion to inhibit the convent from using the common seal for any alienation. ${ }^{8}$ Again in 13 1 8 Bishop Sandale addressed a stern letter to the abbot bidding him check the careless monks who neglected meditation and their claustral duties, and complaining of the lukewarmness of his rulc. ${ }^{9}$ Odiham's rule was but brief. On 2 I May, I3 19 , the abbot was seriously ill, and the monks sent their steward to the king to try and arrange for the custody of the temporalities during the expected vacancy. The abbot however died on June 5 before the matter could be arranged, so that it was not until June Io that the monks reccived the agreement, whereby it was arranged that the convent might retain the custody on payment of 200 marks to the Crown, provided the vacancy did not exceed two months.

Walter de Fifield, a monk of the house, had the temporalities restored to him as abbot (the agreement of June $\mathrm{r} O$ being held to be void) on August I. Between this abbot and his convent there were many disputes, the chief contention of the prior and brethren being that he was wrongfully increasing the separate abbatial revenue at the expense of the house at large. The matter came frequently before Bishop Stratford, with the result that the abbot was virtually acquitted. ${ }^{10}$ The bishop made a formal visitation of the abbey in February, 1325, and issued as the result an elaborate series of decrees, which were in the main of the usual character. The attendance of all at the night and day offices was enjoined; brothers in priest's orders were to celebrate daily ; close custody was to be kept of the doors; the disturbance

8 Pat. 30 Edw. I. m. 16.

7 Cal. of Papal Letters, ii. $51,63$.

- Winchester Epis. Reg., Woodlock, f. 174 b, 175.

- Ibid. Sandale, f. 27 (vide supra, p. 27).

10 Ibid. Stratford, ff. 162,163 . 


\section{RELIGIOUS HOUSES}

caused by boys chattering on the south side of the farmery was to be stopped; the access of men and women into the church and cloister at inordinate hours and times was to cease; no brother was to frequent the nunneries of Winchester, Wherwell, or Romsey under pain of a year's confinement at Hyde ; particular injunctions were laid down as to eating and drinking; playing at chess or dice was forbidden; frocks or cowls of fustian or worsted were not to be allowed, but were to be of black serge according to their rule; cinctures or burses of silk were forbidden; nor were they to have lockers save in the cloister carols. ${ }^{1}$ To this visitation and its consequent decrees the abbot raised formal objections, but he was overruled.

Bishop Orlton visited the abbey on 7 November, I 334, preaching in the chapter-house from 'Ut ambuletis digni Deo per omnia placentes.' The same bishop also visited on 29 May, $1337 .^{2}$

By the aid of 1346 for making Edward the Black Prince a knight we find that the Abbot of Hyde held with Robert Payne an eighth part of a knight's fee in Abbots Worthy (Hidebourne Wordy), three knights' fees in Mitcheldever, a hide in Northington with Henry de Nonhampton, and half a fee in Bicton with Roger Gervays. ${ }^{3}$

In 1344 there was an outbreak of the villeins of Chisledon, Wilts, against the abbey rule, for which they received chastisement at the abbot's hands. The fearful Black Death of I 349-50 reduced the abbey to penury, so that in order to avoid utter wreck it surrendered itself absolutely into the hands of William Edingdon, Bishop of Winchester and Chancellor of the kingdom. The annalist does not proceed to state what measures the bishop took for the relief of the abbey or how he administered their funds. It would, however, appear that after the election of Thomas de Pechy, the new abbot, in 1 362, by good management the monastery had partly regained its prosperous condition, for in 1377 it was able to lend Richard II. the sum of £50. Nicholas Strode who became abbot in I 4 I 7 took a considerable share in the political affairs of the day, and is described as 'a man of conspicuous parts and secular activity.' He died in 1440, and was followed by Thomas Bramley, to whose election the royal assent was given early in May. In March, 1446, this abbot's name appears among the distinguished signatories to the

1 Winchester Epis. Reg. Stratford, f. 1 74 b.

2 Ibid., Orlton, i. ff. 1ob, 54 .

${ }^{3}$ Feudal Aids, ii. 326, 329, 334. final foundation charter of Eton College. In the same year the great bell-tower of Hyde Abbey, with its eight bells, was destroyed by fire. In 1447 Cardinal Beaufort died, and left $£ 200$ for the repairs of the church, doubtless in consequence of this misadventure.

Abbot Bramley died in February, I465, and was succeeded by Henry Bonville, the prior. This election caused much dissension in the abbey. Bishop Waynflete, on appeal, sent the new abbot to govern the priory of Boxgrove, Sussex, whilst the new prior of Hyde, Thomas Worcester, virtually governed the abbey. In $147 \mathrm{I}$ an arrangement was made by which Abbot Bonville was to receive $£ 50$ a year from the abbey revenues, and to attend convocation, council, or parliament as abbot; but he was not to come near Hyde Abbey for three years." Meanwhile however in 1472 Bonville died, and Thomas Worcester was at once elected in his place. ${ }^{5}$

On the election of Richard Hall in April I 488 Henry VII. granted a pension, which a newly elected Abbot of Hyde was bound to grant to a clerk of the king's nomination from the abbey funds, to Pcter Carmelian. Peter was a native of Brescia, who had been naturalized that very month; he was a court poet, and chaplain and Latin secretary to Henry VII. ${ }^{6}$

Bishop Wykeham was a firm maintainer of all the episcopal privileges of the see. There was an ancient custom that, on the confirmation of a new bishop, the abbot of Hyde should present him with a choral cope, comely and suitable for a bishop's estate, for use in the cathedral church. On Wykeham's appointment Thomas Pechy, then abbot of Hyde, neglected to supply the customary cope, and ignored frequent reminders. At last, in October, I 368 , the abbot was cited to appear in the church of St. Mary Overy to show cause why a cope should not be rendered.? The issue is not stated, but doubtless it was in favour of the bishop. In 1390, Bishop Wykeham entered in his register the grant made by Pope Boniface IX. to Abbot Eynesham, authorizing his use of mitre, ring and pastoral staff; ${ }^{8}$ on 8 February, 1387 , the $8 \mathrm{~b}$.

4 Winchester Epis. Reg., Waynflete, ii. ff. 106-

5 Pat. 4 Edw. IV. pt. ii. m. 2.

- He also received corrodies or pensions from other ecclesiastical foundations; see Dict. of Not. Biog.

7 Ibid. Wykeham, iii. f. 15.

8 Ibid. f. 249 a. 


\section{A HISTORY OF HAMPSHIRE}

same bishop issued an elaborate series of injunctions for the better government of the abbey $;^{1}$ and by his will left to the abbot a silver-gilt flagon worth $\oint_{1} \mathrm{O}$; to each monk in priest's order, $£_{2}$; and to each in lower orders, $f \mathbf{r}$.

Dr. Hede, as commissary for the Prior of Canterbury during the vacancy of the see, visited this abbey on 3 March, I 501 . Richard Hall, the abbot, gave written and viva voce answers to the visitation articles. He stated that the abbey was in debt fifty marks when he entered on his office. The common seal was kept under four keys held respectively by the abbot, prior, sub-prior and precentor. Richard Romsey, the prior, said that the abbot had also placed in his hands the office of sacrist. John Lavender, sub-prior; William Salisbury, almoner; Thomas Wrighton, steward; Thomas Gloucester, guestmaster ; Henry Curtes, precentor; John Forest, cellarer (vinetarius); William Chusylden, the third prior and infirmarer; John Alta, master of the works; William Winchester, sub-chanter; and various others, who did not hold office, summed up their testimony in the effective phrase of omnia bene. Edward London, one of the monks, stated that the novices and two other young brothers did not attend the grammar school, and that it was the fault of the abbot. Anthony Stavely complained that the prior heavily punished the young monks and others without cause. There were also certain complaints on the part of two or three of insufficient food in the farmery.

Abbot Hall's government was lax. At a visitation held by Dr. Dowman, the bishop's vicar-general, in January, 1507 , the prior and six senior monks were summoned to the chapter-house and faced with various serious charges as to the access of women to the precincts, the frequenting of taverns in the city, and insufficient instruction of the younger monks. This was followed by the summoning of twenty-five junior monks who were duly admonished. Then the vicargeneral conferred with the abbot and seniors as to reformatory measures. The seniors admitted laxity as to egress, alleged their ignorance of all foundation for the graver charges, spoke of the difficulty of a strict observance of the Benedictine rule, but promised vigilance and increased exertion for the future. ${ }^{2}$

Two years later the abbot died, and was

1 These are printed in full, from a MS. in the custody of the Warden of New College, Oxford, in Dr. Birch's Liber Vita, pp. Ixxvii.-xcvi.

Winchester Epis. Reg., Fox, ii. f. 42. succeeded on I 9 February by Richard Romsey, the prior, who was the last of the honestly elected abbots of Hyde. He governed the community for nearly twenty-one years under the episcopates of Fox and Wolsey. During the latter part of his life the aged Bishop Fox visited Hyde every fifteen days. In 1522 certain episcopal injunctions were issued which reveal some irregularities, the gravest whereof referred to some of the younger monks practising long-bow archery in the Hyde meadows. In August, 1526, Abbot Romsey received a communication from Wolsey, and wrote asking for a month's time to deliberate over his proposals. $\mathrm{He}$ pleaded that he was 'somewhat diseased,' and not well able to travel to see Wolsey, especially as he was expecting the king in the following week. The tenor of Wolsey's letter can be gathered from the reply. $\mathrm{He}$ had acknowledged that Romsey had ordered his house 'discreetly as yet,' but now that he was suffering from age and weakness he urged him to resign. The old abbot replied, with some spirit, that he was not so aged or impotent of body or wit, but that he was able to exercise his office to the pleasure of God, the increase of good religion and the wealth of his house. ${ }^{3}$

At the close of 1529 Abbot Romsey died, and on 28 January, 1529-30, the monks of Hyde gathered for the last time in their chapter house for the election of an abbot. A portion of the community struggled hard to appoint one of their own number, but others had been won over to support the election of John Salcot, alias Capon, who was already Abbot of Hulme, Norfolk. After several adjournments, the election of the nominee of Wolsey and the Crown was secured. Salcot was a strenuous and ostentatious supporter of the king's divorce. In I 534 he was consecrated by Cranmer, Bishop of Bangor, and in 1539 translated to Salisbury. Among all the absolutely unscrupulous turncoats and time-servers of those strange times the last Abbot of Hyde certainly bears the palm." Salcot on his appointment set to work to prepare for the end, and in 1534 or a little later Cromwell designed a strange and most lax regulation for the fraternity ${ }^{5}$; but if ever this came into operation, it was of short duration. In April, I 538, the surrender was signed, and in September of the same year

3 Letsers and Papers Hen. VIII. iv. 2394.

- See the strong but just account of his career in Edwards's introduction to the Liber de Hyda, lxiv.-1xx.

- Cott. MS. Cleop. E. iv. 29. 


\section{RELIGIOUS HOUSES}

came the visitors, Pollard, Wriothesley and others, vandalizing with their own hands.

The number of inmates of the monastery in 1507 was an abbot, a prior, six senior and twenty-five junior monks, making in all thirty-three members. ${ }^{1} \quad$ This number at the time of the dissolution of the house, was reduced to twenty-one. ${ }^{2}$ In the eleventh, twelfth and thirteenth centuries, however, it would appear from the lists of admissions to the monastery given in the Liber Vitae, the number of members was slightly greater. Pensions were assigned to all those who signed the deed of surrender. The abbot's pension probably ceased immediately, as he was rewarded with the bishopric of Salisbury. The prior's pension was $E_{1} 36$ s. $8 d$. a year ; three senior monks had $£$ io each, two had $£ 8$, and the rest $£ 6$. Annuities were also granted from the monastic funds to Cromwell, Wriothesley and others. In 1557 there were only the prior and ten of the monks left in receipt of pensions. To Wriothesley were granted some of the richest manors of the abbey, including Micheldever and Stratton, as well as a short lease of the entire site of the abbey, its church and appurtenances. Wriothesley pulled the abbey down with extraordinary rapidity and sold the materials; the reversion of the site, together with the demesne lands, passed by royal grant to Richard Bethell.

At the time of the dissolution of the house the monastery held the hundred of Micheldever, the manors of Abbots Worthy, 'Slackestede,' Woodmancote, Micheldever with the rectory ,'Dottesley,' North Stoneham, 'Owers,' East Stratton, Preshaw, Loomer, Alton Eastbrook, 'Bicketon,' Brown Candover, Fullerton and Leckford, Abbots Anne, Winterbourne, Pewsey, 'Thiseldon with Burythorpp,' Collingborne, Puddletrenthide, 'Southese, Tytlescombe,' Heighton and Doughton with the rectory. The rectories of Alton, Puddletrenthide and the chapels of Popham, Northampton, Stratton, and lands in Winchester and elsewhere. ${ }^{3}$

When Leland visited Winchester in 1539 , so rapidly had Wriothesley done his work that he could find nothing but the site, merely recording that 'in this suburb stood the great Abbey of Hyde.' In Camden's time there are said to have remained some ruinous outhouses, a gateway and a large barn supposed to have been the abbot's hall. ${ }^{5}$ William Cole,

1 Liber de Hyda, Introd. lxii.

2 Newminster (Hants Rec. Soc.), Pref. 1.

3 Dugdale's Monasticon, ii. $44^{8}$.

- Leland's Itinerary, iii. 86.

${ }^{5}$ Dugdale's Monasticon, ii. 432.

II the antiquary, was here in 1723 , and could merely discover the convent barn and holes whence even the foundations had been dug. ${ }^{\circ}$ In 1788 the county magistrates purchased the abbey field as the most suitable spot for the erection of a county gaol! There seems good reason to believe that at this time the grave of Alfred was destroyed and his dust scattered. ${ }^{7}$

\section{Abbots of Newminster}

Grimbald, 903

Beornhelm,

Ethelgar, 965-83

Elfsige, circa 983-97

Brightwold, 995 or $997-1012$

Brithmere, I $012-21$

Alnoth, 1021-35

Alwyn, 1035-57

Alfnoth, 1057-63

Alwyn II., 1064-66

Wulfric, 1069-72

Rewalan, 1072-

Ranulf Flambard

Herbert Losinga

Robert Losinga, I091-93

Herbert Losinga, ${ }^{8}$ I 093

Hugh, I I 00-6

Geoffrey, $1106-24$

\section{Abbots of Hyde}

Osbert, I $124-35$ (?)

Six years' vacancy

Hugh de Lens, I $142-9$

'Two years' vacancy

Salidus, 1 I $5 \mathrm{I}-7 \mathrm{I}$

Five years' vacancy

Thomas, $1177-81$

John Suthill, I I 8 I- I 222

Walter Aston, 1 222-48

Roger of St. Valery, 1 248-63

William of Worcester, 1263-8 I

Robert, or Roger, of Pophain, 1282-92

Simon Canning, ${ }^{9}$ 1292-1 304

Geoffrey of Ferringes, ${ }^{10}$ I $304-17$

William of Odiham, $1317-19$

Walter of Fifield, ${ }^{11}$ 1 3 I $9-62$

Thomas Pechy, ${ }^{12}$ I $362-80$

- Add. MS. 5828 , f. 175.

7 Archaeologia, xiii. 309-1 2.

${ }^{8} \mathrm{Mr}$. Edwards in the Introd. to Liber de Hyda, xliii. states that Ranulph Flambard re-entered after the death of Robert Losinga.

9 Pat. 20 Edw. I. m. 6.

10 Ibid. 32 Edw. I., m. 4, 3, 2 ; Winchester Epis. Reg., Pontoise, f. 46.

11 Register of Sandale (Hants Record Society), Pp. $108-9$.

12 Winchester Epis. Reg., Edingdon, i. 116. 


\section{A HISTORY OF HAMPSHIRE}

John of Eynesham, ${ }^{1}{ }_{1} 381-94$

John Letcombe, I 394-1408

John London, ${ }^{2}$ 1 $408-16$

Nicholas Strode, $1416-40$

Thomas Bramley, 1440-65

Henry Bonville, $1465-72$
Thomas Worcester, $1472-9$

John Collingborne, 1480-5

Thomas Forte, $1485-8$

Richard Hall, 1488-1509

Richard Romsey, 1509-29

John Salcot, $153^{0-38}$

\section{HOUSES OF BENEDICTINE NUNS}

\section{NUNNAMINSTER, OR THE ABBEY OF ST. MARY, WINCHESTER}

To the north-east of St. Swithun's, and immediately to the east of the New Minster, stood the great abbey of St. Mary, the nuns" minster, usually known as Nunnaminster. It was founded jointly by Alfred and his queen Eahlswith, about the close of the ninth century, ${ }^{3}$ but the buildings were completed by their son, Edward the Elder. After Alfred's death, the queen retired to this monastery, where she died. It would seem probable that she should have been made abbess, but Leland describes Edburga the daughter of Edward, who died in 925 , as the first abbess. ${ }^{4}$

The endowment of the monastery seems to have been inadequate for its maintenance, and it is said to have fallen into great poverty. King Edred bequeathed to it Shalbourn and Bradford in Wiltshire; ${ }^{5}$ but notwithstanding this addition to its revenues, Bishop Ethelwold, possibly on account of its poverty but more probably with a view of establishing there the stricter form of Benedictine rule, practically refounded it in $963,{ }^{6}$ and apparently re-endowed it.

By the Domesday Book we learn that the abbess held Lyss, Froyle, Leckford Abbess, Long Stoke, Timsbury, and Ovington in Hampshire; Coleshill in Berkshire; and Urchfont and All Cannings in Wiltshire. We know nothing of the history of this monastery from this date till the middle of the twelfth century, when during the civil war between Maud and Stephen the city of Winchester, together with this monastery, was burnt in

1 Pat. 4, Ric. II. pt. I, m. I ; 4 Ric. II. pt. ii. m. 33; Winchester Epis. Reg., Wykeham, i. ff. $113,114$.

${ }_{2}$ Winchester Epis. Reg., Beaufort, ff. 4, 5 .

a William of Malmesbury ascribes the foundation solely to Alfred, but the Hyde Chartulary (Harl. MSS. 1761, f. 14) describes the queen as fundatrix ecclesie Sancte Marie sanctimonialium Wynton'.

1 Ann. Monastici (Rolls Series), ii. 10.

- Liber de Hyda, 346 and note.

- Ang. Sax. Chron. (Rolls Series), ii. 93.
I $4 \mathrm{I}^{7}$ It was a rule that upon the election of an abbess, the convent was bound to find in early times a corrody and later a pension for a person nominated by the Crown, and in this way it appears that Juliana de Leygrave, niece of the king's (foster) mother, Alice de Leygrave, who suckled him in his youth, received at the election of Maud de Pecham in 1313 a nun's corrody for life, the value to be received by her wherever she might be, and a suitable chamber within the nunnery for her residence whenever she might wish to stay there. ${ }^{8}$ This prerogative of the Crown seems to have been exercised at each election of an abbess, and writs for the payment of such corrodies or pensions are to be found among the public records. ${ }^{9}$ "The Crown also seems at a later date to have claimed a right to nominate a nun for admission to the monastery at the coronation of each sovereign, ${ }^{10}$ and a like privilege was exercised by each Bishop of Winchester at his consecration. ${ }^{11}$

Besides the professed nuns and their household the abbey of Nunnaminster supported a certain number of chaplains or canons who had prebendal stalls in the abbey. ${ }^{18}$ The original idea of having canons attached to these old Benedictine foundations seems to have been to provide the nuns with suitable chaplains, as well as with priests who could superintend the management of their temporalities. The canons of Nunnaminster could, however, as a rule, have been of little or no service to the monastery, whose income they drained. For instance, at his own request, the pope granted Roger Holm, canon of this monastery in 1349, the church of Elvydon,

7 Ann. Monastici (Rolls Series), ii. 52.

8 Close, 6 Edw. II. m. 4 d.

- See grant to William de Boiston, clerk, of a pension in 1337 (Close, 11 Edw. III. p. 2, m. 5d); and to Richard Withers in 1527 (Letters and Papers, Hen. VIII. iv. $3213[3])$.

10 See the nomination of Agnes Denham in 1418 (Pat. , Rich. II. pt. 2, m. 3).

i1 See mandate for the admission of Dyamunda daughter of Richard de Sutton in 1320 (Winton. Epis. Reg., Asserio, f. I) ; the same for Joan Testwood in 1367 (ibid. Wykeham, iii. f. 1ob).

12 Dugdale's Monasticon, ii. 452 . 


\section{RELIGIOUS HOUSES}

in the diocese of Salisbury, notwithstanding that he was also the holder of canonries in Lincoln and London, and was expecting a benefice from the Abbot of Ramsey. ${ }^{1}$ Or again, Canon Richard of Norwich of this convent had papal sanction in 1355 to hold a London canonry, although in addition to the prebend from Nunnaminster he drew the emoluments of prebends from Salisbury and Kilkenny, and held the church of Adesham. ${ }^{2}$ Throughout the papacy of Clement VI. (1342-52) pluralism was specially rampant, and there were few worse cases than those of the holders of prebends in the Hampshire nunneries of Nunnaminster, Romsey and Wherwell.

In I 3 I 7 papal sanction was obtained for Roger de Inkepen, a wealthy and beneficent citizen of Winchester, to found and endow a chapel in the cemetery of Nunnaminster, to be served by two priests, the patronage of which was to belong to him and his heirs. ${ }^{3}$ This chapel was dedicated to the Holy Trinity; one of the priests was termed the warden and the other the chaplain; they lived together and had a common table; they were ordered to say daily mattins and evensong in the chapel in addition to the masses." In December, I 321 , this chapel was defiled by shedding of blood, when the bishop commissioned Peter, Bishop of Corbavia, to reconcile it. ${ }^{5}$ We have mention also of another chantry in the monastery founded at the altar of St. Peter at the east end of the south quire aisle by Robert de Wambergh, Archdeacon of Wells, in 1328. It was endowed with lands at Urchfont for the support of a chaplain to pray for the souls of Emeline Longspee and others. $^{6}$

During the fourteenth and fifteenth centuries the abbey, like other similar foundations, seems to have got into pecuniary difficulties. In 1343 the convent attributed one of the chief causes of their poverty to the action of the king in taking the profits of the temporalities during a vacancy, and to assist them they petitioned the pope for licence to appro-

1 Cal. of Papal Petitions, i. 152.

2 Ibid. i. 28I; see also the petition for a canonry for William de Meon in 1343 (ibid. $i$. 58). Reference has already been made to the rebuke by the bishop in 1318 of the unseemly dress of one of the chaplains of the nunnery (supra, p. 28).

3 Ibid. ii, 160.

- Pat. II Edw. II. pt. I. m. I; I 2 Edw. II. pt. I, m. 20 ; St. Swithun's Chartulary, ff. 60-Ib.

s Winton. Epis. Reg., Asserio, f. 7 b.

- Pat. 2 Edw. III. pt. I, m. I I. priate the parish church of Froyle. To this the pope assented, but ordered that it should be done through the diocesan. ${ }^{7}$ The preliminary arrangements for this appropriation had been carried out by Bishop Orlton just before his death; but on the succession of Bishop Edingdon, that prelate, with the support of the Archbishop of Canterbury, refused his sanction. Whereupon the convent in 1346 again approached the pope, setting forth the state of affairs, and pleading the sterility of their lands, the destruction of their woods, the diminution of their rents, and the excessive number of nuns and sisters, whereby they were unable to pay their debts, provide for the inmates, or repair the buildings. They further pleaded the reduction of their temporalities through royal administration. The pope in reply empowered the Bishop of Hereford to carry out the appropriation. ${ }^{8}$ In the same year Bishop Edingdon issued an inhibition to the abbess not to receive sisters beyond the ancient number. ${ }^{9}$

A few years later in 1349 the monastery suffered on account of the Black Death. The abbess, Maud Spine, apparently succumbed to this plague, at all events there was a vacancy in that year. ${ }^{10}$ The cattle plague which followed the Black Death severely affected the convent. This, coupled with the general reduction of their rents and the barrenness of their lands, caused by the sparsity and dearness of labour, were among the causes again pleaded on behalf of Nunnaminster, in a petition to the pope in 1352 , for the appropriation of the church of Gretford, in the diocese of Lincoln, valued at 40 marks. The prayer was granted, and the ordinance of the vicarage was committed to the Bishops of Salisbury, Worcester and Wells. ${ }^{11}$ Notwithstanding that the custody of the temporalities during a vacancy was granted to the prioress and convent at a rent to the Exchequer in $1464,{ }^{12}$ which, as we have seen, was a concession much sought after by the convent, the abbess and convent in 1468 again complained that they were so burdened with the repair of their houses and church, and with the payment of tenths and other imposts that they could not

7 Cal. of Papal Petitions, i. 56; Cal. of Papal Letters, iii. I12. The licence had been obtained for this appropriation as far back as 1330 , but it had never been completed (Pat. 4 Edw. III. p. I, m. 39).

${ }^{8}$ Cal. of Papal Petitions, i. 122.

- Winton. Epis. Reg., Edingdon, ii. f. 3 b.

10 Ibid. i. f. $5 \mathrm{x}$.

11 Cal. of Papal Petitions, i. 230.

12 Pat. 4 Edw. IV. pt. 2, m. 7. 


\section{A. HISTORY OF HAMPSHIRE}

fulfil the obligations of their order as to hospitality. To assist them in their distress King Edward IV. granted that they should have view of frankpledge and assize of bread and ale, with waif and stray at their towns of Urchfont and Allcannings, in the county of Wilts, from all their tenants and other residents. ${ }^{1}$ In 1476 a further grant was made, as the previous one was not so valid as had been hoped, that the nuns should have all sums of money and rents due to the king from themselves or their tenants or other residents in the same towns. ${ }^{2}$

On 24 January, 1370 , the bishop excommunicated certain persons who had been instrumental in the abduction of one of the nuns $;{ }^{3}$ and in June of the same year he issued his mandate to the abbess to re-admit a nun, Isabel Gerway, who had apostatized, but was then anxious to return." The name of the abducted nun is not given in the first of these documents, and they both probably refer to the same sister.

Some idea as to the internal rule of the house can be obtained from the frequent visitations of the bishops of the diocese. In 1308 Bishop Woodlock commissioned Lawrence, sub-prior of St. Swithun, and Master Stephen de Dene, his commissary general, to visit the nunnery; on 16 March, I 309 , he issued an elaborate series of injunctions for the better government of the house, divided into thirteen heads. ${ }^{5}$ Bishop Stratford (I 323-33) also held, or caused to be held, various visitations of his monastery, and on two occasions cited the Abbess Maud for the correction of excesses. ${ }^{6}$

It is recorded that Bishop Orlton (1 333-45) personally visited Nunnaminster on 9 April, 1334, when he preached in the chapter house from the text, 'Deo per omnia placentes.' In 1336 he commissioned his official to visit for the correction of excesses (the usual phrase), and there was a further visitation in $1337^{\circ}$ Bishop Wykeham paid considerable attention to the monastery. In 1384 he addressed a mandate to the abbess for the correction of nuns who were disobedient to their officers, and censured the superior for lack of discipline. ${ }^{8}$ In September, 1396 , the bishop commissioned Nicholas Wykeham, Archdeacon of Wilts, and John Elmere, the offi-

1 Pat. 8 Edw. IV. pt. 3, m. 3.

2 Ibid. 16 Edw. IV. pt. 1, m. 20.

3 Winton. Epis. Reg., Wykeham, iii. f. zoa.

- Ibid. 36b.

- Ibid. Woodlock, f. 150.

- Ibid. Stratford, ff. 56, 57b, 79, $176-7$.

7 Ibid. Orlton, i. ff. $10 \mathrm{~b}, 4^{1}, 54 \mathrm{~b}$.

- Ibid. Wykeham, f. 2 I 2 a. cial, to visit the abbey, ${ }^{9}$ and on 14 June, 1403, he granted his licence to the abbess and nuns to hear divine service in their new Lady Chapel adjoining the quire. ${ }^{10}$ By his will Wykeham left to the abbess five marks, and each of the nuns one mark.

Dr. Hede visited St. Mary's on 2 March, 1501, when Abbess Joan Legh was able to give satisfactory evidence as to the order and administration of her house. The common seal was kept in a chest, the three keys of which were in the respective possession of the abbess, prioress and sacrist. Margaret Fawcon, the prioress, testified that all the sisters had their meals in the frater, save one who was very aged. Agnes Tystede, subprioress, testified that all the convent rose at night for mattins, save the sick and aged. Christiane Whytyngton, infirmarer, stated that the annual balance sheet was duly presented in chapter. Margaret Bawdewin, precentor, testified that omnia bene. Agnes Trusset, the second cantor, Agnes Kyng, the third cantor, and Agnes Massaw, the fourth cantor, gave brief evidence to the same effect, and so also did Alice Tystede, scrutator, Agnes Byrcher, Margaret Shafte, Agnes Cox, senior teacher (dogmatista), and Margaret Legh, mistress of the novices. Elia Pitte, the librarian, was also well satisfied with that which was in her charge. ${ }^{11}$

The first commissioners appointed for visiting the Hampshire monasteries were Sir James Worsley, John and George Poulet, and William Berners. Their report of St. Mary's, Winchester, was highly favourable. They visited this nunnery on 15 May, 1536, and examined on oath Elizabeth Shelley, the abbess; Thomas Lee, auditor; Thomas Legh, receiver; and Thomas Ticheborne, clerk. They found in the convent 102 persons, namely, 26 religious, 5 priests, 13 lay sisters, 9 women servants, 20 officials and waiting servants, 3 corrodiers, and 26 children. Their names are all set forth in full. Of the religious persons, all, save four, were professed, and 'every of them entende to kepe theyr habits and religion to what house religious or ever they shall be comytted by the kinge's highness, Dame Frith Welbek only excepted, which desireth thanne to be comytted to any oder house to have capacite.' All the professed are termed Dames. The five chaplains were Master John Hazard, confessor, and four others.

2 Ibid. iii. f. 29 r.

10 Ibid. $356 \mathrm{~b}$.

11 Sede Vacante Register, Canterbury Priory. 


\section{RELIGIOUS HOUSES}

Among the women servants were Jane Sherley, 'the abbas gentyllwoman,' as well as a servant. The prioress, sub-prioress and 'sexten' (sacrist) had each their servant in their respective houses, and so had 'Dame Maud Burne in her house.' The other three were 'lavenders' (washerwomen) to the abbess and convent. The officials and servants were a general receiver, clerk, 'curtyar' (curtiler), cater, butler, cook, under-cook, baker, convent cook, under convent cook, brewer, miller, porter, under-porter, porter of Eastgate, two 'churchemen,' 'Peter Tycheborne chylde of the high aulter,' and two servants of the receiver and clerk respectively. The corrodiers were Thomas Legh, John Lichfeld and Richard Yeckley.

The twenty-six 'chyldren of lordys, knyghttes and gentylmen brought up yn the sayd monastery' were : 'Bryget Plantagenet, dowghter unto the lord vycounte Lysley; Mary Pole, dowghter unto Sir Gefferey Pole knyght ; Brygget Coppeley, dowghter unto Sir Roger Coppeley knyght ; Elizabeth Phyllpot, dowghter unto Sir Peter Phyllpot knyght ; Margery Tyrell ; Adryan Tyrell; Johanne Barnabe ; Amy Dyngley; Elizabeth Dyngley; Jane Dyngley; Frances Dyngley; Susan Tycheborne; Elizabeth Tycheborne; Mary Justyce; Agnes Alymor ; Emma Bartue; Myldred Clerke; Anne Lacy; Isold Apulgate; Elizabeth Legh ; Mary Legh; Alienor North; Johanne Sturgys; Johanne Fylder; Johanne Francis; Jane Raynysford.'

The commissioners put on record that the religious persons of this house 'have been and are of very clene, vertuous, honest, and charitable conversation, order, and rule synce the furst profession of thym, which is also reported not only by the Mayors and Comynaltye of the Citye of Winchester, butt also by the most worshipfull and honest persons of the Contre adjoynynge thereunto, which have daylye made a contynuall sute unto the said Commyssioners to be suetors unto the Kinges highnes for tolleracon of the said monastery.'

'Item the said monastery is in a very good state of Reparacon and standeth nigh the middell of the Citye of a great and large compasse envyround with many poor householdes which have theyr only lyvynge of the said monastery, and have no demaynes whereby they may make any provysion butt lyve only by theyr handes, making theyr provysion in the markettes.'

They returned the monastery as out of debt, and reported that the convent seal was put in a bag sealed with the seal of Richard Poulet, locked in a coffer with three keys, which remained in the custody of the abbess and two of the chief governors of the monastery; that the value of the lead on the church and houses was I $_{54}$ IOs., and there were five great bells and one little one, worth $£ 28$ 2s. 6d.; that the inventory of the jewels, ornaments, household stuff, stock and stores amounted to $f_{4} 86$ I $3^{\text {s. }} 7 d$. ; that $f_{24} 6$ s. $8 d$. was owing to the monastery; that the annual value of the lands and possessions was $£ 330$ I 8 s. $6+d$., and that the value of the woods was $\ell_{2} 31$ 6s. $4 d{ }^{1}$

The Valor of 1535 returned the gross annual value of the abbey as $f_{2} 45$ I 7 s. $2 \frac{1}{2} d$., whilst the clear value was only $f_{1} 79$ 7s. $2 d$., which brought it well within the limit of the Act of the following year for the suppression of the smaller monasteries. It is difficult to account for the great discrepancy between this valuation and that made by the commissioners in 1536 as given above even after making allowance for the former being an assessment value. It was possibly owing to this higher estimate that St. Mary's escaped the destruction of those houses whose revenue was less than $£ 200$ per annum, but more particularly on account of the payment of the great sum or bribe of $£ 333$ 6s. 8d. On 27 August, 1536 , letters patent placed the establishment on a new and diminished foundation, the Wiltshire manors of Urchfont and All Cannings being granted to Sir Edward Seymour (Viscount Beauchamp) and Anne his wifc. Elizabeth Shelley was at the sane time confirmed in her position as abbess. ${ }^{2}$

But the respite was not for long. In September, 1538, Cromwell's commissioners proceeded 'to sweep away (from St. Mary's) all the rotten bones that be called relics.' ${ }^{3}$ At last, on I 5 November, 1539, the 'surrender' was signed, beforc Robert Southwell and other commissioners, pensions being granted to the abbess of $£_{2} 6$ I $3^{s .} 4^{d .}$; to the prioress, $£_{5}$; to two nuns, $\ell_{4}$; to two, $£_{2}$ $16 s .8 d$; and to seventeen others, $£_{2}$ I $33^{s .} 4 d^{4}$

In the following years these pensions were confirmed, as well as $6 \mathrm{~s} .8 d$. each to twelve poor women called sisters, and the site granted to John Bello and John Brarholme. The 'houses' that were recommended to be 'susstained' were the abbess' lodging, stretching from the church to the frater on the north, with its court and appurtenances, the buttery, pantry, kitchen and larder; the gatehouse; the barn; the bakehouses; the brewhouse; the garner; the stables; and the mills. Among

1 Aug. Off. Misc. Books, cccc. 24.

2 Pat. Hen. VIII. pt. 2. m. 14, vide supra.

3 Letters and Papers, Hen. VIII. xiii. (2) 401.

- Aug. Off. Misc. Books, ccxlv. 96 . 


\section{A HISTORY OF HAMPSHIRE}

the superfluous buildings was of course the church, and also the cloister, chapter house, dorter, frater, farmery, convent kitchen, the two garners on the south side of the court, the priest's lodging and the plumber's house. The lead on the church, quire, aisles, steeple, cloister and other houses was estimated at 220 fothers. There were five bells, but no 'jewels.' There were 1 i 8 ounces of plate, and the ornaments, goods and chattels had been sold for $£_{6}^{6} 9$ I 5 s. $4 d^{1}{ }^{1}$

At the time of the dissolution of the monastery the possessions included the manor of Froyle with the rectory, the manors of Itchen, Leckford Abbess, Timsbury, Greatford with the rectory, and Braceborough, and lands, rents, etc. in the city of Winchester, Lyss Abbas, Wetham, Godsfield, Shamelhurst, Swindon, 'Hacheborne,' Shipton Moyne, Blandford and 'Barnethorpe.' '

In the days of Camden, at the beginning of the seventeenth century, there were considerable remains of the Nunnaminster; but now no traces of it exist save the name and certain watercourses. It stood between High Street and Colebroke Street.

\section{Abbesses of Nunnaminster}

Edburga, died 925

Ethelreda, 963

Edith, in the time of King Edgar

Beatrice

Alice, ${ }^{3} 1084$

Avice," I I 20

Clarice, I 174

Agnes, ${ }^{5}$ I $236-64$

Euphemia, ${ }^{6}$ I $265-70$

Lucy, ${ }^{7} 1270-87$

Christine de Winton, ${ }^{8}$ 1 287-99

Agnes de Ashley, ${ }^{\circ}$ I 299-1 313

Maud de Pecham, ${ }^{10}$ I $3^{1} 3^{-3}-37$

Maud de Spine, I337-49

Margaret Molins, I 349-64

Christiane Wayte, $1364-5$

Alice de la Mare, ${ }^{11}$ I $365-85$

Joan Denemede, ${ }^{12}$ I 385-1410

1 Aug. Off. Misc. Books, ccccxciv. ff. 1 I-5.

2 From the first Minister's Account cited in Dugdale's Monasticon.

${ }^{3}$ Ann. Monastici (Rolls Series), ii. 34 .

1 Ibid. 52.

s Ibid. 102 ; and iv. 455 .

- Ibid. ii. 102.

7 Ibid. 109 ; and iv. 460.

8 Pat. 16 Edw. I. mm. 3, $18,15$.

- Ibid. 27 Edw. I. mm. 37,36 .

10 Ibid. 6 Edw. II. pt. 2, mm. 16, 15, 13; and Winton. Epis. Reg., Woodlock, f. 180.

11 Winton. Epis. Reg., Edingdon, i. ff. $112,129$.

12 Ibid. Wykeham, i. f. 16 I ; Pat. 8. Rich. II.
Maud Holme, ${ }^{13}$ 1410-4

Christine Hardy, ${ }^{14}$ I 4 I 4-8

Agnes Denham, 1418-49

Agnes Buriton, ${ }^{15}$ I449-86

Joan Legh, 1486-1527

Elizabeth Shelley, 1527-39

\section{THE ABBEY OF ROMSEY}

The statements with regard to the early foundation of Romsey are confusing and conflicting, but it would seem probable that Edward the Elder founded this house about the year 907, and that his daughter St. Elfleda became abbess and was buried there. ${ }^{16}$ In 967 Edgar, grandson of Edward the Elder, reconstituted the abbey, dedicating it to the honour of St. Mary and St. Elfleda, and placed there nuns under the Benedictine rule over whom he appointed Merwenna as abbess. ${ }^{17}$ In this reconstitution Bishop Ethelwold (963${ }^{84}$ ) took a considerable part. ${ }^{18}$

Of Merwenna little is known; she is said to have been of noble Irish birth. Elwina, the second abbess, succeeded about 993, when Hampshire was overrun by the Danes, and it is supposed that the abbess and her nuns had to take refuge in Winchester.

The considerable holdings of the abbey at the time of the Domesday Survey consisted of the vill of Romsey, fourteen burgesses in Winchester, Itchenstoke, Sidmonton, a hide in Totton and a hide in Sway in Hampshire, and Edington and Steeple Ashton in Wiltshire.

In 1086 Christine, sister of Edgar Atheling, took the veil at Romsey, as stated in the Saxon chronicle, and became abbess. To the same retreat Christine was followed by her young niece Maud, but she did not take the vows, and became the Queen of Henry I., being married at Martinmas, $1100 .^{10}$

Mary, daughter of King Stephen, became abbess here about II60, and it was her uncle, Henry de Blois, Bishop of Winchester (I $129-$ $7 \mathrm{I})$, who was probably the builder of the greater part of Romsey Abbey as it now stands. Abbess Mary in i 60 left her monastery to become the wife of Matthew, son of

pt. 2, mm. 35, 29, 23 ; Add. Charters, I 7, 497508 .

26.

1a Winton. Epis. Reg., Beaufort Registers, f.

14 Add. Charters, 17, 509.

16 Winton. Epis. Reg., Waynflete, f. 1 ob.

10 Liber de Hyda (Rolls Series), 112 , and Lands. MSS. $46_{3}$.

17 Florence of Worcester (Thorpe's ed.), i. I4I.

18 William of Malmesbury, iii. 149.

10 Vide Eccl. Hist. supra, p. 10. 


\section{RELIGIOUS HOUSES}

Theodoric, Earl of Flanders. By him she had two daughters, but was afterwards separated from her husband. According to Matthew Paris this separation was brought about by the censure of the Church, and she returned in penitence to Romsey.

In 1283 this nunnery was visited by the energetic Archbishop Peckham. Among the numerous decrees, issued as a result of the visit, was the forbidding the abbess to have more than two secular maids; the loss of her pittance in the frater by any nun breaking silence in the cloister; forbidding a nun ever speaking to a man (save in confession) unless two of her sisters were present ; confessions to be made in the church, either before the high altar, or at the side of it towards the cloister; forbidding the nuns to eat or drink in any house in Romsey under pain of a year's suspension; and the forbidding of the entry of any male, under pain of excommunication, into the rooms of the nuns, save in times of sickness to the farmery, and then only the confessor, the doctor, or a near relative. At the same time Peckham decided a dispute as to the steward, Richard de Chalfhunte, who held office against the will of the convent, and ordered the abbess to take to her aid three coadjutors from among the nuns, and to transact no convent business without their assent, namely Margaret de Verder, Philippa de Stoke, and Joan de Ronedonne. ${ }^{1}$

In August, I 286, Arch bishop Peckham issued a mandate to William Shirlock, a prebendary of Romsey, charged with illicit wandering (inhoneste devagantem) through the town of Romsey and elsewhere, not to dare to enter the cloister nor the abbey church of Romsey so long as there were probable grounds of suspicion against him. This was accompanied by an inhibition addressed to the nuns of Romsey to hold no manner of conversation with this prebendary in their house or elsewhere. At the same time a mandate was despatched to Master Henry, official of Winchester diocese, directing him to inquire into the case of William Shirlock, accused of disturbing the nuns of Romsey, and leading a dishonourable and dissolute life. ${ }^{2}$

The taxation of I29I valued the temporalities of the Abbey of Romsey in the archdeaconry of Winchester at $£ 78$ 7s. $6 d$., in the deanery of Potterne (Sarum) at $£ 100$, in the deanery of Wyly, IOs., and in the archdeaconry of Gloucester at $£ 5$, giving a total of $£_{18} \quad 175.6 d$. In addition to this

1 Archbishop Peckham's Registers, ff. 231, 232.

2 Ibid. ff. 1 22a, 122 b. the abbess received a pension of $£ 56$ s. $8 d$. from the church of Inmere (Sarum), and of $693^{\text {s. }} 4^{d}$. from the church of Weston (Worcester).

In I30I Bishop Pontoise visited the Abbey of Romsey, and as a result injoined that a balance sheet should be audited twice a year in the chapter house; that a bell should be rung for all the hours; that high mass should always precede nones; that the chaplains should be inhibited from ever celebrating after nones; that the doors of the cloister and dorter be better warded; that the safe custody of the seal be secured; that there should be no eating nor drinking with any religious or secular person in the town of Romsey; and that no corrody nor pension should be granted without the bishop's sanction. ${ }^{3}$

In February, 1305, the abbess found herself so infirm that she nominated Roger Bandet and Roger de Presland to act as her attorneys for three years $\mathbf{i}^{4}$ and in June, 1307 , a grant was made to the prioress and nuns of the custody of their abbey on the death, cession, resignation, or deposition of their Abbess Philippa. ${ }^{5}$ This order was confirmed by Edward II. on his accession to the throne.

The convent was visited in 1310 , and the decrees consequent on the visitation are set forth in the bishop's register both in Latin and French. The decrees were divided into thirteen heads, and ordered that the mass of the Blessed Virgin, with at least eight nuns present, and the farmery mass should be celebrated daily, and that no seculars of any condition or age should come within the precincts to hear mass in the farmery; that a bell should ring for all the hours, and that high mass should be celebrated before nones; that no secular women should enter the convent at any time; that there should be a half-yearly balancing of accounts before the chapter; that the seal should only be affixed in chapter to documents read intelligibly; that two nuns should be appointed to assist the prioress in the receiving and disbursing of rents; that the doors of the cloister and the dorter should be warded, and that there was to be no eating nor drinking in the frater after compline ; that children were not to be admitted to the dorter, nor to be in the quire when divine offices were celebrated; that curtains (if any existed) before the beds in the dorter were to be removed ; and that woodmen and other work-

3 Winton. Epis. Reg., Pontoise, f. 32.

- Pat. 33 Edw. I. m. 17.

Close R. 1 Edw. II. m. 19. 


\section{A HISTORY OF HAMPSHIRE}

men were to be excluded from the convent. Special rules were also laid down as to the dietary of the farmery, and as to bloodletting. ${ }^{1}$

The claim of the Crown to enforce the payment of corrodies and pensions from monasteries under its patronage, to persons nominated by it, was frequently insisted upon at Romsey. In June, 13 IO, Juliana la Despenser was sent with letters under privy seal to the abbess and convent to be provided with fitting maintenance for herself and her maid during her lifetime. ${ }^{2}$ In 1315 the abbess and convent were enjoined to give a pension to Richard de Ayreminn, they being obliged to grant a pension to one of king's clerks on account of the new creation of an abbess. ${ }^{3}$ For the same reason John de St. Paul obtained a pension in 1333, and Thomas Sampson, a scholar, in $1515 .^{\circ}$ The bishops of Winchester in like manner claimed the right to nominate a nun to be admitted to the abbey at their consecration. ${ }^{6}$

On 1 I May, 1 315, Alice de Roffa and Margaret de Middleton, nuns of Romsey, brought news to the king of the death of Abbess Alice, and obtained the necessary licence for another election." It was alleged that the late abbess had come to her end by foul means, and on 28 May the justices, Henry de Scrop, John Daubernoun and John Bluet, were appointed a commission of oyer and terminer touching the persons who killed the late abbess at Romsey, on the confines of the counties of Hants and Wilts, from which two counties the jurors were to be selected. The cause of death is stated in the letters patent to have been intoxicatione, which we take to be drugging or poisoning, and not 'forced inebriation,' as Dugdale has it. ${ }^{8}$ To this commission John Randolf ${ }^{\theta}$ was added in July, but the result of the trial has not been recorded.

Meanwhile the king gave the custody of the abbey to Master Richard de Clare, but

1 Winton. Epis. Reg., Woodlock, f. I 53.

2 Close, 3 Edw. II. m. 3 d.

3 Ibid. 9 Edw. II. m. 23 d.

- Ibid. 7 Edw. III. p. 2, r 7 d.

5 Letters and Papers Hen. VIII. ii. 914, 915, $935,942,1008$.

Winton. Epis. Reg., Sandale, f. 2 ; and Asserio, f. I.

7 Pat. 8 Edw. II. pt. 2, m. 17 Cal.

8 Ibid. p. 2, m. I od; Dugdale's Monasticon, ii. 507. The Calendarist of the Patent Rolls has also blundered over intoxicatio, as if it meant drunkenness.

- Ibid. 9 Edw. II. p. I, m. 3 Id. the prioress and nuns recovered it on paying a fine of forty marks. ${ }^{10}$

On 20 February, 1316, order was issued to the abbess to examine the rolls, etc., of Nicholas de Romsey, late justice-in-eyre of the forests this side Trent, which were said to be in her treasury, and all other muniments touching the said matters in her possession, and to send them under seal to Westminster. ${ }^{11}$

Bishop Orlton visited the house on November 28 and preached in the chapter house from the text, ' 2 ue parate erant intraverunt cum eo ad nuptias.' 12

In 1336 Edward III. granted to the convent the custody of the temporalities of their house during a vacancy, for which they were to pay $£_{20}$ for each month of the vacancy. ${ }^{13}$ By the return of the aid for making Edward the Black Prince a knight it appears that the abbess held in perpetual alms half a knight's fee in Sidmanton. ${ }^{14}$

In I 370 Bishop Wykeham authorized the abbess to appoint one or two chaplains, clean in life and pure in conscience, to confess herself and the sisters. ${ }^{15}$ Later in his episcopate the bishop adopted the better plan of himself appointing the confessors. By an undated commission, apparently circa I 395, Ralph Basyng, a monk of Winchester, and two other priests were appointed to confess the abbess and nuns of Romsey. ${ }^{16}$ Basyng was appointed to a similar position for the nuns of Wherwell in 1393 . At the time of the nomination of Basyng and his two colleagues as confessors, the confessor's licence held by Friar John Burgeys was revoked, and a monition was issued to the abbess warning her not to allow any secular priest serving in the conventual church or in the town of Romsey to have access to her in the rooms or cloister of the abbey, nor to hold with them any conversation save in the presence of an honest and trustworthy sister nun.

On 29 May, 1372, Bishop Wykeham wrote to the Abbess and Convent of Romsey desiring them, at the request of William, Earl of Pembroke, to receive his noble kinswoman, Dame Elizabeth de Berkele, during the absence of Maurice Wytht, her husband, on foreign service with the earl. ${ }^{17}$ The letter was to be taken as an episcopal licence, for

10 Close, 8 Edw. II. m. 1 .

11 Ibid. m. 25.

12 Winton. Epis. Reg., Orlton, i. f. I I.

13 Pat. 10 Edw. III. p. i. m. 43 d.

14 Feudal Aids, ii. 331.

15 Winton. Epis. Reg., Wykeham, iii. f. 38.

18 Ibid, f. 291 b.

17 Wykeham's Registers, iii. f. 6gb. 


\section{RELIGIOUS HOUSES}

without such leave the reception of a guest would have been quite irregular. At the same time a like letter was sent to the nunnery of Wherwell, so that Dame Elizabeth could make her choice of houses or change her residence during her husband's absence. The Earl of Pembroke was in charge this year of the disastrous expedition to relieve Rochelle, when his ships were burnt by the Spanish fleet and he himself taken prisoner.

A curious dispute arose in the time of Bishop Wykeham between the (canon) sacrist of the abbey church and the vicar of the parish church of Romsey. An order from the bishop to the rural dean of Sombourn to inhibit the vicar, John Folyot, and his chaplains, pending the decision of a cause promoted by the abbess and convent against them, states that it had been the usage, time beyond memory, for the sacrist of the abbey church to bless the palms and boughs of other trees used at mass on Palm Sunday, and that from the high altar and not elsewhere; nevertheless the vicar and chaplains had interrupted the sacrist in the exercise of this privilege. ${ }^{1}$ The instruction to the rural dean is dated 13 March, 1 372, and as Easter that year fell on March 20, the inhibition would be in good time to prevent a scandal on the ensuing Palm Sunday. The north aisle of the great abbey church of Romsey was used as the parish church. The high altar would be in the nuns' quire. It can therefore be readily understood that the vicar ministering to the people would resent the palms being blessed out of sight of the congregation.

At this time there was also a dispute between the town and the abbey as to the repair and maintenance of this north aisle or chapel, and on 15 March, 1372, the bishop appointed Thomas de Sheptone, canon of Wells, and two other commissioners to hold an inquiry in order to settle upon whom this responsibility lay. ${ }^{2}$ On Io May, I 403, a faculty was granted to the vicar and parishioners of Romsey to pull down and rebuild the wall of the north aisle of Romsey Minster from the transept to the porch in order to enlarge it. The petition of the parishioners stated that the aisle was so narrow and confined that on Sundays and festivals there was no suitable or even decent accommodation for the worshippers, and they expressed a desire not only to make their part of the minster larger, but fairer. The bishop granted the faculty in language strongly approving of the

1 Wykeham's Registers, iii. f. 65 b.

8 Ibid. f. $88 \mathrm{~b}$. beautifying of God's sanctuary, and of providing fully for the numerous population of both sexes of the town of Romsey, for whom this north aisle was their only parish church; but he made it a condition that not only was the work to be done at their own expense, but it was to be sustained in like manner. On the day following the grant of this faculty the bishop sent a letter to the abbess and nuns of Romsey advising and exhorting them to show favour and kindness to the project of the vicar and parishioners. ${ }^{3}$

Henry, Bishop of Annadown, acting as suffragan to Wykeham, was at Romsey abbey on Sunday, I 9 September, I 400, when he received thirteen novices, Margery Camoys, Alice Warennere, Joan Stratford, Alice Northlode, Alice Forester, Elizabeth Sampson, Maud Lovell, Katherine de la Mare, Alice Chamberlayn, Isabel Lekforde, Alice Artone, Juliana Shirnham, and Joan Umfray. ${ }^{4}$ From the names it may be assumed that the abbey received ladies of position and good birth among its professed members.

The abbess, Dame Lucy Everard, was apparently ailing in 1402 . In August of that year licence was granted her for a twelvemonth to hear divine service in her oratory in the presence of one of the sisters and her servants.

After having held the position for about thirty years, Elizabeth Brooke, who was elected abbess in 1472 , brought the gravest discredit on the abbey. The scandal of her life was naturally accompanied by general laxity of discipline and by the. decay of the fabric. In 1494 Archbishop Morton caused Robert Sherborne (afterwards Bishop of Chichester), treasurer of Hereford Cathedral, to visit those religious houses of Winchester diocese that were subject to diocesan control. Abbess Brooke confessed on that occasion to a debt of $\ell^{80}$; she suspected that the nuns made egress through the church gates, but denied that any frequented taverns or suspected places. Isabel Morgan, prioress, testified, on the contrary, that some of the nuns did frequent taverns, and went into the town without leave ; she also hinted at a scandal concerning the abbess. Various of the nuns were examined, and one of them complained that their sins or faults were not punished, and that the doors were not kept shut. ${ }^{5}$

This nunnery was again visited on 27 March, 1 502, by Dr. Hede, the commissary of the Prior of Canterbury, during the vacancy

3 Ibid. ff. 355,356 .

- Ibid. f. 328 .

- Archbishop Morton's Register, ff. 90, 91. 


\section{A HISTORY OF HAMPSHIRE}

of the sees of both Canterbury and Winchester. The abbess stated that the statutory number of nuns was forty, that they did not take their meals in the frater but in certain rooms assigned them by the abbess, that there were no debts and no valuables pledged, that there was a secular chaplain in the monastery according to their statutes. Isabel Maryuleyn, prioress, testified to the due observance of the night and day offices; that the abbess was very remiss in correcting the delinquencies of the sisters. Cecily Reed, sub-prioress, had but little to say. Joan Skelyng stated that the abbess was wont to pay certain salaries to the nuns of Ios. or $6 s$. $8 d$.; that a great scandal had arisen concerning the abbess and Master Bryce super mala et suspecta conversatione; that lately, at the instigation of Master Bryce, the abbess had been negligent in correcting the sisters. Joan Paten, precentor, said that tenements in the town of Romsey belonging to the monastery were in decay through the fault of the abbess; that since the coming of Master Bryce the abbess had conducted herself badly towards the sisters, and that she would accept no one's advice but his; that since his coming she had not taken her meals with the nuns, and that there were rumours of incontinence. Thomasine Ashley, alnoner, stated that the bread had diminished in quantity; that one Gilbert de Wilshire had certain letters pertaining to the convent under the common seal without the consent of the chapter; that the abbess and her accomplices had broken open the chest in which the common seal was enclosed, and that Joyce Rowse, who had the custody of one key by the mandate of the late Bishop of Winchester, could testify to this. Edith Holloway, cellarer, said that Mary Tystede and Agnes Harvey wore their hair long. Anne Rowse, sacrist, said that the abbess was somewhat remiss in correction, and made further charges of a pecuniary character against Master Bryce. Joyce Rowse agreed with Thomasine Ashley as to the custody of the common seal and the dismissal of the holders of the keys; she further said that the abbess under the influence of Master Bryce behaved cruelly towards her sisters and that there was a great scandal about them; that the roof of the chancel was defective through the fault of the abbess, and she gave particulars as to various defalcations in the priory accounts. Maria Fystede, cantatrix, referred to the condition of the accounts in the time of the late abbess Joan Brygges, and said that rents which were then only 90 marks under the present abbess had grown to 300 marks; but that the bread and cheese in the convent had lessened in measure through the intervention of Master Bryce; that Bryce was suspected of being the father of a girl in Wiltshire; that houses in the town as well as the dorter and the chancel were in decay through the fault of the abbess, and that Master Bryce kept two or three horses at the expense of the monastery; that he had obtained a large salary under the common seal as chaplain of the farmery, and that he sat at table with the abbess and that there was common scandal about them. Ellen Tawke, third cantatrix, testified that the dorter and chancel were defective in their roofs; that the abbess had been in that office for thirty years, but what gain she had brought the monastery she was ignorant, but rather believed that the annual rents had increased to I I I marks from 50 ; that the houses of the monastery were in decay through the fault of Master Bryce, whose advice was followed by the abbess, and that scandal had arisen about them. Christine More, fourth cantatrix, said that the house was not in debt more than twenty marks, and that as for the rest it was omnia bene. Avice Haynow said that the chancel and the dorter were in decay, so that if it happened to rain the nuns were unable to remain either in quire, in the time of the divine service, or in their beds, and that the funds that the abbess ought to have expended on these matters were being squandered on Master Bryce, and that there was a grave scandal about these two. Agnes Harvey, sub-sacrist, made similar statements as to the roofs of the quire and dorter, and that the actual fabric of the monastery in the stone walls was going to decay through the fault of the abbess, and gave further particulars of the expenses incurred through Master Bryce. She also asserted that Emma Powes was guilty of incontinence with the vicar of the parish church. Emma Powes, who had been professed in a certain priory near Derby, and from that place had been removed to another priory in Hereford diocese, where she had been prioress, and thence had come to this house, said that silence was not observed in the dorter, and that the roof of the quire and the lady chapel were in decay. Alice Whytingstale, mistress of the school, said that the abbess at various times had prohibited her from receiving the Eucharist and from making her usual confession, and that since the arrival of Master Bryce the abbess had not conducted herself amicably towards her sisters. She also gave evidence as to the faulty roofs, and that a corrody had been granted to Master Bryce of the annual value of $£_{2} 20$, and that he had caused a great scandal. The testimony of six other nuns were also set forth of a brief 


\section{RELIGIOUS HOUSES}

character. The visitation is left incomplete, much of the last folio being blank. ${ }^{1}$

The result of this grievous exposure seems to have brought about the enforced resignation of the aged and evil abbess, and in June, 1502, Joyce Rowse was elected abbess and received the temporalities. ${ }^{2}$

It was difficult for the abbey to recover from the long laxity that had so unhappily prevailed under Elizabeth Brooke, and in 1506 Bishop Fox had to remove the sub-prioress and to administer severe censures. ${ }^{3}$

Abbess Joyce resigned in September, 1515 , and on the 16 th of that month the conge d'elire was granted to the prioress and convent, who elected Anne Westbrook, 'sexteyn' of the monastery, as their abbess.

Elizabeth Ryprose, the last abbess, was elected on 15 December, 1523. The documents relative to this election are set forth in great detail in the episcopal registers. ${ }^{\star}$ The temporalities were restored in the following month. ${ }^{5}$ In November 1537 the abbey, alarmed at the fate of the smaller houses, procured an elaborate inspection and confirmation of all their royal charters from the time of Henry I. downwards. ${ }^{6}$ But this was so much waste of parchment and fees.

Sir Richard Lister wrote to Cromwell in September, 1537, informing him that the nuns of Romsey, hearing they were in danger of suppression, were making leases and alienating their goods. He desired to know whether he was to stay them in this."

On 28 December, 1538, John Foster reported to Sir Thomas Seymour as to the state of the house of Romsey. He pronounced the house out of debt; that the plate and jewels were worth $£ 300$; the bells worth $£ 100$. The church is described as a great sumptuous thing, all of freestone and covered with lead, and worth $£ 300$ or $£ 400$ more. The annual rents are returned at $£_{48} \mathrm{I}$ Is. $8 d$. The names of the abbess, Elizabeth Ryprose, the prioress, Edith Banester, and the subprioress, Katharine Wadham, are set down, together with twenty-three other nuns. Mr. Foster wrote: 'In answer to your letter by Mr. Flemynge, whether the abbess and nuns would be content to surrender their house,

1 Sede Vacante Register of Canterbury Priory.

${ }^{2}$ Lansd. MS. 963 , f. 55.

a Winton. Epis. Reg., Fox, iv, f. 80. The confessions are given of Alice Goreyn for slander and Margaret Dowman of incontinence.

4 Ibid. v. ff. 54-62b.

${ }^{5}$ Letters and Papers, Hen. VIII. iv. 66.

- Ibid. xii. I 150 (5).

7 Ibid. xiii. 352. the truth is, that, in consequence of the motion made by your kinswomen and other friends, they will be content to do you any pleasure, but they would be loath to trust to the commissioners' gentleness, as they hear that other houses have been straitly handled.' ${ }^{8}$

Nearly a third of this community had made their religious profession in July, I 534, very shortly before the beginning of their troubles. One of these was Katherine, youngest daughter of Sir Nicholas Wadham, Governor of the Isle of Wight, whose sister Jane had also been for some years a professed nun of the same abbey. John Foster, whose letter to Seymour has just been cited, lived at Baddesley near Romsey, and was convent steward. His reference to 'kinswomen' applied to the two Wadham nuns and to another nun of the name of Elizabeth Hill. Sir Nicholas Wadham's first wife was a daughter of Robert Hill of Antony, and his second was Margaret, sister to Queen Jane Seymour and Sir Thomas Seymour. Through their influence it was hoped that a quiet surrender would be made. ${ }^{9}$

Whether this was effected or not cannot now be asceertained, for there is no extant formal surrender. But the abbess and convent in January, 1 539, had licence to alienate their lordships or manors of Edingdon and Steeple Ashton and all their lands and tenements in Hampshire and Wiltshire to Sir Thomas Seymour. ${ }^{10}$

The clear annual value of the abbey was reckoned by the commissioners at $£_{\mathrm{I}} 6_{1}$ 75. rod. ${ }^{11}$ The lands returned on the first minister's account after the dissolution of the house were the manors of Romsey with the rectory and fair, Moor Abbas, 'Moor Malwyn,' Itchenstoke with the rectory, Sway, Sidmonton, Holm Lacy (Hunlacey) with 'Torleton juxta Coates,' and 'Bardolfeston' in the parish of Puddle. ${ }^{12}$

The parishioners of Romsey managed to save the fine old conventual church from destruction by buying it back from the Crown in 1554 for $f_{100}$. This is much below Steward Foster's valuation; but it must be recollected that the parish had an unassailable right to a considerable portion of it, which even Henry's counsellors could not ignore.

The pointed oval seal, of late twelfth cen-

${ }^{8}$ Ibid. xiii. 1155.

- Abbot Gasquet's Hen. VIII. and the English

Monasteries, i. 310-3.

10 Letters and Papers, Hen.VIII. xiv. 191.

11 Aug. Off. Misc. Books, cccxlii. f. 9.

12 Noted in Dugdale's Monasticon, ii. 510. 


\section{A HISTORY OF HAMPSHIRE}

tury date, of which an illustration is given, represents St. Elfleda, the abbess and patron saint, in full length with crozier in right hand and book in left. Legend : sIGIL's MARIE . . ROMES' ECL'E.

\section{ABBESSES OF ROMSEY}

Elfleda, died in 959

Merwenna, 974

Elwina, 993

Elfleda, 996

Christine, 1086

Hadewis or Avice, $1130-55$

Maud, I I 55-60

Mary, I 60

Juliana, ${ }^{1}$ died in 199

Maud Walerand, ${ }^{2}$ I $199-1219$

Maud Paria or Paricia, 1 2, 19-6,

Amice, 1263

Alice Walrand, 1290-8.

Philippa de Stokes, ${ }^{3}$ 1 298-1 307

Clementia de Gildeford, ${ }^{4} 1307^{-14}$

Alice de Wyntereshulle, 1315

Sibil Carbonel, 1315-33

Joan Icthe, ${ }^{5} 1333$

Isabel de Camoys, ${ }^{6}$ 1 $352-96$

Lucy Everard, ${ }^{7}$ r 396

Felicia Aas, ${ }^{8}$ died in 1419

Maud Lovell, I419-62

Joan Brygges, $1462-72$

Elizabeth Brooke, ${ }^{9}$ I 47 2-1502

Joyce Rowse, I 502-1 5

Anne Westbrook, 1515

Elizabeth Ryprose, 1 523-39

\section{THE ABBEY OF WHERWELL}

The Benedictine nunnery of Wherwell was founded about 986 by Elfrida, the widow of King Edgar, in expiation for her part in the murders of her first husband Ethelwolf and of her son-in-law King Edward. Here she spent the latter part of her life in penitence, and here she was buried.

Elfrida died on 17 November, 1002 , and the nuns ever after observed her obit on that

1 Wharton's Anglin Sacra, i. 304.

2 Ibid.

3 Pat. 26 Edw. I. m. 17.

4 Ibid. I Edw. II. pt. 1, m. 18, 14 ; Winton. Epis. Reg., Woodlock, f. 6gb.

5 Winton. Epis. Reg., Stratford, ff. 8 r b, 134 b ;

Pat. 7 Edw. III. pt. 2, mm. 30, 25.

6 Winton. Epis. Reg., Edingdon, i. f. 75.

7 Wykeham's Registers, i. ff. 260, 261 .

8 Harl. MS. 6962 , f. 148 . She was cousin of Bishop Wykeham.

9 Pat. 12 Edw. IV. pt. 1, m. I 3, 10, 5 ; Winton. Epis. Reg., Courtenay, f. 20. day. An account of the founding of this abbey and its various obits, as well as an elaborate transcript of its evidences, is preserved in a stoutly bound chartulary, purchased by the British Museum in 1869 , which has hitherto escaped attention. ${ }^{10}$

This chartulary of the abbey of Benedictine nuns of St. Cross, Wherwell, was compiled in the fourteenth century, and contains copies of 463 charters, records of suits and other documents, in Latin and French, from the confirmation by Henry III. of the foundation charter to 1364 . There are also thirty-two charters of later insertion, and a few documents from the reign of Richard II. to that of Henry $V$. are copied at the end.

In the year of Elfrida's death, and apparently immediately after its occurrence, King Ethelred granted a charter of confirmation of all his mother's gifts to the abbey, which was then under the rule of the Abbess Heanfled. This grant included exemption from all earthly service, and the gift of land and houses at 'Edelingdene,' Winchester and Bullington. ${ }^{11}$

According to the Annals of Winchester and Florence of Worcester, Emma the mother, and Edith the wife, of Edward the Confessor were both for a time under confinement in the monastery of Wherwell, but there is some confusion between the king's wife and mother, and it seems doubtful whether Emma ever was sent to Wherwell. ${ }^{12}$

The Domesday returns of the abbey property, which lay entirely in Hampshire, comprised the vills of Wherwell, Tufton Goodworth, Little Anne, Middleton, Bullington, and houses in Winchester. ${ }^{13}$ The annual revenue then amounted to $£ 14$ ros.

About I I 86 the Abbess Maud 'of sweet memory,' and of 'good and noble birth,' began her rule over the abbey, which she maintained for forty years, dying at the age of eighty. She was succeeded in 1226 by her friend and fellow worker Euphemia, in whose time a large number of undated charters relative to small gifts or grants was made.

She died on 26 April, 1257. Her benefactions to the abbey and her kindly rule are gratefully acknowledged by the compiler of the chartulary at considerable length. The following is a free English rendering of this important and interesting entry :-

On the 6th of the Kalends of May, in the year of grace, 1257, died the blessed mother abbess

10 Egerton MS. 2104 . The account of the founding is on $f .43$.

11 Ibid. ff. I $5,16$.

12 Freeman's Norman Conquest, ii. note H.

13 V.C.H. Hants, i. 475. 


\section{RELIGIOUS HOUSES}

Euphemia, most worthy to be remembered, who, by our affection and good fellowship, and with divine sanction, succeeded the late abbess Maud of sweet memory. It is, therefore, most fitting that we should always perpetuate the memory, in our special prayers and suffrages, of one who ever worked for the glory of God, and for the weal of both our souls and bodies. For she increased the number of the Lord's handmaids in this monastery from forty to eighty, to the exaltation of the worship of God. To her sisters, both in health and sickness, she administered the necessaries of life with piety, prudence, care, and honesty. She also increased the sum allowed for garments by $12 d$. each. The example of her holy conversation and charity, in conjunction with her pious exhortations and regular discipline, caused each one to know how, in the words of the Apostle, to possess her vessel in sanctification and honour. She also, with maternal piety and careful forethought, built, for the usc of both sick and sound, a new and large farmery away from the main buildings, and in conjunction with it a dorter and other necessary offices. Beneath the farmery she constructed a watercoursc, through which a stream flowed with sufficient force to carry off all refuse that might corrupt the air.

Moreover she built there a place set apart for the refreshment of the soul, namely a chapel of the Blessed Virgin, which was erected outside the cloister behind the farmery. With the chapel she enclosed a large space, which was adorned on the north side with pleasant vines and trees. On the other side, by the river bank, she built offices for various uses, a space being left in the centre where the nuns are able from time to time to enjoy the pure air. In these and in other numberless ways, the blessed mother Euphemia provided for the worship of God and the welfare of the sisters. But notwithstanding all this, she also so conducted herself with regard to exterior affairs, that she seemed to have the spirit of a man rather than a woman. The court of the abbey manor, owing to the useless mass of squalid outbuildings, and the propinquity of the kitchen to the granary and old hall, was in much danger of fire; whilst the confined area and the amount of animal refuse was a cause of offence to both the feet and nostrils of those who had occasion to pass through. The mother Euphemia, realizing that the Lord had called her to the rule of the abbey of Wherwell, not that she might live there at ease, but that she might, with due care and despatch, uproot and destroy and dissipate all that was noxious, and establish and erect that which would be useful, demolished the whole of these buildings, levelled the court, and erected a new hall of suitable size and height. She also built a new mill, some distance from the hall, and constructed it with great care in order that more work than formerly might be done therein for the service of the house. She surrounded the court with a wall and the necessary buildings, and round it she made gardens and vineyards and shrubberies in places that were formerly useless and barren, and which now became both serviceable and pleasant. The manor house of Middleton, which occupied a dry situation and was close to a public thoroughfare, and was further disfigured by old and crumbling buildings, she moved to another site, where she erected permanent buildings, new and strong, on the bank of the river, together with farmhouses. She also set to work in the same way at Tufton, in order that the buildings of both the manor houses in that neighbourhood might be of greater service and safer against the danger of fire. These and other innumerable works, our good superior Euphemia performed for the advantage of the house, but she was none the less zealous in works of charity, gladly and freely exercising hospitality, so that she and her daughters might find favour with One Whom Lot and Abraham and others have pleased by the grace of hospitality. Moreover, because she greatly loved to honour duly the House of God and the place where His glory dwells, she adorned the church with crosses, reliquaries, precious stones, vestments, and books. And because the bell tower above the dorter fell down through decay one night, about the hour of mattins, when by an obvious miracle from heaven, though the nuns were at that moment in the dorter, some in bed and some in prayer bcfore their beds, all escaped not only death but even any bodily injury, she caused another bell tower of worked stone to be erected, conformable to the fair appearance of the church and the rest of the buildings, of commanding height, and of exquisite workmanship. But as she advanced in years, towards the end of her life, there was imminent danger of the complete collapse of the presbytery of the church; by the advice of skilled builders, she causcd the presbytery to be taken down to the last stones of the foundations; and because the ground was found to be undermined and unsafe, she caused the damp soil to be dug out to a depth of twelve feet till firm and dry ground was found, when, having invoked the grace of the Holy Spirit, with prayers and tears she laid with her own hands the first stone of the foundations. Moreover she rcjoiced to have found favour with God, so that before her last days were ended she saw this work that she had begun brought to its desired end. Thus she, who had devoted hersclf when amongst us to the service of His house and the habitation of $\mathrm{His}$ glory, found the due reward for her merits with our Lord Jesus Christ, through the prayers and merits of the Blessed Virgin Mary and of the blessed apostles Sts. Peter and Paul, in whose honour, at the instigation of the abbess Euphemia, this church was dedicated, who with the Father and the Holy Ghost, ever liveth and reigneth God through all the ages of eternity. Amen.

The taxation of 129 I valued the temporalities of the Abbey of Wherwell at the very considerable sum of $f_{2} 201$ I 8 s. $5 \frac{1}{2} d$.; and, in addition to this, the abbess received pensions of EI Ios. from the church of Wallop and EI 6s. 8d. from the church of Berton.

On 12 August, 1291, Pope Nicholas IV. granted a relaxation of one year and forty 


\section{A HISTORY OF HAMPSHIRE}

days of enjoined penance to penitents who visited the church of the Abbess and Convent of Wherwell, on the four feasts of the Blessed Virgin, and on that of the Holy Cross and its octave. ${ }^{1}$

Bishop Pontoise visited this house in 1301 , and ordered that silence should be better observed, and that there should be more diligence in the care of temporal matters; he also rebuked two of the religious for being quarrelsome. In 1308 Bishop Woodlock visited Wherwell, but the visitation did not result in any injunctions. ${ }^{3}$ In August, 1315 , Abbess Isabel, staying in perpetual seclusion in her house like other abbesses and nuns of that order, according to a new constitution, nominated Robert de Cormailles and John de Swyltenham her attorneys for one year. ${ }^{4}$

Bishop Sandale, in March, 1317, directed the Archdeacon of Surrey to make inquiries respecting a poor clerk, John de Apola, in the town of Guildford and the district, whence he is said to have come, whether he was freeborn and legitimate, and of good life and honest conversation, and whether there is any papal or canonical obstacle to his holding a benefice. The result was to be made known to the Abbess and Convent of Wherwell, whence it would seem probable that John was a chaplain of that house, and about to be presented to one of their benefices. ${ }^{5}$

The right of the Crown at each election of an abbess to nominate a clerk to receive a pension from the monastery until he should be provided with a suitable bencfice was exercised from time to time. ${ }^{\circ}$

On 14 August, 1319 , the Abbess and Convent of Wherwell were cited by the bishop to a visitation that he proposed to hold at their house on the day after the feast of the nativity of the Blessed Virgin. As this visitation did not lead to any injunctions, it is fair to assume that the result was omnia bene.

In June, I32 I, Bishop Asserio wrote letters to the convent requesting that Isabel, the daughter of Richard de Sutton, might be admitted as a nun. ${ }^{7}$ In December, 1324, the bishop appointed John Berman to hear the nuns' confessions. ${ }^{8}$

1 Cal. of Papal Letters, i. $54^{\circ}$; Egerton MSS. 2104 , f. $33 \mathrm{~b}$.

2 Winton. Epis. Reg., Pontoise, f. 32

3 Ibid. Woodlock, f. 159.

1 Pat. 33 Edw. I. m. 14.

5 Winton Epis. Reg., Sandale, f. 9.

- Close, 7 Edw. III. pt. 2, m. 5d. and Letters and Papers Hen. VIII. ii. 4031.

7 Winton. Epis. Reg., Asserio, f. 2 b.

Ibid. f. I 2 b.
At the beginning of the year 1330 Abbess Isabel Wyntreshull was probably seriously ill, for on I I January the convent obtained letters patent granting that whenever her place became void through death or otherwise, the prioress and convent should have the custody and full and free administration of the temporalities. ${ }^{9} \quad$ This grant was confirmed two years later. ${ }^{10}$ In March, 1331 , the bishop interfered, and appointed a nun to preside over the convent in consequence of Isabel's impotence. ${ }^{11}$

There is evidence at this time of the widespread possessions of this convent (confined entirely to Hampshire at the Domesday Survey), for mandates for the restitution of the temporalities of Wherwell in 1333, to Abbess Maud, were sent to the escheators of the counties of Bedford, Berks, Bucks, Cornwall, Devon, Dorset, Hants, Oxford, Somerset and Wilts. ${ }^{12}$

In I334 an indulgence was obtained for the altar constructed in the conventual church of Wherwell in honour of our Lord's resurrection. ${ }^{13}$ On 23 May, 1337, the house was visited by Bishop Orlton."

In the time of the Abbess Maud (1333-40) an inventory of the ' jewels' in the custody of the sacrist was drawn up. It comprised a cup of silver gilt within and without, the gift of Abbess Maud, with thirteen gold rings affixed above, and precious stones affixed to the foot, pro Corpore Christi; a cup of silver not gilt, the gift of Abbess Ellen de Percy; a gilt cup for a ciborium; another gilt cup in the shape of a tower for a ciborium; another cup well gilt within and without for a ciborium ; a silver pyx pro Corpore Christi; a cup (ciphus) of silver, with a foot on which was depicted St. Thomas of Canterbury; a gilt cup which bore the figure of St. Thomas of Canterbury; a lesser chalice gilt within and without; three small broken chalices; two small chalices for the high altar; a small chalice for the altar of St. Cross; a chalice for the altar of St. Catherine; a chalice for the altar of St. Mary Magdalene (the sum of the chalices pertaining to the church of Wherwell was eleven); two great crosses ; two silver basins for the high altar; four silver cruets for wine and water for the altars; two silver cruets for daily use at the high altar; two silver candlesticks; a good censer of silver,

9 Pat. 3 Edw. III. pt. 2, m. 5.

10 Ibid. pt. 1, m. 34.

11 Winton. Epis. Reg., Stratford, f. 66.

12 Pat. 7 Edw. III. pt. 2, m. 5.

13 Winton. Epis. Reg., Orlton, i. f. 5.

14 Ibid. f. 54b. 


\section{RELIGIOUS HOUSES}

and two worse ones of silver; two ships for incense, with two small spoons; a small silver crown, with eleven gold rings fixed in it, for the high altar; another better crown of silver, with nineteen gold rings; and two silver basins for the high altar. ${ }^{1}$

Wykeham was consecrated bishop on Io October, 1367 , and on the 17 th received the temporalities from the king. He did not lose much time in making good his right to nominate a novice for the Wherwell nunnery, for on 14 October he ordered the abbess and convent to receive Joan Krompe, a lady of good and honourable condition. ${ }^{8}$ In the following year the bishop sent letters to the Abbess of Wherwell straitly enjoining her, for the avoidance of scandalous gossip, never to allow friars nor any other religious or secular men to stay the night in the convent, and threatening canonical penalties if this order was neglected. ${ }^{3}$

On 3 March, I 377, Bishop Wykeham appointed Walter Chapellayne, a Franciscan of Winchester, to confess the nuns until the quindene of Easter. ${ }^{4}$ This interim appointment was continued for between fifteen and sixteen years, when Walter Chapellayne's confessor's licence was revoked, and the abbess and convent were admonished, on I August, 1393, to accept Ralph Basyng, a monk of Winchester Cathedral, as their confessor. ${ }^{6}$

On $30 \mathrm{July,} \mathrm{I} 378$, an inspection and confirmation was granted to the abbess and nuns of Wherwell, on a fee of one mark, of an unauthentic charter of King Alfred, purporting to grant the nuns the wood of Wherwell Harewood. ${ }^{6}$ And again in December, ${ }^{1} 3^{8} 4$, letters patent were granted to the abbess, to the effect that during the king's life she should have chattels of fugitives. The abbey held Mestowe Hundred, and among other liberties the chattels of fugitives. In the late king's reign Henry Harold of Wherwell killed his wife Isabel and fled to the church of Wherwell. The abbess asserted her right, and his chattels were seized, to the value of £.35 4s. 8d., by Gilbert Josep, her reeve. The question was tried by the judges of the

1 The sacrist of the church of Wherwell had various important duties, and there were special rents, realizing a total of 725 . 10d., attached to the office. The chartulary contains no fewer than thirty-two charters relating to the office of the sacrist (ff. 2002-1 I b).

2 Winton. Epis. Reg., Wykeham, iii. I 1 b.

3 Ibid. f. 25 a.

4 Ibid. f. $150 b$.

5 Ibid. f. $26 \mathrm{Ib}, 262$.

6 Pat. 2 Ric. III. pt. 1, m. 38.
Bench in the late reign, but though judgment had been found for the abbess to the effect that the king had no right to such chattels save in the time of voidance of the abbey, the decision was not formally delivered by reason of a difference of opinion among the justices. The signet letter of Richard II. also provided that the abbess should not be molested for the sum seized in the case of the fugitive Harold. ${ }^{7}$

On 16 June, 1393, excommunication was denounced against certain persons unknown who abducted Katherine Faukener, a nun of Wherwell. ${ }^{8}$ A different colour is however given to this 'abduction' by an entry in the episcopal register seven years later, namely on I 2 April, I400, when the Abbess of Wherwell was enjoined to receive Katherine Faukener, who had run away, the bishop urging that the Church ought never to shut its bosom to any one returning, in the firm hope of a fruitful penitence. ${ }^{9}$

On 31 March, 150I, the priory was visited by Dr. Hede, acting as commissary for the Prior of Canterbury, during the vacancy of the see. Maud Rowse, the abbess, testified to the regular attendance at the night and day hours; that the yearly rents had risen to 40 marks; that the house was not in debt nor any of its valuables pledged; that a balance sheet was presented in chapter every Michaelmas; that the common seal was kept in the treasury within two chests having six keys, of which two pertaining to the outer chest and one to the inner were in her custody, one of the outer and another of the inner chests in the custody of the prioress, and the other of the inner chest in the custody of the sacrist; and that there was sufficient store of grain and other things for the current year. Maud Byrte, prioress, stated that silence was duly observed at the customary times and places. Katherine Polton, sacrist, and Christine Hopkyn, precentor, and eighteen other members of the convent, including six novices, also gave evidence that omnia bene. ${ }^{10}$

The Abbess Maud died on 24 January, 1518 ; the convent obtained the conge d'elire on 3 February. In a letter of Bishop Fox to Wolsey, dated 15 February, he thanks the Cardinal for expediting the king's letters for a free election of a new Abbess of Wherwell. As the sisters had made a choice pleasant to God and true to the king, he begged his

7 Ibid. 8 Ric. II. pt. 1, m. 5.

8 Winton. Epis. Reg., Wykeham, iii. f. 258.

9 Ibid. iv. f. $319 \mathrm{~b}$.

10 Sede Vacante Register, Canterbury. 


\section{A HISTORY OF HAMPSHIRE}

favour for the bearer to obtain the royal assent. The sister who carried the letter was Avelene Cowdrey, the subprioress, selected by her fellow nuns as their abbess. The king gave his assent on 26 February, the bishop confirmed the election on 3 March, and on 13 March the temporalities were restored. ${ }^{1}$

In October, I 533, one John Cooke, a confidential servant of the Crown, was commended to the Abbess of Wherwell for a 'farm' both by the king and Cromwell, but the abbess declined. ${ }^{2}$ It was probably owing to this among other causes that Sir William Poulet and Thomas Legh were instructed in the following April to move my lady of Wherwell to resign her office on an honest and competent pension, with liberty to stay in her own house, or in any other place of religion she liked. ${ }^{3}$ In the first instance she plainly answered that she would in no case resign until she had spoken with the king himself. Disgraceful charges were now made against the abbess in connection with the Bishop of London, and she was summoned to London and appeared several times before the Council. A commission was appointed in June, 1534, to examine into the charges. ${ }^{4}$ There is no formal record of the result, but it may be safely taken for granted that the scandal was rebutted. In September, I 535, those birds of ill-omen, Thomas Legh and John Ap-Rice, visited Wherwell monastery at Cromwell's command, and on the promise of the large pension of $£ 20$ per annum induced the prioress to resign. ${ }^{5}$

The election of Abbess Kingsmill on 25 September seems to have been arranged, as it was expected that she would be a ready tool in the hands of Cromwell for 'resignation' purposes.

The low scheming to get hold of the plums of the falling abbeys receives apt illustration in the case of Wherwell. Abbess Kingsmill wrote in January, 1538 , to Wriothesley, begging him to labour for the advowson of the prebend of Middleton for Dr. Legh. Now that it was void, Mr. Cooke pretended to a title to it, but the abbess hoped that Dr. Legh might enjoy their gift, for his learning and excellent qualities may profit her and her monastery, and not such as may buy it of Mr. Cooke, who, as she understands, has sold it to two or three already. ${ }^{6}$ On 15 June of the same year, Mr. John Kingsmill, brother

\footnotetext{
1 Letters and Papers, Hen. VIII. ii. 3920, 3952, 3970, 4006. 2 Ibid. vi. I361.

Ibid. vii. 527-9. I Ibid. vii. 907.

5 Ibid. ix. $344,439.6$ Ibid. xiii. 8.
}

of the abbess, wrote to Wriothesley, begging for the prebend of Bath pertaining to the house of Wherwell, just vacant by the death of the prebendary, who was vicar of Wherwell. The next nomination was in Cromwell's hands, and if his lordship and Wriothesley esteemed it too small for them, he would like it for a friend of his sister the abbess or for himself.?

It was originally intended that the house should be granted to John Kingsmill, brother of the abbess, but on the eve of its surrender, Thomas West, Lord de la Warre, made such strong representations to Cromwell, because the nunnery stood so wholesomely in the country where he was born, and that his wife had no house to dwell in if he should die before her, that the site and estates of the house were eventually granted him. ${ }^{8}$ Wherwell was surrendered on 2 i November, 1 539, when the complaisant abbess received the large annual pension of $£ 40$, the prioress $£ 6$, and twenty-three other nuns pensions varying from $£ 5$ to $£^{2} 1^{3}$. $4 d$.

At the time of the surrender 'The Houses and Buyldings assigned to remayne' were 'the late abbess lodging with the houses within the quadrante, as the water leadith from the easte side of the cloister to the gate, the farmery, the mylle and milhouse, with the slaughter house adjoynynge, the bruing and baking houses, with the granaries to the same, the barne and stabulles in the utter courte. Possession thereof delyvered to the Lord La Ware by force of Mr. Chancellor's letters.' The parts 'demed to be superfluous' were 'the church, quayer and steple covered with leade, the cloister covered with tyles and certain gutters of leade, the chapitre house, frayter, dormytory, convent kitchyn, and all th'olde lodgings betwene the granarie and the halle dore, covered with tyles.' The commissioners reserved 'to th' use of the king's magestie' $512 \frac{1}{2}$ ounces of silver plate. The ornaments, goods and cattle of the monastery, reserved for a like use, realized $£ 75$ i 8 s. There were five bells in the steeple.

In addition to the pensions, three of the late religious of the monastery received by way of 'reward' or temporary forestalment of pension 40s. each, and four 20s. each. The sum of $£ 253^{5}$. was also divided amongst forty-eight persons who had been chaplains, officials, or servants of the late monastery.

At the dissolution the lands returned as belonging to this abbey are the manors of

7 Ibid. xiii. I 190.

8 Ibid. xiv. 425, 1427, 544, 547-9 ; Pat. R. 3 I Hen. VIII. pt. 4. m. 4 . 


\section{RELIGIOUS HOUSES}

Wherwell, Weston, Middleton, 'Totington,' Bullington, Good alias Goodworth, Clatford, Little Anne with all the prebend of Good alias Goodworth, 'Aisshesey' in the Isle of Wight, East Compton with the portion of the tithes in 'Fowleston,' Bathwick, Woolley, 'Mattockesford' in the parish of Botley, and lands, rents, etc., in Tetbury, 'Wringmershe,' Upton, 'Hethefylde' and 'Bromeley,' Appleshaw, Wyke, Hursley, Estaston in the parish of Middleton, Winchester and Southampton. Also lands, rents, tithes, etc. in 'Hanydon' and 'Mildeston' in Wiltshire; in Newbury and Inkpen in Berkshire; in 'Ertingdon,' Guildford and St. Nicholas next Guildford in Surrey.

The patronage of churches named by the commissioners includes the prebends of Wherwell and Milton and the vicarage of Goodworth in Hampshire, the vicarage of Compton in Berkshire, the parsonages of Collingborne and Everley in Wiltshire, and the prebend of Bathwick in Somerset. ${ }^{1}$

\section{AbBesses OF WherweLL}

\author{
Heanfled \\ Maud, I $186-1226$ \\ Euphemia, 1226-57 \\ Mary, ${ }^{4} 1259$
}

Constance, ${ }^{5}$ 1 261-2

M. de Ticheburne, ${ }^{6} 1262$.

Mabel, 1270-81

Ellen de Percy, ${ }^{7}$ I $282-98$

Isabel de Wyntreshall, ${ }^{8}$ I 298-1 333

Maud de Littleton, ${ }^{9}$ 1 $333-40$

Amice Ladde, ${ }^{10}{ }^{1} 340-6$ I (?)

Constance de Wyntereshall, ${ }^{11} 1361$

Joan Cotterell, ${ }^{12}$ I 36 I-75

Cecily de Lavyngtone, ${ }^{13}$ 1375-1412

Alice Parys, ${ }^{14} 1412$

Sibyl Boolde, died in 1451

Alice Serle, ${ }^{15}$ I 45 1-2

Julian Overy, 1452-94

Maud Rowse, ${ }^{16}$ I 494-1518

Avelene Cowdrey, ${ }^{17}$ 1 $518-29$

Anne Colte, ${ }^{18}$ 1529-35

Morphita Kingsmill, ${ }^{19}$ I 535-39

\section{HOUSES OF CISTERCIAN MONKS}

\section{THE ABBEY OF QUARR}

The Cistercian abbey of Quarr, dedicated to the honour of the Blessed Virgin, situate on the northern shore of the Isle of Wight, in the parish of Binstead, was one of the earliest foundations of that order in the kingdom. It was founded by Baldwin, the second de Redvers, Lord of the Wight, in 1131 . By a charter of that date he granted to Geoffrey, abbot of his Norman monastery of Savigny, land on which to build the monastery, the manor of Arreton, the land of Sheat (Sieca), 'Boccumba,' the mill of Christchurch and the mill of 'Boleherst.' ${ }^{8}$ This grant was confirmed by William de Vernon, Earl of Devon, the son of the founder, about II 95, together with various subsequent grants of lands and salt pits, and of the chapel of St. Nicholas in Carisbrooke castle; the grantor also gave liberty to the monks of Quarr to buy and sell free of toll in all his lands. ${ }^{3}$

Henry, Duke of Normandy, before he came

1 Aug. Off. Misc. Books, ccccxciv. 17-21.

2 Worsley's Hist. of Isle of Wight (1781), app. li. Although there is no extant chartulary of this abbey, the number of charters cited in the Monasticon and in Madox's Formulare are considerable. There are also about a hundred original charters among the calendared 'Ancient Deeds' of the P.R.O.

3 Ancient Deeds, P.R.O., D. 942.

II to the throne, gave to the monks of Quarr land in 'Lacwella' ad faciendam ibidem capitalem abbatiam, from which it is evident that the island abbey was considered capable, within twenty years of its foundation, of dispatching a colony to found another monastery. ${ }^{20}$ About II 50 a composition was

4 Egerton MS. 2104 , f. 35.

5 Ibid. f. 45 b. 6 Royal Letters, 2437.

7 Pat. 1o Edw. I. m. 18.

8 Ibid. 27 Edw. I. m. 27. The Wherwell Chartulary contains copies of the letter of Prioress Benedicta to the bishop, asking him to confirm the election of Isabel (Jan. 25), and of the bishop's letter of consent dated February 2 (Egerton's MSS. 2104 , ff. $119,119 b, 184$ b.

9 Winton. Epis. Reg., Stratford, f. 139 ; Pat. 7 Edw. III. pt. 2, m. 11 .

10 Ibid. Orlton, f. 87 ; Pat. 14 Edw. III. pt. 1, m. 23.

11 Ibid. Edingdon, f. 11 ib.

12 Tanner's Notitia, xlii.

13 Winton. Epis. Reg., Wykeham, i. ff. 66, 67. Reference has already been made to this election in the Ecclesiastical History section.

.14 Ibid. Beaufort, f. 48 b; Rymer's Fcedera, viii. $764-5$.

15 Ibid. Waynflete, i. ff. $40,50$.

16 Tanner's Notitia.

17 Letters and Papers, Henty VIII. ii. 3920, 3952, 3970,4006 .

18 Ibid. iv. 5799,5838

19 Pat. 27 Hen. VIII. pt. i. m. 44.

20 Dugdale's Monasticon, v. 317. 


\section{A HISTORY OF HAMPSHIRE}

entered into between Hillary, abbot of Lire, and Gervase, abbot of Quarr, by which the former conceded to the latter, in return for a yearly pension of 40 s., the tithes and profits of the manors of Arreton, Haseley, Luccombe, Titchingham and Shalcombe. This arrangement was renewed in 1239 with a further sum of 10 s. a year for the support of the church of Carisbrooke. ${ }^{1}$

In 1238 Gregory IX. issued a bull allowing the community to choose a confessor from their own body.

Edward I. in 1284 granted the abbey free warren over all their manors in the Isle of Wight.?

At the time of the taxation of I29I, the annual value of the temporalities of the abbey in Winchester, including four mills and the profits of tanneries in the island, amounted to $£ 963^{s .} 4 d$. The abbot had also temporalities at Forwood, in Exeter diocese, of the annual value of $f_{1} 36 \mathrm{se} 8 \mathrm{~d}$.

The Crown imposed a life pensioner on the community on I 3 April, I330, when Benedict de Glannvyll, who had long served the king and his father, was sent to the abbey to receive such maintenance for life as John le Hunte had had in that house in his lifetime, by the late king's request. ${ }^{3}$

On 9 March, 1339, William Trussel, admiral of the fleet from the mouth of the Thames towards the west, received orders from the king to supersede the exaction made on the abbot of Quarr for finding a ship prepared for war with sixty men, mariners and others, well armed and supplied with necessaries, to set out with other ships under royal command. The abbot had successfully besought the king to be released from this obligation, inasmuch as he was already maintaining ten men-at-arms and no small number of archers in the Isle of Wight for its defence at a great expense, and was quite unable to support any further charge."

We find by the feudal aid of 1346 that the abbot held half a knight's fee in perpetual alms in Sheat in Gatcombe. ${ }^{5}$

In I 366 Edward III. granted the abbey licence to crenelate as a safeguard against foreign invasion, and about the same time

1 For these and other early particulars see Worsley's Hist. of Isle of Wight, app. 1.-lxxviii., and Stone's Arch. Antig. of Isle of Wight, pt. i. p. 110 , note $\$$

${ }^{2}$ Charter Roll, 12 Edw. I. No. 4 I.

3 Close, 4 Edw. III. m. 36d.

- Ibid. 13 Edw. III. p. I. m. 35.

- Feudal Aids, ii. 339. letters patent were issued that all wine ships belonging to the community should come and go free of duty. ${ }^{\circ}$

The abbots of Quarr held a distinguished position in the Isle of Wight. When a commission of array was issued in April, 1380, on information of an intended invasion by France and Spain, the abbot of Quarr headed the list of eight gentlemen nominated by the Crown, preceding even Sir Thomas de Beauchamp, the governor of Carisbrooke castle. ${ }^{7}$ John Cheselburgh, abbot of Quarr, occupied a like honourable position, in royal commissions of 1461 and 1462 , to summon the king's subjects of the island and of the counties of Hampshire, Surrey and Sussex to defend the Isle of Wight against the French. ${ }^{8}$

The Valor of 1535 gives the clear annual value of the house as $£_{1} \mathrm{I} 343$ s. I Id.

In December, 1535, Abbot Ripon wrote to Cromwell about farms that the lord privy seal and his nephew Richard had desired to obtain. The abbot protested that the farms in question were the demesnes of the monastery by which hospitality and the household were maintained, and that without them the abbot could not continue the house. Besides the demesne, the monastery could not spend yearly above $f_{120}$, and fifty persons had to be kept, besides such as resorted thither from the country. $\mathrm{He}$ trusted therefore that Cromwell's servant would be contented with the reversion of any farms he might have to let, and to secure his favour he would give the fine to him and his nephew. ${ }^{\circ}$ The last abbot's anxiety as to his farms was not however of long duration, for being under $£ 200$ of annual value the monastery was dissolved in 1536 .

Special efforts were made in the locality to secure the king's good will for this monastery and for Netley on the other side of the water, but all in vain. The particularly good report of the county commissioners, Sir James Worsley and John and George Poulet and William Berners, presented on 30 May, 1536 , was treated as so much waste paper. They reported that the abbey of Quarr was: 'A hedde house of Monkes of the ordre of Cisteaux beinge of large buyldinge scituate upon the ryvage of the sees by raporte greate

- Pat. 39 Edw. III. pt. 2, m. 23 ; 40 Edw. III. pt. I, m. 15.

7 Ibid. 3 Rich. II. pt. 3, m. 2 Id.

8 Ibid. 1 Edw. IV. pt. 1. m. 3 d ; 2 Edw. IV.pt. 1, m. $17 \mathrm{~d}$ (Cal.).

- Letters and Papers, Hen. VIII. ix. 925. 


\section{RELIGIOUS HOUSES}

refuge and comforte to all th'inhabitantes of the same yle and to strangers traveillinge the seid sees'; $£$ i 56 ros. $1 d$. ; 10 monks, all priests, of good religious conversation, eight of whom desire to continue in religion, and two to have capacities ; 39 other inmates, viz. Io waiting servants, 7 servants in the church, 8 officers in the household, ro hinds, 2 lavendors, ${ }^{1} 6$ dairymen, and one 'corodur'; church, mansion and building in convenient repair, lead and bells worth $£ 19$; plate and jewels, $f_{4} 8$ I 4 s. $3 d$.; ornaments, $£_{1} 7$ I os. $8 d$.; stuff, $£_{23}$ 1 3 s. $4 d$.; corn and grain, $£_{20}$; stocks and stores, $£ 220 \mathrm{Igs.} ;$ owing by the house, $£ 558$ s. $9 d$.; owing to the house, $\ell_{9}$ I 8 s. $4 d$.; woods, etc., $£ 122$ 1 8 s. $4 d .^{2}$

At the time of the dissolution the monastery held the manor of Quarr with the site of the abbey and the manor of Newenham there; the manors of Arreton, Staplehurst, Sheat in Brixston, Shaldcomb, Newport, Comley, Fowewod cum Forewey; the granges of Compton, Haseley, Lovecombe, Hampstede, Roughbarowe, Bydeborough, Charke in Rowner ; the rectory of Caresbrook ; messuages, rents, etc., in Newport, Whippingham, Newchurch, Southwick, Portsmouth, Christchurch, Swey, Milford, and tithe of salt in Lymington. $^{2}$

On 17 February, 1537, Thomas Wriothesley, the great devourer of monastic property in the west, obtained most of the manorial rights of the abbey by grant from the Crown. The Devonshire manors and other property of the abbey were also granted him in the following November. ${ }^{4}$

A lease of the actual site of the monastery, together with certain tithes of Arreton, was granted by the Crown to John Mylle of Southampton in March, $1537 .^{\circ}$

Much of the stonework of the abbey was used in 1539 towards the making of two blockhouses at East and West Cowes for defensive purposes. ${ }^{\circ}$

An illustration of the seal of the abbey is here given. It is round and shows the Virgin standing with child on left arm and St. John Baptist under a double canopy, and below the half-length figure of an abbot. The legend is

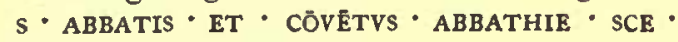
MARIE $\cdot$ DE $\cdot$ QVARRARIA

I Washermen.

2 Aug. Off. Chantry certificates, No. 1 I 2.

a First Mins. Acct. after dissolution, cited in Dugdale's Monasticon, v. 320.

Letters and Papers, Hen. VIII. xii. (1), 538 (45); xii. (2), 1150 (7).

5 Aug. Off. Misc. Bks. ccix. f. 44.

- Letters and Papers, Hen. VIII. xiv. (1), 899.

\section{AbBots oF QUaRr}

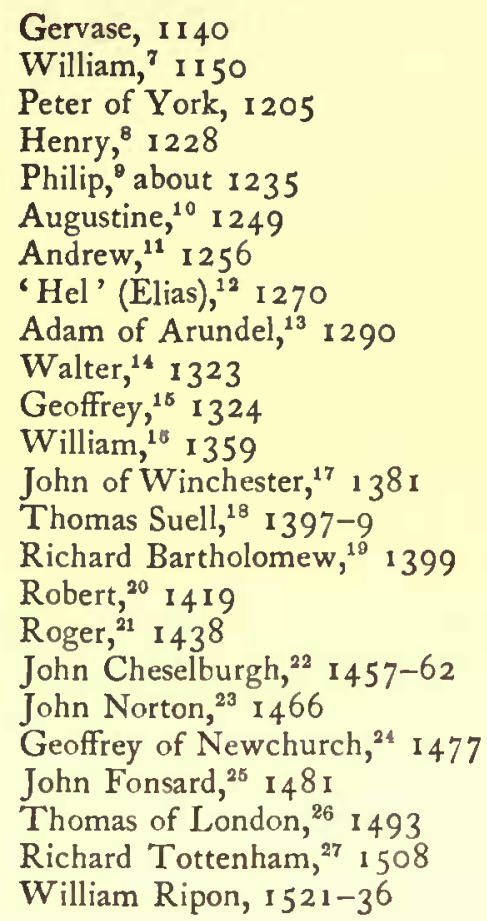

7 Cal. of Doc. France, 296.

${ }^{8}$ Madox, 374.

Ancient Decds, P.R.O., B. I I $5,890,3447$.

10 Ibid. B. 3692, D. 154.

11 Madox, 222 ; Ancicnt Deeds, D. 231.

12 Ibid. B. $2642,2946$.

13 Ibid. B. 686, 707, $1192,275^{8}, 2811,2815$, 2830 ; Madox, 383 (A.D. 1303).

14 Ancient Deeds, B. 1151 ; Madox, 164, 226. 15 Winton. Epis. Reg., Stratford, f. $11 \mathrm{~b}$; Ancient Deeds, B. 7 10, $1175,2713,2715,2717$, 3793.

16 Ancient Deeds, B. 2680.

17 On 25 January, 1381 , Abbot John of Winchester received benediction at the hands of Bishop Wykeham in the chapel of Esher promising canonical obedience salvo ordine meo (Winton. Epis. Reg., Wykeham, i. f. 114, B. 2682, 2684).

18 Thomas Suell was elected unanimously by his brethren to be abbot, in the place of John of Winchester, deceased, on 22 March, 1 397, in the presence of the abbots of Wardon and Standing (Winton. Epis. Reg., Wykeham, i. f. 268).

10 Richard Bartholomew was elected on 13 November, 1399 , on the resignation of Thomas Suell, in the presence of the abbots of Rewley and Netley (ibid. i. f. 299, B. 2683).

20 Ancient Deeds, B. $668,2834,3247$, D. 887 .

21 Ibid. B. 678 .

22 Ibid. B. 2843 ; Pat. 1 and 2 Edw. IV.

23 Winton. Epis. Reg., Waynflete, i. f. $14^{86 .}$

24 Ancient Deeds, B. 3244.

25 Ibid. B. $107-9,2841$.

26 Ibid. B. 110, 1 19, 3248, 3249, 3546.

27 Ibid. B. 2843, D. 486 . 


\section{A HISTORY OF HAMPSHIRE}

\section{THE ABBEY OF BEAULIEU}

It would appear that in 1203 King John granted to the house of St. Mary of Citeaux, as the head of the Cistercian order, the manor of Faringdon in Berkshire, where some monks of this order had established themselves, upon the condition that a monastery should be built there. ${ }^{1}$ In the following year the king founded in the New Forest the monastery of St. Mary of Beaulieu of the same order with provision in it for thirty monks. ${ }^{2}$ The foundation charter is dated 25 January, $1204-5 .^{3}$ By this charter the bounds of the precincts are accurately defined, and the monks were endowed with the manors of Great and Little Faringdon, Great and Little Coxwell, Shilton and Inglesham, and the churches of Shilton and Inglesham and the chapel of Coxwell, and all that the king had in Langford. Beaulieu being thus founded the monks of Faringdon were transferred to it, and Faringdon was made a cell to Beaulieu.

The small chartulary of I 79 folios, in the Cotton collection, ${ }^{4}$ opens with a transcript of the charter of King John, dated 2 November, 1203. This is followed by three charters of Henry III. and an elaborate confirmation charter of Edward III., dated 23 February, 1328. The particulars with regard to the diffcrent vicarages, and more especially as to the customs of the numerous manors (Shilton, Great and Little Faringdon, Great and Little Coxwell, Langford, Inglesham and Westbrook), which are given in great detail, are of considcrable interest but pertain to the history of Berkshire.

Among the Harley MSS. is a transcript of a register or chartulary of Beaulieu, copied from one in the possession of the Duke of Portland, in 1739, and collated with the original in 1836 by Sir F. Madden. ${ }^{5}$ It opens with the long foundation charter by

1 See King John's charter of confirmation to Beaulieu enrolled on Charter Roll, 53 Hen. III. m. 13, and printed in Dugdale's Monasticon, v. 683.

3 Chron. Joh. de Oxenedes (Rolls Series), 118.

3 Printed in Dugdale's Monasticon, v. 683. The legend as to the first establishment of this important house is to the effect that King John, having grossly illtreated some Cistercian abbots at a parliament at Lincoln, was so alarmed at a dream about the crime and its consequences, that he resolved to found an abbey of that order at Beaulieu for thirty monks. The story, as told originally in a Kirkstall chartulary, is not improbable, for the innately cruel are usually superstitious.

4 Cott. MS. Nero A. xii.

- Harl. MS. 6603, ff. 253-398.
John, relative to the important cell at Faringdon. This is followed by the charter of Henry III., regarding the New Forest, and confirming the grants of Bishop Peter and William Briwer. The third charter is that of the same king confirming 239 acres of land in the New Forest, granted at the dedication of the church, when the king and Queen Eleanor and Prince Edward were present. The charters referring to the possessions of the abbey in Berkshire are numerous; there are also many pertaining to Soberton, Bucks; Blacheford, Hants; the town of Southampton, and the church of St. Keverne, Cornwall.

In 1204 John gave the monks a hundred marks towards the construction of the abbey, a gold chalice, and a hundred cows and ten bulls for their dairy; in 1205 they obtained the royal gifts of twenty additional cows and two bulls, further money, and a large grant of corn ; in 1206 came the first gift of a tun of wine for the use of the church from the officers of the king's prisage at Southampton ; and in 1207 further large grants of oxen and corn. ${ }^{8}$ On 16 August, 1205 , the king sent letters to all the Cistercian abbots entreating their assistance in the building of the new abbey. ${ }^{7}$

In March, I 208, came the famous interdict of Innocent III. over all England which lasted until the king's submission in May, 1213, at which time Hugh, the first abbot of Beaulieu, acted as an intermediary between the king and the pope. On 4 April, 1208 , the abbot obtained the royal passport for the conveyance of himself and servants and five horses across the Channel at Dover, evidently on a mission to Rome touching this business. ${ }^{8}$ In the following month the pope issued a monition to King John to fulfil his promise to the abbot of Beaulieu to receive the cardinal Archbishop of Canterbury and to make due restitution, and again in the following August he instructed the Bishops of London, Ely and Worcester to warn and induce the king to carry out at once his various promises made to the abbot of Beaulieu. Meanwhile the king, whilst staying at Waverley, the earliest of the English Cistercian foundations, on the immediate confines of the county, issued an order by which he restored to the monks all the lands which had been seized by occasion of the interdict. Abbot Hugh returned to

- See entries from the Close Rolls cited in Woodward's $H$ istory of Hants, iii. 78-9.

7 Close Roll, John (Rec. Com.), 32 b.

8 Ibid. I o8b.

- Cal. of Papal Letters, i. 31. 


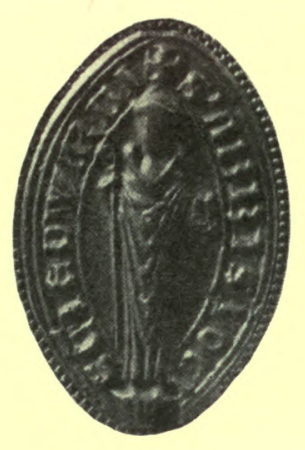

Netley Abbey.

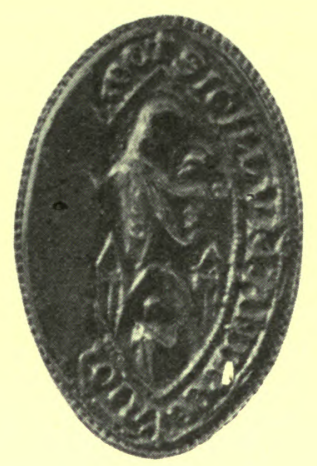

CARISBROOKL PRIORY.
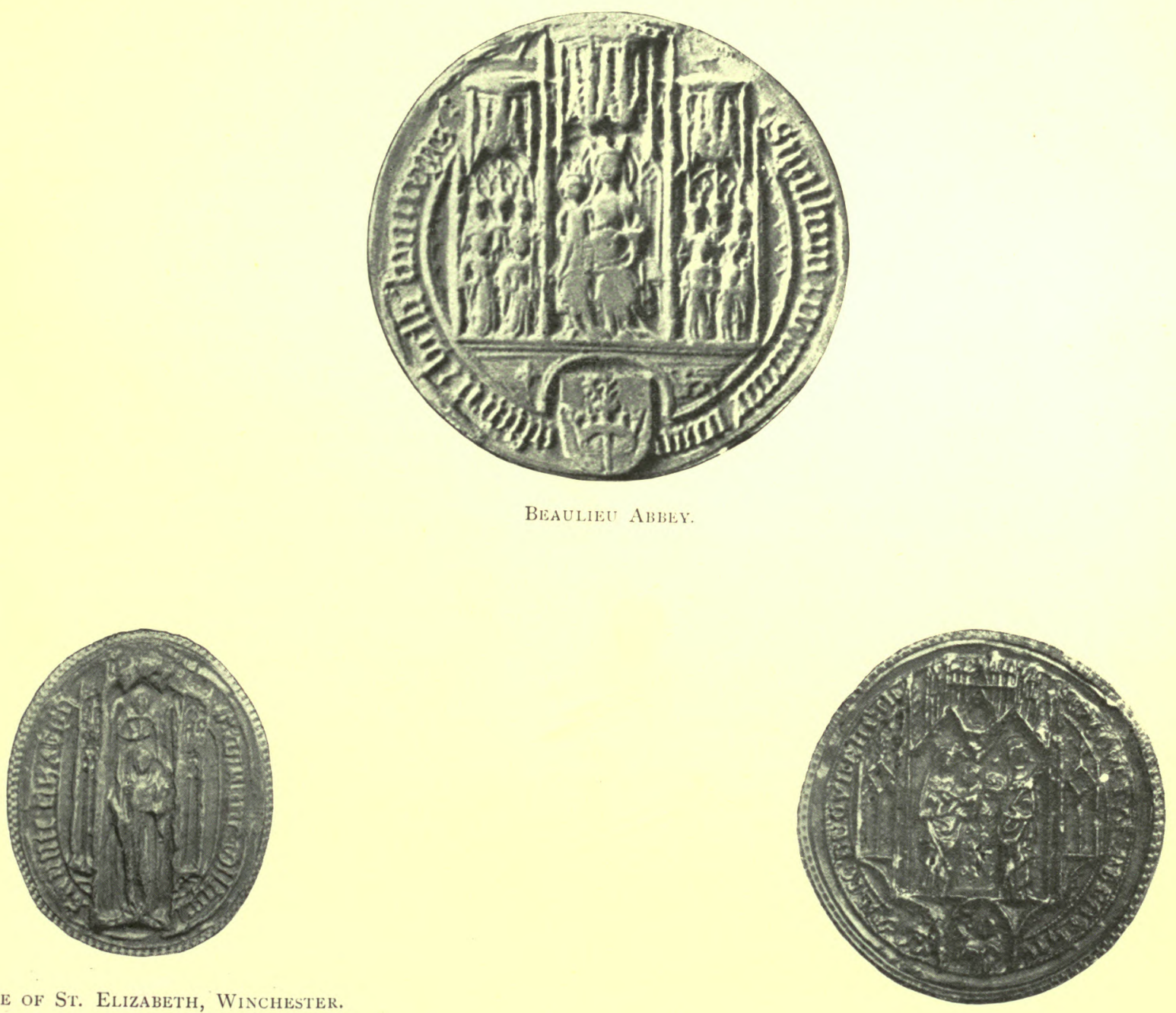

College of St. Elizabeth, Winchester.

QUARr AbBey. 


\section{RELIGIOUS HOUSES}

England in November, and received from the king 30 marks for himself, 30 marks for fees and vails, and 40 s. to buy himself a palfrey.

When the trouble of the interdict was over the building at Beaulieu was immediately resumed. In 1213 orders were made by the king for 400 marks towards the building at Michaelmas, and 500 marks at Michaelmas of the next year, and in 1214 an additional £200.' In 1214 a prior was elected, Anastasius by name; to him the second donation of $£ 100$ of that year was addressed, when the abbot was probably absent. ${ }^{2}$ On 9 April, 12 I 5, John made his last donation, 50 marks, to the monks of Beaulieu. ${ }^{3}$

The abbot of Beaulieu was the fourth of the envoys sent by John to Pope Innocent in September, 1215; and in that capacity, as one of the king's proctors, he exhibited articles against the Archbishop of Canterbury at the fourth Lateran Council."

On 24 February, 1219 , Abbot Hugh was consecrated Bishop of Carlisle in York Minster. ${ }^{5}$ He died in $1223 . \quad H$ is successor, Azo of Gisors, was a good deal engaged in diplomacy, and was dispatched by the king to France in the year of his appointment.

Henry III. carried on his father's work at Beaulieu with vigour. On I5 March, 1217 , he instructed the keeper of his herd of horses in the New Forest to hand over all the profits to the monks of Beaulieu until November, $1220 .^{\circ}$ In 1220 the king gave 50 marks, in 1221 , I $7 \frac{1}{2}$ marks, and in $1222, f_{100}$ to the building. ${ }^{7}$

The annals of Waverley, which can scarcely in such a matter be wrong, describe the monks of Beaulieu as entering with great joy into their new church on the vigil of the Assumption, $1227 .^{8}$ This entry has been supposed to clash with the definite statement of the same annals and of Matthew Paris twenty years later. The term ecclesia however is

1 Close Roll, John (Rec. Com.), I44, 175b, $2 \mathrm{IIb}$.

${ }^{2}$ It is stated in Woodward's History of Hants that Anastasius was termed abbot in the grant of f, 100 on 4 November, 1214 ; unfortunately there are no references in that history, but the Close Roll entry of 4 November calls him prior.

${ }^{3}$ Close Roll, John (Rec. Com.), 194.

- Matth. Paris, Hist. Angl. (Rolls Series), ii. I 68.

- Woodward calls him Henry, a mistake made also by others. There seems a little uncertainty whether this Hugh was the first abbot or a second of that name.

- Close Roll, John (Rec. Com.), 299.

7 Ibid. Hen. III. (Rec. Com.), 44I b, 457b, 486,521 .

8 Annales Monastici (Rolls Series), ii. 304. sometimes used to apply to the whole of a religious house, and the explanation seems to be that the great conventual church was opened in 1227 , but that the cloister and conventual buildings as a whole were not ready for occupation until 1246 .

The king's generosity to the Cistercians of Beaulieu continued year by year; it would be tedious to reiterate the specific benefactions. At last the whole of the great fabric was finished, the monks quitted their temporary building (doubtless of wood), and on 17 June, 1246 , the conventual buildings were dedicated by the Bishop of Winchester in the presence of the king and queen, the Earl of Cornwall, and a great concourse of prelates and magnates of the realm. At the feast of the dedication the abbot made an offering of 500 marks. The young Prince Edward was also present at the dedication, but was seized with illness, and the queen stayed at the abbey three weeks to nurse him, in contradiction, as the annalist says, of the Cistercian rule. As a proof of the strict observance of their rule, it is recorded that at the next visitation both prior and cellarer were deposed from their offices, because they had supplied seculars with meat on the occasion of the dedication festival. ${ }^{8}$

Pope Gregory IX., in I23I, granted a licence, at the request of Henry III., to the abbey of Beaulieu to appropriate the churches of Shilton and Inglesham, with the chapel of Coxwell, in the dioceses of Salisbury and Lincoln. ${ }^{10}$ The same pope, in 1235 , licensed, at the request of the king and his brotlser, the Earl of Cornwall, the appropriation by the abbey of the church of St. Keverne, Cornwall, the patronage of which, together with ten marks rent in Helston, the earl had already granted for the health of his soul and that of his father King Jolun, due provision being made for a vicar. ${ }^{11}$ This appropriation led in 1236 to a dispute between the rector and the convent as to the right of presentation. The convent sent a proctor to Rome, asserting that the Earl of Cornwall had given them the patronage, and alleging that they needed money for hospitality; but they concealed the fact that they had a $£ \mathrm{I}, 000$ of yearly rents, and being in a desert place had little or no hospitality to exercise. It was stated on behalf of the rector that the convent of Beaulieu revelled in their goods, which could support many more monks, and that they had turned the church of St. Keverne into

Ibid. ii. 90, 337 ; Matth. Paris, Chron. Maj.

(Rolls Series), iv. 562 .

10 Cal. of Papal Letters, i. 129.

11 Ibid. p. 145 . 


\section{A HISTORY OF HAMPSHIRE}

a grange, and admitted scarcely a single guest. ${ }^{1}$

In the first instance Gregory seems to have been willing to listen to any attack on the monks of Beaulieu, and in his original mandate to the legate Otho (given in full in the chartulary) he denounces them, writing of them as debachantes in their monastery. Naturally the abbot as well as the Earl of Cornwall protested. The result announced in the pope's name by Otho in February, 1237, was that Beaulieu retained the appropriation, and that the rector was to receive from the monks a pension of 20 marks until he obtained a competent benefice. ${ }^{2}$

Isabel of Gloucester, the wife of Richard, Earl of Cornwall, died on 17 January, I 239 ; and was buried before the high altar of the new church of Beaulieu, her heart being sent to Tewkesbury. ${ }^{3}$ The Earl of Cornwall, among his various deeds of piety, founded the monastery of Hales, for the establishment of which in 1246 twenty monks and thirty lay brothers were sent from Beaulieu." About the same time another party of monks left Beaulieu to colonize the newly founded monastery of Newenham in Devonshire. The monastery of Netley had already been colonized from Beaulieu in $1239 .^{5}$

At the end of the chartulary proper, already referred to, ${ }^{8}$ come certain memoranda, among which is one to the effect that in 1274, at the general Council of Lyons, when a subsidy for a crusade for six years was enjoined, the pope granted to the Cistercians that the abbot of Citeaux should be responsible for the contributions of their whole order. The abbot, with the advice of the chapter-general, taxed each individual house of the order, according to his will, for the six years. Beaulieu, with its three daughters of Netley, Hales and Newenham, for the first and second year were to pay $\AA^{26}$; namely Beaulieu, $£_{1} 3$; Hales, E5 6s.; Netley, $\ell_{4}$ 14s.; and Newenham, f3. In 1276, when the English Cistercian houses paid $f_{\mathrm{I}, 000}$ to Edward I., twothirds of which were due from Canterbury province, Beaulieu's share came to $£_{23} 6 \mathrm{~s}$. 8d.;

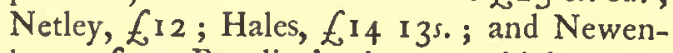
ham, $f_{5}$. Beaulieu's share was higher than

1 Cal. of Papal Letters, i. 155.

2 Harl. MS. 6603.

3 Annales Monastici (Rolls Series), i. I 13.

I Ibid. ii. 337.

5 Ibid. p. 323. Newenham in Devonshire was another Cistercian house colonized in the thirteenth century from Beaulieu. Dugdale's Monasticon, v. 693.

- Harl. MSS. 6603. any other of the forty-nine Cistercian houses of the province; the next on the list was Wardon, rated at $£^{22}$ I $3^{\text {s. }} 4 d$.

In January, 1 275 , the takers of the king's wines at Southampton were ordered to serve the abbot with three tuns of wine at a cost of $60 s$. for use in his church, for the first three years of the king's reign, in accordance with claim made under a charter of Henry III. Order was issued yearly for this tun of wine until 1279, when a mandate was served on Matthew de Columbariis, the king's wine-taker at Southampton, and his successors to deliver the tun yearly without having to obtain a special letter or other mandate. ${ }^{7}$ In February, I 275, the abbey received a further or second tun of wine from Southampton, in lieu of the tun that the king's steward received from the warden at Beaulieu for the use of the royal household on the occasion of the king's last visit. $^{8}$

Edward I. frequently sojourned at Beaulieu; he was there in 1275 and 1276 , and again in 1285 . It seems somewhat inconsistent with subsequent royal visits to find that in July, 1276 , protection was granted by letters patent for the abbey of Beaulieu, in accordance with the ordinances passed in the first parliament of Edward I., when it was ordained that no one should be lodged in a house of religion, or take victuals or carriage therein, or in any of its manors. ${ }^{\theta}$

About this period the abbots of Beaulieu were frequently abroad on the business of their house and order. In March, I 274, the abbot (probably Dennis), who held the king's licence to cross the seas, appointed two of his brother monks to act as his attorneys until the following feast of All Saints. In May, 1 276, he appointed two other monks as his attorneys, for a like reason, until Christmas, unless he returned in the interval, and in April, I 279, a like arrangement was made. ${ }^{10}$ The abbot also obtained leave to cross the seas from 8 September to Midsummer in 1282 ; from 7 September to Christmas in 1285 ; and from April to All Saints in $1286 .{ }^{11}$ These absences would be mainly to attend the general chapter which was held at Citeaux every year, opening on 14 September. Every abbot was bound to attend, under pain of a

7 Cal. of Close Rolls, Edw. I. i. 145, 148, 149, $265,365,462$; Cal. of Patent Rolls, Edw. I. i. 301 .

8 Close, 3 Edw. I. m. 22.

- Pat. 4 Edw. I. m. 14.

10 Cal. of Close Rolls, Edw. I. i. I16, 341, 559 .

i1 Cal. of Pat. Rolls, Edw. 1. ii. 35, 191, 236. 


\section{RELIGIOUS HOUSES}

severe penance, unless there was a legitimate excuse, in which case he was to acquaint some neighbouring abbot and to send letters. From this duty of yearly attendance, exemptions were made from time to time on the score of the poverty of the house or its distance, notably at the general chapters of 1260,1263 and 1270.1

Some light is thrown upon the history of the monastery as a trading community by the grant of a protection and safe conduct to the abbey in $128 \mathbf{1}$ for taking a ship laden with corn and other goods from time to time to Gascony and other places within the king's power, and bringing thence wine and other goods. 2

From the taxation roll of $129 \mathrm{r}$ we find that the temporalities of Beaulieu in the archdeaconry were then valued at producing an annual income of $\mathrm{f}_{\mathrm{I}} \mathrm{O}$, of which the immediate environs of the abbey supplied $£_{66}$ I $3^{5}$. $4 d$. The temporalities in the archdeaconry of Berks produced an income of $f 91$ is. $8 d$.; those of the archdeaconry of Oxford $£ 3^{2}$ Is. Iod. There was also $f_{1}$ I I I Is. $8 d$. from St. Keverne in Cornwall, and $f_{6}^{6} 13^{\text {s. }} 4 d$. from houses and fisheries in Little Yarmouth. In spiritualities there was the rectory of Shilton with an income of $£ 76 \mathrm{~s} .8 d$., and Inglesham with an income of $£_{4} 6 s, 8 d$.

In 1312 licence for alienation in mortmain, in favour of Beaulieu, was obtained for messuages and lands in Upton and Holebury, on payment of a fine of $30 .^{3}$ In 1316 the abbey obtained a valuable grant of a messuage, mill, 60 acres of land, Io acres of meadow, and 6 acres of wood at Hipley, and in March of the following year confirmation was given to six small grants to the abbey. ${ }^{5}$

The advowson of the church of Ringwood was granted to the abbey in February, 1329, by Edward III. in fulfilment of a wish of the late king; and on condition that four monks should be maintained beyond the thirty-two then at Beaulieu, to celebrate mass daily for the souls of himself, his mother and his heirs. In 1332 this grant of Ringwood made by the procurement of Roger de Mortimer was revoked. ${ }^{7}$ By the return of knights' fees of I 346 we find that the abbot of Beaulieu held

1 See Torks Arch. and Topog. Assoc. Cistercian Statutes, by J. T. Fowler, ix. 223; x. 51, 217 , 388, 502 ; xi. 95.

2 Pat. 9 Edw. I. m. 6.

3 Ibid. 5 Edw. II. pt. 1, m. 1.

- Ibid. 10 Edw. II. pt. I, m. 33.

5 Ibid. pt. 2, m. 23.

- Ibid. 3 Edw. III. pt. 1, m. 35 .

7 Ibid. 6 Edw. III. pt. 3 , m. I 2 . one fee in Over Burgate in perpetual alms. ${ }^{8}$ In the return for Berkshire for the feudal aid of 1316 he held the hundred and vill of Faringdon with Coxwell, Inglesham, and Little Faringdon, and he and others held Langford, Shilton and 'Bernynton.'

The abbot of Beaulieu, whose predecessors had sat in Parliament since I260, by fine of ten marks, obtained in 134I the king's sanction to be freed, for himself and his successors, from attendance at Parliament, inasmuch as all the abbey lands were held in free alms, and not by barony or otherwise of the king in chief. ${ }^{10}$

Abbot Herring presided for twenty years, and on his death the custody of the abbey was assigned, on 6 January, 1392 , to Thomas, Earl of Kent, and Tideman de Winchecombe, one of the monks. ${ }^{11}$ After some delay Tideman de Winchecombe was elected abbot, but he only ruled for a very brief period; for in August, 1 393, he was elected Bishop of Llandaff, at the instigation of the pope.

A grant of Edward III. in I 468 gave the monks of Beaulieu a weekly Thursday market within the precincts, and confirmed their rights of pasturage in the forests of Bere and Porchester, with other former privileges. ${ }^{12}$

On 15 December, 1483 , the abbot of Beaulieu was summoned, together with two of his community, by Richard III. to appear at Westminster, and bring with him all muniments and writings by which he claimed special sanctuary rights, within six days after the receipt of the mandate. ${ }^{13}$ It has been conjectured, with much probability, that this summons arose from the abbey having given shelter to the enemies of the Yorkist faction. Every church and churchyard had certain temporary sanctuary rights pertaining to them ; but in a few instances, of which Beaulieu was the most celebrated English example in the south, these rights were extended for an indefinite period and over a far wider area than the actual consecrated site. At Beaulieu Innocent III. had granted these special sanctuary rights to the whole of the original grant of land to the monks made by John, the bounds of which were clearly defined in the charter. Among those of note who availed themselves of this sanctuary may be mentioned Perkin Warbeck, Lady Warwick,

\footnotetext{
8 Feudal Aids, ii. 327.

9 Ibid. i. 51.

10 Pat. 15 Edw. III. pt. 3, m. 35.

11 Cole MS. xxvi. f. 87 b.

12 Woodward's Hist. of Hants, iii. 86

13 Harl. MS. 6603 , f. 336.
} 


\section{A HISTORY OF HAMPSHIRE}

after the field of Barnet in 1471 , and according to some writers, Margaret of Anjou.

Abbot Thomas Skevington was consecrated Bishop of Bangor at Lambeth on 17 June, 1509, but he continued to hold the abbey in commendam until his death in 1533 .

'The abbey's share towards the 'king's personal expenses in France to recover the Crown,' in 1522, was the large sum of f66 I $33^{\text {s. }} 4 d^{1}$. $^{1}$

In a butlerage account of customs paid on wine out of various ships at Southampton and Portsmouth, in 1526, which yielded a sum of \&15 ros. on I 55 tuns, it is stated that the total prisage of wine was fifteen tuns, whereof five tuns (one tun each) were delivered to the monasteries of Beaulieu, Tichfield, Netley, Waverley and St. Denis. ${ }^{2}$

The abbot of Beaulieu was summoned to Convocation in 1529 , but he was not present. ${ }^{3}$

In a list of 'fines made with divers persons by the king's commandment' of I $53 \mathrm{I}$ occurs the name of 'the Bishop of Bangor otherwise called the abbot of Beaulieu,' for the heavy sum of $£ 3336$ s. 8d., for his offences against the statutes of provisions and præmunire. ${ }^{4}$ In the following year however we find the abbot-bishop was put on the commission of the peace for Hampshire. ${ }^{5}$

On 17 August, 1533, Abbot Skevington died, and on the following day Harry Huttoft wrote to Cromwell begging that the post might be given 'to one of the same religion, a good man, the abbot of Waverley,' adding, 'he will do his duty every way, and if you knew of his manner of living you would be his assured good master.' On 20 August, Sir William Fitzwilliam wrote from Windsor to Cromwell concerning the abbot's death, and stating that he was in the king's displeasure for offences against the royal game. 'I chanced, in communication with the king, to mention one who a virtuous man and a good husband(man), and had ever been good to his game though the forests of Wolmer and Windsor and other places are about his house, and I thought he would make a good abbot of Beauley. On his asking who he was, I replied, the abbot of Waverley. $\mathrm{He}$ said it was truth, and willed me to write to you to put him in remembrance, on his coming to London, that he might take order for the same. I assure you the suggestion came from myself alone, and not from any solicitation of the abbot.'

1 Letsers and Papers, Hen. VIII. iii. 2483.

2 Ibid. iv. $2528 . \quad 3$ Ibid. iv. 6047 .

4 Ibid. v. 657 .

I Ibid. v. 1694 (2).
On the same day Lord Audeley wrote to the Duke of Suffolk as to the vacancy at Beaulieu, for which much suit was being made. He did not make any specific suggestion, but urged that whoever was appointed abbot should be 'a man of great gravity and circumspect, and not base of stomach or faint of heart when need shall require, the place standeth so wildly ; and it is a great sanctuary, and boundeth upon a great forest and upon the sea coast, where sanctuary men may do much displeasure if they be not very well and substantially looked upon.' " In accordance with the king's wish John Browning, abbot of Waverley, the preserver of the king's game, was speedily made abbot of Beaulieu. In September Huttoft wrote a grateful letter as to the appointment to Cromwell.

The Valor of 1535 , taken when Browning was abbot, gave the gross annual value of Beaulieu as $£ 4286$ s. $8 \frac{1}{4} d$., and the net value $£ 326$ i 3 s. $2 \frac{3}{4} d$.

Under the Act of 1536 , dissolving the lesser monasteries, more than two-thirds of the Cistercian abbeys were suppressed. Their inmates were, as a rule, transferred to the larger houses of the order. In March, 1536, Abbot Browning died, and Thomas Stevens or Stephens, abbot of Netley, was appointed his successor. In the following February Netley was suppressed, and the whole of the monks went to their mother house at Beaulieu. ${ }^{7}$

Lord Lisle was most anxious to obtain the fine spoils of Beaulieu, and wrote both in February and June of 1536 to servants of Cromwell to endeavour to secure them. On the first occasion he was told that there was no likelihood that Beaulieu would be suppressed; and on the second application he was assured that it would be lost time to sue for it, and recommended to try for St. Mary's, Winchester, or for 'Waverley, which is a pretty thing.' ${ }^{8}$

Shortly after Stevens' appointment as abbot, we find him eager to curry favour with Wriothesley. Hearing through a servant that he wanted a horse-'My Lord of Beaulieu said he had nothing but should be at your commandment, and sent his men to take up for you his own riding horse, which you will receive herewith. His only fault is that he is too. little for you, though the biggest in all his park." ${ }^{9}$

\footnotetext{
- Letiers and Papers, Hen. VIII. vi. 1001, 1006, 1007 .

7 Gasquet's Henry VIII. and the Monasteries, ii.

8 Letters and Papers, Hen. VIII. x. 339, 1058.

- Ibid. xi. 1455.
} 453 . 


\section{RELIGIOUS HOUSES}

With regard to the ancient right of sanctuary at Beaulieu, it is not surprising to find that neither Cromwell nor his royal master had any scruple as to its violation. In September, 1537, the abbot received a letter from Cromwell demanding the delivery to the bearers of the body of James Manzy, a Florentine. He replied that he would have done so, but that Manzy had left sanctuary on the previous Sunday when he was absent from home. On hearing further from the Lord Privy Seal, the abbot wrote to say that in conjunction with Master Huttoft he had gathered together all the conveyers of James Manzy, and had so used them that he thought they would 'love the worse hereafter to steal sanctuary men from Beaulieu.' Manzy hid day and night in woods, bushes and old barns, and the abbot indignantly repudiated the suggestion that he had connived at his escape. At the same time Huttoft wrote to like effect to Cromwell. 'I have made search with my lord of Beaulieu these two days, both aboard ship and in all the forest, and have this night ( 28 September) found the said James in a hay loft on a farm besides Hampton. He was hidden half the mow deep, and when discovered seemed more dead than alive. After a while he fell to weeping, saying his abuse was only for fear of your lordship, and that his keepers menaced him to be carried up like a prisoner. I beg you will have pity on him for he has been severely handled. The bearer Parpoynt has spoken many words more than needeth. My Lord of Beaulieu has used very good diligence in this matter, and is also much discouraged by the reports made of him.' 1

On 2 April, $153^{8}$, the subservient abbot signed the surrender of this great monastery of royal foundation to the notorious commissioners Layton, Petre and Freeman, and induced twenty of the monks to do the like. ${ }^{2}$ The site was immediately granted to Thomas Wriothesley (afterwards Earl of Southampton). Crayford, one of the sub-commissioners for suppression of monasteries, wrote to him on 17 April, saying that Abbot Stevens, immediately before his surrender, let out the mill, parsonage, etc., of Beaulieu, and the lodge at St. Leonard's grange to his sister. ${ }^{3}$ On 26 April, the ex-abbot wrote to Wriothesley, protesting against the detraction of his "lewd monks, which now, I thank God, I am rid of.'

1 Letters and Papers, Hen. VIII. xii. (2), 728, $765,766$.

${ }^{2}$ Dep. Keeper's Reports, viii. appendix ii. 9 .

${ }^{3}$ Letters and Papers, Hen. VIII. xiii. (I), 750.

- Ibid. 847,848 .
At the time of the dissolution the monastery held in Hampshire the manors of Colbury, Hilton, Upton, 'Ippeley,' Holbury, and the manor of Frerencourte in Fordingbridge, the rectories of Beaulieu, and lands, rents, etc., in Southampton, Lymington, 'Esthamlode' in the Isle of Wight, 'Gooreley,' 'Blayshford, Bremmer' and Avon, and Newchurch in the Isle of Wight; in Berkshire the manors of Great Faringdon, Little Faringdon, Inglesham, Shilton and Wyke, and rents in Westbroke and Langford; in Cornwall the manor of St. Kirian, a mill at Tregonon, and rent in Helston; and a messuage in Southwark in Surrey. ${ }^{5}$

Stevens obtained a pension of 100 marks, but in February, 1540, was instituted to the rectory of Bentworth near Alton. In I 548 he was collated to the treasurership of Salisbury Cathedral, and died in 1550 seized of both these preferments. Seventeen of the monks also obtained small pensions.

With the suppression came the end of the historic sanctuary rights throughout what was termed 'the Great Close of Beaulieu.' On the day of the surrender the commissioners wrote to Cromwell stating that there were thirty-two sanctuary men there for debt, felony and murder, who had their houses and grounds where they lived with their wives and children. They declared that if sent to other sanctuaries they would be undone, and desired to remain there for their lives, provided no more were admitted. The commissioners wished to know the king's pleasure. The ex-abbot also wrote to Wriothesley, begging him to be a good master to the Beaulieu sanctuary men who were there for debt. He said they had been very honest while he was their governor, and it would be no profit to the town if they were to leave, for the houses would yield no rent. Crayford also wrote to Wriothesley about the same time, asking for the king's protection for the 'miserable debtors,' stating that all the inhabitants of Beaulieu were sanctuary men, and urging the immediate departure of the murderers and felons as 'hopeless men.' In the end the debtors were allowed to tarry for their lives, under protection, at Beaulieu ; and one, Thomas Jeynes, who had slain a man at Christchurch, was granted a pardon. ${ }^{\circ}$

The circular elaborate fifteenth century seal, of which an illustration is given, represents the crowned Virgin seated in a canopied

5 The first Mins. Acct. recited in Dugdale's Monasticon, v. 683 .

${ }^{6}$ Letters and Papers, Hen. VIII. xiii. (1), 668, $792,796,877$, I 309 (23). 


\section{A HISTORY OF HAMPSHIRE}

niche with the Holy Child on left knee; on each side, in canopied niches, are five kneeling monks. In base is a crown enfiled with a crozier. Legend: Sigillum : Commune : MonasteriI : Belli : Loci : Regis.

\section{Abbots of Beaulieu}

Hugh, ${ }^{1}$ about $1208-19$

Azo of Gisors, $123^{8}$

Dennis, ${ }^{2}$ about $1274-80$

William de Gisors, cellarer, ${ }^{3}$ I 28 I

Robert de Boclonde, died in 1302

Peter de Chichester

William de Hameldon ${ }^{5}$

John Peres

Walter Herring, ${ }^{8}$ I 37 2-92

Tideman de Winchecombe, about 1392-3

Richard de Middleton, ${ }^{7}$ 1 394-7

John Gloucester, ${ }^{8}{ }_{1}^{1} 397-1400$

Richard de Middleton, ${ }^{8} 1400$

Richard Bartelmelo, ${ }^{10}$ I 4 I 5

William Salbury, ${ }^{11}$ 1 425-9

William Woburn, 1429

Humphrey, I 490

Thomas Skevington, ${ }^{12}$ 1509, 1533

John Browning, abbot of Waverley, I 533-6

Thomas Stevens, abbot of Netley, I 536-8

\section{THE ABBEY OF NETLEY}

The abbey of Netley, Letley (Latus Locus), or Edwardstow (Loci Sancti Edwardi), dedicated to the honour of the Blessed Virgin and St. Edward the Confessor, was founded for Cistercian monks by Henry III. in 1239. It appears that Peter des Roches, Bishop of Winchester (1205-38), purcliased the land of 'Hanseta' and 'Cedrigia' from William, Bishop of Angers, and the dean and chapter of Angers; lands in Wellow from the abbot of St. Mary de Pratis, Leicester ; lands at Kingston Deverel from the bishop and chapter of Le Mans; land called 'Ayhsleg' in

1 He was made Bishop of Carlisle in 1219 and died in 1223 .

2 Pat. 6 Edw. I. m. 10.

3 Annales Monastici (Rolls Series), ii. 395, iv. 479.

'Dugdale's Monasticon, v. 693.

5 Ibid.

6 Winton. Epis. Reg., Wykeham, i. f. 42.

7 Ibid. i. f. 232.

${ }^{8}$ Pat. 20 Rich. II. pt. 2, m. 6.

- Ibid. 11 Hen. IV. pt. 2, m. 6. Richard de Middleton had been ejected and was restored.

10 Lateran Regesta, cluxv. $278 \mathrm{~b}$.

11 Salbury and the subsequent abbots are given in the list in the Cole MSS.

${ }^{12}$ Made Bishop of Bangor in 1509.
Dorsetshire from the abbot of Croix St. Leufroy ; and some other parcels of land, apparently with the object of founding this monastery. The bishop, however, died in $123^{8}$, before the completion of his object, and the actual foundation was carried out by Henry III. in the following year. ${ }^{13}$ Hence the king was usually referred to as the founder. So soon as the monastery was completed it was colonized by monks from the Cistercian abbey of Beaulieu, who arrived at their new home on St. James' Day, I 239. ${ }^{14}$

In August, I 243, Roger de Clare sold to the abbey for 300 marks the tilled land and pasture which lay between their manor of Gomshall and the highway from Guildford to Dorking, and also the advowson of the church of Shere, ${ }^{15}$ which grant was confirmed by John de Warren, Earl of Surrey, in 1252.

In 1244 Innocent IV. sanctioned under certain conditions the appropriation by the abbey of Netley of the churches of Shere and Wellow, valued at $£ 30$ per annum. ${ }^{10}$ The same pope in the following year confirmed to the abbot and convent of Netley the privileges of not being compelled by bishops or others to attend synods or assemblies outside their order, save only pro fide, and of exemption from sentences of excommunication, suspension or interdict. ${ }^{17}$

In the same year Robert, abbot of Netley, released to the Bishop of Winchester the manor of Esher, with the advowson of the church and all its appurtenances, save roos. worth of land in Dorsetshire. ${ }^{18}$ In August, 1 247, the abbot and convent of Lieu Dieu, in the diocese of Amiens, sold to the abbey of Netley for 600 marks their English manor of Nordley, their rents in Oxford, their rents and rights in Chaddleworth and their rent of five marks from the church of Henton. ${ }^{19}$

Henry III. on 7 March, 125I, confirmed to Netley Abbey (Sancte Marie de Loco Sancti Edwardi) the site of the monastery with the lands of Netley, Hound, Wellow, Totton, Gomshall, Nordley, Kingston Deverel, Waldon, Aynsley and Lacton, with rents in Charleton, Southampton and Southwark, a

${ }^{13}$ Charter Roll, 24 Hen. III. No. 34. The latter part of this charter is faded and torn. See also Pat. 1 Rich. II. pt. 4, m. 35.

14 Annales Monastici (Rolls Series), ii. 323. In this Peter des Roches is referred to as the founder.

15 Woodward's Hist. of Hants, iii. 365.

16 Cal. of Papal Letters, i. $211,286$.

17 Ibid. i. 212.

18 Pat. Io Edw. II. pt. 2, m. I, cited in confirmation at that date.

${ }^{19}$ Ancient Deeds, P.R.O., D. 153, 302. 


\section{RELIGIOUS HOUSES}

hundred acres in Shere manor and the church there, as well as many liberties and privileges. A fortnight later the king granted to the abbey free warren on their lands in Netley, Hound, Shotteshale, Westbrook and Sholing (Hants), Waddon and Aynsley (Dorset), and Gomshall and Shere (Surrey), a weekly market at Hound on Monday and a two days' fair at Wellow on the vigil and day of St. Margaret. ${ }^{1}$ Henry III. continued his benefactions to the abbey, and on $24 \mathrm{July,} 1253$, granted to it three carucates of land, of I00 acres each, in the New Forest, with licence to enclose and cultivate them; and in 1256 he gave special licence to enclose the same against the king's deer. ${ }^{2} \mathrm{He}$ also further granted to the abbey a tun of wine yearly out of the prisage at Southampton, to be used for the celebrations in the abbey. Edward I. instructed the taker of the king's wines at Southampton in 1276,1277 and 1280 to duly supply this wine according to the late king's charter ${ }^{3}$; but in I28 I Edward I. granted 20 s. yearly in alms in lieu of the wine, as the prisage at Southampton was assigned to Eleanor, the king's mother, as part of her dower. ${ }^{4}$

In June, 1290, Abbot Walter de Cheseldene, who had just previously been elected, obtained permission to attend his general chapter. $^{5}$

The taxation of 129 I gives the income of the abbey in temporalities in the Winchester archdeaconry at $£ I 7$ Is.; namely Netley Grange $£ 2$ 2s., Wellow Grange £3, Raydon Grange $\ell^{I}$, Gomshall Grange $\ell_{10}$, and $I$ gs. of rents in Winchester and Southampton. At the same time the rectory of Hound, with its chapel of Netley, was valued at $\AA^{6} 13^{\text {s. }} 4 d$. the year. The churches of Shere and Wellow, which were appropriated to the abbey, were respectively valued at E23 6s. 8d. and fio. The abbot also held property in Salisbury diocese of the annual value of $£ 24$ Is. The total revenue of the abbey amounted at that time to the substantial income of $£^{8} \mathbf{1} 2$ s. $^{6}$

1 Ancient Deeds, P.R.O., A. 3239 (1).

2 These charters are cited in an inspection and confirmation of Edward IV. (Pat. I Edw. IV. pt. $6, \mathrm{~mm} .26,25)$.

3 Close, 4 Edw. I. m. 16; 5 Edw. I. m. 8.

- Pat. Io Edw. I. m. 2 I.

- Ibid. $18 \mathrm{Edw}$. I. m. 25 .

- The editors of Dugdale make the curious mistake of only noticing the first of these items, and then estimating the income at "scarcely more than $£ 17$.
The abbot of Netley was summoned to the parliaments of $1295,1296,1300$ and 1302.

On ro February, I 3 I 1 , licence for alienation in mortmain to the abbot and convent of Netley was obtained by a fine of roos. for various plots of land in Wellow and Hound, together with a salt pit in the latter parish. ${ }^{7}$ In the following year similar licence was obtained for two messuages and 45 acres of land in East Wellow. ${ }^{8}$ And in May, 1328 , Robert de Vere, Earl of Oxford, obtained licence by a fine of ten marks to alienate to the abbey in mortmain the Hampshire manor of Mansbridge of the yearly value of twentyfour marks. In return for this the abbey was to find two monks as chaplains to celebrate daily mass in the abbey church for the souls of the earl, his ancestors and heirs; and the earl was to obtain licence to present two secular clerks to the abbot for admission as monks, promotion to the priesthood and appointment to the said chantries. ${ }^{9}$

Notwithstanding this increase of property, on 25 May of the same year letters of protection had to be obtained by the request of the chapter, as the house was burdened with debt and impoverished by bad government. At the same time the king appointed John of Mere to the custody of the abbey, during pleasure, by whose advice the abbot was to apply the revenues to the payment of debts. Meanwhile no minister nor sheriff of the king nor any other person was to lodge at the abbey or in any of its granges, or to meddle with anything thereto belonging, without the king's consent. ${ }^{10}$ It was probably in consequence of their embarrassed position that the abbey, soon after this date, parted with a considerable share of its property. Letters patent of January, I 331, confirmed to Henry Darcy and Hugh Totehill, his brother, a grant made by Abbot William and the convent of their mill at Stone and all their possessions in Laghton, Morthing, Hoton Ker, Torcroft, Brokehouse and Stone, absolutely, with villeins, chattels and services of free tenants. ${ }^{11}$

The abbot and convent again petitioned the Crown (as a house of royal foundation) for relief in $133^{8}$, alleging as one of the causes of the impoverishment of this estate the situation of the abbey on the sea coast and the frequent coming and going of mariners. Letters patent were consequently granted enabling them to

\footnotetext{
7 Pat. 4 Edw. II. pt. 2, m. 24.

8 Ibid. 5 Edw. II. pt. 1, m. 13.

- Ibid. 2 Edw. III. pt. I, m. 9.

10 Ibid. pt. 2, m. 32.

11 Ibid. 4 Edw. III. pt. 2, m. 17.
} 


\section{A HISTORY OF HAMPSHIRE}

assign to Roger of Petersfield and Henry Deverel of Netley and their heirs, at an annual rental of $£ 40,30$ acres of meadow, I IO acres of heath and 40 acres of turbary, together with their fisheries on Terstwood and Totton, as well as forty bondmen in villenage in the same towns. ${ }^{1}$

The taxation of February, I 34I, shows that the church of Hound, with the chapel of Netley, was endowed with two messuages, a curtilage, a yardland of arable worth ros. yearly; the tithes of milk, hay, fish and salt, valued at 135.; the oblations on appointed days, 10s.; and tithes of gardens, orchards, pigs and mortuaries, I Is. The ninths of lambs and wool were that year IOs. below the average, because sailors and others appointed to guard the coast had robbed the parishioners of sheep and lambs. The ninths wanted 8 s. of their usual value, as a good part of the corn land was left fallow through dread of foreign invasion and the marauding of the king's sailors. ${ }^{2}$ In 1346 Netley was returned as holding half a knight's fee in Wellow in perpetual alms. ${ }^{3}$

On 7 December, 1461, Edward IV. inspected and confirmed three charters of Henry III. and letters patent of Richard II."

From a butlerage account of 1526 it seems that the annual payment to Netley Abbey of a tun of wine for sacramental purposes, out of the prisage wine of the port of Southampton, had been resumed in kind; at all events in that year Netley was one of the five monasteries that received a tun of wine from the king. ${ }^{5}$

In 1529 Thomas Stevens, abbot of Netley, was summoned to Convocation; he did not appear personally, but was represented by the prior of Breamore. ${ }^{6}$

The ominous Thomas Cromwell appears on the scene in 1533. In December of that year he wrote to Abbot Thomas, desiring him to grant his friend John Cooke a new lease for sixty years, at the old rent, of the farm called Roydon; being near the seaside it would be convenient for Cooke to serve the king in his office of the Admiralty in those parts. ${ }^{7}$

A royal commission was issued in 1535 , which empowered Thomas, abbot of Forde, to visit various Cistercian houses, including Netley and all those of Winchester diocese.

1 Pat. 12 Edw. III. pt. 1, m. 4.

2 Woodward's Hist. of Hants, iii. 367.

${ }^{3}$ Feudal Aids, ii. 323.

- Pat. I Edw. IV. pt. 6, mm. 26, 25.

5 Letters and Papers, Hen. VIII. iv. 2528.

- Ibid. iv. 6047. 7 Ibid. vi. 1502.
The Valor of 1535 estimated the gross revenue of Netley Abbey at $£_{1} 602 s .9 \frac{1}{2} d$., whilst the clear income was only $f_{1} 100$ I 2s. 8d.; it therefore came under the heading of the lesser monasteries. Being of exempt jurisdiction, no particulars are given in the return.

On 30 May, 1536 , Sir James Worsley and his brother commissioners presented their report on the religious houses of Hampshire. Netley is described as 'A hedde house of Monkes of thordre of Cisteaux, beinge of large buyldinge and situate upon the Ryvage of the Sees. To the Kinge's Subjects and Strangers travelinge the same Sees great $\mathrm{Re}$ lief and Comforte.' 8 The commissioners estimated its total revenues at $f_{1} 8$ I $2 s .8 d$. They found there seven monks, all priests, 'by Raporte of good Religious conversation, whereof desieren to Contynne Religiar vj, and to have capacite j.' 'There were thirty-two other inmates, namely 'ij freeres observantes comytted by the Kinge's highnes,' four waiting servants, four officers of the household, eleven officials of the convent, seven hinds and three 'for the dayery.' 'The church, mansions and buildings were in good repair. The lead and bells were worth $£ 57$; plate and jewels, $f_{43}$ 2s. I I d.; ornaments, $£ 39$ 4s. 8d. ; stuff, $£ 9$ 3s. 4 d.;

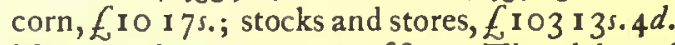
The woods were worth $£^{8} \mathbf{1}$. The debts of the house were $£ 42$ 3s. $4 d$., but there was $£ 28$ 5s. owing to the house. ${ }^{9}$

The abbey of Netley retained most of its early endowments, and at the time of its dissolution the lands belonging to it were, besides the site, the manors of Wellow, Totton, Roydon, Nordley, Gomshall, Kingston Deverel and Hound; and lands and possessions in Southampton, West Setley, Mitcomb Regis, Charleton, Shottishale, Sholinge and Shamelhurst. ${ }^{10}$

On 3 August, 1 536, the king gave to Sir William Poulett, the comptroller of his household (two of whose brothers had been the commissioners who reported so favourably of this house in the previous May), the site and buildings of the suppressed abbey, together with the grange, mill and lands in Netley; the manor of Hound; lands and windmill, etc., in Hound and Sholing; the manor of Townhill ; lands, etc., in Townhill and Shamelhurst ; and the manor of Waddon and the

8 There seems little doubt that the monks of Netley, as well as those of Quarr, maintained a light for the guidance of mariners (vide supra, p. 56).

P. Aug. Off., Certif. of Coll. and Chant. 112.

${ }^{10}$ From the first minister's account cited in Dugdale's Monasticon, v. 696. 


\section{RELIGIOUS HOUSES}

farm of Aisheley in Dorsetshire. ${ }^{1}$ The manor of Kingston Deverill (Wilts) was bestowed on Sir Edward Seymour in the following year. ${ }^{2}$ The reversion and rent reserved upon a lease granted in 1502 by Abbot John Burges of the manor of Gomshall, Surrey, was given in I 538 to Sir Edward Braye. ${ }^{3}$ The tithes of Wellow rectory and land there were granted in 1539 to Sir Richard Lyster, chief baron.4

The pointed oval seal, illustrations of which and the counterseal are given, of the year 1329 represents an abbot, with crozier in right hand and book in left, standing between four monks, two on each side. The legend reads : COMMUNE A ABB ..... DE - LETTEL ...

The reverse has a smaller pointed oval counterseal. The full length abbot has crozier in right hand and book in left.
Legend : + s' ABB'IS $\cdot$ LOCI $\cdot S C I \cdot$ EDWARDI.

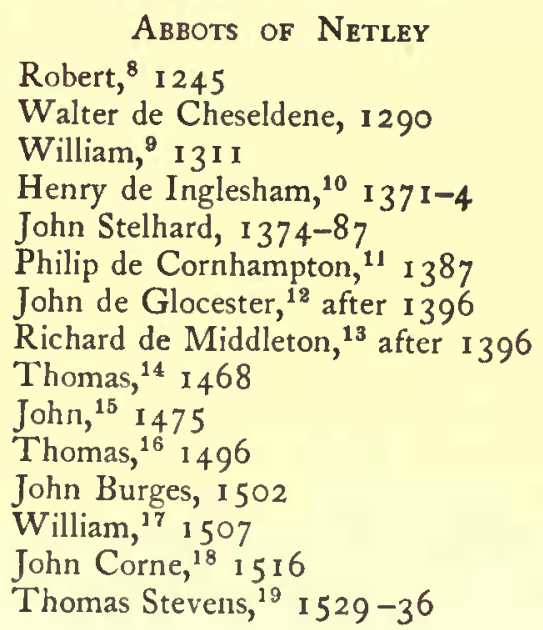

\section{HOUSE OF CISTERCIAN NUNS}

\section{THE PRIORY OF WINTNEY}

A small priory of Cistercian nuns, dedicated to the Blessed Virgin and St. Mary Magdalene, was founded at Wintney in the twelfth century. Occasionally its superiors were termed abbesses. According to the obituary of the convent calendar, Richard Holte and Christine his wife, the daughter of Thomas Cobreth, founded the house and Geoffrey Fitz Peter the first cliurch towards the end of the twelfth century. Leland names Roger Cobreth and his son Thomas as the founders. ${ }^{5}$ Various members of the Cobreth family were benefactors; and we find that Dame Diana Cobreth had her heart buried before the high altar.

In 1234 the temporary church or chapel of wood was succeeded by a stone church, which was dedicated on 4 October. ${ }^{6}$ Richard de Herriard was the founder of this church; his obit was kept on April 6. Several other members of that family, who took their name from an adjacent parish, were also benefactors of this convent.

Among the Cotton MSS. is a handsome twelfth century volume in excellent preservation which belonged to the nuns of Wintney. ${ }^{7}$ Its chief contents is the rule of Benedictine

1 Letters and Papers, Hen. VIII. xi. 385 (3).

2 Ibid. xii. 617 (1).

3 Ibid. xiii. 646 (39).

- Aug. Off., Misc. Books, ccx. f. 59.

5 Leland's Collectanea, i. 69.

6 Cott. MSS. Claud. B. iii.

7 Ibid. nuns set forth both in Latin and English in parallel columns. At the end is a fine calendar, in which are entered the names of benefactors, prioresses and sisters of the convent according to their several obits. This obituary ${ }^{80}$ mentions six Bishops of Winchester, beginning with Godfrey de Lucy (I I 89-1205); two Bishops of Bath; six abbots of Reading, beginning with Elias (1200-13); two priors of Southwick ; and Adam, abbot of Waverley, 1216-29. There are a few entries of the fifteenth century. Eleven prioresses of Wintney are named, but in no case is any year given; they are in calendar order, Emma, Sabina, Isilia, Clarice, Lucy, Julia, Alice, Lucy II., Havisia, Cecily and Rose. The last prioress commemorated in the obituary is Alice de Dunmore, elected in I 301 . There is also mention of Maud de Quincy, who founded the dorter.

8 Cal. of Papal Letters, i. 212.

9 Ancient Deeds, P.R.O., D. 630.

10 Winton. Epis. Reg., Wykeham, iii. 38.

11 Cole's MSS.

12 Dugdale's Monasticon, v. 695.

13 Ibid.

14 Pat. 7 Edw. IV. pt. 1, m. 22.

15 Ibid. 15 Edw. IV. pt. 1, m. 26.

${ }^{6}$ Ancient Deeds, P.R.O., B. 2724.

17 Ibid. D. 815.

18 Ibid. D. 1216.

19 Letters and Papers, Hen. VIII. iv. 6047.

20 This obituary was printed, though with many mistakes, by Thomas Hearne in 1729, among the notes to Trokelowe's Annales Edwardi II. pp. 38493. 


\section{A HISTORY OF HAMPSHIRE}

In 1302 Bishop Pontoise visited the house, and in 1308 the official of the diocese, Peter de Grunmill, issued a mandate to the convent citing them to a visitation by Bishop Woodlock. ${ }^{2}$ No injunctions followed the visitations of 1302 or 1308 , so that the inference may be fairly drawn that neither bishop found any cause of complaint. Bishop Woodlock held another visitation of Wintney in December, 1315, and in the following January he sent a series of injunctions of the usual kind as to stricter observance of their rule to the convent as the result of the visit. ${ }^{3}$ On 14 May, 1316, only a few weeks before his death, Bishop Woodlock received a letter from Walter, Archbishop of Canterbury, as to the reports that had reached him concerning the nuns of Wintney and the decay of their house. The archbishop stated in his letter that through negligence and bad administration the affairs of the house were reduced to such a state that it might altogether collapse unless staying hands speedily intervened, inasmuch as the nuns, vowed to abandon a secular life, were dispersing themselves in the world because no proper provision was made for their food. The archbishop urged his suffragan to take prompt action to correct and reform these abuses, and to recall the scattered flock. ${ }^{4}$ Immediately on receipt of the primate's letter, namely on 16 May, the bishop issued a commission to Master Gilbert de Middleton, canon of St. Paul's and vicar-general of the diocese, associating with him Master Andrew de Bruges, canon of Chichester, who frequently acted as bishop's official, and Master Stephen de Dene, rector of Abbotstone, to hold a visitation at Wintney, with full power to correct and to amend whatever was amiss. ${ }^{5}$ Meanwhile Bishop Woodlock died on 28 June, and commissions of his appointment ceased to be valid. The archbishop evidently thought the scandal of the dispersion of the Cistercian nuns of Wintney a grave and urgent matter, and on 20 July, during the vacancy of the see, he issued a commission to Andrew de Bruges and three others with full powers to visit the nunnery and to inquire, correct, reform and punish the excesses of delinquents. ${ }^{6}$ There is possibly some degree of excuse to be found for the deplorable condition of the Wintney convent and the lack of food for the inmates, when it is recollected that a most grievous famine

1 Winton. Epis. Reg., Pontoise, f. 23.

2 Ibid. Woodlock, f. 85.

- Cant. Archiep. Reg., Reynold, f. $39 \mathrm{~b}$.

- Winton. Epis. Reg., Woodlock, f. 206.

- Cant. Archiep. Reg., Reynold, f. 117 b. afflicted England in 1315 and continued for three years.

This action seems to have led to a better state of affairs, and, for the assistance of the house, letters of protection for the goods and crops of the prioress and nuns for one year were granted on 6 February, $1321 .^{7}$

In 1367 Bishop Wykeham licensed the prioress of Wintney to receive Beatrice Paynell as a paying guest. ${ }^{8}$ The licence, without which, according to the Benedictine rule, no visitor even on payment could be entertained, describes Beatrice as a woman devoted to God and honourable, and sister to Sir John Foxley, a neighbour, a friend, and favourably inclined to the prioress, at whose special request the permission was granted. The licence, dated 20 December, was to permit Beatrice's residence at Wintney until the next feast of St. John Baptist. Sir John Foxley lived at Bramshill, about four miles from the priory; he was the son of Thomas Foxley, constable of Windsor Castle, under whose directions W ykeham had been in his earlier days. Both father and son were among the bishop's most intimate friends, and he was doubtless glad of the opportunity of serving Sir John's sister.?

Bishop Wykeham licensed John Lydezorde, rector of Elvetham (a parish adjoining the priory) in April, 1380, as confessor to the prioress and nuns. ${ }^{10}$

In 1398 the prior of Christchurch was appointed to collect throughout the diocese the second moiety of the tenth voted by convocation, with the sole exemption of the priory of Wintney. ${ }^{11}$ A like exemption was made in favour of this priory when another moiety of a tenth was being collected in January, I 404. It is there stated that Wintney was exonerated from the payment because it is a house of poor nuns heavily encumbered. It is also stated that the appropriation of the church of Herriard by the priory in Bishop Orlton's time was permitted for a like reason. ${ }^{12}$

In April, 1404, the bishop commissioned John Elmere, one of his two recently appointed coadjutors, and Robert Ketone, his chancellor, to visit the priory. ${ }^{13}$

On 16 October, 1420, an inventory was taken of the goods pertaining to the frater in consequence of the death of Alice Preston, who was in charge of the hall. The goods

\footnotetext{
7 Pat. 14 Edw. II. pt. 2, m. 2 I.

8 Winton. Epis. Reg., Wykeham, iii. f. 22.

- Moberly's Life of Wykebam, 2 1, 22.

10 Winton. Epis. Reg., Wykeham, iii. f. $185 \mathrm{~b}$.

11 Ibid. iii. f. 300 .

12 Ibid. f. $36 \mathrm{I}$.

13 Ibid. f. 394.
} 


\section{RELIGIOUS HOUSES}

were-two worn tapestry hangings for the wall at the back of the high table; two choice seat cushions; fifteen table napkins; four tablecloths of Paris work; two linen tablecloths; ten hand towels; a worn basin at the lavatory; a pewter salt-cellar; and two latten and one pewter candlesticks. ${ }^{1}$

Wintney was visited on 3 April, I 501, by Dr. Hede, commissary of the prior of Canterbury. Anne Thomas, the prioress, stated that the income of the house was $£ 50$, that on entering into office the house was in debt 20 marks, 15 of which had been paid; Joan Swayne, sacrist, testified that in the time of the former prioress a certain blank form ${ }^{2}$ of charter under the common seal was given to the vicar of Herriard without the knowledge of the sisters. ${ }^{3}$

On 7 April, 1534, Henry, Marquis of Exeter, wrote to Cromwell, understanding that the election of the prioress of Wintney was in his hands, begging that he would give it to his wife's kinswoman; she was well able to execute the office, and would fully content the king in all his wishes."

The first commissioners appointed by the king to survey the religious houses of Hants were far too favourable and apparently honest in their views to give any satisfaction to the intending spoilers. On 23 May, 1536, Sir James Worsley and John Poulet, George Poulet and William Berners reported that they had visited the priory of Wintney, 'a hedde house of nuns, order of Cisteaux.' They estimated its annual value at $£ .525 \mathrm{~s} .8 \mathrm{~d}$. and found there ten nuns, "by reporte of good conversation, which trooly desieren to contynue in the same religion.' 'The other inmates were two priests, a waiting servant, thirteen hinds, nine woman servants, and two 'corediers' with their two servants. The church and mansion were in good repair save the tiling, but the kitchen and brewhouse were in great decay. The lead and bells were worth $£ 28$ Is. $4 d$.; the plate and jewels, $£ 35$ os. rod.; the ornaments, $£ 521$ is. $6 d$.; stuff, $£_{1} 3$ os. $6 d$.; grain of all kinds, $£_{1} 6$ I gs. $8 d$.; stocks and stores, $f_{1} I_{4} 45.6 d$.; and woods, $£_{42}$ 135. Iod. There was also the sum of $f 72$ I 6 s. owing to the house. ${ }^{5}$

On 24 September, I 536, Cromwell's amenable tools and commissioners, Dr. Legh and

1 This inventory is on the back of the first folio of Cott. MS. Claud, B. iii.

2 Quedam pecia pergamene voc'. 'A blank.'

3 Sede Vacante Register, Christ Church, Canterbury.

Cott. MS. Vesp. F. xiii. 97.

5 Aug. Off., Certif. of Chantries and Colleges, 1 I 2.
Join Ap-Rice, were at Wintney, and wrote to their master from the priory. ${ }^{6}$ The actual surrender took place on 22 July, $1536 .^{7}$

In August, 1536, Sir William Poulet, comptroller of the king's household and brother of two of the commissioners of May, I 536, obtained a grant of the site and lands of the monastery lately held by Elizabeth Martyn as prioress of Wintney. ${ }^{8}$

In May, 1538 , the king granted to Richard Hill and Elizabeth his wife the house and site of the dissolved priory of Wintney, with the church, steeple and churchyard of the same, the manor and rectory of Hartley Wintney and all lands pertaining of the annual value of $£_{26}$ i 4 s. $9 d$., at an annual rental of $535.6 d^{9}$

An undated letter of Richard Poulet, of the year I 538, to Mr. Hill, sergeant of the king's cellar, ordered him, in the name of the king's commissioners, to cease to deface any of the buildings of the late priory of Wintney besides those which the king had given him, which were only the cloister and the dorter. ${ }^{10}$

\section{Prioresses of Wintney}
Lucy, 1225
Cecily, 1294
Lucy II., $1294^{-}$
Alice de Dunmore, ${ }^{11} 1301$
Christiane, died I 329
Alice Westcott, ${ }^{12}$ I $329-36$
Camina de Mareys, ${ }^{13}$ 1 336
Einma de Wynterburn, ${ }^{14}$ I 349
Alice Fyshill, resigned I 4 I 4
Joan Bunbury, ${ }^{15}$ 1 4 I 4
Eleanor Squerell, 1452
Alice Somerset, ${ }^{18}$ I $452-60$
Petronilla Pigeon, ${ }^{17}$ I 460
Anne Thomas, ${ }^{18}$ I 497
Elizabeth Martyn, about $153^{19}$

In addition to the above names we have in the obituary of the priory the following who are entered as having been prioresses, but without date or order: Sabina, Isilia, Clarissa, Julia, Cecily, Hawisia and Rose.

6 Letters and Papers, Hen. VIII. ix. 423, 424.

7 Aug. Off., Misc. Books, cccc. 23.

8 Letiers and Papers, Hen. VIII. xi. 385 (3).

9 Pat. 30 Hen. VIII. pt. I, m. 16.

10 Letters and Papers, Hen. VIII. xiii. 1292.

11 Winton. Epis. Reg., Pontoise, f. 23.

12 Ibid. Stratford, f. I 15.

13 Ibid. Orlton, ii. f. 46 b.

14 Ibid. Edingdon, i. f. 54 b.

16 Ibid. Beaufort, f. 50.

16 Ibid. Waynflete, f. $58 \mathrm{~b}$.

17 Ibid. f. 102b.

18 Tanner's Notitia, xlii.

19 Letters and Papers, Hen. VIII. xi. 385 (3). 


\section{A HISTORY OF HAMPSHIRE}

\section{HOUSES OF AUSTIN CANONS}

\section{PRIORY OF CHRISTCHURCH, TWYNEHAM}

The secular canons of the Church of the Holy Trinity, Twyneham, had large holdings in Hampshire at the time of the Survey, which they held in the time of Edward the Confessor. These possessions consisted of 5 hides and a virgate in Christchurch Twyneham, a hide in the Isle of Wight, Bortel Bashley in Milton, and 8 acres in Audret in the New Forest Hundred, together with certain tithes in Christchurch, Twyneham, and Holdenhurst. ${ }^{1}$ The establishment consisted of twenty-four canons, who served their own minster as well as the churches of Herne, Burton and Preston. One of them, by name Godric, was regarded as their head ; but, like Southwell Minster throughout its history, the canons did not recognize any one as dean (of which name even, as the chronicle says, they were ignorant), but regarded Godric as the elder and father of their household. They were accustomed to divide the mass offerings and the profits from the churches under their control after an approved and equitable manner. Meanwhile, Ranulph Flambard, of infamous memory, obtained from the king a grant of the church and town, coveting the possession, as the chronicler states, because the minster was so prolific in miracles, and hence abounded in treasures and relics. He beguiled the canons into allowing him to appropriate all their incomes, saving a bare sustenance, in order to build a greater church. He pulled down the old church (primitivam ecclesiam), and nine other churches, or rather chapels, that stood within the surrounding churchyard. As Godric and ten of the other canons successively died, Ranulph suppressed their prebends, and is said to have applied the income to the church building.

With the death of the Red King came the downfall of Ranulph Flambard, who was imprisoned, and, escaping, fled the kingdom. He died on 5 September, I 128 . The minster of Twyneham, with its poor remnant of five canons, was granted to Gilbert de Dousgunels on the overthrow of Ranulph. He restored, as much as was possible, the old order of services, and continued the building of the church and canonical houses. When all was finished, Gilbert set out for Rome to obtain licence for the due refounding of the house, but died on the return journey.

$$
1 \text { V. C. H. Hants, i. } 476 .
$$

Meanwhile Henry I. gave the manor, town and church of Twyneham to his cousin, Richard de Redvers, and Richard persuaded one of his barons, Roger del Estre, to give to the canons his manor of Apse in the Isle of Wight. A clerk, Peter de Oglander, about the same time gave the manor of Ningwood, and the parishioners of Twyneham agreed to pay their tithes to the canons. Then Richard de Redvers appointed Peter de Oglander dean over the canons, and gave him the church of Twyneham and all its privileges, which Ranulph and Gilbert, the deans, had held, with all the possessions, to wit, the towns of Herne, the land of Bortel, Stanpit, Huborne, Stroud and 'Duslecompa,' and the two Prestons, Apse, Hampstead, Ningwood in the Isle of Wight, and certain churches and chapels. ${ }^{2}$

Ralph was the next dean of Twyneham, and he was succeeded by Hilary, a clerk of Henry de Blois, Bishop of Winchester.

Baldwin de Redvers, Earl of Devon, confirmed to Dean Hilary and the canons, in a long charter, all the lands and liberties, and all the privileges they enjoyed, which included the town school. They were to havc tithe of wreck happening in the de Redvers fee except great fish, a fishery for their servants, save the salmon fishing at the junction of the Avon and Stour, and were entitled to the first salmon of the season. They could also claim two cartloads of fuel daily, and a hundred cartloads of peat annually for use in the kitchen, provided they had not a sufficient supply in their own lands, and certain rights in the market at Christchurch. ${ }^{3}$

2 Cott. MS. Tib. D. vi. (printed in Dugdale's Monasticon, vi. 304). This first chartulary of the Priory of Twyneham, compiled in 13 1 2, was much injured in the fire that destroyed so much of the Cotton library, but has been cunningly restored and mounted, and is now for the most part legible. It consists of 310 large folios bound in two volumes. Some charters of a later date have been inserted, the latest being of the year 1459 . The account of the foundation of the priory, and of the canonical church which preceded it (ff. 193, 194), has been printed in Dugdale. Strange to say, the larger Dugdale (1830) states that this chartulary was lost in the Cottonian fire of 1731 . Richard de Redvers' charter is copied on f. 13 a. There are five pages of excerpts from another chartulary of this priory in Cott. MS. Claud. A. viii., but they are of no special importance.

3 Cited in Pat. 3 Hen. V. pt. 2, m. 3 (printed in Dugdale's Monasticon, vi. 304 ). 


\section{RELIGIOUS HOUSES}

In the year II50, Dean Hilary (who had been consecrated Bishop of Chichester in 1 142), in conjunction with the Bishop of Winchester, petitioned Richard de Redvers to turn the house into a priory of canons regular of St. Austin. With the sanction of Baldwin, Earl of Devon, Richard's father, this was accomplished. ${ }^{1}$ Reginald was placed at its head as the first prior, and the house was termed Christchurch. It was arranged that the secular canons should receive their prebends for life, subject to good conduct and obedience to the prior. Those in charge of churches or chapels pertaining to the priory were not to be disturbed in their benefices; on their death no hereditary claim of parents or others was to be admitted, but the canons were to provide for the due service of the churches. On their establishment as a priory further charters were granted both by Baldwin and Richard de Redvers. ${ }^{2}$

Reginald ruled as first prior of Christchurch for thirty-six years. Ralph, second prior, was elected in 1186 ; he died in 1195 , and was buried in the chapter-house.

The date of the consecration of the high altar and the altar of St. Stephen gives the time of the completion of the quire of the great church. On 29 December, I 195, the altar of the Saviour, the high altar of the canons, was dedicated by Rainald, Bishop of Ross, ${ }^{3}$ in which altar there were deposited the following relics: fragments from the place in which our Lord was born, from the manger in which $\mathrm{He}$ was placed and of $\mathrm{His}$ cradle, from the place where His feet stood, from Gethsemane and from the place of lamentation; also parts of the cloth in which the cross of Christ was wrapped, and parts of His sepulchre.

On the same day and year the same bishop dedicated the altar of St. Stephen. The relics that were placed in this altar were bones of Saints Stephen, Lawrence, Victor, Blasius, Hypolytus, and part of the hair shirt, of the sandals and the cowl of St. Thomas of Canterbury. ${ }^{4}$

It would appear, from the date of altar dedications, that the building of the nave of the great church was not finished until about 1234.

1 Cott. MS. Tib. D. vi. pt. i. f. I 3 b.

2 There are two lists of the twenty-six priors of this house given in the chartulary, pt. ii. ff. $32 \mathrm{~b}, 134 \mathrm{~b}$. Dugdale's Monasticon, vi. 302, only gives eight.

3 Rainald or Reginald, Bishop of Ross, was consecrated I 195 and died I 2 I 5 .

4 Cott. MS. Tib. D. vi. pt. ii. f. $149 \mathrm{~b}$.

II
On 12 November, 1214 , the altar of the Holy Trinity, which was the parochial altar in the nave, was dedicated by Walter, Bishop of Whitherne (1209-25). The relics placed in the altar included parts of the manger, the sepulchre and the table of our Lord. On the same day the same bishop also dedicated the altar of the apostles Peter and Paul. The relics included bones of both those saints, and of St. Bartholomew and the Holy Innocents. At the same time a third altar was dedicated to the honour of St. Augustine. The relics enclosed were some of the hair of St. Bernard, some of the bones of St. Columba, part of the girdle of St. Peter, part of the wood of St. Martial, and part of the girdle of St. Malachy. On 7 December of the same year an altar was dedicated by the same bishop to the honour of St. John Baptist. The relics placed therein were exceedingly numerous, and included parts of the vesture and robe of our Lord; part of the vestments of the blessed Virgin; bones of St. John Baptist and of Sts. Peter and Paul ; some of the blood of St. Stephen; bones of Sts. Lawrence, Blasius, Victor, Vincent, Alban, Hippolytus, Polycarp, Urban, Chrysogonus, and Holy Innocents; bones of the martyrs and confessors, Martin, Julian, Simplicius, and Joseph of Arimathea; some of the oil of St. Nicholas, monk of Rome ; and bones of the virgin saints, Agnes, Alice, Lucy, Julianna, Perpetua, Margaret, Agatha, Barbara, Beatrice and Martha. On the same day and year the same bishop dedicated a third altar to the honour of St. Edmund, placing therein some bones of Sts. Peter, Lawrence, Blasius, Hippolytus and King Oswald. ${ }^{5}$

In 1221 , Nicholas, Bishop of the Isles, ${ }^{6}$ dedicated an altar to the honour of St. Michael the Archangel. The relics were remarkably numerous, and included portions of the manger and cradle of our Lord, and of the stone upon which our Lord stood when speaking in the Temple; fragments from Gethsemane, from the Sepulchre and from Mount Sion; part of the vesture of the blessed Virgin; some of the bones of St. Columba; parts of the chasuble and altar-pall of St. Remigius, and part of the shroud in which he rested 400 years; and a piece of the sepulchre of St. Anne, the mother of the Virgin.

At the same time Bishop Nicholas dedi-

5 Ibid. vi. f. 149 b.

6 'Episcopo Insulari.' Possibly this was Nicholas of Meaux, Abbot of Furness, Bishop of the Isle of Man; see Stubbs' Registrum Sacrum Anglicanum, pp. 2 IO-1 (2nd edit.). 


\section{A HISTORY OF HAMPSHIRE}

cated another altar to the honour of St. Martin, the relics of which are not enumerated. ${ }^{1}$

Whilst Peter was prior, the house had repeatedly to entertain an expensive and doubtless unwelcome guest. King John tarried at Christchurch, sometimes for two or three days, in the years 1200, 1204,1205 , 1206 , 1208, 1210,1212 and $1215 .^{\circ}$ In January, 12 I6, the king confirmed to the canons the gift of the manor of Fleet.

By an undated grant Prior Nicholas assigned to the Abbot of Quarr land called 'la Gore' in the manor of Apse, Isle of Wight, and a yearly rent from the same manor; in return for which the abbot granted to the prior and convent of Twyneham all the lands in the manor of Fleet, which he had of the gift of Hawise de Redvers. ${ }^{3}$

The chartulary supplies minute particulars as to the receipts and expenses of the different manors pertaining to the priory, as well as customaries, about the year 1270 . An entry of that date gives particulars of the synodals paid to the bishop and procurations to the archdeacon, on behalf of different churches and chapels, by the sacrist of the priory. In synodals the payment was 4 s. $4 \frac{1}{2} d$. ; namely the church of Twyncham and the chapel of Milton, each I $5 d$, ; and the chapels of Holdenhurst, Winkton and Haytokesle, $7 \frac{1}{2} d$. each ; whilst the archdeacon received $22 s$. $4 \frac{1}{2} d$., being $75.5 \frac{1}{2} d$. from cach of the three churches of Twyneham, Hope and Milford."

The taxation of 129 I returned the annual value of the temporalities of the priory in Hampshire at $£ 35175.2 d$, whilst the rectory of Twyneham and chapels were estimated at $£ 3^{6} \quad 13$ s. $4 d$. In the diocese of Salisbury they held temporalities to the annual value of $£_{32} 3^{s} .4 d$., with $£_{4}$ from the rectory of Fleet, and a pension of $£_{1}$ from the church of Iwerneminster and the chapel of Hinton.

Prior Mawry died in I 302 ; his sepulchral slab is still to be seen in the south aisle of the quire. On 3 April the royal assent to the election of William Quyntyn as eleventh prior was signified to the bishop, and he was duly installed. The temporalities were restored on 16 April. ${ }^{5}$

In November of the same year Peter de

1 Cott. MS. Tib. D. vi. f. 150.

2 John's Itinerary, Introduction to Patent Rolls (1201-16), vol. i.

Ancient Deeds, P.R.O. i. B. 91.

4 Cott. MS. Tib. D. vi. pt. ii. f. 131.

b Pat. $30 \mathrm{Edw}$. I. mm. 27, 24. There is a full transcript of all the formalities in Pontissera's Register, f. 34 .
Donewyco, the king's clerk, was appointed to act in conjunction with the sheriffs of Sussex, Hants, Somerset, Dorset, Gloucester, Devon and Cornwall, to induce the bailiffs and good men of various towns to send ships furnished with men and necessaries to be ready to set forth by the feast of the Ascension against the Scots, at the king's wages. Twenty-five was the total of the ships demanded from these shores; Southampton was to send two, Portsmouth and Gosport one jointly, and Yarmouth and Lymington another jointly. Only three ships were to be supplied at the expense of the religious houses of this district, which embraced the whole of the west of England. The abbot of Battle was to supply one, the alien sea-coast houses of Hamble and St. Helen's another, and the prior of Christchurch a third. ${ }^{6}$ This may be taken as a proof of the importance and supposed wealth of this priory, but it was an honour with which the canons would gladly have dispensed.

In 1306 a mandate was issued by Bishop Woodlock interdicting John de Warham, sub-prior of Christchurch, from leaving the monastery, and in quire and chapter he was to be on a level with the rest of the canons. ${ }^{7}$ This bishop visited the priory in 1310 , on the Thursday after the feast of St. Benedict. ${ }^{8}$ His register contains no adverse decrees.

It was during Prior Quyntyn's term of office, viz. in 1312 , that the very elaborate chartulary of the priory's evidences and possessions was drawn up, which is in itself a proof of vigorous temporal administration.

The priory was renowned for the amount of its alms to the poor. On each of the anniversaries of Richard de Redvers the elder, of Adeliza his mother, of Hadewise his daughter, of Richard his son, and of Baldwin, William and Baldwin, Earls of Devon; of Lady Joan de Briwere, of Bishop Henry de Blois, of Roger Martel, of Adeline of Stampit, and of the priors Reginald and Nicholas, after solemn high mass for the benefactors, forty poor persons received a loaf of bread, a pottle of beer, and a dish from the kitchen. On the anniversaries of Isabel de Fortibus, Countess of Devon ; of Nicholas de Lakinges, sub-dean of Sarum; and of Walter de Herford, the mason, one hundred poor folk were similarly entertained; on the anniversary of Ralph Bardolph, sixty poor; and on the anniversary of Richard de Orestull, who gave to the priory the church and

6 Pat. 30 Edw. I. m. 2.

7 Winton. Epis. Reg., Woodlock, ff. $53 \mathrm{~b}, 56$.

8 Ibid. ff. 146, 161 . 


\section{RELIGIOUS HOUSES}

mill of Stourpayne, fourteen poor. On the anniversaries of other priors, thirty loaves and thirty gallons of beer were distributed. The total anniversary distributions to the poor for each year amounted at that time to 1,354 loaves, 467 gallons of beer and 934 dishes from the kitchen, in addition to broth (potagium).

Up to Prior Quyntyn's time four black (rye) loaves and four dishes were distributed on the anniversary of a canon; but Quyntyn further directed that on the death of a canon 100 loaves should be given to the poor, fifty on the obit and fifty on the morrow, the former from the almonry and the latter from the cellarage. It was further enjoined that for the year the deceased canon's corrody in the frater should be given to the poor.

On the anniversaries of Mabel, Countess of Devon, and of Hadewyse, daughter of Baldwin the elder, $6 s .8 d$. was divided among forty poor folk. On the anniversary of Peter, Bishop of Winchester, 5s. worth of bread was distributed at the gates; and on the anniversary of Edward of Porchester 50s. was divided among one hundred poor. ${ }^{1}$

Every day two masses were said in the priory church for benefactors, one of our Lady and one of the Holy Ghost. At the beginning of each month there was a special solemn mass for the souls of friends and benefactors. The year's total of masses, in addition to the regular mattin mass and high mass and private masses, was $1,468 .^{2}$

In the year 1316 Prior Quyntyn's health began to fail. He was an old man, for at the time of his death he had been a canon of the house for fifty-nine years. In consequence of his age and feebleness, Bishop Sandale granted him a dispensation, dated 30 November, 1316, for meat in Advent. ${ }^{3}$ He died in April, 1317, and the convent elected Walter Tydolneshide, one of the canons, in his place. ${ }^{4}$ On 14 August, 1319, Bishop Sandale cited the prior and convent to appear at his forthcoming visitation of the priory. ${ }^{5}$ As this visitation is not followed by any decrees, it may be presumed that everything was satisfactory. In October of the same year the priory was ordered by the bishop to receive Stephen de Stapelbrugge, a brother of the late order of the Temple, in his first tonsure. ${ }^{6}$

1 Cott. MS. Tib. D. vi. pt. ii. ff. 32,33 b.

2 Ibid. f. $32 \mathrm{~b}$.

3 Winton Epis. Reg., Sandale, f. 1.

4 Ibid. f. 11 b.

5 Ibid. f. $33 \mathrm{~b}$.

6 Ibid. f. $34^{\mathrm{b}}$ (vide supra, p. 27).
On 30 April, 1 324, Bishop Stratford wrote a letter of monition to the prior as to the grave excesses of John de Sandon, one of the canons, but no particulars are given. ${ }^{7}$ In the following year Canon Thomas de Montague was excommunicated for laying violent hands on John Wastour, clerk; but the bishop absolved him by commission. ${ }^{8}$ A visitation was held by the bishop in January, 1327 , and various articles of reformation were forwarded to the prior at the end of the month. These articles dealt with the attendance at the offices of all save the obedientaries, steward and cellarer; the number of masses at particular altars; the appointment by the prior of four confessors for the monastery; the observing of silence, and that talk at permitted times should be in Latin or French, and on no account in English; the custody of the doors of the cloisters, etc. ; a bell for each service; abstinence and dietary; money affairs and the steward; the custody of the seal ; prohibition of games of chess and dice; prohibition of keeping hounds save by the prior, according to custom, if he desires it ; and the prohibition of writing letters or causing them to be written, without leave from the prior or sub-prior. The bishop also enjoined on the prior to finish the new cloister with all despatch. ${ }^{9} \quad$ There was evidently much criticism in the priory of this decree that covered so wide an area of conventual discipline. News of this talk reached the bishop, and on 30 July, 1328 , he ordered an inquiry to be held as to certain canons defaming their diocesan in connection with his recent visitation and forwarded a citation asking for names. ${ }^{10}$

On 1 January, 1328 , the prior of Christchurch was ordered to appear before the king at York, on Monday after the Purification, to answer for his contempt in not obeying the king's late order to come to him to treat of certain of his affairs. ${ }^{11}$

Bishop Stratford inhibited the prior on 19 November, 1331, from celebrating in the chapel of St. Katharine on the Hill of Rishton, constructed on the soil of the priory, on account of the lack of certain formalities. Licence for celebrations in the chapel was not granted until 1 February, $1332 .{ }^{12}$

In January 1333 restitution was made by

7 Winton. Epis. Reg., Stratford, f. 46.

8 Ibid. f. 13 b.

9 Ibid. f. 179.

10 Ibid. ff. $39 \mathrm{~b}, 40$.

11 Close, I Edw. III. pt. 2, m. 2d.

18 Winton. Epis. Reg., Stratford, ff. 63b, 68. 


\section{A HISTORY OF HAMPSHIRE}

the Crown to Prior Edmund, in mortmain, of the advowson and lordship of the house of St. Leonard, Rishton, by Palmersbridge, on payment of a fine of ten marks. The original grant of the premises had been made by Elias Deverel without the licence of Edward I., and the king, in consideration of the fine made by the present prior, pardoned the trespass committed by his predecessor, Prior Quyntyn, in entering upon the premises without licence. ${ }^{1}$

On 9 February, 1 337, Bishop Orlton visited Christchurch and preached in the chapter house from the text, "Ascendente Fesu in naviculam, secuti sunt eum discipuli ejus.' 2

In the following month Prior Edmund died, and the convent, with the consent of their patron, William Montague, Earl of Salisbury, elected Richard de Bustehorne as their fourteenth prior. ${ }^{3}$ There was clearly some great irregularity about this prior, for in July, 1337 , after a rule of only a few months, the bishop ordered the sub-prior to administer the affairs of the priory, and appointed a commission to inquire into and punish the excesses noted in his late visitation. "The bishop held another visitation in July $1339 .^{5}$

During the previous voidance of the priory on the death of Prior Edmund, the Crown ordered Ralph de Middleneye, the escheator, not to meddle further in the manors of Piddleton, Little Piddle, Bernardsley, and Fleet, co. Dorset, removing the king's hands and restoring the issue. The king had granted to William Montague and his wife the castle and manor of Cliristchurch, and the escheator had considered that the custody of the priory (which was appurtenant to the castle and manor) pertained to the king during a vacancy, and had not permitted the sub-prior and convent to intermeddle with it. For this action the zcalous escheator was reprimanded. ${ }^{6}$

In March 1342 licence for alienation in mortmain was obtained on payment of the heavy fine of twenty-four marks, by William Everard and Elizabeth his wife, of a messuage, 60 acres of land, $4 \frac{1}{2}$ acres of meadow and 7 Is. $2 d$. of rents in Odeknolle, Southwelbergh and Eccinswell, to find a canon of the priory as chaplain to celebrate at the altar of St. Andrew in the parish church of Twyneham for their good estate and their

1 Pat. 7 Edw. III. pt. 1, mm. 15, I3.

2 Winton. Epis. Reg., Orlton, i. f. 50.

3 Ibid. f. 53 ; and chartulary lists.

4 Ibid. f. 56 b.

5 Ibid. f. $77 \mathrm{~b}$

6 Close, il Edw. III. pt. I, m. 17. souls after death, and for the ancestors and heirs of Elizabeth, and also a wax light to burn before the altar on the five feasts of Our Lady, from the beginning of first vespers to the end of second vespers. The chaplain was to be paid 135. 4d. beyond what other canons received, to celebrate the anniversary of William and Elizabeth as was usual for a founder of the house, to transmit the obits to every religious house of the same order in England, as was wont to be done for a deceased canon, and to distribute early on the days of the obit and anniversary, bread and beer and a dish from the kitchen to sixty poor persons of the town of Twyneham.

From a relaxation of penance enjoined on the canons of Christchurch at a recent visitation, dated 23 May, 1343, we learn that Bishop Orlton must have held another visitation shortly before this date. ${ }^{8}$

By the feudal aid of 1346 , it appears that the prior of Christchurch held a quarter of a knight's fee in Whippingham and a twelfth part in Delbourne. ${ }^{9}$

In 1359 Prior Henry made a most interesting and precise statement before the bishop's official as to the vicarage of 'Twyneham, giving the value of all the numerous payments in kind, and citing the original ordination of the vicarage and its augmentation in 1312. It was stated that the annual value of the corrody for the vicar and his servant came to fio 14s. The vicar received weekly seven loaves of convent bread, $3 \frac{1}{2} d$.; twenty-one gallons of good beer, $21 d$.; and a daily dish from the kitchen, $14 d$. His servant received fourteen loaves (one of oats and one of barley, daily), $2 \frac{1}{4} d$.; three gallons of beer, $3 \frac{1}{2} d$.; and dishes from the kitchen at $\frac{3}{4} d$. per day, $5 \frac{1}{4} d$. He received for his horse a share of a meadow worth 13s. 4d., and oats worth 5s. He was also paid a salary of $\mathrm{I} O$ s., as well as $2 d$. every Sunday and a candle worth $I d$. As to offerings, there was a population of 2,000 at Christchurch, and the confession offerings of one penny were estimated at 4 Is. $8 d$., showing that a fourth were expected to be of age for that sacrament; and the pennies at burial masses, purifications and marriages were estimated at $f_{10}$. The parish also gave the vicar ten quarters of oats valued at $16 \mathrm{~s} .8 \mathrm{~d}$. The rental value of the vicar's manse was I $3^{\text {s. }} 4$ d., and it was repaired by the priory ; so that the profits beyond the corrody were worth $\AA_{15} 13$ s. a year. The vicar had no synodal or procuration burdens, nor had he

7 Pat. 16 Edw. III. pt. I, m. 32.

8 Winton. Epis. Reg., Orlton, i. f. 120 b.

9 Feudal Aids, ii. $337,340$. 


\section{RELIGIOUS HOUSES}

to find books, vestments, wax, bread or wine. He also received ten loads of peat yearly, worth 3 s. $4 d$. ; half a quarter of barley a day, 8s. $8 d$.; a robe once a year, 20s.; in pence, 35. $4 d$. ; legacies, $6 d$. Moreover, the vicar had wine on the greater and double feasts and some other occasions, which was worth on the average $35 \mathrm{~s}$. $4 \mathrm{~d}$. The prior estimated the total value of the vicar's portion at the then large sum of $f_{2}$ I 2 s. $10 d^{1}$

Prior Henry's eyesight began to fail him in 1367 , and at last his blindness increased to such an extent that he was unable to discharge either the spiritual or temporal functions of his office. In January, I368, the bishop formally enjoined the prior to provide himself within six days with a coadjutor. He nominated Peter Travers, a canon of the house ; the bishop in sanctioning and confirming this appointment in the following June described the prior as wholly deprived, by the will of the Most High, of the sight of both eyes. ${ }^{2}$

About this time one of the brethren, John Cossham, absconded and assumed a secular garb. On expressing his penitence, he was absolved by the bishop and sent back with a letter to the prior and convent ordering his readmission with suitable discipline. The prior however refused to admit him, alleging that he had been a sower of tares among them, as well as guilty of a diversity of crimes. The bishop replied, expressing his fear of losing a soul, and formally citing the prior and convent to show cause why the penitent brother should not be readmitted. ${ }^{3}$

On 2 I March, I 360 , Wykeham addressed a long and serious remonstrance to Sir William Montague, second Earl of Salisbury, for quartering his people on the canons of Christchurch. The prior had complained to the bishop that the earl, sometimes for a year and sometimes for half a year, was in the habit of occupying all the houses of the priory with his whole household of both sexes, to the great oppression and considerable disturbance of the religious, and that his servants kept the keys of the houses in the earl's absence. He was further charged by the prior with causing the convent and their representatives to be treated unfairly at the hundred and manorial courts. Moreover, the prior had in the past kindly permitted a bridge to be made for the entry and exit of the Lady Katharine, his mother, now deceased, for her quiet and honourable use; but that now it was giving rise to scandals to religion and to the house.

1 Cott. MS. Tib. D. vi. pt. ii. ff. 228 b, 229.

2 Winton. Epis. Reg., Wykeham, iii. ff. 4 b, 102.

3 Ibid. iii. f. 5 a.
The bishop reminded the earl that he was as patron of the monastery not to subject it to a military thraldom, nor to oppress it, but rather to defend it from all attacks, and concluded with a strong appeal to his sense of religion and charity of heart to cease all this oppression and wrongdoing, and formally cited him to remove his family from the houses of the priory before the Feast of the Holy Trinity next ensuing.

In April I 386 Prior Wodenham received a mandate from Bishop Wykeham, directing him to censure severely, and to canonically punish for any further offence, those canons who disobeyed the claustral prior. ${ }^{5}$ In the following year a commission was directed by the bishop to John Sydeforde, the official, and another, to visit Christchurch amongst other priories. ${ }^{6}$

In February 1402 there was a grievous rebellion in the priory. Seven of the canons, Roger Milton, John Andrew, John Manere, Thomas Portlande, John Wymborne, Thomas Snoke, and Thomas Corf, animated by a devilish spirit, entered into a conspiracy binding themselves by an oath on the Blessed Sacrament violently to eject the prior and their other superiors, and afterwards made an apostate flight, taking with them after a sacrilegious and furtive manner, certain goods and valuables of the priory. The bishop commissioned John Elmore, the official, and Robert Keeton, to inquire into the matter and report. The commissioners held the inquiry, associating with themselves the priors of two other Austin houses, Mottisfont and St. Denis, as assessors. They found all the accused, except Snoke, guilty and deserving of deprivation, but proceeded to modify their sentences. Milton, who is described by them as the ringleader and an intolerable whisperer of slander and a scandalous mischief-maker, as well as a thief of conventual goods, was sentenced to removal to another priory in the diocese, there to undergo penance. Manere, who is called a man of great astuteness, dangerous, and given to contumely, and the counsellor of Andrew, himself an evil man, received a like sentence; they were both to be kept in solitary confinement. The others were sentenced to penance (solitary confinement) in their own priory, and were disqualified for holding any office for two years. These sentences were pronounced on 13 March, but on 22 March the bishop revised the sentences

4 Ibid. f. 8 b.

6 Ibid. f. 222.

6 Ibid. Wykeham, f. 229. 


\section{A HISTORY OF HAMPSHIRE}

on Portlande, Wymborne and Corfe, namely that they were to be strictly confined to the cloister and not suffered to speak to any secular person until Michaelmas; to receive discipline openly from the president in chapter every Friday up to the Feast of the Holy Trinity; to receive discipline humbly and devoutly from the whole convent on the first Friday after this sentence; to leave their stalls in the quire for the like time and to sit with the servants and novices; and to take their share of the menial work ; and for a whole year after this sentence to fast on Fridays, Corfe and Wimborne on bread, beer and broth, and Portlande on bread and water.

On 3 July of that year, Manere was released from solitary confinement elsewhere, and restored to Christchurch, but to undergo a sentence there like that just detailed on his three colleagues. ${ }^{1}$ Meanwhile Andrew and the other canons took proceedings against the prior for false imprisonment in the Arches Court, and on 8 February, 1403, the prior was discharged from further observance, and the matter remitted to the bishop and the archbishop. ${ }^{2}$ Previously to this, however, namely in November, 1402, the ringleader Milton, who was undergoing solitary confinement in another Austin house, convinced the bishop of his penitence, and was discharged from his obligations to Christchurch, and received the episcopal licence to enter a stricter rule of religion. ${ }^{3}$

On Wykeham's death the religious houses of Winchester diocese were visited during the vacancy of the see by John Maydenhith, dean of Chichester, acting as commissary for the Archbishop of Canterbury. Christchurch priory was visited in November, 1404 ; amongst the findings of the visitor may be noted that there were twenty-two canons instead of the statutory number of twentysix; that there were twelve sick in the farmery; and that Prior Borard had not rendered a proper balance sheet in the presence of the chapter. ${ }^{4}$

Sir Thomas West, who married Janc, daughter of Roger, Lord de la Warre, by his will dated 5 April, 1405, ordered that his body should be buried in the new chapel of Christchurch, where his mother Alice was buried. He left $£$ I 00 to the priory building fund, as well as large chantry bequests.

Thomas Talbot, the twentieth prior, died

3 Winton. Epis. Reg., Wykeham, iii. ff. 343 b, $346 a$.

${ }_{3}^{2}$ Ibid. iii. f. 353 b. ${ }^{3}$ Ibid. iii. 35 Ib.

4 Cant. Archiep. Reg., Arundel, i. 502b, 503. in August, 1420; his sepulchral slab is in the north quire aisle, while that of his predecessor, Prior Borard, is in the south quire aisle.

An inspection and confirmation of royal charters was granted by Edward IV. to the prior and convent of Christchurch on 23 June, 1461, for a fee of five marks, when charters of William II., Stephen, Henry II., John, Richard I., Edward I., Edward II. and Richard II. were produced at Westminster. ${ }^{5}$

On 12 November, 1494, the priory was visited during the vacancy of the see by Robert Sherborne of Hereford (afterwards Bishop of Chichester), as commissary for Archbishop Morton. At this visitation the prior and each of the canons were severally examined. Prior Draper deposed 'nil'; the sub-prior and fifteen other canons followed his example. It was reserved for Canon Thomas Selby to make the only complaint to the archbishop's commissary, which was duly entered in the metropolitical register, namely that the convent beer was remarkably weak (valde tenuis). ${ }^{6}$

This priory was again visited on 22 March, 1501 , by Dr. Hede, the commissary of the priory of Canterbury, in the vacancy of that see. The prior, John Draper, stated that the attendance at the night and day offices was regular; that the sub-prior of the house also held the offices of sacrist and master of the mills, of which an annual balance sheet was furnished; that the common seal was under four keys, kept respectively by himself, the sub-prior, the steward and the third prior; that none of the valuables of the house were pledged, and that there was no debt. William Eyre, sub-prior, John Warner, steward, Richard Cogin, third prior, Nicholas Bryght, precentor, John Baker, almoner, John Gravy, cellarer, John Gregory, warden of the frater, William Beaver, warden of the chapel of St. Mary, Walter Lodge, master of the works, and various other canons holding no particular office testified omnia bene. Robert Godewyn, sub-deacon, stated that the sick in the farmery did not have what was necessary for them. The prior expressed his inability to state the statutory number of the canons of Christchurch, but Thomas Wimborne, one of the canons, on the following day (for the visitation extended over two days), testified that the number was twenty-four.

Prior Draper died on 12 November, I 501, and the convent elected William Eyre, the sub-prior, in his place. It was afterwards alleged, on the accession of Henry VIII.,

5 Pat. I Edw. IV.pt. 5, mm. I I and 10.

6 Cant. Archicp. Reg., Morton, f. 91 b. 


\section{RELIGIOUS HOUSES}

that this appointment was invalid in consequence of the Royal assent not having been obtained, and an inquisition held by the abbot of Quarr and others confirmed this statement. Finally, however, in 1515 , this inquisition was declared untrue, and the Master of the Rolls was ordered to cancel it. ${ }^{1}$ Prior Eyre died on 6 December, 1520. To him succeeded, as twenty-sixth and last prior, John Draper II., who was installed on $3 \mathrm{I}$ January, $1521 .^{2}$

Sir James Worsley and the other commissioners first appointed to visit the Hampshire houses with a view to their overthrow reported in May, 1536, most favorably of Christchurch ; and Prior Draper (who was Bishop of Neapolis partibus infidelium) addressed an able letter to the king, which has been already cited, ${ }^{3}$ pointing out what a great convenience and boon the priory was to the surrounding district. But this priory was far too wealthy to be treated after any exceptional fashion. Visitors of a totally different character to the first commission, including the notorious Dr. London, paid several visits; and by threats and cajolery induced what was termed a 'surrender.'

The surrender was made on 28 November, 1539. The original letter announcing the surrender, dated at Christchurch, 2 December, and signed by Southwell, Carne, London, Poulet and Berners is extant. The commissioners say, "We founde the prior a very honest conformeable person, and the house well furnyshyd with juellys and plate whereof some be mete for the kinges majestie in use, as a litell chalys of golde, a gudly large crosse doble gylt, with the foote garnysshyd and with stone and perle; two gudly basons doble gylt. And ther be also other thinges of sylver right honest and of gudde valew as well for the churche use as for the table reserved and kept to the kinges use. In thy churche we finde a chaple and monument curiusly made of Cane (Caen) stone preparyd by the late mother of Raynolde Pole for her buriall wiche we have causyd to be defacyd and all the arms and badges clerly to be delete. The surveying of the demasnyes of this house wiche be lardge and baryn and some parte thereof $x \mathbf{x}$ myles from the monastery wiche we also do survey and mesure hath causyd usse to mak longer abode at thys place than we intendyd.' * The visitors declared the clear annual value to be

1 Letters and Papers, Hen. VIII. ii. 1236.

2 Winton. Epis. Reg., Fox, iv. ff. 3t-6.

3 Supra, pp. 57, 58.

4 Cott. MS. Cleop. E. iv. f. 324 . f5rg 3s. $6 \frac{1}{2} d$. The buildings to be sustained were, "the late prior's lodging wholly as it are sette in a quadrauntly,' with hall, buttery, pantry, kitchen and lodgings over the same. Also the gatehouse to the base court, the bakehouse, and brewhouse, with stable and barn. The buildings deemed superfluous were the church, cloister, chapter house, frater, farmery, and sub-prior's lodging, with outer cloister and gallery, with the chapel in the same cloister and all the houses thereto adjoining. The lead on the church, cloister and buildings was 38 fodders. There were seven bells, of which five were assigned to the parish. The ornaments, goods and chattels sold realized $\ell_{1} 77$ os. rod., whilst there were 26 ounces of gold plate and $1,907 \frac{1}{2}$ ounces of silver-gilt, parcel-gilt and silver plate reserved for the king. ${ }^{5}$

The 'conformable' Prior Draper was rewarded with the big pension of $£_{1} 336 \mathrm{~s} .8 d$. as well as the mansion house of Somerford Grange, where there was a prior's lodging, for life. Robert Beverey, the sub-prior, obtained a pension of $\oint_{10}$, and seventeen other canons pensions varying from $£^{6}{ }^{1} 3^{\text {s. to }} £ 36$ s. $8 d .^{6}$

There was however sufficient influence in the county and neighbourhood to save the splendid church, which Cromwell's visitors naturally deemed 'superfluous.' The quire, body, bell-tower, with seven bells, stones, timber, lead of roofing and gutters of Twyneham priory church, together with the cemetery on the north side, were granted, in 1540 , to the churchwardens and parishioners. ${ }^{7}$

At the dissolution this priory held the manor of Christchurch Twynham, with the toll of the fair and the rectory, the manors of Somerford, Aisshe and South Chewton, Hinton, Herne, Milford with the rectory, Lymington, Walhampton, Sway with the rectory, Ningewood, Shalfleet, Apse, 'Barnerdesligh,' 'Hynbury,' Puddletown, Eastington, Fleet, 'Odiknolle,' and 'Chameleygh.' Also the rectories of Buldoxley, Brockenhurst and Southdown, and land and rents in Gorley, Brookhampton, 'Gunter,' Rackhams and Radcliff, 'Swartelinghide,' Boldre, Paynshill, Northampstead, Easthampstead, Avon and Ripley. They likewise had the manor of Clopton and lands at Porton in Wiltshire, the rectory of Blandford and tithes, etc., in Hampreston, Westport, 'Penyton,' and elsewhere in Dorsetshire. ${ }^{8}$

5 Aug. Off., Misc. Books, ccccxciv. ff. 23-8.

6 Ibid. ccxlv. f. 65 .

7 Pat. 32 Hen. VIII. pt. 3, m. 43.

8 The first Minister's Account quoted in Dugdale's Monasticon, vi. 306. 


\section{A HISTORY OF HAMPSHIRE}

Deans or Heads of the House

Godric

Ranulph Flambard, to 1128

Gilbert de Dousgunels, 1128

Peter de Oglander

Ralph

Hilary, about I 140

\section{PrioRs}

Reginald, about 1150

Julian, ${ }^{1}$ I 16 I

Ralph, $1186-95$

Peter, 11 95-1225 (?)

Roger, 1225

Nicholas de Warham

Nicholas de Sturminster, 1272

John de Abingdon, 1 272-8

William de Nitheravene, 1278

Richard Maury, ${ }^{2}$ 1287-1302

William Quyntyn, ${ }^{3}$ 1302-17

Walter Tydolneshide, ${ }^{4} 13^{1} 7$

Edmund de Ramsbury, 1323-37

Richard de Bustehorne, ${ }^{5} 1337$

Robert de Legh, ${ }^{6} 1340$

William Tyrewache, ${ }^{7}$ I $345-57$

Henry Eyre, 1357-77

John Wodenham, ${ }^{8}$ I 377-97

John Borard, ${ }^{9}$ I 397

Thomas Talbot, d. 1420

John Wimborne

William Norton

John Dorchester, ${ }^{10}$ about 1450

John Draper I., 1477-150I

William Eyre, ${ }^{11}$ 1 $501-20$

John Draper II., ${ }^{12}$ I 521-39

\section{THE PRIORY OF ST. DENIS, SOUTHAMPTON}

The priory of St. Denis was founded by Henry I. about the year 1124 for Austin Canons. The foundation charter, directed to Bishop Gifford, William de Ponte Arche, the sheriff, and the burgesses of Southampton, granted to God and the church of St. Denis

1 Charter at Belvoir.

2 Winton. Epis. Reg., Pontoise, f. 4.

3 Pat. 30 Edw. I. mm. 27, 24 (There is a full transcript of all the formalities in Winton. Epis. Reg., Pontoise, f. 34).

4 Winton. Epis. Reg., Sandale, f. 1 rb.

6 Ibid. Orlton, i. f. 53 ; and chartulary lists.

6 Ibid. i. f. 95 ; and chartulary lists.

7 Ibid. Edingdon, i. f. 43 ; chartulary, f. 134 b.

8 Ibid. Wykeham, iii. f. 86 , and also chartulary.

9 Ibid. ff. 277-9. Full details of the confirmation and installation are given.

10 Ibid. Waynflete, ff. $47 \mathrm{~b}-53$, c. 1450.

11 Leters and Papers, Hen. VIII. ii. 1236.

12 Winton. Epis. Reg., Fox, iv. ff. 31-6. and the canons serving God there, for the health of his soul and of the souls of his father and mother, Maud his wife and William his son, a parcel of land between Portswood and the Itchen, having a rental of 11 s. $6 d$., together with another parcel of land near the sea to the east of the borough, having a rental of $41 s .6 d$. Girard, the canon named in this charter, was doubtless the first prior. ${ }^{13}$ King Stephen confirmed to the canons the grant of land at Baddesley made by Robert de Limesey. ${ }^{14}$

William son of Audoenus gave to Adelard the prior and the canons in 1151 the manor of Northam, which grant was confirmed by charters of Henry II., Bishop Blois and St. Thomas of Canterbury. Henry II. also granted to the canons his chapels of St. Michael, the Holy Rood, St. Lawrence and All Saints within Southampton. The possessions of the priory during this reign consisted of three ploughlands in Portswood, three groves of woodland, 100 acres of pasture, 40 acres of meadow, and 400 acres of marsh. ${ }^{15}$ On 8 September, 1189, Richard I. gave to the priory Kingsland and the wood called Portswood. The chartulary has a most interesting mention of the customary work which the men of Portswood did for the king as lord of the manor before Henry I. gave it to the canons. Subsequently the same services were rendered to the prior. ${ }^{16}$

Hadewise, Abbess of Romsey (1 $130-55$ ), granted a perpetual corrody of meat and drink, such as was served for one of their nuns, to her brothers and benefactors, the canons of St. Denis. ${ }^{17}$ Geoffrey Hose, one of the justices of Henry II., about 1180 granted to the priory a parcel of land at Edboldington and the church of Little Faccombe. ${ }^{18}$

In 1201 King John granted a confirmation charter, and in $\mathrm{I}_{20} \mathrm{O}_{4}$ Bishop Godfrey de Lucy confirmed the gift of William Aliz, which consisted of a tithe of his yearly rents and pannage at Aldington, 5s. annually from the mill of Aldington, and pannage in his woods for thirty pigs. Humphrey de Bohun, Earl of Hereford, confirmed in the time of Edward I. the gift made by his father of the church of

13 Dugdale's Monasticon, vi. 2 I 3. 14 Ibid.

15 Add. MS. 15314, f. 100. The references to the above-named and subsequent charters are taken from this MS., which is a chartulary of the priory, of 126 folios, purchased by the British Museum in 1844 . It lacks some folios both at the beginning and end. Good use was made of it in Davies' History of Southampton (1883), pp. 433 $-42$.

${ }_{18}$ Add MSS. 15314, f. $99 \mathrm{~b}$.

17 Madox's Formulate Anglicanum, p. $24 \mathrm{I}$.

18 Ibid. p. 278 , also chartulary. 


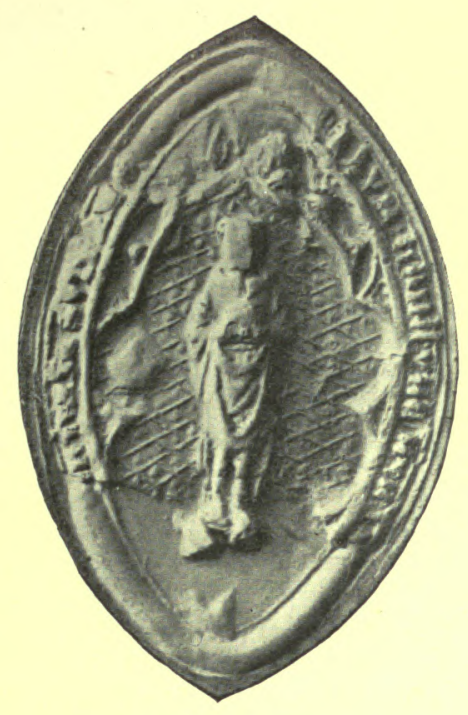

St. Denis Priory.

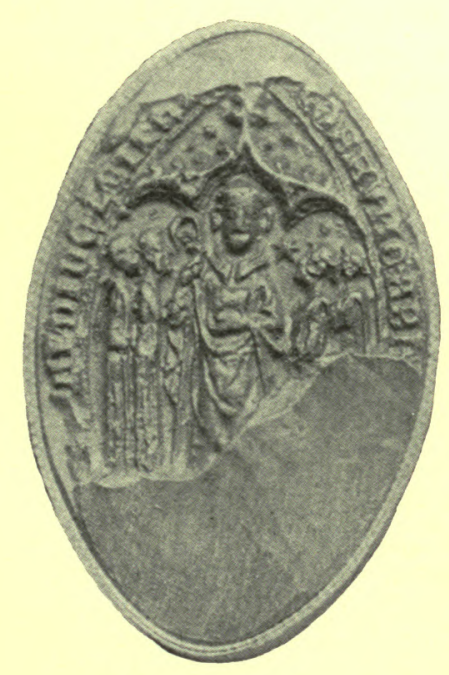

Netley Abbey.

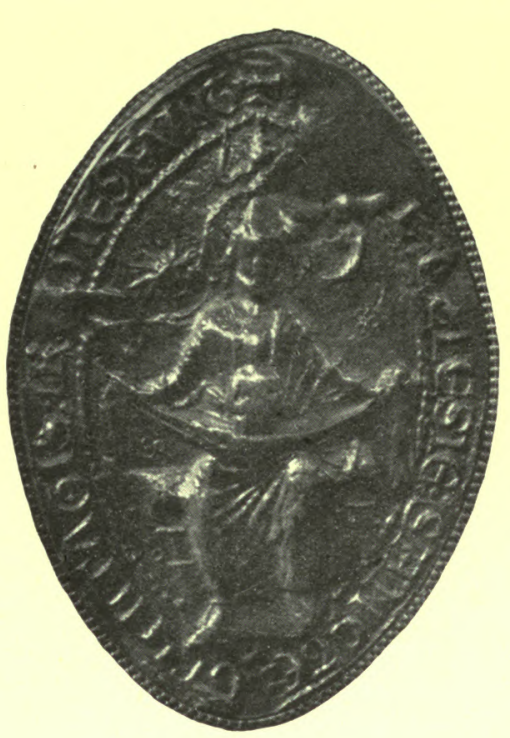

Mottisfont Priory.

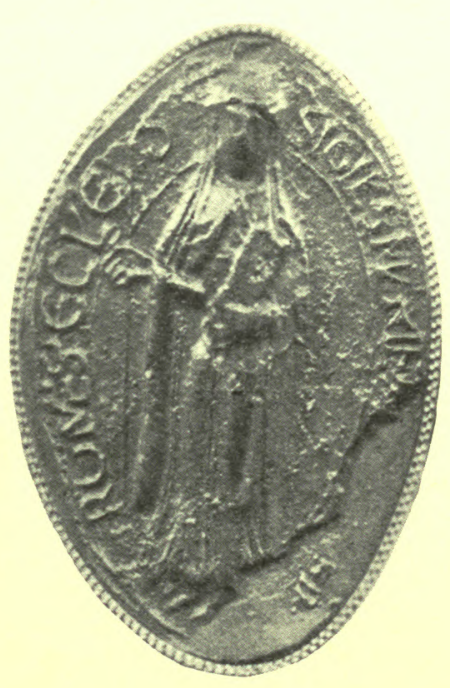

Romsey Abbey. 



\section{RELIGIOUS HOUSES}

Chilworth with all its appurtenances. William Musard, about 1290 gave $3^{\text {s. rents in the }}$ village of Eldon on condition of the canons always burning a wax taper before the Lady altar of their conventual church, where his wife Isabel was buried. There were also numerous bequests of houses, tenements and messuages in the town of Southampton during the thirteenth and fourteenth centuries. ${ }^{1}$

The taxation of 1291 gives the total annual value of the priory in Hampshire at 613 16s. 8d. In the archdeaconry of Sarum they held temporalities yielding an annual income of $f .74$ s. $8 d$. ; in the deanery of Marlborough, the rectory of Chiselbury was entered at $f_{2} \mathrm{I}^{3}$. $4 d$.; and there was a holding at Burbage worth an annual rent of IOS.

Henry de Hamelton held the office of prior for fourteen years. On 18 August, 1294, the bishop sanctioned his resignation on the grounds of infirmity of both mind and body. ${ }^{2}$ On 2 I August the king's assent to the election of Richard de Chacombe, one of the canons, was sent to the bishop, and on the morrow the bishop's mandate to the archdeacon to induct, and to the sub-prior and convent to obey their new prior were sent forth. ${ }^{3}$ At the beginning of the year 1298 Prior Richard was in poor health, and by reason of his weakness obtained leave from the Crown to nominate brother Robert de Stanham and Roger de Preselande his attorneys for two years. In 1300 the prior, by reason of his continued feebleness, was allowed to renew the nomination of the same two attorneys for another two years. ${ }^{5}$ Bishop Woodlock had to interfere with the rule of this house on several occasions, whilst the feeble Richard de Chacombe was prior. In March, 1307, the selling of corrodies without episcopal licence was forbidden; in September of the same year the bishop wrote about the internal management of the house; in April, 1300, he held a visitation of the priory and promulgated certain statutes for its better regulation, and he caused the house to be again visited by commission in May, $1309 .^{\circ}$

Prior Richard resigned at the close of the

1 A large number of these grants are among the Ancient Deeds of the Public Record Office, which have been recently calendared.

2 Winton. Epis. Reg., Pontoise, f. 14.

3 Pat. 22 Edw. I. m. 11, and Winton. Epis. Reg., Pontoise, I. 14.

1 Pat. 26 Edw. I. m. 28.

6 Ibid. 28 Edw. I. m. 5 .

- Winton. Epis. Reg., Woodlock, ff. 56, 64b, $152 \mathrm{~b}, 107 \mathrm{~b}$.

II year 1313 , and on 23 January the king notified the bishop of his assent to the election of Robert de Stonham, cellarer, and the temporalities were restored to him on 22 February. ${ }^{7}$

In 1318, Edward II. sent Walter de la Marche, who had long served him and his father, to the priory to provide him with the necessaries of life in food and clothing. ${ }^{\circ}$ A return of the same year as to the value and stock of the episcopal manors at the death of Bishop Sandale, mentions, under Bitterne, that the jury reported brother William Fymarc, a young canon of St. Denis, who had been ordained deacon in 1316 , for breaking into the lord's warren with four others, and taking young rabbits.

In January, 1328 , Bishop Stratford wrote to the priory stating that as he was about to attend the meeting of parliament at York, he could not give immediate attention to the reformation of the defects he noticed at his recent visitation, but that, God willing, he would speedily do so on his return ; meanwhile he enjoined that none be permitted to leave the house without the express sanction of the prior or sub-prior. ${ }^{10}$ John de Vienne, clerk, was sent to the priory by the king on 4 March to have such maintenance there as John de Ash, deceased, had at the request of Edward I. ; a year later John atte Lane, yeoman of the king's kitchen, was sent to fill the same vacancy, so that apparently John de Vienne ${ }^{11}$ went elsewhere.

On 9 March, 1328, the sub-prior and convent obtained licence to elect, on the resignation of Robert de Stonlıam, and their choice fell on Thomas de Newton; the royal assent was signified on 12 April. ${ }^{12}$ The bishop however declined to confirm this election for some irregularity of procedure. It was a serious matter for a small convent to have a prolonged voidance, for during that time the revenues went to the Crown; but on the petition of the priory the king granted to them on 13 May, in consideration of their poverty and debt, the custody of their temporalities, save the knights' fees, advowsons and escheats, yielding to the king for this privilege eight marks until the feast of the Assumption, and if the voidance should last longer, then at the

7 Pat. 7 Edward II. pt. 2, m. 25, 24, 21.

${ }^{8}$ Close, $12 \mathrm{Edw}$. II. m. Igd.

9 Hants Record Society, Sandale's Register, p. 244.

${ }_{10}$ Winton. Epis. Reg., Stratford, f. $34 \mathrm{~b}$.

11 Close, 2 Edw. III. m. 14d.; 3 Edw. III. m. 27 d.

12 Pat. 2 Edw. III. pt. 1, m. 16, 13. 


\section{A HISTORY OF HAMPSHIRE}

rate of $£ 10$ a year. ${ }^{1}$ On 28 June the convent gave way to the bishop, and put the selection of a prior from among their canons into his hands, with the result that William de Wareham was appointed, and received the episcopal benediction on $18 \mathrm{July}^{2}{ }^{2}$

In 1330 , the priory received letters patent granting that on the death of the royal pensioner John atte Lane, who took the place of John de Ash, deceased, they should not be called upon to admit any one in his place. $^{3}$ This grant was made on 10 May, but on 1 June the king insisted on his right to send a new pensioner clerk on the new creation of a prior, and sent to them Master William de Kirkham. ${ }^{4}$

Edward III. granted the priory of St. Denis a charter to secure to them yearly a tun of winc, between Christmas and the Annunciation, for use at masses for the souls of the faithful departed; and in February, 1334, Richard de la Pole, the king's butler in the port of Southampton, had orders to deliver to the prior a tun of red wine of the first wines brought to the port. ${ }^{5}$

Bishop Orlton visited St. Denis on 22 November, 1334, and preached in the chapter house from the text, 'Israel shall dwell safely.' ${ }^{\theta}$ In the same month the bishop confirmed to the priory the appropriations of the churches of East Tytherley, Shirley and Chilworth, and the chapels of Holy Trinity and St. Andrew, Southampton, also pensions from the following Southampton churches: St. Michael, 60s.; St. Cross, 13s. 4d.; St. Lawrence, 13 s. $4 d$.; and All Saints, 26 s. $8 d^{7}$

In 1346, Bishop Edingdon licensed for celebrations an oratory lately built over the outer gateway in honour of St. Katherine. ${ }^{8}$

A commission of three was issued by Bishop Wykeham in September, $138 \mathrm{I}$, to visit the priory of St. Denis on the Saturday after Michaelmas Day ; as no injunctions followed there could have been no serious defect. ${ }^{\theta}$ In the same year, John Stamford, one of the

1 Pat. 2 Edw. III. pt. 1, m. 5 .

2 Ibid. 2 Edw. III. p. 2, m. 29 ; Stratford's Register, ff. $108 \mathrm{~b}, 109 \mathrm{~b}, 110$. The bishop's scribe makes the mistake in two places of describing the iate prior as Peter de Stanham.

3 Pat. 4 Edw. III. pt. I, m. 24.

1 Close, 4 Edw. III. m. 3od.

5 Ibid. 8 Edw. III. m. 37. This order to the king's butler at Southampton was repeated in 1336 , 1337 and 1338. The last time that there is evidence of the delivery of this wine is in 1528 .

- Winton. Epis. Reg., Orlton, i. f. I I.

- Ibid. f. I 2 b.

8 Ibid. Edingdon, ii. f. $2 \mathrm{~b}$.

- Ibid. Wykeham, iii. f. r 90. canons, was appointed coadjutor in consequence of the infirmities of Richard de Stamford, the prior..$^{10}$

On 19 May, 1382, Richard II. inspected and confirmed in favour of John Machon of Quidhampton, and Edith his wife, three indentures for corrodies with the priory of St. Denis : (a) A grant, dated 1365 , for the life of Edith of a white loaf and a gallon of ale daily, a canon's pittance of food and drink daily from the kitchen, and six yards of coloured cloth of the suit of esquires for her robe on All Saints' Day, provided that John did not leave the convent's service. (b) A grant, dated 1376, to John Machon and Margery his daughter for their lives and the life of the longer liver, of a white loaf and a black loaf called 'sweynlof' daily, and of the reversion on the death of Edith of the livery granted to her. (c) A life grant, dated 1372, to the said John of the chamber over the middle gate of the priory, with free ingress and egress for himself and his household, a white loaf such as a canon had, and a gallon of ale daily, a canon's pittance daily from the kitchen, and a robe yearly such as one of the free servants of the prior had, or IOS. in lieu thereof, also two cartloads of firewood yearly, with power, in case of default, to distrain on their manors in Hampshire. ${ }^{11}$

The town of Southampton was a long time in recovering from the serious damage done in 1338 , when a large portion was sacked and burnt by the French. In April, I 385, protection was granted to the priory of St. Denis and its possessions, it being recited that much of its property had been burnt and destroyed by the French, putting the convent to immense cost in repairing their tenements and in fortifying the town, so that they were deeply in debt and had not the means to pay pensions and corrodies or to maintain their canons. Thomas, Earl of Nottingham, and three others were appointed to the custody of its temporalities. ${ }^{12}$ The same custodians were reappointed for two years in $1387 .^{13}$

William of Wykeham left by his will twenty marks for the repair of the church of the priory of St. Denis.

In 1465 Edward IV. inspected and confirmed to the priory a great variety of charters from Henry I. to Richard II.

This priory was visited on 15 March, 1501 , by Dr. Hede, the commissary of the priory of Canterbury, in the vacancy of the sees of both

10 Ibid. f. 194a

11 Pat. 5 Ric. II. pt. 2, m. II.

12 Ibid. 8 Ric. II. pt. 2, m. 16.

13 Ibid. 10 Ric. II. pt. 2, m. 25. 


\section{RELIGIOUS HOUSES}

Canterbury and Winchester. Robert Wode, the prior, reported that Canon John Somerset was absent through sickness. He stated that at the time of his entry into office there was a debt on the priory of a hundred marks; the common seal was kept under three keys, one in the custody of the prior, and the two others in the charge of the senior canons. Thomas Wardle testified that the house in the time of the predecessor of the present prior was burdened to the extent of $f_{60}$, of which the present prior paid $£ 30$; and that a certain silver vessel called a 'spice plate' was pledged by him to one Dorothy of Southampton, but for what sum he knew not. Brief statements as to the debts incurred by the late prior were also made by Canons William Thurley, John Scott, Walter May and Richard Lynton. ${ }^{1}$

On the death of Wode in February, 1509, Walter May, the last prior, was elected. ${ }^{2}$ Soon after this election Bishop Fox visited the priory, and subsequently sent them a decree of twenty-four articles, enjoining a stricter observance of their rule in various details; the canons were also ordered to go about two by two and never to frequent towns, nor were they to go to Portswood or Southampton to dine, except by leave, lest by secular conversation their quiet be disturbed, and they be tempted to worldly thoughts and desires. ${ }^{3}$

The Valor of 1535 gave the clear annual value of the house as $£ 80$ Irs. $6 d$. At the time of the dissolution in the following year there were nine canons in addition to Prior May. The prior obtained a pension of fil 6 s. $8 d$., and also the free chapel of the Blessed Mary with its appurtenances for life. ${ }^{4}$ The holding of this chapel (which belonged to St. Denis) was a post of some value, for it was a place of pilgrimage known as St. Mary of Graces; here in 1510 Henry VIII. made an offering in person of $6 s .8 d .^{5}$

From the first ministers' account, after the dissolution of the monastery, we find that it held various possessions in Southampton, including the manor of St. Denis, and pensions from the churches of the Holy Rood, All Saints, St. Laurence and St. Michael's, the manors of Northam, 'Leverley,' 'Berfords,' 'Bremerton' and Quidhampton, the rectories of 'Estadderley, Aulworth' and Shirley, and lands, rents, pensions, etc., in Aldington,

1 Sede Vacante Register, Christ Church Priory, Canterbury.

2 Winton. Epis. Reg., Fox, ii. ff. 108b, I 10.

3 lbid. f. 1 i 9 .

- Aug. Offic., Misc. Books ccxxxii. 17b; cccoxdii. 406.

'Davies' History of Southampton, p. 231-2.
Portswood, East Dean, Broughton, Houghton, King's Somborne, Romsey, Ablingeton, Appleshawe, Burbage, Chisbury, 'Brinknoll,' 'Shreton,' and Stapleford together with Wilton in the county of Wilts, and Sturminster and 'Lichette' in the county of Dorset. ${ }^{6}$

The site and certain possessions of the priory were granted in $153^{8}$ to Francis Dautry, namely, the house and site of the grange and lands at South Stoneham; two gardens, the tenement called 'le Bordelhouse' and three cottages in Southampton, and the manor of Lockerley in East Dean. The clear annual value of these was estimated at $£ 3215$ s. od, and the rental for the same was 65s. $6 d^{7}$.

The sole relic of this ancient priory, so closely connected with the history of the town for four centuries, is a fragment of grey ruined wall on the right bank of the Itchen, about three miles above the dock entrance.

The pointed oval early fourteenth century seal, of which an illustration is given, represents St. Denis standing on a corbel, holding a book to his breast. The background is diapered lozengy. Legend : ... Llum : COMMUNE: MONAST ... JUXTA : SUTHAM ...

Priors of St. Denis

Girard, 1124

Adelard, 1151

Nicholas, ${ }^{8}$ resigned in 1280

Henry de Hamelton, ${ }^{9}$ 1 280-94

Richard de Chacombe, ${ }^{10}$ I 294-1313

Robert de Stonham, ${ }^{11}{ }_{1} 3_{1} 4-28$

Thomas de Newton, ${ }^{12}{ }_{1328}$ (elected, but not confirmed)

William de Wareham, ${ }^{13}$ 1 $328-49$

Richard de Stamford, ${ }^{14}$ 1 349-91

John Stamford, ${ }^{15}$ 1 $391-97$

John Ryal, ${ }^{16}$ I 397-I 412

Thomas Winchester, ${ }^{17}{ }_{1} 412$

Thomas Arnewode, $1435-57$

William Norman, ${ }^{18}$ 1 457-62

${ }^{6}$ Dugdale's Monasticon, vi. 2 I 4.

7 Pat. 30 Hen. VIII. pt. 6, m. I 9.

8 Ibid. 8 Edw. I. m. 9 .

9 Ibid. mm. 8, 6 .

10 Ibid. 22 Edw. I. M. II ; and Winton. Epis.

Reg., Pontoise, f. 14.

11 Ibid. 7 Edw. II. pt. 2, mm. 25, 24, 21.

12 Ibid. 2 Edw. III. pt. 1, mm. 16, 13 .

13 Ibid. pt. 2, m. 29; Winton. Epis. Reg., Stratford, ff. $108 \mathrm{~b}, 109 \mathrm{~b}, 110$.

14 Winton. Epis. Reg., Edingdon, i. f. 43 b.

15 Ibid. Wykeham, ff. 2 10, 211.

18 Ibid. ff. 280,281 ; Add. MSS. 15314 , f. 80.

17 Ibid. Beaufort, f. 38 .

18 Ibid. Waynflete, i. f. 80 ; Add. MSS. I 5314 , f. $79 \mathrm{~b}$. 


\section{A HISTORY OF HAMPSHIRE}

Thomas Robys, ${ }^{1}{ }_{14} 62$

John Foster, ${ }^{2}$ 1 490-99

Robert Wode, ${ }^{3}$ I 499-1509

Walter May, 1 509-36

\section{THE PRIORY OF SOUTHWICK}

Henry I. in 1133 founded in the church of St. Mary, Porchester, a priory of Austin canons. The foundation charter assigned to the canons the appropriation of the church of Porchester, timber for fencing, building and fuel, as well as common pasture in the wood of Hingsdon; the manor of Candover ; a hide of land in Southwick, and a hide of land in Applestead. The charter gave the canons every possible manorial right over their lands. This charter was witnessed, amongst others, by the Bishops of Winchester, Salisbury and St. Davids, and by the Bishops elect of Durham and Ely. ${ }^{5}$

An undated deed of the early part of the thirteenth century records a grant by Luke, the prior of Southwick, to John the goldsmith, of the plot and house which Robert, the sacrist of Southwick, built in Portsmouth, in exchange for half a virgate of land in Kingston. ${ }^{6}$

In 1204 King John granted the canons of Southwick a confirmation charter of the manor of Dean, ${ }^{7}$ and in 1214 he issued general letters of protection for the monastery. ${ }^{8}$ In 1234 , Henry III. granted the priory a weekly market and an annual fair.

Pope Innocent IV., in February, I254, issued a mandate to Berard de Nimpha, a papal agent, living in England, to imprison for life and deprive of their benefices certain forgers of papal letters, and to cite to Rome (with six others) the prior of Southwick, who

1 Winton. Epis. Reg., Waynfletc, i. f. I23b ; Pat. 2 Edw. IV. pt. 2, mm. 1 8, 13.

2 Winton. Epis. Reg., Courtenay, f. II.

3 Add. MS. I 5314 , ff. 94 b, 101 .

4 Winton. Epis. Reg., Fox, ii. ff. 108b, 110.

s Cited in the Inspection and Confirmation Charter of Edward III. (Charter Roll, $27 \mathrm{Edw}$. III. m. 9, No. I9). Add MS. 32, 280 chiefly consists of the late Sir F. Madden's transcript of the greater part of a chartulary of Southwick, which was then in the possession of Mr. Thistlethwayte. It is described as a large quarto of 271 folios, and containing copies of 1,016 instruments. It was compiled in 1396 , under the direction of Prior Hursley. It appears to be strictly a chartulary, and to contain no narrative account of the house, or of its buildings and administration.

- Ancient Deeds, P.R.O., D. 100.

7 Charter Roll, 5 John, m. 5.

\& Close, I6 John, m. 19. is mentioned in the letters suspected to be false, that he may, if possible, prove his innocence. 9

Licence was granted to the prior and canons in May, 1278 , after injunction made by the sheriff, to enclose with hedges and a ditch a certain way opposite the great gate of their priory leading southward, upon condition that they made another way on their own ground of the same width. ${ }^{10}$

In 1280 the prior of Southwick was called upon to show by what right the convent held the manors of Dean and Colemore; whereupon the prior, who appeared personally, produced the charter of King John, and the jurors decided in favour of the monastery. The prior's right to gallows, a market, and assize of bread and ale in the town of Southwick was also called in question by the counsel for the Crown. The prior produced charters of Henry III. to substantiate his claims to gallows and a Wednesday market, but with regard to the assize of bread and ale he pleaded a prescriptive title. The jury found that the prior was only entitled to this assize on the market day, and that it pertained to the king on all other days of the week."1

On 10 January, 1281 , Archbishop Peckham, from information he had received, deemed it advisable to interfere in the affairs of Southwick priory and removed Prior Andrew from his post. On his removal the archbishop drew up an ordinance as to his future treatment. The ex-prior was to receive daily two loaves called miches, ${ }^{12}$ one chopyn, ${ }^{13}$ and two gallons of convent beer, and from the kitchen and for his clothing the same as were supplied to the sub-prior. He was also to have commons for one servant. An honorable chamber was to be selected for his use and that of one other canon as his companion. He was to receive half a mark in money on the feasts of Christmas and Pentecost. The ex-prior was to be regular in attendance in the quire and chapter, and on solemn days to take his meals in the frater with the rest of the convent This order was dated 12 February, $1282 .^{14}$

The energetic archbishop again visited the monastery of Southwick in 1284 and found it disturbed in spiritualities and most desolate in temporalities. He forwarded a long visitation

9 Cal. of Papal Letters, i. 303.

10 Pat. 6 Edw. I. m. 16.

11 Placita de Quo Warranto (Rec. Com.), 767, 768.

12 Miche or Micche, signifying a loaf, is used in Chaucer, etc.

13 Chopyn, probably a coarse wheaten loaf (see Halliwell's Dict. 'chobbins' and 'cob-loaf').

11 Cant. Archiep. Reg., Peckham, f. I 72 b. 


\section{RELIGIOUS HOUSES}

decree on 4 February. The arch bishop therein strongly condemns the late Prior Andrew, stating that the temporal difficulties of the priory were chiefly his fault. The ex-prior is ordered to sleep in the dorter and eat in the frater the same as the rest of the canons. If he presumed to eat elsewhere, so often as he thus offended he was to be excluded from the church and given a diet of bread and water. A door communicating from the garden, attached to the chamber where the ex-prior had been quartered, within the outer court, was ordered to be built up with stones and mortar. Andrew was also to be strictly confined to the cloister and its surrounding offices, until he could produce in chapter to the satisfaction of the archbishop or diocesan a proper balance sheet of his accounts. The lack of observance of silence by the canons both in quire and cloister was severely admonished. Any future offender was to be proclaimed in chapter and for the first offence to be deprived of the first pittance in the frater, for the second offence to have no other drink but water, and for the third to suffer both of these penalties. ${ }^{1}$

In 1289 licence was obtained for an alienation in mortmain by Richard de Burhunt to the priory of Southwick of 50 acres of land and the site of a mill in Southwick, in exchange for a mill and 15 acres of land there. ${ }^{2}$

In I 291 Pope Nicholas IV. granted a faculty to the prior and convent of Southwick to wear caps or amices on their heads in church, which were to be removed at the gospel and the elevation. ${ }^{3}$ The taxation of this date gave the annual value of the temporalities of the priory in the archdeaconry of Winchester at $£ 27$ I 7 s. $8 d$.

In the days of Bishop Woodlock there were various troubles at Southwick. In 1307 the papal nuncio in England interfered in the case of one Richard Spede, a canon of the house, relative to effusion of blood, and also granted him dispensation with regard to certain simoniacal irregularities." On 28 October, 1308 , the bishop sent a mandate to the prior of Southwick against Canon Philip de Winton on account of scandals, enjoining that he should not depart from the cloister until the bishop's visit, that he was to write no letters nor cause any to be written, that all writing materials were to be taken from him, and that

1 Cant. Archiep. Reg., Peckham, f. 232 b. Besides the entry of this decree another copy of it, on a separate piece of parchment, is stitched into the register.

2 Pat. 18 Edw. I. m. 45

3 Cal. of Papal Letters, i. 533.

-Winton. Epis. Reg., Woodlock, ff. 75 b, 76. no secular servant nor outsider was to have any communication with him, save in the presence of one of the brethren of the house. ${ }^{6}$ On the following Christmas Day, the bishop gave notice of his approaching visitation through the archdeacon. ${ }^{\circ}$ On 19 February, I 308 , the bishop communicated with the prior as to the liberating from prison of Richard Spede ; he was not to depart out of the cloister or the buildings round the cloister. After the bishop's visitation various injunctions were forwarded relative to the hours of mass, the religious habit, talking with women, dietary, and quarrelling.

On the Saturday after the feast of St. Matthew, 1310, Bishop Woodlock again visited the priory $;^{8}$ as no decree is entered in his registers it may be assumed that all was then satisfactory.

Edward II. maintained his right to send pensioners to the house of Southwick. On 21 December, 1316, John de Sheford, who had long served the king, was sent under privy seal to the prior and convent of Southwick to receive maintenance in food and clothing. ${ }^{\circ}$ Just a week later William de Spyny, another old servant of the Crown, was sent to Southwick priory in like manner. ${ }^{10}$

On 14 November, 1334, Bishop Orlton visited the priory and preached to the canons in their chapter house from 'Est puer nunc bic qui babet quinque panes bordaceos et duos pisces.' In 1336, Prior John de Gloucester petitioned the king to the effect that although his house was bound to supply sustenance for one only of the king's servants, he had lately, at the king's request, admitted Simon Bacoun into the house in the lifetime of John le Vyneour, another of the king's servants, and prayed for an indemnity. The Crown thereupon ordered an inquisition to be held whether the house had in the past been charged with one or two of the king's servants. The jurors found that the house was liable for one only, and on 2 October letters patent were sent to the prior, recording the verdict, and granting that the admission of Simon should not prejudice the house as a precedent. ${ }^{11}$

The priory was excused payment to the king of tenths or tallages in 1342 for three years, in consequence of their lands and rents in Portsmouth and Southampton, wherein

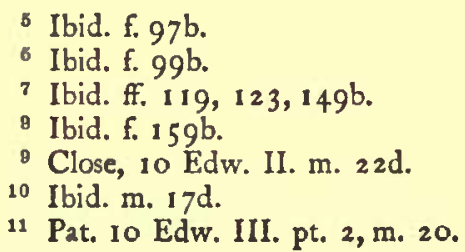

${ }^{5}$ Ibid. f. 97 b.

${ }^{8}$ Ibid. f. $159 \mathrm{~b}$

${ }^{9}$ Close, 10 Edw. II. m. $22 \mathrm{~d}$

11 Pat. 10 Edw. III. pt. 2, m. 20. 


\section{A HISTORY OF HAMPSHIRE}

were their chief means of support, having being burned and consumed by the French. ${ }^{1}$

In July, 1343, the bishop granted absolution to certain canons of this house, Richard de Cittesthorn, Henry Dene and Richard Botiller, who had been guilty of violence. ${ }^{2}$

By the return of knights' fees made in 1346 it is recorded that the prior of Southwick had two parts of a fee in Ellisfield. ${ }^{3}$

The University of Oxford, in 1366 , petitioned the pope on behalf of Thomas Cranlegh, bachelor of canon law, for a benefice to be reserved for him by the prior and convent of Southwick. The prayer was granted by Urban V., as well as a subsequent one of the same year, for an augmentation of the value of the benefice in the gift of the priory of Southwick to twenty-five marks, with cure of souls, and ten without."

At an inquisition held at Southwick before Thomas de Weston, the escheator of the county, on 4 May, 1381 , on the death of Prior Richard Bromdene, the jury declared that the prior, on the day of his death, held, in Southwick, $f 10$ of rents, 193 acres of land of the annual value of $32 s .2 d$. at $2 d$. the acre, $4 \mathrm{I}$ acres of pasture of the annual value of $35.7 d$. at $1 d$. the acre, and 22 acres of meadow, $7 s .4 d$., at $4 d$. the acre; that the woods and underwoods, the dovecote and water mill were of no value; that the perquisites of courts, with two views of frank-pledge, averaged $3^{s .} 4 d$.; customary payments averaged 6s. 8d. Particulars were also given of the various other Hampshire manors pertaining to the priory. Similar inquisitions are recorded as held for the possessions of the priory in Wilts, Sussex and Oxon. The vacancy lasted thirty days, namely from 28 April to 27 May, and the sum due to the Crown for that period was $f_{12} 7$ s. $6 d$. The entries conclude with a copy of the restoration of the temporalities by the king to Prior Nowell. ${ }^{5}$

Bishop Wykeham took much interest in this house and founded therein a chantry for the souls of John and Sibil, his parents. On 22 August, 1383, Thomas Gervays and Thomas le Warenner, two canons of Southwick, were sworn before the bishop to duly maintain this chantry. ${ }^{\circ}$ Solemn oaths for the maintenance of this chantry were also renewed by the canons in 1386 and in 1394 .

Another chantry was founded here in

1 Pat. I6 Edw. III. pt. 3, m. 2 .

2 Winton. Epis. Reg., Orlton, i. f. I 2 lb.

3 Feudal Aids, ii. 330.

- Cal. of Papal Petitions, i. 516, 521.

8 Add. MS. 32,280, f. 506.

- Winton. Epis. Reg., Wykeham, iii. f. 202 b.
March, 1385. Sir Bernard Brocas of Roche Court, near Fareham, a great friend of the bishop and his chief parker, granted to Prior Nowell and the convent of Southwick 5 acres of land and 3 acres of meadow at Southwick, together with the manors of Hoo and Havington (with certain exceptions) in free alms, on condition of finding a chaplain to say a daily mass at the altar of Sts. Katharine and Mary Magdalen, on the north side of the chancel of the priory church, for King Richard and Sir Bernard Brocas and Katharine his wife, as long as they should live, and afterwards for their souls, also for the souls of Edward III., and of Mary, Sir Bernard's deceased wife, and his brother, sisters and benefactors and all the faithful departed. The priory was also bound to other works of piety : the prior and his successors were to pay one penny to the canon who should say mass; Ioos. for celebrating the obit of Sir Bernard and his wife on the eve of the Annunciation, with Placebo and Dirige, and the tolling of the bells, and again on the eve of St. Michael the Archangel, and the feast of St. Mary Magdalen ; and 6s. 8d. for distribution amongst the brethren on each of those three days. The prior and convent bound themselves to the bishop and to Sir Bernard, in the penalty of $f_{1} \mathrm{r}$, to perform the conditions, and that they should be read aloud every year on those three days at the meeting of the chapter. $^{7}$

In the like month and year, Prior Nowell was appointed by the Crown to supervise the works which the king had ordered to be executed at Porchester Castle by Robert Bardolf, the constable thereof, and to control all the sums expended. ${ }^{8}$ In October of the same year the bishop issued his mandate to Prior Nowell forbidding the sale of corrodies. ${ }^{9}$

The bishop visited Southwick priory on 6 May, 1397 , and had no complaints to record..$^{10}$ After Bishop Wykeham's death, the priory was again visited on 25 October, 1404, by the commissary of Archbishop Arundel, but he found nothing to correct. ${ }^{11}$

In May, 1465 , inspection and confirmation was granted by Edward IV., to Philip the prior and the convent of Southwick of all their royal charters from 3 John to I 5 Richard II. ${ }^{12}$

On 7 November, 1494, the house was

7 Ibid. f. 213 ; Pat. 8 Rich. II. pt. 1, m. 36.

8 Pat. 8 Rich. II. pt. 2, m. 19.

-Winton. Epis. Reg., Wykeham, f. 220 b.

10 Ibid. iii. f. 292 a.

11 Cant. Archiep. Reg., Arundel, i. f. 502.

12 Pat. 5. Edw. IV. pt. 3, m. 21. 


\section{RELIGIOUS HOUSES}

visited, during the vacancy of the see, by Robert Shirborne, treasurer of Hereford (afterward Bishop of Chichester), as commissary of the Archbishop of Canterbury. Prior Stanbrook deposed that all the canons were men of religion and good morals and conversation, and that there were two tenements in the town of Southwick belonging to the priory which had been destroyed by the last high wind. Eleven of the canons appeared before the visitor, but had no depositions to make. ${ }^{1}$

The priory was again visited on 12 March, I 501 , by Dr. Hede, as commissary for the prior of Canterbury, during the vacancy of the see. John Lawder, the prior, stated that it had not deteriorated during his time and that the value of the rents and profits had grown to $f 300$, and was sufficient to support all their burdens; that none of the valuables of the priory were in pawn, and that the common seal was kept under the four keys of himself and the sub-prior and two other of his brethren. Thomas Kent, sub-prior and sacrist, said that silence was observed at all the appointed times and places; he differed from his superior as to the number of keys to the chest in which the common seal was kept, for he stated there were five, three of which were kept by the other canons in order of seniority. William Whyte, another canon, maintained however that there were only four keys, whilst Peter Elton, the precentor, agreed with the sub-prior that there were five. We wonder whether the commissary ordered the chest to be produced that he might count the number for himself. John Pince, the warden of the chapel of St. Mary, and Thomas Sketle, the sub-chanter, were content to report omnia bene. The matter of the keys seemed to be the only point in dispute.

Henry VIII. passed through Southwick in September, I5 IO, and made an offering of 6s. $8 d$. at Our Lady of Southwick. ${ }^{2}$

In January, I 5 I4, the Crown granted a licence to Prior Thomas Kent and the monastery of Southwick to hold a fair for three days on the feast of St. Philip and St. James and the two following days; instead of a fair for two days on the eve and day of the Assumption of the Virgin, which had been granted by Henry III., and which was said to injure the neighbouring fairs. ${ }^{3}$ Thomas Annesley, a gentleman with the Queen Consort, in November of the same year, was granted a corrody in this house, in the place of Thomas Parker, deceased. $*$ On the surrender of this corrody by Annesley it was granted in October, 1530, to Robert Wenham, master of the children in the collegiate church of Windsor. ${ }^{5}$

There are various letters of Prior Norton to Lord and Lady Lisle at the Public Record Office, but they are of no interest as regards the priory. In 1534 he seems to have retired, for in September of that year he wrote to Lady Lisle saying that the visitation of God (the plague) was very sore and extreme in the marine ports, and that many of her loving friends had died; adding that he was living peacefully at his hermitage of St. Leonard's. It concludes, 'scribbled with a comfortless heart, in ade beremitica divi Leonardi." However, in 1535, when the Valor Ecclesiasticus was taken, William Norton is named ' modo Prior.' The total clear annual value of the priory was then estimated at $\$ 257$ 4s. $4 d$.

Cromwell found a tool ready to betray the house in one of the canons, James Gunwyn. On 20 January, I 536, Gunwyn wrote as follows to Cromwell : ' $\mathrm{We}$ are bound by the will of William Wykeham to have daily five masses in our church, which have not been said for more than forty ycars. On 26 May last the Commissioners sat in our place to ascertain the yearly value of our lands, that a tenth part might be assessed according to Act of Parliament, when my master (the prior) delivered them a book of the yearly rents which was not in all points made truly. Also on 22 September last we had a visitation of our house by Dr. Layton, when we had certain injunctions given us to be observed, several of which have been neglected hitherto. I send you this information in discharge of my oath of obedience, and would have done it earlier if I could have had a trusty messenger, for if my master knew of my writing he would convey away the plate, money and jewels in his keeping.'?

A letter to Lord Lisle of 16 March, I 538 , stated that the priory was to be suppressed, and that 'Our Lady of Southwick' was taken down. On 2 I March, John Husee, a solicitor and servant of the Lisles, wrote to Lord Lisle that 'Pilgrimage saints goeth down apace as Our Lady of Southwick, the Blood of Hales, St. Saviour's and others.' On the following day the same correspondent wrote to like effect to Lady Lisle. ${ }^{8}$ Leland referred to the
1 Cant. Archiep. Reg., Morton, i. 9 Ib.

2 Letters and Papers, Hen. VIII. ii. 144 d.

3 Pat. Hen. VIII. pt. 2, m. 1.
4 Letters and Papers, Hen. VIII. i. 5552.

5 Ibid. iv. 6, 1751 . Ibid. vii. I153.

7 Ibid. x. 138 . 8 Ibid. xiii. $514,564,580$. 


\section{A HISTORY OF HAMPSHIRE}

fame of the pilgrimage to Our Lady of Southwick. ${ }^{1}$

On 7 April, 1538 , the surrender of this monastery, with all its possessions in Hants, Wilts, Oxon and elsewhere, was signed by the prior, William Norton, and twelve of the canons. The signature next to the prior's is that of James Gunwyn. ${ }^{2}$ The surrender was made to the notorious Layton. Two days later Husee wrote to his master that Southwick was suppressed, adding, "I think the most part will down.'

The lands belonging to the priory at the dissolution were: the manors of Southwick with the rectory, Newland, Hannington, Sutton Scotney, 'Moundesmer,' Preston Candover, 'Oldfishborne,' Farlington with a fishery, Denmead Molens, Clanveld and Aldbourn, Weralles in Dorchester with the rectory, Colmer, Stubbington, Hoe, West Boarhunt, Boarhunt, Harbert and Bury ; the rectories of Nutley, Swindon, Portsea, Portsmouth and ' Wanstede,' and lands, rents, etc., in Prior's Dean, the city of Winchester and Andover. ${ }^{3}$

The priory of Southwick was assigned to one John White, a mean, fawning servant of Wriothesley's. He wrote to Wriothesley five days after the surrender, saying that by the provision of God and his master's help he has attained what he had desired all his life, namely, an honest house in which to bid his guests welcome! $\mathrm{He}$ complained however that the stuff in the house was but slender, only four feather-beds and the furniture old and in manner rotten. He also was much aggrieved with Dr. Layton, for he took from hence twelve of the best of the twenty bacon hogs hanging in the roof, which the other visitors had given him. It is not surprising to learn that he was in such trouble with the monastery servants that he knew not what to do. Not one of the husbandry servants would stay with him, though they knew in what need he stood of them for the sowing of barley.

The prior received the large pension of $£^{66} \mathrm{r}^{3}{ }^{5 .} 4$. $^{\mathrm{s}}$

Among the books of this house Leland noticed during his visit Henricus Huntingdunensis, Beda de die judicii et Historia Bedee Saxonice.

1 Leland's Itinerary, iii. 98.

Dep. Keeper's Report (P.R.O.), viii. app. ii. 4 I.

3 Dugdale's Monasticon, vi. 244.

4 Letters and Papers, Hen. VIII. xiii. 748.

6 Ibid. xiv. 1355.

- Leland's Collectanea, iv. I48.
No sooner had White gained possession of the priory, than he imitated his master Wriothesley at Titchfield, and pulled down the conventual church, establishing himself and his household in the prior's lodging and adjacent parts of the buildings.

\section{PrIORS OF SOUTHWICK}

\section{Guy, ${ }^{7}$ about I I go-I 2 I 7}

Luke, early in the thirteenth century

Walkelin, died in 1234

Matthew, 1234-66

Peter de Maupol, I 266-73

Andrew de Winton, ${ }^{8}$ 1 273-81

John de Clere, ${ }^{8}$ I 28 I-9 I

Robert de Hempton or Hewton, ${ }^{10}$ I $291-$ I 315

William de Winton, ${ }^{11}$ I 3 I 5-6

Nicholas de Cheriton, ${ }^{12}$ I 3 16-34

John de Gloucester, ${ }^{13}$ I 334

Richard Bromdene, I 349-8 r

Richard Nowell, ${ }^{14}$ I 38 I-9

William Husselegh, ${ }^{15}$ I $389-98$

Thomas Courteys, ${ }^{16}$ I $398-1432$

Edward Dene, 1432-55

John Soberton, ${ }^{17}$ 1 455-63

Philip Stanbroke, ${ }^{18}{ }^{1} 463$

John Lawder, about 1494

Thomas Kent, I 5 I 4, I 521

William Norton, ${ }^{19}$ I $521-38$

\section{THE PRIORY OF BREAMORE}

The priory of St. Michael's, Breamore, was founded for Austin canons by Baldwin de Redvers and his uncle Hugh towards the end of the reign of Henry I. The confirmation charter of that king is cited in inspections and confirmations of Edward III., Henry IV. and Henry VI. The charter of Henry I. enumerates, as the original foundation, three

7 Catalogue of charters in the possession of Lord Fitzhardinge, p. 37, No. 92.

8 Pat. 2 Edw. I. m. 24.

9 Ibid. 10 Edw. I. mm. 22, 21.

${ }^{10}$ Ibid. 20 Edw. I. mm. 28, 27 ; Winton. Epis. Reg., Pontoise, f. I I.

11 Pat. 8 Edw. II. pt. 2, mm. 12, 11.

12 Ibid. 9 Edw. II. pt. 2, mm. 32, 30 ; Winton. Epis. Reg., Woodlock, f. 203 b.

${ }_{13}$ Pat. 7 Edw. III. pt. 3, m. 3 ; 8 Edw. III. pt. I, m. 42 and pt. $2, \mathrm{~m} .3 \mathrm{I}$.

14 Winton. Epis. Reg., Wykeham, i. f. II8 ;

Pat. 4 Rich. II. pt. 2, mm. 6, 2.

15 Winton. Epis. Reg., Wykeham, i. ff. 197-9.

10 Ibid. i. ff. $288,289$.

17 Ibid. Waynflete, i. f. 76.

18 Ibid. f. 128 b. ; Pat. 3 Edw. IV. pt. 2.

19 Pat. 12 Hen. VIII. pt. 2, m. 8. 


\section{RELIGIOUS HOUSES}

liides of land at Stanfit, the church of 'Sappeleja' (' Stapeley) with a virgate of land and 6 acres of meadow in that town, the church of Whitsbury with the tithes of the whole manor, and lands at Breamore. To this the king added pasturage for a hundred beasts of the canons, and pannage for a hundred pigs in the New Forest, together with as much dead wood as they required for fuel.

All grants of churches, chapels, lands, tithes, meadows, mills, fisheries, etc., that had been made to the canons of Breamore were confirmed to their prior Robert by Bishop Henry de Blois (1 I 29-71). ${ }^{1}$ The same bishop confirmed to them the appropriation of the neighbouring church of Rockburne, with the assent of the patron Manasser Bisset, and of the priest Crispin, to whom was assigned a pension of two shillings. ${ }^{2}$ Manasser Bisset was also the donor of $22 \frac{1}{2}$ acres to the priory of St. Michael. He placed in the priory an additional canon, who was to specially serve (in masses) him and his ancestors. ${ }^{3}$

In the reign of Henry II. a composition was entered into between Prior Geoffrey and the canons of Breamore and the lazar house of Bradley, whereby it was covenanted that the church of Rockburne, which was near to Breamore Priory, should pertain to the canons, but that they should pay therefrom a yearly sum of 100 s. to the house of Bradley. ${ }^{4}$

Among the ancient deeds of the Public Record Office is a grant in frankalmoin by Henry, son of Thomas son of $\mathrm{Hugh}$ de Tarente Keynes, with the consent of Joan his wife, to the canons of Breamore, of a curtilage and lands in Pimperne, Dorset, with pasture for fifty-two sheep, paying 3s. yearly to the abbess and convent of Tarente. It is an undated deed, but of the first half of the thirteenth century. ${ }^{6}$

Towards the end of the reign of Henry III. the priory church of Breamore required re-roofing, and the king granted ten oaks in the park of Melchet for the purpose, and gave orders to this effect to Stephen de Eddesworth, bailiff of Clarendon. The canons however only obtained two oaks, and in the reign of Edward I. petitioned the king on the subject in 1278 , when he was at Winchester. The king instructed Roger de Clifford, justice of the forest on this side Trent, to make inquiries, and if it was so to cause the

1 Madox's Formulare Anglicanum, 39.

2 Ibid. 292.

3 Charter at College of Arms, cited by Dugdale.

- Madox's Formulare Angliconum, 22, 368.

5 Ancient Deeds, P.R.O., B. 2917. prior and convent to have the remaining oaks. ${ }^{6}$

There are three references to this priory in the proceedings of 2uo Warranto at the beginning of the reign of Edward I. The prior had made claim to wreck of the sea in regard to his lands in Somerset. As however neither the prior nor his proctor put in an appearance for the hundred of Carhampton, the claim went by default. A like course of non-appearance, with a like result, happened with regard to the prior's claim to have gallows and assize of bread and ale at Langley. Probably both these cases were too weak to defend, and were encroachments made on the royal prerogative in the troublous times of Henry III. When the prior's claim to a virgate of land at Shirenewton (Newton Tony), with its appurtenant rights, was called in question at like proceedings for Wiltshire, Prior Thomas appeared in person, and produced evidence showing that this right had been conferred on the priory by Henry II. and confirmed by John and Henry III., so that the jury had no difficulty in returning a verdict in his favour. ${ }^{7}$

On 27 February, 1 286, licence was granted for the alienation in mortmain by the prior and convent of Breamore to Robert, Bishop of Bath and Wells, of the advowsons of the churches of Stanton Drew and Chelworth. ${ }^{8}$

At the taxation of 1291, the priory's temporalities in the archdeaconry of Winchester (Breamore, etc.) were valued at $f_{07}$ 9s. od.; in the archdeaconry of Bath (Portbury) at $\mathrm{f}^{6} \mathrm{~F}$; in the archdeaconry of Dorset (Pimperne) at $f_{3} 16 \mathrm{~s} .6 \mathrm{~d}$.; and in the archdeaconry of Sarum (Eblesborne and Corton) $£_{4} 8$ s. 6 d. There was also a pension of $£_{\mathrm{I}}$ payable to the priory from the rectory of Stanton Drew, making the total annual value \&22 I4s. Od.

In September, 1294, the prior of Breamore, in common with the great majority of the heads of the religious houses, received protection for one year in favour of the persons and goods of the priory, in consequence of the convent having contributed according to the taxation made for a tenth for the Holy Land. ${ }^{9}$ A like protection was granted in 1297 on making fine before the chancellor. ${ }^{10}$

In March, I30I, grant was made in free alms to the prior and convent of Breamore of

- Close, 6 Edw. I. m. 10.

7 Placita de Quo Warranto (Rec. Com.), 698, 776,867 .

${ }^{6}$ Pat. I 4 Edw. I. m. 20.

9 Ibid. 22 Edw. I. m. 8.

10 Ibid. 25 Edw. I. m. 15 d. 


\section{A HISTORY OF HAMPSHIRE}

the advowson of the church of Brading, Isle of Wight, in exchange for the priory remitting to the king 500 marks, wherein the king was bound to them for corn, stock and other things in diverse manors. This was done at the request of Thomas, prior of Breamore, Richard, prior of Christchurch, and Gilbert de Knovill, who were the executors of the will of Isabel de Fortibus, Countess of Albemarle, and for the good of the soul of the said countess and her ancestors whose bodies were buried in the priory church of Breamore. ${ }^{1}$

The bishop sent letters early in 1310 announcing his intention to visit Breamore, and eventually fixed on Saturday next after the feast of the Annunciation as the day. ${ }^{2}$ There are no entries of decrees after this visitation.

On II December, 1327 , Bishop Stratford forwarded to the prior and convent his visitation decree. The orders were arranged under ten heads: ( $\mathrm{I}$ ) That all the canons and obedientiaries should attend the day and night hours and the great mass, and four canons the solemnly sung mass of our Lady. (2) That the door into the nave of the church be kept firmly and securely closed; and that the door into the quire be kept open until the beginning of the mass of our Lady, and after the end of the high mass, until the beginning of vespers, and from the end of vespers until the beginning of the said mass of our Lady, day by day ; that the door from the cloister to the prior's hall be kept diligently by the cellarer; and that the sacrist or cellarer be held responsible to the chapter for the due warding of all the cloister doors. (3) That silence be observed at the customary times and places, and that no conversation be held with any women, secular or religious, save in honest places, from a reasonable cause, with the sanction of the prior or sub-prior, and in the presence of a brother canon. (4) That no canons of the house, save the obedientiaries (office holders), depart out of the monastery precincts without the express sanction of the prior or sub-prior. (5) That the chantry in the manor house of Hugh Courtenay be served by a secular priest at the charge of the priory ; and that at the times of pilgrimage or devotion of the faithful at the chapel of St. Thomas near their house, one of the older canons or a trustworthy secular be appointed to collect their oblations. (6) That the prior or sub-prior should daily visit the farmery to see that there is suitable food for the infirm and to superintend the distribution of alms to the poor ; and that the laudable custom of assign-

1 Pat. 29 Edw. I. m. 19.

2 Winton. Epis. Reg., Woodlock, ff. 146, 161. ing to the poor the goods of a deceased canon for his soul's sake be maintained; and that there be one breviator ${ }^{3}$ in the house, according to custom. (7) That the beds of the canons in the dorter be arranged so that they can be openly seen, and that all curtains or other impediments be removed and destroyed; also that the orologium ${ }^{4}$ and lavatory be repaired according to the bishop's injunction. (8) That the common seal be kept under three keys, one in the custody of the prior, another of the sub-prior, and the third of one of the canons chosen by the chapter, and that it be not used save in the chapter house and with the consent of the chapter. (9) That there be two treasurers, namely the sub-prior and one appointed by the chapter, to have all dealings with the bailiffs and other servants of the priory, and to present an annual account. (I0) That the novices should serve in the frater, and that proper novice masters should be appointed for their instruction. ${ }^{b}$

In June, I 332 , the priory received a visit from Robert de Kelleseye, one of the king's clerks, bearing a letter to the prior inviting a subsidy towards the expenses of the marriage of Eleanor, the king's sister, with Reginald, Count of Guelders. ${ }^{6}$ The canons granted the sum of 6os., and in the following year they received an acknowledgment, together with a pledge that the subsidy should not be construed into a precedent for them or their successors. ${ }^{7}$

The prior and convent seem at this period to have been good sheep farmers. In November, I 339, they received letters patent promising to pay, at the Purification and Easter, $£ 28$ 5s. 5d. for five sacks and thirty-eight cloves of the better wool at roos. the sack, taken by Robert de Popham and his fellows as collectors of the customs for Hampshire. ${ }^{8}$

3 The breviator of a religious house was one of the brethren appointed for the purpose of carrying round to adjacent religious houses of various orders the brief or document testifying to the death of any professed member, so that the due services might be offered for his soul. The brief was inscribed with the name of each house visited, together with the date. In certain houses a monk or canon was nominated by the superior to undertake this circuit as each death occurred; in other houses one of the staider brethren was appointed beforehand to undertake the duty as necessity required.

1 Possibly the clock, but more likely the sundial on the south side of the north wall of the cloister.

s Winton. Epis. Reg., Stratford, f. 178 b.

- Close, 6 Edw. III. m. I6d.

7 Pat. 7 Edw. III. pt. I, m. 12.

8 Ibid. 13 Edw. III. pt. 2, m. 37. 


\section{RELIGIOUS HOUSES}

On 13 February, 1336, Bishop Orlton visited Breamore Priory and preached in the chapter house. As there was no subsequent decree the presumption is that the bishop was satisfied. ${ }^{1}$

In 1347 the church of Brading, Isle of Wight, was transferred by Peter, prior of St. Helen, to John de Wallup, prior of Breamore, at the king's request. There are a variety of deeds relative to this release at the Public Record Office. ${ }^{2}$ The transfer had originally taken place in 1301, when permission was granted to Breamore to appropriate the church, ${ }^{3}$ and was confirmed in I 315 , but there seems to have been some dispute and uncertainty about it.

The priory, like most religious houses, had a fraternity into which laitywere received as associates. On the Saturday after the Epiphany, 1348, John, the prior, and the convent of Breamore, received John de Brommore, Gena his wife, and John their son, into their brotherhood, to partake of all benefits pertaining to their house. At the same time the priory undertook to celebrate their anniversaries with Placebo and Dirige, and a mass for them, and for John and Agnes the said John's parents, and would distribute three shillings' worth of bread to a hundred and forty-four poor people in Fordingbridge on their anniversary. ${ }^{4}$

Shortly after this there must have been a vacancy in the office of prior, for in 1356 there was a demise from Thomas, prior of Breamore, and the convent, proprietors of the church of Brading, to Walter Burgeys of the parish of Godshill in the same island, of the rectory of Brading with all its tithes. ${ }^{5}$

In January, 1376, Bishop Wykeham directed John de Wormenhale, his official, and the prior of Mottisfont, to hold a visitation at the priory of Breamore in consequence of the laxity alleged against them, but there is no record of any decree. ${ }^{6}$ During the vacancy of the see in 1404, the priory was again visited (November 3 ) by the commissary of Archbishop Arundel. ${ }^{7}$

Dr. Hede, commissary of the prior of Canterbury, in the vacancy of the see, visited this priory on 24 March, 1501 . The visita-

1 Winton. Epis. Reg., Orlton, i. f. 50.

2 Ancient Deeds, P.R.O., B. 533, 534, 535, $536,539,677$. See also Percy Stone's Arcb. Antiq. of the Isle of Wight, i. 19, 98, 99.

3 Pat. 8 Edw. II. pt. 2, m. 9.

4 Ancient Deeds, P.R.O., B. 3593.

5 Ibid. B. 675 .

5 Winton. Epis. Reg., Wykeham, iii. f. I $36 \mathrm{~b}$.

7 Cant. Archiep. Reg., Arundel, i. f. 503. tion was held in the Lady chapel, for the chapter house was in a state of decay. John Chandler, the prior, stated that when he entered on his office the house was indebted to the extent of $f 600$; that he had paid this off and had redeemed valuables and corrodies that had been pledged by his predecessor for about $£ 200$; that the rents had increased to the annual amount of 206 Is. 10d.; that divers valuables of the house were still in pledge ; that by their old statute there were three canons and five brothers in priests' orders; that the burdens of the house, although the debts had been paid, amounted this year to $f_{102}$ I0s. 9d. Richard London, the sub-prior, stated that when the present prior succeeded, the house was burdened to the extent of $£, 700$ or thereabouts, of which the present prior had paid about $£ 100$. Canon William Ladoke stated that the prior had redeemed two silver cups that had been pledged by his predecessor to Sir Hugh Conwey and paid to him for them $£_{22}$. Canons John Wynne, William Tary and Richard More also testified to the burdens of the house, and their reduction by the present prior, but their statements are somewhat contradictory. ${ }^{8}$

When Henry VIII. exacted a 'loan' in I 522 from the spirituality for the king's personal expenses in France for the recovery of the Crown, the priory of Breamore paid the very large sum of $£ 666^{1} 3^{s .} 4 d^{9}$

In I 529 Prior William was summoned to Convocation, and attended personally. ${ }^{10}$

The last prior of the house seems to have been quite ready to pay court to the civil power as the storms gathered round the religious houses. He wrote on 8 August, 1533, to Cromwell, proffering his services, and offering, if there was anything in their poor house to pleasure Cromwell, to put it at his service. ${ }^{11}$ In June, 1535, Prior Finch wrote again to Cromwell in a similar strain, proffering his service and that of his house, and desiring a continuance of Cromwell's favour. ${ }^{12}$

In that year the Valor Ecclesiasticus was taken, when the annual value of the priory was returned at $£ 2005$ 5. I $\frac{1}{2} d$., together with two pounds of pepper. Alms and other obligatory outgoings amounted to $f_{45}$ I Is., so that the clear annual value, in addition to the pepper, was only $\ell_{1} 54$ 14s. $1 \frac{1}{2} d$. This brought the house well within the limit of

8 Sede Vacante Register, Canterbury Priory.

9 Letters and Papers, Hen. VIII. iii. 2483.

10 Ibid. iv. 6047.

11 Ibid. vi. 957.

12 Ibid. viii. 840. 


\section{A HISTORY OF HAMPSHIRE}

the first series of dissolutions, and it was surrendered on 10 July, $153^{6 .}{ }^{1}$

The site of the priory was granted in November of that year to Henry, Marquis of Exeter, and Gertrude his wife, together with all its possessions. The grant particularizes these as the manors of 'Bulborne Haywode' (Breamore), 'Robstead' and Langley, Hants ; Wilton, and 'Corton with Ostum St. George,' Wilts; Canford and Pimperne, Dorset; Portbury, Somerset ; and Northcote, Devon; with all lands in those places and in 'Bernes,' South Charford, Hardley, Creech, Fordingbridge, Gorley and Ibsley, Hants ; Ebbesborne and 'Gysardston,' Wilts ; and the rectories and chapels of Breamore, Rockburne, Whitsbury and Brading, Hants. The marquis was also to receive as much fuel as he required out of the New Forest, and all other rights that had been enjoyed by the prior. A rental was reserved to the Crown of $£ 16$ I5s. $7 d^{2}$

The sycophancy of Prior Finch met with its reward. On 26 June, 1536 , he was assigned a pension of $£, 18,{ }^{3}$ and in March, I $53^{8}$, he was appointed to the suffragan bishopric of Taunton. ${ }^{4}$ He was consecrated in the Lady Chapel, Blackfriars, by the Bishops of Rochester, Colchester and St. Asaph on 7 April ; ${ }^{5}$ he died in 1559.

\section{Priors of Breamore}

Robert, ${ }^{8}$ about 1129

Geoffrey, ${ }^{7}$ time of Hen. II.

S., ${ }^{8}$ about I 244

Thomas de Pimperne, ${ }^{9}$ 1 286, 1301

Thomas Dounton, ${ }^{10}$ elected ${ }_{13} 308$

William le Eyr, resigned 1327

James de Wyttenham, $1327,{ }^{11} 1339^{12}$ (?)

John de Wallup, $1342{ }^{13} 1352^{14}$

Thomas, about $1356^{15}$

John de Tyneham alias Sussebury, ${ }^{16}$ I $361-90$

1 Aug. Off., Misc. Books, cccc. 23.

2 Pat. 28 Hen. VIII. pt. I, m. 8.

3 Aug. Misc. Books, ccxxxii. f. 17.

- Rymer's Fadera, xiv. 587 .

5 Cant. Archiep. Reg., Cranmer, f. 214.

- Madox's Formulare Anglicanum, 39.

7 Ibid. 22, 368 .

8 Ibid. 84 .

9 Ancient Deeds, P.R.O.

10 Winton. Epis. Reg., Woodlock, f. 86 b.

11 Ibid. Stratford, f. 10.

12 Madox's Formulare Anglicanum, 92.

13 Winton. Epis. Reg., Orlton, i. f. 112.

14 Ancient Deeds, P.R.O., B. 611.

15 Ibid. B. 675.

16 Winton. Epis. Reg., Edingdon, ii. f. 107.
John Berard, I390-I 431

John London, ${ }^{17}$ I 431

Thomas Hunspill, ${ }^{18}$ I 435-67

Robert Stokys, ${ }^{19}$ I $467-90$

John Herries, ${ }^{20}$ I 490

John Chandler, elected before 150x, resigned in 1508

William Hollyngborne, ${ }^{21}$ 1508-about I 5 II

William Finch, $151 x-36$

\section{r4. THE PRIORY OF MOTTIS- FONT}

This priory of Austin canons, dedicated to the Holy Trinity, was founded by William Briwere about $1200 .^{22}$ His chief gifts were lands at Mottisfont, Hale and Eldon, and the churches of Longstock and Ashley. To these his brother John Briwere added the church of Little Somborne. King John granted a confirmation charter of these gifts, dated 23 October, I 204, and added thereto, as his own donation to the canons, the church of Eling. On the death of his wife Beatrice, the founder gave to the priory all his lands in the adjacent parish of Michelmarsh, and five marks in rent from Barbache, to keep her anniversary. William Briwere, the son of the founder, gave them the church of King's Somborne, and the mill and 40 acres of land at Stockbridge, together with rents at Mottisfont and elsewhere, to keep his anniversary. Margery de la Ferte, daughter of the founder, confirmed all these gifts, and also materially increased the priory's endowment, particularly with lands at Trusbury and Compton, and with lands and buildings at Winchester, both within and without the walls. ${ }^{23}$

The obituary of the Mottisfont canons shows that they observed the anniversary of Peter de Rivallis, a brother of the founder, on 23 November. It is stated that he was known as 'The holy man in the wall,' and that many miracles were worked through him. He gave a large sum of money and many jewels to purchase a rent-charge to secure the keeping of his anniversary. Queen Eleanor also conferred many possessions and goods on the priory to secure the perpetual keeping of

${ }_{17}$ Cole MS. and Ancient Deeds, P.R.O., B. 3262.

${ }_{18}$ Ancient Deeds, P.R.O., B. 95, 844 .

19 Winton. Epis. Reg., Waynflete, i. f. 15 b.

${ }^{20}$ Ibid. Courtney, f. 8 b.

${ }^{21}$ Ibid. Fox, ii. f. 99.

22 Briwere was a judge of some eminence; see Dict. Nat. Biog., vi. 297.

${ }^{23}$ Dugdale's Monasticon, vi. 481. 


\section{RELIGIOUS HOUSES}

her obit, which was observed by all the priests of the house. The queen provided that seven poor widows should daily receive refreshment in the house in her memory, and that five poor persons should sit at table on her anniversary.

Laurence de Colshull gave a large sum of money, many jewels, and much furniture, to provide for the daily saying by a canon of a mass for him and others, with special collects. John Forstbury and Joan his wife gave all their lands and tenements at Westley for their anniversary. It was provided in their behalf that each week two canons should celebrate mass at the altars of the Holy Trinity and the Blessed Virgin respectively. And Agnes Betune, widow, gave all her lands and tenements at Ogden and Bentley, for keeping her anniversary on the first Thursday in Lent.'

An indult was granted in 1241 by Pope Gregory IX. to the prior and brethren of Mottisfont to hold to their uses, on its voidance, the church of Somborne, of their patronage, reserving a vicar's portion. ${ }^{2}$

The prior of Mottisfont at this time seems to have been respected at the papal court, as he was twice ordered to see to the enforcement of the papal authority in this country. ${ }^{3}$

Roger de Clifford, justice of the forest on this side Trent, was ordered, in January, 1275, to cause the prior and convent of Mottisfont to have four oaks fit for timber in the wood of Melchet, which is within the forest of Clarendon, for the work then in progress at their church."

Archbishop Peckham visited this priory on 26 January, 1284, and issued long injunctions to be observed by the canons. Amongst them was one permitting the employment of women over sixty years of age for certain domestic work. Mention is also made of the duties of prior, sub-prior, sacrist, chanter, cellarer and treasurer. ${ }^{\circ}$

The taxation of I29I gave the annual value of the temporalities of the priory in the archdeaconry of Winchester at $£ 27$ ros. The church of Mottisfont was at the same time declared of the annual value of $£ 30$. The priory was also possessed of lands at Kidwelly, in the distant archdeaconry of Cardigan, which were worth 20s. per annum.

1 The foundation charters and this obituary were all cited in Dugdale's Monasticon, ii. 322-5, ex Cod. MS. in Scacc. penes Remem. Regis; but there is no such chartulary now at the Record Office.

2 Cal. of Papal Letters, i. 193.

3 Ibid. i. 195, 202.

- Close, 3 Edw. I. m. 23.

- Cant. Archiep. Reg., Peckham, ff. $290 b, 230$.
In the same year, licence was granted for the alienation in mortmain, by John de Rivers the younger, to the prior and convent of Mottisfont, of an acre of land in Roswyk in Pengareg and the advowson of the church of Mullion, Kerrier (Cornwall). ${ }^{6}$ This was confirmed by Edward II., together with leave to appropriate the church. ${ }^{7}$

Licence from the Crown to clect in vacancies of religious houses was only required when the Crown was patron. Owing to the minority of the heir of Briwere the founder, the king claimed the ad interim patronage of this house in $129 \mathrm{I}$. The patronage is stated to have belonged to Maud daughter and heir of Patrick de Cadurcy the king's ward, in $1294,{ }^{8}$ but soon afterwards it devolved wholly on the Crown, by whom it was conferred on the Earl of Lancaster.

From the episcopal registers we find that Thomas de Barton was instituted as prior on 21 February, 1294, and on the same day the the bishop's mandate was issued to the archdeacon for his induction. The various proceedings of the election are set forth with much detail; the election was by way of compromise, and eleven canons (the full number) recorded their votes for him. ${ }^{9}$

In 1310 Bishop Woodlock issued his mandate for visiting this priory, appointing the Saturday after the feast of St. Matthew as the day. No decree was issued as the result of this visitation, so it may be concluded that the bishop was satisfied.

In April, I316, licence was obtained for the alienation in mortmain by William Russell, to the prior and convent of Mottisfont of a messuage, 80 acres of land, 4 acres of meadow, and 5s. $2 d$. of rents in Barton Stacey. ${ }^{10}$

The documents relative to the election of John de Dernford as prior in 1330 are set forth at length in the episcopal registry, and include the consent of Henry, Earl of Lancaster, as the patron. ${ }^{11}$ In I33I, the bishop issued a mandate to the new prior to report as to the condition of the priory and to produce a statement of accounts. ${ }^{12}$ On 26 November, 1334, Bishop Orlton visited Mottisfont, and preached to the canons in their chapter-house from the text 'Omnia boneste et cum ordine fiant.' ${ }^{12}$

- Pat. 19 Edw. I. m. 16.

7 Ibid. 3 Edw. II. m. 26.

8 Ibid. 22 Edw. I. m. 24

8 Winton. Epis. Reg., Pontoise, ff. 13, 92, 93.

10 Pat. 9 Edw. II. pt. 2, m. 25.

11 Winton. Epis. Reg., Stratford, ff. 12 Ib, 122

12 Ibid. f. $56 \mathrm{~b}$.

13 Ibid, Orlton, i. f. 11. 


\section{A HISTORY OF HAMPSHIRE}

In 1349 Robert de Bromore, sub-prior, was elected prior, Prior Dernford having probably died of the plague, and in the following year Richard de Caneford was elected prior, on the death of Prior Bromore, probably from a like cause. In I 352 Ralph de Thorleston, a canon of Leicester, was made superior, as there was apparently no suitable priest left of their own house. ${ }^{1}$

In December, I 353, Henry of Lancaster petitioned the pope for an indulgence to those who visited the Augustinian priory of Mottisfont on Trinity Sunday, or who contributed to it. The petition stated that the duke's mother Maud was buried in the priory church. ${ }^{2}$ A special effort was apparently being made to revive the house after the shock of the Black Death, which must have greatly reduced the income of the priory as well as thinned its numbers. Pope Innocent VI. lent a ready ear to this influential petition, and in the same month that the application was received, granted the relaxation of a year and forty days' penance to penitents who gave helping hands to the priory of Mottisfont, the indulgence to hold good for five years. At the same time a relaxation of a year and forty days of enjoined penance was granted to penitents who visited this church on the feasts of the Holy Trinity, the Assumption and Nativity of the Blessed Virgin, and those of the Holy Cross and St. Michael. ${ }^{3}$

In July, I 354, Pope Innocent VI. granted a dispensation to Walter de Bocland, canon of Mottisfont, being the illegitimate son of a married woman, to hold any dignity or office in the Austin order, short of the abbatial. ${ }^{4}$

During the vacancy of the see in 1404 , this priory was visited by the commissioners of Archbishop Arundel on 8 November, when all was found to be satisfactory. ${ }^{5}$

In 1456 a commission appointed by Bishop Waynflete declared the priory vacant, because William Marlynburgh, the prior elect, did not exhibit sufficient title. Whereupon William Westkarre was elected. ${ }^{6}$

Henry VII., patron of Mottisfont (through the duchy of Lancaster), finding the priory seriously reduced in numbers and income, and being desirous to change it into a collegiate church for a dean and prebendaries, applied to the pope for a bull for its suppression. In response to this application Alexander VI.

\footnotetext{
1 Winton. Epis. Reg., Edingdon, i. ff. $48 \mathrm{~b}, 69 \mathrm{~b}$,

${ }^{2}$ Cal. of Papal Petitions, i. 253.

${ }^{3}$ Ibid. iii. $514 . \quad$ Ibid. iii. 537.

${ }^{5}$ Cant. Archiep. Reg., Arundel, i. f. 504.

- Winton. Epis. Reg., Waynflete, i. f. 13.
} $74 \mathrm{~b}$. in 1494 issued a bull for the suppression of the priory, in favour of a college. It is stated that the priory, instead of supporting eleven canons, according to the original foundation, was then only able with difficulty to maintain three, and that the annual income did not exceed $f_{1} 20 .^{7}$ Henry however changed his mind and resolved to annex the priory to his Windsor foundation; but, changing yet again, he determined to assign it to his great chapel at Westminster Abbey. Alexander VI. complacently issued another bull, in the year 1500 , authorizing the suppression of Mottisfont priory, together with Luffield priory in Lincoln diocese for the last of these purposes. ${ }^{8}$ But, strange to say, neither Henry VII. nor the abbot of Westminster availed themselves of this papal sanction to seize the priory, and it continued until the dissolution of the lesser monasteries.

The priory was visited by the commissary of the prior of Canterbury, during the vacancy of the sees of both Canterbury and Winchester, on 30 March, I50I. John Edmunds, the prior, stated that the annual rents had increased to two hundred marks; that when he entered on his office the house was burdened to the extent of $£ 40$; but that at the present time it was not in debt, save with respect to 300 marks, duc to the king within a certain time for excusing the appropriation of the house to the monastry of Westminster. Richard Wraxton, subprior, John Colmer, sacristan, Thomas Edmunds, the cellarer, and Robert Marleys, another of the canons, were also examined.

The report of the first commission to visit Hampshire houses, made by Sir James Worsley and his brother commissioners on 30 May, 1536, stated that the priory of Mottisfont had been 'dissolved and possession thereof delivered to Sir William Sandes of the most honourable Order of the Garter, Lord Chamberleyne, according to the King's pleasure.' It was stated to be of the annual value of $\mathrm{EI}_{4} \mathrm{r}$ 12s. $6 \mathrm{~d}$.; that there were ten canons, eight of them priests and two novices; that one of them had been committed to the monastery of Christ Church, Twyneham, eight given 'letters of capacity,' and 40s. ' of the kinge's reward,' and one novice sent to his friends with 30 . ; that there were twentynine other inmates who had been discharged; that the church and mansion were in convenient repair, but the outhouses in ruin and decay; that the lead and bells were worth E155, which had been delivered to the Lord

7 Rymer's Fadera, xii. 562.

8 Ibid. 738. 


\section{RELIGIOUS HOUSES}

Chamberlain; that the plate and jewels worth $\AA_{42} 3^{\text {s. }} 8 d$. and ornaments worth $63^{8}$ I 5s. $4 d$. were reserved for the king; that corn, stock and stores worth $f_{67}$ i is. $4 d$. had been delivered to the chamberlain; that the house owed $\mathrm{EIO}_{3} 2 \mathrm{2s}$; was owed $\ell^{2} \mathrm{I}^{\text {s. }} 4 d$.; and that the woods, etc., were worth $£ 106$ I 3 s. $4 d^{1}$

In $1529 \mathrm{John}$, prior of Mottisfont, was duly summoned, with the heads of the other Hampshire religious houses, to the Convocation of the province of Canterbury. ${ }^{2}$

The Valor Ecclesiasticus of 1535 names William Christchurch as prior, and gives the clear annual value as $£_{1} 243^{\text {s. }} 5^{\frac{1}{2}} d$.

On 26 March, I 536, Harry Huttoft, a Southampton customs official, when writing to Cromwell about charges to be levied on goods at the port, stated that there was much talk there about the suppression of religious houses, adding, with the assurance that was characteristic of most of Cromwell's friends and tools, "Let me be a suitor for one, viz. the house of Mottisfont, where there is a good friend of mine with as good a master and convent as is in the country. If none are to be reserved, but all must pass one way, please to let me have it towards my poor living.' 3 The house was actually surrendered on 22 May following."

Huttoft did not however succeed in getting his longed-for share of the monastic plunder, for Mottisfont fell to the lot of a much more influential person, William, Lord Sandys, K.G., the king's chamberlain. The grant, dated I 4 July, I 536, conferred on him and Lady Margery, his wife, the site and the whole of the possessions and advowsons of the late priory. ${ }^{5}$

The prior, William Shepperd, alias Christchurch, who seems to have been entirely complacent, obtained the large pension of f20. ${ }^{6}$

Lord Sandys speedily set about the work of altering the priory for his own convenience. A letter from Mottisfont of August, $153^{8}$, says that the lord chamberlain had been keeping house there since the beginning of May and intended to continue there till Allhallow-tide to oversee his works. The writer expressed the opinion that he was

\footnotetext{
1 Aug. Off., Certif. of Colleges and Chantries,

${ }^{2}$ Letters and Papers, Hen. VIII. iv. 6047.

3 Ibid. X. 557.

- Aug. Off., Misc. Books, cccc. 23.

- Pat. Hen. VIII. pt. i. m. 9.

- Aug. Off., Misc. Books, 232 , f. 17.
} 112. making a goodly place of the priory and intended to lie there most of his life. ${ }^{7}$

What had become of the seven poor widows of Queen Eleanor's foundation, who were to receive daily food at the house of Mottisfont, is not stated.

The pointed oval seal of thirteenth century date (see illustration) affords an unusual method of representing the Holy Trinity. The Father, with nimbus, seated holds a half-length figure of the Son in a cloth extended on His knees; overhead is the Holy Ghost in the form of a dove. On the field is a sun and moon and several groups of three annulets or stars. Legend: +..... I Ecclesie : Sancte : Trinitatis : de : Motesfunt.

\section{PrIORS OF MOTTISFONT}

Henry de Wynton, d. 1294

Thomas de Barton, ${ }^{8}$ I 294

William, ${ }^{9}$ I 300

John de Dwineford, ${ }^{10}$ 1 $317-23$

Walter de Wallup, ${ }^{11}$ I 323

Benedict de Wallup, resigned 1330

John de Dernford, ${ }^{12}$ elected 1330

Robert de Bromore, 1349-50

Richard de Caneford, 1350

Ralph de Thorleston, ${ }^{13} 1352$

John Netherhavene, ${ }^{14}$ I 356

William Marlynburgh, prior elect, 1456

William Westkarre, ${ }^{15} 1456$

John Edmunds, 1 501-29

William Christchurch, alias Shepperd, 1 535-6

\section{THE PRIORY OF SELBORNE}

The priory of St. Mary, Selborne, was founded in 1233 by Bishop Peter des Roches for Austin canons. The original foundation charter of the bishop, with the confirmation of the king, are still extant, together with a vast store of other evidences pertaining to the priory, among the muniments of Magdalen College, Oxford. Selborne is one of the very few cases in which the entire store of original monastic muniments have come down to our own times. They were transferred en bloc to Magdalen College at the time of its foundation, and are faithfully preserved in the Founder's Tower. They were calendared some

7 Letters and Papers, Hen. VIII. xiii. 176.

8 Pat. 2 Edw. I. mm. $24,23$.

- Dod's MS. lxxvi. 4.

10 Winton. Epis. Reg., Sandale, ff. gb, rob.

11 Cant. Archiep. Reg., Reynolds, p. 301.

12 Winton. Epis. Reg., Stratford, ff. 121 b, 122.

13 Ibid. Edingdon, i. ff. $48 \mathrm{~b}, 69 \mathrm{~b}, 74 \mathrm{~b}$.

14 Ibid. i. f. 13 Ib.

15 Ibid. Waynflete, i. f. 13. 


\section{A HISTORY OF HAMPSHIRE}

years ago by the Rev. W. Dunn Macray, M.A., F.S.A. ${ }^{1}$ In 1891 the Hants Record Society issued a printed calendar of the charters and documents relative to Selborne and its priory, the more important of them being given in extenso, which was edited, with a valuable preface, by Mr. Macray. In I 894 this society issued a second volume, edited by the same gentleman, giving a calendar of the deeds relating to lands of the priory in other places than Selborne itself. To these scholarly volumes we are indebted for all the information given in this brief notice, save where it is otherwise stated. Much, too, of the history of this priory has long been accessible in the fairly accurate account given of it by the immortal Gilbert White in his Natural History of Selborne.

By the foundation charter, dated 20 January, I 233-4, the canons acquired the manor of Selborne, with every possible privilege, the lands which the bishop had obtained by the gift of James de Acangre, James de Norton, and King Henry III., and the churches of Selborne, Basing and Basingstoke were at the same time appropriated to their use. In September, 1 235, Pope Gregory IX. confirmed the foundation and conferred certain privileges.

The first prior was John, whose name occurs in charters from 1234 to 1258 . In I 250 there is an early instance of a corrody. Roger de Cherlecole conveyed to the prior, in free alms, two messuages, a mill, and divers acres of land and meadow, on condition that the priory should provide him and his wife Isabel with the weekly allowance, during life, of i 8 canons' loaves, 28 servants' loaves, 15 gallons of the convent beer, I 4 gallons of the second beer, and $12 d$. for meat and pottage; the allowance was to be reduced by one half on the death of either of them.

In July, I 254, the vicarage of Selborne was formally ordained. The vicar was to receive the tithes of gardens and plots tilled by spade husbandry, as well as all the small tithes, oblations, legacies, and other obventions that pertained both to the mother church and to the chapels of Oakhanger and Blakemore. The vicar was to reside at the mother church, and pay annually roos. to the priory. He was to be provided with a suitable manse near the church, and also to hold the land with garden and a curtilage at Oakhanger. The priory was to be responsible for all episcopal, archidiaconal, and other dues, to keep the chancel in repair, and to make good all pre-

1 Hist. MSS. Commission, Eighth Report, pp. sent defects in books, vestments and other ornaments of the church, for which however the vicar was to be responsible in the future.

The second prior was Richard of Kent. ${ }^{2}$ He succeeded in 1261 , and ruled the convent till 1267. Prior Richard granted leave, on 24 June, 1262, to Sir Adam Gurdun and his wife Constance to construct an oratory in their manor house at Selborne and to celebrate mass therein. This Sir Adam Gurdun became the outlawed adherent of Simon de Montfort, who fought in 1266 his famous duel with Prince Edward. ${ }^{3}$

Whilst Peter de Disenhurst was prior, there were special bequests for maintaining the light of the high altar and the light of St. Katherine in the conventual church. In I 270 Henry III. granted a weekly market and yearly fair to the priory, to be held in the town of Selborne in a place called 'La Pleystowe,' to the south of the church. ${ }^{4}$ Inquests at the beginning of the reign of Edward I. show that the prior had the right to gallows, assize of bread and ale, and view of frank-pledge on the manor of Selborne, and also the right of chasing fox and hare within the king's forests. ${ }^{5}$

In 1285 Prior Richard and the convent of Selborne granted to Lady Ela Longespeye, Countess of Warwick, in return for 100 marks, that one canon should always celebrate for her at the altar of Sts. Stephen, John Baptist, and Thomas the Martyr, specifying the collects to be used. It was also provided that high mass should be celebrated for her monthly at the high altar, that her name should be written in every missal and in the martyrology, and her soul mentioned in all prayers when the soul of the founder was mentioned; and that on the news of her death the classicum with all the bells should be tolled, as for a prior, every priest-canon celebrating thirty masses and saying ten psalters, and every lay-brother one hundred and fifty 'Our Fathers' and the like number of 'Hail Marys.'

In 1290 Bishop Pontoise re-ordained the vicarage, specifying the small tithes, and adding to the former endowment 10 acres of arable land and $I$ acre called Orchard's

${ }^{2}$ Dugdale in the Monasticon gives Nich. de Cantia, which is a misprint for Rich. de Cantia.

${ }^{3}$ Mr. Macray corrects the errors into which Gilbert White fell with regard to the pedigree of Gurdun of Selborne (Charters and Documents of Selborne Priory, I. x.)

- Charter R. 54 Henry III., pt. i. m. 3 ; Macray's Selborme Charters, i. 64.

' Hund. Rolls (Rec. Com.) ii. 224. 


\section{RELIGIOUS HOUSES}

Crop which the rector used to hold. The prior and convent were also ordered, at their own expense, to erect anew sufficient buildings for the vicar, and yearly to deliver to him three quarters each of wheat, of barley, and of oats, good measure, and if three months in arrear after Michaelmas, to give double. The priory was to receive all the great tithes, that is the sheaves only, and they were to provide candlestick, books, and bread for the celebration, as well as to repair the chancel and be responsible for all dues.

The taxation roll of 129 I gives the annual value of the church of Selborne and its chapel at $£ 22$; whilst the priory is credited with an income of $£ 9 \mathrm{I} 6 s .2 d$. in the archdeaconry of Winchester under temporalities.

William de Basing, the fifth prior, was elected in $1299 .^{1}$ His name occurs in the evidences from I 299 to 1323 . Pardon was granted on I I May, I 302, to Prior William and his convent for acquiring in mortmain 32 acres of land and 5 acres of wood in Bromdene by feoffment of Walter Launcel, and I 8 acres of land there by feoffment of Richard de la Putte. ${ }^{2}$ In I 305 royal confirmation was obtained of a grant (made long before the statute of mortmain) by John de Vernuz to the priory, of 20 acres of land in East Worldham and the advowson of the church of that town. ${ }^{3}$ In January, 1307 , licence was obtained for the alienation in mortmain, by William Turner and Alice his wife to the priory of Selborne, of a messuage and 24 acres of land in La Rode. ${ }^{4}$ In the following May, William and Alice Turner granted to the priory all their land in La Rode, after the death of Alice, on condition of their granting to William and Alice for life the livery of one canon, namely one white loaf and one gallon of beer or cider of the better drink of the convent.

Bishop Orlton visited the priory on 2 I February, 1336 , and preached in the chapter house from the text ' Quicunque fecerit voluntatem Patris mei qui in coelis est.' ${ }^{\circ}$ In June, I338, the bishop wrote to the prior and convent with respect to the transference to their house, in consequence of his excesses, of William de Preston, a canon of Breamore. ${ }^{6}$

In January, I 339, Prior Walter entered into an agreement with Roger Tichborne, son of Sir John Tichborne, whercby the priory,

1 Winton. Epis. Reg., Pontoise, f. 22.

2 Pat. 30 Edw. I. m. 22.

3 Ibid. 33 Edw. I. pt. 1 m. 15 .

- Ibid. 35 Edw. I. m. 40:

b Winton. Epis. Reg., Orlton, i. f. 33.

- Ibid. 6rb. in consideration of a grant to them of Roger's whole tenement in La Rode, with its messuages, gardens, and woods, covenanted to pay six marks a year to a chaplain celebrating for the soul of Roger, and John and Amicia his parents, and their ancestors and successors, in a chantry which he had established in the chapel of his manor of Tichborne. The priory also covenanted to admit from time to time one fit person, presented by the said Roger, as a canon of their house, and to provide a chaplain to celebrate daily in their conventual church, at the altar of St. Stephen, for the souls of Roger, John and Amice. In the same year the king, when at Southampton, confirmed a considerable number of recent grants to the priory. ${ }^{7}$

On 5 June, 1352 , there was another alteration in the ordination of the vicarage of Selborne, when Prior Edmund and Vicar Adam Seyncler entered into an agreement, ratified by the diocesan, for the increase of the latter's stipend, so as to avoid a lawsuit. The recent pestilence and the consequent scarcity of the times had rendered an alteration imperative. The chief additions of a permanent character were four cartloads of wood from Priorswood, a cartload of hay from the tithe hay at Norton, and a cartload of straw at the courtyard of Gurdun, each load to be such as three horses could draw; and all the tithes, great and small, from the tenements and lands of the prior and convent which were formerly Sir Adam Gurdun's, Alice Roberd's, and of the manor of Rode, and of the moiety of oblations at the chapel of Waddon. The vicar was to find a chaplain to celebrate in the chapels of Oakhanger and Blakemere. In addition to this, there were certain special provisions made for Vicar Seyncler only for his life, such as a rent of 2s. $6 d$., and the tithes of wool and the mills, excepting those of the convent.

In 1376 that energetic diocesan William of Wykeham suspended Prior Nicholas for waste and lax administration of the spiritualities and temporalities of the convent, placing the rule of the priory's affairs in the hands of the sub-prior and another of the senior canons. On 7 August the bishop sent his mandate to the rural dean of Alton to serve the prior with three formal monitions required by the canons. ${ }^{8}$

Eventually Prior Nicholas resigned through old age and infirmity on 18 February, $1378 .^{9}$

On 29 June, 1387, Wykeham commis-

7 Pat. 12 Edw. III. pt. 3 m. 3.

8 Winton Epis. Reg., Wykeham, iii. f. 1442.

- Ibid. i. f. 90. 


\section{A HISTORY OF HAMPSHIRE}

sioned Lydeforde, his official, and John Ware to visit Selborne and other monasteries. Their report was apparently a serious one, for it resulted in a personal and searching visitation made by the bishop himself. On 27 September, Bishop Wykeham issued an exceptionally long series of injunctions, thirty-six in number, which afford evidence of laxity and neglect of rules. Mr. Macray says, but without sufficient warranting evidence: "The prior and canons, without being guilty of any gross and crying scandal, had become a society of worldly gentlemen living carelessly and very much at their ease.' The following is a summary of the injunctions, which in many respects are the same as those laid down by Wykeham for observance by the monks of St. Swithun, and may therefore be taken as a matter indicating Wykeham's ideal for a monastic house rather than necessarily directed against specific offences. The night and day hours and the customary masses were to be attended by all ; contumacious absentees to fast on Fridays on bread and water; the rules of silence to be observed; masses for founders and benefactors to be duly celebrated; the cloister not to be used by lay persons of either sex on pain of the greater excommunication; the doors of church and cloister to be duly closed; ignorant brethren who could not read Holy Scripture aright were to be duly taught ; the papal constitutions of the Austin Order were to be read twice a year in chapter, and the novices were to learn the rule of the order by heart; no allowance in money was to be made for clothes and shoes, and the old clothes were to be given to the poor; the canons and brethren were not to leave the priory without special leave, nor without a canon as a companion; hunting and the keeping of hunting dogs (saving any customary right) were strictly prohibited; two canons were to visit the manors twice a year; the full number of fourteen canons was to be kept up; the prior was to inquire twice a year into private ownership of property on the part of the canons; annual accounts were to be rendered; dilapidated buildings of the priory and granges were to be repaired; no corrodies nor pensions were to be granted without the bishop's leave; chantries were to be duly served; alms were to be duly distributed to the poor, as well as the fragments left from meals; offenders were to be duly corrected without respect of persons, officers liable to be suspended, and special penance inflicted on the prior for neglect; pittances on anniversaries were to be duly distributed ; no important business was to be transacted without the consent of the majority of the chapter; the common seal was to be kept under five keys; the statutable boots were to be worn, and not coloured shoes nor leggings, and all luxurious dress forbidden in detail; sacred vestments and vessels were to be kept clean, and the sacramental wine to be pure and good and not sour (acetosum); relics and sacred vessels were not to be pawned; diligent private reading of Holy Scripture was to be maintained; and the injunctions were to be written out, and read before the whole convent twice yearly.

Apparently Bishop Wykeham was satisfied that his visitation injunctions were being observed at Selborne; otherwise he could scarcely have issued a mandate, in March 1389 , to the prior and convent of Selborne to receive John Chertese, a canon of Newark, guilty of a grave scandal, to do penance there, and to be kept in seclusion until further orders. ${ }^{1}$

Wykeham's registers afford, however, a better and later proof of that bishop's good opinion with regard to Selborne. At the time of the appointment of Weston as prior, namely in 1377 , the generous diocesan had discharged the debts of the house, which then amounted to $£ 73$ I gs. Iod. Some years after the visitation Wykeham again saw fit to extend his generosity to this house, for in May, I 40I, Prior Weston sent a formal acknowledgment on behalf of his chapter of the bishop's great goodness and liberality in presenting them with a hundred marks; he promised (though that seems to have been no condition of the gift) that two of the canons should for ten years say masses daily for the good estate of Wykeham, or for his soul when he died. ${ }^{2}$

John Stepe, the twelfth prior, was elected about 14 I5, and his name occurs in evidences down to 1453. Among the Magdalen muniments is an interesting and full inventory of vestments and church goods delivered to Peter at Berne, sacrist, by Prior John Stepe, on 7 October, 1442, as well as one of a somewhat later date. The inventory included sixteen copes, seventeen chasubles, three white chasubles for Lent, five albes without apparel for Lent. The relics enumerated are a pax with a bone of the little finger of St. John; a gold ring of St. Hippolitus; a silver gilt ring of St. Edmund of Canterbury, and a comb and pome (calefactorium) of St. Richard of Chichester. $^{3}$

The affairs of the priory became much in-

' Winton. Epis. Reg., Wykeham, iii. f. 242 b.

${ }^{2}$ Ibid. iii. f. 334 ; Moberly's Life of Wykeham, 262-3.

3 Macray's Selborme Cbarters, 1. II1, 112. 


\section{RELIGIOUS HOUSES}

volved about the middle of the fifteenth century. From an estimate of the revenues and debts of the house, drawn up in 1462 , it appeared that the total income was $£ 86$ I os. $6 d$., and the clear value $f 71$ ros. $8 d$. The house then sustained only four canons and their four servants, the cost of whose board and clothing was estimated at $£ .30$; divers creditors had received $£ 15$ 15s. $4 d$.; the repairs of churches, houses, and the walls and cloister of the priory had also consumed $£_{15} \mathrm{I}_{3}{ }^{s .} 4 d$.; whilst $f$ ro was the annual life pension assigned to the prior. In 1 463-4 the prior was twice sued for debts in the sheriff's court.

In 1468 Prior Richard resigned, and John Morton was elected fourteenth prior. ${ }^{1} \mathrm{He}$ held office till 1471, when William Windsor was appointed; but owing to irregularity of election this appointment was almost immediately annulled, and Thomas Farwill or Fairwise elected as fifteenth prior in his place. In 1472 Peter at Berne was reappointed prior, and held office for the second time until 1478. On 21 April, 1478, a visitation was made of the priory by the priors of Breamore and Tortington, under the authority of the general chapter of the Augustinian Order.

Prior Assheford seems only to have been appointed to further the suppression of this overburdened house. On 2 September, 1484 , Bishop Waynflete appointed Richard, prior of Newplace, and two others to hold a commission for the annexing of the priory to Magdalen College of the bishop's founding. The greatest care was taken to justify this action to the church and the world by the elaborate nature of the evidence taken on oath before the commission. The evidence of the prior (an old man of seventy-two), of the bishop, and many others as to the hopeless condition of the priory, which was then destitute of a single canon and utterly dilapidated, was conclusive, and the decree of annexation was pronounced on II September. In the following year the transfer was confirmed by Pope Innocent VIII.

On the suppression of the priory an annual pension of $f^{6} \mathrm{I}^{3} 3^{\text {s. }} 4 d$. was assigned to Assheford, and a chantry priest was maintained at Selborne, who received yearly from the College $f_{9} 6$ s. $8 d$. The founder of the priory was also, by Waynflete's order, commemorated at one of the quarterly obits observed at Magdalen College. ${ }^{2}$

1 Winton. Epis. Reg., Waynflete, i. f. 1576.

2 The commemoration of Peter de Roches at Magdalen, long forgotten, has recently been revived, and is now regularly maintained.
An inventory of goods remaining at the priory in May, 1490, in the custody of Simon Hiltofte, chaplain there, shows that there were then a full equipment of church service books, altar plate, vestments, and other ornaments. There were also some books remaining in one of the chambers, including a copy of the Acts of the Apostles, and commentaries on the Gospels and on the Book of Job.

In 1534 a grant was made by the president and scholars of Magdalen to Nicholas Langerige, M.A., of the chaplaincy in the late priory of Selborne, for forty years, if he should live so long, to celebrate there for the souls of all the benefactors of the priory and college, assigning him an annual pension of $£ 8$ with two chambers on the north side of the chapel, with a kitchen, a stable for three horses, and the orchard; also 26s. annually to find a clerk to serve him at the altar and in other necessary matters; and ten cartloads of wood to be given him at the Easter progress of the president and fellows, provided he did not sell or give away any of it. It was further provided that Nicholas was not to absent himself from the priory more than two months in the year without special leave from the college, and when absent must provide a sufficient substitute.

\section{Priors of Selborne}

John, about 1234,1250

Richard of Kent, ${ }^{3}$ I $261-7$

Peter de Disenhurst, 1267, 127 I

Richard, 1277, I291

William de Basing, ${ }^{4}$ I 299-1 323

Walter de Insula, ${ }^{5}$ elected 1323

John de Winton, 1339

Edmund, 1352, I 357

Nicholas de Wynton, ${ }^{6}$ I 36 I -78

Thomas Weston, ${ }^{7}$ 1 378-1410

John Winchester, ${ }^{8}$ 1 4 IO, 1413

John Stepe, $1415(?)-59$

Peter at Berne, ${ }^{\circ}$ I $459-68$

John Morton, ${ }^{10}$ I 468-7 I

${ }^{3}$ Dugdale gives Nich. de Cantia, which is a misprint for Rich. de Cantia.

4 Winton. Epis. Reg., Pontoise, f. 22.

${ }^{5}$ Pat. 17 Edw. II. pt. I, m. 14; Winton. Epis. Reg., Stratford, f.6. In the margin there is a curious entry relative to customary episcopal fees in kind. It is stated that the official who inducted Prior Walter received, in nomine episcopi, his palfrey, saddle, bridle, cloak and boots.

${ }^{8}$ Winton. Epis. Reg., Edingdon, f. 113.

7 Ibid. Wykeham, i. f. 90.

8 Ibid. Beaufort, f. 23.

- Ibid. Waynflete, i. f. $69 \mathrm{~b}$. Peter at Berne resigned in 1468 , and was re-elected in 1472 .

10 Ibid. f. 1576 . 


\section{A HISTORY OF HAMPSHIRE}

William Windsor, 147I, election annulled Thomas Farwill or Fairwise, 1471-2

Peter at Berne, I 472-8

John Scherpe, elected 1479

Thomas Assheford, 1484-5

\section{THE ORATORY OF BARTON}

The oratory or priory of Barton, dedicated to the Holy Trinity, whose priests followed the rule of St. Augustine, was situated in Whippingham parish, Isle of Wight. It was founded in 1275 by Thomas de Wynton, rector of Godshill, and John de Insula, rector of Shalfleet. ${ }^{1}$ The oratory was endowed with land in Whippingham, Arreton, Span, Appleford, Kerne, Rookley, Dolcoppice, La Snape, Walpan, some pasture on St. Catherine's Down, two corn mills in Newport, and with some house property at Southampton.

The foundation charter laid down that the oratory was to consist of six chaplains with a clerk, who were to live an honest life, follow the Austin rule, and celebrate perpetually both for the living and the dead. One of their number was to be presented to the bishop to serve as archpriest or superior, and within twenty days of any vacancy among the chaplains a fit person was to be chosen and presented to the diocesan. The chaplains were to be under the immediate control of the bishop, and their servants under the archdeacon. They were to hold their goods in common, and the effects of any chaplain dying were to go to the oratory. There was to be only one dish, with a pittance, at each meal, save on great festivals, when there was to be a third dish. The chaplains were to be diligent in their prayers and reading; they were not to go outside the precincts of the house without the archpriest's leave; in the oratory they were to wear surplices with black copes, and when outside humble habits of one colour, black or brown (burnet), with a frieze cloak and cap. At table, the archpriest was to sit at the head, next him the chaplain who had celebrated high mass that morning, and then in their respective order the chaplains who had celebrated the masses of the Blessed Virgin, the Holy Trinity, and Requiem. The chaplains were to sleep in a common dormitory where silence was to be observed. In all offices they were to follow the use of Sarum; one of the chaplains was to be appointed precentor and draw up the order of services. The archpriest was to be respon-

1 Inspeximus of original charter (Stone's Arch. Antig. I. $W$. pt. i. p. 121 , note b). sible for the temporalities of the house. Thirteen poor brethren were to have their food daily, for which purpose the revenue from Crudmore farm, in Carisbrooke parish, was appropriated.

In the return of knights' fees made in 1346 it appears that the archpriest of Barton held a quarter of a fee in Span and a seventh part in Barton. ${ }^{2}$

In 1386 the bishop committed the charge of the house to Gilbert Noreys, one of the chaplains. ${ }^{3}$ In a short time however grievous complaints reached the bishop with regard to warden Gilbert's conduct. His brother chaplains accused him of having given away or sold, without their consent, 180 of the best sheep, worth $12 d$. apiece; 20 of the best beasts, worth $£_{\mathrm{I}} \mathrm{O}$, for 10 marks; all the wool and sheepskins; a saddle horse for 30 s.; a mare and foal, well worth 20 s., for $5 \mathrm{~s}$.; several barge loads of timber and bricks; as well as 30 quarters of barley, 30 quarters of oats, and Io quarters of pease. Moreover he had pawned a chalice and vestments and other silver. In addition he was accused of grave incontinence, and of tavern haunting, requiring an attendant to lead him nightly to his lodging. Bishop Wykeham commissioned the abbot of Quarr and two others to inquire into this charge, with the result that Gilbert Noreys was removed, and William Love, one of the chaplains, admitted as archpriest on 7 June, 1387.4

Meanwhile the affairs of the oratory did not improve, the buildings got into a sad state, and Love, the archpriest, was taken prisoner by the French. In his absence his jurisdiction was formally suspended, and in 1390 the custody of both spiritualities and temporalities were assigned by $W$ ykeham to his suffragan, Simon, bishop of Achonry. ${ }^{5}$ Soon after this Love escaped or was released from his imprisonment across the scas, and resumed his rule. Under pressure of his diocesan, in January, 1394, a covenant was entered into between William Love and Richard Lathbury, a tiler and mason, by which the latter covenanted to keep the buildings in order, Love providing materials and a labourer, and allowing Lathbury his victuals and IOS. a year and keep for a horse. ${ }^{6}$

But the house speedily got into further

2 Feudal Aids, ii. 337, 340.

3 Winton. Epis. Reg., Wykeham, i. f. 172 b.

4 Ibid. iii. $229 \mathrm{~b}, 230$.

5 Ibid. i. f. 205 ; iii. f. 245.

6 See Archeologia, lii. 297-313, for an article on the evidences of this Oratory among the Winchester College muniments by T. F. Kirby, F.S.A. 


\section{RELIGIOUS HOUSES}

trouble ; Love became a prisoner in the Fleet, we know not on what charge, and in October, 1394, the custody of the Oratory was committed by the bishop to the joint care of Nicholas, rector of Niton, and William Smyth, vicar of Brading. ${ }^{1}$ In 1403 a commission was directed to the abbot of Quarr and the rector of Niton to inquire into charges of apostacy, sacrilege, and other grave offences preferred against Love, which resulted in his removal."

In I 439 Warden Thurbern, of Winchester College, petitioned Cardinal Beaufort to permit the appropriation of the oratory to the college on the ground of the insufficiency of their income, which had been recently much impaired by a fire among their house property at Andover. Walter Trengof, the archpriest, who had just been appointed archdeacon of Cornwall, his native county, raised no objection. The cardinal bishop gave his consent, and the return to writ ad quod damnum was favourable. On 27 March, I 439, the royal licence to $\mathrm{W}$ alter 'Trengof to alienate, and to the warden and scholars of Winchester to ac- quire and hold in mortmain the possessions of the oratory was duly sealed.

The college covenanted to maintain a chaplain in the chapel of the Barton oratory, to deliver a pound of wax annually to the warden of St. Mary's altar in the minster of St. Swithun, and to celebrate Trengof's obit in consideration of his surrender.

The chaplain's stipend of $f, 6$ was duly paid and service maintained at Barton until the days of Edward VI., when all divine worship ceased within its walls.
Archpriests or Priors of Barton
Jordan de Marisco, 1275
Simon in the time of Edward II.
Nicholas de Alresford, elected 13 ro
Richard, 1343
Roger Pope of Exeter, I 349
Robert Somborne, 1366-83
Gilbert Noreys, I 386
William Love, I $387-1403$
John Godewyne, 14 I 7
John Bradshawe, 1423-4
Walter Trengof, ${ }^{5}$ 1424-39

\section{HOUSE OF PREMONSTRATENSIAN CANONS}

\section{THE ABBEY OF TITCHFIELD}

The Premonstratensian Abbey of Titchfield, nine miles south-east of Southampton, was founded by Bishop Peter des Roches in the year 1222, when a colony of White Canons were invited to settle there from the Shropshire Abbey of Halesowen. By the foundation charter the Abbey of St. Mary ${ }^{3}$ was endowed with the manor of Titchfield and its appurtenances, and with lands in Swanwick, Porchester, Walsworth and Cosham. This was confirmed, with grants of the fullest privileges, by Henry III. in $1231 .{ }^{4}$ Other important grants were those of the manor of Cadlands and lands in Hythe, Stanswood, and Woodcott and Felde (in Fawley parish) by Eva de Clinton, daughter and heiress of Roger de Escures; the manor and lands of Inkpen (Berks) by the Mansels ; the manor and lands of Corhampton and the wood of Charlwood by the founder; lands in Stubbington and Chark by the Rayners, Bretts and St. Johns.

I Winton. Epis. Reg., Wykeham, iii. f. 280.

2 Ibid. f. 357 .

3 The church was dedicated in honour of the Assumption of the Blessed Mary (Add. MSS. 4935, f. 61).

\footnotetext{
- Dugdale's Monasticon, vi. 93 I.
}

The Harley MSS. 6602 and 6603 contain transcripts and extracts from three Titchfield registers belonging to the Duke of Portland, which were made in 1739. Their accuracy is assured, for they were collated with the originals in $1830-1$ by Sir F. Madden, and corrected in red ink. The first register gives a large number of grants and customs of manors; at the end is a list of abbots, ${ }^{6}$ drawn up about 1390 , when John de Romsey was abbot, and afterwards brought down to the eve of the dissolution. The following is a translation of the list :-

Richard, the first abbot, came from Halesowen with his brethren in the year $\mathbf{1 2 2 2}$, and ruled this church well and religiously. He died on 16 June, and was buried before the door of the chapter-house.

Isaac was the second abbot; in his time the manors of Cadlands and Inkpen were acquired. He died on 19 June, and was buried in the cloister before the door of the chapter-house, on the right hand of the monument of the first abbot.

After his death, Henry de Branewyk succeeded him. He was afterwards sought as abbot of Halesowen, and there rested in peace.

5 Stone's Arch. Antig. I. W. pt. i. p. 62

6 Harl. MS. 6602, pp. 140-3; f. 214 of the original register. 


\section{A HISTORY OF HAMPSHIRE}

To him Henry de Spersholte succeeded, in whose time the manor of Newland was acquired and lost. He died on 22 September, and was buried in the cloister.

To him succeeded Brother Yvo, in whose time the manor of Mirabel was acquired and lost. He died on 3 March, and was buried in the cloister.

Adam, third abbot of this church, ruled with honour. 1 He died on 14 September, and was buried in the cloister on the left of the monument of Abbot Peter de Wynton.

William de Byketon, the fourth abbot, was a vencrable ruler of the church; he died on 8 November, and was buried in the church, at the altar of St. Richard.

John Sydemanton, fifth abbot, ruled well, and died on 3 December. He was buried in the cloister, between the door of the library on the south and the monument of Abbot Wynton on the north.

Roger de Candever, sixth abbot, ruled this church honourably and religiously for about eighteen years. He died on 5 August, and was buried in the cloister at the entrance to the church near the altar of St. Peter.

John de Combe, seventh abbot, in whose time the manors of Crofton and 'Fontelegh-Pageham' were acquired. He ruled this church for about twenty years, and died on 5 May, and was buried in the cloister, at the head of the monument of Abbot Roger de Candever.

Peter de Wynton, eighth abbot, ruled this house religiously for one year and six months. He died on $16 \mathrm{July}$, and was buried in the cloister between the monument of Abbot Adam on the north and Abbot Sydemanton on the south.

William de Wollop, ninth abbot, ruled this church in the best possible way for twenty years, nine months and three day's. In his time the land and tenement of Markes and 'Brykoresland ' were acquired and appropriated. $\mathrm{He}$ also acquired, but did not appropriate, the land and tenement of Ward, the land of 'Froghemour,' the land of 'Firsteburyesland' at Chirk, and the tenements which were John Goudale's in Titchfield. Also in his days John Edindon gave his manor of Portsea and "Copenore" to the priory. He died on $23 \mathrm{May}$, and was buried in the cloister, north of the monument of Abbot Candever.

John de Thorni, tenth abbot, ruled prudently over this church for nineteen years, thirteen weeks and five days; in his time the lands and tenements mentioned under his predecessor were all appropriated. He died on 30 September, and was buried in the cloister at the feet of the image of the Blessed Virgin, which he had erected there in honour of the Mother of God by a buttress.

John de Romsey, eleventh abbot of this church, ruled honourably. ${ }^{2}$

1 It is not easy to understand why Adam is called the third abbot when he appears to have been the sixth; it may be that the three abbots bsfore Adam succeeded each other rapidly, and were never duly confirmed.

2 From here the entries are in a later hand.
Thomas Bensteade, thirteenth abbot, ruled well, and resigned his staff under compulsion.

William Winchestour, alias Fryer, was fourteenth abbot, and ruled six and a half years.

William Auyten, fifteenth abbot, ruled this church well for sixteen years. He built the house commonly called 'The Grete Place.' He also restored the windows of all the chambers, and built another house near the cross in the body of the town. He died 25 October, and was buried near the monument of John Thorny.

Thomas Coyk, sixteenth abbot, ruled for twentyone years.

Thomas Blankpayn, seventeenth abbot, ruled for twenty years, and resigned on a pension.

The Rev. Father John, Bishop of Elphin in Ireland, abbot in commendam of Welbeck and Titchfield, prebendary of York and Southwell and visitor of the Premonstratensian Order, the eighteenth abbot, rebuilt the ruinous church.

The second register opens with an account of the library, as catalogued in the year 1400. It is often forgotten how large a portion of his time the professed monk or canon was expected to give to the study of the Scriptures and of other literature. 'This was particularly the case with the order of Premontré. The rule of the White Canon was in this respect more stringent and definite than that of the Black Canon, as appears in various particulars. The office of librarian was joined to that of chanter in the Austin houses, but was a separate office in the Premonstratensian houses. The later canons were distinctly invited to study not only the Scriptures, but theology, philosophy and Litera Humaniores The original statutes are much more precise as to the times of reading than those of the Black Canons. The Premonstratensian rule provided that after sext, which followed immediately after high mass, the time was to be given to reading (whilst the servants and reader dined) until the bell rang to enter the frater. In the winter most of the convent had light refreshment (mixtum) after terce, and dinner was not served until after nones; and in that half of the year the long interval between sext and nones was assigned to reading. Again, after evensong throughout the year, there was reading until the bell sounded for collation. ${ }^{3}$ "The importance of reading is emphasized by a special chapter being assigned to 2uomodo se habeant fratres tempore lectionis. All the brothers were to read at the appointed hour, save those engaged on necessary duties, and they were to make all speed to attend lection. They were to sit in cloister when

3 Statuta Ordinis Premonstraten' (printed 1530), Distinctio I. caps. vi. vii.

4 Ibid. Dist. I. cap. ix. 


\section{RELIGIOUS HOUSES}

reading, conducting themselves with all decorum, each reading his own book, save those who might be singing from antiphoners, graduals, or hymnaries, or giving readings to others. If any one was obliged to leave he was to replace his book in the case, or if he wished to leave it on his seat to signify by sign to a brother sitting near that he left it in his custody. At all times of lection the brothers were to wear their slippers (nocturnalibus botis). No manuscript was to be kept in. the cloister carrols nor in the dormitory chests without leave of the abbot.

The librarian, called armarius, from the armarium or case in which the books were kept, was to mend and care for the books and to open and shut the case as required. He was to mutually assign and change the books as they were wanted, but not without leave of the abbot or prior, or without making an entry. He was also required to keep a numbered list of the books. ${ }^{I}$ The Premonstratensian rule underwent various changes on the authority of the General Chapter in the seventeenth century, and was finally revised in 1630 . The librarian was then termed bibliothecarius; he was ordered to arrange his books, in the place where they were kept, according to their subject or faculty. ${ }^{2}$ This had been done at Titchfield for at least two and a half centuries before the passing of this revised statute.

The usual places for books in religious houses were cases in recesses of the cloister. It was not until a comparatively late period that a few of the larger houses thought of providing a special room or building for the library. ${ }^{3}$ Titchfield was only a daughter house of no great wealth, and from its having in I 400 so large and valuable a library in a special apartment opening out of the cloister, and from the general character of the White Canons as a reading order, it may perhaps be assumed that the Premonstratensians usually had a particular chamber to serve for the books or manuscripts.

There were in the library of Titchfield, as is specifically described, four cases (columna) wherein to place the books. It would seem that the door was on the west side of the chamber, for there were two cases against the

1 Statuta Ordinis Premonsteratn', Dist. II. cap. vii. 2 Statuta Ordinis Premonstratensis Renovata (I 630), Dist. II. cap. xiv. p. 109.

3 See Gasquet's Notes on Mediaval Monastic Libraries (1891); James' Catalogue of MSS., Peterbouse, Cambridge (1899); and Willis Clark's Customs of Austin Canons (1897). east wall, a third against the south wall and a fourth against the north wall. Each of these cases had eight shelves (gradus), marked with a letter of the alphabet, representing a division of the library and not the special shelf. In case I., were the Bibles and the patristic glosses on the different books; II., the Fathers and general theology; III., sermons, legends, rules and canon and civil law; IV., medical and surgical works, grammar, logic, philosophy and varia. The alphabet letters gave further classification; thus $B$ was affixed to seven shelves of case I., containing the glosses on the Scriptures; and D was marked on five shelves of case II., whereon stood the works of St. Augustine and St. Gregory. The first folio or the cover of each volume contained not only the shelf letter, but a number indicating its position on the shelves. The very volume that gives the library list has on its first page the mark 'P.x.' On turning to the catalogue there is found entered Rememoratorium monasterii et omnium maneriorum de Tychefeld, as the tenth book on shelf $P$.

The total number of volumes was 224 , but it must be remembered that many of these MS. volumes contained a variety of treatises, which if printed after modern fashion would make several separate books. ${ }^{4}$

Several of the other volumes of this library must have been of exceptional bulk or unusually close writing. Only one book is named as written in English, viz. a copy of the Golden Legends (E. vii.); but under the letter $Q$ are various books in French. Among the more curious theological tracts may be mentioned: De ortu et educatione Pontii Pilate, and De ortu Fudee Iscaritis. At the end of the library catalogue a list is given of upwards of a hundred other volumes pertaining to the divine office, and usually kept in the church.

The library catalogue is followed by an itinerary, or distance in miles, of the various English houses of White Canons from Titchfield; the nearest being Durford in Sussex, 16 miles, and the most remote Alnwick in Northumberland, 276 miles. ${ }^{5}$

The next matter that is illustrated in this interesting register is the very serious way in which the monasteries, in common with the rest of the country, suffered from the awful Black Death of 1349-50. The local annalist cites an inventory of the monastery and

4 Thus the library of the great Benedictine Abbey of Peterborough only numbered 268 volumes, but these contained about 1,700 works.

b This list corresponds with that of the whole order compiled in 1320 , as given in Le Paige's Bibliotheca Prem. Ord. (1633), p. 33. 


\section{A HISTORY OF HAMPSHIRE}

its manors and granges of the year before the plague. In the eighth year of the rule of Abbot Peter de Winton, namely on 4 July, 1348 , the monastery and its manors had 170 quarters of wheat, I 75 of barley, 198 of oats and 22 of winter wheat; also 41 horses, 24 draught horses (affi), 30 oxen, 9 bull-calves, I 82 bullocks, 10 bulls, 93 cows, I 8 heifers, 20 calves, 273 swine, 940 muttons, 18 rams, 137 ewes and 768 lambs. In the tenth year of Abbot John 'Thorny, namely on 27 June, 1370 , the condition of the monastery was so exhausted and its burdens so heavy that there was no wheat in the house or in its manors, and but 5 quarters of barley, 2 quarters of dredge 1 and 16 quarters of oats. As to livestock, they had 23 horses of both kinds, 27 oxen, 2 I colts, 190 bullocks, I o bulls, 66 cows, 44 steers, $3^{8}$ heifers, 16 yearlings, 24 calves, 9 boars, 20 sows, 50 pigs, Ioo hogs, 25 suckling pigs, 780 muttons, 19 rams, $55^{\circ}$ ewes and 280 lambs.

The chief reason of the great contrast in bread stuffs between $134^{8}$ and 1370 (when it might have been thought that the country would have recovered from the shock of the plague), was that the great scarcity of labour and its higher price caused so much of the arable land to remain untilled or to be changed into pasture.

In 1370 an inventory was also taken of the plate as follows :-

A small cross with foot, silver gilt; a gospeller (textus), silver-gilt (cover) adorned with relics; a crystal vase for relics; 17 chalices, of which 9 were gilt; a silver-gilt pix for the high altar ; 4 silver cruets; 6 silver bowls, of which 2 are large and 4 smaller, for double feasts ; 2 pastoral staves ; 3 silver candlesticks, one of which is small for midnight mass on Christmas Day; 3 silver-gilt censers ; 4 silver-gilt cups, 3 with covers; 3 great silver goblets (bolle) with feet, with covers; 42 pieces (pecie) of silver, 5 of which have small feet and covers ; 5 'ance pedate,' 2 with silver covers; 2 flagons (olla) of silver, for wine; 2 small silver basins (lavatoria); a silver plate with a foot; a silver gilt pipe (fistula) for communicating the infirm; and 81 spoons.

There was no money found in the treasury, and the debts of the house amounted to the serious sum of $f_{202} 16 \mathrm{~s} .9 \mathrm{d.}^{3}$

At the end of the second register of Titch-

1 Dragium is considered by Thorold Rogers (Agriculture and Prices, i. 27) to be a peculiar and inferior kind of barley; but the term dredge is still used for a mixture of barley and oats.

2 No satisfactory solution of ance has been suggested.

3 A third schedule dated 9 November, I 390 , is also entered in this register. field is written out this prayer, to be said with the greatest devotion on getting into bed :-

In Monte Celyon requiescunt Septem Dormientes, Malchus, Maximus, Constantinus, Dionysius, Serapion, Martinianus, atque Johannes. Per istorum merita det michi Deus noctem quietam et soporem quietam. Amen.

To this is added-

Hxc oratio abunde testatur quibus in tenebris istud versabatur seculum.

The reference is of course to the beautiful Syrian legend of the Seven Sleepers of Ephesus, first made known in western literature by Gregory of Tours.

In the third register of Titchfield, which is termed a rental, particulars are given of the customs of their manors.

In I 334 the king's officials of the New Forest seized certain cattle belonging to the Abbey of 'Titchfield, for continuous feeding within the bounds of the forest to the grave prejudice of the king. The abbot claimed through his attorney the right of common pasture for his beasts of Cadlands in the New Forest; the abbot also claimed a parcel of land within the forest, lying in la Whitefeld at 'Wyndhall,' as part of his manor at Cadlands. The chief forester, on the part of the Crown, admitted the abbot's right to the parcel of land within the forest, but that his cattle and sheep did not remain there, and strayed generally in the forest. To this the abbot's attorney replied that they made an annual payment of $18 \mathrm{~s}$. for this very right, and prayed a search of the rolls. Search was made and judgment was given in favour of the abbey.

By the aid for making Edward the Black Prince a knight in 1346 , we find that the Abbot of 'Titchfield held half a knight's fee in Soberton, half a fee and a quarter of a fee in Crofton and a third part of a fee in Cadlands. 5

The Premonstratensian Order was absolutely free from diocesan visitation or control, but the energetic Wykeham secured certain recognition from Titchfield as a house founded by one of his predecessors in the episcopal chair of Winchester.

On 20 November, 1390 , Richard, abbot of Halesowen, presented John Romsey, abbotelect of Titchfield, appointed by the brethren of that convent, rightly and canonically, according to the privileges of their order (to which house he stood in the position of

- Harl. MS. 1603, ff. 1 30-3.

- Feudal Aids, ii. 336, 340. 


\section{RELIGIOUS HOUSES}

father abbot), to Bishop Wykeham, praying for his benediction. Abbot Romsey made his due profession to the bishop, describing himself as elected and confirmed, recognizing the bishop as (through his predecessor) the founder of their house, and promising to do all things which pertained by right or custom to the founder and patron of the house. Even to this recognition of the bishop, the abbot added the qualifying phrase providing against anything contrary to all the customs and privileges of his order. The bishop thereupon, when celebrating pontifical mass in his private clapel, after the abbot had signed a promise of canonical obedience and reverence, gave him his benediction. ${ }^{1}$

The houses of the White Canons were visited yearly by the father-abbot, that is, the abbot of the house from which they had their origin, save in those years when there was an authorized visit by commission of the General Chapter of Prémontré. On 12 June, 1420, Titchfield was visited by John Poole of Halesowen, as father abbot, with the assistance of the Abbot of Durford, at a time when there had been a vacancy in the office of abbot, and when Richard Aubrey, the prior, had been elected by his fellow canons to fill the post. Abbot Poole duly confirmed the election. The visitors found that there was no money in the treasury, that there was owing to the house $£ 434$ s., but that the debts amounted to $£_{62}$ os. $6 d$. A return was made of the valuables both in the sacristry and the treasury. This inventory corresponds in the main with that of 1370 ; the silver spoons had increased from 81 to 84 , whilst the chalices had decreased from 17 to 14 . The livestock was: 24 horses, I 0 draught horses, 4 colts, 154 oxen, 7 bulls, 69 cows, 17 heifers, 10 steers, 28 yearlings, 29 calves, 381 muttons, 207 'burtis et muricis,' 121 hogsters, 100 lambs, 17 boars, 24 sows, 33 pigs, 126 hogs and 89 suckling pigs. Neither in the granary nor bakehouse was there anything. There was hay enough, at a reasonable estimate, to last till the Assumption for use at their hospice. ${ }^{2}$

Titchfield was visited in 1478 by Richard Redman, Bishop of St. Asaph and Abbot of Shap, in conjunction with Hubert, commissarygeneral. In answer to the set form of visitation questions, it was stated that the Abbot of Halesowen was their father abbot, that their church was dedicated in honour of the Assumption of the Blessed Virgin, because on that day one Brother Richard, with other canons of Hayles, had first come to Titch-

1 Winton. Epis. Reg., Wykeham, i. ff. 208, 209. \& Dugdale's Monasticon, vi. 935.

field, and that they held two churches, the perpetual curates of which were both canons. ${ }^{3}$

On 3 July of this year one Thomas Borrell, canon of the house of Langley, Norfolk, was sent to the Abbot of Titchfield to undergo in the latter house forty days of penance for a grave fault. This was done in accordance with the decree of Bishop Redman as visitor. Thomas brought with him sufficient clothing for his body and bed, to last a year. The Abbot of Langley commissioned his brother of Titchfield to hear the penitent canon's confession."

The Valor of 1535 gives the gross income of the abbey at $£_{280} 19 \mathrm{~s} .10 \frac{1}{2} d$. and the

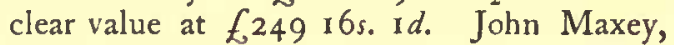
Bishop of Elphin, was then abbot.

John Salisbury, the twentieth and last abbot, was consecrated suffragan Bishop of Thetford on 19 March, 1536, by Archbishop Cranmer and the Bishops of Salisbury and Rochester. ${ }^{6}$ In May, 1538, he was appointed Canon of Norwich, and in the following year dean; in 1571 he was made Bishop of Sodor and Man, and died in 1573.

On I May, 1537, the Bishop of Thetford wrote to Wriothesley saying that he intended to send his steward to him the next week to pay his fee for the half year, and desired that he would continue his favours to his poor house. ${ }^{6}$ The income of the house put it outside the first Act of Parliament for dissolution, and for such cases a variety of schemes for 'surrender' were devised. Apparently Salisbury had been put in office, through some cajolery, to secure surrender. Sir Thomas Audeley, the chancellor, wrote a letter of reply to Cromwell in December, 1537, touching the dissolution of this house, and saying that a deed of gift by the abbot and convent, if they were content to give up their house, sealed before some judge of record, would suffice; but if Cromwell wished to have a fine or recovery he explained how it might be taken.?

Meanwhile John Crawford and Rowland Lathum were made the king's commissioners to secure the surrender of 'Titchfield, which

3 Add. MS. 4935, f. 61. The Premonstratensians possessed the unique privilege of eligibility to the charge of secular parishes without papal or other dispensation. Bishop Redman, who held the Abbey of Shap in commendom, was consecrated Bishop of St. Asaph in 1471, was translated to Exeter in 1495 and to Ely in 1501 ; he died in 1505.

4 Ibid. 4935, f. 62.

- Cant. Archiep. Reg., Cranmer, ff. 187-8.

6 Letters and Papers, Hen. VIII. xi1. 1108.

7 Cott. MS. Cleop. E. iv. ff. 195, 198. 


\section{A HISTORY OF HAMPSHIRE}

was promised to Wriothesley. The commissioners wrote to him on 22 December, 1537 , saying they had made careful inquiries of the state of the monastery and how many grants had been passed under the convent seal. They described the church as being most naked and barren, being of such antiquity, saying that 40s. would buy all except the vestment Wriothesley had given and two old chalices. Evidently the canons had had plenty of warning, and had before this stripped their church of its valuables. It would be interesting to know what became of their library. At Michaelmas last there were two team of oxen, but now not one ox. They found a dozen rusty platters and hangings worth 20 s., and described the lands as very ruinous. The abbot and convent confessed to having granted pensions to the old abbot and others to the extent of £50 per annum. The debts amounted to $f_{200}$; the abbot and convent expected to be assured of $£ \mathrm{I} 35$ a year for their lives, I 00 marks to the abbot, $\AA^{6}$ i $33^{s} .4 d$. to each of eight priests and $£ 5$ each to three novices. The house owed the king above 200 marks for first fruits, and the expense of alterations would be at least 300 marks; so the commissioners were right in assuring their patron that his first entry would be expensive."

Though Crawford and Lathum wrote on 22 December of Titchfield as "the late monastery,' the formal surrender by John, 'perpetual commendatory of the abbey' and the convent, of the house, with all its possessions in Hants, Berks and elsewhere, was not signed until 28 December. ${ }^{2}$ Thomas Wriothesley at once obtained a grant in fee simple of the site, church and the whole of the possessions of the abbey in Hampshire, including the advowsons of the churches of Titchfield, Lomer and Corhampton, as well as of the manor and lands of Inkpen in Berkshire. ${ }^{3}$

On 2 January, 1538, the commissioners, Crawford and Lathum, wrote to Wriothesley thanking him for his new year's gift, mentioning the sale of marble stones, altars, etc., from the conventual church, and making light of the plucking down of the church in a scandalous letter already cited. Later in the same month Wriothesley received news from Titchfield that the carpenter had siayed in his work of pulling down the church because he was "loath to adventure with him before the change of the moon, and that the pavement of the nave was taken up, but scarce the tenth tile saved because they were so worn.' ${ }^{4}$ Two

1 Letters and Papers, Hen. VIII. xii. (2) 1245.

2 Ibid. 1274.

4 Ibid. iii. (1), I 5 I. more letters were written by Crawford to Wriothesley in the following April, wherein he described the alterations in progress at Titchfield, and stated that he had offered the bells to one Mr. Myls for $£ 60$. $^{\circ}$

At the time of the dissolution the possessions of the monastery were the manor of Wyker in Porchester, the manors of Titchfield, Abshot, 'Posbroke,' 'Newcourt Parva,' Fontley, Swanwick, Crofton, Mirables, Newland, Walsworth, Portsea, Copner, Cadlands, Corhampton ; various lands, etc., in Wickham, 'Warishassefeld,' Brooke, Porchester and elsewhere; the rectories of Titchfield, Lomer and Corhampton, and the manor of Inkpen in Berkshire. ${ }^{6}$

When Leland visited Titchfield he wrote in his Itinerary: ' $\mathrm{Mr}$. Wriothesley hath builded a right stately House embatelid, and having a goodely Gate, and a conducte castelid in the Midle of the Court of it, yn the very same Place wher the late Monasterie of Premostratences stoode caullyd Tichefelde.' ${ }^{7}$

\section{Aвbots of Titchfield}

\author{
Richard, ${ }^{8}$ I 222 \\ Isaac \\ Henry de Branewyk \\ Henry de Spersholte \\ Yvo \\ Adam \\ William de Byketon \\ John Sydemanton \\ Roger de Candever \\ John de Combe \\ Peter de Wynton, elected about 1340 \\ William de Wallup \\ John de Thorny, elected about 1360 \\ John de Ramsey, elected about $1379^{\circ}$ \\ Richard Aubrey, 1420 \\ Thomas Bensteade \\ William Winchestour, alias Fryer \\ William Auyten \\ Thomas Coyk \\ Thomas Blankpage \\ John Maxey, Bishop of Elphin, about \\ 1535-6 \\ John Simpson, 1536, resigned in the same \\ year ${ }^{10}$ \\ John Salisbury, 1536-7
}

5 Ibid. 749-50.

6 The first Mins. Acct. after the dissolution, noted in Dugdale's Monasticon, vi. 935.

7 Leland's Itinerary, iii. 111.

8 Most of the names of the abbots are taken from the transcripts of the registers in Harl. MSS. $1602, \mathrm{~J} 603$.

9 Winton Epis. Reg., Wykeham, i. ff. 208, 209.

10 Cole's MS. xxrii. f. 88 . He received a 


\section{RELIGIOUS HOUSES}

\section{HOUSE OF KNIGHTS HOSPITALLERS}

\section{THE PRECEPTORY OF BAD- DESLEY OR GODSFIELD}

Henry of Blois, Bishop of Winchester (I 129-7I), granted his land of Godsfield to the knights of the Hospital of St. John of Jerusalem in England, ${ }^{1}$ and in 1207 Adam de Port gave to the same community all his lands and manor of Godsfield in free alms. ${ }^{2}$ Walter de Audely also granted lands in Chilton Candover, Laurence rector of the church of Serveton granted his small tithes, and many other persons made grants of small parcels of land and houses in Preston Candover and Child Candover. How early a preceptory of the Hospitallers was formed here is not exactly known, but the first preceptor of whom we have mention is Thomas le Archer, whose name appears in a deed concerning a tencinent in Fleshmonger Street, Winchester, in 1304. From this date the grants are for the most part to the brethren of Godsfield, and not as heretofore to the parent house in London.

In 1355 John Pavely, prior of the Hospitallers, confirmed to Thomas Purchas a messuage and lands in Ibsley at a yearly rent of I $2 d$. to the preceptor or warden of Baddesley. This is the first mention in the chartulary of a preceptor of Baddesley; it probably denotes the date, soon after the Black Death, when the headquarters of this preceptory were moved from Godsfield to Baddesley.

In 1338 , when Prior Philip de Thame made a return to the Grand Master of the possessions of the Hospitallers in England, full particulars

pension of $\{20$, but in 1538 he offered to resign it if Wriothesley would obtain for him the living of Horsted in Sussex (Letters and Papers, Hen. VIII. xiii. (1), 381, 728 .

1 Charter Roll, 1 John, p. 1, No. 114 , printed in Dugdale's Monasticon vi. 808.

${ }_{2}$ Harleian MSS. 6603 (pp. 141-252). This is a transcript of a register of the preceptory of Baddesley, in the possession of the Duke of Portland, made in the year 1739, and collated with the original in 1830 by Sir F. Madden. By its title this register claims to be a calendar of all the charters and muniments of Godsfield, Baddesley, Rownhams and all other manors pertaining to the manor of Godsfield, drawn up by William Hulles, brother of the Hospital of St. John of Jerusalem in England, and preceptor of Baddesley in the year 1397. The register gives extended copies of upwards of one hundred deeds and indentures. At the end is added a rental, with a customal of the manor of Baddesley as it was held in 5 Henry IV., and also in 9 Henry VIII. when brother William Weston was preceptor. were given of the 'Bajulia de Godesfield,' with its members of Baddesley and Runham.

At Godsfield there was a messuage with the buildings in poor repair, with a garden valued at 3 s. $4 d$. a year ; 300 acres of land worth $58 s .4 d$. ; house rents that were actually fixed at $£_{20} 3^{s .} 4 d$. were then only $£_{1} 4$ IOs. od. on account of the sterility of the land and the firing of Portsmouth and Southampton by foreigners; an acre of meadow at Swarton, 2s. ; harvest work of the villeins, IOs. $6 d$.; pleas and perquisites of the court, 13 s. $4 d$.; pastur-

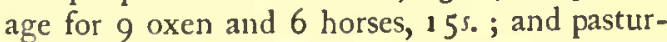
age for 900 sheep, 75s. Another important item of the income of every preceptory, though bound to be fluctuating in amount, was the voluntary contribution from the district, which was probably regularly collected. The total of this amount, usually termed confraria, from the whole of England, even in a bad year like $133^{8}$, reached the large sum of $£^{888} 4^{\text {s. }} 3^{d}$. The voluntary contributions of the Hampshire preceptory averaged 60 marks; but that year, owing to the distress of the country, the royal exactions, the taxes on tenths and fifteenths of all movables from year to year, the dues on wool, the warding of the seas, and many other oppressions that crop up (emergunt) from day to day, as the return states, there had been great difficulty in gathering 40 marks.

At Baddesley there was a messuage with a garden, the herbs of which, together with a pigeon cote, were of the yearly value of ros.; 360 acres of land; 18 acres of pasture; 40 acres of meadow; pasturage for 24 oxen; pannage for pigs ; pasturage for 30 cows ; pasturage for 400 sheep; with certain rents and works of tenants. At Baddesley there was also a wood of large timber, 100 acres in extent, which was common, so that nothing could be taken from it for sale, but it was reserved for repairing the houses of the preceptory, and of the bailiwicks of Templecombe, Ansty, and other places of the Templars that were in decay.

At Rownham there was a messuage in decay and ruin, of the annual value of $12 d . ; 80$ acres of land ; pasturage for 200 sheep ; pasturage for 8 oxen; and pasturage for 30 bullocks.

The whole realized a total annual receipt of $£ 66$ I 3 s. I I $\frac{1}{2} d$. for the preceptory.

As to the outgoings, the members of the house were brother William de Multon, the preceptor, and brother John Couffen, the chaplain. The number of the household servants was four ; and it is noted that the expenses in- 


\section{A HISTORY OF HAMPSHIRE}

cluded hospitality to visitors, which they were bound to exercise according to the will of the founder of the house. Thirty-three quarters of corn had been used in the year for making

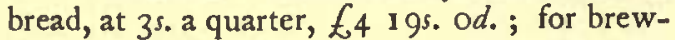
ing beer, 20 quarters of barley at 2s., and 20 quarters of oats at I $6 d ., £ 66$ os. $8 d$. ; Hesh, fish, and other victuals in the kitchen, 104 s. ; robes, mantles and other necessaries for the preceptor and the chaplain-brother, 69 s. $4 d$. ; a life corrody to Ralph de Basing of $6 \frac{1}{2}$ quarters of corn, at 3 s., 19s. $6 d$.; a steward's robes for use at courts, 20s.; dress for four servants, 32s. ; the wage of a labourer acting as wood-warden, IOs.; at the visitation of the prior for four days, $£ 4$; repair of the houses, 20s. ; and the stipend of a chaplain (without board) serving the chapel of Godsfield, 4 marks. There were also small payments due every year to the Bishop of Winchester, the church of Afford, the abbess of St. Mary's, Winchester, the prior of St. Swithun's and others. The total of the expenses and payments came to $£ 303$ s. $8 d$., leaving $a$ balance for the treasury of Ł.36 ios. $3{ }^{1}{ }^{1}$

The house at Baddesley had the honour of having among its preceptors three who became much distinguished in the Order, two of them being Grand Priors of England. Thomas Launcelyn, who was preceptor of Baddesley, and afterwards of Dalby and Rothely, was appointed Turcopolier by bull of the Grand Master, dated Rhodes, 3 October, 142 I. He died in 1442. William Tornay, preceptor of Baddesley and Mayne, became successively Receiver-general of England and Bailli of Aquila, and was finally appointed Grand Prior of England by bull of the Grand Master, dated Rhodes, 29 August, 147 I. He died in $1476 .^{3}$

Sir William Weston, preceptor of Baddesley, was elected Turcopolier in the chapter held in Candia after the expulsion of the Order from Rhodes in 1523. He commanded the grand carracque of the Order, and was named Grand Prior of England by bull of the Grand Master, dated Corneto, 27 June, 1527. During his rule came the conflict between Henry VIII. and the pope, when the Order resolutely resisted the divorce of Queen Kath-

1 Larking's Knight Hospitallers in England (Camden Society, 1857), PF. 21-3.

${ }^{2}$ Porter's Knights of Malta, ii. 288.

a Ibid. ii. $284,293$. arine. The result was the complete overthrow of the English Order or Language and a bitter persecution which lasted from 1534 to 1540 , during which many of the knights died on the scaffold. In April, 1 540, an act of parliament vested all their property in the Crown. A pension was granted to the venerable prior, but he died of grief at the utter annihilation of the English Language, on Ascension Day, 1540 , in the very year that it was granted. $\mathrm{He}$ had been present at the siege of Rhodes in 1522 , when he greatly distinguished himself. ${ }^{4}$

The Valor of 1535 returned the total annual value of the preceptory of Baddesley, both in spiritualities and temporalities, at $\oint_{\text {I }} 3$ I I 4 s. I $d$., and the clear value at $\oint_{1} 18$ 16s. $7 d$. After the suppression of the preceptory, its lands were granted first to Sir Thomas Seymour, and afterwards, in 1551, to Sir Nicholas Throckmorton.

It has been conclusively established that the preceptory of Baddesley, which first bore the name of Godsfield, had its headquarters in later years at North Baddesley, and not at South Baddesley as usually asserted.

\section{Preceptors of Godsfield or Baddesley}

Thomas le Archer, ${ }^{6}$ I 304, 1306

Robert de Coneygrave, ${ }^{1} 3^{12}$

Simon Launcelyn, 1315

William de Basing, ${ }^{6}$ I 325

William Hulles, 1388 , I 397

William de Multon

Thomas Launcelyn

William Tornay

Sir William Weston, 15 I 8, time of Hen. VIII.

In addition to the preceptories or commandories, the Order also possessed smaller estates called camere or chambers, where there was usually no establishment, and which were as a rule farmed out. This was the case with their estate at Woodcote, Hants ; it was farmed out in 1338 , and produced a rental of £. 3 6s. $8 d$.

- Ibid. $284,289,319$.

5 This list is compiled from entries in Harl. MSS. 6603.

- Hc describes himself in a deed relating to North Shorewell as custos bumilis et devotus domus de Godesfeld (ibid.). 


\section{RELIGIOUS HOUSES}

\section{FRIARIES}

19. THE HOUSE OF THE DOMINICANS OF WINCHESTER

At the second general chapter of his Order held at Bologna in May, 1221 , St. Dominic decided to send thirteen friars to England to establish the Dominicans in that country. This first missionary band of friars-preachers journeyed in the train of Bishop Peter des Roches, who was then returning to his diocese. The bishop first endeavoured, in 1225, to establish these Dominicans at Portsmouth ; but the project fell through, probably owing to his absence from his diocese from I 226 till 1230 . The date of their establishment at Winchester is somewhat uncertain, but it was between 1231 and $1234 .^{1}$

According to Matthew Paris, it was one of these friars who preached the crusade in Winchester in I 234, when Richard, Earl of Cornwall, the king's brother, and many other magnates took the cross. The site assigned for their convent was in the High Street, near the Eastgate, with the river Itchen on the east and Busket Street on the west. 'The ground round the house, exclusive of the buildings, was about $2 \frac{1}{2}$ acres, for which they paid to the Crown the yearly rent of 3 s. $5 d$.

Henry III. was their munificent patron throughout his reign, particularly in helping them with their buildings. In 1235, he gave forty oaks for building out of the forest of Bere; in 1236 , ten oaks out of the same forest for fuel ; in 1239, 100s., and in 1240,20 marks for building; in 1 246, 15 marks for the works; in 1256 , ten oaks to finish the frater; in 1260 , six oaks fit for timber towards their church, then in progress; in $126 \mathrm{r}$, six oaks fit for timber out of Pembere Forest, which the bailiffs of Southampton were to deliver; in 1262 , ten oaks; in 1265 , twelve oaks fit for timber; in 1269 ten good oaks for the repair and ornamenting of the church $^{2}$; in 1270 , six good oaks for ceiling the church, then approaching completion; and in $127 \mathrm{I}$, ten more oaks, five from Porchester Forest and five from Pembere, for the construction of the farmery.

The king further bestowed on the Winchester Dominicans other gifts in kind, the record of which affords information as to their number. In I 239, each of the twentyeight friars received from Henry III. a pair of

1 Reliquary, iii. (n.s.) 207 (Rev. C. F. R. Palmer).

\& Ad ecclesiam suam inde reparandam et lambruiscandam. shoes and four ells of cloth tor tunics. Like gifts of clothing were made for the next five years, when the friars numbered thirty-one. In 126 I they had a royal grant of $£$ io to buy winter clothing and shoes. Cartloads of wood or dead oaks for fuel were frequently granted them by the Crown, and on one occasion a tun of wine. ${ }^{3}$

In 1266 licence was granted by the Crown for the friars to enclose a small lane which was adjacent to their site.

The church of the friars-preachers of Winchester was dedicated to St. Katharine, the patroness of the Order. The buildings when finished could accommodate from forty to fifty of the friars. Edward I. did much for the house, but now that it was finished there was not the same necessity for royal bounty. He gave them on several occasions leafless or dead oaks for fuel, and in 1298 ten oaks fit for timber out of the forest of Bere."

When the king visited Winchester in 1 302, he gave this convent an alms of 38 s. for three days' food. When Edward II. visited the city on 29 April, 1325, he gave to the forty-six Dominican friars an alms of 15s. $6 d$. for a day's food, being at the rate of $4 d$. a head. Edward III. on his arrival in Winchester on 23 November, 1331, found thirty-six friars in the convent, and rendered an alms of $12 s$. for the like purpose. ${ }^{5}$

When the provincial chapter was held at Winchester in 1259, Henry III. gave the friars I oos. towards their expenses. In 1315 a provincial chapter was again held at Winchester, when Edward gave Ioos. or three days' food for himself, and the like amount both for his queen and for his son Edward. When the Order assembled here on 16 February, 1339, Edward III. gave the like sum of 15 ; and on 21 October he diverted to the same purpose the $£ 20$ which the Crown usually bestowed on the general chapter, as the chapter of that year was held at Clermont, France, with which country England was then at war. ${ }^{\circ}$

Some information has already been given with regard to episcopal licences to the Dominicans and other friars for preaching and

3 The references to the Close and Liberate Rolls for all these grants are given in Father Palmer's article on this house, Reliquary, iii. (n.s.) 207-I 5 .

Close, 27 Edw. I. m. I3.

- Expense Rolls, cited by Father Palmer.

6 Ibid. 


\section{A HISTORY OF HAMPSHIRE}

acting as penitentiaries. ${ }^{1}$ It may be of interest to note that the episcopal registers show that during the episcopacy of Bishop Asserio $(1320-3)$ three acolytes, two sub-deacons, six deacons and six priests were ordained from this convent ; that during Wykeham's rule of the diocese (1367-1404) two acolytes, one deacon and ten priests were ordained; and that from I5I I to 1527 thirty-six received orders from this house.

Various friars of the Winchester convent were distinguished in their Order. Brother Matthew was prior or warden of Winchester in 1 242, and also English provincial. Brother William of Southampton, who died about 1 278, was head of the Winchester house, and elected provincial in 1272. He was a distinguished theological writer. ${ }^{2}$ Robert de Bromyard, who was licensed to preach in the diocese in 1300, was doubtless prior of the Winchester convent, for he was elected provincial in 1304 ; he was also penitentiary of the diocese from 1307 until his death in I 3 10. Nicholas de Stratton, D.D., who was provincial from I 306 to 1311, and also diocesan penitentiary, was a Winchester prior. William de Horleye was prior in 1326. Thomas de Lisle, who was ordained in St. Elizabeth's chapel in 1322, was the next prior. He was employed in an embassy to the papal court in 1340-1, and was consecrated Bishop of Ely on 24 July, 1 345, at Avignon, where he died in exile in 1361 . William Alton, born at Alton, Hants, a renowned preacher and writer, a doctor of Paris University who flourished about 1350, was probably of the Winchester convent. John Payne was prior in 1373. The Court Rolls of Winchester name as prior John Derle, 1377 and 1387 ; Nicholas Monk, 1404 to 1426 ; and Walter Alton, 1455.

James Cosyn, B.D., who was prior in the time of Henry VIII., adopted the most extreme tcnets of the reformers. He preached a sermon from St. John xvi. 23, in the parish church of 'Chusel' on 27 February, I 536, of which the following are passages: "If thou put an whole stoup of holy water upon thy head, and another stoup of other water upon thy head, the one shall do thee as much good as the other in avoiding of any sin. As much other bread of thine own blessing shall do thee as much good as so much holy bread.

1 Supra, p. 16.

2 His works were: Postilla in Isaiam, In moralia Gregorii, Sermones de Sanctis, Sermones de tempore, Super IV. Gibros sententiarum, and Questiones Theologice (Scriptores Ordinis Pradicatorum [1719], i. $602 \mathrm{~b})$.
And as for confession, I will not counsel thee to go to any priest to be confessed, for thou mayest as well confess thyself to a layman, thy christian brother, as to a priest, for no bishop or priest have any power to assoil any man of any sin. And I myself have shriven a woman this day here in this church, but I did not assoil her, no, I will never assoil none.'

Whereupon this 'soul-murderer,' as the vicar of Stoke styled him, was arrested and indicted for heresy, and committed by the sheriff to the custody of Dr. Edmund Steward, the chancellor of Winchester. But on 3 I March William Basing, prior of St. Swithun, wrote to Cromwell beseeching his favour 'to a friar named Cosyn, wrongfully vexed in these parts.' Soon after a testimonial in Cosyn's favour was forwarded to the same quarter by certain gentlemen and yeomen of Winchester. The result was that on 24 April, Hilsey, the ex-friar who had just been madc Bishop of Rochester, wrote to Dr. Steward informing him that 'Mr. Secretary' had discharged Prior Cosyn, and allowed him 'to use his licence to preach by the authority granted to him by the king, our supreme head next to Christ.' $^{3}$

Cosyn appears to have resigned the priorship, and was succeeded by Richard Chessam, D.D., who was prior when the convent was suppressed in $153^{8}$, as already set forth in detail.

Richard Ingworth, the suffragan bishop of Dover, as commissioner for suppressing the friars, forwarded to Cromwell an inventory of all the goods of the Winchester Dominicans, with their value as appraised by Alderman Burkyn and Master Knight, chosen by the mayor. The inventory, as might be expected of a convent of friars, is a singularly poor and simple one and therefore does them much credit. So few friars' inventories remain that it is well to give it in extenso ; it is somewhat surprising to find a pair of organs in a church so sparsely furnished. The church goods were :-

Viij corporas caasys wythout the corporas, $x x d$. ; iiij surpelys, ijs. ; v Coopys for men and ij for chyldren, xijs.; a sute of dune sylke wythout albys, amycis, or stoolys, iijs.; Item, deakyn and subdeakyn of whyet branchyd sylke, without albys, amycis, or stoolys, iijs. iiijd.; a sewte of Whyet chamlet lacking deakyn, xiijs. iiijd.; a syngle vestyment of the same, iiijs.; a complet sute of

J Cott. MSS. Cleop. E. iv. 127 ; Cleop. E. vi. 257 ; Letters and Papers, Hen. VIII. x. 512 , 513,588 .

Supra, p. 58 


\section{RELIGIOUS HOUSES}

Whyet bustyan, lacking ij albys, viijs. ; iiij syngle vestyments of the same viijs.; a sewte of red sylke xs.; a sewte of blue sylke xvjs. ; a sewte of coarse grene $x$ s.; a complete sute of dune sylke without albs, vjs. iiijd. ; a syngle vestyment of blue satten, iijs. iiijd. ; ix vestyments without albys or stoolys, x. ; ye hangyngs of ye quere, vjd.; a paynted clothe for the Rode, xijd.; a frontelet, $\mathrm{xxd}$. ; an albe, xijd. ; iij aulter clothys, xiiijd. ; ij frontelets, viijd. ; ij candelstycks, viijd. ; a payre of organs, vs.; an altare (sic) of nedylwerke, $x s$.

The house contained :-

iij fether bedds with iij bolstors $\mathrm{ij}$ pillows and $\mathrm{j}$ pillow bere and one blankett, xvjs. viijd. ; vj payre of scheytts, iijs. ; vj Coverletts, xviijd.; a flocke bedde and a mattres, ijs. iiijd. ; ye hangyngs and ye tester in ye provyncyalls chamber, iijs.; iij table clothys, j towell, ij tabylls, v cliearys, ij joyned stooles, $j$ cupburde, and $j$ oyst' borde, iij formys, j long cheyar, vijs.; a chafyng dysche, vjd.; a possenet, xijd.; a pan and a kettell, xijd; iij platters, iij pottyngers, $j$ sauser, and iij dysshes, vjs. viijd. ; a colender, ij candelstycks, and a salte, xiiijd.; ij dryppyng panys, a fryeng pan, and a gyrdyren, ijs. ; iij broochys, ijs. ; iij brasse potts, vjs. viijd.; a baasen and an ewer of laten, xvjd. ; iiij Cobyrons, iiijs. ; a yeryn and hangells to hange on potts, xiiijd. ; ij handyryns, vjd.

A special chamber assigned for the use of the English provincial points to this convent being considered one of importance in the Order. The total value of church and house goods came to only $f 9$ 15s. $2 d$. To the inventory is appended a note in the suffragan's handwriting to the effect that 'thys house with ye stuff is in the custody of Master Arthur Roby and a chalis with it. Richard Dovoren.'

The church and the buildings of the cloister, the prior's lodging ( $20 \mathrm{ft}$. in length by $16 \mathrm{ft}$. in breadth), with the churchyard, gardens and all within the precincts, were let by the Crown to Arthur Roby, a fuller of Winchester, for 20s. a year. In 1543 , Winchester College, by exchange, became possessed of the site of all the four Winchester friaries. ${ }^{2}$

\section{Priors or Wardens of the Dominicans OF W INCHESTER}

Matthew, 1242

William de Southampton, elected provincial, 1 272, died 1278

Robert de Bromyard, about 1300

Nicholas de Stratton, about 1306

William de Horleye, 1326

Thomas de Lisle

1 Misc. Books, Excheq. T.R. cliii.

2 Mins. Acc. 30-1, Hen. VIII. I 36 ; Partic. for Grants, 35 Hen. VIII. ; Pat. 35 Hen. VIII. m. 16.
John Payne, I 373

John Derle, 1377,1387

Nicholas Monk, $1404-26$

Walter Alton, 1455

James Cosyn, in the time of Hen. VIII.

Richard Chessam, $153^{8}$

\section{THE HOUSE OF THE FRAN- CISCANS OF WINCHESTER}

There is but little to be added to what has already been stated in the Ecclesiastical History with regard to the coming of the Franciscans to Winchester, their recognition by the bishops as diocesan penitentiaries and preachers, and the dissolution of their house through the agency of the ex-friar Richard Ingworth. Their church was dedicated to St. Francis.

On 4 May, 1278, the keeper of the forest of Ashley received orders to supply the friarsminors of Winchester with four oak stumps for their fuel of the king's gift. ${ }^{3}$

During the episcopate of Bishop Sandale (1316-23), three acolytes, three sub-deacons, one deacon and two priests were ordained from the Franciscan house at Winchester. During the episcopate of Bishop Asserio (1320-3), five acolytes, three sub-deacons, four deacons and six priests were ordained from this convent.

In April, 1330, the pope sent his mandate to the bishops of Winchester, Lichfield and London, directing that the body of Edmund, Earl of Kent, on the petition of Edmund, his elder son, and of Margaret his widow, should be exhumed from the Franciscan church at Winchester and be buried at Westminster; the earl having provided by will that the place of his burial should be left to his widow.

The Franciscans, or 'Graye frearys of Wynchester,' had their goods appraised at the same time as the Dominicans. The inventory which seems to betoken a larger church than that of the Black Friars, is as follows :-

A paule and a fruntlet, xijd.; ij alter clothys, xviijd.; iiij crossys, ijs.; ij seynt Johns headys ijd.; j paxe of copper, xvjd. ; ij paxyes of wodd, iiijd.; ij pyllows of sylke, viijd.; ij small candelstyckes, $\mathbf{x} d$. ; a crysmatorye, $\mathbf{1} d$. ; a desk and a masse boke (nil); ij great candelstyckes, iiijs. ; Item an holy-watter stope, $x d$.; Item a lampe hangynge, xijd.; ij cheyrys for ye quiere, viijd. The Valans. Item a paule and a fruntlet, ijd.; ij altar clothys, vjd.; ij candelstyckes, vid.

Saynt Clementtes altar. Item a paule and a fruntlet, vjd. ; ij altar clothes, vjd.; $\mathrm{j}$ candelstycke, viijd. ; j payr of crewettes, $\mathrm{ij} d$.

${ }^{3}$ Close, 6 Edw. I. m. 10.

4 Cal. of Papal Letters, ii. 349. 


\section{A HISTORY OF HAMPSHIRE}

Saynt Fraunces altar. Item a paule and a fruntlet, iiijd.; Item ij altar clothes, iiijd.; a candelstyck, iijd.; ij crewettes, ijd.

In ye vestry. Item xviij corporasseys, iijs.; iij sudorys, iiijd.; ij panles, vjd.; v. fruntlettes, $\mathrm{xxd}$.; $\mathrm{j}$ small towell, $\mathrm{j} d$.; I tem a cuscheynge of golde, $\mathbf{x x d}$. ; Item $v$ settes of vestymenttes, xxviijs. ; Item ij syngle vestymenttes of Requiem, iijs.; Item xiiij syngle vestymenttes with amys and without, xvjs. viijd.; A sewt of Requiem withont albys, ijs.; Item ij grene tewnakyllys (tunicles) without albys, xvjd.; ij great altar clothys and ij small, xiiijd. ; Item vj surples and v coopes, xxxs. ; vij lent clothes, vjs. viijd. ; ij super altares (nil); Item iij small albys, xxd.; Item iij flock beddys and a mattres (nil); vj busshels of whete ; Item a payre of old organes, iiijs.

Kechyn. Item ix platters, iiijs. ; iiij dysshys and iiij sawsers, xxd.; ix eyrye (iron) dyssheys, xvjd. ; a chaffer with ij eyrys, ijs. ijd.; Item iij skcllets, xxd. ; Item iij panys, ijs.; Item ij kettels, xijd.; ij fryying panys, ijs.; Item a chaffer, ijs. ; ij broochys, $x d$. ; ij awndyryins, xviijd.; a dryppyng pane, iiijd.; ij trevetts, vjd. ; Item ij gyrdyrynes, vjd.; Item ij pothokes, iiijd. ; Item iij hangars to hang pottes on, xijd.; Item a colendar, iijd.; Item a chaffyng dysche, vjd.; Item vj pottes small and great, ixs.; Item a great yren, xvjd. ; Item a furnes, vs. $\mathrm{xxd}$.

The Buttrey. Item ij tabylclothys and a towell,

In Mayster Denhamys chamber. Item a fether bed a bolster and a coverlet, vs.; Item ij cuschyenes, iiijs. ; Item a tester with ij curteynes, xijd. ; Item ij baasyns and ij ewers, iijs. iiijd. ; Item a pewter bassyn and ij pottes, xijd.; Item iij candelstyckes, xiiijd.; Item a carpett, ijd. ; Item a counter, ijs. ; Item a cobborde, ijs. ; Item a chayrc, iijd. Summa ix li. iijd. ${ }^{1}$

There were debts on the house to the amount of $\mathrm{I} 6 \mathrm{~s}$.

The site, with those of the other friaries, came into the hands of Winchester College.

\section{THE HOUSE OF THE AUSTIN FRIARS OF WINCHESTER}

There is but little to add to what has been said in the Ecclesiastical History with respect to the establishment of the Austin friars, or friars-hermits of St. Augustine at Winchester in the reign of Edward I.

In 1302, Geoffrey Spiring of Fareham gave to the Austin friars a messuage in the suburb of Winchester for the enlargement of their area $;^{2}$ and in 1313 , Hugh Tripacy granted them a plot of land, I 2 perches long by 6 perches wide, adjoining their dwelling place, for further enlargement. ${ }^{3}$

1 Misc. Books, Excheq. T.R. cliii.

2 Pat. 30 Edw. I. m. 2 r.

${ }^{3}$ Ibid. 7 Edw. II. p. I, m. 8.
Bishop Sandale (1316-20) ordained three friars from the Austin house at Winchester; and his successor, Bishop Asserio (1320-3), the like number.

In July, 1328 , the grant of the Bishop of Winchester to the Austin friars of the lane called Sevenetwychene, in the south suburb without the walls contiguous to their house, for the enlargement of the site, was confirmed by the king. ${ }^{4}$

In June, I 343, Pope Clement VI. instructed the Bishop of Winchester to grant licence to the prior and Austin friars of Winchester to accept a manse in the city given them by Oliver Bohun, knight, and Margaret his wife with King Edward's licence, and thither to transfer themselves, and build a church and necessary offices; their place without Southgate being in a dangerous, lone and unfit site. ${ }^{5}$ The bishop however, for certain reasons, opposed this removal ; but in May, I 346 , the prior received the pope's sanction to at once proceed to the new site without any longer waiting for the consent of the diocesan. ${ }^{8}$ Milner says that the site of this house after its removal was opposite St. Michael's church, in a close called College Mead.

The following is the meagre inventory of the goods of the friars taken at the time of the dissolution of the house.

$\mathrm{M}^{\mathrm{d}}$ this stuffe under wryttyn ys praysed by Mayster Burkyn, alderman of Wynchester and Mayster Knyght at the mayorys assygnacion by ye syght of the kynges vysytor under the lorde privye seal for ye kynges grace the whyche longyd to the austen frearys, that is to say : iiij great candelstykes ij small, a stop (sic) and copper crosse about an $\mathrm{C}$ and an halfe, vjs. viijd.; Wyll'm Alen berebrewar axythe for bere; iiij aulter clothys, ijs. iiijd.; ij payntyd clothys, $\mathrm{x} d$. ; a sensor, $\mathrm{xvj} d$. ; iiij antepaynys, $x x d . ; 2$ surpples and a rochet, viijd.; vj coupys, xiijs. iiijd.; ij towellys, ijd.; a myeter, jd.; ij small crossys coveryd with sylver, iijs. iiijd. ; a banner clothe, viijd.; ij quysshons, xijd.; iiij corporasys with the casys, xvjd. ; a sute of grene wantynge an albe, vs.; viij vestymenttes with ther albes, xxs.; a crosse and a laten baason and a paxe, iiijs.; ij deske clothys, $\mathbf{x} d$.; viij lent clothys, iijs. viijd.; iij chests, ijs. ; a paxse, ijd.; iij fether beedes and a bolster, ixs.; ij coverys, vjd.; iiij brasse pottes and ij panys, xvjs. ; ij cobyrons a trevet-a pothooke a hoke eyaryn (iron), xviijd.; a bason, ij coverys, ij borddes, xxd. Summa vii. vijs. ixd.?

There were debts on the house to the amount of 27 s.

4 Ibid. Edw. III. p. 2, m. 29

- Cal. of Papal Letters, iii. 85.

${ }^{6}$ Ibid. iii. IgI.

7 Misc. Books, Excheq. T.R. cliii. 


\section{RELIGIOUS HOUSES}

\section{THE HOUSE OF THE CARMEL- ITES OF WINCHESTER}

Of the Carmelite house that stood near that of the Austin friars which was founded in 1278 and dedicated to the Blessed Virgin, there is little to chronicle.

It seems to have been only a small establishment. Bishop Sandale ordained six from this convent, and Bishop Asserio three.

At its suppression, the dwelling and the land on which it stood only realized a rental of 6s. $8 d$. yearly.

There is no inventory extant of the Winchester Carmelites. Apparently they were dispersed before Richard Ingworth's visitation.

\section{THE FRANCISCANS OF SOUTHAMPTON}

The Franciscans or Grey Friars were established at Southampton probably as early as 1237, as it would appear by certain deeds printed by Madox. ${ }^{1}$ The convent at Southampton must therefore have been among the earliest of their English houses, for they were not introduced into this country until 1224. Their house was in the midst of the poor, and closely adjoined God's House. The Franciscans were forbidden by their original rule to have more substantial buildings than those made of clay and timber, but the goodwill of the Southampton burgesses soon supplied them with a cloister of stone. On this coming to the knowledge of Albert of Pisa, the provincial of England, about 1236, he insisted on the destruction of so strong a building and carried his point. ${ }^{2}$

In the middle of the eighteenth century, there existed a brief register of this convent among the corporation archives of Southampton, but it has long been missing. Fortunately Dr. Speed made a transcript of the more important parts, and they are reproduced by $\mathrm{Mr}$. Davies in his admirable history of Southampton. $^{3}$

Isabel de Chekebull, who granted the site for the building, was considered the chief founder; she died in 1253 . Walter le Flemyng, bailiff of the town in 1237 , was one of the earliest benefactors. The first stone of the chapel was laid on $8 \mathrm{July}, 1280$, the rigidity of the rule as to building being now relaxed, it was first used on the feast of St. Francis, 16 July, 1287. This chapel or church must have been of considerable size, for Bishop Sandale held a large ordination therein on 26 February, 1317." Interments within the church were much sought after by the burgesses, from whom the friars received many small bequests. On Christmas Day, I 29I, the friars entered their new dorter, and in the same year their chapter house was built.

In 1290 the convent was granted a water supply by Nicholas de Barbeflet from his manor of Shirley ; but it was not until I 304 that they began to bring the water down to their house. In 1 374, John le Fouster and William Putton obtained licence for giving the convent a toft with its appurtenances for the enlargement of their premises ; ${ }^{5}$ and in April, I 368 , the friars obtained licence for adding to their cemetery an area of 120 feet by 100 feet, to the west of their church ; it was consecrated by Thomas, Bishop of Achaden, acting as suffragan for Wykeham. ${ }^{\circ}$

Prior Robert Horewood, in I 420, conveyed to the town all the rights of his house in the conduit-head and pipes for the supply of water. ${ }^{7}$

In July, I 499, this Franciscan house was changed by Henry VII. into a house of the reformed order of Observant Franciscans. The curious story of the resistance to a wouldbe visitor in 1534 has already been told. ${ }^{8}$

After the dissolution the site passed by purchase, in 1545 , to John Pollard and William Byrt, and in 1551 to Sir A. Darcy. Nothing is now left of the priory buildings.

Priors or Wardens of the Franciscans OF SOUTHampton

Jordan de Downton, about I 326

Robert Horewood, ${ }^{10}$ about 1420

\section{HOSPITALS}

\section{THE HOSPITAL OF ST. CROSS, NEAR WINCHESTER}

The far-famed hospital of St. Cross, which still stands about a mile from Winchester, between the Itchen and the Southampton road, was founded about I 36 by Bishop Henry de Blois.

1 Madox's Formulare Anglicanum, 196, 279, and Davies, Hist. of Southampton, 442.

2 Monumenta Franciscana, Rolls Series, 55.

3 Davies, Hist. of Soutbampton, pp. 444-8.

II
The small chartulary, or register of St. Cross, still extant, ${ }^{11}$ gives copies of two bulls confirm-

4 Winton. Epis. Reg., Sandale, ff. 52, 52b; not on 18 March, 1317 , as stated by Davies.

5 Pat. 48. Edw. III. pt. 1, m. 8.

- Winton. Epis. Reg., Wykeham, iii. f. 194.

7 Davies, Hist. of Southamptor, p. 115.

8 Supra, p. 54.

- Winton. Epis. Reg., Stratford, p. 15.

10 Davies, Hist. of Southampton, p. 115.

11 Harl. MS. 1616; a thin 8vo volume. 


\section{A HISTORY OF HAMPSHIRE}

ing the foundation of the hospital ; one was granted by Innocent II. in I 137 , and the other by Lucius II. in I 144. The charter of the founder delivered to Raymond, prior of the Knights Hospitallers, the hospital founded for the weal of his soul and those of his predecessors and the kings of England, and provided for the reception, clothing and entertaining of 'thirteen poor impotent men, so reduced in strength as rarely or never to be able to raise themselves without the assistance of another.' In addition to this a hundred other poor men of good conduct were to be entertained daily at dinner, and permitted, on departure, to take away with them the remnants of both meat and drink. ${ }^{1}$ The first master mentioned, in a grant of Bishop Blois, was Robert de Limosia.

Serious disputes arose with respect to this hospital during the next episcopacy (Richard of Ilchester, I I 74-88), between the bishop and the Hospitallers. At length, on ro April, II 85 , the Order formally gave up the management to the diocesan, ${ }^{2}$ by which agreement the bishop undertook to provide daily for 200 men instead of the original 100 . The chartulary shows however that the Order of Hospitallers did their best to recover the management, and actually obtained two papal awards in their favour of the years 1187 and 1189 . In I 197, Pope Celestine III. commissioned the Bishops of London and Lincoln and the abbot of Reading to settle the dispute, and they gave their award in favour of the bishop. Nevertheless, only two years later King John again confirmed the hospital to the Hospitallers. ${ }^{3}$

The decision however of the papal commissioners was upheld, and in 1204 the Bishop of Winchester appointed a master, which right has since been maintained by the bishops down to the present day. The Hospitallers nevertheless clung to the muniments and records until 1379, when the energetic Bishop Wykeham obtained them from Prior Robert Hales. The prolonged dispute as to the valuable patronage of this hospital had seriously impeded the intentions of the founder, and delayed its completion. The great church was not finished until the year 1255, when special appeals were made for assistance.

The gross mismanagement of this grandly

1 This charter is in Bishop Stratford's register (f. 186b), as well as in the chartulary. It has been rendered into English in the 37 th Report of the Charity Commissioners, and reproduced in Notes and Queries, 1 st ser. xi. 42.

2 Harl. MS. 1616, f. 27.

3 Charter Roll, Fohn (Rec. Com.), 16.

- Harl. MS. 1616, ff. 10, 29. conceived foundation, and the alienation of so large a share of its funds from the poor to wealthy pluralists, which made the mastership of St. Cross a scandal and a byword for full six centuries, began at an early date.

On 16 June, I321, the Bishop of Winchester received orders from the king to induct the king's clerk, Geoffrey de Welleford, to the house of St. Cross, which he had deferred doing, although he had verbally admitted Geoffrey at the king's presentation; pretending that the house was filled by Robert de Maidstone, the king having ordered him to admit a suitable person notwithstanding the claim of the late Bishop of Winchester, because the king had recovered in his court the presentation by reason of the late voidance of that bishopric. The obedient prelate duly inducted Geoffrey, for the second time, by proxy, on 26 June. ${ }^{8}$ This was followed on 28 June by a more imperative order to the bishop, telling him to certify by the bearer if any further resistance should be offered; as the king was informed that when the bishop ordered his commissary to induct Geoffrey's proctor, the commissary found many persons at the house who actively resisted him so that he could not execute the order. The resistance continued, and on 3 July the bishop made a third induction of Geoffrey, with a solemn warning to all who should resist. On 12 July the sheriff of Hampshire was ordered to take with him sufficient power of the county, and to go in person to the house of Holy Cross, and to the churches annexed thereto, and to remove all lay or armed force from the house and churches, and to put Geoffrey de Welleford in possession. He was further instructed to imprison any one resisting the execution of the order. In this mandate it was also recited that the sheriff's bailiff had reported that he visited the house on Friday after the Translation of St. Thomas to remove all lay or armed force, and that he found no force nor resistance, and therefore did nothing in the matter, 'at which answer the king marvels, especially as it is testified before him by trustworthy men that a lay and armed force was then and is still in the house of St. Cross, and that the bailiff's answer was made frivolously and derisively. ${ }^{8} \quad$ The king's next step, in this determined assertion of his authority and rights, was to prohibit the archbishop from attempting anything prejudicial thereto. A further writ on the same subject was addressed to the

${ }^{5}$ Close, 14 Edw. II. m. 2 d.

( Winton. Epis. Reg., Asserio, f. 15.

7 Close, 14 Edw. II. m. Id.

8 Ibid. 15 Edw. II. m. I 3 d. 


\section{RELIGIOUS HOUSES}

archbishop on 23 October. ${ }^{1}$ On 4 September a commission of oyer and terminer was granted on the complaint of Geoffrey de Welleford, that, after due induction, Robert de Maidstone, Nicholas his brother, and divers other persons, had taken and carried, of the hospital property, livestock to the value of $\oint_{\mathrm{I}} \mathrm{Oo}$, goods and chattels to a like amount, as well as charters and muniments. A second commission, dated 6 November, particularizes the missing property, and increases its value to the then great sum of $£ 500 .^{2}$

The bishop, on 9 February, 1322 , issued a commission of inquiry relative to the dilapidation of St. Cross on the entry of Geoffrey de Welleford. ${ }^{3}$ On I I March, Geoffrey, by proxy, promised canonical obedience, as master of St. Cross, to his diocesan." Geoffrey, who had been thus stormily thrust into this valuable mastership, died in August, I 322, having never apparently set foot in the diocese. Bishop Asserio was now able to make an appointment of his own ; but it was no improvement on that of the king. His choice for this valuable and important preferment fell on his nephew, Bertrand de Asserio, a clerk of the diocese of Cahors. He was collated, inducted and instituted (by proxy) on 31 August, 1322, by his brother Gerald de Asserio, vicar-general, in the absence at the Roman court of the bishop. ${ }^{5}$ There seems no reason to imagine that Bertrand ever saw the hospital of which he was the master, although he held it with a rectory in the diocese (Freshwater, Isle of Wight), and a prebend of Salisbury. In August, 1330, Bertrand, as warden of St. Cross, nominated attorneys to act for him, as he was going across the seas for two years. ${ }^{6}$

Provision of the hospital was made in 1333 , by Pope John XXII., to Peter de Galliciano, void by the resignation of Bertrand de Asserio, who had exchanged it for other benefices out of England." Meanwhile Bishop Stratford endeavoured to checkmate the papal appointment by sequestrating the hospital property on the ground of the blindness and inability of the new master, and there ensued a strife between ecclesiastical and civil authorities to the great bewilderment of the tenantry, ${ }^{8}$ the sheriff being called upon in October, 1334 , to assist Peter de

1 Cant. Archiep. Reg., Reynold, ff. 300, 301.

2 Pat. 15 Edw. I1. pt. 1, m. I5d.

3 Winton. Epis. Reg., Asserio, f. 21 b.

Ibid. f. 22

5 Ibid. f. I 8 b.

- Pat. 4 Edw. III. pt. I, m. 10.

7 Cal. of Papal Letters, ii. 385.

- Winton. Epis. Reg., Stratford, f. 78 .
Galliciano, the master, in levying rents due to him. ${ }^{9}$

In I 344, the bishop petitioned Clement VI., signifying that when the hospital of his collation was vacant, he made provision of it to William Edingdon, the king's treasurer, who restored the buildings and improved the condition of the poor therein, spending $£ 1,000$; but on the report that the late Peter de Galliciano, master of the hospital, was chaplain to Clement V., and that the hospital was therefore reserved to the pope, of which the bishop was ignorant, he prayed the pope to declare valid the appointment of William and all that he had done. To this the pope assented, and remitted the fruits he had received. ${ }^{10}$ In the following year Edingdon became bishop, and the pope appointed Raymond Pelegrini, papal nuncio, to the mastership of St. Cross, which was declared to be worth $\oint_{6} 13 s .4 d .^{11}$ Raymond resigned in 1346, and was followed by Richard de Lusteshall and Walter de Wetwang; both of which appointments were brief and disputed.

In 1346 Bishop Edingdon appointed his nephew John Edingdon, a mere lad, to the mastership, who of course neglected all the duties pertaining to his office as grossly as his predecessors. ${ }^{12}$ Provision was made in June, I 348 , of the hospital by the pope, to William de Farlee, notwithstanding his holding canonries and prebends of Winchester, Romsey and Salisbury. ${ }^{13}$ But in 1349 the bishop signified the pope that he had given St. Cross to John Edingdon, his nephew, who was under age, and already held two benefices, there being an ordinance in the foundation that it could be given to secular clerks; but that as it was reported that the pope had reserved the same before Richard's death, he prayed him to confirm the collation. The petition was granted.

In 1366 , Edingdon, having stripped the hospital and its estates, resigned, soon after his uncle's death, and was followed, on exchange, by William Stowell, who in his turn exchanged the mastership in March, 1368 , with Richard de Lyntesford, for the rectory of Burghclere. ${ }^{14}$ In August, 1370, Lyntesford exchanged the

9 Close, 8 Edw. III. m. Iod.

10 Cal. of Papal Petitions, i. 51.

11 Ibid. i. 90.

12 For the evil character of John Edingdon, and the manifold preferments conferred on him by his uncle, see Wilts Arch. Mag. xx. In 1368 he was cited to appear in the bishop's court for having embezzled the materials purchased by his predecessor for rebuilding the chancel of the church of Farnham, of which he was then rector.

${ }_{13}$ Cal. of Papal Petitions, i. 131.

14 Winton. Epis. Reg., Wykeham, i. f. 9. 


\section{A HISTORY OF HAMPSHIRE}

mastership with Roger Cloun for the rectory of Campsall, Yorkshire. ${ }^{1}$

The scandals of St. Cross were now to be arrested. Bishop Wykeham was a very different diocesan to his predecessors. Stowell resigned on 22 March, 1368 , and on the following day the bishop demanded of him an inventory of the stock received by him from Edingdon and handed over to Lyntesford. ${ }^{2}$ The story is a piteous one; whilst episcopal and royal and papal nominees to this benefice were spending the hospital's incomes in their own selfish ways, the great hall had fallen in, the hundred poor were ejected from their daily meal, and the thirteen infirm inmates were turned away to seek shelter where they could.

From 1368 to I 375 Bishop Wykeham, with rare persistency, followed up the iniquities of the four living masters, and at last gained the victory. ${ }^{3}$ On 6 January, 1375, Cloun made his submission to the bishop, and swore he would render an annual account to his diocesan whenever called upon to do so." The bishop however was now strong enough to refuse the master any power of administration, and put in a relative of his own, Nicholas Wykeham, to superintend the affairs of the hospital. By this arrangement further peculation was prevented, the buildings began to be repaired, and the endowments mainly used for the poor. In $3^{82}$, Roger Cloun, the nominal master, died, and $W_{y k}$ eham appointed his great friend John de Campeden, rector of Cheriton, to the mastership. ${ }^{5}$

Wykeham's successor, Cardinal Beaufort (1 404-47), with the consent of Thomas Forest, then master, and the brethren, added, in 1445 , to the original foundation a hospital or almshouse of 'Noble Poverty,' the buildings of which were to be erected to the west of the church. ${ }^{6}$ The troublous times and the triumph of the Yorkists prevented his intentions being carried out in his lifetime, and it was left to Bishop Waynflete to further to some extent the cardinal's intentions. The bishop procured an enabling charter in 1455 , but it was not until 1486 that he carried out his plan and remodelled the statutes. ${ }^{7}$ The cardinal's intended endowments were lost, so that the

1 Winton. Epis. Reg., Wykeham, i. f. 25.

2 Ibid. iii. f. 9 a.

${ }^{3}$ Mr. T. F. Kirby has conveniently gathered all the instruments relative to this at the beginning of the 2 nd vol. of Wykebam's Registers (Hants Record Series, 1899), pp. 28-59. See also Moberley's Wykebem, ch. v. and Harl. MS. 1616.

- Winton. Epis. Reg., Wykeham, iii. f. 103.

s Ibid. i. f. 131.

- Pat. 33 Hen. VI. pt. 2, m. 18.

7 Winton. Epis. Reg., Waynflete, ii. f. 132. additional foundation, designed for two priests, thirty-five brethren and three sisters, was reduced to one priest and two brethren. Those of the new foundation wore a cloak of deep red with a cardinal's hat embroidered in white ; whilst those of the old foundation retained the black cloak, with silver cross-potent, as ordained by the Hospitallers.

The Reformation made but little change at St. Cross. The hospital, though threatened in the time of Henry VIII., escaped confiscation. At a visitation held by Dr. Legh, as Cromwell's commissary, in $\mathbf{1 5 3 5}$, it was directed that the thirteen brethren should receive sufficient meat and drink and not money in lieu thereof, and that the 100 men be daily fed, but sturdy beggars repulsed.

It was further ordained that some discreet and honest priest of the house should hear and teach the poor brethren the Our Father and the Creed in English, which they were to say together in the church before dinner; that the master was to have a library in the house which was to contain printed volumes of the Old and New Testaments and the works of Jerome, Augustine, Theophylact and others of the most ancient fathers; and that mass was to be said for the soul of the founder and for the good estates of the king and Queen Anne. ${ }^{8}$

In 1696 , when Dr. Markland was master, it was alleged that all documents and registers pertaining to the hospital had been burnt, and a 'customary' (consuetudinarium) was drawn up by the master for its future management, and ratified by the bishop. When the scandals of the abuse of this charity were brought before the Queen's Bench in 1851, the judge in delivering judgment described this 'customary' as a 'barefaced and shameless document' and 'a wilful breach of trust.' He was equally severe on the nineteenth century continuation of the scandal. The present wholesome scheme was devised in I 855-7.

\section{Masters of the Hospital of St. Cross, WINCHESTER ${ }^{\circ}$}

Robert de Limosia, I1 36 ?

Roger, 1185

Alan de Sancta Cruse, ${ }^{10}$ I 190

Alan de Stoke, appointed 1204

${ }^{8}$ Woodward's Hist. of Hents, i. 235 ; and Humbert's Memorials of the Hospital of St. Cross, pp. 37,38 .

9 Many of the names of the masters have been obtained from the register of the hospital (Harl. MS. 1616).

${ }_{10}$ Dean and Chap. of St. Paul, Charter 291. 


\section{RELIGIOUS HOUSES}

Henry de Cusia or Susa, ${ }^{1}$ appointed I 24I

Geoffrey de Fernyng, appointed 1250

Thomas de Colchester, appointed 1260

Stephen de Wotton, died 1275

Peter de Sancta Maria, archdeacon of Surrey, 1289-96

William de Welynger or Wendling

Robert de Maidstone, ${ }^{2}$ I 305-20

Geoffrey de Welleford, ${ }^{3}$ 1321-2

Bertrand de Asserio, ${ }^{4}$ 1322-33

Peter de Galliciano, ${ }^{5}$ I 333

William de Edingdon, High Treasurer of England, ${ }^{\circ}$ 1335-45

Raymond Pelegrini, papal nuncio, ${ }^{7}$ I $345-6$

Richard de Lusteshall

Walter de Wetwang

John Edingdon, 1346-66

William Stowell, $1366-8$

Richard de Lyntesford, ${ }^{8}$ 1 368-70

Roger de Cloune, ${ }^{9}$ 1 $370-82$

John de Campeden, ${ }^{10}$ I $382-1426$

John Forest, 1426-44

Thomas Forest, 1444

Thomas Chandler, warden of New College, 1463-5

William Westbury, provost of Eton, 1465

Richard Hayward, died 1489

John Lichfield, I489-9I

Robert Sherborne, 1 491-1500?

Richard Fox, Bishop of Winchester, I 500-I 7

John Claymond, President of Magdalene and Corpus Christi Colleges, appointed 1517

John Incent, appointed $1524^{11}$

William Meadow, 1545

John Leefe, 1557

Robert Reynolds, I 557

John Watson, 1559

Robert Bennett, 1583

1 He was afterwards Cardinal Bishop of Ostia, and one of the most famous canonists of the middle ages.

2 Cal. of Papal Letters, ii. 3. He also held two rectories and a canonry of Chichester. He was deprived in 12 June, 1321.

3 Winton. Epis. Reg., Asserio, ff. 14 b, 15.

1 Ibid. f. 18 b.

- Cal. of Papal Letters, ii. 385 . Provided by Pope John XXII. on the resignation of Asserio.

Pat. 9 Edw. III. pt. I, m. 28. Promoted to the see of Winchester in 1345 .

7 Cal. of Papal Petitions, i. 9o. He resigned in 1346.

${ }^{8}$ Winton. Epis. Reg., Wykeham, i. f. 9.

Ibid. f. 25 .

10 Ibid. f. $13 \mathrm{r}$.

11 He was dean of St. Paul's from 1540 to I 545 , during which time he still held the mastership of St. Cross (Letters and Papers, Hen. VIII. xiv. [2] 3 10.) He was also master of God's House, Portsnouth.
Arthur Lake, 1603

Sir Peter Young, 1616

William Lewis, 1627

John Lisle, I649

John Cooke, 1657

Richard Shute, 1660

William Lewis, 1660

Henry Compton, 1667

William Harrison, 1675

Abraham Markland, 1694

John Lynch, I 728

John Hoadley, 1760

Beilby Porteus, 1776

John Lockman, 1788

Francis North, 1808

L. M. Humbert, ${ }^{12}$ I 855

W. G. Andrewes, I 868

\section{THE HOSPITAL OF ST. MARY MAGDALEN, WINCHESTER}

The original site of the hospital of St. Mary Magdalen was about a mile due east of Winchester, on the down which was called after it Magdalen Hill, now Morne Hill. It does not seem to be possible to trace its first foundation with any certainty, although the cumulative presumptions in favour of Bishop Ilchester (1174-89) being the founder, ingeniously put forth by Dr. Milner, ${ }^{13}$ seem highly probable. Moreover the elaborate drawings made of the remains of its chapel by $\mathrm{Mr}$. Schnebbelie, ${ }^{14}$ in 1788 , corroborate this view, as they show that the main work was apparently late in the Norman style. The first mention of the hospital occurs in the register of Bishop Pontoise (1 280-1 304), where it is named in a list of benefices of which the Bishops of Winchester had been patrons for a long time. ${ }^{15}$ It is mentioned once in Stratford's register, under the year 1325, when it is called a hospital for lepers. ${ }^{15}$ Pope John XXII. in I 333 granted a faculty to the prior and chapter of Winchester to appropriate the church of Wonsington, value $£ 40$, out of which, however, $£_{25} 19$ s. $4 d$. was to be paid yearly to the hospital of St. Mary Magdalen, according to the prescription of Henry, late bishop of the see. ${ }^{17}$ The

12 All pains have been taken with the list of masters. It is the fullest yet published. In some of the earlier instances there is a little doubt (see the lists in Woodward's Hants, i. 240-2, and Notes and Queries, Ist ser. x. 299, 473).

13 Milner's Hist. of Winchester, ii. 202-3.

14 Vetusto Monumenta (Soc. of Antiquaries), iii. plates I, 2, 3 .

16 Winton. Epis. Reg., Pontoise, f. 107.

16 Ibid. Stratford, f. 13.

17 Cal. of Papal Letters, ii. 381. 


\section{A HISTORY OF HAMPSHIRE}

foundation at that time consisted of a priest (master) and nine poor brethren and nine poor sisters.

On 8 September, 1334, the keepers of the temporalities of the see of Winchester, then in the king's hands, were directed to pay to the master and paupers of the hospital of St. Mary Magdalen on the hill, the arrears of a certain fixed sum for their maintenance, as they had been in the habit of receiving such a sum during voidance from the king's progenitors. ${ }^{1}$ In 1336 the taxers and collectors of the tenth and fifteenth in Hampshire were ordered not to molest or aggrieve the master and brethren of the hospital, and to permit them to be quit for that turn, as the hospital was so slenderly endowed that its goods hardly sufficed for the maintenance of the master, brethren and sisters, and of the weak and infirm there, and for other alms according to the foundation. ${ }^{2}$

From Bishop Orlton's registers the interesting fact is established that it was at one time customary for the bishop to collate not only the master, but the various inmates of the house, whether brothers or sisters. Thus in $133^{8}$ Bishop Orlton collated William de Berwick to a portion or share in the house, with all its rights, customs and pittances. In I 339 the bishop collated Margaret Greenway to another portion, which had been held by Henry le Bule, clerk, whilst he remained in the hospital. In 1342 the same bishop collated William de Basynge, clerk, to the perpetual custody of the hospital, assigning to the custodian or master four ' Both in Orlton's and Wykeham's registers the chapel of St. Mary Magdalen is termed a chantry, in consequence of the obligations that rested on the priest and brethren and sisters to pray for the souls of the founders and of all the faithful departed.

According to Trussell's MS. history of Winchester, 'The House of St. Mary Magdalene was founded by Maria de Valentia, daughter of Guido, Earle of St. Pawle of Fraunce, wief of Adamore de Valentia, Earle of Pembrokke, in the dayes of Edwarde the Third.' This is of course incorrect, but it may quite possibly refer to some special benefaction, or scheme of refounding. Certain it is that there was a considerable architectural reconstruction of the

1 Pat. 8 Edw. III. m. 17.

2 Ibid. 10 Edw. III. m. I7.

Winton. Epis. Reg., Orlton, i. ff. 73, 92 ; ii. f. 67 .

- Cited in Woodward's Hist. of Hants, i. hospital in the first half of the fourteenth century.

In 1394, John Melton, who was the first schoolmaster of Winchester College, was collated by Bishop Wykeham to the wardenship of the hospital and chantry, to which, as again stated, was assigned the share of four 'greater portions.' ${ }^{\text {'S }}$ The form of collation reminded the new master of his obligations, for therein is reference to the 2uia contingit bull of Clement, whereby he was bound to make an annual return of the goods and expenditure of the hospital. In the following year the bishop, on the death of William Chaloner, one of the brethren, collated Roger Muleward to his place; John Melton, the master, was ordered to induct the new brother. ${ }^{\circ} \quad$ Much earlier in his episcopate (1369), Wykeham had collated to this hospital one Adam Coudrich, who is described as aged, weak, poverty stricken, and unable with his own hands to gain a maintenance.

Wykeham was as keen to check abuses on a small scale as those on a larger throughout his diocese. Encouraged by the successful issue of his contention with the great hospital of St. Cross, he next turned his attention to the much humbler foundation of St. Mary Magdalen. On I September, I 400, he appointed John Campeden, Archdeacon of Surrey, and Simon Membury, treasurer of Wolvesey, two of his most trusted friends, as commissioners, with full power to visit and inquire into the condition and administration of this hospital. ${ }^{7}$ The report showed that many 'delinquencies, crimes, and excesses, had been brought to light; and Wykeham' on 20 November of the same year, commissioned Campeden and Membury, together with John Elmore, his official, to punish canonically the offenders, and even to expel the master, or any other delinquent, if justice required it. ${ }^{8}$

Among the Harley MSS. ${ }^{\circ}$ is a portion of a rental of the hospital, with an inventory of the furniture of the chapel and house, taken about 1400 . The receipts were : $£_{2} 5$ I gs. $4 d$. from the treasurer of Wolvesey; $£^{6} 9$ s. $4 d$. from the prior of St. Swithun's; 22s. from the abbot of Hyde; 60s. from the bailiffs of Winchester; and $16 s .3 d$. in rents-yielding a total of $£ 376$ s. IId. These receipts were thus allotted. The sum from Wolvesey was for

243.

- Winton. Epis. Reg., Wykeham, i. f. 23 I.

- Ibid. f. 255 .

7 Ibid. iii. f. 238.

8 Ibid. f. 329.

- Harl. MS. 328 , ff. 26-8. Printed in Vetusia Monumenta, iii. II. 


\section{RELIGIOUS HOUSES}

eighteen persons, $5 d$. a week each for victuals, and 6 s. a year each for clothing. From the entries already cited in the registers of Orlton and Wykeham, it would seem that four of these portions were allotted to the master, and that would reduce the other inmates to fourteen, or seven of each sex. It is quite clear from this and other documents that the episcopal founder of this house originally designed it for eighteen inmates, nine of each sex, and that by the fourteenth century a reduction to fourteen, in addition to the master, had been accomplished. ${ }^{1}$ The sum from St. Swithun's was assigned to ten persons, $3 d$. a week for each, namely three farthings on Sunday and on three week days, and nothing for clothing unless the convent, for love of God, gave them some old clothes. It would seem as if this pension, when originally granted, was intended for the partial relief of ten persons outside the bishop's eighteen. From the same source were supplied four flitches of bacon, namely one on each of the eves of Christmas, Ash Wednesday, Easter and Pentecost. The money from the bailiffs and from Hyde Abbey was for the general support of the brethren and sisters. There were also for the support of the house 14 acres of land, and pasturage for $\mathrm{rOI}$ sheep in the pasture of St. Swithun. The oblations received at the chapel on the festival of St. Mary Magdalen were reserved for the repairs of the house and the walls, save 13 s. $4 d$., which was assigned for the reaping and carrying of their corn. Offerings made at other times were divided equally among the inmates. The warden's stipend is named as consisting of four of the greater portions, that is of those provided from the $\mathbf{W}$ olvesey bequest, and came to 6.515 s. $4 d$.

The ornaments of the chapel included in addition to chalices, crosses, vestments, etc., a rochet for (the image of) Magdalen; an old missal; a new one worth IOOs., the gift of William Basinge, a former master; a great noted portifer, worth 60s. ; two old antiphonars ; a legendary of the saints ; a calendar (temporal) ; three psalters; a collectary; a hymnary; a manual and three graduals; a green carpet powdered with birds and roses; and five banners for carrying at Rogation-tide. The inventory of the brass and pewter in the domestic buildings mentions six houses, besides the master's house.

1 It is not a little curious that Wavell, Milner and Woodward (as well as, of course, their mere copyists) all went wrong about the numbers, and have assumed that the total of poor inmates was nine instead of eighteen.
The visitor, according to the list of questions, was to inquire if the chaplain (master) duly celebrated and said the canonical hours; if he lived chastely and soberly and visited the sick and punished delinquents; if he wasted the hospital's substance, or allowed any destructions of houses or trees; and if he reproved evil livers; whether husbands and wives were cohabiting in the hospital or had a house there; if the clerk served the church and chaplain with due obedience; whether there were any living in common, or in separate houses using their portion in any bad or extravagant way ; if there was any one disobedient, or quarrelsome, or wandering contrary to the statutes; whether the goods of a deceased inmate went to the works of the church after the payment of debts; whether any one was unwilling to submit to the justice and discipline of the master; whether any brother or sister was not living in Christian peace; and finally whether any one entered into the house save through the treasurer of Wolvesey.

It seems highly probable, as the rest of this MS. book pertains to Wykeham, that these are the very list of questions drawn up for the guidance of his commissaries in 1400 . From a study of them it seems obvious that there were at that time six houses, in addition to the master's house, in which lived those inmates who drew major portions, as well as others, namely the ten provided for by the St. Swithun's pension, who lived in a common hall and dorter.

The exact issue of Wykeham's inquiry and correction cannot be now ascertained; but it is fair to assume that the condition of the hospital was materially improved, otherwise he would scarcely have made the hospital a bequest in his will, which was drawn up about two and a half years after the inquiry had been held.

Among testamentary bequests to this hospital may be mentioned 6s. $8 d$. in 1420 , by John Fromond, steward of Winchester College under Wykeham, the words of whose will are: Lego ad distribuendum inter leprosos B. Marie Magdalene, Wynton. ${ }^{2}$ This need not however be taken to prove that the brothers and sisters were all, or even any of them, lepers. Like many another hospital founded for the relief of lepers, as the disease disappeared the inmates were selected from other poor and impotent folk. ${ }^{3}$ The Valor

${ }^{2}$ Arch. Fournal, xvi. I 70.

3 Hist. of Winchester (1773), ii. 177. The two small volumes under this title were published anonymously, but they are known to have been 


\section{A HISTORY OF HAMPSHIRE}

of I 535 gave the gross income as $£ 42$ I 6 s. William Atkinson was at that time master.

Hospitals were not included in the Act of Edward VI. for the dissolution of chantries and other like foundations, and therefore St. Mary Magdalene's does not appear in the certificates taken under this Act, but in the certificate of 1545 its value is entered as E4I 6s. 8d., of which $f_{19} 7$ s. 4d. was divided amongst nine poor men and women. After other payments, there was a balance left for the master and the repair of tenements of II $_{3}$ 9s. $4 d$. The certificate states that the hospital was founded by the Bishop of Winchester 'to pray for the soules of ther founders and all crysten soules.' The great reduction in numbers from eighteen to nine is not such a flagrant instance of mismanagement or peculation as might at first seem to be the case. By far the larger part of the hospital's income came from fixed pensions, and the purchasing power of money had certainly lessened by one half in the course of three and a half centuries.

Dr. Ebden, master of the hospital, by indenture dated 2 September, I6II, gave E 10 annually to be divided at the rate of ${ }_{4} d$. weekly to each of the brethren and sisters, and a gown each at Christmas.

At the time of the great Civil $W$ ar the hospital suffered severely from the king's troops. Out of its little flock of sheep thirty-six were killed by the soldiers, and the remainder had to be conveyed away sixteen miles for safety. Much corn was stolen, and the great gates, doors, barn and stable fittings, in short everything of wood was burnt. Even the furniture of the chapel down to the very holy table were used for fuel, and horses of the troopers were stabled in the sanctuary. The master, brethren and sisters petitioned Lord Hopton, general of the Royalist forces in the west, as to the destitution and misery brought on the inmates. In an order dated I 9 March, I643, the general promised inquiry and redress.

The master and poor folk had not long been in their renovated houses, when the government of Charles II., in I665, chose to seize it as a place of confinement for the Dutch prisoners of war, and to order that the almsfolk were to be removed into lodgings at Winchester at the king's expense. The result was most disastrous; the Dutch prisoners used all the woodwork, including that of the restored chapel, for fuel ; and the

written by the Rev. Mr. Wavell, who was at that time master of this hospital. His account extends from pp. 155-211 in the second volume. chapel bell, and all iron and lead were carried away. In short, the hospital was ruined; and the master, brethren and sisters found it impossible to return when the war was over. The estimate for rebuilding and repairing was $f 650$, but the government would only allow fioo. Dr. Gulston was at that time master. His successor, Dr. Darel, who was also archdeacon of $\mathbf{W}$ inchester, purchased, in 1671, some tenements for the poor outcasts in Colebrook Street, which were left after his death in trust for the use of the hospital. In I 788 the remnants of the old buildings, including the beautiful chapel, still bearing many traces of wall painting, ${ }^{1}$ were pulled down, and the materials used for the erection of six plainly built almshouses on the upper side of Water Lane, in the East Soke.

The old buildings are fully described as well as illustrated in the Vetusta Monumenta. ${ }^{2}$ A view of their original state is given at page I 55 of Mr. Wavell's second volume, before referred to, wherein are shown the chapel with master's house and common rooms adjoining, together with the range of small houses for those who held the major portions.

Masters of the Hospital of St. Mary Magdalen, Winchester

William de Basynge, collated $1342^{3}$

John Melton, collated I $394^{4}$

William Waynflete, $1438^{\circ}$

William Atkinson, I 535

Dr. Ebden, I6 I I

Dr. Gulston, 1665

Dr. Darel, I67 I

Mr. Wavell, 1773

\section{THE HOSPITAL OF ST. JOHN BAPTIST, WINCHESTER}

When Leland visited Winchester, abour $153^{8}$, he saw near the east gate 'a fair Hospital of S. John, wher pore syke people be kept. Ther is yn the Chapelle an Ymage

$1 \mathrm{Mr}$. Schnebbelie's coloured sketches of the most noteworthy parts are in the possession of the Society of Antiquaries. The old Norman west doorway of the chapel has been rebuilt as the entrance to the Roman Catholic Church in St. Peter Street.

3 Vol. iii. plates $1,2$.

3 Winton. Epis. Reg., Orlton, i. ff. 73, 92 ; ii. f. 67 .

4 Ibid. Wykeham, i. f. 23 I.

- Afterwards Bishop of Winchester. See Hist. of Winchester (1773), by Rev. Mr. Wavell, ii. 77 . 


\section{RELIGIOUS HOUSES}

of S. Brinstane, sumtyme Bishop of Wynchester: and I have redde that S. Brinstane founded an Hospitale yn Winchester.' This supposition of so exceptionally early a foundation, though frequently copied as a fact into guide books and local histories, seems to have been a mere guess of Leland's suggested by the sight of the image of Bishop Brinstan.

The real history of the hospital begins with the foundation, about 1275, by John Devenishe, alderman of Winchester, of a hospital or hospice for the relief of sick and lame soldiers, poor pilgrims and wayfaring men, to receive there gratuitous food and lodging for one night or longer, according to their ability to travel. He endowed it competently, and furnished the rooms with bedding and other necessaries, and made the mayor custodian to regulate admission to its privileges. The founder attached a chapel to the house, and therein established a priest to celebrate for his soul and for all the faithful departed. About fifty years later one of the same name as the founder, probably his son, made a further bequest to the chaplain of the house, and added to his duties.

In January, I 332 , licence was obtained by John Devenysh for the gift of 100s. of rents in Winchester and Little Somburne, to the master and brethren of the hospital of St. John, to find a chaplain to celebrate daily in the hospital for the souls of the king's progenitors, kings of England, and of the faithful departed. ${ }^{1}$

Mark le Faire, who was mayor of Winchester in 1408 and subsequent years, was a benefactor of the hospital, giving it a part of the George inn, the King's Head, and his own house. At this time the hospital was in the full control of the corporation, for in I 408 an order was made by the assembly that the house of St. John Baptist should be rebuilt during the year and roofed with lead. The cost was to be partly defrayed by voluntary contributions, for the gathering of which the assembly appointed two collectors. ${ }^{2}$

It appears from the Black Book of Winchester that town assemblies were frequently held here in the fifteenth and sixteenth centuries. The Trussell MSS. state, indeed, that this use of the hospital hall for municipal purposes was coeval with its foundation. ' $\mathrm{Yt}$ appeareth by the book of ordinances of this cittie (earlier than the extant Black Book) that in the time of Roger le Long, who succeeded John Devenishe in the place (as alder-

\footnotetext{
1 Pat. 5 Ed. III. pt. 3, m. 3 . f. 3 .

${ }_{2}$ Black Book of Winchester, Add. MS. $60_{3} 6$,
}

man), that there was an ordinance made that everye yeer, uppon the next Sonday after Midsomer day (except upon some extraordinarie occacion hindered, and that not to bee allowed of but by a generall assemblee), the maior and his brethren and all the whole corporation with their wives shoudd meet att this house at supper, whereat over and above the rate sett, the maior for the tyme beeing, and hee that was maior the precedent yeere, were to bestowe a couple of fatt capons; which love-feast and merry meeting was appoynted to revive the memory of the Devenishes. This meeting is observed to this daye." 3 From the same authority we learn that Richard Devenish increased the endowments in the reign of Henry VI.

At an assembly held on 20 August, 1442, as chronicled in the Black Book, it was resolved that the chaplain of the fraternity of St. John was to receive meat and drink and sufficient cloth for a gown (toga) yearly from the steward of the fraternity, and four marks as a stipend.

The corporation in 1442 appointed William Wyke, clerk, as chaplain and keeper of the hospital, and caused the following indenture of the hospital's goods to be drawn up. From the provisions for bedding, it would appear that the house had not given up the exercise of nightly hospitality for wayfarers.

The present indenture bereth Wittness yt Petur Hulle mayre of ye Cite of Wynchester and All ye Commoners of ye same Cite hath delyvered to $\mathrm{S}^{r}$ William Wyke oure keper of oure hous of Synt Johns of Wynchester al oure goodes and catelles underrite, Firste viij corperas, iiij tuellis for ye autres in ye churche goode, and $\mathrm{v}$ holde, ij litel tuelles for ye lavytory olde, $j$ paxebrede of silver and over gyld a $\mathrm{j}$ nother paxbrede, and a hede of Syn John ye Baptis of Alabastre, $j$ Box of silver $w^{t}$ oute over gylde, ij chales of Silver $w^{t} y n n e$ over gylde, $\mathrm{j}$ chales of silver ye gylde w oute, ij ymages of Syn John ye Baptis of Alabastre, $j$ ymage of oure Lady of Alabastre, $v$ chopis (copes) of sylke and a litel pelow, viij proper vestements $w^{t}$ all ye apparell, $i j$ surplis feble, $j$ aube $w^{k}$ parurys, $j$ Crystal stone, $\mathrm{j}$ Box $w^{t}$ dyvers reliquis, iij Missales, ij Antiphones, ij portions, vj sawters, ij legendes, ij Grayellis, $\mathrm{j}$ episteler, $\mathrm{j}$ marteloge, and vij other diverse bokes, iij sakeryng belles, iiij cruettes, ij lamps of brasse, $\mathrm{j}$ mettable (dining table) $w$ ij trestallis, ij belles for ye churche $w^{t} \mathrm{j}$ Trunke, pond' viijc, $\mathrm{j}$ forme, $\mathrm{ij}$ meteclothis conteynynge in lenthe xiiij yerdes $w^{t}$ a towell conteynyng in lenth iij yerdes and a halfe, ij Basonis and $j$ laver, $\mathrm{j}$ litel morter of Brasse for Spices to pounde on weying xij lb., iiij bras pottes, $j$ belle and $j$ litel

a Trussell MSS. (James I.), cited in Woodward's Hants, i, 248. Roger le Long was mayor in 1275 , according to Milner's list. 


\section{A HISTORY OF HAMPSHIRE}

pomette, $\mathrm{j}$ hangynglaver, $x \mathrm{j}$ payre of Shettes, iij payre blanketts, xxiij keverlytes, $\mathrm{j}$ crowl, $\mathrm{j}$ spade, $\mathrm{j}$ shovell, j howe, j rake, j spytele, j Longpyke, $\mathrm{j}$ whelberewe, $\mathrm{j}$ bounde $\mathrm{w}^{\mathrm{t}}$ Ire, $\mathrm{ij}$ cofor in ye chambers $w^{t}$ munnimentes and chartes.

The next entry in the Black Book, immediately following this inventory, is the record of a meeting of the assembly in the house of St. John Baptist on 3 I August, I 485 . Other meetings of the Corporation in the same hall are recorded in 1472,1514 , I 520 and 1523 .

At an assembly held in the gildhall on 6 January, I 524, there was 'granted to my lord Suffrygan Seynt Johns house $w^{t}$ the garden for time of his lyfe yeldying yerely for the seid house xvjs. viijd. and for the garden xs.' Ten years before his death, which occurred in 1528 , Bishop Fox suffered from blindness. Much of the diocesan work was discharged by John Pinnock, Bishop of Syene, who also acted as suffragan Bishop of Salisbury.

At an assembly held in St. John's Hall on 2 March, I 53I, it was ordained that 'from hensforthe every Maire in his tyme shall examyn the Inventory of all the churche goodes of Saynt Jonys and all other goodes belongyng to Seynt Jonys hospitall win ijj months next after the feist of Seynt Michell tharchangell upon payne of forfeture of vjs. viija'. to the use of the Citie.'

At an assembly held on 23 April, 1535 , - hit is granted to Richard Frankelyn, servant of the seid Citie, to have the oversight and kepying of Seynt Jonyes house and the hospitall there as long as it shall please the meare and the Citie to admyt hym.'

The assembly of 8 August, 1546, decided ' $y$ t the supper accustomed to be kept at Seynt John's house shall frome hensforthe yerelye be kept there the Sonday next following the Natyvyte of Saynt John the baptist in as ampel maner as it hathe byn here to fore And every of the beinche shall paye at the same supper xiid., and every other of the xxviij, $\mathbf{x} d$. apece, and of thother franches man viiid. a pece, and that whether thei be present there at the supper or not. And the mayor for the tyme beinge to fynde a capon at the same supper and thalderman of the Highe Strete another capon.'

At the dissolution of such institutions in 1 546, this hospital fell into the hands of Henry VIII, but it was not altogether suppressed, and was by him regranted to the corporation, the hall to be used by them for municipal elections and the like purposes.

$$
1 \text { Add. MS. } 60_{3} 6 \text {, f. } 31 \text {. }
$$

At that time the hospital revenue was but roos. a year, 30s. of which was for the priest's stipend.

In 1558 , Ralph Lamb bequeathed $£ 400$ to the master and brethren of this hospital, for the purpose of adding to it as many poor as the rents of the lands purchased with the bequest would maintain, who were to be called 'The Almsfolk of Ralph Lamb.' An estate was purchased at Amesbury, Wilts, as well as some small properties in Winchester, and six poor and needy widows were estabblished in as many almshouses in a court on the north side of the main building.

In the charter which was granted by Elizabeth in 1588 to the corporation, this hospital, with the addition of the Lamb almshouses, was confirmed to them as its keepers.

In an old account book of the corporation, beginning about r688, the Charity Commissioners (in I 824) found an entry, under the title of 'The poor of St. John's hospital weekly,' of the names of twenty-two persons, men and women receiving $6 d$. a week each, and of six others receiving is. $6 d$. each per week, the latter being probably the almspeople appointed under Lamb's gifts. ${ }^{2}$ At the time of the Commissioners' visit, there were no other almsfolk nor any doles to the poor save those on Lamb's foundation.

In I 8 I I a suit was begun against the corporation for mismanagement and abuse of this and other charity trusts. After almost continuous litigation for nearly twenty years, the corporation surrendered, and in 1829 resigned their powers and responsibilities to the trustees appointed by the Court of Chancery.

After the Reformation, when the chaplain's stipend was appropriated, the chapel was disused. It was rescued from its ruinous condition in 1710 , and turned into a schoolroom for sixty poor children. It was used as a school until 1838 , when it was repaired and restored to its original use.

St. John's House, with its fine hall and chapel, still stands at the east end of the High Street, and behind it are twenty-one commodious almshouses.

\section{THE HOSPITAL OF ST. JULIAN OR GOD'S HOUSE, SOUTHAMPTON}

This hospital was founded for the poor, in the reign of Richard I., about the year $1197,{ }^{3}$ by Gervase le Riche, who was a burgess of

2 Charity Commissioners' Reports, xii. 437.

3 Pipe Roll, 9 Rich. I. 


\section{RELIGIOUS HOUSES}

Southampton and reeve of the town in 1185 . According to an inquisition held in 1229 , Gervase le Riche conferred the wardenship on his brother Roger." The earliest charter now extant is a confirmation of the year II97, by Richard I., of the considerable properties granted to the hospital by the founder, and renewed in $119^{8}$ owing to the former royal seal having been lost. ${ }^{2}$ These gifts included a rent of two marks on the house known as West Hall, in which Gervase lived; eight houses and various plots of land in the town and suburb ; a house and land at Portsmouth; his estate at Gussage in Dorsetshire, and lands in the Isle of Wight. ${ }^{3}$ Shortly afterwards William de Chelegrave granted the whole land at Hickley, at an annual rent of five shillings, and by the annual service of a pair of gilt spurs and a pound of cumin; and William de Redvers, Earl of Devon, granted rights of pasturage and fuel, save for six weeks each year, over the land of 'Werole,' in the Isle of Wight, at a rent of two shillings, paying immediately, through Vincent, the warden, ten marks, and a pair of gilt spurs to Baldwin, the earl's son."

About 1209, Roger son of Mark confirmed to the hospital, for the support of the priests, brethren and sisters therein, and for the aid of the poor thither resorting, his father's gift of the whole land of 'Werole,' at a rental of six pence in lieu of service. ${ }^{5}$

Amongst the other muniments of the house preserved at Queen's College, Oxford, are charters of special protection from both John and Henry III.

Warden Robert de Knowell died about Christmas, I 285, whereupon Queen Eleanor, the king's mother, who held Southampton in dower for life, took possession of the hospital through her bailiffs, and conferred the wardenship on Robert le Stock. The Bishop of Winchester had however, shortly before this date, made good against the town his claim to the advowson in the Court of King's Bench. On hearing of the queen's action, the bishop, through the sheriff, ejected Warden Robert, and appointed in his place, on 3 January, 1286, John le Flemang. A few months later Warden John resigned, and on I I July, I 287 , the bishop issued his mandate for the induction of Richard de Multon. ${ }^{6}$ This dispute was brought to trial at Westminster in Hilary

1 Rolls of Parliament (Rec. Com.), i. 19.

2 Hist. MSS. Com. iv. 451-2.

3 Davies' Hist. of Southampton, p. 320.

4 Hist. MSS. Com. iv. 453-4.

- Ibid. p. 452.

- Winton. Epis. Reg., Pontoise, ff. 4, 5. term, I290, before Gilbert de Thornton and John de Mettingham, the king's justices. The pleadings are extant, and are of considerable length and interest. The judgment was against the bishop, who had to pay $£ 20$ damages, and Robert le Stock, alias le Aumoner, was reinstated. ${ }^{7}$

The bishop, though defeated on technical grounds, was able to make out a good case. He was able to show from episcopal registers, now lost, that Bishop Peter des Roches (120544) appointed Warin, a canon of St. Denis, as warden, in succession to Vincent; that Bishop William de Raleigh (1244-60) appointed John Chilbaton, one of his chaplains, and afterwards Nicholas Rokeland; that Bishop John Gervais appointed William Chernbyne in 1262, and afterwards Robert de Knowell.

Warden Bluntesdon, a favourite of the king, seems to have been the first non-resident warden. The scandal of giving the chief emoluments of hospitals founded for the poor and infirm to men who rarely, if ever, visited the house over which they were supposed to preside, became, alas! the rule and not the exception. At God's House this procedure began about a century after its foundation, and was ever afterwards maintained. In 1297 , when the see of Salisbury was vacant, the king gave Bluntesdon the archdeaconry of Dorset, which he held with this wardenship, as well as with other preferments, until his death in I3I 6.

In 1343 the king granted the custody of God's House to the recent foundation of Queen Philippa and Robert de Eglesfield at Oxford, the provost and scholars of Queen's Hall. By this charter the house with all its appurtenances and rights passed entirely to the hall or college, with the provision that the provost and scholars should sustain all that was required by the original foundation, and should use the surplus (if any) to provide a habitation for any of their scholars who might be afflicted with any incurable or chronic illness. The hall was to enter into possession immediately on the death or resignation of Robert de Eglesfield, the queen's chaplain, who then held the wardenship. After this date the wardens of God's House are identical with the provosts of Queen's Hall, Oxford. In 1347 the king repeated his former charter, stating therein that in consequence of so much of the hospital having been burnt by foreign invaders (1338), when its records were destroyed, relief for its depressed condition caused him to remit to the hospital

7 Rolls of Parliament (Rec. Com.), i. 18-20; Winton. Epis. Reg., Pontoise, ff. 191, 192. 


\section{A HISTORY OF HAMPSHIRE}

and all its lands for ever every kind of toll, pontage, murage, passage, etc. This was confirmed in 1375 by Richard II., who also in 1385 exempted the hospital property in Hampshire from the payments of tenths and fifteenths for that turn. Other royal confirmations were granted in 1399,1413 and $1429 .^{1}$ In 1346 , in the assessment for making Edward the Black Prince a knight, it appears that the prior of God's House, Southampton, held half a knight's fee in Cosham. ${ }^{2}$

Among the muniments at Queen's College are not only the charters of God's House, but also a large number of household account rolls and rent rolls beginning with the time of Edward I. Of the earlier of these Mr. Riley gave in 1877 a long and most interesting analysis, as well as a summary of facts that they establish in connection with this house and its administration, to which we are indebted for the following particulars. ${ }^{3}$

In the time of the first two Edwards, the members of God's House consisted of a master or warden, two priests, a clerk, from two to three brothers, from three to nine sisters, three or more poor mendicants (paupers), and two or three indoor servants, such as cook, washerwoman or dairymaid, and various outdoor labourers, such as carters, ploughmen, and herdsmen of cattle, sheep and swine.

The building contained two halls, probably for the two sexes; chambers were assigned to the warden, which had a cellar beneath let to a tenant ; the priests had also their chambers, and there were separate rooms for the brothers and sisters when in residence. It also seemed probable to $\mathrm{Mr}$. Riley that the paupers lived in the house; judging from analogy it may be assumed that this was certainly the case. The duty of the senior of the two priests was to act as steward or sergeant of the house. The second priest, who had a lower stipend, was the chaplain; though later there was a third priest appointed as chaplain, and the two senior priests were styled the two sergeants.

The brothers occasionally paid handsomely for admission, as with a flock of sheep or money gifts. They were often made bailiffs or stewards of the different manors, and resided at Cosham or Warror in the Isle of Wight, or at Heckley near Southampton. Occasionally they took part in field labour, such as reaping and haymaking. The sisters, too, at times were engaged in winnowing. The sisters, in addition to their meals, received a farthing a day in lieu of clothing. The

1 Pat. Rolls, under dates.

2 Feudal Aids, ii. 339.

2 Hist. MSS. Com. iv. 453. paupers, in addition to their board, received a farthing every other day; when working in the fields they received additional remuneration, chiefly in the form of shoes. No money payment to the brothers is ever mentioned in the accounts, but they had a liberal allowance of materials for clothing.

The warden, who absorbed the greater portion of the revenues, had a mansion or residence at Gussage in Dorset. Occasionally the accounts make mention of a warden residing at Salisbury, Winchester, Odiham, and even Wokingham in Berkshire. Brothers and servants of the house were frequently engaged in the laborious work of carrying wine, cider, ale, stores or provisions to various distant places where the warden for the time might be dwelling. The accounts also reveal that wardens now and again imposed their relatives (nepotes) on the hospital, receiving from it money, clothing, board and education.

In 1373, with characteristic energy, Bishop Wykeham proposed to visit God's House, as one of the most important hospitals in his diocese. When the notice was received by Queen's College as wardens, steps were at once taken to resist the bishop. On 27 June, the chancellor issued a prohibition to the bishop, in the king's name, on the ground that the hospital was held in free alms of the Crown by the provost and scholars of Queen's, and that therefore the Crown was visitor. This prohibition was duly entered in the bishop's register. ${ }^{4}$

In I462, Edward IV. granted to the warden, chaplains and brothers of God's House the alien priory of Sherborne, with the object of securing the increase of divine worship within the hospital of St. Julian or God's House, and perpetual masses for the souls of the king and his successors, and for the souls of 'Richard late Duke of York, our father of famous memory, and of Richard, late Earl of Cambridge, our grandfather who lies buried within the hospital.' ${ }^{5}$ The church or chapel of the house was dedicated to St. Julian, and hence the hospital itself occasionally went by that name. In 1463 the king inspected and confirmed to Queen's Hall the letters patent of Richard II. and the charter of Edward III. granting them the hospital. ${ }^{\circ}$

The Valor of 1535 affords interesting particulars as to the hospital. The gross

4 Winton. Epis. Reg., Wykeham, iii. f. 8.

- Pat. I Edw. IV. pt. 4, m. 13 . The result of this was to grant the Sherborne estates to Queen's Hall. See the account of Sherborne Priory, p. 228. - Ibid. 3 Edw. IV. pt. 3, m. 17. 


\section{RELIGIOUS HOUSES}

revenue amounted to $E_{1} 40$ I 3 s. $10 \frac{1}{2} d$. and included the manors of Cosham and Warror in the Isle of Wight, the manor of Heckley, tenements at Exbury and Hamley, a garden in Winchester, a great number of small tenements and rents in or near Southampton, and the property of Sherborne priory. The charges on the income included, in addition to a variety of payments at Monk Sherborne and dues to divers Southampton officials, $\ell_{\mathrm{I}} 8$ a year to the three priests (Geoffrey Rudde, Thomas Asheley and William Gy) appointed by the founder and Edward IV. to pray for the souls of the founders and others; $\$ 24$ for the maintenance of six poor brethren and four poor sisters, in food, clothing and other necessaries; $£ 20$ for seven beggars indigent and infirm, beds and burial costs, etc.; and $£ 28$ for daily hospitality to wayfarers and strangers from beyond the sea, and daily distribution of alms at the gate. Beyond these deductions the commissioners also asked that the following expenses might be deducted: Commons and stipends of butler, cook and undercook, $£ 9$ 6s. 8d.; stipend of barber, 8s.; stipend of washerwoman, I $6 \mathrm{~s}$.; wax, wine and bread for the chapel, $f_{1}$ I 13 s. $4 d$.; utensils of hall, pantry and kitchen, $f_{\mathrm{I}} 6 \mathrm{~s} .8 d$.; petty daily expenses, $£_{\mathrm{I}} 8$; average loss from unoccupied houses at Southampton, $£ 6$; fuel for hall and kitchen, $£_{2}$ I 3 s. $4 d$. ; and travelling expenses and the like, on the business of the hospital, $£ 3$ I $3^{\text {s. } 4 d}$. From all this it may be inferred that God's House, under the direction of Queen's College, was fairly carrying out the intentions of the founders, and soundly administering the funds.

According to the accounts of $1568-9$, the senior priest was acting as steward, and 'the house was still celebrating the exequies of Edward IV. and Richard, Earl of Cambridge, of Master Pereson, and the founders generally, each at a cost of 4 s. $^{1}$ At the same time the cost of the pauper inmates (including eight brothers and sisters) was $\AA_{4}$ I I 2 s. od.

The old domestic buildings of this house, which dated back in the main to its original foundation and were still substantial, were, grievous to relate, swept away by the college in I861. In their place were erected the present 'somewhat feeble though more commodious buildings,' in two blocks. 'The eastern block accommodates four brethren, whilst the northern range is for the like number of sisters. The old gateway has been renewed, and the chapel of St. Julian ' restored' out of all semblance to antiquity. An account

1 Davies' Hist. of Southampton, 46I-2, citing an account penes Rev. L. L. Carrick. of the occupation of this church by a Walloon congregation has already appeared. ${ }^{2}$

Wardens of the Hospital of St. Julian OR God's House, Southampton

Roger le Riche ${ }^{3}$

William Fulient

Vincent

Warin

John Chilbaton

Nicholas Rokeland

William Chernbyne, 1262

Robert de Knowell, d. 1285

Robert le Stock or le Aumoner, 1285

John le Flemang, I 286-7

Richard de Multon, 1287

Richard le Stock or le Aumoner, reinstated $1290^{5}$

Roger de Estok, resigned in 1293

Henry de Bluntesdon, ${ }^{6}$ 1293-1316

Gilbert de Wygeton, ${ }^{7}$ 1316, 1332

Robert de Eglesfield, about I 343

\section{THE HOSPITAL OF ST. MARY MAGDALEN, SOUTHAMPTON}

The hospital of St. Mary Magdalen, Southampton, frequently styled in the town accounts Le Maudelyne, was founded by the burgesses, at their own cost, as a refuge for lepers, in or about $\times 172-3$, when there is a claim for for allowance on the Pipe Roll of $E_{1} 3^{\text {s. }} 2 d$. for land given to the lepers of Southampton. It was confirmed by Pope Alexander III. in I 179 to the priory of St. Denis, by the name of the chapel of St. Mary Magdalen, but it does not appear that the priory gained any benefit from the hospital till the time of Edward III. Probably it was only assigned to the priory in the first instance in order that they might see that the church or chapel was duly served, and some priest found brave enough to continuously administer to the souls of the lepers.

Originally the burgesses appointed the master or warden of the hospital, but in the reign of Edward I. the Crown claimed the presentation and appointed William Balweys. This intrusion was resisted both by the burgesses and the bishop. The latter, in 1285 ,

2 Supra, p. 75 .

${ }^{3}$ Rolls of Parliament (Rec. Com.), i. 19.

4 Winton. Epis. Reg., Pontoise, ff. 4, 5.

5 Ibid. ff. 191, 192; Rolls of Parliament (Rec. Com.), i. 1 8-20.

- Pat. 2 I Edw. I. mm. 15, I I.

7 Ibid. 6 Edw. III. pt. 2, m. 7 ; Dugdale's

Monasticon, vi. 674 . 


\section{A HISTORY OF HAMPSHIRE}

appointed Robert, rector of the church of St. Cross, Southampton, at the instance of the burgesses, to the wardenship.. Thereupon Bishop Pontoise was charged with purpresture against the king in seizing the advowson ; and at Michaelmas, I 290, when the case was heard, the bishop replied that he had never for himself nor his church made any claim to the advowson, and the sheriff of Hampshire was ordered to seize the wardenship for the Crown. ${ }^{2}$ However, on this followed an inquiry in Easter term, I 29I, when the jury found that neither the bishop nor the king had any right to the advowson, but that it had been uninterruptedly exercised by the burgesses until the Crown appointment of William Balweys. ${ }^{3}$ Nevertheless, in 1342, the Crown again claimed the advowson; and on 6 May of that year Edward III. granted to Richard le Paneter the life custody of the hospital of St. Mary Magdalen, Southampton. ${ }^{4}$

In 1347 the hospital and its possessions werc appropriated by the king to the priory of St. Denis, Southampton, in consideration of the poverty of that house, but under covenant that the canons should perform all the duties of the hospital. ${ }^{5}$ This grant was confirmed by Richard II. in 1390. These grants show that there was from the first a definite obligation to maintain a chantry for a priest to celebrate on certain days.

According to the old ordinances of the Gild Merchant of Southampton, the lepers of La Maudeleyne received a pittance of ale from the alms of the gild. ${ }^{6}$

In November, I 377, a commission was issued to inquire by a jury of the county touching the petition of the prior of St. Denis, which alleged that from time immemorial a penny per tun of wine imported at Southampton, whether by denizens or aliens, had been accustomed to be paid to the warden of the lepers of the hospital of St. Mary Magdalen ; that the late king granted the hospital and all its profits to the priory, and that he was then hindered in receiving the said penny a tun on wine, which was the greatest part of the hospital's profit.?

At a subsequent inquisition, towards the close of Richard's reign, it appeared that the priory was not carrying out its obligations,

1 Winton. Epis. Reg., Pontoise, f. 77. It is here styled the chapel of St. Mary Magdalen.

2 Rolls of Parliament (Rec. Com.), i. 45.

3 Abbrev. Plac. (Rec. Com.), 19 Edw. I. 225.

- Pat. I6 Edw. III. pt. 1, m. 5 .

s Ibid. 22 Edw. III. pt. I, m. 1 .

- Davies' Hist. of Southampton, Pp. $139,449$.

7 Pat. I Rich. II. pt. 2, m. Igd. and the Crown granted the wardenship to John Newport, clerk; but in 1398 this action was revoked at the suit of the priory. ${ }^{8}$ Neither chantry nor hospital were however being duly supported by the priory, and the buildings were becoming ruinous. In $140 \mathrm{I}$, Henry IV. confirmed the property of the hospital once again to the priory, but tacitly sanctioned the abandonment of all the original scheme for the help of the afflicted poor, simply insisting on their praying for his weal whilst living, and for his soul after death. ${ }^{\circ}$

At the dissolution of the priory of St. Denis, the property of this hospital was estimated at an annual income of $£ 16$ 16s. The house in the fourteenth century stood in I 8 acres of land called 'Le Maudelyne,' in the West and East Marlands; the Winchester road now passes through the premises. It also possessed 3 acres in Bove-barre Street, four cottages in Foleflode without the bars, and a few rents in the town and neighbourhood. ${ }^{10}$

\section{Masters of the Hospital of St. Mary Magdalen, Southampton}

William Balweys, in the time of Edward I."11

Robert, rector of St. Cross, $1285^{12}$

Richard lc Paneter, $1342^{13}$

John Newport, in the time of Richard II.14

\section{A. GOD'S HOUSE, PORTSMOUTH}

In the time of King John, a hospital for the relicf of the poor was founded at Portsmouth by Bishop Peter des Roches, which usually went by the name of Domus Dei, or God's House.

The dedication of this hospital apparently fluctuated considerably, generally varying between St. John Baptist and St. Nicholas, the former eventually dying out. This probably arose from the original general dedication of the whole building being changed at a period of refounding or enlarging, and this in its turn differing from the dedication of the chapel. Or there may have been two separate foundations that were amalgamated. It is named St. John Baptist in 1283, 1 284, 1305 and 1308 ;

8 Ibid. 21 Rich. II. pt. I, m. I.

8 Ibid. 2 Hen. IV. pt. 3, m. 6.

10 Ibid. 22 Rich. II. pt. 2, m. 37 ; Madox's Formulare Anglicanum, dccxxvii.

11 Abbrev. Plac. (Rec. Com.), 19 Edw. I. 225.

12 Winton. Epis. Reg., Pontoise, f. 77.

13 Pat. 16 Edw. III. pt. I, m. 5 .

I4 Ibid. 21 Rich. II. pt. I, m. I. 


\section{RELIGIOUS HOUSES}

and St. Nicholas in $1235,1298,1_{3} 14,1349$, 1361, 1356, 1376, I 393, etc.1

On 2 November, I 214 , King John granted a charter of confirmation to the hospital just recently built at Portsmouth in honour of the Holy Trinity, the Blessed Virgin, the Holy Cross, the Blessed Michael, and All Saints, for the maintenance of Christ's poor. The gifts confirmed were eleven messuages from different donors in the town of Portsmouth, land at Westwood in Portsmouth, the gift of the burgesses; and 15 shillings in rents. ${ }^{2}$

In 1224 and again in 1236 there were further grants to this house under the title of the hospital of St. Nicholas. ${ }^{3}$ In 1229 provision was made that the privileges of God's House should not interfere with those of the parish church, and the former was bound to pay 5 s. quarterly as a pension to the mother church." In the reign of Henry III. and subsequently, the head of this hospital was occasionally styled prior, but more usually master or warden.

In June, I 284 , a quitclaim was granted to the Bishop of Winchester of the hospital of St. John Baptist, Portsmouth, whereof the king had recently impleaded him. ${ }^{5}$

The master and brethren of God's House were accustomed to receive I5s. rent charge from the tenants of the manor of $W_{y}$ mering by the gift of the Earl of Albemarle. In 1285 John le Botillier exchanged his manor of Ringwood for that of $W$ ymering, and no mention was made of this charge to which he objected. Whereupon the king, desiring that the gift should be confirmed to God's House, granted John le Botillier I 5s. yearly at the exchequer until he was provided with land to that yearly value. ${ }^{\circ}$

Before this hospital 'for Christ's poor' had been in existence for a century, the usual gross abuse of its funds, namely the providing largely from its small income for an absentee head, began to operate. In January, 1305, Pope Clement V. granted dispensation to Robert de Hartwedon, at the request of Hugh le Despencer, whose clerk he was, to hold the rectories of Dinton and Thingdon, as well as another benefice, conjointly with the Portsmouth hospital of Domus Dei."

1 Wright's Domus Dei of Portsmouth (1873). This is in the main an account of the garrison chapel; but it has a good historical introduction.

2 Charter Roll, 16 John, pt. 1, m. 6.

3 Pat. 20 Hen. III. m. 120.

- Woodward's Hist. of Hants, iii. 334.

5 Pat. 12 Edw. I. m. 11.

- Ibid. 13 Edw. I. m. 14. John le Botillier received this 15 s. from the exchequer until 1293 , when land in lieu was found for him; Pat. 21 Edw. I. m. 5. 7 Cal. of Papal Letters, ii. 10.
In 1306 the right of free warren over the manors of Portsmouth, Fodrington and Feldershey was granted to the hospital. ${ }^{8}$ The advowson of this hospital was granted to the Bishops of Winchester in $1316 .^{\circ}$

In 13 I9 Ralph de Camoys obtained judgment against Robert, the warden of the house of St. Nicholas, Portsmouth, with respect to the moiety of the manor of Lafham, which had been assigned to the hospital in $1299 .{ }^{10}$

A chantry was founded here in 1325 , with the assent of William de Harewedon, warden of the house of St. Nicholas and the convent of the same, and with the bishop's confirmation. The founder was Joan, daughter and heir of Alan Plokenet, and widow of Sir Henry de Bohun. The chaplain was to be presented by Joan and her heirs, and he was to say daily mass for the founder, for Robert de Harewedon, the late warden, and for William the present one, and for their parents and friends. ${ }^{11}$ In 1340 Thomas de Hatfield, the king's clerk, obtained a grant for life from the Crown of the hospital of St. John, Portsmouth. ${ }^{12}$

In I 342 Edmund Arundel, described as brother of the Earl of Arundel and kinsman of the king, petitioned the pope for reservation of a canonry and prebend of Salisbury, notwithstanding that he already held a prebend of York and the wardenship of Portsmouth hospital. The petition was at once granted. ${ }^{13}$ On a vacancy occurring in 1 348 , through Arundel's death, the Bishop of Winchester, instead of hastening to secure the advowson for some resident administrator, at once petitioned the pope for a dispensation to allow his nephew John Edingdon, who, though a B.A., was only in his eighteenth year, to hold the wardenship of St. Nicholas, Portsmouth, in conjunction with a prebend of Lincoln and the rectory of Burghclere. The pope complied.14 The pluralities that Bishop Edingdon so disgracefully secured for his young nephew are specially illustrated in this appointment. A protest was raised at Portsmouth on the appointment to the hospital of John Edingdon, as it was not considered, from the wording of the

8 Charter Roll, 35 Edw. I. n. 8.

8 Ibid. 10 Edw. II. n. 5.

10 Abbrev. Plac. (Rec. Com.) p. 334.

11 Winton. Epis. Reg., Stratford, f. 14. The Patent Rolls of a later date (1331) show that William de Harewedon was not only collated by the bishop to this wardenship, but also to the church of Crondale.

12 Pat. 14 Edw. III. pt. 1, m. 28.

${ }^{13}$ Cal. of Papal Petitions, i. 8 ; Cal. of Papal Letters, iii. 81 .

14 Cal. of Papal Petitions, i. 144, 153 ; Cal. of Papal Letters, iii. 274. 


\section{A HISTORY OF HAMPSHIRE}

papal mandate, that the pope was aware of all the young man's preferments. But neither bishop nor pope were to be thwarted, and in 1350 John was confirmed in the wardenship of St. Nicholas, although it was acknowledged that he then held a canonry and prebend of Lincoln, the church of Cheriton, the hospital of St. Cross, and a canonry of Salisbury, with expectation of a prebend.' The estate of the hospital of St. Nicholas was ratified by the Crown to Nicholas de Wykeham as master on 5 February, 1388 , together with four prebends, the church of Witney and the archdeaconry of Wilts. ${ }^{2}$ Bishop Wykeham, by his will, left a set of vestments and a chalice to the hospital.

On the resignation of the mastership of St. Nicholas by Thomas Kirkeby, in I 46r, Bishop Waynflete collated William Elyot to that office. $^{3}$

When the Valor Ecclesiasticus was drawn up (1535), John Incent held the mastership. The gross annual value was returned at $£ 79$ 135. $7 \frac{1}{2} d$., and the clear value, after distribution of alms, etc., at $£ .33$ 19s. $5 \frac{1}{2} d$., the latter sum being apparently the master's income.

Leland, who was at Portsmouth about I 539, says : "There is also in the west south west part of the town a fair Hospitale sumtyme erected by Petrus de Rupibus, Bishop of Winchester, Whereyn were a late $x i j$ poore men and yet $v j$ be yn it.' This last master of the Portsmouth hospital and of St. Cross, Winchester, is identical with John Incent, born at Berkhamstead in 1480 , who became dean of St. Paul's in 1540. He took the degree of bachelor of laws at All Souls' College, Oxford, in 1507, and in 1513 was made commissary to Fox, Bishop of Winchester. He is best known as the founder of Berkhamstead Free Grammar School in $1541 .^{*}$

This house was formally surrendered to the Crown by John Incent on 2 June, $15400^{5}$ The chapel was spared, being first used as a chapel royal attached to Government House, and afterwards converted into a garrison chapel.

\section{Masters and Wardens of God's House, Portsmouth}

Robert de Hartwedon or Harewedon, ${ }^{\circ}$ I 305, I 319

William de Harewedon, 1325

1 Cal. of Papal Leteers, iii. 357.

2 Pat. I I Rich. II. pt. 2, m. 36.

${ }^{3}$ Winton. Epis, Reg., Waynflete, i. f. 125 b.

- Cussans' Hertfordshire, iii. 76. It is strange that Dean Incent is omitted in the Dict. of Nat. Biography.

'Dep. Keepers' Reports, viii. app. 2. p. 38.
Thomas de Hatfield, ${ }^{7} 1340$

Edmund Arundel, 1342, 1348

John de Edingdon, nephew of the Bishop of Winchester, ${ }^{8}{ }_{1} 1348,1350$

Thomas de Edingdon, nephew of the Bishop of Winchester, resigned in 1366 Nicholas de Portsmouth, 1366

John de Wormenhall, 1376

Richard de Wykeham, 1376-8

Nicholas de Wykeham, ${ }^{10} 1378$

John Stacy, king's clerk," $13^{86}$

'Thomas Kirkeby, 1461

William Elyot, ${ }^{12}$ I 461

John Incent, 1535, $154^{\circ}$

\section{THE HOSPITAL OF ST. JOHN BAPTIST, BASINGSTOKE ${ }^{13}$}

The great Walter de Merton, Bishop of Rochester, and founder of Merton College, Oxford, was a native of Basingstoke. His parents were buried in the church, and his mother had inherited property in the town. There was in the town, by an early foundation of unknown date, a small hospital, dedicated to St. John Baptist, for the accommodation of sick folk and wayfarers. Walter de Merton, in the midst of other works of extraordinary munificence, remembered this small house, extended its area, rebuilt both house and chapel, and then took steps to insure its permanence by placing it under the protection of the Crown, and became its re-founder between 1230 and 1240. For its rule, he appointed a warden, with a chaplain and clerk to carry on divine worship, and made it primarily a place of retirement for aged and infirm priests, though it was still to exercise hospitality towards 'the wayfaring poor of Christ.' After the death of his parents, he bestowed on the hospital the whole of his Basingstoke estate, charging the benefaction with the perpetual maintenance of wax lights at the Lady altar of the parish church, which lights his parents had been

- Cal. of Paper Letters, ii. 10.

7 Pat. 14 Edw. III. pt. 1, m. 28.

8 Cal. of Papal Petitions, i. 144, 153 ; Cal. of Papal Letters, iii. 274.

- Winton. Epis. Reg., Edingdon, i. 134b.

10 Ibid. Wykeham, i. ff. 79, 100.

11 Pat. 10 Rich. II. pt. 1, m. 20.

12 Winton. Epis. Reg., Waynflete, i. f. $125 \mathrm{~b}$.

13 The statements in this sketch are, in the main, taken from the admirable History of Basingstoke, by Messrs. Baigent \& Millard, published in 1889. Where references are given in footnotes, the authorities named have been consulted at first hand. 


\section{RELIGIOUS HOUSES}

accustomed to offer. In Walter's lifetime, the hospital received other bequests. For instance, about I250, the prior and convent of the Cluniac house of Bromholm, Norfolk, granted 'to God and the Brethren of the Hospital of St. John Baptist at Basingstoke' 6s. $8 d$. of annual rent in Basing, to maintain a lamp to burn day and night before the rood in their chapel.

The muniments at Merton College afford information with regard to an early corrody at the hospital. An agreement, circa $1240-$ 50, was made between Thomas le Forester and the warden and brethren of the hospital, whereby Thomas granted them all the tenements in Basingstoke held by him of the chief lord, on their paying him yearly during his life eight quarters of wheat, two of maslin, and two of barley in equal portions at Michaelmas, Christmas, Easter and St. John Baptist's Day; two loads of oats on the feast of the Purification; 6s. 8d. at Michaelmas; and also to find him a fit and competent place to live in within the hospital, namely the upper room (solarium) on the north side of the hall. Also if Joan his wife should survive him, the warden and brethren were to pay her yearly a moiety of the grain. ${ }^{1}$ It does not seem clear from this whether or not Joan was an inmate of the house as well as her husband; but in all probability this was the case. Many of the deeds pertaining to this hospital, from I 240 to 1270 , speak of 'the warden, brethren, and sisters.'

The instrument whereby Henry III. took the house under his special protection and made it a royal hospital was dated in 1262 ; and in 1268 the chapel was exempted from episcopal control by the papal legate, Cardinal Ottobon. The college at Oxford was specially enjoined, by each of its successive codes of statutes, dated respectively 1264 , 1270 and 1274, to maintain and encourage the Basingstoke hospital, and special provision was made for the members of the college having the privilege of residing there if need should arise. Henry III. also granted the hospital perpetual exemption from taxation and payment of subsidies. When the taxers and collectors of the tenths and fifteenths for Hampshire infringed these rights in 1336 , the Crown, on complaint, at once interfered, and letters were addressed to the county

1 Hist. of Basingstoke, p. 598. This agreement is not only sealed by all the parties to it, but also with the seal of Walter de Merton, the founder. The extracts relative to this hospital from the Merton muniments occupy pp. 593-650 of the appendix to the history.

II officials, citing the perpetual freedom from all secular service and exaction granted by Henry III. and ordering the immediate restitution to the wardens of all that they had levied. ${ }^{2}$

Walter de Merton died on 27 October, 1277. To this hospital he bequeathed the large sum of 450 marks, as well as 100 marks towards providing a chaplain to celebrate divine service for ever in its chapel. In February, 1284, licence was granted to Peter de Abingdon, warden of Merton College, to convey to the master and brethren of the Basingstoke Hospital one messuage, I 50 acres of land, 6 acres of meadow, and 4 of pasture with appurtenances in Basingstoke, and 16 acres of land in Iwode. ${ }^{3}$ This purchase of property at Basingstoke and Iwode for the hospital was no doubt done in accordance with the terms of the will, wherein it was provided that if land was not bought within four years after his death with the 450 marks, the college was to take the money and pay to the hospital in its stead an annual pension of f20." The I oo marks for the chaplain was intended for the endowment of the definite chantry founded within the hospital chapel, and sanctioned by a charter of Henry III. in I 253 .

The Hundred Rolls of the beginning of the reign of Edward I. furnish the name of the hospital's warden in 1273-4, when the jury returned that Henry Cardeyf, the warden of St. John's Hospital, had encroached on the king's highway to the extent of 10 perches in length and 3 feet in breadth. ${ }^{5}$

In 1336 Edward III. confirmed to the warden of Merton College the mastership of the hospital, to be held for ever in right of his office." However in May, I 344, Edward III. (probably through some blunder of a Crown official) granted the wardenship to John de Hamelton, then vacant, alleging it was of the king's donation. The warden and scholars of Merton College naturally resisted this obvious infringement of their rights, with the result that the appointment was cancelled in the following July, the Crown admitting its error and removing John de Hamelton from the wardenship.

In 1379 the college began the unhappy principle of leasing the hospital. It was in the first instance leased for a yearly rental of 57s. to John Underwood and his wife for

2 Close, Io Edward III. m. 29.

3 Pat. I 2 Edw. I. m. I6.

4 Hobhouse's Life of Walter de Merton, p. $4^{8 .}$

- Hundred Rolls (Rec. Com.), ii. 222.

- Woodward's Hist. of Hants, iii. 226. 


\section{A HISTORY OF HAMPSHIRE}

their lives jointly and separately, or for forty years as a term. In 1395 it was leased for twenty-five years to John Carter, vicar of Basingstoke, who was to reside there with his own servants, and to receive once a year one of the Merton fellows, with his servant and three horses for a day and two nights. At his entrance the vicar received a missal and breviary, a chalice, vestments, and apparel for the altar, all of which he was to answer for at the end of the term.

Soon after this, attention was drawn to the highly unsatisfactory state of the hospital, and Henry IV. ordered an inquisition as to its actual state. The statement of the jury, sworn at Basingstoke on 30 November, I 4OI, was to the effect that the hospital was founded to maintain a chaplain, a clerk and two poor people, as well as the poor and sick scholars of Merton College; that during the past six years there had been no clerk nor the two poor people maintained there, and this by default of the warden of Merton, who was $e x$ officio warden of the hospital; that the clear yearly value of the hospital was $£ 56$ s., and that the profits and issues had been and still were received by the warden. On the delivery of this verdict, the revenues of the hospital were seized by the Crown in order to secure the fulfilment of its rights and burdens; they were not restored until 1405 .

In 1434 the college again leased the hospital, the holder of the lease being bound to reside there with his servants, to provide a chaplain to celebrate in the chapel, if he was unwilling or unable to celebrate there himself; to keep the houses and enclosures in repair ; to reserve fit chambers (cameras bonestas) for the two poor people or others sent there according to the statutes on account of sickness; to allow any thus sent to serve the chapel if they wished, and if there are several priests sent they are to have portions of the stipend allowed; not to cut down trees or make waste save that which is required for repairs, for fences and for fuel ; and to entertain the bursar or another member of the college at his own expense each year for a day and two nights. The college was to pay 4Os. towards the building of the great barn and for the repairs of the house within three years, and after the three years 13 s. $4 d$.

A lease for seven years made in 1455 , at a yearly rent of $135.4 d$., provided that in case of the re-building of the mansus bospitalis, lately destroyed by fire, the rent of it was to be added to the $13^{\text {s. }} 4 d$. A lease of 1479 has endorsed upon it an inventory of the chapel goods. They included a missal, chalice, corporal and two cases, two dalmatics, one green and the other blue, an albe and an amice, three altar cloths, two cruets, a brass vessel for holy water and a brass handled sprinkler, and a blue coloured stole.

The 20s. yearly stipend due to the chaplain out of the farm of St. John's was claimed by the Crown in 1551, the office of the chaplain being probably of the nature of a chantry priest. Merton College opposed, and by a Chancery decree of November in that year, the college was exonerated from the yearly payment of this sum to the Crown. The leases of the hospital throughout the sixteenth and seventeenth centuries, down to one entered into with Elizabeth Knight at $£_{4}$ rental, for twenty-one years, in 1695 , all provide for maintenance of the chapel ; but no lease after 1543 says anything about a chaplain.

William Sherwin, fellow of Merton, visited the hospital on 16 June, 1697, and reported at length to the college, chiefly as to their lands and woods, which he valued as at least worth $£^{80}$ per annum. As to the fabric he says :-

The house is but low, ordinary and mean, but it is kept in tenantable repair and that is all, though there has lately been some money laid out upon it. The place reserved for such fellows as are distract is separate from the chief house, is extremely dark and fit for none but persons in that condition. There is a sort of chapel near, in which formerly there was preaching once a month and the tenant paying the curate, and was on that account exempted from all tithes. It would be a mighty improvement to our estate, and the tenant would be glad to pay a curate could the custom be revived, but $\mathrm{I}$ am afraid it has been disused too long.

In letters written by Dr. Warton (son of the vicar of Basingstoke), poet laureate and an antiquary, to the bursar of Merton College in 1772 and 1773 , it is stated that part of the chapel of Walter de Merton's hospital still remained, built of flint, with one or two stout-mullioned Gothic windows built up ; it had a semicircular ceiling of boards in small panels, with the founder's arms on little shields at some of the intersections. The dimensions given are extraordinarily small, namely 'about twelve feet long and five broad within the walls' but it must be remembered that at its best this was a very small foundation, merely two resident poor brothers in addition to chaplain and clerk. When Dr. Warton wrote, the little chapel was divided into two floors, a bedroom above, with a kitchen ; it is described as standing on the banks of the Lodon, about 200 yards north-east of the church, 


\section{RELIGIOUS HOUSES}

In 1778 the old hospital house gave way to new brick buildings, but some remains of the chapel were still standing in $18 \mathrm{I} 9$.

\section{THE HOSPITAL OF FORDING- BRIDGE}

Very little is known or can be gleaned with respect to the hospital at Fordingbridge. It was dedicated in honour of St. John Baptist, which was the usual dedication of town hospices, for the transitory relief of poor wayfarers, and the more permanent maintenance of some of the local poor.

It was from an early date under the control of the diocesan. Bishop Pontoise (1282I 304), the first Bishop of Winchester, whose registers are preserved, collated to the wardenship. ${ }^{1}$

In 1328 there was considerable dispute over the appointment of James de Stepellavynton to the wardenship, his collation by Bishop Stratford being opposed, and not accepted until he had threatened Dame Joan Tracy, William her chaplain and six others with excommunication. ${ }^{2}$
On 15 May, 1385, Bishop Wykeham collated William Olyver to this hospital; and on 4 August, 1396, John Tannere."

The advowson of the hospital of St. John, Fordingbridge, was among the very considerable endowments intended to be transferred to the great Hospital of St. Cross, Winchester, by Cardinal Beaufort. ${ }^{\circ}$ This transference or amalgamation formed part of his large scheme that was actually accomplished; for a compotus of St. Cross for the year ending Michaelmas, 1526, includes receipts from the small Fordingbridge hospital. ${ }^{\circ}$

\section{Wardens of the Hospital of Fording- BRIDGE}

Adam de Northaye, ${ }^{7}$ I 3 I 3

James de Stepellavynton, ${ }^{8}{ }_{1} 328$

Clement de Fordingbridge, ${ }^{9} 1329$

Thomas de la More, resigned in 1348

Richard de Mora, $1348-9$

William Wyse, I 349-62

Robert Michel, ${ }^{10}$ 1 $362-9$

Edward Tavenere, 1369

William Olyver, 1385

John Tannere, ${ }^{11}$ I 396

\section{COLLEGES}

\section{THE COLLEGE OF MARWELL}

Bishop Henry de Blois (1 129-7I) founded a small college of secular priests in the church or chapel of Marwell Park, Owslebury, which was augmented by his successors, Bishops Peter des Roches and Woodlock. The foundation charter recites that the church was built by Bishop Blois and dedicated in honour of the martyrs SS. Stephen, Lawrence, Vincent and Quintin. At the same time he erected houses and other buildings near to the church, to serve for four priests, who should there continuously pray for the King of England and the Bishops of Winchester, and for other benefactors and faithful Christians. For the endowment he assigned $£_{1} 3$ of rents at Twyford; of which sum 6os. each was to be assigned to the chaplains, and 20s. for the ornaments and lights of the church. ${ }^{3}$

To Bishop Blois' foundation Peter des Roches added, by a deed dated the second Sunday in Lent, 1226, a deacon, and laid

1 Winton. Epis. Reg., Pontoise, f. 15 b.

2 Ibid. Stratford, ff. $36,103 \mathrm{~b}$.

3 This charter is recited in an inspection and confirmation of Edward II. ; Pat. $18 \mathrm{Edw}$. II. pt. 2, m. 15. It is printed in Dugdale's Monasticon, vi. I 344 . down rules for the general governance of the chaplains on a collegiate basis. The four priests were annually to choose one of their number to act as prior, to whom due obedience was to be paid both within and without the church; no one was to be absent from the saying of the canonical hours, or from their common meals, or at night time, without the prior's special leave; no one was to be granted longer leave than eight days by the prior ; if more was desired the bishop's licence was to be sought ; any one guilty of incontinence or any other serious fault, or even if suspected, was to be expelled without hope of restitution; surplices and black copes were to be worn in the quire; the Sarum use was to be followed from mattins to compline; and of the $£_{12}$ for stipend of Bishop Blois, $£_{I}$ was to be assigned to each for clothes, and the

4 Winton. Epis. Reg. Wykeham, i. ff. 23, 154, 203.

5 Pat. 33 Hen. VI. pt. 2, m. 18.

- Muniments of St. Cross; cited in Woodward's Hants, i. 239.

7 Winton. Epis. Reg., Woodlock, f. 18 I.

8 Ibid. Stratford, ff. $36,103 \mathrm{~b}$.

- Ibid. f. I 17 b.

10 Ibid. Edingdon, i. ff. $33,42 \mathrm{~b}, 1 \mathrm{I} 5 \mathrm{~b}$.

11 Ibid. Wykeham, i. ff. $23,154,203$. 


\section{A HISTORY OF HAMPSHIRE}

remaining $£ 8$ were to be spent for common purposes by the prior with the advice of his brethren. Bishop Peter added an annual gift of fifty quarters of grain. This was to be given by the rector of the church of Bishopstoke on the five feasts of St. Michael, St. Nicholas, the Purification, SS. Philip and James, and SS. Peter and Paul; three quarters of corn, three of barley, and four of oats on each occasion. They were also to receive from the rector of Bishopstoke four reasonable cartloads of hay at the time of hay harvest. The prior was to prepare an annual balance sheet, and if there was any surplus it was to be divided amongst them. ${ }^{1}$

Bishop Woodlock (1 305-16) also added to the property of the college as recorded in his register. $^{2}$ Marwell or Merwell was his birthplace; hence he was sometimes called Henry de Merwell.

From Bishop Wykeham's institution register we find that he collated Richard Merke and John Aubeoyle to priests' offices in capella de Merewell in I37I; Richard Allen in 1373; Walter Oures in 1 376 ; John Mikeltone in 1384 ; William Elkstoke in I395; Richard Beck in 1396; John Wegull in 1398 ; Thomas Tellere in 1399 ; Walter More and John Grene in 1402 ; and Richard Stanstede in I 404.

As time went on and the purchasing power of money became so materially lessened, the pension from the church of Bishopstoke was uttcrly inadequate for the support of four priests. At the time of the Valor (I 535) this small college was termed a chantry, and supported two priests, William Atkinson and Thomas Smyth; the sum of $£ 12$ was then divided between them.

This chantry was of course suppressed; it went with the episcopal estate and manor house of Marwell to Sir Henry Seymour.

\section{THE COLLEGE OF ST. ELIZA- BETH, WINCHESTER}

Near to the gate of his castle at Wolvesey, Bishop Pontoise built, in 1301 , the college of St. Elizabeth of Hungary. The foundation consisted of a number of secular clergy and choristers living under the rule of a provost, with so clearly an expressed object that it was in reality a chantry on a large scale. In the episcopal registers and other documents, it is most usually described as the chapel of St. Elizabeth, but frequently as a college and sometimes as a chantry.

\footnotetext{
1 Pat. I 8 Edw. II. pt. 2, m. I5.

2 Wharton's Anglia Sacra, i. 316.
}

By the foundation charter, ${ }^{3}$ the bishop established three altars in the great chapel. The dedication of the high altar was to the honour of St. Elizabeth; the second to the honour of St. Stephen and St. Laurence ; and the third to the honour of St. Edmund and St. Thomas of Canterbury. To serve these altars and to maintain a stately ritual, the foundation provided for the establishment of seven chaplains, one of whom was to be provost, three were to be in deacons' and three in sub-deacons' orders. All were to be appointcd, as vacancies occurred, by the bishop; they were to live together and have a common table ; to be satisfied with one dish and pittances on week days and two dishes on Sundays and double feasts; to dress humbly, and to wear in chapel surplices and black copes; to receive annually in addition to their board for clothes and other necessaries : the provost 6 marks, the chaplains 40s. and the clerks 20s.; to have a common dorter for the clerks save in sickness; each chaplain to have a young shaveling, between the age of ten and eighteen, to wait on him, and to sing in surplice in church; and the choristers to dine together in hall at a separate table. Their clerical duties were to rise each day at daybreak and say together (submissa voce aperte et distincte) mattins of our Lady, and afterwards to chant antiphonally mattins of the days ; after mattins to celebrate solemn Lady mass after the use of Sarum; next to intone the proper day hours, followed by the hours of our Lady in a low voice; immediately afterwards, the mass of St. Elizabeth was to be sung, followed by the saying of three masses at the three altars, two for the departed and one of the Holy Spirit ; and about nine o'clock "high mass was to be solemnly sung. Each chaplain was to say at each mass six special collects (I) for the founder, (2) for the then Bishop of Winchester, (3) for all the departed bishops of the diocese, (4) for the king and queen and their children, (5) for kings and queens and all faithful departed, and (6) a general collect for the quick and dead, but especially for the prior and convent of St. Swithun's. Before evensong, all the chaplains and clerks were to say, in low but distinct voice, Placebo and Dirige; afterwards to say evensong of our Lady, and to sing evensong of the day, to be followed by compline of our Lady and compline of the day. Everything was to be according to the use of Sarum; the provost and

3 Printed in Dugdale's Monasticon (from the Patent Rolls), vi. I 339-4 I.

4 The third hour; but the actual time would vary materially according to sunrise. 


\section{RELIGIOUS HOUSES}

chaplain were to appoint one of their number as precentor, to order the masses and services. The provost, in the presence of the chaplains and the treasurer of Wolvesey, was yearly at Winchester to deliver a statement of account, and a report as to the condition of the chapel and house. No one was to be absent from masses or hours save by special leave. No chaplain or clerk was to be admitted, unless first examined in letters and singing, and in knowledge of the divine offices. Women were not to enter any part of the house, save the chapel and hall. Each chaplain and clerk on admission was to swear to be faithful to the statutes and rules, and to continue in personal residence.

The original endowment included the appropriation of the church of Hursley and 6 acres in the meadows of St. Stephen where the college stood. Soon after the foundation, Simon de Fareham gave to the college the manor and church of Botley. Other gifts were the manors, etc., of Kingsclere and 'Culmestone Gynninges,' and lands at Shedfield. ${ }^{1}$

John de Wynfred was the first provost appointed by the founder.

In 1307, Edward II. inspected and confirmed the letters patent of his father confirming the foundation charter of the chapel of St. Elizabeth with the chapel of St. Stephen ; and at the same time confirmed to Riclard de Bourne, the provost, and the chaplains and clerks, the grant of appropriation of the church of Hursley, which had been made without the licence of the late king. ${ }^{2}$

In February, 1313, licence was obtained sanctioning the gift to the college of the manor of Norton St. Walery by Robert de Harewedon, clerk, and William de Stamford. ${ }^{3}$ In the following April, the provost and chaplains of St. Elizabeth were excused the service of rendering yearly a sore sparrow-hawk for the manor of St. Walery, at the request of Hugh le Despencer the younger, of whom it had been held in chief by that service."

Bishop Asserio collated priests, deacons and sub-deacons to the chapel of St. Elizabeth, ${ }^{5}$ and Peter, Bishop of Corbavia, held ordinations in this chapel, on behalf of the Bishop of Winchester, on 21 November and I 8 December, 1322, and also on 19 February and 12 March,

1 Inspection and confirmation charter of Edward II. (Pat. I 3 Edw. II. pt. I, m. I 3).

2 Pat. 1 Edw. II. pt. 2, m. 9 .

${ }^{3}$ Ibid. 6 Edw. II. pt. $\mathrm{t}, \mathrm{m}$. $\mathrm{t}$.

4 Ibid. 1 Edw. II. pt. 2, m. 15, 11.

b Winton. Epis. Reg., Asserio, ff. 447, 451 , 460,505 .
$1323 .^{\circ}$ The ordination of 18 December was a large one, there being 75 acolytes, 27 sub-deacons, 36 deacons and 47 priests.

We find that in 1346 the college held one knight's fee in Norton and Sutton Scotney, a twelfth part of a fee in Clerewodcott, one fee in Culmeston and half a fee in Botley. ${ }^{7}$

In 1350 , Bishop Edingdon, in direct contravention of his predecessor's statutes, obtained the papal sanction for John de Nubbelaye, rector of Alresford and canon of Romsey, to hold the provostship of the chapel, together with his rectory and canonry, as the income of the chapel was too small to be held by itself. ${ }^{8}$

Bishop Edingdon, when ratifying to the college the gift of Hursley church, contrived in some way to secure to himself and successors the rectory house. The possession of the rectory was however restored to Provost John de Sheptone and the chaplain by Wykeham in 1373 , when the college undertook to pay an annual pension of $13^{s} .4 d$. to the bishop. ${ }^{9}$

In September, I 400, the bishop commissioned John Elmore, the official, and Simon Trembury, treasurer of Wolvesey, to visit the college. ${ }^{10}$

After the death of Bishop Wykeham, the provosts of St. Elizabeth were in the main non-resident and the holders of other preferments.

The college of St. Elizabcth was visited on 4 March, $x 50 x$, by the commissary of the prior of Canterbury, during the vacancy of the see. The visitation entry merely states that Richard Wilmer, precentor, appeared as proctor for Richard Newport, the provost, and gives the names of five chaplains, five clerks and seven choristers who were present.

When the Valor of 1535 was taken, 'Doctor Pers' (Peers) was provost ; the gross annual value was declared at $£ \mathrm{I} 20$ os. $8 d$. and the clear value at $£$ I I 2 I 7 s. $4 \frac{1}{2} d$.

On the dissolution of this college among the smaller houses, in 1536 , it formed one of the numerous grants made by Henry VIII. to Thomas W riothesley, who sold the site to the warden and fellows of Winchester College for $£ 360$.

Leland describes the college of St. Elizabeth as 'situate Est upon the New College; and ther is but a litle narro causey betwixt them.

\footnotetext{
- Ibid. Asserio, Hants Record Society, pp. 544-52.

${ }^{7}$ Feudal Aids, ii. 326, 331, 334, 337.

8 Cal. of Papal Petitions, $i, 208$; Cal. of Papal Letters, iii. 456.

'Winton. Epis. Reg., Wykeham, iii. f. $79 b$.

10 Ibid. iii. f. 327.
} 


\section{A HISTORY OF HAMPSHIRE}

The mayne Arme and Streame of Alsford Water devidid a litle above the College into 2 Armes on eche side of the College. Withyn these 2 Armes not far fro the very College Chirch of S. Elizabeth is a Chapel of S. Stephan." 1

Mr. Kirby describes the acquisition of this site by Winchester College as a piece of good fortune. It stood in what is now the warden's kitchen garden, facing the cloisters. On the ordnance map, in the meadow near the school bathing place, is marked 'site of St. Elizabeth College'; but the foundation of an oblong building on that site really belonged to the chapel of St. Stephen.

When Wriothesley sold St. Elizabeth's to Winchester College, he imposed a condition that the buildings should be either pulled down or converted into use as a grammar school before Pentecost, 1547. In the deed of sale, 18 April, 1544, the college of St. Elizabeth is described as having a church, belfry and cemetery, and containing $4 \frac{1}{2}$ acres. Possibly there may have been orginally some idea of turning St. Elizabeth's into a boarding house for scholars; but within a year of the purchase the new owners began the work of demolition, stripping the lead from the church, and using the stones for building the wall which bounds the south side of Meads. ${ }^{2}$

The rather clumsy fifteenth century oval seal (see illustration) represents St. Elizabcth of Hungary standing in a canopied niche, with a palm branch in the right hand and a book in the left. Behind her is an angel with extended wings holding a crown over the saint's head. The idea of this seal is far better than its execution. Legend: s' ComMUNE - COlLLgil - SANCTE - ElizABETH.

\section{College of St. Elizabeth, Winchester Provosts}

John de Wynfred, 1301

Richard de Bourne, 1307

Adam de Capel, ${ }^{3} 1316,1317$

Nicholas de la Flode, ${ }^{4}{ }^{1}{ }^{20-2}$

John de Gorges, ${ }^{6}{ }_{1}{ }^{2} 22$

John de Thynden, ${ }^{\circ} 1334$

1 Leland's Itinerary, iii. 85.

2 Kirby's Annals of Winchester College, 256-8.

3 Winton. Epis. Reg., Sandale, passim.

- Ibid. Asserio, f. 14. Provost Adam exchanged with his successor for the rectory of Newchurch, Isle of Wight (ibid. f. 23).

5 Ibid. f. 23.

- Pat. 8. Edw. Ill. pt. 1, m. 35 ; pt. 2, mm. 33 , 25.

\author{
John de Nubbelaye, ${ }^{7}$ I 350 \\ John de Peveseye \\ John de Sheptone, ${ }^{8} 1373$ \\ Thomas Boys, ${ }^{9}$ 1 $381-7$ \\ John de Ketone, ${ }^{10} 1387$ \\ Simon Wylet, $1387-97$ \\ John Hulyn, "1 $1397-1401$ \\ Walter Hardene, 1401 \\ Richard Newport, about 1501 \\ Dr. Pers or Peers, 1535, 1536
}

\section{THE CHAPEL AND GILD OF THE HOLY GHOST, BASING- STOKE $^{12}$}

The extensive and beautifully situated ruins of the chapel of the Holy Ghost, in a large and well-planted cemetery to the north of the town, are well known by sight, as they stand so close to the railway station and at once attract attention.

Hasty observers might be apt to conclude that the cemetery was of comparatively late origin, but on the contrary it is far older than the ruins. It is supposed that this extramural burying-place for the town had its origin during the interdict in the reign of John (1208-14), when churchyards were closed. On the removal of the interdict the ground would be consecrated, and a chapel probably erected for masses for the faithful departed there buried. At all events it is an historic fact that a chapel of the Holy Ghost stood in the liten or corpseland, as it is still called, prior to the year $\mathbf{1 2 4 4}$, when William Raleigh, Bishop of Winchester, assigned a third of the offerings in that chapel to the vicar of Basingstoke. Simon, chaplain of the chapel of the Holy Ghost, is one of the witnesses to a deed of 1250 in the muniment room of Merton College.

That the chapel was one of considerable size and importance becomes manifest when it is mentioned that David Martin, Bishop of

7 Cal. of Papal Petitions, i. 208 ; Cal. of Papal Letters, iii. 456.

8 Winton. Epis. Reg., Wykeham, i. f. $4^{8}$; iii. f. $79 \mathrm{~b}$. Provost Shepstone exchanged the church of Smarden with the preceding provost.

9 Ibid. i. f. 129.

10 Ibid. iii. f. 23 1a. Prorost Ketone, treasurer of Wolvesey, held for six months in commendam.

11 Ibid. i. f. 178, 271 .

12 A short account of the history of this chapel and gild was issued by Rev. S. Loggon in 1742, of which an enlarged edition was printed in 1819 . The History of Basingstoke by Messrs. Baigent \& Millard (1889) deals thoroughly with the subject, pp. 110-71, and appendix 663-77. The sketch here given is mainly based on this last volume. 


\section{RELIGIOUS HOUSES}

St. David's, acting for the Bishop of Winchester, held a large ordination therein on 24 May, 1309. The numbers then ordained were 45 first tonsure, 30 acolytes, 24 subdeacons, 20 deacons and 22 priests. ${ }^{1}$

In 1463, Michael Skylling conveyed to John Powlett, William Brocas and others (as trustees) certain messuages, gardens, lands and tenements in Basingstoke which he had lately had by the gift of John Bettys, for the endowment of an obit to be kept yearly in the chapel of the Holy Ghost on the anniversary of John Bettys. The trustees were to keep the buildings in repair, and to distribute on the Monday next after the Ascension to the priests, clerks and poor people attending 3s. $4 d$., yielding the surplus to the wardens of the chapel for the remuneration of the chaplain there celebrating. At what time a gild was attached to the chapel has not been ascertained. The licence or charter granted by Henry VIII. on the joint petition of Bishop Fox and Lord Sandys is dated November, 1525, and recites that the townfolk, 'out of their devotion to the third person in the Divinity,' had long before begun and tontinued the maintenance of a gild or fracernity in honour of the Holy Ghost which the king desired to establish on a permanent basis. The brethren and sisters were accordingly vested with powers to receive and hold gifts of land and other property, being constituted a corporate body with a common seal, and were empowered to elect an alderman and two wardens annually for their better government. No provision was made for a chaplain (one had been already endowed), nor was there any reference to any educational object.

The Valor of 1535 gave $£^{6} \quad 13$ s. $4 d$. as the chaplain's income. The tithe of all ecclesiastical benefices having been assigned to the king, the sum of 13 s. 4 d. was demanded. But the warden of the gild for the year 1536 refused payment, and the bishop together with the collector petitioned to be exonerated on certain specified grounds. Thereupon the Crown ordered the sheriff to hold an inquiry, with the result that a return on oath was

\section{ALIEN HOUSES}

\section{THE PRIORY OF ST. HELEN}

The small Cluniac priory of St. Helen, situate on the northern shore of Brading Haven, was founded circa 1090. ${ }^{2}$ It is

- Winton. Epis. Reg., Woodlock, ff. $320 b, 321$.

2 Stone's Arch. Antig. I.W. pt. i. p. 102, note A. made, testifying that long before the passing of the late Act, certain wardens of the gild, out of their devotion and freewill, and by reason and consideration of the unhealthiness of the air and of the pestilential infection which frequently broke out in the parish and town of Basingstoke, maintained a chaplain to celebrate divine service in the chapel of the Holy Ghost, and were accustomed to pay him the yearly stipend of $f^{6}$ I $^{\text {s. }} 4 d$. provided he in all things behaved himself well; that the said chaplain had no possessory title except the will of the wardens and was removable at their pleasure; and that there was no fixed chantry, nor ever had been in the said chapel. The wardens either forgot or conveniently ignored the obit endowment of 1463 which was among their documents. The exchequer, in 1540, devised the exoneration, and the wardens were released from any further demands.

This gild of the Holy Ghost escaped the operation of the Act of 1545 for the suppression of such institutions, on account of the king's death; but it fell a victim to the renewed legislation of Edward VI. In 1550 the Crown granted the confiscated possessions of the gild to John Doddington and Williain Warde for the sum of $£_{1}, 6754$ s. 8d. In 1552 a portion of the estates were leased by the Crown for twenty-one years to John Carter. In 1556 the townsfolk petitioned Philip and Mary for a revival of the gild and a restoration of its endowments. A new charter of incorporation was granted, wherein, in reviving the fraternity, it was stated that the licence of Henry VIII. provided for the celebration of divine service in the chapel and for the instruction and education of young men and boys within the town. The estates were restored and the old government of aldermen, wardens, and brethren and sisters re-established. The funds were to be used for providing a suitable priest who was to be responsible for the chapel services and for the education of the young.

The later history of the gild will be found in the section upon the Schools of the county. mentioned in 1292 with a long list of other houses of the Cluniac order, to whose superiors the king granted protection. ${ }^{3}$ In 1295 there was but one professed monk (an Englishman) in the house, in addition to the prior. The

3 Pat. 22 Edw. I. m. 7. 


\section{A HISTORY OF HAMPSHIRE}

prior left the island and the monk joined the Carisbrooke community. ${ }^{1}$

Brother Aymo, the prior of St. Helen, together with the majority of the beneficed priests of the Isle of Wight, got into serious trouble with Bishop Sandale, apparently for resisting his diocesan authority, and were excommunicated. In the case of Prior Aymo, the excommunication was relaxed, and due intimation of his absolution forwarded to the secular authorities on 20 November, $1316 .^{2}$ In 1347 Peter de Chirlu, prior of St. Helen, quitclaimed to John de Wallup, prior of Breamore, the advowson and rectory of Brading. ${ }^{3}$

On 8 May, 1388 , Richard II. remitted for seven years the annual farm of 50 s. with all the arrears, by which the priory of St. Helen was held of the Crown by Richard Newbury, the prior thereof, during the wars with France on account of the poverty of the house. This remission was made on condition that Prior Newbury continued in residence, and maintained divine service and the buildings so far as the means of the priory admitted. ${ }^{4}$

St. Helen was suppressed with other alien houses in 1414 and made over to the Crown. At Michaelmas, I 461, the priory was granted by Edward IV. to William Beaufitz for ten years, and in the following year this grant was renewed for twenty years. ${ }^{5}$ Nevertheless, in 1467 , Edward IV. granted it to Eton College; and again in 1474 , in free alms, to the warden or dean and canons of the king's free chapel of St. George within the castle of Windsor. ${ }^{6}$

\author{
Priors of St. Helen \\ Aymo, I 316 \\ Peter de Chirlu, I 347 \\ Richard Newbury, 1388
}

\section{THE PRIORY OF HAYLING}

The island of Hayling is stated by the Winchester Annals to have come into the possession of the cathedral church of St. Swithun, partly by the gift of Queen Emma, the wife of Ethelred, and partly by the gift of Bishop Alwyn.

A charter of William I., probably of the year 1067 , in which he describes himself as

1 Stone's Arch. Antig. 1.W. ii. 197.

2 Winton. Epis. Reg., Sandale, ff. 5, 2 zb.

3 Ancient Deeds P.R.O., B. 533-5, 539, 677 ; see the account of Breamore Priory.

- Pat. ii. Rich. II. pt. 2, m. 4.

c Ibid. 1 Edw. IV. pt. 4, m. 22, p. 5, m. 6.

- Ibid. 7 Edw. IV. pt. 3, m. I3; 14 Edw. IV. pt. I, m. I.
Lord of Normandy and King of England by hereditary right, for the profit of his soul and at the urgent advice of his councillors, bestows on the famous abbey of St. Peter of Jumièges the manor of Hayling. The charter concludes with a prayer that any one infringing this gift may be removed from the communion of saints. " A charter of Henry $I$. between I IOx and r I06, addressed to Archbishop Anselm, William, Bishop of Winchester, Henry de Port, sheriff, and all his lieges of Hampshire, granted to the abbey of Jumièges, Hayling with all its appurtenances and privileges. A charter of Bishop Henry de Blois, between 1139 and I 142, refers to the strife between the churches of Winchester and Jumieges concerning the right to a portion of Hayling Island, and states that he and the whole convent of Winchester at the prayer of Pope Innocent, and in consideration of the poverty of the church of Jumieges, grant the said portion of the island to that church as its possession for ever, and will never again stir up strife concerning it. The first witness to this charter was King Stephen, and the second Archbishop Theobald. But notwithstanding this solemn covenant the dispute still lingered. In 1150 Theobald, Archbishop of Canterbury, wrote to Bishop Henry of Winchester saying that the monks of Jumieges had lately approached him, imploring him to bear witness to the truth as to the agreement made in his presence between them and Bishop Henry as to Hayling. He therefore stated simply what he remembered of it. His recollection was that, for the peaceful and quiet possession of the land, the monks promised him to pay 100 marks, of which Henry, if he will kindly remember, remitted 20; of any other undertaking given him, neither Theobald nor any of those who were present have any recollection. He bears witness to what he heard. The archbishop concluded with the pious aspiration that Henry might be pleased to approve what so many witnesses declare to have been done, and that God would grant him eternal bliss. ${ }^{8}$

About the year 1174 Henry II. granted a general charter of confirmation to the abbey of Jumièges of their English possessions. Therein is specified the "greater part of the island of Hayling, with the church and tithes of the whole island, except the tithes of pulse and oats in the land of the Bishop of Winchester, and in the same island sac and soc and thol

7 Round's Cal. of Frencb Documents, i. 526 ; see also vol. i. V.G.H. Hants, p. 435 , as to the Domesday entry.

8 Round's Cal. of French Documents, i. 55, 56. 


\section{RELIGIOUS HOUSES}

and theam and infangenethef and all other customs." From this it is evident that the whole of the land of the island was not then in the possession of the abbey, but that the monks had manorial rights and franchises over the whole. The grant of 'thol' would be of much importance and value. They also held the whole of the ferry rights.

In 1248 there was a fierce dispute relative to the right of presentation to the church of St. Peter, Winterborne Stoke, in the diocese of Salisbury. Eventually the pope issued his mandate to the Bishop of Salisbury formally to induct one of the claimants, and stated in his communication that the prior of Hayling, who claimed the church by gift of Pope Gregory, deserved to forfeit Pope Gregory's grant because of his violence. ${ }^{2}$

The church of St. Swithun managed to keep a foothold in the island, and in 1284 transferred their tenants of Hayling to Bishop Pontoise and his successors. These lands in the north of the island remained in the possession of the Bishops of Winchester, as part of the manor of Havant, down to I $553 .^{3}$

It has been more than once asserted that the priory of Hayling was not founded or erected till the reign of Henry III., but this is improbable. The abbot and convent of Jumieges would be quite sure to send over a colony of monks to the island so soon as the Conqueror gave them so valuable a gift, and a cell or priory, with suitable buildings, including a chapel or conventual church, would be speedily erected.

A dispute arose during the episcopate of John de Pontoise respecting the chapel of St. Peter in the north of Hayling Island, sometimes termed the chapel of Northwood. The bishop's award was to the effect that the vicar of Hayling and his successors were faithfully to serve the chapel as had been customary; namely that during the weeks of Christmas, Easter and Whitsuntide, and on double festivals and on every Sunday, there was to be full and complete service, namely mattins, evensong and compline, as well as masses, and that mass should also be celebrated on Mondays, Wednesdays and Fridays every week. * The dispute was however renewed in 1317 between the parishioners of the chapel of St. Peter and Michael, the vicar, inasmuch as he had for some time neglected to give them mattins, evensong or compline on any of the

1 Dugdale's Monasticon, ii. 1087.

2 Cal. of Papal Letters, i. 257.

3 Winton. Epis. Reg., Pontoise ; Longcroft's Hundred of Brosmere, p. I 76.

- Winton. Epis. Reg., Pontoise, f. 42 b.

II appointed times. The vicar was summoned before the bishop, and pleaded as an excuse that no books were provided for such services. The vicar and parishioners lowever agreed to accept implicitly the bishop's ruling. The bishop, recognizing the right of the rector of the church of Hayling, to which the chapel was annexed, summoned the prior of Hayling, as proctor for the abbot of Jumieges, as well as the vicar and parishioners to appear before Master Henry de Clife, his commissary. After deliberation, the vicar of his own free will undertook to follow out precisely the ordinance of Bishop Pontoise, and also took upon himself the burden of finding the necessary books. The bishop gave his formal decision, reciting the action of the vicar, on 9 December, I 3 I $7 .^{5}$

The priors of Hayling were simply nominated by the foreign abbot and were removable at will, and so we look in vain for any reference to them in the episcopal books. On an aid being granted to Edward I., the prior of Hayling was summoned, but he pleaded that the priory was alien and not conventual, and that all the priors of the same, from time whereof the memory of man ran not to the contrary, had been appointed or removed at the motion and will of the abbot of St. Peter of Jumièges in Normandy and were not perpetual and were not inducted. ${ }^{\circ}$

The taxation of 129 I returned the prior of Hayling as holding in the island $\$ 20$ of rents, agricultural land taxed at $£, 5$, a mill taxed at I 3 s. $4 d$. , a dovecote at $4 s$. , a garden at $6 s$. , and service of villeins at 20s., yielding an annual income of $£_{2} 273$ s. $4 d$. At the same time the rectory of Hayling, which was in the hands of the prior on behalf of the abbot of Jumieges, was returned at the high annual value of $£ 80$, whilst the vicarage was worth EI 4 6s. $8 d$.

This priory suffered much from two causes, war and the encroachment of the seas. In I 294 Edward I., in consequence of war with France, seized all the alien priories in England which were dependent upon the abbeys of Normandy. The prior himself was for a time taken into custody, the goods and chattels seized, and an inventory of the lands and tenements forwarded to the exchequer. In this return of the priory of Hayling, it is stated that the prior's garden and dovecote within the precincts were worth by the year 50s., and that there were 366 acres of waste land in demesne worth by the year $£_{12}$ 4s. 2d. ; 10 acres of wood, 20s.; 100 acres of

- Ibid. Sandale, f. 2 I.

- Longcroft's Hundred of Brosmere, p. 177. 


\section{A HISTORY OF HAMPSHIRE}

sheepwalk, 16 s. $8 d$.; and a watermill, 6os.; giving a total of $f 19$ 1os. Iod. The annual value of the whole manor, including the church at $f_{0} 80$, was $f_{144} 8$ s. $3 \frac{1}{2} d$. The goods and crops were estimated at $f^{6} 6716$ s. ; under this heading were included a palfrey worth, 60s.; a sumpter horse, 40s.; and two asses, 4s. The prior himself was probably released, as was the case with the heads of other alien houses, on finding sureties to observe neutrality during the continuance of the war. ${ }^{1}$

On the renewal of hostilities with France in the reign of Edward II., the alien priories including Hayling were again seized. A return was made of its possessions in January, 1325 , by authority of a commission addressed to Ralph de Bereford and Richard de Westcote, keepers of the alien houses of Hampshire. The prior of Hayling however appeared in person before the barons of the exchequer at Westminster, and pleaded that his house and its appurtenances might be committed to him for safe custody. His prayer was granted on condition of his finding security for the safe custody of all the goods and chattels.

And now another misfortune befell the priory. From the beginning of the reign of Edward I. the sea had been making gradual encroachments on the west shore of the island, and lessening by degrees the property of the monks. But in $1324-5$ the whole line of our south coast suffered much depredation, and a very considerable portion of the island of Hayling was definitely submerged beneath the waters, including the priory church and conventual buildings. The prior forwarded a statement to the Crown, and on 8 March, 1325, an inquisition was held before Ralph de Bereford and Richard de Westcote, as wardens of the alien houses, to ascertain the truth. The jurors found upon oath that 206 acres of arable land of the priory demesne had been inundated and destroyed by the sea since $\mathbf{1 2 9 4}$, and that they were worth $£_{1} 06$ s. by the year, because the better land of Hayling was that nearest the sea; that 80 acres of pasture belonging to the priory had been submerged, worth 20s. a year; that six virgates of the land of customary tenants had been destroyed, the rental of which was $48 \mathrm{~s}$. ; that nearly the whole hamlet of East Stoke with lands pertaining, as well as a great part of the larger hamlet of Northwood and its lands, which belonged to the parish church of Hayling and which the prior had for his proper use, were submerged,

1 Add. MS. 6164, ff. 4, 5 . diminishing the annual value of the priory by $\oint_{2} 6_{1}{ }^{1} 3^{\text {s. }} 4 d$.; that the two priory mills were less by 20 s. a year because the tenants used to grind at these mills; that the court fines and perquisites were less by 20 s. a year ; and that the full annual value of the possessions destroyed by the sea amounted to the considerable total of $f_{42} 7$ s. $4 d$. They returned the then annual value of the lands, tenements and church at $£ 488$ s. $5 d^{2}{ }^{2}$

In November, I313, John Abel, escheator citra Trentam, received orders to desist from demanding fealty from the prior of Hayling for the priory lands, and to permit him to hold the same without hindrance, as he complained of being distrained for fealty of the lands he held of the king in Hampshire, Wiltshire and Somerset of the gift of William the Conqueror in free alms, without doing any secular service. It was definitely stated in this order that none of the priors of Hayling nor the abbots of St. Peter of Jumièges, of which the priory was a cell, had done fealty at times of voidance of either the priory or the abbey. ${ }^{3}$

The priory was bound to provide support for two of the king's pensioners. In February, 1318, Oudinus Bruant, king's yeoman, was sent to the prior and convent of Hayling to receive the same maintenance for life as Philip Walrond, deceased, had received in that house by order of Edward I. ${ }^{4}$ In 1334 Simon Bacon was sent to the house of Hayling to receive such maintenance as Philip Walrond had had there. ${ }^{5}$

These were bad times for even the best established of the alien houses. The heavy exactions of the Crown led the manorial villeins in some cases into the mistake of thinking that the law would not intervene for the maintenance of their rights. In February, $133^{8}$, the prior of Hayling, who was holding the priory and its lands of the Crown at a rental of $f_{0} 80$, complained that though his predecessors time out of mind had had divers villeins in the manor of Hayling, from whom they used to receive corporal ransom at their will, and fines in any voidance, yet these had by their confederacy among themselves and others refused to make such ransoms and fines or other services and customs to the prior ;

2 Extents of alien priories, $18 \mathrm{Edw}$. II. P.R.O.

3 Close, 7 Edw. II. m. 18.

4 Ibid. 1 I Edw. II. m. 10 .

5 Ibid. 8 Edw. III. m. 37 d. The name of William, prior of Hayling, occurs about this time on recognizances dated 1330 and 1337 . Close, 4 Edw. III. m. 39d; and 11 Edw. III. pt. 2, m. $23 \mathrm{~d}$. 


\section{RELIGIOUS HOUSES}

had rescued distraints made for these; and when the prior and his bailiffs and servants would have taken other distraints had rescued them with armed force. Commissioners were thereupon appointed to take an inquisition at Hayling as to all the particulars.

Nor had the inundations come to an end with the winter storms of $1324-5$. The sea continued to encroach on Hayling throughout the fourteenth century. In 1340 there was a further grievous incroach of the water to such an extent that men then living officially testified that they had known the first church of Hayling (which was originally all in the centre of the island) standing in good preservation by the sea shore, and that it was then two miles (leucas) from the shore, and so deep in the water that an English vessel of the larger class could pass over it. ${ }^{1}$ Jurors in I 341 testified to the greatly diminished value of the priory and the church, so much having been destroyed by the sea. ${ }^{2}$

In I 39I, Simon Dubosc, abbot of Jumiéges, retired from the abbey to Hayling, having obtained a restoration of the priory through the Duke of Lancaster, while he was in France as an ambassador endeavouring to arrange terms of peace. Three monks accompanied him from the mother abbey to re-establish discipline at Hayling Priory. ${ }^{3}$ The abbey continued to enjoy a considerable share of the revenues of the priory until 1413 , when the general dissolution of the alien priories came about, and Henry V. granted Hayling to the monastery of Sheen in Surrey.

A chartulary of Sheen in the British Museum contains a catalogue, covering many folios, of the various evidences and charters of the suppressed house of Hayling that had come into their keeping. ${ }^{4}$ Among the long list of muniments were indentures binding the prior to find life corrodies for two men at the king's mandate ; a charter of free-warren from Henry I., the titles to the churches of Hayling, Winterborne Stoke and Chewton, 'a byll of supplication made by the tenantys of Hayling to the priour and convent of Shene,' also 'a byll of supplication made by the tenantys of Hayling to the Comons in the Parlyament of ther sume of dymes to be diminished,' and a bull of Pope Innocent as to the appropriation of the church of Hayling and the chapel of Northwood.

\footnotetext{
1 Longcroft's Hundred of Brosmere, p. 220.

2 Inquisitones Nonarum, f. 120.

8 Deshayes' Histoire de I Abbaye de Fumilges, pp. 87,88 .

Cott. MS., Otho B. xiv. ff. 53-68.
}

\section{THE PRIORY OF ANDOVER}

Among the various English gifts that the Conqueror bestowed on the Benedictine abbey of St. Florent, Saumur, was the church of Andover, with a hide and 14 acres of land, tithes of all the demesne lands in the parish, and extensive pasture rights, with wood for fuel, for fencing and for building purposes. ${ }^{5}$ In I yoo William Rufus renewed the gift to St. Florent of the church of Andover, with its tithes and all its appurtenances, and directed, with characteristic fierceness, that all churches built under the mother church of Andover should be utterly destroyed, or should be held by the monks of St. Florent. ${ }^{6}$ In I 146 Pope Eugenius III. confirmed to the abbey the church of St. Mary of Andover, with the chapel of Foxcote, and this confirmation was repeated ten years later by Pope Adrian IV., and by Pope Urban III. in $1186 .^{7}$

The abbey of St. Florent placed a colony of monks at Andover, and established there a priory or cell directly after the church was given them. The homes of the monks are described as being juxta ecclesiam. In the present large churchyard, a little to the north of the parish church, a piece of trim ivycovered walling is still standing, which is said to be the only remnant of the old priory.

Between II 60 and II 73 an agreement was made and confirmed at Andover between the monks of St. Florent and Philip Croch, in the presence of Froger, abbot of St. Florent, concerning three virgates and two acres of land held by the church of Andover at Easton, of the fee of Matthew Croch. Philip was to pay the prior of Andover half a mark of silver annually for that land as long as he lived. The prior was to do no service to the king nor any one, but Philip was to acquit it in everything. On the day of Philip's death the monks were to have the land freely. Philip swore, with his hand on the four gospels, that he would never seek directly nor indirectly to deprive the priory of that land or rent. ${ }^{8}$

In the time of Pope Urban IV. there is a curious instance of papal interference, when the prior of Andover was Master Berard of Naples, papal subdeacon and notary. On 29 May, I 264, a papal letter was addressed to him, reciting that by custom he had, as

5 Pat. 8 Edw. II. pt. 2, m. I. The charter of William the Conqueror is cited in an inspection and confirmation of Edward II.

6 Round's Cal. of French Documents, i. 415.

7 Ibid. p. 403, 404.

8 Ibid. p. 4 I 5 . 


\section{A HISTORY OF HAMPSHIRE}

prior of Andover, the right to present a fit person for the perpetual vicarage of St. Mary, Andover, to the abbot of St. Florent, to which the priory was subject, to be by him presented to the bishop ; but that as the vicarage had been long void, and as on account of the disturbance of the realm the prior (who was nonresident and an Italian) had had no notice of the voidance, so that neither he nor the abbot could present, the said prior and abbot were licensed to present a fit person within six months from the time that the prior was aware of the voidance of the vicarage; any collation, provision or investiture of any ordinary notwithstanding. ${ }^{1}$

In 1 294, when the priory of Andover was seized by Edward I., it was found that the prior's messuage and dovecot within the precincts were worth 5 s. a year, and 48 acres of lands 24s., and 12 acres of meadow I $2 d$. Rents from diverse tenements realized 68 s., and the tithes of the church $f_{66} \mathrm{I}^{\text {s. }} 4 d$. The total annual value came to $£ 7$ I I 8 s. $4 d .^{2}$

On 22 October, 1305 , Robert de Combor, a monk of St. Florent, was instituted to this priory by Bishop Woodlock. In the previous year there had been a great dispute between John de St. John, prior of Andover, and Robert de Combor as to the latter's violent intrusion into the priory. During the vacancy of the see of Winchester the matter was referred to the Archbishop of Canterbury, and immediately on Bishop Woodlock's appointment, the primate issued his mandate to the bishop to execute speedy justice in this quarrel. The bishop appointed the rural dean of Andover to report, with the result that Robert submitted, renounced all rights, and was absolved. However, he was shortly afterwards formally instituted, probably on the resignation of Prior John. ${ }^{3}$

Prior John de Pomariis is mentioned in the Close Rolls of I33I, where his name appears in conjunction with the parson of Horncastle as owing 200 marks to two merchants of Florence. The amount was to be levied, in default of payment, on their lands and chattels in Hampshire. ${ }^{4}$ In the following year Prior John de Pomariis and his brother ecclesiastic were in a yet more serious pecuniary dilemına, for they owed on bonds the large sums of E 30 to Bartholomew Richo, merchant of Kerio, and $f_{1} 13$ 6s. 8d. to Asselinus Simonetti, merchant of Lucca, and Bindus Gile of

1 Col. of Papal Letters, i. 418.

2 Add. MS., 6164, f. 8.

3 Winton. Epis. Reg., Woodlock, pp. I, 1ob, etc.

4 Close, 5 Edw. III. pt. I, m. 2 d.
Florence; these debts were ordered to be levied in default of payment on their lands, chattels and ecclesiastical goods in the county. ${ }^{\circ}$ In 1334 the amounts due to the merchant of Kerio were still unpaid, for in that year Bartholomew Richo put in his place William de Newenham, clerk, to prosecute the execution of a recognisance for f8I made to him in Chancery by John de Pomariis, prior of Andover, and Master Peter de Galiciano, parson of Horncastle church, in the diocese of Lincoln, and of another recognizance for $£ 50$ made to Bartholomew by the same prior and Peter. ${ }^{\circ}$

Andover was another of the alien houses expected to keep at least one royal pensioner. In November, I333, John de Baddeley, yeoman of the king's napery, by reason of his good and long service, was sent to the prior and convent of Andover to receive such maintenance from that house for life as Richard le Naper, deceased, had received at the request of Edward II.

On I October, I337, pardon was granted to Prior John de Pomariis of his outlawry in Hampshire for non-appearance before William de Shareshull and his fellow justices of oyer and terminer to answer touching a trespass against the king at Winchester. ${ }^{7}$

The Patent Rolls of 134 I have a long entry relative to the priory of Andover, which is of much interest as illustrating the intricacy of the dealing with alien houses. John de Pomariis, the late prior, had been removed by his superior, the abbot of St. Florent, to the priory of Sele, Sussex, which was another cell of this great house of Anjou. Prior John, in a petition to the king, recited that he had held the priory of Andover as well in the time of Edward II. as of the present king, when the alien priories were taken into the Crown's hands through the war with France, without fine or farm, because he was born of the duchy of Acquitaine, and was not of affinity or confederacy with the king's enemies; he therefore asked that as he had been removed to Sele the king would order him to be discharged of the farm of fifty marks which the last prior of Sele, because he was born of the power of the king's enemies, was held to render. The king, because John had been born of his duchy and was his liege man, and because the priory of Andover had come into the hands of an alien of the power of the king's enemies, and had on that account been taken into his hands and would remain in

6 Ibid. 6 Edw. III. mm. $38 \mathrm{~d}, 36 \mathrm{~d}$.

6 Ibid. 8 Edw. III. m. Iod.

7 Ibid. 11 Edw. III. pt. 3, m. 19. 


\section{RELIGIOUS HOUSES}

them during the war with France, granted that John should hold the priory of Sele without fine or farm, and commanded the sheriff of Hampshire to take Andover priory into his hands and to account for the true value thereof from the date of the removal of Prior John.

On 23 October, 1399 , Nicholas Gwyn, on the death of Prior Denys, was instituted to the priory of Andover by Bishop Wykeham at the king's presentation. Nicholas was an English Benedictine monk, and he held the priory under the condition of paying the apport of forty marks to Henry IV. and his successors, so long as the war with France continued, and in addition maintain sundry English monks, chaplains and officials. At the general dissolution of the alien priories in I 414, Gwyn was permitted to alienate the priory to Winchester College. The college however could not have gained any profit from the transaction for some time, as the possessions of Andover priory were held by them subject to a yearly pension of forty-five marks to the Crown, of twenty marks yearly to Queen Joan, the widow of Henry IV., as part of her dower, and of a life pension of fifty-two marks to the ex-prior, Gwyn. ${ }^{2}$ The college tried its best to get released from the pension to Queen Joan, but without effect; she did not die until I437. Gwyn enjoyed his pension for twenty years.

This grant to the warden and scholars of Wykeham's college was confirmed by Edward IV. in $1461,{ }^{3}$ in consequence of an attempt that was made that year to refound the priory of Andover by a Bill in Parliament.

In 1535 the Winchester accounts returned the Andover priory property at $£ 3^{1}$ a year, but there were probably some arrears or special deductions for that year, as in 1548 it produced $f^{81}$. $^{4}$

\section{Priors of Andover}

Berard of Naples, about 1264

John de St. John, I 304

Robert de Combor, ${ }^{5}$ I 305

Helias de Combor, ${ }^{6} 1307$

Ralph de Combor, 1316

1 Pat. 15 Edw. III. pt. 3, m. 12.

2 Wykeham's Register (Hants Record Society), i. 221 ; ii. 615 ; Kirby's Annals of Winchester College, p. 173 .

\& Pat. Edw. IV. pt. 7, m. 31.

1 Leach's Winchester College, 146-7.

- Winton. Epis. Reg., Woodlock, pp. 1, Iob, etc.

- This and the following institutions are quoted from a writ for return of presentations to alien priories, 2 Hen. IV., given in Wykeham's register,
Helias de Combor, ${ }^{7}$ I 320

John de Pomariis, ${ }^{8}$ I 33 I, 134 I

Philip Maghe, I 34 I

Denys Canoun, I 363-99

Nicholas Gwyn, I399-I 4 I 4

\section{THE PRIORY OF HAMBLE}

The priory of St. Andrew, Hamble, was a cell of the great Benedictine abbey of Tiron, near Chartres, which was founded in 1109. Tanner is wrong in describing Tiron as a Cistercian abbey. The priory of Hamble was placed on the rise or point of land at the junction of the Hamble river with Southampton Water, and was hence usually termed 'Hamble-en-le-rys' or 'Hamblerice,' now Hamble-le-Rice. William Giffard, Bishop of Winchester, II00-28, was the founder. The original charter is not extant, but there is a confirmation of Giffard's grant of Hamble to the monks of St. Andrew among the Winchester College muniments. ${ }^{\circ}$ That charter, from the witnesses, cannot be later than 1140 .

A bull of Pope Innocent II., of the year I 132 , addressed to his dear son William, abbot of Tiron, confirming to him several English endowments, specifies the church of St. Andrew in England (ecclesiam Sancti Andree de Anglia) with its appurtenances, which other charters prove to be that of the priory of St. Andrew at Hamble. An undated charter, but apparently about I I 35, is from Emma, wife of Roger Alis, notifying her gift to the monks of Tiron dwelling at St. Andrew's, Hamble, of the lands and meadows that she held at 'Auditon.' 'The charter recites that she made this gift in chapter of the monks of St. Andrew and placed it on the altar in the presence of Prior Geoffrey. About I I 42, Ascelina, wife of Guimond, gave to God and the monks of Tiron at St. Andrew's, in the presence of her brothers who were dwelling there, the house and land pertaining to it, which had been given her by her brother Roaudus, who was then a monk. In I 47 Pope Eugene III. confirmed to the abbot and convent of Tiron, inter alia, the church of Hamble, which was again confirmed about I I 75 by Pope Alexander III. On 23 August, I 179, an elaborate papal

but in each case the actual episcopal register has also been examined.

7 This was probably a re-appointment. Priors of alien houses were frequently moved from one priory to another.

${ }^{8}$ Close, 5 Edw. III. pt. 1, m. 2 d.

- Archaologia, 1. 259. 


\section{A HISTORY OF HAMPSHIRE}

confirmation of all the benefactions and privileges of the abbey of Tiron enumerates the priory of St. Andrew in England.'

Among the Winchester College muniments is a charter of Henry II. confirming the rights of the monks of Tiron to a yearly pension of fifteen marks for their shoes (calceamenta), which had been granted them by Henry I., and another charter of the same king, exempting the monks of Hamble from toll, passage and pontage, etc., throughout England and Normandy.

Another interesting Hamble evidence preserved at Winchester is a lease by Prior Beaumont, in the year I 320 , to John Poussant de tous les servises corvus et coustumes of Hamble Manor. Raoul dit l'Ermite, prior of Andwell, was at that time proctor-general of the abbey of Tiron, and was a party to the lease. ${ }^{2}$

When Edward I. seized Hamble Priory in 1294, it was found that the prior held a house and garden and dovecot, valued at $4 \mathrm{~s}$. a year ; 79 acres of land, I $3^{\text {s. }} 2 d$. $; 8$ acres of meadow, 5s. $4 d$. ; pannage over 4 acres of wood, I 8d.; and wood necessary for house repairs and fences. There were also four free tenants holding $2 \mathrm{I}$ acres of land, paying a rental of $6 s$.; twenty-seven customary tenants holding 4 acres of land and paying $28 s$. $4 d$., whose labour was worth nothing, propter capcionem cibarum, and sixteen cottars, who paid $12 d$. a year. A pension of bread and of beer from St. Swithun's, Winchester, was valued at 58 s. a year ; the tithes of Worldham, 40s.; and land and meadow at Hunteborn at 22s. The total annual value of the priory was reckoned at $\ell_{1} 8$ I $4 s .8 d^{3}$

Several of the religious connected with the three alien houses of Hampshire pertaining to the abbey of Tiron were accused in 1313 of conspiring to destroy charters. A commission of oyer and terminer was issued on the complaint of Master Robert le Wayte of Chiriton, that Alan, prior of Hamble; Ralph, prior of St. Cross in the Isle of Wight; Brother Robert de Andwell and Master Ralph de Mallings, with others, broke three charters and a deed of covenant at Andwell and Hamble."

In I 33 I a difference arose between the prior of Hamble and the parishioners as to the repairing the ruinous bell tower of the (parish) church. The bishop appointed John de Erde-

1 Merlet's Cartulaire de I Abbaye de Tiron, charters $182,262,291,292,326,328$.

2 Archeologia, 1. 251-62, a valuable article on this priory by $F$. Kirby.

3 Add. MS. 6164, ff. 4, 5 .

4 Pat. 7 Edw. II. m. 14d, 9d, 5 d. sope to act as his commissioner in inquiring into and settling the dispute. ${ }^{6}$

In May, I334, Nicholas, abbot of Tiron, had letters nominating Richard de Beaumont, prior of Hamble, and another his attorneys in England. ${ }^{8}$

Hamble affords an instance of the peculiar use to which the incomes of alien priories were occasionally put. In 1352 Edward III. granted an annuity of ten marks to Agnes Pore, nurse to his daughter Margaret, to be paid yearly from the farm of the priory of Hamble as long as the war with France lasted, and when it was ended, by the exchequer. During the peace of I $360-8 \mathrm{Ham}-$ ble was relieved of the pension, but at the latter date, on the renewal of the war, the priory had again to pay the ten marks. On the accession of Richard II. this grant to Agnes Pore and its payment by Hamble was re-affirmed.?

The priory was vacant in 1375 , and as the abbot of Tiron neglected to present, the appointment lapsed to the bishop. Wykeham collated William de Foxele, or Foxle, a monk of Chertsey, to the priory on IO August of that year. ${ }^{8}$ It has been suggested that the new prior was possibly of the family of Thomas Foxley of Bramshill, the constable of Windsor Castle, under whom Wykeham served in early life.

Before the youthful Richard had been a month on the throne, a French expedition harassed the English coast, and in August, I 377 , did sad havoc in the Isle of Wight and on much of the seaboard of the mainland. The priory of Hamble, notwithstanding its dependency on a French abbey, suffered much from the burning and plunder of its possessions. Its grievous condition was brought to the knowledge of the council, with the result that the priory and its possessions were ratified by privy seal to William Foxle, the prior, and he was exempted during the war from payment of any farm rent and pardoned all arrears, to the intent that the rents and profits should be spent on repairs."

Prior William Foxle died on 3I May, I 386 , and in the following August the king granted the priory for their lives, without any rent, during the continuance of the war, to Sir Bernard Brocas, knight, and Tydeman the monk. ${ }^{10}$

6 Winton. Epis. Reg., Stratford, f. $58 \mathrm{~b}$.

- Pat. 8 Edw. III. pt. 1, m. 17.

7 Ibid. 1 Rich. II. pt. $5, \mathrm{~m} .13$.

8 Winton. Epis. Reg., Wykeham, i. 62 b.

- Pat. 3 Rich. II. pt. 2, m. 19.

10 Ibid. 10 Rich. II. pt. 1, m. 37. 


\section{RELIGIOUS HOUSES}

In I 39I the abbot of Tiron presented two clerks, John Beck and John Kent, to the bishop, and he admitted Beck to the priory on 20 February.

The priory was however purchased by Bishop Wykeham later in the same year from the abbey of Tiron, to assist in the foundation of Winchester College. Particulars as to its value have been given under Andwell.

Soon after Hamble came into the hands of Winchester College, namely in $1401-2$, the large sum of $\oint_{1} 77$ s. Id. Was spent on the church, chiefly in providing it with.a new roof. The manor was also furnished with a new dovecot. In 1410-1 the bell tower of the church was either entirely rebuilt, or underwent very considerable repairs. In the following year three new bells were provided for this tower; they were cast by Richard Brasier of Wickham, who was paid 40s. in addition to the three old bells. ${ }^{1}$

In 1404 the French, though a nominal truce existed, were making descents on our shores. The college, mindful of the severe losses of Hamble Priory from that cause in 1377 , equipped a party of men and sent them down to their newly-acquired possessions at Hamble, but the expected foreigners did not land. The entry in the college balance sheet for that year includes a sum of $£ 6$ gs. under the heading, Custus pro defensione patrie. ${ }^{2}$

In I4I I one Nicholas Diford, a copyholder of Meonstoke, came to the audit with IOO oysters in payment of his quit rent. These doubtless came from Hamble, which was formerly in high repute for its oysters. The prior of Hamble used to render 20,000 oysters at mid-Lent to the monks of St. Swithun as an acknowledgment for an annual corrody of six gowns, six pairs of shoes, six pairs of boots, together with twenty-one loaves and forty-two flagons of ale weekly, which he and his brethren received from that monastery. After the property became vested in Winchester College, the corrody, valued at fro yearly, was made the endowment of Wykeham's chantry in the cathedral church. ${ }^{3}$

Mr. Kirby is probably right in surmising that this early corrody is an indication that the monks of Hamble numbered six at the time of its foundation. If that was the case, the amount works out at half a loaf and one flagon daily for each monk. The weekly delivery of this food at Hamble must have been a serious charge on the Winchester house, though Bishop Lucy gave them the

1 Archaological Fournal, vii. 86, 87.

2 Ibid. p. 156.

3 Ibid. p. $158-9$. advantage of water carriage all the way by making the river Itchen navigable to Southampton.

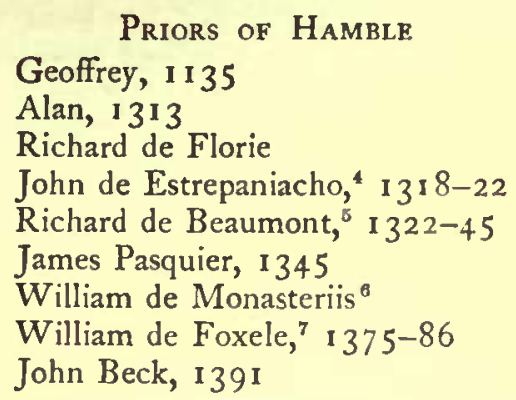

\section{THE PRIORY OF ANDWELL}

This small priory was a cell or dependency of the great Benedictine abbey of Tiron. It was founded early in the twelfth century by Adam de Port of Mapledurwell. His grant of lands in Nately and other rents were confirmed by a charter of Henry I. Roger de Port, the eldest son of Adam, much increased his father's benefaction by giving to the monks of St. Mary of Andwell lands at Winchester, the mill of Andwell before the gate of their house and a virgate of land pertaining to it, and a virgate of land at Mapledurwell. The churches of Stratton, Hinton and Bradford were also granted to them, together with numerous minor gifts by the De Port family of Mapledurwell. ${ }^{8}$

The church of this priory, the successor no doubt of an earlier structure, was dedicated by John, Bishop of Ardfert, acting as suffragan for Peter de Roches, Bishop of Winchester, about the year 1220. An indulgence of forty days was granted to all who, having confessed and repented, had come to the consecration and offered alms, and also of ten days for those who had made like attendance at the dedication of the altars, which had taken place on the Feast of the Holy

4 Winton. Epis. Reg., Sandale, f. 42. Prior Estrepaniacho resigned in 1322 .

5 Ibid. Asserio, ff. I 2b, 24b. Prior Beaumont had been appointed in 1320 to act during the absence of Prior Estrepaniacho.

${ }^{6} \mathrm{He}$ was presented during the episcopate of Bishop Edingdon (1346-70). These last two institutions are taken from Bishop Wykeham's return of all the alien priory appointments. The date of the latter is not given.

7 Winton. Epis. Reg., Wykeham, i. 62b.

8 See article on the alien priory of Andwell by Rev. W. H. Gunner (Arch. Fourn. 1852, ix. 2466I), corrected by Mr. Round in Genealogist, n.s. xvi. 7-10; also Lucien Merlet's Cartulaire de rAbbaye de Tiron, 2 vols. (1882-3). 


\section{A HISTORY OF HAMPSHIRE}

Innocents. The church was dedicated in honour of St. John Baptist. The thirteenth century seal of the priory represents that saint carrying an Agnus $D_{e i}$ in his right hand, with a monk kneeling before him, and the legend Sigillü Prioris de Anedewelle.

Only one of the grants in the Cartulaire de Tiron mentions Andwell by name; this occurs in the charter of Roger de Port, circa I I 50 , by which he gave to his monks at Andwell (Henedewella) the mill before their gate with the land belonging to it, as freely as he held it on the day of the gift. But several of the papal confirmations of English grants to Tiron, such as those of Eugenius III. (I 47 ) and Alexander III. (I I 79), specify the church or priory of Mapledurwell. As the parish of Mapledurwell adjoined the extraparochial district of Andwell, and as Tiron held land and served a chapel in that parish, there can be no doubt that it is but an alias for the priory of Andwell. ${ }^{1}$

In 1223 an agreement was come to between Theohald, abbot of 'Tiron, representing the cell of Andwell, and Alan Basset. The abbot and convent released to Alan all claim in Hookwood, and gave him land in the field of the chapel at Mapledurwell, retaining a third of the moor called Eastmoor. He restored to them a way sufficient for a laden horse to go along with his leader at the head of his tillage toward the water of Mapledurwell to the house of Andwell. ${ }^{2}$

Richard de Beaumont and James Pasquier, who were priors in succession of the sister priory of Hamble, wcre also priors of Andwell. Probably Pasquier, who died whilst prior of Hamble and who was instituted to that house in March, 1345, on the resignation of Bcaumont, exchanged priories with the latter. The absence of all reference to the admission of priors to Andwell throughout the episcopal act books makes their succession doubtful.

In 1274 the prior had in Up-Nately ten tenants who held of him in villenage five yardlands that formerly belonged to Basingstoke manor. In 1290 the holdings of the prior of Andwell at Nately and Mapledurwell were worth $£^{2}$ per annum, whilst in his own manor the rents, meadow and mill were valued at $\ell_{3}$ yearly. An extent and inventory of the possessions of the priory taken in 1294 show that within the precincts were a messuage, garden and dovecot worth Ios. yearly, whilst the lands and other possessions yielded a total of $£ 6$ I 4 s. 2d. From free tenants the prior received $£_{4} 8$ s., and twenty-

1 Round's Cal. French Documents, i. 358, 527.

2 Ancient Deeds, P.R.O., A. 3242. one customary tenants who held three virgates paid $48 \mathrm{~s}$.; but deductions left a clear rental of 43 s. $8 d$., so that the whole income of the priory only came to $£^{8}$ i7s. Iod. ${ }^{3}$ The inventory showed that the priory stock included a horse worth a mark; two carthorses, $8 s_{\text {. ; }}$ six plough-horses, I 9s.; a mare and foal, 6 s. $8 d$. ; three colts, $6 s_{\text {s. }}$; eighteen oxen, I08s.; two cows, 7 s. $6 d$.; three better cows, 15 s.; three yearling bullocks, 2 s.; one heifer, $2 s .6 d$.; thirty-three sheep, I 4s. 2d.; forty-two lambs, 20s.; twelve hogsteers, 8 s. ; and twenty hogs, 20s.; yielding a total of 612 IOs. $8 d$. The dead stock was worth 2gs. $4 d$., by far the largest item being a brazen pot in the kitchen at I6s. 8d. The seed-corn and crops were valued at $\ell_{12} 12$ s., leaving the total value of the inventory at $£ 26$ I 2s. ${ }^{4}$

It would seem that the priors of Andwell were simply the nominees of the abbot of Tiron, and were apparently removable at pleasure. The distance of the controlling force and the complete freedom from episcopal supervision or even recognition, worked evilly for the discipline of the house. The exactions of the Crown during the reign of Edward III., when there was war with France, in seizing not only the apport or usual annual tribute to the abbey of Tiron, but further sums under the guise of securing the custody of the house to the respective priors, were also a sore burden. Eventually in May, I368, Bishop Wykcham sequestrated the priory of Andwell (together with that of St. Cross, Isle of Wight) for dilapidations. In the document securing this, addressed to the archdeacon of Winchester and the warden of the college of St. Elizabeth, the bishop comments severely on the faults, negligences and carelessness of the priors which had brought about the loss and collapse of both the spiritual and temporal affairs of the priory ; adding that the house and buildings would soon be in irreparable ruin unless some speedy remedy was provided.

In 1385 the priory was in the hands of Thomas Driffielde and Eleanor his wife, and was returned as being of the annual value of E13 6s. 8d. ${ }^{5}$ It was let to farm by the king's treasurer in order to secure the apport. After Richard came to the throne it was let to one Thomas Thorpe for $£_{10}$ a year, and in December, 1387 , John de Uvedale, sheriff of Hampshire, and four others were appointed to inquire touching waste and defects in the

${ }^{3}$ Add. MS. 6164, ff. 6, 7 .

4 Roll 22 Edw. I. P.R.O. ; Woodward's Hampshire, iii. 283-4.

${ }_{5}$ Winton. Epis, Reg., Wykeham, iii. f. 213. 


\section{RELIGIOUS HOUSES}

alien priory of Andwell, before its custody was committed, at a certain yearly farm, to Thomas de Thorpe. ${ }^{1}$

During the latter part of the reign of Richard II. the parent monasteries of these alien houses were permitted to sell them to other religious houses, or to particular persons who desired to use them for founding chantries, hospitals or other works of charity. ${ }^{2}$ Bishop Wykeham availed himself of this privilege by purchasing Andwell from the abbey of Tiron, and paying Thomas Thorpe $£ 20$ for his interest therein. The bishop bestowed the priory and its lands on his newly founded college at Winchester, to which it still belongs.

Andwell at the time of its purchase was valued at fio 10s. a year. The other Hampshire purchases made by $W$ ykeham from the abbey of Tiron were Hamble, valued at E. 13 6s. ; St. Cross, Isle of Wight, valued at $£_{5}$; and Worldham Chapel, valued at $£_{1}$. Roughly speaking, he obtained $£ 30$ a year for about $£_{3} 80$, rather more than twelve years' purchase."

Wykeham no sooner secured the Andwell property than he saw to its repair. In a list of extraordinary expenses incurred by the college from the opening day in 1393 down to 1401 , occurs the then very large sum of $£ .53^{8} 4$ s. for the repairs of manors, rectories and chancels that had been secured from various alien priories. The items are not separated, but the repairs included the grange and chamber at Andwell.4

At Epiphanytide, I4IO, the warden kept open house for two days to a number of country gentlemen. The manor of Andwell contributed a heronshaw towards the feasting; the man who brought it to Winchester, a distance of twenty-two miles, received Is. for his pains. ${ }^{5}$

$\quad$ Priors of ANDwell
Hugh"
Walter Britell
William de Pulchra Quercu
Gervase, I210, I2167
Nicholas, time of Henry III.

1 Pat. 2 Rich. II. pt. I, m. Id.

2 Rymer's Fodera, vii. 697.

3 Leach's Winchester College, p. 145.

4 Kirby's Annals of Winchester, Pp. $150-1$.

5 Ibid. p. 158.

- This and the two following names are taken from the Winchester College muniments,

7 Ancient Deeds, P.R.O., A. 24 I.

This and the following names are taken from the Winchester College muniments.

II
Robert, time of Edward I.

Richard " " Edward II.

Ralph " ", "

Godfrey de Insula, time of Edward III.

Richard de Beaumont

James Pasquier

\section{THE PRIORY OF ST. CROSS, ISLE OF WIGHT}

The small priory of the Holy Cross at the north end of the town of Newport, Isle of Wight, was a cell of the Benedictine abbey of Tiron. It was founded about 1120 . On 30 May, I147, a bull of Pope Eugenius III. confirmed the church of the Holy Cross in the Isle of Wight to the abbey of Tiron, and again a bull of about the time of Pope Alexander III. confirmed to Stephen, abbot of Tiron, inter alia, the church of the Holy Cross of the Isle in the diocese of Winchester. ${ }^{9}$

A survey of alien priories of the year I 295 names, among the possessions of St. Cross, a horse for the prior, 5 heifers, a two-year-old colt and filly, 2 bulls, 10 oxen, 6 cows, 6 bugles, 2 calves, I boar, 5 sows, 4 pigs and 14 young pigs. ${ }^{10}$

In 1391 the annual values of the temporalities of this priory were assessed at $£_{1} \circ 3^{s .8 d}$. With other alien houses it was seized in time of war with France and administered by the Crown.11

In May 1369 the priory's income was sequestrated by Bishop Wykeham in consequence of the dilapidated condition of the buildings. ${ }^{12}$

On 20 April, I390, licence was granted by the Crown to the abbot and convent of Tiron to alienate the advowson and patronage of the church or chapel of St. Cross in the Isle of Wight, called the priory of St. Cross, and all lands and tenements of the said convent to the warden and scholars of Winchester College. The conveyance to the college is dated I September, I39 I.

Soon after the priory came into the hands of the college a considerable sum was spent on the repairs of the hall, the chamber, and the chapel of St. Cross and on a new waterwheel. ${ }^{13}$

- Round's Cal. of French Documents, i. 358.

10 Stone's Arch. Antig. of I. W. ii. 197.

11 Cal. of the Patent Rolls, passim Edw. I. and III.

12 Winton. Epis. Reg., Wykeham, iii. f. 12b.

13 Kirby's Annals of Winchester College, 1 50-1. 


\section{A HISTORY OF HAMPSHIRE}

\section{THE PRIORY OF MONK SHERBORNE}

The largest of the alien priories established in Hampshire was that founded by Henry de Port, in the time of Henry I., at Monk Sherborne, otherwise called West Sherborne, which pertained to the Benedictine abbey of St. Vigor, at Cerisy in Normandy, now Cerisy-laForêt (Manche). His selection of this abbey for his gift was doubtless due to the fact that it lay only some twelve miles from his Norman home at Port-en-Bessin, while its priory of Deux-Jumeaux was half way between the two. Though subject to St. Vigor and sending doubtless from the earliest times its apport or tribute to the parent house, Sherborne was in the exceptional position of being an alien priory or cell which had its true conventual life and a certain degree of genuine independence. The prior and convent of Sherborne, not the abbot and convent of St. Vigor, were accepted by the Bishops of Winchester as patrons of such livings as Bramley and Church Oakley, whilst the later priors received episcopal institution. It is on this account, we suppose, that Bishop Wykeham paid no attention to Sherborne when drawing up for the crown, in I $40 \mathrm{I}$, the list of institutions to alien priories that were to be found in the various episcopal registers of the diocese. Nevertheless, as will be noted, Sherborne was regarded throughout as an alien priory by the civil authorities.

Hugh de Port, at the Domesday Survey, was possessed of a great barony, of which Basing was the head. He had too a son and heir, Henry, who, in his foundation charter, gave to God and St. Vigor of Cerisy the whole of West Sherborne with its woods and church and tithes. To this he added the meadow of Longbridge and the mill and meadows of "the other Sherborne' (Sherborne St. John), all his tithes in Basing and certain other lordships, and the churches of Bramley, Newnham, and Upton (Grey). ${ }^{1}$ These gifts were confirmed by John de Port, Henry's son, together

1 Dugdale's Monasticon, VI. 1013-4. The originals of this and the other De Port charters given by Dugdale are preserved at Queen's College, Oxford. The series of charters quoted in this and the following pages are all to be found among the muniments of Queen's College (see Hist. MSS. Commission Appendix to Fourth Report, pp. 451-5). In his Baronage (i. 465) Dugdale cites a charter, as at Queen's College, in which Adam de Port, of the Mapledurwell line, gave the chapel and tithes of Newnham, on the day of that chapel's dedication, with the tithes of Mapledurwell to the monks. This Adam, who (probably later) founded the priory of Andwell, also gave the tithe of his de- with small additional gifts by himself and his mother Hadwise. His confirmation is granted to the monks of Sherborne (among whom he desired to be buried) and not to the abbey of St. Vigor. John de Port was living as late as II67. His son Adam, who succeeded him, granted to the Sherborne monks the tithes of all his mills at Sherborne in exchange for the possession of the mill granted by his grandfather as above; the first witness to his charter is his wife Sibyl, who is styled comitissa. William de St. John, son and heir of Adam de Port, who took the name of St. John from his mother Mabel, granted a short charter of confirmation of certain lands which had been bestowed on William Fitz-William by Adam de Port in conjunction with the prior and convent of Sherborne. ${ }^{2}$ There is another charter of this William de St. John extant, wherein he makes mention of William, prior of Sherborne ; it is witnessed by Gervase, prior of Andwell.

The charter of Bishop Henry de Blois confirming those of Henry and John de Port to the monks of Sherborne is amongst the Queen's College muniments; it is witnessed by Ralph, archdeacon of Winchester and Robert de Inglesham, archdeacon of Surrey, and dates therefore between the years I I 30 and I I 40 .

Amongst the same muniments is a grant, probably of the time of Henry II., to the priory of St. Fromond, Normandy, of the church of Shaw (Berks), a grant to the same prior of a 'pension' of 40 . out of the rectory of that church made by Herbert, Bishop of Salisbury, in 1207 , and also a notification by James, prior of St. Fromond to R., Bishop of Salisbury (probably Richard Poore, 121 7-28), of the grant of the church of Shaw by his house to the prior and convent of Sherborne, together with the grant itself from the one priory to the other. ${ }^{3}$

Among the Sherborne evidences now at Oxford, is an interesting deed from a social point of view, whereby Baldwin de Portsea, a knightly tenant of John de Port in I 166 , conveyed a virgate of land at ' $F$ roditonia' (Fratton in Portsea) to the monks of Sherborne, and

mesne at Littleton, Wilts, to the priory of Deux Jumeaux, which gift was confirmed, at a later date, as to the monks of St. Vigor.

${ }^{2} \mathrm{Mr}$. Round's papers on 'The families of St. John and of Port' and on 'The Ports of Basing and their Priory' in Genealogist, n.s. xvi. pp. 1 et seq. ; xviii. $137-9$.

9 St. Fromond had been colonized by monks from St. Vigor. The church of 'Sagie' or 'Sageys,' as it is styled in these documents, is identified throughout in the Historical MSS. Report as that of Seez (a cathedral) in Normandy; but Mr. Round has identified it in the Genealogist as that of Shaw, 


\section{RELIGIOUS HOUSES}

two men, William and Ernulf, dwelling on it, together with their children. ${ }^{1}$

In 1273 Lawrence, abbot of St. Vigor, set forth in a deed, still preserved at Queen's College, that his monastery had two priories, one the priory of Deux-Jumeaux ( $D_{\ell} D u o b u s G_{\ell-}$ mellis) in Normandy, and the other of Sherborne in England, and that the prior and monks of both these priories desire to act honorably to each other; therefore the chapter of St. Vigor, Cerisy, for their own good and peace and that of the two priories, ordained that the sum of ten shillings a year, which the Bishop of Salisbury has been wont to pay to the priory in Normandy from 'Lavintone' [Lavington, Wilts] should henceforth be always paid to the priory of Sherborne (the expense and trouble of transferring the money to France being so great), due compensation having been made to the French priory by the monks of Sherborne. There is also another deed of the same year by which the abbot and convent of Cerisy appointed Richard de Bourdigny, prior of Sherborne, and Bartholomew, called 'Robyn,' of Cerisy, dwelling in that priory, their attorneys to receive the rent of ros. payable yearly by the Bishop of Salisbury. Licence was granted by the Crown, during pleasure, in 1275 , to the priors and monks of Shireburn to take weekly two cartloads of dead wood in the forest of Pamber for their hearth. ${ }^{2}$

The priory acquired other endowments; for in 1291 the prior was rector ex officio of Aldermaston, Berks, and his house was in receipt of 'pensions' from the churches of Padworth, Sulhamstead, and Shaw in that county, of St. Frideswide's at Wallingford, and of Lavington, Wilts, in addition to owning temporalities at Sotwell, Berks, which was held by the family of De Port under Hyde Abbey. ${ }^{3}$ And in 1316 the prior was returned as one of the lords of West Shifford, Berks, where his house had received an early endowment from the same family. That the house had received benefactions from other quarters is shown by an interesting suit of 1233 as the result of which the prior lost the advowson of Windlesham, Surrey, which had been given to his house by a huntsman of Henry II. who made his son a monk there.

The extent and inventory of Sherborne priory, taken in 1294, names 300 acres of land

1 ،... cum duobus hominibus, videlicet Guillemo et Ernulfo, in eadem terra manentibus, et simul infantes eorum' (Gerealogist as above).

2 Pat. 3 Edward I. m. 32.

3 Taxation of Pope Nicholas.

- Feudal Aids, i. 50 (where the entry is wrongly assigned to Sherborne Abbey, Dorset). of the annual value of $655 ., 20$ acres on the hill (super montana de Schireburn unde potest seminare), 3s. $4 d$., 10 of meadow, IOs., 6 of moor, 3s., pasture, 2s. 6d., common pasture, 6s. 8d., and pannage, 23 s. $4 d$. ; total, $£ 63^{\text {s. }}$ Iod. The rents paid by twenty-four tenants realized $f_{22}$ I gs., and their labour for the lord was estimated at 20s. Pensions, spiritual dues, and portions came to $£ 57$ I 2s., yielding a total income for the priory of $\{87$ I 4 s. Iod. The livestock inventory reached $£_{2} 7$ 1 4s. $6 d$. The monks had an abundance of corn-seed, including wheat enough for forty-three acres and oats for 86 acres. The dependent churches paid the monks $£_{42}$; namely, Upton, 9 marks, Chinham, Io marks, Sherborne, Io6s., and Bramley 36 marks; the church of Aldermaston was farmed to Nicholas, clerk of Herriard. It had been a bad wet year for the hay; it is entered at only I 3 s. 4d., residuum inundatum.

In June, I 338 , the prior, who was in arrears to the extent of $£ 53$ of an annual payment of $£_{80}$ to the king for the custody of his priory, was ordered to pay that sum forthwith to Menaudus Brocas, one of the keepers of the king's great horses. ${ }^{\circ}$

In the autumn of the same year, distraint was made on the prior of Sherborne to find a man-at-arms by the keepers of the seaboard of Hampshire; but, on the petition of the prior to the king, alleging that he and his monks had nothing left wherewith to live after rendering the $£ 80$ yearly, the distraint was superseded. ${ }^{7}$

The heavy rent demanded by the Crown involved this unhappy priory in such financial difficulties that resort was had to exceptional measures. In July, I340, protection with clause nolumus, that is to say, immunity from the seizure of his cattle by the Crown officials, was granted for the prior, whilst Nicholas de la Beche and James de Wodestok were appointed overseers and chief keepers of the priory during pleasure, to receive the revenues and to apply them to relieve the estate of the house by advice of the prior and some of the more discreet members of the convent. The priory is described as grievously burdened with debt and of the foundation of the ancestors of the heir of John de St. John, tenant in chief, the king's ward. ${ }^{8}$

The election of the prior Inguerand de Duino, monk of Cerisy, on the death of prior William Bernand, is set forth with much detail in Wykeham's first register. On 12 August,

s Add. MS. 6164, f. 7 .

- Close, 12 Edw. III. pt. 2. m. 23.

7 Ibid. p. 3, m. 15

8 Pat. R. 14 Edward III. pt. iii. m. 52. 


\section{A HISTORY OF HAMPSHIRE}

1375, Inguerand appeared before the bishop at Waltham, bringing a letter from the prior and convent of Cerisy, sealed with green wax and verified by Master Stephen de Rippia, notary public, praying that their choice might be confirmed. On 28 August the bishop issued his mandate to the official of the Archdeacon of Winchester, ordering him to proceed to the priory of Sherborne on 30 August, and there to make proclamation that if any wished to object to the form of the election of Inguerand or to him personally, they were to appear before the commissary and before Giles and Peter, monks of Sherborne and their fellows, and John Atte More, steward of the house, and John the porter, on a day and time named. The due setting forth of this proclamation was testified to the bishop under the seal of the rural dean of Basingstoke who was present. Any objectors were cited to appear on the Wednesday after the feast of the Exaltation of the Holy Cross in the cliapel of the Castle of Farnham. Subsequently, on 26 September, the bishop, at his manor at Southwark, commissioned Master William Lozinge, canon of Salisbury, his chancellor, to sit in the church of St. Mary Magdalen, Bermondsey, and there to give his judgment. The chancellor pronounced the election null and void by reason of various defects of procedure and form, but admitted Inguerand on account of his many virtues (as stated elaborately in the usual form), in exercise of a power of provision delegated by the bishop. ${ }^{1}$

In May, I 370 , the bishop commissioned his official to correct a delinquent monk of Sherborne, William le Valeys, for abusive words to his prior and brother monks and for general disobedience to the rule. ${ }^{2}$

In April, 1380 , a grant was made to Inguerand, the prior, of the custody, without rent, of the priory of Sherborne, with the issues, from the death of William, the late prior (in the king's hands on account of the French war), by mainprize of John Atte More and Roger Savage as granted to William in $1369 .^{3}$ Three years later, certain letters patent which had been granted to one John Slegh, as custodian of Sherborne priory, were revoked in favour of Prior Inguerand, as neither John, after notice from the sheriff, nor the king's attorney had shown cause against the revocation." Nevertheless, as is shown by frequent entries about this date on the Patent Rolls, the king pre-

\footnotetext{
1 Wykeham's Registers (Hants Record Society), i. 63-66.

Ibid. iii. f. 34 b.

3 Pat. 3 Ric. II. pt. 3, m. 16.

- Ibid. 6 Rich. II. pt. 3 , m. Io.
}

sented to various benefices pertaining to the priory, as holder of the temporalities during the war.

Among the official instruments in Wykeham's registers is a form, undated, of commission to take an inventory of the goods of Sherborne, when it was thought that Prior Inguerand was dying. His condition is therein stated to be so serious as to render him quite incapable of attending to the affairs of his house, and that there was hardly any hope of his recovery. It was also alleged that in the event of his death the priory, in which there were but few monks, would be in sore straits in both sacred and secular affairs. ${ }^{\circ}$ Inguerand died early in 1397, and on 2 February of that year, the bishop admitted as prior Walter Marshall of Bristol, a Benedictine monk. The form of admission recites that the priory of Sherborne, under the rule of an alien priory, was vacant by the death of Inguerand, and that in accordance with the legislation of I Richard II., during the war with France, the bishop entrusted Walter with the rule and governance of the priory (on the nomination of Sir Thomas de Poynings, Lord St. John), on condition of his supplying mattins, mass, and the other desired offices according to ancient use, and of his keeping the conventual church and house and buildings in proper repair, and checking all waste. ${ }^{6}$

In the same year there was another vacancy, apparently through the resignation of Walter Marshall. On 3 October, 1397, Bishop Wykeham having first formerly annulled his election made by the alien abbey, as he was willing to act graciously, accepted Guilliaume Trenchefan, monk of St. Vigor, as prior of Sherborne, with the personal assent of Sir Thomas Poynings. After the general suppression of the alien houses, the priory of Monk Sherborne was given by Edward IV. to the Hospital of St. Julian, or God's House, Southampton. God's House had, however, been given by Edward III. to Queen's College, and hence the endowments and muniments of this priory were transferred to that college, which college still holds them.

\section{Priors of Monk Sherbornk}

William, early thirteenth century

Richard de Bourdigny, 1273

Thomas, ${ }^{7}$ about 1329

Robert Corbet, $1347-9$

5 Winton. Epis. Reg., Wykeham, iii. f. 291 b.

- Ibid. i. f. 266.

7 Close, 3 Edw. III. m. 8 d. 


\section{RELIGIOUS HOUSES}

Denis Vanceyo, ${ }^{1} 1349$

William Bernand, ${ }^{2}$ about 1369

Inguerand de Duino, ${ }^{3}$ I 375-97

Walter Marshall, 1397

William Trenchefan, ${ }^{4}$ I 397

\section{THE PRIORY OF ELLINGHAM}

An alien priory was founded at Ellingham, as a cell to the Benedictine Abbey of St. Sauveur-le-Vicomte, in the diocese of Coutances, by William de Solariis in the year 1160 . The charter specifies the church of St. Mary of Ellingham with all its appurtenances, together with 43 acres of land and 20 of meadow in that vill, and 3 acres near the church on which to build. ${ }^{5}$ A charter of Henry II. notifies that the endowment of William de Solariis at Ellingham was under his care and protection. ${ }^{\circ}$

A charter of Walter de St. Quintin, circa I 70 , granted to the Abbey of St. Sauveur, for the honour of God and the Blessed Virgin, and for his weal and that of his friends, his chapel at Rockford (a mile to the east of Ellingham) and all his demesne in his fee of Rockford; the chapel to be subject to the church of Saint Mary and All Saints of Ellingham, as daughter to mother, and to receive from it the service of masses three days a week at the hands of the chaplain of Ellingham, or of a monk (of the priory). The chartulary of St. Sauveur also records two other small bequests of land to the priory of Ellingham of about the same date, ${ }^{7}$ and two others, at Fordingbridge and Chardford, occur in the charters at Eton.

In 1292 Bishop Pontoise assumed the custody of the priory in consequence of the prior having departed across the sea without a licence ; ${ }^{\theta}$ but on 13 July, 1292 , the bishop instituted to the priory, on the death of Michael the last prior, Thomas dit le Petit, presented by the abbot of St. Sauveur. In

1 Winton. Epis. Reg., Edingdon, i. ff. 30, 58.

2 Ibid. Wykeham, iii. f. 17 a.

3 Wykebam's Registers (Hants Record Society), i. 63-66.

4 Ibid. f. 260.

- Round's Cal. of Documents in France, i. 348. The foundation charter is recited in Winton. Epis. Reg., Pontoise, f. 102b. It differs somewhat from the above and is of the year 1163 ; the acres of land are increased from 43 to 72 , and the church is described as the church of All Saints with the chapel of St. Mary. This latter charter is still preserved at Eton, together with its confirmation by Richard, Bishop of Winchester.

${ }^{6}$ Ibid. i. 349. 7 Ibid. i. 35 I.

B Winton. Epis. Reg., Pontoise, f. 11.
1298 Thomas de Bere, acting for the Bishop of Winchester, made an award in favour of William Cancelot, then prior, who claimed to present to the church of Ellingham.

Of the next two priors there is apparently no record of their institution, but in September, 1305 , the official of the Bishop of Bath and Wells made an award in favour of Geoffrey, prior of Ellingham, who claimed half a mark yearly from John, rector of Babington, Somerset, of which the church had been given to St. Sauveur by William Fitz John of Harptree, temp. Henry II. ${ }^{2}$ On 10 April, I3I I, Bishop Woodlock granted Prior Geoffrey leave of absence ${ }^{10}$ until I August; and on 5 September, 1318, Bishop Sandale granted leave of absence to John le Vyonn, prior of Ellingham, to visit his abbey, from that date until the next feast of St. Peter ad Vincula (1 August). He was enjoined, after this eleven months' absence, to return without further delay. ${ }^{11}$ A second leave of absence to cross the seas was granted to Prior John by Bishop Strafford on 19 October, 1327. His death occurred whilst he was abroad, and the priory was sequestrated by the bishop on 19 January, $13^{28}{ }^{12}$

When Edward I. seized Ellingham priory in 1294, in consequence of the war, it was found that the prior held a messuage and $10 \frac{1}{2}$ acres of land worth by the year ros. $3^{d}$., that there were thirteen tenants holding 23 acres of land and $10 \frac{1}{2}$ acres of meadow, paying a rental of 4 Is. $7 d$., a pound of pepper, and a pound of cinnamon worth $8 d$., and that the church was worth $£ 12$ a year.

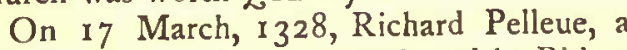
monk of St. Sauveur, was instituted by Bishop Stratford, on his abbot's presentation. Protection was granted in July, 1337 , to various aliens to secure the goods in their custody, among whom was Prior Pelleue. ${ }^{13}$

The references to Ellingham Priory on the Patent or Close Rolls are very few. In May, $13^{85}$, the king, by reason of the alien priory being in the hands of the Crown through the war with France, presented William Olyver, keeper of the neighbouring hospital of St. John's, Fordingbridge, to the vicarage of Ellingham. ${ }^{14}$

At an inquisition held at Ringwood on 10

- His charter of donation is now among the Ellingham deeds at Eton. Hist. MSS. Com. Rep. ix. App. I. p. 350.

10 Winton. Epis. Reg., Woodlock, f. 163 .

11 Ibid. Sandale, f. $30 \mathrm{ob}$.

12 Ibid. Stratford, ff. $32 \mathrm{~b}, 34 \mathrm{~b}$.

13 Pat. I I Edw. III. pt. 2, m. I 3.

14 Ibid. 9 Rich. II. pt. 2, m. 15 and m. 8. 


\section{A HISTORY OF HAMPSHIRE}

September, 1397, concerning the true value and extent of the priory of Ellingham by virtue of a letter of the king to the escheator, the jurors declared the clear annual value at $£$ I I 6s. 8d., and stated that Thomas Trewyn, who had been appointed by letters patent custodian of the priory, had secured the tithes of corn and hay for that year about the feast of St. Peter ad Vincula (1 August). ${ }^{1}$

After the final dissolution of the alien priories the rent reserved to the Crown from Ellingham Priory was bestowed by Henry VI. on Eton College, to which Edward IV., in 1462 , added the fruits of the parish church of Ellingham. ${ }^{2}$

\section{Priors of Ellingham}

Richard de Wauville, ${ }^{3}$ I 240

Michael, died 1292

Thomas dit le Petit, ${ }^{4} 1292$

William Cancelet, 1298

Denys, instituted 1301

Geoffrey, 1305, 1311

John le Vyoun, 1318, 1327

Richard Pelleue, instituted 1328

Galicanus de Hamberga, instituted 1347

William de Albigneye, instituted I 361

\section{CARISBROOKE PRIORY}

The priory of Carisbrooke, which was situated on the high ground to the north-west of the castle, was dedicated to the honour of the Blessed Virgin. It was a cell of the Benedictine abbey of Lire, and established to collect the dues of the parent house in the Isle of Wight. The church of Carisbrooke, and other property, had been granted to the abbey of Lire, probably by William Fitz Osborne, Earl of Hereford. They were at all events owned by that house while he held the lordship of the Isle of $\mathrm{Wight}^{5}$ (circa 1067-70). The priory of Carisbrooke is said to have been founded by Baldwin de Redvers about 1156 .

1 Add. MSS. 6165, p. 113.

2 Pat. 1 Edw. IV. pt. 3, m. 24.

3 Charter in archives of St. Lo.

4 This and other episcopal institutions to Ellingham priory are taken from a return made by Bishop Wykeham in 1401 of all the Winchester institutions to alien priories recordcd in the episcopal registers; but in each case the original has also been consulted.

${ }_{5}$ Transcript of the chartulary of Carisbrooke priory in the possession of W. A. Lindsay, K.C., F.S.A., Windsor Herald, p. I. Charter by Baldwin de Redvers to Hildebrand, abbot of Lire, of the church of Carisbrooke, to hold it as ever the abbot held in the time of William Fitz Osborne or Richard de Redvers father of the grantee. See also V.C.H. Hants, i. 407-8.
He gave to the abbey of Lire all the churches, tithes, lands, rents and benefits that he held throughout the island. Further grants by his son, William de Vernun, were made direct to the church of St. Mary, Carisbrooke, and to the monks there serving God. Henry II.'s confirmation charter to Lire Abbey particularizes their possessions throughout England. The abbey then held in Hampshire the churches of Clatford and St. John's, Southampton, and in the Isle of Wight the churches of Carisbrooke, Arreton, Freshwater, Godshill, Whippingham, Newtown and Newchurch. ${ }^{6}$ Godfrey, Bishop of Winchester (1189-1205), empowered the abbot to convert the church of Carisbrooke and chapel adjoining it ad usus suos proprios. ${ }^{7}$ Several churches were afterwards granted to the monastery by various persons.

Edward I., in 1285, licensed the prior and monks of Carisbrooke to hold a road going through their priory from the south gate to the north gate, which they closed to keep out persons wandering there day and night, and in exchange for which they made another road, 40 feet long, to the west of the said priory, with the assent of Isabel de Fortibus, lady of the Isle of Wight. ${ }^{8}$

Simple protection was granted by the Crown for a year in 1290, and again for a like period in 1292, both to the abbot of Lire staying in Normandy, and for the prior and monks of Carisbrooke, ${ }^{9}$ and in 1298 Edward I. recognized the right which Isabel de Fortibus had granted to the monastery of Lire of the custody of the temporalities during a vacancy in the priory. ${ }^{10}$

A survey of alien priories of the year 1295 shows that the priory had granges at Sheet, Chale and Northwood. The prior had a palfrey worth $€ 4$ I $3^{\text {s. }}$ od., a pack-horse worth 20s., and a white horse. The expenses of the prior and five monks in removing from the island to some place remote from the coast by royal command amounted to 4 s. $4 d$. When taken into the hands of the Crown by reason of the war, there were found, besides grain, I I plough horses, 2 draught horses, a two-year-old colt, a mule, 51 oxen, I bull, 22 cows, 8 heifers, 15 calves, 3 sheep, 106 lambs, I boar, 4 sows, 42 pigs, 23 young pigs, 7 sides of bacon, 2 poids of cheese and 3 sacks of wool."1

- Dugdale's Monasticon, vi. 1040-1.

7 Transcript of Carisbrooke chartulary.

${ }^{8}$ Pat. 13 Edw. I. m. I.

9 Ibid. 18 Edw. I. m. 16; 20 Edw. I. m. 9.

${ }_{10}$ Transcript of chartulary of Carisbrooke, p. 20.

11 Stone's Arcb. Antig. I. W. ii. 197. 


\section{RELIGIOUS HOUSES}

In I 333 the prior of Carisbrooke, as proctor in England for the abbot of Lire, contributed five marks towards the expenses of the marriage of Eleanor, the king's sister, with a proviso that such contribution should not prejudice the priory as a precedent. ${ }^{1}$

In 1374 the prior of Carisbrooke petitioned the king against the exactions of the sheriff, pleading that the enemy had burnt their granges and cowhouses, as well as their conventual buildings, and had despoiled their tenants and parishioners. ${ }^{3}$

The monks of Carisbrooke served the chapels of Newport and Northwood, receiving from the former town the annual pension of two marks granted to them by Richard de Redvers circa I I 80 . They had also under their care the burial ground, with its chapel dedicated to the Holy Cross, under the castle of Carisbrooke, consecrated by Bishop Henry of Winchester (probably Henry Woodlock, 1305-16), as a place of sepulture for the small religious communities in the Isle of Wight.

The seal of the priory (here illustrated) is oval in shape, and shows the Virgin and Child and below a kneeling figure. The legend runs : + SIGILLVM : ANDREE : PRIOR ... ROC.

The grants to the priory were of small extent and value, ${ }^{3}$ the parent community of Lire treating the prior as their locum tenens and absorbing the larger benefactions.

The priory was seized by the Crown during the reigns of Edward I.4 and Edward III., and being in the king's hands was granted by Richard II. to the Carthusian priory of Mount Grace, Yorkshire. Restored to Prior Thomas Val Oseul by Henry IV. on condition of the 'apport' or customary tribute to Lire being paid to the Crown, and future appointments of monks being filled by Englishmen, it was seized again by Henry V. and bestowed on his new charter-house at Sheen, and the monks dispersed.

The temporalities of Carisbrooke priory were declared of the annual value of $f^{28}$ Is. $2 \frac{1}{2} d$. by the taxation of 1291 . The various rectories of the island pertaining to the priory or the abbey of Lire were then of great annual value-Carisbrooke, $£ 80$; Freshwater, $£^{60}$; Godshill, $£_{66}$ 1 $^{\text {s. }} 4 d$. ; Newchurch, $£ 66$ I 3 s. 4d.; Arreton, $£ 336$ s. $8 d$. ; Whippingham, $£_{24}$; and Newtown, $£^{8}$. Two of these, namely Carisbrooke and Arreton, were at that time appropriated to the abbey of Lire.

1 Pat. 7 Edw. III. pt. 2. m. 20.

2 Stone's Arch. Antig. I. W. ii. 198.

3 Transcript of chartulary already referred to.

4 Pat. 5 Edw. I. pt. i. m. 12 d.
A survey of the priory made in 1385 gave the annual value at $£^{86}$ i 3 s. $4 d$. In 1446 the value was $f_{1} 194$ I s. $2 \frac{1}{2} d$., whilst in $153^{8}$ the annual worth of the priory as parcel of the possessions of Sheen was declared to be £I 33 6s. 8d.

\section{Priors of Carisbrooke}

Hugh, temp. Henry II.

John de Insula, ${ }^{5}$ circa I I 90

William de Glocester, ${ }^{\circ}$ circa I 205

Robert of S. Pier-sur-Dire, circa 1257

Andrew, circa 1264

Richard Preause, circa I 279

John de Caleto, ${ }^{7}$ circa 1286

Warin Pyel, ${ }^{8}$ circa I 298

John Poucyn, ${ }^{9}$ circa 1313

Blase Doubel, circa 1336

John Pepyn ${ }^{10}{ }^{10}$ circa 1348

Nicholas Gavaire," circa 1361

Peter de Ultra Aquam, ${ }^{12}$ circa ${ }_{1} 363$

Thomas de Val Oseul, 137 I

Odo de Ulmis, 1401

Nicholas de UImis, 1405

\section{THE PRIORY OF APPLEDUR- $\mathrm{COMBE}$}

The priory of Appledurcombe was founded (circa) 1100 as a cell to the Benedictine abbey of Montebourg in the diocese of Coutances, on the manor of the same name which had been granted that community by Richard de Redvers in 1090.

The priory held land in Sandford, Week, Appledurcombe and $W$ ydcombe.

A survey of 1295 shows that the priory possessed 2 horses, I bull, 8 oxen, I 2 cows, 2 bugles, 9 calves, 130 sheep, 248 ewes, 160 lambs, 4 boars, 12 sows, 48 pigs, 28 young pigs, and 4 hens and a cock..$^{13}$

In I 339 Edward III. gave orders for the removal of the prior of Appledurcombe and his monks from their priory near the sea coast to Hyde Abbey owing to the war with France. We suppose the order was carried out, as it is entered in the episcopal registers together with an injunction to the abbot of $\mathrm{Hyde}$ to see to its due performance. ${ }^{14}$

${ }^{5}$ Ancient Deeds (P.R.O.), B. 2836.

B Transcript of Carisbrooke chartulary, p. 16.

7 Ibid. p. $20 .{ }^{8}$ Ibid.

${ }^{9}$ John Poucyn presented to the rectory of Newchurch in 1322. He is described as prior of Carisbrooke and proctor of the abbot of Lire. Winton. Epis. Reg., Asserio, f. 23.

10 Winton. Epis. Reg., Edingdon, i. f. 33.

11 Ibid. f. 110 b. 13 Ibid. f. 123.

13 Stone's Arch. Antiq. I. W. ii. 197.

14 Winton. Epis. Reg., Orlton, i. f. $158 \mathrm{~b}$. 


\section{A HISTORY OF HAMPSHIRE}

In 1385 the annual value was returned at $£ 45 .^{1}$ On 27 March, 1395, orders were conferred in the priory church or chapel on four sub-deacons, three deacons, and four priests by Simon, Bishop of Achonry, acting as suffragan of Winchester. ${ }^{2}$

The prior, temp. Richard II. petitioned the king and council for relief in consequence of the devastation caused to their property by the enemy from both France and Spain. ${ }^{3}$

The priory was held by the Crown during the wars with France in the reigns of Edward

1 Winton. Epis. Reg., Wykeham, iii. f. 2 I 3.

2 Ibid. f. 406.

${ }^{3}$ Stone's Arch. Antiq. I. W. ii. 198.
I. and III., and was suppressed with other alien houses in 1414, and was bestowed by the Crown on the Nuns Minoresses without Aldgate. In 1528 the prioress, Dame Dorothy Comberford, granted a thirty-three years' lease of Appledurcombe to Sir James Worsley. ${ }^{4}$

Priors OF APPLEDURCOMBe ${ }^{5}$

Hugh, in the time of Stephen

Lawrence Bertram, 1331

Peter de Mouster, 1385

Thomas atte Tounesende, 1403

4 Winton. Epis. Reg., Wykeham, f. 406.

${ }_{5}^{5}$ Prior Stephen de Collevilla in an undated charter mentions as a former prior Peter de Mymbrantot. 


\section{EARLY CHRISTIAN ART AND INSCRIPTIONS}

T $\mathrm{N}$ classifying the archæological materials derived from any particular geographical area it will be found that they consist chiefly of fixed structures and portable objects. The first of these come under the heads of architecture or engineering, whilst the second are treated of amongst the finds of antiquities. There still remain however inscribed and sculptured monuments which form a class by themselves as they are neither structures nor are they portable objects. It is also impossible to separate the inscribed from the sculptured stones because many of the latter are also inscribed. Then again both the inscriptions and the sculptured decoration of the monuments are related to the illuminated MSS. of each period, the forms of the letters and the style of the ornament being the same whether executed in stone or drawn on parchment. A knowledge of palæography, inconography and the evolution of decorative art are essential to the study of the inscribed and sculptured monuments, so that they lie altogether outside the domain of architecture pure and simple, although in certain cases both sculpture and inscriptions form parts of ecclesiastical structures; but not being essential features of architecture it is better that they should be investigated by themselves. ${ }^{1}$

1 The inscriptions of the period we are considering-namely between A.D. 450, after which wellformed Roman capitals ceased to be used in Great Britain, and A.D. II 50, when Lombardic characters were first introduced-are of the following kinds as regards the forms of the letters :-
(1) Ogams.
(2) Debased Roman capitals.
(5) Anglian or Old Northern Runes.
(3) Anglo-Saxon capitals.
(4) Hiberno-Saxon minuscules.
(6) Scandinavian or Later Runes.
(7) Norman capitals.

The languages of the inscriptions are :-
(1) Latin.
(3) Anglo-Saxon.
(2) Celtic
(4) Old English.

The purposes for which the inscriptions have been cut are :-

(1) For sepulchral epitaphs.

(2) For dedication stones of churches.

(3) To describe the sculptured figure-subjects with which they are associated.

(4) To give the name of the sculptor.

(5) To illustrate the meaning of a figure-subject or the use of a sculptured object by means of a text from Scripture, a verse of poetry or some appropriate sentence.

With regard to the respective ages of the different kinds of letters in use during the early Christian period in Great Britain the oldest are Ogams and debased Roman capitals, which occur on rude pillar 


\section{A HISTORY OF HAMPSHIRE}

Only three inscriptions belonging to the early Christian period have been found in Hampshire, namely, (I) on the Ogam pillar from Silchester, now in the Reading Museum ; (2) on the Anglo-Saxon headstone of Frithburga at Whitchurch, between Basingstoke and Andover ; and (3) on the south transept arch of Breamore Church, on the outskirts of the New Forest. The Silchester Ogam stone has already been mentioned by Mr. F. Haverfield, ${ }^{1}$ but although dug up on a Romano-British site, it belongs to a class of monuments which, taken as a whole, are certainly

stones dating from about A.D. 450-650. Next come Anglo-Saxon capitals and Anglian Runes. These were employed contemporaneously and sometimes on the same monument, say from A.D. $650-850$. Anglo-Saxon capitals are found at a later date, with some slight modifications in the forms of the letters, but after the Viking invasions the place of the earlier Anglian Runes was taken by a later kind of Runic 'futhorc' or alphabet, similar to that used in Scandinavia at the same period. Hiberno-Saxon minuscules occur chiefly on the elaborately decorated crosses from A.D. 750-1050.

A study of the geographical distribution of the inscriptions in different kinds of letters shows that the Ogams and debased Roman capitals are confined to Wales, Scotland, Ireland, the Isle of Man, and those parts of England where Celtic influence was strongest in pre-Norman times, namely in the counties of Cornwall, Devon, Somerset, Dorset, Hants and Northumberland. Anglo-Saxon capitals and Anglian Runes are found most frequently in Northumbria and Mercia. Hiberno-Saxon minuscules, although common in lapidary inscriptions in Ireland and Wales, are comparatively rare in England. The later Runes belong more especially to the districts where there were Norse settlements in the tenth and eleventh centuries, as the Isle of Man and the coast of Cumberland.

There almost always exists a definite relation between the class of letter in which the inscription is written and the language. Thus all the Ogam inscriptions are in the language of the Goidelic Celts; the earlier Runic inscriptions are in Anglo-Saxon; the later Runic inscriptions are in Norse or Danish ; the inscriptions in debased Roman capitals are in illiterate provincial Latin; the inscriptions in AngloSaxon capitals and Hiberno-Saxon minuscules are generally in Latin, but sometimes also in the vernacular of the district.

Lastly a few words as to the leading characteristics of the alphabets used in the early Christian epigraphy of this country.

The Ogam alphabet was in all probability invented by a Goidelic Celt in the south-west of Ireland or in South Wales somewherc about A.D. 400, and is obviously derived from the Roman alphabet by dividing it into four groups of five letters, each of which was represented by straight strokes varying from one to five in number. The Ogams are either cut on the angle of a stone or on each side of a stem-line, and the alphabet or 'Bethluisnion' is as follows :-
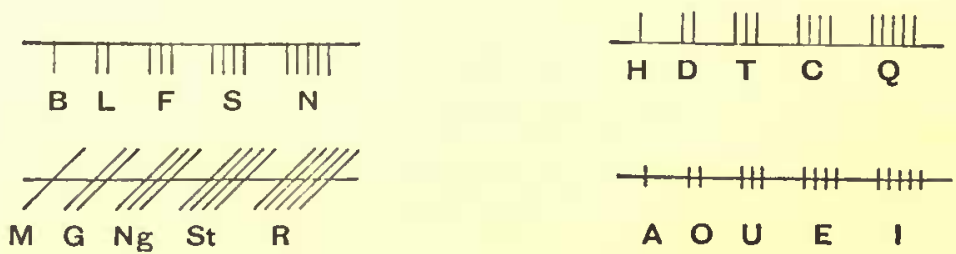

The Runic futhorc or alphabet was possibly derived from the Greek alphabet in early Byzantine times. It resembles the Ogam alphabet in two respects-(1) that the letters are formed of straight lines; and (2) that they are arranged in groups, but in thrce groups of eight letters instead of four groups of five letters. The Anglian Runic futhorc is as follows, the four last being extra letters :-

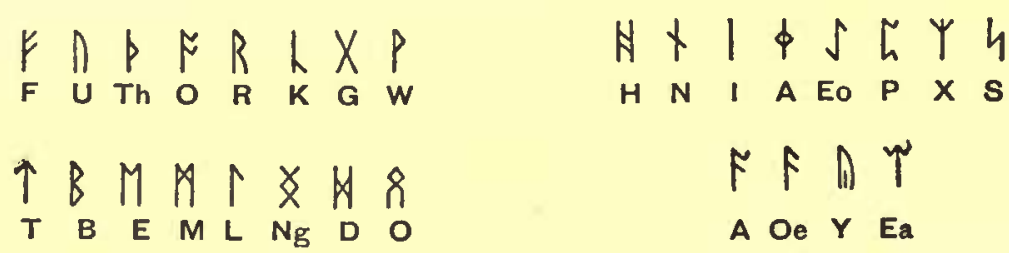

The later Runic Scandinavian futhorc was derived from the Old Northern Runic futhorc by modifying the forms of some of the letters and discarding others altogether. It is given below :-

1 Victoria History of Hampshire and the Isle of Wight, i. 279. 


\section{EARLY CHRISTIAN ART AND INSCRIPTIONS}

Christian rather than Pagan. Possibly the Silchester example may be the oldest ${ }^{1}$ Ogam inscription yet discovered, and it is remarkable as being the only one known to exist in Great Britain outside the Celtic area of Ireland, Scotland, the Isle of Man, Wales and West Wales (i.e. Devon and Cornwall). The Silchester Ogam inscription has upset the previously accepted theory that the Ogams cut on a stem-line are of more recent date than those cut on the angle of a rectangular pillar.

The Ogam stone from Silchester was found in 1893 at a depth of 9 feet in a well in Insula IX. It is a stele or pillar of friable sandstone with a moulded base, standing on what was originally a square plinth and surmounted by a rude fir-cone or phallic emblem. The stone is I foot II $\frac{1}{2}$ inches high; the plinth must have been when perfect about

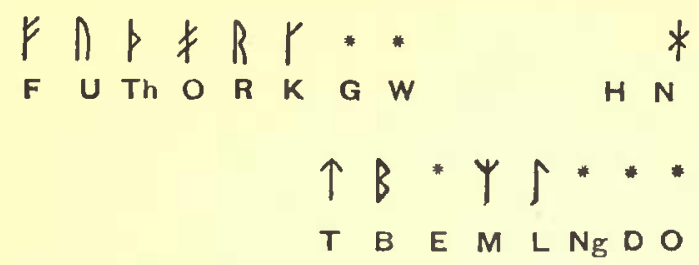

The Manks Runic futhorc is similar to the above except for the following letters :-

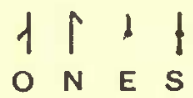

The debased Roman capitals, which are in many cases associated with Ogams on the sams monument, differ from the letters of the classical period in being very rudely formed with the strokcsloping instead of being horizontal and vertical. The horizontal I placed thus -, and the sicklee shaped $\mathbf{G}$ something like an $\mathbf{S}$ thus, $\mathbf{S}$, are characteristic features.

The Anglo-Saxon capitals are well formed, their chief peculiarity being their angularity as in the following :-

$$
\begin{array}{llllll}
\text { C } & \text { 디 } & G & \bar{\Omega} & 0 & S \\
\text { C } & D & G & 0 & 0 & S
\end{array}
$$

The letters $\mathbf{M}$ and $\mathbf{N}$ were made thus :-

and new characters introduced for

$$
\begin{aligned}
& H \text { H } N \\
& M N N
\end{aligned}
$$

$\bigoplus P Y$

Th $W$ \&

Hiberno-Saxon minuscules were gradually evolved from Roman capitals in the process of devising such forms as could be most quickly written with a pen in the early Irish and Saxon MSS. This evolution may be clearly traced in the early Christian inscribed stones of South Wales and Cornwall. The oldest are entirely in debased Roman capitals, then a few minuscule letters such as $\mathrm{d} \epsilon \mathrm{z} \mathrm{h} \mathrm{m} \mathrm{c}$ are introduced, and lastly we get inscriptions entirely in minuscules. The Hiberno-Saxon minuscule alphabet is as follows:-
$a b$ c $\delta$ e $F \mathrm{~h}$

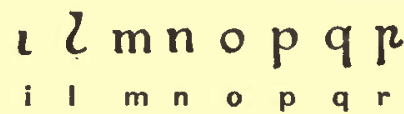

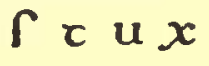
a b c d e f g h
s $t u x$

1 The only other instance of an Ogam inscription on an undoubtedly Roman stone is that on the altar at Loughor, Glamorganshire (Archeologia Cambrensis, ser. 3, xv. 258).

2 The earliest example of an Ogam inscription cut on a stem-line hitherto known was probably that at Maumenorigh near Dingle, co. Kerry (R. Rolt Brash's Ogam Inscribed Monuments of the Gaedbil, pl. 2 I). The use of the stem-line was supposed to be of late date because it is suitable for writing in a MS. or engraving on metal, whereas the Ogam character seems to have been obviously suggested by notches cut on the corners of a square stick or stone. 


\section{A HISTORY OF HAMPSHIRE}

1 foot 2 inches square, and the fir-cone is $10 \frac{1}{2}$ inches in diameter at the bottom and 7 inches at the top. The Ogam inscription is on two vertical stem-lines and reads from the bottom upwards thus :-
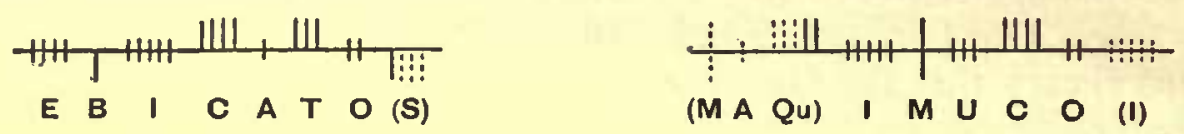

' (The gravestone) of Ebicatus the son of the descendant of . . .' This stone was first described by Professor John Rhys, LL.D., in the Academy (August 19, 1893), and blocks reproduced from photographs by Mr. S. Victor White of Reading are given in the Illustrated Archaologist (June, I894), which show the state of the stele shortly after its discovery and before it was affected by exposure to the atmosphere.

According to Prof. Rhys the meaning of the name Ebicatus is 'One who fights with arrows or with a javelin.' Maqui is known to signify 'the son of' because on the bi-literal and bi-lingual Ogam stone at St. Dogmaels, ${ }^{1}$ Pembrokeshire, its equivalent is given in Latin as fili. The modern form is the familiar Scottish mac, which is rendered in Welsh as map. The occurrence of the word maqui shows that Silchester Ogams were cut by a Goidel (or ' $Q$ Celt') and not by a Brython (or ' $\mathrm{P}$ Celt'). ${ }^{2} \quad$ The word mucoi is coupled with maqui in a great many of the Ogam inscriptions in Ireland, and there has been much discussion as to its exact meaning. Prof. John Rhys in his Welsh People (p. 52) translates maqui mucoi as 'son of the kin of,' and gives as an example the Ogam inscription at Dunmore, ${ }^{3}$ co. Kerry, which reads Maqqui Erccias maqqui mucoi Dovinias, and means ' (The monument of) Mac Erce, son of the kin of Dubinn.'

The Anglo-Saxon headstone of Frithburga at Whitchurch, was taken out of the wall of the north aisle of the church when the building was restored in $\mathrm{r} 868$, and the monument now stands on a new pedestal in the nave near the north pier of the chancel arch. Attention was first called to its existence by the late C. Roach Smith in the Builder (Nov. I I, $187 \mathrm{r}$ ), and it has been subsequently described by J. Romilly Allen in his Cbristian Symbolism, and by the Rev. G. W. Minns, F.S.A., in the Hampsbire Field Club Papers (iv. 1899, p. 171).

The headstone of Frithburga has a semicircular arched top. It is I foot $\mathrm{I} O \frac{\mathrm{I}}{2}$ inches high, by I foot 8 inches wide, by 8 inches thick at the top and I I inches wide at the bottom. It is sculptured in relief on the front with a bust of Christ having a cruciferous nimbus round the head, and giving the benediction with the right hand, and holding a book in the left. The sculpture on the back is incised and consists of elegant scrolls of foliage issuing from a central stem and interlaced. The inscription which is in two lines of Anglo-Saxon capitals commences near

1 Archaologia Cambrensis, ser. 3 , xv. 155 ; the Latin inscription reads SAGRANI FILI CVNOTAMI, and the Celtic Ogams SAGRAMNI MAQuI CVNATAMI.

2 See Prof. J. Rhys, Celtic Britain (S.P.C.K.), p. 21 I.

8 R. R. Brash's Ogam Inscribed Monuments of the Gadbil, pl. 7. 


\section{EARLY CHRISTIAN ART AND INSCRIPTIONS}

the bottom of the narrow edge on the left, and reads round the top and down the other side as follows :-

\section{HIC CORPVS FRIDBVRGAE REQVI :-
+ ESOIT IN PACE SEPVLTVM \\ 'Here lies the body of Frithburga, buried in peace.'}

The chief peculiarities of the palæography of the inscription are the use of the square $c$ and square $G$, and the full-stop made with three dots, thus :- as in some of the Hiberno-Saxon MSS. and on some of the early sculptured stones in England, Wales and Scotland. ${ }^{1}$ The $O$ is of the round shape, and the $Q$ is made like a $P$ reversed thus, q. The third letter of the name Frithburga may either be $\boxplus$ (i.e. Dh) or the Greek $\Theta$, and the last letter but one has a $\mathbf{v}$ cut over the $A$ apparently through a mistake on the part of the cutter of the inscription. It is not certain whether the word which precedes 'sepultum' is to be read 'pace' or 'pacem.' For ' requiescit ' there should be 'requiescat.' The meaning of the name Frithburga is 'Pledge of peace.'

The inscription in Breamore church, nine miles south of Salisbury, is cut on the front of the voussoirs of the arch of the opening between the part of the nave below the central tower and the south transept. This is the only one of the original four arches beneath the tower now remaining, the one on the north having been blocked up, and those on the east and west replaced by arches of the fifteenth century. The south tower arch is of Saxon date and is 4 feet II inches wide. On the face of the arch inside the tower is cut the following inscription in AngloSaxon capitals 6 inches high :-

\section{HER SPVTELAĐ SEO GECPYDRAENESĐE}

'Here the covenant becomes manifest to thee.'

When found the letters were filled in with plaster and coloured red, with a red line above and below. The palæographical peculiarities of the inscription to be noticed are the use of the square $C$ and $G$, the angular $s$, the Saxon $\boxplus$ for $D h$, and $P$ for $W$ and the joining together of the letters HE and TE. It may here be remarked that the shape of a letter is not always a certain guide to date, as in the present case although one $s$ is made angular the two others are of the modern curved form. The language of the inscription is Old-English, pronounced by Dr. H. Sweet to be not much earlier than the middle of the eleventh century. It is probable that the inscription was continued round the other arches, as a fragment of stone built into the adjoining wall bears the letters DES.

The discovery of the Saxon remains in Breamore church was first published in the Athencum (August I 4, 1897), and a full account of the building, by the Rev. A. du Boulay Hill, shortly afterwards appeared in the Archeological Fournal (lv. 34).

Having now concluded the examination of the early lapidary in-

1 On the dedication stone at Deerhurst, Gloucestershire; on the crosses at Llantwit Major, Glamorganshire ; and on the 'Drosten' cross-slab at St. Vigeans, Forfarshire. 


\title{
A HISTORY OF HAMPSHIRE
}

scriptions of Hampshire, we will proceed to consider the sculptured stonework of the Anglo-Saxon and Norman periods in the county. The examples of Saxon sculpture in Hampshire are comparatively few in number and are as follows:-

\author{
Headstone of Frithburga at Whitchurch. \\ Fragment of a cross-shaft at Steventon Manor. \\ Font at South Hayling. \\ Rood at Headbourne Worthy. \\ " at Breamore. \\ " inside Romsey Abbey. \\ Sundial at Corhampton. \\ " "Warnford. \\ " " "St. Michaels, Winchester.
}

The first of these has already been described. The fragment of a cross-shaft at Steventon Manor was found built into the old manor house, and is now fixed in a wall so as to preserve it and at the same time allow all the carving upon it to be seen. It is a mere fragment 3 feet high by I I inches wide, showing portions of two faces of the shaft. On each face are portions of two panels containing zoömorphic

1 It may be remarked before going further that the scope of the present inquiry is confined to the study of the decorative sculpture (whether consisting of symbolical figure-subjects, zoomorphs, foliage, or purely geometrical ornament) which occurs upon Christian sepulchral and other monuments, and the details of ecclesiastical buildings from the seventh to the twelfth century.

Now it is a curious fact that in the pre-Norman Christian period decorative sculpture is almost exclusively found on sepulchral monuments and crosses which were erected for various purposes and hardly ever on the details of churches, whilst in the twelfth century exactly the reverse is the case. With few exceptions the sculptured stonework still in situ in Saxon churches belongs to a late period, i.e. the eleventh century, and is comparatively unimportant in quantity, so that it is hardly necessary to classify it. With the sculpture in Norman churches it is different. In these buildings the largest surfaces of dressed stone available for decoration and at the same time those which occupied the most prominent positions were the tympanum over the outside of the entrance doorway and the baptismal font. It is therefore the Norman tympana and fonts which furnish us with the most important examples of symbolical and ornamental sculpture. The other details of Norman churches which exhibit sculpture are of minor importance, and may be classed under the general head of 'miscellaneous.' They consist principally of arch-mouldings with beak-heads or medallions enclosing figures, capitals of columns, corbels and slabs built into walls.

The subject of Christian iconography has been so little studied in this country, and writers on architecture and antiquities have been so constantly in the habit of dismissing all early sculpture with such contemptuous epithets as rude, uncouth, or grotesque, that a few words may not be out of place as to the frame of mind in which such representations must be approached if they are to be made to yield any meaning. In the first place we must at once dismiss the idea that what appears to us as grotesque was anything of the kind to the artist of eight or nine hundred years ago. It cannot be supposed that the ecclesiastical sculptor of the twelfth century would purposely throw ridicule on such subjects as the Last Supper or Christ in Glory, and yet some of the figures in these scenes carved on Norman tympana and fonts are as archaic and barbarous to look upon as many a South Sea idol. Another frequent source of misapprehension is the juxtaposition of such obviously sacred subjects as the Agnus Dei or the symbols of the Four Evangelists with monstrous centaurs, griffins, dragons et boc genus omne. A superficial knowledge of the medieval bestiary would at once show that from the point of view of the mystic zoology of the middle ages there was nothing incongruous whatever in associating scriptural symbols with creatures which conveyed under an uncouth exterior an equally pregnant Christian moral to the initiated. Again, many ludicrous mistakes have been made in the attempted interpretation of ancient figure sculpture because it has been supposed that they necessarily have reference to the use of the object upon which the representations occur. For instance according to our modern idea of the fitness of things the scenes sculptured on a font should refer to the rite of baptism, but an examination of a large number of Norman fonts shows that this was the exception rather than the rule. In fine the only possible chance of extracting any meaning from an ancient sculpture is by ruthlessly setting aside our preconceived notions of what it ought to mean according to our twentieth century methods of thought, and endeavour by a careful study of the history, literature and art of the middle ages to assume the same attitude of mind towards the physical and spiritual worlds as existed a thousand years ago. 

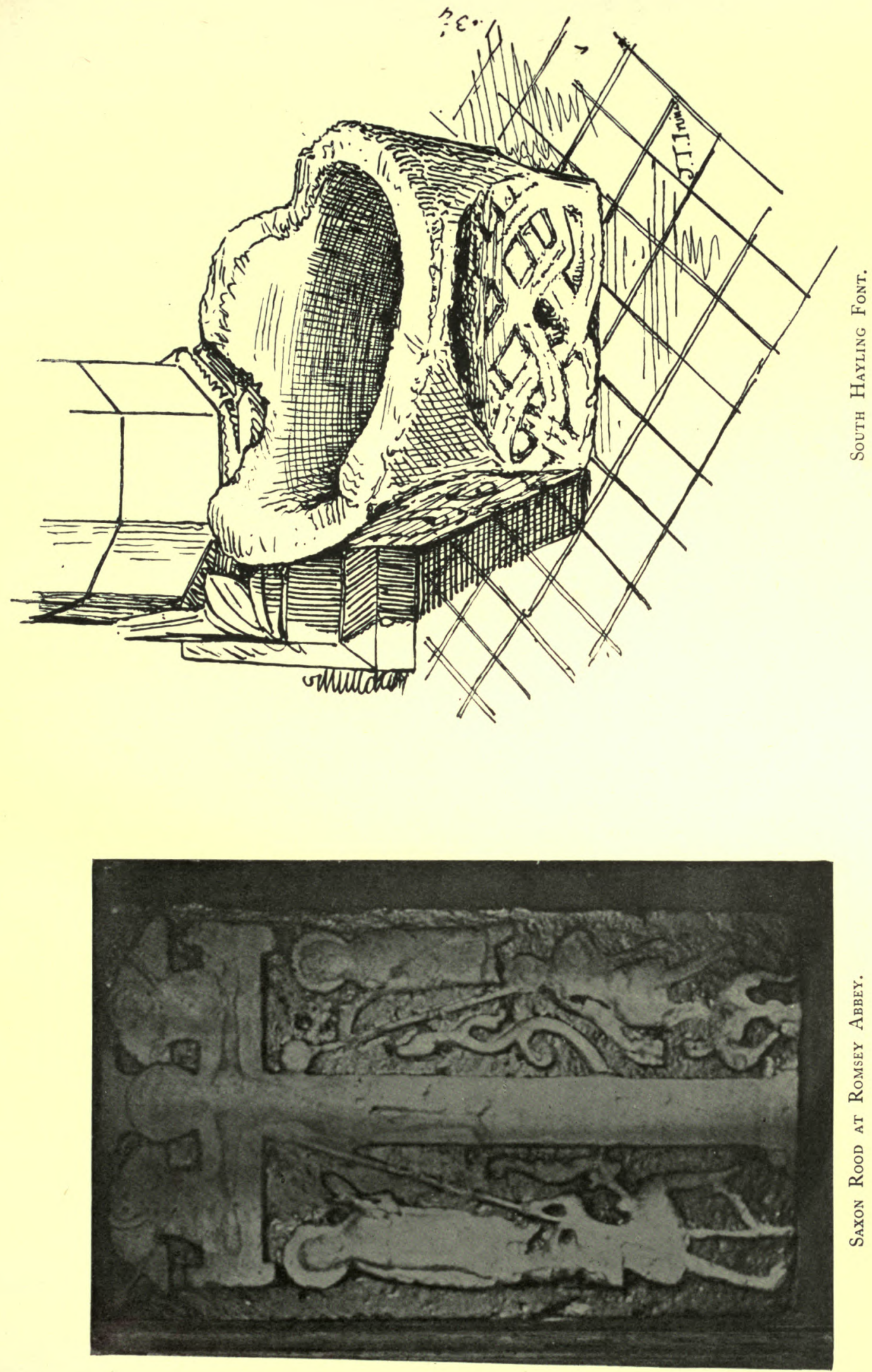

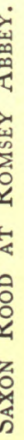





\section{EARLY CHRISTIAN ART AND INSCRIPTIONS}

interlaced ornament much defaced. There is a roll moulding on the angle of the shaft and a smaller moulding surrounding the panels. The bodies of the beasts have a central rib with diagonal corrugations on each side to indicate conventionally the texture of the skin. ${ }^{1}$ On the Steventon Manor cross-shaft the wider parts of the bodies of the beasts are the principal feature in the design, and the interspaces of the background are occupied by the narrower parts which form a series of loops interlaced with each other and with the wider parts of the bodies. This kind of interlaced work based on the idea of loops is akin to that used in Scandinavia, and altogether different from the Celtic interlaced work, which is derived from the plait. Although Prof. G. Stephens assigns a seventh century date to the Brunswick ivory casket, it seems probable that the sculptured monuments of the Wessex school belong to the end of the pre-Norman Christian period rather than to the beginning. Mr. Henry Harris, the proprietor of Steventon Manor, who has kindly furnished particulars about his cross-shaft, writing on January I 4, I 895, says : 'I have also preserved bundreds of tons of Norman worked stones which had been built into old walls [about twelfth century work], and out of which I believe the old manor-house here, the residence of the Brocas family, is built.'

An ancient font preserved in South Hayling church has interlaced work upon it which may be of the Saxon period. The illustration here given was supplied by the late Mr. J. T. Irvine, F.S.A.Scot, and explains itself.

The Saxon roods at Headbourne Worthy ${ }^{2}$ and Breamore, although they have both been sadly mutilated by over-zealous iconoclasts, are still of very great interest.

The former is built into what was the original west wall of the nave just above the old Saxon west doorway, but although still in the same position it is within a western annexe, which was built in the fifteenth century for the protection of the rood and to afford shelter to its worshippers. At the time the church was restored by the late Mr. George Edmund Street in 1865-6 the western annexe was windowless and had been taken possession of by two owls and their four young ones, who were forcibly ejected. The crucified Saviour is represented on the cross in the ancient Byzantine manner, ${ }^{3}$ with the body unbent and the limbs extended straight on the arms of the cross. On each side are the figures of St. Mary and St. John and above is the Dextera Dei issuing from a cloud. The feet of the Saviour are supported on a suppedaneum, and those of St. Mary and St. John on brackets.

1 This peculiar treatment is found on other sculptured stones of the ancient kingdom of Wessex at Colerne, Wilts ; Roberrow and West Camel, Somersetshire ; and Dolton, Devonshire ; and also on the ivory casket in the Ducal Museum at Brunswick, bearing an inscription in Anglian Runes stating that it was made by Nethii for the most noble victory-lord in Montpellier of Gaul.

2 This has been described and illustrated by the Rev. J. H. Slesson in his Notes on the Church of St. Swithun, Headbourme Worthy, p. 15 ; by Owen B. Carter in Weale's Quarterly Papers on Arcbitecture, iii. I ; and by the late Father Daniel H. Haigh in his paper on 'The Saxon Cross at Bewcastle' in the Archeologia ALliana, n.3. i. 174.

3 See J. R. Allen's Christion Symbolism, p. I41. 


\section{A HISTORY OF HAMPSHIRE}

The Saxon rood at Breamore, ${ }^{2}$ which is built into the exterior wall of the nave above the south doorway, resembles the Headbourne Worthy rood except that the body of the Saviour is bent, which would indicate a later date.

The rood at Romsey is built into the south wall of the choir on the inside. The crucifixion is treated in the Byzantine manner with the limbs unbent. On each side of the top arm of the cross is an angel and on either side of the shaft are St. Mary and St. John, and below the soldiers with the spear and sponge some foliage is to be seen near the foot of the cross. The shaft of the cross is made unusually long to allow of the figures of the soldiers being placed below those of the chief mourners.

It is impossible not to associate these Hampshire roods with two other representations of the crucifixion belonging to the Winchester school of Saxon ecclesiastical art, namely the miniature in the psalter written by $\mathbb{E}$ lsinus $^{3}$ (a monk and afterwards abbot of New Minster) between A.D. 978 and 928 , and now in the British Museum Library (Titus. D. xxvii.) ; and the magnificent golden cross given by king Cnut to New Minster, the donation of which is illustrated in the Register of Hyde Abbey ${ }^{4}$ (A.D. 984-1005). ${ }^{\circ}$

The three Saxon sundials in Hampshire at Corhampton, Warnford and St. Michaels Winchester, are all very much alike, and all are cut on a square stone with a leaf-like ornament at each of the four corners. The dial faces are in all three cases enclosed within a double circle, and the lines indicating the divisions of time radiate from the centre, but do not go beyond the circumference of the inner circle. In the Corhampton and Warnford sundials the lower half of the circle is divided into four equal angles, but in the Winchester one the quadrant on the left side is divided into six equal angles, whilst the quadrant on the right side is divided into four equal angles. Three of the radial lines have small crosses on the end next the circumference, a peculiarity which may be noticed in many other Saxon sundials. The object of the crosses is to mark the principal divisions of the day more clearly. All three of the Hampshire sundials were intended to be placed vertically. The one at Corhampton, which is in sitû, is built into the south wall. Warnford church although founded by Wilfrid was rebuilt in Norman times by Adam de Port, as is recorded by two inscriptions in Lombardic capitals, one in the north wall and the other inside the south porch. The sundial no doubt belongs to Wilfrid's Saxon church. St. Michaels Win-

1 Described by the Rev. A. du Boulay Hill in his paper on the church already alluded to in the Archeological Foumal, lv. 86.

2 Reproduced in Dr. W. de Gray Birch's Early Drawings and Illuminations in the British Museum.

3 C. J. Wall's Alfred the Great, p. 25.

4 The characteristics of the Saxon type of crucifixion are given in J. R. Allen's Christian Symbolism, p. 1 55. It generally includes representations of Sol and Luna, and has St. Mary and St. John at either side instead of the soldiers with the spear and sponge, which are universally used in the Irish type of crucifixion. Saxon roods are by no means common, but there are examples at Daglingworth, Gloucestershire, and Little Langford, Wilts. Others of early date exist abroad at Montmille Priory near Beauvais, France, and at Horn, Westphalia. 


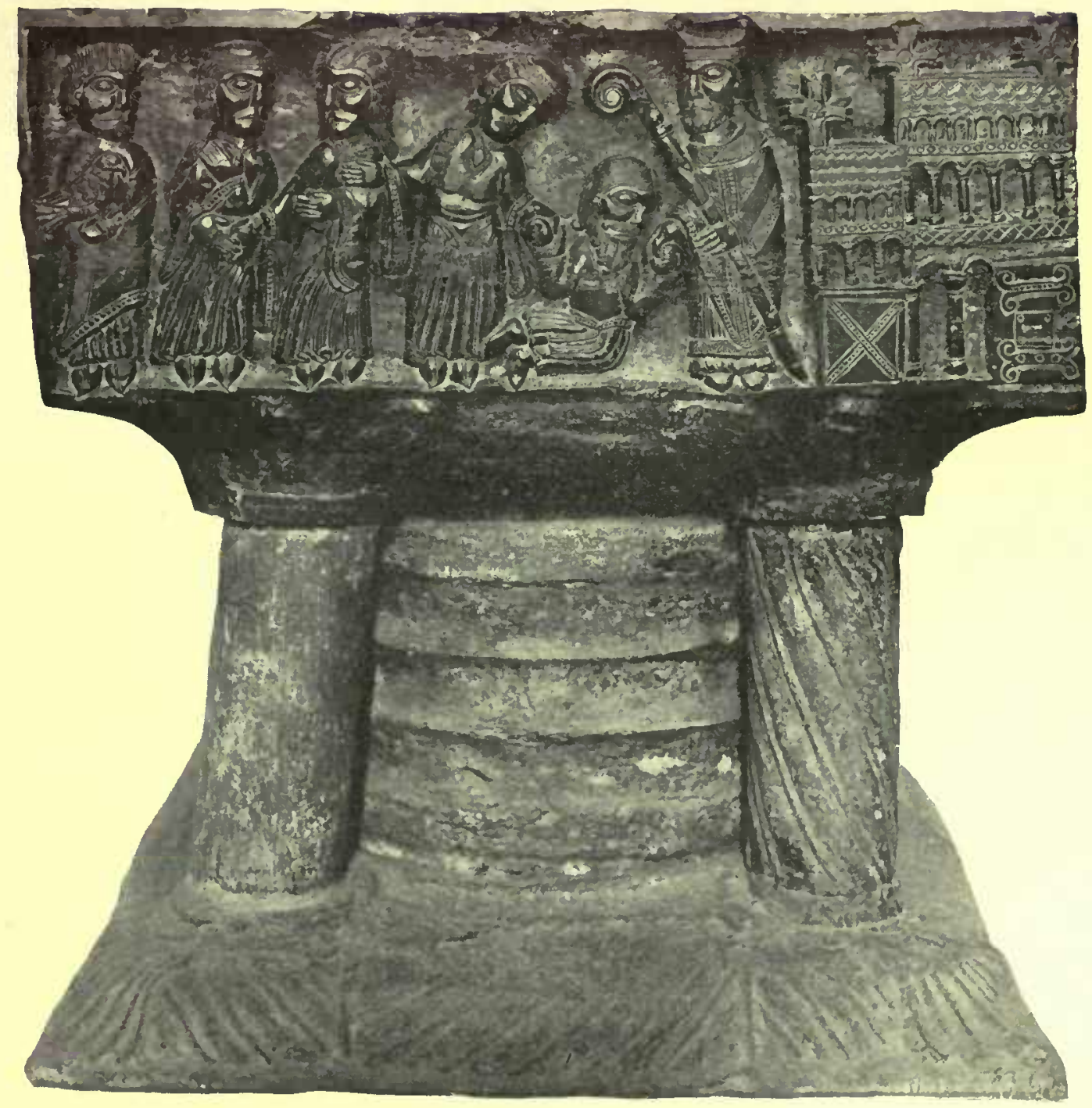

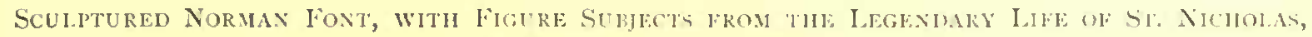
IN WIXCHESTLK CATHIIRAM.

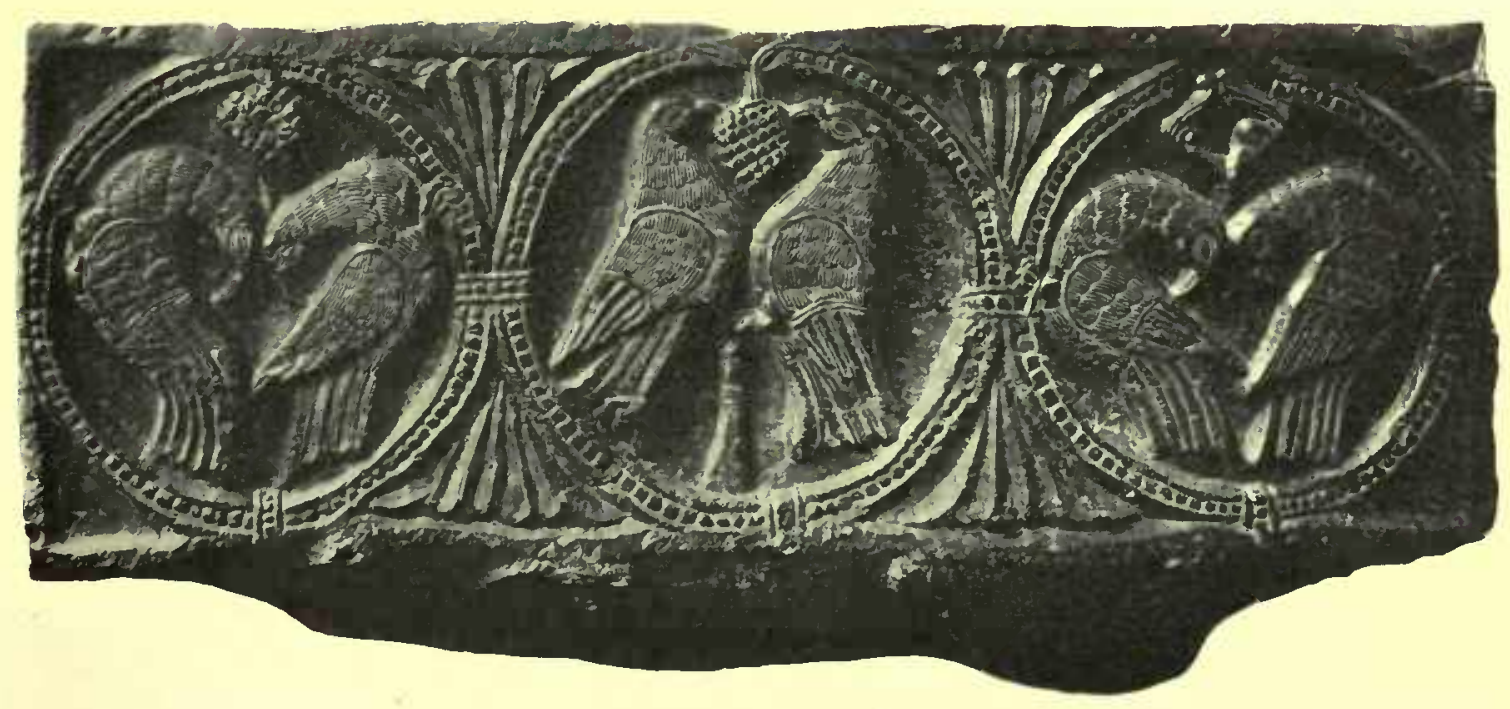

Face of Norman font in Winchester Cathlodrat scut.ptured with Patrs of Doves ani bunches OF GRAPES. 



\section{EARLY CHRISTIAN ART AND INSCRIPTIONS}

chester was entirely rebuilt in 1822 , but the sundial, which has been preserved, is so exactly like the other two that we can have no hesitation in assigning it to the Saxon period. ${ }^{1}$

The examples of Norman figure-sculpture in Hampshire are as follows :-

\author{
Fonts- \\ East Meon. \\ St. Mary Bourne. \\ St. Michael's, Southampton. \\ Winchester. \\ Porchester. \\ Tympana- \\ Shalfeet, Isle of Wight.
}

\author{
Miscellaneous- \\ Romsey Abbey (exterior rood). \\ Oakley (slab). (capitals of columns). \\ St. Michael's, Southampton (slab). \\ Binstead, Isle of Wight (arch-stones). \\ Whippingham, Isle of Wight (slab). \\ Winchester Cathedral (capital of \\ column).
}

The first four of the fonts given in the above list form a group by themselves, on account of characteristics which they possess in common, and because of their obvious connection with another similar group of fonts in France and Belgium. They have not been inappropriately termed fonts of the Winchester type, and their material, shape and style of decoration are clear indications of a common origin. The black marble of which they are all made is unknown in England but has been traced to the quarries near Tournai in Belgium. The shape of the bowl rectangular on the outside and round within, being supported on a large central column with four smaller detached shafts at each of the angles. The decoration consists chiefly of vine scrolls and scenes from the legendary lives of saints, which are rare in the art of the twelfth century in England but comparatively common in the sculpture in the north of France and Belgium at the same period.

Let us commence with the font in Winchester Cathedral which

1 No Saxon sundials now existing have preserved the gnomon, but it is most likely that it projected horizontally. In any case these sundials must have been very imperfect contrivances for the measurement of time, as their makers were evidently entirely ignorant of the true principles on which their setting out depends. Whatever the position of the face of the dial, the gnomon should be parallel to the axis of the earth, and there is only one kind of sundial in which all the hour angles are equal, and that is when the face of the dial is at right angles to the gnomon, and therefore parallel to the plane of the equator. Such a dial is called an equatorial dial, and the size of the angles between the radial lines for all other positions of the dial-face with regard to the gnomon can be found by a simple geometrical construction, or what mathematicians call the process of 'projection.' Every one who is familiar with the seventeenth and eighteenth century vertical sundials still to be seen on the south walls of our churches will have observed that the hour angles are very large near the horizontal diameter, and get gradually smaller and smaller towards the vertical diameter or the mid-day hour line. Now as the Sayons made all the angles equal, it will be at once seen how extremely inexactly the time must have been shown. There is a drawing of a sundial in a Saxon psalter in the British Museum (Tib. c. vi. fol. 7) of the eleventh century, which shows all the hour angles made equal, and consequently that the proper geometrical way of setting out the lines of a sundial was not known at that period. The inefficiency of sundials thus designed is possibly one reason why such time-tellers are so rare between the twelfth and the sixteenth century. After the invention of clocks, sundials became to a great extent unnecessary, and the later sundials of the seventeenth and eighteenth centuries may be looked upon more as attempts to display the newly acquired knowledge of mathematics than as really useful appliances for the measurement of time.

Ample information on this subject is given in Father Haigh's papers on 'Yorkshire Dials' in the rorksbire Archaological Foumal (v. 134) and on 'The Saxon Cross at Bewcastle' in the Archacologia Eliana (n. s. i. 149), in both of which illustrations of the Hampshire sundials will be found. 


\section{A HISTORY OF HAMPSHIRE}

\section{has been taken as typical of the group in this country. The subjects represented on the four sides of the outside of the bowl are as follows:-}

West Side.-Two stories from the legendary life of St. Nicholas of Myra each shown in two scenes, but so jumbled up together that it is not an easy matter to separate them. The three figures in the ship on the right of the panel and the figure lying horizontally below the ship illustrate the first part of the story of the childless nobleman, who made a vow that he would present a gold cup to St. Nicholas if a son and heir were born to him; and the rest of the story is told by the two figures on the extreme left of the panel. This is the story as given in The Golden Legend.' "Another nobleman prayed to S. Nicholas that he would, by his merits, get of our Lord that he might have a son, and promised that he would bring his son to the church, and would offer up to him a cup of gold. Then the son was born and came to age, and the father commanded to make a cup, and the cup pleased him much, and he retained it for himself, and did do make another of the same value. And they went sailing in a ship toward the church of S. Nicholas, and when the child would have filled the cup, he fell into the water with the cup, and anon was lost, and came no more up. Yet nevertheless the father performed his avow, in weeping much tenderly for his son; and when he came to the altar of S. Nicholas he offered the second cup, and when he offered it, it fell down, like as one had cast it down under the altar. And he took it up and set it again upon the altar, and then yet was it cast further than tofore and yet he took it up and remised it the third time upon the altar; and it was thrown again further than tofore. Of which thing all they that were there marvelled, and men came for to see this thing. And anon, the child that had fallen into the sea, came again prestly before them all, and brought in his hands the first cup, and recounted to all the people that, anon as he was fallen into the sea, the blessed S. Nicholas came and kept him that he had none harm. And thus his father was glad and offered to S. Nicholas both the two cups.'

The meaning of the sculpture on the font is now clear. In the first scene on the right of the panel we see the ship containing the nobleman (with a beard, seated near the bow and holding up his hands in astonishment probably at the roughness of the sea); his son (a beardless youth on the left of the mast, resting his elbow on the gunwale and supporting his face with his right hand); and the captain of the vessel (with a beard and having the tiller under his right arm). The figure with a cup in his hand lying in a horizontal position below the ship on the left is no doubt intended for the nobleman's son, who has tumbled overboard. The second scene on the extreme left of the panel shows us S. Nicholas with his episcopal mitre and crozier holding the wrist of the nobleman's son, who is distinguished by having the cup in his hand. The two groups of figures in the middle of the panel represent the murder of the three children by the wicked host and their subsequent miraculous restoration to life by St. Nicholas. The incident is thus related by the writer of an article in the Pall Mall Gazette of December 5, 1896 :-

- Many strange legends have gathered around the name of St. Nicholas, but the strangest of them all is that which tells how he became the patron of schoolboys. And a ghastly little tale it is. A pork butcher - there were pork butchers, it seems, even in those days - was sitting one night in his shop when three little boys who had lost their way appeared at the door, and begged for a night's shelter. The man welcomed them quite kindly, gave them some supper and a bed, but no sooner were they well asleep than he chopped off their heads, for his supply of sausage-meat had run short that morning. Just as he had finished packing their little bodies away in the brine, St. Nicholas knocked at the door and asked for food and lodging. He wished to sup, he said, on the three little boys who were in the brine-tub. The butcher, conscience stricken, recognized his visitor, and made a full confession; whereupon the Saint restored the small boys to life there and then, and became the guardian of them and all their kind.'

Immediately to the right of St. Nicholas and the nobleman's son with the gold cup, at the left end of the panel, the wicked host stands axe in hand with his equally detestable wife and partner in his crimes looking over his shoulder. In front of him below the axe are the heads of the three children appearing out of the salting-tub arranged in a vertical row, one below the other. To the right of this group is St. Nicholas with his crozier and mitre bringing the children to life.

1 Dent's Temple Classics edition, ii. 120. 


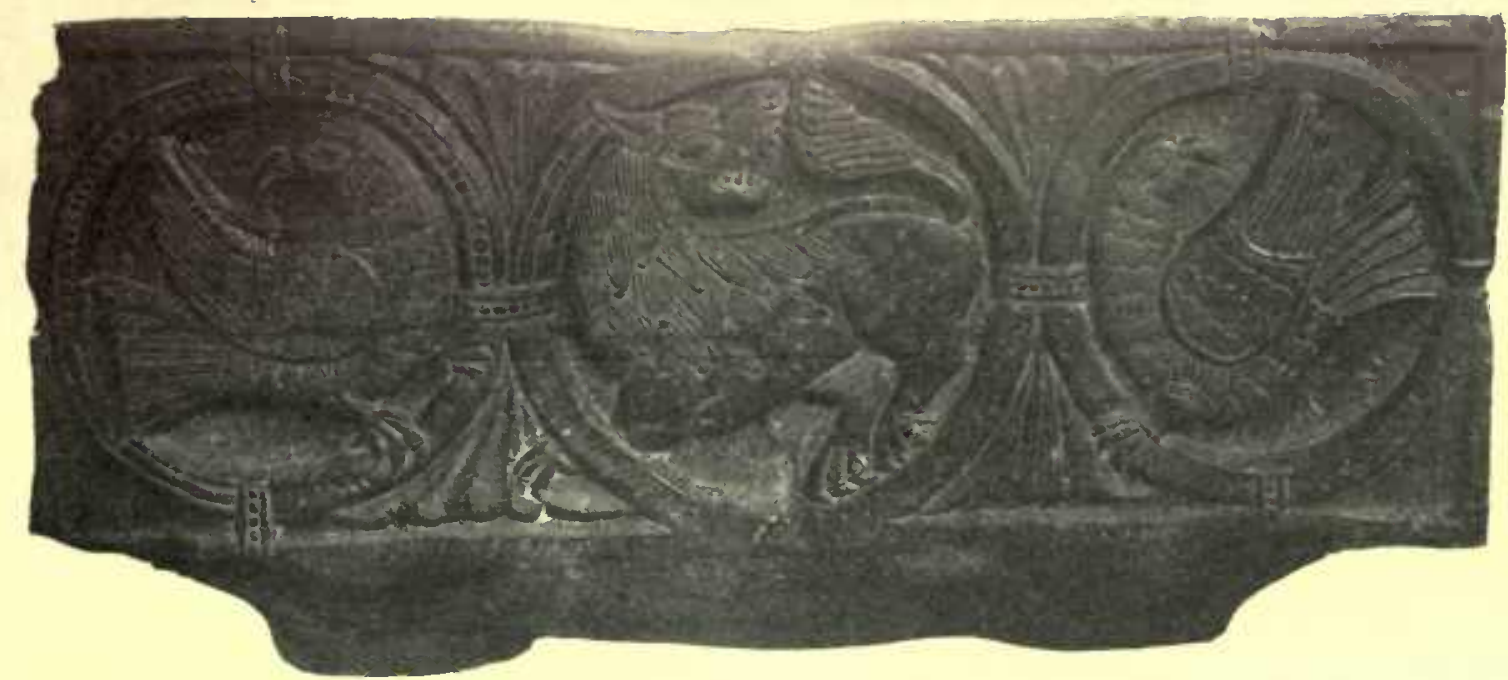

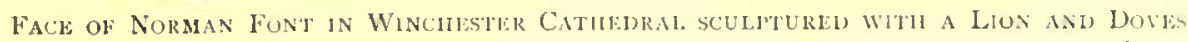

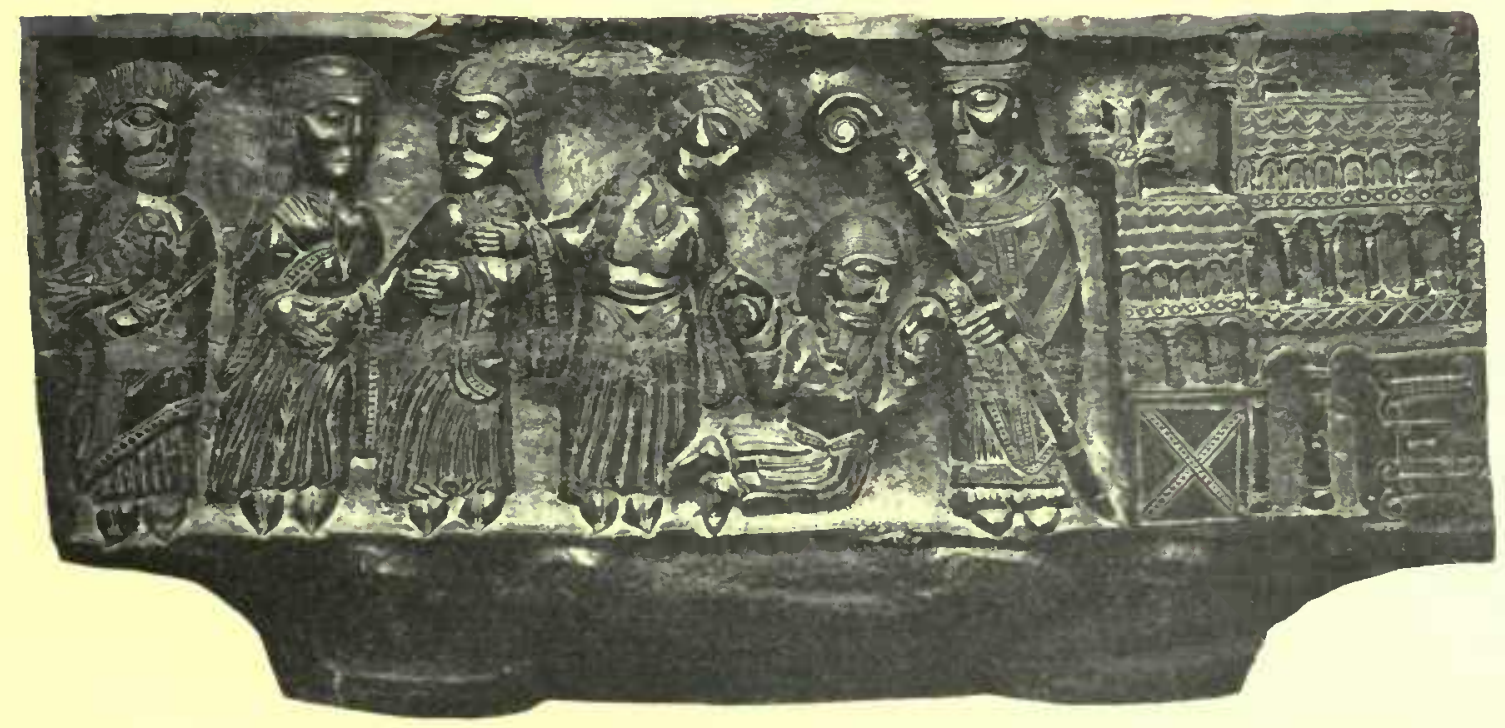

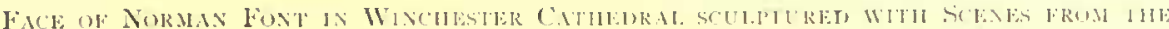

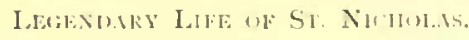

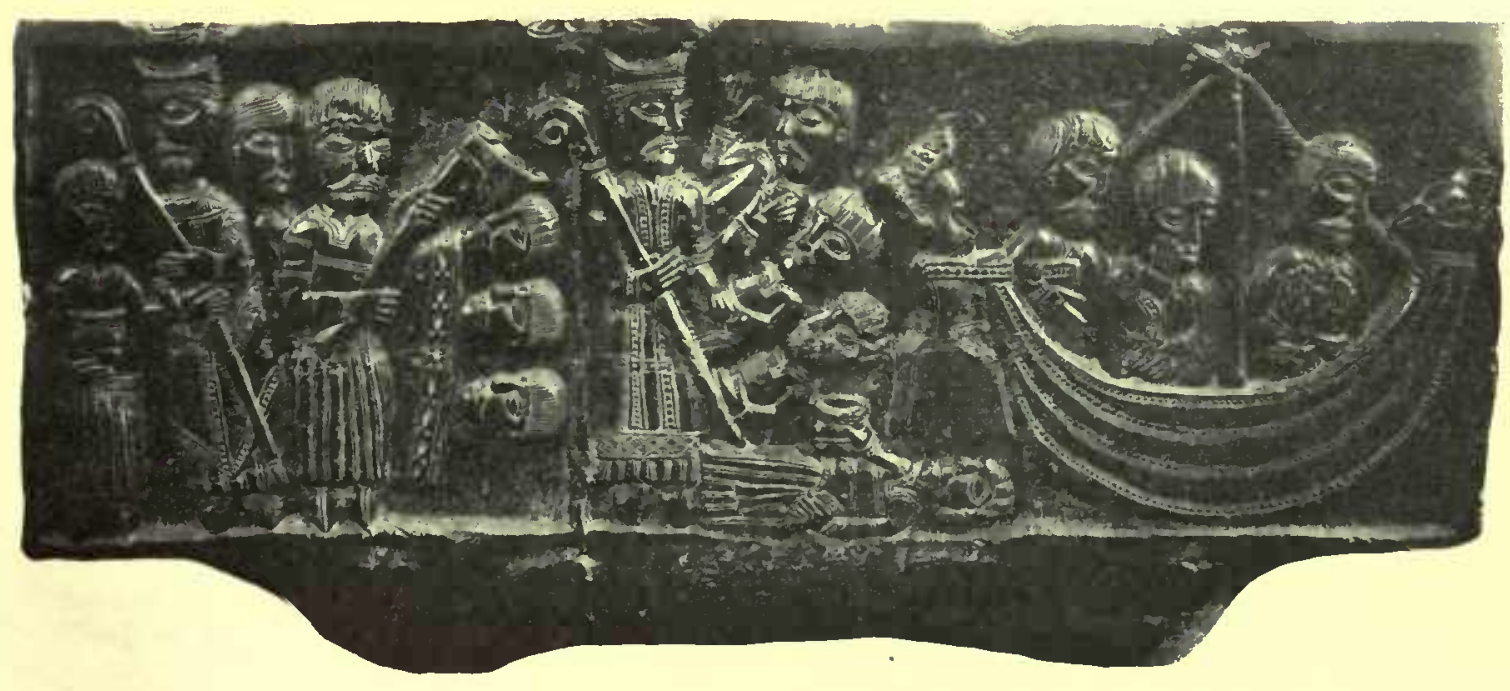

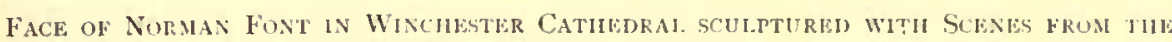
Legexiday LifF Ol: St, Nicholas. 


\section{EARLY CHRISTIAN ART AND INSCRIPTIONS}

South Side.-The story of St. Nicholas saving the three daughters of a poor nobleman from leading a life of shame is here represented in one scene. At the right end of the panel is a very elaborate church ornamented with arcades of round-headed arches, and having a door with wrought iron straps and keyhole-plate. St. Nicholas habited as a bishop stands in front of the church, and the poor nobleman who is kneeling at his feet receives a purse of gold from St. Nicholas with the left hand, and conveys it with the right hand to his daughter. The two other daughters are standing close to the first, holding each other's hands sympathetically ; and at the extreme left end of the panel is to be seen the bridegroom with a hawk resting on his wrist, ready to marry one of the ladies that St. Nicholas' generosity has provided with a suitable dowry.

The story as related in The Golden Legend' is as follows: "And it was so that one, his neighbour, had three daughters, virgins, and he was a nobleman; but for the poverty of them together, they were constrained, and in very purpose to abandon them to the sin of lechery, so that by the gain and winning of their infamy they might be sustained. And when the holy man Nicholas knew hereof he had great horror of this villainy, and threw by night in to the house of the man a mass of gold wrapped in a cloth. And when the man arose in the morning, he found this mass of gold, and rendered to God therefor great thankings, and therewith he married his oldest daughter. And a little while after this holy servant of God threw in another mass of gold, which the man found, and thanked God, and purposed to wake, for to know him who so had aided him in his poverty. And after a few days Nicholas doubled the mass of gold and cast it into the house of this man. He awoke by the sound of the gold, and followed Nicholas, which fed from him, and he said to him: "Sir, flee not away so but that I may see and know thee." Then he ran after him more hastily and knew that it was Nicholas; and anon he kneeled down, and would have kissed his feet, but the holy man would not, but required him not to tell nor discover this thing as long as he lived.'

East Side.-Three circular medallions containing (I) in the centre a pair of doves pecking at a bunch of grapes; and ( 2 and 3 ) on the right and left a pair of doves with their necks bent back so that their beaks touch their wings.

North Side.-Three circular medallions containing (1) in the centre a beast with its head bent back, biting the end of its tail ; and ( 2 and 3 ) on the right and left a dove with its head turned backwards and the feathers of the wings and tail spread out.

Although the outside of the bowl of the Winchester font is square, the inside is circular and surrounded by an elegant wreath of running foliage. Two of the spandrels at the angles are filled in with foliage, whilst in each of the other two are a pair of doves drinking from a vase surmounted by a small cross.

The large column on which the bowl is supported in the middle is ornamented with horizontal flutings, and two of the smaller columns at the corners have a moulding twisted spirally round them, so as to make them look like a cable.

The dimensions of the Winchester font ${ }^{2}$ are as follows :-

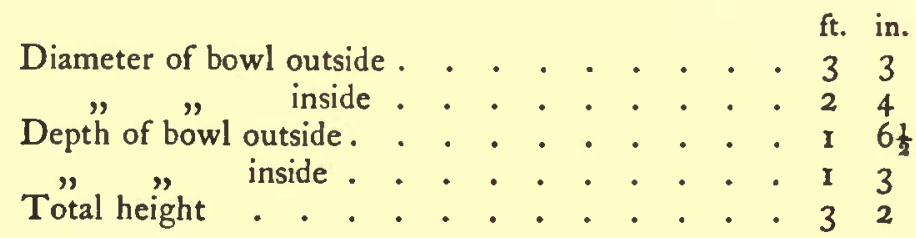

Next in interest to the Winchester font comes the one at East Meon, which is of similar design but I inch higher and I inch wider.

1 Dent's Temple Classics edition, ii. 110.

2 Illustrated accounts of this font will be found in the Vetusia Monumenta, vol. ii. pl. 39 ; the Reliquary, x. 206 and n.s. iv. 262 ; Foumal of the British Archeological Association, 1. 6, 20; Milner's History of Wincbestér, ii. 76 ; and Woodward's History of Hampstire, i. 49. 


\section{A HISTORY OF HAMPSHIRE}

The figure-subjects on two of the sides of the font at East Meon are purely scriptural. ${ }^{1}$ The scenes are taken from the opening chapters of the Book of Genesis, and are arranged from right to left, beginning on the north side and continuing on the east side, the subjects being as follows :-

On the North Side--(1) The creation of Adam; a group of two figures; the Almighty on the right, represented as Christ with the cruciferous nimbus, placing His right hand on Adam's left shoulder. Adam is on the left, holding up the right hand and hiding his nakedness with the other.

(2) The creation of Eve; a group of three figures; the Almighty standing on the right and Adam lying down on the left, with Eve coming out of his side. The Almighty is placing His right hand on Eve's left shoulder in the same way as He places it on Adam's shoulder in the preceding scene.

(3) The Temptation of Adam and Eve; a group of two figures, a tree and serpent; the Tree of Life in the centre with the serpent coiled round it. On the right Eve receiving the apple from the serpent with the right hand and covering her nakedness with a fig-leaf held in the left hand; and on the left Adam raising the apple to his mouth with the left hand and hiding his nakedness with a fig-leaf held in the other.

On the East Side.-(1) The Expulsion from Paradise; a group of three figures and a building; the angel standing with a drawn sword in front of the gates of paradise (which are conventionally treated as a Byzantine architectural composition) driving Adam and Eve before him, who are still hiding their nakedness with fig-leaves held in the right hand.

(2) The Curse after the Fall; a group of three figures. On the right the angel showing Adam who is on the left how to dig with a spade; beyond on the left Eve with a distaff and spindle. Adam and Eve are represented wearing clothes in this last scene.

The remaining two sides of the font are ornamented with arcading surmounted by a frieze sculptured with winged dragons, doves and animals.

The top of the bowl has a circular wreath of conventional vine scrolls round the inside rim. Two of the spandrels at the angles are filled in with foliage, and the other two with pairs of doves drinking from a vase surmounted by a cross, as on the Winchester font.

The bowl of the font at St. Mary Bourne is sculptured on two sides with panels each containing a pair of conventional vines, and on the other two with arcading surmounted in one case by fleurs-de-lys and in the other by pairs of doves drinking from a vase. The top of the bowl is ornamented in the same way as in the fonts at Winchester and East Meon, except that the pairs of doves in the spandrels at the angles are drinking from a vase which is not surmounted by a cross.

The font at St. Mary Bourne ${ }^{2}$ is the largest of the series, the bowl - the only ancient part now remaining-being 3 feet 7 inches across, or 4 inches wider than that at Winchester.

The last font of the Winchester type in Hampshire to be described is in St. Michael's church, Southampton. ${ }^{3}$ It is 3 feet 4 inches wide and 3 feet 6 inches high, so that it is the same width as the East Meon tont, but 3 inches higher. The bowl of the font at Michael's is sculp-

1 The East Meon font has been described and illustrated in the Archeologia, x. 183.

2 This font has been described and illustrated in Dr. Steven's History of the Parish of St. Mary Boume and in the Fournal of the British Archaological Association, xxxvi. 30.

${ }^{3}$ The font at St. Michael's, Southampton, has been described and illustrated in the Rev. J. S. Davies' History of Soutbampton. 


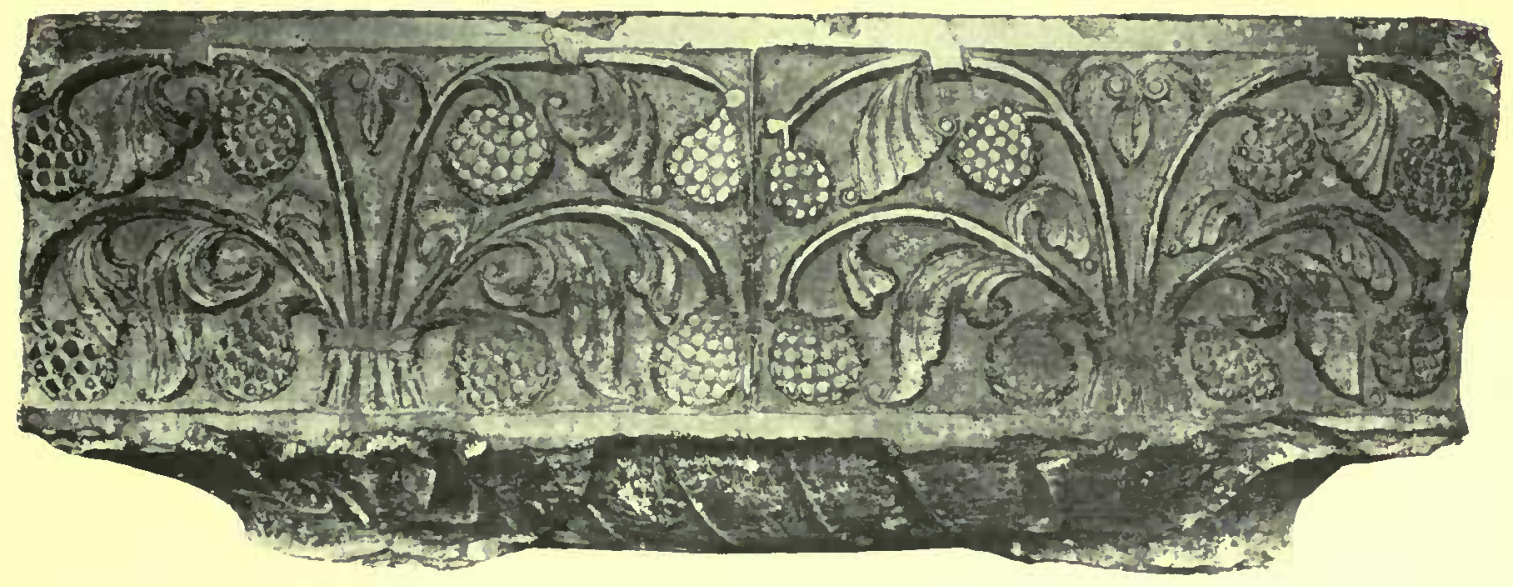

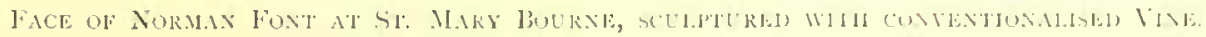

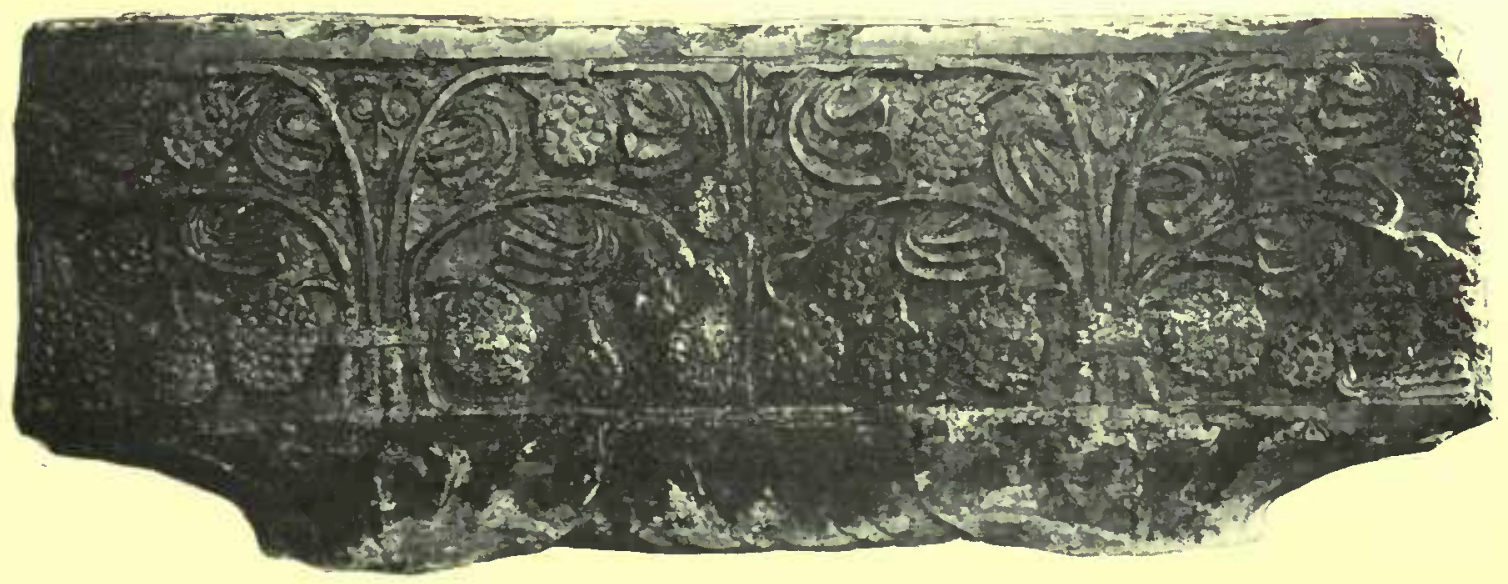

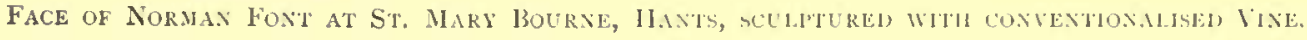





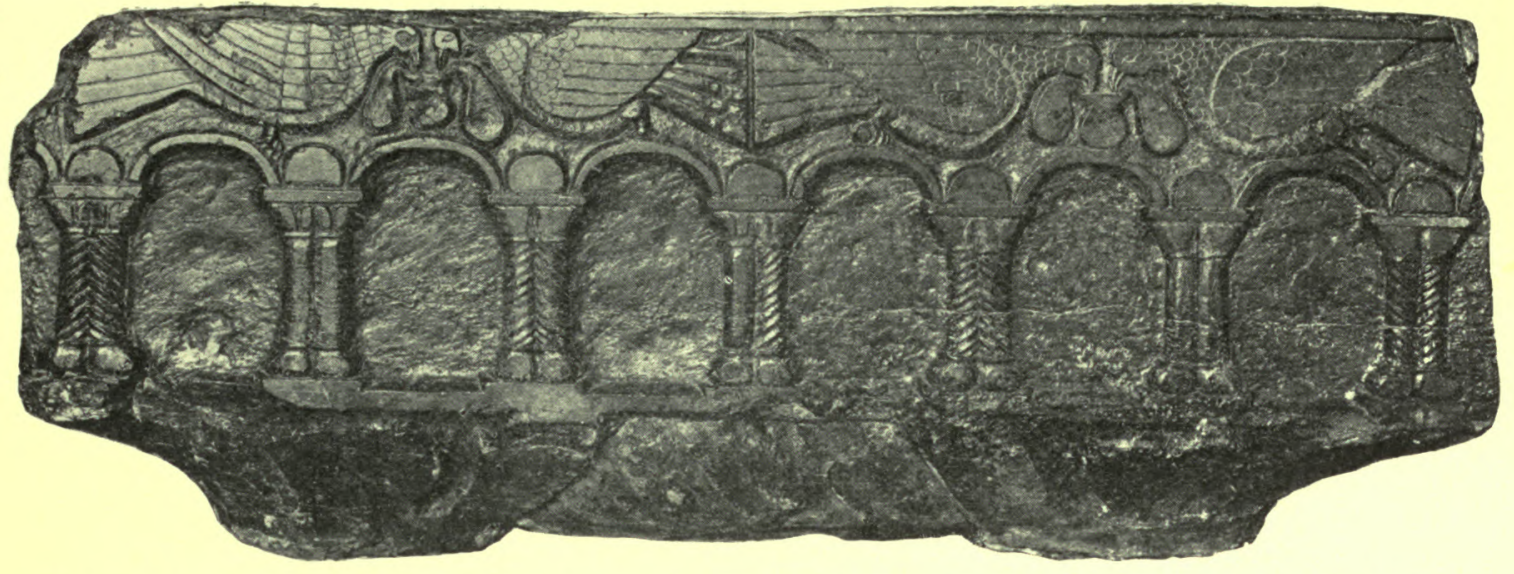

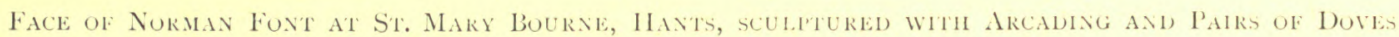
DRIXKING RROM VASES.

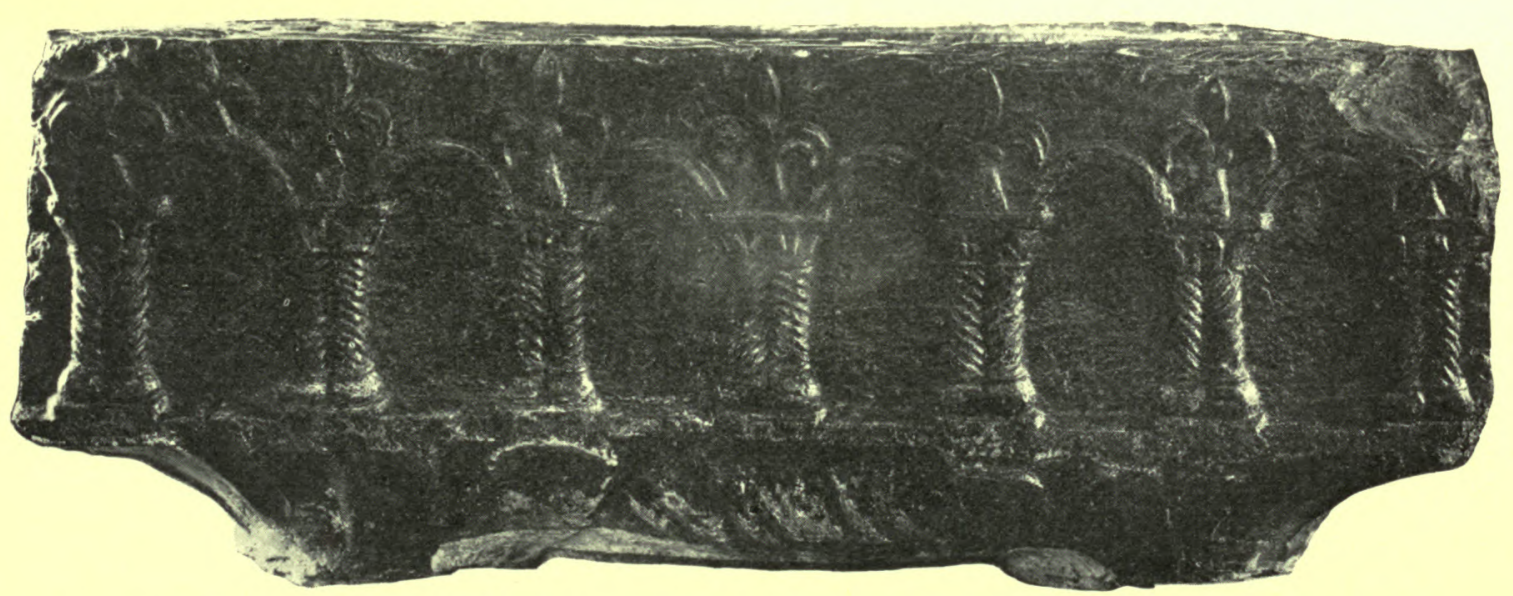

Face of Norman font al St, Maky bourne, Hants, sculptured with Arcaing and Fleurs-de-Lys. 



\section{EARLY CHRISTIAN ART AND INSCRIPTIONS}

tured on the west side with the eagle of St. John, the lion of St. Mark and the angel of St. Matthew, each enclosed within a circular medallion. The three other sides have similar medallions enclosing beasts, some with wings, others with their tails bent round between the hind legs, but all looking backwards and grinning so as to show a horrible set of teeth.

The top of the bowl is decorated in the same way as in the case of the other fonts of the series.

Having now given an account of all the details of the four fonts of the Winchester type in Hampshire, we are in a position to examine the group as a whole. ${ }^{1}$

The Hampshire series of fonts are interesting as perpetuating three of the most ancient Christian symbols-the dove, the cup or vase and the vine, all of which were originally borrowed either from a Jewish ${ }^{2}$ or more probably from a classical ${ }^{3}$ source, and are used either separately or

1 It may be remarked that the Hampshire examples are not the only ones of the kind in England, there being at least three others, namely (1) in Lincoln Cathedral ; (2) in St. Peter's church, Ipswich ; and (3) in Thornton Curtis church, Lincolnshire. Fonts belonging to the same class exist at the following places on the continent :-

\section{BELGIUM}

Zedelghem near Bruges (Reliquaiy for 1898, p. 259).

Termonde near Ghent (P. Saintenoy's Font Baptismaux, p. 91, and Messager des Sciences et des Atts de la Belgique for 1838 , p. 233).

Lichtervelde (Messager des Sciences, etc., for 1857 , p. 144).

\section{FRANCE}

Montdidier, Somme (Viollet le Duc's Dictionnaire raisonnèe de l'Architecture, v. 536, and C. Enlart's L'Architecture romane dans la Règion picarde, $\mathrm{p} .37$ ).

Nordpeene, Nord (Rev'ue de l'Art chrètien for 1895, p. 313).

Vermand, Aisne (ibid. p. 319).

Ribemont, Aisne (ibid. p. 3 I 2).

Noiron le Vineaux, Aisne (Nesfield's Continental Sketches).

St. Just, Oise (A. de Caumont's Cours d'Antiquitès monumentales: Atlas, pl. 87).

$\mathrm{La}$ Neuville less Corbie (La Picardie Historique et Monumentale, No. 6, 1899, p. 473).

The Very Rev. G. W. Kitchin, D.D., F.S.A., formerly dean of Winchester and now dean of Durham, has shown in his valuable paper on the 'History of the Cathedral Font, Winchester,' in the Fournal of the British Archoological Association (1. 6), that all the fonts enumerated in the above list were made at Tournai in Hainault from a hard marble of a dark blue-black colour, obtained from the neighbouring quarries on the banks of the river Scheldt. There appears to have been a very remarkable school of ecclesiastical art in the twelfth century at Tournai, and the sculptured fonts which were produced there at that period were so much appreciated that they were exported from Belgium to the north of France and to England. The transport of such bulky objects was in all probability effected as far as possible by ship. Dean Kitchin points out that the popularity of St. Nicholas in Europe dates from the time when ' in 1087 Italian merchants trading with the East brought over to Bari, on the south Adriatic coast of Italy, besides their ordinary merchandise, the bones of St. Nicholas.' In England St. Nicholas became known through the mystery play written by a Benedictine monk named Hilary in A.D. I I 25, and Wace's Anglo-Norman Life of St. Nicbolas written in the middle of the twelfth century. From these facts Dean Kitchin concludes that the date of the Winchester font must be some time in the latter half of the twelfth century, and therefore must have been brought over from Belgium either by Henry of Blois, Bishop of Winchester (A.D. 1229 to 1271), or his successor in the episcopate, Richard Toclive (A.D. II 74 to II 88). The shape of the mitre worn by St. Nicholas as represented on the Winchester font points towards the same period. The only other instance of the occurrence of scenes taken from the legendary life of St. Nicholas in Norman sculpture is on the font in the parish church at Brighton, which is dedicated to that sxint. The font at Brighton is cylindrical and therefore of an entirely different kind from that at Winchester. The font at Zedelghem near Bruges however, given in our list, has scenes from the life of St. Nicholas sculptured upon it, and treated very much in the same way as on the Winchester font.

2 Dean Burgon's Letters from Rome, pp. 130, 163, 233.

3 The celebrated mosaic from Hadrian's Villa at Tivoli now in the Capitoline Museum at Rome represents four doves perched on the edge of a bowl of water, and one of them drinking from it, as described by Pliny (lib. xxxvi. c. 60). 


\section{A HISTORY OF HAMPSHIRE}

in combination. The dove as depicted on the sepulchral inscriptions of the catacombs at Rome of the first four centuries A.D. is Noah's dove with the olive branch in its mouth, either accompanied by the ark (rendered literally as a rectangular box with the lid open) or more frequently by itself. The dove symbol is equivalent to the words IN PACE of the inscription it illustrates, and it also signifies the Holy Ghost and therefore in another sense the soul ${ }^{1}$ of the departed. Doves in early Christian art are usually arranged symmetrically in pairs facing each other with a vase, or the Chi-Rho monogram of Christ, or the cross in the centre between them. On a sculptured sarcophagus of the fifth century in the Lateran Museum at Rome engraved in J. W. Appell's Monuments of Early Cbristian Art (p. 2 I) a pair of doves are perched on the horizontal arms of the cross with the Chi-Rho monogram above. On the sarcophagus of the emperor Honorius in the mausoleum of Galla Placidia at Ravenna the pair of doves are perched on the arms of the cross which is combined with the Agnus Dei standing on the mountain with the four rivers of paradise flowing from its foot. The two-handled cup or vase was perhaps, as Dean Burgon has suggested, the Jewish Passover cup adapted to Christian purposes. In shape it resembles the vases which are seen so frequently on Romano-British mosaic pavements forming the central object, on each side of which the rest of the design is arranged symmetrically. In early Christian art the two-handled cup is no doubt used as a eucharistic symbol, and in support of this view it may be mentioned that the most ancient chalice now in existence ${ }^{2}$ is of this shape. It is also used as a symbol of baptism in the well-known mosaic in the baptistery of the basilisca at Salona ${ }^{3}$ near Spalato in Dalmatia. The cup occurs in the third or fourth century catacombs at Rome "with a dove holding the olive branch on each side and the Chi-Rho monogram of Christ, and in the seventh century we find the same symbol, but with the olive-branches omitted, the vine added and the cross substituted for the monogram. ${ }^{5}$ Sometimes again the doves are replaced by a pair of peacocks. ${ }^{6}$ The Christian vine was clearly copied from Roman art, ${ }^{7}$ and its

1 In the twelfth-century Spanish Commentary on the Apocalypse in the British Museum Library (Add. MSS. No. 11,695 ) doves or birds flying are inscribed 'anime interfectorum.'

2 The chalice now in the Bibliothèque Nationale at Paris, found at Gourdon, Chalons-sur-Marne, with medals of Anastasius and Justinian A.D. 508-527 (A. de Caumont's Abécédaire d'Archéologie-Architecture Religieuse, p. 117 ).

3 The vase here represents the Fountain of Life, and there are stags on each side drinking from it. The inscription, 'Sic ut cervus desiderat ad fontes,' etc, explains the meaning of the subject. (Dr. R. Munro's Boznia, Herzegovina and Dalmatia, p. 264; and R. Garrucci's Storia dell' Arte Cristiama, iv. 278.

4 P. Aringhi's Roma Subterranea, ii. 348.

5 On the end of the sarcophagus of Archbishop Theodore in the church of S. Apollinare in Classe at Ravenna (J. W. Appell's Monuments of Early Christian Art, p. 30).

${ }_{6}$ On a sculptured parapet in the church of S. Apollinare Nuovo at Ravenna, and on the sarcophagus of Archbishop John in the church of S. Apollinare in Classe at Ravenna. A cross and pair of peacocks but without the vase occurs on the front of the cathedral at Athens (A. N. Didron's Cbristian Iconograpby, i. 389).

7 The ceiling of the vaulted aisle of the church of S. Constantia (A.D. 320) at Rome, and a sculptured sarcophagus with the Good Shepherd in the Vatican Museum are decorated with vintage scenes which are more suggestive of the worship of Bacchus than of anything Christian. A fine example of the ceiling of a chamber in the catacombs at Rome with the Good Shepherd in the centre and the classical vine is given in Dr. E. L. Cutt's History of Early Christian Art, p. 163, after Bottari, pl. 3. 


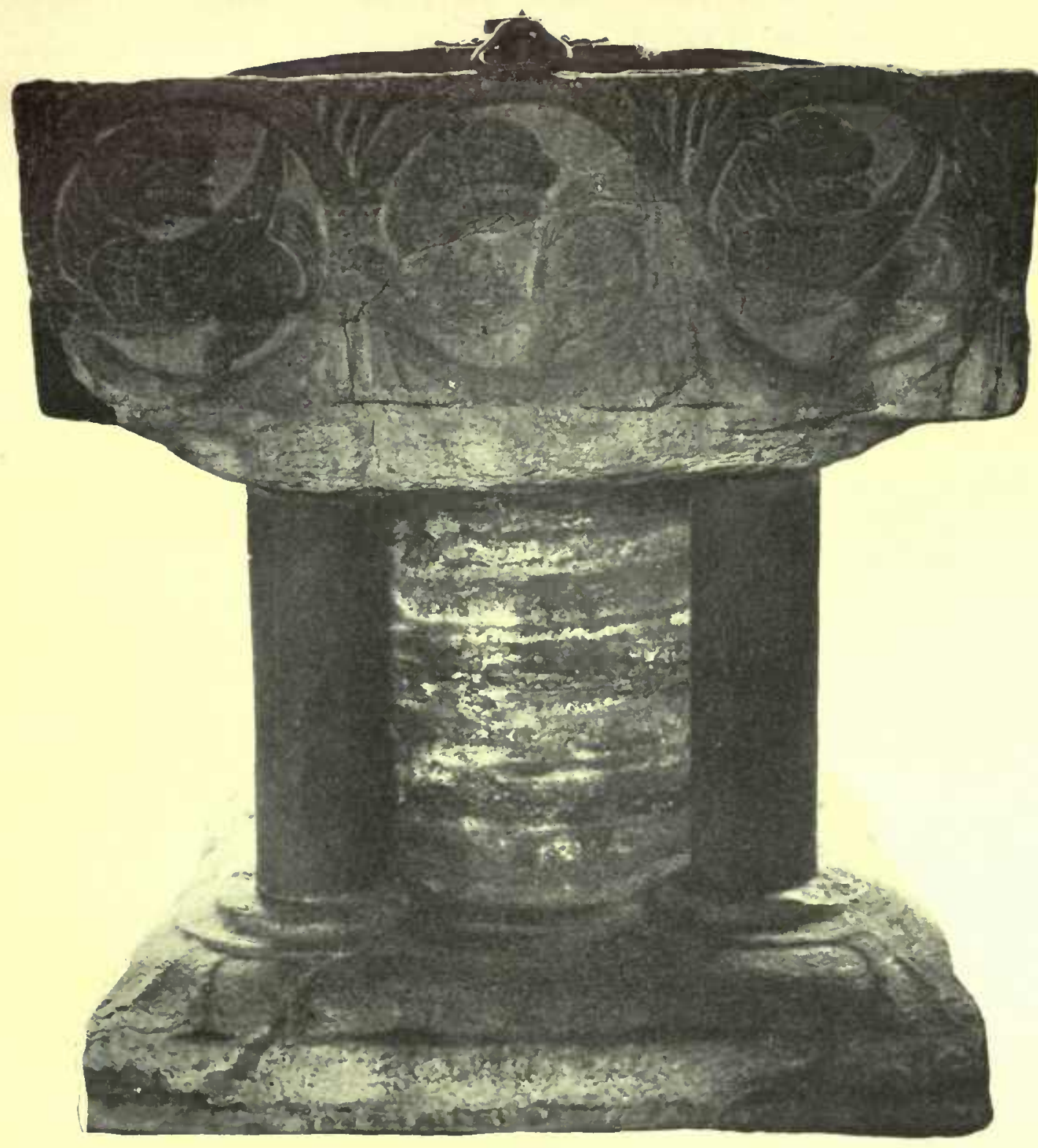

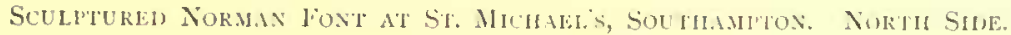

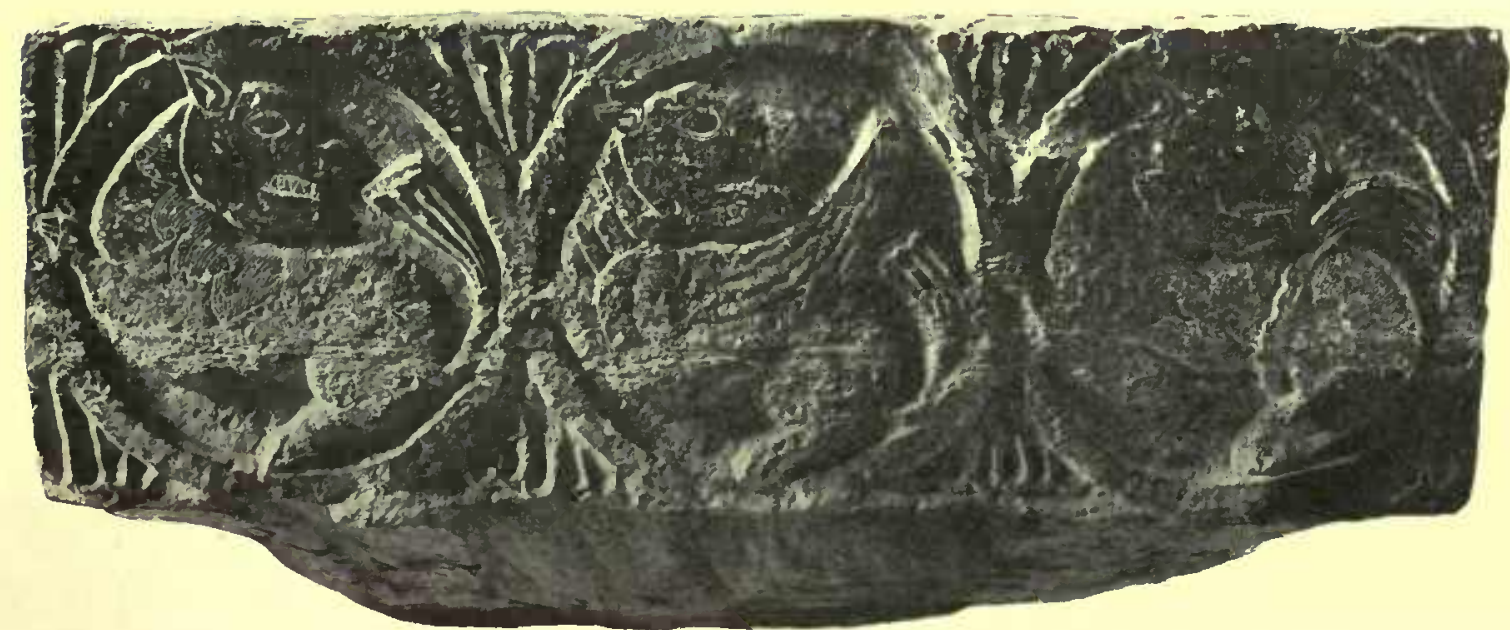

East Face of Norman Font at St. Michael's, Southampton, sculptured with a Winglal blast and Lions. 



\section{EARLY CHRISTIAN ART AND INSCRIPTIONS}

significance is explained by the passage in St. John's Gospel (xv. I-5) commencing, "I am the true vine.' Both the dove ${ }^{1}$ and the peacock are found in combination with the vine and are generally placed symmetrically in pairs. The dove is usually shown pecking at a bunch of grapes.

The facts just stated enable us to elucidate the meaning of the symbolism of the fonts of the Winchester type in Hampshire. The vine forms the chief motive of the decoration of the font at St. Mary Bourne, and it is interesting to observe that the treatment corresponds almost exactly with that of the font at Montdidier, near Amiens in France, except that in the latter case the significance of the symbolism of the vine is made still more clear by placing a figure of Christ giving the benediction in the centre. These two fonts afford a remarkable instance of the transformations produced by successive copying. The bunches of grapes being the most essential feature have degenerated least, whilst the leaves are so highly conventionalized as to be altogether unlike the reality. The bunches of grapes, although not sufficiently pointed at the ends, can be easily recognized.

The pair of doves pecking at a bunch of grapes in the central medallion of the east side of the Winchester font may be taken to mean the souls of the faithful obtaining spiritual nourishment from Christ the true vine. The pair of doves drinking from a vase on the top and one of the sides of the St. Mary Bourne font, and the pair of doves drinking from a vase surmounted by a cross on the tops of the fonts at Winchester, East Meon and Montdidier mean the souls of the faithful obtaining spiritual nourishment from the fountain of $\operatorname{life}^{3}$ at baptism or from the chalice when receiving the sacrament of the Mass. The symbol of a pair of doves drinking from a vase is extremely rare in Norman sculpture in England, the only other example besides those just mentioned being on a sepulchral slab in Bishopstone ${ }^{4}$ church, Sussex.

The font in Porchester church is of an entirely different kind to those of the Winchester type. It is cylindrical and is ornamented round the lower part with intersecting Norman arcading and round the top with a band of beautiful foliage having figures of men, beasts,

1 Dr. J. S. Northcote's Epitaphs of the Catacombs, p. 162 ; Dean Burgon's Letters from Rome, p. 233. Many of the pre-Norman crosses of Northumbria are decorated with vine scrolls and birds pecking at the bunches of grapes.

2 On the ambone from the church of S. Salvatore, Brescia (R. Cattaneo's Architecture in Italy, p. I I I), and on the ivory chair of Maximian at Ravenna (R. Garrucci's Storia dell'Arte Cristiona, vol. vi. pls. 4 ( 4-23).

${ }_{3}$ See representations of the mystic fountain in the baptistery at Salona already mentioned and in the Gospels of Charlemagne in the National Library in Paris (Auguste Molinier's Les Manuscrits et les Miniatures, p. I 2 I, after Count Bastard). The Fountain of Life, which in the baptistery at Salona in Dalmatia is shown flowing from a two-handled vase, is in other mosaics of the sixth century symbolized by the four rivers of paradise flowing from the foot of a small mountain surmounted by the cross or by the Agnus Dei. The symbolism of the mystic fountain is explained by the decoration and the inscription in Greek, 'Drink water with joy,' on an early Christian leaden cup from Tunis, illustrated in Dr. E. L. Cutt's History of Early Christian Art, p. 331.

4 Allen's Christian Symbolism, p. 333. 


\section{A HISTORY OF HAMPSHIRE}

birds and winged dragons involved in the scrolls. Only the upper half of the font is ancient, the rest being a modern restoration. This font has been described and illustrated in the Arcbaological Fournal, iii. 3 I 6 .

There is only one Norman tympanum sculptured with a figuresubject in Hampshire, namely at Shalfleet in the Isle of Wight. It has upon it a representation of Daniel in the den of lions, treated as in the paintings in the catacombs at Rome. Daniel stands in the centre with a lion on each side. This tympanum has been engraved in Sir H. C. Englefield's Description of the Isle of Wight (p. I I I) and in Britton's Arcbitectural Antiquities, vol. v. pl. I7. In Yaverland ${ }^{1}$ church in the Isle of Wight there is a Norman tympanum ornamented with a diaper pattern, but part of it has been cut away to make the doorway higher, and in Burghclere church there is a tympanum with a scale pattern on it.

The most interesting examples of miscellaneous Norman figuresculpture in Hampshire are the capitals of the columns at the east end of the north and south aisles of the chancel of Romsey Abbey and the rood built into the exterior west wall of the south transept of the same building close to the Norman doorway leading out of the cloister. On the capital of the column in the north chancel aisle a battle scene is represented with two kings and two angels taking away their swords in the foreground, and a riderless horse and birds of prey flying away with the limbs of the slain in the background. On the capital of the corresponding pillar in the south chancel aisle the kings again appear, one enthroned on the left and the other in the middle holding a conical object in his hand. An angel stands between the two kings, and on the right side of the capital is a grotesque with a seated figure on each side. The capital has two angles, on each of which is a v-shaped label, one inscribed ROBERT ME FECIT and the other ROBERT TVTE CONSVLE DS. No satisfactory explanation has been yet given of the meaning of these remarkable sculptures, although many ingenious conjectures have been hazarded by Sir H. C. Englefield, Dr. John Latham, and Mr. W. Latham in the Arcbaologia (xiv. 136, I 41, and xv. 304). Illustrations of the capitals will be found in the Arcboologia (iv. 136) and in J. Carter's Ancient Sculpture and Painting (i. 139). The rood on the exterior wall of the south transept of Romsey Abbey shows the Saviour on the cross in the ancient Byzantine fashion with the limbs unbent. Round the head is the cruciferous nimbus, and above the Dextera Dei issuing from a cloud. There is a loincloth round the waist and the feet are supported on a bracket. The Romsey rood has been illustrated in J. Carter's Specimens of Ancient Sculpture and Painting (vol. i. pl. 2) and in J. R. Allen's Gbristian Symbolism (p. I65). The writer is indebted to the Rev. J. Cooke Yarborough of Romsey for the very valuable assistance he has given in supplying information about the sculptured details of the

1 Engleficld's Isle of Wight, p. 102. 


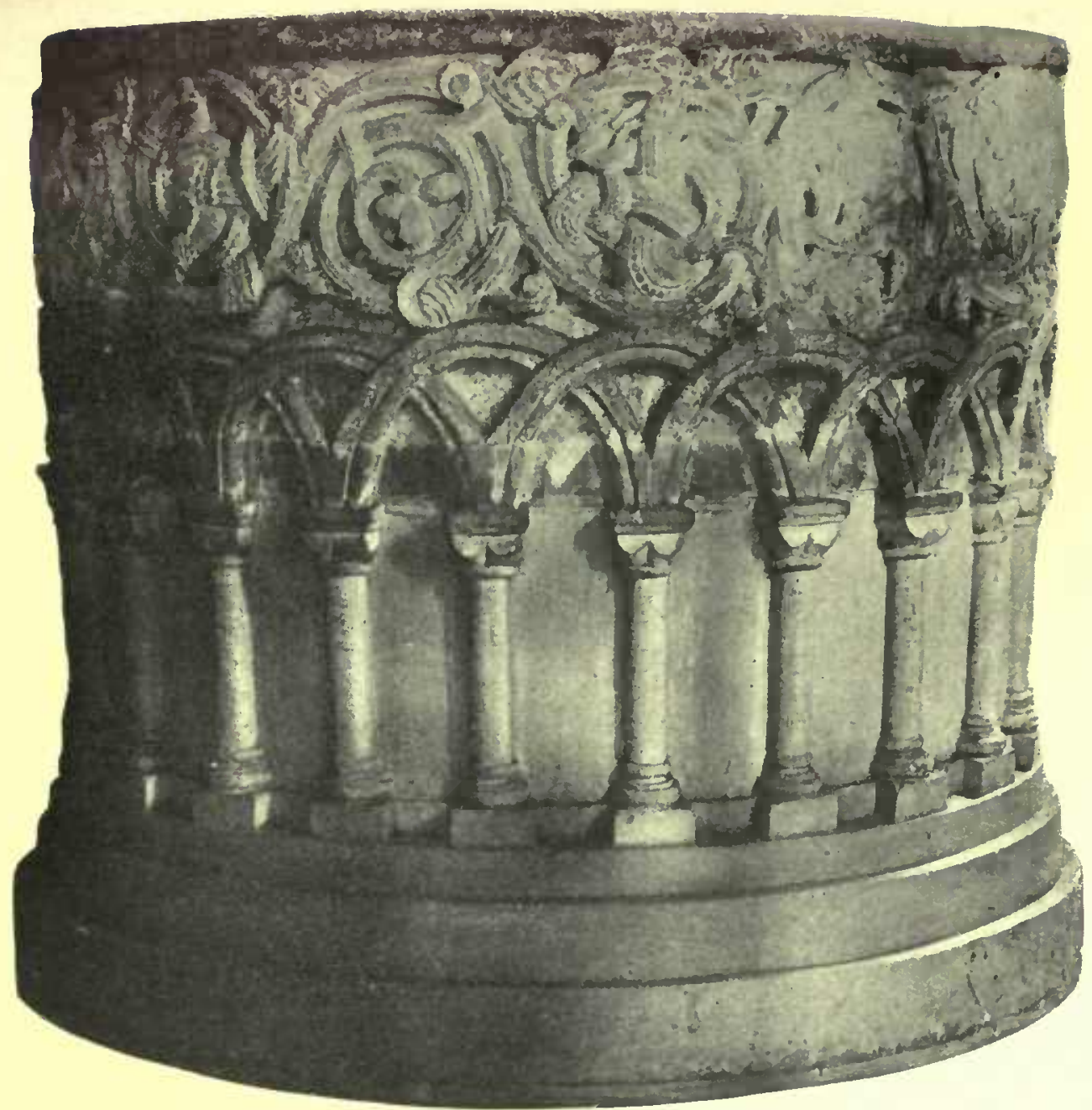

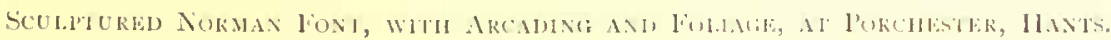

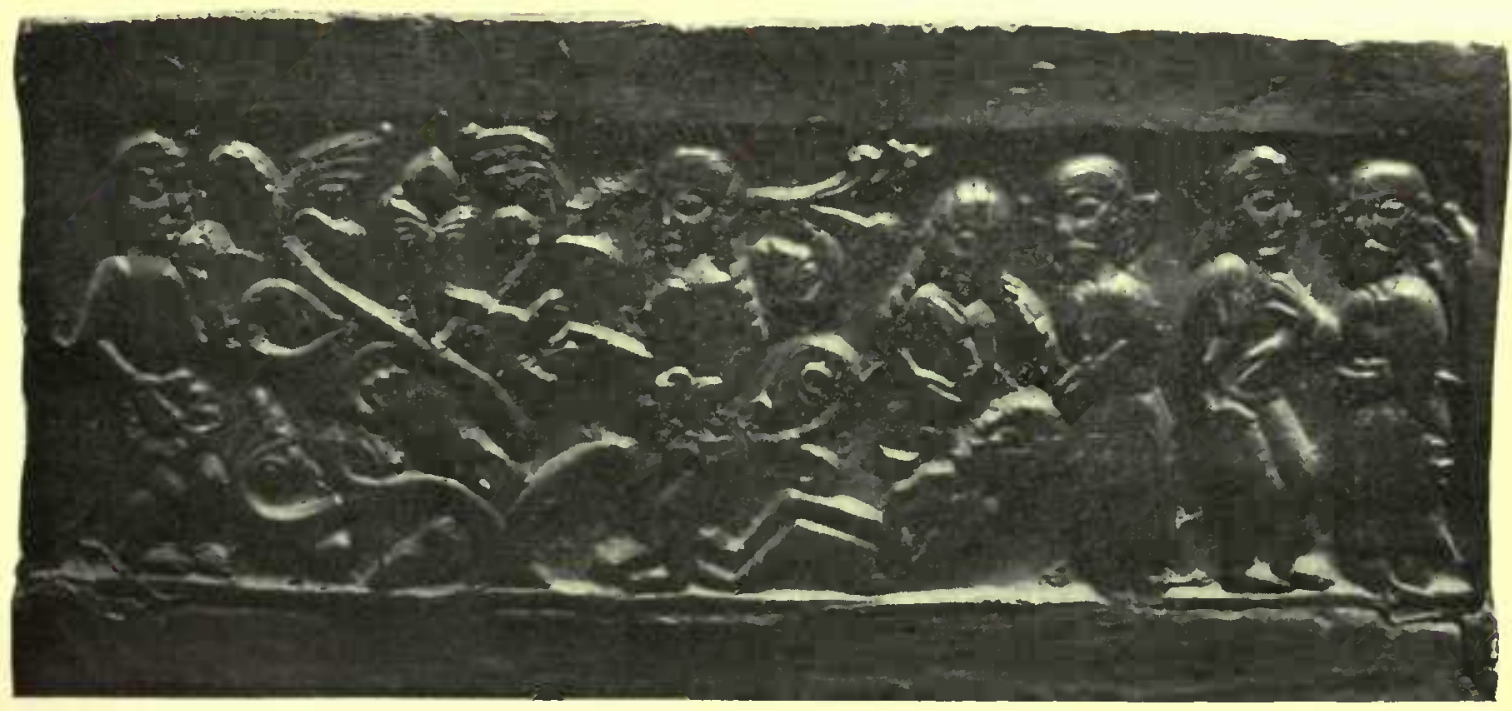

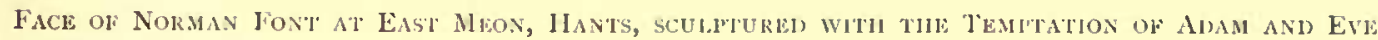
AND the CReation of Eve. 


\section{EARLY CHRISTIAN ART AND INSCRIPTIONS}

Abbey, and also to Mr. H. Guard, ex-mayor of Romsey, for taking photographs of the Saxon rood and carved Norman capitals.

The other miscellaneous Norman sculptures in Hampshire given in our list consist of mere fragments of no great importance, except perhaps the slabs with the symbols of the evangelists built into the west wall of the modern church of Binstead, which are engraved in Percy G. Stone's Arcbitectural Antiquities of the Isle of Wight (pl. 6). 



\section{SCHOOLS}

$\mathrm{H}$

AMPSHIRE and its capital may claim the first place in the history of English education with even more assured title than they claim it in the history of the English State. The cradle and seat of the power which first made England a united kingdom was also the centre in which was erected the school which became the model of all the public schools, which have been of infinite value in the political and social development of England, and are the one feature of our educational system (if such it can be called) which provokes the unfeigned admiration of other nations. While the political supremacy of Hampshire had long disappeared and the political and commercial greatness of its capital were already passing away when Winchester College was founded, the school itself remains the Mecca of the public school pilgrim, where he can still see the most vigorous and successful exposition of its principles and practice. It is strange that in a county of such ancient civilization there is, save at Winchester, an almost absolute blank in the early history of its schools. Except, as we shall see, for the merest scintilla of evidence at Alton, Basingstoke, Odiham and Godshill, I.W., there is no evidence of the existence of any grammar school before the Reformation, taking as the boundary date of that event the Act for the Dissolution of Colleges, Chantries and Gilds in the first year of King Edward VI., A.D. 1 547. Even in the four places named the evidence is of the scantiest, consisting in the bare statement of the fact that there was a grammar school. Yet it is impossible to doubt that a great town like Southampton, which gave its name to the county, a great seaport like Portsmouth, a great place of industry like Andover, the records of whose merchant gild rank as among the oldest extant, as well as Twyneham ${ }^{3}$ with its collegiate church of Christ, dating from before the Conquest, the name of which has superseded the old place-name, did maintain grammar schools, when we find them in such relatively insignificant places as those named, while in the much less civilized county of Yorkshire they existed by the score.

\section{WINCHESTER CITY GRAMMAR SCHOOL}

At Winchester we find sufficient proof of the existence of a general grammar school many centuries before the present college was founded.

At Christchurch there was a school as early as the middle of the twelfth century. Baldwin de Redvers' charter printed in Dugdale's Monasticon, vi. 304, which continued till the reign of Henry VII. (Letsers and Papers, Hen. VIII. xiii. [1], No. 1117 ). 


\section{A HISTORY OF HAMPSHIRE}

From the analogy of other cathedral churches, such as Canterbury and York, we cannot doubt that there was a school maintained by the bishop in connection with his cathedral church from the earliest times, when in 676 Winchester became the West Saxon capital and the West Saxon see was moved there from Dorchester in Oxfordshire. But we have no direct evidence of it till the days of Alfred the Great. That king himself has been claimed as a Winchester scholar ${ }^{1}$ of the local saint, Bishop Swithun, but the claim is unsupported by evidence. Alfred's early youth was spent in Rome. After his return Winchester and nearly the whole of Hampshire ${ }^{2}$ were abandoned to the Danes. Again recently ${ }^{3}$ his father Ethelwulf has been claimed as Swithun's scholar; but the authority (not cited) appears to be the utterly untrustworthy fifteenth-century historian Rudborne. We may however accept the statement in the Life of Alfred by the so-called Asser, that Alfred's youngest son ${ }^{4}$ was educated at Winchester at the public grammar school, not indeed as conclusive evidence of the fact, or even as evidence that there was such a school in Alfred's days, but as presumptive evidence that there was such a school in the days of the compiler at the end of the tenth or the beginning of the eleventh century, and that he thought the school existed or might have existed in the days of King Alfred.

Edward the eldest son and Elfthryth the eldest daughter were bred in the king's court, 'nor among their other pursuits appertaining to this life were they suffered to pass their time idly and unprofitably without liberal learning. For they carefully learnt the Psalms and Saxon books, especially Saxon poems, and are continually in the habit of making use of books.' But 'Ethelward the youngest, by the divine counsels and the admirable prudence of the king, was sent to the Grammar School (ludis litteraria disciplina), where with the children of almost all the nobility of the country, and many also who were not noble, he prospered under the diligent care of his masters. Books in both languages, namely Latin and Saxon, were diligently read in the school. They also learned to write, so that before they were of an age to practise manly arts, namely hunting and such pursuits as befit gentlemen (nobilibus), they became studious and clever in the liberal arts.'

1 Winchester, p. 1 2, by G. W. Kitchin, Dean of Winchester (Historic Towns Series). 'The kindly saint had gifts of influence and teaching ; the youth of Alfred the Great was spent at Winchester under his eye."

2 Saxon Chronicle, A.D. 857,861. See History of Winchester College, by A. F. Leach (Duckworth \& Co., I 898), hereafter cited as History, p. I 4 .

3 History of the English Church, by the Rev. William Hunt.

4 Annales Alfredi, ed. F. Wise (Oxford, 1722), p. 42. It is impossible after reading the annals analytically to accept them as genuine. Except where they are a translation or adaptation of the Saxon Chronicle they contain no historical facts as to Alfred's public life, while the account of his private life and of that of Asser are so full of statements, both self-contradictory and contrary to known historical facts, besides being per se absurd, that they cannot be accepted. The authority they derived from the supposition that the only ancient MS. (Brit. Mus. Cotton Otho, A. XII.) was contemporary with Alfred is destroyed by this MS. being now admitted to be of the date, about 100 years after Alfred's time, above indicated. Mr. Hunt, who maintains its genuineness 'as a whole' (History of the English Church, p. 267), admits that "the text has been so much tampered with that its statements must be received with caution except when supported by other good authority.' 'The famous passage invented by Camden in his printed edition to show that Alfred founded Oxford University was not in any MS. at all. 


\section{SCHOOLS}

The public grammar school of Winchester next appears as the subject of a contest for the mastership and the master's right to a monopoly of teaching in the twelfth century, in the case, to adopt modern terminology, of Phantom v. Jekyll, reported in John of Salisbury's Letters. ${ }^{.}$

The plaintiff, Jordanus Fantasma in Latin, and in Anglo-Norman Jordan Fantosme, was afterwards the author of a poem ${ }^{2}$ on the war between Henry II. and his rebellious son in I I 74. The case seems to have been heard some time between II 54 and I I 58, when John of Salisbury was acting as official principal of the prerogative court of the archbishop of Canterbury. ${ }^{3}$

'The case of master Jordan Fantosme and master John Joichel, clerks of the lord bishop of Winchester, has been carried before me. Having heard the case and inspected the documents, we inhibited the said John against teaching school in the same city against Jordan's will.' The parties alleged mutual breach of faith, and Joichel appealed to the pope ; but John of Salisbury, while reserving this question, says that he ' being clear on the right of master Jordan to the school, after consulting the bishops of Chichester, Hereford and Worcester, charged the lord of Winchester not to suffer the said Jordan to be further vexed by the said John on the matter of the school, on pain of excommunication. A few days afterwards however the parties came before us again, Jordan alleging that John had usurped the school again and incurred excommunication. He denied it and was prepared to swear that he had desisted from the mastership after the injunction.' Jordan was ready to produce witnesses, but the other 'refused a day' on the ground that he was 'starting for Rome.' 'Pray,' says the harassed judge, 'by the help of the Lord put an end to their litigation.'

In the next reign the Winchester School appears under the patronage of royalty, King John ${ }^{4}$ on I $_{3}$ April, I 205, directing William of Cornhill 'to make the bearer Geoffrey attend school (scolas) at Winchester and find him reasonable necessaries' and send his account in to the king. Towards the end of the century among certain diocesan statutes ${ }^{\circ}$ made in 1295 occurs one concerning the distribution of holy water to the sick. It directed that 'in churches which were near the schools of the city of Winchester or of the fortified towns (castrorum) of the diocese only scholars were to be allowed to carry it,' and, by implication, earn the fees for doing so. The same statute directed rectors and other parish priests to see that the boys in their parishes knew the Lord's Prayer, the Creed and the Ave Maria, and how to sign themselves rightly with the sign of the cross. 'And parents should be induced to let their boys learn singing after they know how to read the

I No. xix. ed. J. A. Giles, 1848 .

2 Surtees Society, No. II, 1840, ed. Francisque Michel.

3 This appears to be the position he occupied, and not that, as I mistakenly said in History, p. 37, of papal delegate to Pope Adrian.

t Close Rolls of King John (Rec. Com.) under date.

s Winton. Epis. Reg., John de. Pontissara, f. 55. 


\section{A HISTORY OF HAMPSHIRE}

psalter, so that after they have learnt higher subjects they may not be obliged to go back to this, or not having learnt it be less fit for divine service.' The assumption that all boys were to have sufficient education to read their psalter, which was of course in Latin, is remarkable. William of Wykeham on 3 January, ${ }^{1} 368-9$, enforced ${ }^{3}$ the statute of Pontissara. It, he says, had been observed to within a short time back, 'but some, jealous of our scholars, in spite of the constitution and of custom hitherto observed, have given the holy water to married men, dissolute ${ }^{2}$ men not capable of this kind of schooling, especially in the city of Winchester and churches near.' The Official was therefore directed to revoke anything which had been attempted in the matter to the prejudice of ' our said scholars of Winchester.'

The words 'our scholars' cannot mean the boys of the college not founded for nearly twenty years afterwards, though they may include the school which, as will be seen, Wykeham was maintaining in 1373. At all events it includes the scholars of the City Grammar School, of the continued existence of which there is fortunately specific contemporary evidence. This is afforded by a conveyance, now in the college archives, dated Sunday after the Epiphany, 4I Edward III., i.e. I366-7, of a house with Calpe Street, now St. Thomas Street, on the west, with Minster Street, now Symonds Street, on the east, 'and a tenement of the prior and convent of the cathedral church, where the school is now held, on the south.'

In $1377^{\circ}$ William Balet was fined $3^{d}$. in the city court for unlawful detention of $6 s .8 d$. from William 'Scolmaystere,' which he acknowledged and was ordered to pay within a week.

The conveyance of 1367 , taken in conjunction with two other deeds, one in $1450^{4}$ and the other in $1483,{ }^{4}$ and the note of a lease of the 'High School House' in $1544,{ }^{\circ}$ definitely fixes the site of the City or High School on the west side of what is now Symonds Street and the north side of Little Minster Lane at their junction.

An undated twelfth century grant ${ }^{6}$ by one Pentecost and Alditha (Edith ?) his wife to the priory of St. Denis, Southampton, of land described as in Minster Street, "between the house which was Jordan Fantasma's and the house of Reiner the Squire,' or as it is described in

1 Wykebam's Register, Hants Record Soc., ii. 75.

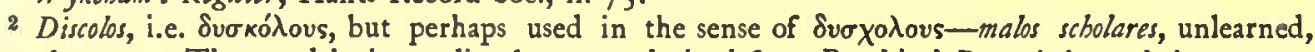
lewd or laymen. The word in its medieval use was derived from Boethius' De regimine scolariun.

3 City Muniments, Court Roll, Io Richard II. rot. xvi. b.

4 November 20th, 29 Henry VI., Robert Erlegh to Thomas Forest, clerk, and other trustees, grant of house in Calpe Street between a tenement of Richard Prikher, N. and 'le scole hows' and the lane leading from Minster Street to Calpe Street, S., Minster Street, E., and 'Calpstrete,' W.

November 24th, I Richard III., lease by William Barnstaple, surviving trustee of the same house to Stephen Bramden, 'valet of the Crown,' between the late John Prikier's tenement, N., and the king's way leading to 'le scolehous,' E., a stone wall of the garden, S., and Colstrete, W.

Not-as printed in History, pp. 43, 44-1 440 , I 484 .

- Cathedral muniments. Note by Chapter Clerk, 1643 , of lease by Dean and Chapter in 1544 to Alice Tytridge for forty-one years at $3 s$. $4 d$. a year of tenement and garden called High School House, having Minster Street east and Calpe Street south.

- Chartulary of St. Denis Priory, Southampton. Brit. Museum Add. MSS. 15,314, f. 117. The next deed is dated 52 Henry III., i.e. $1267-8$. 


\section{SCHOOLS}

another deed 'between land of Jordan Fantasma and land which belongs to Rainer the clerk (clerici) at a rent of 2s. for all service to Mr. John Judicalis' (the Jekyll of the trial), points to the school having been in the same place in the days of Bishop Henry de Blois as in those of Bishops William of Wykeham and William Wayneflete. In a roll ${ }^{1}$ of Richard II.'s reign, among the city records, being a list of rates levied for the maintenance of the city walls, this school is called the High School (alta scola), and the master of it is mentioned among "The Tenants of the Prior of St. Swithun's,' the cathedral monastery. This school was not however what is commonly meant by the Priory School. Though the school-house was on cathedral land it was outside the cathedral precincts. The mastership was in the appointment of the bishop, not the prior; the master was a secular clerk, not a monk, and the name of the school was not the Priory School but the High School or Grammar School or Great Grammar School of the city of Winchester.

It must have been well frequented by the citizens. In a great suit ${ }^{2}$ which took place in 1373 between William of Wykeham and three masters of St. Cross, who were charged with malversation and breach of trust, twenty-eight witnesses were produced and examined before the abbot of Hyde, sitting, as an Official Examiner of the High Court does now, to take the depositions of witnesses in the case. Of these twentyeight, half were laymen, of whom eleven are described as litterates, i.e. learned in Latin, who must have got their learning for the most part in the City Grammar School. The first witness, Walter of Sevenhampton, rector of Middlemarsh and prebendary of Romsey, who had been six years steward of the hospital, gave evidence that every day in the hospital of St. Cross one hundred poor were given dinner in the 'Hundredmenne Hall'; a loaf of coarse bread weighing 5 marks, 3 quarts of weak beer, pottage enough, and a herring and two pilchards, or two eggs and a farthing's worth of cheese. Among them were 'thirteen poor scholars of the Grammar School, sent there by the Master of the High Grammar School of the City of Winchester' (magistrum summe scole gramaticalis civitatis Wynton).

The next witness, Robert Frere, himself a brother of the hospital, eighty years old, corroborated Sevenhampton, adding that there was a cook called 'Hundred-men-coke,' who cooked for the poor men's dinner pottage in a great pot called the 'Hundred-men-pot,' and a great spoon was kept to ladle pottage from the pot called 'Hundred-menladel.' This witness speaks of the thirteen poor scholars simply from ' the school of the city.' Both he and the next witness, Adam Jacob, clerk, also upwards of eighty years old, born by the gate of the hospital and sacristan there for thirty years, spoke $^{3}$ to the thirteen poor scholars from the Grammar School (a scolis gramaticalibus) named by the master of this Grammar School (scole gramaticalis), as being sent

1 Regula Muragii, now kept in the Mayor's parlour.

2 MS. in possession of the warden of New College, beginning on f. 2, 'Processus delegationis inter Episcopum Wyntoniensem et Custodem Hospitalis,' f. 4I.

${ }^{3}$ Ibid. f. 29. 


\section{A HISTORY OF HAMPSHIRE}

there in their youth sixty years back, i.e. about $\mathrm{I}^{\mathrm{r}} 3$. They all add 'of the city' (civitatis Wynton) to the title of the school. This school did not cease on the foundation of the college, for we find in January, $1407,{ }^{1}$ the master teacher (magister informator) of the High (alta) School supping at the high table of the college; while, in September, 14r I, Mr. Ralph Greenhurst, master of the High School and himself an ex-scholar of the college, dined and supped with the fellows. In 1416 the same master is recorded" as holding the "High Schole,' a tenement of the prior and convent of St. Swithun which, and the garden on its west, were subject to a 'tarrage,' 'terrage' or assessment on land of $6 d$. each, payable to the city authorities. 'Rafe Greenhurst' is named by Foxe, ${ }^{3}$ the martyrologist, as one of those who, 'either in Wycliffe's time or after his time, springing out of the same University, were partakers of his persecution,' and ' mencioned in auncient writers,' 'which being excommunicate by Pope Eugenius IV., A.D. 1446, appealed unto a General or Ecumenical Council.'

The latest document yet found relating to this school is a confirmation, ${ }^{4} 8$ October, 1488 , of a licence by the bishop through his Official ${ }^{5}$ to John Furnew (modern Furneaux), granting him for life 'special licence, authority and power to teach and inform in grammar and literature in the school of Winchester, called in the vulgar tongue "The High Scole," situate by the churchyard of the cathedral church of S. Swithun, any wishing to be instructed and informed in this sort of learning.' The appointment or licence was enforced by an inhibition against any one else 'teaching grammar in the High School, or elsewhere within the city or suburbs of Winchester, or instructing or informing scholars coming to it,' ' the master and scholars of the Blessed Mary's College, founded by the Lord Wykeham, only excepted.' This document is of great value in the general history of education, as it shows that the real Priory school, the monastic school, if school it can be called, which existed in Winchester cathedral priory as in every large monastery, was not regarded by the world as a grammar school at all - at least not as a public school-and that it did nothing for outsiders. A document which only within the last few months came to light, approximately fixes the ending of the High School. This is an Obedientiary Roll which had escaped the notice of Dean Kitchin, and was found by the cathedral librarian, the Rev. F. T. Madge; an account roll of the keeper of the altar of the Virgin Mary for the year 1529-30. Among receipts from tenements in the city in St. Laurence's parish are 'from George Bowsum 5s. for the tenement of the High School there, which used to be rented at $16 s$, and no more, because it stood vacant and no one wished to take it at a higher price (carius);

1 College Muniments, Steward of Hall's Books under dates given.

2 Add. MS. 6, 133 , f. 3 .

4 Cath. Mun., Prior's Register, i. f. 134. De Alta Scola.

- John Lychfield, LL.D., Scholar of Winchester, 1462, Fellow of New College to 1481, Master of St. Cross Hospital, 1489-92. 


\section{SCHOOLS}

from John Bochere Ios. for a garden adjoining the High School.' In the Valor Ecclesiasticus ${ }^{1}$ of 1535 , the rental of the keeper of the chapel of the Blessed Mary for divers tenements and gardens in the city of Winchester, together with the High School (unacum Alta Scola), is returned at a total of $£_{4} 48 \mathrm{~s} .8 \mathrm{~d}$., but no details are given.

\section{THE NOVICES' SCHOOL}

We now pass to the internal monastic or priory schools. There are traces of two so-called schools in the priory, the Novices' School and the Almoner's School. The Novices' School no doubt existed from the beginning of the priory, but it was entirely confined to novices and, in the times of which we have any records, from I 3 I 2 onwards, never exceeded nine in number and sometimes contained no scholar. Indirectly we have evidence ${ }^{2}$ of the Novices' School in the entries in the Almoner's Rolls for 13 I 2 and I $352 .^{3}$ In the first is a charge of $3 \frac{1}{2} d$. for beer sent to the 'youths' bishop' on Innocents' Day ; and in the last a charge for a 'courtesy,' or present, sent to the officers of the monastery and 'five youths' at the time of St. Giles' Fair. This courtesy is explained by subsequent account rolls, that for I 390 containing the entry 'to two youths in school for their knives 2s.'; while the Hordarian's Roll for $1495-6$ " distinguishes between 'twenty-four brethren out of the school' who received I $3 d$. a head 'for their knives' and 'four youths in school' who were paid I $2 d$. each for the same. It hardly says much for the quality of the steel that these knives, dinner knives presumably, were bought new every year. In I 533 there were thirty-seven brethren out of school and only one in school, who with the prior, sub-prior, third and fourth priors and two students at Oxford made up the total number of the convent to forty-four. The convent does not appear to have ever exceeded sixty-five in number and in 1353 , after the ravages of the Black Death, was under twenty. It is not surprising therefore that the highest number of 'youths' ever in the school was nine in $1459-60^{5}$; that out of thirty-six years, from I 353 onwards, in which the numbers are given, in only eight years was the number in school as high as six; and that in $1485^{5}$ and $15^{1} 6^{5}$ there were no scholars in school at all-in the latter year the entry in the Almoner's Roll running, "for knives this year nothing, because no one in the school this year.' They are always called 'youths' (juvenes) not boys (pueri),

I Vol. vi. Appendix, p. x.

2 The Obedientiaries or Officers' Account Rolls of the monastery furnish the evidence. Obedientiary Rolls of St. Swithun's, Wincbester, by G. W. Kitchin, D.D. Hampshire Record Society, 1892 ; p. 398 cf. p. 401 ; p. 406 cf. p. 4 rr.

3 Ibid. p. 413.

4 Ibid. p. 30r. It is not quite clear whence the hordarian (hordarius) derived his name, but he was more probably the grain-kecper (bordeum). He owned several manors, producing in 1327 an income of $f_{1262}$ odd, of which $\{2436$ s. $8 d$. was paid over to the kitchener at the rate of $13 s$. $4 d$. a day. Ibid. pp. 254,255 .

s Ibid. pp. $450,298,464$. 


\section{A HISTORY OF HAMPSHIRE}

because, in the times for which the records exist, there were no boys strictly speaking - that is, under fourteen years of age-but novices or young monks all above that age, and what they learnt in school was not so much school learning as the Benedictine rule. Indeed at Canterbury the master of the novices was called, as a rule, not schoolmaster but magister ordinis. Monks at that date appear to have been ill-educated. In some injunctions ${ }^{1}$ given after a visitation of the cathedral monastery in 1387 William of Wykeham commented severely on some of the monks, who were so ill-educated that they were 'almost wholly ignorant of grammar and could not understand what they read, and in singing and reading the lessons put shorts for longs and vice versa',' ' and walking in the wilderness out of the way, defiled and perverted the sound meaning of the scriptures, and so, being unable to enjoy Holy Writ, were rendered prone to do what they ought not.' He thereupon ordered the prior to follow the rule and provide a master to teach the novices and others insufficiently learned. There is indirect evidence that Wykeham's injunction was observed in a letter of Prior Alton ${ }^{2}$ to Cardinal Beaufort, bishop of Winchester, saying that since his appointment as prior he had sweated, so far as his grace and strength allowed, to secure that the little garden under his care might be watered with the stream of twofold learning, namely song and grammar. He says that while one person was teaching grammar (in gramaticalibus) another priest, named Robert Bygbrooke, was assigned to teach the junior monks singing. Beaufort had carried off Bygbrooke to sing in his own chapel choir, and the prior entreated that he might be returned as he was also organist, and in his absence the organ was dumb. The letter shows that the novices' grammar-master was not a monk, but, like the song-master, a secular priest. The employment of a secular was allowed by the Benedictine statutes of $\mathrm{I} 337$, but it is not one which suggests that the monasteries were homes of learning. A single appointment of a grammar-master of the young monks is preserved, ${ }^{3}$ Io August, I 497, that of Mr. Peter Druett, M.A. He was to be paid 6 marks a year $\left(f_{0} 4\right)$ and receive for his livery four yards of cloth of 'the gentlemen's suit' (secta generosorum), to have his meals in the prior's hall at the gentlemen's table, unless he was ill, when he could have them sent to the chamber provided for him in the precincts. His boy (garcio) or servant was also to have a chamber and dine with the chapel boys in the prior's hall. Two cartloads of fuel or 2s. were also stipulated for. A special proviso forbade $\mathrm{Mr}$. Druett to teach any secular boys with the young monks, unless with special leave from the prior. In $15 \mathrm{IO}^{4} \mathrm{Mr}$. William Parkhous was appointed to teach the monks dialectic (in dialecticis) and to act as medical adviser, with the same provisions in other respects, but he was to dine at either the prior's or the gentlemen's table, and he received $£ 6$ a year

1 Harl. MS., 328, f. 3, b.

2 Cath. Mun., Prior's Register, i. 54. $\quad 3$ Ibid. ii. f. 1, b. Thomas Hunton, Prior.

4 Ibid. f. 146, b. 'Carta concessa Magistro Parkhous, clerico, pro informacione monachorum.' Thomas Silkstede, Prior. April 12. 


\section{SCHOOLS}

salary and provender for a horse. In $153^{1}$ John Potynger was appointed at a salary of $f_{0} 4$ a year, with the same additions, his chamber being 'at the east end of our dormitory called the Second Dorter.' He was to teach grammar, not only to the younger brethren, but also-sign of the changing times - "the boys whom we board and educate in the monastery, "the chyldern of the chapell" and "the chyldren of the almery." This John Potynger was presumably the same person who was rector of Oakley and Hostiarius or Second Master of the college from Michaelmas, I 535 to 1537 , and had been a scholar in 1527 . A note to his name in the College Register, seemingly by way of reproach, says he was afterwards married (post duxit uxorem).

\section{THE ALMONRY SCHOOL}

The children of the chapel and the almonry were the choristers who sang in the Lady Chapel and the charity boys who performed menial services and were kept in the almonry or almshouse (elymosinaria). In the absence of the priory registers before 1400 it is impossible to ascertain when choristers were introduced. It was almost certainly not before the building of the existing Lady Chapel in the fourteenth century. In 1402 there were only four of them, as we learn from the appointment of John Dyes, ${ }^{2}$ their master. He contracted to serve the prior and convent for twenty years in the daily Mass of our Lady at our Lady's altar in singing and organ playing, and in the choir on the greater feasts when the organ was played; and to teach the boys, who were not to exceed four in number, singing. Like the grammarmaster of the young monks, he was to have a room in the precincts and a robe with fur, but only of the clerks' not of the gentlemen's suit ; and he only dined in the prior's hall during the Christmas and Easter holy days and on double feasts or when 'he sang to the organ' (cantaverit organice) in choir. His salary was $\oint_{5} 6 \mathrm{~s} .8 d$.

In 1404 the prior and convent contracted ${ }^{3}$ with William of Wykeham for the maintenance of Wykeham's chantry in the cathedral, the masses to be done by three monks, while every evening the boys of the almonry 'living by the alms of the priory' were to sing there the anthem Salve Regina or Ave Regina and the psalms De Profundis with the prayer Fidelium or Inclina. The prior was to pay $6 s .8 d$. every year at Lady Day for the boys' benefit. This identifies the almonry boys with the choristers.

The next choristers' master of whom we hear was Edward Pyngbrygge, appointed by Prior Hunton on Michaelmas Eve, $1482 .{ }^{4}$ The choristers had then been doubled in number, for he was to teach 'all the boys of the said prior and convent now serving or hereafter serving in the choir in chant and descant, to the number of eight or less, never

1 Cath. Mun., Prior's Register, iii. f. 53. December 5. William Basyng, Prior.

2 Prior's Register, i. f. I 5 b. September 29. 'Indentura Dyes ad terminum 20 annorum.'

8 Ibid. f. 18 . August I6.

4 Ibid. f. 107. 'Carta Edwardi Pyngbrygge.' 


\section{A HISTORY OF HAMPSHIRE}

more.' No organ is mentioned, but he had to attend the mass of Jesus on Friday in the nave as well as the other services. In other respects his duties were the same as those of his predecessors. But his grant was

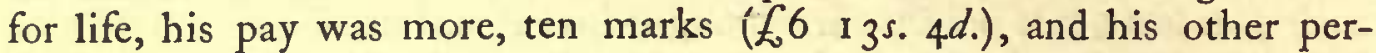
quisites were the same as those of the grammar-masters. In $1510^{1}$ the Prior's Register contains a document headed ' deed granted to Edward Pynbrigge for teaching the boys.' It contained all the provisions of the former grant, except that the salary was reduced to nine marks, and playing the organ was mentioned, while teaching the boys was not. The description of the deed seems to be a mistake of the scribe as the leaf before contains an appointment, dated eight days after ${ }^{2}$ the other, of Thomas Goodman or Gudemane to perform the same duties, but in addition to teach chant and descant to ten boys or less, receiving seven marks a year during Pynbrygge's life and eight marks afterwards. In the last Prior's Register, ${ }^{3}$ on 5 February, 1 537, Matthew Fuller, 'syngyngman,' was appointed to perform the same duties, teaching eight boys only, with the same perquisites, but his salary was only $f_{0} 46 s .8 d$., and he was to dine at the cellarer's table, not the prior's.

Neither the grammar school for the young monks, nor the almonry song school for the choristers, can be regarded as in any real sense constituting a school. If they can either of them be regarded as a school, then there was also a school at St. Elizabeth's college and another at St. Cross hospital. For the latter the evidence given in Wykeham's great suit shows that the staff of the hospital consisted, besides the Master, of four priests, thirteen secular clerks, and 'seven poor educated' (litterati) boys. These boys lived on the alms of the master's hall, and were called choristers. Each of them received a loaf of bread a day, and beer, meat and fish from the fragments of the table of the whole hall, and attended all divine services and the canonical hours in the church, " and when they were finished used to attend school (solebant scolas exercere) in the said hospital.' One of the witnesses, Walter of Edyndon [Edington], rector of St. Mary de Vallibus (Wyke), who was one of the thirteen secular clerks and afterwards one of the four priests, spoke of the clerks as 'seculars,' and said that of the seven poor boys two were called choristers, that all attended the services, and when the services were over used to learn and be taught (solebant addiscere et informari) in the hospital. If therefore there was a priory school at Winchester at all, there were two priory schools, besides a hospital school at St. Cross and a college school at St. Elizabeth's college. The net result was that more than a score of boys received an education of a sort, and learnt at least to read and write and the elements of the Latin tongue. The City Grammar School was the only real school.

1 Prior's Register, ii. f. 44b. Thomas Sylkestede, Prior. 12 March, $1509-10$.

2 Ibid. f. 44. Carta Thome Gudeman concessa pro informatione puerorum capelle Beate Marie. 20 March, 1510 , which is almost certainly a mistake for 1509 , i.e. $150 \frac{9}{10}$.

3 Prior's Register, iii. f. 73. William Basyng, Prior.

4 MS. New College, f. 23 b. 
. 


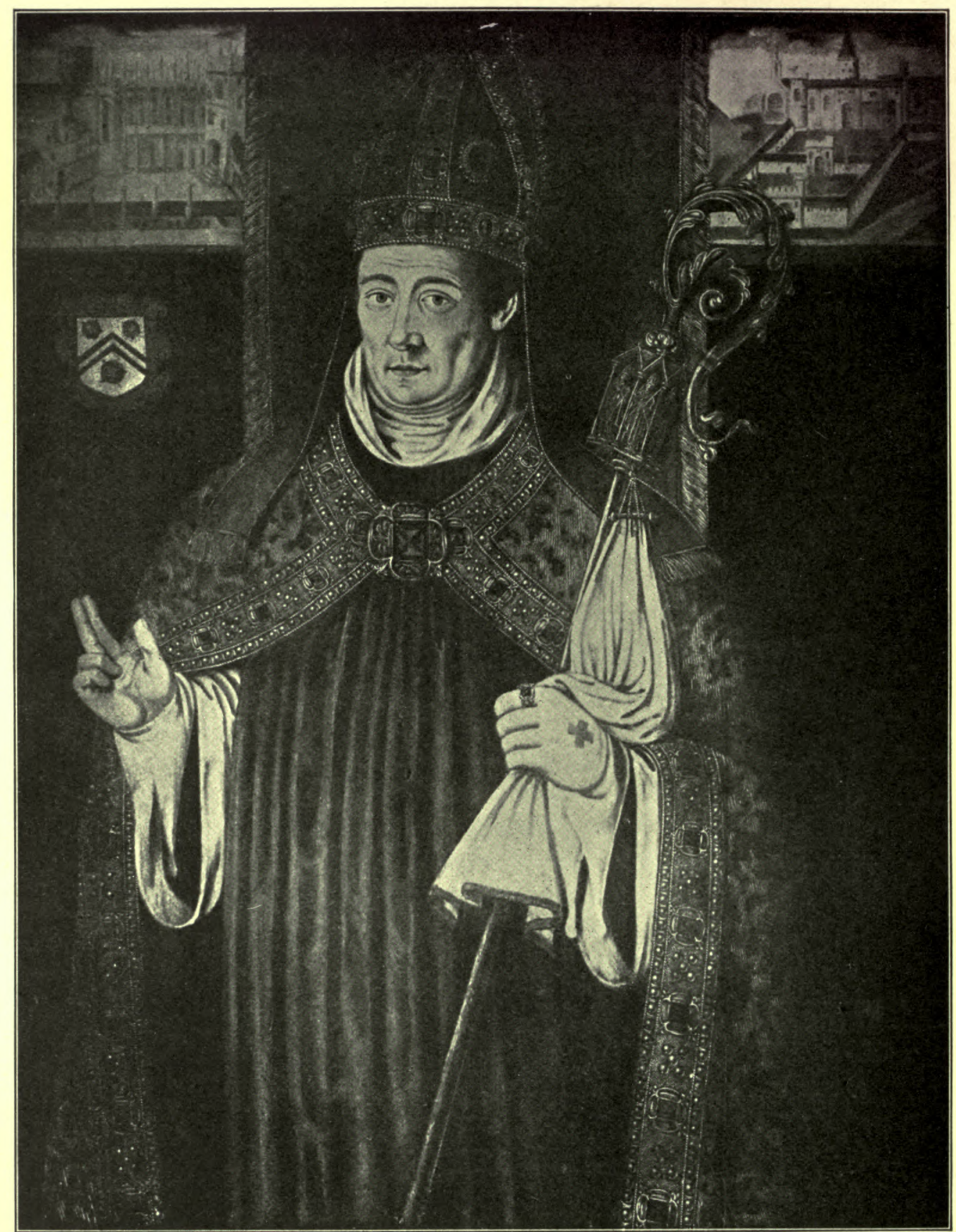

Photo by W. E. Abley.

William OF WYKEHAM.

From his portrait in Winchester College Hall. 


\section{SCHOOLS}

\section{WINCHESTER COLLEGE}

\section{The Foundation}

The exact time at which Wykeham began to collect the boys who were afterwards incorporated as Winchester College is not known. $\mathrm{He}$ became bishop of Winchester in 1366 . In February, ${ }^{1}$ I 369 , his agents acquired the site of New College at Oxford. On I September, I 373, he was already maintaining a school at Winchester. He then made an agreement with $\mathrm{Mr}$. Richard of Herton, grammarian (gramaticus), that for ten years he should teach and instruct in the art of grammar the poor scholars whom the bishop maintains and will maintain at his own cost, the bishop undertaking to find another fit person to help him ; in other words, an usher or assistant master. Herton was not to take any other boys to be taught without leave of the bishop. If ill, or during a single visit to the court of Rome, he was allowed leave of absence, finding however a substitute. In I 376, when Wykeham had been convicted (wrongfully) of misfeasance in the chancellorship, and deprived of the temporalities of the bishopric, he 'brake up's his household, 'sending also to Oxford, where upon alms and for God's sake he found seventy scholars, that they should depart and remove every one to their friends, for he could no longer help or find them.' In I $378,{ }^{4}$ having been restored, he again began buying land in Oxford. He obtained a bull ${ }^{5}$ of Pope Urban VI., dated I June that year, for the foundation of Winchester College; the erection of colleges being a matter of papal prerogative. The terms of the bull for 'a college of seventy poor scholars, clerks, to live college-wise and study grammar (gramaticalibus) near the city of Winchester,' suggest that the site had already been selected. The bull said that the bishop, 'as he states, has for several (pluribus) years of his life, from the goods given him by God, supplied the necessaries of life to scholars studying grammar in the same city, and for their better maintenance had asked for the appropriation of the church of Downton, near Salisbury, in the patronage of the bishop of Winchester. The bishop of Rochester was directed to act on the bull as soon as the endowment of the college had been settled. On 26 November, $1379{ }^{\circ}$ the charter for New College was executed, and the temporary warden, Richard Tunworth, gave place to Nicholas Wykeham, the founder's nephew. Next year, 5 March, I 380,7 the buildings at New College were begun, and on 14 April, I386, were formally entered. Meanwhile Wykeham put himself in a position to claim the execution of the bull for Winchester. In I 380 he purchased the manors of Meonstoke Ferrand and Meonstoke Perrers for the endowment. The site of the college, a messuage and

1 Pat. 3 Ric. II. pt. I, m. 32.

2 Winton. Epis. Reg., Wykeham, iii. 98.

3 Appendix B to Introduction, Cbronicon Anglia, Rolls Series 1874, p. lxxx. ; Moberly, p. 137.

4 Wood. Hist., ed. Gutch, iv. 177.

5 Recited in Licence under it by Thomas Brinton, Bishop of Rochester (printed Annals of Winchester College, by T. F. Kirby, Bursar [Henry Froude, I 892], hereinafter cited as Ann., p. 436).

6 Charter as to New College, cf. Moberly, p. Igz.

7 Ibid. 193. 


\section{A HISTORY OF HAMPSHIRE}

five acres of land in the [Bishop's] Soke outside the city were then bought from the priory, and two messuages from private owners. In October, 1382 , letters patent containing license in mortmain from the Crown were obtained, and a fortnight later the foundation charter was executed by the founder in the chapel of his manor house in Southwark.

A warden, Thomas of Cranley, S.T.B., a fellow of Merton, and afterwards warden of New College and archbishop of Dublin, was appointed, and seventy scholars were admitted, and their names are stated to have been entered in the muniments of the college. The register so made is not now to be found, so that the names of those admitted between I 382 and 1394, from which date the present register of the scholars commences, cannot be ascertained except for such of them, about one in five, as went to New College and are found in the Hall Books or in other documents there.

Hence it is that it has been doubted whether Archbishop Chicheley, the founder of All Souls' College, Oxford, was a Wykehamist. There is in truth no reasonable doubt about Chicheley, or any other fellow or scholar of New College admitted after I 382 , since the statutes of both colleges required the members of the one to be recruited from the other. Chicheley's name appears among the scholars in the earliest Hall Book (the list of those who dined in hall in each week) preserved at New College-that for $1386-7$-in the $37^{\text {th }}$ week, which fell in June, 1387. We have direct evidence that as early as I 388 the system of election to New College prevailed. In that year a letter ${ }^{1}$ from Wykeham to the electors to New College and Winchester, viz. : Mr. Nicholas Wykeham and Mr. Thomas Cranlegh, the two wardens of New College and Winchester, Sir John Keton, probably a fellow of New College, ${ }^{2}$ and John Melton, the headmaster, directed them to elect the best scholars of Winchester College for admission to New College, without partiality. For admission to Winchester they were to choose, first the best four from Broughton and Downton parishes, if fit, and then 'from the places defined in our statutes.' If the statutes were in this respect the same as the later statutes of the year I 400 , these places were, first, where the college had estates, next, the diocese of Winchester, and then others in succession. Broughton in Oxfordshire belonged to Wykeham and is the home still held by the descendants of Wykeham's nephew, the Wykeham-Fiennes, Lords Saye and Sele, and Downton was the place near Salisbury, the church of which, worth $f_{1} 100$ a year, was then the richest possession of the college.

A direction was added that while the college remained in the parish of St. John the Baptist on the Hill, the scholars were to attend the parish church on Sundays and Feast-days. Attendance at chapel as

1 Lowth's Life, App. p. 364, from Wykeham's Register, iii. 83 b.

2 Robert Keton, or Ketone, appears as a scholar of New College in 1387, and on I April, 1399, being then B.C.L. was appointed chancellor and the great (episcopal) seal delivered to him by Wykeham: Register, ii. 489 (f. 313 a). The executors of William Ketone, chaplain, were discharged 13 July, 1377. Ibid. ii. 271 (misprinted Kelm). 


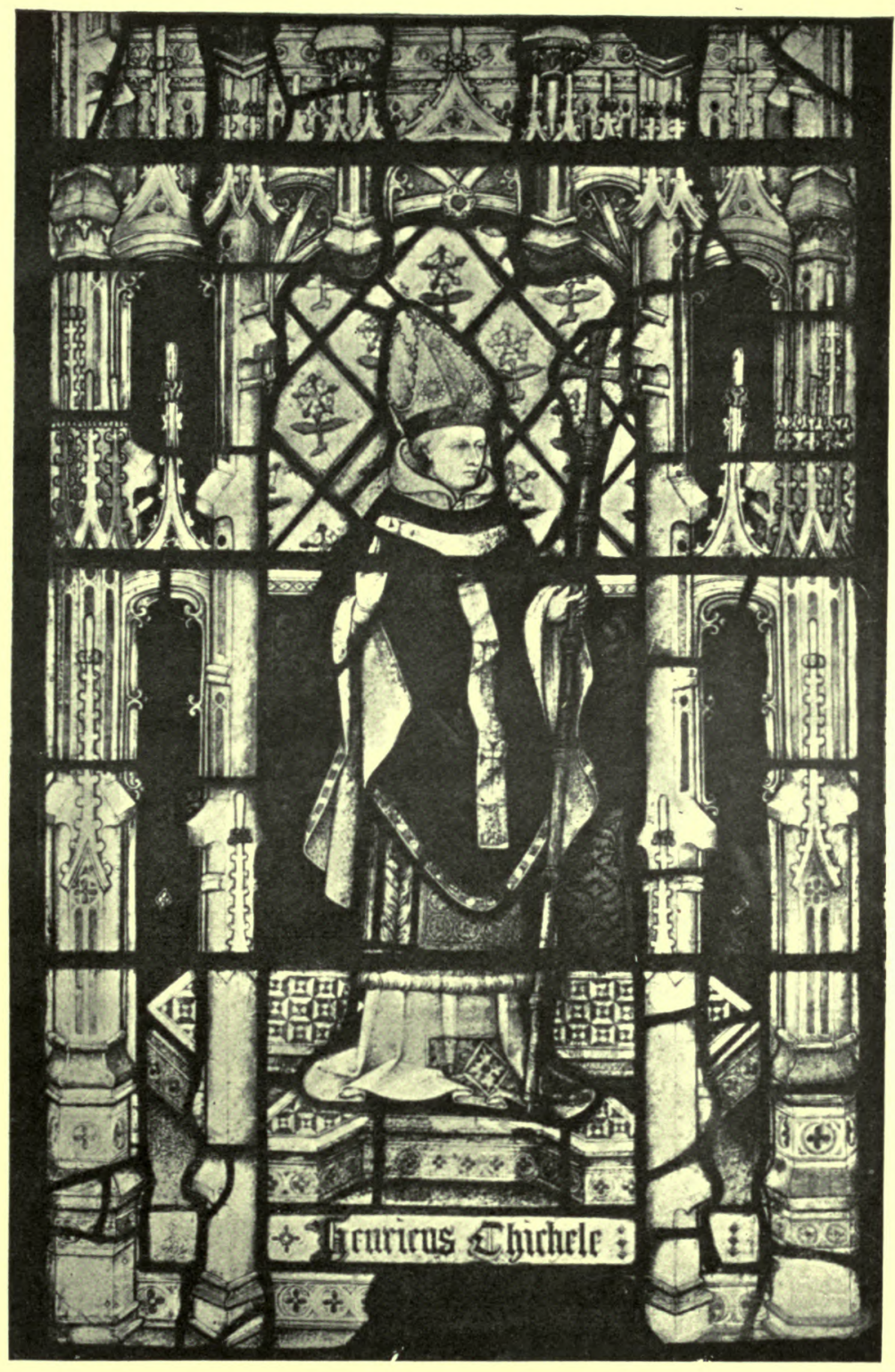

Archishop Chicheley. College c. 1384-7.

From Windon in All Souls' Collegre Chapel, Oxford. 



\section{SCHOOLS}

required by the statutes was of course impossible when the chapel was not built. The site of the school before the building of the present college is thus fixed. It was just beyond the east gate of the city on the lower slope of St. Giles' Hill.

The true date of the foundation of Winchester College is 20 October, 1382 , and from that time the corporate existence of the warden and seventy scholars has been continuously maintained. The succession of scholars had begun still earlier, certainly in I 379, most probably before 1373 , the date of the appointment of Richard Herton as master, and perhaps as early as 1369 , when New College was in process of being founded.

The college however was not moved to its present buildings for some years. The foundation stone of the new buildings was laid on 26 March, I 387 . William Winford, mason, was the architect, and Simon Membury, clerk, treasurer of Wolvesey, the surveyor or clerk of the works. The buildings were so far completed by I 4 March, I 394 , that a new warden, John Morys, fellow of New College, and an old Wykehamist, ${ }^{1}$ then went into residence. A fortnight afterwards, at 9 a.m. on Saturday, 28 March, $1394,{ }^{2}$ the warden, headmaster, second master and scholars ' marched in procession with cross up-lifted before, and solemn chant' and took possession. Outer Gate was not then commenced and Chapel was not finished; the former was begun in November ${ }^{3}$ following and the latter was consecrated on I 7 July, I $395 .^{4}$ The Society which took possession of the buildings on 28 March, 1394, consisted of a warden, headmaster, usher, chapel clerk and sixtynine scholars. The full tale of the society was not made up for a year or two.

\section{The Object of the College}

Wykeham's views of the purport of the foundation of his college are fully stated in the foundation documents. The charter of $\mathrm{I}_{3} 82$ states the reasons for which he had lately founded a college 'of seventy poor scholars, clerks, to study theology, canon and civil law, and arts, in the University of Oxford.' In a long and involved sentence we are given to understand that Wykeham founded the college at Winchester as a preparatory school for the college at Oxford; because without a knowledge of the Latin literature and language it was impossible to begin or satisfactorily carry on the study of the higher faculties for the promotion of which the Oxford college was designed. The college was not intended for all who wanted a knowledge of the classics, but chiefly for those whose means were not sufficient, without assistance, to enable them to stay at school long enough to master it.

1 His name is found as a fellow in the first New College Hall Book, I386. He came from Gloucester diocese.

2 The date was treated as 1393 when the Quingentenary of the college was celebrated in 1893. But there is no doubt that 1394 is the correct date as the earliest Account Roll shows. See chapter xi., 'Our opening Day,' of History, p. 127, for an exhaustive discussion of the question.

3 History, p. 109.

Ibid. p. 134. Not December I 3, as in Annals. 


\section{A HISTORY OF HAMPSHIRE}

For those reasons he founded the college, and directed that it should consist of 'seventy poor and needy scholars, clerks, living college-wise in the same, studying and becoming proficient in grammaticals, or the art and science of grammar,' and gave them a 'common chest,' willing that they 'should work together as collegial and collegiate persons in the same college and there in college-wise remain and live' under the rule of the warden, and according to the statutes of the college to which they were sworn. He granted them the site of the college 'to hold and possess common-wise and in common.'

But what was the founder's object in founding New College, for which Winchester College was to be the nursery? 'To find out this we must read the statutes of his two colleges together; the two being parts of one whole. As Wykeham says, in Rubric iv., urging the two colleges to help each other in all contests and difficulties: "Our two colleges aforesaid, though situate in different places, issue from one stem, and flow from one spring, and differ not in substance, having no diverse effect. They are next-of-kin, and are called by one name.' For while Winchester was 'Seinte Marie College of Wynchester,' New College was 'Seinte Marie College of Wynchester, in Oxenford.' It is difficult or impossible to say which was the object Wykeham had most at heart, to benefit Winchester School by sending its boys on to become Oxford scholars, or to benefit Oxford University by sending it Winchester schoolboys. On the whole the names seem to show that Winchester was the object of his attachment. Still New College was the first founded, it was the ' greater light,' and the larger world for which Winchester was the nursery. It is to its statutes we must look first to find the final cause of Winchester.

The first clause of the New College statutes, after the usual pious preamble, sets forth with great clearness the object of the foundations, and shows that Wykeham's intention was to provide educated clergy, not monks but seculars (for a scholar 'entering religion' was instantly to lose his scholarship), to fill up the gaps caused by the Black Death.

The effects of the plagues at Winchester were marked. The monks of St. Swithun's priory numbered sixty-four in I $325^{1}$ We do not know the numbers of those who died in the Black Death or subsequent plagues, but in $13^{8} 7^{2}$ a generation afterwards there were still only forty-six. At the Sustern Spital, ${ }^{3}$ now ' Commoners,' the normal number of brethren and sisters was twenty-one; in $135^{2}$, three years after the Black Death, there were only six, in 1353 ten, in $13^{8} 7$ they had only risen to sixteen. On 18 February, I $374-5$, Wykeham ${ }^{4}$ certified the king that the parish of St. Anastasius by Wyke had been depopulated by the first pestilence and was still so poor as not to be able to support a rector, and therefore asked that it should be exempted from the tenth lately granted.

1 Obedientiary Rolls, Hants Record Soc., p. 12.

2 Wykeham's Injunctions to S. Swithun's Priory, Harl. MS. 328, f. 3 b ; cf. his Register, ii. 389.

3 'The Sisters' Hospital : Obedientary Rolls, pp. 408, 410, 413.

4 History of Parish Church of Wyke, by F. J. Baigent (Winchester, 1865), p. 6. 


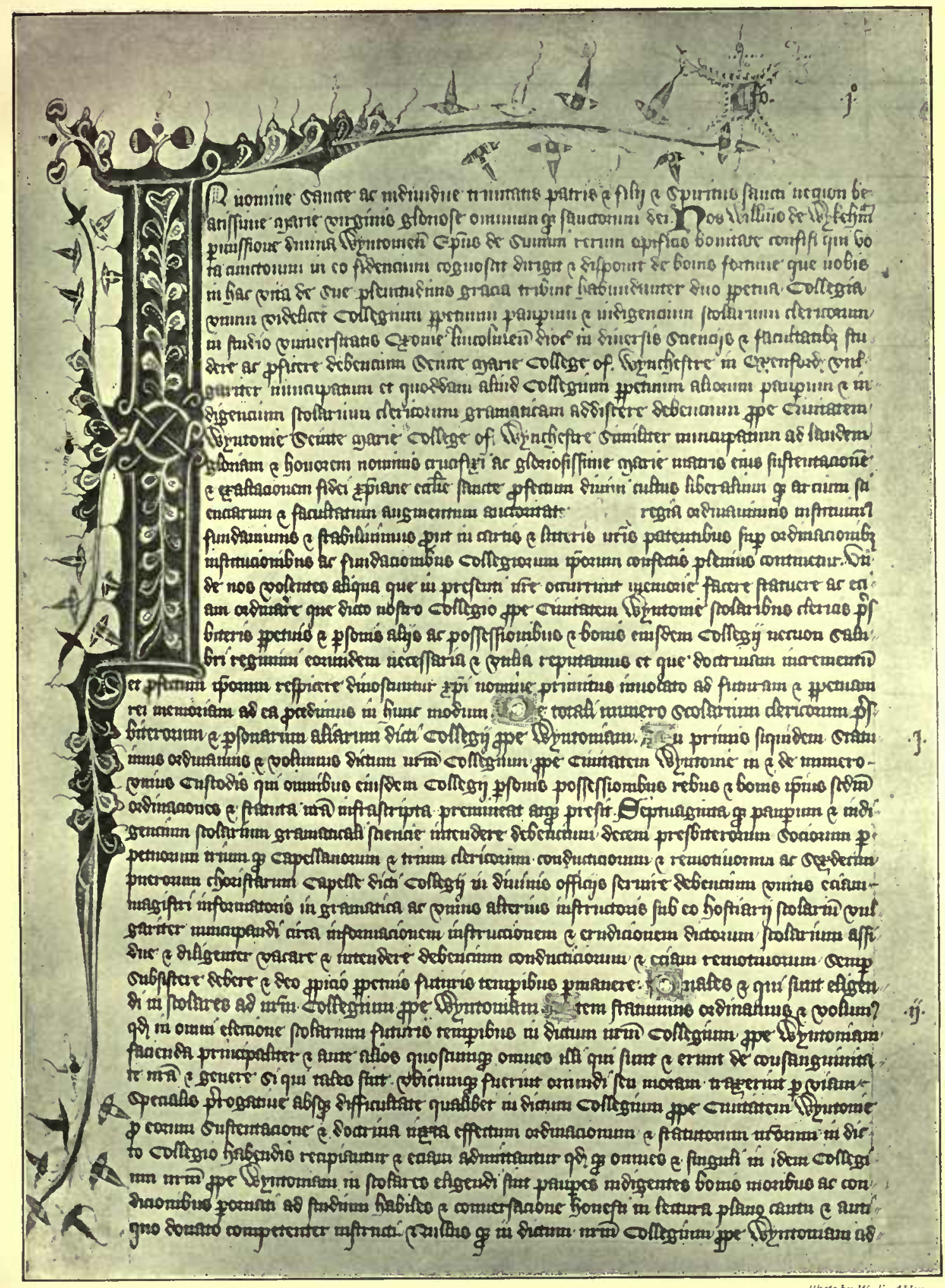

Photo by W. E. Abley.

Winchester College Statutes. 1400. Title Page. 



\section{SCHOOLS}

The plague was then in sober truth the proximate cause of the foundation of Winchester College, the ultimate cause being the wish to have a learned clergy to carry on the duties of the Church and the business of the State to the best advantage.

It has been said and repeated that Winchester College was not an ecclesiastical foundation. This is a fundamental error. All educational foundations were then also ecclesiastical. All education was a matter of ecclesiastical cognizance. At Oxford even the bookbinders and parchment sellers were clerks. No college could be founded without a papal bull, such as Wykeham duly obtained for Winchester, Henry VI. for Eton and Cardinal Wolsey for Christchurch. Colleges were indistinguishable from collegiate churches. When Eton was founded the parish church was specifically made into a collegiate church. The whole cast of the constitution of Winchester and New College is that of a collegiate church. We have only to study the statutes to see this.

\section{The Statutes}

In the foundation charter Wykeham specially reserved power to make further statutes and rules for the direction of school life and the school arts. ${ }^{1}$ We know from the account rolls that there was a new edition of the statutes in 1394 , and another probably in 1397. But these are not preserved any more than the first edition of 1382 .

The founder put the finishing touch to his work by the authoritative issue of a revised edition of the statutes on I I September, 1400. To them all members of the college above fifteen years of age were required to swear obedience. These statutes were the binding rules of the place until a goodly number were repealed by the Oxford University Commissioners in 1857 . The beautifully written original with Wykeham's seal attached, the headings of the statutes rubricated and the initial letters illuminated, is preserved in the muniment room together with a like copy of the final statutes of New College issued in the same month of the same year. In I 399-1 400 a copy of the statutes-was it this splendid book? - cost exactly 16 s. $8 d$. for the scribe, including the binding.

Of forty-six chapters, or rubrics as they are called, only six deal in any way with scholars and learning. The other forty might belong to any collegiate church. While some of them deal with the duties of warden and fellows and their management of property, by far the longest and most elaborate, rubric xxix., is entirely concerned with the services and works to be performed, to which also two other statutes are devoted. The incorporation consisted of ' the warden and scholars, clerks (clerici).'

The whole society consisted of the warden, headmaster, ten 'perpetual' fellows, three conducts or stipendiary chaplains, usher, three chapel clerks, seventy scholars, sixteen choristers, ten commoners; in all, excluding the latter, who were not 'on the foundation,' one hundred and five persons. 


\section{A HISTORY OF HAMPSHIRE}

The warden was to be a priest and to wear in chapel an 'amice' of grey such as canons of a cathedral wore, while the ten fellows, who were priests, were to wear 'furred amices' like vicars choral of the cathedral churches. All scholars were to have 'the first tonsure' within a year of admission if not before (except founder's kin, who might put it off till the age of fifteen), and were to be competently instructed before admission in plain song, so as to sing the services, were to wear surplices in chapel, and the elder ones to occupy stalls. None were to be admitted who had any bodily defect which 'would render them unfit to take holy orders.' They were to wear 'long gowns with hoods,' and were not to wear 'striped, variegated, or parti-coloured clothes, or any not befitting their clerical order.' The servants were all to be males.

The fellows were perhaps the most markedly ecclesiastical element. They were an addition to the original foundation of warden and scholars, dictated perhaps by the desire to make the college more like an Oxford college, and to provide more gorgeously for the chantry services and masses for the founder's soul than the three hired and removable chaplains could have done. A fellow of Winchester is recorded as dining in hall at New College in 1 392-3. ${ }^{1}$ The first fellows (socii perpetui) to be found in Winchester records appeared under that name in September, 1 394, though the first recorded appointment of one is in Wykeham's Register in the December following. But two priests (sacerdotes)-the fellows were obliged to be priests - had been in commons from a month after the entry on the new buildings. ${ }^{2}$ There was some difficulty in filling up the number; as in I 396-7, Mr. Turks or Turke, one of them, who was sub-warden, was paid $8 \mathrm{~s}$. $9 \mathrm{~d}$. for riding to New College 'to get fellows and chaplains of the college.' In I 397 the Fellows' Register, written up about 1424 , records the names of three fellows as admitted. In I 399 the full tale of ten was completed and so always continued. Till the Reformation they were practically chantry-priests, who had to celebrate daily masses for Wykeham's soul, and take their part in the canonical hours. As sub-wardens and bursars they had also to assist the wardens in the management of the estates, while another fellow, changed every week, was steward of hall and responsible for the dinner and the dinner bill.

There were ten servants, besides the choristers who waited at table and were fed on the broken meats, steward (dispensator), cook (who was also manciple or emptor victualium), porter, pantry-man, butler (garcio buterie), under cook, cook's boy, gardener, two warden's servants. There were besides a baker, brewer, warden's clerk, a barber (generally the porter) and a clotheswasher. All the servants were to be males, ${ }^{3}$ but if a male clotheswasher could not be found there might be a laundress, who was to receive the dirty linen outside the outer gate at the hands of a

1 New College Hall Book for that year, if the date is correctly guessed, which is a matter of inference from the names appearing in it; not easily verifiable.

2 College Muniments, First Account Roll, kept by Warden Morys, Lady Day to Michaelmas, 1394.

3 Statutes, r. 45. 


\section{SCHOOLS}

sworn servant specially appointed by the college for the purpose. Margaret the laundress appears nevertheless in $14^{1} 7^{1}$ as dining and supping in hall with the servants.

It was because the college was an ecclesiastical foundation that Richard II. by charter, 28 September, 1395 , "for the increase of divine worship and the catholic faith,' freed the college from tenths, aids or exactions when the clergy (clerus) of England granted them to the king or the pope imposed them for his own benefit. If the college had not been clerical no such exemption would have been required.

In later days it was held by the lay courts that though the University colleges might be composed of clerical or ecclesiastical persons they were not clerical or ecclesiastical foundations and were subject to the cognizance of the lay courts. Such a decision was convenient and beneficial. But it was in defiance of all law and history, and could not have been even conceived in 1382 , nor yet in 1535 , when the colleges at Oxford, Winchester and Eton were included as ordinary ecclesiastical foundations in the great survey known as the Valor Ecclesiasticus.

The great length of the statutes is largely due to the elaborate and complicated oaths which were prescribed for the various members of the college. Oaths were a potent safeguard. Breach of an oath fixed the swearer with the guilt of perjury, and enabled him to be instantly excommunicated. Wykeham gave the reason for his precautions in 'End and Conclusion of all the Statutes,' in which he said that after long study he had nowhere found the rules of founders observed according to those founders' intentions, and had therefore hesitated whether he would not distribute his property among the poor himself instead of putting it in trust in perpetuity; but in his intense desire to help poor scholars he hopes he may rely on them, when learned men, to keep his statutes according to their plain grammatical construction.

\section{Wykeham's Models}

That Wykeham chose to found a college seems to have been largely due to the influence of Merton College, Oxford, which was his model throughout.

When Wykeham first began to set about his preparations for founding New College in 1369 the people he employed to buy the land were two fellows of Merton, John of Buckingham, canon of York, and John Rouceby, clerk. He with John of Campden, another fellow, and bursar of Merton, witnessed the agreement by Wykeham with the master of his Winchester school in I 373, and together with the warden of Merton, John of Bloxham, then archdeacon of Winchester, witnessed the foundation charter of Winchester College in 1382 , in which Thomas of Cranley, another fellow of Merton, was named the first warden, just as Richard Tunworth, another fellow of Merton, had been first warden of Wykeham's scholars at Oxford in 1376 before their formal incorporation in New College. 


\section{A HISTORY OF HAMPSHIRE}

The selection of Merton as the model for Winchester College is not surprising. The earliest of Oxford colleges (for though the original endowments of University and Balliol were earlier, their organization as colleges took place later), it still remained in spite of the foundations of Exeter, Queen's and Oriel-all founded, like Merton, by successful king's clerks - the largest and greatest. Edward III. in a letter to the pope in I $33^{I^{1}}$ called it ' a magazine of the church militant,' and this was just what Wykeham designed his college to be.

The statutes of New College and Winchester are clearly adapted in all the main provisions from those of Merton. The name of the head is 'warden' as at Merton, not master as at University or Balliol, or provost as at Oriel and Queen's. The title provost would be specially avoided as being that of the head of St. Elizabeth's College next door to Wykeham's College at Winchester. As at Merton, followed also by Oriel and Queen's, a certain proportion of the fellows were to be not theologians but lawyers, civilians and canonists. But the proportion of such at New College was larger, twenty out of seventy instead of four or five only as at Merton, while in addition two might-and were required to-study medicine and two astronomy. The institution of deans, the bible-reader in hall, the scrutinies or terminal stated meetings, the progresses of the warden and fellows to visit the estates, the provisions for chaplains to do the praying and singing on ordinary days while the scholars stuck to their studies, the direction for Latin to be spoken in hall, even the preference for election to founder's kin and the diocese of Winchester and then for other dioceses in which the college estates lay, are all taken from the statutes of Merton. A few additions have been adopted from the statutes of Queen's, notably among them the provision for the fellows acting in turn as stewards of the hall, and the provision for the services being in a private chapel, while Merton had simply 'collegiated' an existing church.

The boys at Winchester were not required to attend chapel at all except on Sundays and feast days, nor were any special prayers or hymns prescribed for them. The full round of religious services was left to the fellows.

Even in the main innovation of placing his college for boys in a different place from his Oxford college, Wykeham was to a large extent following precedents. A grammar school was, as has been stated already, a recognized appendix to a collegiate church. Thus when Bishop Grandisson founded the collegiate church of Ottery St. Mary by an ordinance dated 22 January, I $337-8^{2}$ for eight canons, eight vicars choral, eight clerks and eight choristers, he provided also for 'a master of the grammar school (scolarum gramaticalium) there, and to teach the said boys,' i.e. he was not only to teach the choristers but keep a general grammar school.

The chief novelty of Winchester College was in the first place the

1 Brodrick's Memorials of Merton College, p. 34.

2 Grandisson's Registers, ed. Rev. J. C. Hingeston-Randolph, pp. 12 I seq. 


\section{SCHOOLS}

scale on which the foundation was carried out. The mere number of the scholars of New College-seventy-was almost equal to the whole number of the scholars of all the other colleges put together, and its endowment did actually exceed that of them all put together. If Winchester were reckoned the preponderance of Wykeham's foundations was of course immensely increased.

But the really important new departure taken was that Wykeham made his school a separate and distinct foundation independent of the Oxford college. Others had erected collegiate churches for university students. He erected one for schoolboys. The old collegiate churches had kept grammar schools, and flourishing grammar schools, but they were, though inseparable accidents, still accidents. The new collegiate churches at the university, called colleges, substituted growing scholars for grown priests, and study for psalm singing as the essence of the institution, but the schoolboys remained an accident, and a rather unimportant accident. In Winchester College the accident became the essence. The corporate name of 'warden and scholars, clerks' stamped the school and the schoolboys as the aim and object of the foundation. The collegiate church form was afterwards adopted, the fellows occupying the place of canons, but instead of the boys being subordinate to the canons, the canons were subsidiary to the boys. For the first time a school was established as a sovereign and independent corporation existing by and for itself self-centred and self-governed.

\section{Scholars AND COMMONERS}

Though Winchester was an independent corporation it was bound by close ties to New College. New College elected the warden of Winchester, who was to be a past or present fellow of New College or of Winchester, and the fellows of Winchester were preferentially to be or to have been fellows of New College.

Every year the warden and two fellows of New College were to visit Winchester and hold a visitation, which was called, as at Merton, a 'scrutiny,' of everybody there. At this visitation they, with the warden, sub-warden and 'master teacher in grammar' of Winchester were to elect the scholars from Winchester to New College and also from outside to Winchester. The election to New College was (except in the case of founder's kin, who had a right of admission if fit, even up to the age of twenty-five) strictly by competitive examination among those who were or had been scholars of Winchester. The fittest (magis $y$ donei) were to be elected. The election to Winchester was also on examination, but the examination was not seemingly to be competitive. Founder's kin, wherever born, had an absolute right to admission at any age from seven to twenty-five. The others were to be 'poor and needy scholars, of good character and well conditioned, of gentlemanly habits, able for school (ad studium babiles), completely learned in reading, plain song and old Donatus.' They were to be between eight and twelve 


\section{A HISTORY OF HAMPSHIRE}

years old, but might be admitted up to sixteen years old if they were sufficiently advanced to be able to be perfect in grammar by eighteen. Preference was to be given first to inhabitants of the places where the estates of the college and of New College lay; next to natives of Winchester diocese; then to inhabitants of the counties of Oxford, Berks, Wilts, Somerset, Essex, Middlesex, Dorset, Kent, Sussex and Cambridge, in the order named; and lastly to inhabitants of the kingdom of England. Choristers of the college were to be eligible and to be examined with the other candidates. No conditions were laid down as to selection if there were more candidates than one, each equally qualified by residence and 'able and fit,' the examiners not being bound to elect 'the fittest.' Either it was not contemplated that there would be more than enough candidates of equal qualifications to fill the vacancies, or it was intended that the electors should have a power of patronage. Certain it is that the omission of the little word magis resulted in a system of absolute patronage of the electors, tempered only by corruption and founder's kinship, and up to the eighteenth century by patronage of the Crown and the bishop of Winchester.

The scholars were to be 'poor and needy.' This has sometimes been interpreted to mean the poor in the sense of the poor law, the destitute poor, or at least the poor labouring classes. There is no justification for any such interpretation. The test of poverty to qualify for admission as a scholar is to be found in the oath which every scholar had to take on reaching fifteen years of age: 'I, N., admitted to the college of St. Mary, near Winchester, swear that I have nothing whereby I know I can spend beyond five marks a year.' The limit of value for the exemption of church livings from taxation for the tenths payable to the pope was fixed at five marks a year. There were sixty-seven livings below that value in the diocese of Winchester. ${ }^{1}$ Many of them were only worth $\oint_{\mathrm{I}}$ a year; many more only $\oint_{2} 2$ a year. The test was therefore only provided for the exclusion of the really wealthy.

It may indeed be doubted whether the use of the phrase pauperes et indigentes was much more than a necessary common form, arising from the 'constitutions' of the legates Otto and Ottobon in the thirteenth century, which had forbidden the appropriation of churches unless the inmates of the houses to which they were to be appropriated were in such stress of poverty that they could not otherwise be supported. It was necessary for Wykeham to protest the poverty of the scholars for whom he was appropriating churches and priories.

That the choristers were eligible to become scholars ${ }^{2}$ is shown by the Hall Books. In the first Hall Book, beginning Michaelmas 1395, four choristers, in the fourth week eleven choristers dined in Hall, and

1 Pope Nicholas' Taxation, 1291 (Rec. Com.).

2 In History I wrote: 'The choristers were, it is true, eligible only for scholarships, but whether they were elected is another matter.' I had not then, but have since, examined some of the Hall Books on that point. The evidence stated in the text conclusively shows that not only were the choristers elected, but that it was the rule to elect them; and that more than half the choristers in any given year became scholars. 


\section{SCHOOLS}

in the ninth week twelve. Except one certainly, and possibly two others, every one of these became a scholar.

Again in the Hall Book for 13 Henry IV. (I $410-11$ ), of the full tale of sixteen choristers, no less than eleven became scholars; one of them, Waplode or Wappelode, becoming a commoner in the interim. There can be no doubt about the transfer from one class to another, because in several cases the name is crossed out in the list of choristers or commoners and appears in the list of scholars the same week.

In the Hall Book for 5 Henry V. a still more remarkable interchange takes place; for Staunton a commoner actually became a chorister; while of two Masons, one was a commoner and the other a chorister, and one of the two became a scholar.

Passing on to a generation later, in 22 Henry VI. out of fifteen choristers twelve became scholars, and another had a namesake a scholar. In 33 Henry VI. a scholar by name Ewen, when superannuated, became a commoner, and ten of the choristers of the year became scholars. As late as 1490, out of fifteen choristers nine became scholars, including Fleshmonger, who as Dean of Chichester gave the scholars the oaken bedsteads which were only destroyed twenty years ago. Lastly, in one of the last complete Hall Books, that for 3 Henry VIII. ( 5 I I-2), out of the full tale of sixteen choristers, no less than seven were admitted into college that year and three others followed in subsequent years. Being a chorister was therefore a more certain way into college than being a commoner. Of those choristers who attained fame may be noticed John Stanbridge, whose Grammar took in its day the place of Kennedy's Latin Primer, and Nicholas Harpsfield, of a very wellconnected family, the Marian persecutor of Protestants.

From the instances given it is clear that up to the eve of the Reformation, certainly more than half, probably a full three-quarters of the choristers got into college; and, that on the other hand a quarter of the whole number in college at any given moment had been drawn from the ranks of choristers. It must be remembered that it would not be thought derogatory for boys even of good family and social position to take what the eighteenth century called the 'servile' office of choristers, when the normal means of educating the sons of the nobility was to send them as pages in great men's houses, including especially bishops, who had themselves in some cases risen from the ranks of choristers.

What happened between I 520 , when the Hall Books end, and I 653, the date of the first Long Roll, lack of materials conceals from us. But of the sixteen choristers on the Long Roll of 1653 , four may be noted as having become scholars: Parsons in 1654 , Burges and Stevens in I6 55 , and Morgan in 1656 .

The institution of commoners is of itselt sufficient to disprove the pauper theory. A sort of postscript to rubric xvi., "Of not introducing strangers at the charge of the college,' contains the famous clause which, by opening the college to commoners or paying scholars drawn from the aristocratic class, proved to be the germ of the Public School system. 


\section{A HISTORY OF HAMPSHIRE}

It has been said ${ }^{1}$ that the provision for commoners was not in the original scheme of Wykeham, but added 'about two years after the college was opened.' But as the college buildings were opened in I 394, as additional statutes or new statutes were made in that year, and commoners appear on the earliest extant Steward of Hall's Book, beginning at Michaelmas I 395, this theory will not hold.

James Ramsey appears in this book as an extraneus commensalis, or 'stranger commoner.' He was admitted a scholar on 28 October, I 395. Another commoner was Richard Stanstede, who appears in the fourth week with ve. po. or venit primo against his name. After a few weeks he became 'chapel clerk,' and then a chaplain.

Next year, I 396-7, two classes of commoners are found, with a distinction which prevailed till the fifteenth century, some being what were afterwards termed fellow-commoners, from having their meals or commons with the fellows, and the others called in the Hall Books in the language of the statutes, extranei commensales, or strangers admitted to table, who dined with the scholars. The first fellow commoners are described ${ }^{2}$ as 'two sons of John Uvedale,' that is John Uvedale of Bletchingley, who had married the heiress and in $13^{8} \mathrm{I}^{3}$ inherited the estates of Sir John Scures (Wykeham's first patron, when constable of Winchester Castle), the lord of Wickham, Hants, from which Wykeham took his name. The other commoners were eleven in number, comprising two Cranleighs, senior and junior, ${ }^{4}$ no doubt relations of the warden and archbishop of that name, and one Thomas Clerk, who is described as puer officialis. As he would have exceeded the statutable number of commoners, it is probable that he occupied some position like that of a pupil-teacher or 'bear leader' to some of the commoners. Of the ten commoners half became scholars; three, Cranlegh or Cranley, Banbury and Mordon the same year, and two more, Pope and Bannyng, the year afterwards. In the seventeenth century this was still the case ; many of the commoners strictly so called, the commoners in college, were boys who were afterwards admitted as scholars, and had gone as commoners pending a vacancy.

In 1400 another commoner, John Popham, one of the knightly family of Pophams of Popham near Micheldean in Hampshire, and now of Somerset, Dorset, and the Isle of Wight, was pardoned thirty-one weeks' arrears of commons ' by the founder.' The Hall Book of I $40 \mathrm{I}-2$ provides another list of commoners with the sums they paid for commons, which varied from $16 d$. to $8 d$. a week; a shilling a week being the amount of a fellow's and $8 d$. a week the allowance for a scholar's commons.

1 Annals, p. rog.

2 Coll. Mun.; Computus Magistri Johannis Morys, 20-2 I Richard II.

3 The Family of Brocas, by Professor Montagu Burrows (Longmans, Green \& Co., 1886), p. 328 ; cf. Wykebam's Register, ii. 279, 329.

4 In these early documents senior and junior are used indiscriminately with major and minor for two brothers. In later days Winchester settled down to senior and junior only, while Eton adopted major and minor only. 


\section{SCHOOLS}

But the benefits of the school were not confined to the intending clerics, the scholars or the few select gentlemen's sons who boarded with them. Beyond these there were, almost certainly from the first and with the founder's knowledge, other boys attending the school, boarding in other places for the purpose. There are preserved among the college archives some documents relating to St. Elizabeth's College, a foundation of nearly 100 years before, over against the gates of Wolvesey, and so called the Old College, in comparison with St. Mary's College, the New College, which was next door to it. Among them is an Account Roll of its steward for the year 2 Henry IV., I 400-I, which shows the receipt of the considerable sum of ' $55^{5}$. $4 d$. from divers commoners (commensalibus) this year.' Later accounts of the same college in the year 1461-2 contain the same item of 'cash from commoners,' but show only one commoner, William Norton, who is described as 'attending school' (scolatizantis) ' in the New College.' He paid 3 Is. $8 d$. or Iod. a week for thirty-eight weeks. A later account, for $146_{3}-4$, shows nine to twelve boys commoning in St. Elizabeth's, and the last extant account, for I 468-9, shows $f_{2} 20$ i 5 s. 7 d. ' received from Mr. John Bourchenyer and other commoners at the table in the inn' (bospitium; the provost also filled the office of seneschallus bospitii), ' and schooling in the college.' Further evidence is forthcoming in a mandate from Wykeham's successor in the bishopric, Beaufort, addressed to John Morys, warden of 'our' college of Winchester, Io April, I4I2. After reciting that the statutes provided for seventy children at the cost of the college, and ten outsiders (extraneos), sons of friends of the college, the Visitor went on to say that he was informed that the master continually instructed and taught from eighty to one hundred outsiders beyond the statutable number, 'contrary to the pious founder's intention.' On the ground that one man was not enough to teach so many, he therefore forbade the warden, under pain of canonical fulminations, to admit any more than the statutable number. But the saving clause is added : "Nor allow them to be admitted without your special license in that behalf.' The saving clause kept an open door for the admission of such select personages as Mr. Thomas Bourchier, a son of the Earl of Essex and Eu, and others whose names have unfortunately perished in the provost's 'papers,' to which the accounts of St. Elizabeth's College refer for the names of its commoners. The fact that at Eton, which was expressly modelled on Winchester, the statutes from the first provided for the admission of all coming from any part of England as well as the scholars, is also strong evidence that Beaufort's mandate did not exclude, and was not probably intended to exclude other commoners, or oppidans as they were called both at Eton and Winchester in the seventeenth century, or town boys as they were and still are called at Westminster. We know unfortunately next to nothing of this class of town day-boys. But we have presumptive evidence of their existence up to the first quarter of the seventeenth century. In 156 I a new master was appointed to Southampton Grammar School, succeeding Robert Knaplock, the first on the new foundation of the school, with a 


\section{A HISTORY OF HAMPSHIRE}

salary of $f_{0}$ io a year and $f_{3} 6 \mathrm{~s} .8 \mathrm{~d}$. allowance for board. It was ordered that he might charge fees of $6 d$. a quarter to town boys and 1s. $4 d$. a quarter to country boys, ' after the order of Winchester.' ${ }^{1}$ It will be seenthat they probably came to an end in 1630.

The age to which the scholars were to stay, eighteen, is somewhat surprsing, in view of the common notion that degrees were taken at Oxford at a very much earlier age than they are now. ${ }^{2}$ It is probable that the ordinary idea is founded on one or two striking but exceptional instances, such as Wolsey, the 'boy-bachelor' at fourteen, and so on.

As ' regards sleeping accommodation, the allegation that the boys slept on straw, and had no beds or sheets, supported by the fact that clean straw 'is still Wykehamical for clean sheets,' appears to be a mistake. Sixty-four beds were bought in the first year at a cost of a shilling each, representing at least fI now. In I 397-9 the 'Expenses of Founder's Kin,' which in accordance with the statutes were paid for by the college for two sons of T. Warrener, are given in the accounts. They include 12 ells of linen for sheets, shirts, and breeches, which with the making cost 7 s. I I $\frac{1}{2} d$.; 5 ells of canvas for their bed, $23^{s .} \circ \frac{1}{2} d . ; 4 \frac{1}{2}$ yards of blanket for the bed, 4s. 6d.; a coverlet and pillow, 8s.; and straw for their beds, $2 d$. Therefore the straw must have been merely the material sewn into the canvas to make a mattress. For the rest they had sheets, blankets, and a pillow, exactly like the modern boy. But founder's kin were not treated differently from any other scholars, except that, while other scholars had to pay for their bedding and other chamber furniture, founder's kin had theirs provided by college. The statutes forbade them to sleep three in a bed (as at the Wells Choristers School in 1460 ), or even two in a bed after they were fourteen.

For the scholars' dress; in chapel they and the masters wore surplices such as are seen in Chandler's drawing. At other times the rubric 'On Liveries' tells us the master had a long cloth gown, with $3 s$. $4 d$. worth of fur on it. The gowns of the scholars and the chapel clerks were to be a livery in one suit of cloth, those of the choristers in another. Black, white, grey, russet, or brown was forbidden; white was presumably forbidden because of the neighbouring Carmelites or White Friars; black, because of the Black Monks of St. Swithun's and Hyde Abbey, and the Black Friars; brown and grey, because of the Austin and Franciscan Friars. On the other hand, their clothes were not to be striped, or spotted, or particoloured, because no doubt that savoured of the fashionable laity. What then was left ? The fellows at Queen's were to dine in scarlet gowns (palliis purpureis), the chaplains in white; and the grammar boys, as they were also choristers, probably followed the chaplains. The inmates of St. Elizabeth's College dressed in blue, as appears in one of their Account Rolls.

We get two indications of what colours were actually worn by the

\footnotetext{
1 History of Southampton, by Rev. J. Sylvester Davies (Gilbart \& Co., Southampton, 1883).

The greater part of this section is taken from History, chap. xiv,
} 


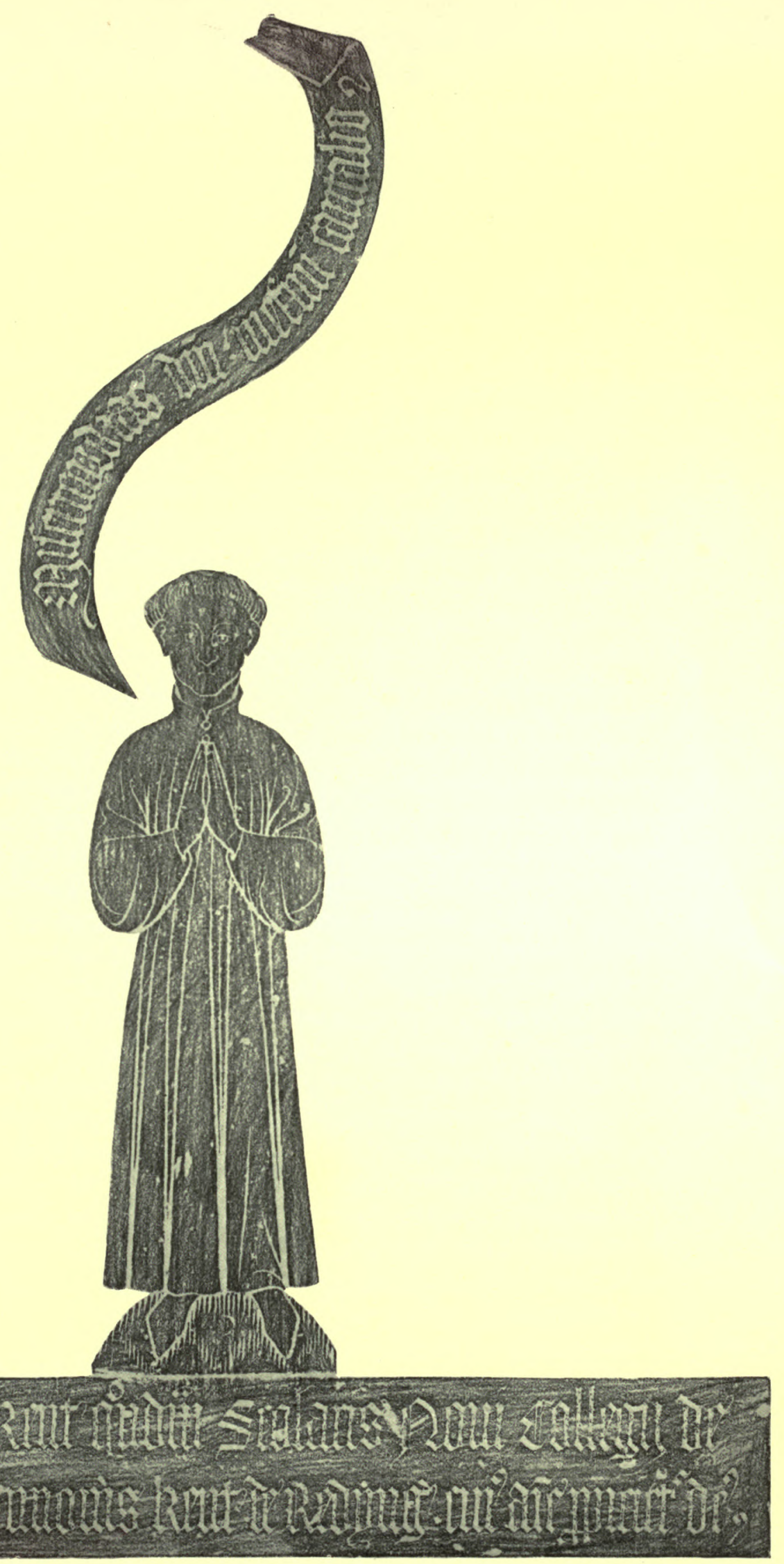

John Kent. College 1431-4.

From a rubbing of a brass in Headbourne Worthy Church. 



\section{SCHOOLS}

scholars of Winchester. In I 398-9, two founder's kin in college had gowns of white russet at All Saints' Day for Michaelmas term, and gowns of green cloth for the summer term, while at Christmas, when they went for leave out, they had gowns of the founder's livery. The other scholars no doubt followed suit, except as to the Christmas livery. In I 403-4 three founder's kin (who offered a halfpenny each, paid for by college, at the founder's obit!) had gowns of blue frieze. The colour of the scholars' gowns therefore varied from year to year. It is generally called simply coloured cloth in the accounts. The one colour that they did not wear was the 'customary suit of solemn black' which they are now made to wear, which is wholly unhistorical, and probably Puritanical.

The shape of the clothes was not dictated, except that the gowns were to be long. They were nearly the same as now, as we know for certain from the brass of John Kent, a scholar who came in I43 I and died in 1434, and was buried in the church of Headbourne Worthy, about a mile and a half up the Itchen valley from Winchester. His gown appears to be simply the ordinary gown of the time, reaching to the ankles (talaris). The sleeves are full to the wrist, not puffed to the elbow and there cut off as now. His collar appears to be the same as that of the present gowns. ${ }^{3}$ There is nothing on his head, on which the tonsure does not show. Scholars were forbidden by the statutes to wear anything on their heads, a prohibition which until 1870 extended to all inferiors, whether college men or commoners, anywhere within the precincts, but is now limited to college juniors in chamber court.

The scholar was allowed to wear his livery in its first year only on Sundays and holidays, or at processions or solemn assemblies (convocation$i b u s$ ), and had to keep it for three years, not being allowed to sell, pledge, give, or dispose of it outside the college during that time. A similar restriction applied to the warden, fellows, chaplains, and masters for no less than five years, but they might within that time give it to a poor scholar (all scholars therefore were not 'poor'), or a chorister, 'by way of charity.'

The allowance for a scholar's commons was $8 d$. a week (Rubric xiii.). There were only two regular meals a day, dinner and supper; but boys under sixteen were allowed breakfast as well. Egglesfield at Queen's, it may be noted, had allowed his poor boys breakfast out of the broken victuals and commons of the fellows. In the fourteenth century dinner was at ten, and nothing was taken before it. This was the rule even in 1526 in the king's household." 'The first dinner in eating days to begin at ten of the clock or somewhat afore, and the first supper at four of the clocke on week-days.' When the king's hall was not 'kept,' dinner was at eleven a.m. and supper at six p.m.

1 I was misled (History, p. 172) by the drawing of it given in Kirby's Scholars into thinking that the collar was high up in the neck, but a study of the original and the reproduction of a rubbing given in my History show that it was not.

2 Furnivall, Babees Book, lxxx. 


\section{A HISTORY OF HAMPSHIRE}

As regards the boys' inner life, we know that they were divided then as now into the two great classes of 'prefects' and 'inferiors.' Wykeham is commonly credited with the invention of the prefectural system not only per se but in all its ramifications, including the institution of 'tunding,' which some writers seem to regard as the special glory of Winchester and the public school system. Wykeham certainly did provide for prefects, ${ }^{1}$ three scholars in each chamber to oversee the rest and inform the authorities of their morals, behaviour and advancement in learning. This provision was not however of Wykeham's devising. ${ }^{2}$ It has escaped notice that it appears in the statutes of New College, ${ }^{3}$ in the very same words, except that one fellow only is assigned for the purpose in each chamber; but the proportion of prefects is as nearly as possible the same, there being at New College only four 'scholars or fellows' in each chamber, save one which had only three. It was imported into the Statutes of New College from the Statutes of Merton of $1274,{ }^{4}$ the last clause being in the same words as those found in the Statutes of Oriel in 1329.

We can hardly credit Wykeham therefore with the invention of a prefectural system. In this as in other matters, he was only repeating for the scholars of Winchester a provision made for scholars at Oxford, which applied at Oxford also to the boys ${ }^{5}$ at Merton, as well as to the young men there.

It is clear that he did not contemplate that the prefects should be not merely magistrates, but 'administrators of the law.' They were not magistrates at all but policemen. Their duty was to inspect and report only. There is not a hint that they were to enforce the laws or themselves inflict punishment. There is no mention of the "officers ' ${ }^{6}$ of later days-the prefect of tub (now extinct), the prefect of hall, of school, and two of chapel.

It is to be inferred that the prefect system was developed when the warden and fellows became mostly non-resident, or when resident did not dine in hall; and the masters devoted themselves to looking after commoners, leaving college to itself. When finally, the warden retired to a married life outside chamber court altogether, and the headmaster removed to 'commoners,' the fagging and 'tunding' system developed itself.

Of holidays, it may be said that there were plenty of holy days, but no general holidays. The collegiate example was directly followed. To the fellows of a college, the college was their home for life. The collegiate schoolboy was regarded as under much the same conditions. No holidays were contemplated. For more than a century there was no breaking-up day and no general emigration home. There were however

1 Rubric xxriv.

2 As stated in Wykehamica, by H. C. Adams, p. 56.

Rubric, lii. 4 Caput vii.

5 At Merton one of the boys actually acted as bursar for the rest in 1347-8 (English Miscellany, loc. cit. p. 425).

o Wykebamica, loc. cit. 


\section{SCHOOLS}

pretty regular and fairly general exeats. Such an exeat (a word not used at Winchester) took place almost immediately after the entrance into college. There were sixty-nine scholars ' in commons' the first week of April, I 394, and seventy-one the second week; but only fifty-nine the third, and fifty the fourth, while in the fifth week there were again sixty-four. Easter day was on 19 April, so the twenty absentees enjoyed an Easter holiday. In the eleventh week or the week beginning Sunday, 7 June, I 394, there was again a drop from sixty-five scholars to forty-seven, which represents a Whitsuntide vacation. In the next account, still I 394, there was a big drop in the thirteenth week, fortyfive only being in full and eight in half commons, while in the first week of the second term, the first of the new year, there were thirty-six scholars only in commons. In the second week there were thirty-eight ; in the third week fifty-five. This was a Christmas vacation, but it was complicated by illness probably, as the number does not go above sixtyfour at all, and is generally below sixty, and three boys are specially mentioned as being sick out of college, one of them for five weeks. Easter week is not marked by any diminution, but there is a drop from fifty-six to forty-two in the thirty-sixth week of the year, at Whitsuntide. No inference can be drawn from there being only thirty-eight in commons in the last week of the year (September) as from the fortysixth week, when the numbers fell to thirty-six, they never again rose above forty-clearly an epidemic. In I 395-6, during which the number of scholars was full, there was again a drop to forty-five in the fourteenth week (Christmas), and the two sons of Uvedale, fellow-commoners, were away that week and the week before. In the thirty-seventh week (Easter fell early, on 2 April), there was again a drop to fifty-two. Next year there were only forty-one present in the fourteenth week, and the sons of Uvedale were again away. In the ninth week of the third quarter (Whitsuntide), there were only twenty-eight present. Lastly, in I 397-8, there were forty-eight scholars in the first week of the first quarter (Christmas) ; twenty-five only in the eighth week of the third quarter (Whitsuntide); and forty-eight only in the following week. For these two weeks the headmaster was away; the only time that he was away so long during the whole of the first four years through which I pursued this subject. It seems to be clear that the school never closed as a whole in the first few years, and Mr. Kirby says not until ${ }_{15}{ }_{1} 8$. A considerable and increasing number went away for holidays at Christmas, Easter, or Whitsuntide, and the last was the most popular holiday time. It should be added that commoners were in much the same position as the scholars. Only a few of them went away at Christmas or Whitsuntide.

Christmas must have been rather a good time to be at school. The statutes provided for the celebration of the function of the boybishop. After directing that the warden and fellows were to perform the services on the principal saints' ${ }^{1}$ days, and others according to

1 Rubric xix. Ann. p. 503. 


\section{A HISTORY OF HAMPSHIRE}

direction on other saints' days, the founder proceeds, 'We allow however that on the Feast of Innocents the boys may say and perform vespers, mattins, and other divine service to be read or sung, according to the use and custom of the church of Sarum.'

In the festivities, which centred round the boy-bishop, ${ }^{1}$ the medieval schoolboy found the relaxation and reaction which were to compensate him for the restraint and repression of the year. It is certain that the boy-bishop was almost universal, not only in every cathedral and collegiate church, and wherever there was a school; but, in later times at least, in every parish church where there was a sufficient band of choristers to furnish forth the boy-bishop's ceremonial, or sufficiently well-to-do parishioners to be worth laying under contribution.

At Winchester College the inventory contained ' a mitre of cloth of gold of the gift of the Lord Founder, with trappings of silver gilt of the gift of one of the Fellows, for the Boys' Bishop, and a pastoral staff of copper gilt for the same.' At Wykeham's Oxford College, where the boy-bishop was probably a chorister, and not a scholar, the mitre was of bawdekin only.

We have evidence that the boy-bishop's ceremonial was duly observed at Winchester in pursuance of the allowance in the statutes. Thus in $140 \mathrm{I}$ the actors (bistriones) dined with the fellows at this time; and in 1404 the city minstrels were paid $2 s$. for their presence on Innocents' Day. In I 400 the college paid $2 d$. for two founder's kin, Philip Bryan and William Aas ' to St. Nicholas' light,' and in 1403-4 $3 d$. for three of them for the same. A penny was no doubt paid by every boy, as was the custom still in the sixteenth century, when Colet's statutes ${ }^{2}$ for St. Paul's directed that 'the children shall every Chyldermasse day come to Paule's church and here the Chylde Bysshope's sermon, and after be at the hye masse, and eche of them offer I $d$. to the Childe bisshopp; and with theme the maisters and surveyors of the scole.' In I 462 the warden seems to have thrown his contribution on the college, as there is an item in the accounts of ' $4 d$. given to the Bishop Nicholas visiting the Lord Warden in his lodgings on S. Nicholas' night.' At Winchester there is still a lingering reminiscence of Bishop Nicholas in the fact that the great football match of the year, 'Six and Six,' between college and commoners, now called 'Sixes' and become a triangular duel between college and the two divisions of commoners, 'Commoners' and 'Houses,' is still played on the Hatchthoke or Thursday nearest 6 December.

Besides these grand performances at Christmas, every saint's day was, and continued to be till i 880 , a whole holiday; but so much chapel-first and second evensong, mattins, mass, processions, and the other canonical hours, terce, sext, nones, and compline-was involved, that the scholars must have felt like those at King Harold's College of the Holy Cross at Waltham, afterwards Waltham Abbey, who 'went

1 See an article by me in the Fortnightly Review, Jan. 1896, entitled ' The Schoolboy's Feast.'

Colet's Life, by J. H. Lupton (1887), p. 278 . 


\section{SCHOOLS}

from school to church and church to school like canons." ${ }^{1}$ There were also the four obits a year for Wykeham's soul, besides the actual anniversary of his death. Those days were, no doubt, specially grateful, as besides the improved meals of a feast, 'a pittance worth $6 s .8 d$.' was specially directed.

Wykeham's obit was in course of time followed by a good many more, nineteen of them being recorded in the account roll ( $1 \& 2$ Edward VI.), the year immediately preceding the Chantries Act, which put an end to such ceremonials. Among them may be noticed those of three out of the first four wardens-Baker, the alleged inventor of the 'bibling rod,' being the exception : Cardinal Beaufort; T. Beckington, bishop of Bath and Wells; J. Bedyll, an ex-scholar, mayor of Winchester ; and W. Danvers, Earl of Oxford, an ex-commoner.

No reference whatever is made in the statutes to the ancient Wykehamical institution of 'Hills,' or the march two and two of the boys to St. Katherine's Hill, about a mile south-east from college, where the line of the downs breaks into a rounded peninsular hill immediately above the water meadows of the Itchen. It is impossible not to suppose that this march was originally a procession of a religious character. Why the boys went there, and what they did when they got there, we can only conjecture. The earliest known mention of it as a playground is about 1564 , ; while Montem, ${ }^{2}$ or Salt Hill, at Eton was also used for similar purposes at the same time.

\section{The Early Headmasters}

The statutes relating to the masters mark an advance on existing school arrangements, which it has been reserved for our own age to make generally applicable. The statute dealing with them is Rubric xii. It is headed ' Of the Master Instructor (Magistro Instructore) and Usher (Hostiario) under him.' In the body of the statute the title used is master teacher of the scholars (Magister Informator scolarium), and this always remained the full official title. Informator was the usual title for a headmaster at that date. It is applied in the college hall books to the headmaster of the City High School when he dined there. In the account rolls and hall books the headmaster appears under all manner of titles : Magister Informator, Magister, Scolarium Magister, Informator Scolæ, Magister Scolis, Magister Scolæ. The last was the term prevailing for common use. In later centuries he was called Archididascalus, Preceptor and other fanciful and high sounding names. The term Informator was not unfrequently used. The second master is always called Hostiarius in the old official documents, and this term was often used in common parlance to within a few years ago. Usher was the English corruption of it. In the sixteenth and seventeenth centuries he was very commonly called Pædagogus, Subpædagogus and Hypodidascalus. The term second master did not come into vogue till there 


\section{A HISTORY OF HAMPSHIRE}

were other masters regularly recognized, and that was not till the present century. It has now entirely superseded all other titles except on 'Long Roll,' the Latin school list published once a year in roll form.

The qualifications required of the headmaster were that he should be "sufficiently learned in grammar, having experience of teaching, a man of good repute and behaviour.' His duties were 'diligently to instruct and teach (instruat et informet) the scholars of the said college in grammar and diligently attend to them, and carefully look after their life and conduct.' 'The lazy or negligent in learning or otherwise offending,' he was, 'without exception of persons, to scold, or duly punish and chastise, with this caution always that he in no way exceed moderation in his chastisements.' This was a most necessary caution in medieval times, when Spartan views prevailed of the medicinal value of mere flogging. The absence of any formal investiture by ' rod and birch,' such as took place for instance at Hereford Cathedral Grammar School in $1385,{ }^{1}$ taken together with this injunction about moderation in chastisement are an indication of opinion highly favourable to Wykeham's educational good sense. Of each of the two masters it is expressly laid down that he should be ' a hired servant and dismissible (conductitius et remotivus),' the same terms that are used for the conducts or chaplains; unlike the fellows who were to be 'perpetual.' The headmaster was dismissible by the warden at a quarter's notice, and was to give half a year's notice. Nothing is said about any notice to or by the hostiarius, who was probably dismissible absolutely at pleasure. The term of office indicated by Wykeham in his agreement with Herton, ten years, which was also apparently that of Melton's tenure and was surpassed by Romsey who succeeded him, marks a distinct advance in school arrangements. In the old collegiate churches the statutory term of office ${ }^{2}$ was three years extendible to four or five. The term of office of a regent or teaching master at the universities was two years. It was intended apparently that they should always be young men on their promotion. But the dearth of qualified persons caused by the Black Death had in the case of the ancient and famous school of St. Peter's, York, caused an extension of the term in I 368, 'until the master obtains an ecclesiastical benefice,' and later, in 1486, the chancellor, Chandler, an ex-warden of Winchester, appointed one for life. At the same time the growth of the chantry schools, in which the schoolmaster, being also chantry priest, held the chantry on the same terms as any ecclesiastical benefice was held, viz. as a freehold for life, tended to lengthen the tenure of masters too much. Winchester and Eton enjoyed the great benefit that while no term was fixed for the master's office, he was dismissible at pleasure at three months' notice. It was not until the late seventeenth century, when the headmaster had become a greater man than the warden who was sup-

1 Register Gilbert, Dec. 26, 1385.

2 Early Yorkshire Schook, pp. 13, 23, 90, 97, 99. 280 


\section{SCHOOLS}

posed to control him, that the depressing effects began to be felt of a headmaster practically possessed of a freehold, and continuing in office long after age and custom had spoilt his efficiency.

Though the master was inferior to the fellows in status as regards the terms of his tenure, he was in fact the next person to the warden, and in matters of teaching supreme. His allowance for commons was a shilling a week, his livery eight yards of cloth, the same as that of the sub-warden and fellows, while the chaplains had only six yards and the usher five yards. In hall he sat at the high table with the warden and sub-warden, and ranked above the three or four senior fellows who were allowed to share it, the other fellows sitting at a side table. Last, but not least, his salary, $f_{0}$ io a year, though only half that of the warden $(£ 20)$, was double that of a fellow $(£ 5)$. He had moreover other profits. He was indeed absolutely forbidden 'to exact, ask or claim anything from any of the Scholars aforesaid, their parents, or friends, for his labour spent, or to be spent, on or about the said Scholars, in, or because of, their instruction before-mentioned.' But no such embargo was imposed as to the ten commoners, from whom no doubt from the first he took toll ; while, as we have seen, there were other boys attending the school who of course had to pay fees. The school was a free school only to the scholars. The charge for others did not perhaps exceed the $8 d$. a term authorized by the statutes of Oxford University in the fourteenth century, ${ }^{1}$ and the statutes ${ }^{2}$ of Ipswich Grammar School in 1482 . But $2 s .8 d$. a year, multiplied by eighty, would make the very comfortable little sum of $\oint_{1} 103^{s} .4 d$. There would be in addition entrance fees (probably $4 d$.), and presents at Christmas and Shrove Tuesday.

The Hostarius was a much less exalted personage. His name no doubt is derived, not from his really keeping the door, but from the ecclesiastical personage of that name who in primitive times did keep the door, and was later identified with the parish clerk, who often performed the function of an elementary teacher. The statutes provided that 'in the College under the Master Teacher, is to be another instructor likewise hired and removable, to be appointed by the $W$ arden and Fellows, sufficiently learned in grammar,' but previous experience in teaching was not required of him. He was 'diligently to assist the Master in the premises, and supply his place in his absence.' His commons were the same as those of the fellows and chaplains, $12 d$., his livery was only five yards of cloth, and in hall he sat with the chaplains, ranking next below them. His stipend however was five marks $\left(£_{3} 6\right.$ s. $8 d$. $)$, or one mark more than the chaplains $\left(\oint_{2} \mathrm{I} 3^{s} .4 d.\right)$. He was evidently considered merely the master's assistant, as in the second account roll his salary is entered thus: 'For the stipend of Mr. Thomas of Romsey, Master Teacher of the Scholars, and of John Huet, his Usher of the. School, yearly $\oint_{\mathrm{I}} \mathrm{I} 36 \mathrm{~s} .8 d \mathrm{~d}$; of which for the Usher $66 \mathrm{s.} 8 d \mathrm{~d}^{\prime}$

A master and usher for seventy boys, supposing them to divide

1 Munimenta Academica, Rolls Series II. p. 377 seq. from A. f. 44 , B. f. 38 .

2 Ipswich Legacies (1 747), p. 104. 


\section{A HISTORY OF HAMPSHIRE}

equally, gave thirty-five for each; a number that was regarded as none too big for a class even thirty years ago.

There were however other assistants. In the Hall Book for I 396-7 appears ' Goring, cs-adjutor,' and in the accounts for that year and the next his commons were paid for by the college until the fourth term of the year. This was clearly not an expense legally chargeable to the college, and he does not appear again. But we get occasionally such entries as this, two or three times repeated in the twelfth week of the fourth term of 1416 , 'A priest of the Schoolmaster's to dinner with the Fellows.' 'This points to a priest kept by the headmaster to assist him with his duties, probably in much the same position as the commoner tutor of later days.

The first headmaster of Wykeham's scholars was, as we have seen, Mr. Richard Herton, in I 373. The next we know of was Mr. John of Melton, mentioned in the letter already quoted as to the election of scholars to New College, of 8 April, I388. He had then been master some little time, as the two wardens and John Keton, fellow of New College, presumably acting as ' poser' or examiner, were directed to see that he duly observed the injunctions given, 'in obedience to the oath which he made to us.' 'The first known usher is also named in that letter, 'John Seward his (Melton's) vice-gerent.' It is probable that Melton succeeded Richard Herton, whose ten years would have expired in $13^{8}$. As Melton is called master he must have been a master of arts, no doubt of Oxford.

A stain has been cast upon his character by his being identified with a clerk of the same name who appears in Wykeham's Episcopal Register as convicted of stealing cloth at Hursley, a place about four miles from Winchester, and it has been stated that he lost his situation as headmaster in consequence. The dates however disprove this statement. The college account roll ${ }^{1}$ shows that Melton ceased to be headmaster exactly at Michaelmas, I 394, having been appointed master of the Magdalen Hospital on St. Giles' Hill by Winchester on Io May, I $394,{ }^{2}$ no doubt by way of a retiring pension, and the thief of the same name was convicted in May, I 397.

Of Melton's successor, Thomas Romsey, little is known. Somewhere about I 560 Christopher Johnson, then headmaster, wrote a series of ' distichs' or two line Latin epigrams (published in I 573 with the poems of Richard Willes or Willis), on the wardens and headmasters up to his time, which sometimes furnish curious bits of information about them. All that Christopher Johnson could find to say of Romsey was that he was both lucky and unlucky, in that he saw Wykeham alive and then

1 The 2nd Roll, Computus Magistri Morys, Custodis, from Saturday before Michaelmas, Sept. 26, I 8 Rich. II. to Sept. 26, 19 Rich. II. Mag. John Melton appears as dining in hall the first week, while Mag. Thomas Romesey appears in the second week. Melton must therefore have retired at Michaelmas, after six months' statutable notice given.

* See History of Winchester College where the date, 1 393, given in Kirby's Annals, was corrected from the extract from Wykeham's Register printed in Vetusta Monumenta, iii. 3. In Mr. Kirby's edition of Wykeham's Register, i. I 90 , the date is now correctly given as 1394 . 


\section{SCHOOLS}

dead. He was probably a Wykehamist and a New College man, in the sense of being one of Wykeham's scholars at Winchester and Oxford before the actual foundation, since his name imports that he came from Romsey, Hants, and it is not to be found in the lists of any of the earlier colleges. Being called Magister T. Romsey, he was certainly an M.A. While still headmaster he was, in $140 \mathrm{I}$, presented by Wykeham ${ }^{1}$ to the living of Patney, Wilts, the patronage of which belonged to the see of Winchester. He retired from the headmastership at Easter, I 407, having held office for over twelve years. After the resignation of his successor he held the headmastership again for four years, from I 414 to 14 I8. His total term of sixteen years was by far the longest before the Reformation, and was not exceeded until after the Restoration, when Harris held from 1678 to 1700 . After his retirement the steward of hall's books exhibit him frequently at Winchester dining and supping in hall as a guest, the last time that has been noticed being in 1424 .

Romsey's successor was John Pole, who was certainly a Wykehamist and New College man, as his name appears on the book of the steward of hall at New College, fourth on the roll of scholars in $1392-3$, when both foundations were in full working order.

John Pole must have been a successful headmaster as it was during his rule, in I 4I2, that Cardinal Beaufort issued his injunction against the admission of commoners beyond the statutory ten, stating that he was informed there were eighty or one hundred beyond that number. As has already been pointed out, the admission of outsiders being left to the warden, it is quite probable that no change was made. From what Christopher Johnson says of Pole it would seem that at that time Pole's note-books were preserved.

Rosa licet Polum tamea adversaria produnt

Debetur blattis gratia quanta vide.

Worm-eaten though they be his note-books show

John Pole to us. What a debt to worms we owe!

- a somewhat ambiguous remark, which would lead us to suppose that Johnson did not think Pole's note-books much of a treasure. Would we had them now! The note-books of a fourteenth century schoolmaster, and that schoolmaster one who had known Wykeham, would be worth their weight in gold.

After Pole's departure Romsey resumed office, a circumstance which makes Johnson ask in surprise :

\section{Aerumnose senex, iterum Romseie redisti? \\ Saltem his arumnis debuit esse modus.}

Returned in age to thy old cares, my friend

Romsey, should not such cares have had an end?

Romsey left behind him a memorial in the shape of ' a grammar

1 Wykeham's Register, i. 


\section{A HISTORY OF HAMPSHIRE}

treatise on phrases, called Iron.' ${ }^{1}$ It was a large book as, when it was written or copied in 1400 , the parchment of its twelve quires cost 3 s. $8 d$., and the scribe, Peter of Cheesehill, received a mark for writing it. ${ }^{2}$ But it has disappeared-with the fifteen other grammatical works in the library, as indeed have all the other I $24 \mathrm{MSS}$. in the old catalogue except three.

Of the next headmaster, Richard Darsey or Darcy (1418-24), little can be learned. Whether he was a Wykehamist or not does not appear. If he was one, he had left New College before I 386 . The only thing recorded of him is that he resigned on account of illness. He gave the college library a 'Grecismus' and a Doctrinale with notes by Pictaviensis and Horiliensis, which was valued at $£_{3}$, the equivalent of $f 60$ now.

At Darcy's retirement several competitors were invited for the vacancy. One Fellow rode to Maidstone, to Mr. John Baddesden, presumably grammar master of Archbishop Courtnay's College there; then to Master Thomas Alwyn at Newport Pagnell, Bucks; another went to Oxford and thence to St. Alban's, where there was an ancient Grammar School (not a monastic one), and other places; and a third to Richard Maslyn at Salisbury; while Richard Davy, master of Gloucester Grammar School, ${ }^{3}$ came to Winchester ' to be Informator of the scholars' and was paid 6s. $8 d$. with a shilling to his clerk. Presumably the payment was for his expenses in coming to be looked at rather than for acting as locum tenens. Alwyn was paid 3s. $4 d$. for the same. Alwyn or Walwayn, as he is also called, obtained the appointment. He was one of the scholars who had entered the new buildings in 1394 . He held office for eleven years, and after he had regained his liberty for a dozen years was 'sucked in by the dread Charybdis again' as Johnson has it, when Waynflete, his successor, left for Eton.

It is a strange thing that so little is known of Wayneflete's extraction or early career. It is still a moot point whether he was a Wykehamist or not. It is known that his father's name was Pattene alias Barbour, and it is assumed, from the erection of his father's tomb by him in Wainfleet Church, Lincolnshire (now barbarously destroyed and the tomb removed to Magdalen College, Oxford), that he was born at Wainfleet, the name of which he took on taking orders. The name of Wayneflete is not on the Winchester Scholars' register. It is just possible that he was the William Patney of Patney "who was on the roll for Winchester in 1403 , two places below Bekynton, though there is nothing but his name to connect him with Patney. This William Patney left Winchester in 1406, and did not go to New College, and the

\footnotetext{
1 Archaological Fournal, xv. 74. Item quidam tractatus grammatice super dictionibus vocatus 'Ferrum,' ex dono Magistri Thome Rumsey, et continet in fine Summam Raymundi. $2^{\circ}$ folio, distinguendum est.

: Annals, p. 67.

B Richard Davy is described as magistro scolarum gramaticalium Gloucestrie. Gudiciioles (Ann. p. 188) is a misprint.

4 Willelmus Patney de eadem.
} 


\section{SCHOOLS}

New College registers ${ }^{1}$ know neither Patney nor Wayneflete. It seems certain from Thomas Chandler's picture of famous Wykehamists, where Wayneflete is shown with his mitre on, not lifted off his head, as is the case with the other prelates except Wykeham (who we know was not at the university at all), to show their doctors' caps, that Wayneflete was not a doctor, and therefore in all probability was not at the university. The New College admissions are most carefully kept, and it must be accepted as practically certain that Wayneflete was not a New College scholar. But if Wayneflete was Patney it is curious that Wayneflete is not mentioned by Chandler specifically as a Wykehamist. A passage was quoted by Richard Chandler in his Life of Wayneflete from Thomas Chandler's Life of Wykebam which he refers to William Waynflete. ' There is also springing from the root of such a foundation, like a flourishing shoot, which now by the help and assistance of Thomas, most beneficent lord, most choice prelate of this church of Wells, has grown as it were into a mighty cedar, William, dean of the Chapel Royal and of S. Paul's Church. Him, like a precious stone of the foundation, or a tree planted by the waterside, we have known as an illustrious doctor of sacred theology, we have experience of him as a benefactor, which we hope will be enlarged in the future.' ${ }^{2}$ The person thus referred to was not however William Wayneflete, who was never dean of St. Paul's, but William Say, a much younger man, admitted scholar in 1425 , only four years before Wayneflete became headmaster, which was in 1429 . Unless therefore Wayneflete was Patney or was a commoner at Winchester and at New College he was not a member of either college.

Of Wayneflete as headmaster no more is known than the dates of his coming in $143^{\circ}$ and going in $144 \mathrm{I}^{3}$ That he must have been successful his twelve years' term of office, followed by his selection by Henry VI. for his Wykehamical adviser as the first headmaster of Eton, sufficiently testify. To Eton he took with him, as the tale used to be told, half the Winchester scholars or thirty-five. The Winchester Scholars' register has however only six scholars noted as having gone, 'recessit ad collegium Regale de Eton,' three of whom were the same year admitted among the first fellows of King's College, Cambridge, which bore the same relation to Eton that New College, Oxford, bore to Winchester." Two fellows of New College also went to be fellows

1 The writer of the article on 'Wayneflete' in the Dictionary of National Biograpby argues that it is certain that Wayneflete was at New College, because he made New College men eligible for the wardenship and fellowships of Magdalen. But his headmastership at Winchester would be enough to account for that. The New College men were his pupils. He was directly imitating Wykeham.

2 The passage is on f. 51 of Chandler's MS. at New College. In my History I had not verified Chandler II.'s quotation and so asserted positively that Chandler I. established that Wayneflete was a Wykehamist. That assertion must now be recanted.

3 These have hitherto been wrongly given as 1429 and 1442 , owing probably to confusion over the year of the king and the year of our Lord. Sir Henry Maxwell-Lyte also speaks of Eton School beginning in 1442. But it seems certain, from the date of Wayneflete's departure from Winchester, that it may add another year to its age and date itself from Michaelmas, I 44 I. Its charter was given in October, 1440. The earliest account roll is for 1443 when Westbury was headmaster.

4 The names of the six were John Langporte of Twyford, close to Winchester, admitted 1432 ; Robert Dommetge or Dommett of Hinton, Hants, admitted 1435; Richard Cove of Burnham, 


\section{A HISTORY OF HAMPSHIRE}

of Eton. It is perhaps a tribute to the gap left by Waynflete's departure that it was filled for two years by the return of his predecessor Ailwyn. Wayneflete's headmastership of Eton was almost as short as the stay of half the Winchester scholars, for in I 443 he became Provost. Henry VI.'s uncle, Cardinal Beaufort, Bishop of Winchester, died on 9 April, 1445. The same day the king wrote to the monks of St. Swithun's Priory, with whom, as the chapter, the election of the bishop nominally rested, to recommend Wayneflete, and on the $\mathrm{I} 3^{\text {th }}$ he was elected. In June he was consecrated in Eton College Chapel, when the Winchester authorities attended and gave the Eton scholars a mark among them, or about $2 d$. apiece. A few months afterwards, I 9 January, I 448-9, Wayneflete was enthroned in the presence of the king. This was by no means the first time that Henry had been at Winchester. All his visits are carefully recorded in a special entry made in the College Register. ' 'The first coming of the most serene Prince Henry VI. to this College was on the last day of July in the I gth year of his reign (144I) on which day he was present at first Vespers and next day at Mass and second Vespers, and he offered I 3 s. 4d.,' which was the customary royal offering at mass. On St. Cecilia's Day, 22 November, 1444, he came again, 'was present at Vespers and Mass, and besides his daily offering ( $13^{s} .4 d$.) offered 100 nobles for the embellishment of the high altar, and gave a notable sum of gold, viz.: $\int 6 \mathrm{I}^{\text {s. }} 4 d$. to the scholars and choristers; and further of the abundance of his most affluent grace confirmed and enlarged the privileges, liberties and franchises of the College. Wherefore his name is worthy to be had in everlasting remembrance.' He came again on St. Cuthbert's Day (4 September) I 445 and was present at first and second vespers and mass and gave 'the College his second best robe furred with sables to the glory of God and the honour of the Most Blessed Mary the Virgin.' The college in turn gave an organ recital by the cathedral organist, Robert Derby, clerk (not, be it noted, a monk) on 2 I and 22 November, for which the organist was paid a noble ; while expenses on his household cost $5^{5 .}$, and 9 gallons of red wine bought for the occasion cost 4 s. $9 d$., or a fraction over $6 d$. a gallon. During the parliament held at Winchester in June and July, I 449, the king attended mass in the college chapel every Sunday except 29 June, St. Peter and St. Paul's Day, when he went to cathedral 'because it was a local feast,' the old dedication of the cathedral church being to those saints, so on that day he came to Chapel to vespers only. Wayneflete officiated one Sunday, Beckington another, and on Thomas Becket's translation, the archbishop, John Stratford, then chancellor, officiated, with Wayneflete and the Privy Seal,

admitted last on the roll in 1436; John Payn of Wood Street, London, and John Mustard of Wimborne, Dorset, both admitted 1437, and Richard Roche of Taunton, Somerset, admitted I 439. The first three went off to King's. It by no means follows however that more did not go. Unfortunately the early Eton registers have disappeared. Worcester.

1 Misprinted in History of Winchester College, p. 209. It was the day of St. Wulstan, Bishop of

Printed Lowth, App. p. 370. 


\section{SCHOOLS}

Adam Moleynes, Bishop of Chichester. The bishop and archbishop gave the boys 40s. for refreshment (refectione). On the last day of the parliament, I 6 July, the king attended the Lady mass, offered half a mark and afterwards ' gave to the high altar a tabernacle or canopy of gold,' presumably to receive the silver gilt statue of Our Lady which his uncle, Cardinal Beaufort, had given. On i 6 July the courtiers were entertained at dinner in hall, and a pipe of claret (red wine) was bought for $f_{0} 8$ for the purpose. On Palm Sunday, I 45 I, the king came again and was present at mass and procession, when Thomas Chandler, the warden, preached, and gave $f_{5} 5$ over and above the usual mark. He also gave a pair of silver gilt dishes with the royal arms in the middle, weighing 9 lb. odd and costing $\int_{2} 93^{\text {s. }} 9$ d. Christopher Johnson, in his 'distichs' on the headmasters, attributes to John Bernard or Barnard the pleasure of having been the headmaster at this time.

\section{You Barnard saw the King full many a day \\ His gifts upon our heaped up altars lay.}

But in point of fact Ive, or Ivo, as Johnson calls him, who had succeeded Ailwyn in 1444, was the reigning Informator. Of him Johnson only guessed.

Ive was perhaps akin to Ive of yore,

The Fellow; but my Muse knows jothing more.

'Yve,' as he is spelt in the register, was a fellow from I4I I to I 432. William Ive the headmaster was an Oxford man, ${ }^{2}$ but his name is not to be found in the lists of Winchester or of New College scholars. He took his M.A. degree as a member of Magdalen Hall in I 449, while he was headmaster. He afterwards became master or warden of Sir Richard Whittington's College in St. Michael's Royal, London, and created some stir by his sermons against what was described as the heresy of the Friars, who claimed Christ as a professional mendicant.

Bernard, who succeeded Ive in I454, was a Wykehamist, and a Hampshire man from Over Wallop, admitted a scholar under the name of John Barnard in 1 435. He became a scholar of New College in 1 440, and was made an M.A. on 30 October, $1453 .^{\circ}$ Next year he was dispensed residence for a month in order to appear before the prior of Canterbury sede vacante for promotion. From his time till Easter, 190 I, none but a scholar of Winchester College has sat in the chair of the Magister Informator of Winchester College; and till I766 every Informator was not only a scholar of Winchester but also a fellow of New College.

\section{The Endowments}

The endowment given by Wykeham to the college at its first opening amounted to $\AA_{307}$ a year, but by the time of his death it had

1 Kirby's Scbolars, p. 4 .

2 Boase's University Register. I I Nov., 1449, he received a dispensation as M.B. and 30 June, 1456, was admitted B.D. ; 1 I Feb. 1460, disputed as D.D. ; $1460-1$, vice-chancellor.

3 Boase, Register, under date. He is not there said to be a member of New College. 


\section{A HISTORY OF HAMPSHIRE}

been increased to about $\oint_{4} 45^{\circ}$ a year, or, taking the rough and undoubtedly too low approximation of twenty times the value, about $\oint_{0} 9,000$ a year of our money. By the time of Edward VI. this income had been about doubled by gifts given by later benefactors. Since that time the only increments have been in the shape of special gifts for special purposes, leaving exhibitions, prizes, buildings and extension of 'Meads,' as the playing fields are called.

The earliest and largest individual piece of endowment given by Wykeham was the rectory of Downton near Salisbury, which he bought from his see and appropriated by papal bull to his own table and then transferred to the college. For this purpose licence in mortmain was obtained in 1384 , enabling the college to hold lands up to $f_{0}$ I 00 a year in value, which was the value of Downton rectory in tithe and glebe at the time.

The next endowment was the manors or manor of Meonstoke Ferrant and Meonstoke Perrers. The former was bought from John of Blewbury, a noted Berkshire ecclesiastic of the day. The two Meons were worth about $f_{0} \mathrm{r} 3$ a year each.

At about the same time Combe Bissett in Wiltshire, producing about $f_{0} 20$ a year, was acquired. In $\mathrm{r}_{3} 87$ another $f_{2} 20$ a year was purchased in Ropley, Hants. Then came the great purchases of 'alien priories' which have made the name of Wykeham famous as a precursor of the confiscation of the monasteries, and have gained him the reputation of having set the example which Chicheley, Wayneflete, Wolsey and other great founders, including Henry VI. and Henry VIII., followed in diverting to the secular clergy and to education, endowments originally given for 'religious' purposes, that is for monasteries.

In point of fact the precedent of expropriating the possessions of foreign houses in England to English uses had been set when Bishop Grandisson of Exeter established the college or collegiate church and grammar school of Ottery St. Mary in Devonshire by purchasing, after very keen bargaining, in 1334-7 from the dean and chapter of Rouen, to whom it was appropriated, the church and manor of Ottery. ${ }^{1}$ The Rouen chapter found it more profitable to sell their alien properties and concentrate their possessions at home. Grandisson was only following the example of the Archbishop of York who had previously made purchases from the same house. Ottery manor however was not a monastic possession.

Wykeham's first purchase in this kind was that of the alien priories in Hampshire of Hamble-en-le-Rise, Andwell near Basingstoke, and St. Cross, or Croos as it is spelt in the Accounts, in the Isle of Wight, all belonging to the abbey of Holy Trinity, Tiron, near Chartres.

A more extensive purchase was that of possessions of the house of St. Valery-sur-Mer in Picardy, which included a batch of churches on

1 Grandisson's Register, ed. R. C. Kingeston Randolph, pp. 280-1, 285, 288 and 117. 


\section{SCHOOLS}

the banks of the Thames, Isleworth, Twickenham and Hampton-onThames. From the abbey of St. Katharine's Hill, Rouen, was derived a possession as rich as Downton, the rectory and manor of Harmondsworth. New College took for its share other possessions of the same houses. Durrington and Fernham (Vernham), Wilts, by private purchase from Lord De la Warr, completed the endowment by Wykeham.

The first complete year in which the accounts are rendered by the two bursars, yearly elected by the fellows, who then first superseded, according to the statutes, the warden, till then the sole estates manager and accounting officer, is for the year I 398-9. The account was as follows-

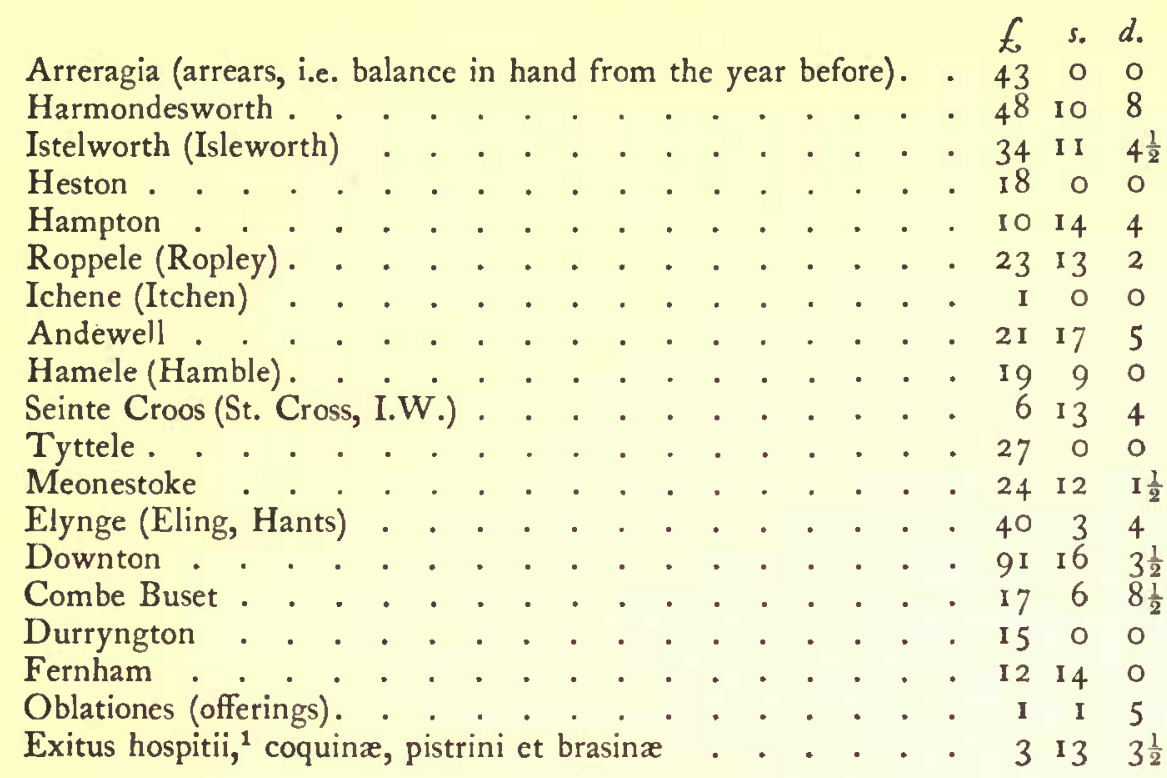

On the final dissolution of the alien priories in Henry V.'s reign the college acquired ${ }^{2}$ its first considerable accretion to Wykeham's original endowment, by the assistance of his successor as bishop, Cardinal Beaufort. This was St. Mary's Priory at Andover, Hants, a dependency of the abbey of St. Florent of Saumur in Anjou, to which it had been given by William the Conqueror. The last prior received a pension for life of fifty-two marks out of it, and there were other payments secured on it, with the result that though the property was conveyed to the college in $\mathrm{I}_{4} \mathrm{I}_{3} 3$ it only acquired the beneficial value in 1437.

A transaction of a somewhat similar nature was the appropriation to the college of a small collegiate church of the Trinity, Barton, in the Isle of Wight. This was not an alien priory or a monastic establishment at all, but a college of secular clergy, presided over by an archpriest ${ }^{3}$ or warden. Beaufort appropriated it to the college in $14390^{4}$ Cardinal Beaufort also founded an obit in the college with a bequest for the pur-

\footnotetext{
1 Issues of the hall, kitchen, bakery and brewery, i.e. extras supplied to and paid for by members of the college.

Annals, p. 182. 3 Wykeham's Register, Kirby, ii. 401, 458, 550. \& Annals, p. 201. 


\section{A HISTORY OF HAMPSHIRE}

chase in 1447 of a manor called Butts, afterwards exchanged for that of Holland or Hulland at Tilehurst in Berkshire. This was one of a series of obits which brought considerable accessions of territory to the college, the value of which for maintenance purposes was considerably increased when obits were abolished by the Chantries Act of Edward VI. While they lasted they were not unpleasing extensions of the 'dead hand,' as all the members of the college who were present at the service for the dead in the college chapel in commemoration of the donor received small sums of money. The usual tariff was-

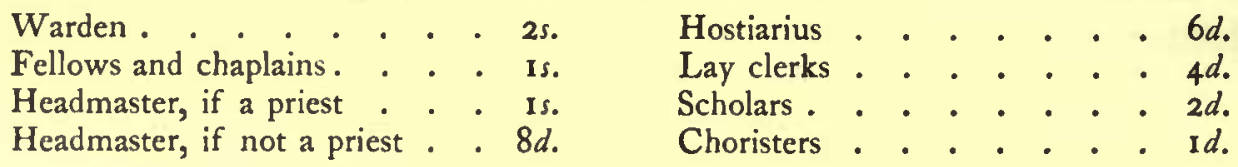

It is noteworthy that the obit foundations of Cardinal Beaufort, Warden Chandler, Ede and others contained a clause differentiating the payment to the headmaster, according as he was or was not a priest, in which latter case his prayers were more valuable. This shows that the necessity of the sacerdotal headmaster was by no means recognized during those ages of faith. Sometimes the later gifts took the form of a noble $\left(3^{\text {s. }} 4^{d}\right.$.) for a 'pittance' or extra dish at dinner for the scholars, or $6 d$. to each of the six chambers (scholars) and $4 d$. to the seventh chamber (choristers). At Ede's and Rede's obits money was given for candles for the scholars in chambers. The last foundation of an obit was in 1557 , after the abolition by Edward VI., by John Pullie, keeper of Wolvesey Castle, but it was not perpetual, being only for fifteen years, and contained no gifts to the masters or boys. Excluding this, which probably never came into operation, but including Wykeham's, there were twenty-one obits in all. They were those of Wykeham, Beaufort and Beckington, bishops; Morys, Thurburn, Chandler, Baker, Clyff, wardens; Farlington, headmaster; Laws and Gynner (or Chynnore), H. Keswyk, T. Aschebourne and J. Whyte, fellows; Hugh Sugar, chancellor of Wells, Robert Colpays, William Tystede, formerly scholars; J. Fromond and J. Bedyll, stewards, the latter a scholar and mayor of Winchester ; Richard Rede, porter of Wolvesey, and Stephen Ede, fathers of scholars; and Sir W. Danvers, Earl of Oxford, probably a commoner. Kesewyke's obit founded in 1419 was one of the earliest. He gave property in Southampton. Fromond's lands were mostly in or near Winchester. Thurburn's were at Romsey; Colpays' at Otterburne. The chief accretions of land came through purchases, largely made by Warden Baker (1454-82), but whether out of accumulations of income or gifts of money does not seem to be clear and could only be determined by an exhaustive analysis of the deeds and account rolls.

In 1544 a great, and as things have turned out, a most unfortunate change in the college endowment was caused by an exchange made with King Henry VIII. He took from the college Harmondsworth and the four Thames-side rectories, and the manors of Shaw and Calthrop 


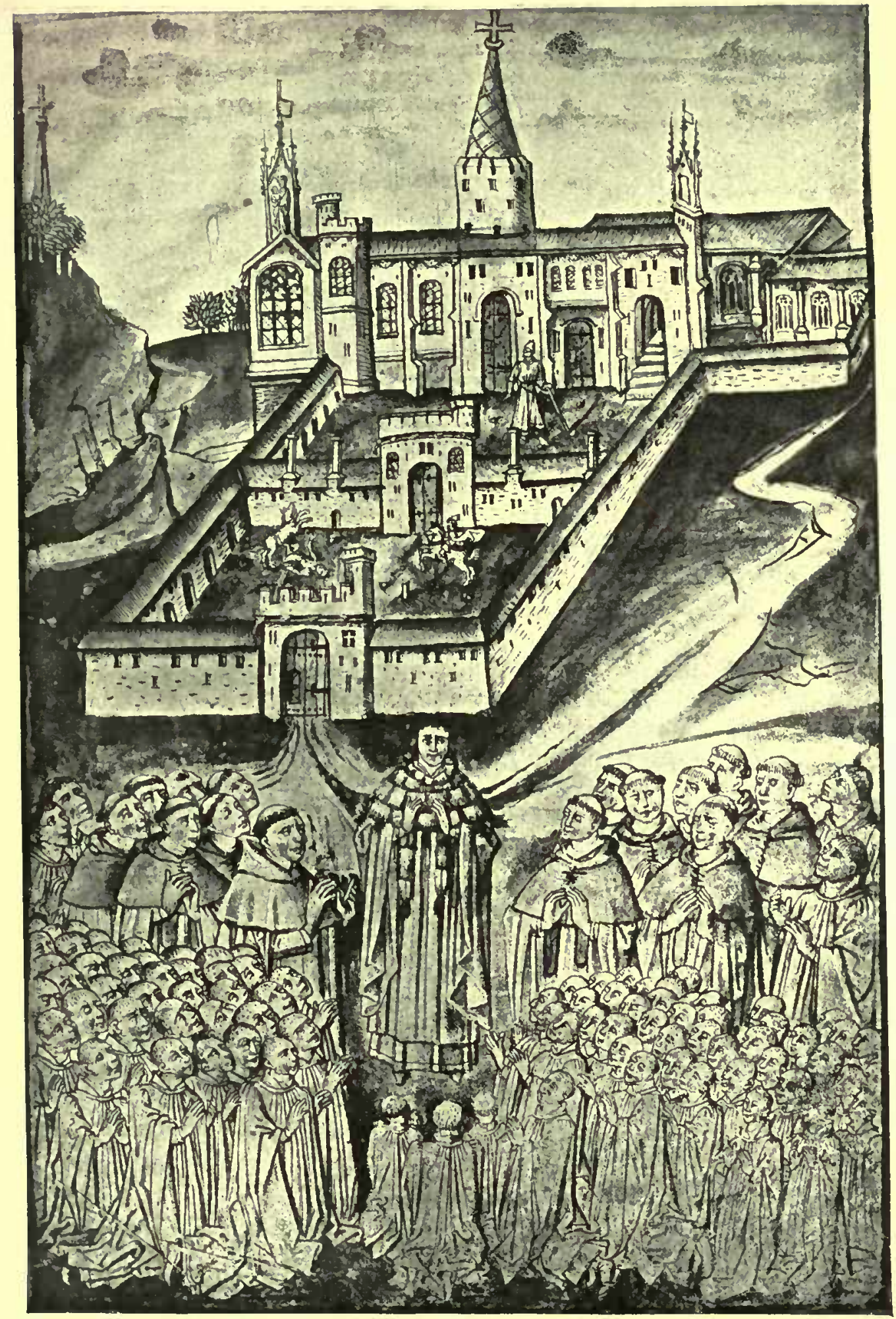

Winchester College, c. 1460. 



\section{SCHOOLS}

in Berkshire, and gave in exchange lands in Hampshire, Dorsetshire and Wiltshire which belonged to various dissolved monasteries. The four houses of friars at Winchester, particularly those of the Carmelites in what used to be Sickhouse Meads, and Meads, and the Austin or Augustinian Friars close by, were no doubt a valuable acquisition, while the rectories of Portsmouth and Portsea have proved not unprofitable. But the other exchanges have turned out from the point of view of the college to be 'of gold for brass, the worth of roo oxen for that of nine.' It gave away the prospect of an enormous ' unearned increment ' arising from land which, owing to the growth of London, has become valuable building land, for scattered and distant agricultural farms. Probably neither party contemplated anything like the difference that has since taken place in the prospective value, but we may be pretty sure that the college would not willingly have exchanged a compact property near London for the remote and scattered fragments it received. In consequence the account roll in Edward VI.'s first year exhibits far greater change of property from that of 1398 than any that has occurred since. In fact except for the further exchange made by Edward VI. of the manor of Endford, Wiltshire, for half a dozen scattered manors in Surrey, Somerset and Gloucestershire, and the sale to Queen Victoria of a large part of the Barton property for the creation of the Osborne House estate, the property remains substantially unaltered.

\section{Early Celebrities}

The opening of the college in its new buildings was an event of national importance. It is mentioned in the chronicles of the time, while the Account Rolls and Hall Books bear witness to the large number of strangers who came to see it and were hospitably entertained. Among the more notable visitors were the Duke of Brittany, who came in 1396 , and was entertained with French bread among other luxuries; while Henry IV. in his first year paid a visit in state, and received a present of two swans, his bread and pastry being specially baked by the founder's baker, lent for the occasion. The college was called in Hampshire for some centuries, as its sister college at Oxford still is, par excellence, the New College. The Old College of St. Elizabeth, which received a quit rent of $2 d$. a year on 'meads,' the cricket field, entered it as received from 'the New College'; and in the accounts of the corporation of Basingstoke 'the Warden of the New College,' viz. of Winchester, is entered among the landowners of the borough throughout the fifteenth century. In the reign of Henry VIII. Gardiner, when Bishop of Winchester, wrote of it as 'the New College beside Winchester.' The disappearance of the old college in the reign of Edward VI. saved it from being for ever labelled, like St. Mary's College, Oxford, with that anachronistic title, though it was still occasionally used, as in Queen Elizabeth's letters patent, in 1560 , allowing the Latin Prayer Book.

The school was immediately and marvellously successful in its primary object of turning out learned clerics. Winchester scholars 


\section{A HISTORY OF HAMPSHIRE}

took the offices of Church and State by storm. The career of Henry Chicheley, Archbishop of Canterbury, Henry V.'s prime minister, is too well known to need special mention. As a founder he followed Wykehám, though longo intervallo, in the foundation of All Souls' College and Higham Ferrars School. To his place in the State succeeded Thomas Beckington (Bekenton in the College Register on his admission in 1403), ' first queen's, then king's secretary, and Bishop of Bath and Wells, where the bishop's palace and his chantry in the cathedral testify to his being a builder (in the sense of an employer of builders) not inferior to Wykeham himself. Owing to his having taken pains to keep copies of his correspondence, his letters and those of his younger correspondent, Thomas Chandler (scholar 1430), Warden of Winchester and of New College, and himself a Secretary of State, remain in evidence ${ }^{2}$ to entirely disprove the ridiculous allegations of the absence or the decay of learning and Latin in the fifteenth century. Chandler, indeed, who has left behind at New College a panegyric on Wykeham, usually credited to him but which he himself says in a preface dedicated to Beckington, who had given him a canonry and the chancellorship of Wells Cathedral, was composed by one of his pupils, is an absolute bore with his perpetual quotations of Plato and Aristotle, Cicero and Seneca, Horace and Ovid. He tells us how ${ }^{3}$ Beckington had been sent to Winchester in tender years to learn grammar, and there being noticed by Wykeham was placed on the foundation of the college-a curious piece of testimony to the continuance of a grammar school, no doubt the High School, after the foundation of the college, and serving as a kind of preparatory school to it. Chandler, when Warden of Winchester, ${ }^{4}$ invoked the munificence of Beckington to the college, which he described as being in such a state that 'its very walls seem to shed tears and bewail their approaching ruin.' He held out to him as an attraction that any new endowments would rank with the old, in giving the boys of the places where they lay a preference for election as scholars. Beckington responded with large gifts of plate, vestments and money; and later left lands at Week, near Winchester, and Vale Barn, as endowment for an obit in the college. Chandler himself also founded an obit, for presence at which the headmaster received a shilling if a priest, and $8 d$. if a layman. The panegyric of Wykeham, written about 1460 , contains some extremely curious water-colour drawings, which give a vivid picture of the twin foundations. Two of them ${ }^{5}$ depict the two colleges with their inmates-the 'two hundred clerks' of whom Wykeham was the father. Another ${ }^{\circ}$ shows the famous Wykehamists of the day surrounding a seated figure of Wykeham.

1 History, p. 291.

2 Official Correspondence of Thomas Bekynton, Rolls series, No. 56 (1872). See also some of his letters in Letters of Margaret of Anjou, Camden Society, C.S., No. 86.

3 Some extracts were printed in Bekynton's Correspondence, ii. 315, 26.

Ibid. i. 268.

5 Frontispiece to History, taken from a photograph made for the Warden of New College. See also Archaologia, liii. pt. I, p. 229.

6 History, p. 216 . 


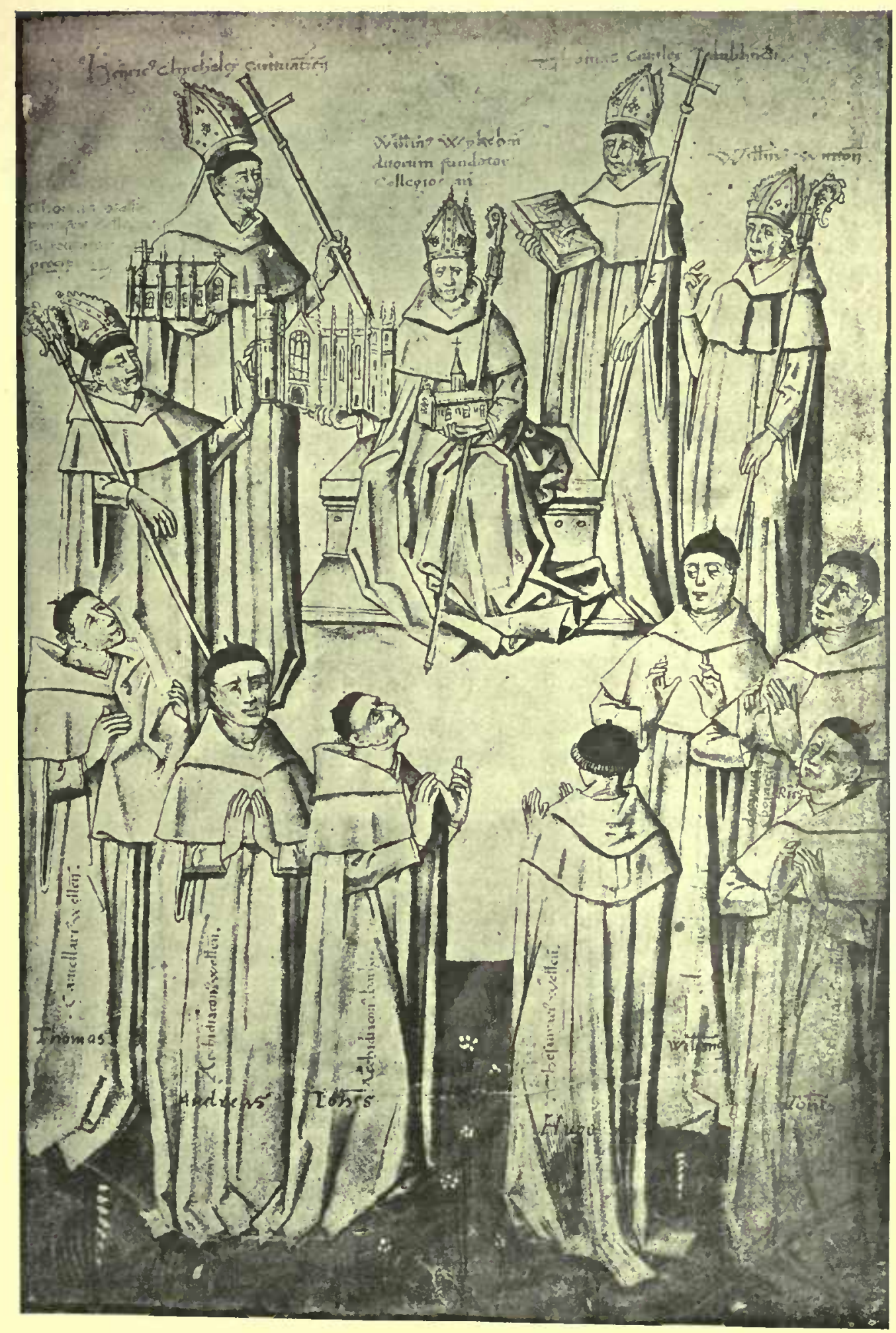

EMINENT WYKEHAMISTS. C. 1460.

From Warden Chandler's MS, New Coltege, Oxford. 



\section{Fifteenth Century Headmasters}

Of the headmasters of the fifteenth century John Green, I 460-4; Clement Smith, I 464-6; Richard Dene, I 466-84; John Rede, I 48490; Richard Festham or Fescam, 1490-5, almost nothing is known. Except Clement Smith, who came from Southwark, they were all Hampshire men. Smith was headmaster at the colleges of Higham Ferrars and Eton before coming to Winchester, returned to Eton and died there. Of Dene, all that Johnson finds to say is to congratulate the boys on being able to tread on the head of their terror when he was dead, he being buried on the floor in cloisters. His brass has long disappeared. ${ }^{1}$ Rede, possibly a son of the porter of Wolvesey Castle, who shared in the expenses of the reredos in College Chapel in $1470-1,2$ and perhaps uncle of the scholar of 1524 who became Chancellor of Ireland, was a more distinguished person. He became, in 1500 , tutor to Prince Arthur, the eldest son of Henry VII, who was born at Winchester in I 489 . Rede's selection is no doubt a tribute to his success as master of the chief school of the day. Rede became master of Magdalen Hospital ${ }^{3}$ at Winchester, and retired on canonries at Chichester and Lincoln, returning to Winchester as warden in I $50 \mathrm{I}$. While there he received, on 29 January, I $508,{ }^{4}$ what appears to have been a special tribute to his dignity - the cap of D.D. from a deputation of the vice-chancellor and two proctors instead of in full congregation. In 1520 he became warden of New College, where within a few months he died, and lies buried.

The last headmaster of the fifteenth century, William Horman or Herman, was a man of greater fame, and has left a book behind him which was perhaps the most noted school-book of its day, and is to us both singularly interesting in itself and valuable as an illustration of the English of the time. Horman is said to have been of German extraction, and to conceal the name Hermann under the anglicized spelling. $\mathrm{He}$ is entered on the Winchester register in 1468 as of Salisbury. He went to New College in I475, and after ten years' study there became headmaster of Eton in 1485 , and 'went up higher' to Winchester in I 495, Christopher Johnson incorrectly representing him to be 'the terror first of Winchester and then of Eton.' In 1502 he returned to Eton as vice-provost, and died there in 1535 , leaving a brass to his memory. But his most enduring monument is his Vulgaria, or Vulgars.

The book consists of English sentences with Latin translations under them, arranged in chapters under various headings, as religion, irreligion, school, games, war and the like.

1 What is probably his tombstone remains at the south-west corner of cloisters.

2 Annals, p. 52.

3 Not also master of St. Cross Hospital, as Annals, p. 228 . The masters of the time were Richard Hayward, a Wykehamist of 1439, 1475-89; John Lichefelde (see above, p. 6 n.), 1489-92; and Robert Sherborne, also a Wykehamist, 1492-1 508, when, for the first time for 100 years, a non-Wykehamist, John Claymond, a Magdalen man, president of Corpus Christi College, held it till 1524.

- Boase, Register, Oxford University, under date. 


\section{A HISTORY OF HAMPSHIRE}

An interesting thing about this book is that the contract for its being printed by R. Pynson, 28 June, 1519 , is preserved, and has been printed by Dr. Furnivall in the Philological Society's Transactions. No less than " 800 hole and perfytt books of suche vulgars as be contenide in the copy ' were to be printed at the price of 'for every hole reme, 5s.' Forty shillings was paid down, and 'full for 500' was to be paid on delivery of 800 , and that day twelvemonth payment was to be made for 'the three resydue hundred.'

In the latter half of the fifteenth century the supply of bishops and magnates turned out by Winchester School was not less good than in the preceding half century. The roll of honours is made up of two archbishops; again one of Canterbury, Warham, another of Dublin, Yng ; two bishops, another Bishop of Bath, William Knyght ; another Bishop of St. David's, then of Chichester, Robert Sherborne; two suffragan bishops (in partibus infidelium), John Yong, Bishop of Callipoli or Gallipoli, warden of New College, with a fine brass in ante-chapel there; and Thomas Wellys, Bishop of Sidon. Chandler, dean of Hereford, as warden of Winchester and then of New College, was the Janus through whom the passage from the 'old' to the new 'learning' was made. While he celebrated the past glories of Wykeham and Beckington and the earlier generation of Wykehamists, he passed on the torch of learning to be carried into new regions by Warham and Grocyn. There was another dean of York, another John Yong, who was also Master of the Rolls, and was buried in the Rolls Chapel. The fine monument erected to his memory is in the Public Record Office Museum, which was built upon the site of the Rolls Chapel. There were other deans: Geoffrey Simeon, dean of Lincoln and the Chapel Royal, William Fleshmonger, dean of Chichester, and so forth. All these bishops and deans were, it must be remembered, no mere ecclesiastics; generally, indeed, their ecclesiastical promotion was in an inverse ratio to the time which they spent on ecclesiastical matters. Their rectories, their canonries, their archdeaconries were their pay for civil and legal service, and their bishoprics, if not, as they commonly were, accompanied by high office, were in the nature of retiring pensions.

Warham was one of the great figures of the age, and would have stood out as perhaps its greatest figure in England if, in his old age, he had not been overshadowed by that last and greatest of all English ecclesiastical statesmen, Wolsey.

The name of Grocyn suggests his fame as the 'First Grecian' in England. This was vindicated for him by Montagu Burrows, Chicheley Professor of Modern History, in an article $\grave{a}$ propos of a newly discovered list of his library in $1890 .{ }^{1}$ Grocyn headed the roll for college in 1 463, and went to New College in 1465.

In the first quarter of the sixteenth century Winchester went on the even tenor of its way, developing with the development of the new

1 Oxford Historical Society's Collectanea, pp. 316-89. 


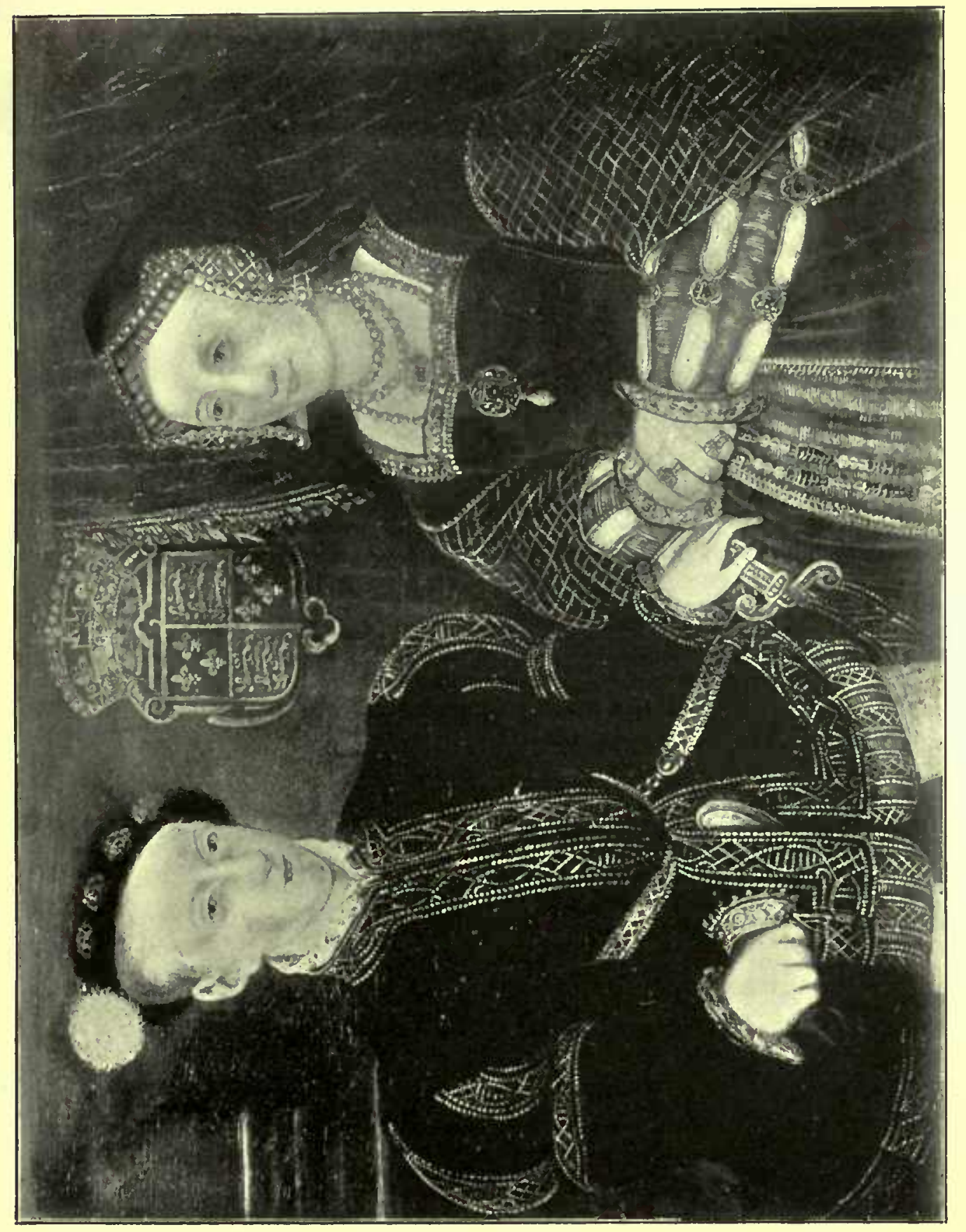

要 



\section{SCHOOLS}

learning. In 1502 John Farlington, no doubt of Farlington in Hampshire, became headmaster. So little is ascertainable about him that even his name has been rather persistently confounded ${ }^{2}$ by the annalist with that of an entirely different person, by name Darlington. Darlington was a scholar of 1474, who became a fellow of Winchester in 1490, vicar of Isleworth in 1498 and of Greenwich in 1509 , while Farlington was a scholar fifteen years later, scholar of New College in 1493 and headmaster in 1502, and died vicar of Wadhurst, Sussex, in 1527. By his will he gave' to the Newe College in Oxford, called Wynchester College,' $f_{0}$ io and the choice of two 'reliques,' and to 'the New College in Winchester' $f_{0} 5$, a chalice 'thorough gilte' and the other of his two 'reliques.' Farlington, like his successors, Edward More in I 508-17, and John Twychener I 526-31, retired on a canonry at Chichester, a mark of the strong Wykehamical policy of its bishop, Robert Sherborne who had been master of St. Cross, Winchester, before Farlington became headmaster. He showed his love for Winchester by founding four new canonries or prebends there, which are tenable only by Wykehamists, and, though non-resident, were specially saved from extinction when other non-resident canonries were swept away in 1848 . He made the formularies and prayers at Winchester School the model for his foundation of Rolleston School in Staffordshire in $1520-2$.

More had a reputation as a flogger, which made Christopher Johnson ask Farlington's boys whether, when more suo they wished him away, they did not repent when they got More; and he congratulated those who were not under More that they lived in softer times. More left his mark at Chichester in his arms on the gateway of the Vicars' Close. From Chichester he returned as warden in 1526 and has left a signal memorial of himself in Election Cup, a silver gilt bowl which managed to escape Charles I., and is the oldest piece of plate the college now possesses. It only appears on table at Election, or, as it is now commonly called, Domum dinner. His successor, Erlisman, had been headmaster of Eton from I $5 \mathrm{II}$. To him, or to the warden of the time, Rede, not surely to More, must be attributed the credit of having first given a complete summer holiday to the whole school; for, according to Mr. Kirby, in the first week of 1518 not a single scholar was in commons, a thing which had never occurred before, and must have been more or less of an accident, as it did not occur again till I 522 . The fact is, that whether a scholar went home for the holidays in those days depended not so much on the authorities as on his parents. There was a regular exeat for about a fortnight at that time, when a scholar could go away if his parents lived near enough or were rich enough to send for him. As late as 1682 it was not a universal rule for every

1 Annals, p. xi.; Scholars, pp. 83,91,98. He is called in the Account Rolls Mr. Farlton and John Farlyngton, and in his will P.C.C. Porch 22, John Farylton, William Farlton being his brother and executor. 


\section{A HISTORY OF HAMPSHIRE}

one to go home for the holidays, as a young Verney wrote ${ }^{1}$ in a most anxious strain-

I desire to let you understand that we shall Breack up on the Whensday before holy thursday. And, Sir, I would desire you to let your horses be here on the Satterday following that I may be going on Bloddy munday, upon which day all the Children and Commoners and Gentleman Commoners goe home and after that day noe body stays but some of the Children which the Warden makes stay here for some notorious action they have committed. Sir, I being a Commoner in the Coledge I can't stay after the time which I might if I was as Mr Coper is. I write this to you, Sir, to let you know that we Cannot stay after the time as you used to do when I was at Bister, but such a thing was here never known, for Gentleman Commoners to be sent for after the time it would be a very Great disgrace, besides I doe not know whether the warden will let me stay after the time.

In I 526 came a headmaster of whom hitherto little beyond his bare name has been recorded, which is rather a peculiar one, John Twychener. He and his brother and successor in I 53 I, Richard, came from Wokingham, Berks, where was an ancient grammar school, founded by Moleyns, dean of Salisbury, in the reign of Henry VI. His name puzzled the scribes of the day, who give it the most varied form, Tuechener, Touchener, Tochyner, Touchner. Johnson speaks of Richard with unstinted praise-

Te tua posteritas pro miti laudat et aquo

Invideo fame jam Twichenere tua.

Thee mild and just posterity proclaim

I envy thee still, Twychener, thy fame.

The elder brother he seems to have looked on as more of a parson than a schoolmaster-

\footnotetext{
Grammaticen, Twichenere, licet docuisse feraris, Summa tamen studii pagina sacra fuit.

Twychener taught grammar, so 'tis said,

But 'twas theology he chiefly read.
}

Yet by a curious piece of fortune we know more about what he taught as a master than any of his predecessors or than any of his successors until we come to Christopher Johnson himself.

A most interesting discovery has now to be related. This is nothing less than the curriculum of the two chief schools in England in the year I 530 . In 1525 the foundation ordinance of the grammar school of Saffron Walden in Essex was made by the sister and heiress of the founder, John Leche, vicar of the parish, who may perhaps be the John Leche who was scholar of Winchester in 1445 . He in $1514^{2}$ had founded, or rather procured a legal licence for, the brotherhood or gild of the Trinity in the parish church, and had intended that the priest of the gild should also 'teach children in the said town their grammar freely (i.e. gratis) and others that would resort there,' but, dying, he 'referred the ordering of the said priest to Dame Johanna (Jane) Bradbury,' his sister. She procured a licence in mortmain, dated 24 August, I 522, for the foundation of a school in 'Cheping Walden,' as Saffron Walden was then called, and 


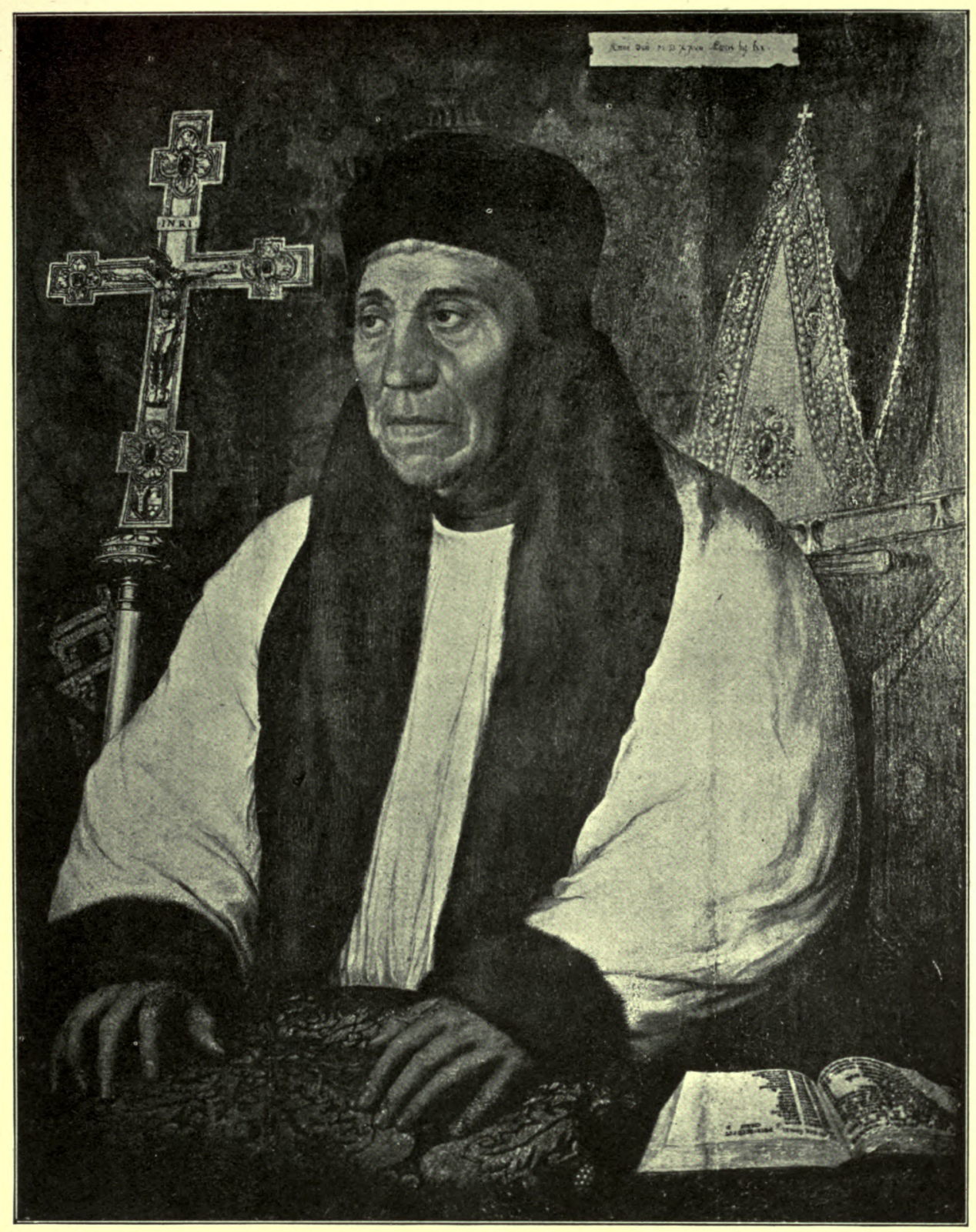

William Warham, Lord Chancel.lok, Akchbishop of Canterbury. College, i469-7I. From a picture in the possession of Lord Dillon. 



\section{SCHOOLS}

endowed it with an annuity of $£_{\mathrm{I} 2} 2$ a year, or not much less, allowing for his having to find himself, than the pay of the headmasters of Winchester and Eton. By an order of I 5 May, I 525, she appointed William Dawson, who had already taught children grammar there for four years and 'approved himself a profound grammarian,' the first chaplain-master for life, and directed that the treasurer and chamberlains of the gild should appoint his successor, who was always to be a 'sufficient and able chaplain, not being beneficed nor advanced to any spiritual or temporal promotion, being a sufficient grammarian to teach children grammar after the order and use of teaching grammar in the schools of Winchester or Eton,' and he was to teach 'after the form and use of one of the said schools that should be there taught,' not only 'literature but good manners' (bonos mores, i.e. morals and manners). The gild and school were confiscated by Edward VI., but the town bought them back, and the municipal corporation which took the gild's place took also the duty of maintaining the school, which still flourishes and does good work after its kind. In 1852 the noted antiquary, Thomas Wright, published ${ }^{1}$ from the town records what he called 'Rules of the Free School at Saffron Walden in the reign of Henry VIII.' In his edition one of the two papers so dubbed purports to be signed 'By me Johan Twithener, schoolmaster. By me Thomas Brownyng, Ussher.' Mr. Wright conjectured that Twithener was 'evidently the same who in the list given by Lord Braybrooke in his History of Saffron Walden is called Worthend, and who was Master of the school from 1545 to I 547.' The assumption was somewhat violent, though not perhaps without justification, since Lord Braybrooke had misread an injunction in favour of the grammar school in 1423 , allowing the curates of the church to teach 'the alphabet and graces but not higher books' into an injunction that they might "teach the Greek alphabet,' and Saffron Walden has consequently been quoted as the first school in England to teach Greek at a quite impossible date. The graces were simply the graces before and after meat. In fact, the name of the schoolmaster who signs the document in question is neither Worthend nor Twithener. It is that of our good friend John Twychener ${ }^{3}$ when he was headmaster of Winchester, as is conclusively proved by Thomas Brownyng signing with him as usher, while the other document is signed 'By me Richard Cox, Schoolmaster.' Now Richard Cox was the contemporary headmaster of Eton. It is clear that the profound grammarian, William Dawson, or the foundress, Lady Bradbury, since the school was to be conducted after the 'use' of Winchester and Eton, had taken the wise course

1 Archaologia, xxxiv. 37.

2 The original document is at Audley End now. It is perfectly plainly in alpbabeticis et graciis not alphabetis gracis. Oddly enough this same passage was converted by Mrs. Green in Town Life in England in the Fifteenth Century into an inference that there were fifteenth century 'schools of deportment,' the graces being supposed to be connected with the Three Graces. Lord Braybrooke also dubbed schoolmaster Dawson a knight because he found him called, like William of Wykeham in Froissart and Hugh Evans in Shakespeare, 'Sir' William Dawson.

' The ' $c$ ' has, as so often happens, been misread ' $t$ '. It is perfectly plain in the original book at Saffron Walden. 


\section{A HISTORY OF HAMPSHIRE}

of going to the fountain head and obtaining from the masters of Winchester and Eton exactly what their 'use' was. The date is fixed to $153^{\circ}$ as nearly as possible. For John Twychener, scholar 1515, M.A. 1525 , became headmaster in 1526 and left in 1531 ; Thomas Browning, scholar 1519, became usher 1529 and retired in 1533; while Richard Cox became headmaster of Eton in $1528^{1}$ and retired in 1534. The date therefore lies between I529 and I531. While the Eton document ${ }^{2}$ is intact, the Winchester document has most exasperatingly lost its first leaf. To judge from the Eton document, it began with a general statement of the hours of school, the arrangements as to discipline, including that of 'prepositores in the feld when they play, for fyghtyng, rent clothes, blew eyes or siche like,' and also for 'ill-kept hedsys, unwasshid facys, fowle clothys and sich other.' All that the master asked of a new boy at Eton was 'what frendys he hathe, whether there be any plage,' showing how the plague was still endemic. After the general statement followed a tabulated scheme of work. The statement as to Winchester now starts with such a scheme of work, in the middle of a sentence, 'Ovide Metamorphosesos the Thursday, Salust the Fryday, with the vij forme, and at afternone rendering of there rulys. The Saterday lyke as the vij forme. The Sonday lykewise.' Next comes the heading 'the Vth forme,' to be followed by headings of 'the Third,' 'the Seconde' and 'the Fyrst forme.' To any one acquainted with Winchester School or its history this is startling. For hitherto from time when the memory of man runneth not to the contrary up to the present day Winchester has known only three forms, called Sixth, Fifth and Fourth Book. It has been a subject of much discussion whether there ever were any other forms, and if so when the others disappeared. Now we learn for a fact that at Winchester, as then at contemporary Eton, and as at Westminster from its foundation thirty years later until now, there was a Seventh Form above Sixth Book and three forms below Fourth Book. Premising that, owing to the loss of the first page, we only know for certain what the Fifth and lower forms did, the work may be thus summarized.

The first work in the morning on coming into school at seven o'clock, from Monday to Thursday inclusive, seems to have been the giving out of grammar rules. In the Fifth to Third Forms these were taken from Sulpicius, a schoolmaster at Rome, of Veroli in the Campagna, who published many grammatical works in Latin between I 487 and 1506 . One of the Sixth Form gave them out to the Fifth, and one of the Fifth to the Fourth, but the usher gave them out to the Third. Form V. did 'versifical rules' or rules for making verses; Form IV. the rules for preterites and supines; and Form III. the rules for genders and heteroclites or irregular declensions, all of which

1 Sir H. Maxwell-Lyte says that the Eton Accounts show Richard Cockys paid fo $106 s .8 d$. in 1528-9, of which 6s. 8d. for the previous year, so he must have come early in September, 1528 .

2 This document did not escape Sir Henry Maxwell-Lyte's eagle eye in his History of Eton; but he accepted it as applying to Saffron Walden, and did not perceive that it belonged to Eton itself. 


\section{SCHOOLS}

were separate works of the most heart-rending detail. Forms II. and I. took their rules from the Parvulorum and Vocabula (the Babies' Book and Word Book) of Stanbridge. On Friday morning they were examined on these rules, and Friday afternoon 'rendered' them, which appears to mean said them by heart. After rules were given out, Forms V.-III. were examined on a verb which they had 'set up' over-night, and made 'vulgars' on it, i.e. Latin phrases, as in Horman's Vulgaria. V. and IV. together then 'write down the Latin that one of them shall make by the assignment of the Master,' or as it is phrased for III., 'they have a theme to be made in Laten, the which Latyne one of the said forme at the pleasure of the master makith openlie dyverse ways. And after that they write the master's owne Latyne,' that is, the master dictated his own version of the piece. Form V. also learnt by heart Sallust on Monday, Tuesday and Wednesday, and four verses of Ovid's Metamorphoses on Thursday. For translation, or 'construction' as it is called (which was apparently done not 'up to books,' i.e. in form, but in 'books chambers,' sitting at their separate 'toys' or desks in chambers), they did Virgil's Ecloges every day except Friday and Saturday. On Friday they translated Tully's, or as we say, Cicero's Letters. On Wednesday they composed Latin verses, on Thursday Latin epistles. On Saturday, V. and IV. said twelve verses of Ovid 'without book,' and were examined on them and showed up their Latin prose. In the afternoon they construed Cicero and showed up their epistles. The Fourth, instead of doing Virgil, did Terence from Monday to Thursday inclusive, which the master construed to them in the morning and they construed and parsed (parce) to the usher in the afternoon, and were examined in it on Saturday afternoon. Form III. construed Æisop's Fables on Monday and Wednesday, and Lucian's Dialogues, presumably in Latin, on Tuesday and Thursday; while Forms II. (and I. ?) construed Assop's Fables every day except Saturday, when they had repetition of four verses of Cato and examination of it.

On Sunday the Sixth Form did 'lykewise' to the Seventh Form, and the Fifth Form did 'as the other hie formys dothe'-but what they did is denied us through the loss of the first page. It was certainly not a day of rest. For the Fourth Form on "the Sunday with other low holy dayes' did 'an English of an epistle to be made in Latyn diverse wayes, and somtyme Tullie's Paradoxes to be construyd,' the Third Form had ' a dialogue of Lucyane or a fable of Æsop to be said without book and construed,' and the First, and presumably the Second, 'a fabull of Æsope.'

The books used in the higher forms can only be inferred from the Eton list. They comprised in the Fifth Form Despauterius, who calls himself Ninivita and was headmaster of Bergis (? Bergen-op-Zoom) School or 'versifying rules' and letter-writing; and in the Sixth Form the Figurae of Mosellanys, a schoolmaster named Schade of Leipzig, terribly detailed excursuses on the figures of speech, and Erasmus' Copia Verborum. The authors read were: in the Fifth Form Sallust for the three first days 


\section{A HISTORY OF HAMPSHIRE}

of the week; and in the Sixth and Seventh Horace or Cicero; while all three Forms read Cicero on Thursday, and the Eneid on Friday and Saturday.

A fortnight in every quarter was given up to examinations.

John Twychener must have been more of a schoolmaster and less of a theologian than Johnson thought. In 1535 the Valor Ecclesiasticus ${ }^{2}$ reveals him to us as still engaged in the practice of his profession at the Grammar School, or, as it is now called, the Prebendal School, of Chichester Cathedral. Under the heading of the Prebend of Highleigh is 'John Tychenour, clerk, prebendary there.' The prebend is said to be worth $f_{1} \mathrm{r} 36 \mathrm{~s} .8 \mathrm{~d}$. clear, after a pension paid to the Dean and Chapter of 3 Is. $8 d$. and $f_{2} 2$ paid towards the annual salary of an undermaster of the Chichester Grammar School. The prebend had been annexed to the mastership of the Grammar School by a statute of the cathedral made by Bishop Storey 18 February, $1498 .^{2}$ It may seem strange to us now that the mastership of the Prebendal School, Chichester, was promotion for the headmaster of Winchester. But though the nominal yearly value of the place may not have been any greater, and was indeed rather less, yet its being coupled with a canonry and with prebendal estates, the fines for renewing the leases of which accrued to the schoolmaster, while probably the number of ' grammar scholars flocking to the said school' was considerably less than at Winchester, perhaps made it a more desirable piece of preferment. In I 538 Twychener justified, or perhaps gave occasion to Johnson's view of him, by passing on to the prebend of Wittering, to which the theological lectureship of Chichester Cathedral was attached.

\section{The Dissolution}

The second Twychener was succeeded in the headmastership in 1535 by a person who fell on troublous times and made some trouble in the world himself, John White. He came of a good family, being the younger brother of Sir Thomas White of Farnham, who was lord mayor of London, and a cousin of the Sir Thomas White whose name is well known in the annals of charities, having founded a loan charity for money to be lent to poor tradesmen in twenty-four cities and boroughs, mostly now applied in aid of schools in the respective localities.

The commissioners appointed under the Act for First Fruits and Tenths did their work quickly. The commission for Hampshire was issued on I February, I 535, and by 2 May the return was finished and sent in. Latin) :-

Their certificate for Winchester is as follows ${ }^{3}$ (the original is in

1 Valor Ecclesiasticus, Record Commission (1 8 I 1), i. 301 .

\& History and Constitution of a Catbedral of the Old Foundation, by Dr. Swainson (1 880), p. 107.

3 Valor Ecclesiasticus, ii. 4 . 


\section{SCHOOLS}

College of the Blessed Mary by Winchester, is worth in the rent of lands, with all other revenues, as well spiritual as temporal as appears by a book ${ }^{1}$ (quaternum) signed by the hands of the Commissioners . . . . . . . . . . .

Reprises in alms, fees and other payments, as appears by the said book

$$
\begin{aligned}
& \text { E. } d \text {. } \\
& 71080 \\
& 81146
\end{aligned}
$$

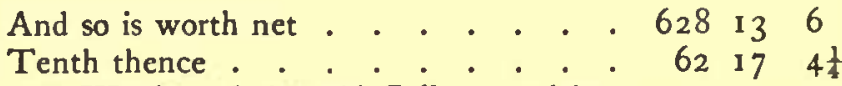

$$
\begin{aligned}
& \begin{array}{lll}
74 & 4 & 2
\end{array} \\
& \text { I } 185 \\
& 49 \quad 4 \frac{1}{2} \\
& \begin{array}{lll}
6 & 13 & 4
\end{array}
\end{aligned}
$$

Edward More, now Warden of the said College, and has of the goods of the College, and the rents aforesaid yearly . .

Wm. Pyle, Jn. Hasard, Jn. Harvey, T. Basset, Jn.

Chubbe, Edmund Keyt, T. Brownyng, Rt. Stevyns, Wm. Baker, Jn. Rytte, Fellows. These yearly take for dividends from the aforesaid rents

John White, layman, Master (pedagogus) of the boys receives yearly from the rents aforesaid.

Richard Sedgrave, Under-master (sub-pedagogus). . . .

Richard Philippes, Chantry Priest (cantarista), in the said College of the foundation of John Fromond takes yearly from the rents aforesaid

The college took exception to the valuation for two reasons, stated in a letter from Bishop Gardiner, the head of the commission. ${ }^{2}$ First, they objected to being charged at all in regard to the chapel of the Holy Ghost in the Isle of Wight, or other places where 'Chantries be not perpetually assigned to any spiritual man; where there groweth no profit to the incumbent by any special revenue, and that he may be removed at pleasure.' Secondly, 'Considering the act maketh mention of all alms to be allowed, given by foundation, therefore finding of poor children in the New College beside Winchester ought also to be deducted : being their portion so little that it cannot be less.'

Gardiner observed on this, "The title of almes; although in our judgment we understand it, and have made allocations thereafter, in the finding and nourishing of old and impotent and lame men; yet we have not so deemed it in the finding of young children to school. We used herein a distinction of finding which in poor and impotent men is without other shift necessary to live by. But in children no such necessity to find them to school.' So the 'children' in the return were treated as a quantité négligeable and not even mentioned.

There is every reason to believe that the valuation, which was made by the parties to be charged to a commission of which the bishop was everywhere the head and the returning officer, erred, if at all, on the side of undervalue. Certainly it was so with the college; for at the closer scrutiny which took place twelve years afterwards the income was returned at no less than $\oint_{2} 5^{\circ}$ more, and the warden's income at $\oint_{0} \mathrm{I} O \mathrm{I}$ instead of $\oint_{0} 22$.

One of the most interesting points disclosed by this return is that the headmaster was a layman. It is highly probable that White's

1 Unfortunately this book is not forthcoming.

2 Strype, Ecclesiastical Memorials, vol. i. pt. i. 328 . 


\section{A HISTORY OF HAMPSHIRE}

immediate predecessors and successors as headmasters were laymen also. Nor would it be surprising that they should be so, as they were for the most part very young men. White was twenty-eight on his accession; his predecessor Richard Twychener, only twenty-five ; and his brother and predecessor, John, only twenty-four. Erlisman was thirty-four, but then he had been headmaster of Eton first for some six or seven years. The usher, Richard Sedgrove, a scholar in 1518 , was older than either the headmaster or his predecessor, but he was only thirty. We know that the great Elizabethan headmaster, Christopher Johnson, was a layman, for he retired to practise as a physician in London.

The college, in Mr. John White's first year of office, had to undergo three distinct and different visitations. The first was by Master Dr. Cox, as commissary of the Archbishop of Canterbury, in virtue of his provincial supremacy as primate of all England. This cost $£ 54 \mathrm{~s} .8 d$. The next, the ordinary visitation by the warden and posers of New College, with Dr. London as warden, cost $£_{7} 7 \mathrm{~s}$. 9d. The third, that of Dr. Lee, 'Commissioner of Master Thomas Cromwell, coming with the same Master Thomas Cromwell, General Visitor of the Lord the King' was the least expensive, costing only $£_{3} 3$. This is a valuable historical entry. It has been represented ${ }^{1}$ that the visitation was directed only against the monasteries or the universities, which Gasquet represents as ' regarded as monastic institutions,' and as mainly for the purpose of laying on them excessive contributions. It was, in fact, simply a visitation to assert the king's supremacy, modelled on the visitations made by Archbishop Warham and others as papal legates. The only present given even to so great a man as Cromwell, the 'King's Vicar-General in Spirituals' was an old silver salt-cellar, mended up at the cost of $5^{\mathrm{s}}$. rod.; a gift of no greater value than was habitually given to judges of assize and other 'great ones.' The king himself came to Wolvesey at the same time, and was presented with 'two oxen, ten sheep, and twelve capons for his favour in matters concerning the College,' at a cost of fo 6 s. $4 d$. Was this favour, one wonders, anything to do with the act of parliament passed in 1536 , which exempted the universities and their colleges, and Winchester and Eton, from the payment of the tenths to ascertain which the Valor was made? This Act (27 Henry VIII. c. 42) was entitled 'An Acte concernyng the exoneracyon of Oxford and Cambryg from payment of there fyrst frutes and tenths.' The reason for it is stated to be that Henry, "With the fervent zeal his Majestie hath conceyvid and bearith ... to th'increase of the knowledge in the 7 liberall sciences and the 3 tonges of Laten, Greeke, and Hebrewe to be by his people applied and larned, Consideryd that if his Highes shulde use his right in the Universities of Oxforde and Cambridge, or in the College of our Ladye of Eton besydes Wyndesore, or Saynt Marie College of Wynchestre besides Wynchestre, where youth and good wytts be educate and nourysyhed in vertue and larnyng ... the same should percaas 


\section{SCHOOLS}

discorage mannye of his subjectes, whiche be both apte and wyllyng to applye theymselfes to larnyng, and cause theym, by reason of the tenuytie of lyvyng, to withdrawe and gyve their mindes to suche other thynges and fantacies as shulde neyther be acceptable to God nor profittable for his publique welthe.'

In consideration of the remission, each college at the universities was to maintain a public lecturer in such science or tongue as the king should appoint, while the chancellor of the university, the provost of Eton, and the warden of Winchester were each to maintain-

Two masses to be there solempnely sung, whereof one shall be of Holye Trynyte the 8 day of Maye, and the other of th'olye Gooste the 8 day of October, for the presarvacion of the Kynges Highesse and the mooste excellent Prynces, Quene Anne his wyfe, and the right noble Princes Elizabeth, daughter of our said Soveraiyne Lorde and of the said Quene Anne, during their lyves; and after the decease of our said Sovereiyne Lord' two anniversaries 'with dyrige over night and mass of requiem in the next morrowe' of those days.

This coupling of Eton and Winchester with the universities, as if they were part of them, had a most important effect, and was the means of saving them from destruction in the general dissolution of colleges.

The dissolution of monasteries which began that year could not in any case have been long delayed. Wykeham and Chicheley had dissolved monasteries by purchase to apply them to the purposes of the secular clergy and of general education, then an ecclesiastical purpose. Waynflete, Wolsey, Fox and 'Saint John' (Fisher), as by papal authority he is now officially designated, armed with papal bulls, confiscated monasteries on the ground of uselessness or irregularity, without payment, for the like public purposes.

We recognize two of the most prominent of the monastic visitors who took part in the dissolution of the monasteries as Wykehamists. One of them, Dr. London, who had been domestic chaplain to the 'saintly and venerable' Warham, was warden of New College and dean of the ancient college of Wallingford. Another, perhaps the first in the field, was Dr. Bedyl, who was secretary to the same archbishop, archdeacon of London and clerk of the council. Both of them in the usual way were canons of divers cathedrals.

In the last years of Henry VIII. the history of the college narrowly escaped being brought to an abrupt conclusion. Colleges, hospitals and chantries were included in the Act of 1539, which confirmed the suppression of the larger monasteries already made or to be made. Under this Act Chicheley's college of Higham Ferrars disappeared, being granted to the Dacres, now Fitzwilliams; and at Winchester the Old College (Pontissera's college of St. Elizabeth) found its way by purchase into the hands of Thomas Wriothesley, knight, Lord Wriothesley. He was a Hampshire man and steward of Winchester College. It was granted him by letters patent ${ }^{1}$ on 29 March, 1 543, in considera-

1 Pat. 35, Henry VIII. p. 9, m. 33-4. 


\section{A HISTORY OF HAMPSHIRE}

tion of $£_{5} 500$ and a rent of $£_{3}$ I 5 s. for the lands and 2s. for the site and buildings. On 18 April, he sold it to Winchester College for $£_{3} 360$. The college covenanted that they would before Whitsuntide, I 547-

Transforme and make of the said late Collegiate Church, College or Chappell a Grammar School; and therein to be dayly tawght the number of persons nowe usually tawght within the said Newe College of Seynt Mary besyds Wynchester afforsead; and in that case, within the said tyme, to deface the howse of the said College of Seynt Elyzabeth, or the gret parte of the same, or elys within the saide tyme to enrace, pull down, and utterly deface the said Church Collegiat.

This seems to mean that they were to use the college as school instead of what is now Seventh Chamber. The condition shows that the original school was already overcrowded, and to use St. Elizabeth's as a school would have set free Seventh Chamber for more commoners. It is greatly to be regretted that this step was not taken. Not only should we have had a building of perhaps the most beautiful of all styles of architecture preserved, instead of the 'Glorious Revolution' building we now enjoy, but the site and grounds of college would have received a great lateral extension, and the school would not have had its development curtailed for a hundred years and more by lack of playing fields. But the college either shrunk from the expense, or as is more probable were too fossilized in their notions to give up the old school. They preferred to pull down St. Elizabeth's and use its stones for the extension of their own 'Meads' wall, so that the new part looks much finer and more ancient than the loftier wall built by Wykeham. The alternative of total demolition was not uncommon. It was the practice at the dissolution of the monasteries to deface the buildings and take the lead off the roofs so as to prevent the possibility of the return of the inmates.

Long before Whitsuntide, I 547, the New College itself was included in the 'Act for Dissolution of the Colleges,' commonly called the Chantries Act ; ${ }^{1}$ or, as it is more exactly headed in the chancery rolls, 'An Act for the Dissolution of Colleges, Chantries, and Free Chapels at the King's pleasure.' Section 6 of the Act, by including ' all colleges as well chargeable as not chargeable' to first-fruits and tenths, deliberately swept all the colleges in the Universities, together with Winchester and Eton, into the net. Power was given to the king to issue commissions whenever he pleased, and take them 'into the King's Highness, his heirs and successors for ever.' The first thing to be done however was to find out what there was to take, and commissions of 'survey' were therefore issued to every county on 13 February, 1546 . Hence the appearance of Winchester College in the first series of chantry certificates.

\section{Comitatus Southampton' et Berk'.}

Sir John Wellesborne, Kt., Walter Hendley, Richard Worseley, George Powlet, Richard Powlet, Esquyers, and John Hammond, gentylman, Commyssyoners.

1 Stat. 37 Henry VIII. c. 4 .

- English Schools at the Reformation, pt. ii. p. 58. From Record Office, Chantry Certificates, No. 5 I. 


\section{SCHOOLS}

\section{The Suburbse of the Towne of Wynton}

One Colledge of our lady there, founded by-

William Wykeham, somtyme Bysshope of Wynton, by the licence of Kynge Rycharde the Secounde ; For one Master or Warden, 70 Scolers, 10 felowes, beying prestes, 3 Conductes, prestes, 3 clerkes, 16 queresters, one Scole master, and one vssher of the gramer scole, And Also one master of the songe scole for the queresters aforsaid, All whiche nomber ar there Resydent, euery of them at this present to do His Offyce.

The said Colledge ys scytuate nyghe Wynton, almoste vnder the Walles of the said Towne of Wynchester.

The value of All the londes apperteynynge or belongynge to the said Colledge, $£ 947$ 7s. 7d. Whereof-

For Annuall Fees and for Rentes Resolute, pencions, procuracions, and Sinodals, by yere, $£ 96$ 6s. I I $\frac{1}{4} d$.

For the Warden's Stipende, with His Commons, fior i 8 s. $8 d$.

For 70 scolers and 16 querysters for theyr porcion and Comons, $£ 3084$ s. $8 d$.

For Io Fellowes For theyr porcion and comons, $f_{1} 54$ 2s. $4 d$.

For the porcion of 3 Conductes, 3 Clarkes, the Master of the songe scole, the Master of the gramer scole, the vssher, and other officers belongynge to the same Colledge, and for theyr Comons, $\oint_{1} 22$ 7s. $10 \frac{1}{2} d$.

For Wages and lyuers ${ }^{1}$ for certyn seruauntes in the said Colledge, $£ 32$ I 7 s. $4 d$.

For the stipend of one Chauntre prest, ${ }^{2}$ founded in the Cathedrall Churche of Sarum, $£ 7$ 6s. $8 d$.

For Almes, $£^{8}$ os. $20 d$.

For diuers expenses for the said Colledge, as for the progresse, seruauntes lyuerye for progresse, Visitacions of the Bysshoppe; For Wex, wyne, oyle and candelles, f4I I 4 s. $2 \frac{1}{2} d$.

The Tenth Reserued of all the Hole possessions of the said Colledge, $£_{3} 2$ 2s. $4 \frac{1}{2} d$. [total] $\left\{905\right.$ 2s. $8 \frac{3}{4} d$.

And so Remayneth $£ 42$ 5s. I $\frac{1}{4} d$., Whych ys ymployed towardes the Repayrynge of the tenementes and londes.

Ornamentes, plate, Juelles, goodes and catalles merely Apperteynynge vnto the forsayd Colledge, as Apperyth by the Invetory thereof made to the sayde comyssyoners, nott Praysed.

One Chauntre within the colledge of our Lady Aforsaide. Founded by-

John Froreman, ${ }^{3}$ and Mawde, hys $\mathrm{Wyff}$, to the entente to haue a prest to synge in the chappell within the Cloyster of the saide Colledge three tymes in the Weke, And so to serue And singe in the quyer of the same Colledge one the Holydayes.

The said Chauntre ys scituate in the said Chapell within the Cloyster of the said Colledge.

The value of the said Chauntre ys in Mony nombred $£^{6}$ i $3^{\text {s. }} 4 d$.

Whych the prest hath and dothe Receyve For His Annuall stipend.

Ornamentes, plate, Juelles, goodes and catalles merly Apperteynynge to the said chauntre there are none, but yt ys seruyd with the ornamentes of the said Colledge.

When the amount given in the Chantry certificate is compared with that given in the Valor Ecclesiasticus two years before, the two would hardly seem to refer to the same institution. The gross value is raised from $\oint_{0} 700$ odd to $\oint_{947}$. The wardenship instead of being put at $f_{0} 22$ odd is represented as worth $f_{0} \mathrm{I} O \mathrm{I}$ I $8 s .8 d$. The seventy 'scolars' and sixteen 'querysters' appear instead of being ignored, and ' theyr porcion and commons' are put at $\oint_{3} 308$ 4s. 8d., while those of the ten fellows are given at $\oint_{1} 542 s .4 d$.

The extra $£ 200$ a year now shown must have made the college

1 Liveries.

II
2 Hulse's Chantry.
3 Mistake of the scribe for Fromond. 


\section{A HISTORY OF HAMPSHIRE}

seem a very tempting morsel. That it would not have been long spared is likely by the example of the colleges of Pleshy, Hastings, a royal chapel; Tong, which was not saved by its grammar school; and St. Edmund's College, Salisbury, which even its title as one of the earliest of university colleges, did not preserve. These were all taken in the last few months of 1 546. But in January, 1547 , Henry VIII. died. The powers of the Act were only for his life, and by his death the college was saved.

Edward VI.'s parliament met in November, I 547, and very soon passed a new Chantries Act, under which, according to the preamble, the chantries and colleges were to be converted 'to good and Godly uses, or in erecting of Grammar Schools,' and 'the further augmenting of the Universities.' After such a preamble the colleges in the universities could hardly be destroyed, and accordingly a special clause was put in to exempt the colleges, hostels and halls of the universities and chantries therein: the new chapel of St. George the Martyr in the castle of Windsor, 'St. Mary's College of Winchester of the foundation of Bishop Wickham, and the college of Eaton.'

Mr. B. Wilson, writing the history of Sedbergh School, Yorkshire, ${ }^{1}$ complained of the 'shameful partiality' with which Winchester and Eton were specially exempted. It certainly was a strange way of improving grammar schools to rob them of all the lands they possessed, as this Act did in the case of some 250 grammar schools. ${ }^{2}$ In the case of Sedbergh, founded by Roger Lupton, a provost of Eton, it must have seemed peculiarly hard that while his chantry at Eton, wholly superstitious, was preserved, his chantry at Sedbergh, where the priest's main duty was to teach a school, was destroyed. But the partiality was not so scandalous as it seems at first sight. Winchester and Eton were not saved on their merits so much as because they were regarded as part of the universities. Winchester was really inseparable from New College, Oxford; Eton from New College, Cambridge, as King's was sometimes called. With the university colleges they were exempted from subsidies in 1496, when nearly all other ecclesiastical foundations were made subject to them. With the university colleges they were as we have seen exempted from tenths and first-fruits in 1536 . Magdalen College School and Wainfleet School were saved for the same reason, though without express mention, as they actually received their endowment from the college. Winchester and Eton, though nominally independent as regards estates, were really more intimately connected with the universities than Wainfleet. The plainest statement that they were regarded as part of the universities is contained in a letter from the privy council to the commissioners for church goods for Hampshire in $1553^{\circ}$

Forasmuch as it is fit that New Colledge of Winchester within the same county, being a member of th'University of Oxon., should have and enjoy such liberties as the said University doth, His Majesty is pleased that the said college shall have and

1 Sedbergh School Register, p. 3 (Richard Jackson, Leeds, 1895).

2 English Schools at the Reformation, p. 91.

3 Annals, 241. 


\section{SCHOOLS}

enjoy all their plate and other ornaments belonging to their church, so as they convert the same from monuments of superstition to necessary and godly uses for the maintenance of the same College.

So too Queen Elizabeth allowed Winchester and Eton to retain Latin services like the universities. The Commonwealth placed Winchester under the Oxford University Commission; and in our day the Oxford University Commission of 1857 made statutes for it as part of the university. It was therefore precedent not partiality that saved Winchester and Eton from Edward VI., 'spoiler of schools.'

Winchester thus saved from destruction was not left to its own devices. It was promptly visited by a royal commission of reform, which issued a batch of injunctions. ${ }^{1}$ They directed that the Biblereading in hall should be in English-

distinctly and apertly in the midst of the Hall, above the hearth where the fire is made, both at dinner and supper.

Grace and other prayers were also to be in English, and 'they shall henceforth omit to sing or say "Stella cali" and "Salve regina," or any other such like untrue and superstitious anthems.' 'Thus was the queen of heaven deposed in her own college.

These injunctions are remarkable for the very strong official recognition they gave to commoners. Injunction 2 directs that-

As well all the scholars of the said College and foundation, and others coming to the same School, being able to buy the New Testament in English or Latin shall provide for the same betwixt this and Christmas coming.

Injunction 6 has the same expression with regard to the provision of Erasmus' catechism, which the warden or a sufficient deputy should read with them, 'proving every article thereof by the scripture.' $\mathrm{He}$ was also to read to the unhappy boys the Proverbs of Solomon or Ecclesiastes for a whole hour every Sunday or holy day. The use of the primer set forth by the king's authority, otherwise King Edward VI.'s Latin Grammar, was commanded, and 'in all prophane authors' the warden and schoolmaster were directed 'to refute and reply by allegation of scripture all such sentences and opinions as seem contrary to the word of God and the Christian religion.' Injunction IO and I I directed that-

As well the Warden or every Fellow and Conduct teaching the children shall have for his and their pains one yearly stipend of the common goods of the College, taxed by the Warden, with the assent of the more part of the Fellows: and the Schoolmaster and Usher to have the old accustomed stipend of Commensals, and the Warden, Fellow or Conduct to require no part thereof. Ix. Item, that no person in the said College have the correction of the Grammarians besides the Warden, Schoolmaster, Usher, and such Fellow or Conduct as shall control them in the Warden's absence; and that there be no excess correction, but that the same may be mitigated by the Warden's direction.

The injunctions suggest that there was a considerable number of commoners attending the school, who were neither scholars nor commensals. They also show that the schoolmaster and usher were not left

\footnotetext{
1 Wilkins' Concilia, iv. 8.
} 


\section{A HISTORY OF HAMPSHIRE}

single-handed to deal with them. It is strange to find that not only the fellows and conducts used to assist in teaching but the warden himself. The words can hardly refer only to the lectures in religion to be given under the injunctions; so that it is just possible that the real origin of the Beaufort injunction against commoners was the warden's desire to share in the profits of teaching them, and the effect to enable him to do so. This may account for so many of the headmasters being elected wardens.

There is rather striking testimony to the efficiency of Everard's teaching in spite of his heavy hand. In the autumn of 1552 , Edward VI. and his council made a sort of progress through Surrey and Hampshire, spending the greater part of July and the whole of August there, and visiting Winchester on 5 September. The congratulatory verses written by the boys on this occasion are preserved in the king's library at the British Museum. ${ }^{1}$

No less than forty-three boys wrote copies of verses, of whom five were commoners; at least their names do not appear in Scholars. The verses were in all varieties of metres, sapphics, alcaics, iambics and other Horatian metres, as well as hexameters and elegiacs; and the general average of merit is very high. One of the cleverest is a dialogue between 'A Child' and 'Echo,' by a small boy, Edward Tichborne, only twelve years of age, admitted only the year before. There is one very creditable copy of Greek iambics by Thomas Stapleton, who, becoming a canon of Winchester under Mary, turned a Roman Catholic, retiring abroad at the purgation of New College in 1562, and died professor of divinity at Louvain.

When Queen Mary came in and was married to Philip in Winchester Cathedral, the boys greeted them with equally loyal and learned effusions, under the guidance of White as Warden, who as headmaster under Henry VIII. had ' 'made certain verses extolling the King's supremacy, and against the usurped power of the Bishop of Rome, which said verses he caused his scholars to learn, and to practise them in the like argument.' Shortly after as Bishop of Lincoln he was trying and sending Cranmer to the stake ' for the like argument.'

Boxall succeeded him as warden. He was made archdeacon of Ely, and in 1556 employed as ambassador to France on matters concerning Calais. In 1557 he became Secretary of State, ${ }^{8}$ and was endowed with three deaneries-Peterborough, Norwich and Windsor. College therefore could not have been much troubled with his presence.

White, translated to Winchester on Gardiner's death, preached the funeral sermon on Queen Mary. It is impossible not to admire the mixture of dignity and impudence with which he praised his dead mistress. "She had left a sister to succeed her, a lady of great worth also, whom they were bound to obey, for "better is a living dog

\footnotetext{
1 Royal MS. A. xxxiii.

3 Acts of the Privy Council, 1556-8, p. 70.

2 Foxe's Martyrs, ed. 1, ii. 845 . 


\section{SCHOOLS}

than a dead lion," and I hope she shall reign long and prosperously over us. But I must say with my text, " the dead are more to be praised than the living," for certain it is " Mary hath chosen the better part." He was very tenderly treated for this utterance, being only commanded to keep his house, and released even from that after a 'good admonition ' by the lords of the council.' But as he afterwards 'would needs preach, which he did, seditiously in his Romish pontifical vestments,' he was sent to the Tower in April, I 559, and eventually deprived. $\mathrm{He}$ found in the end that discretion was the better part of valour, ' and upon acknowledgment of his misdemeanours he was set free, and died at Sir Thomas White's place in Hants,' I 2 January, $1559-60 .^{2}$

His brass in chapel, placed there by him when warden, is interesting as that of the last of the Roman Catholic wardens, robed in a magnificent cope.

James Trobylfelde or Turbervil, another Wykehamist, who was a Marian bishop and deprived by Elizabeth, is worthy of note as having kept his see of Exeter unspotted from the fires of persecution.

\section{The Elizabethan Era}

The beginning of the new régime in the state under Queen Elizabeth was marked by the advent of a new régime at Winchester. The Marian warden indeed, Thomas Stempe, conformed and continued. He lived till 9 February, $15^{8} \mathrm{r}$, but little is recorded of him save that according to his epitaph he had been a good civilian and was a popular preacher. ${ }^{3}$ As warden he judiciously bought up some chantry lands to add to the college property in Andover and elsewhere.

The headmaster, Hyde, disappeared, and was succeeded by one of his own pupils, who saluted him with a scoff :

$$
\begin{gathered}
\mathcal{T} u \text { quoque, praceptor meus, } H_{y} d e \text {, latentis } \\
\text { E re nomen babes, Numinis istud opus. }
\end{gathered}
$$

Thy name to fit thy actions, hiding Hyde,

My master once, some god did sure provide!

Hyde died at Douay in 1597. The vacant chair was filled by one of the most pleasing figures that has graced the throne of Winchester School, that of Christopher Johnson. He came from Derbyshire, and became a scholar of Winchester in 1549 , a scholar of New College in 1553, and went straight from his fellowship there to be headmaster in $156 \mathrm{r}$, when he was twenty-four years old. He suffered much as a junior under the heavy hand of Everard, and he seems to have taken the lesson against severity to heart. His own mild

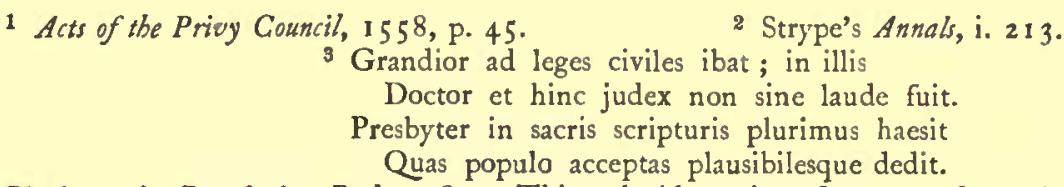

Blackstone's Benefaction Book, p. 82. This valuable series of extracts from the college archives, made by Charles Blackstone, fellow of Winchester, in 1748 , is in the possession of the warden. Most of it has now been printed in Mr. Kirby's Annals of Winchester College. 


\section{A HISTORY OF HAMPSHIRE}

and equable rule of ten years seems to have endeared him to the hearts of his scholars, so much that two of them have preserved his memorials, so that we know more of him as headmaster than of any of his predecessors or successors for two centuries. His 'distichs' or couplets on the wardens and headmasters who preceded him were preserved and published, together with a poetical life of Wykeham in Latin, in an appendix to his own Latin poems, by Richard Willis in I 573, under the title of Carmina C. Jobnsoni, poetce eximii, scbola Winton. Informatoris 26 (i.e. 26 th headmaster), ex adibus Tottellianis (i.e. published by Tottell). These couplets by themselves might have kept Johnson's memory green, but they could not have given us the vivid pictures of the man and the school which have been preserved to us by another of his pupils, William Badger of Winchester, in a MS. volume ${ }^{I}$ now in the British Museum. Badger became a scholar at the age of ten, in Johnson's second year, and continued under his rule for over eight years, until he was admitted a scholar of New College, 2 April, i 569, where he remained till I 574. For the last half-century Johnson himself has been credited with an even more elaborate and vivid picture of the school life in the sixteenth century by reason of a Latin poem preserved in the college archives and published ${ }^{2}$ in 1848 by Charles Wordsworth, afterwards Bishop of St. Andrews, then second master of Winchester. He attributed it to Johnson, but the attribution has now been shown to be devoid of external authority, while it is refuted by internal evidence, which points to a date about a century later. It cannot therefore be quoted $^{3}$ as an authority for 'a day at Winchester School in I 550 .' Badger's manuscript on the other hand is authentic and very curious. It consists of dictata or Latin prose and verse tasks dictated in Johnson's time to the boys, being his model versions of themes previously set to and done by them.

Badger's scholastic career raises an interesting question about the arrangement of the forms in the school. For two and a half centuries at least there have been only three forms at Winchester-Sixth, Fifth and Fourth. Yet, as we have seen, in 1529 there was a Seventh above the Sixth, and three forms below Fourth Book. In Badger's book only Sixth, Fifth and Fourth Books appear. At the beginning of the book, probably Michaelmas, I.563, he was in Fourth Book, and so remained till the term he calls 'after Easter,' I 565, when he entered Fifth Book, and passed into Sixth Book 'after Michaelmas,' I 566. As he thus rapidly passed through Fifth Book and eventually got a scholarship at New College, which was given then as now on competitive examination, he must have been a clever boy. What then was he doing during the two years from his admission in I 56 I to $5_{5} 63$ ? Was he in Fourth Book the whole time or were there then a Third, Second or First Book

1 Add. MS. 4379 ; entitled by the binder 'Themes at Winchester School.'

2 The College of St. Mary Winton, near Winchester (G. \& H. Parker, Oxford and London; D. Nutt, Winchester, 1848). See The Wykehamist, July and August, 1899, and Feb. 1900.

3 As it was in my History, xx. 266-78. I had not then examined the original. Mr. J. S. Cotton showed the true date in the Wykebamist, July, 1899. 


\section{SCHOOLS}

through some of which he was passing? Now the whole of the Dictata in the book are entered as delivered by Johnson who was the headmaster, except in the term called 'Election time,' when they were delivered by ' $\mathrm{Mr}$. Miller.' Mr. Miller was the hostiarius, though no one answering to the name is to be found in the list of Winchester scholars, and no list of hostiarii has yet been compiled. The Account Rolls show that he came as usher in the fourth term (i.e. 24 June), 1563 . It would thus appear that the informator, except at Election time, when he went off to cloisters with the eighteen prefects and those preparing for election, taught the whole of the three upper books. Is not the inference to be drawn that the hostiarius was teaching the lower school consisting of three lower books? We know that there were no lower books than Fourth a century later, when the work of the whole school is given in the pseudo-Johnson poem, while Long Rolls or school lists are extant from ${ }_{1} 62$, which show that there was nothing below Fourth Book then. But in the interval between 1563 and $165^{\circ}$, viz. in $163^{\circ}$, there was an incident to be hereafter related which may very well have caused the disappearance of the lower books.

Another circumstance pointing in the same direction is the great amount of attainment not only in Latin but in general mental capacity shown in the themes themselves. They were infinitely beyond those that would have been thought fitting food for the undeveloped intelligences of Fourth Book in later days, passing as they do from considerations suggested by the headmaster's anatomical experiments to questions of constitutional government, dialectics and philosophy; from discussions on Lenten fasts to the use of cockfights. The range of reading was wide. One day Johnson asks, "What effect has Cicero, your delight and mine? what Livy? what the poetic chorus? Do they take hold of you ?' while at another time he refers to 'Plautus and Alcmena, which you have sometimes read,' and engages in a critical comparison between Plautus and Terence. When Badger was in Fifth Book one of the themes refers to 'Juvenal's teaching in that satire which you have in your hands,' another to 'Virgil's wonderful description of bees in the volume you have in hand,' i.e. the Fourth Georgic. A running subject covering many themes is a translation into Latin hexameters of Homer's Battle of Frogs and Mice, afterwards published by Willis. Of Badger's Sixth Book days we unfortunately possess only two themes, but they include at least one copy of Greek verses with a Latin verse translation. Every year there are references to the plays performed by the boys, chiefly at Christmas, when they took the place of the old 'boy-bishop' performances. When Badger's notes began, Winchester was being visited by an outbreak of plague, then endemic rather than epidemic, and Johnson, a physician himself, in one of the first themes, invokes the ' heavenly physician' with quotations from the episode of the plague in the Iliad. The school was at this time removed to Moundsmere, a manor formerly belonging to Southwick Priory, acquired by the college in $154 \mathrm{I}$, and used as 'an asylum in the time of plague,' as it is phrased in 


\section{A HISTORY OF HAMPSHIRE}

the account book of the year. ${ }^{1}$ Johnson was a humorist, and in his humorous way in this first theme condoles with 'the exiles from Winchester' on the discomforts to which they are subjected. ' Not the least is that through lack of water, you have to draw it from a very deep well, and are yoked like oxen to drag it to the top of a hill.' 'Having no breakfast especially when getting a bigger dinner in consequence, the lack of rods, often playing in a meadow, and not less often hunting in the wood, all these are the sort of discomforts which you bear methinks after the fashion of the poet, "What can't be cured must be endured."

Their exile was consoled with the performance of a play, ${ }^{2}$ probably a dress rehearsal of one being prepared for Christmas. Johnson tells the "boys that though much annoyed at their having collected a crowd for it, he had determined to abstain from their persons, especially as he had indulged in strong language, which illustrated in real life some of the characters in the play. A little while after their return to college, apparently at Christmas, he congratulates them on the performance of the previous day, and says that they will be able to boast in their old age of having shared a glory which their ancestors never knew-a Greek play. ${ }^{3}$ Unhappily the name of the play is not given. The next year Johnson enlarged ${ }^{4}$ on the Christmas play which they had lately exhibited, and its educational value in teaching oratory, pronunciation and action, and in raising and lowering the voice 'as you shewed cleverly enough.' These plays were continued long after Johnson's day. Thus there are entries in the accounts for 1574 ' for putting up a stage and taking up and down, 'domunculos' or stage houses 'in Hall,' for a ship, i.e. a lamp in that shape, for 'seven ly links' and a dozen candles ' to light it and for carrying the organ from Chapel to Hall and back for the plays of comedy and tragedy for three nights.' Similar charges of $£_{3} 33^{\text {s. }}$ rod. for erecting scenes for comedies in $\mathrm{I}_{5} 83,{ }^{\circ}$ and of $\mathrm{I} 3$ s. $6 d$. to two carpenters for making a theatre in 1590 , show that the college authorities fully appreciated the value of the drama. At least on one occasion, ${ }^{8}$ apparently on Shrove Tuesday, ${ }_{5} 65$, Johnson himself wrote the play that was performed, which was of the character of the old Moralities, as he speaks of ' Chastity the daughter of Abstinence, whom I introduced into the comedy,' who was to be admired and followed 'as much as Gluttony, whose daughter Lechery was to be avoided.' But though Abstinence was admirable, the Lenten fast was remitted to the two Universities and to Winchester College, and the boys were invited to render musical

1 Mackenzie Walcott, p. 255. 'For 1200 short boards for the asylum in the time of the plague,' 1564.

2 Add. MS. 4379 , f. 20 (b).

Tractasse recordor
Me puero, quæ Græca forent, hic actor et ille
Pars aliqua ipse fui, dicetis, et haec erit illa
Quæ nunquam proavos decoravit gloria vestros.

4 8. 'Ludicis istis scenicis, quos publice spectandos nos exhibuimus.' This seems to negative the inference drawn from the entries in the accounts of repairs to the hall that there was a riot and no play. Annals, p. 257.

DEenefactions Book under date, Walcott, p. 205.

${ }^{\circ}$ Add. MS. 4379 , f. 100. 


\section{SCHOOLS}

honours to the Archbishop of Canterbury for the indulgence, ' ' grates pro gracia, pro carnibus carmina.' On Shrove Tuesday the play was seemingly accompanied by an entertainment which appeals less forcibly to modern ideas, a cockfight. Johnson's theme for the occasion was to the effect that the spectacle of cocks fighting to the death merely for honour made Iphicrates and Themistocles fight more bravely for their country and induced the Athenians' to have annual cockfights, "which custom you are to know is allowed you for no other reason than that as spectators of the fight you may with them eagerly find in it a spur to bravery.' This appears to be the only allusion at Winchester to the cockfights on Shrove Tuesday which were usually exhibited by schoolmasters, who in free schools made them an opportunity for taking fees under the name of presents from the boys or their parents.

Johnson's themes being largely concerned with topics of school interest preserve to us an extraordinary amount of information on the school life. The great divisions of the school into scholars and commoners, prefects and inferiors clearly appear. Commoners he calls 'Oppidans,' on one occasion complaining that they went off to the fair, probably St. Giles' Fair, in spite of an express prohibition. At another time he inveighs against their idling, after the great expense their parents had incurred in sending them to school.

Johnson's injunctions to prefects are frequent. He tells them that they should pass over in silence what they decently can so as to obviate censure; but that they are the eyes of the headmaster and must not omit to report serious delinquencies. He lectures the prefect 'who is called Ostiarius or Diarius,' the door-keeper or day man (so-called because he was ' in course' for a day only, not like the Bible-clerk who was on duty for a week), for not reporting those who offended.

We have already noticed one of the most peculiar customs at Winchester, that of 'Hills.' 'Hills' was precisely the same in ${ }_{15} 6_{3}$ as it was in 1863 . Johnson in one of his dictations pretends to wonder that boys will go on doing wrong though invariably detected and punished. ' For it is no new thing for some to shirk Hills in play time (a montibus abesse aliquos cum luditur), School in school time, Chapel in service time, while still oftener, though it is never done with impunity, you reverse the places, and play in School, idle on Hills, and are noisy in Chapel.' Johnson does not tell us what games they played on 'Hills,' but in some verses about himself he says that as a boy he 'cared much more for balls, quoits and tops than he did for books or school.' The references to hunting in the woods are frequent, and once a year the boys went nutting in the woods, as did Eton.

Various glimpses of the dress of the period are given. Johnson

1 Add. MS. 4379, f. 102, cf. Walcott, p. 157, from Strype's Parker I. ii. c. 25 :-Letter from William Cecil, Secretary of State, saying that 'the Queen's Majesty at the humble suit of the Warden of Winchester is pleased to dispense with the scholars there, in like sort as she hath for the Universities of Oxford and Cambridge, touching the observation of Wednesday made a fish day by politic constitution,' and directing the archbishop to issue a dispensation accordingly. It was the queen they should have thanked. 


\section{A HISTORY OF HAMPSHIRE}

once gave out three privileges: the remission of the evening declamation called 'books,' the invention of which is credited to Thomas Chandler in I $45^{\circ}$; the right to collect wood at pleasure for fire after supper in Hall or chambers; and first and foremost the use of braces or garters. ${ }^{1}$ But these privileges were on three conditions: that there was no swearing, quarrelling, or abuse of the mother tongue, which, as he subsequently explained, means talking English instead of Latin or Greek. Another time he pictures to himself what Wykeham would say ' if he could come to life again and see his scholars, some disorderly in manners, others in clothes, hear them talking English, swearing, and boasting of their birth rather than their learning, fighting, frequenting the town instead of school, showing their pride in their cloaks, wearing frilled shirts which they turned in when the headmaster forbad them, only to be brought out again at the first opportunity; if he could go and see the swelling loads of breeches in chambers, or even hid under their gowns, Spanish furs, foreign-dyed tunics, and other clothes, silk and velvet borders to their doublets; if he saw all this, would he not wonder whether they were members of his family or a lot of armed and scented courtiers-or rascals ?' Presumably the puffed hose which are familiar to us in the Elizabethan fashions were just coming in. They must have looked rather comic under the long clinging gown of the cleric.

We must linger no longer with Johnson and his Boswell, Badger, but conclude with Johnson's picture of himself. 'If your friends ask you what I'm like,' he says, 'nothing extenuate or set down aught in malice. Say that I am thin and weak, sleeping till daylight to avoid the cold, delighting in poetry, not very industrious, but liking change of occupation : as far as you are concerned, quick to anger at your faults, yet easily appeased, pardoning the multitude a multitude of sins; but the worse character anyone has the more sharply I am down on him.' His lying in bed is a very modern touch. Indeed on one occasion he chaffed the boys for not daring to ask him why he had not been in chapel. $\mathrm{He}$ seems to have thought schoolmastering something of a servitude. $\mathrm{He}$ told the boys to ask their fathers what they paid their servants of various kinds, and they would find that teaching was worse paid than hedging and ditching, let alone cooking or game-keeping. After his ten years of office he betook himself to life in London and a lucrative medical practice, became treasurer of the College of Physicians, and died in 1597. Johnson was succeeded as headmaster in 157 I by Thomas Bilson, a native of Winchester, who left it for New College in Johnson's first year, and was twenty-eight years old at the time of his accession. He had not been long in power before, in $1573,{ }^{2}$ the College received the honour of a state visit from Queen Elizabeth. The lucubrations of the boys at the

1 Add. MS. 4379 , f. 5. 'Primum est ut subligaculis qui volet femoralibus, quas aut braccas aut caligas appellatis, pro arbitrio quisque utatur.' Stanbridge's Vulgario translates subligacul, garters. Does it mean that they may use braces 'to the leg coverings, which you call breeches or hose,' or breeches ? If the latter, did they before that time go bare like Highlanders?

2 Not 1570 as in Walcott, p. 157, followed by Annals, p. 281, and my History, p. 291. For at least five of the boys who took part in it were not admitted till 1573 . 


\section{SCHOOLS}

reception ' of the most serene and illustrious prince' are preserved in the Bodleian Library in a beautiful little quarto ${ }^{1}$ MS. bound in white vellum with gold ornaments, with the dedication illuminated in red and flowers, and the names of the boys in green. It is to be remarked that no less than forty-three of the boys contributed their salutations, all in Latin elegiacs, except those of William Phillips, which were in Sapphics, and those of William Tooker or Tucker (afterwards Dean of Lichfield), Andrew Mortimer, ${ }^{2}$ and Henry Lloyd or Phloid, as he spells himself in Greek characters, which were in Greek elegiacs. Only three of the forty-three were commoners, Richard Dudley, William Warrin and Robert Bosvile (? Boswell). The large number shows a high standard of classical attainment at Winchester. Among the Winchester scholars who congratulated the princess was John Pittes, otherwise Pits, who left New College in 1578 to become a Roman Catholic priest, wrote the famous De Illustribus Anglice Scriptoribus, and died Dean of Liverdun, and William Wigge or Wygge, who was executed at Kingston in I 588 for denying the royal supremacy.

In I 592 the scholars were sent for by the queen on her visit to Hampshire; but if they fired off the customary salvo of Salves they have not been preserved. Ten years later, presumably on the occasion when the queen visited the Marquis of Winchester at Basing House and Bishop Bilson at Farnham Castle, the most elaborate series of all was concocted, ${ }^{3}$ though it is not clear where or when they were actually delivered. They were a veritable tour de force. No less than seventytwo boys contributed effusions. John Reynolds, the head of the school, appeared ten times in every variety of metre, Latin and Greek, sometimes elaborately arranged in the shape of different objects, a cup, a garland, and what not. Hugh Robinson, a future headmaster, and Roger Pinke, afterwards warden of New College, also broke out into all sorts of metres in both languages. Robinson contributed a harp in elegiacs and a heart in irregular metre, while some of Pinke's verses made a candlestick, Fawne's a star, and Thomas Chandler punned on his own name with a candle. Most elaborate of all was an imperial crown done in elegiacs by Richard Colenett. The boys' facility in verse was certainly marvellous.

The queen took only too much notice of Winchester College, and was always asking for leases for her friends or places for her petitioners. Not that these attentions were confined to Winchester; on the contrary, nearly every college in either university was the recipient of similar favours. The college wisely fortified themselves in 1566 by making Mr. Secretary Cecil, as their predecessors had made Mr. Thomas Cromwell, the college steward. In their Latin letter ${ }^{4}$ the college expressly say they are following the example of Cambridge University who had made him chancellor, and of New College' to which this

I Bodleian, Rawl. MS. poet. I 87 .

2 He appears by mistake as Martyne in Scholars.

3 Bodl. MS.

4 Walcott, p. I6I (who prints I 568 for I 566 ), from Lansd. MS. Io No. 5 I. 


\section{A HISTORY OF HAMPSHIRE}

School is the nursery,' who had made him patron, and they ask him ' not to despise the lowly name and office of procurator or first seneschal of their lands.' He did not disdain the salary of $f_{5}$ a year, emphasized as it was by occasional perquisites, as when in $15^{8} 7^{1}$ he received $f_{2} 2$,

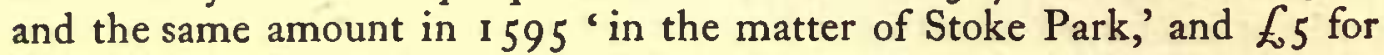
release of the college from tithes. In 1567 he was specially invoked to get a Mr. Cobham, for whom the queen had asked for a lease in reversion, which they could not give without breach of statute, to induce her to be content with their having ' in such friendly wise dealt with him that, as we trust, he holdeth himself right well contented and satisfied,' and to stop such attempts for the future. In $15^{81},^{2}$ however, the queen extracted from the college a lease of the rectory of Downton for the clerk of the council, Thomas Wilkes, which was sent with the expression of a vain hope that it would not be taken for a precedent.

Her Majesty was, however, worsted in the chief contest of all, when she took upon herself to intrude on the college a non-Wykehamical warden.

Johnson's successor as headmaster, Bilson, had ruled not always quietly, for in $1579^{3}$ some of the scholars had run away, and the complaints of the scholars had to be met at court, but with success seemingly, as he became warden on Stempe's death in I 582. Under Bilson's wardenship the college passed through one of the gravest crises which ever threatened its position as a public institution. This was caused by the revival under Warden Stempe of the rights and privileges of founder's kin.

We saw how Wykeham, following Merton, had made provision, by way of compensation for the legal portion of his natural heirs diverted to the endowment of the College, for preference of admission for his relations, with special privileges in the way of age of admission and leaving, payments for clothes and other necessaries and expenses on proceeding to New College.

This right, though in terms absolute, ought to have been interpreted in accordance with the principles of the canon law, which recognized no kinship after the seventh degree. In Wykeham's case, he being an enforced celibate, there could only be collateral next-of-kin. Wykeham had no brothers and only one sister, Agnes. She became Agnes Champneys, and her only child Alice married William Perot. The pair had three sons, who all assumed the name of Wykeham. The eldest, William, was admitted to New College in 1387 , but left the same year. He married, but died without issue. The third, John, became one of the earliest founder's kin recorded at Winchester, having been admitted before the opening day (not on it, as Annals), and had his expenses on going up to New College paid for him in 1394 (not I 395, as Annals, p. 94 note). He became a priest, and therefore left no descendants.

\footnotetext{
1 Annals, p. 283.

2 Walcott, p. 158, from Strype's Annals, III. i. chap. 5 ; State Papers, Domestic, Eliz. 142,13 March, $158 \frac{1}{2}$. 


\section{SCHOOLS}

The second son, Thomas, who had been admitted at New College in 1390 and left in 1394, and had, no doubt, been first a founder's kin at Winchester, was endowed by Wykeham with the manor of Otterbourne near Winchester, and with Broughton Castle near Oxford. $\mathrm{He}$ had a daughter, who married one Wilkesey, but their son took the name of Wykeham, and this son's daughter married a Fiennes, Lord Saye and Sele, and took the castle and estates of Broughton with the name of Wykeham, to him. His descendant, Wykeham-Fiennes, Lord Saye and Sele, still holds Broughton. One of this Saye and Sele's younger sons, Richard 'Fynes,' a spelling which gives the pronunciation better than the modern spelling, claimed, and was admitted as founder's kin in 1465 . He was in the fifth degree, according to common law, which determines the inheritance of real, and the sixth according to civil law, which determines the distribution of personal, property. No later member of the family claimed it, nor were any founder's kin admitted to college for a period of seventy-two years, from 1476 to 1548 . It was perhaps owing to the privilege having been so sparingly used by the Wykehams, that when in 1569 the son of the then Lord Saye and Sele applied for admission as founder's kin, the college welcomed him, without scrutinising too closely whether he was or was not a step too late in the pedigree, the strict canon law being then discredited, especially as he was the heir-apparent to a peerage.

But it was an unfortunate precedent. It opened the hatches to a flood of founder's kin, and the prospect rose before the college of their descendants in geometrical progression thronging in, not subject to any test of fitness, and threatening to convert it from a national institution into the private possession of a few families.

For the number of persons who could claim was enormous. The founder's aunt, Alice, had no less than thirteen daughters, and they all, or nearly all, had families. The grandchildren of one daughter, Edith Ringborne, in the fourth degree, were admitted in I 449 and I 454 . The representative of another daughter, John Maryle, appeared in 1427, and of yet another, Bartholomew Bolney, in 1415. Then there were the descendants of the founder's uncle, Henry, who has been written down as an Aas, probably representing the modern Ash, one of whom, already in the fourth or fifth degree, was admitted as founder's kin in I 4I 3. Finally, there were representatives of Wykeham's mother's family, Strattons of Stratton, one of whom, John Benyt of Botley, was given a chance of succession in the entail of the manor of Otterbourne by Wykeham in 1400 .

Yet with all the possible developments of these various lines, only thirty-seven founder's kin were admitted during the whole ninety years from 1386 to 1476 . The reason, probably, was that as a rule enforcement of the right meant dedication to the Church and to celibacy, and those who accepted it did not, of course, leave children to take on the title. Moreover, the absolute cessation after I 476 of any admissions of founder's kin points to some legal decision or advice, that the right 


\section{A HISTORY OF HAMPSHIRE}

had come to an end through lack of real kinship, by dissipation through so many generations.

The admission of John Bolney in I 548 as founder's kin does not appear to have produced a new crop of claimants. But that of Richard Fiennes in 1569 , being perhaps more widely known through his noble birth and prospects, and perhaps regarded as something of a scandal, produced further claimants.

The question became a burning one when, in 1572 , the Wykehams of Swalcliffe near Broughton, but no relation to the founder, put in their claims as founder's kin, a claim resisted by the Fiennes, as it confused their pedigree, while its admission would have let in new hosts on the college. The case was taken to Chancery, and Lord Keeper Bromley decided against the claim and made the claimant renounce it, but, by a curious sort of compromise, directed that the claimant's son and four degrees of descendants might be admitted as kin. Afterwards the college turned restive against the Fiennes and Bolneys, and Chancery proceedings were taken. The matter was referred to the Bishop of Winchester, Thomas Cooper, by Christopher Hatton, Lord Chancellor, with an expression of opinion by the Court that-

The public benefits of the realm for the education of children in learning, chiefly intended by the founder, would be greatly hindered if any of the children of the said complainants should be admitted into the said colleges, being at this instant a great many in number, and in a short time likely to spread and increase and grow into more generations sufficient of themselves to fill the number of both the colleges.

The bishop in his award ${ }^{1}$ in 1589 repeated this reasoning in other words, and also added a very interesting reason of his own, viz. that the revenues of the college had been

greatly augmented and enlarged with many grants, privileges, lands, and possessions
by the free gift of the Queen's most excellent Majesty and others, Her Highness's
most noble progenitors, and of divers other well-disposed persons, . . Without which
augmentation. . . the ancient possessions given by the said founder were nothing
like sufficient to answer the ordinary and necessary charges yearly to be spent and
employed about the education and maintenance of half the number by the Founder
appointed to be brought up and maintained.

He also said that it appeared that the founder only allotted $\oint_{20}$ among all the founder's kin in either college, 'at the rate of 4 marks a kinsman,' which would allow only seven in all. He proceeds-

It is evident by the records of both Colleges that there hath not been allowed or admitted as kinsmen to the said Founder above the number of eighteen persons of all descents whatsoever, and at all times since the first foundation of the said Colleges, till some of these persons now complaining werc admitted.

The exact date to which the number of eighteen is to be reckoned is by no means clear, and would appear to be about half the correct number if it refers to the whole number of founder's kin admitted up to 1 548. It gave the bishop, however, ground for the somewhat illogical decree that there should not be above the number of eighteen founder's

1 Annals, p. 526. 


\section{SCHOOLS}

kin within the said two colleges altogether, and that the number should be divided so that in Winchester there should not be more than ten at a time; that is, he conceded the right to have in any single year the same number of founder's kin as he believed to have been admitted in the whole I 54 years before.

The objection to the privileges of founder's kin was not only that it converted a public school into a private inheritance, it also tended to lessen learning, for they had an absolute preference for New College up to the age of twenty-five, and that without competition. When the founder's kin difficulty arose nearly 200 years later at All Souls' College, the Archbishop of Canterbury, acting on the advice of an All Souls' man, Blackstone of the Commentaries, reduced founder's kin to ten. The limitation procured by Warden Bilson saved Winchester as a public school.

Warden Bilson achieved a rare distinction among wardens in becoming a well known author. Of his books, The True Difference between Cbristian Subjection and Uncbristian Rebellion, was much quoted at the time of the Civil War, and The Perpetual Government of Christ's Church, in defence of episcopacy, procured him the bishopric of Worcester in I 595, and translation to Winchester two years afterwards. On his promotion the queen provoked a constitutional crisis in the college by trying to treat the wardenship as if it had been an ordinary ecclesiastical benefice, to which, on the promotion of its occupant to a bishopric, she had the right to appoint. Mr. Cotton, one of her chaplains, who lived at Winchester, asked for it, ${ }^{1}$ urging that he 'is wished to the same by the town, county and church.' The rival candidates were John Harmar, the headmaster, George Ryves, a fellow of Winchester, and Dr. William Tooker or Tucker. After four months' struggle, with quips and quibbles the queen withdrew in favour of Harmar.

While from this time forward the provostship of Eton came to be treated as a Crown appointment, the stout opposition of Wykehamists effectually prevented any further attempt on the wardenship of Winchester in favour of outsiders.

\section{The Stewarts}

The Stewart period at Winchester opened with a characteristic exercise of the prerogative on the part of the monarch from Scotland which none of his Plantagenet or Tudor predecessors had ever thought of attempting. By a privy seal ${ }^{2}$ of I November, I603, he turned the college, warden and all, out of house and home, in order to make room 'for the lodging of our Judges and Sergeants' so that they might be near the 'Bishop's Pallace there called Wolvesey,' in which he had appointed 'our Courts of Justice to be kept.' The plague in London was the ostensible reason, but the trial of Raleigh was perhaps the real reason for 'appointing the term to be kept at our Citty of Winchester.' 


\section{A HISTORY OF HAMPSHIRE}

The scholars were deprived of their chance of seeing this famous state trial by being sent to Silkstead, a farm some three or four miles off on the downs.

A visitation of the college by Archbishop Bancroft occurred on I I January, $1605 .^{1}$ The injunctions issued as a result do not throw much light on the internal economy of the school, being mainly concerned with the administration of the property and with ensuring the concurrence of the fellows in it, particularly as regards the taking of fines, which were now becoming more important than the rents. The order that the 'dyett' of the fellows shall only be taken in the college hall, except in case of sickness, witnesses to the beginning of the breakup of the collegiate life. The most important from the school point of view is that (No. Io) which directed the electors both to Winchester and New College to act as a body in electing the most worthy and 'not singly to name any scholar to be chosen, or report or give cause to report this or that place to be the place, nomination or election' of any one elector. It is probable therefore that the system was already in vogue under which the election to Winchester was become a system of patronage, or at least the members of the electoral body took it in turn to nominate. The order of electors was this :

I. Founder's kin, who had an absolute right solong as there were not already ten in the college. 2. The Crown. 3. The Bishop of Winchester. 4. The Warden of New College. 5. The Warden of Winchester. 6. The Senior Poser. 7. The Junior Poser. 8. The Subwarden of Winchester. 9. The Headmaster; and then thelast six in order da capo.

That this was the method of election in $1686^{2}$ has been shown by notes on the Long Roll in that year, which follow the same order as was publicly set out, as the recognized mode of election, in the history of Winchester ${ }^{3}$ published in 1773 , except that the Crown and the Bishop had then ceased to nominate. That it existed probably in I 569 may be inferred from the statement of Headmaster Harmar quoted above, that he was 'Her' (i.e. the Queen's) Scholar. Accordingly his name comes second on the roll for that year, next below Richard Fiennes, afterwards Lord Saye and Sele, who was founder's kin, while Adam Horne, who bore the name of the Bishop of Winchester of the time, was third. There are no means of knowing who appointed the rest, but the significance of the beginning of the roll is highly suggestive. The practice was too natural and too profitable to the electors to be abandoned at the bidding of Archbishop Bancroft, an outsider who had no practical means of enforcing his orders. It continued to thrive till competitive examination was instituted nearly two centuries and a half later.

Equally futile was the next injunction that 'neither the School-

1 Wilkins' Concilia, iv. 434 .

2 Holgate's Long Rolls, pp. xlvii., lv.

3. The History and Antiquities of Winchester (printed by J. Wilkes, 1773), i. 173. 


\section{SCHOOLS}

master, Usher, nor any Fellow of that house at any time extort, challenge, or insert into his accompts, or anyways take or receive any sum of money for chamber rent, or for being tutor to any of the schollars within or without the said College.' The Visitor could hardly suppose that while the warden and fellows were fattening themselves on fines and making nice allowances for diet, the headmaster of what was still beyond all doubt the most important school in the country could be got to live upon his statutory stipend of $f_{0} \mathrm{I} O$ a year, increased only to $f_{\mathrm{O}} \mathrm{I}$ I I os. in I 560 ; still less the usher on his miserable $f_{0} 36 \mathrm{~s}$. 8d., augmented at the same time to $f_{0} 43^{s} .4^{d}$. Light is thrown on this point by some bills of John Hutton, son of Sir Timothy Hutton of Marske, Yorkshire, who was a commoner in I6I9, and admitted to College in I620.' From them it appears that he paid Mr. Phillips, in whose house he boarded, 'for his dyet from August the I6th to September 3 Ist (sic) (i.e. when he went

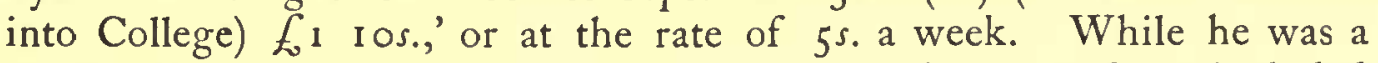
commoner he paid 'for quarterage 2s. Iod.', but this must have included an entrance fee, as the quarterage for the three succeeding quarters is only Is. $6 d$. The fee had thus risen only $2 d$. a term since I $56 \mathrm{I}$. When he got into college no 'quarterage' or 'diet' was paid, but there was an item 'for tutorage' most unfortunately left blank. The only items charged in the nature of school fees is the amazing one of I 4 s. 'for learning to write' in the 'Lady quarter,' as it is called in one of the bills, after he got into college. As he had already been in the school a year and a quarter, and was provided with ink, a psalter, a Nowell (i.e. Dean Nowell's catechism) and grammar, a table-book and 'inkehorne' in his first term, and was doing 'Terrence' and Ovid, it cannot really mean that he had not learned to write before; the item must represent some customary charge coming down from the days when a speaking acquaintance with plainsong and old Donatus was really the extent of the attainment of the new 'child,' and he had not yet learnt to write. Two other charges may be regarded as in the nature of school fees, ' $2 d$. for sweeping the school,' and 4d. 'for birche,' which are charged in the midsummer quarter only in each year. It was customary even in free schools to make charges of this kind. Candles of course he paid for, at the rate of $4 \frac{1}{2} d$. a pound. Colet for his 'free scole of Powles' had prescribed that his scholars should use wax candles only, at the cost of their friends. In lieu of the diet paid for in 'commoners,' there were in college sums for 'batlings' or 'battlings' varying from $5 \mathrm{~s} .6 \mathrm{~d}$. or $6 \mathrm{~s}$. in midsummer quarter, to 'for battlings on fastings days, with the Lent 9s. $8 d$.' in the Ladyday quarter. The warden, be it observed, was allowed by the college 100 oysters for every Friday and fast-day, over and above twice a fellow's fish allowance. The religious observance of the fasts by the college was tempered to the scholars by private dispensation of 'dispars,' at all events to those who could afford it.

1 Hutton Correspondence, ed. J. Raine, Surtees Society, No. 17, 1844, pp. 237-44. The bills are not printed in the correct order, the latest, that for 1623 , being put first instead of last. Walcott's Will. of Wykeham and bis Colleges, p. 166. 


\section{A HISTORY OF HAMPSHIRE}

Young Hutton had, on entrance to college, to pay for a gown, I6s. 9 d. ; a surplice, I6s. Id.; for powling money (probably for haircutting), Is.; for chamber stock, Is. $6 d$. ; to his predecessor for glass windows (the college presumably not finding glass windows to chambers in the fourteenth century), $2 s . ;$ while his bedding cost $f_{2} 26 s .8 d$. The bedding of two brothers, founder's kin, who slept in one bed, had cost for $2 s .7$. in 1397 . But their mattress was filled with straw, while young Hutton had $30 \mathrm{lb}$. of flock for his. Washing was charged is. $6 d$. a term.

Among books bought, showing what was taught in the school, was ' a sett of Ovids,' 5s. 4d.; ; 'Tullies Offices,' is. 2d.; ; a booke of Rhetorike Is.,' 'a Tusculan Questions, Cambden (Camden's Greek Grammar) and Greek Testament, 4 s. I I d.'

Altogether, while a year in 'commoners' cost $\oint_{0} 20$ I 4 s. $4 \frac{1}{2} d$., and the first year in college cost $f_{0} 152 s .7 \frac{1}{2} d$., a later year in college (1623) cost $f_{0} 96 \mathrm{~s} .7 \frac{\mathrm{I}}{2} \mathrm{~d}$. only, clothes included.

Headmaster Stanley was certainly not very popular. Two years after his appointment, John Imber, who had been hostiarius from 1627 , married a widow of a member of the Corporation and set up a school in the disused chapel of St. John's Hospital, at the bottom of High Street, allowed him by the Corporation for the purpose. He appears to have taken with him a large contingent of day boys from college, as Stanley complained to Abbot, the Archbishop of Canterbury, from whose ' Master of the Faculties' Imber had obtained a general licence to teach school. The archbishop at first ordered that Imber's faculty should be 'so interpreted and restrained that the said Imber shall not teach within five miles of Winchester.' But the city complained in their turn, and the archbishop on I9 August, 1630, referred the matter to the dean, the warden and the chancellor of the diocese. What the settlement was does not appear. Imber seems to have remained in the neighbourhood, as he was given the living of Christchurch, Hants, by the dean and chapter in 1640 ; and after ejectment during the Commonwealth died vicar there in 1671 or 1673 . He probably, therefore, continued his school undisturbed. Thus, seemingly, was effected the greatest revolution which took place in the constitution of the school. The oppidans, or town day boys, who had in all probability constituted if not the majority, at least a large proportion of the school, seem to have finally departed with this hostiarius; with them, it has been reasonably conjectured, departed also the then lower 'books,' first, second and third. Thenceforth the school was reduced to the scholars, the commoners properly so called, who lived and commoned with them, and such other commoners, "sons of noble or powerful persons or special friends of the College,' as had in old days lodged in St. Elizabeth's College, and afterwards in the old Sustern Spital, which in the succeeding century acquired the name of Commoners' College, and when rebuilt in the nineteenth century that of 'Commoners' pure and simple. So the school became purely a boarding school, a thing until then entirely 


\section{SCHOOLS}

unknown, rejecting the children of the citizens at its doors, who had rejected it, and relying on strangers from a distance.

When Warden Love died on 10 September, 1630 , Stanley, in spite of a royal letter on his behalf, failed to secure election to the wardenship. The determined attack made on him by some fellows of New College, perhaps his old pupils, in a letter for the new warden is interesting as showing that already the headmaster was in the habit of living outside college, probably for the sake of taking commoners as boarders, and had, as was natural, virtually become commander-in-chief over everything to do with the boys. They tell the warden that he may require the schoolmaster and usher 'to lodge within the College though married sometimes, and Bishop Andrews (1618-27) was very angry at the neglect,' and 'to attend prayers in chapel every morning. For this cause they have breakfast allowed them, which the Fellows do not.' ' He may hold the Schoolmaster to his school hours, viz. 7 to 9 a.m., and 2 to 5 p.m. The use of late has been 3 to 5 p.m. and 8 to 9.30 a.m., being too short.' They also remind him that he may reserve the giving of ' remedies,' and cited Westminster and Eton, where the dean and provost had kept that power in their own hands 'by a good token that Dean Mountain denied Bishop Bilson a play-day after he was a Privy Councillor.' To him belonged granting leave out into the town. He could also appoint scholars' tutors. 'The number and cumber of so many pupils doth hinder the Schoolmaster in his main duty.' He can also call up before himself 'any great and enormous fault which may seem to deserve above five stripes.' They also complain that the "partial lenity lately used hath wronged the school much more than the old severity.' 'Diligent attendance of the scholars at School, Church, Hall, Chambers and Hills' (it is noteworthy that play-time is thus put on a level with school-time) ' will prevent faults and save much of that severity which hath been used, and otherwise must be used still or else the school will continue as disorderly as they now are.' Also the warden may examine the boys, especially in Greek-Dr. Lake used to do it even as sub-warden. Then the complainants perorate : 'If there be not more attendance and teaching, lesse charges and whipping than is reported, the School will never thrive nor the College recover its power again.'

As usual we are left in the dark as to whether the new warden took the advice given him. Stanley, at all events, whether he combined favouritism to some with severity to others, laxness of discipline with copiousness of 'bibling,' or not, remained schoolmaster for another dozen years; during which, in 1639 , he had become a canon of Winchester.

During his mastership, Archbishop Laud visited the college jure metropolitico. His injunctions ${ }^{1}$ for the most part concern the chapel (where he caused the communion table to be replaced at the east end and railed in) and the wardens' and fellows' allowances. The only injunction

1 Wilkins' Concilia, iv. 517. 


\section{A HISTORY OF HAMPSHIRE}

concerning the boys was 'that the fellows' and scholars' commons be augmented according to the statute of provisions; and fire allowed in hall in winter-time on such days as your statute doth require.'

\section{The Civil War}

The Civil War affected the school very little, if at all. There is indeed a legend that it was once in imminent danger of destruction by a Parliamentary army, but escaped through the interposition of a Deus ex macbina in the shape of an old Wykehamist, a 'rebel' officer, variously reputed as a captain of foot and a colonel of dragoons, who, drawn sword in hand, at the hazard of his life, stood guard over it. But it is a legend merely, and seemingly a quite modern legend, dating from no farther back than the latter half of the eighteenth century. It however betrays a total misconception of the whole history of the times in relation to schools in general and Winchester in particular.'

As to the college, there is not the smallest foundation for the supposition that it was ever in the smallest danger. So long as there was no active opposition to the ruling powers, neither Royalists nor Presbyterians showed any desire to meddle with schoolmasters, much less with schools. Parliament did not make war on schools or learning. On the contrary, learning was on the Parliamentary side, and fared far better at its hands than at the hands of the king's party. On 29 October, I 642, Parliament considered the sequestration of the revenues of deans and chapters, and was careful on the matter being brought before its notice to order ${ }^{2}$ - 'That it be referred to the committee for the king's revenue to consider of the college of Westminster, the colleges of Eaton, of Christ Church in Oxford, and Winchester, to provide for those colleges that none of the revenues assigned for the scholars and almsmen of those colleges may be stopped, or the payment thereof intercepted, notwithstanding the ordinance of sequestering the rents and profits of archbishops, bishops, deans, and deans and chapters.'

A few months later, 17 February, I642-3, on a petition from Cambridge University, it was declared that 'the statute which imposeth the wearing of surplices upon all graduates and students . . reinforced by the canons, made I603, ought not to be pressed or imposed upon any .. . it being against law and the liberty of the subject.' Three days afterwards ${ }^{3}$ it was resolved that the colleges of Westminster, Eton and Winchester be added and comprehended within the order of 17 February 'concerning the imposing upon young scholars of the wearing of surplices.'

After the complete triumph of the Commonwealth, on 29 May,

1 'The legend first appeared in The History and Antiquities of Winchester, 1773, attributed to Rev. Mr. Wavel. The officer's name is given as Cuff, but no one of that name appears in the register of scholars. At first he is only accredited with having protected Wykeham's monumenf, but Dr. Milner, in his History and Antiquities of Winchester, assigns to him the credit of having preserved the college also. Nathaniel Fiennes and Nicholas Love have likewise been mentioned as those who saved the college on this occasion.

'Common' Foumals, ii. 827 .

3 Ibid. ii. 972. 


\section{SCHOOLS}

I $649,{ }^{1}$ ' an Act declaring that the Act for abolishing of Deans and Chapters doth not extend to the Colleges of Winchester and Eaton this day read and upon the question passed.' Nor was this all. The Act abolishing deans and chapters ${ }^{2}$ contained an express proviso, recited in an ordinance of the Protector, 15 February, 1654, that 'all the revenues, rents, ... . which before I December, I64I, had been or ought to have been paid for the maintenance of any grammar school or scholars, or for or towards the reparation of any almshouse, or for any other charitable use,... should be and continued to be paid and allowed as they were.'

Winchester in particular had little reason to fear damage from Parliament, as there is every reason to suppose that its authorities were on the Parliament side. Winchester was then, far more than it is now, a Hampshire school, and Hampshire as a county was predominately 'Presbyterian true blue.'

The Bishop of Winchester and the 'sweet cathedralists' were of course mostly Royalist ; but the college was in the opposite camp. The warden, John Harris, was elected a member of the Assembly of Divines, of which a fellow Wykehamist, William Twisse, rector of Newbury, and formerly headmaster of Southampton Grammar School, was prolocutor. Harris was appointed to preach before the House of Commons ; from which however he excused himself on the ground of a weak voice, and on 16 October, I 643 , he was excused attendance at Westminster to keep his residence as warden at Winchester. He was a friend of Nicholas Love, the eldest son of the headmaster and warden whose name he bore, who held the post of one of the Six Clerks in Chancery, a lucrative and important office, and was a man of considerable influence in London. Several of Love's younger ${ }^{3}$ brothers were in college ; but Nicholas' name does not appear on the register. From the extraordinary interest he showed in the college, as exhibited in some of his letters to Warden Harris preserved among the college archives, it would seem certain that he was a Wykehamist, no doubt as a commoner. Of the politics of the headmaster, John Potynger, who succeeded Stanley in I 642, the year of the outbreak of the Civil War, nothing is certainly known. But the date of his accession and his holding office till 1653 , point to his being a Parliamentarian. His conforming to the Directory, which was substituted for the Book of Common Prayer, and presumably taking the engagement ${ }^{5}$ imposed on I 2 October, I 649, show that he was not at least a violent Royalist. His successor William Burt, the headmaster of Thame School, which was under the tutelage of New College, was stigmatized by Anthony Wood as a violent Presbyterian and 'breeder of

1 Commons' Fournals, vi. 219.

2 Ordinances and Proclamations, I653-6, p. 72 I (1649, cap. 24).

3 Christopher, 1620; John, 1624, a captain in the Royalist army, taken prisoner 1644; Barnaby, 1631 ; Robert, 1631 ; Joseph, 1634 .

- Not in 1652 as in Annals, p. 345. The fact that he held for another year is important in this connection.

5 State Papers, Domestic, 1649-50, p. 338. 


\section{A HISTORY OF HAMPSHIRE}

Hampden and other like rebels.' Under date 18 July, I644, a Parliamentary newspaper' says that Sir William Ogle had taken 'from the Master of Winchester College fifteen oxen and three hogsheads of beer, upon suspicion that he was a Roundhead.'

In the bursar's book for I $642-3$ there are expenses relating to the war, which were first brought to notice by Mackenzie Walcott, ${ }^{2}$ who apparently saw in them a reward to the soldiers for abstaining from destroying the college. He notes only ' given to $\mathrm{Mr}$. Fines' soldiers fo 29 5. 6d.' This was not however a single payment, but is a summary of several items, paid at quite different times. The entries point to no unfriendly relations, and we may well believe that the warden, suspected by the castle, would have welcomed one of the leading old Wykehamists of the day, and a founder's kin, to billet in the college, quite apart from any protection required from an imagined furious soldiery.

The college accounts show other warlike payments. Besides those above mentioned under the heading of 'Distribution to the poor' in $1642-3$, we find Is. paid to a wounded soldier and Is. $6 d$. to a soldier lately a prisoner, and to divers soldiers at divers times, $3^{s}$. Which side was favoured in these payments is not stated. The reticence shown is still more tantalizing next year, $1643-4$, when the warden was paid $\oint_{2} 249$ s. $8 d$. in the fourth term (June-Michaelmas I 644) 'for extraordinary expenses incurred in the billeting of divers soldiers this year' - a sum nearly as large as that paid on Fiennes' visit the year before ; while $f_{4} 4 \mathrm{I} 6 s .4 d$. was expended in the same term on Mr. Jones, one of the fellows ' going and returning between Winchester and Oxford and divers "tips" (regardis) given by him to obtain the king's protection for the college'-a protection necessary because of the castle being in the king's hands, and the seizure of college property by the garrison. The college now kept men under arms. In Michaelmas term Seyward and Pudsey were paid I 2s. for bearing arms at divers times, and for keeping guard for two days and nights $6 s$., at the rate of $3^{s}$. a day and night ; while Pudsey and Tongue were paid 4 s. "for carrying arms on December 6 th and 8 th.'

Though the college was not at any time in danger of destruction, it suffered by the Civil War financially, like other landlords, in the loss of rents. Its income which had been $\oint_{0} 2,665$ in $1640-1$ and $\oint_{0} 2,545$ in I $64 \mathrm{I}-2$ fell to $\oint_{2} 2,33 \mathrm{I}$ in $\mathrm{I}_{642-3}$ and sank a whole thousand pounds to $f_{1}, 319$ in $1643-4$. Recovery came quickly. In $1644-5$ the income rose again to $f_{2} 2,022$. The arrears must have been paid up in the two following years, when the income reached the highest total then recorded of $\oint_{0}, 218$ and $f_{0}, 370$, while in $1647-8$ the sum was $£_{0} 4,047$, a figure not attained again for the best part of a century. The spring and autumn progresses of warden and bursars to visit the estates and the journey of the warden and posers of New College to Winchester for the election

1 Godwin, p. I60.

2Walcott, p. 172, 1643. Dat militibus Magistri Fines (Colonel Nathaniel). 


\section{SCHOOLS}

seem to have gone on every year without interruption. Even the annual hunt of the boys went on, as the item of $5^{5}$. for the waggon on the hunting day occurs as usual. ${ }^{1}$

How little Winchester School had to fear is shown by the attempt made by Warden Harris to obtain the exemption of the college from the excise imposed by Parliament in 1646, through Nicholas Love, their correspondence being preserved in the college muniments.

The excise question took a long time to settle, for on $26 \mathrm{March}$, 1647, Love wrote to Harris, 'till we come to handle the matter for Oxford, little can be done in the House. The Committee is going down to visit the Colleges, and uppon their report a rise will be taken by all schollers and schollers' friends to exempt them from publique impositions. For the meantime I have prevailed with the Commissioners of the Excise to intimate a connivency.' In the result the college was not exempted, though Winchester does not seem to have paid anything except on beer sold to strangers (biria batillata ab extraneis).

The visitation of Oxford University was a serious affair to Wykehamists. On the death of Warden Pincke, who had taken a leading part in organizing Oxford volunteers for the king, on 2 November, I 647 , Parliament forbade a new election. The fellows applied to Lord Say, who told them that they would be free to elect Josiah White, 'the patriarch of Dorchester,' a good Wykehamist. But they foolishly elected Henry Stringer, a violent Royalist, whose election was of course quashed, and George Marshall, a Parliamentary chaplain, of St. John's College, Cambridge, was intruded in his place. The fellows pleaded their oaths on admission as the reason for refusing to admit any visitation but that of the bishop, and were expelled to the number of thirty, out of a nominal total of seventy.

At first efforts were made to fill the void with Wykehamists, the Parliamentary Committee ordering, ${ }^{2} 2$ August, I 648, that first founder's $\mathrm{kin}$, then scholars of Winchester, and then superannuated scholars should be elected. On 6 June three founder's kin, George, John and Nathaniel Danvers, and five 'Winchester College superannuates' were nominated for election by 'Mr. Nathaniel Fines, but the bulk of the fellowships were filled up from outsiders, though the Winchester boys do not seem to have been actually deprived of their rights for even one election.'

Meanwhile, on $4 \mathrm{May}$, 649 , Parliament had directed that the committees for regulating Oxford 'take care of the regulating of the University of Cambridge and Winchester College,' and Sir Henry Mildmay, General Ireton and Mr. Love (Nicholas Love) were, amongst others, added to the committee. On I 4 June Love wrote to the warden, hoping that he and the warden of New College would so settle things at the election that both colleges ' may rest without any further disturb-

1 e.g. Bursar's Book, $1642-3$, at end of second term, i.e. near Lady-day, 'In solutis 5s. pro plaustro die venationis.'

${ }^{2}$ Register of the Visitors of the University of Oxford, 1647-58 (Camden Society, 1881, No. 29, ed. by Professor Montagu Burrows), p. 180. 


\section{A HISTORY OF HAMPSHIRE}

ance.' But he had his misgivings. 'Though I delight to serve you and the college yet I am inwardly perplexed to see you soe often troubled.' $\mathrm{He}$ advised the warden to secure at the next assizes the services of 'Mr. Hill, a Parliament-man and a lawyer-for when I moved the other day on your behalf, he and his friends of the House fell in cordially to preserve the College, and this I would have you take notice of and thank him for." ${ }^{\prime}$ The warden took the advice, and a retaining fee of $f_{5} 8 s .9 d$. was paid to Mr. Hill, and a similar fee was paid in 1650 and for several years afterwards.

The visitation took place soon after 3 January, I 649-50. Warden Harris produced a full statement of the establishment at the visitation, wherein one may note with interest that the fellows and chaplains had chapel twice a day, at ro a.m. and 4 p.m., and also in the morning 'for the children before they go to school,' 'not according to the Common Prayer Book, but in a generall forme such as is usual in families.' 'The children' had 'a catechism lecture every Lord's Day in the afternoon, and, before it begins, the Usher is appointed to spend half an hour in particular examination of them, what they remember of the former lecture.'

The 'catechetical lectures' were due to Edward VI.'s injunctions. We find in the accounts payments of $6 s .8 d$. to the warden and fellows for the 'catechetical lectures,' and a similar payment to the hostiarius for his examination, and this went on at least down to $177^{2}$, and probably longer. The children had also to take notes of the Sunday 'forenoon sermon, and give account thereof to the schoolmaster in writing.' Every Saturday they learnt part of Nowell's catechism. Daily 'after they are in bed a chapter of the Bible is read by the Prepositor in every chamber.' The public school at this epoch was by no means deficient in religious demonstrations and dogmatic instruction.

A series of articles was presented ${ }^{2}$ against the warden himself, presumably by, or at the instance of, Sir Henry Mildmay. Fourteen in number they were somewhat frivolous in character and were answered by Harris point by point. They refer to his advocacy of 'corporal bowing at the name of Jesus,' and a justification of the ceremonies imposed by the bishops in convocation; that he 'maintained the lawfulness and antiquity of organicall music in the Quire'; and as to surplices he was accused of saying they would 'take away the gown also and leave the poor priest stark naked.' 'He hath only served the times,' for at his first coming to the College he used no adoration to the high altar, but afterwards with other superstitions fell to that; at the first convening of Parliament he left it again (never) used it since, and now forswears it." This he practically admitted. Then there were political charges, that he prayed for the Lord Ogle (the Royalist Governor of Winchester Castle), and compared the king to David who was hunted as a partridge ;

1 In Annals, p. 336, where this letter is quoted, it is added, 'It does not appear that this advice was followed.' But it was.

2 Annals, p. 339, where they are printed in full. 


\section{SCHOOLS}

and telling the soldiers that the kingdom by birthright was his 'although Scott born,' and they should obey him, and that the enemy's cause was just. He pleaded guilty to the partridge, but said his point was: 'Have not kings their troubles as other men ?' To the most substantial charge that he "with the rest of the College hath sent to the King money, horsemen, and plate,' he said that he never sent any horsemen nor plate. ' I have kept it and it is heere to be seene this day,' and he never gave any money to the king before the city became a garrison, and then only for ransom from the violence of Sir William Ogle.

The visitation produced no results. The college and its members were left alone; and the judicious Harris deserves no small credit for having so admirably ' served the times.'

The college did not even lose the customary venison which the Bishop of Winchester used to contribute from his park at Hursley, only it ${ }^{1}$ came from 'the Lord Cromwell' instead. Sporting festivities too received recognition, and it is at this period ${ }^{2}$ that payments first appear of a shilling 'to Mr. Symes' man bringing a fox to college' and 'to mending the fox's chain.' For nearly two centuries a fox was kept at Winchester. ${ }^{3}$

It is a strange thing for those who think that schools under Parliament were in a state of imminent dissolution to find that at Winchester two of the documents which throw most light on its internal economy date from this period.

No school lists exist anywhere of an earlier date than the Commonwealth, and both at Winchester and Westminster the earliest specimen dated from that period. That at Westminster is dated in 1656 , that at Winchester is three years earlier, 1653. This earliest 'Long Roll " is like its successors at the present day in the form of a roll and in Latin. It unfortunately gives no Christian names (as indeed the present ones do not to the masters and fellows), while college and commoners are in separate lists. There are three lists of college, first in school order, then in order of seniority of admission, and thirdly, arranged according to chambers. In later rolls the number of his chamber is prefixed to each scholar's name. In the school order there are twenty-three scholars in Sixth Book, a line being drawn after the eighteen prefects, eighteen in Fifth Book, twenty-three in Fourth Book, and six in Lower Fourth (Secunda 2uarta). Then follow the commoners in college, seven in number, of whom two are described as ' at the Masters' table,' i.e. fellow-commoners, the fellows being commonly called magistri; and five, including two Stanleys, sons of the late schoolmaster, another son being in college ' at the table of the Scholars (puerorum).' A Love, a son presumably of Nicholas, the Parliamentarian, is among these last. The choristers are inserted between the commoners in and out of college. These last only

1 Bursar's Book, I654-5.

2 Ibid. $1657-8$.

3 One was still kept by the 'Slype' at New College when I first went up in 1869.

-Winchester, Long Rolls, 1653-1721, by C. W. Holgate (Wells, Winchester, 1899). 


\section{A HISTORY OF HAMPSHIRE}

number fifteen, among them being a Fiennes. Next come four names, headed 'Pueri Domini Ludimagistri.' One of them was named Burt, and they no doubt lived in the headmaster's chambers. Then follow the rolls ad Oxoniam, the names of those elected to New College, if a vacancy should occur during the year, and ad Wintoniam, those similarly elected to Winchester. This Winton Roll contains ten names, headed by that of Nicholas, afterwards warden, and comprises three of the commoners. The roll for New College does not coincide either with the order in the school or that of seniority, so that it would seem to have been really founded on examination. The number of commoners is so small that it almost suggests that at this time, day-boys having been dropped, the college did not hold itself out to receive any one but gentlemen commoners, and a few who came in the hopes of getting into college. Of the twenty-five commoners five had the same names as, and were no doubt relations if not brothers of, boys in college.

After the list of the servants, in which the two cooks and the manciple receive the title of Dominus like the fellows, comes a list of 'officers.' It is headed by the prefect of tub, who was neither head of the school or senior in standing, but as low as eighth in the former and nineteenth in the latter; then comes prefect of hall, who inhabits, as now, sixth chamber, but was fifth both in school and seniority order. The prefect of school in this roll was Turner, afterwards Bishop of Ely, who was twenty-seventh in seniority, seventh in school, and thirteenth on the roll for New College. Next, under the heading Pueri Domini Ludimagistri, came the head of the school, second on the roll for New College, Thackham and Fauchin, who is thirteenth in the school; and under Pueri Domini Hypodidascali appears one boy only, Lowe, second in the school and eighth on the roll for New College. Were the two head boys called headmaster's and second-master's 'child' respectively, or had they some connection with commoners as tutor or prefect? The name does not occur in the later Long Rolls; and in the third extant, that for 1672 , of the three senior commoners out of college two are definitely described as prefects. Last on the Roll of I653 came two Prefecti Templi, or prefects of chapel.

\section{The School in I $65^{\circ}$}

About the same time as the first Long Roll, in the full height of the political revolution, as if to prove how little politics affected or were likely, whichever side won, to affect the schools, there made its appearance one of the most lively sketches of school life that has ever been seen. This was the poem, De Collegio seu potius collegiata scbola Wiccamica Wintoniensi ("Of the College, or rather Collegiate School of Wykeham at Winchester '). As has been already said, this poem, which was printed for the first time in 1848 by Christopher Wordsworth, was wrongly attributed by him to the Elizabethan headmaster, Christopher Johnson, when he was a boy, i.e. about $155^{\circ}$. It has been accordingly 


\section{SCHOOLS}

quoted as such by all writers on Winchester School, ${ }^{1}$ and many other school histories. It has now been shown ${ }^{2}$ beyond reasonable doubt to be, in its present state at all events, pretty well a century later. The internal evidence which fixes the date consists mainly of two passages. The first of these is the description of the 'Remedy Ring,' the ring given by the headmaster to the prefect of hall as a sign of the grant of a remedy or holiday, that the signet ring of gold may be sent to the boys, which carries leave to go and return to Hills or Meads. A note adds, Annuli inscriptio: POTENtiam GERo feroque (I give and take away power). The syllables printed in capitals give the name of Potenger, who was headmaster from the beginning of the Civil War, I642 to 1654. There was indeed a second master of the same name from 1536 to 1538 , but the granting of remedies has never rested with the second master. It is an inevitable inference from the rebus in the posy of the ring that the poem was written when Potenger was headmaster, or at least not earlier than his time.

The second passage which assisted Mr. Cotton to fix the date was one on the books read in school, which include

\section{Atque Robinsoni si sis orator, in borto}

$R$ hetorices varios fas est decerpere fores.

Robinson's Rhetoric is, it seems, a book, or part of a book, published at Oxford in I6I 6 by Hugh Robinson, who was headmaster from 16I3 to 1626 . The poem therefore cannot be earlier than that date; so, whoever may be the author, he cannot be Christopher Johnson. It may be further pointed out that the poet says that Conduit, the covered washing place ${ }^{3}$ in Chamber Court, had just had a new post and pillars. The accounts for I $_{5}$ I contain entries which show the erection of five new and gorgeously worked columns, which with their capitals and their founder's arms above were painted and gilded at a cost of $f_{0} 4$ I $5^{\text {s. }}$ Lastly, the poet describes as a conspicuous object on the north wall of school a map of the world, and there is an item in the Bursar's Book for I 6 56-7 of $\oint_{\mathrm{I}}$ I $7 s .6 d$. paid to the informator for a mappa mundi for school. All that we know of the author is that he was, or pretended to be, a boy in the school.

The actual date of the poem makes however little difference to the school life described in it. It is almost as applicable to I $55^{\circ}$ and to $175^{\circ}$ as it was to $165^{\circ}$, which we may put as its approximate date. It is a most succinct and lifelike picture of the school of the day. The poet first states the number of the community, with the interesting information that the fellows as well as the two masters were called masters, another indication that they did assist in the tuition. The prefect system was in full force. 'The eighteen seniors are rightly called

1 Not excepting myself (History, xx. 266-78).

2 By Mr. J. S. Cotton (college, 1861), formerly fellow of Queen's College, Oxford, and for many years editor of the Academy, in the Wykehamist for July, 1899.

${ }^{3}$ Only a tap and stone trough with the marks where the roof-gable leaned against the kitchen wall now remain to mark the spot. 


\section{A HISTORY OF HAMPSHIRE}

Prefects; by their example and warning (monitu) they preserve the discipline of the school, but should they turn mad or be spree their names are placed on a roll, and the roll is handed to the Master who sets all right with the four-fold rod.'

The poet carries us through the day. At 5 a.m. is first peal. " "Get up," (surgite) shouts the prefect'; not, be it noted, the junior as in later days. We have to get up; doublets, hose and shoes are snatched up. They ${ }^{2}$ hurry to their class, and if the bell has done begin the Latin hymn half dressed. Afterwards chambers are swept, hair brushed, beds made, face and hands washed, and at 5.30 second peal calls to chapel. Two prefects of chapel overlook the children to see that they do not talk, that they have their own books, do not recite anything wrong, and are not absent without leave. At 6 the small bell calls to the Muses. But there are prayers first- $A$ Gove principium' to ask God to wipe away the clouds of ignorance.' Then a 'vulgus' is done. 'We rack our brains for a verse which will fit the subject, each bound as tightly to his scob (cista) as God-like Prometheus was of old to the rock on the Caucasus.'

At 9 was breakfast, preceded by grace. The butler serves the drink, the bread-butler (artopta) the bread. Both consumed, prefect of hall calls 'Down,' and at once we all go down. Till I I we are intent on our studies, i.e. 'Books Chambers.' School is from I I till 12.

From school the small bell calls to hall. One of the ten prefects says grace; another, then called Bible clerk, reads a chapter of the Old Testament. He has a week for his proper muses. ${ }^{3}$ The prefect of tub sends prefect of hall a portion of beef, and during hall walks about and afterwards has his dinner with the servants. He gives the 'children' their portions; the junior cuts it into four equal parts. The junior also fills the cup; a leather jug, 'Black-jack,' stands by. 'When we have satisfied our howling stomachs,' Bible clerk goes to the round table, bows to the warden (dominus), who nods his head. The tablecloths are thrown into tub. Then we say grace, singing a psalm in alternate voices. After this the Muses summon us. The old women gather up the broken meats, the servants and choristers have their dinners.

In summer at 3.30 is 'Bevers,' when the boys may quench their thirst after showing their tasks to the master. At 5 there are prayers, and then you may go circum. At 6 is supper in hall. From hall to chambers. A little while after a late supper is given. At 8 is chapel in which a psalm is sung. 'And so to bed,' as Mr. Pepys says.

1 'Qui quadripartita bene corrigit omnia virga.' This 'bibling-rod,' four apple-twigs tied on a wooden handle about 3 feet long, was supposed to have been invented by Warden Baker, and was in use till 1880 .

2 The poet throughout changes, presumably according to the exigencies of metre, from the first to the third person.

3 'This seems to be an obscure way of expressing that he was in course for a week and during that time did not go 'up to books,' i.e. did not do lessons in form. This custom prevailed till the summer of 1869. 


\section{SCHOOLS}

Such was the daily round, the (literally) trivial task. But that was only on Monday, Wednesday and Friday. On Sunday if there was a sermon you had to take notes and write them down in a notebook. On Tuesday and Thursday, if fine, was 'Hills,' or, as the poet puts it, 'we shall visit the grateful tops of St. Catherine's Hill.' If the master has given a remedy (the exigencies of verse have converted the word from remedium into otia) a gold ring is sent to the boys, which equally gives or takes away leave for Hills or Meads, or fire in hall :-

The Prefect lifts the ring on high; straight the 'Scobs' bang. Then our Hundred-eyed Argus (the Prefect of Hall) sees that due order is kept in games and sports. Rule must be observed even in our playing.

Names are called at Middle Gate, every one answering 'adsum,' prefects standing on the right, inferiors on the left, "lest they annoy the Warden with their chatter.' Then we go to the green slopes of the lofty mountain, 'with a socius ${ }^{1}$ each must go: with a socius return, in line '-

Incedat sociata cobors, sociata recedat-

till the top of Hills is reached. Here they break off, but must not go beyond Trench, nor dare to sit on the ground for fear of fever. Then they play games, quoits, handball, batball or tennis, or football, and other games 'which I will not describe.' If the lazy poet had only described them his poem would be much more valuable, but he probably could not even conceive a time in which, even at school, games would be regarded as infinitely more important and interesting than anything else. But as they are, we must transcribe the actual lines describing this all-important part of school life.

\section{Hic tamen ejecto discas bene ludere disco \\ Seu pila delectat palmaria, sive per auras \\ Sape repercusso pila te juvat icta bacillo, \\ Seu pedibus calcata tuis.}

At 9 the prefect calls 'domum,' and home they go. After dinner back the Wykehamical bees fly to the green hill till 3 o'clock. But if it is frosty weather they have a fire in hall instead, the coals for which are sent by prefect of hall ; or if it is very hot they go to Meads. Then the bloody day of Friday draws near-

and I say bloody, because if you have sinned during the week, you will suffer cruel pain. Down on your knees, and two boys, duly summoned, will loose your braces and let down your breeches.

The poet kindly draws a veil over the rest.

We are told exactly what books are read, by what classes and on which days. The classes were divided then into Sixth, Fifth, Fourth and Lower Fourth (Quarta Secunda) Books. The word 'books' does not appear, but Horman in his Vulgaria translated it by classis, and the poet, who no doubt knew his Horman well, followed suit.

\footnotetext{
1 The word is still in use at the school for a companion.
} 


\section{A HISTORY OF HAMPSHIRE}

The time table may be summarized thus :-

\section{SCHOOL HOURS, I650}

5.0 Get up. Sing Latin psalm in chambers.

5.0-5.30 Clean chambers, make beds, wash hands and face, brush hair.

5.30-6.0 Chapel.

6.0-9.0 School.

9.0 Hall. Grace. Breakfast.

9.30-11.0 Books Chambers.

11.0-12.0 School.

12.0 Hall. Grace. Dinner, during which chapter read by Bible clerk. Grace.

1.0-3.30 School. Verse tasks.

$3.30 \quad$ Bevers.

4.0-5.0 School.

5.0 Prayers. Go circum in cloisters.

6.0 Hall. Supper (Crena, modern tea).

6.30-7.45 Books Chambers.

7.45 Merenda (modern supper).

8.0 Chapel.

8.15 Chambers. Bed.

The authors read are stated, and may be reduced to the following table :-

AUTHORS READ, 1550

\begin{tabular}{|c|c|c|c|c|}
\hline Book & Monday & Wednesday & Friday & Saturday \\
\hline VI. & $\begin{array}{l}\text { Martial } \\
\text { Robinson's Rbetoric }\end{array}$ & $\begin{array}{l}\text { Martial } \\
\text { Virgil's Eneid or } \\
\text { Cicero }\end{array}$ & $\begin{array}{l}\text { Homer } \\
\text { Terence }\end{array}$ & $\begin{array}{l}\text { Nowell's Greek } \\
\text { Catechism } \\
\text { Musæus } \\
\text { Hesiod } \\
\text { Virgil }\end{array}$ \\
\hline V. & $\begin{array}{l}\text { Martial } \\
\text { Cicero's Tusculan } \\
\text { Disputations }\end{array}$ & Same as VI. & $\begin{array}{l}\text { Pindar } \\
\text { Horace's Satires or } \\
\text { Epistles }\end{array}$ & Same as VI. \\
\hline IV. & $\begin{array}{l}\text { Cicero's De Officiis } \\
\text { Ovid's Tristia }\end{array}$ & Same as Monday & $\begin{array}{l}\text { Ovid's Metamor- } \\
\text { phoses }\end{array}$ & $\begin{array}{l}\text { Nowell's Latin } \\
\text { Catechism } \\
\text { Ovid's Tristia }\end{array}$ \\
\hline IV. 2 & $\begin{array}{l}\text { Ovid's Fasti or } \\
\text { Erasmus' Colloquies }\end{array}$ & Same as Monday & & \\
\hline
\end{tabular}

The authors read on Tuesday and Thursday, which were 'remedies,' are not stated. There was no school on those days, and 'Books Chambers' from 9.30 or Io to I I was probably devoted either to preparation or to verse and prose tasks. There are some difficulties about the list. The attribution of Pindar to Fifth Book on Friday is derived from the line-

\section{Audiet ad Lyricum modulantem Quinta Poetam.}

This might, of course, mean Horace's Odes, which otherwise would be neglected. But as Horman in 1519 calls Pindar the best of poets, and Sixth Book were reading a Greek poet on that day, probably Pindar was meant. There is a mysterious line about Theognis- 


\section{SCHOOLS}

\section{Et Quinta Sermo vel Epistola docta legetur, \\ Carmina nec Megarus recitabit docta Theognis.}

The first line certainly points to Horace's Epistles or Satires. The second would appear to mean that Theognis, a gnomic Greek poet, or moralist in verse, had lately been ousted from the curriculum in favour of Horace.

Saturday's list raises doubts as to the Lower Fourth's work.

Tristibus exonerat Naso precordia Quarte,

Quarta secunda vetat nimium lugere, propinquans,

Ni male decipiant Fasti, lux aurea solis.

Ovid lightens the hearts of Fourth Book from sadness, while the approach of the golden Sunday, unless the Fasti deceive, forbids the hearts of Lower Fourth to grieve overmuch.

This seems to mean that the Fourth Book reading Ovid's Fasti or Calendar would remind Lower Fourth, who were doing the Tristia, that next day was Sunday, the day of rest, the red-letter day of the calendar.

Having finished with the authors read, the poet goes on to a new subject, namely, what is still called Cloister Time, when those who were candidates for election to New College retired to cloisters to pursue their studies in peace by themselves.

After the annual holidays, twelve Prefects are chosen from the seniors. Woe to other boys who now enter the ungrateful Cloisters, and beat again with their feet the oft-trod pavements. As School, so Cloisters demand a Prefect, to be ready to go to the door if any stand without and knock, but the duty is taken in turns. As soon as election begins, farewell Cloisters. ${ }^{1}$

We have already seen that in Johnson's day there was an ostiarius or usher, a prefect, not the same as the bostiarius or second master, but a real doorkeeper in those days, as in later days. His seat was inscribed

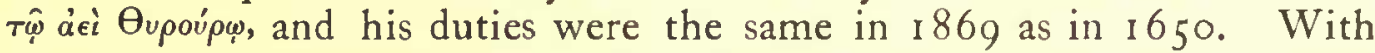
the substitution of class-rooms for school in 1869 the name and office disappeared. Bible clerk continued until the end of I 884 , school being occasionally used as such till that year. With its final disuse as a schoolroom he also disappeared.

The general practice of doing lessons in cloisters may remind us of Milton's wish in Il Penseroso-

\section{And may my due feet never fail}

To walk the studious cloisters pale.

In monasteries the cloister was the usual and only place of study, and the novices' school was held near its south-west door. So persistent are names that the summer term is still called cloister time, though no one has done lessons in cloisters for more than a hundred years, probably not since school was built in 1687 .

1 This passage was wrongly punctuated and misprinted in Wordsworth's edition. The original is as given here. 


\section{A HISTORY OF HAMPSHIRE}

Having finished the day and landed the boys in bed, our poet gives no more details, though he whets our curiosity, only to baulk it, by such questions as : "What am I to say, Cleopatra, of your noble kitchen ?' We should like to know more of the good lady cook-or was it a male ?- - who rejoiced in the name of Egypt's queen of love. We resent the poet's 'passing by' 'the garden of Alcinous and the green isles of Tempe.' Was the Tempe of 1550 the same as that of 1860 - the ditch passed on the way to Hills, just beyond Blackbridge ? We strongly object to his abstinence from water-' No hand shall be dipped in the descending stream, though Conduit has just had a new roof and pillars' (Ductus aqua quamvis sit plumbo et poste novatus) -and still more to his Muse's abstinence from beer : 'My muse shall drink no flagons in the cellar.'

While we regret that the poet did not tell us more, we must be thankful that he has told us so much. His word picture is characteristically like the paintings of the contemporary Dutch school, with its quaint realism and careful, yet easy, reproduction of life. Its value is the greater in that it is undoubtedly a picture which must in the main have been true of the school life I 50 years before, as it undoubtedly was of the school life 150 years afterwards.

In Dr. Moberly's school days-i 816-22-the hours and arrangements, as he used to tell them to his pupils in 1865 , were almost exactly the same as in Johnson's poem, particularly in the terrible interval between getting up at 5 and breakfast at 9, and in the curious relic of Roman Catholic times in 'going circum,' of which no satisfactory explanation is forthcoming.

One point on which Johnson's and the elder days seem to have been infinitely superior to the latter days is the marked absence of fagging and tunding. There is not a word to suggest that such a thing existed. Prefects' duty appears to have been to report delinquents and rebels to the master, not to punish them themselves. The ground-ash does not whistle through these pages! In early nineteenth century descriptions of Winchester, fagging and tunding occupy the most prominent place of all. If they had existed to anything like the same extent in the sixteenth century, our poet could scarcely have failed to mention them. The boys clearly had to make their own beds and to sweep out their own chambers, and no doubt the juniors had to do most of the work. But there was not room for much other fagging. Fagging is connected chiefly with games or with meals of supererogation. Organized games hardly existed, and seemingly only took place on Hills. Additional meals were almost impossible when merenda or supper was provided by college, when the boys went to bed at eight, and no boy ever went outside Middle Gate except to go on Hills or by special leave. It is also extremely probable that flogging was not nearly so frequent as afterwards. A punishment reserved for a single day in the week, and so judicially inflicted, could not have been so often inflicted as when it went on every day. 


\section{SCHOOLS}

\section{The Restoration and Revolution}

At the end of the Commonwealth period the college bells rang with even peals to celebrate the proclamation of the Lord Protector Richard in 1658 and the coming of Charles II. in 1660 , the tariff on each occasion being five shillings, or a shilling a bell. Nicholas Love, having sat in the court which sentenced Charles I., fled for his life to the continent, and like many of the other regicides found a delightful haven of safety on the Lake of Geneva. After the Restoration, Winchester becoming again for a time a royal city, the college again became a royal school. Under the patronage of sprightly Charles II. it enjoyed another golden age such as it had enjoyed under the saintly Henry VI.

The first year after the Restoration there was a brilliant roll of scholars. It included a future Lord Chief Justice, Lord Edward Herbert ; a Secretary of State, John Trenchard; a bishop, Thomas Manningham, Dean of Windsor and Bishop of Chester; a Public Orator at Oxford, Cradock; the most successful headmaster of the century, Dr. Burton; and the Lord Chief Justice, Lord Edward Herbert, son of Lord Herbert of Cherbury, who went from his fellowship at New College to the bar, and twenty years later became Lord Chief Justice.

We do not know the names of the commoners contemporary with the brilliant scholars of $\mathrm{I} 66 \mathrm{I}$, as after $\mathrm{I} 653$ no Long Rolls are known to exist before 1668 . In that year the commoners numbered only thirty-six, of whom thirty-one are described as 'out of college,' the others being ' in college.' 'The Lord of Falkland ' headed the list, on which Otway the dramatist was third, of the commoners ' in college.'

Another interesting point in this Long Roll is that it shows that the practice of sending boys as commoners as a half-way house for entrance to college still continued, for the name of Otway the poet was on the roll 'ad Winton' for admission to Winchester College, though he never got in, the last on the roll who was admitted being the next above him. Two of his fellow-commoners headed the roll : Henry Morgan, son of Sir Thomas Morgan, Bart., who was nominated by the king, and Eustace Moore, who received a nomination from the bishop, Morley.

It is remarkable that two of the choristers also obtained entrance to college : Pettye, who, to judge by his place, was nominated by the warden, and Herrin, who was admitted the next year, the Long Roll for which is missing.

An examination of the rolls from 1690 to 1720 has shown four certain and ten practically certain cases of choristers going into college. How late the practice went on is not ascertained. In 1758 William Crowe the poet was admitted to college, after appearing as a chorister on the Long Roll of the previous year. Dr. Goddard, headmaster from I 793 to 1809 , elected to college in $177 \mathrm{I}$, went first as a chorister. But the practice was at the end of the seventeenth century probably falling into desuetude. When the scholars were relieved of making their own

1 By Mr. Herbert Chitty. The Wykehamist, May, 1901. 


\section{A HISTORY OF HAMPSHIRE}

beds as ' a servile and foul office' in 1708 , and college, through fees to servants and payments to headmasters, became an expensive place, the class of choristers became marked off from that of scholars, and only very extreme poverty could induce parents of the professional classes to send a boy as a chorister on the chance of admission to college.

The lists of commoners during the seventeenth century shows how gilded was the youth that then flocked to Winchester. Thus in 1674 Lord Powlett, Worsley and Wyndham, senior, headed commoners out of

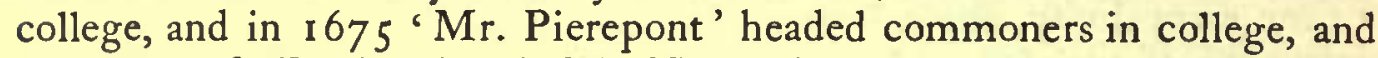
the 'Erle of Wiltshire' and 'Mr. Nowell' were at the top of commoners out of college, whose rear was brought up by 'Ashly,' who is pretty certainly one of the Ashley Coopers. Ten years later, in I685, the latter family appear in force, the gentleman commoners being Lord Ashley, afterwards the Lord Shaftesbury who wrote 'the Characteristics'-Lord Shaftesbury complained 'that after seven years at school given up to Latin and Greek he could neither make nor construe a sentence; but as he never got beyond Fourth Book that was perhaps more his fault than the school's-Lord Guilford, Mr. Ashley, med. (in these days he would be called secundus), Mr. Ashley, junior, and Mr. Fiennes (Lord Saye and Sele).

A complaint was that there were 'scarce any' at Winchester' that escape the mother vice of drinking,' but as Shaftesbury reprobates a dictum of the Bishop of Oxford 'that Palmer was the only sober man' in New College, saying that 'the numbers were little more than proportionable through most of the Colledges,' we may perhaps discount this charge also. Drinking was the fashion of the day, and while boys were brought up on beer morning, noon and night it is not surprising if they sometimes took too much. Against this attack of one of its alumni we may set the evidence of the father of another, Ralph Verney, who, writing in 1682 to the headmaster, Dr. Harris, said, ' William of Wickham's Foundation is, I believe, the best nursery of learning for young children in the world, and perhaps never was better provided with abler teachers than now at this present, yourself for a master, Mr. Horne for an usher and Mr. Terry for a tutor.' The remark has some interest in another connection as showing the existence of a commoner tutor at this date who was practically an assistant master, though so little recognized by the foundation as not to appear on the Long Roll for the period. ${ }^{3}$ Indeed the school was certainly in great repute for the period from 1679 to 1696. In the former year there had been a double change in the heads of affairs. The warden of New College, John Nicholas," succeeded Dr. Burt " as warden of Winchester; while the headmaster, Henry Beeston," succeeded Nicholas as warden of New College. It was a strange

1 Shaftesbury Papers, P.R.O., quoted in History of New College (1901), by H. Rashdale and R. S.

2 Verney Memoirs, iv. 219 (1899), quoted in Winchester Long Rolls, p. luxiii.

3 That is for 1681 and 1683 , there being no roll yet discovered for 1682 .

4 All Hampshire men. 


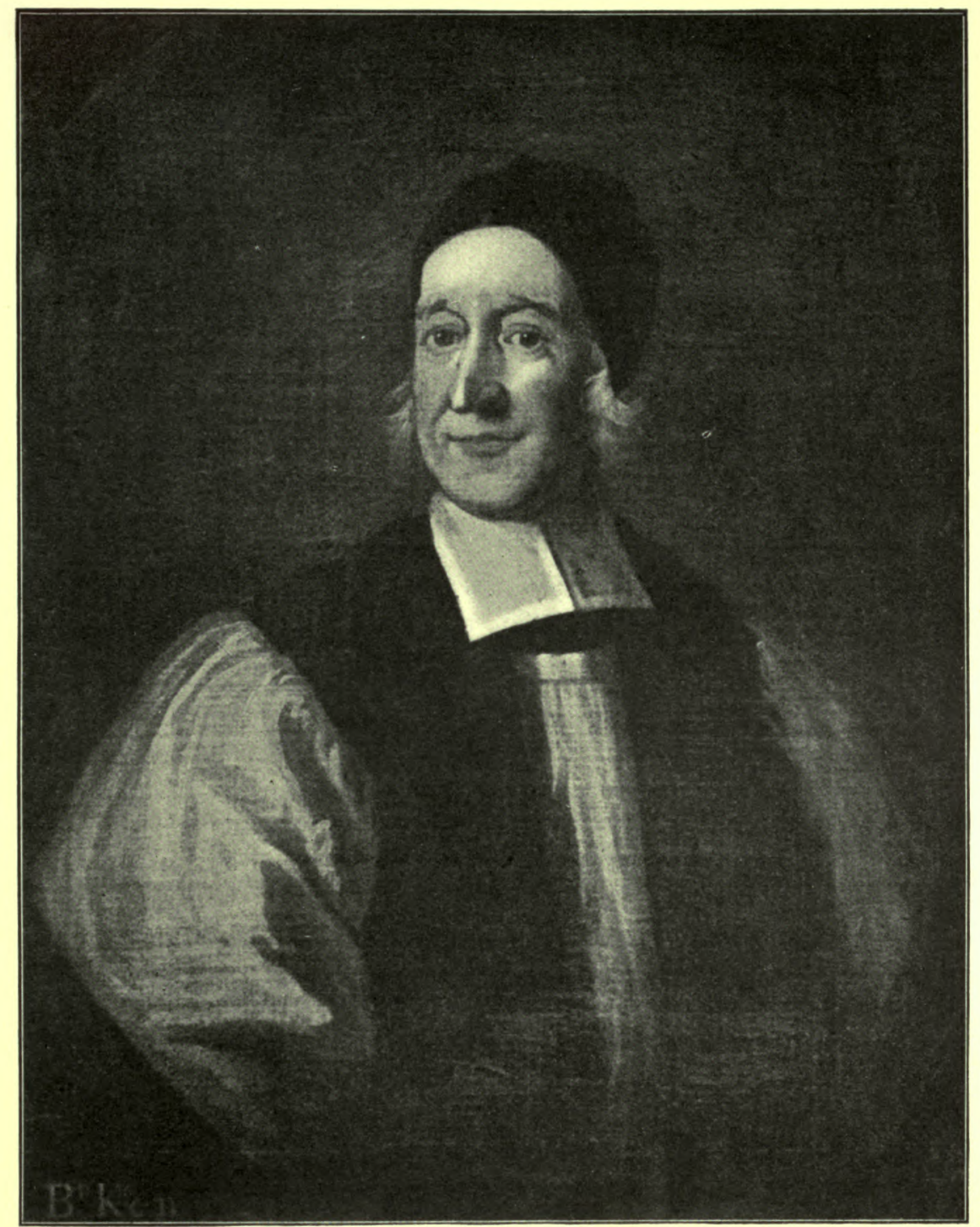

Thomas Ken, Bishop of Bath and Wells. Commoner, then College, i65i-7. From his portrait in the Warden's Lodgings, Nezw College, Oxford. 


\section{SCHOOLS}

thing, the head of 'the greater light' thus descending to rule ' the lesser light.' But the precedent thus set by Nicholas was followed by his successors in the wardenship of New College for nearly a hundred years, and was founded on solid and substantial reasons. In the course of time the wardenship of Winchester, which was intended by Wykeham to be only half as valuable as that of New College, had become the richer manger, and the strongest horse got it.

Under Warden Nicholas and Headmaster William Harris ${ }^{1}$ the number of commoners went on increasing. The rising numbers caused the first great change in the outward appearance and arrangement of college since Wykeham's time by the building of a new, now old and disused, school. Its erection caused the addition of a new quadrangle called School Court. There had been a court-area it is called in the old accounts-there before, but it was not of public resort. The cutting of Seventh Chamber Passage through the old school added this new area to the general pile. The quarters of the ' children' were proportionately enlarged by the addition of a seventh chamber to the original six. This however did not take place till $\mathrm{r} 70 \mathrm{I}$, when under the new headmaster, Cheyney, the number first appears in Long Rolls as the number of a chamber. It may be suspected that Seventh Chamber was until then used to find additional accommodation for commoners, and thus Warden Nicholas was able to get repaid some of the $f_{0} \mathrm{I}, 400$ he contributed to this new building.

The new development was very successful for a time. The numbers went on rising. In 1688 , owing probably to the uneasy state of politics, there was a decline to sixty-seven, among whom Baron Guilford appears in a heading all to himself as a Nobilis commensalis, while Dominus Fiennes, Dominus Ashley, Tho. Putt and Tho. Wroth. Baro. (for Baronetti) appear in a separate class.

June 30 , I 688, was a proud day for Winchester College, when of the 'Seven Bishops' tried for seditious libel in signing a petition to James II. against the Declaration of Indulgence three, Thomas Ken, Bishop of Bath and Wells, Francis Turner, Bishop of Ely, and William Lloyd, Bishop of St. Asaph ; and of the four judges of the King's Bench who tried them two, and those the two who at the risk of place and fortune preferred the law to the king and summed up for an acquittal, Richard Holloway and Powell, were Wykehamists. ${ }^{3}$

\section{The Eighteenth Century}

With the eighteenth century the modern era of schools begins. Records are more abundant and the historical interest becomes less for a work like the present. We must therefore pass over the ground more rapidly and lightly.

The first quarter of the century was not one of the great periods of Winchester College. Domestic dissensions and national dissensions in

1 A Hampshire man.

2 The first two named bishops and the first named judge in college, the other two commoners. Lloyd was a commoner at New College, and therefore almost certainly at Winchester. 


\section{A HISTORY OF HAMPSHIRE}

which the college took the wrong side were the probable causes of the indifferent repute in which it appears to have been held. The number of commoners, the record of which henceforward forms a fairly accurate gauge of its position, was steady at about fifty for the first ten years under the rule of Thomas Cheyney, the headmaster from I701. But in I7ro a decline began, and in I 17 there were only twenty commoners on the roll, though they were headed by the august name of 'His Grace ye Duke of Hamilton and Brandon.'

Domestic dissensions began over the disputed election of a fellow in I 708, in which Warden Nicholas had procured the election of a fellow, at a meeting held at twenty-four hours' notice, on 30 December, with only two fellows present. The rest protested and appealed to the visitor, the Bishop of Winchester. The election was confirmed. Apparently by way of retaliation, the sub-warden and other fellows then began an attack on the warden's allowances and perquisites. This resulted in another appeal to the visitor by the warden, a denial of jurisdiction by Ralph Bridcombe, his consequent expulsion from his fellowship, proceedings in Chancery and the Queen's Bench, and a published Plea of the Fellows of Winchester College against the Bishop of Winchester's local and final visitutorial Power over the said College. ${ }^{1}$ This publication is chiefly interesting for its collected record of all the archiepiscopal visitations, cited to show that the bishop's visitations were not final, and for its full account of a queer quarrel which had arisen between the warden and fellows in 1608 and produced a visitation by Archbishop Bancroft. In February, I7 I 2, before the case was determined, Warden Nicholas died. Meanwhile, the quarrels of their rulers for once benefited the ruled. The scholars obtained improvements in their ' commons,' which the fellows said were 'industriously misrepresented,' as ' the Warden, for some private reasons, constantly opposed these as well as all other alterations,' and endeavoured 'to make them be thought of less advantage to the scholars than they really are.' The table compiled by the fellows to show the improvement effected is a curious example of the way in which the interests of the scholars, the main object of the foundation, had been sacrificed to those of the fellows, a mere afterthought and appendage, who, with the warden, had shared the bulk of the unearned increment of the college revenues.

\section{TABLE}

A Scholar's Commons, as Lately

A Scholar's Present Commons

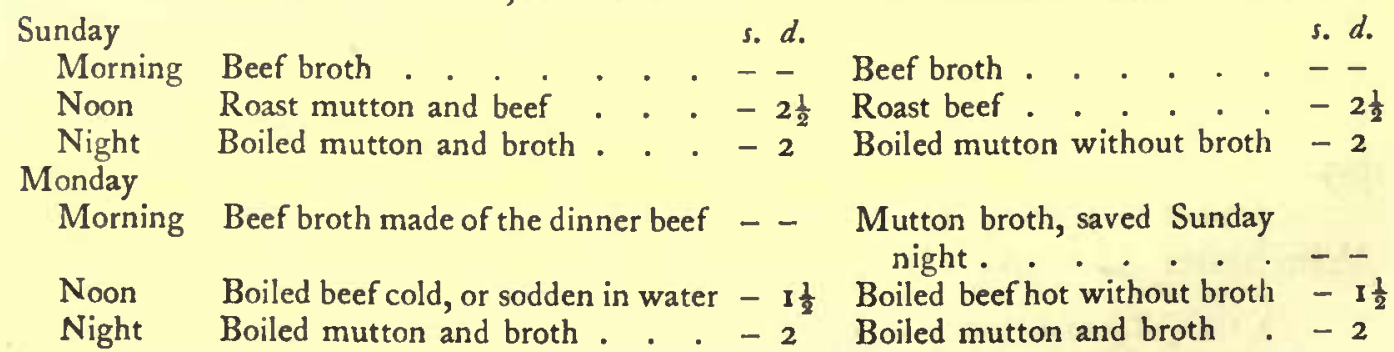

1 London: Printed by George James for Jonah Bowyer at the Rose in Ludgate Street, 17 I I. 


\section{SCHOOLS}

A S
Tuesday
Morning
Noon
Night
Wednesday
Morning
Noon
Night
Thursday
Morning
Noon
Night
Friday
Morning
Noon

A Scholar's Commons, as Lately

\section{A Scholar's Present Commons}

s. $d$.

Beef broth saved Monday . - -

Boiled beef hot without broth - I $\frac{1}{2}$

Boiled mutton and broth . - $1 \frac{1}{2}$

Beef broth saved Tuesday . - -

Boiled beef hot without broth $-I_{\frac{1}{2}}$

Boiled mutton and broth . -2

Beef broth saved Wednesday - -

Boiled beef hot without broth $-1 \frac{1}{2}$

Boiled mutton and broth . - $1 \frac{1}{2}$

Beef broth saved Thursday . - -

Baked pudding made of flour, bread, fruit, spice, milk and butter . . . . . $-I_{\frac{1}{2}}$

Boiled mutton without broth -2

Night

Saturday

Morning

Noon

Night
Nothing

Nothing

Cheese and butter . . . . . - I

Baked pudding made up with water $-1 \frac{1}{4}$
Mutton broth saved Friday . - -

Baked pudding and butter . - I $\frac{1}{2}$

Boiled mutton and broth.-2

$$
\text { Total . . } \overline{19 \frac{3}{4}} \text { The total weekly } \overline{20 \frac{1}{2}}
$$

One wonders how the modern schoolboy's stomach would stand the awful period from Thursday night to Sunday morning, with nothing through the whole of Friday but one midday meal of bread, cheese and butter, and on Saturday the same, tempered by a batter (?) pudding on Saturday night, especially when all the floggings of the week were accumulated for that grim Friday. The self-flattery of the fellows on the augmentation of $2 \frac{1}{4} d$. a week on each scholar's commons strikes one as quaint. Their memorandum however pointed out that a further improvement had been made by giving supper on certain fast days, vigils, Rogation days, Ember days, and the eves of 'Gaudies,' though the cost of it was probably saved by reducing 'Gaudies' to the level of Sundays. Also the 'Lenton Diet' had been made the same as at other times. That however cost the fellows nothing, as Dr. Harris, the late headmaster and warden, had left $f_{2} 200$ for the purpose of substituting veal for salt fish, his experience having no doubt shown him the folly of starving the schoolboy in the most trying time of the year in our climate.

The subject of drink was dealt with separately. Perhaps to modern notions the most astonishing item in a dietary so scanty in solid food was the abundance of beer. In that article there had never been any stint. It bore much the same relation to the commons as Falstaff's sack to his bread. We have seen how the boys who dined at St. Cross in the fourteenth century had three lagene, commonly translated gallons, allowed them. In 1709 the three chaplains had between them seventy quarts a week, or at the rate of something over three quarts a day, and the scholars and choristers had an unlimited quantity, though it is stated 'three pints per diem each is more than they are observed to drink.' Under the new arrangement 'the beer allowed the scholars is such a certain 


\section{A HISTORY OF HAMPSHIRE}

quantity to each table at every meal, which is after the rate of something more than a pint to each scholar at dinner and at supper, and something less than a pint to him at breakfast.' 'This was in addition to 'BeaverBeer after dinners and suppers in summer time.' This Beaver or Beverbeer drinking still existed in the memory of living Wykehamists, and the interval from 4.30 to 5 p.m. on whole school days survived this custom, and retained the name of Beavers for many years after it had ceased to be celebrated by drinking, up to about the year $\mathrm{x} 860$. It was the equivalent of the modern 'five o'clock tea' of grown-up people. The amount of beer allowed was unlimited. As for the beer at meals, a quaint instance of the proverbial conservatism of schoolboys is recorded. "The "House" did kindly intent to have it divided equally among the scholars by giving each of them a separate quantity in a copper pot by itself, which was provided for that purpose, but the scholars, showing an unbecoming dislike of this provision, they have a certain quantity set down at every meal, which they are to share among themselves as they can agree.' The copper pots in question cost $f 8{ }_{1} 5_{5}$. or $2 s .6 d$. each. ${ }^{1}$

The whole question of ways and means as regards the boys was seemingly under review, as in a paper of Warden Nicholas of the same year (1709) a list is given of the various fees or tips, as we should call most of them, exacted from Wykeham's 'poor and necessitous scholars' as well as from the 'sons of the noble' commoners.

Fees from a Child at his Firs
Entrance
Ye Prepostor of Hall
Ye Prepostor of School
Chamber stock

Quarterly

Ye Bedmaker

Ye Almoner

School and foricus

After Christmas

Cause money

Church money

\section{After Whitsuntide}

Rod money

Nutting money

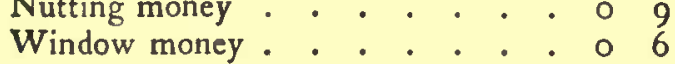

$$
\begin{aligned}
& \text { Fees from a Commoner at his First } \\
& \text { ENTRANCE s. } d \text {. } \\
& \text { Ye Prepostor of Hall . . . . . } 26 \\
& \text { Ye Prepostor of School . . . . . } 26 \\
& \text { Chamber stock . . . . . . . I } \\
& \text { Quarterly } \\
& 60 \\
& \text { Quarterage . . . . . . . } 16 \\
& \text { School and foricus . . . . . } 02 \\
& \begin{array}{llllll} 
& & & 1 & 8 \\
\text { Upon changing chambers . . . } & \text { I } & 0
\end{array} \\
& \text { After Michaelmas }
\end{aligned}
$$

Fire money . . . . . . . . I 0

Chamber stock . . . . . . . I 0

Candle money . . • • • • • I 0

After Christmas $\quad 30$

Cause money . . . . . . . . 10

Fire money - . . . . . . 10

Church money . . . . . . 02

Candle money . . . . . . 10

After Whitsuntide $\quad 32$

Rod money . . . . . . . . I 0

Nutting money . . . . . . I 6

Window money . . . . . . 06

1 Annals, p. 381. 


\section{SCHOOLS}

from a New Prepostor

$\begin{array}{ccccccc}\text { Fres from a } & \text { New Prepostor } & £ & \text { s. } & d . \\ 0\end{array}$

Fees from a New Officer

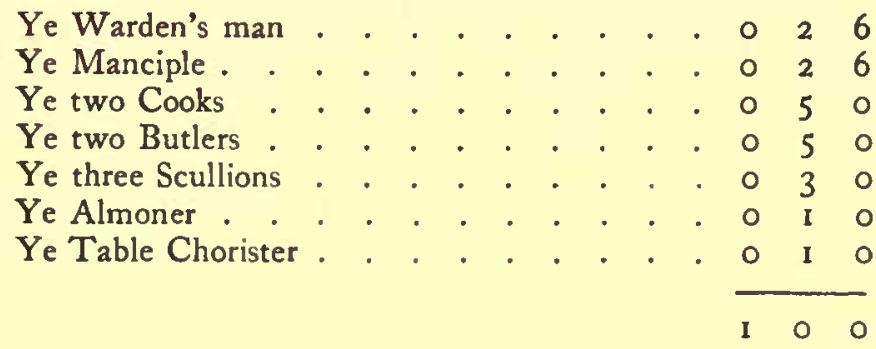

There are several items in this statement which would strike the modern parent as odd, e.g. that a scholar should pay for his chamber ware, the college only supplying beds, even the daily making of these being an extra; that he should pay for keeping the school and the latrines (foricus = foricas, the 'notion' still in use) clean, should 'tip' his own schoolfellows the then not inconsiderable sum of half a crown for the performance of those prefectural functions ${ }^{1}$ and subscribe another halfcrown for their benefit on leaving as superannuated. Enforced charity as evidenced in a shilling to the almoner is, of course, nothing unusual even now. The 'officers,' the five senior prefects holding certain offices of Prefect of Hall, School, Chapel and Library are still mulcted in customary tips, though not on entrance into office or to quite so many functionaries. 'Rod money,' or paying for the provision made for your own chastisement, was an item known in many, perhaps in all, ancient schools, as at Hexham, where it was provided for in the statutes in I 590, ' and the Schoolmaster's ferules of every of his scholars born without the parish shall be $4 s$., that is, $12 d$. at every of the said quarter days.'

Nutting money was for the expenses of carriage for the September outing to gather nuts, which Malim's Elizabethan account of Eton shows to have been an institution there also. Window money is for the breakage of windows, a constant item of expense in all old school accounts, when, there being no regular outlet for superfluous energies in games, the boys were apt to take it out on the windows. 'Cause,' probably pronounced 'causey,' money was for maintaining the footpath across the fields from Blackbridge to Hills, now nearly destroyed by encroachment of town and railway. 'Church money' is said to be a payment to the vergers for keeping the seats in the cathedral, whither the school repaired on Sunday mornings. Commoners, it may be observed, paid also fire money and candle money, from which the 'children' were exempt by reason of special endowments such as Thomas Chandler's, who commemorated his own name by the provision of those luxuries. Commoners seem to have been exempt from almsgiving, the almoner being perhaps a purely college officer.

Hardly had the domestic discords between Warden Nicholas and

\footnotetext{
Eton still.

1 The modern Wyckhamist will notice that prefects were then commonly called prepostors, as at 2 Annals, p. 383.
} 


\section{A HISTORY OF HAMPSHIRE}

the fellows ceased by the former's death, and the school, as tested by numbers, begun to revive under Warden Braithwaite, than it fell again under the stress of political animosities aroused by the death of Queen Anne and the Jacobite rebellion of I 7 I 5 .

On 6 March, I 7 I 6-7, the Grand Jury of Hampshire presented the college 'Warden, Fellows, Master, Usher, and children for their known disaffection and corruption of manners.'

It being notorious that the late unnatural Rebellion and present threatened Invasion are the effects of Prejudice and bad Educacion . . . being credibly informed that the Scollars of that noble Foundation, commonly called Winchester Colledge, are now taught to emulate each other in factious and party Principles, by being told they are to be distinguished and preferred according to their several degrees of zeal; and they do frequently treat most as are known to be well affected to the King's Government with opprobrious language and ill-usage (particularly several Justices of the Peace) with impunity from their Masters and Governors; from whence it is naturall to infer that their said Masters and Governors are also inclined to faction and disaffection.

In 17 i 6 the numbers of commoners fell to thirty-one, next year to twenty. On I2 August, I7 18, the Secretary of State (Craggs) found time to spare from his severer labours to write to the warden for the chastisement of 'many of the youths of Winchester School, and particularly those upon the Foundation.' This was for going to cathedral on the king's accession day ' in a very extraordinary and indecent manner, with Rue and Time on their Breasts, and some with mourning hatbands on their hats, by which it appears that these poor children, instead of being taught their Book, and instructed in the principles of the Church of England, have learnt somewhat to concern themselves in disloyal party divisions and distinctions. I give you this notice of it that you may direct them to be whipt, and take care that no enormity of this kind may be committed there for the future.' The warden's answer was that they did not go to cathedral till after celebrating the accession in chapel. 'There were seven or eight of them, little boys, had rue and time in their hats for which they were punished by the Master, according to the method in the school. None of the upper boys, or Præpositors, as we call them, had any. I cannot find that above three or four had mourning hat-bands, and that occasioned by the late death of relations, and besides this, I believe there is not a mourning hat-band in the College. I am very well informed they that were whipt knew it not to be a party badge.'

If the warden was stating facts, so innocent a tribe never suffered the rod until Keate at Eton insisted on whipping the boys sent up for confirmation.

In 1720 the changing of Warden Braithwaite for Warden Cobb, a younger son of Sir Thomas Cobb, Bart., may remind us how delightfully early in those days people obtained their promotions. He was only thirty-five when he became warden of New College, and he became warden of Winchester at the age of forty-three.

In 1724 there was a clearance. Warden Cobb gave place to Warden Dobson. Cheyney illustrated the saying that a successful head- 


\section{SCHOOLS}

master can always get made a bishop and an unsuccessful one a dean by going off to the deanery of Wells. He was succeeded by John Burton. The improvement was immediate. Commoners rose from thirty-five to forty-six in 1727 ; by 1730 they numbered eighty-seven ; in $173^{2}$, one hundred and eleven, and in 1734 one hundred and twenty-three. This was high-water mark, never again reached till 1804 . The quality of the attendance, or rather the attendance of the quality, improved with the quantity. Both quantity and quality had been as good in the previous century, and these produced the new, now old, school. The increase under Dr. Burton was destined to produce even greater developments in school and school buildings. He seems to have determined to make the increase of numbers permanent, and to secure at least some of the profit to himself by building a new house under his own control for the reception of commoners. So he has been called "the Founder of Commoners'-a misleading misnomer.

When Dr. Burton came to the headmaster's throne, and for some years afterwards, he did not, nor did the commoners proper, live in ' Commoners.' They lived in college. ' In 1724 the college passed a resolution that 'either Dr. Burton or Mr. Eyre shall constantly reside in the College, dividing the time equally between them, so long as Mr. Eyre continues Usher.' Now that Eyre, not Burton, lived outside college seems proved by Eyre's being tenant of the Spital from $1720{ }^{2}$ while Charles Blackstone in the Benefactions Book records ${ }^{3}$ that Burton 'in 1727 expended a considerable sum in new buildings in the Schoolmaster's lodgings, and in repairing and ornamenting the old.' In 1727 Philip Yorke, son of Lord Hardwicke, the Chancellor, was asked to advise whether commoners being admitted as headmaster's boarders would subject the college brewhouse to excise duties. He replied in the negative.

Again from a letter written on 21 October, 1731,4 it is clear that the headmaster still lived in college and restricted himself to the statutory ten filii nobilium.

' You that are in the midst of the Beau Monde and think of nothing but Foreign Dukes, etc., will not be entertained with what I can relate from hence, which only consists of the pleasure of the Field, where last Monday we were particularly well pleased. For by invitation we had Dr. Burton, the Master of Winchester School, and his ten young noblemen's sons that live with him, for which he has $\oint_{2} 200$ a year for each, and is as a private governour to them, and they also have the advantage of a publick school at the same time, which surely must be a fine way of educating them. These with four other young gentlemen of the School met us in the field a-hunting. They and their attendance and ours made in all 40 people, and after very good sport all came home to dine here. Indeed, I have not seen a finer sight than those boys and

1 Anrals, p. $392 . \quad 3$ Ibid. p. 124.

1 Political and Social Letters of a Lady of the Eighteenth Century, edited by Miss E. F. D. Osborn (London, 1890 ), p. 45. 


\section{A HISTORY OF HAMPSHIRE}

their master together. Lord Deerhurst and his brothers Coventrys, Lord Ossulston, Lord Brook, Master Duncomb and Sir Robert Burdet, Master Greville, Master Wallop (Lord Lymington's son), also Lord Drumlanrich, the Duke of Queensberry's son, who is under his peculiar care, though not in the house, because he would not exceed his fix'd number.'

The portraits of all the boys mentioned, except Master Duncomb and the elder of the two Coventrys, were given by Dr. Burton's will in 1774, with a direction that they should 'hang in the school-master's great room,' the present second-master's dining-room, of which, though their gay colours are somewhat faded, they still form a most interesting ornament. In 1733 the distinction between commoners in college and other commoners still appears in the Long Roll for that year, and according to Mackenzie Walcott's copies of Long Rolls, contained in the British Museum, is traceable till 1736. In 1739 a quarrel broke out between Hostiarius Eyre and Dr. Burton, and the former among other gravamina asked the warden and fellows: 'Have I a right to the chambers in the College assigned to me by the College, but possessed by Dr. Burton without any leave ever asked?'

The headmaster then occupied the old joint chambers of the headmaster and usher and the commoners' chamber. The quarrel arose through Burton having said that 'the Scholars, at the Usher's end of the School, do not make due progress in their learning.' To remedy this he had introduced an assistant-master, Ashley by name, without Eyre's consent or knowledge. Two commoners being ' taken from the Usher's end of the School and sent to Ashley's'; the outraged usher, missing them in school, went in pursuit, and the boys 'stamped downstairs' in $\mathrm{Mr}$. Ashley's hearing. What stairs? School had none. Mr. Kirby reasonably conjectures that Mr. Ashley was teaching in the commoners' chamber over Fifth. Eyre resigned as the result of the quarrel, and was succeeded by Samuel Speed, who also became tenant of the Spital. ${ }^{1}$ In 1755 Joseph Warton was, on the resignation of the Rev. Samuel Speed, elected second master of Winchester School, 'with the management and advantages of a boarding-house'; and his biographer says ' the sons of a prime minister ${ }^{2}$ were in his boarding-house while he was Second, and the heir-apparent of a secretary of state while he was First Master of Winchester College.' Warton also became tenant of the Spital. At least as late, then, as Dr. Warton's headmastership, the second master lived in a separate and independent boarding-house.

In the Spital precincts Dr. Burton occupied only the 'Sistern houses' -out-houses seemingly - 'so much of them as is not already demised to other persons,' let to him by the chapter on 25 November, 1748 , and again 20 June, 1759. Instead of these he built a new and, probably, superior boarding-house, with a house for the headmaster. It was no doubt a great improvement. The new house, filling up the front to the

1 Biographical Memoirs of the late Dr. Joseph Warton, by Dr. Wooll, headmaster of Rugby (London : T. Cadell \& W. Davies, 1806), p. 30.

2 Lord Bute's sons, one of whom became Bishop of St. David's and Archbishop of Dublin. 


\section{SCHOOLS}

street, converted the whole into 'Commoners' College.' In the end the headmaster's house, like Aaron's rod, swallowed up its rivals, and with the chapel and the Spital became 'Old Commoners.' But that was not till long after Burton's time. The title of 'Founder of Commoners' is therefore only applicable to Burton in a very limited sense.

In 1737 there were 93 commoners, including the Duke of Richmond's eldest son, Lord March, the Marquess Clydesdale, the Duke of Queensberry's eldest son, Lord Drumlanrig, Lord Elcho, Lord Charles Douglas, Sir Richard Wrottesley, Sir Richard Bamfylde and many other 'great' people, making 179 boys in all. Then, perhaps because of the Eyre quarrel, a grave depression ensued. In $174^{\circ}$ the number of commoners had fallen to less than half, $4 \mathrm{I}$; in 1742 to 28 ; while in the middle year of the century, 1750 , there were 10 , and in $175^{1}$ just 8 commoners. Not until 1756 , when Dr. Warton came as second master, did the numbers rise again above 20 .

The frequent falls in the numbers of commoners at Winchester are paralleled at Eton, though the total number at Eton was much larger, being in 1706 , including 70 collegers, 353 , and in 1744 only 144 .

Burton's own view of the cause of decadence is on record in some interesting letters ${ }^{1}$ apropos of the election of Warden Lee in 1763 . Dr. Burton, Joseph Warton, then second master, and a fellow of New College named Phelps, who dates from Whitehall and was apparently in the Treasury, were much exercised at the election of Lee, whom they called King Log.

In Lee's 'sovereignty,' which lasted from ${ }^{2} 763$ to 1789 , the school returned to more than its former prosperity of numbers. As the change for the better did not take place till after Burton's own resignation in 1766, when he was seventy-four years old, and had been no less than forty-four years headmaster, it is to be feared that it was his too lengthened stay and not the rule of this or that warden, which led to its decadence.

Christopher Eyre, the second master, who was also a canon of Winchester, and Dr. Burton each left a memorial of their prosperity. There had always been a difficulty about providing for those scholars who did not ' get off to New,' i.e. have the good luck to be elected to New College. To meet this, Warden Dobson, with Eyre and Burton, started the Superannuates Fund, with a yearly subscription list and donations, Burton giving $\oint_{1} 10$ a year and Eyre $\oint_{5}$ a year and $f_{0} 100$ down. In 1742 Burton and his kinsman Bohun Fox, an old Wykehamist and founder's kin, gave half the prebend of Bedminster, in Salisbury Cathedral, and $£_{40}$ a year charged on certain rents from Commoner's College, for the same purpose. The exhibitions are now given to those who do get scholarships at New College as well as to those who go elsewhere.

Joseph Warton was one of the most interesting figures that has ever

1 Stowe MS. 799, p. 153. 


\section{A HISTORY OF HAMPSHIRE}

sat in a headmaster's chair. The son and brother of a professor of poetry at Oxford, the brother, Tom Warton, succeeding Whitehead as poet laureate, Joseph Warton himself 'lisped in numbers, for the numbers came.' If he had not preferred the more lucrative career of teaching he might have been a greater poet than any of the school. His earliest effort, 'Sappho's advice,' was published by him in the Gentleman's Magazine, above the signature Monitorius, when he was a prefect at Winchester, together with a shorter poem by Tomkyns, and a sonnet by Collins.

He edited Virgil in Latin and English with éclat in 1753 . This largely, no doubt, procured his appointment as second master at Winchester in 1755 . We are told that-

Dr. Burton had long been inclined to resign his situation, could he have secured it to Mr. Speed. But parties ran high in the Wykehamical society. Speed was a Whig ... Dr. Burton, unable to carry his point, remained. Mr. Speed retired and was succeeded by Dr. Warton.

Next year, in spite of his boarding-house and school work, he published his Essay on Pope, dedicated to the author of the Night Tbougbts, Edward Young, himself a Wykehamist of an earlier date (college, I694). In 1766 , on Burton's too-long-delayed retirement, Warton became headmaster. He had to meet from Pope much the same objection as has been levelled against public school, or rather classical, education many times since, that it consisted of 'words alone.' His defence is an anticipation of much recent argument :-

To read, to interpret, to translate the best poets, orators, and historians of the best ages, that is, those authors that supply most axioms of prudence, most principles of moral truth, most examples of virtue and integrity, most materials for conversation, cannot be called confining youths to words alone, and keeping them out of the way of real knowledge; and as to plying the memory and loading the brain, it was the opinion of Milton, and is a practice in our great seminaries, "that if passages from the heroic poems, orations, and tragedies of the ancients were solemnly pronounced, with right action and grace, they would endue the scholars even with the spirit and vigour of Demosthenes or Cicero, Euripides or Sophocles.'

It may be remembered that in our own day Matthew Arnold wished the same system adopted, and succeeded to a large extent in getting it adopted, in public elementary schools.

Wooll writes of Warton's headmastership :-

The fame of the school under such auspices could not be otherwise than great. Whilst a far larger number of commoners than had been known at any former period filled the boarding-houses at Winchester, the university honours, particularly those procured by poetical efforts, were successfully borne away by members of New College.

Nor is this the opinion only of an insider. A writer in the Gentleman's Magazine in 1775, expostulating with Lord North, then chancellor of the university, against the Wykehamist monopoly of university distinction, asked: 'Is genius confined within the walls of a single college? Or have Wykehamists effectually kept Minerva among themselves by those iron rails, with which they have surrounded the present image of her ?' (now disappeared). 


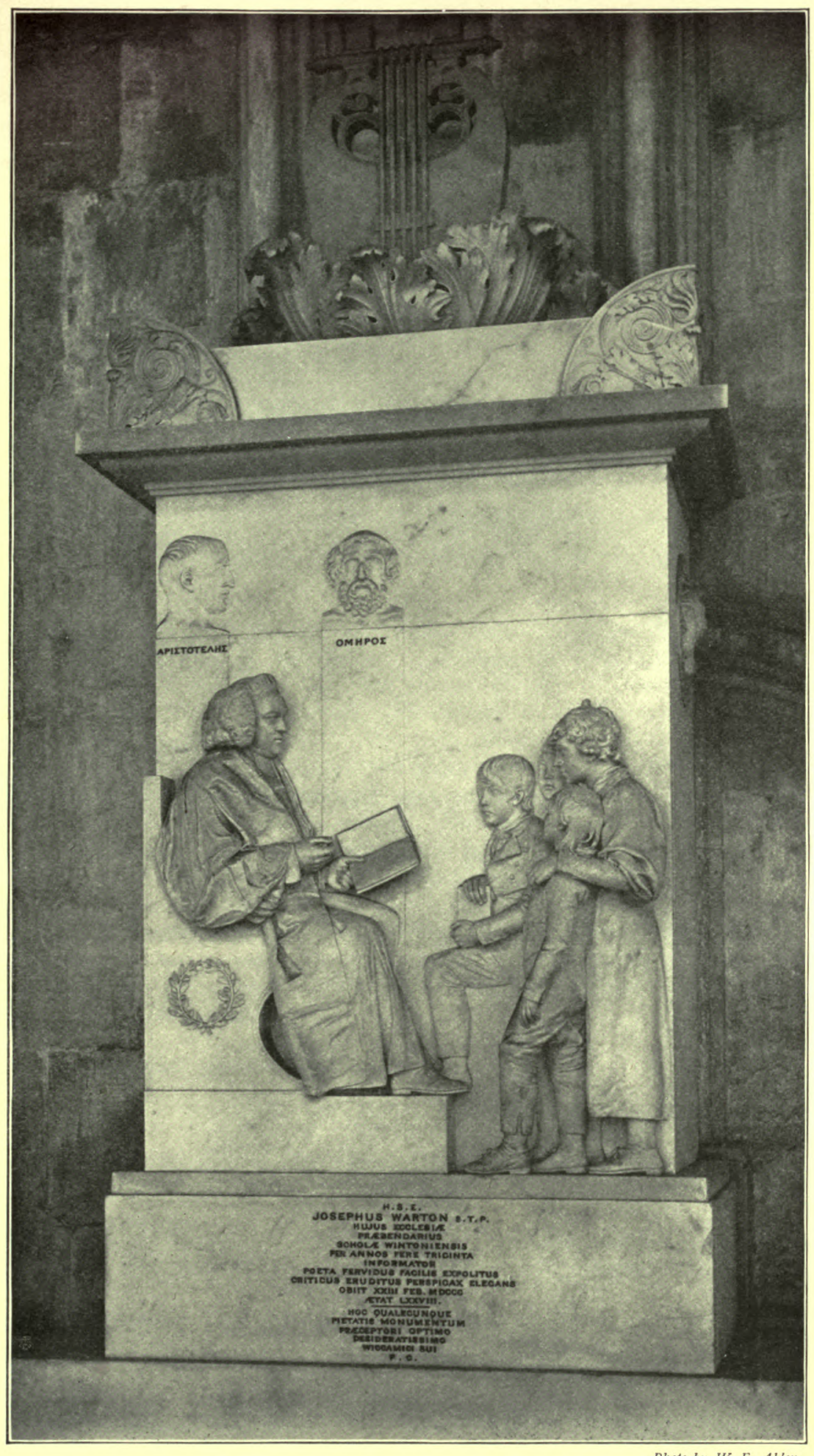

Photo by W. E. Ables.

Monument of Joseph Warton by Flaxman in Winchester Cathedral. SCholar i726. Headmaster 1766-1793. 


\section{SCHOOLS}

The chancellor's prize for Latin verse was established in 1769. Eleven times out of twenty-eight $(1769-98)$ it fell to Wykehamists.

Warton, though successful as a teacher, was singularly unsuccessful as a disciplinarian. His reign was one of slackness, tempered by rebellion. There were rebellions in $1770,1774,1778$, and the last and crowning one in the year of the French Revolution, 1793.

Of the first two we have graphic accounts in the letters of the first Earl of Malmesbury, James Harris. He came of Wykehamical stock and was a commoner in 1762 . At the age of twenty-four he was ambassador at Madrid, and won golden opinions by his treatment of Spain. He was a keen Wykehamist, finding Winchester a paradise after a brutal schoolmaster at Salisbury. In $\mathrm{I} 77^{2}$ he wrote to his father that he was much satisfied ' in having given the Parliamentary Journals to Winchester College rather than to Merton. I received great civilities certainly from this last body, but none equal to what I owe to the first.'

His mother kept up a constant correspondence with her son, and wrote to him 23 February, 1770 (Life and Letters of First Earl of Malmesbury, i. I 94) :-

This post brought Mr. Bowles a letter from his son at Winchester, giving an account of a great riot in that School. It began on some affront given, I think, Monday, by the townsmen to some of the Commoners. Tuesday evening a detachment of Commoners set out, armed with bludgeons, and some with pistols. Dr. Warton, on hearing this, locked up what boys remained in the Commoners' Hall, but they forced the door open and would join their friends. The College was also locked, but they also grew outrageous, and they were let out to join in the fray. About 8 they were got home all of them and put to bed. One townsman was wounded by a shot in bis leg. Wednesday night they sallied forth again, armed with weapons of all kinds, and fought in the churchyard. The riot was so great that the magistrates were obliged to interfere and the Riot Act was read. At length they dispersed, and I do not hear of any further mischief than bruises. Master Bowles was not in it, but by his manner of writing he seems greatly terrified. I am sorry for all this, as the School had got into great repute, and it must give Dr. Warton infinite concern, but the spirit of riot is gone forth into all degrees.

\section{On 3 March she wrote again :-}

. . . The riot I mentioned in my last, at Winchester, is all over, and no one expelled. It was a formidable thing, for they had several brace of pistols. It began, as I hear, by the landlord of the White Hart desiring some of the Commoners, who were drinking at his house, not to drink any more, but to go home. This gave such offence, that the next day some went and broke his windows. The man was obliged to call his neighbours to his assistance, so that brought on the battle between the townsmen and the scholars. The great hero's name is Hare, he had been expelled from Eton.

This riot, though the cause of it shows a curious state of manners, and a slack state of discipline which could admit a boy expelled from Eton, did not do any harm apparently.

Mr. Harris, sen., went to Winchester in July 'to hear the gentlemen speak for Lord Bruce's medal.' This medal was one of the precursors of the queen's medals of to-day. Two silver medals were first given by Lord Bute, presumably when his boys were in Warton's house as second master. In I76I a gold and two silver medals were given by the Earl of Aylesbury, who had been a commoner, and continued to be given by 


\section{A HISTORY OF HAMPSHIRE}

him or his family as late as 1787 . The silver medals were, as now, one for English and one for Latin speech, the gold for composition. When people who had not sons in the school took the trouble to go over from Salisbury for medal-speaking, it must have been a very different performance to what it is now.

In November, I774, was another rebellion at Winchester on a small scale, of which Mrs. Harris gives an account to her son at Berlin :-

P.S.-There has been a foolish riot at Winchester, and forty of the middle class of the Commoners have set off. Our neighbour Seaman, Dr. Warton locked up. Lord Shaftesbury stayed at school; Knatchbull went to your uncle Harris's, and is still there. Seaman desired to be sent for home, and so he was. He tells me it all arose from some boys dressing up like the housekeeper, who has a hump back, and she desired the assistant, Huntingford, to order them all to bed before their usual time. That they would not comply with. Then Dr. Warton came into the Hall ; the boys hissed him, and said either Huntingford or they must quit the house. So all this trouble is owing to a silly old woman, who now, too late, repents her complaining.

A less clear account is given from a letter of T. Wood Knollys to his aunt, Lady Wallingford ${ }^{1}$ :-

The first cause of it was that they had two masquerades among themselves in the Common Hall, which the Master hearing of went in, and, seeing a mask and a wig hanging up, made the boy whom he supposed they belonged to take them down and burn them, saying he would have no masquerades. Upon Dr. Warton leaving the Hall all the boys hissed him. Upon that he returned and said, 'So, gentlemen! what, are you all metamorphosed into serpents,' and then a second time they hissed him out. And a third time he came and attempted to speak, but they reiterated their hisses, and would not give him the hearing, upon which he was obliged to leave them. This was of a Saturday, and he went immediately to Mr. Stanley's, where he stayed throughout the next day.

The quarrel then resolved itself into an ultimatum against the commoner tutor (G. I. Huntingford, afterwards warden and Bishop of Hereford), that he or they should leave the school, and on Monday morning off they went. Very few had any money. 'The first day they suffered much hunger and fatigue, and at night going to inns they, by leaving their watches, or other means, got credit sufficient to forward them to their several homes.' The writer adds that 'everybody condemns the boys.' He condemns Dr. Warton, who had prospered as long as his wife lived : 'she excelled, and was a downright slave as to the domestic business of providing for the boarders. In short, she was the admiration of every one, and none could equal to her.'

In 1776 we find a boy removed 'for tunding Philip Lys.' In 1778 almost a riot took place in the case of William Moody. Mr. Kirby ${ }^{2}$ gives some of the letters in the case. ' Though Moody was a 'junior,' it was not a case of bullying a little boy. $\mathrm{He}$ had been five years in the school, and the boy principally concerned was of his own year. The allegation was that having refused 'to cut at cards a shilling a game' with Western, a prepostor, he was afterwards found 'playing at commerce for nothing with some little boys,' and was thereupon tunded with a horsewhip. Another time going to Hills his shoe came down, when Western and another came up and drove him before them, and

$$
1 \text { Annals, p. } 404 .
$$

2 Ibid. p. 406. 


\section{SCHOOLS}

when he fell down wiped their shoes in his gown. The father came up and removed his son, but the college boys followed them through the close and stoned them there.

In 1778 George III. visited the school in state and, after his wont, asked many questions. William Chamberlayne (of the Chamberlaynes of Cranbury Park), a scholar, spoke the Latin oration 'Ad Portas,' while Lord Shaftesbury, a commoner, delivered some English blank verse written by Dr. Warton, ${ }^{1}$ which reflects small credit on its composer.

George III.'s visit was the occasion of the 'Trusty Servant ' changing his coat to its present colours. Whether this change was ill-omened, or the Moody story did the damage, certain it is from that year Dr. Warton's star paled. 'Commoners' sank from one hundred and sixteen to one hundred and five in 1779 , and to seventy-seven in 1780 , and so downwards to thirty-eight in I 788 . It was during this time that Sydney Smith was in college $(1782-7)$ almost contemporaneously with Sir George Rose (1781-6). Sydney Smith is reported by his daughter ${ }^{2}$ ' even in old age to shudder at the recollections of Winchester: the whole system was then, my father used to say, one of abuse, neglect and vice.' But the account is certainly confused and inaccurate, as Sydney Smith is represented as 'one year Præpositor of the College, and another, Præpositor of the Hall,' and speaks of him as captain of the school, a term unknown to Winchester. An absurd story too is told how he and his brother Courtenay 'received a most flattering but involuntary compliment from their school-fellows, who signed a round-robin to Dr. Warton, then Head-master or Warden of Winchester, refusing to try for College prizes if the Smiths were allowed to contend for them any more, as they always gained them.' Another tale is told of his schoolfellows crowding round to hear him read his mother's letters, so exquisite were they. One is inclined to doubt whether the tale of horror represents anything more than Sydney Smith's humorous exaggerations on the subject of college commons and the awful length of hours before breakfast. A life of misery could hardly have been the lot of one who 'was not only leader in learning, but in mischief,' nor could vice have been the chief characteristic of boys who crowded round to hear another boy's letters from his mother.

In I 793 came the great rebellion, which produced Dr. Warton's retirement. His biographer, Dr. Wooll, ignores it altogether, and represents his resignation as wholly voluntary; and the second volume, which would have contained the correspondence relating to this period, never appeared. 'What great events from little causes spring.' The great rebellion at Winchester was due to the band of the Bucks Militia! It was in the habit of performing in the 'churchyard,' or cathedral close, which, it should be observed, is about a hundred yards from college gate. The boys were accustomed to attend the ceremony, a harmless pursuit enough, one would think. The warden thought otherwise, and

1 Wooll's Life of Dr. Warton, p. 163.

${ }^{2}$ Memoir of the Rev. Sydney Smith (2 vols., Longmans, 1 855), p. 6. 


\section{A HISTORY OF HAMPSHIRE}

forbade it. 'If one individual is peccant he shall be severely punished; but if numbers are seen the whole school shall be punished by being refused leave to dine with their friends on Easter Day just coming.' The boys had Easter holidays then, but only for a few days and did not leave the school. A day or two after the edict the second master meeting a college prefect at the band reported him, and the warden, instead of punishing him alone, refused leave-out to the whole school. ${ }^{1}$ The forty seniors, resenting this breach of proclamation, bound themselves by oath to stand together, and sent a Latin letter of remonstrance, which ended: 'While they had implicitly obeyed him, they hoped that in future he would act differently.' To this no answer being given, except, perhaps, a verbal one through Dr. Warton, another letter was sent asking for an answer. The warden replied :-

If the Scholars are so forgetful of their rank and good manners as to insult their Warden by letters of consummate arrogance and extreme petulance, the Warden can give no other answer than that he shall continue to refuse all indulgence till the Scholars behave better.

The boys thereupon sent to the masters to say "they would not trouble them to go to school.' Dr. Warton stayed at home. Goddard, the usher, went to school and found the boys armed with clubs, and 'metamorphosed into serpents.' He was pelted with marbles, for it seems that marbles were then played at public schools. The warden sent for the prefects, who refused to go. The boys then took the keys from the porter, broke into the second master's house, and blocked the passage to the warden's lodgings in Middle Gate with seats, then entered the warden's lodgings and kept him, Goddard and a fellow, prisoners in his dining-room all night. In the morning the warden went out of college, but was followed by the boys shouting epithets, and the gates were locked behind him. He tried to hold a college meeting in the headmaster's house, but one fellow being imprisoned in college the quorum of four could not be obtained. The warden then sent a message that he gave them "leave of absence till 28 April, and if the masters approve, the scholars are desired to go home immediately.' Doubting his good faith, they refused to go. The warden then went off to the town hall where the magistrates were assembled to draw up a loyal address to the Crown. The high sheriff and others went down and tried to persuade the boys to submit. But they found Outer Gate barricaded, while the paving of Chamber Court had been taken up and carried up to the top of Tower for ammunition, and the parapet loosened ready to hurl down upon any assailants. Swords and bludgeons were there and the red cap of liberty hoisted. The sheriff left this formidable fortress unassailed. Next day Dr. Warton began a parley, which, through the mediation of the sheriff, ended in the capitulation of the school and a proclamation by the warden :-

The warden promises for the future not to punish the community for the sake of an individual, and to grant a general amnesty, provided the keys are given up. 


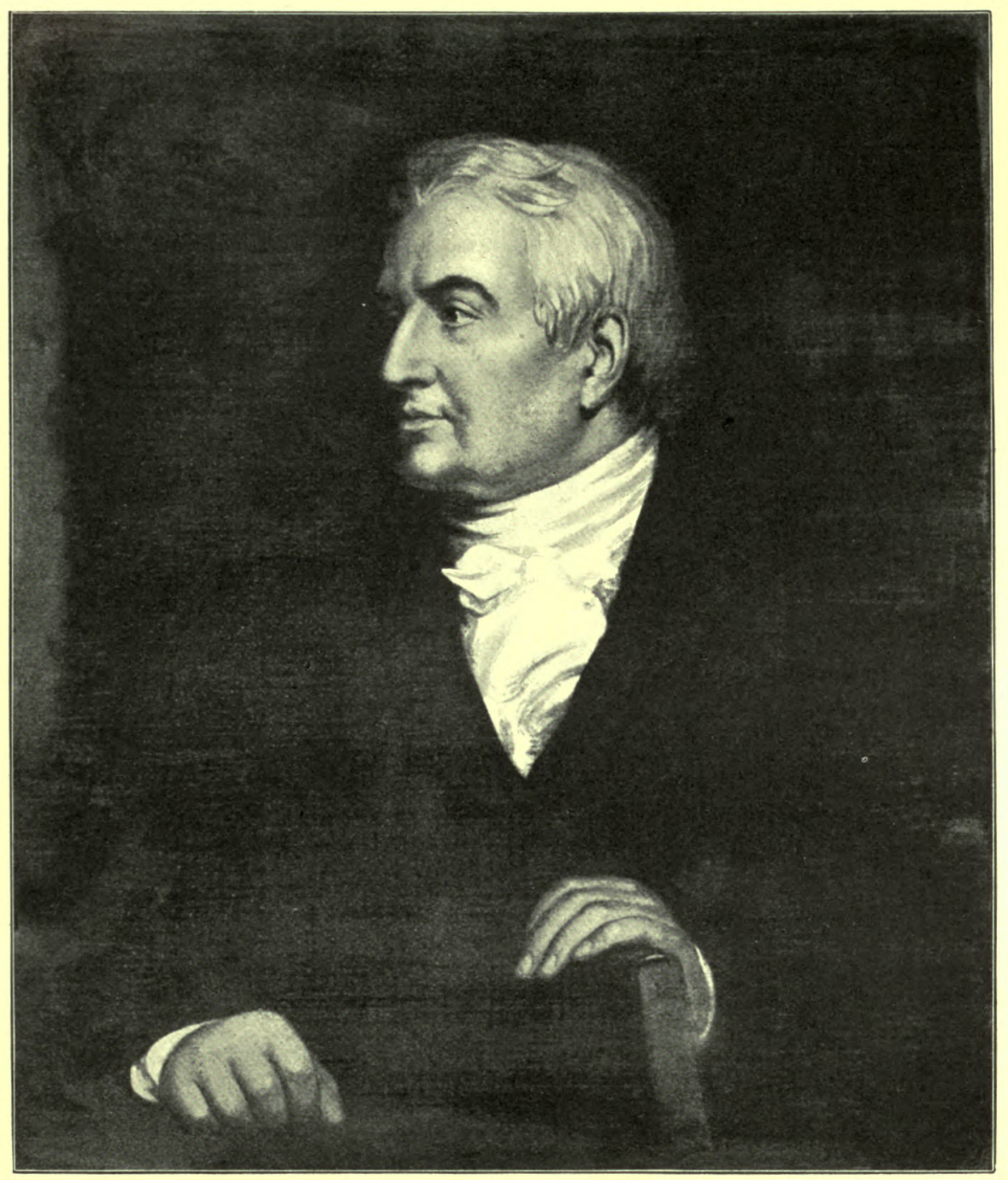

Sydney Smith. College, $1782 \cdot 7$.

From his portrait at New College, Oxford. 



\section{SCHOOLS}

The terms of peace are thus a complete justification of the rebels. The rebellion threatened to break out again next day owing to the second master demanding the surrender of four guns taken from his house. This was said by the boys to be a breach of the amnesty, but on the argument that the demand for restitution of stolen property was not a breach of amnesty the guns were surrendered. But the warden chose to consider the first refusal of surrender of the guns a breach of amnesty by the boys, and addressed them on their insubordination in ante-chapel, in the course of which he is said ${ }^{1}$ to have paused for a reply with the words 'Eloquar an sileam,' and to have received it in the word 'Sileas,' anglicè, 'Silly ass.' He told them that if they did not intend to obey the statutes they had better go. They asked for a copy of the statutes, which was given, and a statement as to what in particular was required, which was refused. Meanwhile, the boys found that, in spite of the amnesty, the warden had been putting pressure on parents to compel their sons to apologize or resign. One of them, Dr. Budd, a physician, went to Winchester and enforced the alternative on his son, who preferred resignation. Thereupon the 'whole of his schoolfellows' complained in writing of the breach of amnesty and sent in their resignations. They wished to withdraw them next day, but the warden had taken the resigners at their word, and thirty-five or thirty-six were made to go. The expelled included Richard Mant, who became Bishop of Down, and Thomas Silver, Professor of Anglo-Saxon at Oxford. Certainly the expelled scholars who exchanged arts for arms at that exciting crisis had no reason to regret the insidious conduct of the warden.

The headmaster however, and not the warden, was made the scapegoat. Dr. Warton retired in the summer of 1793 . He survived till February, 1800 , busied to the last in poetry on an edition of Dryden, of which he published two volumes and left two others ready for the press. A monument to his memory by Flaxman in the south aisle of the nave of Winchester Cathedral presents an excellent likeness of the genial old headmaster in his magisterial throne.

\section{Nineteenth Century}

If it had been done on purpose for our ensample, there could have been no more conspicuous object-lesson in the right and the wrong ways of managing a public school than was seen in the first two headmasters of Winchester at the beginning of the nineteenth century. The principle of confidence between master and boys, self-government by prefects against ushers, the English system, in a word, was in force under one; the principle of mistrust and usherdom, the French system, under the other.

William Stanley Goddard, the second master, followed Dr. Warton as headmaster in 1793 , and reigned till 1809 . His father was a merchant, who had his boy's name entered as a commoner; but becoming bankrupt, the boy went first as a chorister, but was soon taken by Thomas Collins, who 


\section{A HISTORY OF HAMPSHIRE}

had succeeded Warton in the second mastership and the boarding house attached to it, as a commoner in his house, until in $177 \mathrm{I}$ he was admitted to college. He was a contemporary with Henry Addington, speaker and prime minister, afterwards Viscount Sidmouth, and Thomas Burgess, Bishop of Salisbury, who gave him a prebend there. Goddard had the distinction, like Warton before him, and Moberly and Ridding after him, of having failed to get a vacancy at New College. He was at Merton, but quickly returned to Winchester as commoner tutor. As second master he was the first who, after a long interval, returned to reside in the college, in the old chambers of the masters, which have ever since been the sole possession of the second masters. When he became headmaster he slowly but surely restored the numbers in commoners. He found forty-one in 1793 ; next year there were fifty-two; in 1796 , seventy-five; and they gradually rose to ninety-eight in $180 \mathrm{I}$. In I 804 Dr. Goddard finally completed 'Old Commoners' by acquiring Wickham's or the Sustern Chapel, and connecting it with the rest of the hospital premises as part of a single boarding house, under the immediate control of the headmaster. This caused the numbers to rise to I33, which seems to have been the extreme number which the buildings would properly accommodate, as the numbers ranged from 137 to 132 for the next forty years until the building of 'New Commoners.' That the whole body of buildings inextricably mixed up together should thus be brought under one control no doubt contributed to good order.

We get a very pleasant picture of Dr. Goddard. He had ' a handsome face, with a clear blue eye and a kindly smile." He always dined at two o'clock, before going into afternoon school, and appeared afterwards in full dress, his wig perfectly powdered, his cassock, black silk stockings and the buckles in his shoes all in the trimmest order. But he could not abide foppery on the one hand, or neglect of ceremony on the other, in the instance of his pupils. One of them who presumed to wear silk stockings and to carry an umbrella-unheard-of dandyisms in those days-greatly aroused his indignation. One day this youth was walking through seventh chamber passage, umbrella in hand, when he was suddenly charged in the rear by the headmaster and his umbrella confiscated.'

Goddard was a man of a most sensitive honour, and the high standard he maintained, and his kindly relations with his boys and the confidence he reposed in them, set the model to Thomas Arnold, which he transplanted to Rugby.

Mr. Gale wrote of Dr. Goddard ${ }^{2}$ :-

He has told me many a time that he owed the prosperity of the school to the influence of a few boys of very high stamp, and he instanced three of them one dayRolfe, Inglis, Lefevre. 'Sir,' he said, 'one is a Baron of the Exchequer, who will live to be Lord Chancellor, another is Member for the University of Oxford, and the third, Speaker in the House of Commons. Rolfe and Lefevre are Whigs, in spite of all I can say, and yet there never were better boys.'

${ }^{2}$ Wykehamica, p. 170.

${ }^{3}$ Ibid. p. 164 . 


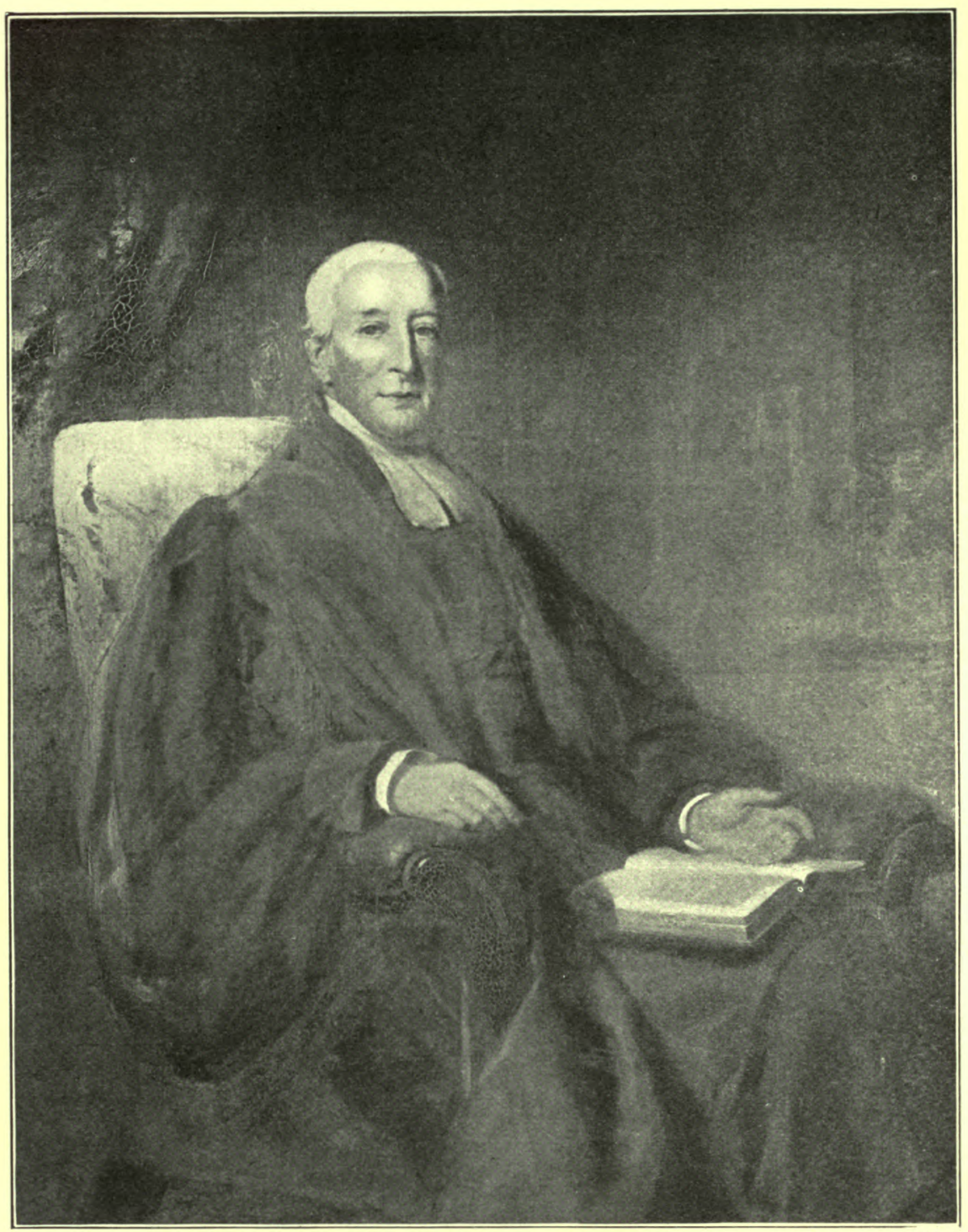

Photo by W. E. Ables.

Dr. Goddard. College 177i. Head Master 1793-1809.

From his portrait in the Warden's Gallery, Winchester. 



\section{SCHOOLS}

Sir Robert Inglis, the member for Oxford University, was the hero of the Toryism of the reform days, and was succeeded by another old Wykehamist of the same stamp-Sir William Heathcote. The names of Rolfe and Lefevre bring Goddard's days very near to our own.

Of all Goddard's scholars the most famous name is that of the man who followed his own profession, and adopted his principles-Thomas Arnold, headmaster of Rugby. His name, not so much through Dean Stanley's sober life as through Thomas Hughes's romance in Tom Brown's Schooldays, has made the tour of the world.

Arnold had the advantage, after his experience of the true method of trust and self-government of boys under Goddard, to see the false method of suspicion and usher-spying under Gabell, the most potent object-lesson that a vigorous mind could receive.

The most signal instance of Dr. Goddard's conscientiousnessmarkedly reproduced in his pupil Arnold-was his action in regard to the payments made by boys in college. It had become the practicewhen and how does not exactly appear-that though the scholars were by statute and in theory 'free scholars,' they should pay ten guineas a year as 'a gratuity' for the benefit of the headmaster and usher. In I 776 this practice was solemnly condemned at a scrutiny as 'contrary to the obvious intention of the Founder, a grievous imposition upon the "pauperes et indigentes scholares," and "grave scandalum" to the College itself.' But the only remedy recommended was that the 'children' should be admonished 'to inform their parents or friends that they should not present' the gratuities for the future, while the warden and fellows were advised to stop the practice. But as they could only stop it by paying the masters 'out of the revenues of the College for their labour and trouble in the discharge of their offices,' that is, out of the surplus divided by the Fellows, the Injunction remained a dead letter. The only difference made was, that in the bills the charge was entered as ' gratuity, if allowed.' Dr. Goddard, in 1834 , some years after his retirement, gave $\oint_{2} 5,000$ Consols, in trust, to pay the income to the headmaster in lieu of the 'gratuities,' saying, 'It has been such a distress of conscience to me to receive this money, I am determined no headmaster in future shall suffer the same.' Dr. Goddard did not die till I 845 , when the Goddard Scholarships, a prize of $£ 25$ a year tenable for four years, formerly competed for at Christmas, now in July, and awarded to the head boy in the examination, were founded in his honour.

On Goddard's retirement, again a second master, Henry Dison Gabell, succeeded. $\mathrm{He}$ is said to have been an excellent teacher, but a sad falling-off after Dr. Goddard. He adopted the principle, not of trust, but of mistrust of his boys. A boy returning a day late on account of an aunt's illness-a suspicious reason certainly-was told, 'You have been a long time fudging up that aunt of yours.' And another time going round chambers in the evening, seeing a boy with a black handkerchief round his throat for a sore throat, he whipped him in spite of all asseveration for going into bed with his clothes on. 


\section{A HISTORY OF HAMPSHIRE}

He was also credited with spying and listening to spies, a habit which resulted in 1818 in a rebellion of the type of that of 1793 . A certain commoner tutor had extracted from some of the prefects at a dinner given by him that some of them were in the habit of 'shirking out' into the town. A particular walk was therefore forbidden, one of the two weekly ' remedies' suppressed, and the place of 'names' calling' on ' hills' altered in a way thought objectionable. On 7 May, which should have been a remedy, a rebellion was organized. Commoners went into college and with the scholars seized the keys, locked the gates, and turned out all the servants but a cook, retained to perform his office. A watch party sat up all night in Middle Gate, drinking beer and telling ghost stories. After breakfast next morning, described as consisting of flour, potatoes and bacon, which appeared in separate and solid layers in a would-be soup, a Canon Barnard, who had been summoned as a magistrate to read the Riot Act, asked to address the rebels. He was brought in and made an eloquent speech from a rostrum of 'scobs' and 'washing stools,' but without effect. A rumour was spread that soldiers had been seen in the warden's garden, so the door of his house was made fast, in spite of the threats of the headmaster that the fastener "should be brought on his knees before the House of Lords for imprisoning a peer of Parliament' - the warden was Bishop of Hereford-' in his own house.' A commoner tutor was then sent to the window to announce ' that the Riot Act had been read, and soldiers sent for, but as the authorities were anxious to prevent injury to the College, all the boys, if they would surrender the keys, were at liberty to go home for a fortnight.' The boys, with headlong thoughtlessness, accepted the terms, and are represented as at once rushing off townwards to go home. In the close, in the narrow part called the Slype, or slipway, they encountered a company of soldiers, headed by an officer. The officer was knocked down. But bayonets were too much for fists and the boys ran, pursued and captured by the soldiers, 'the more willingly as they had recently had a quarrel with the boys about one of their bathing-places.' The officer pursued too, 'pricking with his sword one of the big College boys,' Charles Pilkington, afterwards canon of Chichester. Going past college the boys found themselves confronted by another company of soldiers with fixed bayonets. Hemmed in on both sides they returned to college. They were told that twenty would be expelled. Commoners had to attend names' calling in Commoner Hall. The ringleaders were summoned one by one before the masters. The senior prefect, Porcher, and Alexander Malet, afterwards Sir Alexander, a famous diplomatist in German courts, were expelled without parley; the second senior, William Page Wood, afterwards Lord Chancellor Hatherly, ' having gained the prize in each form,' and 'being only sixteen,' was allowed the offer of apology. He asked what had become of the other two, was not answered, and was sent into another room. From this window he talked to the others, learnt they were expelled, and at once, ' as a paper had been signed by the first three forms that all would share 


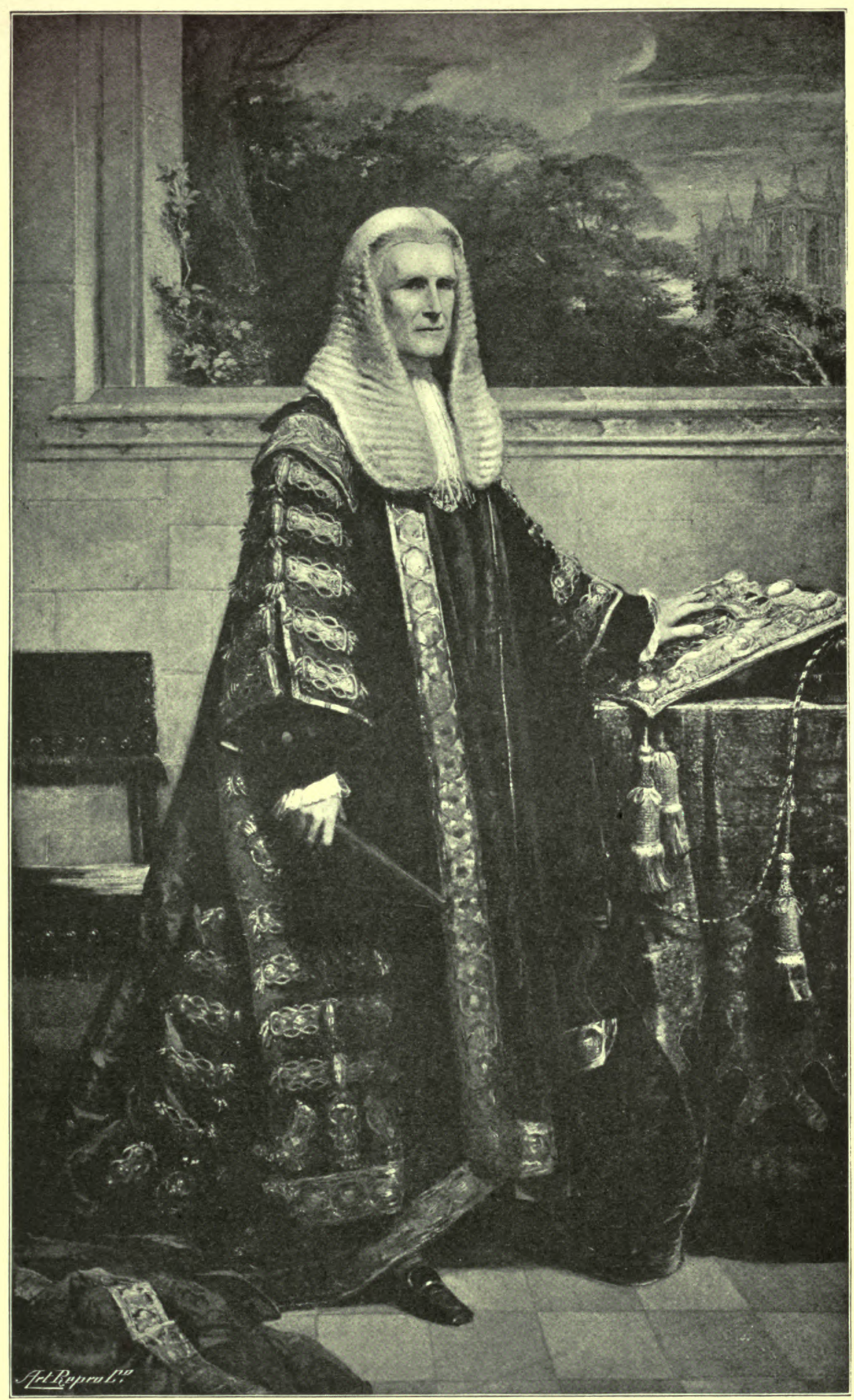

William Page Wood, Lord Chancellor Hatherley. Commoner 1789-1793. From his portrait in the National Portrait Gallery. 



\section{SCHOOLS}

a common fate,' stated he must follow their example. He took his younger brother with him, though the brother afterwards went back.

The action of the authorities against the rebels was emphatically condemned at the next scrutiny.

The $W$ arden and Posers required the removal of the obnoxious Commoner Tutor, they restored every boy who had been put down in the School to his former place, they publicly expressed their regret that they were unable to recall those who had been expelled. The Junior Poser (J. Poulter, afterwards M.P. for Shaftesbury) was so overpowered by the sense of wrong which could not be set right, that he is related to have laid his head down on the table in Election Chamber and fairly wept aloud with indignation. ${ }^{1}$

Five college boys and fifteen commoners were the victims. The rebellion did no harm to the school's reputation, perhaps because both Eton and Harrow were also in the throes of rebellion. Rugby, too, rejoiced in its great rebellion of 1797 , when also it enjoyed the distinction ${ }^{2}$ of soldiers being called in to put it down, and another in 1822 .

Warden Huntingford died at the age of eighty-four in 1832 , having had the longest reign of any warden-no less than forty-two years. Dr. Gabell stayed on as headmaster for another five years. Of his merits and thoroughness as a teacher Page Wood and others have left their testimony.

In 1823 'Gaffer' Williams, the second master who had been cheered during the rebellion, succeeded as headmaster. He was founder's kin, and therefore, and not because of any superior merit, went to New College as a fellow at sixteen. 'Gaffer' is a common term in Wales for a ' grand old' boy, possibly a corruption of grandfather. 'Tall, powerful and handsome, he excelled in all games and was the hero of the cricketfield no less than of Election Chamber.' He rode a white horse, believed to have been chosen because visible a long way off, so as to give warning to errant boys to get out of the way! In his time there were two small outbreaks, not against the masters but against prefects, both in Commoners. The first in 1827 was a personal row between a sixth book inferior and a prefect. An account of the second is given by Lord Selborne in his autobiography, marked by that detached and impartial manner which made him so great a judge.

The discipline of the School was in $1825-30$ dependent on the 'præfects,' . . only eight in Commoners. . . A A regulated system of fagging is the best security against tyranny by the strong and thoughtless idlers . . . whose place in it is generally low in comparison with their growth. It was from this class of boys that all the bullying of which I ever had experience, both at Rugby and Winchester . . . proceeded. . . . The system always worked well when the prafects had physical strength and moral courage, as was generally the case. It was only when these conditions were wanting ... that it broke down. This happened in 1829 , when I myself was a præfect. We were a weak set altogether-I do not mean intellectually, but physically -and none of us had that skill or reputation in school games which goes further than intellect. William George Ward . . . was senior præfect . . . awkward, eccentric

Wykehamica, p. 189.

2 Not unique, as Mr. Rouse says, History of Rugby School, p. 185 (Duckworth, 1898).

3 Memorials Family and Personal, by Roundell Palmer, Earl of Selborne, i. 96 (Macmillan, 1896).

- One of the leaders, or led, of the 'Oxford Movement,' who crossed the Rubicon to Rome. His book, The Ideal of a Christian Church, published in 1844 , created no small stir in clerical circles. 


\section{A HISTORY OF HAMPSHIRE}

and not like other boys, a butt for practical jokes rather than an object of fear. Some of the bolder juniors resolved to try their strength with him, and when one day he called for fagging in the hall a spirited and popular junior boy, he found himself defied. When he attempted by the usual means to enforce his authority, the whole mass of juniors rose in rebellion, rushing upon him, springing upon his neck, and clinging to his legs and arms, so as to make it difficult enough for him, even with the assistance of his weaker colleagues (he was himself able-bodied enough, but unskilful in all bodily exercises) to get out of the hall without suffering worse damage than the loss of his coat tails.

The rebels had a real grievance-namely, whether boys in a particular form were or were not liable to be fagged in hall. At Winchester the remedy was found by increasing the number of prefects to twelve, two more than the number in 'full power' in college. Lord Selborne gives an interesting account of the education in his day. The relics of the old rhetoric and sophistry still survived in 'Declamations.' 'Three boys were appointed, two to maintain or contradict, and the third to leave in doubt a thesis proposed to them, in Latin prose of their own composition, which they recited publicly in the school. A dull performance it almost always was.'

The obvious reform of having the Declamations in English did not occur to the scholastic mind, and this useful engine of education is now abandoned. Classics did not exclude general information however. There were ' gatherings'- ' English notes compiled or collected by ourselves on certain portions of our school lessons, the choice of matter and manner being left entirely to our own taste and discretion. This exercise (which I always found interesting) led us to search for information on the subjects of which we had been reading, wherever we could find it in books accessible to us.'

'Standing-up,' practised in the Middle and Junior Parts (Fifth Book), consisting in lengthened repetitions from Latin and Greek books, as in full vigour. Lord Selborne mentions one boy who took up the whole Eneid, and passed successfully 'through every test of his memory or his intelligence which the second master thought fit to impose,' for the book taken up had to be construed and understood as well as known by heart.

The most wonderful case was that of Henry Butler, a younger son of the then Earl of Carrick, who afterwards went into the army, acquired early fame by the heroic defence of Silistria, and was among the gallant $W$ ykehamists who died in the Crimean War. He took up and passed well in all Homer's 'Iliad.'

A very brilliant set the 'commoner prefects' of the 1827 rebellion turned out to be. Three of them-Roundell Palmer, afterwards Earl Selborne, Lord Chancellor ; Robert Lowe, afterwards Viscount Sherbrooke; and Edward Cardwell, afterwards Viscount Cardwell-left their mark permanently on the institutions of the country over which as Cabinet Ministers in Mr. Gladstone's first Ministry they presided.

\section{'New Commoners'}

Gaffer Williams retired from the headmastership in 1835 , and five years later became warden of New College in succession to P. N. $35^{8}$ 


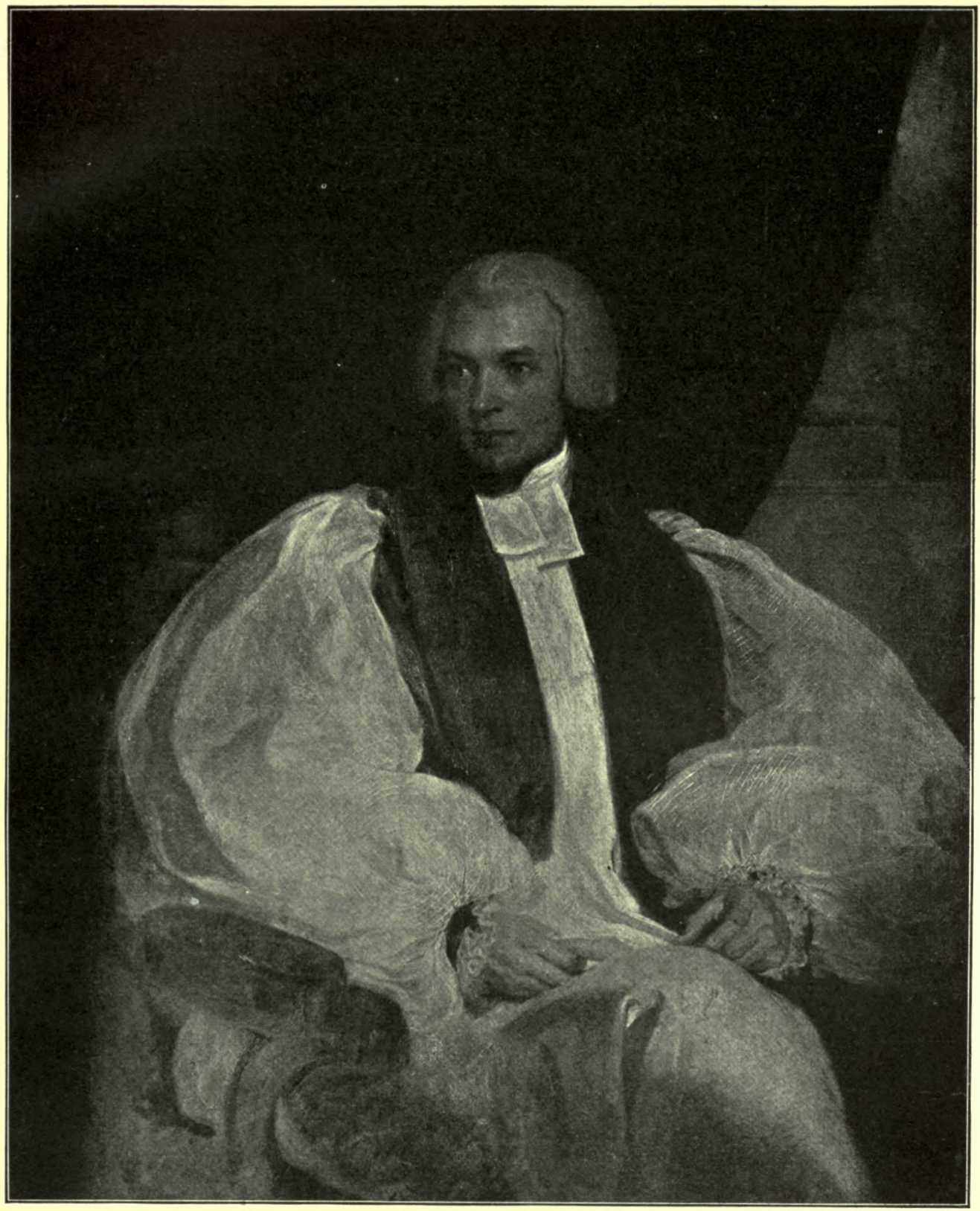

Archbishop Howley. College 1779.

Proto by W. E. Abley. From his portrait (taken when Bishop of London) in Warden's Gallery, Winchester. 



\section{SCHOOLS}

Shuttleworth (college, I796), made Bishop of Chichester. Williams died in I860, just as brighter days began to dawn for Wykeham's Colleges after a period of decided depression.

Yet under Dr. Moberly the first prospects of Winchester seemed bright indeed. The accession of the girl-queen, Queen Victoria, was announced to her at $5 \mathrm{a}$ a.m. on that famous summer morning in 1837 by a Wykehamist and a Hampshire man, ${ }^{1}$ William Howley, who, as Archbishop of Canterbury, was, next to the blood royal, the first subject in the realm. A pupil of Dr. Warton's (college, 1779), he returned to Winchester straight from New College as a fellow, and at the early age of forty-six became Bishop of London. Under these auspices, almost the first work of Dr. Moberly was to compass the destruction of the picturesque but crowded and insanitary 'Old Commoners.' The freehold of the Sustern Spital being acquired from the dean and chapter in $183^{8}$, ' New Commoners ' was built at a cost of over $f_{0} 27,000$, ${ }^{2}$ of which the college contributed $\oint_{1} 17,739$, arising chiefly from the investment of money accrued from falls of timber. The plan was simple and excellent, but the elevation was truly appalling. The building was of raw, red brick, with a low-pitched slate roof. Its unredeemed ugliness was surely the most lugubrious effort in architecture even of the Early Victorian era. This was due to the building being done cheaply. The effect of the constitution of the college, the division of surplus among the warden and fellows, was that Winchester, with an income of $\oint_{0} 20,000$ a year, was worse off than Rugby with half that amount. For $£_{0}$ ro,000 out of the $\oint_{0} 27,000$ which 'Commoners' cost, the headmaster was personally responsible, and had to pay interest. Yet, unattractive as it was, the immediate effect of the building was to attract. The numbers went up to 148 -its utmost capacity.

Then came the discovery that the building was as faulty inside as it was hideous outside. There were no chimneys or other ventilation in the bedrooms. Below the building the branch of the old Lort-burn which had served the Sustern Spital, and should have been diverted, was choked by the mass of matter thrown in to form the foundation, ' converting the subsoil into a subterranean marsh, redolent with malaria.' ' In 1846 there was an outbreak of fever. The numbers in a single year fell to I I 2 . The city also, by refusing to be drained, contributed a reputation of unhealthiness. So in spite of sanitary reforms the fall went on.

An incipient rebellion in Commoners in 1848 probably did not mend matters, though it was suppressed with much promptitude. It began in the prohibition of a bonfire and fireworks on a Saturday night, simmered through Sunday, and on Monday manifested itself by a barring-in, the boys refusing to leave their rooms. They were taken at their word, and a master was posted in each 'gallery' to see that they maintained their refusal. When they tried to leave they were sent back. In a few hours they were starved out and surrendered at discretion.

1 Born at Ropley.
2 Public Schools Commission, iii. 331.

3 Wykehamica, p. 237. 


\section{A HISTORY OF HAMPSHIRE}

While other schools, notably Harrow and Rugby, were improving their organization and modernizing their methods of learning and mode of living Winchester stood still. It seemed stricken with decay. With Macbeth it might have said, 'The thanes fly from me.' Families like the Wallops, the Ashley-Coopers, the Bathursts, the Heathcotes, the Harrises, who had been Wykehamical for generations, went elsewhere, not with advantage to themselves it is true, but with disadvantage to Winchester.

College was depressed owing to the decadence of New College. The privilege enjoyed by New College of not suing for graces for degrees, originally intended to make, and apparently succeeding in making, New College men more industrious than those of other colleges, proved fatal when the system of university examinations and class lists for honours was introduced exactly roo years ago, the first class appearing at Easter, 1802 , and New College claimed exemption. The rest of the university competed, and the fame of the successful was noised abroad. A New College man might be as hardworking, as industrious and as able, but his light was hid under a bushel. ' Fame is the spur that the clear spirit doth raise,' and the spur was entirely wanting to the best boys in college who went to New College. But this was not the sole defect. The privilege of exemption was abandoned in 1834 . Yet this was the cruel comparison drawn by the Oxford University Commission ${ }^{1}$ between New College, filled from Winchester, and St. John's, recruited from Merchant Taylors' School.

Since that time (1834) it has produced one First Class man, viz. in 1842 , and, in 1843, the same gentleman obtained a University Mathematical Scholarship. St. John's has but $50^{2}$ on the Foundation, but its Fellows have obtained eight First Classes and a University Mathematical Scholarship. The chance of securing candidates of superior ability is infinitely diminished in consequence of the practice of converting the nomination of boys on the Foundation of Winchester College into private patronage, which is often practised on behalf of mere infants. Wykehamists who have never been on the Foundation, and even some of those who have lost their election by superannuation, often obtain high distinctions in the University.

In the view of the Commissioners the cause of the difference was that while the scholarships at St. John's were freely competed for by the whole of Merchant Taylors' School, the scholarships at New College were competed for by less than 70 boys out of 200, and those selected by mere patronage. With very narrow competition at Winchester, no competition at Oxford and the certainty of a provision for life by the putting on of a white tie, college was almost intellectually dead.

Commoners, on the other hand, suffered from its old-fashioned accommodation. The arrangements of 'Old Commoners' were terribly out of date, and another cause that no doubt tended in the downward direction was the reputation of Dr. Moberly and the second master, Charles Wordsworth, as extreme high churchmen, when high church principles had not become fashionable. It was unfortunate for Win-

1 Report, 1852, p. 50.

${ }^{2}$ As against 70 at New College. 


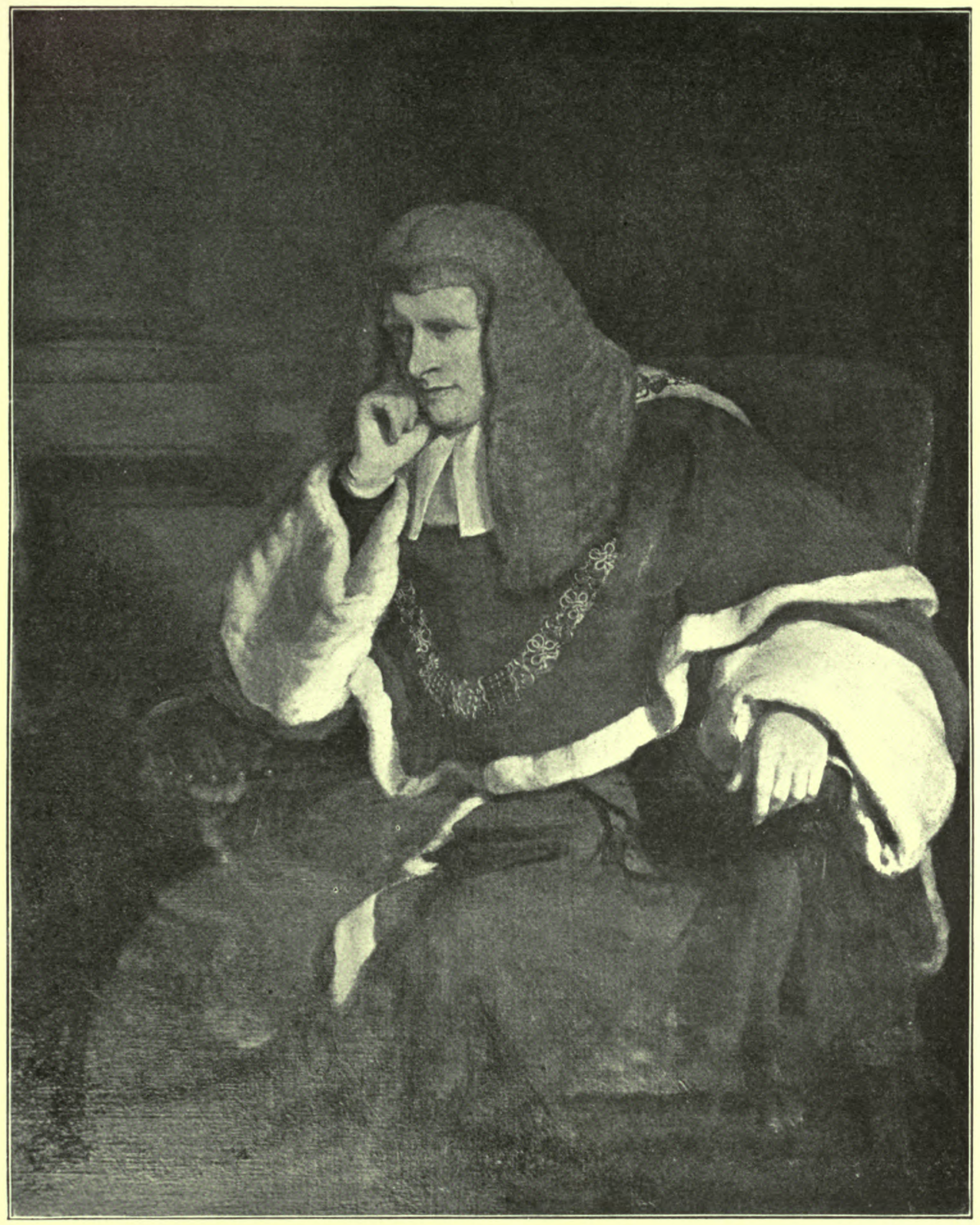

William Eri.e, Chief Justice Common Pleas. College i804-i8it.

From his portrait at New College, Oxford. 


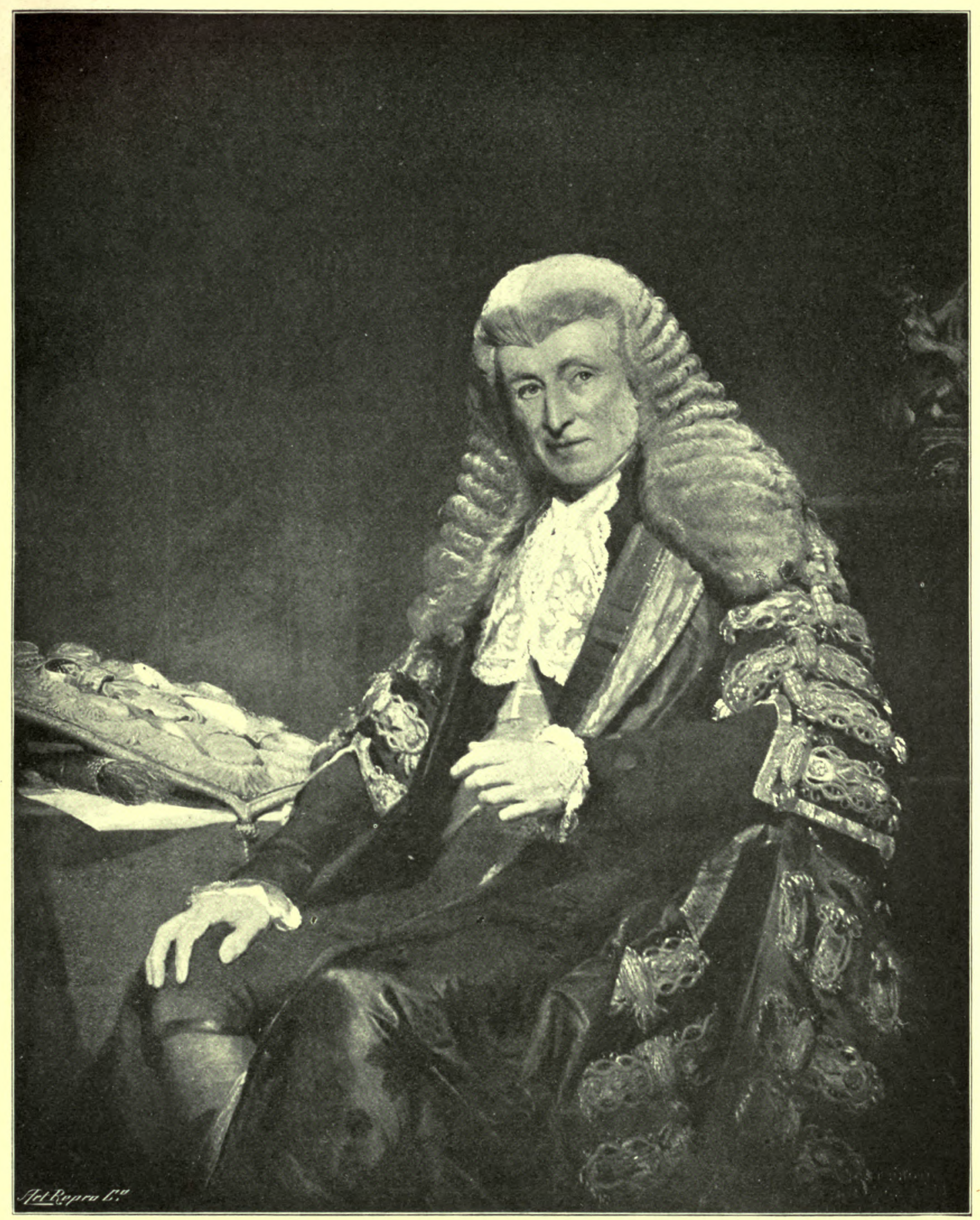

Rolfe, Lord Chancellor Cranworth. Commoner i8io. From his portrait in the National Portrait Gallery. 


\section{SCHOOLS}

chester that Radley was started by a Wykehamist, William Sewell, on the most extreme high church lines and that Charles Wordsworth was selected as first warden of Glenalmond. From all these causes combined the school went down and down, till in 1856 it reached the nadir of 138,68 commoners only beside the 70 in college.

The turn of the tide came from an unexpected quarter. The 'Ordinary' proved useful, and Eton led the way in reform. In I 852 Provost Hodgson, forced on the fellows by the Crown in 1848 , threw college at Eton open to competitive examinations for admission, while making great improvements in the accommodation. College filled rapidly, and very soon the Newcastle Scholarship-corresponding with 'Goddard' at Winchester-was won by a colleger, who was hailed as a prodigy in consequence. ${ }^{1}$ Two years later the Bishop of Winchester, Sumner, 'being on the most intimate terms with Dr. Hawtrey, thought it would be a good thing to introduce it (competition) here.' But it was remarkable that this happy thought only occurred after the Oxford University Commission was appointed. Dr. Moberly candidly admitted to the Public Schools Commission ${ }^{2}$ that he had opposed the change at the time, but that it had been 'essentially successful.' There were then on an average 100 candidates for I 4 vacancies, and the competition for college had sent up the number of commoners. "Of old-this was really only true of the previous thirty years-' we had a small connection and a considerable narrowness in the system altogether. This open competition brings boys of all abilities, of all families, from all parts of the country, and so spreads our connection very widely.'

In 1857 Winchester was for the last time dealt with as in the days of Thomas and of Oliver Cromwell, as part of the University of Oxford, the University Commissioners making statutes for Winchester as well as for New College. They abolished at last the rights of founder's kin. They statutably confirmed competition in regard to scholarships at Winchester, and provided that 'the electors may refuse to admit as a candidate any one whom they may deem to be not in need of a scholarship, and all other things being equal, shall have regard to the pecuniary circumstances of a candidate.'

This rule worked exceedingly well. Although the preference for poverty was only what is technically termed a ceteris paribus preference, it operated, as was intended, to keep out the rich. The University Commissioners gave further impetus to the school by changing the New College scholarships from probationary life-fellowships into bursaries for five years, throwing them open to commoners and fixing the number at six a year. They also provided for twenty competitive exhibitions for commoners at Winchester.

Under the influences of competitive examination Winchester rose again. When 'Commoners' began to overflow, !Dr. Moberly followed the example of the other great public schools, or rather reverted to the

\footnotetext{
1 Annals of Eton College, by Wasey Sterry, p. 302 (Methuen, I 898).

2 Minutes of Evidence (1864), iii. 340 .
} 


\section{A HISTORY OF HAMPSHIRE}

original example set by Winchester, and, instead of having all the commoners in the headmaster's house, opened 'tutors' houses,' or boarding houses kept by assistant masters, for some of them. The experiment tentatively and hesitatingly made in 1860 by the opening of Chernocke House, a charming red brick eighteenth century house in St. Thomas' Street, was immediately successful. Since then the numbers have only been kept down by a cast iron rule limiting them.

The second quarter of the nineteenth century will be distinguished in school history, not for its achievements in learning so much as in the development of games. We may claim for Winchester School the earliest poet of cricket, and the chief of its earliest heroes. Hampshire, and in particular Hambledon, one of the possessions of the college, was, as is well known, one of the earliest haunts of scientific cricket. George Huddesford (scholar, 1764), writing in 1769 a cricket song ${ }^{1}$ for the Hambledon Club already proclaims it as the established national game.

There are many descriptions of the school life at this time, more books having been written about Winchester than about any other school. In one way this has been unfortunate. The idea that Winchester was exceptionally rough is chiefly due to the exaggerations of writers, who put down the most striking instances of hardship or ferocity that they had seen or heard ot, and piled them together in such a way as to give the impression that they were everyday or all day occurrences. In point of fact, at Winchester there was infinitely less bullying and other hardships than at other schools. In the middle of this century it was a paradise compared with less organized schools. That it would appear exceeding rough and unpleasant to the college or commoner junior of to-day is certain, that it was less rough and unpleasant than other schools at that date is also certain.

The most curious custom, now disappeared, was that of 'pealings.' At the beginning of 'cloister-time,' when middle and junior part were joined together as one division for purposes of 'standing-up,' they assembled in school before the masters came in, and sitting 'up to books' under the presidency of the commoner court-keeper or fag-master, who took the headmaster's chair, chanted derisive sentences on the prefects standing on the steps of the stove. The formula ran, 'Once, twice, thrice, followed by the name or nickname of the prefect, with some remarks, usually uncomplimentary, on him, with cheers to punctuate them. The samples quoted ${ }^{2}$ are not very witty. 'Once, twice, thrice: Thompson's score in Harrow match,' when he had made 'Crocketts,' or, in vulgar slang, ' a pair of spectacles,' was harmless and dull enough. The custom curiously recalls the 'Saturnalia' and Soldiers' Chorus at triumphs in Roman history, or the 'despotism tempered by epigrams' of later times. Then there were pealings in Commoner $\mathrm{Hall}$ on the three last Fridays in the half after breakfast. The 'Once, twice, thrice' on the first Friday was followed by 'Locks and keys,' on the next by 'Boots and leathers,' and 


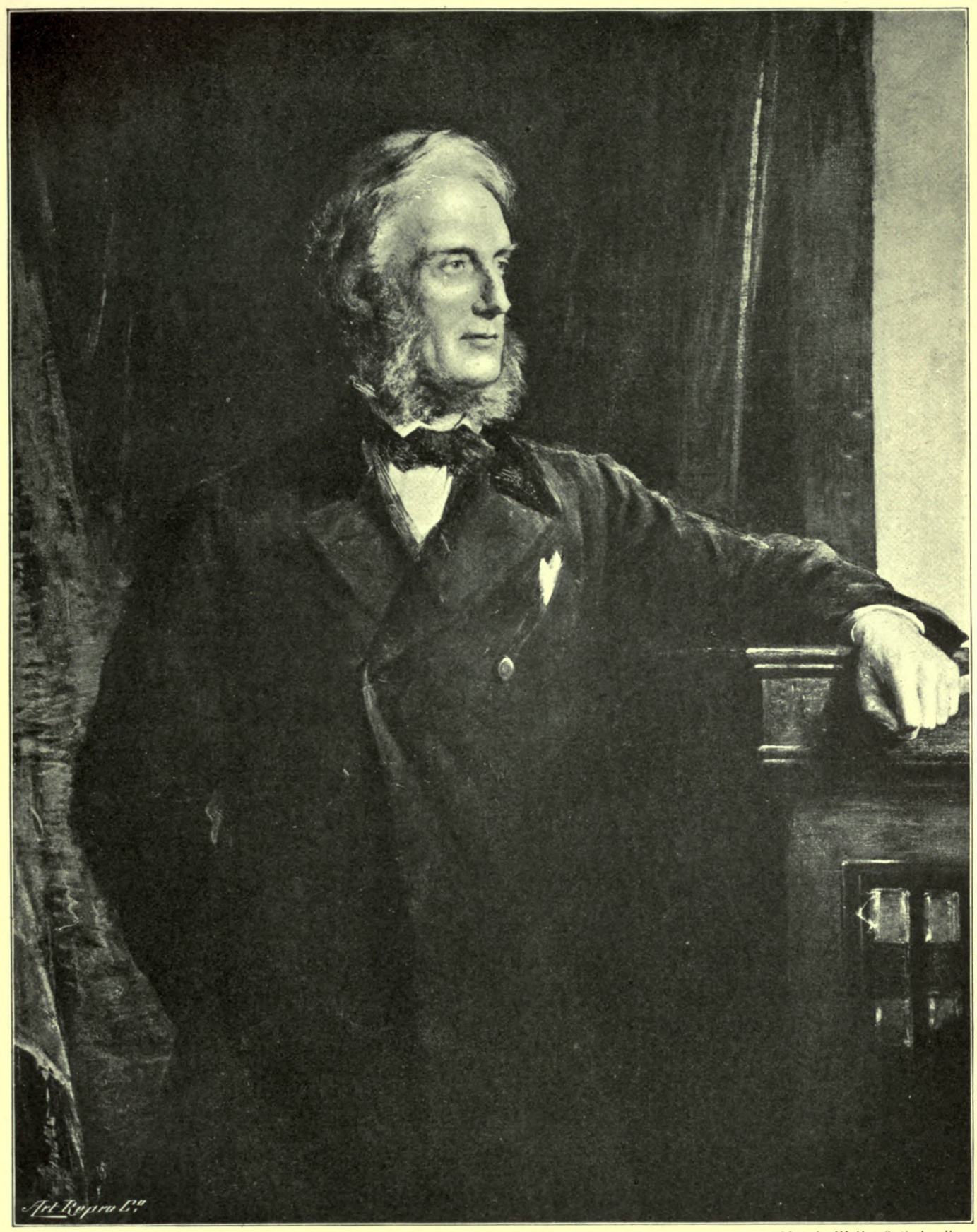

Thoto by llatker \& cockerelt

Cardweli, Secretary for War, Viscount Cardweil. Commoner i824.

From his portrait in the National Portrait Gallery. 



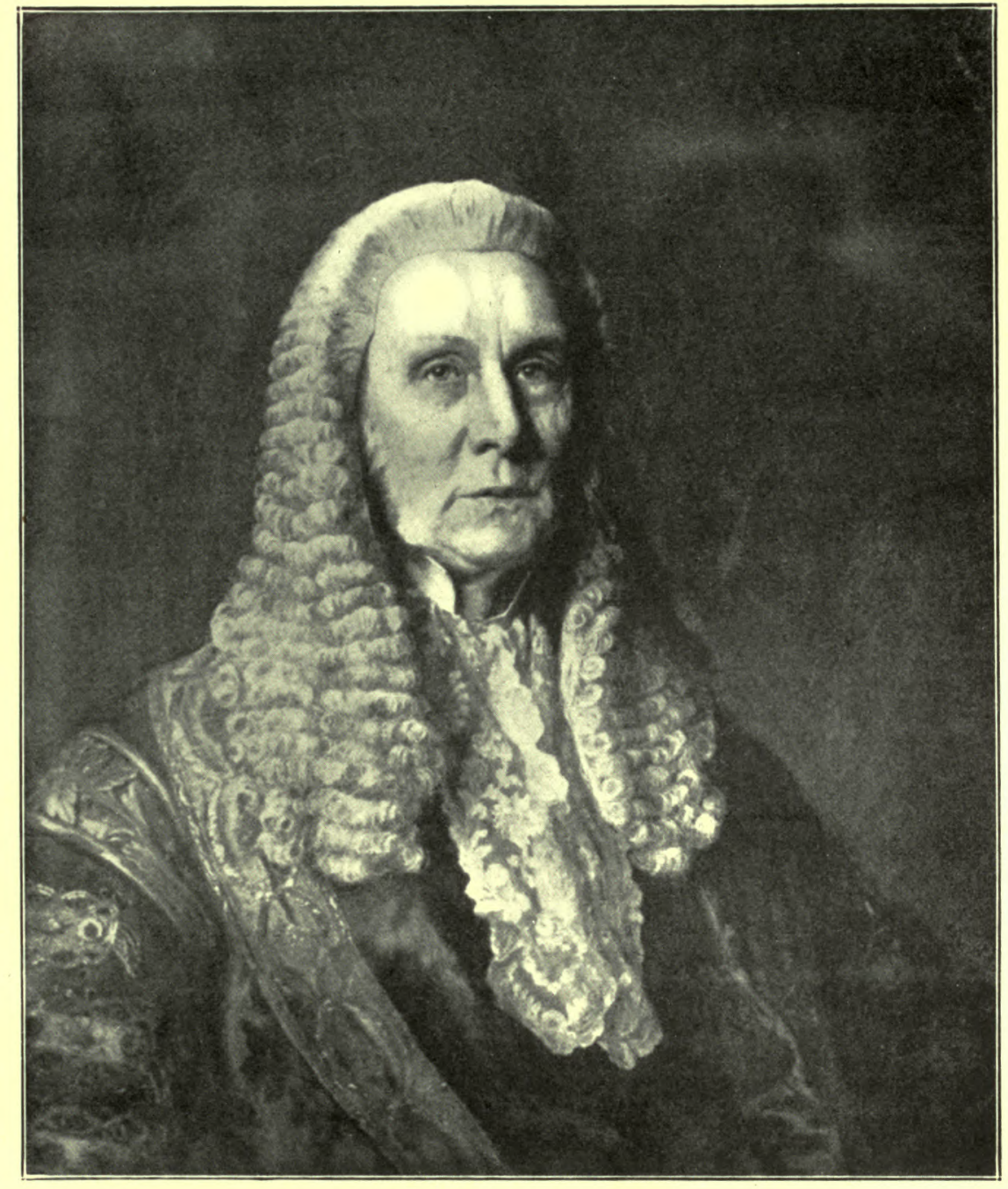

Rouniell. Palmer, Lord Chancellor, Earl of Shlborne. Commoner 182530. From his portrait at Trinity College, Oxford. 


\section{SCHOOLS}

on the last by 'Gomer hats.' This last means, ${ }^{1}$ the ' beaver' hat, shaped like a gomer or pot, not the 'go-homer hat,' as was guessed. These pealings were followed by 'sticking-up.' Some unfortunate boy selected by prefects and juniors, on different days, for 'spreeness' (uppishness) was stuck up on the top of 'toys,' to be pelted at by the assembled multitude with 'pontos' or bread pellets. Fortunately, accuracy of aim on such occasions is not always commensurate with viciousness of intention, and the victim was allowed, like the ostrich according to the showman, 'from that exalted position to present his back to his baffled pursuers.' Mr. Adams mentions one case in which a boy was 'stuck up' for a reputation for writing Greek verses. Is the common phrase 'stuck-up' derived from this barbarous method of repressing uppishness? In a lively article in the Quingentenary number of the Wykebamist, Dr. S. R. Gardiner, the historian of the Civil War, ${ }^{2}$ tells us that when in his time (I 84I-7) this custom was abolished, the boys 'all thought that the floodgates of revolution had opened.'

There were other pealings on the last three Sundays in the half, after dinner, consisting in the same chorus of 'Once, twice, thrice,' with different refrains- 'Party rolls,' 'Money and direction rolls' and 'Packing up.' In Mr. Prickard's time (18 54-7) the pealings had sunk to two, and the day had been altered from Sunday to Tuesday. One would like to know when they finally disappeared. They were all delightfully old-fashioned. 'Party rolls' and 'Money and direction rolls' were redolent of pre-railway days, when the boys were despatched in parties on coaches, or perhaps the still earlier days of post-chaises. 'Boots and leathers' recalls a remoter time, when, obedient to the words of 'Domum,' Roger led out the nags, and the boys mounted them and rode away home.

This may, by the way, have some bearing on the date of 'Domum,' which has never been ascertained. Every one knows the story-for legend it is not-that the words of this famous song were written by a boy who was left behind during the holidays for some offence, chained to Domum Tree, and after cutting 'maze' on 'hills,' breathed forth his soul in this swan-song. Mr. Adams spent much space in showing that the story might be true, only that the boy was not chained to Domum Tree, but to 'post' in 'Seventh' (chamber). It really is the case that there was a solitary scholar ' in commons' from 28 September, I 543 , to January, I 544, apparently because of some epidemic; and perhaps a sportive antiquary, Charles Blackstone or another, built the story on the fact. But the song is so clearly a mere joyous breaking-up song that we need not distress ourselves to find any particular occasion for its creation. It might have been originally composed for any one of three hundred Whitsuntide holidays. The earliest mention I have found of it is in one of George Huddesford's poems, published in I789, 'On a threat to destroy the Tree at Winchester round which the Scholars on 


\section{A HISTORY OF HAMPSHIRE}

breaking-up sing their celebrated song called Dulce Domum.' But it is represented as 'the choral song . . . the strain of joy and liberty', in a poem by Tom Warton the younger in the Wiccamical Chaplet written between I768 and I77I. A note informs us that the 'choral song' means ' a Latin song, sung with instrumental accompaniment, on the day before the commencement of their Whitsuntide vacation by the Scholars of Winchester College.' Milner's History of Winchester (1798) says that it can be traced to the distance of about a century. 'The tune is commonly credited to John Reading, organist of Lincoln Cathedral, temp.William III. The words are not sufficiently in jingle to be medieval, and the expression 'Daulias advena' for the swallow is too elaborately classical for the preReformation period. Probably both words and tune date from Reading's time, I 68 I to I 69I ; but this has been doubted, because it was said that he had no connection with Winchester. ${ }^{1}$ He was, in fact, organist of Winchester Cathedral, and in 1682 became organist of the college, receiving $f_{0} 45$ a year ${ }^{2}$ instead of the $\oint_{0} 5$ a year which his predecessors had received.

Domum Tree was a great elm tree, half of which still exists, by the river just beyond Blackbridge, at the last house, Clark's, on the way to ' hills.' For many years, since 1835 at least, Domum has not been sung round Domum Tree but in Meads. After what used to be called election, but is now called Domum dinner, at which the whole of college and commoner prefects who are 'medalists " ${ }^{3}$ or 'in Lord's' and a number of bidden guests attend, the company descends to meads, and, with the whole school and a mixed multitude of unbidden guests, solemnly sing Domum to the accompaniment of a military band. It is sung again and again after intervals, during which the band discourses sweet music. At ten o'clock the evening ends with a last Domum, sung in Chamber Court with more than religious fervour. Under a clear sky and in the balmy airs that come from the near sea, and breathe across the scented water-meadows, 'Domum' is a moving ceremony.

Of Winchester College since 1865, under the rule of George Ridding, now Bishop of Southwell, and W. A. Fearon, who retired at Easter, 1901, it will be sufficient for the purposes of this history to say that it has been one of continuous progress, and that never has the name and fame of the school stood higher. Dr. Ridding (college, 1840-6), a 'Craven' scholar, fellow of Exeter, Latin essayist at Oxford, became second master, as his father had been before him, in 1863 , and headmaster in January, 1866. He retired to a bishopric in 1884 . He enlarged the borders of the school physically with the splendid accretion to the ancient Meads along the banks of the Itchen, with its spreading views of St. Catherine's Hill and the green downs. He enlarged its borders equally in men and manners by abolishing 'Commoners' as a

1 Wykehamica, p. 410.

2 Specially noted as being 'per consensum,' showing that it was a new allowance and not statutory (Bursars' Book, 1683-4).

2 i.e. winners of one of the gold and silver medals given by the queen or king.

i.e. in the cricket Eleven which used to play Eton and Harrow at Lords, but now plays Eton alone at Eton or Winchester. The introduction of the Eleven is an innovation since 1870 . 


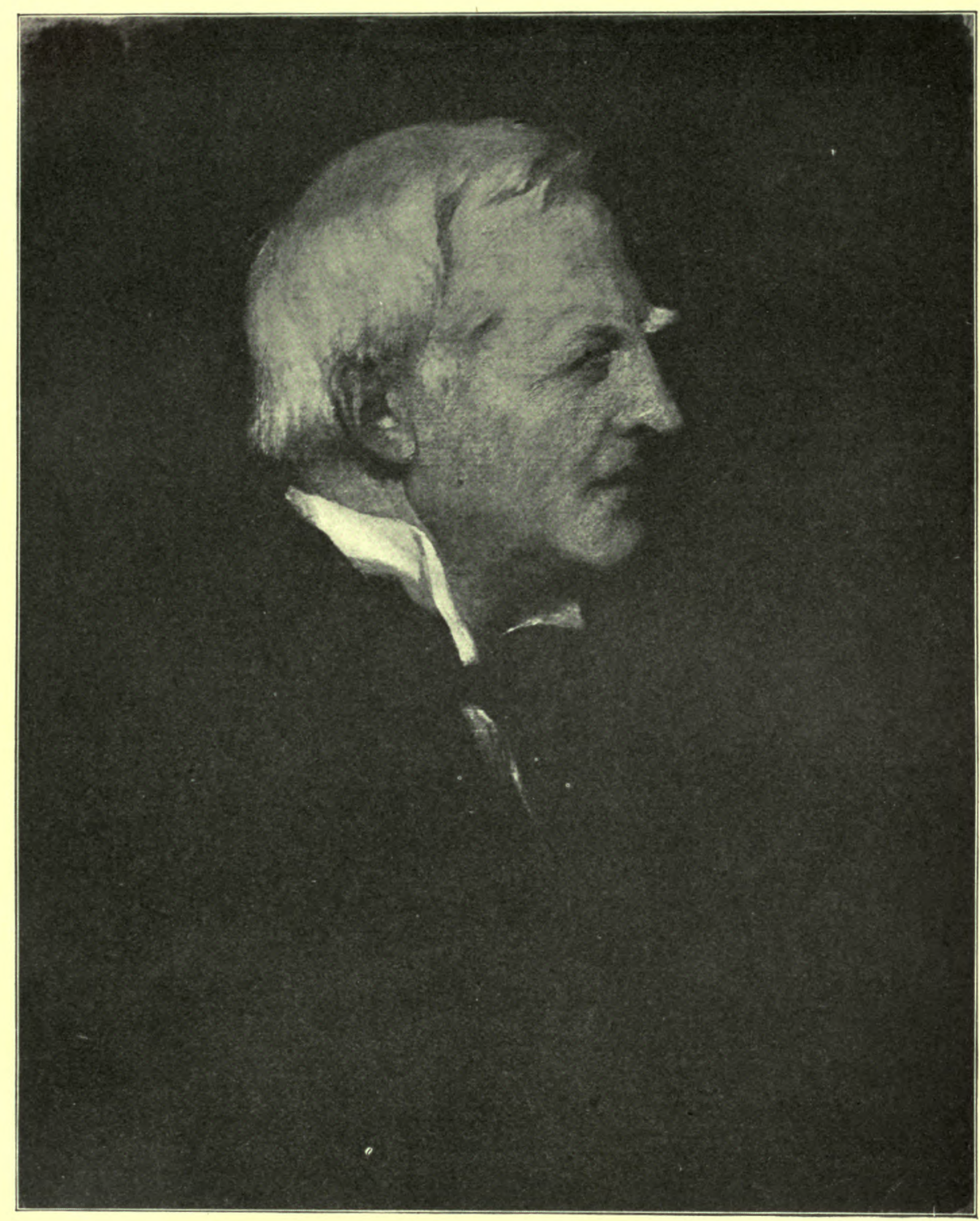

Photo by F. Holyer.

Robert Lowe, Chancellor of the Exchequer, and Viscount Sherbrooke. CoMmoner 1825-1830.

From his fortrait in the National Portrait Gallery. 



\section{SCHOOLS}

headmaster's house and dispersing the residents among new houses under house masters, and encouraging milder methods in discipline and life. $\mathrm{He}$ enlarged its borders intellectually by the introduction of new subjects of study, and making mathematics, French and science, which had been mere bywords before, a real part of the school curriculum. Dr. Fearon, the first 'Winchester scholar' of New College, when scholarships first ceased to be probationary fellowships and were thrown open to competition among the whole school, was a brilliant specimen of the results of competition. At Winchester he won both 'Goddard' and 'Duncan,' the scholarships for classics and mathematics; at Oxford he won a 'double first,' first classes in both classics and mathematics, both in 'Moderations' at the end of two years and in the 'Final schools' at the end of four years of the University course, and became a fellow of New College. He opened a new house at Winchester in I 868 . From I 854 to $190 \mathrm{I}$ he begot a constant succession of successes in the schools, and Oxford colleges are replete with Fellows of his production.

At Easter, I 901, he gave place to Dr. H. M. Burge, the first headmaster who, for $45^{\circ}$ years, has not hailed from Winchester, and he is a scion of Bedford Grammar School, a Wykehamical offshoot. It was long under the tutelage of New College and still governed by one who may claim to be a second founder, J. S. Phillpotts, scholar of Winchester (I 852 ) and fellow of New College, who found a school of 150 and now governs a school of 800 and upwards. The only fault that can be found with Winchester School at the present time is the retention of a fixed limit of numbers of about 420 boys, fixed by the number of houses and a supposed capacity of 'chapel' and 'chantry.' We may trust that a man coming fresh from outside may not reverence a limitation not more than a generation old, which cramps the development and narrows the influence of the 'doyen' of our great public schools.

\section{Wardens and Headmasters of Winchester College, I 373-1902}

The names and dates of wardens are taken mainly from Mackenzie Walcott's William of Wykebam and bis Colleges, I 852 ; those of headmasters from the account rolls and bursars' books up to I 772 , supplemented from the register of New College, which was compiled by the present warden, the Rev. Dr. J. E. Sewell, chiefly from the records of the admission of scholars and fellows there.

\section{LIST OF WARDENS}

Thomas de Cranle (Cranleigh) of Cranley, John Baker of Aldermaston, Berks, 2 July, Surrey, 20 Oct. 1382

John Westcott, 23 May, I 389

John Morys of Gloucestershire, 8 Feb. I 393-4

Robert Thurburn, I0 Dec. 1413 I 454

Michael Clyve (Clyff, Cleve) of St. Ebbs, Oxon. 7 Nov. 1487

John Rede (Read, Reede) of Kingsley, Hants, I 8 Nov. I 501

Thomas Chandler of St. Cuthbert's, Wells, Ralph Barnacke (Barnake) of Alresford, 30 Nov. 1450 I 8 Dec. 1520 


\section{A HISTORY OF HAMPSHIRE}

Edward More of Havant, 29 Oct. 1526

John White of Farnham, Feb. $154 \frac{1}{2}$

John Boxall of Bramshott, 29 Oct. 1554

Thomas Stempe (Stampe) of Winchester, 21 Nov. 1556

Thomas Bilson of Winchester, 11 March, 1580

John Harmar of Newbury, 8 July, 1596

Nicholas Love of Froxfield, Hants, 29 Oct. 1613

John Harris of Hardwick, Bucks, son of Rd. Harris, 30 Sept. I63o

William Burt of Winchester, son of $\mathrm{Wm}$. Burt of Thame, Mus. Doc., 28 Aug. 1658 (Walcott), 9 Sept. 1658 (Kirby)

John Nicholas of West Dean, 23 July, 1679
Thomas Braithwaite of Enham, Hants, 24 March, 17 I I

John Cobb of Adderbury, I 720

John Dobson of Chiddesden, $17 \mathrm{Dec}$. 1724

Henry Bigg of Chilton Foliat, 25 Jan. 1729-30

John Coxed of Bucknell, 18 Aug. 1740

Christopher Golding of Midhurst, 29 June, 1757

Harry Lee of Coton, Salop, 26 Dec. 1763

George Isaac Huntingford of Winchester, 5 Dec. 1789

Robert Specott Barter of Cornworthy, I 8 May, 1832

Godfrey Bolles Lee of Froyle, I861

\section{LIST OF HEADMASTERS}

Richard Herton, I Sept. I 373

John Melton (Milton), I 388

Thomas Rumsey, Mich. 1394

John Pole, Mich. I 407

Thomas Romsey, Oct. I 414

Richard Darcy, Mich. I 418

Thomas Alwin (Walwyn, Alewynne) of Estford, Linc. Dio., 24 June, 1424

William Waynflete (Wanneflet, Waneflett, Wanflet), Pattene als. Barbour, of (?) Patney, Wilts, 24 June, 1430

Thomas Alwin, Mich. I $44 \mathrm{I}$

William Ive, 24 June, 1444

John Bernard of Over Wallop, Hants, 24 June, I 454

John Grene of Chilcombe, Dorset, Mich. (?) 1459

Clement Smith of Southwark, 24 June, ${ }_{4} 64$

Richard Dene of Hambledon, April, I 467

John Rede of Kingsley, Mich. 1484

Robert Festham (Fescam) of Vernham (Fernham), April, I 490

William Horman (Harman, Herman, Hoorman) of Salisbury, 25 March, I 495

John Farlington (Farlton, Farylton) of St. John's, Smithfield, London, Mich. I 501

Edward More of Havant, Mich. I 507

Thomas Erlisman (Erillisman) of Gatcombe, I.W., Lady Day, I 515

John Twychener (Towchenar, Tochyner, Tohynare, Tuechyner, Tychenor) of Okynggame (Wokingham), Mich. I 525

Richard Twychener (Touchner) of Wokingham, Mich. I 53 I

John White (Whyght, Whyzth) of Farnham, Surrey, April, 1535

Thomas Bailey of Portisham, Hants, Mich. I 54 I
William Evered (Everard, Etherodd) of Fifehead Magdalene, Dorset, Mich. 1546

Thomas Hide of Newbury, Mich. I 553

Christopher Johnson of Kyddesley, Derbyshire, 24 June, 1561

Thomas Bilson of Winchester, Xmas, I $57 \mathbf{I}$

Hugh Lloyd (Floyde, Floyd) of Carnarvon, 24 June, 1579

John Harmar, I 588

Benjamin Heyden (Heydon) of Winchester, 1596

Nicholas Love, 1602

Hugh Robinson of Anglesey, I6 I 3

Edward Stanley of Chichester, 1627

John Potinger of Burghfield, Berks, I 643

William Burt of Winchester, Mich. 1653

Henry Beeston of Titchfield, Hants, Mich. 1658

William Harris of Colerne, Wilts, 24 June, 1679

Thomas Cheyney (Cheney, Cheiny, Cheyny) of Titcombe, Wilts, 12 Nov. 1700

John Burton of Keresley (Caresley near Coventry), Warwickshire, 1724

Joseph Warton of Dunsfold, Surrey, 7 May, I 766

William Stanley Goddard of Stepney, 26 July, I 793

Henry Dison Gabell of Winchester, 29 Jan. I 8 ro

David Williams of Lasham, Hants, I 5 Jan. I 824

George Moberly of St. Petersburg, I 836

George Ridding of Winchester, Xmas, I 866

William Andrewes Fearon of Assington, I 884

Hubert Murray Burge of Meerut, India, Easter, I 901 


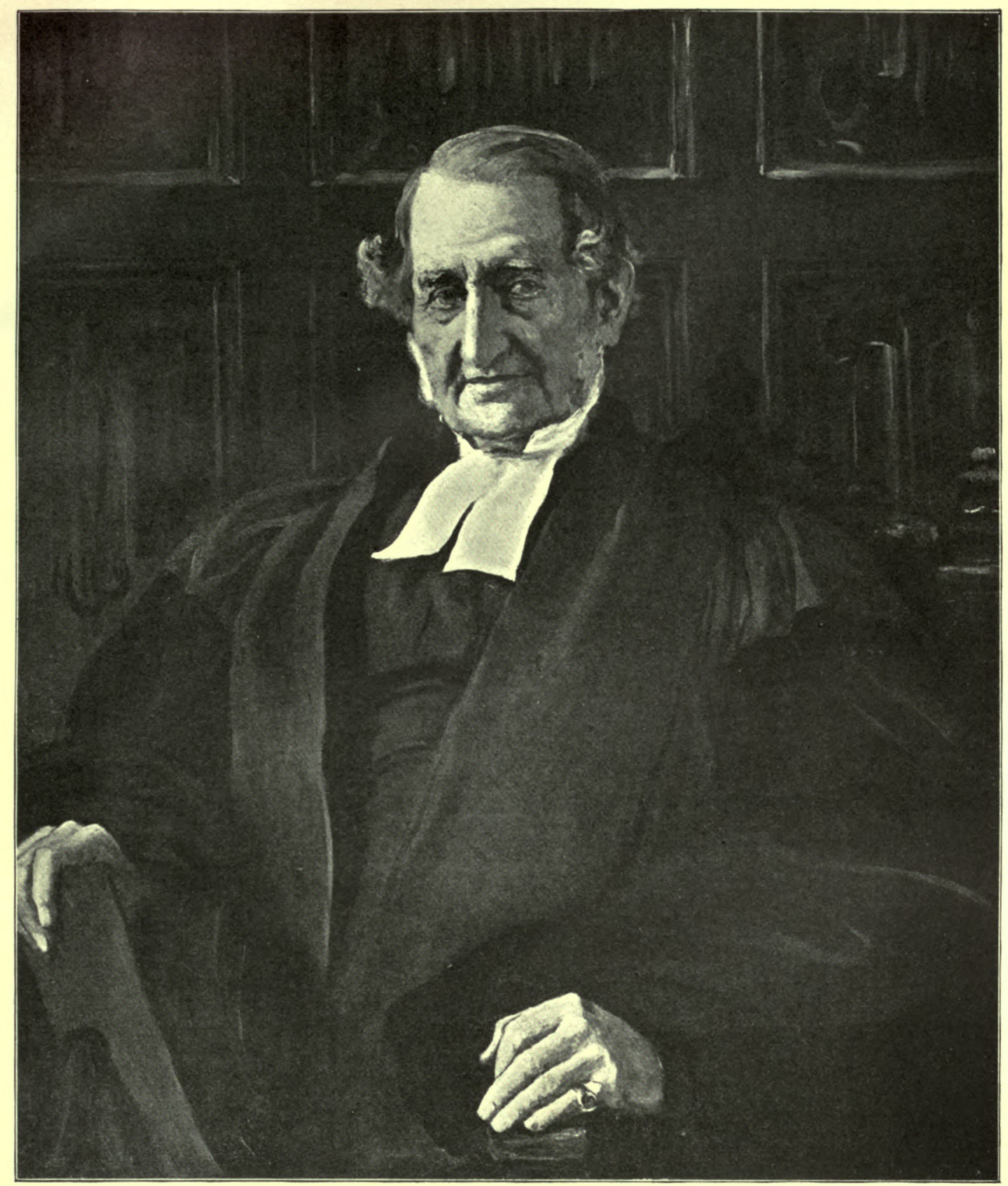

James Edwards Sewell, Warden of New College, Oxford, i86o. College 1821-1828. From his portrait by Herkomer, at New College, Oxford. 



\section{SCHOOLS}

\section{ALTON, ODIHAM, GODSHILL SCHOOLS}

Next to Winchester College, whose history we have now related, the oldest school in Hampshire of which any record remains was that of

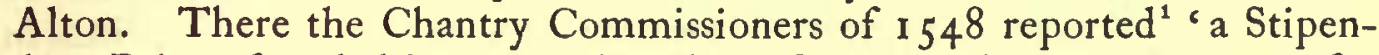
dary Priest, founded by one John Chawnflower, to have continuance for ever, to the intent to assist ministration in the church of Alton and to teache children grammer.' The lands belonging to this priest were worth $£_{\text {I I I }}$ s. 3 d. a year gross, and after some outgoings and the founder's obit, which cost i Is. 8d., £i 0 is. $3 d$. clear. But it does not seem that the schoolmaster took the whole salary, as it is said that he had ' of the said landes for his salary yerely payd by the wardens of the same town $f_{0} 6$ I 3 s. $4 d$.', though what was done with the rest is not stated. The priest at the time of the dissolution in 1548 was named Gregory Bacon. The founder of this chantry school, called 'Champflower's Chauntrie' in the patent of foundation in $1472,{ }^{2}$ was probably the son of the 'John Champflour, squyer,' who in the year I 405 received $^{3}$ a retaining fee of 20s. a year as counsel for Winchester College in the 'Common Bench,' i.e. Court of Common Pleas. But unfortunately we know no more of this school, whether it was continued by order of the Chantry Commissioners or simply perished when its endowment was confiscated to the Crown. The existing Alton Grammar School, founded by Eggar in 1638 , its feoffee's incorporated by Act of Parliament in I642, appears to be a new foundation.

The same is true of the two other grammar schools mentioned by the Chantry Commissioners. ${ }^{4}$ At Odiham (Odiam) there was a stipendiary priest founded by public subscription ' of the benevolence of the inhabitantes,' 'to be assisting and aiding to suche ministracion as is required to be emonges the people by the word of Godd, and to the intent to teache children gramer.' He had lands to the value of $f_{0} 7$, the clear 'remanet' of which $f_{0} 6$ I 3 s. $8 d$. 'is yerely paid to Hugh Laner, whose age is ' 40 yeres, for his salary, who hath none other lyving.' A memorandum adds that there was a chapel of ease in Northwarnborough (about half a mile away), "which is emploid in time of the plage for ministration and for a place to teach children in.' There does not seem to be any traceable connection between this school and the present Odiham Grammar School founded by Robert May in I 694 with an endowment of about $\oint_{0} 100$ a year.

At Godshill in the Isle of Wight ${ }^{5}$ there was a chantry founded by Sir John Ligh, knight, which had lands worth $£_{0}$ I I $2 s .4 d$. net. 'The incumbent thereof is one John Griffithe, Master of Arte, of the age of 40 yeres, and hath besides $£ 6$ pension out of Hales monasterie during lief, who teachethe there grammar to many yong children.' But

1 English Schools at the Reformation, p. 90, from Chant. Cert. 54 No. 12.

2 Pat. 12 Edw. IV. The Privy Seal for the patent was dated 25 February; the patent 20 October. Licence in mortmain up to $£$ ro a year.

- English Schools at the Reformation, p. 89.

- Ibid. p. 9 r. 


\section{A HISTORY OF HAMPSHIRE}

this chantry is not stated to have been a grammar school by foundation, and teaching was perhaps only the voluntary occupation of the chantry priest. This school was apparently continued by the Chantry Commissioners, though its lands disappeared. It was partially re-endowed by Lady Ann Worslcy with 20 marks a year, at a date unknown, recited in a deed of 20 March, I6 I 5, by which her great grandson, Sir Richard Worsley, granted to the 'Free Grammar School' the old Chantry House in which it was still carried on. Other small endowments were given ; in February, I 595, a rent charge of $£_{5}$ was granted, while separate endowments were given for the usher in 1617 and 1622. It remained a real grammar school until I8I3, when one of the Worsleys was appointed master, and proceeded to execute his duties by deputy, the deputy being an elementary schoolmaster. Since then the whole endowment and school have been appropriated to elementary education.

\section{SOUTHAMPTON GRAMMAR SCHOOL}

At Southampton, attached to the church of St. Mary, which is sometimes called a collegiate church, and had a considerable staff of priests under a rector, commonly called the precentor, which was also the title of the head of the collegiate church of Crediton, we should surely have found a grammar school from early times. But unfortunately our good neighbours the French were continually burning and pillaging Southampton, and it is supposed that in one of their raids the muniments of the church were destroyed. At all events they have disappeared. The town records, also very scanty, display no evidence of the school. The foundation of the existing grammar school dates from I 554, when Robert Knaplock, who had been a scholar of Winchester, fellow of New College, and second master at Winchester from I 55 I, became its first headmaster. This cannot establish its claim for special attention here as an 'ancient' school within our definition, as existing before the Reformation, that is before the dissolution of colleges and chantries by the Chantries Act of Edward VI.

\section{BASINGSTOKE GRAMMAR SCHOOL}

Few travellers on the London and South-Western Railway can have failed to notice at Basingstoke station a picturesque ivy-clad ruin standing on a hill immediately north of it, in the grounds of the town cemetery. This ruin is all that now remains of the ancient Basingstoke Grammar School, otherwise the Holy Ghost School, and of the Chapel of the Holy Ghost, maintained by the Gild or Brotherhood of the Holy Ghost, of Basingstoke.

'The historic name of the Holy Ghost School, a name venerable by the traditions of three centuries, was under a scheme made by the Court of Chancery on I I June, I 852 , changed ${ }^{2}$ by some prudish modern

1 Char. Com. Rep. xv. 476. mișsioner.

- Scbools Inquiry Com. Rep. (1867), ii. 315. Report of Mr. C. H. Stanton, Assistant Com- 


\section{SCHOOLS}

sentiment into that of "The Queen's Free School." By the existing scheme, made by the Charity Commissioners under the Endowed Schools Acts and approved by the queen in council on 6 May, 1886 , the old name was not restored, but the school was dubbed Queen Mary's School. This misleading misnomer lends authority to the false derivation of the school from Queen Mary, of ensanguined memory, and diverts attention from its real founders, those inhabitants of Basingstoke and the neighbourhood who were members of the Brotherhood or Gild of the Holy Ghost, which maintained it.

When exactly either the school or the brotherhood of the Holy Ghost was founded cannot be determined. In I 867 the Schools Inquiry Commission, following the report made in 1825 of the 'Commissioners of Inquiry concerning charities, ${ }^{1}$ commonly called Lord Brougham's Commission, reported that the school and gild were founded by Richard (Fox), Bishop of Winchester, and Lord Sandys, under licence from Henry VIII. in I 525 , and re-established by Philip and Mary in 1557 . But, as will be shown, the licence from Henry VIII. in I 524 was not a foundation of the gild, nor did the foundation take place under it; and the school is not mentioned in the licence.

The first certain mention of the existence of the school is in 1548 , when the commissioners under the Act for the dissolution of Colleges and Chantries of the first year of Edward VI., commonly called the Chantries Act, reported ${ }^{2}$ that there was in Basingstoke subject to the Act a 'Brotherhood of the Chapel of the Holy Ghost,' the endowments of which, amounting to $\oint_{5} 17 s$. $5 d$. a year net, were employed in paying a schoolmaster to teach children grammar, and had so been for the last ten years. As this document, which is the foundation of the history of the school, has been incorrectly printed in the History of Basingstoke by Mr. Baigent and Mr. Millard, late vicar of Basingstoke, it is here given in full. ${ }^{3}$ The commissioners for Hampshire were Sir John Mason, kt. ; George Powlet, John Kingsmill, Nicholas Tichebourne, esquires; Edmund Clarke, Nicholas Vaux and Richard Gifford, gentlemen. They report under the heading of :-

\section{Decanatus de Basingstoke}

\section{BASINGSTOKE}

The Brotherhood of the chapell of the Holly goost. Founded of the devocion of the inhabitantes at the begynnyng, there to fynd a prest for ever, and sythens employed to the intent to fynd a schole Master to teache children grammar, whiche hathe been so continually kept thes Io yeres last past unto this daye ; whereunto belongen, viz.: Landes and tenements in Basingstoke to the yerely value of $£^{6} 13$ s. Whereof

Resolute, I 5s. $4 d$. Et Remanet, $£_{5}$ i 7 s. $8 d$. whiche is yerely paid to the said schole Master. Ornamentes and plate belonging to the same brotherhood, Delyvered by Inventory Indented by the commissioners to the wardens of the said Brotherhood, valued at $28 \mathrm{~s}$.

1 Report referred to as Char. Com. Rep. xiv. 377.

2 A History of the Ancient Town and Manor of Basingstoke, by Francis Joseph Baigent and James Elwin Millard (C. J. Jacob, Basingstoke, 1889). This book is afterwards referred to as Basingstoke.

${ }_{3}$ English Schools at the Reformation, 1 546-8 (Archibald Constable \& Co., Westminster, 1896), p. 89 .

Chant. Cert. No. 54 Hants. 


\section{A HISTORY OF HAMPSHIRE}

Memorandum : the said chapell of the Holly goost, and the yard enviring the same, is the common buryeing place for all the said parishe, and the Vicar there findithe a curate, And the same Vicarage is of the yerely value of $£ 26$ 2s. $9 d$. , Benefice. ${ }^{1}$ Houseling people there, ${ }^{8} 304$.

The wording of the chantry certificate suggests that it was only of then recent years, perhaps only for the previous ten years, that the Brotherhood of the Chapel of the Holy Ghost had appropriated their endowments to the maintenance of a grammar school. 'This suggestion is to a certain extent supported by the fact that the licence in mortmain ${ }^{3}$ of Henry VIII. for the establishment of the gild, dated 16 November, I 524 , does not mention any school or teaching. But then that licence does not mention the chaplain of the brotherhood, or any of its objects, cxcept the furtherance of divine worship. It was purely formal to formally incorporate and license under the Statutes of Mortmain a body which had long existed, without formal incorporation and without a licence in mortmain, probably because it was created before any statute of mortmain had been passed.

The licence begins by reciting 'that the King's beloved subjects, the inhabitants of our town of Basingstoke, incited, stirred and moved by the very great and pious devotion which they held and bore towards the Third Person in the Deity, the Holy Ghost, did long since virtuously begin; and to the present time have quietly and peacefully continued, a certain brotherhood or gild to the praise of God and the furtherance of divine worship in honour of the Holy Ghost within the chapel, near the said town, which has been built in honour of the same,' but the brethren now 'fear that that brotherhood or gild was by no means begun or continued according to the requirements of the law,' and desire that the same should be made permanent. The king, on 'the report of' Richard (Fox), Bishop of Winchester, and William Sandys, knight, Lord Sandys, 'wherein the same Bishop and William have most humbly petitioned us that we would be pleased to deal graciously with our aforesaid subjects in this behalf,' ' having a hearty regard for the pious intention of our said subjects,' grants 'licence to the said Bishop and William that they their executors or assigns or any of them may have power to found a perpetual gild to be called the Brotherhood of the Holy Ghost in the chapel of the same, near the town of Basingstoke, in the county of Southampton.'

The gild so founded was to have power to admit persons willing to belong to it as brethren and sisters (for, as usual, women were included as well as men), and the brethren were to elect every year an alderman and two wardens (custodes) to manage its property. It was to be a

1 This word is a note, written in a different hand, and no doubt made by an officer of the Court of Augmentations to call attention to the fact that the vicarage was an ecclesiastical benefice, not a chantry, and therefore not within the Act.

2 Houseling people means communicants, including all above 12 years of age, showing a population of not much over 600 .

3 Basingstoke, p. 120, translated from Pat. Henry VIII.

1 Not 1525 as incorrectly given in Basingstoke, p. 118 (though correctly on p. 120), and in Char. Com. Rep. loc. cit. 


\section{SCHOOLS}

body corporate with a common seal; the alderman and wardens being empowered to acquire and hold lands and sue for them in the corporate name. The brethren had power to hold meetings and make statutes and ordinances. The grant was made without any fine ${ }^{1}$ or fee.

It is not to be inferred from the absence of any mention of the school in the licence that the school did not exist, or was not intended to be created. Unfortunately the ordinances, if any, which were made by the nominal founders, the Bishop and Lord Sandys or the alderman, wardens and brethren, are not forthcoming. But the letters patent of Philip and Mary, 24 February, I 556, reciting the re-foundation of the gild under licence from her father, distinctly says that a school was intended to be part of that re-foundation : 'From the revenues of which fraternity or gild a priest was to have been provided and supported as well for the celebration of divine worship within the said chapel as for the education of youths ${ }^{3}$ and boys in literature within the said town, as we have heard from persons worthy of credit.' Many gilds, like the famous gild of the Holy Cross of Stratford-on-Avon, in whose school Shakespeare received his education, kept grammar schools, by maintaining a chaplain who was authorized or required to teach grammar. Yet there is no mention in the licence for the foundation of the Holy Cross Gild of Stratford of any school, though there is positive evidence that one was maintained from, if not before, its formal incorporation in 1405 . Silence therefore in the licence of Henry VIII. is no argument that in the royal manor and town of Basingstoke the gild of the chapel of the Holy Ghost had not maintained a grammar school for ten

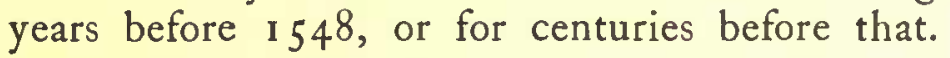

\section{The Holy Ghost Chapel}

The first mention of the chapel itself as yet known is in an order" by William Raleigh, Bishop of Winchester, in I 244, for the establishment of the vicarage of Basingstoke, in consequence of the appropriation of the rectory to Selborne Priory by his predecessor, Bishop Peter de Rupibus, in I 234. According to that ordinance the vicar was to maintain two chaplains in Basingstoke under him, 'one to celebrate for the living and the other for the dead, as was usual in times past.' The oblations of the chapel of the Holy Ghost of Basingstoke, excepting those which were offered for the dead buried there, or of parochial right, were to be divided into three portions and were to go, one-third each to the priory, the vicar, and repairs of the churches, viz. of Basing and Basingstoke. The vicar was to do ordinary repairs to the

1 Fine, not, as oddly translated in Basingstoke, 'without limit.'

${ }_{2}^{2}$ Translated from Pat. 3 \& 4 Philip and Mary in Basingstoke, p. 663 seq.

3 This and not 'young men,' as in Basingstoke loc. cit., is the proper translation of juvenes. Boyhood ended, strictly speaking, at 14, and as boys stayed at grammar schools in the middle ages as now till 18 , the term youths was correct.

4 Basingstoke, p. 14. The reference is not given; but the order seems to come (p. 655) from a Selborne Priory document preserved at Magdalen College, Oxford, from an Inspeximus Charter passed in 1318 by Bishop John Sandal. 


\section{A HISTORY OF HAMPSHIRE}

chancels of the churches, but extraordinary burdens were to be borne by the priory and vicar, "each discharging their portion ; saving this, that the Prior of Selborne shall competently maintain the chapel of the Holy Ghost.' This chapel then was already well established before 1244 , or presumably 1234, and its chaplain was no doubt the chaplain referred to, who, under the control of the vicar, celebrated for the dead, 'as was usual in times past.'

Yet there is not extant a scrap of evidence to prove the existence of the gild earlier than 1480, when a rental of Basingstoke, still in the possession of the Corporation,' shows 'the Wardens of the Holy Ghost' paying rent. Even that entry might conceivably refer simply to chapel wardens, and not necessarily imply that there was a gild. In fact it is only from the recital in Henry VIII.'s licence in mortmain that we know positively that the gild had long existed.

In 1548 the chapel itself and the gild with its possessions were confiscated as superstitious under the Chantries Act ${ }^{2}$ of ${ }_{1} 547$. The Brotherhood of the Holy Ghost therefore ceased, and its possessions passed to the Crown. The school appears to have ceased also. The Act indeed contained a provision for the continuance of grammar schools, but apparently only for those which were specifically part of the original foundation. 'The Commissioners,' it said, 'shall appoint in every place where a gild or fraternity, or the priest or incumbent of any chantry, by the foundation, ordinance or the first institution thereof, should or ought to have kept a Grammar School, and has done so, since Michaelmas, 1 547, lands, tenements and other hereditaments of any such chantry to remain and continue in succession to a School Master for ever, for and towards the keeping of a Grammar School.' The return made to the commissioners, as we have seen, only showed that a grammar school had been kept for ten years past, and did not assert that it was of the foundation or first institution. Therefore, in odd contradiction to the preamble which held out a promise of converting chantries not theretofore used for schools into schools, the Act swept away those that were already used as schools, if such user was not in accordance with the original foundation.

In 1557 the school was re-founded, and by a provision which is probably unique the gild was re-founded with it. In the re-foundations of Edward VI., as for example at Stratford-on-Avon and Saffron Walden, the schools formerly maintained by a fraternity or brotherhood were now placed under the government of the town corporation, which took the place of the extinct gild. In other places, as at Louth, where a gild had formerly maintained the school, a special body of governors was created to govern the goods, possessions and revenues of the resuscitated school. The revival at Basingstoke is significant of the attempt then being made

1 Basingstoke, p. 380 .

2 Mr. Baigent speaks of the gild ' founded by license from Henry VIII. himself, escaping the operation of the Act passed in the thirty-seventh year of his reign for the suppression of such institutions.' It was however included in the Act, which was permissive, and allowed the king to enter on what he chose during his life. As he died within a few months after it came into operation it was acted on in a very small number of cases, of which the Basingstoke gild was not one. 


\section{SCHOOLS}

to effect a restoration of the confiscated property of monasteries and chantries to pious uses. The letters patent re-establishing the gild are dated 24 February, I 557. They recite ${ }^{1}$ that ' the gild or fraternity lately, through the schism of heretics, the church being decayed on every side, had fallen and was destroyed,' but 'the inhabitants having humbly prayed for the restoration of the brotherhood,' the king and queen 'considering that the chapel and its cemetery are places in which the bodies of the inhabitants are sometimes buried, at the request of the most reverend father-in-chief, Reginald Pole, legate ex latere and Archbishop of Canterbury,' decreed that the brotherhood be founded anew, and proceeded in set terms to found it under its old name.

The brethren living in the town were empowered to elect an alderman and wardens (gardiani), John Runnygear being named as the first alderman and Richard Hall and Roger Reve as the first wardens. Then the lands were granted. The messuage, "Frymles, otherwise called the Hollie Goste Ferme' ; the horse-mill in Water Street ; Herriards (called Dingley's in 1480) in North Brook Street ; Spicer's (also a possession of I 480) in ' Hollie Goste Street, otherwise Whitewaye,' in the occupation of Simon White (whence perhaps its alias); the Holy Ghost Barn and Ioo acres. All these were granted with the intention that the alderman and wardens 'shall for ever find a fit priest as well for the celebration of divine service in the chapel as for the instruction and education of the youths and boys of the said town.'

The history of the resuscitated gild has been well preserved. Its first account book, extending over close on a hundred years from i 557 to I654, fortunately reposes in the Hartley Institution at Southampton. It shows that the resuscitated gild lost no time in reassembling. One of its first acts was to have a dinner, which produced $f_{0} 6$ i $8 s$. I $0 d$. for the gild funds, while subscriptions to the extent of $\oint_{\mathrm{I}} 4 \mathrm{IOS}$. $4 d$. were forthcoming. The costs however of the "suit for our corporacion' cost $£ \mathrm{I} 9$, and repairs of the chapel $£_{7}$; while making the image and dressing the chapel account for other expenditure. The only item mentioning a priest is 'wine for the Holly Gost preste, 4d.', and no schoolmaster is mentioned at all. In $155^{8}$ the priest was paid for one year $f_{0} \mathrm{I}$, while he also received ' at sundrye times when he lacked his dynner,' one shilling. The rental of the lands was about $f_{5}$ I $10 s$., but $f_{0} 24$ Ios. was received from the tenants for fines on the grant of leases, Goodyer paying $f_{0} 6 \mathrm{6s} .8 \mathrm{~d}$. for lands worth $f_{2} \mathrm{I}_{3} 3^{s .} 4 d$. a year. No schoolmaster is mentioned till we come to the time of Queen Elizabeth. For the first century afterwards the school history consists of little more than the names of the masters and the amounts of their stipends. In 1559 the schoolmaster received a salary at the rate of $\oint_{12}$ by the year. One quarter at the school was enough for him, since at Christmas we find 'Mr. Vicar' paid ' for teaching the school after $£_{4} 4$ by the year, $£_{1}$,' and so the vicar continued to teach, getting $f_{0} \mathrm{I}$ a quarter, till Midsummer, I 560 . The living of Basingstoke belonged to Magdalen College, Oxford, and the vicar,

\footnotetext{
1 Basingstoke, p. 664. The letters patent are in Latin.
} 


\section{A HISTORY OF HAMPSHIRE}

Thomas Browne, formerly King's Scholar of Christ Church, Oxford, who in ${ }_{5} 65$ was also made vicar of Kingsclere, was a competent person. As he left the cure of Basingstoke to a curate he no doubt could find time from his clerical duties to teach the school adequately. In 1560 we find a 'schoolmaster' again appointed; 3 s. $4 d$. was paid 'when we,' the wardens, ' made bargayn with him.' This schoolmaster was again a nameless bird of passage, as after two quarters' payment to him we again find 'Master Vycar' paid for teaching the school for a quarter in $1561,13 s .4 d$; and for three quarters in $156 \mathrm{I}-2$ at the rate of $\oint_{4} 46 \mathrm{~s} .8 \mathrm{~d}$. a year. In 1560 the school received its first additional endowment in the shape, common enough in medieval times, of five ewes, which Agnes Yate, widow, gave 'of the bequest of Rychard Yatte to the brothered of the holy goste and to the mayntenanses of the scholle; wyche,' say the wardens, 'we have lett to Thomas Yate by a andenter (indenture) for $2 s$. $8 d$. by the yere.' For many years the accounts duly contain the entry of $2 s .8 d$. rent of the five ewes, whose capital value was thus estimated at £2 I 3 s. $4 d$.

In 1562 there was again a 'skolemaster' for Midsummer and Michaelmas quarters, this time at the rate of $£_{5}$ a year, but as the vicar is mentioned as again acting as schoolmaster from Christmas quarter at the same rate he was probably the same person as the schoolmaster and taught for the whole year. He was also given $4 s$. $6 d$. for his 'dyner and reward.'

In I $_{5} 6_{3}$ a new schoolmaster came. He received is. as 'earnest,' while the wardens laid out 'at the time of drinking with him, $7 d$., and for his chamber, 3s. 4d.' His salary was only $f_{0} 10$ a year. The endowment proved insufficient for his maintenance, as we find entries of payments by the scholars of $8 s .8 d$. for Christmas quarter, of 15 . for Lady-day quarter and of $f_{\mathrm{I}} \mathrm{I}$ s. for three quarters in 1564 . At the rate of $8 d$. a quarter, which was the traditional amount, this would mean thirteen pupils for the former quarter and twenty-two for the latter, a very fair number for a town the whole population of which amounted to under 1,000. This schoolmaster disappeared after Midsummer, i 564, and ' $\mathrm{Mr}$. Brown, Vycar,' taught until November, I 567, what was then called the ' free skoole,' apparently because no fees were charged when he was doing the work. Then a determined effort was made to put the school on a better basis. A more permanent addition to its resources than the five ewes of Richard Yate's gift was made by a bequest of Richard Holloway by his will, which took effect in 1564 , of 10 s. a year rentcharge out of his house 'towards the maintenance of the schole.' This house was in Holy Ghost Street, now called by the uninteresting name of Chapel Street. Richard Holloway, his son, lived in it until I 570, when the vicar bought it for $£_{1} 8$ and gave' the house 'to the Alderman and

1 Will dated 4 June, 1586 , proved at Winchester 21 June, 1588 (Basingstoke, p. 668). Mr. Baigent in a note on p. 148 seems to have misapprehended the difference between Richard Holloway's gift of a rentcharge of 10 s. on the house in 1569 and Thomas Browne's gift of the house itself in 1588 . In 1626 the house was let on a building lease to Charles Butler at 16 s. a year. 


\section{SCHOOLS}

Wardens of the School called the Holy Ghost School, towards the maintenance of the schoolmaster there.' He had already, he says, ' surrendered the deeds to the bailiffs, constables, aldermen and wardens with divers other honest freeholders of Basingstoke and to their heirs for ever as feoffees in trust.' He died in $15^{8} 5$. Mr. Harry Wallop, one of the family of the Earls of Portsmouth, gave $35.4 d$. and 'divers persons of the town' fir IIs. 3 d.

At length in November, I 567 , there came a schoolmaster whose name is recorded. This was Nicholas Sheffield, who received a salary of E1 2 a year.

What were presumably either school fees or voluntary contributions were levied in aid of the school funds, amounting to $\oint_{\mathrm{I}} 4 \mathrm{~s} .2 d$. in I $569-70$, to $f_{0} \mathrm{I} 6 \mathrm{~s} .2 d$. in $\mathrm{I} 57 \mathrm{I}-2$ and to $f_{0} 2 \mathrm{Is}$. $4 d$. in $\mathrm{I} 572-3$.

An interesting entry in the accounts for 1577 shows that the chapel services were still kept up, as there is a note that 'of organ pipes, great and small, there were 42 , whereof i 2 be of tin.'

The rule of James Pearse, I590-5, was inaugurated by a considerable expenditure on 'mending the schole,' glazing the windows of the chapel and making a new window of glass in the school. In 1592 more glazing was done 'against the Queen's coming' at a cost of $5^{5 .}{ }^{1}$ It is curious that there is no other record preserved of this visit of Queen Elizabeth to Hampshire, unless it is the one referred to in a letter to Cecil, the great secretary, written in May, I 595, by Harmar, headmaster of Winchester College ${ }^{2}$ : 'At Her Majesty's last being in Hants she had the scholars before her at Aberston (? a misreading of Alton) at which time she vouchsafed to take notice of my being her Scholar; of my travels,' etc. James Pearse was the first of the schoolmasters to take a lease of the close of pasture called 'the holly gost litten' adjoining the chapel, probably for a playground. He paid a fine of I os. for it and a rent of I $2 s$. a year. The lease is still preserved among the school papers. The accounts contain an entry of $6 d$. paid 'for a chain for the book given by Mr. Cunliffe and two staples.' William Alen, joiner, was also paid 4s. $4 d$. for ' a dex (desk) at the holie ghost to keepe the booke given by Mr. Cunliffe, and other worke, with locke and key to the same.' The precious book in question was ${ }^{3}$ Cooper's Dictionary. In Cunliffe's last year the school received a new benefaction in the shape of 'foure skoore pounds' given by $\mathrm{Mr}$. William Wig, or Wigge, 'the use whereof is to be paid unto the schoolmaster for teaching of a child to be brought from Bramley in the county of Southampton.'

In the first year of the mastership of John Mason the accounts contain an entry which is of some value in the history of schools. 'Memorandum, that in the time of the said William Purchier, Alderman, William West and Thomas Hill, Wardens, of the Fraternity or Guild of the

\footnotetext{
1 Basingstoke, p. 580 .

2 History of Winchester College, p. 3 I 8.

${ }^{3}$ Nuncupative will of Edward Cunliffe. Dated 13 November, 1605 ; proved 3 March, 1606 (Basingstoke, p. 143).
} 


\section{A HISTORY OF HAMPSHIRE}

Holy Ghost, the said schoole, by the benevolence of good benefactors, Sir James Deane and others, with consent of the Fraternity of the said Guilde, is erected a Free School, A.D. I 609.' We have seen that the earlier accounts contained entries of payments by the scholars and of contributions by the inhabitants. These were applied to make up deficiencies in the endowment and for repairs to the school-house and so forth. The formal adoption of the term 'free school' shows that these charges now ceased, and that no payments were thenceforth required of the scholars or their parents.

The benefactors in question were chiefly Sir James Deane and his cousin, Sir James Lancaster. Probably Sir James was an old grammar school boy. In his will, I 9 August, 1607, he says that finding 'the town of Basingstoke had been and then was destitute of a good and godly preacher' (the vicar was too often a non-resident pluralist) he gave an annuity of $\oint_{2} 20$ a year issuing from his manor of Ashe, of which $£_{0} 0$ was to be paid to a preacher 'to teach and instruct the people in the principles of religion,' and other $f_{1} 10$ to 'some good and learned man, being a good scholar and a learned grammarian, to teach and instruct the children and folks of the town in their grammar rules and other good learning.' Both of these objects were assisted by Sir James Lancaster, one of the great Elizabethan merchant seamen, whose adventures are recorded in Hakluyt and who has left his name in Lancaster Sound.

By his will, dated 18 April, I6 1 8, ${ }^{1}$ Sir James Deane gave permanent endowments both to the Basingstoke lecturer and the school. The will recites certain indentures of 2 April, I6I5, made between himself and Sir William Cockaine, knight, Richard Wych, skynner, and Robert Butman, skynner, whereby fines had been levied of the manors of Maidenwell and Fareford in Lincolnshire, 9 acres of land in Claythorne, I 5 acres in Somercote, a farm at Abie and a wood of 24 acres in Hawnby, formerly part of Hawnby monastery, and three messuages in Pember, Hants. It mentions also an indenture enrolled in Chancery, granting an annuity of I 00 marks out of lands 'which are or were the Lord Wotton's.' The income of these lands and the annuity were to be paid to the 'Master, Wardens and Commonalty of the Mystery of Skinners, London,' to this intent, that they shall pay out of the same 'Imprimis, unto the Churchwarden, the Lecturer and the Bailiffs of the town and parish of Basingstoke in the county of Southampton, where I was born, and to their successors, one yearly payment or sum of $f_{0} \mathrm{IO}_{3} 6 \mathrm{~s} .8 \mathrm{~d}$.' $^{\prime}$ Out of this they were to distribute $f_{3} 3$ among the poor of Basingstoke, 'and also one yearly payment of $\oint_{2} 20$ towards the maintenance of the free school in Basingtoke aforesaid for ever, so long as the Schoolmaster and Usher be there from time to time chosen and allowed by the said Bailiffs and Burgesses.' And ' out of the said sum of $\oint_{0} 20$ there shall be yearly paid unto the Usher of the said School for the time being the sum of $£_{1} 6$ of lawful money of England, and the other $£_{4} 4$ thereof shall be yearly paid either to the

1 From copy at the Skinners' Hall, Dowgate, London, for access to which and to other documents I am indebted to the clerk to the company, Mr. W. H. Draper, barrister-at-law. 


\section{SCHOOLS}

Master or Usher of the said free School, or both of them, in the good discretion of the said Bailiffs and Burgesses for the time being.' The residue, $£_{\mathrm{I}} 36 \mathrm{~s} .8 \mathrm{~d}$. more thereof, 'was to go to the maintenance of a petty schoolmaster, to be chosen and allowed as aforesaid in Basingstoke aforesaid, who shall teach little children to write and read, but especially to read, and to learn the Catechism in the principles in (sic) religion. And I will and appoint that the lecturer or preacher for the time being shall once in every week come to the school where the children shall be taught and there appose ${ }^{1}$ some of them to see how they shall profit therein. And I will that the scholars both of the Free School and of the said Petty School shall be present at every lecture which shall be preached at Basingstoke aforesaid whereby they may be better instructed.'

Out of the rest of the profits he made provision for three poor scholars to be appointed by the Skinners' Company who 'shall study divinity in the Universities of Oxford or Cambridge,' $£_{0}$ I 5 each.

A codicil, sealed 25 April, provided for the purchase by the executors of lands or houses in London to the value of $£_{30}$ or $£ 40$ a year, to be vested in the Skinners' Company to augment the payment to the Basingstoke poor to $f_{4} 45$ a year and add a further poor scholar.

The will was duly put into execution, and, as far as Basingtoke was concerned, the payment to the corporation was duly made from I6I9 onwards to the time of the Great Fire of London in 1666.

The bequest for a 'petty Schoolmaster' was applied not in the establishment, as was perhaps intended, of a lower department of the grammar school, but of a separate elementary school, ${ }^{2}$ which in I77 I was described, on the appointment of a new master, as 'the Petty School adjoining the Church of Basingstoke.' The corporation appointed the master, who was always, until $\mathrm{I} 77^{\mathrm{I}}$, the parish clerk. From very ancient times parish clerks acted as elementary schoolmasters. In I 77 I the offices of parish clerk and schoolmaster were separated. But the separation, meaning a decrease of stipend, was not a success. From i 810 the mastership of the Petty School was therefore annexed to that of the Blue Coat Hospital, a small charity school on the Christ's Hospital model, for seven boys founded under a bequest to the corporation of $\oint_{0} 2,000$ by Richard Aldworth in $1646 .^{3}$ The United School served as the principal elementary school of the town until board schools were opened 22 February, 1857, when the Petty School and Blue Coat School ceased. The endowments have since been converted into an exhibition fund.

The Lancaster bequest to the Free or Grammar School effected a considerable change in its management. Until then if there was any lower master or usher he must have been found by and at the expense of the master. No trace of the existence of one has been found in the gild accounts or elsewhere. Oddly enough one does not seem to have

1 The examiners at Winchester College are still called posers, and the breaking-up day at St. Paul's School, London, is Apposition Day.

${ }^{2}$ Basingstoke, p. 705.

${ }^{3}$ Ibid. p. 706. 


\section{A HISTORY OF HAMPSHIRE}

been appointed for some years after Lancaster's bequest. For though the Holy Ghost Gild accounts for 1618-9 contain a payment of ' 16 s. for a pue (pew) for the Usser to sit in,' the Skinners' minute books contain an entry under date 13 November, I6I9, that a letter was read from $\mathrm{Mr}$. J. Mason, schoolmaster, asking ' that the arrerages of $f_{0} 4 \mathrm{might}$ be conferred on him.' They were not given him, but it was ordered that it 'should be ymployed in publique books for the benefit of the schollers of the said schole' and afterwards it should be paid to Mr. Mason 'hee continewing painfull in his callinge.' By what right the $f_{0} 4$ a year given to the master or usher was thus applied to buying books for the scholars is not clear. The gild accounts in 1620 give an inventory of books ' given by the Worshipful Company of Skinners, London,' with a note that these books were bought with $\oint_{4} 4$ which 'should have binne paid to the Usher if there had binne one, and because the schollers had no Usher to benefitt them, therefore it was thought meet it should be layed out upon bookes for the use and benefit of the schollers, which are these bookes here above specified.' The appointment of the usher having been vested by Lancaster's will in the bailiffs and burgesses or corporation of Basingstoke, and the stipend of $f_{0} \mathrm{r} 6$ a year being paid through them, both appointment and payment would appear in their accounts and not in those of the gild. What became of the usher's full pay of $\oint_{0} \mathrm{I} 6$ a year does not appear. Presumably it fructified in the pockets of the Corporation of Basingstoke. The next year an usher appears in the account. From this date there was a regular succession of ushers, though their names are not all ascertained.

The list of books given to the school in 1620 is of some interest showing that Greek was taught in the school, though only, it would seem, of an elementary kind.

In 1621 the school became the subject of proceedings in Chancery, when a commission ${ }^{1}$ was issued under the Statute of Charitable Uses owing to the withholding of some of the endowments.

During the rest of the mastership of John Mason things seem to have gone smoothly. His place must have been much pleasanter after Lancaster's bequest had nearly doubled his salary, besides providing a second master. In his will made 16 September he describes himself simply as gentleman. His bequests to his son show that he was possessed of considerable landed property in Basingstoke and Wildbore, while a daughter and another son were given legacies of $£_{2} 200$ apiece. He was buried in Basingstoke Church 18 September, 1639.

Under an Inquisition of Charitable Uses ${ }^{2}$ held at Winchester on 13 September, I642, before Sir Henry Clarke and William Kingsmill, it was found that Thomas Hall, reputed alderman, and Richard Brackley and Richard Woodrofe, wardens of the gild, and fifteen others, including the Marquis of Winchester and Sir Henry Wallop, brethren, had been

1 Petty Bag, Inq. of Charit. Uses, Commission to Bishop of Winchester, Sir Benjamin Tichborne and nineteen others. Bdle. 9, No. 3.

2 Petty Bag, Inq. of Charit. Uses, Bdle. I 4, No. 2 I. 


\section{SCHOOLS}

elected on 26 September, 1639 ; but no brethren, wardens or aldermen had been elected for more than thirty years before, in accordance with the charter of Philip and Mary, and therefore the corporation had expired for lack of members before the election in 1639 . It was also found that a priest had not been appointed schoolmaster as required by the charter. For Mason was, it must be remembered, a layman. The gild was therefore held dissolved, and its possessions escheated to the Crown. Thereupon, on I 3 November, I642, by letters patent, the king granted ${ }^{1}$ the lands and 'the priest's place ' to Edward Webb, who was then in orders and licensed curate to his father the vicar.

There can be little doubt that these proceedings were in some way mixed up with the strife of parties then raging.

Deane's and Lancaster's endowments being given on condition that the schoolmaster and usher should be appointed by the corporation, the corporation had to a considerable extent superseded the aldermen and wardens of the gild as the governing body of the school, if, indeed, at the time of these bequests the gild had not already become practically merged in the corporation. Probably the election of gild officers in I 639 took place simply and solely for the purpose of re-constituting the gild for the purpose of appointing the master, who was really nominated by the corporation. The then vicar, the schoolmaster's father, was probably an anti-Puritan, as on I 2 March, I642-3, he was ordered by the House of Commons to allow 'Mr. John Brockett, clerk, the use of the pulpit in Basingstoke Church according to the intention of the benefactors,' i.e. Deane and Lancaster ; for these lectures were a Puritan innovation and one which Laud strenuously endeavoured to put down. It was no doubt through animosity to the corporation, who were Parliamentarians, that Edward Webbe tried to get the school and its property out of their hands. His triumph, if he did triumph, was of short duration. For in 1643 began the siege of Basing House, held by the Marquis of Winchester, and Basingstoke became the headquarters of the Parliamentary besieging force, so Mr. Edward Webbe betook himself to the vicarage of Kingsclere, from which he was ejected in $1648,{ }^{2}$ Ambrose Webbe, the vicar of Basingstoke, dying in that year.

From I 640 the accounts of the gild were very irregularly kept. Stray memoranda, mentioning Richard Brockley as alderman and James Wittier and Edmund Pitman as wardens in I 646-7-9 appear to show that the alleged dissolution of the gild was ignored and that it was treated as still alive.

There was a large expenditure on its buildings in $1652-3$. In the former year $\oint_{34}$ I os. was spent, I I ,000 bricks being purchased at a cost of $f_{0} 48 \mathrm{~s}$., while in the latter year the accounts for 'repayering the chapel school and finishing it' came to over $£_{5} 2$. Archives.

${ }^{1}$ Basingstoke, p. 671, from Bill of Edward Webb in 1667 , among the Basingstoke Corporation

2 Ibid. p. 24, correcting Walker's Sufferings of the Clergy, p. 405 (ed. I 764), which gives the name of Edmund Webbe. 


\section{A HISTORY OF HAMPSHIRE}

After the death of Pocock, the master, there seems to have been an interregnum. As a consequence of the Fire of London in 1666, the payment of Lancaster's gift by the Skinners fell into arrear. For that year they only paid $f_{0} 80$ instead of $f_{0} 108$ to the Basingstoke corporation. Then Edward Webb, now D.D., who had now recovered his rectory of Kingsclere, sought also to recover the mastership of the school, or rather its revenues, as he seems to have had no intention of performing its duties. In $\mathrm{I} 667$ he filed a Bill in Chancery against the corporation and the gild. He alleged that in the late plague ( 1665 ) they had 'made the school a pesthouse, and, under pretence of repairing the chapel, cut down the trees and converted them to their own use.' After the usual dilatory proceedings the cause was heard on 27 October, 1669, and by the Lord Keeper referred to the arbitration of George Morley, Bishop of Winchester. He awarded ${ }^{1}$ on 2 I February, 1669-70, that Webb should give up the school and its revenue to a master to be nominated by the bishop during Webb's life. On 7 March the bishop exercised the patronage he thus conferred on himself by the appointment of Marcus d'Assigny, M.A., a Jersey man, vicar of Penrith in Cumberland. Webb did not quietly acquiesce in so adverse an award, and lodged exceptions against it, but they were not admitted and the award was confirmed 18 May, I670. Thereon Webb filed a new Bill, but without effect. He never recovered possession. The corporation celebrated his defeat in a Latin inscription on the Holy Ghost School walls, ${ }^{2}$ in honour of Bishop Morley as meriting everlasting praise by his restoration of the school. On 29 July, I673, the Reverend John James was elected 'preceptor' by the mayor and burgesses and signed the three articles contained in the sixth canon on receiving his licence to teach on 22 September, $1673 .^{3}$ John Clarke, licensed by Bishop Morley I 5 April and appointed by the corporation on 22 August, 1673, came as usher at the same time. James held the mastership for a long time until 1717 , combining with it, from 1697, the vicarage of Basingstoke. In his time the Sandys chapel and tower were finally allowed to go to ruin. The steward of Sir John Mills, nephew and heir of the last Lord Sandys of the Vine reported, March, 1692, that he had been informed that 'the repair of the chapel and covering the tower or staircase' would cost $f_{2} 20$. The steward ' thought it might be done for fir2.' Sir J. Mills wished it done but ' intended to make the town bear a part in the charge because of burying in the chapel yard.'

Disputes, meanwhile, had arisen with the Skinners' Company as to Lancaster's gift. The Skinners could no longer obtain the old rents from the Lincolnshire estates under the will or from the London property bought to satisfy the codicil. On 28 January, $1684-5$, they wrote ${ }^{8}$ to

1 Basingstoke, pp. 147,675. There is an irreconcilable difference as to the dates given in the book, through a mistake as to the regnal year apparently.

2 Ibid. p. 147.

3 Ibid. p. 655. Mr. Baigent seems to be mistaken in thinking that John Rogers, whom he interpolates here, was master. He seems to have been usher only.

Ibid. pp. $114,678$.

'Skinners' Court Minute Book under date. 


\section{SCHOOLS}

know if Basingstoke and Kingsclere would consent to a decree in Chancery, transferring the trust to them, and, 'if not, a Bill to be exhibited.' On I 6 February, Basingstoke offered to accept the trust, but without abatement of the payment. The case went into Chancery, and by a decree of 26 June, 1685 , it was held that the gifts to Basingstoke took priority of the rest, but they only were to abate in proportion to the abatement of the rental. The matter then slept awhile. In Queen Anne's reign the Attorney-General, at the relation of the Basingstoke Corporation, filed a Bill in Chancery. On the Skinners' insisting that the rents would not meet the charges, Lord Chancellor Cowper ordered, 5 October, I7ro, that the charges should abate proportionately. The corporation asked for a rehearing, and offered, if the estates were transferred to them, to pay all charities in full. By decree of 18 July, 1713 , Lord Chancellor Harcourt ordered this to be done, disallowing however the sum of $f_{0} 35$ a year to the Skinners' Company given them by Lancaster for their trouble in managing the trust, as they were now relieved of the trouble, and allowing the corporation to take to themselves any profit there might be, after meeting the charitable charges. The estates were transferred accordingly and remained in the hands of the Corporation of Basingstoke until the Municipal Corporations Act, I835. They must have made a very considerable profit on the transaction when in later years rents began to rise by leaps and bounds. It was not an advantageous one to the school, which lost all chance of participation in any increase, while it did not even gain in the certainty of its income, as the Corporation developed an unpleasant habit of making agreements with incoming ushers to abate something from the full payments.

The headmaster of this period, John James, was one of the violent kind who spared not the rod. He seems at last to have been indicted' for it, as an affidavit is preserved by the mother of one of the boys named Alexander Kew, who died from the effects. She alleged that a relation named Robert Kew had run away as far as Salisbury in consequence of his ' unreasonable correcting and whipping of them,' and died of consumption from the hardships he experienced. Alexander Kew received a bruise on the liver which killed him, "by Mr. James causing two or three boys to draw him up the end of the table to be whipped.' ' Four or five' boys had fallen into a consumption and died, and divers others were taken away and sent to school to others ' to be educated in grammar learning.'

For the next few years the history of the school was one of constant struggle for existence under men who combined the inconsistent professions of parish priest and schoolmaster. The first of these was Alexander Lytton, an M.D. who is said to have practised physic. ${ }^{3}$ In 1724 he obtained the rectory of Eastrop, which is practically a part of Basingstoke, in addition to his other professions of schoolmaster and physician. In 1732 he became vicar of the neighbouring church of Sherborne St.

1 Skinners' Court Minute Book, p. 678.

${ }^{2}$ Ibid. p. $15 \mathrm{I}$. The dates are very much mixed. 


\section{A HISTORY OF HAMPSHIRE}

John and retired from the schoolmastership. Whether it was filled up or not does not seem certain; but Mr. James Ordd, schoolmaster, is recorded in the parish register as being buried on 20 April, 1737, and it would seem that he was de facto if not de jure schoolmaster. On Lytton's retirement disputes arose as to the right of patronage. In 1732 the mayor and corporation presented a petition to the Crown for the re-establishment of the Fraternity of the Holy Ghost, which had again died (if it had ever really been revived) with the death of the last alderman, Richard Woodroffe, some years before, and for a grant of the lands. On 27 July, 1733, the law officers of the Crown reported that the lands could only be leased in accordance with the Civil List Act of the first year of Queen Anne. On I August the corporation raised the question whether the lands were not the property of Lord Sandys and so had never come to the Crown under the Chantries Act. A counter-petition was presented to the Crown by John Wallop, Lord Lymington, Lord Harry Poulet, Sir John Cope, Anthony Chute and others accusing the corporation of misappropriating the revenues, especially Lancaster's gift to the usher, they having only paid John Hyde, the then usher, appointed in 1724, about a third of the salary to which he was entitled. Apparently however he was accused of neglect of duty or insufficiency, as on 23 May, 1735, he was called upon to resign. He did not however do so until 5 October, $173^{8}$, when he had become rector of Tunworth. He was succeeded by Nathaniel Ball of St. John's College, Cambridge. But he too seems to have been neglectful, and on 5 October, 1740, was removed by the corporation 'for absenting himself in parts remote from the towll and school, imposing one Mr. Wimbolt in his stead.' A week afterwards the Reverend Samuel Loggan was appointed to succeed him as usher. $\mathrm{He}$, on 18 July, $1743,{ }^{1}$ obtained a patent from the Crown appointing him to "the place or office of presbyter, minister or chaplain, as well for the celebration of divine service as for the instruction and institution of young men and boys, in the chapel of the Holy Ghost,' and thereon resigned the ushership. Next year he petitioned the Crown for a receiver of the rents, which he said amounted to only $£_{2} 26$ a year, while a surveyor had estimated that the repairs of the buildings would cost $£ 3578$ s. $6 d$., or nearly fourteen years' rental. He objected that the corporation had detained 2 acres of land worth $£_{3} 3$ a year and Wigg's gift, while 5 acres were withheld by Edward Dennier, and more property of the school might be discovered, but he could not afford actions at law, so asked the Crown to conduct them for him. He had previously asked the corporation to do the repairs. Not getting any satisfaction he 'frequently absented himself from the town'; when there, only ' attending school for one or two hours a day.' He was, in fact, curate, becoming in 1746 rector of Stratfield Turgis. The corporation on 7 October, 1745 , ordered proceedings to be taken, and in 1746 petitioned the Lord Chancellor to make Loggan do his duty or resign office. As 


\section{SCHOOLS}

in 1748 he resigned the rectory of Stratfield Turgis, he perhaps then resumed his duties to the school. From this time forward until the existing scheme of 1886 the appointment of the master was made by the Lord Chancellor on behalf of the Crown, and the appointment of usher by the corporation in virtue of Lancaster's gift. As we hear little of the school beyond the names of the masters from this time, it may be hoped that it flourished better than during the incessant disputes which make up its previous history.

In 1825 Lord Brougham's Commission of Inquiry concerning charities reported ${ }^{1}$ on the school, which was not then in a very robust condition. The Reverend William Workman, M.A., of St. John's College, Cambridge, was master. $\mathrm{He}$ had been appointed by Lord Eldon 28 November, 1816 , to the 'office of master or teacher of His Majesty's Free School, and of chaplain to the chapel of the Holy Ghost near Basingstoke, then void by the death of the late teacher and chaplain,' viz. Isaac Williamson, who, appointed in 1793 , had combined with the school the rectory of Eastrop from 1805. At the time of the report there were only six boys in the school, none of whom were really free, the free instruction being limited to the classics (literis) prescribed in Philip and Mary's charter; boys in the town being given instruction in English and arithmetic at the rate of $15 s$. a quarter or $f_{0} 2$ a year, and those beyond the town at $\oint_{0} 44$ s. a year, and a small sum for firing. The previous master had charged 15 s. a quarter for all boys. The income from endowment at this time was about $f_{0} \mathrm{rgo}$ a year, out of which repairs and other expenses had to be deducted, while $\oint_{3} 30$ was paid to the usher, then William Dennis, who also received $f_{3} 30$ from Lancaster's gift. The remuneration of the headmaster was therefore not magnificent, though, for an 'average number of about twelve' boys during his term of office, up to 1825 , not perhaps inadequate. In 1835 the Municipal Corporations Act necessitated the substitution of municipal charity trustees, appointed by the Isord Chancellor for the corporation, as the trustees of Lancaster's gift.

On the death of Workman, 17 November, 1849 , the school was closed and was again in Chancery, the Bishop of Winchester being allowed, by an order of the Court of 5 February, $185^{\circ}$, to visit in respect of discipline. A scheme dated 31 May, 1850 , was made, but was found unsatisfactory and a new one was put out in June, 1852 . This created a separate body of eight trustees of the school, the vicar and mayor being ex-officio; three appointed by the town council and three by the municipal charity trustees, all of whom were, such was the view taken by the Court of Chancery in those times, bound to be members of the Church of England. The school was to be called 'The Queen's Free School in Basingstoke,' and the boys who 'participate in the education other than Latin and Greek' were to pay the old fees if under fourteen years of age, but above that age $f_{0} \mathrm{I}$ a quarter if sons of inhabitants of the 


\section{A HISTORY OF HAMPSHIRE}

parish and $f_{0} \mathrm{I}$ Ios. if not. The appointment of master and usher was left to the Crown and the town council respectively, with provisions enabling the Chancellor to remove the master on resolution of the trustees, and the trustees te dispense with the usher appointed by the corporation. One chief object of the scheme was the provision of new school buildings, including a playground and a house for the headmaster, in which he could take boarders. In i 855 the new buildings were opened in Salisbury Road, about half a mile from the town, on a site of 4 acres purchased by public subscription, increased by the purchase of an additional acre in 1871 . In 1856 the land by the old school, the 'Litten' and the 'Maiden Acre' were sold to the Burial Board for $\oint_{5} 500$, and the double use of the land as burial-ground and playground (by no means so uncommon as might be supposed) finally ceased after some three hundred years.

The first master under this new scheme was William Barlow Lightfoot of Trinity College, Cambridge, the numbers of the school fluctuating from ten to forty. The Schools Inquiry Commission in $1866^{1}$ found twenty-six boys in the school, thirteen day boys and thirteen boarders. For some years the headmaster received no income from endowment, the whole going to pay off the debt on the school premises. In 1866 he received $f_{0} 40$ from endowment, $£_{3} 35$ from capitation fees and the profits on his modicum of boarders, who paid from $f_{5} 5$ to $f_{0} 60$ a year. In five years five boys had been sent to the university. In $1870 \mathrm{Mr}$. Lightfoot retired to a vicarage in Lancashire. After a two years' interval under Arthur Charles Wilson, B.D., student of Christ Church, Oxford, Mr. Arthur Forster Rutty of Pembroke College, Cambridge, was appointed 20 July, i 873 . In 1874 and 1877 new schoolrooms were added; the number of the scholars had quickly increased until in 1878 there were fifty boys, of whom twenty-nine were boarders. After ten years Mr. Rutty left Basingstoke for St. John's School, Leatherhead, carrying off all or nearly all the boarders. The present headmaster, the Reverend James Herbert Chadwick, M.A., Exhibitioner of Hertford College, Oxford, was appointed I I August, 1883. Amendments being needed, particularly in reference to the tuition fees, a new scheme was prepared by the Charity Commissioners under the Endowed Schools Acts, I 869-75. In I 884 there were fifty-three boys in the school, of whom only six were boarders, so that for the first time, probably, for 150 years the school was again efficiently doing its proper work as a secondary school for Basingstoke and the neighbourhood. The new scheme became law on its approval by the queen in council, 6 May, I886. It created a new governing body-the sixth or seventh the school has had-consisting of eleven members, four appointed by the town council of Basingstoke, four by the municipal charity trustees, and three co-opted by the rest. It fused into one fund all the endowments of the school, abolished the patronage of the Crown and the municipal

1 Schools Inquiry Com. Rep. (1868), xi. 318 . 


\section{SCHOOLS}

charity trustees and the separate office of usher, placed all boys on an equality in respect of fees, at the rate of $\oint_{5}$ to $\oint_{0}$ ro a year at the governors' discretion, and made the headmaster dismissible at pleasure and the other masters dismissible by him. In 1890 there were seventy boys in the school paying $£ 8$ a year, of whom one-tenth were boarders. The teaching of science had been introduced, but it was not until 1898 that a physical laboratory was erected with the assistance of grants of $\oint_{3} 00$ from the county council of Hampshire, and $\oint_{0} 105$ from the town council of Basingstoke. In 1900 the boys numbered eighty-seven. The school still contributes scholars to the universities; and as a 'modern' school, laying stress on physical science and modern languages as well as classics, is more flourishing than it has ever been.

\section{MASTERS OF BASINGSTOKE SCHOOL}

Nicholas Sheffield, Nov. 1567 , to Michaelmas, $157^{1}$

John Browne, 1571-2

Heley (? Henry Reley), Michaelmas, $1572-3$

Mr. Eleybye, 1573 to Lady Day, 1574

- Deane, Michaelmas, 1575, to Midsummer, 1577

George Bennet, 1578

Nicholas Dannell alias Donnell, 1578 to Michaelmas, 1583

Dukidale alias Dugdale, $1583-5$

Fawkner, Michaelmas, 1585, to Lady Day, 1588

— Williams, 1588

- Fawkner, 1588 , to January, 1590

James Pearse, I 590-4

Fawkner, 1594-5

Charles Butler, 1595-1600

Knowles, Michaelmas, 1600, to Christmas, 1602

Edwin Cunliffe, 1602 to November, I 605
Florentine Eyles, 1605

- Merritt, Lady Day, 1606, to Lady Day, I 608

John Mason, Lady Day, I608, to 18 September, 1639

Edward Webbe, 1639-43

- Mountague, I650

Robert Pocock, I650-7

Marcus d'Assigny, M.A., I670

John James, 29 July, I673-1717

Alexander Lytton, M.D., I $717-32$

James Ordd, 1737

Samuel Loggan, 18 July, I 743

Isaac Williamson, 1793-1816

William Workman, M.A., 28 November, 1816 , to 17 November, 1849

William Barlow Lightfoot, $1855-70$

Arthur Charles Wilson, B.D., I $870-3$

Arthur Forster Rutty, M.A., 20 July, I 87383

James Herbert Chadwick, M.A., I I August, 1883

\section{HARTLEY UNIVERSITY COLLEGE, SOUTHAMPTON}

The education of the county higher than secondary is represented by the Hartley University College at Southampton. This institution owes its foundation to Henry Robinson Hartley, who had inherited in I 800 a fortune made in the Southampton wine trade by his father Henry Hartley, an emigrant from Yorkshire. Soon after he had come into his inheritance the younger Hartley departed from Southampton, leaving his house in the High Street shut up and deserted. When he died at Calais in $185^{\circ}$ it was found that his will, dated I 3 August, I 843 , had given his whole residuary personal estate, amounting to $f_{1} 02,000$, to the corporation of Southampton to be used 'for the study and advancement of the sciences of natural history, astronomy, antiquities and classical and Oriental learning in the town.' The will was disputed, but after a 


\section{A HISTORY OF HAMPSHIRE}

suit in Chancery, the taxed costs of which amounted to no less than $\oint_{03}, 000$, the corporation found itself in 1859 in possession of $£_{42}, 425$ and a scheme of the Court for the establishment of a Hartley Institution. On 15 October, 1862 , the institution, erected on the site of the founder's house, augmented by Queen's College, Oxford, was opened. It included a museum, library, chemical and physical laboratories, lecture theatre and so forth. For some time it was a kind of glorified Mechanics' Institute, chiefly useful for its evening classes, its day classes being little more than a secondary day school, a substitute for a modern side at the Grammar School, specially attractive to youths who wished at an early age to escape the restraints of school. Its most successful students were sent as from a school with scholarships to the Universities of Oxford and Cambridge, while others took London degrees. Under the present principal, S. W. Richardson, D.Sc., London, the institution has been transformed. By a certificate of the Board of Education, under the Charitable Trustees Incorporation Act of 1872 , made on 20 November, 1902, the trustees were incorporated as 'Hartley University College at Southampton (founded I 850, registered I 902).' By a scheme of the Board of Education made under the Charitable Trusts Acts, 1853 to 1894 , on 23 September, I902, the objects of the college are declared to be 'the provision of a liberal education, and such instruction as may enable residents in the county borough of Southampton, and in the administrative counties of Southampton, the Isle of Wight, Dorset and Wilts, and the county boroughs of Portsmouth and Bournemouth, and others to qualify for degrees at any universities in the United Kingdom; the giving of such legal, medical, technical or other instruction as may be of service in professional, commercial or industrial life; the spread of higher education . . . and generally the promotion and increase of knowledge.' This wide programme is to be carried out under a president, the first president being Arthur Charles, Duke of Wellington, and a court of governors and a council widely representative of all the local authorities and educational institutions in Wessex, the old universities and the professional associations, such as the General Medical Council. But like all higher educational institutions it needs funds, its endowment other than buildings amounting only to $f_{6} 648$ ios. $4 d$. a year.

\section{SECONDARY EDUCATION}

The public provision for secondary education in the county is represented by the following schools, arranged in order of date of foundation :- 
SCHOOLS

\begin{tabular}{|c|c|c|c|c|}
\hline $\begin{array}{l}\text { Date of } \\
\text { Foundation }\end{array}$ & School & Founder & Date of Scheme & $\begin{array}{c}\text { Number } \\
\text { in School } \\
1903\end{array}$ \\
\hline 20 Oct. $13^{82}$ & $\begin{array}{c}\text { Winchester, Saint Mary's } \\
\text { College of Winchester }\end{array}$ & $\begin{array}{l}\text { Bishop William of } \\
\text { Wykeham }\end{array}$ & & 416 \\
\hline I6 Nov. 1524 & $\begin{array}{l}\text { Basingstoke, The Holy } \\
\text { Ghost or Queen Mary's } \\
\text { Grammar School }\end{array}$ & Holy Ghost Gild & $\begin{array}{l}6 \text { May, I } 886, \\
\text { and I } 5 \text { Oct. } \\
\text { I } 894\end{array}$ & 67 \\
\hline Before $154^{8}$ & $\begin{array}{l}\text { Godsbill Grammar School, } \\
\text { now National School }\end{array}$ & & 25 April, 1899 & - \\
\hline 3I July, I550 & $\begin{array}{l}\text { Southampton, King Edward } \\
\text { VI.'s Grammar School }\end{array}$ & Dr.William Capon & $\begin{array}{l}26 \text { Oct. I } 875 \text {, } \\
\text { altered I } 6 \text { Nov. } \\
\text { I } 883 \text {, and } \\
\text { I July, I } 900 \text {, } \\
\text { amended } \\
8 \text { Aug. I } 899\end{array}$ & I 70 \\
\hline I 8 Dec. 1586 & $\begin{array}{l}\text { Ringwood Grammar School, } \\
\text { now National School }\end{array}$ & Richard Lyne & & - \\
\hline 1 Oct. $16 I_{4}$ & Newport Grammar School & $\begin{array}{l}\text { Sir Thomas Flem- } \\
\text { ing and subscrip- } \\
\text { tions }\end{array}$ & & \\
\hline 31 Mar. 1638 & $\begin{array}{l}\text { Alton, Eggar's Grammar } \\
\text { School }\end{array}$ & John Eggar • • & I 7 May, 1879 & 35 \\
\hline 2 I June, 1668 & $\begin{array}{l}\text { Lymington Grammar School, } \\
\text { now National School }\end{array}$ & $\begin{array}{l}\text { William Coke and } \\
\text { subscriptions }\end{array}$ & 8 Feb. 1870 & \\
\hline 1694 & Odiham Grammar School & Robert May . . & $\begin{array}{l}20 \text { Oct. I } 874, \\
\text { amended } \\
29 \text { June, } 1878, \\
\text { and I } 5 \text { Oct. } \\
1894 \text {, altered }\end{array}$ & 20 \\
\hline & & & $\begin{array}{l}\text { I } 6 \text { May, } 1884 \text {, } \\
\text { and } 22 \text { Dec. } \\
\text { I } 899\end{array}$ & \\
\hline I9 Jan. 1696 & $\begin{array}{l}\text { Alresford, Perin's Gram- } \\
\text { mar School }\end{array}$ & Henry Perin . & 7 Oct. 1899 & $\begin{array}{l}\text { Boys, } 24 \\
\text { Girls, } 28\end{array}$ \\
\hline I4 Nov. 1719 & $\begin{array}{l}\text { Holybourne, Free School, now } \\
\text { Elementary School }\end{array}$ & Thomas Andrews & I 6 May, I 893 & 150 \\
\hline 24 Aug. I 72 I & $\begin{array}{l}\text { Fareham, Price's School, } \\
\text { formerly a charity school }\end{array}$ & William Price & I 3 May, I 901 & $\begin{array}{c}\text { Not yet } \\
\text { opened }\end{array}$ \\
\hline 16 Jan. 1722 & $\begin{array}{l}\text { Petersfield, Churcher's } \\
\text { College }\end{array}$ & Richard Churcher & $\begin{array}{l}28 \text { Nov, I } 876, \\
\text { altered } \\
\text { I } 9 \text { May, I } 893 \text {, } \\
30 \text { April, I } 897 \text {, } \\
\text { and } 20 \text { Nov. } \\
\text { 1900, } \\
\text { amended } \\
\text { I5 Oct. I } 894\end{array}$ & 70 \\
\hline 1752 & $\begin{array}{l}\text { Portsmouth Grammar } \\
\text { School }\end{array}$ & Dr.William Smith & $\begin{array}{l}4 \text { Feb. I } 875 \text {, } \\
\text { altered } \\
26 \text { July, I } 892\end{array}$ & 230 \\
\hline $\begin{array}{c}\text { I5 Feb. I } 752 \\
\text { Will. School } \\
\text { established } \\
1760\end{array}$ & $\begin{array}{l}\text { Southampton, Taunton } \\
\text { Trade School }\end{array}$ & Richard Taunton & $\begin{array}{l}26 \text { Oct. I } 875 \text {, } \\
\text { altered } \\
\text { 23 June, I } 882, \\
\text { and I } 7 \text { Oct. } \\
\text { 1 } 893 \text {, } \\
\text { amended } \\
\text { 29 June, I } 882\end{array}$ & 240 \\
\hline
\end{tabular}




\section{A HISTORY OF HAMPSHIRE}

\begin{tabular}{|c|c|c|c|c|}
\hline $\begin{array}{l}\text { Date of } \\
\text { Foundation }\end{array}$ & School & Founder & Date of Scheme & $\begin{array}{l}\text { No. in } \\
\text { School, } \\
\text { Igo3 }\end{array}$ \\
\hline I 884 & $\begin{array}{l}\text { Winchester, Girls' High } \\
\text { School }\end{array}$ & Subscribers & & \\
\hline 1896 & $\begin{array}{l}\text { Winchester, Peter Sy- } \\
\text { monds' School }\end{array}$ & $\begin{array}{l}\text { Peter Symonds, } \\
\text { Christ's Hospital, } \\
\text { partly almshouse, } \\
\text { partly charity } \\
\text { school, founded } \\
\text { I } 586\end{array}$ & $\begin{array}{l}\text { I3 May, 1 } 896 \text {, } \\
\text { altered } \\
6 \text { April, 1900 }\end{array}$ & $\begin{array}{l}170 \\
70\end{array}$ \\
\hline I 898 & $\begin{array}{l}\text { Bournemouth High School } \\
\text { for Girls }\end{array}$ & Miss Mary Broad & & 230 \\
\hline 1901 & Bournemouth New School & $\begin{array}{l}\text { Hants County } \\
\text { Council and } \\
\text { Bournemouth } \\
\text { Town Council }\end{array}$ & & 133 \\
\hline I goI & Gosport & & & 84 \\
\hline
\end{tabular}

The history of the only schools entitled to be called 'ancient,' as existing before Edward VI., has already been given.

At Southampton it is suggestive of there having been an ancient grammar school in connection with St. Mary's Church, that the existing grammar school owes its foundation to the last precentor, William Capon, D.D., who had held the office at least from the date of the Valor Ecclesiasticus in 1535 . By will of $3 \mathrm{I}$ July, I $55^{\circ}$, he gave $f_{1} \mathrm{I} 00^{\circ}$ to the town of Southampton to the erection, finding, and maintenance of a Grammar School there.' The mayor and recorder and four 'antients' or ex-mayors, were to have 'the order and oversight thereof.' They were to lend the money to five persons at 10 per cent interest on bonds to be renewed every year, the corporation, the mayor, bailiffs and burgesses also entering into a bond with Capon's executors ' justly and truly to employ the said sum of $\oint_{\mathrm{r}} \mathrm{o}$ yearly for and towards the finding and maintenance of the said Grammar School for ever and to no other use.' If they made default there was a gift over to the corporation of Salisbury for the money to be distributed among the poor of Salisbury for the health of Capon's soul. The will was proved on i I October, I $55^{\circ}$, by John Capon, Bishop of Salisbury, his brother, Christopher Robinson and William Areton, the executors.

The corporation then procured a charter from the Crown providing for the erection of the school with a licence in mortmain to hold lands to the extent of $f_{4} 40$ a year. The charter, dated 4 June, I 553 , granted that there should be a grammar school in the town and county of Southampton which should be called the Free Grammar School of the mayor, bailiffs and burgesses of the said town and county for the education and instruction of boys and youths in grammar for ever, and 'to consist of a master and usher.' The mayor and bailiffs for the time being were constituted a special corporation 'to be and to be called the governors of the possessions, revenues, and goods of the said school.' The appoint- 


\section{SCHOOLS}

ment of the master and usher was not vested in this special school corporation but in the general town corporation, the mayor, bailiffs and burgesses, who with the advice of the Bishop of Winchester were given the power of making statutes for the school, choosing the masters and having 'the government and disposition of the rents and revenues appointed and to be appointed for the support of the same.'

The school started in I 554 under the headmastership of Robert Knaplocke ${ }^{1}$ of Gillingham, Dorset, a scholar of Winchester College in I 539, who returned from his fellowship at New College, Oxford, to be hostiarius (usher or second master) of the college in I $55 \mathrm{I}$, and so remained till his appointment at Southampton. The salary of the headmaster at Southampton was $£_{1} \mathrm{O} O$ a year with $£_{3} 6 \mathrm{~s}$. $8 \mathrm{~d}$. for board. The usher at Winchester only got $f_{0} 63^{s .} 8 d$. and board. Knaplocke retired in $156 \mathrm{I}$, and is apparently the Robert Knaplocke who was town clerk of Southampton in 1563 and mayor in $1575 .^{2}$ In 156 i the town council settled the fees payable in the school at $6 d$. a quarter for town boys and $16 d$. for country boys, ' after the order of Winchester.'

The status of the school was apparently well maintained, as another Winchester scholar and fellow of New College, Isaac Bathe, who had been second master of Winchester College from 1582 , became headmaster in 1596 . A greater name of the same kind was that of William Twisse or Twiste, scholar of Winchester in I 590, and of New College in 1597, who was headmaster from i6 i to i6 16. He became rector of Newbury, was a sturdy Puritan and famous as the Prolocutor of the Assembly of Divines at Westminster during the ascendency of Parliament. Thomas Wareham, who was headmaster for no less than thirty years, during the whole of the stormy period of the Civil War, I 624 to I 654, was another Winchester scholar.

Southampton being too much of a Parliamentary stronghold to be even attacked, its school went on throughout untroubled. Another Wykehamist, Thomas Butler, who was rector of Milbrook in I6 6 , and probably usher, succeeded to the headmastership in 1660 . He became vicar of St. Michael's, and in 1675 was removed from the mastership for neglect, preferring no doubt the lighter clerical to the more onerous scholastic duties. It was perhaps owing to his delinquencies that on I I February, I674-5, statutes were made for the school by the town council, with the approval of George Morley, Bishop of Winchester. The fees were now largely increased. There was an entrance fee of 5s. to the master, 2s. $6 d$. to the usher and $6 d$. each to two prapositors, one of them a prefect of school, 'to watch them at church and out of school.' 'Instead of the gratuities which heretofore used to be paid at breaking up,' a quarterly fee of 5 s. was to be paid to those under the

1 In Kirby's Scholors his name is mis-read Knaplode and his birthplace Fillingham. The place is fixed by one William Knaplocke holding land of St. Katharine's Chantry in Gillingham granted to Sherborne School and was named one of its first governors in 1550 ('Sherborne School,' Arcb. Journ. (898).

Davies' Southampton, pp. 31 I, 187, 295 . 


\section{A HISTORY OF HAMPSHIRE}

master and $2 s .6 d$. to those under the usher; but poor boys nominated by the council were admitted free. The scholars of the first two forms were only to speak Latin, unless by special leave. A portentous list is given of the Greek and Latin authors read. Erasmus' Dialogues were still used, and Terence was still popular. But the list includes Florus, Quintus Curtius, Sallust, Martial and Juvenal, besides the usual Ovid and Virgil ; and in Greek, Lucian, Isocrates, Herodotus with Homer, Pindar and the Antbology. The school hours were from 6 a.m. to I I a.m. in summer and from 7 a.m. to I I a.m. in winter; and from I p.m. to 5 p.m. There were to be three vacations-at Christmas, Easter and Whitsuntide, but holiday tasks were to be imposed. At the breaking up at Whitsuntide there was to be an examination by the corporation and clergy of the town, and declamations in Greek and Latin.

The school was originally in Winkle Street, but in I 695 was removed to an ancient hall called the West Hall in English Street, and was at that time a very fine building for a school. Under its latest Wykehamical headmaster, Richard Mant (the father of a more famous man in his day, the Bishop of Down), from 1770 to 1795 , the school had a great name. In 18 I $9^{1}$ it was reported as only containing boarders. Later the premises became out of date for boarders. After the Municipal Reform Act removed the government of the school from the town council to a body of municipal charity trustees, disputes arose as to the endowment. The case went into Chancery, and from I 854 to 1860 the school was closed altogether. After a compromise had been effected, under which the school received $f_{1} 50$ a year from the corporation and a new schoolroom, it re-opened under C. W. Hawkin, B.A., on a different basis. In 1867 it contained eighty-three day boys and sixteen boarders, and practically ceased to send boys to the universities. Its curriculum became what was intended to be popular, but its government remained a close corporation of co-optatives. A scheme of the Charity Commissioners under the Endowed Schools Acts approved by the Queen in council and dated 20 October, I 875 , established a governing body of sixteen members, of whom the mayor is one, six appointed by the town council, two by the school board (which will soon cease to exist under the Education Act, I 902), and seven co-optative. In I 880 the present headmaster, James Fewings, B.A., B.Sc., was appointed. In 1896 the school was moved to new buildings. The school is not however on a scale commensurate with the growing greatness and needs of the town. It is subject to competition from below by the Taunton Trade School, which undersells it by a lower tuition fee, and from above by the Hartley University College. There is need for another Hartley to convert the Grammar School into a school to serve Southampton as Hymer's College serves the rival seaport of Hull.

A somewhat unfortunate career has been that of Portsmouth Grammar School. A priori it might have been supposed that there could be no better governing body of a grammar school than a college in a university. 


\section{SCHOOLS}

But the Schools Inquiry Commissioners found that colleges instead of being nursing mothers to the schools under their charge were hard stepmothers. Portsmouth is a signal instance of this. Dr. William Smith, M.D., by his will dated $173^{2}$ and proved in 1733, gave lands in the parish of Arreton in the Isle of Wight to Christ Church, Oxford, for a grammar school at Portsmouth. The master was to have $\oint_{5} 0$ a year and the usher $f_{3}{ }^{\circ}$. The dean and chapter, that is the college, were "to order and direct the management of the School.' The school house in Penny Street does not seem to have been built till $175^{\circ}$. After about half a century of unprosperous existence the school became the subject of a suit in Chancery which lasted from I 8 I I to I $82 \mathrm{I}$. The Rev. J. G. Russell and the Rev. Dr. Forester and the Rev. R. H. Cumyns had a day school of about sixty to eighty boys paying fees. The decree of Chancery in 1821 ordered the introduction of fifty free boys. This seems to have effectually deprived the school of what little utility it possessed, for though by custom the number was reduced to twenty, the free boys kept away others.

In $1867 \mathrm{Mr}$. Stanton for the Schools Inquiry Commission found sixteen free boys and ten others paying four to six guineas a year. Christ Church had shown their care for the school by having no visitation or examination between I 835, when Dr. Pusey had examined it in classics, and I 867, the year of Mr. Stanton's visit; which provoked him to remark that 'out of sight out of mind' had been the guiding principle of its management. Since a scheme under the Endowed Schools Acts in I 875 it has flourished abundantly, and now numbers 230 boys.

Of the other early grammar schools of Hampshire there seems little to relate. They were local in their character and never attained to any great number or note; though that of Alresford under Richard Steele, from 1796 to 1818 , was a place of considerable resort for the sons of 'persons of quality.'

The school of Newport, the chief town in 'the island,' as the inhabitants of the Isle of Wight fondly call it, was, like Southampton, fostered from Winchester College. The origin of the school, so far as is now known to history, was the gift of a site by Sir Thomas Fleming on I October, 1614. A subscription was set on foot, and the principal islanders, Richard Worsley, John Serle and others, contributed lands and money, the lands being conveyed by deed in 1623 for a free grammar school. Matters however moved slowly, for it appears by an Inquisition of Charitable Uses ${ }^{1}$ dated 4 September, I634, that Robert Newland of Newport, merchant, had been entrusted with the subscriptions amounting to $£_{4} 4672 s .6 d$. in money, seventy tons of oak timber given by Sir Thomas Fleming, and ten tons more by Sir William Lisle, thirty tons of stone, and a quantity of squared freestone, but refused to account for his receipts when called on by Sir Robert Tillington, bart., until a commission of inquiry was sued out

1 P.R.O. Chan. Petty Bag, Charities, Bdle. I 5, No. 5. 


\section{A HISTORY OF HAMPSHIRE}

of Chancery, when Sir W. Meux and the other commissioners ordered him to pay the costs. Apparently the school was only then just built, and the first headmaster was Robert Soper, scholar of Winchester in 1619 and fellow of New College until his appointment in 1632 . The school, a fine room for the age, fifty feet long, became the scene of an important interview between Charles I. and the Parliamentary Commissioners in October, r648. The school apparently pursued the even tenor of its way through the war, and received another Winchester scholar, Thomas Thackham, as its master under the Protectorate in 1656 . It seems to have been up to the present century what would now be called the public school of the island, attended by the sons of the gentry, who shared the government of the school and the appointment of the headmaster with the corporation. In $1818^{1}$ there were fifteen free boys, appointed by the mayor, and fifty others under the Rev. George Richards of Corpus Christi College, Oxford, whose terms for boarders, including tuition fees, were $£_{2} 8$ a year. But 'the pupils that receive a classical education are generally removed to Eton or Winchester about Io or I I years of age.' Fifty years later, under the Rev. A. Wallace, the school had sadly shrunk, being deserted by the gentry and better class of tradesmen. In 1867 it had only twenty free scholars and six others. ${ }^{2}$ No scheme has yet been made for it under the Endowed Schools Acts.

Churcher's College at Petersfield is a remarkable instance of the want of adaptation of means to ends exhibited by school founders, and the signal ill success of specialized schools, at least in places where there is not sufficient population to produce a specialized class large enough to fill it. Churcher's College owed its foundation to the great outburst of interest in the navy, caused by the Dutch wars of Charles II., of which the naval school at Christ's Hospital (1673-4) and the mathematical school at Rochester (1708) were probably the models which suggested the foundation of this college. Richard Churcher had made a fortune as an East Indian merchant, and by his will dated 16 January, 1722 , gave $f_{0} 500$ to build and $f_{0} 3,000$ bank stock to endow 'Churcher's College in Petersfield to consist of a Master and ten or twelve healthful boys to be taken out of and belonging to the borough of Petersfield of any age from 9 to I4,' whose parents were to oblige them 'as much as in them lay' to become apprentices to masters of ships 'making their voyages to the East Indies.' They were to be boarded and clothed and taught free ' in the arts of writing, arithmetic and the mathematics, chiefly such part as relates to navigation.' 'The master was expressly directed to be a layman, with an annual income of $f_{0} 40, f_{0}$ ro a head for each boy's board and 40s. for their clothing : viz. a blue gown with the badge of the East India Company and a blue cap. For about twelve years, from 1732 to 1744 , endeavours were made to carry on Churcher's College according to the founder's intention. In 1744 a bill was promoted in 


\section{SCHOOLS}

Parliament by the borough to convert it into an ordinary school. The preamble of the Act states that ' $\mathrm{few}$ of the inhabitants were inclined or consenting to have their children instructed in mathematics and navigation only,' and if they were, the parents were not able to place them as apprentices on board East India ships, or if they were, "the captains or masters thereof refused to take such apprentices,' besides which the revenues were insufficient for the purposes intended. The Act then extended the benefits of the college to any boys of Petersfield to be instructed in the three R's, 'and such of them as the trustees should think fit in that part of mathematics relating to navigation.' The trustees were empowered to apprentice them to any trade, and to pay $£_{4} 0$ for apprentice fees if to a ship, $£_{3} 30$ to other trades, with $£_{3}$ for clothes. The school was thus reduced to an ordinary blue coat school with elementary instruction. From 1784 to 1797 the master was a clergyman instead of a layman. From 1770 till 1802 the school was practically in the hands of the Jolliffe family, of whom William Jolliffe was acting trustee. His loose and autocratic method of management produced in 1806 an information by the Attorney-General and the transfer of the school funds into Chancery. There they remained for twenty years, while the school was conducted apparently as a kind of higher elementary school, with about I 00 boys, of whom half were boarders, the proper objects of the charity being, it was alleged, neglected. In November, I 822 , the cause was heard and a decree made on 5 February, 1823 , from which the trustees appealed. At last on I I February, I 835, a new scheme was made by the Court limiting the boarders to fourteen, leaving out all reference to navigation in the curriculum, and raising the master's salary to $f_{1} 100$ a year. Practically the school went on as before. The income of the trust then amounted to about $f_{6} 600$ a year entirely in the funds. By $1864^{1}$ the income had increased to $\oint_{0} 88$ a year. Yet there were in the school only thirty boys, five paying boarders at fees of $£ 20$ to $£ 27$ a year, and eleven day boys, of whom six were under ten years old. The education was rather below than above that of the elementary school of those days, though some pretence was made to teach Euclid. The only arrangement for washing was 'a small shed $4 \frac{I}{2}$ feet wide and 9 long, which contains a pump and is approached from the schoolroom by a passage open to the air on the side of the playground.' 'No trust,' said the Assistant Commissioner who reported on it in 1867 , 'could have more completely failed to carry out the plain and simple intention of the founder.' Yet it took the Endowed Schools and Charity Commissioners, set in motion chiefly by Mr. John BonhamCarter, then M.P. for Petersfield and Chairman of Committees in the House of Commons, to carry the existing scheme under the Endowed Schools Acts of 28 November, 1876. Under this scheme the school is flourishing.

Taunton's School at Southampton, founded about a generation after 


\section{A HISTORY OF HAMPSHIRE}

Churcher's College, under the will of Alderman Taunton in 1792, also aimed, but not exclusively, at 'fitting children for the sea.' By a scheme made in 1760 , when the funds were released from a Chancery suit, the boys, not exceeding twenty, were to be taught 'navigation' and ' at proper ages to be put out apprentices to masters of merchant ships or to commissioned or warrant officers in His Majesty's navy.' But in $1825^{1}$ the school was an ordinary 'charity school,' the master only engaging to teach the boys navigation, if required. As now reorganized by a scheme under the Endowed Schools Acts it is a lower grade secondary school of the ordinary type, at cheap fees.

The worst fate happened to Ringwood, Lymington and Godshill, which fell from their estate as grammar schools in the early part of the nineteenth century, and were appropriated to elementary education to save the rates or subscriptions of the landlord, the parson and the farmer.

The second quarter of the nineteenth century marked the lowest ebb in the history of education. The grammar schools seemed stricken with paralysis. Their methods and their matter were mistrusted outside, while within the authorities were mainly actuated by a desire to keep things as they were, and to keep out what they considered undesirable persons whether as governors or scholars. But this state of things has changed under the schemes of the Endowed Schools and Charity Commission, and the Board of Education. Secondary education of a kind as good as that in the public schools is now open to all, and the schools are filling up.

\section{ELEMENTARY EDUCATION}

The wonderful development which has meanwhile taken place in the sphere of elementary education is summarized in the following table, in which the public elementary schools of the county are given under the names of places arranged alphabetically. 
SCHOOLS

\section{HAMPSHIRE PUBLIC ELEMENTARY SCHOOLS}

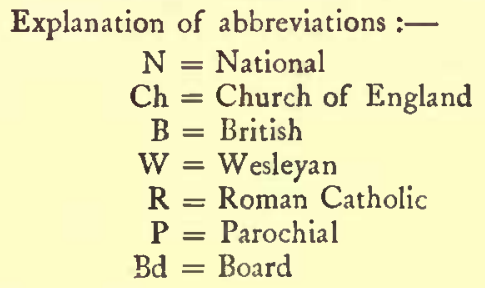

An asterisk (") denotes that a Building Grant was made by the Treasury or by the Committee of Council on Education

\begin{tabular}{|c|c|c|c|}
\hline $\begin{array}{c}\text { Date of } \\
\text { Foundation Deed } \\
\text { of of first } \\
\text { establishment } \\
\text { of School }\end{array}$ & $\begin{array}{c}\text { Date of } \\
\text { Building } \\
\text { or } \\
\text { Opening } \\
\text { of } \\
\text { School }\end{array}$ & $\begin{array}{c}\text { School District } \\
\text { and } \\
\text { Name and Denomination } \\
\text { of School }\end{array}$ & $\begin{array}{l}\text { No. of } \\
\text { Scholars } \\
\text { for whom } \\
\text { accom- } \\
\text { modation } \\
\text { is } \\
\text { provided }\end{array}$ \\
\hline \multirow{10}{*}{1716} & \multirow[b]{2}{*}{1831} & $\begin{array}{l}\text { AdMinistrative } \\
\text { County of } \\
\text { Southampton }\end{array}$ & \multirow[b]{2}{*}{158} \\
\hline & & $\begin{array}{l}\text { Abbot's Ann }{ }^{1} \cdot P \\
\text { Aldershot :- }\end{array}$ & \\
\hline & 1859 & Aldershot $^{2} \cdot \mathrm{N}$ & $190^{*}$ \\
\hline & 1872 & St. Joseph's . R & 308 \\
\hline & 1872 & West End ${ }^{3}$. Bd & 1466 \\
\hline & 1874 & East End. Bd & $94^{8}$ \\
\hline & & $\begin{array}{l}\text { North Town. Bd } \\
\text { Aliesford. See New } \\
\text { Alresford, North- } \\
\text { ington and Old } \\
\text { Alresford } \\
\text { Alton :- }\end{array}$ & 107 \\
\hline & 1840 & Alton. . N & $468 *$ \\
\hline & 1867 & Alton ${ }^{5} . \quad$ B & 375 \\
\hline & 1876 & $\begin{array}{l}\text { All Saints . } . \text { Ch } \\
\text { Alverstoke :- }\end{array}$ & I 29 \\
\hline $\begin{array}{c}\text { Deeds } 30 \text { Oct. } \\
\text { I } 832 \\
\text { I I Sept. I } 87 \text { I }\end{array}$ & 1830 & $\begin{array}{l}\text { Forton } \\
\text { S. John }{ }^{B} \cdot . \mathrm{Ch}\end{array}$ & $753^{*}$ \\
\hline & 1831 & $\begin{array}{l}\text { Gosport } \\
\text { Trinity }{ }^{7} \cdot \mathrm{Ch}\end{array}$ & $4^{22}$ \\
\hline & $\begin{array}{l}1842 \\
1844\end{array}$ & $\begin{array}{l}\text { Alverstoke }^{8} \cdot \mathrm{N} \\
\text { Gosport }\end{array}$ & $55^{* *}$ \\
\hline $2 \mathrm{May}, \mathrm{I} 845$ & & S. Matthew's N & $523^{*}$ \\
\hline Deed & - & Elson . $\mathrm{N}$ & $269^{*}$ \\
\hline & 1850 & Gosport Royal & \\
\hline & 1853 & $\begin{array}{c}\text { Marine } \\
\text { New Town }\end{array}$ & $\begin{array}{l}622 \\
766^{*}\end{array}$ \\
\hline & 1871 & Gosport S.Mary's R & 136 \\
\hline & 1894 & Leesland .. $\mathrm{N}$ & 774 \\
\hline & 1898 & Children's Home & 105 \\
\hline
\end{tabular}

1 Endowed with $£_{3}$ a year by Thomas Criswick in 1716.

2 Enlarged 1897.

a Enlarged 1883

Enlarged 1888 and 1894 .

6 Boy:' School built 1867 ; Girls' and Infants' School, 1877.

- Enlarged in 1870,1882 and 1887 .

7 Girls' School built 1831 ; Infants' School, I 863 ; Boys' School, 1884 ; enlarged 1897.

8 Enlarged 1897 .

- Enlarged 1879.

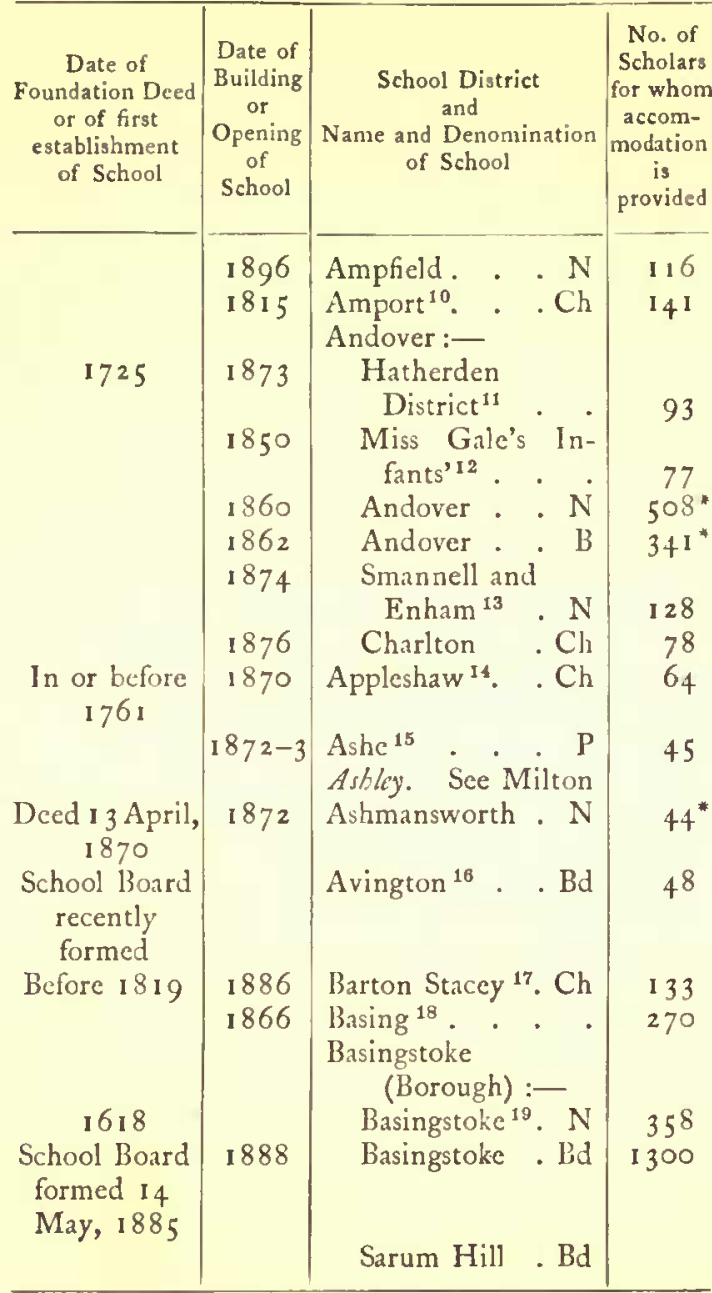

10 Enlarged 1892 and 1898 . Endowed by Miss Sheppard in 1817.

11 Endowed by James Sambourn in 1725, and enlarged in 1873 .

12 Part of the foundation of Miss Gale's School of Industry.

13 Partly supported by the Dewar endowment.

14 Endowed with $\& 5$ yearly, the bequest of Miss Frances Offley in 1761 .

15 Enlarged in 1879 and 1888.

16 Formerly the National School.

17 The Free School of Elizabeth and Dorothy Wright was amalgamated with the National School, built in 1819 , burnt down in 1886 , and rebuilt.

18 Enlarged 1871 and 1885 . Endowment of $f_{0}^{20}$ yearly was left in 1863 by Miss Sheppard.

19 Boys' School founded by James Lancaster and others in 1618, and Girls' School founded by Rev. Dr. Sheppard 1816 . 


\section{A HISTORY OF HAMPSHIRE}

\begin{tabular}{|c|c|c|c|}
\hline $\begin{array}{l}\text { Date of } \\
\text { Fouadation Deed } \\
\text { or of first } \\
\text { eatablishmeat } \\
\text { of School }\end{array}$ & $\begin{array}{c}\text { Date of } \\
\text { Building } \\
\text { or } \\
\text { Opeoing } \\
\text { of } \\
\text { School }\end{array}$ & $\begin{array}{c}\text { School District } \\
\text { and } \\
\begin{array}{l}\text { Name and Denomination } \\
\text { of School }\end{array}\end{array}$ & $\begin{array}{l}\text { No. of } \\
\text { Scholars } \\
\text { for whom } \\
\text { accom- } \\
\text { modation } \\
\text { is } \\
\text { provided }\end{array}$ \\
\hline $\begin{array}{c}\text { Deed } 23 \text { June, } \\
1843\end{array}$ & $\begin{array}{c}1843 \\
1841 \\
1870 \\
1873 \\
\text { (about) }\end{array}$ & $\begin{array}{l}\text { Baughurst }^{1} \cdot \mathrm{N} \\
\text { Beaulieu :- }^{2} \\
\text { Beaulieu } \\
\text { Park } \cdot \mathrm{N} \\
\text { Beauworth }: \text { Ch } \\
\text { Bedhampton :- }\end{array}$ & $\begin{array}{r}356 \\
86 \\
52\end{array}$ \\
\hline $\begin{array}{l}\text { School Board } \\
\text { formed } 15 \\
\text { Aug. I } 871\end{array}$ & I 868 & Bedhampton ${ }^{3} \mathrm{Bd}$ & 225 \\
\hline $\begin{array}{c}\text { Deed } 6 \text { Feb. } \\
1843\end{array}$ & $\begin{array}{l}18+2 \\
184^{8} \\
1840\end{array}$ & $\begin{array}{l}\text { Bentley . . N } \\
\text { Bentworth } 4 . \mathrm{N} \\
\text { Bighton . . . N } \\
\text { Binsted :- }\end{array}$ & $\begin{array}{r}113 \\
82\end{array}$ \\
\hline $\begin{array}{c}\text { School Board } \\
\text { formed } 3 \text { June, } \\
1878\end{array}$ & 1873 & $\begin{array}{l}\text { Binsted } \cdot \mathrm{N} \\
\text { Rowledge } \\
\text { Bishopstoke and } \mathrm{N} \\
\text { Stoke Park, U.D. }\end{array}$ & $\begin{array}{l}222^{*} \\
193^{*}\end{array}$ \\
\hline $\begin{array}{c}\text { Deed } 18+3 \\
\text { Deed } 4 \text { Sept. } \\
1858\end{array}$ & 1895 & $\begin{array}{r}\text { Bishopstoke }^{5} \cdot \mathrm{Bd} \\
\text { Bishop's Sutton } . \mathrm{N} \\
\text { Bishop's Waltham :- }\end{array}$ & $\begin{array}{l}477^{*} \\
121^{*}\end{array}$ \\
\hline $\begin{array}{l}\text { School Board } \\
\text { formed } 27 \\
\text { Sept. } 1878\end{array}$ & 1865 & $\begin{array}{l}\text { Bishop's } \\
\text { Waltham }{ }^{6} . \mathrm{Bd}\end{array}$ & $27^{8}$ \\
\hline & 1896 & $\begin{array}{l}\text { Bishop's Waltham } \\
\text { Infants' } \text { Bd } \\
\text { Blackmoor. See Sel- } \\
\text { borne }\end{array}$ & $15^{\circ}$ \\
\hline $\begin{array}{c}\text { Deed } 15 \mathrm{Dec} . \\
184^{\circ}\end{array}$ & $\begin{array}{c}1850 \\
\text { (about) } \\
1873 \\
\\
1840 \\
1865 \\
1869 \\
1876\end{array}$ & $\begin{array}{l}\text { Blendworth }^{7} \cdot \mathrm{N} \\
\text { Boarhunt :- } \\
\text { North Boarhunt B } \\
\text { Boldre :- } \\
\text { East Boldre }{ }^{8} \mathrm{~N} \\
\text { South } \\
\text { Baddesley }{ }^{9} \mathrm{Ch} \\
\text { Boldre Lane . Ch } \\
\text { Boldre . . Ch } \\
\text { Boscombe. See } \\
\text { Bournemouth } \\
\text { (Borough) }\end{array}$ & $\begin{array}{r}54 \\
130^{*} \\
189 \\
51 \\
175\end{array}$ \\
\hline
\end{tabular}

1 Regulated by Charity Commissioners of I Noy, 1872.

2 Girls' and Infants' Schools, 1841; Boys' School about $185^{8}$.

3 School enlarged on transfer to School Board, I 873 . Endowment for education of girls founded by Henry Snuok. Deed $1+$ September, 1875 .

- Enlarged in 1897.

6 Old School transferred to School Board about 1881.

6 Enlarged 1894-5. The former National Schools were built in 1832. A British School was founded by deed 1865 .

7 There is an eodowment of $f 46$ Ios. yearly.

- Gilpin" School at Boldre was founded by the Rev. William Gilpin, 1804 .

Since enlarged.

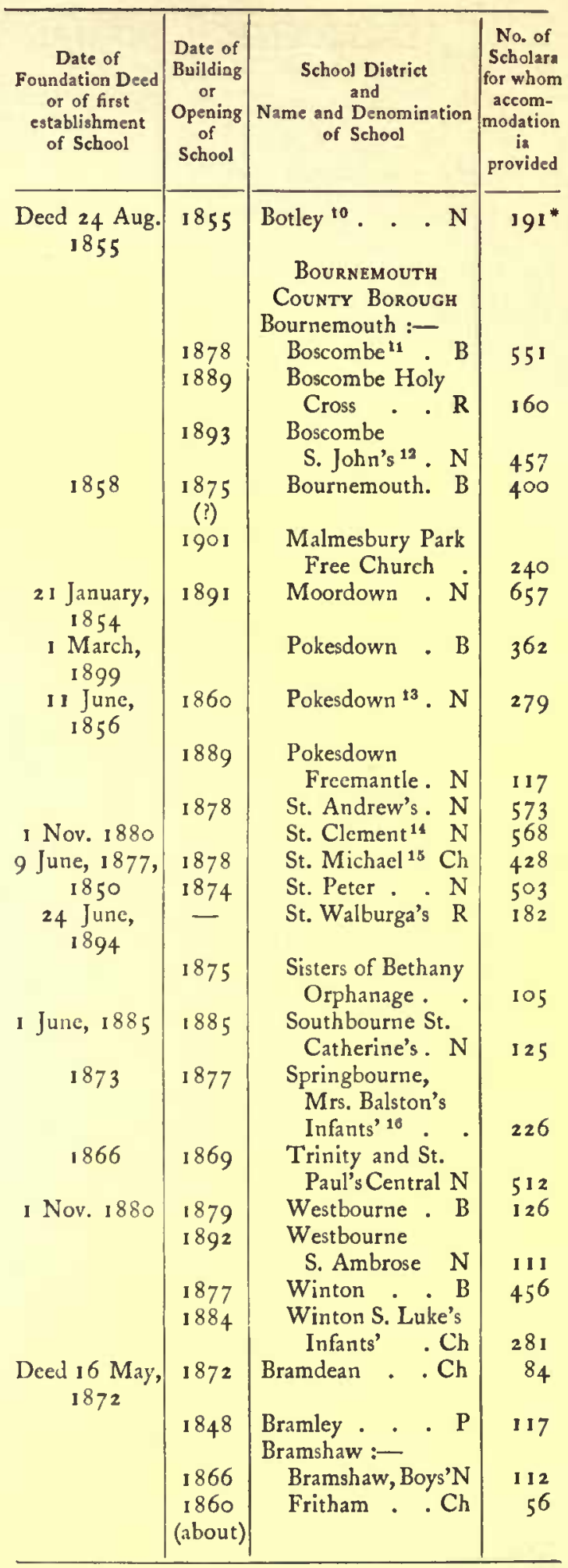

10 Since enlarged.

11 School opened 6 January, 1879.

12 Enlarged in 1896.

13 Building formerly used as a church. Infants' Sehool built 1887 ; enlarged 1894

14 Endowed with land let on building leases.

15. Enlarged I 889 .

to Enlarged 1898 . 


\section{SCHOOLS}

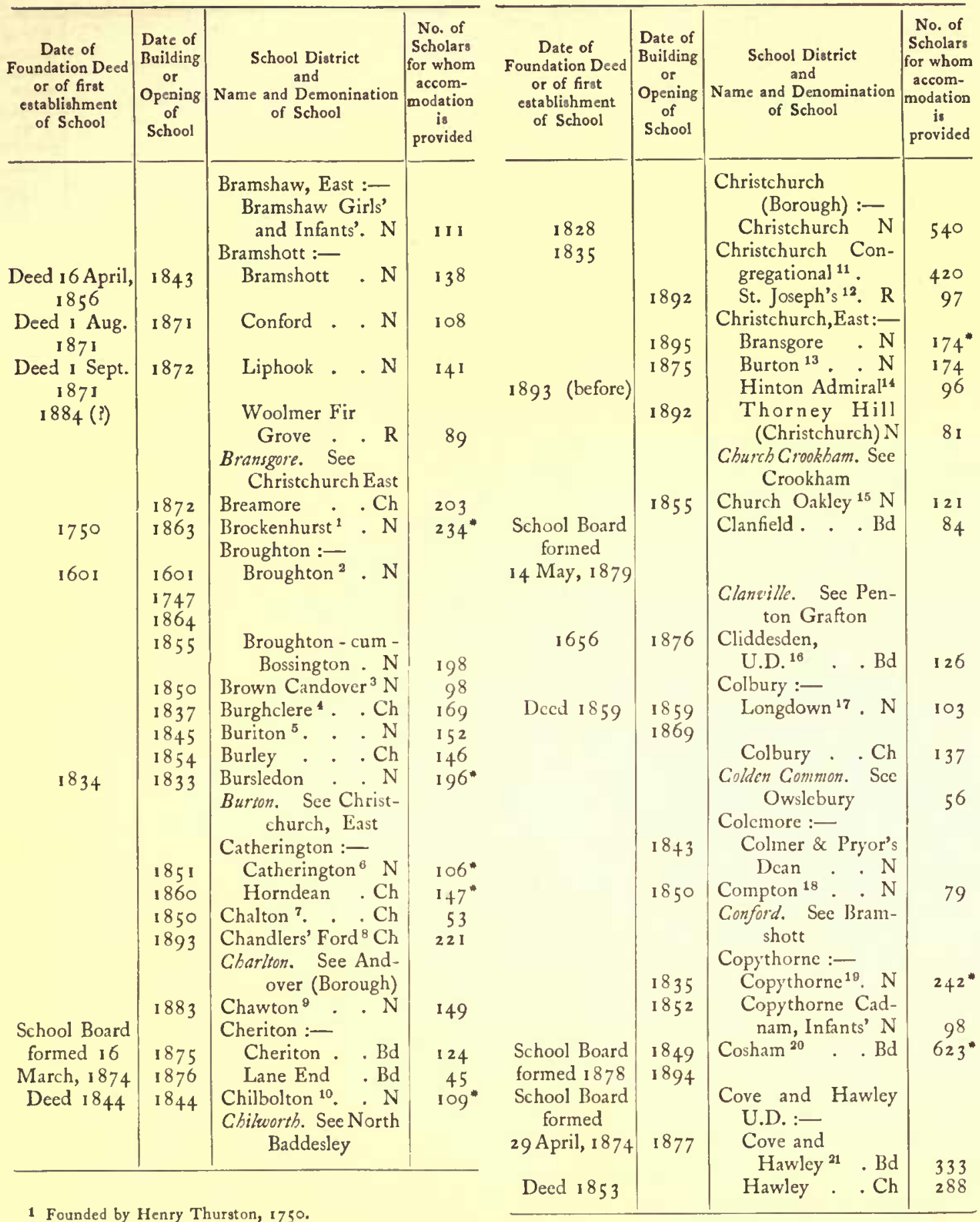

1 Founded by Henry Thurston, 1750 . accounts, under the will of Thomas Dowse. Enlarged 1747 under the will of George Croft, and restored 1864. It receives $E_{40}$ yearly under the bequest of $T$. Baring.

a Enlarged 1854. School provided by Lord Ashburton.

- Enlarged 1877 and 1894 . Partly supported by an endowment.

6 Enlarged 1887 .

- There is an endowment under the will of Mrs. M. L. Henville proved 1866 , and a further endowment for the Girla' School under the will of Miss Anne Harvey, proved 1874 .

7 Opened 1851 .

8 Enlarged 1895 .

9 The date is that of the rebuilding of the school.

10 Enlarged $1872,1878,1894$.

\section{Enlarged 1880.}

12 Apparently otherwise known as the Purewell School.

13 Opened 1876 . The building was previously used as a chapel.

14 School enlarged in 1893 .

16 Enlarged 1872.

16 Founded by Ann Doddington. School Board, formed 1873 , transferred to, in 1876 .

17 Scheme of Charity Commissioners, 24 January, 1873 .

18 Enlarged 187 .

19 Enlarged 1894.

20 Enlarged on transfer to School Board. Infants' School built $\times 894$.

21 Enlarged 1888. 


\section{A HISTORY OF HAMPSHIRE}

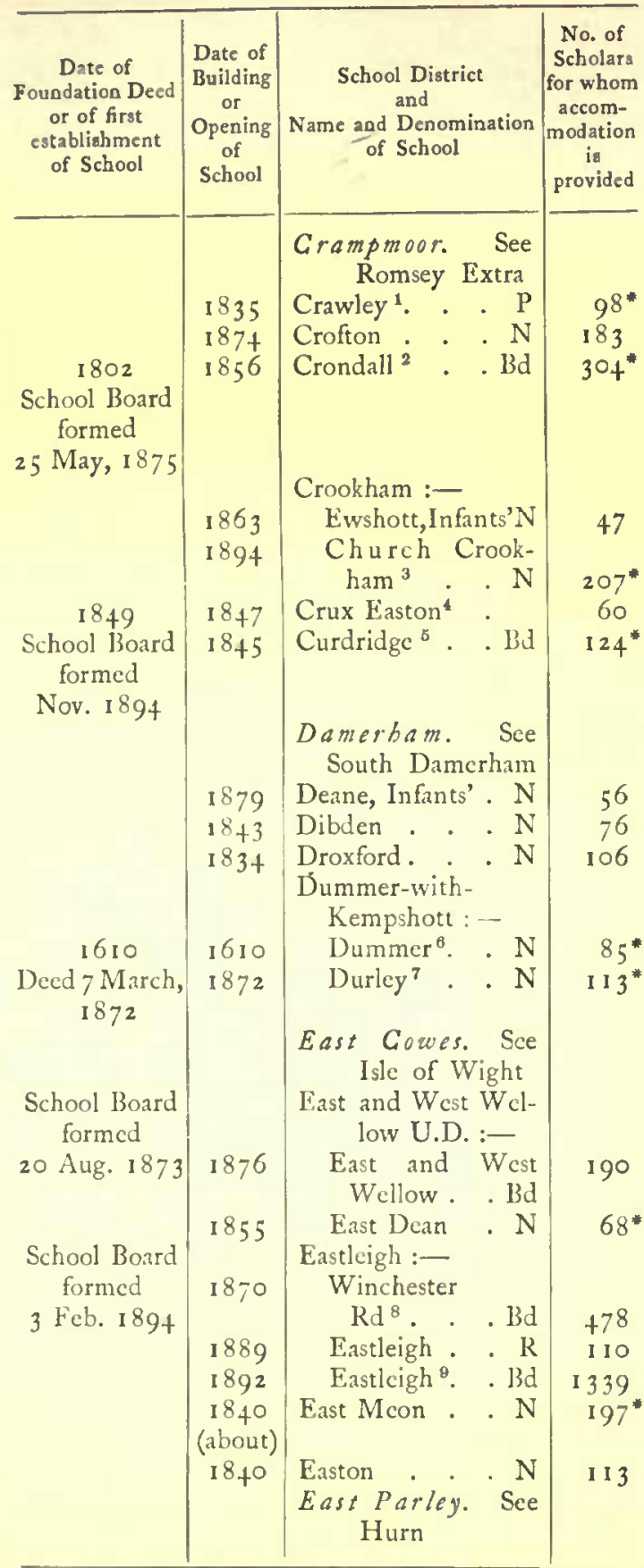

1 Built by Ven. P. Jacob and afterwards enlarged by subscription.

${ }_{2}$ Founded by Elizabeth Oliver, 1802, and Henry Maxweil, 1811. Award, 1849 .

3 The date is that of the rebuilding.

1 Supported by the Earl of Carnarvon.

$\checkmark$ Enlarged 1894. There is an endowment. School leased to the School Board. Under order in 1896 there was a sale of stock for building of teachers' house on terms of replacement.

- Founded by John Millingate 1610. Rebuilt 1815; enlarged 1846,1870 and 1893 . There is an codowment of $\delta_{14}$ yearly.

7 Enlarged 1877 and 1893.

8 Formerly a National School. Enlarged 1882 and 1880

9 Girla' School and Infanta' School in Cranbury Road built 1892 and 1893, and Boy' School in Chamberlain Road built in I 897 .

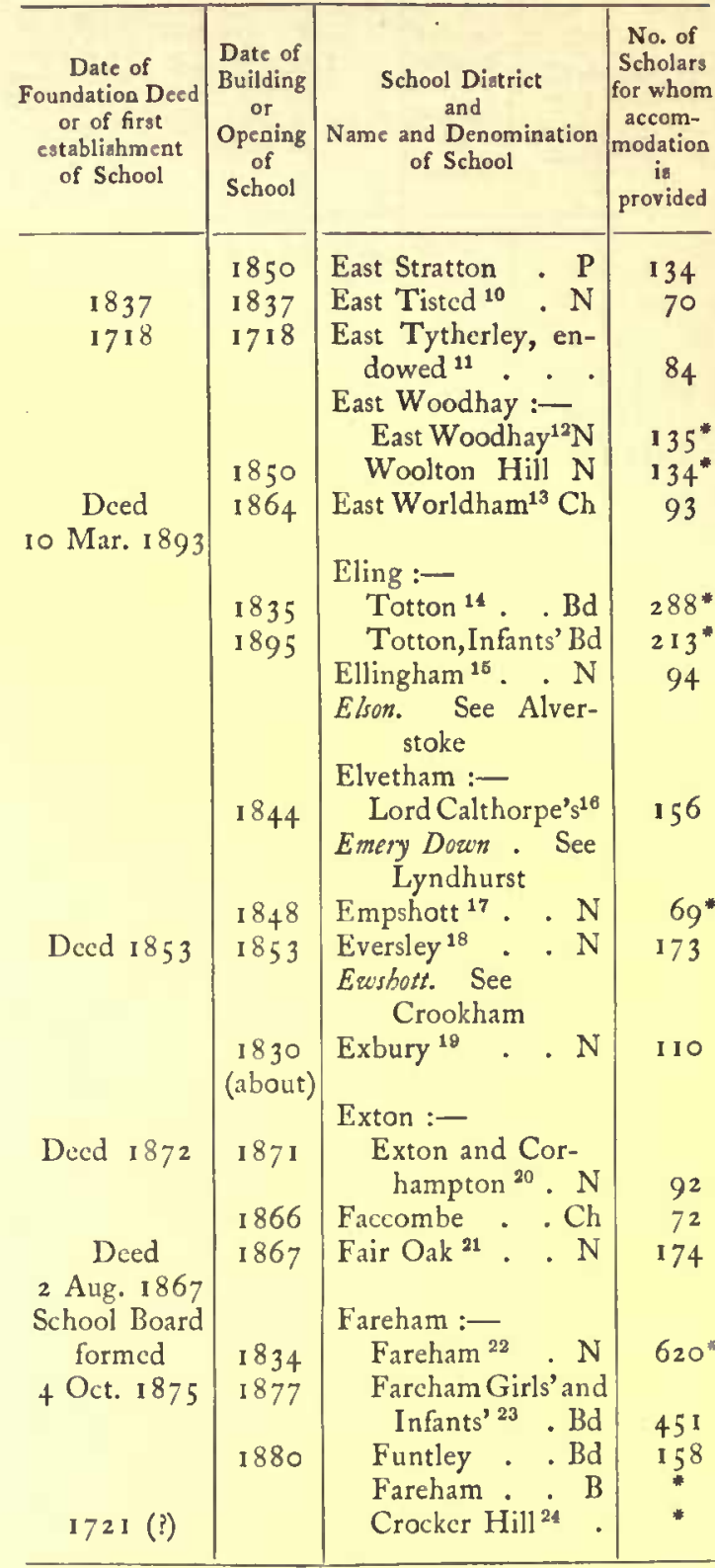

10 Founded by J. W. Scott in 1837 , and partly supported by an endowment.

11 Endowed by Sarah Rolls with about $f_{200}$

12 Endowed with $\ell_{2}^{2} 17^{s}$. $3 d$. yearly by the Rev. J. Wakefield, a former rector.

13 Enlarged in 1897 .

14 Enlarged i 888.

15 Enlarged 1893.

16 Boya' School, 1844 ; Girla' School, 1848.

17 Enlarged 1872.

18 Enlarged 1892 . Scheme of the Charity Commissioners, 28 August, 1891 .

19 Enlarged 1894.

20 With this school is incorporated the Endowed School Scheme of the Charity Commiarioner8, 17 November, 1885 .

21 Enlarged I 875 and 1897.

22 Boya', 1834. Enlarged 1893. Girla', 1881. Infants', I 85 I.

23 Enlarged 1894 .

24 Price' Charity School, founded by William Price I721. 


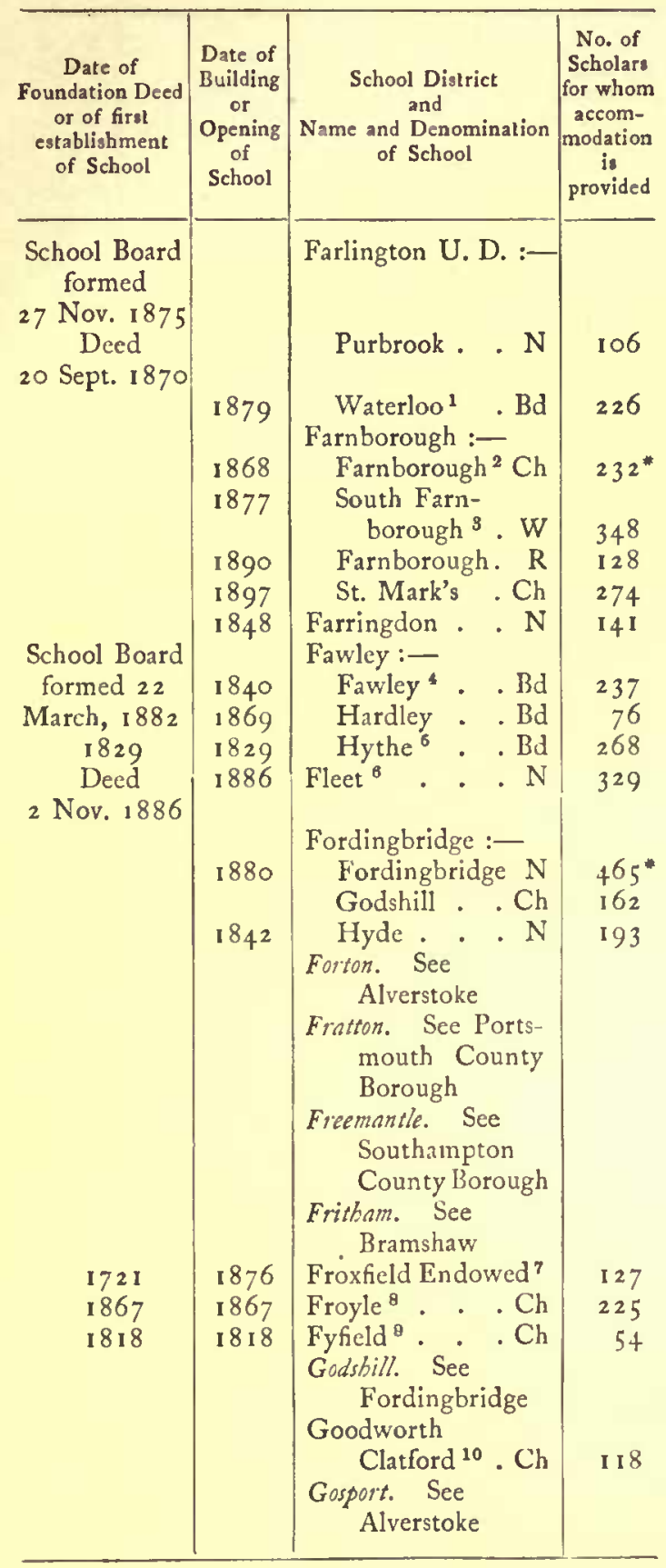

1 Enlarged 1898.

2 Enlarged 8888 .

a Enlarged 1884 and 3886 .

Enlarged 1882

5 Enlarged 1876. Converted into a Board School I 882 , and rebuilt in 1894 .

- Enlarged i 893 .

7 Founded under will of Robert Love. Endowment, $£_{30}^{\circ}$ yearly. Scheme of Education Department, 4 April, 1875 .

8 Founded by Sir C. H. Miller 15 August, 1867. Children are entitled to be educated at Holybourne Endowed School.

9 Sir J. W. Pollen endowed the school with $f_{0} 6$ yearly in $18 \mathrm{rg}$, and Mrs. Shepherd's Foundation is partly for this school (see Kimplon).

10 Founded and endowed by the Rev. L. Iremonger with fi,, 000 Consols.

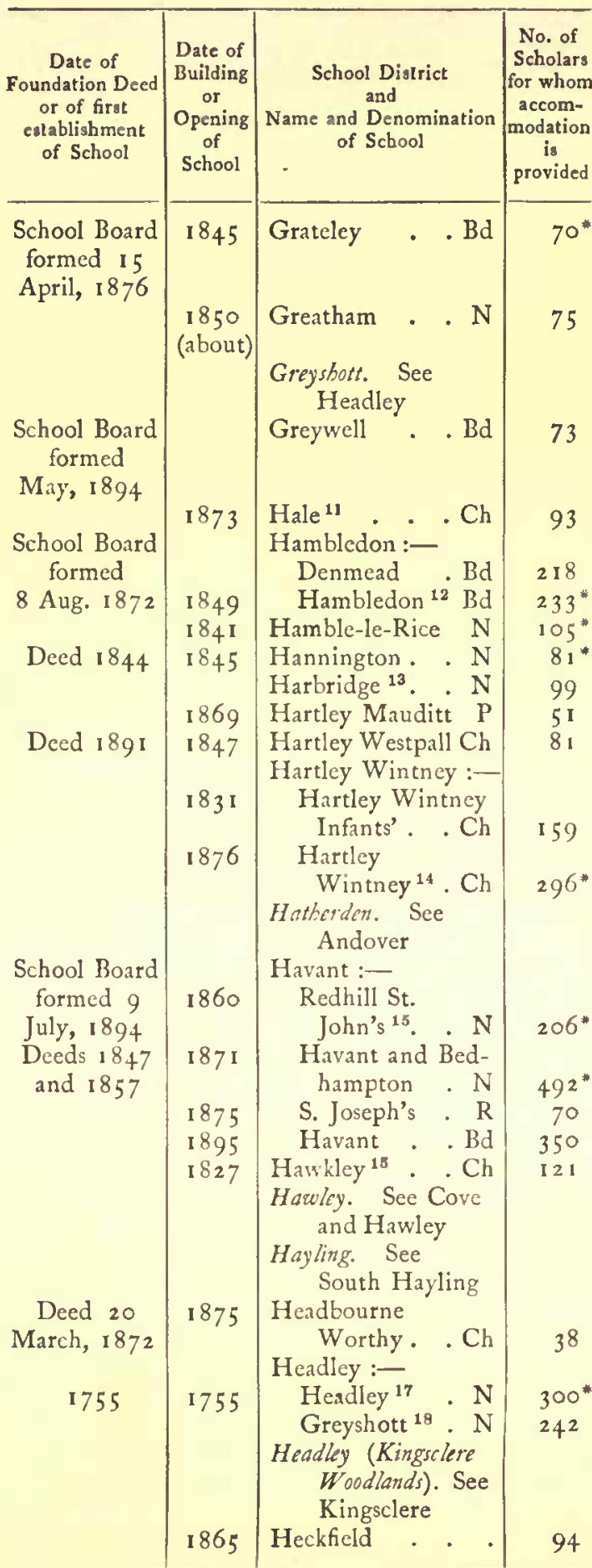

11 Enlarged 1897.

12 Formerly a National School.

13 Built by the late Earl of Normanton.

14 Enlarged 1895. Apparently part of the Bradshaw School Foundation, having an endowment of 6555 s. yearly.

15 Enlarged 1893.

10 School built upon waste of the manor. Buildings altered about 1867

17 Founded by Rev. G. Holmes in 1755. Enlarged 1893-4. Endowment of about $f_{1} 13$ a year.

18 Property of Miss I'Anson. 


\section{A HISTORY OF HAMPSHIRE}

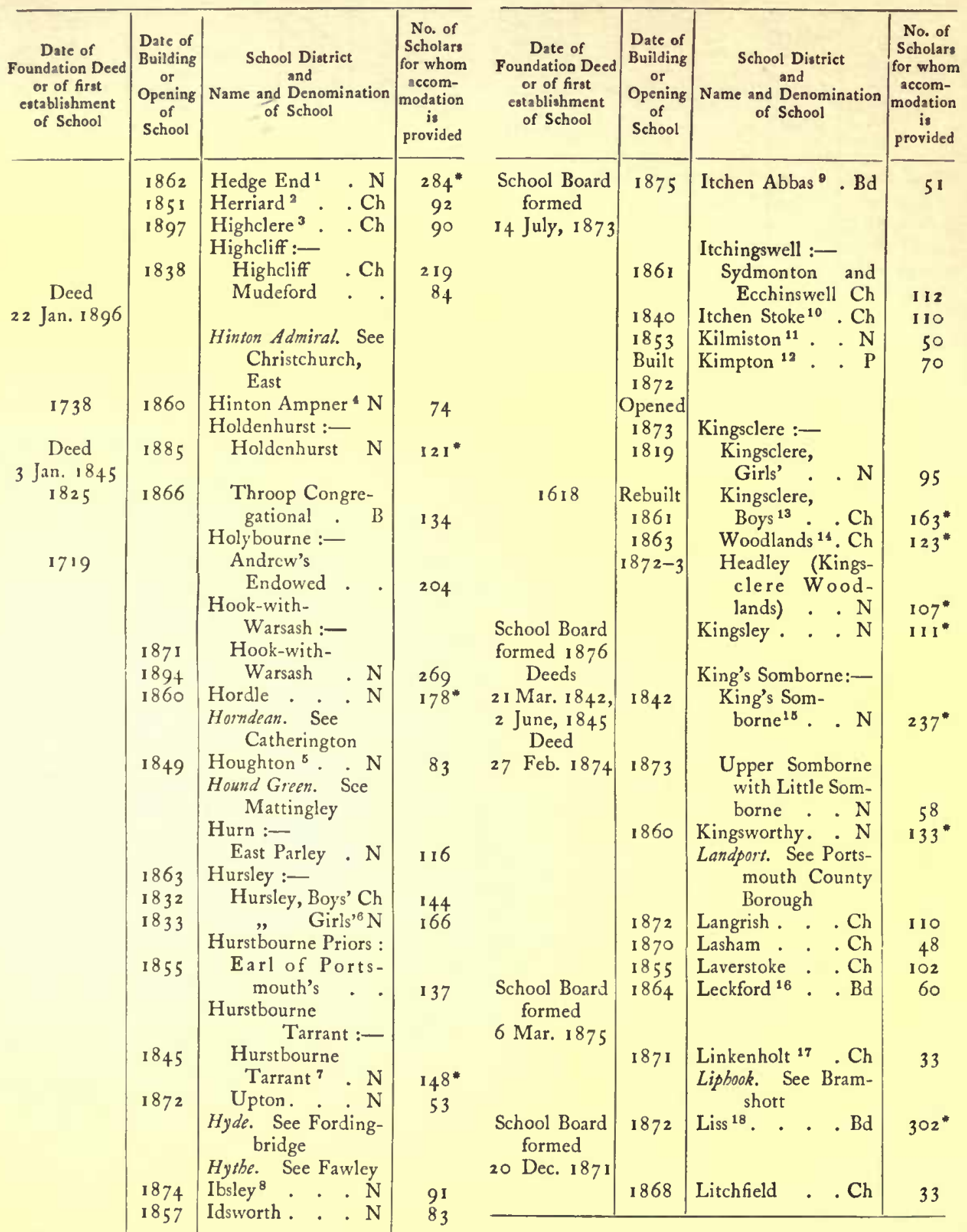

Enlarged 1896 . N. Bailey in 1837 left fo yearly to school purposes.

10 Twice since enlarged.

11 There is an endowment of C $3_{3}, 73.6 \mathrm{~d}$. yearly.

Enlarged 1871,1885 and 1893 .

2 Enlarged 1897 .

3 Built by Earl of Carnarvon.

1 Founded by William Blake with an endowmeat of fi45.

Enlarged 1871 aad 1894.

- Enlarged 1894.

7 Endowed with three sums of $£_{5}, £^{2}$ 10s. and 18 s. respectively.

Built by the late Earl of Normanton.

12 Enlarged 1895. This school is entitled to part of the endowment of Mrs. Sheppard's foundation.

13 Enlarged 1873. Aa endowment of $£_{20}$ left by Sir J. Lancaster in 1618 .

14 Enlarged 1895 .

16 Enlarged in 1873

16 Let to the School Board at a nominal rent.

17 Reopened 1888

18 Enlarged 1878. 


\section{SCHOOLS}

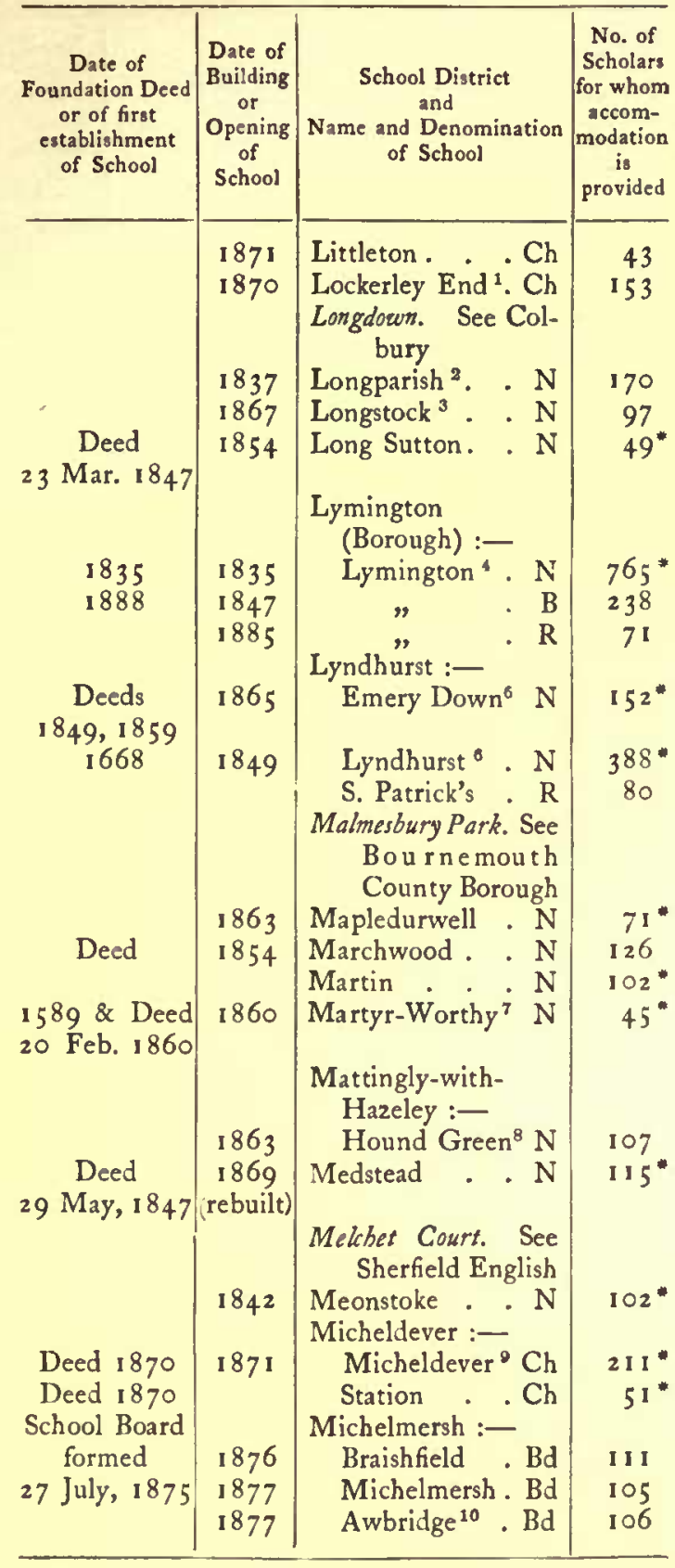

1 Enlarged 1886. A branch of the East Tytherley Charity School, with an endowment of $f 50$ a year by Miss Sarah Rolle.

2 School kept for about eight years previous to the date mentioned. Enlarged 1888 .

3 Opened February or March, 1868.

1 Charity Commissioners' Scheme, 8 February, 1870 . The funds of a grammar school, founded by George Fulford in 1668 , have been appropriated to the National School.

5 Scheme of Charity Commissioners, 27 January, 1882.

- Since enlatged.

7 Endowed with $6^{6}$ 1 3s. $4 d$. yearly, the bequest of Alderman Prenell in 1589 .

8 Built by Viscount Eversley.

- Scheme of Charity Commissioner, 29 May, 1894.

10 Enlarged 1894.

II

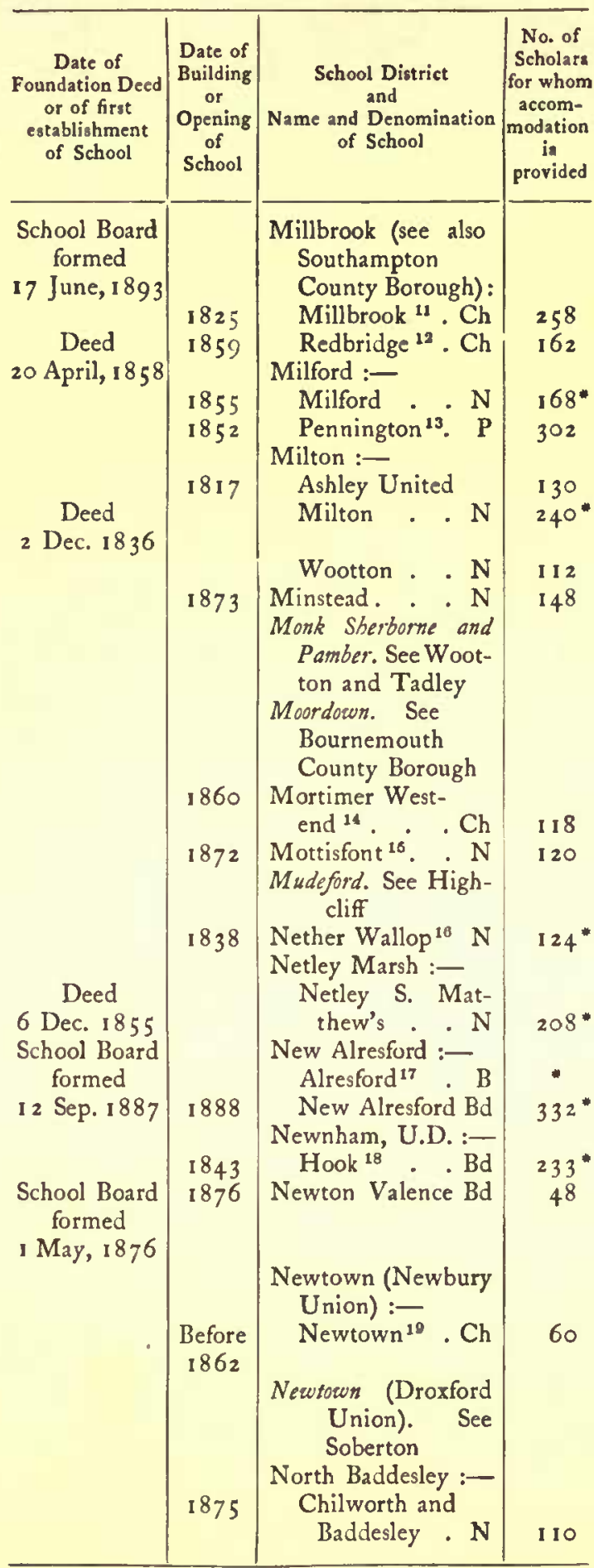

11 New Schools built 1894 .

12 Endowed by Miss Doyle with 445 yearly.

13 Endowed with $\oint_{0}^{20}$ yearly by Rev. R. Pulteney. Infants" School built I 887 .

14 Enlarged 1883

15 Enlarged 1889 .

16 There is an endowment.

17 School in abeyance.

18 Enlarged 1875 and 1896 .

19 A house for mistress built 1862 and school enlarged 1874 . Endowment 610 a year. 


\section{A HISTORY OF HAMPSHIRE}

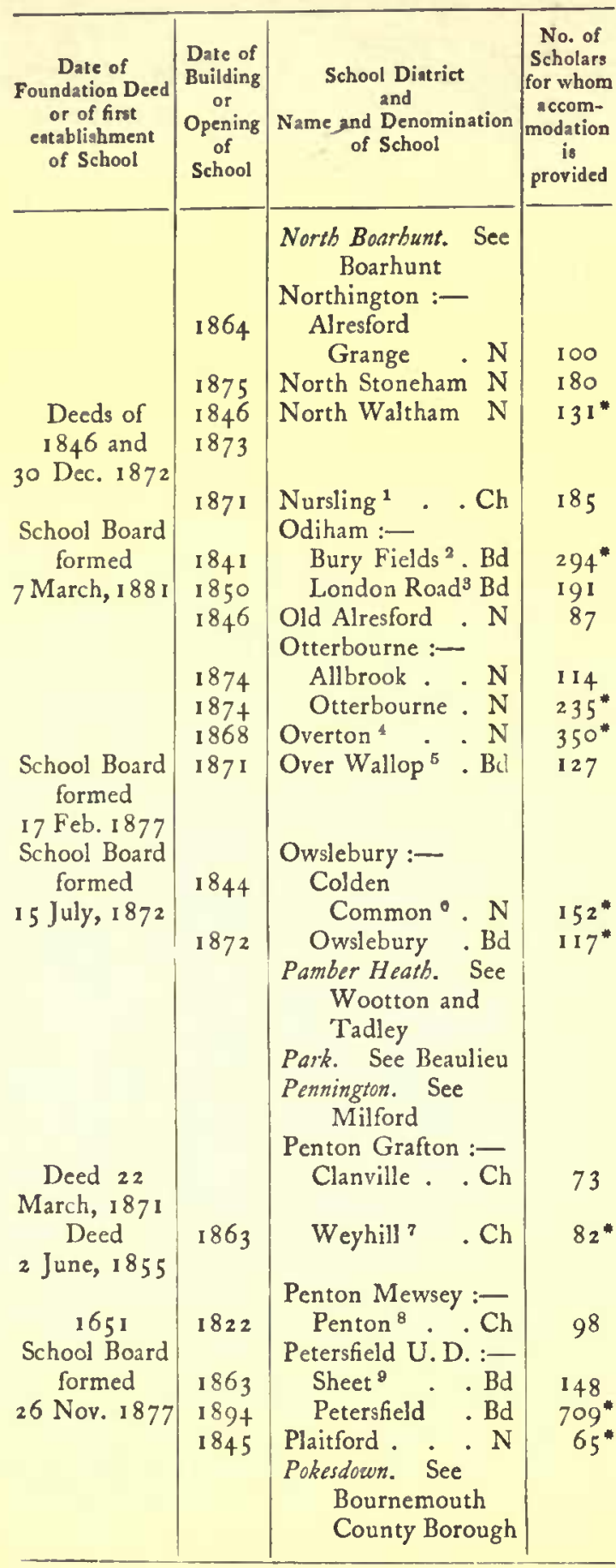

1 Enlarged 1894 .

2 Formerly a National School, built 1841 .

3 Formerly Britiah School.

4 Enlarged 1898. Endowment of $£_{400}$ Consola from Jagoc'a Charity.

5 Enlarged 1892 and 1895 .

- Since enlarged. Charily Commissioners' Sclieme 31 May, 1892.

7 Enlarged 1897

8 Enlarged 1876

- Built an a Memorial School of Mra. Sarah Asken. A new school wan in course of building.

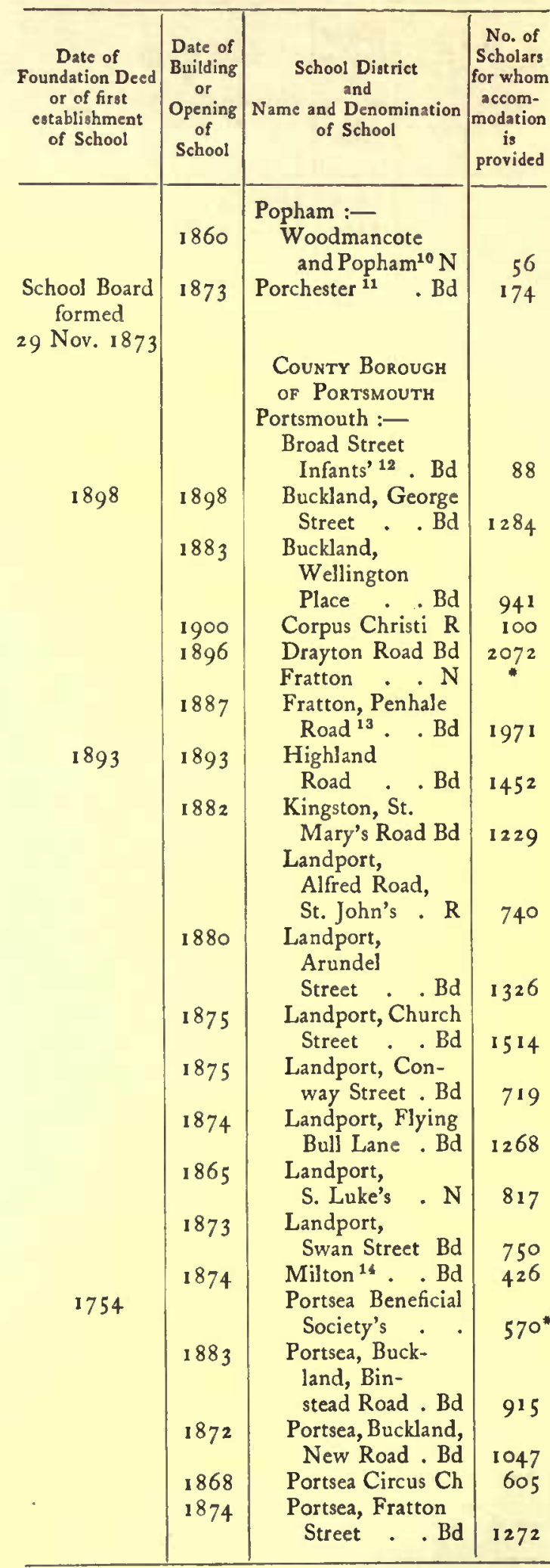

10 Enlarged 1894.

11 Enlarged 1893 .

12 Acquired by School Board in 1876 .

13 Enlarged 1895 .

14 Enlarged $18 \mathrm{~g} 2$. 
SCHOOLS

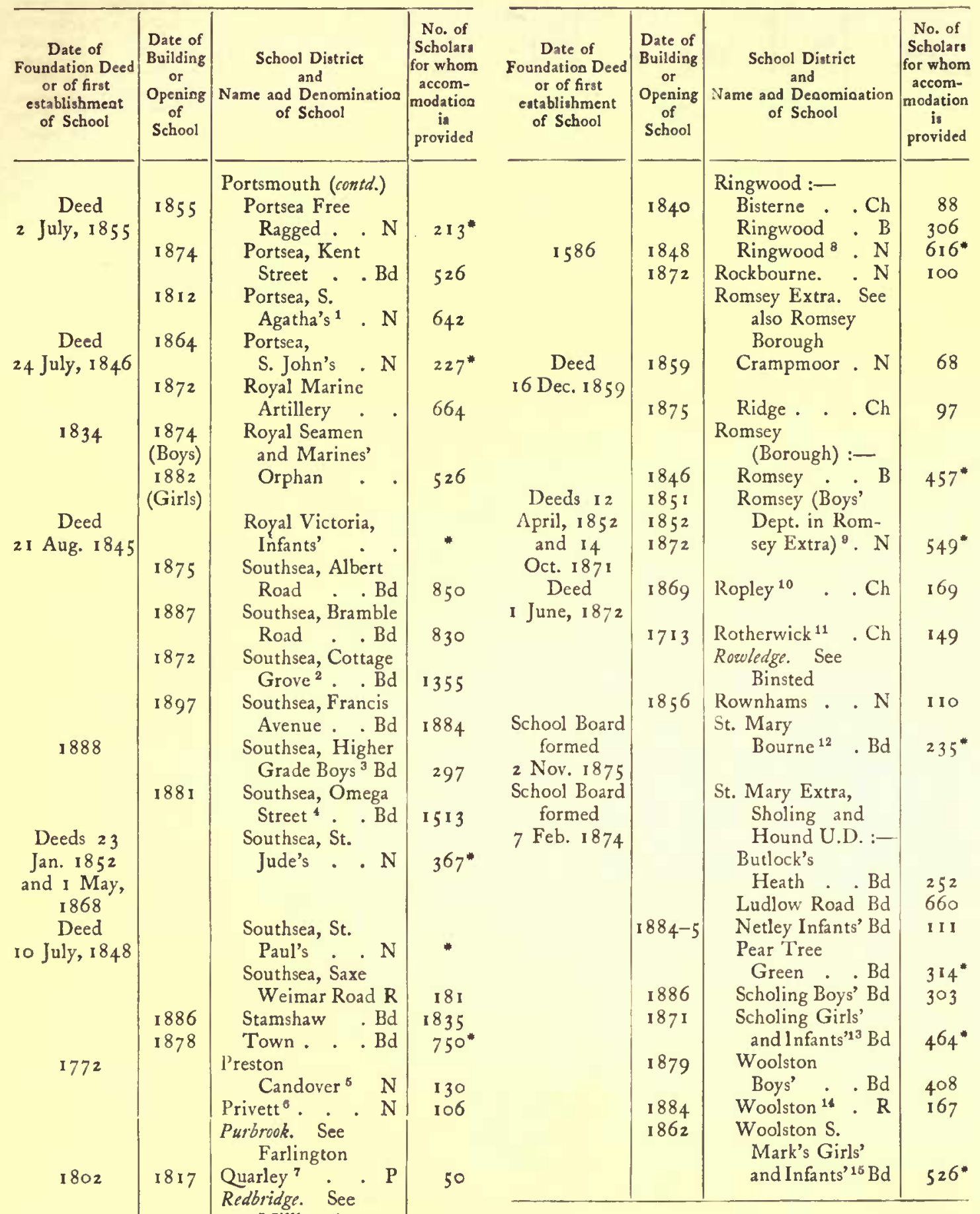

8 Endowments of Grammar School founded in 1586 by Richard Lyne.

9 Boys' School built 1872 and attached to it is an endowment of Mr. J. St. Barbe. Girls' School built in 1851 ; Infants', 3852 . 10 Enlarged 1888.

11 In 1716 Frederick Tylney endowed school with a rent charge of fio yearly. Rebuilt 3872 , enlarged 1896 .

12 Formerly N. School. Transferred to School Board 1875. 13 Formerly N. School. Transferred to School Board 1883 ; enlarged 1887.

14 Charity Commissioners' Scheme of 31 July, 1869.

15 Girls' School built 1862 ; Infants', 1884 , and ealarged 1896. 


\section{A HISTORY OF HAMPSHIRE}

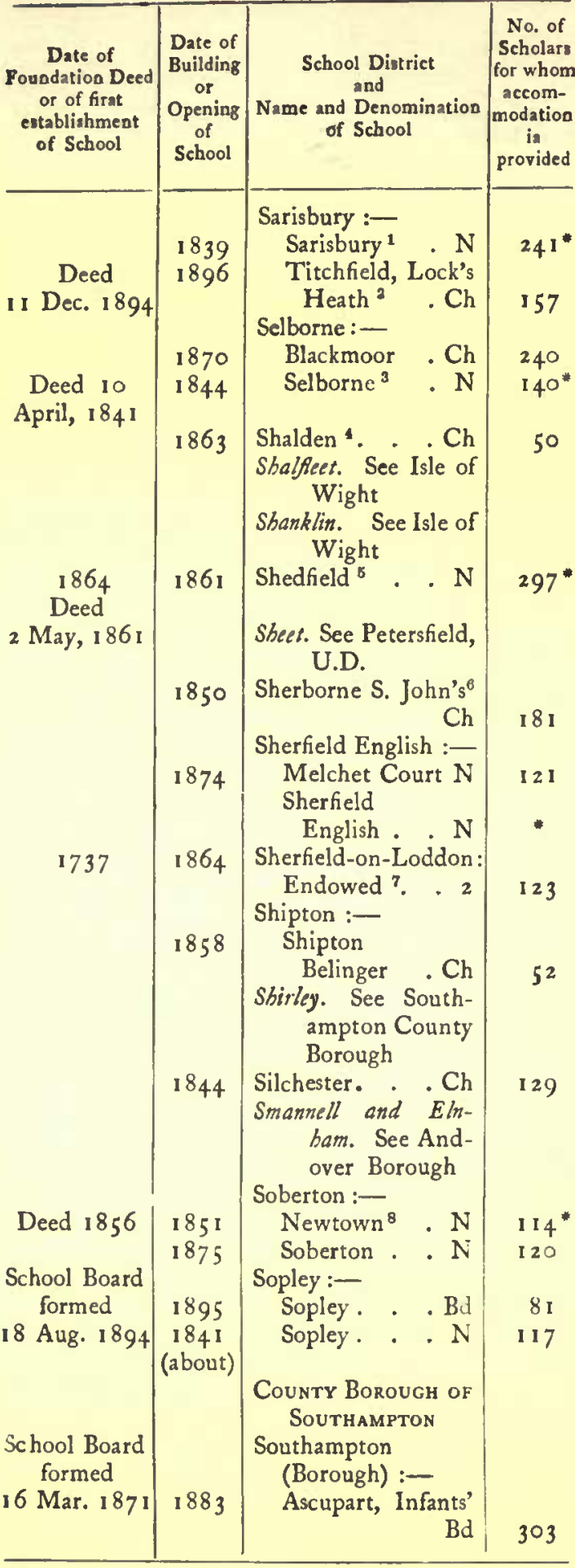

1 Enlarged 1846,1874 and 1894 .

2 Misaion Room adapled for purpose of School.

- In part supported by an endownent.

- Enlarged 2888.

s Enlarged 1864, 2866, 1888, 1890 . Infants' School, 1834 ; enlarged 1837. Girla" School endowed by will of Misa Harvey 1874 .

- Enlarged $1866,1878,1883$, and rebuilt in 1895 .

7 School founded by Jamea Chriatmas in 1737 .

- Since enlarged.

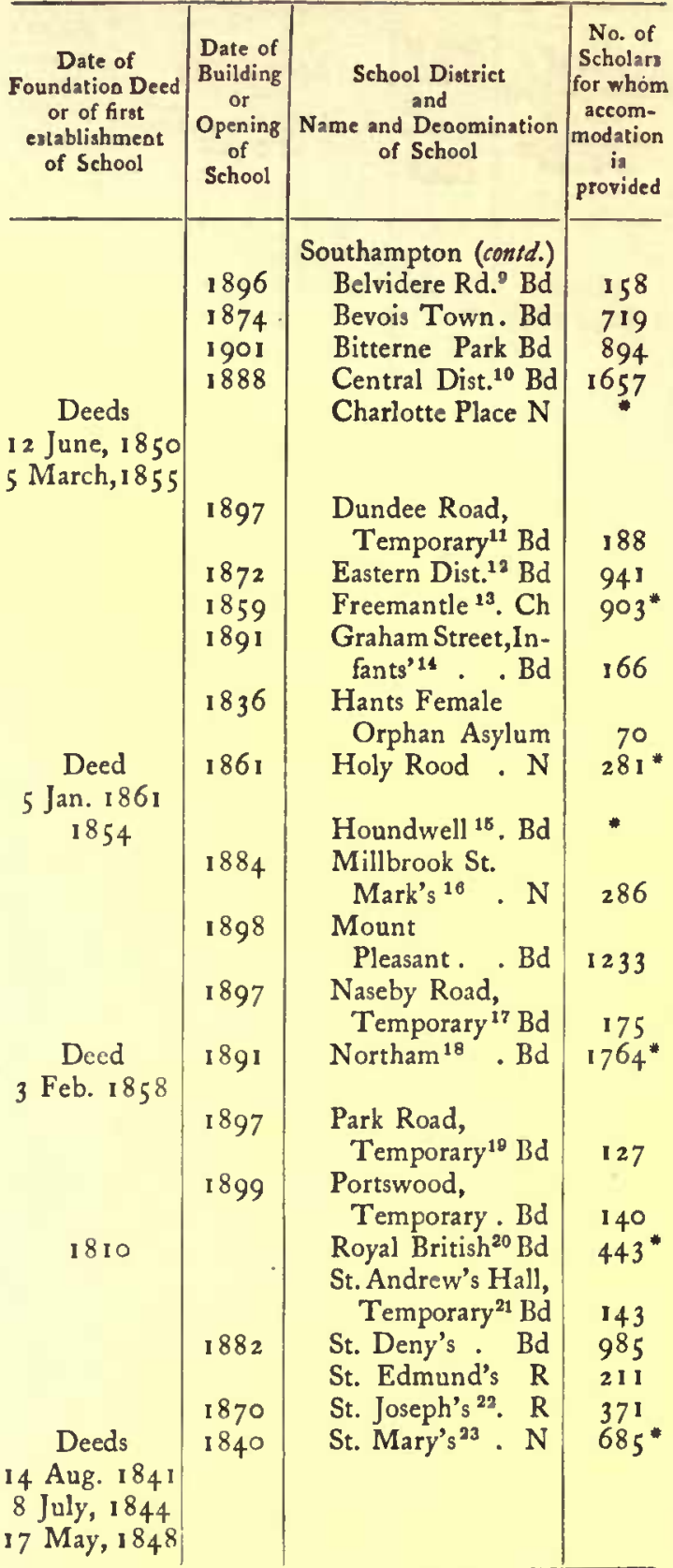

9 Closed 1892 .

10 Enlarged 1900

11 Closed 1902 .

12 Taken over from the Peninsular and Oriental Co.

13 Infanls' School added 1873 and a new Girls' School 1885 ; further additions in 1897 .

14 Closed 1902.

16 Founded as Industrial and Rasged School ; transferred to School Board 1879 .

16 School in Burton Road enlarged 1887.

17 Closed 1902.

18 Enlarged 1901.

19 Closed 1902

20 Founded as British School. Transferred to School Board 1875 ; Infants' School, 1877.

21 Closed.

22 Boys' School added 1895 .

23 Eolarged 1845 and 1856 . 
SCHOOLS

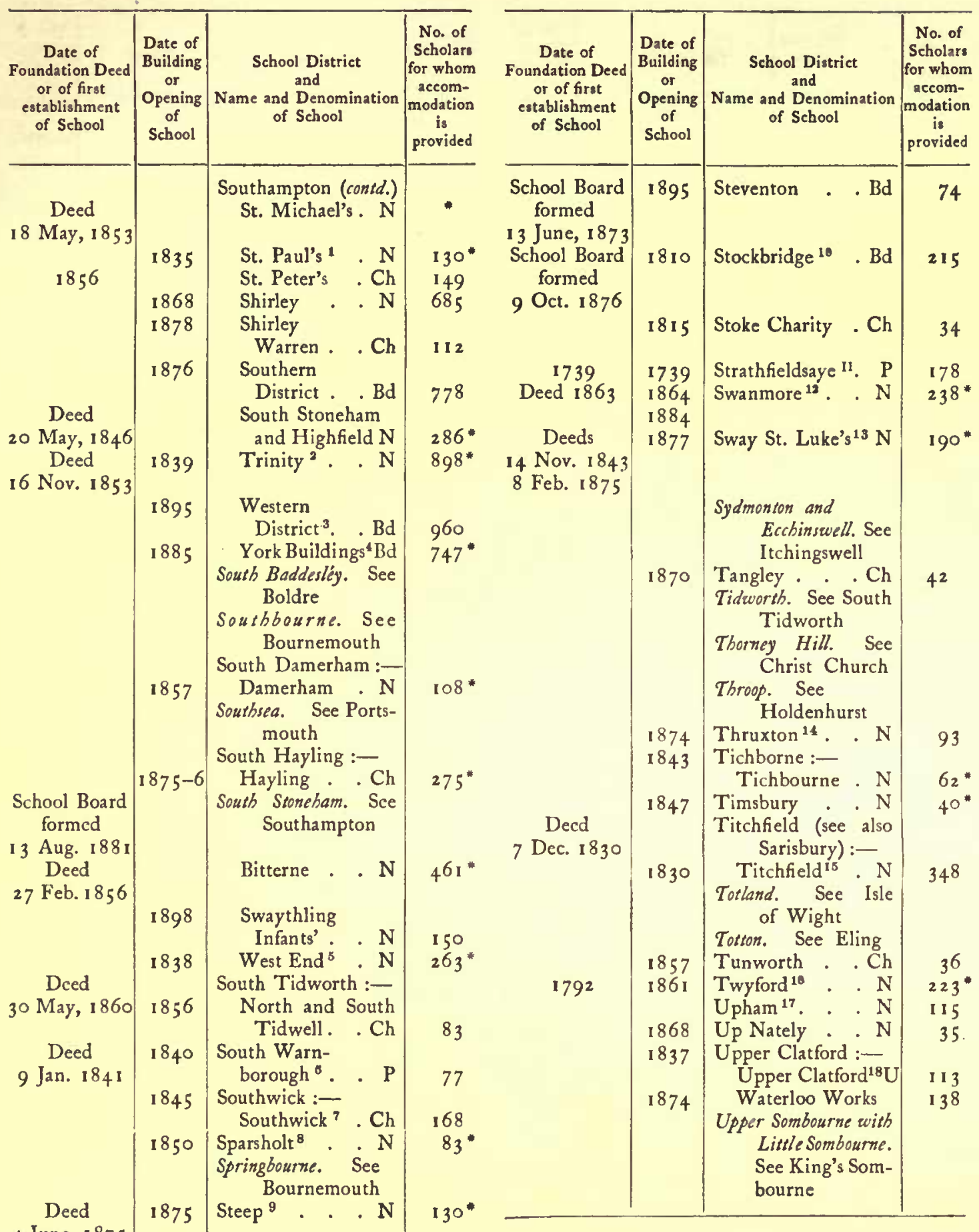

1 Boys' School built 1893 ; Infants' Sehool rented 1900.

2 Rebuilt 1853 ; enlarged 1867.

3 Taken over from Millbrook School Board November, 1895

1 Boys and Girls' Schools taken over from Church of Eogland managers 1882 . Infants' School built 1885

5 Infants' School at Moorgreen built 1871 .

6 Enlarged 1845 and 1897 .

7 Endowed.

8 Enlarged 1876.

- Scheme of 4 June, 1875 ; endowment $K^{6} 15 s .8 d$. yearly.

10 Building formerly used as town hall.

11 Founded by Pitt family. Rebuilt 1843 by first Duke of Wellington; enlarged 1877 by second duke. Infants' School built 1841 .

12 Enlarged 1880 . Endowments of 28 gs. $10 d$. yearly.

13 Infants' School enlarged in 1887

14 Enlarged 1894 . See under Kimptons.

15 Several times enlarged.

16 Endowed 1839 by Archdeacon Clarke $\$ 26$ yearly; enlarged 1893 .

17 Enlarged 1847 and 1874 .

18 Enlarged 1872,1876 and 1897 . 


\section{A HISTORY OF HAMPSHIRE}

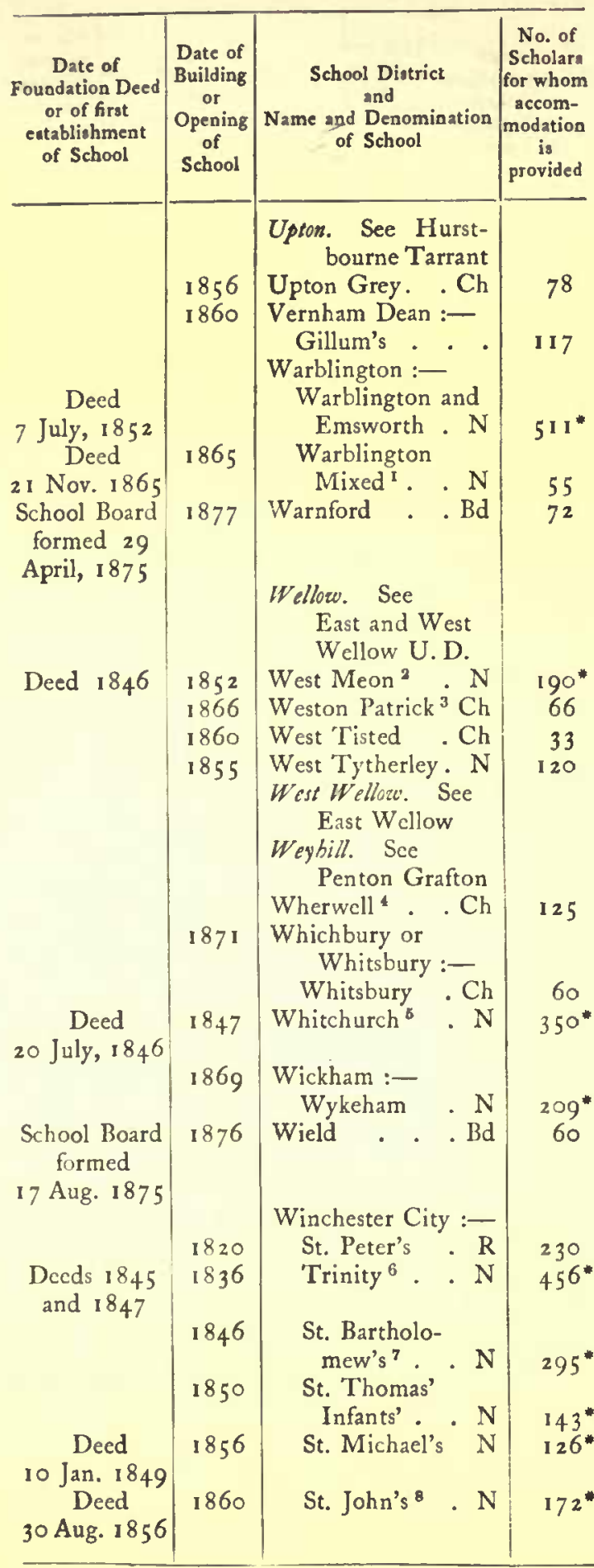

1 The school apparently has an endowment.

2 Miss Touchert endowed the school wilh property producing 617 yearly.

3 Previously to the date mentioned the sebool was held in cotrage.

1 Enlarged 1874.

5 Enlarged 1897 .

- Schemes of Charity Commissioners 22 Dec. $187 t$ and 22 March, 1872 .

7 Enlarged $188_{3}$ and 1894 .

8. The foundation of Henry Knight appears to be applicable to this scheme.

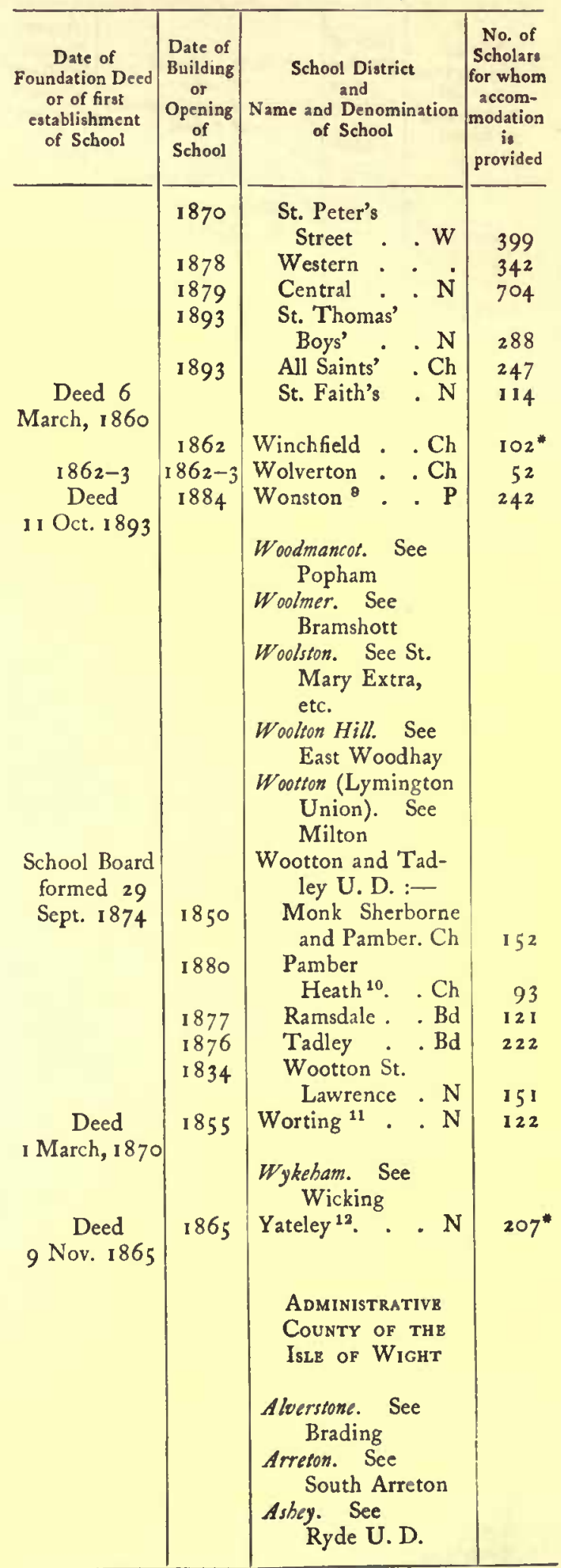

- Enlarged 1895 .

10 Opened 12 February, I 881.

11 Enlarged $188 \mathrm{I}$

12 Enlarged 1894 
SCHOOLS

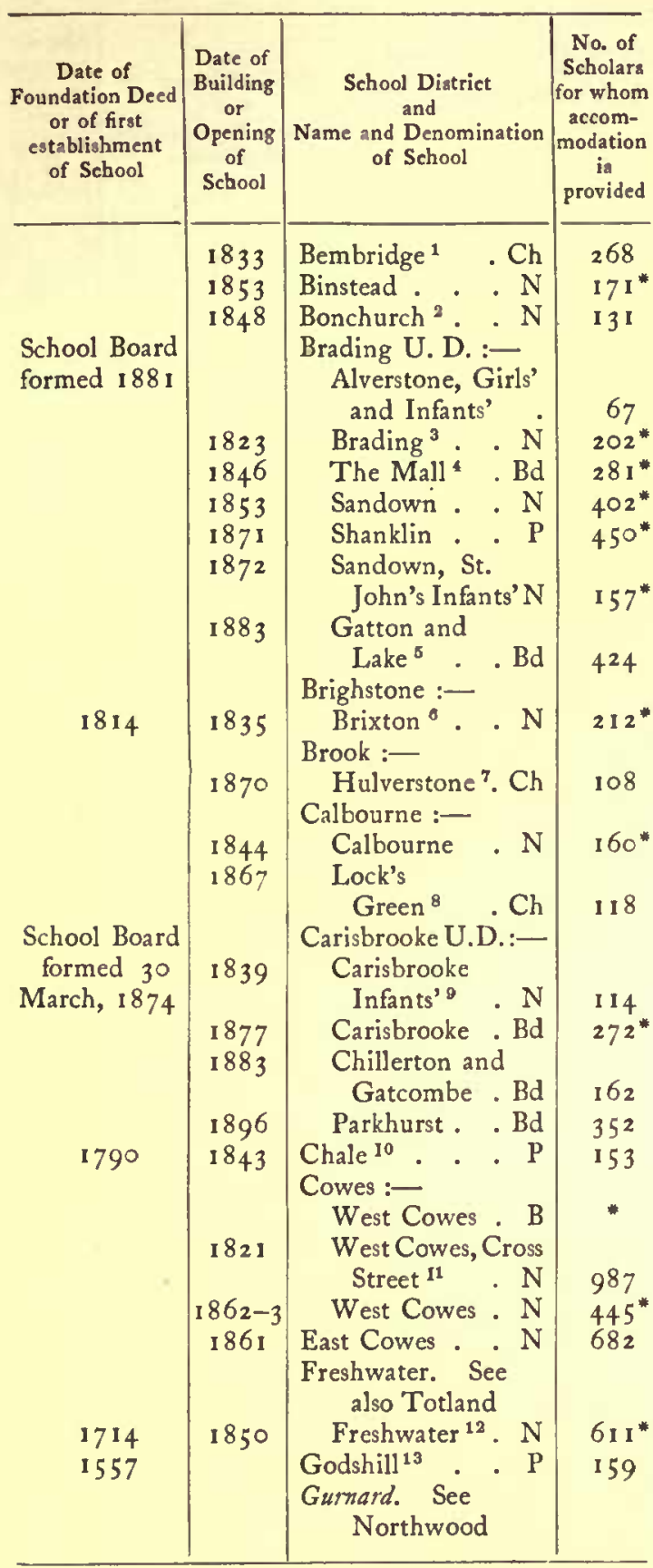

1 Infants' School added 1862.

2 Enlarged 1890.

3 Prizes for acholars are provided under will of Miss M. S. Moore, proved 1876 . Scheme of Charity Commissioners is March, 1890 .

4 Infant:' School built I 887.

5 Since enlarged.

- Since enlarged. Founded by Rev. Noel Digby in 1814.

7 The building was formerly a barn and was converted into a school in 1870 , and enlarged in 1895 .

8 Enlarged 1895 .

3 Enlarged 1893 .

10 Founded by Robert Weeka and John Barber in 1790 and

1797. Endowment $£^{22}$ a year. Enlarged $1895^{-6}$

11 Closed 1863 ; re-opened and enlarged 1875 .

12 Founded by David Urry in 1714 . Since enlarged.

13 A grammar school misappropriated. Rebuilt 1826 and reatored 1848 . Scheme of the Charity Commissioners.

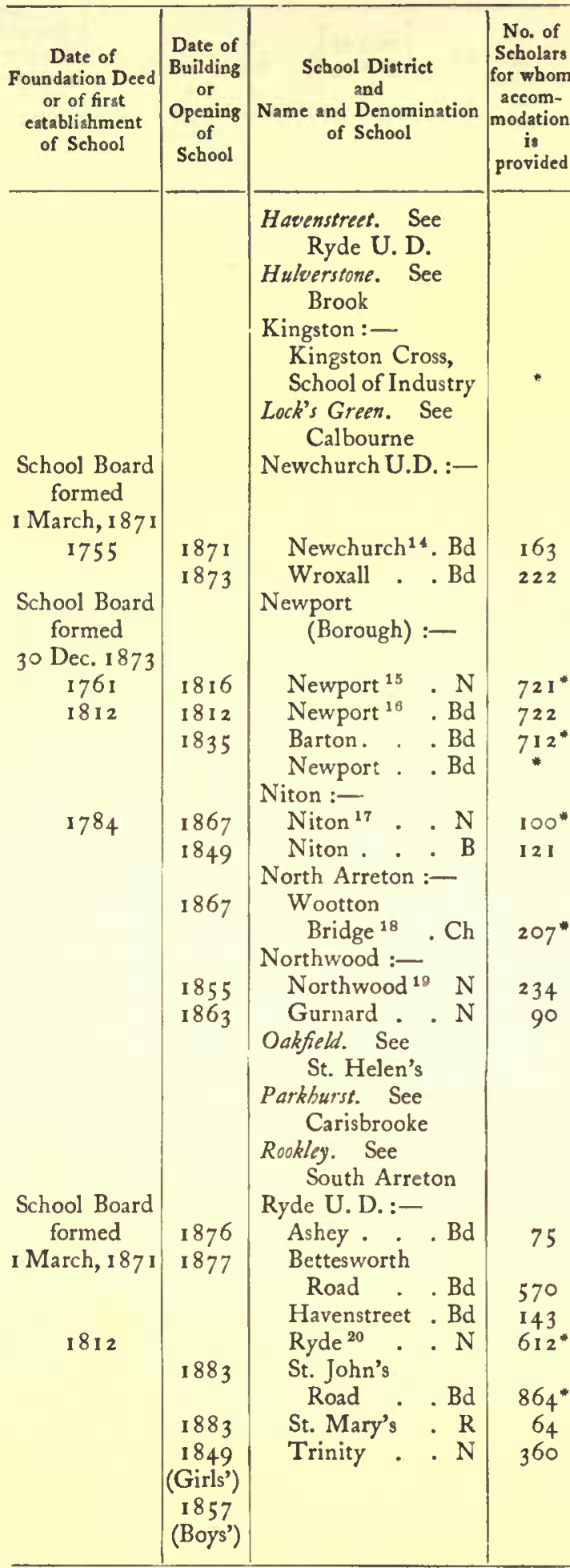

14 Founded by Maurice Buckland and others 1755; sold 1888 .

16 Founded by Benjamin Cooke in $176 \mathrm{r}$.

16 Originally Lancastrian School, afterwards the Royal British School; transferred to Newport Board in 1875. Reopened January, 1876 ; enlarged 1896.

17 Founded by Robert Weeckes and others 1784

18 Since enlarged.

19 Supported in part by a amall endowment.

20 Apparently the Green Street School established in 1812. 


\section{A HISTORY OF HAMPSHIRE}

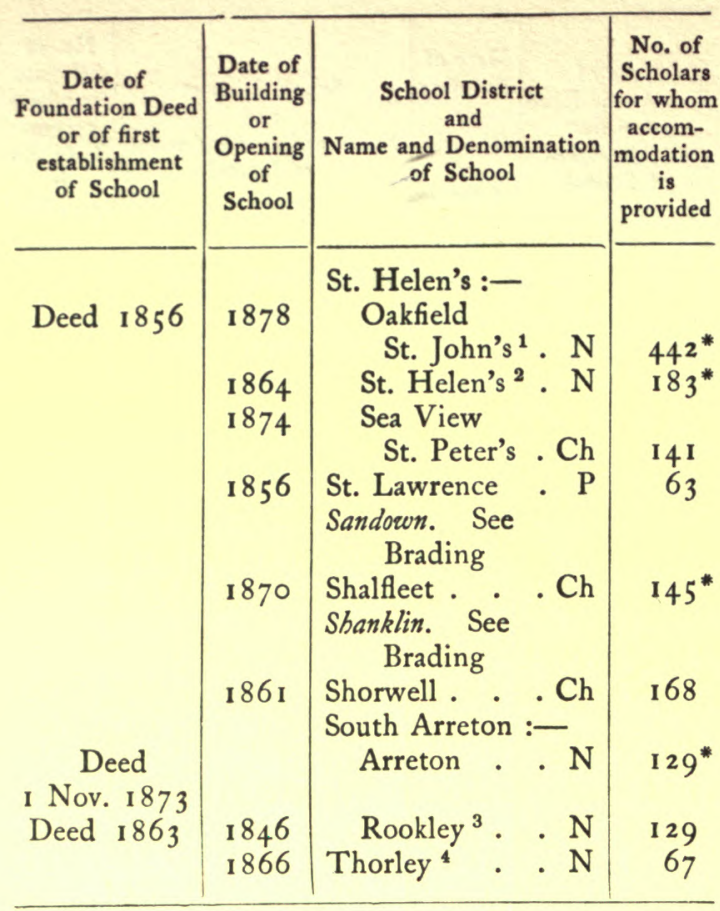

1 Since enlarged. There are endowments under the wills of Lady C. J. and Col. F. V. Harcourt.

2 Endowed under wills of Lady C.J. and Col. F.V. Harcourt.

3 Founded by John Woodward and endowed $£ 400$ India $3 \frac{1}{2}$ per cent stock.

Enlarged 1894

\begin{tabular}{|c|c|c|c|}
\hline $\begin{array}{c}\text { Date of } \\
\text { Foundation Deed } \\
\text { or of first } \\
\text { establishment } \\
\text { of School }\end{array}$ & $\begin{array}{c}\text { Date of } \\
\text { Building } \\
\text { or } \\
\text { Opening } \\
\text { of } \\
\text { School }\end{array}$ & $\begin{array}{c}\text { School District } \\
\text { and } \\
\begin{array}{c}\text { Name and Denomination } \\
\text { of School }\end{array}\end{array}$ & $\begin{array}{l}\text { No. of } \\
\text { Scholars } \\
\text { for whom } \\
\text { accom- } \\
\text { modation } \\
\text { is } \\
\text { provided }\end{array}$ \\
\hline & $\begin{array}{l}1859 \\
1860 \\
1867 \\
1883 \\
1896\end{array}$ & 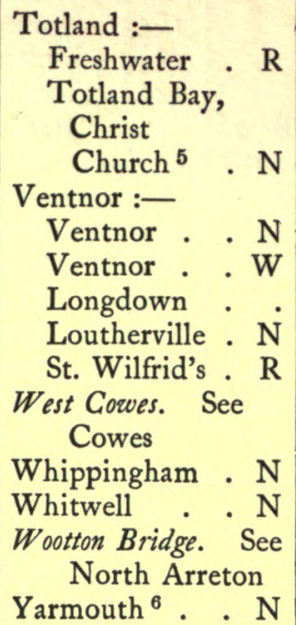 & $\begin{array}{l}203 \\
507^{*} \\
268 \\
170 \\
97 \\
95\end{array}$ \\
\hline
\end{tabular}

5 Since enlarged. Endowed with Bowen Prize Fund by deed 1892 .

6 Endowed by Barnabas Beere and Miss H. B. D. Love. 


\section{FORESTRY AND THE NEW FOREST}

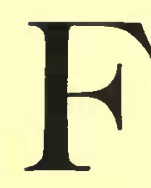

ROM various points of view the forests and woodlands of Hampshire are entitled to be considered unique. They vary greatly in character owing to geological conditions as to soil and physical factors regarding situation, and this variety makes them of special interest to the lovers of all branches of natural history-an interest greatly stimulated by the remembrance that here Gilbert White lived his quiet, peaceful life and wrote his immortal Natural History of Selborne. In early Saxon times, when the king and his court resided at Winchester, the woods and downs and heathery moors were royal hunting-grounds; and when William the Conqueror extended these latter by the formation of the New Forest an historical interest was given to them which has increased as century has succeeded century. From their proximity to England's greatest naval dockyard the oak forests of Hants were for many generations of vast importance in maintaining the supply of timber for the king's navy. Even now this county contains not only the largest remnants of the ancient royal forests but also the second greatest aggregate of woodlands in any of the counties of England. When these facts are considered it may be safely stated that as regards forests, woodlands and forestry Hampshire is the most interesting among the English counties to the historian, the antiquary, the naturalist and the lover of sylvan scenery.

In accordance with the great natural laws relating to competition of different species in the struggle for existence, to special adaptation to environment, and to the survival of the fittest on given soils and situations, we can still easily look back and form a probably fairly correct idea of the primeval conditions of the Hampshire woodlands and barren tracts, because the character of the vegetation must have originally been mainly determined, in addition to the general factor of climate, by the nature of the soil and by its configuration, aspect and elevation.

The geological characteristics of the county need not be fully described as these physical features have already been treated of in detail elsewhere. It may suffice to say here that the county is broadly divisible into the two distinct areas consisting of the chalks of the Secondary system in the northern half and the Bagshot sands and other Tertiary deposits towards the south. These two areas are, however, flanked by other formations. Thus on the eastern or Surrey and Sussex borders the 


\section{A HISTORY OF HAMPSHIRE}

older beds of the Upper Greensand, Gault clay, and Lower Greensand, also belonging to the Cretaceous system, make their appearance; while northwards, towards Berkshire, the younger Eocene formations are found, principally as large stretches of London Clay and Bagshot and Bracklesham beds, separated from the chalk downs by a narrow but very well defined continuous outcrop of the Woolwich and Reading beds. The latter are equally well defined though broader along the southern limit of the Chalk, where also the belt of London Clay is narrow and soon gives place to the sandy and gravelly Bagshot and Bracklesham beds which predominate throughout the New Forest and occupy the whole of the north-western portion of it. To the south-west, south and south-east of Lyndhurst these give place to the somewhat older Hamstead, Bembridge, Osborne and Hendon beds of the Oligocene formation, which extend thence to about the middle of the Isle of Wight, where they again give place to the older strata. As in the north of the county, so here too, a ridge of chalk downs forms the backbone of the island, the southern portion of which consists chiefly of Lower Greensand, though in the other beds of the formation Upper Greensand, Gault and Weald clay are also all to be found.

This rich geological variety, providing chalk, clay and sandy soils, having very distinctive mineral composition and physical properties, would of itself be sufficient to furnish the natural conditions for wide differences in the flora generally, and in the natural distribution of the woodland trees in particular. The influence of these primary petrological factors is, however, greatly increased on account of the differences in configuration by which they are accompanied. Thus while the chalk lands consist in the main of uplands and elevated, breezy, wind-swept downs, the clays, sands and gravels of the two younger formations have more the character of the lower undulating country, of sandy moors and of low-lying, often water-logged, gravelly tracts with peat-bogs, water-springs and swamplike ponds; while the older beds of the Cretaceous system yield good sands, clays and loams, separated by the steep hillsides of the Upper Greensand (malm) known locally as 'hangers,' and familiar by name to all admirers of Gilbert White.

The chalk downs, the highlands of Hampshire, occupy from about one-third to two-fifths of the county. Consisting now of smooth rolling downs and undulating tracts, wooded here and there, but otherwise bare, bleak-looking and devoted to rough pasturage, they were probably at one time thickly wooded, though there are now only the scattered remnants of these primeval woods. Elevated considerably above sea-level, mostly bare, easily permeable to rainwater, and of immense depth, these higher chalk tracts have an essentially dry climate. Heavy downpours of rain rapidly disappear without even forming springs in the coombes or bends in the hillsides, although the water reappears in the shape of springs and streams in the Lower Chalk of the gently undulating land near the Greensand. To the north and north-east the climate is also dry, the land consisting principally of sandy heaths between 200 and 300 feet above sea-level, overlooking lower and more fertile loams and clays. Towards 


\section{FORESTRY AND THE NEW FORES'T}

the east, from Farnham to Buriton and including the Selborne country, the clays, loams and sands of the Gault and Greensands form lands generally of low elevation, interrupted by the steep 'hangers' or escarpments usually facing eastwards, but which run up to over 800 feet at Hindhead. In this latter tract, and particularly in the neighbourhood of the Gault clay, the climate, despite the somewhat low average rainfall of about 33 to 35 inches, is already somewhat damp as compared with the dry chalk downs. But it is in the Tertiary area forming the south-western part of the county, and comprising within it the whole of the New Forest, that the climate is dampest; and the principal cause is due to the nature of the soil far more than to mere proximity to the sea-coast.

The area covered by these Eocene and Oligocene beds extends to about one-third of the county, and consists chiefly of low-lying tracts though reaching an elevation of 400 feet in the northern part of the New Forest. Sheets of flint-gravel prevail in many of the central portions, and the soil is often water-logged and filled with springs, bogs and streams, making the local climate hot, steamy and relaxing.

The existing woodlands are naturally distributed as under such circumstances one would expect them to be. The predominating tree on the chalk lands is beech and the flora is that characteristic of limy soil, juniper being one of the principal shrubs of spontaneous growth. The low lands and heavy clay soils of the Gault are still partly, as formerly, occupied by oak woods; the fertile tracts of the Lower Chalk have mostly been cleared and are now good, well-watered agricultural land; while the New Forest district consists of woodlands interrupted by large tracts of open moors, seldom more than two or three feet deep and resting on a hard bed of gravel, or by stretches of heather, bracken, broom and gorse, and by swampy bogs and peat-moors fringed with alder, birch and willow, the trees least sensitive to frost and thriving most easily on sour, wet lands. In many parts of the forest minor trees like holly and hawthorn, shrubs like blackthorn, and weeds like briar, often grow luxuriantly and sometimes form dense tangled thickets.

It is not difficult to form an idea of the primeval woodlands of Hampshire. It is more than probable that the whole county was originally densely wooded, and that these chalk downs, as well as the Cotswolds, the Chilterns and all the hills of similar character forming the backbone of the southern counties of England were mainly covered with beechwoods, of which those still existing in patches varying in size are but the poor, scattered remnants. When the earliest settlers, at first nomadic and afterwards permanent, fixed their abodes near the watercourses they probably subsisted mainly on wild fruits and roots, and then went through the hunter-stage of development before attaining higher evolution. It is not improbable that swine formed their first and for long their only possessions in the way of domestic animals, just as is now the case among the Karens and similar hill-tribes in the vast forests in Burma. The herds of swine could be taken out into the woods to feed on the beech-mast, and by wallowing and breaking up the ground with 


\section{A HISTORY OF HAMPSHIRE}

their snouts, either in pursuit of mice or in wantonness after having eaten their fill, would be of very real service in securing the natural regeneration of the woods by means of seed.

With the introduction of fire and the improvement of primitive implements, efforts would be made (as can still be observed in many densely wooded, uncivilized parts of the world) to destroy a sufficient portion of the woodlands to permit of primitive agriculture. The chalk soil, deep, fissured, extremely permeable to water, and easily becoming heated through exposure to the sun, would soon lose its virgin fertility and become deteriorated, when fresh clearances would have to be made for agricultural purposes. And so the clearances would gradually extend till the only woodland tracts remaining would be those actually necessary for the maintenance of the large herds of swine. Once the poor chalk soil became denuded of its covering of tree growth there would be practically no tendency towards spontaneous regeneration of the original woodlands, because even now the successful sowing or replantation of deteriorated chalk soils (or indeed limy soils of any description) is one of the most difficult operations in forestry. When cattle were afterwards kept in addition to swine the cleared spaces abandoned for agriculture would naturally form the open grazing lands of the flocks and herds.

That the hills were cleared before the more fertile portions of the lower tracts seems probable, because our present observation and our past knowledge of savage, of uncivilized and of semi-civilized forest tribes show that they keep to the hilly country first of all, and only gradually settle down afterwards in the richer agricultural tracts of the valleys and plains.

Of what the lower stretches of woodland must once have been we can form some idea from the evidence of the submerged forests which fringe our southern coast and give evidence that the chief trees were at one time oak, beech, birch, pine and hazel, while the wild animals comprised the urus, red deer, roe deer, wild boar and the shorthorned ox. The pine subsequently disappeared from the woodland flora of this part of the country-whether as the result of fires, or of attacks of injurious insects, or of epidemics of fungous diseases it is impossible to say-and was only reintroduced so recently as 1776 (see p. 454), although it now forms one of the characteristic features of Hampshire scenery and is one of the few kinds of trees really suitable for the great stretches of sandy and gravelly soils. The clay soils of the low tracts being favourable to the growth of oak, this probably covered large areas interrupted here and there by barren peat-bogs and swamps, the whole coast district remaining uncleared and undrained till long after the Teutonic immigration took place.

We have but little of accurate special information regarding the Hampshire woodlands throughout the times of the Britons and the Romans. But it is reasonable to suppose that during the early centuries of our era they were vast and dense, and had much to do with its political history. The Andredswald, the Weald to the east, the wooded slopes of the Downs, Bearroc, Harewood, the various woods included within the 


\section{FORESTRY AND THE NEW FOREST}

New Forest and many others formed Saxon strongholds when the lower courses of the rivers fell into the hands of the Teutonic invaders, while the hill-forts, the long lines of ditch and rampart and other works of Roman engineering were all evidently intended for defence and for offering opposition to any hostile advance. The Roman remains indicate that the population was mainly confined to the central chalk lands, while the humid, forest-covered, swampy and probably unhealthy tracts were then practically uninhabited except at the military stations along the chief lines of communication. To the Romans we certainly owe the introduction of the English elm, sweet chestnut, lime and poplar, which are to be found thoroughly naturalized in the Hampshire woods along with the indigenous oak, beech, birch, ash, aspen, alder, sallow, yew, and minor trees and shrubs like hawthorn, holly, gorse and juniper. They also introduced the plane and the walnut together with other ornamental trees and fruit-bearers which never became of true woodland growth.

There can be little doubt, however, that after the four centuries of Roman occupation the Britons had adopted Roman methods of agriculture, while the various Teutonic invaders-Saxons, Angles, Jutes and Frisians alike-were still mostly dependent on their flocks and herds, which fed themselves upon the herbage and mast of the woodlands.

During the Saxon and the Danish periods the whole of the county, except the wide stretches cleared on the chalk hills and the great swamps and peat-bogs on the water-logged tracts, called Ytene or 'furze heaths' by the Saxons, was probably still thickly tree-clad, while the scanty population was, in addition to the agriculture then practised, mainly dependent on the woodlands for many kinds of food as well as for the pannage of their large herds of swine which throve on the acorns and beech-mast shed in autumn. The woods abounded with game, while the chase, free to all, furnished nourishing food in plenty.

As husbandry gradually began to acquire greater importance under later Saxon rule, the enclosure of land became necessary for the improvement of agricultural methods and for the protection of the crops, while the beasts of chase were so far as possible kept out of such fields and enclosures, and driven back into the recesses of the woodlands. This is precisely what one now sees going on in other parts of the world, as in the heart of the vast tree-jungles of Burma, where the scanty woodland population is passing through (though under vastly different circumstances as to government and administration) a stage very similar to that which existed in southern England about a thousand to fifteen hundred years ago. As cultivation gradually spread patches of the woodland were cleared and enclosures for cultivation extended, while the deer and other game were driven back into the depths of the woods. In process of time the woodlands, the great hunting-grounds, became something like vast sanctuaries for the herds of deer, wild boar, and other beasts of venery; and gradually the most influential and powerful of the local men usurped the rights of the common people, probably by first of all restraining them from exercising such rights freely, and then ultimately 


\section{A HISTORY OF HAMPSHIRE}

by reserving for themselves the amusement of the higher chase after red deer in certain specified tracts. And when these powerful, masterful men having great local influence became the thegns and earls of the Saxon kings-titles originally not of dignity but of service-the rights they had usurped from the common folk were, a fortiori, entitled to be exercised by their overlord and sovereign, the king. As the king became more fully representative of his nation he no doubt exercised these rights of the chase, for the hunting of red deer and wild boar has ever been the most royal of sports.

Thus in Hampshire, as in other parts of the Saxon kingdoms, the royal appropriation of large tracts of land, and especially of great stretches of woodlands within which big game was most plentiful-tracts which ultimately became known as forests, a name having a very definite legal meaning-seems to have taken place as early as the Heptarchy (455-827 A.D.) ; and when Egbert became the "first king of all England" (827839 A.D.), he found himself the overlord of many such forests in different parts of England. The process of the formation of 'king's land ' (terra regis) and 'king's wood' (silva regis) or 'royal hunting-grounds,' which later on became the 'forest' (foresta) of the Norman kings, cannot be accurately described. Most likely the royal demesnes and the royal woods of the Saxon and the Danish kings often included parts of the original 'Folc-land'- ' the Land of the vulgar People, who had no Estate therein, but held the same under such Rents and Services as were accustomed or agreed, at the Will only of their lord the Thane.' ' Long previous to this time, however, the great economic importance of the woodlands for the pannage of swine, apart from the amusements of hunting, was recognized in the laws of King Ine, the earliest extant specimens of WestSaxon legislation, published between 690 and 693 A.D., by which penalties were imposed on the burning of trees lest the woods should be destroyed by fire, while the value of a tree was estimated according to the number of swine that could find shelter under it. So far as hunting was concerned it seems that, from being exercised first of all in common by all, it gradually became restricted after the formation of royal huntinggrounds, when a freeholder still had the right of the higher chase after big game upon his own land, but was forbidden to follow it into or upon the king's woods. The lower chase could still, however, down to the time of the Norman Conquest, be enjoyed by the holder of the land even if it formed part of the royal hunting-grounds within which the higher chase was reserved for the king. That such was the case seems clear even from the supposititious forest laws of Canute the Dane (IOI7-35 A.D.), now known to have been Norman forgeries, as well as from the customs known to have been existing from then down to the time of Edward the Confessor (1042-66 A.D.). There can be no doubt that definite laws relating to hunting and woodlands were in force during both the Saxon and the Danish periods, but only untenanted tracts appear to have been

1 Cowell's Law Dictionary (1708), article on 'Folc-land.' 


\section{FORESTRY AND THE NEW FOREST}

placed under ban as royal hunting-grounds, while the penalties for offences against the royal enactments were mild in comparison with the savage punishments inflicted on those who transgressed against the forest laws introduced by the Normans shortly after the Conquest.

There is still less of accurate information extant concerning the woodlands of the Isle of Wight during the Saxon and Danish periods. The river Medina, flowing towards the north, was flanked by ancient woods of which Parkhurst Forest alone remains in the shape of any large compact block. It was a scantily populated island during the Roman period, and became later on occupied chiefly by Jutes ; and it probably remained thickly wooded until comparatively late times, except on the chalk downs where woodland covering could easily be destroyed beyond hope of natural regeneration.

It is, however, with the making of the New Forest by William the Conqueror in 1079 , registration of land tenures and assessments to 'geld' tax, and the great Domesday Book in $108 \mathrm{I}-6$, that its special position was acquired by Hants with regard to English forestry, because the New Forest was one of the forests mentioned in Domesday, along with Dean in Gloucester, Windsor in Berkshire, Huchennode (Whichwood) in Oxfordshire, Winburne (Wimborne) in Dorset, and Gravelinges in Wiltshire. And it is still, as it always has been, the most important and the most interesting of all the royal forests as regards its history and its administration. The Saxon and the Danish kings loved the chase well, but with the Norman kings it was a passion. Moreover, a change in the game laws existing at the time of the Conquest became a necessary measure in introducing the feudal system into England, so the game laws gave place to forest laws and the 'king's woods 'became 'forests.' For political purposes it was desirable not only to curtail and abolish many of the privileges previously enjoyed by the earls, thegns and other landholders, but also to prevent them, so far as possible, from using arms; and one most effective step in this direction was to prohibit them from exercising the rights and privileges they had hitherto enjoyed as regards the chase. Hence William the Conqueror, for political purposes as well as from personal inclination, decreed that the right of hunting was vested solely in himself, and could only be exercised by him or by those of his nobles to whom he was graciously pleased to accord such privilege. Thus the Norman king usurped the monopoly of hunting within the royal preserves, whereas before the Conquest two descriptions of chase had been recognized, the higher being reserved for the king and the lower enjoyed by the landholder.

Manwood is frequently quoted ${ }^{1}$ as saying of the New Forest that it is ' the newest forest in England.' He does say this, it is true ; but his remarks, thus construed, seem rather confused. What he wrote was, 'The Newest Forrest, that is in England at this day (i.e. 1 598), is the new Forrest in Hampshire, for ther is no Forrest that doth now

1 Third Report of Commissioners on Woods, Forests, etc. (1788), p. 7 ; and other works. 


\section{A HISTORY OF HAMPSHIRE}

remaine a Forrest, that was made since the making of the New Forrest in Hampshire (the Forrest of Hampton Court onely excepted ${ }^{1}$ ), and therefore the same is called New Forrest; yet the same was made a Forrest in William the Conqueror's time: But there is no other Forrest in England, whereof the beginning or making can be shewed, neyther by the Chronicles, Histories, nor Record, so auncient are all the other Forrests of this land.' 2 The far older 'royal hunting-grounds' are here apparently confused with the 'forests' which were for the first time afforested by the Conqueror. This was a work of transformation and extension, but not altogether a new creation. If not the very oldest 'forest,' the New Forest must certainly be one of the oldest 'forests' in England: of that there can be no doubt. Manwood seems to overlook the further afforestations, often no doubt forming extensions of 'royal hunting-grounds' that had been converted into 'forests' by William II. and other kings down to Henry II., all of which afforestations were subsequent to the formation of the New Forest, and some of which remained forest in whole or in part down to 1598 . In fact, Manwood himself states ${ }^{3}$ that ' certain Gentlemen of great accompt . . . made their repaire to the King, and earnestly besought this King John, to graunt them, that they might have all those new afforestations, that were so afforested by King Henry the Second his father, King Richard the first his brother, or by King John himselfe, disafforested againe.'

Previous to the introduction of the Norman forest laws each of the great tracts of land forming the 'royal hunting-grounds' or silva regis seems to have been under four thagend or thegns, under whom other four lestbegend, also called jungmen in the Danish dialect, or thegns of lower degree, ranged the woods in charge of 'vert and venison,' the woodlands and the game. These were assisted in their duties by tinemen, or petty officers, upon whom devolved the nocturnal care of vert and venison, and other servile employments. All of these royal officials were armed and mounted. Enclosures were formed to prevent red deer and wild cattle from roaming beyond the bounds of the royal hunting-grounds; but the shooting of wolves, wild boars and foxes was permitted to landholders outside the enclosures. The local villeins were liable to be called upon to perform service in enclosing and stalling big game, and for this purpose every two villeins had to keep a dog. The administration was vested in the chief thegns or tbeegend who, responsible only to the king, controlled the establishment subordinate to them and dealt with offences against vert or venison.

The existing system appeared to fall far short of what William I. desired and intended to have. Soon after the Conquest he seems to have reserved as royal hunting-grounds many of the village lands remaining unenclosed, while the Crown lands were also augmented by the confiscation of the estates of landowners who had fought against him under King Harold at Senlac. At least 17,000 acres were thus appropriated

1 Hampton Court was never a 'forest,' but only an 'honour' (31 Hen. VIII. c. 5).

2 Manwood, A Treatise of Forrest Lawes (1 598 ), cap. i. fol. 5 .

8 Ibid. fol. 128. 


\section{FORESTRY AND THE NEW FOREST}

or laid under ban during the twenty years that elapsed between the Conquest and the survey for Domesday Book, and which included the date of the formation of the New Forest (1079).

Even this, however, did not go anything like far enough to satisfy the personal tastes and the feudal intentions of the Conqueror. Determined to carry out in the strictest manner the principles of the feudal law, he held that as hunting was the pastime of kings the right of the chase and of following and taking all manner of beasts of venery belonged solely to the king, and could only be exercised by those obtaining the royal license through special favour. All the animals included under game were 'ownerless property' (bona vacantia) and were therefore the property of the king. By royal prerogative he consequently had the right of pursuit and capture anywhere, and he could grant to great nobles or special favourites privileges relating to the chase in whole or in part.

Fearless, ruthless, and determined, William resolved to introduce new forest laws of far greater severity than the old English game laws, and to carry them out with stringency. But the evidence of history proves that even he shrank from boldly making new enactments in the shape of forest laws so stringent as to create grave discontent among his own Norman followers as well as to exasperate the Saxon landholders and drive them headlong to acts of sheer despair. So he determined to gain his end by fraud. Thus it came about that among the archives at Winchester a document was found purporting to be a Charta Canuti or charter of Canute the Dane, grantèd at a parliament held there in 1018 A.D., during the first year of his reign, in terms of which the sole and exclusive right to pursue and take animals of the chase was vested in the king and in those obtaining such privilege from him. This charter having been discovered, its provisions were merely carried out more regularly than had previously been done; that was all. And the 'afforestation' of the New Forest took place under the authority of this document. The authenticity of Canute's statute remained for centuries unquestioned till Lord Coke raised doubts about it, while the subsequent researches of Stubbs and Liebermann have shown that Coke's suspicions were justified, and that this supposititious charter was nothing but a Norman forgery intended solely to make what were new and very harsh and cruel Norman laws seem to be merely the stricter application of the existing English laws instead of the innovation they really were. Thus Canute was made to declare ' in the Danish tongue . . . in English this" ${ }^{1}:-$

I will and graunt that each one shalbe worthie or such venerie as he by Hunting can take eyther in the playnes or in the woods within his own fee or dominion, but each man shal abstaine from my venerie in every place where I will that my beasts shall have firme peace and quietness, upon paine to forfeit as much as a man may forfet.

By right of conquest William I. acquired not only the demesne lands which had belonged to Edward the Confessor, but also the estates

1 See Manwood, A Treatise of the Forrest Lawes (1 598), fol. I 3. 


\section{A HISTORY OF HAMPSHIRE}

derived from confiscation. And he, of course, also became possessed of all the hunting rights previously exercised in the woodlands and the open stretches comprised within the 'royal hunting-grounds.'

In making the New Forest, in 1079, William the Conqueror greatly enlarged the extent of the 'royal hunting-grounds' previously appropriated by the Saxon and the Danish kings, formed them into a compact block, and applied to their administration certain new forest laws, which were exercised in a way that entailed much oppression upon the villeins forming the rural population locally. The tracts to which the forest laws were made to apply became 'afforested,' and whole manors and villages were altogether included instead of only a portion as formerly. But just as the Norman fraud connected with the supposititious statute of Canute was not suspected for many centuries, so too were the exaggerated versions of the tyranny of William I. in the making of the New Forest accepted for a still longer time as truthful historical statements of what had really taken place. It seems unnecessary to quote at full length these various highly coloured monkish versions of the matter merely for the purpose of immediately showing that they must indeed be exaggerations and misrepresentations of the measures, harsh enough in themselves, which were actually carried out. What Henry of Huntingdon wrote (in Latin) in his history, apparently completed soon after I I 35 , may be taken as a sample of all these historians, and more especially because it formed the original text upon which many later monkish chroniclers merely rang slight changes:-

He (William the Conqueror) wrung thousands of gold and silver from his most powerful vassals, and harassed his subjects with the toil of building castles for himself. If any one killed a stag or a wild boar his eyes were put out, and no one presumed to complain. But beasts of chase he cherished as if they were his children; so that to form the hunting-ground of the New Forest he caused churches and villages to be destroyed, and, driving out the people, made it a habitation for deer.

That no official or unofficial denial of the above exists can easily be explained, seeing that the books then written were neither published nor criticized like works that have appeared since the invention of printing.

Henry of Huntingdon's version was repeated shortly afterwards by Walter Mapes, chaplain to Henry II., and again by John of Brompton, who wrote in the reign of Edward III. ${ }^{1}$ For more than six and a half

1 The most vituperative of these monkish historians was John of Brompton, who wrote thus (Cbronicon Fobannis Bromton, col. 981 of Twysden's Historia Anglicance Scriptores X. Antiqui, 1652) :-

Erat autem iste supradictus rex Willielmus sapiens sed hastutus, locuples sed cupidus, gloriosus sed famx deditus, affabilis quidem et humilis Deo servientibus, sed durus et severus sibi resistentibus : Principes namque et Consules in carcerem posuerat, Episcopos et Abbates possessionibus suis privaverat, fratri proprio non pepercerat, nec qui resisteret sibi erat. Potentissimus eciam auri et argenti multa bona ab aliis auferebat. Ad castella construenda solus omnes fatigebat. Si cervum quis caperet aut aprum, oculos ei evellebat, nec erat qui murmurat: Feras namque tanquam pater earum erat, amavit, Unde in silva venationis quae nunc Nova Foresta vocatur, villas et ecclesias plures eradicari, gentem extirpari et a feris inhabitari fecit; nam Deus ad exterminium Anglorum præordinaverat ferocem populum Normannorum quadam prarogativa sæviciei singularis præminentem, quorum natura est, ut cum hostes suos adeo depresserint quod adicere non possunt, ipsi se deprimant, et terras proprias et substancias suas in vastitatem et 


\section{FORESTRY AND THE NEW FOREST}

centuries the statements of the monkish historians seem to have been accepted without question until Richard Warner and Gough (vide Mr. Round's article in vol. i. p. 4 I I), both in 1789 , made out a good case for discrediting them to a great extent as but highly coloured versions of what actually did take place. The indictment cannot be better given here than in Warner's own words ${ }^{1}$ :-

Foresta. A forest in general : but it more particularly means, here, the New Forest, a tract of land which the Conqueror had afforested, a few years before the time of the survey. William of Malmesbury, H. Huntingdon, Walter Mapes, and some other prejudiced monkish writers, have vilified the Norman for this measure, which they reprobate as an act of merciless injustice. But a perusal of that part of our extract which relates to the forest, will convince us they cannot altogether have adhered to truth in their account of this transaction. We shall there find that the lands comprised in this tract appear, from their low valuation in the time of the Confessor, to have always been unproductive in comparison with other parts of the kingdom; and that notwithstanding this pretended devastation they sunk (in many instances) but little in their value after their afforestment. So that the fact seems to have been, William, finding this tract in a barren state, and yielding but little profit, and beingly strongly attached to the pleasures of the chase, converted it into a royal forest, without being guilty of those violences to the inhabitants, which the abovementioned writers complain of.

From the above, Warner seems to have been too much of an apologist for the Conqueror. William wished the royal hunting-grounds enlarged and more strictly dealt with : sic volo, sic jubeo: and it was done. The individual feelings of the landowners and the villeins concerned were probably rather ruthlessly dealt with, and the fraud practised regarding the forgery of the supposititious Cbarta Canuti shows that there was not likely to be any sticking at trifles. But things almost as nasty as the monks said about William have been said of the great afforestations or ' reserved forests' made within the last quarter of a century by the Government of India for the benefit of the people, of agriculture, and of the State.

The manner in which the afforestation of the New Forest was carried out may perhaps be very fairly shown by the following entries relative to part of the terra regis or 'king's lands' in the hundreds of Ringwood and Boldre, the former of which seems to have comprised some of the largest of then still wooded tracts, judging from the assessment of one holding alone as containing 'silva de 189 porcis, de pasnagio.'

pauperiem redigant; semper enim Normannorum domini cum hostes contriverint, et crudelius agere nequeant, suos hostiliter conterunt.

Besides thus reproducing Henry of Huntingdon's version of the afforestation, John of Brompton again refers to the matter in thus describing the death of William Rufus in I 100 (op. cit. column 996):-

Cumque rex Willielmus patrio more ad natale apud Gloverniam, ad pascha apud Wyntoniam, ad pentecostem apud Londoniam curiam suam gloriose tenuisset, ad novam regiam forestam Anglice Y $\mathrm{CHEN}$ dictam, quam pater suus Willielmus bastardus hominibus fugatis, desertis villis, et subreptis ecclesias per $\mathbf{x x x}$. et eo amplius miliaria in saltus, et lustra ferarum redigerat, iiij. nonas Augusti feria quinta venatum ivit, ubi quidam miles Francus Walterus cognomine Tyrell sagittam cervo incaute dirigens, regem casu, infortuito non voluntarie ad mortem percussit.

1 See R. Warner's Hampsbire extracted from Domesday Book (1 789), Glossary, p. 4, article 'Foresta.' 


\section{A HISTORY OF HAMPSHIRE}

\section{IN RincVede HundRET}

The King holds Rincvede [Ringwood] in demesne. Earl Tosti(g) held it. It was then assessed at 28 hides; now at nothing. When the sheriff received it, there were but ro hides; the rest were in (the Isle of) Wi(gh)t. There are now (only) 6 hides, the remainder being in the forest. There is land for 16 ploughs. In (the) demesne are 4 ploughs, and (there are) 56 villeins and $2 \mathrm{I}$ bordars with 13 ploughs, and I 'Radchenist' with half a plough. There is a church to which belongs half a hide in almoine. There are 8 serfs, and a mill worth 22 shillings, and 105 acres of meadow. T.R.E. it was worth 24 pounds, and afterwards 16 pounds, now 8 pounds and Io shillings; but it pays 12 pounds and 10 shillings of 20 (pence) to the ounce. On 4 hides, which are now in the forest, dwelled 14 villeins and 6 bordars with 7 ploughs; (there were) also a mill worth 30 pence and wood (land) worth I 89 swine from the pannage. That part which the King has is worth 7 pounds, 10 shillings by tale.

Again, as to Bovre hundred :-

\section{IN Bovere Hundert}

The King himself holds Linhest [Lyndhurst] which appertained to (jacuit in) Ambresberie [Amesbury], (which is) of the King's ferm. It was then assessed at 2 hides. Of these 2 hides, Herbert the forester holds now I virgate, and pays geld for that amount; the remainder is in the forest. There are now only 2 bordars. It is worth ro shillings. T.R.E. it was worth 6 pounds.

These entries apply to 'king's land,' but reductions of assessment occur very frequently with regard to land included within other estates. Thus, for example, regarding the land of Ralf de Mortemer in Mantesberg hundred :-

\section{IN Mantesberg Hundret}

The same Ralf holds a manor (called) Stradfelle [Stratfield Mortimer], which Cheping held T.R.E. It was then assessed at 5 hides, now at $\mathrm{I}$ hide. There is land for 5 ploughs. In (the) demesne are 2 ploughs; and (there are) 4 villeins and 9 bordars with I plough. There are 6 serfs, and 2 acres of meadow. T.R.E. it was worth 12 pounds, and afterwards Io pounds; it is now worth 6 pounds.

In the enquiry into the titles, tenures and assessments of the various estates the elders of the people had their full say, they forming the jury or bundredum. Thus, respecting land of Robert, son of Gerold, in Cillei [Chuteley] hundred, it is recorded that-

\section{In Cillei Hundret}

There is half a virgate of land in Gerlei [

] which Bolle held of King Edward as an alod (in alodium); but Robert added it (apposuit eam) to this manor. The (jurors of the) hundred, however, affirm that it never belonged to it (ibi). The whole, T.R.E. and afterwards, was worth 15 shillings; (it is) now (worth) 20 (shillings).

Here, again, we see the rights of the villagers represented in very much the same manner as now obtains with regard to the formation and settlement of State ' reserved forests' in all parts of our Indian empire.

If brutal harshness and inhumane indifference had been exercised, as alleged by the monks, in the afforestation of the tracts forming the New Forest, it seems highly improbable that so careful and exact a statement of the details of the various estates would have been recorded. Indeed, there is occasional evidence of a certain amount of consideration having been exercised, as in the following case of remission of taxation in one 


\section{FORESTRY AND THE NEW FOREST}

holding as compensation for disturbance on account of losing the 'right to the use of the woods belonging to it.' In the land of Bernard Pancevolt in Manesbrige [Mansbrige] hundred-

\section{In Manesbrige Hundret}

The same Bernard holds Celeorde [Chilworth]. Godwine held it of King Edward. It was then, as now, assessed at 2 hides. There is land for 2 ploughs. In (the) demesne is I plough; and (there are) 4 villeins with I plough. There are a church and 4 serfs and 3 houses in Hantune [Southampton] worth 18 pence. T.R.E. it was worth Io pounds, and afterwards 8 pounds. It is now worth (only) 4 pounds, because Bernard has no power to use (potestatem in) its woodland.

Again, in the Breston hundred-

\section{IN BRESTON HUNDRET}

The same Bernard holds Emelei [Embley in East Wellow]. Godwine held it of King Edward as an alod (in alodium). It was then assessed at half a hide; now at nothing. There is land for half a plough. It was worth ro shillings; (but) it is now waste.

And, as a final example, from the Sirlei [Shirley] hundred-

\section{In Sirlei Hundret}

Ulviet the huntsman holds Riple [Ripley in Sopley] of the King. He himself held it of King Edward as an alod (in alodium). It then paid geld for 5 hides; now for 2 hides. There is land for 2 ploughs. In (the) demesne is I plough; and (there are) 8 bordars and 4 serfs with 2 ploughs, and 40 acres of meadow.

Of this manor, 3 hides and all the wood are in the King's forest. T.R.E. it was worth 8 pounds; (it is) now (worth) 50 shillings. What is in the forest is worth I00 shillings.

Previous to the Norman Conquest offences against the game laws were punishable by fine. William I., however, who 'loved the tall (red) deer as if he were their father,' punished with mutilation offences against his forged forest laws relating to them; while William Rufus went further and exacted the death penalty, not only from Englishmen but also from Norman barons of high degree, and even from blood relatives of his own. The enforcement of the forest laws became, indeed, so oppressive during the time of William II. that the Norman barons as well as English landowners groaned under their tyranny, while the scanty rural population was grievously oppressed and harassed under their provisions. The grinding oppression of Rufus lived long in the memory of the county, as in other parts of England, where he largely increased the afforestations of the Conqueror ; and his tragic death by the arrow of Walter Tyrell in the New Forest was held to be the just judgment of Heaven for his brutal and cruel severity. Henry I. had to relax these harsh laws on coming to the throne, but later on he showed the same tendencies as his father and grandfather. So too, when his nephew usurped the throne, the new king, Stephen, was likewise full of concessions and anxious to conciliate the great landowners and the rural population at large; but he also afterwards failed to keep these early promises.

During the period of the House of Plantagenet matters in connection with the forest laws reached a crisis. Many encroachments and 


\section{A HISTORY OF HAMPSHIRE}

trespasses had been made in the king's forests during the unsettled times of Henry I. and Stephen, but during the reign of Henry II. the forest laws and their administration attained a special, well defined position side by side with the common law, and special justices were appointed to accompany the circuits of the 'justices in eyre,' who administered the forest laws; and a general visitation of all the royal forests throughout the country was made by two justices in 1166 . He promulgated a code of forest laws known as the Assize of Woodstock in I 184. In this he revived a more stringent application of the laws, though at the same time he relaxed their cruel severity by substituting fines only for the punishment of forest offences in place of the then existing brutal penalties of mutilation by loss of eyes or cutting off hands and feet. Even the clergy, untouched by English common law, were then made subject to forest law, and the royal foresters were ordered to apprehend them if found trespassing. On land included within a royal forest a landowner could cut nothing except fuel in his own woods, and such trees could only be felled in view of the forester. This Assize of Woodstock is the first genuine enactment extant with regard to forest laws and their administration.

Henry's son, Richard I., had the Norman passion for the chase. Had Cœur de Lion stayed in England in place of crusading, the forest laws would probably have been very harshly and stringently administered. After John ascended the throne matters drifted from bad to worse, with the well-known effect that the great barons revolted in defence of their own and of the people's rights, and forced him to sign the Magna Charta in I 2 I 5, by which, for the first time, the most cruel and oppressive of the provisions of the Norman forest laws and their more recent developments were practically repealed (in secs. $44,47,48,53$ ).

When the boy-king Henry III. succeeded to the throne in 1216 the question of placing forest legislation on a more satisfactory footing was one of those uppermost in the mind of parliament, and the regent, William Marschall, earl of Pembroke, on November 6, 1217 , issued a Cbarta de Foresta in the king's name. It gave the forest law a more clearly defined and important position than hitherto, side by side with the common law, and it removed some of the grossest abuses under which the people had suffered and groaned throughout a century and a half. Hitherto the penalty for killing a 'royal beast' or stag had cost a bondman his life, an unfree man his liberty, and a freeman his freedom-penalties almost as great as those exacted for the murder of a human being. Even to chase a stag so as to make it pant brought outlawry to a bondman and the loss of a year's liberty to a freeman. The Forest Charter now provided that henceforth nor life nor limb should be destroyed for killing the royal deer, but that only a fine should be exacted, with imprisonment for a year and a day in default. On his imprisonment coming to its end the offender had to find sureties for future good behaviour, or else be banished out of England. Any lord, lay or spiritual, when passing through a forest, was free to take two 


\section{FORESTRY AND THE NEW FOREST}

beasts in view of the forester; while, if no forester were present, a horn had to be sounded to show that it was a legal right he was exercising and no theft which was being committed. This Forest Charter was followed, in 1218 , by a pourallee or perambulation of all the royal forests in order to determine, now and henceforth, their true boundaries and extent. After these perambulations had been made, a new and more important Cbarta Foresta was brought on the statute book on February 1o, 1 225, about two years before the king attained his majority, in which all lands throughout the kingdom afforested by Richard or Henry I. were declared to be disafforested, except demesne woods of the Crown, while afforestations made by Henry II. were also to be disafforested wherever they could be shown to cause damage to the owners of the woods. The substitution of fines for more grievous punishments was again enacted, and, in fact, this statute can well be ranged alongside of the Magna Charta as one of the two great enactments safeguarding the lives and liberties of the king's subjects at that period and for long after. Its sixteen sections ${ }^{1}$ dealt with the following matters :-

(1) Certain Grounds shall be disafforested. (2) Who are bound to the Summons of the Forest. (3) Certain Woods made Forest shall be disafforested. (4) No Purpresture (or enclosure), Waste (or clearance), or Assart (or stubbing up roots), shall be made in Forests. (5) When Rangers shall make their Range in the Forest. (6) Lawing of Dogs in Forests. (7) In what only Cases Gatherings (i.e. collections of oats, corn, lambs, pigs, etc.) shall be made in Forests, and the Appointment of Foresters. (8) Where Swainmotes (and other Forest Courts) shall be kept, and who shall repair to them. (9) Who may take Agistment (or fees for the grazing of cattle in the royal forests) and Pawnage (i.e. the 'pawnes' or money taken for the pannage of swine in the royal woods) in Forests. (10) The Punishment for killing the King's Deer. (I I) A Nobleman (spiritual or lay) may kill a Deer in the Forest ; but this was only if 'coming to us at our commandment.' (12) and (13) How a Freeman may use his Land in the Forest. (14) Who may take Chiminage or Toll in a Forest, for what cause, and how much. (15) A Pardon of Outlaws of Trespass within the Forest. (I6) How Plea of the Forest shall be holden.

It is hardly possible in these days to realize how greatly such a charter benefited the whole of the rural population throughout England. A freeman was enabled ' henceforth, without danger' to do acts 'in his own wood' that had apparently been previously forbidden, or had at any rate led to exactions by foresters ; he could even, among other things, 'have also the Honey that is found with his Woods.' Only a forester in fee, paying farm to the king for his bailiwick, could collect chiminage from trading licensees or toll ' of those only that come as Merchants . . . to buy Bushes, Timber, Bark, Coal (i.e. charcoal) and to sell it again.' But section 10 , no doubt, afforded by far the greatest relief from the past cruel severity of the laws themselves and the brutal oppressiveness with which they must have been exercised by the forest officials, when misused to extort money from actual offenders or from those charged with offences, real or trumped up for this purpose :-

1 The full text of the Charta Foresta will be found in Owen Ruffhead's Statutes at Large (1769), i. 11-15, from which work many of the other quotations subsequently made are also taken. 


\section{A HISTORY OF HAMPSHIRE}

No man from henceforth shall lose either Life or Member for killing of our Deer : (2) But if any man be taken and convict for taking of our Venison, he shall make a grievous Fine, if he have anything whereof: (3) and if he have nothing to lose, he shall be imprisoned a Year and a Day : (4) and after the Year and Day expired, if he can find sufficient sureties, he shall be delivered; and if not, he shall abjure the Realm of England.

This great Forest Charter was formally confirmed by Edward I. in I 299, and again, along with Magna Charta, in section I of the twenty Articuli super Cbartas of $\mathrm{I} 300$, when he was in straits for money wherewith to prosecute his French war. In I 306 an Ordinatio Foreste was also passed for amending and regulating the procedure in presenting, trying, and punishing forest offences, and for dealing with lands disafforested and commons in the forests. There had been regulations brought into force before this however, such as the Assiza et Consuetudines Foresta, supposed to have been promulgated in or about 1278 (or later) for prescribing more clearly than heretofore the procedure to be adopted and the penalties to be inflicted for certain forest offences, and the statute De Malefactoribus in Parcis, 'In what Cases the killing of Offenders in Forests, Parks, and Chases, is punishable, and in what not,' in 1293 (or later). A second pourallee or general perambulation of the forests was held in 1299 to inquire into and rectify the infringements of the Cbarta Foresta of 1225, and in I 305 an Ordinatio Foreste was passed that 'They whose Woods are disafforested, shall not have Common or other Easement in the Forest.' But the statute of 1306 was by far the most important of these, as it ordained that alleged offences against vert (e.g. greenhew or cutting timber, etc.) or venison should be presented at the next swainmote and should there be tried in the presence of the foresters, verderers and other ministers of the forest. It secured, in a certain measure, something like the right of trial by jury, because the verderers (who were now to form a part of the bench) were to be chosen by the local freeholders and then appointed by writ of the king. This forest ordinance is second in importance only to the Cbarta Foresta. In the small extent of six sections' it relieved the people at large, the rural population of all classes, from many grievous hardships still experienced from the provisions of the forest laws and the tyrannous oppression of the foresters. Malpractices were common; the number of foresters was often excessive; and, poorly paid, they made money by extortion, by trumping up false charges, and by illicit traffic in vert and venison.

No forest legislation was enacted in Edward II.'s reign. But on Edward III. ascending the throne in ${ }^{2} 327$ the very first Act passed contained a section (caput 8 ) as to 'how he shall be used that is taken for any Offence in the Forest : Bailment of him,' which ordained among other matters 'That from henceforth no man shall be taken nor imprisoned for Vert or Venison, unless he be taken with the Maner (i.e.

1 (1) How Offences done in the Forest shall be presented ; (2) An Officer dying, or being absent, another shall be put in his Place; (3) No Forester shall be put in Assizes or Juries out of the Forest; (4) The Punishment of Officers surcharging the Forest ; (5) Grounds disafforested ; (6) Common in the Forest. 


\section{FORESTRY AND THE NEW FOREST}

practically 'red-handed'), or else indicted after the Form before specified.' His second Act, passed in the same year, was one of such enormous importance to the people that the first section and so much of the second as relates to the forests may well be quoted in extenso :-

Cap. i. First, That the Great Charter of the Liberties and the Charter of the Forest be observed and kept in every Article; (2) And that the Perambulations of the Forest in time of King Edward, Grandfather to the King that now is, be from henceforth holden in the like Form as it was then ridden and bounded; (3) and thereupon a Charter to be made to every Shire where it was ridden and bounded. (4) And in such Places where it was not bounded, the King will that it shall be bounded by good men and lawful, and that a Charter be thereupon made as afore is said. Cap. ii. Every Man that hath any Wood within the Forest may take Houseboot (i.e. timber for repairs to houses and tenements) and Heyboot (i.e. brushwood for hedges and fencing) in his said Wood, without being attached for the same by any Ministers of the Forest, so that he do the same by the view of the Foresters.

Again and again such confirmation of Magna Charta and the Charta Foreste formed Caput i. of statutes passed by new parliaments between 1328 and 1377 ; but the legislation brought on the statute book in 1327 ensured immense relief from the oppression and vexatious interference with the natural rights and privileges of those owning or holding land within or in the vicinity of a royal forest. That extortion and illicit practices seem to have then been rife, however, is made clear by the provisions of sections 6 and 7 of the Statute of Purveyors passed in I 350, which enacted that 'Cap. vi. A Purveyor (for the navy) shall not take Timber in or about any Person's House,' and 'Cap. vii. Keepers of a Forest or Chase shall gather notbing without the Owner's Good Will.'

Extortion and administration of the forest laws in a vexatious manner seem to have continued or to have been revived later on, because in $13^{8} 3$ Richard II. enacted (cap. iii. and iv. of statute in anno 7) that ' $A$ Fury for a Trespass within the Forest shall give their Verdict where they received their Charge,' and 'None shall be taken or imprisoned by the Officers of the Forest without Indictment.'

No forest legislation took place during the period of the House of Lancaster, but when the country had recovered from the effects of the Wars of the Roses An Act for inclosing of Woods in Forests, Chases, and Purlieus was passed in 1482 (anno 22 Edw. IV., cap. vii.). Though short, consisting of only one section, this statute was of great importance. Hitherto owners of woodlands had only been allowed to enclose, for natural regeneration and reproduction, their coppices and copses for not longer than three years after each fall ' to save the young Spring of their Wood so cut,' but now it was enacted by the king-

That if any of his Subjects, having Woods of his own growing in his own Ground, within any Forest, Chase, or Purlew of the same, within this Realm of England, from the First Day of this Parliament, shall cut, or cause to be cut the same Wood, or Part thereof, by Licence of the King, or of his Heirs, in his Forests, Chases, or Purlews, or without Licence in the Forest, Chase, or Purlew of any other Person, to make any Sale of the same Wood; it shall be lawful to the same Subjects, Owners of the same Ground whereupon the Wood so cut did grow, and to such other Persons to whom such Wood shall happen to be sold, immediately after the Wood so cut, to cope and inclose the same Ground with sufficient Hedges, able to keep out all Manner 


\section{A HISTORY OF HAMPSHIRE}

of Beasts and Cattle forth of the same Ground, for the preserving of their young Spring; and the same Hedges so made, the said Subjects may keep them continually by the Space of Seven Years next after the same inclosing, and repair and sustain the same as often as shall need within the same Seven Years, without suing of any other Licence of $\mathrm{Him}$, or of his Heirs, or other Persons, or any of their Officers of the same Forests, Chases, and Purlews. ${ }^{1}$

The love of the chase seems to have been so strong about this period as to have led to such frequent offences against the forest laws that three years later, in 1485 , cap. vii. of the statutes enacted during the first year of Henry VII.'s reign was An Act against unlaweul Hunting in Forests and Parks, in the final clause of which it was decreed:-

That if any Person or Persons hereafter be convicted of any such Huntings, with painted Faces, Visors, or otherwise disguised, to the Intent they should not be known, or of unlawful Hunting in Time of Night, that then the same Person or Persons so convict to have like Punition, as he or they should have, if he or they were convict of Felony-And the punishment for Felony was Death.

But Henry VIII. (more suo) even went a good deal further than this (cap. xii. of statutes anno 3 I, I 539 A.D.) :-

It shall be Felony to take in the King's Ground any Egg or Bird of any Faulcon, Goshawk, or Laner, out of the Nest ; or to find or take up any Faulcon, Jerfaulcon, Jerkin, Sacer or Sacerit, Goshawk, Laner or Lanerite, of the King's, and having on it the King's Arms and Verviles, and do not within twelve Days bring or send the same to the Master of the King's Hawks, or to one of his Faulconers, or to the Chief of the Shire; (2) or between the rising of the Sun, and setting of the same, with his Face hid or covered with Hood, or Visert, or painted, or disguised, to the Intent he would not be known, to enter into any Forest, Chase, or Park of the King's, Queen's, Prince's, or any of the King's Children, or into any other Ground of either of theirs inclosed with Wall or Pale, ordained for the Keeping of Deer, to the Intent to steal any of them, or to drive any of them forth of the same Forest, etc. or in or at any Time of the Day, with his Face hid or disguised, to kill any Conies or Rabbits, within any Ground, being the lawful Warren of the King's, etc. in or within any of his or their Parks; or in the Night to enter into any Park, Chase, or Forest of the King's, etc. to the Intent to steal any Deer, or into his or their Warren to kill and steal any Conies.

This statute was further extended to any 'lawful Warren or Park' during the following year (cap. xi. 32 Hen. VIII. I 540 A.D.), but both of these enactments were repealed in 1549, soon after Edward VI. ascended the throne. Two minor statutes of Henry VIII., also passed in 1540, were An Act concerning the Breed of Horses of Higher Stature (cap. xiii. anno 32), better known as the 'Drift of Forests' - which ordered that the forests, heaths, chases, commons and waste grounds should be driven once a year, on St. Michael's day or within fifteen days after it, for ascertaining that the forests were not burdened by too many horses and cattle owned by those possessing common rights, and for killing weakly mares and foals-and An Act that Fustices of the Forests may make Deputies (cap. xxxv. anno 32) for the more speedy execution of 'all things concerning the King's Forests, Parks, and Chases, and all other Things concerning the Office and Offices of the Justice of the Forests.'

1 A 'purlew' or 'purlicu' was land once afforested but subsequently disafforested after a pourallee or perambulation to determine and demarcate the true boundaries of the royal forests. Whether intentionally or unintentionally, this appears to have been the first time in which a subject is referred to as having a forest. 


\section{FORESTRY AND THE NEW FOREST}

To provide more adequate supervision over the valuable oak and other timber in the royal forests, the 'Master of the Woods' was in I 542 made an ex officio member of the "Court of the General Surveyors of the King's Lands' ( 33 Hen. VIII. cap. xxxix.).

More important, however, so far as the growth of timber and the well-being of the woodlands were concerned, was the Act for the Preservation of Woods of 1543 (anno 35 Hen. VIII. cap. xvii.), wherein specific instructions were given which will be more particularly referred to later on, when treating of arboriculture in the Crown forests (see pp 036-8).

The repeal by Edward VI. of the irrationally harsh laws of Henry VIII. as to poaching and stealing game was only what might have been expected of that gentle sovereign; and as his immediate successors on the throne were women, Mary and Elizabeth, they naturally felt less concern than men in hunting and the pursuit of game to the death. Hunting was, however, a favourite pastime of the great landowners, so an Act was passed (anno 5 Eliz. cap. xxi. 1562 A.D.) for the punishment of trespass and of poaching or unlawful hunting in 'Parks and Inclosures'; and this Act was subsequently amplified in 1605 (anno 3 James I. cap. xiii.) by An Act against unlaweful Hunting, Stealing of Deer and Conies, applying it to enclosures made subsequent to the former Act and determining the procedure with regard to the trial of offences. Later on, in I66I, there was passed (anno 13 Charles II. cap. x. I66 I A.D.) An Act to prevent the unlareful Coursing, Hunting, or Killing of Deer ' in any Forest, Chase, Purlieu, Paddock, Wood, Park or other Ground where Deer are or have been usually kept within the Realm of England or Dominion of Wales.' A more generally comprehensive Act for the better Preservation of Game and for securing Warrens not inclosed, which authorized the appointment of gamekeepers, was passed in 1670 , but neither this nor any of the subsequent enactments regarding game in general had special reference to forests or woodlands.

Close attention was given during Elizabeth's reign to the timberproducing resources of the royal forests, and a report was drawn up in I 565 by Roger Taverner, the queen's surveyor, concerning the condition of all the forests south of the Trent, while about twenty years later his successor, John Taverner, also made similar surveys ( $5^{84}$ ). The Book of Survey made by Roger Taverner $(1565)$ shows that the various woods within the New Forest were situated in the Burley Bailiwick (454 acres), Frytham Bailiwick ( 884 acres), Batramsley Bailiwick (648 acres), North Bailiwick ( I , I 90 acres), West Linwood Walk (345 acres), Goddes-

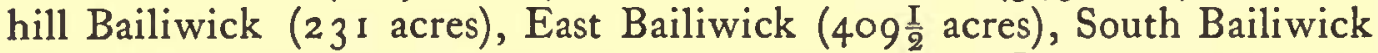
( 589 acres), Inne Bailiwick ( 540 acres), total $5,290 \frac{\mathrm{I}}{2}$ acres. All these various woods were catalogued as to their acreage, description, and the condition of the crops thereon (vide also p. 38 ). During the first year of Elizabeth's reign (1 558) there was passed An Act that Timber sball not be felled to make Coals for burning of Iron (anno I, cap. xv.), which applied to any 'Timber-tree or Timber-trees of Oak, Beech, or Ash' growing within fourteen miles of the sea or of any navigable river or stream. In 


\section{A HISTORY OF HAMPSHIRE}

I $57^{\circ}$ Henry VIII.'s Act was amended by increasing the time of enclosure for regeneration ( 13 Eliz. cap. XXV. sec. I 8-I9); and in I6OI (anno 43 Eliz. cap. vii.) An Act to avoid and prevent Divers Misdemeanours in idle and lewd Persons ordained, among other things, 'punishment for illicit cutting and mischievous spoiling of woods, trees or poles.' Queen Elizabeth alienated portions of the forest lands by letting them on lease or in fee-farm, and this led to a good deal of wastage even though the leases stipulated that the woodland tracts were to be preserved as woods or coppices. The same policy was continued when James I. ascended the throne. It was general, in fact, during subsequent reigns down to $170 \mathrm{r}$, when it was enacted (I Anne, cap. vii. sec. 5) that no 'Grant, Lease or other Assurance' should be made 'of any Manors, Messuages, Lands, Tenements, Rents, Tithes, Woods, or other Hereditaments (Advowsons of Churches and Vicarages alone excepted)' unless it were made for a term 'not exceeding one and thirty years, or three lives, or for some term of years determinable upon one, two, or three lives.' Ever since Edward IV.'s statute of I 482 , regarding enclosure for seven years, and intended to check 'waste,' there had been a gradual clearance of the woodlands for transformation into arable and pasture land. Henry VIII. legislated to check this, but the tendency towards clearance received a fresh impetus under the agricultural policy of Elizabeth and James I., although at the same time the latter, who had already in Scotland continued the attention given by his predecessors (James II., James IV. and James V.) to the preservation and improvement of woods, more than once issued proclamations relative to the 'storing' of timber-trees when the copsewoods were felled, and generally to give better effect to the intentions of Henry VIII.'s Act of I 543.

That James I. was evidently very anxious to preserve the timber in the woodlands is clearly shown in the instructions issued to a Commission concerning 'Woods' (State Papers, Domestic: I607), which orders that 'These things are to be considered in the execution of the Commission by the Commissioners and the Jury, that is to say-A Survey of the number of Coppice woods; how many acres each Coppice containeth ; of how many years' growth the same is; what every Coppice is worth by the acre; in whose possession the same is; if granted to any person, then for what term and upon what consideration; whether the trees and the standels be preserved in every Coppice according to the Statute; and what waste and spoil hath been made in the same Coppices or any of them, and by whom. . . . To consider how many acres of Coppice Woods will be necessarily reserved for the fencing and enclosing of new

1 It was otherwise, however, with specific regard to the New Forest. By the Act of 1698, more particularly referred to on Pp. $430,45 \mathrm{I}$, it was decreed that ' $T o$ the end the said Forest and premises may be perpetually estated and preserved in the Crown for public use as aforesaid, and may not be granted to any private use or Benefit, be it further enacted that in case any person or persons whatsoever shall presume to take or shall obtain any gift, grant or estate or interest of and in the said Inclosures or Wastes or any woods or trees growing thereon, every such gift, grant, estate or interest shall ipso facto be null and void, and the person or persons so taking or obtaining the same shall and is hereby made and declared utterly disabled and incapable to have, hold or enjoy any such gift, grant, estate or interest, etc.' 


\section{FORESTRY AND THE NEW FOREST}

woods to be raised that the number of the trees sold may be trebled by that planting, and whether the aldermores (i.e. little bogs), lops of thorns, and such like underwoods will be sufficient for continuing the enclosure.'

Under Charles I. certain abuses of the forest laws were again revived. He alienated large portions of the Crown forest lands by grant and sale, while he endeavoured to claim and to possess himself of tracts previously leased by Elizabeth and James I. Straining the laws he made the chief justice in eyre hold a justice seat annually in place of only once in three years, and juries were suborned to find by inquisition the king's title to such lands. Charles' action in endeavouring to extend the boundaries of the royal forests and the territories to which the forest laws applied, was curbed by An Act for the Certainty of Forests, and of the Meets, Meers, Limits, and Bounds of the Forests (anno I 6, cap. xvi. I640 A.D.), better known as the 'Act for the Limitation of Forests.' This determined the limits and boundaries of the royal forests, once and for ever, as being what they had been in the twentieth year of the reign of James I.- ' any Perambulation or Perambulations, Presentments, Extents, Surveys, Fudgments, Records, Decrees, or other Matter or Thing whatsoever to the contrary notwithstanding'-for the no longer loyal Commons 'in this present Parliament assembled' were tired of the grinding oppression and vexatious tyranny of the forest laws and were resolved to end the nuisance. Where no justice seat, swainmote, court of attachment, etc., had been held within sixty years, such place was not to be accounted forest ; commissions were to be issued for ascertaining the boundaries of all forests, as in 1622 , and lands thus disafforested were to be excluded from the forests subject to forest laws; and the tenants, owners, etc., of such excluded lands were to enjoy their ancient rights of 'Common and other Profits and Easements within the Forest.' This gave the death-blow to the previous tyranny of the forest laws, and it very speedily led to the virtual abolition of the forest courts. Indirectly it also gave fresh impetus to the transformation of woodland tracts into arable and pasture lands, while wholesale clearance and sale of timber turned many wooded parts of England into stretches of barren moor and heathy waste. With the greatest of the naval dockyards situated in Hants, this county must probably have felt in a very considerable degree these indirect effects of the Act of Limitations.

The only Act of Charles II., except that already mentioned (p. 427), applying generally to woodlands throughout England was An Act for the Punishment of unlaweful cutting and stealing, or spoiling of Wood and Underwood, and Destroyers of young Timber-trees ( 15 , cap. ii. I 66 3 ), amplifying and extending Elizabeth's Act of $\mathrm{r} 60 \mathrm{I}$ to misdemeanants, procurers, and receivers, and ordaining punishment of suitable damages to the owner and a fine up to Ios., or in default thereof a whipping and up to a month's detention in the house of correction, for the first conviction, one month's hard labour in the house of correction for a second offence, and on a third conviction they 'shall be taken, adjudged and deemed as 


\section{A HISTORY OF HAMPSHIRE}

incorrigible Rogues.' And in those days a rogue of the second degree could be put to death as a felon if he were above eighteen years of age.

The next measure of forest legislation was one specially affecting Hampshire, as it was An Act for the Increase and Preservation of Timber in the New Forest in the County of Soutbampton, passed in 1698 (9 \& 10 Wm. III. cap. xxxvi.), authorizing the immediate enclosure of 2,000 acres, ${ }^{1}$ and of other 200 acres annually for twenty years, making 6,000 acres in all. Thereafter, as the young woods should outgrow danger from browsing of deer, etc., the enclosures were to be removed and fresh land enclosed, 'to remain in Possession of the Crown for ever, as a Nursery for Wood only,' thus contemplating ultimately bringing up the total to twice 6,000 acres, or I 2,000 acres in all. The pollarding of trees, and lopping and topping to provide browse-wood, were prohibited. Charcoal was not to be made within 1,000 paces of any enclosure, but right of common of pasture, etc., was preserved in the forest, and the Act was not to alter the forest laws. A general Act was also passed (anno 3 \& 4, Wm. \& Mary, cap. x.) 'for the more effectual Discovery and Punishment of Deer-stealers' in forests and parks.

Two Acts in Queen Anne's reign were passed relative to game, but the next enactment referring to woods generally was An Act to encourage the Planting of Timber-Trees, Fruit-Trees, and otber Trees, for Ornament, Shelter, or Profit; and for the better Preservation of the same; and for the Preventing the Burning of Woods (I Geo. I. stat. 2, cap. xlviii. I 7 I 5), holding parishes liable to owners for malicious damage to timber-trees and directing how offenders should be dealt with and punished. This Act was explained and amended in I7 I9 (6 Geo. I. cap. xvi.). Without repealing any former law against deer-stealers, he also passed An Act for the further Punisbment of such persons as shall unlawfully kill or destroy Deer in Parks, Paddocks, or otber inclosed Grounds by transportation to the American colonies for seven years (5 Geo. I. cap. xxviii.), the procedure being slightly amended in I72I (anno 8, cap. xix.). Offences against game and timber appear to have been very frequent about this time, judging from the legislation, and apparently even the royal forest-officers were often poachers and deer-stealers. Thus, in I 7 I 8 (anno 5, cap. xv.), forestofficers illegally killing deer or confederating with deer-stealers were to be fined $f_{5} 5^{\circ}$, or in default thereof to be imprisoned for three years and set in the pillory, while by An Act for the more effectual punishing wicked and evil disposed Persons going armed in disguise, etc., persons appearing armed 'and having his or their faces blacked, or being otherwise disguised,' in any forest, park or enclosed ground, or maliciously destroying trees, 'being there of lawfully convicted, shall be adjudged guilty of Felony, and shall suffer Death as in Cases of Felony, without Benefit of Clergy' (anno 9, cap. xxii. 1722). The 'hunting, taking in toils, killing, wounding, or taking away any Red or Fallow Deer in any open or unenclosed Forest

1 Rufthead and Pickering, in their collections of The Statutes at Large, both inadvertently give the area to be enclosed as 200 acres, although the Act distinctly fixes it at Two Thousand; but it is correctly given in Raithby's issue. 


\section{FORESTRY AND THE NEW FOREST}

or Chase' was made punishable with seven years' transportation to America for a second conviction; and a similar penalty was incurred for beating or wounding forest-keepers and pages (ro Geo. II. cap. xxxii. 1737).

Slight amendments were made to the game laws in George II.'s reign (anno 26, cap. ii. ; anno 28, cap. xii.), but the Acts more immediately concerning woodlands consisted in making the illegal burning 'of any Goss, Furze or Fern, growing or being in or upon any Forest or Chase, within that part of Great Britain called England' punishable with a fine of 40 s. to $f_{5} 5$, and An Act for inclosing by the mutual Consent of the Lords and Tenants, Part of any Common, for the Purpose of planting and preserving Trees fit for Timber or Underwood; and for more effectually preventing the unlawful Destruction of Trees (29 Geo. II. cap. xxxvi.), which was amended in 1758 (anno $3 \mathrm{I}$, cap. xli.).

Apart from enactments more particularly of the nature of general game laws there has been a considerable amount of legislation regarding forests and woodlands during the last 140 years. The more important of these consist of (1) An Act for encouraging the Cultivation, and for the better Preservation of Trees, Roots, Plants, and Shrubs (6 Geo. III. cap. xxxvi. I 766), relating to timber-trees (oak, beech, ash, elm, fir, chestnut and aspen); (2) An Act for the better Preservation of $\mathcal{T}$ imber Trees, and of Woods and Underwoods; and for the furtber Preservation of Roots, Shrubs, and Plants (6 Geo. III. cap. xlviii. I 766), which added walnut, cedar, lime, sycamore and birch to the list of timber trees-afterwards extended in I773 to poplar, alder, maple, larch and hornbeam) ; (3) An Act for the Increase and Preservation of Timber in Dean and New Forests $(48$ Geo. III. cap. Ixxii. I 808), confirming, enforcing and rectifying certain irregularities in William III.'s Act of 1698 ; (4) An Act in 18 I 2 (52 Geo. III. cap. clxi.) authorizing the sale of Crown lands lying intermixed with private lands within the royal forests; and (5) An Act to extinguish the Right of the Crown to Deer in the New Forest, and to give Compensation in lieu thereof; and for otber purposes relating to the said Forest (I 4 \& I 5 Vic. cap. Ixxvi. I $85 \mathrm{I}$ ), better known as the Deer Removal Act. Minor Acts dealt with the disafforestation of the forests of South or Bere ( 8 Io) and of Parkhurst (1812), and with the enclosure of open commonable land within them, as well as with the better cultivation of navy timber

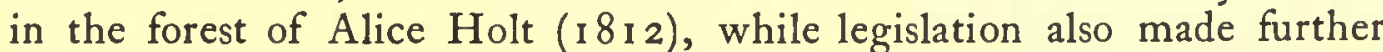
provisions for disafforestation in the Isle of Man (1860, I865); but by far the most important of all these was the Deer Removal Act of I 85 I.

The Statute Book teems, more especially between the years 1796 to 1800 , with private Acts 'for dividing, allotting and inclosing' open fields, commons and waste grounds ; but these appear to be less numerous as regards Hants than those relating to many other counties.

The Timber Preservation Act of 1808 was the outcome of a royal commission appointed by a special Act in 1786 (26 Geo. III. cap. lxxxvii.) to inquire into the state and condition of the woods, forests, and land revenues of the Crown, which submitted seventeen reports 


\section{A HISTORY OF HAMPSHIRE}

during the years 1787 to 1793 . The reports having special reference to Hants are the fifth (1 789 ) dealing with the New Forest, the sixth (1790) concerning Alice Holt and Wolmer, and the thirteenth (1792) relating to Bere. The improvements ordered with regard to the New Forest not proceeding rapidly enough, a map of it was in 1812 ordered to be made and to be completed within five years $(52$ Geo. III. cap. clxi. sec. I 9). ${ }^{\mathrm{I}}$

The Deer Removal Act of $185 \mathrm{I}$, likewise due to the report of a royal commission in 1850 -appointed under An Act to authorize Her Majesty to issue a Commission to inquire into and report upon Rights and Claims over the New Forest in the County of Soutbampton and Waltham Forest in the County of Essex (I 2 \& I 3 Vic. cap. lxxxi.), and presided over by Lord Portman-empowered the enclosure of up to 10,000 acres in lieu of the right to keep deer, and in addition to the 6,000 acres provided by

1 To the exceedingly full and complete (fifth) report on the New Forest in 1789 an excellent map was attached, which still remains the best map ever published of the forest. It was surveyed in separate sections by Messrs. Thomas Richardson, William King, and Abraham and William Driver. A complete terrier was also made out by those surveyors giving a full description and valuation of every acre of land within the perambulation of the forest that either belonged to or had been encroached from the Crown. In 1800 an Act was passed 'for the better preservation of timber in the New Forest and for ascertaining the boundaries of the said Forest and of the lands of the Crown within the same.' Under this Act another royal commission (having no reference to the commission of 1786) was appointed, consisting of Messrs. Nathaniel Bond, John Lens and James Burrough, all barristers-at-law, who were directed "to ascertain and distinguish the boundaries of the said forest called New Forest, and of the lands of His Majesty's subjects within the same, and to enquire of Purprestures, Encroachments and trespasses on the soil of His Majesty within the boundaries of the said forest.' They were further directed to "cause a map or plan to be made of the said forest, in which map or plan the boundaries of the said forest and the lands within the same belonging to His Majesty as ascertained and settled by the said Commissioners shall be accurately and distinctly marked, set out and distinguished, and the lands within the bounds of the said forest belonging to other persons shall also be marked and distinguished in the said map or plan, so far as the said Commissioners shall be able to ascertain the same; and the said Commissioners shall cause two parts to be made of such map or plan, and they or any two of them shall attest and certify the truth and accuracy of both such parts, by signing their names thereto ; and one part of the said map or plan so certified by the said Commissioners, or any two of them, shall be transmitted by them to the Steward of the said forest, or his under-steward, to be deposited among and kept with the records of the Courts of attachment of the said forest, held at Lyndhurst in the said county of Southampton, and the other part of the said map or plan, certified as aforesaid, shall be transmitted to the auditor of the land revenue, to be kept in his office.'

The boundaries of the forest were ascertained and a perambulation thereof made in 1801 , which has been acted upon ever since as defining the true boundaries; but, although the powers of the Commissioners were extended by a short Act passed in 1801 , and again in 1811 , the map (probably for lack of funds) was never made. In 1812 (52 Geo. III. cap. clxi. sec. 19) yet another Act relating to this plan was passed, by which the powers for making it were transferred from the original commission to the Commissioners of his Majesty's Treasury 'to employ surveyors or other proper persons in framing such map or plan, and they are hereby required to complete the same within five years from and after the passing of this Act.' Accordingly, in $1817, \mathrm{Mr}$. Kelsey of Salisbury was employed to make an independent survcy of the New Forest, and to prepare a plan which should show the boundaries of all lands belonging to the Crown within the forest, and of course, incidentally, the boundaries of all private property bordering on Crown lands was also shown, with all the encroachments which had been made from time to time. A plan was prepared on a larger scale than that of Messrs. Richardson, King and Driver of some thirty years previously, and the boundaries of all the lands were accurately laid down, so that for all questions of dispute as to boundaries within the forest it serves to this day as a true record. But the map was never completed in duplicate as originally ordered, nor was it deposited either with the auditor of the land revenue or among the records of the courts of attachment. Neither was it signed and certified according to the instructions to the original royal commission. The map therefore, though useful as a record, has not the effect of being indisputable legal evidence on any such point as to boundaries which it was intended that it should be by the terms of the original act. One copy only exists of this plan, and it is kept in the office of the deputy surveyor of the New Forest, where it is constantly referred to. 


\title{
FORESTRY AND THE NEW FOREST
}

the Acts of 1698 and 1808 , such enclosures to remain in possession of the Crown, freed from all common and other rights. When the trees within the enclosures had outgrown danger from browsing of cattle these areas were to be thrown open and new enclosures made. It also provided for a register being made of all persons having rights of common over the New Forest, and for these rights being defined. The provisions of this Act gave rise, however, to so much bitterness locally, and to such an outburst of æsthetic feeling generally, that work was stopped when about 5,000 acres had been planted up, more or less. From the passing of this Act the ancient character of the forest was changed while it was still maintained intact as a royal forest, and from that date the modern history of the forest may be"said to have commenced; but fuller details concerning this important measure will be found on p. 454 In 1866 An Act to amend the Law relating to the Woods, Forests, and Land Revenues of the Crown was passed $(29 \& 30$ Vic. cap. 1xii.), but it merely affected the issue of licenses for hunting, hawking, fishing and fowling in the New Forest. Subsequently, in 1877, An Act to amend the Administration of the Law relating to the New Forest was passed. This limited re-enclosure and replantation to the plantations formed since 1700 ; and as these are mostly woods still growing, the provisions of the Act are now only partially in operation. Lands previously enclosed could at any future time be re-enclosed and replanted,-

\begin{abstract}
provided that the whole quantity of such lands under inclosure does not exceed at any one time 16,000 acres. Provided also ... that in cutting timber or trees for improving the woods, or for sale, care shall be taken to maintain the picturesque character of the ground, and not wholly to level or clear the woods, but to leave from time to time a sufficient number of the most ornamental trees; and to keep the woods replenished from time to time by protecting the self-sown plants, or by planting trees in the vacant spaces, having regard to the ornamental as well as the profitable use of the ground.
\end{abstract}

The constitution of the Court of Verderers was at the same time amended and their legal status and powers defined. Under this Act the New Forest is now administered more as a great national park than for the growing of timber on commercial principles (vide also pp. 455-464). One of the chief results of the Deer Removal Act was the almost complete extermination of the deer which for centuries had roamed at large within the woods and over the heaths; but specific details concerning red, fallow, and roe deer in Hants have previously been given on pp. 246,247 of vol. i.

The Acts now having general application to woods and trees, etc., are those passed in 1861 in the shape of An Act to consolidate and amend the Statute Lawe of England and Ireland relating to Larceny and otber similar offences $(24 \& 25$ Vic. cap. xcvi. sec. 16 as to 'any Forest, Chase or Purlieu'; secs. $3^{1}, 32,33,35$ as to trees and woods), and the similar Act relating to Malicious Injuries to Property with regard to ornamental trees and shrubs $(24 \& 25$ Vic. cap. xcvii. secs. 20, 2 I, 22, 53).

In Hampshire there are both forests and woodlands; but the forests are not necessarily wooded-they may be either woods or 'wastes'-nor 


\section{A HISTORY OF HAMPSHIRE}

are the woodlands necessarily forests. There is no legal definition of the word forest. Even the Forest Acts passed in India during the last twenty to twenty-five years carefully avoid any attempt at its specific definition. The Hants forests are merely tracts which were at one time afforested by royal command, and to which, not having since been disafforested after any subsequent perambulation, the forest laws still apply. In early times the king merely sent out a commission under the great seal of England, for the view, perambulation, and bounding of certain tracts, wooded or otherwise, which he desired to afforest ; and after this record had been returned into the chancery the sheriff of the county was ordered to proclaim that none should, without the king's special license, hunt or chase any manner of wild beast within the said limits. It thus became a chase (cbaseus), or sanctuary for game and other wild animals; but it was not a forest until certain forest officers had been appointed, when it became subject to particular forest laws and to special courts and officers for administering the same. No subject could appoint or maintain such officers, hence only the king could possess a forest for his own use and recreation. Any forest or portion of a forest granted to a subject consequently again became at once a chase ${ }^{1}$; because, although the other forestofficers might remain, the justice in eyre, the highest officer of all and essential to a forest, could only be appointed by, and act as, the commissioner of the king. A chase was thus a large unenclosed tract forming a sanctuary for beasts of venery. Usually smaller in area than a chase, a park (parcus) was also a sanctuary for wild animals, and held by subjects either through prescriptive right or else by license from the king. But it differed from a chase in being 'imparked' or enclosed within a fence ; and if the enclosure was not maintained the king could seize on it, and afforest it as being a free chase. Still lower than this in degree came a warren (warrenus), defined by Cowell as ' a Franchise or Place privileged, either by Prescription or Grant from the King, to keep Beasts and Fowls of Warren, which are Hares and Conies, Partridges and Pheasants.

A Free-Warren may lie open, for there is no Necessity of inclosing the same as there is of a Park; which ought to be seized into the King's Hands if it be not inclosed.' Chases, parks and warrens were subject only to the common law of England, whereas forests were solely subject to the forest law, at any rate ever since Henry III.'s time, after the passing of the Charters of the Forest (1 1 1, 1 225). From the time of Edward I. onwards most of the great nobles had chases or parks, and the Patent Rolls frequently record the grant of royal license to impark. In Cowell's Law Dictionary, I 727 (2nd edit., article 'Forest') it is said that 'Besides New Forest there are 68 Forests in England, I 3 Chases, and more than 78 I Parks.' These 68 forests are enumerated in detail by St. John in his Observations on the Land Revenue of the Crown, 1787 (pp. 118-22). So far as Hants is concerned, the New Forest, Bere, Alice Holt and Wolmer are there classed as ' real forests, which are

1 Unless by a special Act of Parliament, as in the case of the Forest of Dean, granted, as a Forest, to the Duke of Gloucester in 1390 (14 Richard II. c. 13). 


\section{FORESTRY AND THE NEW FOREST}

reputed to have preserved their jura regalia, that is, the jurisdiction, laws, courts, officers, game, and boundaries' ; while Buckholt, Chute, and Parkhurst, though still under the survey of the exchequer, are included among the "nominal forests and chases, some of which have been inclosed, and are demised as part of the land revenue, and in others the rights of the Crown have been totally granted away.'

In I 788 the New Forest was found to have been previously divided into nine bailiwicks, and subdivided into fifteen walks; and for its administration there were a lord warden, lieutenant, riding forester, bow-bearer, two rangers (of the purlieus), a woodward and under woodward, four verderers, a high steward and under steward, twelve regarders, nine foresters or master keepers, and fifteen under foresters or groom keepers.

The forest itself consisted of vert and venison, the former including all trees, coppices, and turf, and the latter all beasts of the forest (hart, hind, hare, wild boar, and wolf), of the chase (buck, doe, fox, marten, and roe), of the park (as for the chase) and of the warren (hare, rabbit, pheasant, and partridge).

The forest-officers charged with the care of vert and venison, and with the administration of the forest laws, consisted in each forest of a justice in eyre, verderers, regarders, foresters, agistors, woodwards, and a steward ; but besides these there were usually a lord warden, lieutenant, or master forester, appointed by the king in each forest, and there might also be other officers by local custom.

The justice in eyre, the chief forest-officer, was an office of great dignity, generally held only by a peer being a privy councillor. Originally there were three of these, but ever since Henry III.'s Forest Charter there were usually two justices in eyre or justiciarii itinerantes, distinguished from the justices of oyer and terminer because of their touring through their respective provinces north and south of the Trent, since they had no power to delegate their duties to a deputy until 1540 (32 Hen. VIII. c. 35). Each of these two justices in eyre had jurisdiction over all the forests within his district, and no other officer had any general superintendence of the forests before the reign of Henry VIII.

The other forest-officers merely held local appointments. The verderers (viridarii), of whom four were usually appointed to each forest, were judicial officers chosen by the king's writ from among the local gentlemen, and sworn to maintain and keep the assizes of the forest,

1 The Third Report (dated 3rd June, 1788) of the Commissioners appointed to inquire into the State and Condition of the Woods, Forests, and Land Revenues of the Crown gives, in Appendix No. 1 :-

An account of the several Woods, Forests, Parks, and Chases, under the Survey of John Pitt, Esq., as Surveyor General of His Majesty's Woods and Forests; viz. New Forest, Alice Holt and Woolmer Forest, Bere Forest (Hampshire); Windsor Forest and Cranbourne Chase, Windsor Great Park, Windsor Little Park (Berkshire); Richmond Park (Surrey); St. James's Park, Hyde Park, Bushy Park, Hampton Court Park (Middlesex); Dean Forest (Gloucestershire); Greenwich Park (Kent); Waltham als Epping Forest (Essex); Whittlewood Forest, Salcey Forest, Rockingham Forest (Northamptonshire); Whichwood Forest (Oxfordshire). All the above-mentioned Forests and Parks are on the South Side of the Trent. Sherwood Forest (Nottinghamshire), on the North Side of the Trent. 


\section{A HISTORY OF HAMPSHIRE}

and to view, receive and enrol the attachments and presentments of all manner of trespasses against vert and venison to be brought before the justice in eyre. They were judges in the swainmote court, and directed the other local forest-officers. They were expected to have a good knowledge of forest law, but were usually assisted by a steward (senescallus) with regard to technical matters such as mainprise or bailment and the like. The verderers corresponded to the four tbagend, or greater thegns of the Saxon and Danish times, while the regarders corresponded to the lesthegend, or lesser thegns.

The regarders (regardatores), of whom there were twelve for each forest, were officers appointed (under the great Forest Charter) to supervise all the local forest-officers. They had to go through the whole forest once every third year, when a 'regard' or visitatio nemorum was ordered by the issue of the king's writ to the sheriff. During such triennial regards the regarders, accompanied by the foresters and woodwards, were to view all assarts, wastes, and purprestures, and to enquire into all offences in the forest. If any of them died or fell sick, his place had to be filled up before any regard could be made; and all twelve had, like a jury at common law, to be unanimous before they could legally certify a presentment and enrol it for trial. They had also to examine the woods and the falls of timber, the hedges and fences, the forges and mines; to make inquiries about those who had bows, arrows and dogs; and they had to see that the brutal law regarding the laming of dogs or 'expeditation' of three claws of a forefoot (introduced by Henry II.) was duly carried out on all mastiffs owned by landowners, freeholders, farmers, etc., dwelling within the forest.' 'Every one that keeps any great dog, not expeditated, forfeits three shillings and fourpence to the king' (Cowell). Only the dogs of abbots and their monks were exempt from this rule, and Henry VII. granted special exemption in this matter to the abbot and monks of Beaulieu. ${ }^{2}$ The

1 The so-called 'Stirrup of Rufus,' so well known to all visitors to the Verderers' Hall at the King's House, Lyndhurst, has for ages hung there as the ancient gauge of the dogs allowed to be kept in the forest without expeditation, the 'lawing' being carried out on all 'great dogs' that could not pass through the stirrup. From the appearance of the latter, however, it seems highly improbable that its antiquity can be so great as tradition accredits to it.

2 Lewis, Historical Inquiries concerning Forests and Forest Laws (1811), p. 37. As a matter of fact, however, during the fourteenth century the expeditation of dogs seems to have been at any rate sometimes, and perhaps even customarily, compounded for by a money payment in place of being strictly enforced. Thus in the 'Pleas of the Forest in Co. Southampton, at Southampton on Monday next after the translation of St. Thomas the Martyr, 4th Edw. III. (1 330), before John Mantravers, Robert de Asspale, William de Ponte Roberti, and Hugh de Hanslap, justices in eyre, the following entries occur :

'From John son of Richard de Winton Knight and Joan his wife; from Edmond de Kendale and Henry de Harnhulle, tenants of the land and tenements which were of John son of Thomas, at one time keeper of the forest, for two expeditations of dogs received by the said John son of Thomas in his time, 690 . From the heirs and tenants of the lands and tenements of Roger de Inkpenne, at one time keeper of the forest aforesaid, for one expeditation of dogs received by him in his time, $£_{50}$.'

Presumably the keepers died without accounting for the above sums received by them, and their heirs were held responsible. But these are large sums for that date, and the value of such expeditation fees over the whole forest must have been considerable.

Again, at the "Pleas of the Forest at Winchester on the morrow of St. Hilary 8th Edward I., before Roger de Clifford, John Lovetot, Geoffrey de Pyscheford, William de Hamelton, Justices assigned to hear and determine the pleas ... The foresters, verderers, regarders and other powers of the New 436 


\section{FORESTRY AND THE NEW FOREST}

regarders were chosen from among knights at first, but subsequent nominations were made outside this class. They were appointed either by the king's letters patent, or by the justice in eyre, either at the general eyre or 'justice seat,' or at such times as the regard was ordered; and when any of the twelve regarders were absent from a court of swainmote, the justice in eyre could complete the number by a temporary appointment.

The foresters (forestarii) or keepers of the forest, were officers whose duty was 'to walk the forests both early and late, watching both the Vert and the Venison, attaching and presenting all Trespasses against them within their own Bailiwick or Walk' (Cowell, op. cit.). They were usually appointed under letters patent quamdiu se bene gesserint, but some were 'foresters-in-fee,' holding the office for themselves and their heirs on payment of a fee-farm rent to the king; and the appointment might then be held by a woman, her husband acting for her as forester-in-fee. The number of foresters varied with regard to the different forests, according to the discretion of the regarders. The office was liable to great abuses and oppression. Foresters were often appointed in excessive numbers, and lived by extortion and illicit exactions, hence special legislation was necessary from time to time (vide $\mathrm{p} .425$ ) to protect the lieges from persecution and annoyance of this sort. A similar but later appointment (applying to purlieu land only) was the ranger (rangeator), although in some later Acts he is also called regardator, whose 'Office chiefly consists in three points: To walk daily through his Charge, to see, hear, and inquire, as well of Trespasses as Trespassers in his Bailiwick; To drive the Beasts of the Forest, both of Venery and Chase out of the disafforested into the forested Lands; And to present all Trespasses of the Forest at the next Court holden for the Forest. This Ranger is made by the King's Letters Patent, and hath a Fee of Twenty or Thirty Pounds paid yearly out of the Exchequer, and certain Fee-deer' (Cowell). The ranger was therefore properly a purlieu officer, and not really an officer of the forest.

The woodwards (woodwardi) were vert officers (appointed at a comparatively recent date only) subordinate to the foresters, and like them varying in number according to the extent and local circumstances of each forest. They had to walk the woods with bills or hatchets, and might not carry bows and arrows. The nature of their functions may be gathered from their oath :-

You shall truly execute the office of a Woodward of B. woods within the Forest of W., so long as you shall be Woodward there; you shall not conceal any Offence either in Vert or Venison, that shall be committed or done within your Charge, but you shall truly present the same, without any Favour, Affection, or Reward. And if you see or know any Malefactors, or find any Deer killed or hurt, you shall forthwith do the Verderer to understand thereof, and you shall present the same at the next Court of the Forest, be it Swainmote, or Court of Attachment. So help you God.

Forest say upon their oath that the men of the New Forest of Lymithorn (Lymington) are quit, and ought to be, of expeditating their dogs, of the same town, up to a certain number, to wit 32 dogs; And if there are more mastiffs in the said town they ought to be expeditated, or expeditation shall be given for them according to the custom of the assize of the Forest.' 


\section{A HISTORY OF HAMPSHIRE}

The agistors (agistatores), of whom there were four for each forest in which there were woods, were officers appointed to superintend, receive, and account for the agistments or payments made for the pannage of swine and the grazing of cattle within the royal woods. The Domesday record constantly refers to tribute of swine, woods being entered as 'silva de $\mathbf{x}$ porcis,' and the like ; but such tribute in kind was subsequently commuted into a money payment. In early times such pannage probably ranked second in value only to wood for building, fences and fuel, and was of far more importance than rough pasture for cattle and the honey from the wild bees, because the great herds of swine were then one of the peculiar features of rural wealth in Hampshire. Even down to recent times pannage of swine has remained an important branch of rural economy in Hants. 'The hogs in the neighbourhood of the forests feed principally upon acorns and beech-mast, which has given them a superiority over most others in the kingdom; they weigh from I 6 to 40 score of pounds.' ${ }^{\prime}$ The agistments in later times included herbage from woods, open lands and pastures, as well as pannage ; and the agistors had to take in and feed the cattle of those having right of common in the king's forest, to collect the money due for pannage and grazing, to present the accounts thereof to the justice in eyre at each justice seat, and to prevent trespass by cattle. Appointments to the office of agistor were made by letters patent under the great seal.

Besides the above officers essential to a forest, there sometimes (as in the case of the New Forest) was a lord warden, chief warden, lieutenant, or master forester, usually a nobleman of high degree, and performing merely nominal ministerial but not judicial functions; and there might also be other minor officers, such as bow-bearers, riding foresters, and so forth, according to local custom.

Of forest courts there were three distinct kinds: (I) the woodmote (as it was originally called) or court of attacbment (as it was termed in Henry III.'s Charta de Foresta), (2) the swanimote or swainmote, and (3) the justice seat or court of the chief justice in eyre, the highest of the three and the only court of record capable of entering and executing judgments on offenders.

' The first two of these Courts were composed of the Officers in each Forest. The Court of Attachment or Woodmote ought to be held every Forty Days, at which Court every Officer in the Forest should attend. This Court was to enquire into all Offences of every Kind done in the Forest, and to present them at the Swainmote Court, and to the Lord Chief Justice in Eyre.

'The Court of Swainmote, in which the Verderers were the Judges, should be held Three Times in every Year. The First Court should be held Fifteen Days before Midsummer, for the Purpose of clearing the Forest of all Animals (except Deer) for the next Month, called the Fence Month, which is the Fawning Season, during which the Deer ought to be left undisturbed; and a severe Penalty is incurred by introducing any other Beast into the Forest at that Time. The next Swainmote Court should be held Fifteen Days before Michaelmas, when the Herbage Money for Cattle should be received, and the Swine should be admitted into the Forest, to feed on Acorns and Beech Mast, called Pannage, which should be paid for at the Third Court, to be held

\footnotetext{
1 Driver's Agriculture of the County of Hants (1794), p. 27.
} 


\section{FORESTRY AND THE NEW FOREST}

Forty Days after Michaelmas, videlicet, on the Feast of St. Martin. At that Time the Forest should again be cleared, and no Animal (except Deer) admitted, from the I Ith Day of November until the 23rd Day of April (Old Stile) which Period is called the Winter Haining.

'At this Court the Presentments of the Court of Attachments ought to be received, and inrolled, the smaller Offences tried, and those of more Importance presented to the Justice in Eyre, to whom the Rolls of this Court ought to be certified at the next Sessions of Eyre ; and those Rolls should contain an Account of every Offence committed, of every Deer killed, and of every Tree felled in the Forest; by what Warrant, and of what Price or Value ; with every Fine imposed ; and the Agistment, or Money paid for the Pasturage of Cattle and Pannage of Swine.

' The Court of Justice Seat ought to be held in each Forest once in every Three Years, when the Rolls of those inferior Courts should be presented to the Chief Justice in Eyre, and the Offences tried.' 1

The woodmote or forty day court was simply a court of inquest, at which, if the offence charged seemed capable of being proved, the offender could be committed for trial at the next swainmote. In place of being held every forty days as ordered by law, it was wont to be held at the will of the chief officers of the forest; and this gave rise to much oppression and extortion.

The swainmote was a court held under the jurisdiction of the verderers, assisted by their steward and with a jury chosen from among the swains or freeholders of the forest who might be present in court. For the purpose of furnishing a representative jury each town and village within the forest had to send a reeve and four swains, and all the freeholders owed suit and service as jurymen when thus called upon. The swainmote tried all charges presented by the woodmote, committed grave offences to the next justice seat, and ordered conviction and fine as to minor offences brought home to offenders; but as it was not a court of record these convictions had to be certified, under the seals of the jury, to the justice seat for confirmation by the chief justice in eyre before the final judgment could issue and its execution be carried out. The court of swainmote is still in existence, in a greatly modified form, and is held in the verderers' hall of the King's House at Lyndhurst. ${ }^{2}$

The justice seat was the high court for the trial of forest offences of all sorts. Originally held at indefinite periods, upon a general summons being issued to all men within the county-a disturbance which they greatly resented - it was afterwards ordered to be held once every third year for the hearing and determining of 'all trespasses within the forest, all claims of franchises, liberties and privileges, and all pleas and causes whatever therein arising' (Lewis, op. cit. p. 39). Here the chief justice in eyre sat, assisted by some one learned in forest law and by a jury of eighteen, twenty or twenty-four chosen from among the freeholders and others in court. It was the only court of record for inflicting fine or imprisonment for forest offences. The convictions of the swainmote were confirmed and judgments entered regarding minor offences, and decrees were issued for executing them; while it was the court of original trial for all

1 Third Report of the Commissioners, etc. op. cit. pp. 8, 9.

2 In Dean Forest the ancient Court of Verderers exists in the old form and holds its Courts of Swainmote and Attachment as of yore. 


\section{A HISTORY OF HAMPSHIRE}

the more serious charges sent up to it by the swainmote. The proceedings of the justice seat or any miscarriage of justice could only be removed by writ of error into the court of king's bench at Westminster, to which also the chief justice could refer any point of law if he thought necessary.

There were many quaint proceedings at the justice seat, including not only the oath of allegiance to the king taken by all inhabitants of the forest on attaining the age of twelve years, but also various ancient customs connected with the holding of offices, which have now all died out.

The iter, or circuit of the justices in eyre or of their deputies, was continued down to $6_{35}$, when Lord Holland held a justice seat in Alice Holt and Wolmer Forests, the records of which are preserved in the Public Record Office. But the Act of 1640 virtually put an end to these circuits. Charles II. tried to revive the practice, though only one circuit was made, that of Vere, Earl of Oxford, held at Lyndhurst in I 669 and I 670 . The ancient royal coat of arms which was provided for this occasion still hangs, having been carefully restored, in the Verderers' Hall at Lyndhurst. ${ }^{1}$ Seven years after this date a Commission was issued by Charles II. to enquire into the condition of the New Forest and of the various abuses therein. An enquiry was held at Lyndhurst in August, I677, and much evidence of the usual sort was given as to damage to coppices by cutting of trees either illegally or in contravention of the existing leases, by turning cattle into them and similar offences. It was not until I $_{17} 7$, however, that they were legally abolished by An Act to abolish the Offices of the Warden, Chief Zustices and Fustices in Eyre, North and Soutb of Trent (57 Geo. III. cap. 1xi.), when these duties were vested in the first Commissioner of Woods and Forests.

Forest offences were, of course, at one time almost innumerable. Those concerning venison or beasts of chase, and game generally, have been frequently referred to above in sketching the evolution of the forest laws. The chief offences relating to the vert or woodlands consisted in purpresture or trespass and enclosure, waste or clearance of covert, and assart or grubbing up roots to make arable or pasture lands. Purpresture (from pourpris, 'an enclosure') consisted in illegal encroachment on forest land 'by the negligence of the Sheriff or Deputy, or by the long Continuance of Wars, inasmuch as those who have lands near the Crown lands, take or enclose part of them, and lay it to their own' (Cowell). 'Waste of the Forest is most properly where a man cuts down his own Woods within the Forest, without Licence of the King, or Lord Chief Justice in Eyre' (ibid.). It was waste for a freeholder to cut trees in his own woods or to plough one of his own meadows in the forest without either previously obtaining license from the justice in eyre or doing the act in presence of the royal forester, and land wasted could be seized for the king's use till released upon payment of the fine imposed at a justice seat.

1 The records of the transactions at this Justice Seat were republished by the Commissioners of Woods in 1853 as a Blue Book, and are well worth the attention of all who are interested in these ancient records. 


\section{FORESTRY AND THE NEW FOREST}

Assart (from assartir, 'to make plain') was 'an Offence committed in the Forest, by pulling up by the Roots the Woods, that are Thickets and Coverts for the Deer, and by making them as plain as arable Land. This is reputed the greatest Offence or Trespass, that can be done in the Forest to Vert or Venison, containing in it Waste, or more; for whereas Waste of the Forest is but the felling and cutting down of the Coverts, which may grow up in Time again, an Assart is a plucking them up by the Roots, and utterly destroying them, that they can never grow again." ${ }^{1}$ But a man could sue 'for License to Assart his Grounds in the Forest, and to make it several for Tillage ; so that it is no Offence, if done with License'; and it was this wholesale clearance of woodland into arable land, and more particularly into pasturage, which William Harrison so loudly bewailed in the chapter 'Of Woods and Marishes' in his Description of England given in what is generally known as the Holinshed Cbronicles (edition of I 586). That the administration of the forest laws regarding purpresture, waste and assart frequently degenerated into fearful extortion and oppression can easily be conceived. So much was this the case that the Pipe Rolls sometimes show a whole county entered as ' in misericordia pro foresta.' Great nobles enjoying the royal favour could sometimes save themselves from being subjected to legal punishment or illicit extortion by obtaining, before the triennial 'regard' or visitatio nemorum, a special writ of the king to exempt them from payment of fines for waste.

The forests of Hants (i.e. the afforested lands) aggregate over 73,000 acres, ${ }^{2}$ while the woodlands (i.e. the woods and plantations) amount to I 25,674 acres, out of a total area aggregating about $1,050,056$ acres for the county. ${ }^{3}$ Except Yorkshire, which has I 39,589 acres, this is the largest area classified as woodlands in any other county in England, though it is closely approached by Sussex (1 24,632 acres, out of a total area of 93 I,999 acres), the only other county having over 100,000 acres; and in Britain, York and Hants are only surpassed by Inverness ( 150,929 acres, out of a total acreage of $2,784,884$ acres).

1 Cowell, following Manwood's Treatise of the Laws of the Forest.

2 These form four local groups (whose exact area has never been determined), namely :-

\begin{tabular}{|c|c|c|c|c|c|c|}
\hline \multirow{2}{*}{ Name } & \multirow{2}{*}{ Position in County } & \multirow{2}{*}{$\begin{array}{c}\text { Total } \\
\text { forest area }\end{array}$} & \multirow{2}{*}{$\begin{array}{c}\text { Private } \\
\text { property and } \\
\text { encroachments }\end{array}$} & \multicolumn{2}{|c|}{$\begin{array}{l}\text { Forest lands belonging } \\
\text { to the Crown }\end{array}$} & \multirow{2}{*}{ Kind of woods } \\
\hline & & & & Acreage & $\begin{array}{l}\text { Area actu- } \\
\text { ally wooded }\end{array}$ & \\
\hline $\begin{array}{l}\text { 1. New Forest } \\
\text { 2. }\left\{\begin{array}{l}\text { Alice Holt } \\
\text { Wolmer }\end{array}\right. \\
\text { 3. Bere } \\
\text { 4. Parkhurst. }\end{array}$ & $\begin{array}{l}\text { towards the S.W. } \\
\text { to the N.E. } \\
\text { to the S.E. } \\
\text { in the Isle of Wight }\end{array}$ & $\begin{array}{r}\text { acres } \\
92,395 \\
2,745 \\
5,242 \\
\text { unfixed } \\
1,392\end{array}$ & $\begin{array}{r}\text { acres } \\
27,658 \\
653 \\
1,773 \\
\text { unfixed } \\
80\end{array}$ & $\begin{array}{r}\text { acres } \\
64,737 \\
2,092 \\
3,469 \\
1,471 \\
1,312\end{array}$ & $\begin{array}{r}\text { acres } \\
22,170 \\
1,906 \\
715 \\
1,446 \\
1,130\end{array}$ & $\begin{array}{l}\text { mostly oak, } \\
\text { beech \& conifers } \\
\text { mostly oak } \\
\text { oak and conifers } \\
\text { oak and conifers } \\
\text { oak and conifers }\end{array}$ \\
\hline Total . & & & & 73,081 & 27,367 & \\
\hline
\end{tabular}

Of the 64,737 acres forming the Crown lands in the New Forest, the statistics are as follows (Lascelles, 'A Brief History of the Arboriculture of the New Forest,' in the Transactions of the Royal Scot. Arbor. Soc. (1 895), xiv. 16) :-Open heaths and pasture, 40,478 acres; open lands with timber 4,500 acres; plantations enclosed, II, 138 acres; plantations open, 6,532 acres; freehold and copyhold of the Crown, 2,089 acres; total, 64,737 acres.

3 Board of Agriculture Returns (1898), p. 40. 


\section{A HISTORY OF HAMPSHIRE}

Sussex has proportionately more woods than Hants, but the latter is one of the best wooded counties in the kingdom, and it certainly possesses the forests of greatest historical and national interest. Deducting the 27,367 acres of woods on Crown forest lands from the total acreage of 125,674 acres for the woodlands of the county, this gives 98,307 acres as the area of the woods and plantations belonging to private landowners. But beyond this bare fact as to acreage no statistics, official or other, have yet been collected regarding the precise extent of the woodlands on the different estates, or regarding the nature, age, and treatment of the high woods, copses, and coppices. Endeavours have been made to obtain returns regarding the woods and plantations from the owners of estates, but the sum total of the information received from those who have kindly given the returns asked for is so meagre that it fails entirely to furnish any conspectus for the county. Such details as have been made available will be found on pp. 466-70.

Owing to their proximity to the naval dockyards at Portsmouth and to their being within easy reach by water of those on the Thames, the Hants woods and forests furnished large supplies of oak for the maintenance of the navy throughout the many centuries during which England was mainly dependent on the supply of home-grown timber for ship-building. But the records of the past all show convincingly enough that for over $35^{\circ}$ years at least there was a constant danger of the demand far exceeding the possible supply. This is not only proved by the passing of such statutes as those of 1543 , I $55^{8}, 1698$, I 7 I 5 and 1766 , but also by what is said in such works as Harrison's Description of England (1 577), Evelyn's Sylva (I 662), Driver's Agriculture of the County of Hants (1794), Lewis's Historical Inquiries (I 8 I I), and most completely and authoritatively of all, so far as the royal forests of England and Wales were concerned, in the Seventeen Reports of the Commissioners appointed to enquire into the Woods, Forests and Land Revenues of the Crown $(1787-93){ }^{1}$

1 Appendices Nos. 14 to 24 to the Eleventh Report, dated 6th February, I792, give the following details regarding the Hants forests and the national requirements for ship-building :-

\begin{tabular}{|c|c|c|c|c|c|c|}
\hline \multirow{2}{*}{ Forest } & \multicolumn{2}{|c|}{$\begin{array}{l}\text { No. of timber trees fit for } \\
\text { navy dockyards }\end{array}$} & \multicolumn{4}{|c|}{ Tonnage of British fleets } \\
\hline & Survey of 1608 & Survey of 1783 & In year & Naval & In year & Mercantile \\
\hline $\begin{array}{l}\text { New Forest } \\
\text { Alice Holt } \\
\text { Bere . } .\end{array}$ & $\begin{array}{r}123,927 \\
13,031 \\
5,363\end{array}$ & $\begin{array}{r}32,6 \text { II } \\
9,136 \\
256\end{array}$ & $\begin{array}{l}1547 \\
1603 \\
1660 \\
1685\end{array}$ & $\begin{array}{r}12,455 \\
17,110 \\
57,463 \\
103,558\end{array}$ & $\frac{\bar{Z}}{\overline{1}}$ & $\frac{\bar{Z}}{{ }_{486,740}}$ \\
\hline Total & 142,321 & 42,003 & $\begin{array}{l}1760 \\
1788\end{array}$ & $\begin{array}{l}321,104 \\
413,667\end{array}$ & $\begin{array}{l}1780 \\
1785\end{array}$ & $\begin{array}{l}618,853 \\
859,606\end{array}$ \\
\hline
\end{tabular}

The imports of foreign timber were during the eighteenth century, and as they now are, for by far the most part coniferous wood (pines and firs), but the imports of this latter class increased about tenfold between 1720 and 1790 . 


\section{FORESTRY AND THE NEW FOREST}

The woodlands owned by private persons consist in great part of copses or stored coppice, in which the standard trees have been very irregularly stored, and partly also of plantations of pines, larch and firs. This form of arboriculture in Hants is typical of that which has in past times obtained throughout the greater portion of central and southern England, particular attention being no doubt given to all the tracts within easy reach of the naval dockyards.

It would be difficult to fix the date when planting was first done in England; but planting for ornament certainly took place long before planting for profit was ever thought of. "A statute was passed A.D. I 307 and 35 Edward I., the title of which is " $\mathrm{Ne}$ rector arbores in cemetrio prosternat." Now if it is recollected that we seldom see any other very large or ancient tree in a churchyard but yews, this statute must have principally related to this species of tree; and consequently their being planted in churchyards is of much more ancient date than the year I 307.1

Perhaps the earliest definite record for the New Forest is to be found in the returns made in the sixteenth year of Henry VI. by Henry Carter of Welhampton and Thomas Coke of Menestede, who were appointed by letters patent of the king to cut down and sell certain underwoods specified as growing in certain places and to account for ' money paid for enclosing 720 perches of wood and underwood at $4 \mathrm{~d}$. the perch ... and in making three gates to the said enclosure with hinges, hooks, hasps, staples, locks and keys bought for the gates.' A further account of the same date relates to 'the sum of $f_{5} 59 \mathrm{gs} .4 \mathrm{~d}$. for 72 acres 3 roods of wood and underwood sold within the bailiwick of East Lynwode under the supervision of John Hampton and William Soper, verderers. The same accounts in money paid for enclosing 785 perches by a hedge made around the wood, and in making four gates in the said enclosure with hinges, hasps, etc., etc.'

From Edward IV.'s Act of 1482 it is clear that enclosure for natural regeneration and for reproduction of stool-shoots and stoles had long been practised as a common custom previous to that date. The preamble to the Act shows this :-

Item, our said Lord the King, considering that divers subjects having woods growing in their own ground within the forest of Rockingham, and other forests and chases within his realm of England, or purlieus of the same, which have cut their said wood, because the same subjects might not before time cut nor inclose their said ground, to save the young spring of their wood so cut, any longer time than for three years, (2) the same young spring hath been in times past, and daily is destroyed with beasts and cattle of the same forest, chases, and purlieus, to the great hindrance, as well of his said subjects, as of his deer, vert, and venison in their covert, and otherwise likely to be the destruction of the same forests, chases, and purlieus; etc.

But in 1482 enclosure for regeneration and reproduction was legally extended from three to seven years.

In the twenty-sixth year of Henry VIII. there is a note concerning Godshill coppice, a plantation now of oak called by the same name, in the Exchequer (2ueen's Remembrancer's Records) of 'money paid to

1 Gilbert White, Natural History of Selborne, 'Observations on Vegetables : Yew.' 


\section{A HISTORY OF HAMPSHIRE}

divers persons for the making of 10 furlongs 24 perches round the said coppice for the safe keeping of the spring or stools thereof.' Four years later in the account of John Raggott, Richard Samar and John Lathbury a charge appears 'for the making of 3.37 perches of beechen palings round the coppice aforesaid (in this case Walbridge), together with $3^{s .6 d}$. paid for the cutting of oaks for posts and rails necessary for the same works, and also $12 s$. for the making of nine gates to the said coppice.' Similar records as to coppices in the New Forest are very numerous, and prove that the practice of enclosing woods and fostering the growth of both timber and underwood was carefully attended to.

A very distinct advance was, however, made in Henry VIII.'s reign, by the passing of the Act for the Preservation of Woods in I 543-a lengthy Act for those days, as it consisted of twenty-one sections. The key-note to the tenour of the whole Act, best known as the 'Statute of Woods,' was struck in the preamble :-

The King our Sovereign Lord perceiving and right well knowing the great decay of timber and woods universally within this his realm of England to be such, that unless speedy remedy in that behalf be provided, there is great and manifest likelihood of scarcity and lack as well of timber for building, making, repairing, and maintaining of houses and ships, and also for fewel and fire-wood, for the necessary relief of the whole commonalty of this his said realm.

\section{The main provisions of this great arboricultural Act were as follows:-}

That in and upon all and singular several woods, commonly called coppice woods or under-woods, which from and after the feast of St. Michael the archangel, which shall be in the year of our Lord God 1544, shall be felled at twenty-four years growing or under, there shall be left standing and unfelled, for every acre of wood that shall be felled within the said coppice, twelve standils or storers of oak; (3) and if there be not so many standils or storers of oak there, that then there shall be left so many of other kind, that is to say, of elm, ash, asp or beech, as shall make up the said number of twelve standils or storers, likely to prove and to be timber-trees ; (4) the same standils or storers to be of such standils or storers, as have been left there standing at any the felling of the same coppice woods or under-woods, in times past; and in case there be no such standils or storers there standing, which were there left at the last felling of the same coppice or under-woods, then the same standils or storers there to be left, shall be left at this now next felling of the said coppice woods or underwoods, of such most likeliest oaks, and if there be not sufficient of oaks, then of the most likeliest elms, ash, asp or beech, to prove and to be timber-trees, as shall grow within any such several woods, coppice or under-woods; (5) and that the same standils or storers so left, shall be preserved, and not felled or cut down, till they and every of them shall be of ten inches square within three foot of the ground ; (6) upon pain that every owner of every such standils and storers having an estate of inheritance, or an estate for term of life of freehold, or by copy of court roll, or for years, in the ground or soil where the same standils or storers shall grow, causing or commanding any such coppice woods or under-woods to be felled or cut down, and not leaving the said standils or storers there standing in form aforesaid, to lose and forfeit for every standil and storer so not left standing in the said coppice woods or under-woods iii.s. iv.d.; (7) and upon pain that every owner, as is aforesaid, of any such coppice woods or under-woods, causing or commanding any of the said standils or storers, so left as is abovesaid, to be cut down, contrary to the form of this act, to forfeit and lose for every of the said standils or storers which shall be so cut down, iii.s. iv.d.; (8) the one half of which said forfeiture to be to the king our Sovereign Lord, and the other half to be to the party that will sue for the same in any court of record by action of debt, bill, plaint or information, in the which action, bill, plaint and information, no protection, wager of law nor essoin shall be admitted or allowed. 


\section{FORESTRY AND THE NEW FOREST}

It also provided for the enclosure and fencing for four years of coppices worked with a rotation of fourteen years or under, under a fine of $3^{\text {s. }} 4 d$. per rood for every month during the four years 'that the same coppice or underwoods shall happen to lie or be unclosed, not fenced, saved, or preserved.' And similarly, coppices worked with a rotation of between fourteen and twenty-four years were to be enclosed and fenced for six years, upon like penalty. When woods or coppices having standards of over twenty-four years in age were felled or thinned ('weeding'), then 'for every acre so felled, twelve trees of oak of the same such great trees' (or, failing these, of elm, ash, asp or beech) were to be left standing for the next twenty years, and the falls were to be enclosed and fenced for seven years, under penalty of $6 s .8 d$. per tree felled in excess of this statutory injunction and of $3^{s .} 4 d$. per rood per mensem for non-inclosure. No coppice woods of two acres or above in extent should be converted after Michaelmas I 544 into pasture or tillage, if distant two furlongs from the house of the owner or tenant thereof, under penalty of 40s. per acre thus transformed.

The Act was intended to prevent further wastage of woods, which had been going on at a rapid rate, and to check reckless sales of timber : but provision was made for meeting all boná fide domestic and agricultural requirements, namely :-

(vi.) Provided always, that it shall be lawful to every owner or owners of any of the said coppice woods, under-woods, standils or storers, great woods and trees afore rehearsed, to fell, cut down and take any of the same for building, repairing, enclosing and maintaining of houses, orchards and gardens, and every of them, and for paling, railing or enclosing of parks, forests, chases or other grounds, and for making and repairing of waterworks, dampness, bridges, floodgates, making, repairing or amending of ships and all other vessels, and for all such things concerning their own uses or affairs, in such like manner and form as he or they should or might lawfully have done before the making of this Act; anything in this present Act before mentioned to the contrary thereof notwithstanding.

It further provided, among other things, for fellings and enclosures in woods where commoners had rights of pasture, and ordered that swine 'being of the age of ten weeks or above,' taken to the woods for pannage should be 'sufficiently ringed or pegged,' under a fine of fourpence for each swine. It may be noted that whereas the Act of 1482 was purely permissive and applied only to the royal forests and chases, and their purlieus, this Statute of Woods of I 543 was entirely prohibitive and compulsory, and applied to all woods throughout England.

The manner in which the woods were ordered to be worked shortly before the passing of this statute is clearly outlined in an Exchequer record dated November 28, I 542 (33 Henry VIII.), in which Wm. Paulet, Lord St. John, the Surveyor-General of all the Crown Woods, gives instructions 'to Robert Dorne, Deputy Surveyor of the King's Woods in the County of Southampton,' to the following effect, that 'These shall be on behalf of our said Sovereign Lord to authorize you and your sufficient deputies by these presents not only to Survey the King's said woods both great and small with their values and ages in every Lordship 


\section{A HISTORY OF HAMPSHIRE}

and Seignory within the said County and the wastes and sales in them made etc., but also to make sale to the King's use at the best price you can before Easter next coming of as many Coppice Woods of I 4 years' growth and upwards in the said County a Yearly Sale, Provided that in your Sale you suffer no Timber or great trees to be felled or sold Enclosing the same sufficiently at the King's charge for preservation of the spring for 6 years next after each such Sale-making returns of your proceedings in Easter and Midsummer terms next following etc. And this writing subscribed with my hand shall be a sufficient warrant and discharge to you and your Deputies etc.'

Even this great 'Statute of Woods' was soon found to be so insufficient that in 1570 , during Elizabeth's reign (anno I 3, cap. xxv. sec. I 8, I9) the time of enclosure ordered for the different classes of woods had each to be increased by two years, 'for that by experience it is found, that the space and time of the said several years of inclosure or preservation is not sufficient.'

Some of the 'encoppicements' or enclosures then made are now among the most beautiful portions of the New Forest, as, for example, Ridley Wood, which dates from I 57 I or shortly before that, Bratley, Bramble Hill, Malwood, Bignell, and others. But apparently the natural regeneration thus provided for was assisted by planting, as woods are often spoken of, in Roger Taverner's catalogue of the woods in 1565, as 'set' with oak and beech or thorns. In John Taverner's Book of Survey (vide ante p. 427) those woods which were under fence were not uniformly distinguished from those that were open to grazing and deer, but there are in the list no less than thirty-five separate woods where it appears from previous or subsequent records that an enclosed coppice existed. Most of these ancient coppices have since that date been included in the enclosures made in subsequent reigns for the growth of timber after the ancient crop had been realized. This would obviously be the case, for the land in New Forest which is capable of growing hardwood timber is of very limited extent. Hence, before the introduction of the Scots pine, the land suitable for hardwood must have been enclosed and replanted again and again. In the cases of the 'North and South Bemley' encoppicements they are both described in Taverner's Survey as being ' set with under wood' of thirty years' growth. In 1700 the existing crop (which must have been renewed many times if underwood were grown, and at least once if timber were planted) was all cleared off and realized, and a crop of oak planted which now stands, but is past its best and getting towards the stage of decay. So that for over 300 years these particular plots of land have been under regular cultivation for woodland produce, and if the results of former years were equal to those of the last fifty years the average return per acre must have been a very good one.

There is hardly an ancient wood now existing in the forest which does not appear in this survey, in many cases by the present name; those which do not so appear have nearly all been included in more 


\section{FORESTRY AND THE NEW FOREST}

modern plantations and are now growing a successful crop of hardwood. Those which have not been so dealt with consist mostly of beech woods, for the very sufficient reason that successive generations of dockyard purveyors have searched them for oak over and over again in order to provide for the requirements of the Navy. The beeches which are left naturally, considering the great age which (for that species of timber) they have attained, are rapidly becoming very much decayed, and in many cases the woods are disappearing at a sad rate. The soil is as productive as ever, and after a good mast year the crop of seedlings of beech and oak is amazing; but, as has been pointed out elsewhere (vide p. 460), the present conditions of management of the New Forest which Parliament has prescribed do not admit of any protection being given to the young plants against the ravages of the cattle, and so the old Elizabethan woods are perishing instead of being permitted (as formerly) to renew themselves from generation to generation of trees.

But there was waste, and sad waste, in those days also, as is shown by several of Roger Taverner's entries; to wit, 'Gatewood, 60 acres, being utterly destroyed by John Harrison of Bewley and nothing there left but 52 staddles.' It is to be hoped that in consequence of this spoilation John Harrison was made to feel the weight of such forest law as then remained, for a little further we read that 'Ironhill Coppice is lately destroyed by John Harrison and John Hayward,' and so on through the long roll of the woods and the damage done to them. Among the articles which John Taverner was directed in 1584 to 'address to the preservators of woods and other forestal officers,' including, of course, the officers of New Forest, is, "That both the woodward and also the said preservators and the keepers have a diligent respect that the springs of the coppices be kept fenced and preserved from destruction by any manner of cattle or beasts.' And further orders were issued for the impounding and fining of any cattle found trespassing within the enclosed coppices or plantations.

James I., an ardent planter, though making no new enactments, paid much attention to the New Forest, and more than once issued proclamations enjoining the preservation of woodlands as well as closer attention and obedience to the statutes relating to the felling of coppices and the storing of timber-trees. In addition to the instructions concerning ' woods' already given above (p. 428), he had a survey made of the timber in the royal forests in 1608 , and ordered the ploughing of the land for the raising of new woods, the gathering of acorns, and the sowing, planting, or dibbling of them ' by mens' hands.' In fact King James had a rough-and-ready but quite a definite working plan or scheme of management prepared for all the royal woods throughout England. This is to be found among the Cottonian MSS., Titus B iv.; temp. James I., docketed as Treasury Office; Increase of Revenue. Under the head of Planting, Increasing and Preserving of Woods the then existing 30,000 acres of coppices were to be raised to 81,000 by adding 51,000 acres in fifteen years. These 3,400 acres of new woods annually were 


\section{A HISTORY OF HAMPSHIRE}

estimated to cost $\oint_{0} 2,102$ I 8 s. od., or $\oint_{0} 3$ I, 543 ros. od. for the whole 51,000 acres; and the net income derivable after fifteen years was estimated to be $£ 21,600$ per annum.

In the year 1609 a report was submitted by J. Norden 'to the consideration of the Right Hon. the Lord High Treasurer of England and Sir Julius Knight, Chancellor of His Majesty's Exchequer.' In this report Norden recounts the result of an inspection he has made of the New Forest and its coppices, but naïvely remarks that 'the felling therefore of any of the fellable Coppices may be offensive unto His Majesty and therefore dangerous to the instrument unless His Majesty will be pleased to manifest his princely consent by some warrantable declaration of the same.' He goes on, however, with a most interesting and instructive account of the condition of the principal enclosures of that date existing in the New Forest and of the fences surrounding them, most of which required renewal, and the specification and cost of such renewal is very closely computed. A quaint and interesting entry is that of 'Holmsley Copse,' a name attached for many generations to that part of the forest which grew the finest of 'holms' or hollies. It runs thus: ' This Coppice so named containeth by the perch of $16 \frac{1}{2}$ feet 106 acres. .. . It consisteth only of holly or Holm which are for the most part very old, and by reason that the country people have taken the bark of the most of them to make bird lime they are all decayed and dead and if they be not taken they will utterly perish and the covert will be destroyed, whereas the cutting in a seasonable time will revive and continue the same.' This is an interesting record as to country life and what was then called 'birding,' but it is also interesting as showing the ancient knowledge, now so often forgotten, of the proper way to cultivate hollies and similar evergreens, viz. to cut and lop them so soon as they show signs of decay. By this means, and by this only, such shrubs may be kept alive till they attain great age and dimensions; and it is to this method of treatment, chiefly adopted for the purpose of browsing of deer in winter, that the existence of the ancient and often very fine hollies of the New Forest is to be attributed. Those who are familiar with the forest will have noticed that most of these shrubs are found not far from the old keepers' lodges. It was to browse their deer that they cut these hollies as often as they would stand it, and they sought those near home for obvious reasons. The method of cultivation was almost akin to that of the lopping of the old willow pollards along the brooks of Bucks and Berks, and the result is equally successful; but in the case of the holly, where it is allowed to grow to its full dimensions, the effect is not merely successful as a matter of cultivation but is also very beautiful. In the report on Sloden Coppice he says that 'many young sapling oaks and likely young ashes growing as they have been sheltered up which in the demise' (query, lease of the coppice ?) ' are specially to be reserved though now the keepers break off and cut off the principal branches under colour of browse-an abuse intolerable !'

A further note on enclosing of New Forest plantations appears in 448 


\section{FORESTRY AND THE NEW FOREST}

the State Papers Domestic of I6ro: "All the trees are of oak and some small quantity of beech and ash. It is very requisite that the Coppices so soon as they be felled be ditched and hedged round, and that no young saplings be felled for hedge stakes nor any cattle suffered to come in them.'

Most of the remaining documents of this reign relate to the drafting of the terms of leases for the letting of the various coppices; and these are framed obviously with the view of, in the first place, maintaining and preserving the timber which was likely to serve for the purposes of the navy, and secondly for the profit to be derived from the felling of the coppices and the pollarding of such trees as were not fit for navy timber. The provisions of these leases are too long to be quoted in full here, but they are of great interest and show a thorough knowledge and appreciation of the management of woodlands both for realizing income in the present and for growing fine timber in the future.

We also know that in 16 I 3 Arthur Standish published a small book or pamphlet of thirty-four pages entitled New Directions of Experience... for the Increasing of Timber and Fire-wood. This pamphlet urged sowing and planting; and it met with so much approbation from James I. that a second edition was issued in I6 I 5 , which included among the prefatory matters a royal proclamation 'By the King, To all Noblemen, Gentlemen, and other our loving Subjects, to whom it may appertaine.' In this the 'severall good projects for the increasing of Woods' were recommended to 'be willingly received and put in practice,' in order to restore the decay of timber ' universally complained of' within the realm. The aim and objects of this pamphlet are fully set forth in the title-page of the second edition ( 1615 ), which runs thus :-

'NEW DIRECTIONS OF EXPERIENCE AUTHORIZED BY THE King's most excellent Majesty, as may appeare, for the increasing of Timber and Fire-wood, with the least waste and losse of ground. With a Neare Estimation, what millions of Acres the Kingdome doth containe; what Acres is waste ground, whereon little profit for this purpose will arise. Which waste being deducted, the remaine is twenty-five millions; forth of which millions, if two hundred and forty thousand Acres be planted and preserved according to the directions following, which is but the hundred part of the twenty-five millions, there may be as much Timber raised, as will maintaine the Kingdome for all uses for ever. And how as great store of Fire-wood may be raised, forth of hedges, as may plentifully mainetaind the Kingdome for all purposes, without losse of ground; so as within thirty years all Spring-woods may be converted to Tillage and Pasture. By Arthur Standish. Anno Domini MDCxv.'

This interesting little work was the precursor of John Evelyn's celebrated Sylva, or a Discourse of Forest Trees and the Propagation of Timber in His Majesty's Dominions, which, appearing in four editions between its first publication in 1662 and the author's death in 1706 , gave a great impulse to planting both for ornament and for profit. Subsequent editions of the latter by Dr. Hunter continued its influence down to the end of the eighteenth and the beginning of the nineteenth centuries, when the impulse in this direction became strengthened by Sir Walter Scott's 


\section{A HISTORY OF HAMPSHIRE}

writings, and particularly by the celebrated 2uarterly Review articles on arboriculture.

Except such ordinary work as cutting produce and renewing fences round sundry coppices, very little seems to have been done for the improvement of the woods in the reign of Charles I., and nothing at all in the time of the Commonwealth. But in that reign an order was given to 'John Chamberlayne of Lindhurst' for the 'new building of diverse lodgings for our use and service adjoining the old house at Lindhurst in the Newe Forest, as alsoe a Kitchyn, pastrie, larder and other offices, and a stable to contain fortie horse.' This 'lodging' is the present King's House at Lyndhurst, so far as the principal rooms are concerned, the older part which contains the room known as the Verderers' Hall and certain other apartments being the 'old house' which had been repaired and enlarged by an order of Henry VIII. The stable 'for fortie horse' was standing till the early part of this century, and was last used during the time of the war with France for the quartering of a squadron of horse. It has all disappeared except a small fragment of ancient and thick wall which stands in the school playground adjoining the Crown Hotel at Lyndhurst. The site of the stable is granted for a national school, and the 'fortie horse' are replaced by more than three times that number of small scholars.

More attention was given to the New Forest by Charles II. than had been the case for some years previously. Among other matters the work of enlarging and restoring the King's House was carried on and presumably finished by him.

Among the State Papers Domestic of I 664 is found a rather remarkable order addressed-

To our right trusty and well-beloved Cousin and Councillor Thomas, Earl of Southampton, our High 'Treasurer of England ... Whereas we are informed that there are two coppices, the one called King's Coppice . . . the other called New Coppice . . . containing about 100 acres, and that the underwood of the said several coppices are of sufficient growth to be fallen and are valued by the Deputy Surveyor of our woods at $\oint_{1292}$, besides the trees and saplings therein growing and fit to be preserved for our use ... We are graciously pleased, upon the humble petition of Winifred Wells, one of the Maids of Honour to our dearest Consort and Queen, to give unto her the benefit of the said underwoods, etc., etc.

Perhaps this entry speaks for itself, especially if read in conjunction with the account given of the same lady by Mr. Pepys in his diary. A more important order occurs in the Treasury records of December I669, to the effect that-

Whereas His Majesty hath been pleased by warrant under his Royal signature, dated the 13th day of November, to command us to give present order for the enclosing of 300 acres of ground within the New Forest in the County of Southampton, for a nursery and supply of wood and timber there; And whereas some of the regarders of the said forest have certified by writing under their hands dated the 28th day of Novr. last that the said 300 acres may most conveniently be taken for the use aforesaid in three several places that is to say, at Priors Acre in the North Bailiwick, 100 acres; at Dunstan Heath in the Inn Bailiwick, 100 acres more; and the remaining 100 acres at Holm Hill in Fritham Bailiwick, and that the enclosing thereof with a double ditch and a bank between of six feet and a half high 


\section{FORESTRY AND THE NEW FOREST}

and quick set by the same, or sowing it with furze, with the charge of ploughing and sowing the ground, is estimated at $£ 400 \ldots$ These are by virtue of His Majesty's said warrant to require and authorise you forthwith to proceed with all care and diligence in the doing of the said several works.

That this work was done is still evident from the ancient banks at Holm Hill and Prior's Acre, now absorbed in the more recent enclosures of King's Garn and Holm Hill. A subsequent warrant of I 67 I substituted land at Aldridge Hill and Hollidays Hill for that at Prior's Acre and Dunstan Heath. There is also a very ancient bank at Prior's Acre, but that was again enclosed in the early days of Queen Anne under the Act of William III.; and both Aldridge Hill and Hollidays Hill have been enclosed and planted at least twice since 1671 , so that definite traces of the older enclosures are not easy to distinguish from later banks and ditches. The method employed is interesting in respect of the fencing and ploughing ordered to be done. It affords conclusive evidence that these old woods owe their origin to most careful cultivation and management from the earliest of times. And just as no chance system of leaving all to nature produced the old woods in which we delight now, so no such haphazard methods will ever suffice to maintain them for the future. Unless some such care as our ancestors bestowed upon them be given now they must perish in course of time, for nature unassisted will no more be able to renew them than she could 300 years ago.

Nothing of importance seems to have occurred until the year 1698 , when the Act of William III. (vide p. 430) may be said to have inaugurated a system of forest management which, with variations as to the vigour of its enforcement, remained the guiding principle of the forest administration for about 150 years. The Act of 1698 had provided for the immediate enclosure of 2,000 acres-' out of such parts or places in the New Forest as shall be found . . . to be most convenient to be closed and to be most apt and meet to produce wood and timber for the future benefit of the kingdom, and may be best spared from the commoners and highways of the county'-and the further enclosure of 200 acres a year for twenty years, or 6,000 acres in all; and when these said 6,000 acres or any part thereof should have become 'past danger of browsing of deer, cattle or other prejudice' the enclosures could be thrown open to cattle; while further enclosures were to be made in their stead to the like extent of any other part of the waste of the forest. The form of 'encoppicement' which had sprung up during the seventeenth century was to enclose the various woods with ditch and fence, and within the enclosures three acorns were sown triangularly in 'pits or beds of three spits of ground each dug a yard apart . . . and after the ground was fully planted with acorns it was sown with hawes, hollyberries, sloes and hazelnuts, and drains cut where necessary, and traps were set to catch mice, and persons attended daily to re-set the traps and keep off crows and other vermin.' About 1,022 acres were thus at once enclosed, planted, and tended for about fifteen years; then for 


\section{A HISTORY OF HAMPSHIRE}

half a century nothing more seems to have been done. Other 230 acres were planted in $175^{\circ}$, and 2,044 acres enclosed in $177^{6}$; and these 3,296 acres appear to have been all the area dealt with under the Act of 1698 . So slow was the progress made, however, that it was not until the year I 864 that the full powers of this Act were exhausted. In that year the last enclosure taking in the full 12,000 acres was made; but before that date some few plantations had been formed under the Deer Removal Act of $185 \mathrm{I}$, and thus the proceedings under the latter act to some extent overlapped those taken under the earlier enactment.

The timber found fit for the use of the navy in I 608 was I 23,927 trees (see p. 442), but after a century of waste and neglect this stock had dwindled down to 12,476 trees in 1707 . By 1789 , despite the provisions of William III.'s Act of 1698 , the destruction of fences and the damage done by deer and cattle were so great that nothing short of a new Act of Parliament could be hoped to restore the forest to its ancient condition for the production of navy timber.

As might of course be expected, Gilbert White had some interesting remarks to make in connection with the forests and the timber trees towards the end of the eighteenth century, throughout what he calls the 'woody and mountainous' district of Selborne, where the men were wont to 'fell and bark timber' in addition to working in the fields and hopgardens. His letters Nos. i., ii., and vi. to ix. to Thomas Pennant each contain special references to one or other of the forests and to timber trees. Thus he tells us that "As the parish still inclines down towards Wolmer Forest, at the juncture of the clays and sand, the soil becomes a wet, sandy loam, remarkable for timber, and infamous for roads. The oaks of Temple and Blackmoor stand high in the estimation of purveyors, and have furnished much naval timber." And again he describes how at that time, on another part of the Earl of Selborne's estate, long since converted into pasture, 'On the Blackmoor estate there is a small wood called Losel's, of a few acres, that was lately furnished with a set of oaks of a peculiar growth and great value; they were tall and taper like firs, but standing near together had very small heads, only a little brush without any large limbs. About twenty years ago the bridge at the Toy, near Hampton Court, being much decayed, some trees were wanted for the repairs that were fifty feet long without bough, and would measure twelve inches diameter at the little end. Twenty such trees did a purveyor find in this little wood, with this advantage, that many of them answered the description at sixty feet. These trees were sold for twenty pounds apiece." Losels, however, is no longer woodland.

In writing of the royal forest of Wolmer, he describes it as ' a tract of land of about seven miles in length, by two and a-half in breadth, running nearly from north to south. . . . This royalty consists entirely of land covered with heath and fern; but is somewhat diversified with hills and dales, without having one standing tree in the whole extent.'s And in discoursing elsewhere on the perambulation of 1635 , he says that

1 Letter i.
2 Letter ii. 452
3 Letter vi. 


\section{FORESTRY AND THE NEW FOREST}

'In those days, as at present, there were hardly any trees in Wolmer Forest." With the trees and larger cover the red deer seem also to have gone from Wolmer, "for another beautiful link in the chain of beings is wanting: I mean the red deer, which toward the beginning of this (i.e. eighteenth) century amounted to about five hundred head, and made a stately appearance. There is an old keeper, now alive, named Adams, whose great-grandfather (mentioned in a perambulation taken in I 635), grandfather, father, and self, enjoyed the head keepership of Wolmer Forest in succession for more than a hundred years. This person assures me, that his father has often told him, that Queen Anne, as she was journeying on the Portsmouth road, did not think the forest of Wolmer beneath her royal regard. For she came out of the great road at Lippock, which is just by, and reposing herself on a bank smoothed for that purpose, lying about half a mile to the east of Wolmer pond, and still called Queen's Bank, saw with great complacency and satisfaction the whole herd of red deer brought by the keepers along the vale before her, consisting then of about five hundred head. A sight this, worthy the attention of the greatest sovereign!' ${ }^{2}$ Deerstealing and the enormities committed by the 'Waltham blacks' became, however, so bad that the statute known as the 'Black Act' had to be passed in 1722 (9 George I. cap. xxii) to remedy the evil.

Contrasting Ayles Holt or Aisholt-as is it called in ancient rolls, though now known as Alice Holt-with Wolmer, Gilbert White noted the distinct differences in the soil and the results of this as regards growth of irees, when he remarked ${ }^{3}$ that 'Though these two forests are only parted by a narrow range of enclosures, yet no two soils can be more different; for the Holt consists of a strong loam, of a miry nature, carrying a good turf, and abounding with oaks that grow to be large timber; while Wolmer is nothing but a hungry, sandy, barren waste. One thing is remarkable, that though the Holt has been of old well stocked with fallow deer, unrestrained by any pales or fences more than a common hedge, yet they were never seen within the limits of Wolmer; nor were the red deer of Wolmer ever known to haunt the thickets or glades of the Holt.' Wolmer and Alice Holt were at that time held by Lord Stawell for a term of years under grant from the Crown ; and under this he claimed one-fifth of all timber felled, including lop and top. When over 1,000 oaks were winter-felled early in I784, the peasants also claimed the lop and top of the trees, and removed it by force, one man, who kept a team, carrying away forty stacks of wood for his share. This is also mentioned by the Commissioners who reported on the woods and forests, "the Offal Wood, after having been made into Faggots, and a Day appointed for the Sale of it, was openly carried off by the People of Frensham, to the number of 6,365 Faggots, in One Day and Night.'

The Commissioners of $1790^{\circ}$ noted that 'In Woolmer there were

\footnotetext{
1 Letter viii.

Letter vi.

${ }^{3}$ Letter ix.

6 Sixth Report, pp. 15, 66, appendix 20.

4 Sixth Report, 1790, p. 13.
} 


\section{A HISTORY OF HAMPSHIRE}

formerly Red Deer kept, but there have not been any for upwards of 30 years past, Part of what remained . having been removed to Windsor ; and the Remainder given by the Lieutenant to a Gentleman ${ }^{2}$ in the Neighbourhood.' Earlier in the century a previous grantee, General Howe, "turned out some German wild boars and sows in his forests, to the great terror of the neighbourhood, and, at one time, a wild bull or buffalo; but the country rose upon them and destroyed them.' Owing to the results of the Commission that sat from 1787 to 1793 , many plantations of Scots pine were made in Wolmer Forest, which are now mature woods, often of fine growth.

The year 1776 is memorable in the history of arboriculture in Hants as being the date of the reintroduction of Scots pine (Pinus sylvestris), after it had become extinct ages before. The first plantation made then was in Ocknell Clump, an old 'encoppicement ' replanted in 1776 , though probably the pines in Boldrewood also date from about the same time. The plantation of firs (pines) and larch was strongly recommended by the Commission of $1787-93$, but no such use of the Scots pine was made on a large scale until after the passing of George III.'s Act for the Increase and Preservation of Timber in the Dean and New Forests, in 1808 , when commissions were issued in 1809,1814 and 1819 for extensive planting, amounting in all to some 5,250 acres. Parts of these, however, had already been enclosed under previous commissions, and were merely included within the fences of the new enclosures. Most of these plantations are now very flourishing oak woods, but having been grazed for many years by cattle are without undercovert of any kind and are not making fine timber. Since then the Scots pine, one of the kinds of trees best suited for poor, sandy soil, has been introduced so largely into Hants and other southern counties as to be one of the most characteristic features of all sandy and moorland tracts, spreading itself naturally wherever it gets any fair chance of doing so.

In 1848 a committee of the House of Commons discussed the New Forest, and after two sessions of deliberation issued the result of their enquiries in the form of evidence with appendices, but without any complete report. The tendency, however, of the interim report made in 1848 , and of the draft reports discussed in 1849 , seems to indicate that the committee was in favour of disafforestation. When the Royal Commission of $185^{\circ}$ (Lord Portman's) resulted in the 'Deer Removal Act' of I 851 , the prospects of arboriculture in the New Forest became more hopeful; but the provisions then made (vide p. 432) for enclosing I 0,000 acres for plantation, and subsequently throwing it open and enclosing other 10,000 acres- thus bringing up the total area which might be enclosed to 12,000 ( 1698 ) and 20,000 ( 1851 ), or 32,000 acres in allwere frustrated by the action of the commoners and the public generally. By the time about 5,000 acres had been planted, the Act of 1851 had been practically repealed by the passing of the Amending Act in 1877 ,

1 Mr. Bonham of Petersfield.

Letter ix. 


\section{FORESTRY AND THE NEW FOREST}

the law now in force, which permits the enclosure of a total of only 16,000 acres by the Crown at any given time. At the same time it was laid down that only plantations made since 1700 can be enclosed and replanted. ${ }^{1}$ The older woods are being destroyed by gales and the decay of age, while no new growth is springing up to take the place of the old trees 'now dying and falling year by year.' But, ' under existing circumstances no responsibility can attach to the management of the forest for this condition of things, as under the Act of 1877 no effective remedial measures can be taken' (vide Report of Mr. E. Stafford Howard, C.B., Commissioner of Woods, etc., dated June 29, 1899, p. 59).

But public opinion has often been instructed in a very different manner. Thus it has been said that-

Parkhurst Forest, which reaches from near Newport to the Newtown estuary, is a very good example of what a national forest ought not to be, and of what the New Forest would have become had the old Act empowering its inclosure as a State timber farm not been modified. It is an ancient royal forest ; but instead of remaining in its natural condition of a wild furze heath and woodland it is now a solid mass of timber, mainly oak and chestnut, viewless, and almost impenetrable except by the roads cut through it. If any one desires to know how dull a thousand acres of scientific plantation can be he need only spend an hour in Parkhurst Forest. On the other hand it is an economic success. ${ }^{2}$

As a matter of fact, however, the oak and pine woods at Parkhurst are in anything but a flourishing condition generally.

Thus the very Act which was to safeguard the beauty of the old woods as a great national inheritance is preventing their preservation. Under this Act, too, the planting of waste land is prohibited, so that 40,478 acres are now left bare and unproductive although large portions of this might easily be made to produce good and profitable crops of pine and fir timber. In the words of the Hon. G. Lascelles, Deputy Surveyor of the New Forest (op. cit. p. 35): "Arboriculture may for the present be said to be dead in the chief national forest. It is practically restricted to the tbinning of a certain number of plantations of no great age.' The experience of the last twenty-four years shows that there can be no doubt the Act of 1877 requires speedy amendment as regards the preservation of the old woods for æsthetic purposes, and if desired the utilisation of part of the waste lands might easily take place for the production of coniferous timber on commercial principles.

As, however, the questions at issue between the commoners and the Crown are not only of great local but also of considerable national importance, it may be of interest to many to obtain here a more detailed account of the New Forest conflict than is contained in the above short

1 These are now as follows: From $30-40$ years, 5,705 acres; 40-65 years, 4,278 acres; 65-90 years, 4,080 acres; 90-115 years, 2,230 acres; over 115 years, 1,377 acres: Total, 17,670 acres. Of the remaining 47,067 acres belonging to the Crown, 40,478 acres are open heath and pasture; but the enclosure and planting of this is absolutely prohibited by the Act of 1877 . Thus, while the unwooded portions are barren waste and moorland, the old woods are gradually also reverting to the condition of waste lands through the exercise of rights of common being unrestricted.

2 C. J. Cornish, The New Forest and the Isle of Wight (1895), p. 33, part 2. 


\section{A HISTORY OF HAMPSHIRE}

summary. As events turned out, the effect of the Deer Removal Act of $185 \mathrm{I}$ on the New Forest was very far-reaching. The question of the ' rolling power' of enclosure arose ; and though the opinions of the lawyers consulted on both sides did not agree as to the extent of this power, yet it was held by the law officers of the Crown that legally, it did exist. Though far distant as regards time, the result of covering the whole of the forest with timber of one kind or another would undoubtedly have seriously affected the commoner's rights of grazing, because all the lawns where the good pasture lies would (in course of time) have been enclosed and planted; and though in some cases the pasturage would have been improved by draining, still the character of the whole forest would have been changed. Another factor in the situation was the alarm felt by the residents in and near the forest who were in the habit of depending on the open forest for their sport, for their pleasure and their enjoyment generally. It was obviously far better for them to have the use of a large open park in which to ride about, to hunt and picnic in, and to enjoy as if it were their own, than to have similar privileges in and among vast woods. The question of the public purse or revenue did not affect them; thus the whole of the residents in the New Forest were roused against the Act, some on account of their pleasure, others fearing damage to their purse. Hence, as soon as the deer were removed and the expenses of the 'Register of Claims' paid, the commoners, having obtained all the benefit accruing to them on their side of the bargain, proceeded to organize an agitation against the payment to the public of the share due from them. The feeling ran high on both sides, and much was said and done to embitter the contest. It was represented to the public without scruple that the enclosures, in reality made solely against the cattle of the commoners, were intended to exclude the public. Although this was not the case, a large section of the public felt that in a wealthy country such as England the enjoyment of an open park was of more value than the cultivation of the ground under timber. This was a perfectly sound and reasonable view to take provided the country did not object to pay for so costly a demesne.

The whole subject was brought before a committee of the House of Lords in 1868 . The views of the commoners were fully urged before that committee, and a patient hearing was given to them. The result of the inquiry was that the commoners considered they had made a bad bargain in $185 \mathrm{x}$, and that there seemed to be so much difficulty in the way of carrying out the arrangement then made (which the committee appear to have considered equitable in itself) that they advised a cutting of the Gordian knot by the method of disafforestation, allotting to the Crown a portion in fee and to the commoners the remainder to deal with as they thought fit. This obviously meant doing away with the New Forest. It is true that a large acreage would fall to the share of the public, but it was known that the claims of the commoners would be excessive and rigidly enforced. The commission for the definition of 456 


\section{FORESTRY AND THE NEW FOREST}

those claims had not long concluded its labours. Out of 1,3 I I claims put in by commoners, no less than 442 had been disallowed altogether, while every single claim that was admitted had to be amended by the commissioners. It was very clear that, in the apportionment to be made, the commoners would not err on the side of moderation as to the share claimed by them. The public became seriously alarmed, and it was evident that the practical loss of the New Forest would never be borne with equanimity.

This was by no means the first time that the question of disafforestation had come to the fore, owing to the great difficulty of dealing with the conflicting interests involved. So great has that difficulty always been that the remedy of a complete separation was one which must have occurred to every person who studied the matter, and it was no wonder that the Lords' committee should have adopted that view. But so long ago as 1789 the commissioners appointed to examine and report upon the condition of the whole of the royal forests and land revenues had considered the question and expressed the view that 'from an attentive personal view of the forest, we are of Opinion that it would be difficult to make such a Division as would admit of convenient and satisfactory Allotments of Land to the Claimants, for the Purpose of cultivation in lieu of their Common Rights, and would not at the same time be disadvantageous to the Public.' ${ }^{1}$ This was the view which commended itself to those persons who, apart from all question of their own personal profit, desired to see the forest maintained as a whole at any reasonable cost; hence it was felt that fresh inquiry and further legislation were a necessity.

A resolution was therefore proposed in the House of Commons by the late Mr. Fawcett and was passed on June 20 , I 87 I, to the effect ' That in the opinion of this House, pending legislation on the New Forest, no felling of ornamental timber and no fresh enclosures should be permitted in the New Forest, and that no timber whatever should be cut, except for the purpose of thinning the young plantations, executing necessary repairs in the forest and satisfying the fuel rights of the commoners.' This of course brought every thing in the shape of forestry operations of whatever kind and with whatever object (save only thinning plantations) to a standstill, and practically things have remained in this condition ever since that date.

Meanwhile the commoners were very actively engaged in agitation and in making common cause with all those who desired to conserve the forest. As the object of both was to some extent the same, viz. to prevent further enclosure for the sake of obtaining revenue, both parties (though inspired by different motives) were able to act together. On the one hand there was genuine desire to preserve the forest as a national park in such form as should be most enjoyable to the public; on the other there was a keen and very natural desire to maintain all rights or

1 Fifib Report of the Commissioners on Woods, Forests and Land Revenues (June 22, 1789), p. 31.

II 


\section{A HISTORY OF HAMPSHIRE}

privileges which were the source of considerable profits to those owning or exercising them.

There are in the forest two chief classes of commoners : (I) those who own, and (2) those who exercise the rights of common. These form the great bulk of the commoners. The third class, the small freeholder who exercises his own right, forms a smaller section again, but so small that from evidence given before the House of Commons committee of 1875 it appeared that this class of men (owning and cultivating 30 acres and under) owned only 3,554 acres out of 65,000 acres of lands which claim rights of common. The rest of this land is owned by landowners of various capacity; but more than half of the whole area is held by ten owners alone, while over 55,000 acres out of the 6r,500 acres left after deducting the small proprietors is held by thirty-one men. The increased rent chargeable on this large area of land, by reason of the common rights attaching to it and the additional value of the houses possessed of fuel rights, obviously amounted to a large sum well worth fighting for apart from all sentimental feelings as to the preservation of the forest, and it constituted a large factor in the agitation which followed. In 1875 a committee of the House of Commons was appointed, under the presidency of the late Right Hon. W. H. Smith, to inquire into the whole subject. The commoners were well represented on the committee in the person of Lord Henry Scott, one of the members for South Hants and himself the largest owner of common rights, and by Mr. Cowper Temple, the other member for that division of the county. The committee sat for about three months and heard a great quantity of evidence. Its report was as follows :-

That the New Forest shall remain open and unenclosed except to the extent to which it is expedient to maintain the existing right of the Crown to plant trees.

That the ancient ornamental woods and trees shall be carefully preserved and the character of the scenery shall be maintained. The powers of inclosure conferred by statute shall be exercised only on that area which has hitherto been taken in at various times and been either kept or thrown out under the Acts 9 \& 10 Will. III. c. 36 ; 48 Geo. III. c. 72 ; and the Deer Removal Act, 1851 .

That the Crown should retain the power of keeping 16,000 acres of growing timber and trees planted under the Acts of Will. III. and I 851 at all times under enclosure; and that the Crown be entitled to enclose and throw out at will any portion of the area over which the powers of planting are to be exercised, with a view to its unrestricted use in such manner as may be deemed expedient for the most profitable growth of timber and trees; but that the rolling power over the open portion of the forest not now planted or enclosed under the Acts William III. or I 85 I should cease.

That a nominal quit rent be charged by the Crown to the Commoners for the exercise of the right of common during fence month and winter heyning; provision may be made if possible for the payment of such quit rent by some body representative of the commoners.

That all the rights of the Crown reserved under the Acts of Will. III. and 1851 , except as it is herein suggested that they should be modified, be maintained.

That provision be made that in the event of any future severance of interests in the forest between the Crown and the Commoners the limitations now proposed to be placed on the exercise of rights of the Crown should in no way prejudice the claims of the Crown.

It was evident that by this report the commoners profited very 458 


\section{FORESTRY AND THE NEW FOREST}

largely, while the public did not. In the first place their right of common was practically doubled, inasmuch as by the payment of a nominal acknowledgment they were to become entitled to turn out their animals in the forest for twelve months instead of only (in strict law) for five. Further, the compensation to the Crown for the removal of the deer-which by the Act of $185 \mathrm{I}$ was fixed at 10,000 acres (in the first place) to be enclosed for planting and for the production of revenue, and at a further 10,000 acres to be enclosed as soon as the first enclosure was thrown out, and beyond this the rolling power of enclosure amounting to the whole of the forest which was recognized by the committee in their report-was all of it to be wholly surrendered after only 5,030 acres had been enclosed. It was no doubt a matter for discussion as to whether this power need be exercised at once or perhaps at all, but it was a most valuable property vested in the public, as it amounted to a retention (as was doubtless originally intended) of that paramount possession of the whole forest which was vested in the Crown before the removal of the deer. By the powers then existing the Crown had the right to stock the forest to the fullest extent with deer. Under the Deer Removal Act a corresponding power, if it were to be exercised, was vested in the Crown by the right of enclosure. But by the recommendations of the committee of 1875 the right of the commoner or private individual became so enhanced that much of the Crown's possession, and in its right that of the public, was whittled away. It was an asy matter for Parliament or for the Treasury in deference to an expression of public opinion to suspend any powers of enclosure that the Crown possessed. It was another matter to surrender them for ever and thus enable a number of private individuals to assert claims equal to those of the State in this great national possession.

But beyond all this there was one great departure from ancient precedent in the report of the committee of 1875 . It was in the clause providing that 'the ancient ornamental woods and trees shall be carefully preserved, and the character of the scenery maintained.' This was the first occasion on which a legislative body had been brought to recognize that there was a distinct value in the New Forest scenery and amenities, as distinguished from the revenue-producing qualities of the woods or the ability of the forest to afford sport for the sovereign or his licensees. It was a novel and to modern ideas a most welcome and suitable change from ancient tradition. The Act of I 877 (vide p. 433), which followed on this report, was intended above all things to embody and legalize this view of the use to which the New Forest might be turned. It will be seen shortly how far it has succeeded in this direction. The clauses by which this system of management was to be legalized and enforced are clauses 5, 6, 7,8 of the New Forest Act, I877, and they run as follows :-

5. The right of Her Majesty to enclose any lands in the forest for the growth of timber or trees, in pursuance of the Act of 1698 , the Act of 1808 , and the Act of $185 \mathrm{I}$, shall be exercised only on such lands as are at the date of the passing of this 


\section{A HISTORY OF HAMPSHIRE}

Act inclosed, or as have previously to such date been inclosed by virtue of commissions issued in pursuance of the said Acts or some of them.

6. With respect to the lands in the forest which are at the date of the passing of this Act inclosed, or have previously to such date been inclosed by virtue of any such commission as aforesaid, it shall be lawful for Her Majesty from time to time, without the issue of any commission, and when and in such manner and as often as to Her Majesty seems meet, to cause any part of such lands to be inclosed, planted, laid open, replanted or reinclosed, provided that the whole quantity of such lands under inclosure does not exceed at any one time 16,000 acres. Provided also, as regards the lands in this section mentioned, that in cutting timber or trees for improving the woods, or for sale, care shall be taken to maintain the picturesque character of the ground, and not wholly to level or clear the woods, but to leave from time to time a sufficient number of the most ornamental trees, and to keep the woods replenished from time to time by protecting the self-sown plants, or by planting trees in the vacant spaces, having regard to the ornamental as well as the profitable use of the ground.

One month's previous notice shall be given to the Verderers by the Commissioners of Woods of their intention to inclose, lay open or reinclose under the provisions of this Act, but the Verderers shall have no power to object to any such inclosure, laying open or reinclosure.

7. Provides that any inclosures so made shall be held in severalty by Her Majesty free from all rights, privileges or claims, 'except a right of the public to use any highway which may traverse such lands.'

8. The ancient ornamental woods and trees in the forest shall be preserved; and except in so far as is provided by this Act the forest shall remain open and unenclosed, and wood shall be provided for the satisfaction of fuel rights without the sacrifice of ornamental timber.

By clause 5 the whole of the rights of enclosure for the purpose of plantation-which had been allotted to the Crown, and in its right to the public, in lieu of the ancient and enormously valuable right (from a technical point of view) of stocking the forest to the full with deerwere given up to the commoners, whose property in the forest thereby became increased at least fourfold. The whole object of enclosure is merely to protect young trees from destruction by the cattle of the commoners. But by this clause all the beautiful woods of greater age such as the ancient encoppicements of Elizabeth, James I. and Charles II., are excluded for ever from protection of any kind. Naturally from their age alone these ancient woods are precisely those which stand most in need of protection, because the plantations of 1808 and $185^{\mathrm{I}}$ are still comparatively young, though their trees are not liable to be damaged by cattle. The ground was completely covered, and clearly would be so for a great number of years to come. But the older woods, being nearly worn out and greatly decayed, and moreover monopolizing all the best timber-growing soil of the forest, stood much in need of protection, in order that they might renew their youth by means of the self-sown seedlings which abound in and around them, and that they might be replenished and perpetuated from generation to generation through simply repeating the process by which they were first created.

That this was the intention of the Act when it stated that the ' ancient and ornamental woods and trees shall be preserved' must be beyond question. But either by an oversight or through misapprehension the gist of the matter was missed, and the only efficient means of afford- 


\section{FORESTRY AND THE NEW FOREST}

ing the prescribed protection was withheld from the whole class of woods which most require it. Many of the old woods are in the condition described by M. Boppe, an eminent French forester, on his visit to New Forest so long ago as 1885 , of 'hurrying to destruction in a manner deplorable to behold.' The further lapse of years has increased materially this condition of affairs. The older woods are decaying very rapidly. Here and there throughout them are to be seen thickets of thorns or other protecting underwood which are full of young trees, showing what a wealth of reproduction lies within the soil ; but except in a few cases where the woods are quite impenetrable, there exists only sufficient young growth to indicate to future generations the outlines of the magnificent woods that now adorn the best parts of the forest.

That this state of affairs was apprehended in 1877 is clear by the words in the latter part of clause $6:$ ' to keep the woods replenished from time to time by protecting the self-sown plants, or by planting trees in the vacant spaces.'

No one, who has read the evidence that was given before the committee and the various draft reports submitted by different members suggested by that evidence, can doubt that these words were intended to refer to the ancient woods whose decaying though beautiful condition had engaged the attention of the committee. They are without meaning if applied to the comparatively young thickly planted areas taken in under the recent Acts cited. Moreover, full power is already given to 'enclose, plant, lay open, or replant these lands.' There are no vacant spaces in them, and consequently no self-sown plants. In the older woods there are many of both. No doubt these old woods were in the mind of the draftsman, but unfortunately the words ' as regards the lands in this section mentioned,' occurring previously in the clause, limit the whole of its operation to those younger plantations, to which also alone the only possible protection, that of enclosure, can be applied. What could be more unpractical?

The limit to the right of enclosure is further emphasized by the words in clause 8, that ' except in so far as is provided by this Act the forest shall remain open and unenclosed.' Very full advantage has been taken of this clause by the representatives of the commoners, for whose benefit it was inserted, in objecting to every matter, however trifling, which could be twisted into an enclosure. Thus exception has been taken to the stacking of newly sawn timber, to the protection of cricket pitches by a temporary chain fence, to the erection of a rifle butt, and to many similar things. The representatives of the commoners assert that each of such things constitutes technically an 'enclosure,' and much expensive litigation has followed.

So serious have the disabilities of the local community become on this account that this formed one of the special matters dealt with by a committee of inquiry in 1889 and 1890 , which submitted the last Parliamentary report concerning the New Forest.

In May, r889, a Select Committee was appointed by Parliament to $46 \mathrm{I}$ 


\section{A HISTORY OF HAMPSHIRE}

inquire into the administration of the Department of Woods and Forests and Land Revenues of the Crown. In their final report of July 30 , 1890 , they found that 'The allotments set out and allotted to the Crown in severalty in Alice Holt Forest, Bere Forest, and Parkhurst Forest were by the Acts devoted to the growth of timber for the Royal Navy. As no timber is required by the Admiralty from these properties the restriction as to their being devoted to the growth of timber should be repealed." With regard to the New Forest, they found that "The income of $f_{0} 10,777 \cdot 5^{s} .2 d$. derived from this large tract of land appears to be relatively small, but it must be considered that the profitable rights of the Crown in this estate are very limited. The surface of the soil in the open forest is subject to the rights of common, the timber in the recent enclosures has not reached maturity, and even in the older woods the rights of the Crown are greatly restricted by the provisions of the Act of 1877 . The method of dealing with this estate was at that time carefully considered by a committee. The policy then deliberately adopted by Parliament was that the New Forest should be administered principally with regard to the preservation of its ornamental character, and not with an exclusive view to the profit to be derived from it. Your Committee have not thought fit to re-open this question, as they concur in the policy then adopted. They have found nothing in the evidence adduced to show that there has been any departure in the administration of the forest from the principles laid down in the Act of $1877 .^{.2}$

But further on the report ${ }^{3}$ says :-

It is expedient that the powers given by s. 97 of 10 Geo. IV. c. 50 should be extended to the grant of leases for ordinary roads and tramways, for allotment gardens, and for sewage, gas and waterworks, or other works of public utility.

The necessity for this extension is much felt. Towns, villages and hamlets within the ambit and close on the borders of a forest find themselves wholly or partially surrounded by Crown land, and if they cannot secure accommodation on it have great difficulty in providing the conveniences which are requisite for the comfort of the inhabitants.

The owners also of private property in and abutting on the forest sometimes desire a right to make roads across the Crown land in order to get to a public road, and it is frequently desirable that they should have this right in order to prevent the cutting up of the forest by undefined tracks. The extended powers might be limited and guarded so as to prevent any undue exercise of them, and in order to provide a guarantee against an invasion of the rights of the commoners it should be declared that all uninclosed land granted by the Crown in pursuance of the extended power is to be taken to be part of the land which the Crown is authorised to enclose, so that the total quantity which the Crown is empowered to enclose shall not be increased, but only that in regard to the land inclosed under the extended power the Commissioners of Woods shall be freed from any obligation to appropriate it for the growth of timber and trees.

In pursuance of this recommendation a Bill was drafted by the Commissioners of Woods and introduced into Parliament in the session of 1892 precisely embodying the conditions recommended by the committee. So far as the New Forest sections were concerned strong opposition was met with from that portion of the public which concerns

$$
1 \text { Report, p. } 12 . \quad 2 \text { Ibid. p. } 7 . \quad 3 \text { Ibid. p. } 11 .
$$




\section{FORESTRY AND THE NEW FOREST}

itself with the management of commons and from the New Forest commoners themselves.

The objections on the part of the first section apparently were chiefly an intense dislike to seeing the powers of the Crown or of any other landowner 'extended' in any form whatever, whether for the benefit of the community or not. Those of the commoners of the New Forest and their representatives took the form of objecting to the compensation provided for their safeguards, and desiring a further compensation of money to be paid to them, accompanied by restrictions on the powers deemed to be necessary.

The Bill was withdrawn, but again introduced in 1893 , to meet with further opposition and the like fate, so far as concerned the clauses relating to the New Forest. The correspondence between the Commissioner of Woods and the Verderers of the New Forest on behalf of the commoners was published as a Parliamentary paper in I893, in order that the public might understand the reasons for the delay in carrying out the recommendations of the committee of 1889 .

In 1899 the Commissioners of Woods, after consulting the whole of the local authorities in the New Forest and ascertaining that certain of the provisions of the contemplated Bill were urgently needed, introduced another Bill in which as many of the objections and demands of the commoners were met as was possible without altogether destroying the usefulness of the Act. But again the opposition of a section of the commoners could not be conciliated, and since the Government of the day declined to take up the Bill except as an unopposed measure it was again lost, and the question has not been further mooted. The disabilities however and in some cases the dangers continue, while perpetual friction is caused between the exercisers of the small local privileges which the Crown is ready enough to grant and the commoners who conceive that their rights are affected, though in an infinitesimal degree.

It will appear then that a very unfortunate and unforeseen state of affairs has been produced by the Act of 1877 , under which the forest is sought to be administered. The effect of the Act, which had for its object the preservation of the beauties of the forest, has been to promote their destruction by depriving the old decaying woods for ever of that protection from the cattle of the commoners which is essential for their protection and renewal; while its ill-considered and sweeping clauses for the retention of the forest as an open space, without regard to the ordinary necessities of the dwellers therein, have inflicted great hardships and in some cases serious insanitary risks upon whole communities.

While the commoners very naturally hold fast to the great advantages which they obtained in 1877 , yet it is evident that the administration of so large a tract of land containing within its ambit large villages and communities cannot much longer be sacrificed to the interests of only one section of its population. In the present year (1902) the Commissioners of Woods have succeeded with much difficulty in promoting an Act of Parliament which will give them, in conjunction 


\section{A HISTORY OF HAMPSHIRE}

with the Local Government Board, the power of selling and leasing small portions of land for sanitary purposes only, provided that after enquiry by the Local Government Board it is found and certified to the Treasury that the land is immediately required in the interest of the bealth of the locality and that no suitable land outside the New Forest is available without undue expense. Compensation is also agreed to be paid to the commoners if any rights of common are taken away or prejudicially affected. This Act will no doubt assist to mitigate some of the more pressing sanitary necessities in the neighbourhood, but it leaves untouched the disabilities which the new population suffers under in respect of obtaining land necessary from time to time for religious, educational, and many other wants such as rural populations have need of from time to time.

At this stage the legislation on the subject of the New Forest and its effects remains at a standstill. That it will remain in that position is practically impossible, and the next steps to be taken for the preservation of this grand national possession must be awaited with anxiety.

After the Deer Removal Act $\oint_{0} 26,9$ I 8 worth of timber was clearfelled in 1856 in order to provide revenue for new plantations; and for two years before and after that the fall of mature timber averaged $f_{1} 0,000$ a year, the money being expended upon planting immediately afterwards, when great block plantations were made of Scots pine and oak. During the seven years 1884 to I 890 only 2,09 I trees were cut in the old woods, a large portion being assigned as fuel, while the value of the timber was $f_{0} \mathrm{r}, 084{ }^{1}$ There is very little of the New Forest really fit to produce fine mature oak timber, and these selected portions (such as Bentley's and Salisbury Trench) have undoubtedly been planted with oak once or twice in 400 or 500 years. ${ }^{2}$ As a matter of fact no oak is now supplied to the navy, and during 1880 to 1890 the deputy surveyor 'never cut a tree in the Forest that a Navy purveyor would have looked at for a moment,' nearly all of it in the older plantations being 'shaky wood, and in a state of decay."

The 92,395 acres of the New Forest include the great manors of Beaulieu (Lord Montagu), of Brockenhurst (Mr. Morant), of Minstead (Mr. Compton), and Burley and some others, while the Crown has only a limited ownership over 62,648 acres now classifiable as the forest lands belonging to the Crown (being 64,737 acres, less 2,089 acres of freehold and copyhold). The finest oak woods are those planted under William III.'s Act, about 1700 and previous thereto. The plantations made from I 770 to I 820 are chiefly oak and beech, but mainly oak, some of which is of very good growth, although the New Forest generally cannot be considered an oak-growing district. The plantations made during the fifty years from 1840 to 1890 consist of 9,923 acres, the predominant

1 Appendix No. 4 to Report of July 30,1890, p. 80.

2 Mr. Cully, Commissioner of Woods and Forests, in Minutes of Evidence before Select Committee on June 21, 1889; Report, p. 23.

Hon. G. W. Lascelles, Deputy Surveyor, ibid. p. 100. 


\section{FORESTRY AND THE NEW FOREST}

wood of the older of which is beech, while oak predominates in the younger plantations. Many of the low-lying parts were planted with oak and Scots pine, which have now practically become pure pinewoods.

The planting of larch has not proved successful in the New Forest. A fair quantity of it was planted about forty to fifty years ago, but it often began to get unsound at about thirty to forty years of age. It is therefore considered best to cut it as soon as it has become marketable, otherwise the butt of the stem has often to be shortened by about six feet to cut off the part diseased owing to the unsuitability of soil and situation, which are really much better suited for Scots pine and Douglas fir.

Hants is fairly well provided with remarkable trees, though the celebrated oaks in the New Forest are comparatively few over so great an area, and are not so high or large as in many other parts of England. But they make up for this by the picturesqueness of their outlines. Boldrewood contains three well known oaks, the 'Western Oak' girthing 24 feet 9 inches, the 'Eastern Oak' girthing 16 feet, and the 'Northern Oak' measuring I 4 feet 8 inches near its base and 20 feet 4 inches at a thick part higher up; while the 'Knightwood Oak' girths 17 feet 4 inches." A few yards outside the forest boundary stands the 'Moyle's Court Oak,' a handsome tree with a girth of i 8 feet $8 \frac{1}{2}$ inches. The last remains of the celebrated 'Cadnam Oak,' which was famed for putting out young leaves on old Christmas morning, disappeared about twelve years ago. The tree that is now wrongly called the 'Cadnam Oak' on the Ordnance Survey maps stands a little to the north of the Southampton road, where it is crossed by that to Ringwood. It is apparently not yet a very old tree, as it only girths $10 \frac{\mathrm{I}}{2}$ feet at $4 \frac{\mathrm{I}}{2}$ feet above the ground. The 'Oakley Oak,' in a meadow to the east of Oakley farmhouse near Mottisfont Abbey, has a girth of $3 \mathrm{I} \frac{\mathrm{I}}{2}$ feet at the same height, but the stem is hollow. 'The 'Seven Yards Oak,' girthing $2 \mathrm{I}$ feet at $4 \frac{\mathrm{I}}{2}$ feet above ground, stands in Hurstbourne Park near Whitchurch. But by no means the least remarkable of the Hampshire oaks is one known as 'Canon Beadon's Oak,' in the rectory grounds of North Stoneham near Southampton, which was planted by the late Canon Beadon when a schoolboy fourteen years old. Before he died in 1879 he sat under its shade and watched a cricket match in his hundredth year, eighty-five years after he had planted it. In I 893 its girth was I I feet 3 inches at $4 \frac{\mathrm{I}}{2}$ feet above the ground.

The arboricultural condition of the private woodlands varies greatly. Some of the copses are well stocked, but the storing of standard trees has been irregular, and the coppices have often been allowed to fall into a thinly-stocked condition as prices for underwood fell. In this respect the present condition of English arboriculture is far below what it was two centuries ago. Then far greater attention was given to the storing of timber trees (as is clearly proved by Evelyn's Sylva), while the under- 


\section{A HISTORY OF HAMPSHIRE}

woods were also kept thick by plashing or layering of shoots. But at the same time it must be recollected that such woods are now more often maintained as game coverts than for the growth of timber, etc., and therefore they are of course managed on such principles as seem most suitable for preserving the game. Many of the conifer plantations are less productive than they might be through wide planting and injudicious thinning. In the above respects, however, the Hants woodlands are not unique, they merely resemble the great majority of the areas classified as 'woodlands and plantations' throughout the whole of central and southern England.

As already mentioned (on p.442), though the endeavours made to obtain details concerning the private woods and plantations have been only so partially responded to as to fail completely in enabling a full categorical list to be compiled, still they convey a good general idea of the existing woodlands. Such details as have kindly been furnished by the courtesy of the landowners-with regard to (I) the acreage of woodlands and ages of different portions, (2) the nature of crops and kinds of trees, (3) the method of treating the woods, (4) the extent and nature of recent plantations, and (5) the method of planting generally followedmay be summarized as follows:-

The woodlands belonging to His Grace the Duke of Wellington (Stratfield, saye, Mortimer, Berks) on the Stratfieldsaye and Wolverton estates aggregate 2,266 acres, and are almost wholly in the county of Hants. Many of the trees (especially in the grounds near the house) are several centuries old, while there is of course a large proportion of younger trees. For the most part these consist of self-sown oaks, though a few larch were planted about sixty to seventy years ago. Until the last few years no particular method was followed in treating the woods, but latterly a certain portion of maiden land has been planted with larch, while portions of the old woodlands have been cleared of oak and planted with larch. Recent plantations extend only to 60 acres of maiden land and 36 acres of old woodland, which have been almost exclusively planted with larch. The method of planting usually followed is pit-planting on maiden land and planting with the planting-iron on old woodland soil. Two nurseries have been recently established on the estate in order to have a stock of plants close at hand for future planting operations.

The Right Hon. the Earl of Malmesbury (Heron Court, Christchurch) owns woodlands aggregating about 2,000 acres or more. Most of these are old woods, while the oldest of the existing plantations chiefly date from i 800 to 1840 . The soil is well suited for growing timber of fine quality, but for a considerable period the custom on the estate was merely to replant old plantations cleared when mature and not to start new ones. Since I 889 , however, more has been done to replace the older woods by timber plantations. Oak, larch, elm and Scots pine are the chief trees throughout the woods and plantations, while in the vicinity of Heron Court there are fine cedars and eight or nine remarkable stone pines or ' umbrella trees' in the park. Steps are now being taken to convert, so far as possible, the Scots pine plantations into oak, chestnut and larch, Scots pine being still however used to 'nurse' the young oak. Oak and Scots pine seem to find the soil and situation peculiarly suited to their natural requirements, though other kinds of trees also appear to thrive well. One of the most remarkable features of Lord Malmesbury's estate is the fine growth of rhododendron throughout the underwoods, where it comes up in great profusion.

The Right Hon. the Earl of Northbrook's woodlands on the Stratton estate (Micheldever) extend to about 1,200 acres (exclusive of the woods in the park of 203 acres). By far the greatest part of these consist of old woods which have been under timber crops from time immemorial. Oak timber predominates, but intermixed with 


\section{FORESTRY AND THE NEW FOREST}

occasional hardwoods of other kinds. In the early part of last century a large quantity of oak was cut in these woods for ship-building, most of the finest trees having then been apparently taken, so that the greater part of the timber now growing is small and rather poor in quality, while it has apparently been grown from the stool. Except in about I 37 acres which have been cleared and replanted (chiefly with conifers) during the last thirty-two years, the undergrowth throughout the old woodlands is mostly hazel, used for hurdle-making and worked with a rotation of ten to twelve years, and at each fall the oak timber forming the overwood is 'thinned.' The trees, being rather small, are as a rule barely sufficient to supply the requirements of the estate (which extends to about 10,000 acres). Before each fall of the underwood all the young oak saplings, and any other young hardwood trees which are likely to grow into timber, are marked and allowed to stand in the usual way; and where the timber and tellers are very thin, acorns are now annually being dibbled in on the fresh falls. At one time the underwood used to realize from $£^{8}$ to $£$ io per acre, but it now fetches only from $£ 2$ to $£ 5$. The increase permitted in the number of rabbits has been the cause of great injury both to the timber and the underwood, and at the present time the woods are of more value for sporting purposes than anything else. Of the 137 acres planted since $1870,123 \frac{1}{2}$ acres have been replantations of old woods cleared and $13 \frac{1}{2}$ acres have been new plantation, 6 acres of which have been raised for game purposes only. In these recent plantations larch is the prevailing tree, intermixed in some cases with other conifers and in others with oak and various hardwoods. In the plantations of 1870 made of pure larch $(6$ acres) and of 1887 made with larch and a few spruce ( 8 acres) the trees are very much damaged through the canker disease caused by the fungus Pezziza Willkommii. In replanting the old woods the underwood was felled but not grubbed and all the timber was cleared except a few young trees, the ground been pitted and planted. For a few years after planting the stoolshoots springing up had to be cut back till the young trees were able to maintain themselves without further assistance.

The Right Hon. the Earl of Selborne's woodlands at Blackmoor (Liss) consist of about 400 acres of forest, but only about 306 acres are actually stocked with timber in the copsewoods and recent plantations. Of these 171 acres are old copse dating back probably from time immemorial, and 135 acres of young conifer plantations ranging up to thirty-seven years of age. They lie at elevations varying from 300 to 500 feet above the sea level. Many of the ancient copses in this district formerly furnished large supplies of oak for the naval dockyards, but the tracts still remaining under woods vary greatly as regards the quality of the oak timber they now bear. In many cases it seems clear that the finest trees were long since removed, while those left standing consisted mostly of short-boled trees with large spreading branches. In other cases the soil seems hardly deep enough for fine growth of oak, the stems being here also short and the branch development excessive. From about 1864-94 none of the standard trees in the copses had been felled, and no storing of tellers had been made to provide for the future supply of overwood. During that time the only fall made was the cutting of the coppice undergrowth in a rotation of about ten to twelve years. The coppice now fetches only from $£ 4$ to $£ 5$ an acre, whereas formerly it usually sold at from $£$ io to $£ 15$ an acre. Barking of oak, once a remunerative operation, now hardly pays at present rates. During the last two or three years a more definite scheme of management has been introduced (based upon a ten years' rotation), with a view to (I) a more regular and methodical clearance of mature standard trees and to selecting sound young oak or ash poles to take their place as timber, and (2) the improvement and thickening of the underwood. The standards forming the overwood are mostly of oak, varying from 2 to 7 feet in girth and often with enormously branching crowns, and of ash of somewhat inferior growth, all scattered irregularly over the areas; while the bulk of the coppice, often with large blank spaces, consists mostly of hazel, with oak, ash, birch, willow, aspen, and in some falls a little chestnut, beech and sycamore. The manner in which the clearance and the replacement of the mature standard trees are being effected is indicated in the following extract from the scheme of management:-

- Owing to the great irregularity of the present crops, in which old standards are plentiful but young stores scarce, the normal formation of different classes of standards, 


\section{A HISTORY OF HAMPSHIRE}

varying regularly according to age, can only be achieved in course of time. With this end in view the storing of overwood should be regulated as follows:-

Storing of Oak Standards in Copse, the Rotation of the Fall being once every TWENTY YEARS

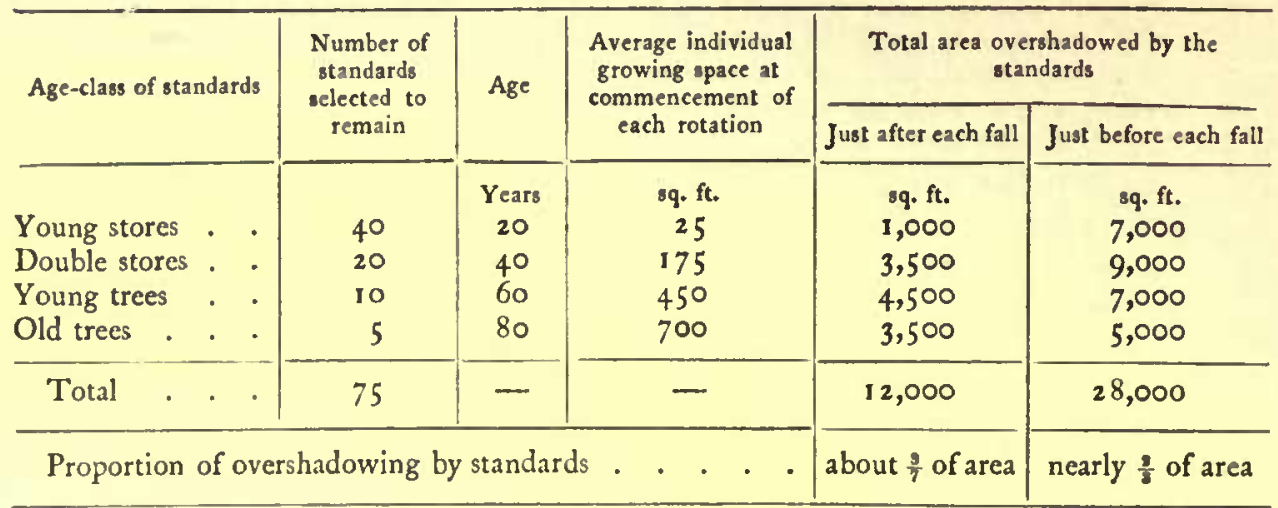

Note.-For ash the number of standards may be 50 per cent in excess of above for oak, and mixtures of oak and ash as overwood should be calculated on these bases.

'Considering the good quality of the soil, the above estimated amount of overshadowing towards the close of each period of rotation does not seem such as will prove excessively prejudicial to the coppice underwood; but the overwood is most to be considered as likely to yield the main portion of the revenue. In addition to the clearance of the coppice, each fall will every twenty years be carried out as follows:-

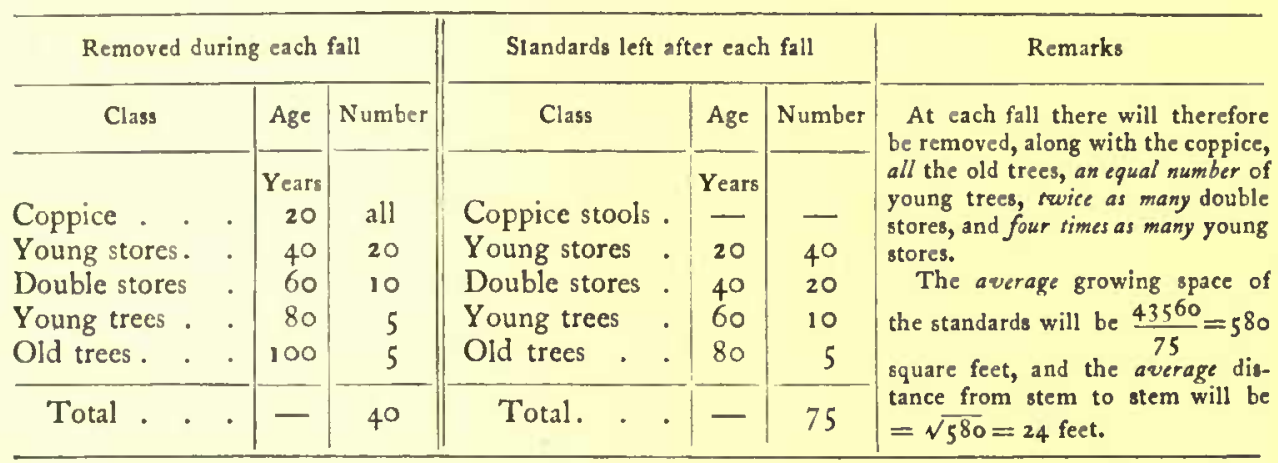

"The young stems selected as stores should be of seedling growth if available, and in any case they should be of good straight development with a well-shaped compact crown of foliage. At each fall the inferior stems of each class in the overwood should be cleared away and utilized, leaving the best to attain the larger and more remunerative dimensions. As the future prospects point to advantage in the storing of ash this tree should, on the whole, receive the preference when selecting the standards, not only on account of a larger number being retainable per acre, but also because, thus treated, it may be expected to attain its full maturity within sixty to eighty years, whereas oak might often require 100 to 120 years, and the latter, involving five classes of standards, seems inadvisable in dealing with the small areas now under treatment. As a general rule it will perhaps be found advisable to remove all the ash standards at the age of eighty years and only to allow oak to grow up as old trees to 100 years of age.

'Where some of the older standards may have to be removed before the fall of the coppice, they should be lopped of all large branches and of the crown in order to reduce the amount of damage done to the underwood when felling.'

The filling of blank spaces and the improvement of the quality of the underwood is being attempted by sowing or dibbling of seeds of oak, ash, maple, sycamore, chestnut, etc., on prepared patches, and by the plashing or layering of stool-shoots of ash and other hardwoods. In the former case many of the seeds are devoured by mice, and in both cases the seedlings and the young shoots are eaten or gnawed by 


\section{FORESTRY AND THE NEW FOREST}

rabbits, which do an immense amount of damage to the unfenced copsewoods, while the formation of plantations would be quite impossible without rabbitproof wire fencing that costs upwards of $£ 3$ an acre. Ash, spruce and larch are here specially attacked, but other kinds of trees are also gnawed. The only tree that seems to possess any tolerable chance of immunity from rabbits seems to be the Corsican pine, probably on account of the large quantity of resin it contains.

The conifer plantations ( 135 acres) ranging up to thirty-seven years of age consist mostly of Scots pine and larch, with Corsican pine, Douglas fir, spruce, ash and sycamore, etc. On the whole their growth is very satisfactory, although some of the young larch plantations have had to be prematurely cleared on account of the canker disease. In some of the young mixed plantations of six and seven years of age the larch are often making shoots of 3 to 4 feet and more in hcight, while the Douglas fir (now that it has thoroughly established itself) is shooting even more rapidly upwards and already gives clear indication that it will probably form the bulk of the mature crop that will be ultimately cleared. Most of these plantations were made at distances of 4 by 4 feet $(2,722$ plants per acre), though actually varying up to 6 by 6 feet; and in these latter cases thick rough branches have been formed which are only now decaying by canopy being maintained in place of unnccessary thinning operations being carried out. The cost of planting larch and pine during recent years has been about $£^{8}$ an acre, including wire fencing against rabbits. Small pure plantations of Douglas fir made in the autunin of 1901 at $3 \frac{1}{2}$ by $3 \frac{1}{2}$ feet $\left(3,556\right.$ per acre) have cost over $£^{8}$ an acre exclusive of wire fencing.

The woods and plantations on the Beaulieu Manor estate (Southampton), the property of the Right Hon. Lord Montagu of Beaulieu, have a total extent of 2,604 acres. They vary greatly in size, ranging from small coppices of 5 to 10 acres up to woods of 150,200, 300 and even about 500 acres in area. They consist principally of oak timber trees, growing over a coppicewood formed mostly of hazel and evidently planted with much care. The present crop of oak, now about 90 ycars old, appears to have been raised from stool-shoots. During the years 1810 to 1812 a very heavy fall of timber, said to have been worth between $£ 200,000$ and $£ 300,000$, took place, and the crop now on the ground was principally formed by shoots springing from the stumps of the trees then felled. Some Scots pine plantations, supposed to have been planted about 120 years ago, are now fully mature or even over mature. Some of these trees are 130 feet high, and their timber is hard and durable. During the last thirty ycars the very small amount of planting done has been chiefly of hardwoods with Scots pine as 'nurses.' Scots pine thrives uncommonly well, and Douglas fir makes wonderful growth, but no plantations have been formed with a view to growing the latter for profit. Larch does fairly well up to about forty years of age, after which it seems to make little progress when the soil is unsuitable. The land under woods is very diversified in character, the soils varying from clay to loam and sand, and brashy ground of poor and damp description. Owing to this and to the prevalence of strong S.W. winds from the sea, oak is of slow growth, though the timber is very hard and good, while the trees soon throw out lateral branches and become flat in the crown. Except beech, few young seedlings spring up. The woods are 'thinned' in rotation when the underwood is being cut. As little has been done to clear the ground for replantation, attempts in this direction have often failed owing to the thick underwood of coppice soon choking the young trees. Unless the coppice-shoots are cut annually for some years there is little hope for the thriving of young trees planted; and as such young shoots yield no return, this process is apt to prove expensive. Though the market value of coppicewood for hurdles, hoops, bavins, etc., is now greatly reduced, it still pays to cut it in regular rotation, and to plant young timber trees to fill up blanks when the oak standards are felled; but the profit is small. Cordwood for fuel sells well, being taken by barges to Portsmouth and elsewhere.

In addition to kindly supplying the above details, Lord Montagu of Beaulieu has also added some very interesting critical remarks concerning his extensive woodlands which indicate only too clearly the urgent need that exists for Government giving practical assistance of some sort if there be any real desire to encourage the growth of timber in Britain : 'It cannot be said that the woods on the Beaulieu estate are in a satisfactory condition. They do not seem likely to fulfil either the condition of growing fine oak timber which at a growth of say I 50 to 200 years can become profitable, or 


\section{A HISTORY OF HAMPSHIRE}

the condition of a short crop of fir say of 30 years' growth fit to bring in a good return for pit-props. To alter the whole method of the existing woods would be extremely expensive and would require a large capital investment, while the return that might be obtained is, to say the least, somewhat doubtful and would certainly be very expensive.'

On the Hursley Park estate (Winchester), the property of Joseph Baxendale, Esq., the woods aggregate about 1,500 acres. The ages of the different portions are not known, but some of them date back to very old times. All the woods consist of mixed copse, the overwood being chiefly of oak and beech, interspersed among which are many yews, which grow very profusely on the limy soil of this district. So far as possible the woods are treated on a ten years' rotation of the underwood, the timber trees being 'thinned' at the same time. Recent plantations have only been of small acreage, and consist mainly of larch pit-planted in holes dug by hand.

The woodlands on the Cranbury Park estate (Winchester), the property of Tankerville Chamberlayne, Esq., M.P., are returned as having an acreage of from 850 to I,000 acres. For the most part the timber is still immature, except in the home coverts and the park, where there are some fine old oak trees. The annual fall usually consists of a small cutting of oak, larch and birch. Oak forms the chief timber on the estate, but there is also a fair proportion of larch, birch, beech, alder, elm, ash, and a small quantity of Scots pine. The few small plantations that have been made of late years consist principally of larch planted at two or three years of age.

On the Burkham estate (Alton), the property of A. F. Jeffreys, Esq., M.P., the woods aggregate from 350 to 400 acres. They are for the most part copses with standard trees of oak and a few ash and beech growing over an underwood of hazel and ash. The underwood is cut in a rotation of ten or twelve years, when the standing timber is then 'thinned out'; and in the following winter young ash are planted on the bare places. The few small plantations recently made consist of larch put in at 3 feet apart after the land has been ploughed. Where labour is available it has been found that, in forming small plantations, trenching of the land well repays the extra cost, as the young trees thrive better.

The woods on the Malshanger estate (Basingstoke), the property of Sir Wyndham S. Portal, have an acreage of 130 acres and consist chiefly of copses of oak timber over an underwood of ash, hazel and birch cut on a rotation of ten years. The standard trees are afterwards looked over and the necessary 'thinning' done, while blanks among the timber or the underwood are filled up by pitting three to four-yearold plants. There have been no recent extensions of the plantations except as regards slight periodical renewals, chiefly for sporting purposes. The timber does not attain large dimensions as the chalky subsoil below the top layer of loam prevents the normal development of the deep taproot. Of late years the value of the underwood has very much deteriorated owing to the fall in the local prices for hoops and the rise in the cost of labour for cutting and making hurdles and faggots.

The only return which has been received from the Isle of Wight relates to the woods at Nunwell (Brading), the property of John H. Oglander, Esq. These consist of about 350 acres, mostly of copses laid out in blocks varying from 20 to 50 acres in size and with standard trees ranging from thirty to seventy years in age. The overwood is mainly oak, while the underwood is almost entirely hazel, but there is also some ash. After the underwood is coppiced and made up into hurdles and faggots the timber trees are 'thinned.' Young oaks springing from self-sown seed on open spaces are usually spared at the next fall of the underwood; but it has been found that if they also are removed at the fall, the young shoots from the stools spring up much straighter. No systematic planting has been done of recent years. 
. 


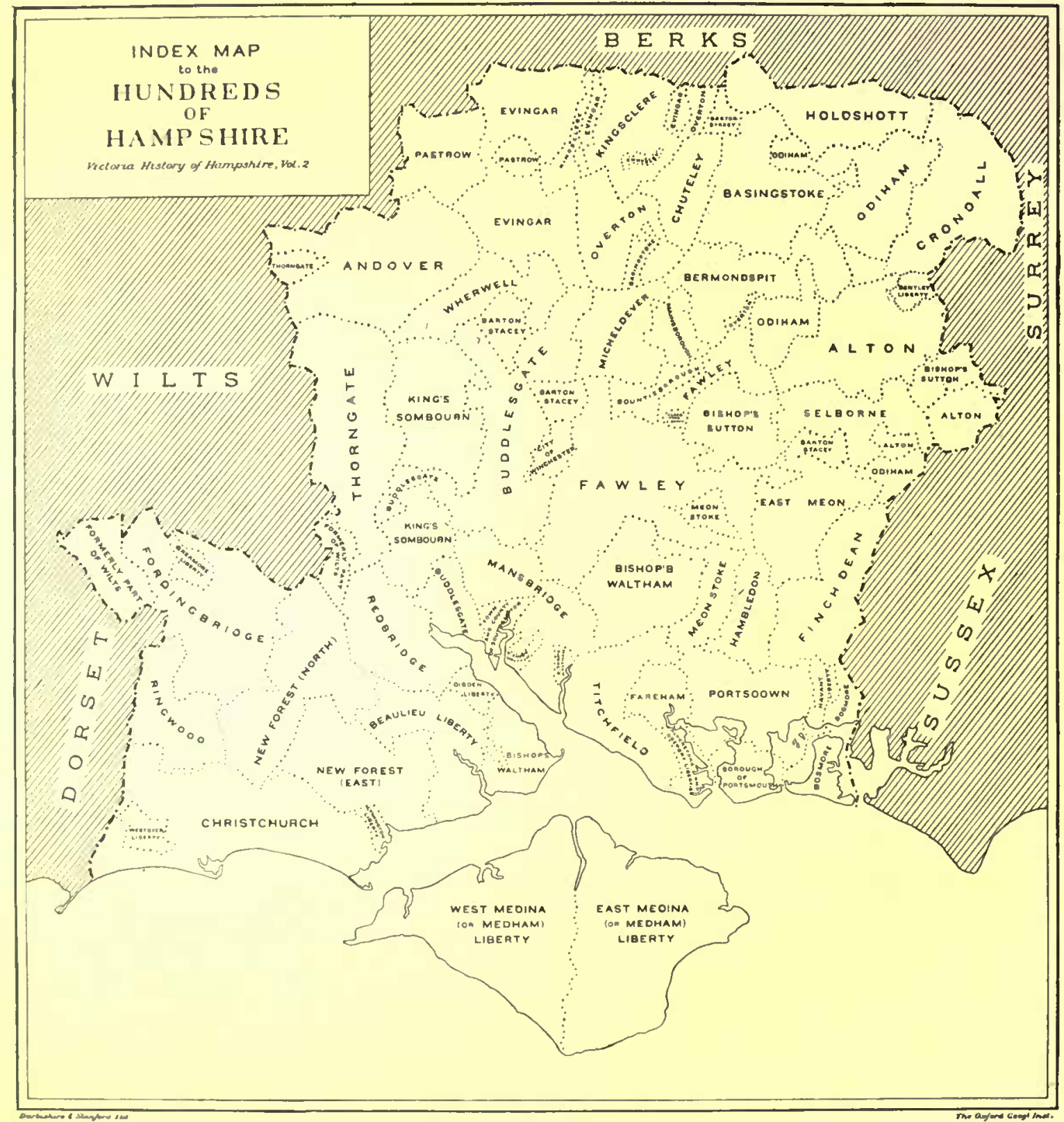




\section{TOPOGRAPHY}

\section{THE HUNDRED OF ALTON}

ALTON
BINSTED
BRAMSHOTT

\author{
CONTAINING THE PARISHES OF \\ CHAWTON \\ FROYLE \\ GREATHAM \\ HARTLEY MAUDITT \\ HOLYBOURNE AND \\ NEATHAM
}

\author{
KINGSLEY \\ EAST WORLDHAM \\ WEST T WORLDHAM
}

The above list represents the extent of the hundred of Alton at the time of the Population Abstract of 1831 . At the present day the parish of Headley is also included in the hundred.

At the time of the Domesday Survey this hundred and that of Selborne were included in the hundred of Neatham, which comprised the following places: Neatham ${ }^{1}$ (possibly extending into Binsted, Wheatley, Kingsley, Alton, Theddon Grange and Willhall farm), Holybourne, Anstey in Alton, Greatham, Chiltley in Bramshott, Selborne, Farringdon, Alton, Froyle, Headley, Chawton, Lidshott in Bramshott, Norton in Selborne, Binsted, Bramshott, Hartley Mauditt, Bradshott in Selborne, Newton Valence, Willhall in Alton, 'Lesborne' (Selborne ?), Larode (in West Tisted ?), Empshott, East Worldham, Broxhead, Oakhanger in Selborne, and Worldham. ${ }^{2}$ At what date the hundred of Neatham was divided into the hundreds of Alton and Selborne is not known, but in $12 \mathrm{I} 7$ we have a reference to the hundred of Alton. ${ }^{3}$ There appear to have been two courts for the hundred of Alton, the one termed the town hundred including the tithings of Anstey, Thedden, Alton Eastbrook and Alton Westbrook, and the other which was held at Holybourne, including the tithings of Lidshott, Bramshott, Chiltley, Greatham, Chawton, Broxhead, East Worldham, West Worldham, Willhall, Holybourne and Froyle."

From the beginning of the reign of Edward I., and probably from an earlier date, the hundred followed the descent of the manor of Alton Westbrook, and is now held by Henry John Dutton, J.P., lord of that manor.

1 Near Alton. $\quad 2$ V.C.H. Hants, i. 450 , etc. $\quad{ }^{3}$ Pat. I Hen. III. m. I I (print, p. 41).

4 The Court Rolls of the hundred and manor are at the British Museum (Add. Rolls, 27,665$\mathbf{2 7 , 6 7 8}$ and 27,765-27,932). The jurisdiction of the court and view of frankpledge of Alton extended over the tithings of Wheatley, Issington, Thedden, Holtham, Rutherfield, Binsted Popham, ' Southheghe,' Westcote ' Frenchemannehegh,' Binsted Kings, Wyke, Kingsley, Holybourne and Alton. The view of frankpledge for Holybourne, which was held at Alton, included the tithings of Willhall, Chawton, Lidshott, West Worldham, East Worldham, Broxhead, Bramshott, Greatham, Chiltley, Froyle and Holybourne.

- See under the parish of Alton, p. 473. 


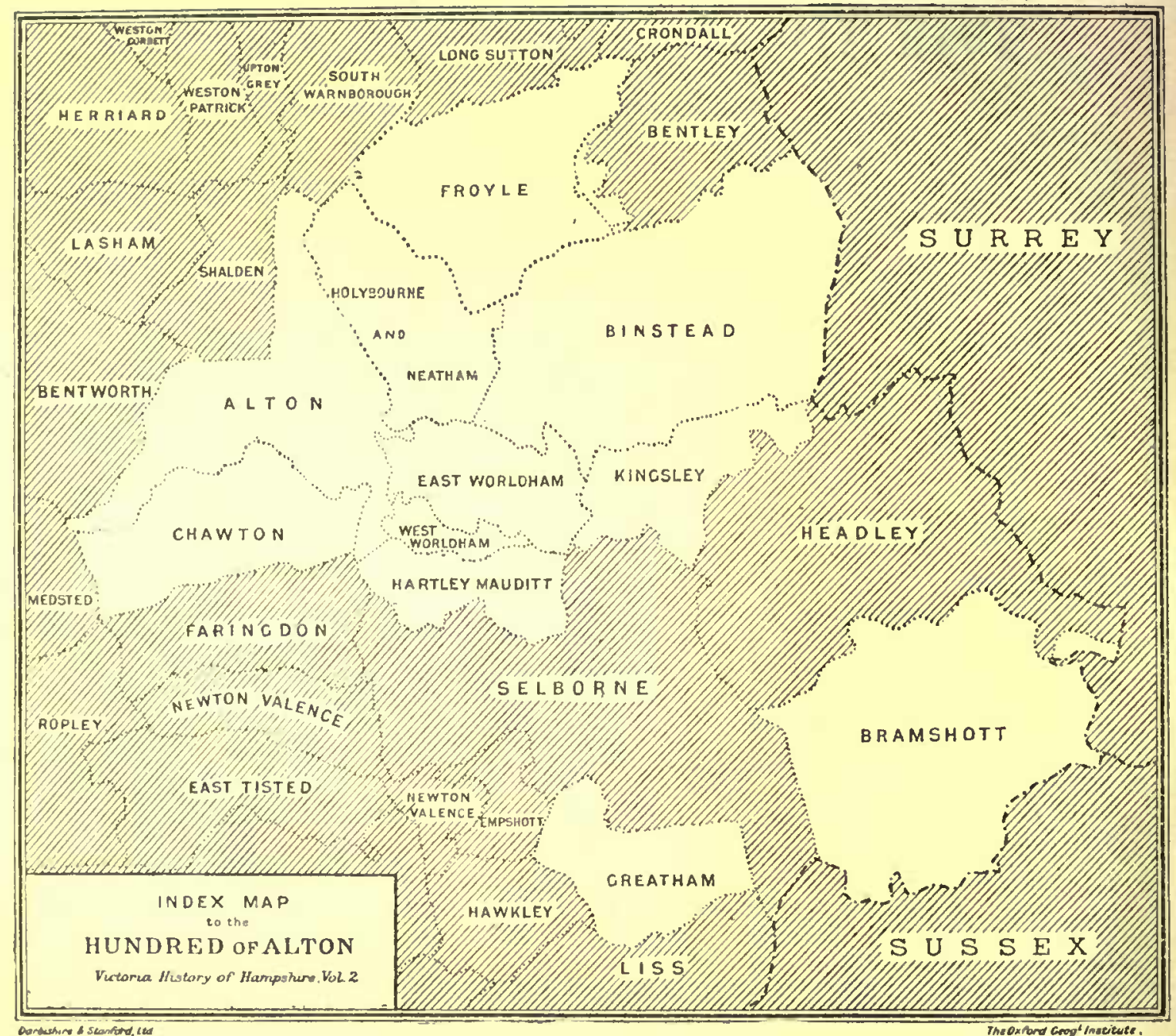




\section{ALTON}

Autune, Aultone (xi. cent.) ; Auelton, Awelton (xiii. cent.).

The town is picturesquely situated between chalk hills in a valley in which rises the river Wey. It consists chiefly of a long street, which is part of the main road from London to Gosport
Alton Westbrook on the right bank, and Alton Eastbrook on the left. In 1602 this river is called 'Alton river.'2 After passing through King's Pond it receives a small stream called the Caker stream, which rises at Trenchants.

The Pilgrims' Way from Southampton to Can-

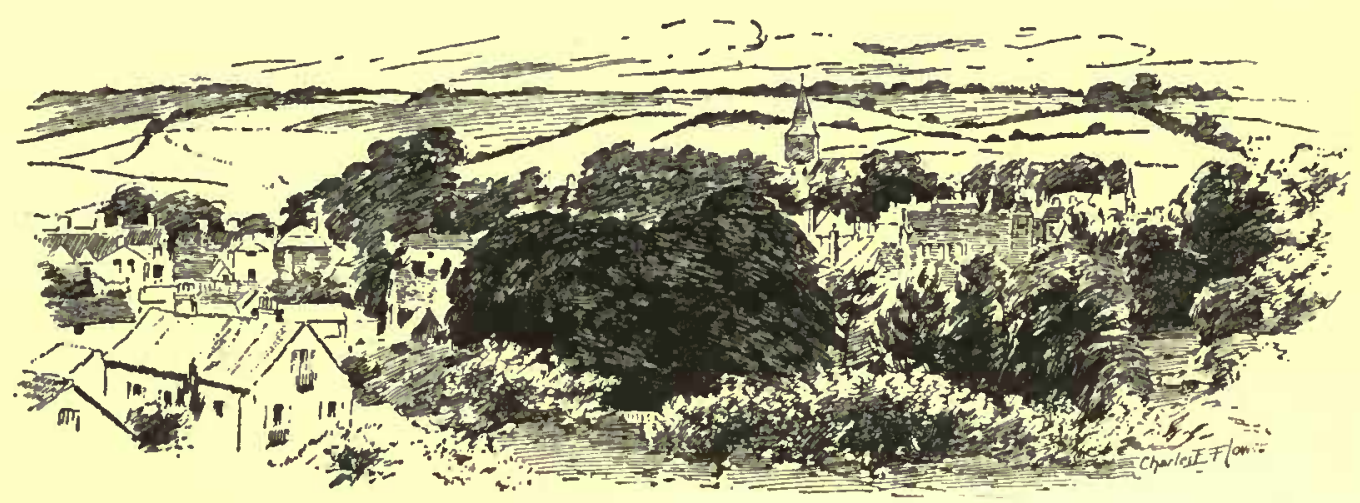

GENERAL VIEW OF ALTON.

and Southampton, and passes through the suburb called Anstey, Normandy Street and High Street to the Butts. Market Street leads past the market square, in which are the Town Hall, ${ }^{1}$ erected in 1812 and enlarged in 1840 and subsequently, and the Corn Exchange, to Basingstoke and Odiham and branches off northwards. Church Street, in which is situated the parish church of St. Lawrence, branches off in like manner. The district church of the parish of All Saints, constituted in 1874 , is at the western end of the High Street. There is a modern extension of the town towards the south, through which passes the Farnham and Winchester branch of the London and SouthWestern Railway, opened to Alton in 1852 and to Winchester in 1865. A light railway from Alton to Basingstoke was opened in 1901, and another from Alton through the Meon Valley to Fareham is about to be opened. In a square on the south side of Normandy Hill are situated the Cottage Hospital, the Museum and Art Schools, and the Assembly Rooms.

The Wey runs covered in through the middle of the town, the High Street sloping down to it on either side. It divides the two manors of terbury passed through Winchester and Alton to Farnham and Guildford.

The road through Alton was called in 1262 the 'passus de Alton.' It went through the king's wood, and on account of divers depredations and murders which had been committed in that wood, Henry III. issued a writ to inquire as to its value and report as to cutting it down and restoring it to cultivation. ${ }^{3}$

The pass of Alton is the traditional scene of the single combat between prince Edward and Adam de Gurdon, an outlawed adherent of Simon de Montfort, whom the former overcame and converted to a loyal adherent by sparing his life. ${ }^{4}$

Down to the fourteenth century the wardens of St. Giles' fair, Winchester, paid five mounted serjeantsat-arms to keep the pass of Alton during the fair.

William Langland refers to the pass in Piers Ploughman :

$$
\begin{aligned}
& \text { Ye, thorugh the pass of Aultone } \\
& \text { Poverte myght pass } \\
& \text { Withouten peril of robbynge. }
\end{aligned}
$$

At the west end of the town there is a large unenclosed green called 'the Butts,' which was anciently used for the practice of archery, and on
1 Whether the present Town Hall was built on the site of the old hall is not known. See post, p. 480 .

II
2 Exch. Dep. 44 \& 45 Eliz. Mich. No, 57.

8 Inq. p.m. 46 Hen. III. No. 27.

4hite's Selborne, p. 336, V.C.H. Hants, under East Worldham; Genealogist, n.s. iv. s-4. 


\section{A HISTORY OF HAMPSHIRE}

which the fair (formerly held in the town) is annually kept in July.

ALTON appears in Domesday Book

$M A N O R S$ as Aultone. It has been claimed as the Aweltun of King Alfred's will, but, although this is probable, it is impossible to be certain as to the identification. Some writers have connected it with the Eweltun granted by king Egbert to the Old Minster, Winchester, in 825, but that is clearly Alton Priors, co. Wilts, as appears by the boundaries. In like manner the sale by Coelwen, widow of Osmod, of land at Aweltun refers to the Wiltshire Alton. The Hampshire Alton has also been identified with Æthelingadene, the site of a battle with the Danes in IOOI. But here again the identification is unsupported by any evidence, and the names themselves have nothing in common.

Alton was a royal manor before the conquest, having been held by Queen Edith. ${ }^{5}$ In 1070 William the Conqueror gave a portion of it to Hydc Abbcy in exchange for a house in Winchester given by the abbot to the king. ${ }^{6}$

The Survey states that Alton contained 10 hides, and that the abbot had five of thcse in demesne. This land, the abbot's manor, came to be known as ALTON EASTBROOK whilst the rcmaining 5 hides bccame known as the manor of Alton Westbrook.

In 1087 Rewalan, abbot of $\mathrm{Hyde}$, allocated to the poor and to pilgrims for ever 'the land which is called Aweltona which King William gave in exchange.' 7

At the dissolution of the monasteries the manor of Alton Eastbrook came to the Crown. The site of the manor subsequently called Amery farm, 8 had been leased by the abbot of Hyde to John Hockley and his wife in 1538 . After the fee had remained in the Crown for five years it was granted to Sir Richard Pexsall, knight, of Beaurepaire, ${ }^{9}$ who three years later exchanged it with the king for other lands. ${ }^{10}$ The manor then remained in the Crown's hands for a considerable time, being leased out to various persons successively. ${ }^{11}$

On 1 I June, 1611 , James I. granted it in fee to John Eldred and William Whitmore, ${ }^{12}$ who, cight days later, sold it to John Knight of Chawton, ${ }^{13}$ with whose descendants it has since remained 14 (vide descent of Chawton).

It was found in 1280-1 that the abbot as lord of the manor of Alton Eastbrook had the right of gallows and the amendment of the assize of bread and ale. ${ }^{15}$ In 1283 the lord had there a mill called ' Johnesmulle,' but the stream on which it stood was held of the king in chief. ${ }^{10}$ In 1602 this mill seems to have been known as Spittal Mill. ${ }^{17}$ At the dissolution of the monasteries the perquisites of the manorial court yielded $2 s$. a year. ${ }^{18}$ The court rolls now in the possession of the lord of the manor begin in 1611. They show that the ale conners and sealers of leather were appointed by the lord, and refer to the cage, stocks, and whipping-post; the last-named stood on Normandy Hill, on the site now occupied by the board room of the Urban District Council.

The manor house of Alton Eastbrook is traditionally connected with a house on the north side of Normandy Hill, known as 'Eastbrook House.' The present building is of the date and style of town houses in the reign of Queen Anne.

At the dissolution of the monasteries the site of the manor, which would include the manor house, was let for $f^{6}$ a year, the lessee being bound to repair the roof with slate and tile, and also the high stone wall. ${ }^{10}$

That portion of Alton which became known as ALTON WESTBROOK was at the time of Domesday held of the king by Herding ${ }^{20}$; to this belonged the hundred court and town of Alton.

It is mentioned as being in the hands of the Crown in 1167 and 1187 on the Pipe Rolls for those years, and in 1190 the sheriff answered for 1 5l. of increase in the profits of Alton. ${ }^{21}$ In 1200 King John granted a portion of it to Peter De Préaux, (de Pratellis) ${ }^{22}$ and in 1208 gave him the remainder (residuum) to hold during pleasure. ${ }^{23}$ In I 2 I 6 the same king granted the manor of Alton to William De Prćaux (his relationship to Peter is not mentioned) and his heirs for ever. ${ }^{24}$ The widows of both Peter and William are referred to as receiving dower from the years 1222 to $1224 .^{25}$ There is evidence that Alton was in the king's hands at various later periods during the reign of Henry III. ${ }^{20}$

In 1273 Edward I. granted the manor to his mother, Queen Eleanor, ${ }^{27}$ who died in 1291 , when it reverted to the Crown and was granted in $\mathbf{1} 299$ as dower to his second wife, Margaret of France. ${ }^{28}$ On the death of Queen Margaret in I 317, it again came to the Crown, and Edward II. gave it in I 319 to his brother Edmund of Woodstock, Earl
5 V.C.H. Hants. i. 470.

- New Minster, Hants Rec. Soc. p. 111 .

7 Hyde Abbey, Hants Rec. Soc. p. 163.

8 Com. Pleas, Deeds enrolled East. 8 Jas. I. m. 25.

Pat. 35 Hen. VIII. pt. 1, m. 37

10 Pat. $3^{8}$ Hea. VIII. pt. $1, \mathrm{~m} .3^{8}$

and Deeds of Purchase and Exchange, E, 79 .
11 Pat. 4 \& 5 Phil. \& Mary, pt. 2 ; 13 Eliz. pt, 10 , etc. etc.

12 Pat. 9 James I. pt. 6, m. I.

13 Exemp. Letters Pat. in possession of lord of the manor.

14 Feer of F. Div. Co. East. 30 Geo. II.

16 Assize R. No. 783 .

18 Inq. p.m. 11 Edw. I. No. 60.

17 Exch. Dep. 44 \& 45 Eliz. Mich. 37.

18 Mins. Accts. 30-31 Hen. VIII.

No. 135 , m. $38 \mathrm{~d}-39 \mathrm{~d}$.
19 Ibid.

20 Domesday, V.C.H. Haats. i. 470.

21 Pipe $R$.

22 Chart. R. 2 Joho, m. 29.

2a Close, 9 John, m. 9 .

24 Chart. R. 17 John, m. 2.

25 Close, 6 Hea. III. pt. 2, m. II

8 Hea. III. p. 2 , m. 17 ; p. 3 , m. 1 .

26 Cal. Close and Pat. R. passim.

27 Pat. I Edw. I. m. 5 .

28 Ibid. 27 Edw. I. m. 4 . 
SKETCH PEDIGREE ILLUSTRATING THE DESCENT OF THE MANOR OF ALTON WESTBROOK

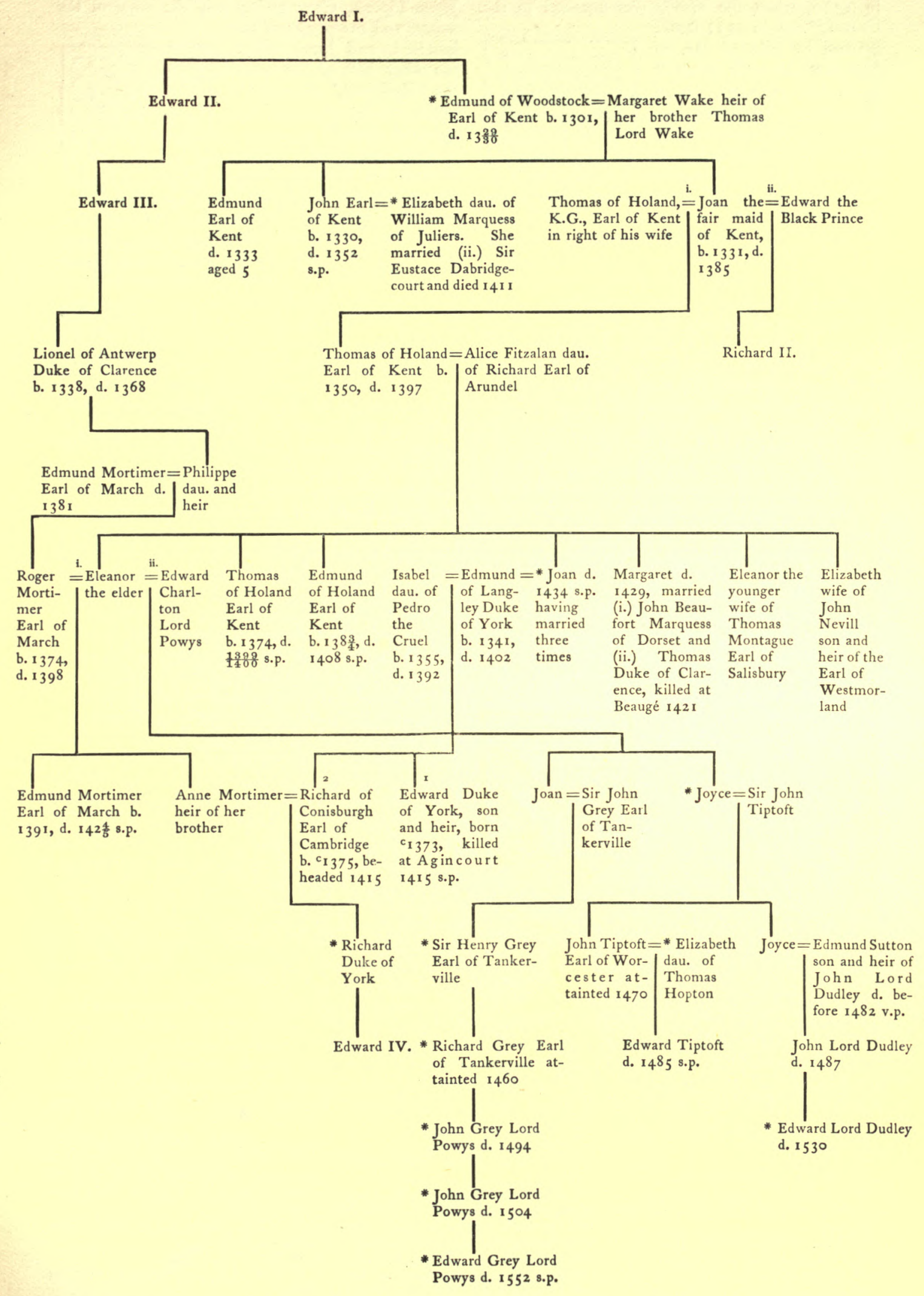

- The asterisks show the descent of the manor of Alton Westbrook. 


\section{A HISTORY OF HAMPSHIRE}

of Kent. ${ }^{20}$ Edmund of Woodstock was attainted in 1330 , when the manor was forfeited to the Crown, ${ }^{30}$ and in 1331 it was granted by Edward III. to Margaret, the earl's widow. ${ }^{31}$ John, Earl of Kent, son of Edmund of Woodstock and Margaret, died seized of the manor in 1352, leaving as his heir his sister Joan, the 'Fair maid of Kent,' then the wife of Sir Thomas Holland, ${ }^{22}$ and afterwards married to Edward the Black Prince. The manor however appears to have been settled as dower upon Elizabeth, widow of John, Earl of Kent, who died in 1411 , so that Joan, who died in 1385 , never possessed it. On the death of Elizabeth it passed to the heirs of Edmund, Earl of Kent, who died an infant in 1333 , eldest son of Edmund of Woodstock and elder brother of Joan the fair maid of Kent. These heirs were the then surviving heirs of Thomas Holand, Earl of Kent, son of Joan, namely Edmund, Earl of March, son of Eleanor the elder, daughter of the same Thomas, Joan, Margaret, Eleanor the younger and Elizabeth, sisters of the same Eleanor the elder. $^{33}$ By the deed of partition Alton fell to the eldest of the surviving sisters, Joan, then the wife of Edmund, Duke of York. ${ }^{36}$

Joan died without issue in 1434, leaving as her heirs Richard, Duke of York, her great nephew, Sir Henry Grey, Lord Powys, andRalph, Earl of Westmorland, her nephews, and Margaret, Duchess of Clarence, and Eleanor, Countess of Salisbury, her sisters, and Joyce, wife of Sir John Tiptoft, her niece. By the partition

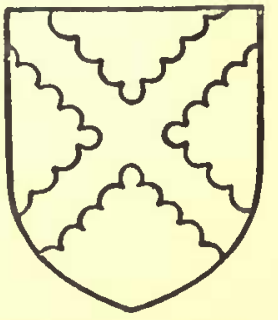

Tirtort. Silver a saltire gules engrailed. among these heirs Alton went to Richard, Duke of York, Sir Henry Grey and Joyce Tiptoft, the two former being the grandchildren and the last the daughter of Eleanor the elder, sister of Joan who last held the manor. By a subsequent division, the manor, hundred, and town of Alton were divided between the said Sir Henry Grey and Joyce Tiptoft, Grey taking half the rents of the manor and the profits of the hundred, and Joyce taking the other half of the rents, the 'Guildhall,' the sheriff's tourn and the profits of the manorial court. ${ }^{35}$

The Grey moiety passed through Sir Richard Grey, son and heir of Sir Henry, ${ }^{36}$ to John Grey, Lord Powys, his son and heir, ${ }^{37}$ and from him to John Grey, Lord Powys, his son and heir, ${ }^{38}$ and from him to Edward

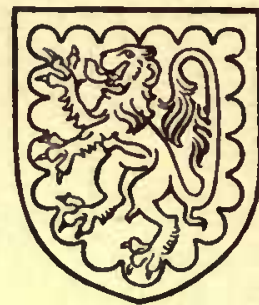

Grev or Powvs. Gules a lion gold witb a border of gold engrailed.
Grey, Lord Powys, his son and heir, who died without issue in 1552,39 and who in 1532 sold his moiety to Sir Andrew Windsor, ${ }^{40}$ from whose son, in $155 \mathrm{l}$, it was purchased by Henry, Earl of Arundel."11

The Tiptoft moiety seems to have passed to Elizabeth, widow of Joyce's son John, Earl of Worcester, beheaded and attainted in 1470 . She was afterwards the wife of Sir William Stanley. ${ }^{42}$ After her death the moiety passed to Edward Sutton, Lord Dudley, a grandson of Joyce, sister of the said Earl of Worcester, who himself appears to have been styled Earl of Worcester. ${ }^{43}$ It is probable that this Edward, Lord Dudley, about the year 1520 , sold the property to William, Earl of Arundel, 14

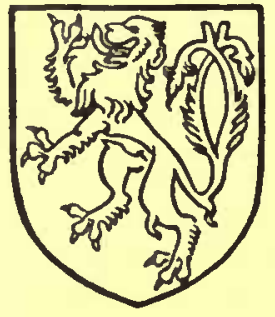

Sutros, Gold a lion green witb a forked tail. who is described as owner of the entire manor in $1540.0^{45}$ This description must however be inaccurate, as one moiety was, as we have seen, acquired by Henry, Earl of Arundel, in 1551 . In 1553 this Henry obtained from Queen Mary a grant of the return of writs, pleas of the Crown, etc. in all his lordships, manors, etc., including Alton and the hundred of Alton. ${ }^{16}$

In 1570 the earl conveyed the entire manor to Sir John White. ${ }^{47}$ His son and heir, Robert White, died

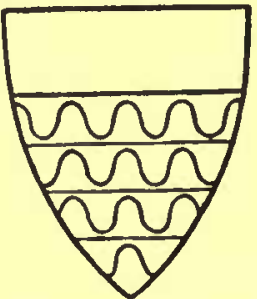

Tichroknx. Vair a cbief gold. seized of it in 1599 , leaving, as his co-heirs, Ellen, wife of Sir Richard Tichborne, and Mary, wife of Sir Richard's brother Walter. ${ }^{48}$ The manor was
29 Chart R. 13 Edw. II. No. 20, and I Edw. III. No. 8 I.

30 Inq. p.m. 4 Edw. III. No. 38.

a1 Pat. 5 Edw. III. pt. I, m. 30.

32 Inq. p.m. $26 \mathrm{Edw}$. III. I st Nos. No. 54 .

at Ibid. 12 Hen. IV. No. 35.

34 Ibid. 12 Hen. VI. No. 43

25 Tower Misc. R. 3-25.

36 Inq. p.m. $6 \mathrm{Edw}$. IV. No. 35 .

a7 Ibid. ser. $2, x, 18$

39 Ibid. ser. 2 , xvii. 70 . a9 Ibid. ser. 2 , xviii. 62, 82 .

40 Feet of F. Hants Trin. 24 Hen. VIII.

11 Pat. 4 Edw. VI. pt. 7, m. 10, and Mem. R. L.T.R. Hil. $5 \mathrm{Edw}$. VI. roll 14 , where the sale is stated to bave been made by Sir William Windsor. 12 Inq. p.m. ser, 2, i. 4 , and ii. 42 42 Ibid. iii. 111 ; iv. 26 , and $x$ i. 121.

14 In 1520 Lord Dudley conveyed his possessions in AIton to W. and J. Muck low and others (Feet of F. Hants, Mich.
12 Hen. VIII.). In the Inq. on Lawrence Wadham, 1535 , Binsted Popham is stated to be held of the Earl of Arundel and Lord Windsor. Inq. p.m. ser. 2, 56, 92.

45 L.T.R. Mem. R. 32 Hen. VIII. Recorda, Trin. R. 9 .

10 Pat. I Mary, pt. 2.

17 Feet of F. Hants, Mich. 12 \& 13 Elix.

18 Inq. p.m. ser. 2, celvii. 3 I \& go. 
thus again divided into moieties. A few years later Walter and Mary conveyed their moiety to Richard and Ellen. ${ }^{49}$ In 1604 the two brothers and their wives conveyed the entire manor by fine to Sir Richard Weston, ${ }^{50}$ possibly for the purposes of a trust, as Sir Richard Tichborne was in possession in $1610 .^{51}$ For some reason, probably an assurance of title, he took from the Crown, in 1617 , a fresh grant of the manor and hundred, with very full general words. ${ }^{52}$

Sir Richard Tichborne's heir was Amphyllis, who in 1619 married Lawrence Hyde, son and heir of Sir Lawrence Hyde, bart. Alton Westbrook must have been part of the marriage settlement, for she died, in 1632 , seized of the manor and hundred, though her husband survived until 1657. She left a son, Robert Hyde, an infant, and three daughters who became co-heirs. ${ }^{\text {s3 }}$ Thomas Chaffin of Chettle, Dorset, married Amphyllis, the eldest, and in 1653 the manor of Alton Westbrook was in his posses-

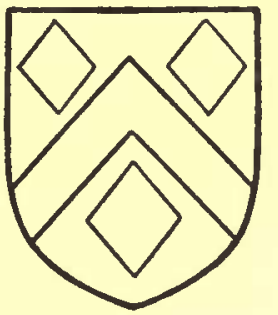

Hyoz. Azure a cbeveron and three lozenges of gold. sion. ${ }^{54}$ On 9 Oct. 1655 , Amphyllis Chaffin, widow of Thomas, conveyed the hundred and manor of Alton, probably in trust. ${ }^{55}$ From May to Nov. 1660 , Bamfield Chaffin appears as lord of the manor, ${ }^{50}$ but in the latter month and up to 1675 Thomas Chaffin held the manor. ${ }^{57}$ It remained in the possession of the Chaffins till 1746, when an Act of Parliament was obtained authorizing the sale of the lands of George Chaffin, M.P., in Hants and Surrey. ${ }^{58}$

In 1752 the manor was held by the Right Honble. Henry Bilson-Legge under the settlement made on his marriage with Mary, Baroness Stawell, and was inherited a bart's bead, silver, for by Henry, second Lord Sta- LegGz, quartered with well, their only son, whose azure a silver rose parted only daughter Mary married wath a golden pomegranate, John, second Lord Sherborne, green, for Binson. whose grandson Henry John Dutton, J.P., of Hinton House, Hinton Ampner, is the present lord of the manor.

There pertained to the manor of Alton Westbrook a nine days' fair, commencing on Whitsun eve. ${ }^{5 \theta}$ This fair was granted by Edward II. to
Edmund of Woodstock, ${ }^{60}$ and is now held on the green called 'the Butts' before mentioned, where it was moved from the High Street and market place a few years since.

The lord had free warren and a water mill and fulling mill; a 'horse mill' is mentioned in 1602 . $^{\circ}$

The profits of the three weeks' court were, in 1434 , 13s. beyond the expenses of the steward and bailiff of the manor.

The Court Rolls for the

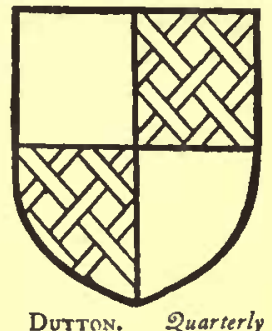

DutTon. Quarterly silver and gules, tbe gules frety gold. manor and hundred of Alton exist at the British Museum from the reign of Edward III. to the seventcenth century in fairly complete sequence ${ }^{62}$; from $174^{\circ}$ the rolls are in the possession of the lord of the manor.

The manor house of Alton Westbrook is traditionally connected with a site at the western end of the High Street, on which a house called 'Westbrook House' now stands.

There were in Alton parish the following manors, or reputed manors, held of the manor of Alton Westbrook: Anstey, Trenchants or Washdells, Thedden and Chauntsingers.

ANSTEY (Hanstige, xi. cent., Anesti and Anstigh, xiv. cent.) gives name to a tithing about a mile and a half north-east of the town of Alton. Queen Edith held it, and at the time of Domesday it was in the king's hands.

In 1275 the abbot of Battle acquired land in Anstey, ${ }^{63}$ and in 1284 William de Anstey, called 'de Bcllo,' gave his tenement of Anstey to Battle Abbey. ${ }^{64}$ Leases of it, describing it as a manor, were frequently made by the Abbey, and courts were held. ${ }^{85}$ The lessees were bound to entcrtain the abbot's receiver and steward twice yearly. ${ }^{00}$

Land within the "liberty of Anstey' held of abbot of Battle is mentioned in $1383 .{ }^{67}$

On the suppression of Battle Abbey the manor of Anstey was granted to Thomas White, clerk of the Crown, Agnes his wife and

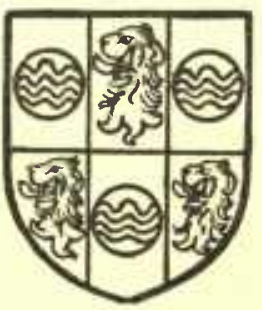

Whнте. Six pieces axure and gold with a lion's bead erased gules between twa roundels silver in the cbief and a like roundel berween two of the like lions' beads in the foot, eacb roundel baving two waves of green. their heirs. ${ }^{68}$ Thomas White died seized of it in
19 L.T.R. Mem. R. Hil. 45 Elix. and Hil. 45 Eliz, roll 22 ; see also Hil. Recorda, roll 22.

60 Feet of F. Div. Co. Mich, 2 Jas. I.

5i Add. Chart. 27,887.

62 Pat. I5 Jas. I. pt. I6, No, 6. The titles of William and Henry Earls of Arundel, Sir John and Robert White, and of Sir Richard Tichborne to the lordship and hundred, were successively called in question by the Crown, vide L.T.R. Memo. R. Recorda, Trin. 32, Hen. VIII. roll 9 ; Hil. 5, Edw. VI. roll 14 ; Easter, 13 Eliz, roll 32 ; Mich. 20 Elix. roll 78 ; Hil. 2 I Eliz. roll I 57 ;
27 Eliz. precepta.

53 Inq. p.m. ser. 2, 14 Chas. I. pt. I, No. I99.

54 Rent rolls in the possession of the resent lord of the manor.

55 Com. Pleas Recov. R. Mich. 1655, Deeds Enrolled, m. 3 .

56 Add. R. 27,887.

57 Ibid. $27,895-98$

58 Com. Pleas Recov. R. Deeds en

rolled Easter 10 Geo. II. m. I, and Act

of Parl, 2 I Geo. II. c, I8.

59 Inq. p.m. 12 Hen. VI. No. 43.
60 Charter R. 14 Edw. II. No. 15.

61 Exch. Dep. 44-45 Eliz. Mich. 37.

62 Add. R. $27,665-78$, and $27,765-$ 932.

63 Feet of F. Hants, 3 Edw. I. No. 17. 64 Battle Abbey Chartulary, Liber Regius de Bello. fo. 55 edit, Camden Soc. 65 Inq. ad. q. d. 6 Edw. II. No. 5 ; Pat. $6 \mathrm{Edw}$. I. pt. 1, m. 18 ; Pat. $8 \mathrm{Edw}$. II. pt. I, m. 3, 15 Edw. III. pt. 2, m. 46, and Court R., P.R.O. 201, I-4.

66 Anc. D. P.R.O., D. 492.

67 Pat. 6 Rich. II. p. I, M. \&, 5.

68 Pat. 35 Hen. VIII. pt. 9, m. 25. 


\section{A HISTORY OF HAMPSHIRE}

$1566^{\circ 0}$ and Sir Richard White in $16130^{70} \mathrm{He}$ left a son and heir, Thomas, then aged six. In 1629 Thomas White of Farnham conveyed the manor to Richard Manning of Norton Green in order that a recovery might be suffered to the use of the said Thomas and his heirs. ${ }^{71}$

From the Court Rolls, which begin in 1690 , in possession of the present lord of the manor of Anstey, it appears that the manor was then held by Edwin Fisher. In 1719 it was held by James Field. Thomas Eyre dealt with the manor by fine in 1725 and $17366^{72}$ In 1798 Ann Dowden (widow of John Dowden) was in possession, and sold it, in 1807 , to William Lee, whose widow, Ann Lee, sold it in 1822 to William Barlow, who sold it in 1832 to General Sir John Sigismund Smith. From General Smith it was acquired by the Misses Elizabeth and Sarah Miller, and it was sold in 1878 , under their will, to Henry Hall, father of Gerald Hall, now lord of the manor.

The present manor house of Anstey was erected about twenty years ago on rising ground above the hamlet of Anstey, near the site of the original manor house, from the foundations of which an avenue of ancient elms extends down to the north side of the road from Farnham to Alton.

The manor of TRENCHANTS or WASH$D E L L S$ takes its name from William Trenchant, who in the thirtcenth century acquired a messuage and carucate of land in Alton, held of the king in chicf, a messuage called Toteshall, and a wood called Kingeswood near Alton. He married Alice, co-heir of Elias de Roucestre, and left a son and heir, Edward, who left a daughter and heir, Alice, married to William Fyfhide, who was found to have occupied it without due title, whereupon Edward 11I. granted the property in 137 I to William Wightman. ${ }^{73}$ Twenty years later claim was made to it by Sir John Sondes, who had married Joan, heiress of the Fyfhides, who alleged that it belonged to William Trenchant's wife Alice, and that it descended to her sister and heir, Margery, wife of Richard Chanyn, who sold it to William Fyfhide. $^{74}$

In 1379 William Serle was paying rent to the lord of Alton for lands and tenements late Edward Trenchant's. ${ }^{78}$

In 1413 Sir Henry de lys gold witb a lion gold. Beaumont died seized of the property, called 'Trenchauntes Place.' 70 His widow died in 1428 holding a third part in dower. ${ }^{77}$

He left a son and heir John, aged four, whose son and heir William, Viscount Beaumont, died, in 1507 , seized of the property ${ }^{78}$ described as Trenchant's manor in Alton. Viscount Beaumont's widow, Elizabeth, afterwards Countess of Oxford, is stated to have held it in 1519 , paying a chief rent of $E_{4}$ to the lord of Alton. ${ }^{79}$ On her death Trenchants came to the Crown, and was leased, in 1538 , to Sir Richard Lyster for 21 years. ${ }^{80}$ In 1555, Philip and Mary granted it to Sir John Gage of Firle, ${ }^{81}$ who, the following year, had licence to alienate it to his son Robert Gage of Halling, Surrey, ${ }^{82}$ who held his first court 3 October, $1559 .^{83}$ In I 572 Sir John White obtained a Chancery decree, ordering Robert Gage to pay to him as lord of Alton the chief rent of $£_{4}$, Alise azure and silver witb which had been paid before a saltire gules.

Trenchants was granted to Sir John Gage. ${ }^{84}$

On 24 November, 1583 , an indenture of bargain and sale of the manor was made by Robert Gage and John Gage, his son and heir apparent, to Nicholas Knight of Chawton and Elizabeth his wife. ${ }^{85}$ In $159^{8}$ John Knight undertook to levy a fine of the manor by which it should remain, in default of heirs of his own body, to his brothers Stephen and Nicholas Knight. ${ }^{88}$ In or about 1600 rent was paid to the lord of Alton from the Lord Chief Justice 'for lands, late Lady Oxford's, recovered from my lord called Trenchins and Washedells,' 405. ${ }^{87}$ The title of the manor was, about I6I7, called in question by commissioners appointed by the Crown, whereupon John Knight, son of Nicholas, compounded with the commissioners and took a new grant from the king and his patentee. ${ }^{88}$ The manor of Trenchants has remained in the family of Knight of Chawton down to the present day. ${ }^{89}$

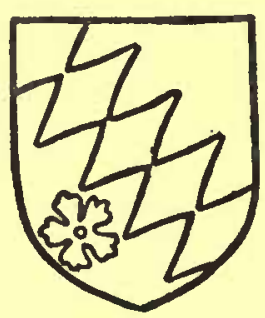

Knight. Vert a bend engrailed gold with o cinqfoil silver in the foot.
In $174^{\circ}$ George Inwood was rated for 'Tronchont's farm.' 90

The Court Rolls in the possession of the present lord of the manor begin in 1539 .

The manor house stands at the foot of Normandy
69 Inq. p.m. ser. 2 , cxlv. No. 9.

70 Ibid. ser. 2, 11 Jas. I. pt. 2, No. 103, \& Wards \& Liveries, bdle. 18, No. 221.

71 Close, 4 Chas. I. pt. 3, No. 32.

72 Feet of F. Hants, Trin. I I Geo. I. and Hil. 1o Geo. II.

73 Inq. a.q.d. 45 Edw. III. No. 5.

74 Inq. p.m. is Ricb. II. pt. 1, 117 and pt. 2, 139 .

76 B. M. Add, R. 27,820

76 Inq. p.m. I Hen. V. No. 45.

7 Ibid. 6 Hen. VI. No. 49.
78 Ibid. ser. 2, xxiv. 34 .

79 Ibid.

80 Pat. 29 Hen. VIII. pt. $4, \mathrm{~m} .16$.

81 Pat. R. 1 \& 2, Ph. \& Mary, pt. 9.

82 Ibid. 2 \& 3, Pb. \& Mary, pt. 9.

83 Information supplied by the present lord of the manor from documents in his custody.

84 Chan. Decree Roll 39, No. 4.

85 Deeds in possession of the lord of the manor and Ing. p.m. ser. 2, Chan. vol. 216 , No. 98 .
86 Com. Pleas Recov. R. Deeds enrolled Easter, 4o Eliz. m. 17.

87 Add. R. 27,893.

88 Information from the present lord of the manor. In 1617 the Crown granted the manor to Sir Thomas Middleton. Pat. 14, Jas. I. p. 17.

89 Feet of F. Div. Co. East. 30 Geo. II.

Do Parish Records quoted in Cartis's Hist. of Alton, p. 87. 
Hill on the south side of Alton High Street. It is just on the Eastbrook side of the river, and consists of the old manor house to which a new front was added by Mr. Henry Hall when he purchased it in 1852 . The grounds include a large garden with deer park, and extend over the Westbrook side of the river. In I 339 William Trenchaunt had licence from the Bishop of Winchester to have divine service celebrated in an oratory in his house."1

The reputed manor of $T H E D D E N$, now called THEDDEN GRANGE (Thuddene xiii. cent., Titden and Thydden xv. cent.) lies about a mile and $\mathrm{a}$ half to the west of Alton.

In 1203 Henry Walens' and William de Insula were parties to a fine as to Thedden. ${ }^{92}$ In I 399 Richard Esteney and Nicholas Wyard paid rent for land there to the lord of Alton. ${ }^{93}$ In 1485 John Pakenham died seized of the manor of Thedden leaving a son and heir Edmund, aged six. ${ }^{04}$ In 1550 it was in the possession of Sir Edmund Mervyn and Elizabeth his wife. ${ }^{95}$ In 156 I Henry Mervyn conveyed it to Thomas Twyne, two years later, died seized of it, leaving a son and heir Thomas, then of age.97 In 16 I9 John Hunt died seized of it. ${ }^{88}$ Rohert Hunt, John's son and heir, died seized of it in 1623 , leaving a son and heir John, eleven years of age. ${ }^{99}$ John Gold was rated for "Thidden farm' in 1740.100 'The property came eventually into the hands of Sir Laurence Halstead, who built a mansion here. He sold it, about I 840 , to John Wood, who in 1854 built Thedden Chapel near to it.

CH AUNTSINGERS Canteshangra xiv. cent.) on the northern side of the clubs resting upor tbe town of Alton. Sir Roger sbields: a cbief of gold inCyfrewast of Cyrrewast of Clewer (Cly- troo feurs de lys of azure. ware), kt., died in 1361

seized of rent there, held of the lord of Basing. ${ }^{101}$ This descended to his son and heir John, who died seized of it in 1394 leaving a son and heir John, aged twenty-two. ${ }^{102}$ The place is called a manor in 1533, when William Thorpe acquired it of Lord Mountjoy. ${ }^{103}$ About the year 1557 Sir John
Leigh purchased it of Sir Richard Lyster. ${ }^{104}$ Leigh died seized of it in 1576 , leaving a son and heir John, ${ }^{105}$ who died seized of it in 1613 leaving a son and heir Thomas, aged six. ${ }^{100}$ This Thomas and Marian his wife sold the 'manor or farm' of Cansangers in 1634 to John Butler of Alton. ${ }^{107}$

It appears as 'Canchongers' in a map of Alton dated in $1665,{ }^{100}$ 'Cantsinger's house and land' is mentioned in 1740, and there is a field at the back of the houses on the east side of Church Street still known as 'Chauntsinger's field.'

The manor of WILLHALL (Wildehel) was held by Ocsen in the time of Edward the Confessor as an alod of the king, but by 1086 it had passed to Walter son of Other, at which time there was a church there. ${ }^{108}$ Walter son of Other was the ancestor of the Windsor family, ${ }^{110}$ which we find held this manor as overlords. ${ }^{111}$ In 1208 John de Vautort, or Valletort, dealt with this manor by fine, ${ }^{112}$ and later in the thirteenth century a John de Vautort held a knight's fee there of the old feoffinent of William de Windsor, who held of Hugh de Audley (Hauldeleye) who held of the king. ${ }^{112}$ This manor was still in the possession of the Vautort family in I 3 I 2-3, when John Vautort held it.11 In 1428 it was held by Thomas Bromflete of Richard Windsor as of his manor of Stanwell in Middlesex ${ }^{115}$ by a rent of $6 s .8 d$., called Wardsilver, payable every twenty-four weeks, 118 and in $145 \mathrm{I}$ the heirs of Thomas Bromflete held it in like manner of Miles Windsor. ${ }^{117}$ This is the latest reference which has been found of the manor, but the manor house is probably represented by Willhall farm.

Material for the history of $T H E$

$A L T O N$ TOWN OF ALTON seems to be exTOWN tremely scanty. The bailiffs were directed in 1215 to pay to the Crown the farm or rent by which they held it. ${ }^{118}$ Four years later 'the men' of Alton had to answer their rent to William De Préaux who had been granted the manor of Alton by King John. ${ }^{119}$ In I 269 the bailiffs were directed to pay the farm of the town towards the works at Winchester. ${ }^{120}$

The town returned two members to the Parliament of $1295,{ }^{121}$ but no subsequent return is extant, though the bailiffs were on several occasions in Edward II.'s reign directed to make one. The town was granted by the king in 1330 to Hugh de Turpyton for life. ${ }^{122}$ After this we find it in
91 Egerton MS. 2031-4.

92 Feet of F. Hants, John, No. 36.

93 B. M. Add. R. 27,820 .

94 Inq. p.m. ser. 2, vol. 2, No. 74 .

05 Feet of F. Div. Co. Hil. $3 \& 4$ Edw. VI. See under Bramshott.

Q6 Feet of F.Hants, Trin. 3 \& Mich. 3 \& 4 Eliz.

97 Inq. p.m.ii. Exch. File 1002, No. 9. 98 Ibid.(V.O.) ser. 2,17 Jas. I. No. 58. 90 Inq. p.m. Wards \& Liveries, 21. Jas. I. ser. 2, vol. 38 , No. $6 \mathrm{I}$.

100 Par. Rec. quoted in Curtis' History of Alton, p. 87.

101 Inq. p.m. $135 \mathrm{Edw}$. III. I a nos. and pt. No. 56 .

103 Ibid. 17 Ric. II. No. 11 I.

103 Feet of F. Hanta, Mich. 24 Hen, VIII.
104 Ibid. Hil. 3 \& 4 Ph. \& Mary. See also Feet of F. Hants, East. 38 Eliz. and Hil. 43 Eliz.

105 Inq. P.M. ser, 2, cloxv. 82 .

108 Ibid. Wards \& Liveries, bdle. I4, No. 97

107 Recov. R. Deeds Enrolled, Mich. Io Chas. I. m. 8.

108 In the possession of M. G. Knight, Esq.; a copy is in the Alton museum. The map is reproduced in Curtis' History of Alton, p. 114.

109 V.C.H. Hants, i. 497.

110 Ibid. 425

11 We have evidence that the family of Windsor held the overlordship of this manor down to 1451 ; see Inq. p.m. 13 Ric. II. No. 32 ; 9 Hen. V. No. 45 ; 6 Hen. VI. No. $46 ; 17$ Hen. VI. No.
36 ; 30 Hen. VI. No. II. For the descent of the family see the manor of Millcourt in Binsted.

112 Feet of F. Hants, John, No. 7 I.

113 Testa de Nevill (Rec. Com.) $233 \mathrm{~b}$.

111 Inq. a.g.d. 6 Edw. II. No. 93.

116 Ing. p.m. 6 Hen. VI. No. 46.

116 Ibid. 9 Hen. V. No. 45 and 17 Hen. VI. No. 36 .

117 Ibid. 30 Hen. VI. No. 11

118 Close, 17 John, pt. I, m. 6, \& 24 .

$119^{\circ}$ Ibid. 3 Henry III. pt. 2, m. 9 ;

Charter R. 17 John, m. 2.

120 Anc. Corresp. ii. 27.

121 Rerurn of Members of Parl. 1, 5. 122 Pat. 4 Edw. III. pt. I, m. 25. 


\section{A HISTORY OF HAMPSHIRE}

the possession of the lord of the manor of Alton Westbrook, and reference is made, temp. Richard II. and Henry IV., to the bailiffs of the person or persons holding the manor. ${ }^{123}$ The head bailiff of the town is mentioned in $1620 .{ }^{124}$

The evidence points to a prescriptive incorporation of some kind, and this corporation evidently held the town of the grantee of the manor and hundred of Alton, the lord no doubt appointing the bailiffs. Unfortunately no evidence has been found as to when this corporation ceased to exist.

'The hall, called the 'Gildhall' is mentioned in 1434 , worth nothing beyond reprises. A court called 'Le 'Turne,' was then held four times a ycar, twice in Easter term and twice in Michaelmas term. ${ }^{125}$

There is little evidence as to the ancient industries of the town, but the number of Alton tradesmen's tokens of the seventeenth century point to much commercial activity. ${ }^{120}$ In 1738 five hundred persons were engaged in making barracan, a coarse sort of camlet. ${ }^{127}$ Fulling, papermaking, tanning and brewing were also carried on extensively in the eighteenth century. Within recent years an iron-implement manufactory and photo-engraving works have been established.

The RECTORY of Alton was granted to the abbey of Hydc, Winchester, in 1070, by William the Conqueror at the same time that he gave to that abbey the manor of Alton Eastbrook ${ }^{128}$ it was one of the nine benefices of which William Giffard, Bishop of Winchester, temporarily seized the revenues in order to help in providing the cost of completing the great Norman cathedral church at Winchester which Walkelin his predecessor had begun.

In 1309 the abbot of Hyde had licence, for which he paid 100 marks, subsequently remitted, to appropriate the church of Alton with the chapels appertaining. ${ }^{129}$ These chapels were Holybourne, and Binsted and Kingsley, which remained part of the parish of Alton until the nineteenth century.

On the dissolution of Hyde Abbey, the rectory of Alton with Binstead and Kingsley was in lease at a yearly rent of $£ 25$ los.; the lessee was to repair the rectory buildings, the roof with straw. ${ }^{130}$ 'The rectory was granted, I May, 1541, to the desn and chapter of Winchester. ${ }^{131}$

On 18 July, 1580 , Dr. John Watson, dean of Winchester and rector of Alton, leased to the Crown the rectory and right of presentation from 9 May, 1600, for the term of eight-four years. ${ }^{132}$ The queen in the following year assigned this lease to Sir Francis Walsingham. ${ }^{133}$ He assigned it to Launcelot Andrewes, afterwards Bishop of Winchester, towards his support at the university.
In 1649 there belonged to the rectory, seized by the Parliament as the property of the dean and chapter of Winchester, "the tythes of all sorts of corne and hay within the parish of Alton, except the villages of Kingsley and Binstead, two barns and other necessary outhousing containing half an acre.' 134

The church of St. Lawrence is for CHURCH the most part of the fifteenth century, and consists of a chancel and nave of seven bays without any structural division, with a south aisle of the same length, but divided midway by a tower of much earlier date, with shingled broach spire, to the east of which projects a small vestry; there is also a south porch, and opposite to the vestry an organ chamber formed out of an old chapel.

The church consisted originally of a chancel, central tower, transepts, and a nave, to which were added a south and perhaps a north aisle. The nave and aisles were certainly of three bays, and may have beon longer.

The date of all this work, with the exception of the aisles, was early Norman, probably circa 1090. The aisles were added about II 40 .

Early in the thirteenth century the chancel, which was probably apsidal, was replaced by a new one, square ended and of greater length, which was widened northwards early in the fourteenth century. About a century later great alterations were made. First the north transept was taken down and the north side of the nave. An arcade was then pierced through the north wall of the chancel, and prolonged westwards as far as the west wall of the nave. This arcade formed the south side of a new chancel and nave, which were carried up with it. The south transept was also taken down, and the tower arch that opened into it walled up. The vestry and stair turret were then built, partly as abutments to the tower, and from the east and west sides of the tower short connecting walls were carried northwards to join the newly built arcade. The arcade on the south of the nave was also walled up, and the aisle removed, and the nave itself widened by taking down its north side and extending it up to the new arcade. The addition of the south porch and of a projecting chapel or vestry on the north side of the new work completed the present somewhat unusual plan.

'The north chapel is probably that mentioned in a royal licence of 20 October, 1473, to Sir Maurice Berkeley, Sir John Parre, Hugh Crikland, perpetual vicar of Alton, and others to found a chantry of one chaplain to celebrate daily ' in a chapel lately built by John Champfloure in the said parish church.' ${ }^{138}$
123 Add. R. 27,8 I6 and 27,826.

124 Monumental brass to him in Alton church.

125 Inq. p.m. 12 Hen. VI. No. 43. In the middle of the ixteench century we have mention of mesiuages called Le Hart and of an inn called Le Pellycan (Mini. Acct. 30-3 I, Hen. VIII. No. 135 , m. $38 \mathrm{~d}$ to $39 \mathrm{~d}$ ).
126 Curtis's Hist. of Alton, p. 114. 127 Hist. MSS. Com. Report on the Duke of Portland's Papers, vi. (x.) I 72. 128 Hyde Abbey, Hants Rec. Soc. p. 110. Stowe MS. 944, fo. 41 .

129 Inq. a.q.d. 2 Edw. II. I 42 ; Pat, 2 Edw. II. pt. 2, m. II, \& Close, 4 Edw. II. m. 26 .
130 Min., Acets. No. 30-3I Hen. VIII. $135, \mathrm{~m} .35$.

131 Pat. 33 Hen. VIII. pt. 9, m. 5-11. 132 Ibid. 23 Eliz. pt. 11, m. 3. 133 Ibid.

194 Parl. Surv, of Ch. Liv. at Lambeth. 196 Pat. 13 Edw. IV. pt. 2, m. 15. 


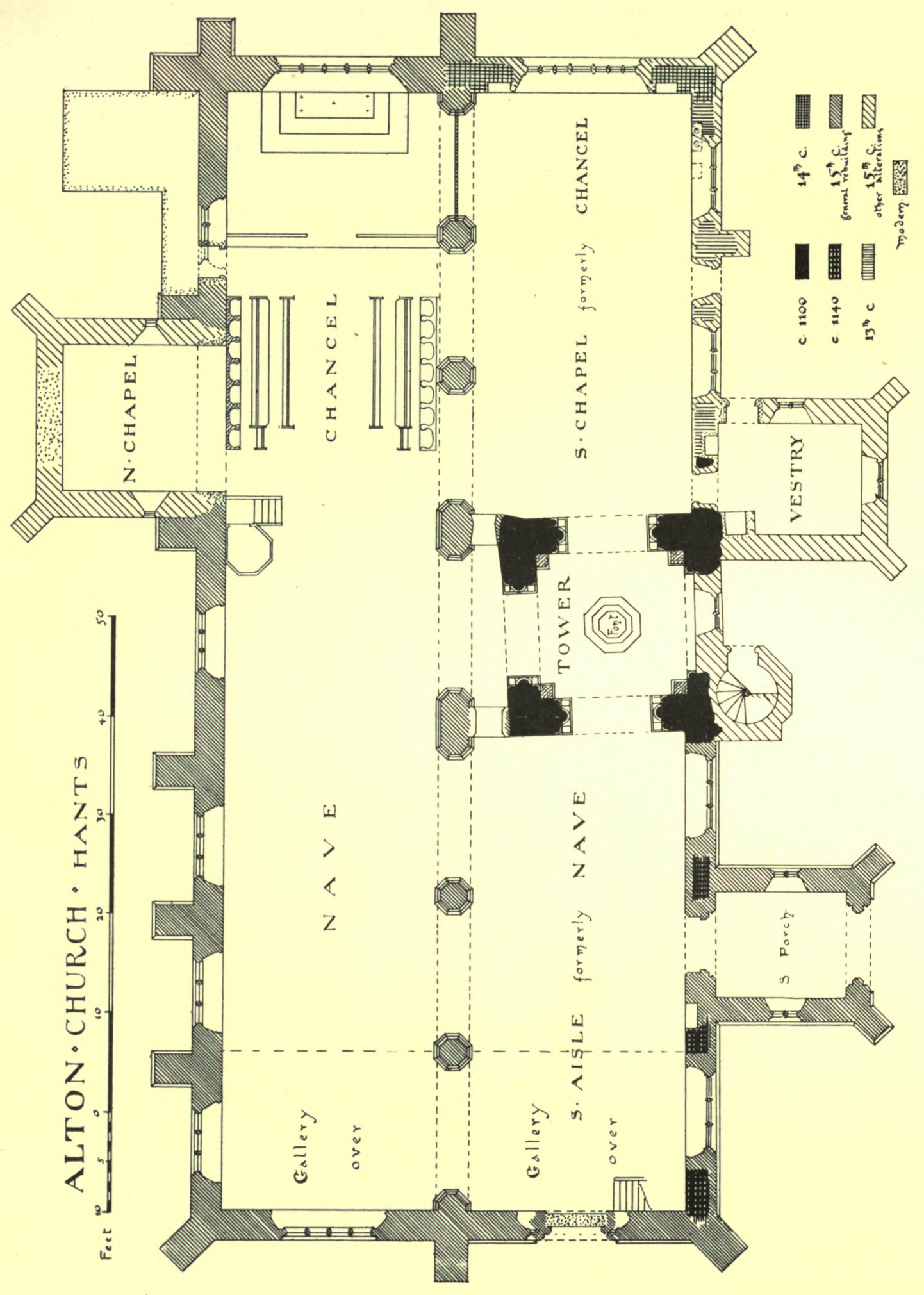





\section{ALTON HUNDRED}

The old central tower still retains its four arches, each of two orders with a heavy roll, with rudely ornamented capitals, in which may be seen lingering traces of the classical volute. Over each arch is a round-headed opening that formerly led into the roofs. In the angles of the tower are the massive oak timbers that support the bell-frame above. The tower is separated from the arcade on the north by a narrow interval, and has arched openings pierced through both the walls now connecting it with the later arcade. The original nave piers were oblong in plan with a simple band of

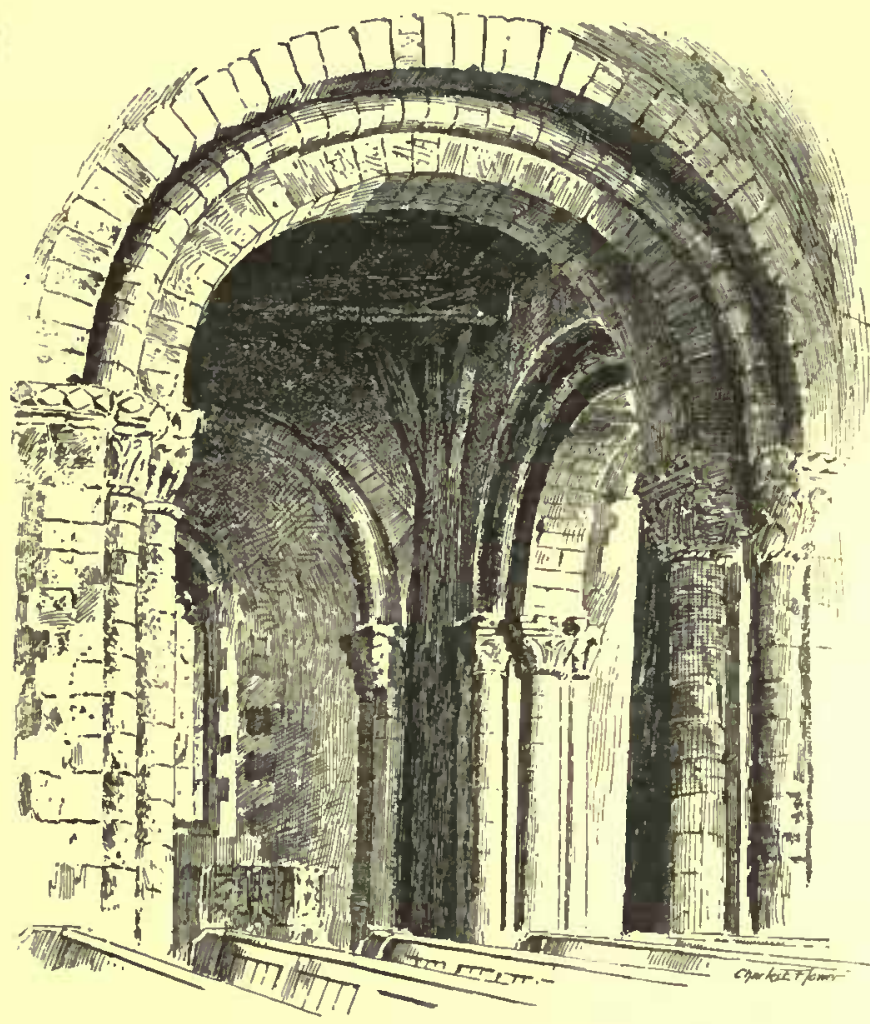

ARCHES OF THE OLD CENTRAL TOWER.

ornament by way of impost. Traces of them are visible in the present south wall.

Of the thirteenth century chancel, the lower parts of the east and south walls remain. The latter has within a trefoiled arch a drain with two bowls and groove for a shelf, and to the west of it a small square locker. There is a tall niche with trefoiled head on the south side of the east window, and a narrower one of like pattern on the north side. These belong to the widening of the chancel northwards in the fourteenth century. In the east wall of the tower and the north jamb of the east window of the south chancel are two stones, each carved with a crosier grasped by a hand in the middle. They are on the line of the north wall of the first chancel and possibly refer to the rectorial liabilities of Hyde Abbey, which were not altered when the parishioners afterwards enlarged the chancel.

The arcade dividing the two chancels and naves is of seven bays with octagonal pillars of good design, but the third and fourth are practically oblong piers to enable them to range with the tower, with which they are connected by the before-mentioned spur walls.

The windows in the north and south walls of the two naves are alike in pattern, of three lights with depressed heads, but the chancel windows are of somewhat earlier character with more massive tracery, and the east windows are of the same date. The west window of the north nave is modern. The sonth nave has a fifteenth century west doorway, now walled up, and another, four-centred, on the south. There are some remains of an arched recess under the second window from the west. Inside the south door, which is covered by a contemporary porch, there is, on the west, a large niche for the holywater stock. The south door itself is original and of massive oak, riddlcd and splintered by the bullets of the Parliamentary soldiers who attacked the Royalist soldiers taking refuge in the church in $1643 .^{136}$

The roofs throughout are of low pitch, covered externally by a larger and modern roof of one span. They are for the most part of the fifteenth century with tie beams. There is part of an old screen in the first bay of the arcade, and the doorway on to the roodloft in the southern nave remains above the opening in the north-east angle. In the north quire are fourteen stalls, seven of which are old, with simple miscricords. There is also a desk with good tracery. All are of the fifteenth century. All the seats in the church, together with the western gallery and the font, which stands under the tower, are modern, dating from 1867, when the church underwent restoration. The pulpit is a very fine and rich example of late Jacobean work with detached pillars at the angles, and near the altar is an old 'poor man's box' with a wooden table above inscribed with the text from Tobit iv. 7 . In the tower hangs a good brass chandelier of many branches, the gift of Thomas Baverstock, gentleman, in 1780 . The elaborate oak reredos and the organ are both of recent date.

Until the restoration of 1867 , "large galleries extended round the church, and one crossed the aisle in front of the communion table, with its back to the east window. One gallery was entered from the belfry. Between each pew door in the north aisle was a small seat for the use of the inmates of the workhouse.' 137
138 Godwin's Civil War in Hampshire, $100-\mathbf{I}$.

137 Curtis's Hist. of Alton, 56, 57, II which contains many details of interest as to work on the church in the eighteenth and nineteenth centuries taken from the churchwardens' accounts. 


\section{A HISTORY OF HAMPSHIRE}

On the north face of the fifth pillar of the arcade are coarsely executed early sixteenth century paintings of St. Cornelius, King Henry VI. and an archbishop, probably St. Thomas of Canterbury.

There are not any old monuments in the church, but on the sixth pillar of the arcade are affixed brass inscriptions to Richard Clarke, ob. I 485, and his daughter Margery, wife of Richard Fylder, ob. 1534, and to Christopher Walaston, 1563 , and a small figure of a lady, circa 1510. There are also other brass inscriptions in the church to Robert Fry, "late Hedd Bailliffe of this Towne,' 1620, Elizabeth Geale, 1638, Robert Lamport, 1667, and Thomas Pinke, 1713, his wife and children; also the figures of three female children.

The east window of the north chancel was filled with painted glass, by a Belgian artist, in 1870 , in memory of the Rev. Edward James, canon of Winchester and vicar for twenty-two years. The painted glass in the other east window was inserted in $\mathbf{1} 88_{4}$ in memory of Dr. Lewis Leslie.

Externally the walls arc rough cast throughout and the roofs tiled.

The tower is of three stages, with, originally, two plain round-headed windows in the east and west faces of the uppermost story, and three like openings on the north and south sides. This last has given place to a modern pseudo-fourteenth century window of two lights. The tower is surmounted by a wooden spire, the old lead covering of which was replaced in 1873 by oak shingles and has at its south-west angle a projecting turret staircase. It contains cight bells, the sixth of which is inscribed: "Thomas Janaway of Chelsea made us all 1785.' 'The seventh was recast in 1890 , as it had become cracked. There are five ringers' boards in the belfry.

The clock, which strikes the Cambridge quarters, was erected in 1889 by Messrs. Benson of London.

The communion plate consists of a silver gilt flagon given in 1711 by Matthew Hawkins; a silver gilt flagon left, in 1721 , together with a gilt paten and a woollen cloth for covering the holy table on all Sundays and festivals, by the will of William Turner; a silver gilt alms dish given in 1722 for the use of the altar of Alton by Edward Fisher ; a silver alms dish, Victorian ; a large silver gilt chalice and paten with no inscription or hall mark; a small silver gilt chalice given in 1818 by Elizabeth Baker; and a small silver paten given in 1859 by William Dyer, churchwarden.

Over the south-east entrance gates to the churchyard there is some fine wrought iron work which may be Jacobean.

The family of Champflour appears as holding lands of the manor of Alton, ${ }^{138}$ and, as has already been mentioned, Sir Maurice Berkeley, kt., the vicar of the church of St. Lawrence, Alton, and several other persons received the royal licence in 1473 to found a chantry of one priest to celebrate daily divine service in a chapel 'then lately built.' It was to be called 'the Champloure Chantry.' 139 This is called in the Chantry certificate of 1545 the 'Blanceflowers' Chantry. 140

The registers begin in 1615 , and previous to 1812 consist of four volumes : i. 1615-1711; ii. $1711-65$; iii. $1754-85$; iv. $1760-1812$.

There is a volume of churchwardens' accounts which commences in 1625 . The tything man and constables were paid by the vestry, and constables were appointed up to 1872 . Penalties are entered of 5 s. for breaking the Sabbath and 1s. for tippling in an ale house on the Sabbath day. Besides church rates is. was paid for each seat allotted in the church. Payments are mentioned for cleaning the church engine. In 1740 the expenses for fifty-five weeks at the workhouse amounted to 6174 Ios. IId.

The new church of All Saints', of the Early English style, was built in 1873 and consecrated in the following year. The tower and spire with three bells were added in 1881 . In the chancel is a stained glass window to the memory of Bishop Samuel Wilberforce. An oak reredos and pulpit were given in 1892 and a chancel screen in 1894 .

The Society of Friends has held meetings at Alton since about $166_{4}$, and the present meetinghousc has been in use probably since 1672 . The Congrcgationalists had a chapel there in 1696 . The Baptists started their meetings in $184^{\circ}$ and the Wesleyans in 1842 .

There was a school in Alton in 1548 , but the present Grammar School was founded by John Eggar in 1638.11

CHARITIES dean and chapter of Winchester, owners of the rectorial tithes of

Alton, by deed dated 25 January, 1841 , granted to the vicar of Alton and others the yard and buildings belonging to the rectory in perpetuity as a school for poor children. The last surviving trustee in 1857 vested this property in the vicar and churchwardens of Alton and their successors.

Mrs. Baker of Alton by her will gave 6100 , the interest to be applied to the support of the Sunday School.

A sum of $£ 1,000$ Consols is made up as follows : Richard Marshall in 1843 left a sum of 6700 to be applied as an endowment of the Sunday and National Schools. At about the same date Jane Exall of Alton added $£ 200$ to Marshall's gift. William James Hawkins, son of James Hawkins of Alton, added $E_{0} 100$ to Marshall and Exall's gifts.

Martha Hutchins by her will dated I 9 January, 187 , left $\{200$, the interest to be applied to increase the salary of the headmistress of the National Schools.

The British Schools were built at the cost of Frederick Crowley of Alton in 1867, and vested by him in trustees for the education of boys. In 1877 a girls' school was added.

We find that in 1548 , 9s. $2 d$. of the revenues of the chantry in Alton went to the relief of the 


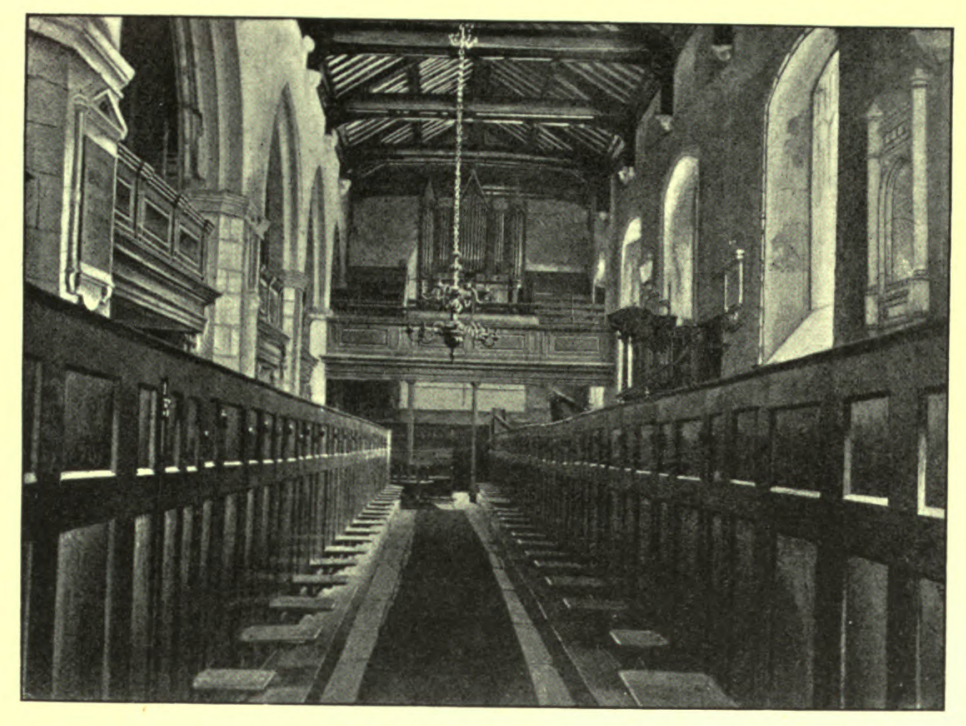

Interior of Alton Church (looking West) before Restoration.

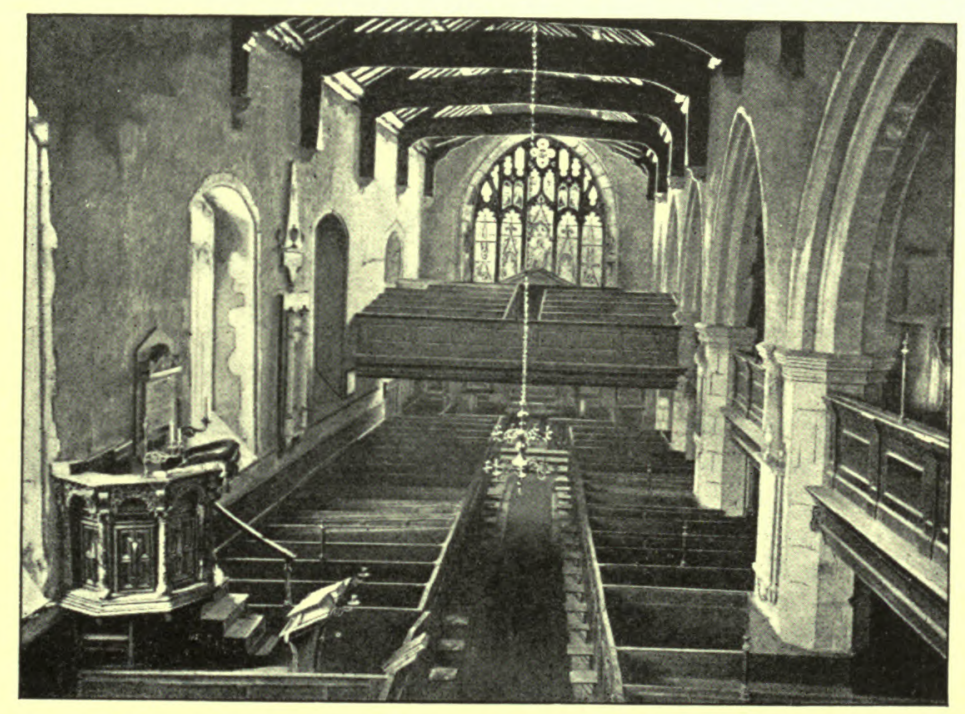

Interior of Alton Church (LOoking East) Before Restoration. 

poor, and there were payments to the poor in connection with obits celebrated in the church. ${ }^{142}$

Town lands. ${ }^{143}$ A piece of garden ground in Normandy Street, and a piece of land in Nether Street Fields, which formerly included 4 perches taken by the Mid-Hants Railway Company under a deed dated 24 March, 1873, at an annual rent charge of $\mathrm{L}_{12} 16 \mathrm{~s} .6 \mathrm{~d}$., payable to the churchwardens and overseers of Alton. The same officials also receive the interest of $\&_{624} 4 \mathrm{~s} .7 \mathrm{~d}$. Consols, being the proceeds of the sale of the following town lands. The site of four tenements on the west side of Cut Pound Street with a piece of land in Lenton Lane communicating with it. The site of two tenements on the east of the upper part of Normandy Street. Half an acre of land behind a barn called Spital Barn.

The following property was diverted from its previous charitable uses during the last century. Five tenements in Normandy Street adjoining Chauntsinger's Field which were sold about 1860 and the proceeds probably paid to the guardians of the poor. A shop in the market-place near the eastern corner of Cut Pound Street, misappropriated before $1824 .{ }^{144}$ An acre of land at Medstead in Middle Field near Bar Stile. A small piece of land at Redhill in Medstead, for which until 1812 an annual rent of 1s. $6 d$. was paid.

Magdalen College, Oxford, pays an annual sum varying in amount, in lieu of 9 bushels of wheat, out of the great tithes of East Worldham, to the vicar and churchwardens of Alton, who distribute it to the poor.

John Stent by his will dated in 1592 gave a yearly rent charge of $\sum^{10}$, less $135.4 d$. land tax, on lands at Wivelrod in the parish of Bentworth, payable to the minister, churchwardens and constables, to be distributed to the poor. By deed dated 2 April, 1765, this annual rent is charged on a messuage and land at Wivelrod, Bentworth.

John Knight of Chawton by his will dated 15 August, 1617 , gave a yearly rent charge of $£_{2}$,

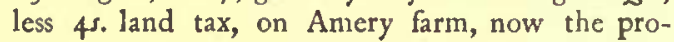

perty of John Gathorne Wood, payable to the minister and churchwardens for the poor.

Sarah Greaves by her will dated I May, I640, gave a yearly rent charge of $f^{2}$, less 4 s. land tax, on lands in Alton, now the property of Messrs. Spicer of King's Mill, Alton, and payable to the poor through the churchwardens.

Thomas Geale by deed dated 27 March, 1649 , gave a yearly rent charge for 1,000 years of $f 2$, less 4s. land tax, on Caker Mead near Caker Bridge in Alton, now the property of Montagu G. Knight, of Chawton, and payable to the vicar and constables of Alton for the poor.

Thomas Geale also left by his will dated 2 May, 1653, four tenements for the use of eight poor people born in Alton. $\mathrm{He}$ also bequeathed to the aged inhabitants of his almshouses $\ell_{4}$ per annum payable out of lands called Ravenshurst in Chobham, Surrey. The payment ceased before 1824 .

Bartholomew Goodyer by his will dated $\mathbf{2 7}$ November, 1789, left $£ 50$, the interest on which was to be given away by the ministcr, churchwardens and overseers in loaves on the first Sunday of every month to old people.

John Fisher of Bristol by his will dated 3 June, 1741 , directed his executors to buy land in Alton to yield $\ell^{8}$ per annum for three sermons to be preached in Alton church on the anniversary of his death, on Good Friday and on St. 'Thomas's Day, and for a distribution of bread and money to the poor. Edward Fisher, nephew of the bencfactor, maintained the charity during his life, and reserved a fee farm rent on a small property at Holybourne near Alton. After his death in 1812 John Fisher his nepliew paid $f_{4}$ for loaves to be given to twenty foor widows as long as they lived in Alton. The payment of the sermon money was discontinued about 1820 by John Fisher, and after his death William Fisher his brother rcfused to make payments to any fresh widows. A fee farm rent of $\complement_{3}$ is still paid in respect of Holybourne Brewcry to the trustees of the will of the late William Fisher.

\section{BINSTED}

Benestede (xi. cent.); Benstede (xiv. cent.); Bensted (xvii. cent.).

The parish of Binsted is bounded by the northern branch of the river Wey on the north and the Surrey border on the east.

Binsted village stands at the intersection of a road leading from Buck's-Horn Oak, in Alice Holt Forest, westward to Holybourne, and a road from Bentley southward to Kingsley. The road from Farnham to Portsmouth passes through the length of Alice Holt, which is an ancient forest of fine oak and beech, stretching across the eastern end of the parish from north to south, where it nearly adjoins Wolmer Forest.
Wyck, one of the hamlets of the parish, is situated on a road from Binsted village to East Worldham, and near it is Binsted Wyck, the residence of Mrs. Wickham. Isington, another hamlet, lies near the river Wey on the northern boundary of the parish, and Wheatley is a hamlet a mile to the south-east of Binsted village.

Amongst other place-names in Binsted we have, in 1339 , a meadow called ']e Kolemede,' a wood called 'le Broke,' and land called 'Ancrades lond' ' 1 in 1358 a croft called 'le Broudehoukes' and a meadow called 'le Houkemede,' lying below 'le Wykes'; ${ }^{2}$ in 1586 a wood called Grymes Grove, a close called Cleypitts, a place

\footnotetext{
112 Chantry Cert. 51, No. 14, \& 52, Mr. William Trimmer, solicitor to the No. 12. 


\section{A HISTORY OF HAMPSHIRE}

named Sturtlemead, and a messuage called Great Inhams. 8 In I 601 messuages called Palmers and Holgate are mentioned. In I6I 1 we have mention of a messuage called 'Teaselies' or 'Theselies.' 6 hides and other lands and a mill in Binsted, then held of the king in chief. ${ }^{8}$ Though there is no actual proof of the fact it may be presumed that the manor remained in the Popham family for a con-

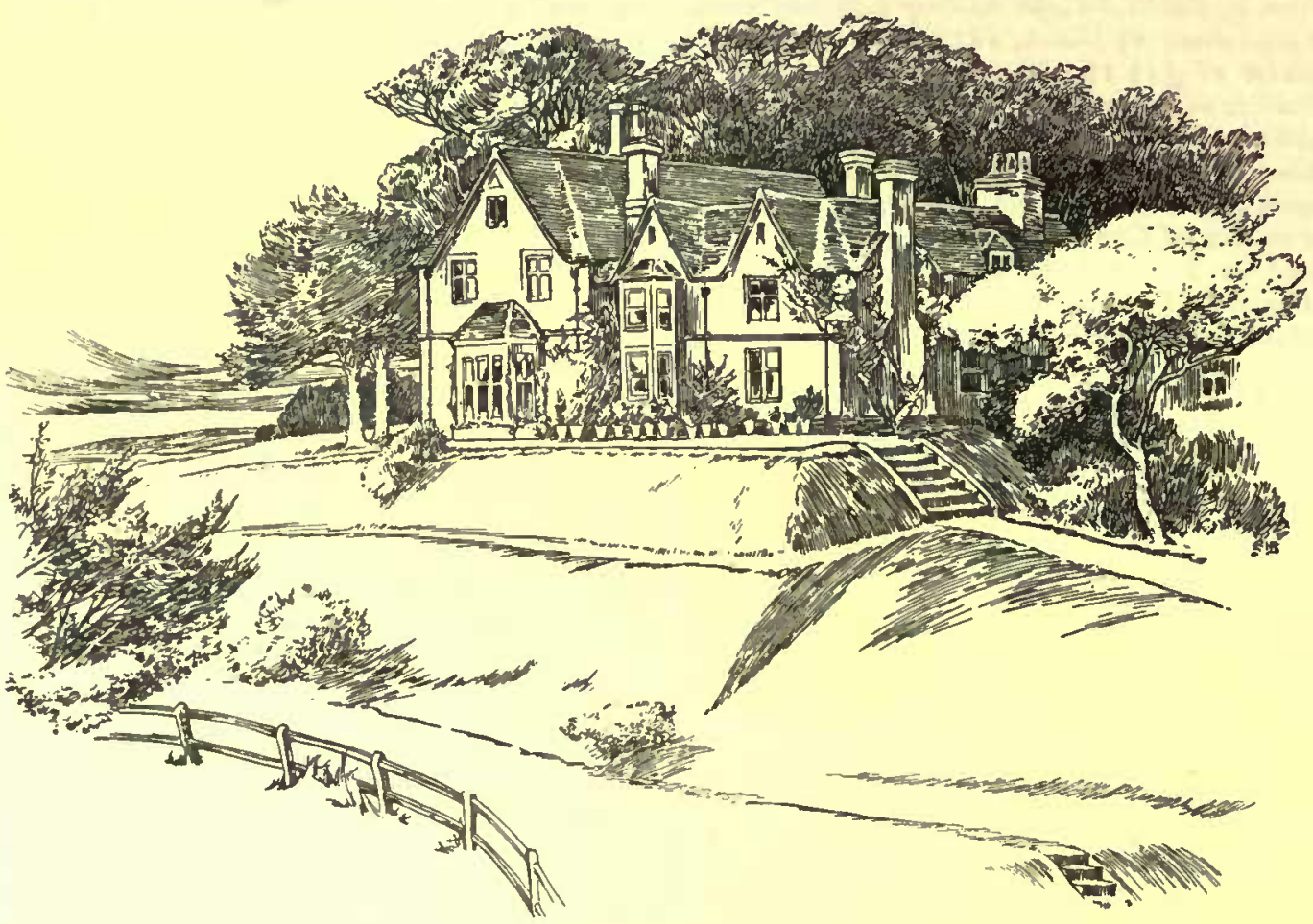

BINSTED WYCK.

(From a sketch taken before the addition of the tower.)

In the time of the Confessor the $M A N O R S$ manor of BINSTED, afterwards known as BINSTED POPHAM, was held by Boda as an alod of the king, but after the Conquest it was held under the Bishop of Bayeux by Hugh de Port, his vassal, who, in addition to his own extensive possessions as tenant in chief in England under the Conqueror, farmed the bishop's many holdings in Hampshire.

Henry I. granted by char- ter to Richard son of Thurstan all the land of Binsted to hold of him in chief.7

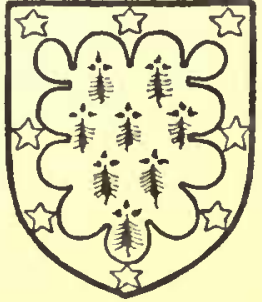

Wiскнам. Ermine a border engrailed gules witb molets of gold. From this Richard it eventually descended to Robert de Popham, living in $1268,^{8}$ who in 1250 was found to be son of Gilbert de Popham and heir to the 'manor' of Binsted, and aged twentyfive years. Gilbert de Popham had in 1225 done homage, as heir of his mother Agnes, for three siderable period, as we find that in 1418 , Henry Popham died seized of it, then described as held of others than the king, but of whom or by what service it was not known. ${ }^{10}$ This uncertainty of tenure is probably to be accounted for by the fact of complications in the descent of the chief manor of Alton at the period (q.v.).

Henry Popham's heir was his son Stephen, who was of age in 1418 . Stephen died in 1445 , and it was found by inquisition that the manor of Binsted was held by him of Sir Henry Grey, knight, as of his manor of Alton, by fealty and an annual rent of 3s. 4d. The manor was worth yearly beyond reprises 20 s. Stephen had enfeoffed certain persons with the property, and left four daughters and co-heirs : Elizabeth the elder, aged eighteen, the wife of John Wadham; Margery, aged ten; Elizabeth the younger, aged six; and Alice, aged one. ${ }^{11}$ The feoffees appear to have permitted Sir John Popham, a kinsman, to occupy the manor during his life, and on his death in 1464 the above-named daughters of Stephen, then all married, were found to be his heirs. ${ }^{12}$ Binsted Popham passed to the eldest daughter Elizabeth, who married Sir John a Close, 28 Eliz. pt. 9, Deed, Lord Windsor to Edmund Marvyn.

Ibid. 43 Eliz, pt. 11. Deed Redynghurat to Savage.
6 Add. Chart. 8,503 and 8,504.

- V.C.H. Hants, i. 486 .

7 Cur. Reg. R. No. 184 , roll 4 . 8 Ibid.
9 Fine R. $9 \mathrm{Hen}$. III. m. 5 .

10 Inq. p.m. 6 Hen. V. No. 36.

11 Ibid. $24 \mathrm{Hen}$. VI. No. 18

12 Ibid. 3 Edw. IV. No. 7. 
Wadham, knight ;3 and Sir Nicholas Wadham, their son or descendant was seized of it and granted it to his son Laurence, who died seized thereof in 1521 , and whose heir was his brother John. Presumably this John $W$ adham alienated half of the manor, as he, in I 577, died seized of only a moicty of it, which moiety descended to his son and heir Nicholas Wadham, founder of Wadham College, who in I609 died seized thereof, leaving as his heirs: John Strangways, grandson of his sister Joan; Frances wife of Thomas White, Elizabeth wife of Thomas Hamon, Ann wife of Anthony Floyer, children of his sister Margaret ; Edward Richards, grandchild of the same Margaret; and Sir John Windham, son of his sister Florence. Nicholas' widow, Dorothy Wadham, and a near kinsman, Edward Wadham, had, in 1613 , occupied the moiety of the manor since Nicholas' death. ${ }^{14}$ Between these heirs the moiety of the manor of Bin-

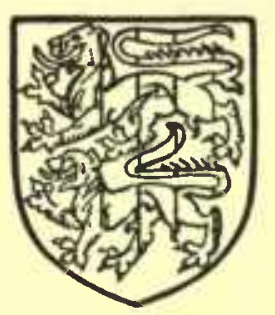
rwo lions passant paly silver and gules.
Strangwayg. Sable

Rivers seems to have been party to a division of the manorial property with Nicholas Wadham. ${ }^{20}$

A manor of Binsted Popham was conveyed, probably in trust, by Sir James Worsley, Bart., to Giles Taylor in $1749,{ }^{21}$ and in 1773 his son and successor, Sir Richard Worsley, together with his son and heir James, executed a disentailing deed in regard to the manor of Binsted Popham and River Hill farm in Binsted parish. ${ }^{22}$

Besides the manor of Binsted Popham there was in Binsted parish a manor of BINSTED held by 2 family named Bensted. In 1323 John de Bensted died seized of a messuage and land in 'Binsted-juxta-Alton' which he held of Alton, and left a son and heir Edmund, aged eleven. ${ }^{23}$ In $135^{8}$ John de Bensted held a messuage, etc., in Binsted of the heirs of John de Popham, as of his manor of Popham (sic), and left a son and heir John, aged five. ${ }^{24}$ In 1375 it was found that this messuage had come to the hands of the king by the death of John de Bensted, senior, and the minority of his son John. Edward Bensted was brother and heir, of the younger John and was then of age. ${ }^{25}$ In 147 I Sir John de Bensted, knight, was found by inquisition to have died seized of the 'manor' of Binsted described as held half of the king and half of the Earl of Worcester as of the manor of Alton. William was his son and heir, then aged sixteen. ${ }^{26}$ But, as appears by the inquisition taken upon his son in 1486 , he had long before his death alienated the manor, ${ }^{27}$ and John White of South Warnborough died seized of it ${ }^{28}$ in 1469 . Robert White was his son and heir; in the inquisition taken on his death the manor of Binsted is not enumerated among his possessions, ${ }^{29}$ but his son and heir, Sir Thomas White, who died in 1566 , owned the manor, ${ }^{30}$ and ' $\mathrm{Mr}$. White' appears as paying a rent of $26 s$. $8 d$. a ycar to the lord of Alton in a rental of which the date is about $1600 .^{31}$

There was also in Binsted parish a manor of $B I N S T E D$ ST. CLARE. In 120 I Robert St. Clare acquired of Humphrey St. Clare a virgate of land in Binsted. ${ }^{32}$ In I 335 John St. Clare died seized of the 'manor' of Binsted St. Clare, held by him, conjointly with Alice his wife, who survived, of Sir John Scures, knight. John St. Clare's son and heir was John, then aged three. ${ }^{33}$ Apparently Queen Philippa had the wardship of this minor, as in 1346 she held half a fee in Binsted, which John St. Clare had held. ${ }^{34}$ In 1391 Philip St. Clare conveyed this manor to the Bishop of Winchester and his successors. At the same time Sir Thomas Wortyng and Isabel his wife, daughter and heir of obviously inaccurate, as one moiety was certainly possessed by the Wadhams. In I607 Marcellus Mallet, ${ }^{18}$ and in 1590 and 1596 by Robert Brett and Christine his wife, who at the latter date sold it to Marcellus Rivers. ${ }^{18}$ It is to be remarked that in these dealings the property is referred to as the manor - not the moiety of the manor-of Binsted Popham, a description 13 Feet of F. Div. Cos. File 75, No. 17.

19 Ibid. Div. Co. Hil. 32 Eliz., and Mich. 38-9 Eliz., and Hants Mich. $3^{8-9}$ 17. No. 56 .

15 Papers in the possession of the Wheeler family at Wheatley.

10 Feet of F. Div. Co. Hil. I2 Jas. I. ; Mich. 13 Jas. I.; and East. 18 Jaa. I. and Comm. Pleas, Deeda Enrolled, East. 19 Jas. I. m. 5 .

17 Will of Henry Wheeler, and papers in the posacsion of the Wheeler family. 18 Feet of F. Div. Co. East. 14 Eliz.
Eliz.

20 Papers in the passession of the Whecler family-indenture of 10 Jan., 4 Jas. I. Wadham to Wheeler.

21 Feet of F. Div. Co. Trin. 22-3 Geo. II.

22 Com. Pleas, Recov. R. Hil. I3,

Geo. III. Deeds enrolled m. 32.

23 Inq. p.m. 17 Edw. II. No. 43.

24 Ibid. 33 Edw. III. 2nd nos. No. Iog.
25 Ibid. 50 Edw. III. I at nos. No. 9.

28 Ibid. I 1 Edw. IV. No. 57.

27 Ibid. Chan. ser. 2, vol. 23, No. 42.

28 Ibid. 9 and 10 Edw. IV. No. 25.

29 Ibid. ser. 2 , vol. 27 , No. 65.

30 Ibid. vol. 145 , No. 9.

31 Add. Chart. 27,893.

32 Feet of F. Hants, 2 John, No. 13.

33 Inq. p.m. 9 Edw. III. 1 st nos. No. 48.

34 Feudal Aids, ii. 335 


\section{A HISTORY OF HAMPSHIRE}

Hugh St. John, confirmed it to the bishop. ${ }^{35}$ Shortly after 139 I the Bishop of Winchester obtained a grant of free warren in his manor of Binsted St. Clare, ${ }^{36}$ and in 1428 the Bishop and John Estney held the property, described as formerly held by John St. Clare. ${ }^{37}$ In 1431 William Lord Botreaux held a free tenement in Binsted ; ${ }^{38}$ and in the inquisition taken on his death in 1462 this is described as the 'manor' of Binsted held of the Bishop of Winchester. He left a daughter and heir Margaret, aged forty, the widow of Robert, Lord Hungerford. ${ }^{39}$ This is the last reference that has been found to the manor of Binsted St. Clare. The bishop has now no possessions in Binsted. There is a fine dated 1527 by which a manor of Binsted was acquired by William Lokke of William Purde and Joyce his wife, with a warranty against the heirs of Joyce and the Abbot of Westminster, ${ }^{30}$ and in a rental of Alton of about 1600 , John Locke paid rent for 'Billinghurst farm' in Binsted." 4

An extent of the manor of Binsted St. Clare taken in 1335 mentions a capital messuage with a garden, 2 acres of pasture, a water mill, 2 acres of wood, pleas of the court, etc. ${ }^{42}$

Held of the manor of Binsted St. Clare, and situated in the parish of Binsted, was the manor of WESTCOTE or WESTCOURT. We first hear of this manor in 1333, when Richard de la Bere, whose son and heir was Thomas, then aged thirty, dicd seized of it, rendering yearly to Richard Folyott of Rolesham a pair of gloves. ${ }^{43}$

In 1346 Nicholas de la Bere held Westcote of the manor of Binsted St. Clare. ${ }^{44}$ In 1363 Thomas de Westcote died seized of it, lcaving a son and heir Richard. ${ }^{s}$ In a rental of Alton, dated $139^{8}$, we find that Richard Westcote paid 55. for certain lands and tenements in Binsted. ${ }^{48}$ In 1428 the property was held by Elizabeth Wayte, ${ }^{47}$ and in $145^{8}$ Richard Holt died scized of it, when it was said to be held of Alton. He left two daughters and co-heirs, Christine, aged fourteen, and Elizabeth, aged ten. ${ }^{\text {s }}$ Christine becamc the wife of Sir Edward Berkeley, knight, who held the manor by courtesy, at her death in 1506 ; it was then held of the manor of Alton. By Christine, Sir Edward had a daughter Laura, who married William,
Lord Mountjoy, who died in 1485 , and his son William, in I 506, was heir to the manor and aged twenty-six. ${ }^{49} \mathrm{He}$ died in 1534 , and the year before his death sold it to William Thorpe. ${ }^{50}$

After this Westcourt was held by Sir Richard Lyster, who died I553. He was succceded by his grandson Richard, who sold it in 1555 to Henry Heighes, who died seized of it in $1595,{ }^{51}$ and was succeeded by his son Nicholas. In $160_{2}$ Nicholas acquired a third part of the manor of William Tuttie and Thomasine his wife. ${ }^{52}$ Nicholas died in $1620 .{ }^{53}$ He had sold the reversion of the manor to Henry Pratt, but his brother Edmund, who was over age at Nicholas's death, is mentioned in the rental of Alton, of about 1600 , as paying $60 s .4 d$. rent for property in Binsted, ${ }^{54}$ though Thomas Locke paid rent for 'Westcotte Ferme., ${ }^{55}$ Edmund left it in 1652 to his wife Joan for life and then to his 'sister's daughter's eldest son,' Samuel Woodford. The manor remained in the Woodford family till $\mathbf{1 7 2 8}$, when the Ridges became owners, ${ }^{56}$ and on the death of Sir Thomas Ridge, a wine merchant at Portsea, in 1768, his creditors, the Earl of Buckinghamshire and Bishop Warburton of Gloucester became owncrs. They conveyed it in 1769 to Dr. John Butler, prebendary of Winchester and afterwards Bishop of Hereford, who died in 1802 leaving it to his nephew, John Butler Ford, who died intestate in 1826 , when the propcrty was inherited by his brother, Frcderick Ford, who in 1831 sold it to Mr. Henry Wheeler of Mill Court, Binsted, in whose family it still remains.

An cxtent of Westcourt in 1332 mentions a capital messuage, dovecote and garden, 64 acres of arable land, $4 \frac{1}{2}$ acres of meadow, two ponds and an acre of wood; the rents of the frec tenants amounted to $48 \mathrm{~s}$. I I $\mathrm{d}^{57}$

Westcourt Mill was the subject of a lawsuit in the reign of James $I .^{58}$

The manor house is situated a short distance to the north-west of the church, and was occupied up to 1894 by tenants of the owner of the manor, but is now divided into tenements for labourers. The present owner does not possess any court rolls of the manor.

In July, 1367, Richard de Windsor died seized of the manor of ' $L A$ MULLE' or MILLCOURT held of Alton, leaving Miles son of James de Windsor his grandson and heir, aged fourteen. $^{39}$ Brian de Windsor held it in $1398 .^{.00}$ Alice wife of Brian Windsor died seized of it in 1406, leaving Richard son of the said Brian her heir. ${ }^{81}$
35 Feet of F. Hants, file 29, Nos. $4,6$.

${ }^{36}$ Chart. R. 14 Rich. II. No. 13.

37 Feudal Aids, ii. 357 .

28 Ibid. p. 363 .

39 Inq. p.m. 2 Edw. IV. No. 15.

10 Feet of F. Hants, Mich. 18 Hen VIII.

11 Add. MS. 27,893 .

42 Inq. p.m. 9 Edw. III. No. 48 .

$\$ 3$ Ibid. 6 Edw. III. Ist nos. No. 73 .

34 Feudal Aida, ii. 335.
45 Inq. p.m. $37 \mathrm{Edw}$. III. Ist nos., No. 74 .

16 Add. Chart. 27,820.

47 Feudal Aids, ii. 357 .

48 Inq. p.m. $36 \mathrm{Hen}$. VI. No. 32.

49 Ibid, ser. 2, vol. 19, No. 89 .

50 Feet of F. Hants, Mich. 24 Hen. VIII.

51 Inq. p.m. Chan. ser. ii. vol, 250, No. 16.

52 Feet of F. Hants, Mich. 44-5 Eliz.
53 Inq. W. and L. 20 Jas. I. bdle. 56, No. 186; and Inq. p.m. 12 Chas. I. pt. 1, No. 49 .

54 Add. Chart. 27,893. 55 Ibid.

50 Feet of F. Hants, Mich. 2 Geo. II.

57 Inq. p.m. $6 \mathrm{Edw}$. III. Ist nos. No.

58 Chan. Proc. Jas. I. c. 26/85.

69 Inq. p.m. $41 \mathrm{Edw}$. III. Ist nos. No. 61 .

60 Add. Chart. 27,820.

61 Inq. p.m. 8 Hen. IV. No. 57. 


\section{ALTON HUNDRED}

In 144 I Miles Windsor died seized of the manor of Millcourt in Binsted, leaving a son and heir Thomas, then aged eleven. ${ }^{62}$ This Thomas died seized of it in 1485 , leaving a son and heir Andrew, then aged cighteen, who was subsequently created Lord Windsor. ${ }^{63}$ The manor was sold by the fourth Lord Windsor in 1584 to John Danett of Croydon, ${ }^{6}$ whose brother Gerard sold it in I 608 to Sir William Jeph-

son of Froyle, whose brother Sir John Jephson sold it in 1624 to Nicholas and Henry Wheeler,

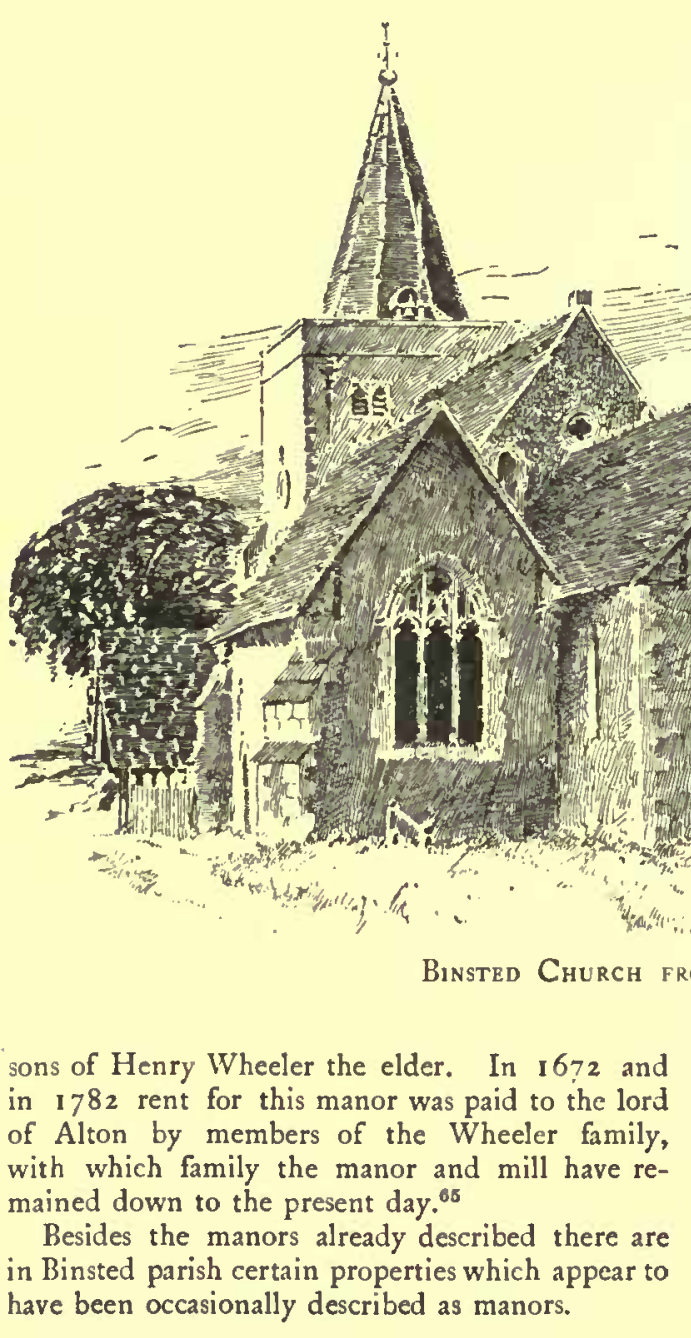

WYKE or WICK is mentioned in 1228 and I 236 when John Cuppying or Kipping, and Ela his wife, dealt with land there. ${ }^{66}$ Certain rents in Wyke were payable to the manor of Alton in $1398 .^{\circ 7}$ In 1462 William Lord Botreaux died seized of the manor of Wyke, leaving as his heir his daughter Margaret, widow of Robert, Lord Hungerford, aged forty. ${ }^{68}$ In I 470 John Whitc died seized of the manor, leaving $a$ son and heir Robert. $^{69}$ In 156 I Sir Thomas White conveyed the manor-presumably in trust -to Chidiock Paulet, ${ }^{70}$ and in 1567 and $16 I_{4}$ respec-

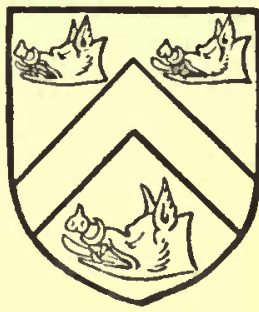

IIrighes. Sable a cheveron silver and stree boars' beads gold. tively Sir Thomas and Sir Richard White died seized of $i t^{71}$

FLOOD or FLOOD PLACE. ${ }^{72}$ - Henry Heighes died seized of this manor in 1595 , leaving
62 Inq. p.m. 30 Hen. VI. No. II.

63 Ibid. Chan. ser. 2, vol. I, No. 14. 61 Feet of F. Hants, Hil. 26 Eliz. 65 By a fine Mich. 7 Geo. I. Nicholas Miller and Mary his wife sold the manor to Alexander Lee (Feet of F.). Edward Beavor and his wife conveyed it to William Horner in 1749 (Feet of $\mathbf{F}$. Hants, Trin. 22-3 Geo. II.), and again in 1759 to Henry Wilmot (Feet of F. Hants, Hil. 32 Geo. II.). There is a rental of Millcourt dated 172 I (no owner named), Add. Chart. 27,990.

66 Feet of F. Hants, Hen. III.

67 Add. Chart. 27,820.

68 Inq. p.m. 2 Edw. IV. No. 15

69 Ibid. 9-10 Edw. IV. No. 25.

70 Feet of F. Hants, Trin. 3 Eliz.
Nicholas his son and heir aged sixteen; it was held of Alton by the rent of 3 Is. $4 d d^{73}$ This rent was paid by Edmund Heighes in or about the year In 1603 Nicholas Heighes acquired a third of the manor of Flood of William Tuttie and Nicholas and Martha his wife dealt with the whole manor, at the latter date apparently selling
71 Ing. p.m. ser. 2, vol. 145, No. 9 ; and 1 I James 1. pt. 2, No. 103.

72 The present site of Flood cannot be identified.

73 Ing. p.m. Chan. ser, 2, vol, 250 , No. 16.

74 Add. Chart. 27,893.

75 Feet of F. Hants, Mich, 44 and 45 Eliz. 


\section{A HISTORY OF HAMPSHIRE}

it to Richard Lock and Henry Wheeler. ${ }^{78}$ Lady Heighes seems to have disputed this sale in a chancery action brought in $1620 .^{77}$ A manor of Flood was sold in 1725 by A. C. Lockman and Elizabeth his wife to Isaac Moody. ${ }^{78}$ This sale may however relate to the manor of Flood in Havant.

HEIGH or SOUTH HEIGH.-In $1268 \mathrm{John}$ de Heighes and Agnes his wife established their title against Robert de Popham to a messuage and 12 acres of land in Binsted which John was to hold in right of Agnes by an annual render of $5 \mathrm{~s}$. to Robert. ${ }^{79}$ Simon de Heighes died seized, in 1362 , of a messuage and carucate of land in 'Heyes' held of the Earl of Kent ; Simon was his son and heir aged twenty-four. ${ }^{80}$ Richard Heighes paid rent to Alton for 'South Heye' in $1399 .^{81}$ In 1595 Henry Heighes died

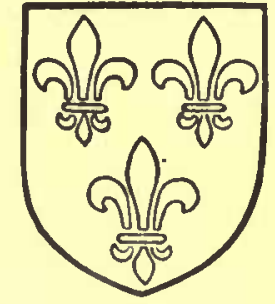

HoLt. Silver tbree feurs de lys azure. seized of the manor leaving a son and heir Nicholas, aged sixteen. ${ }^{82}$ Nicholas acquired a third
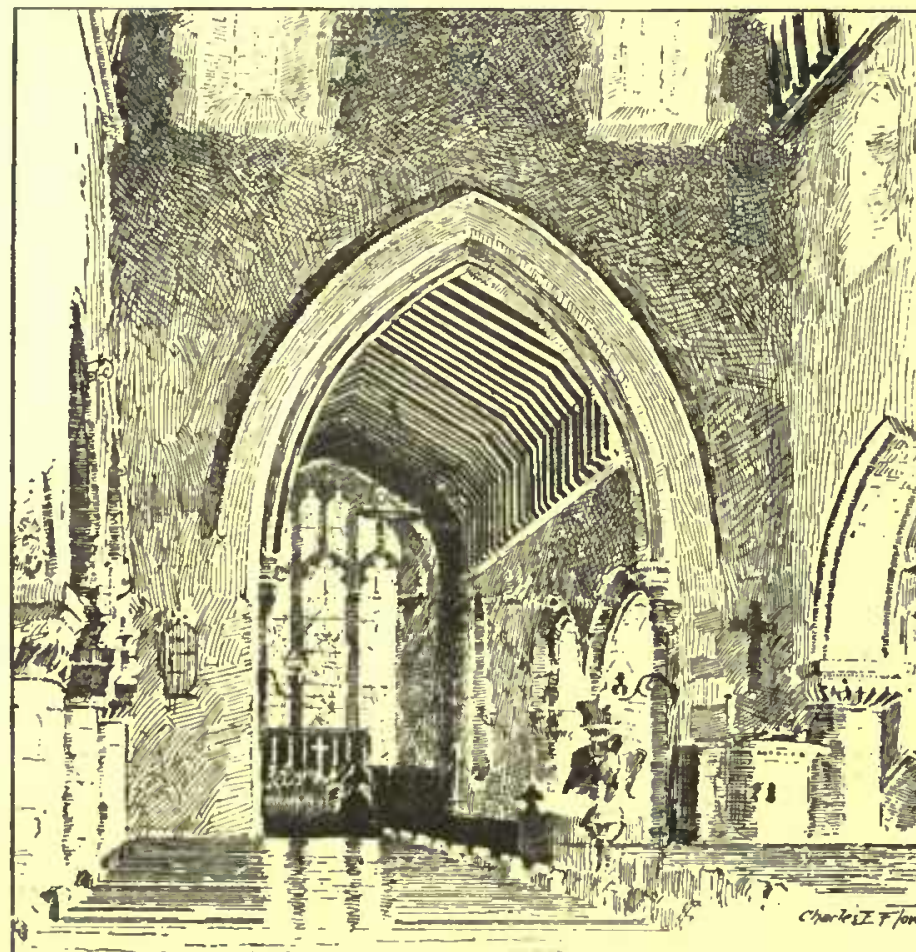
Wheeler. ${ }^{84}$ Heighes Woodford sold it in 1701 to Francis Heatley. ${ }^{85}$

WHEATLEY or WHATLEY. - In 1398 Richard Holt was tenant of land called Budell Whatle. ${ }^{86}$ From 1495, when Joan Holt, widow of Richard Holt, died seized of a messuage in Whatley, down to the present time, this manor appears to follow the descent of Westcourt (q.v.).

THURSTONS. - In 1399 William Thurston paid rent to Alton for land in Binsted which had been his father's. ${ }^{87}$ The property afterwards passed to the Windsor family, with whom it was as early as I 529 , 88 and on 7 May, I 586, was sold as "the manor, capital messuage or farm called Thurstons,' for $£_{276}$ I 3 s. $4 d$. to Richard Hardinge of Waverley, Surrey. ${ }^{89}$ 'Thomas Hardinge died seized of this manor in 1622,90 leaving a son and heir Thomas, of whom John Clifton acquired it in $1625,{ }^{91}$ which John sold it, about the year 1634, to Henry Wheeler and Robert Lock. ${ }^{92}$ From 1695 to 1706 Lord Dartmouth appears as lord of the manor. ${ }^{93}$ The property is now (1902) owned by the Rev. Augustus Legge and consists of a farmyard and two cottages. ${ }^{21}$

The parish CHURCH church of the Holy Cross consists of a chancel with south aisle, north chapel, and north vestry, and a nave and aisles with western tower and south porch. It underwent a restoration in 1863 .

The chancel is three bays in length. In the east wall is a three-light late fifteenth century window, but the first bay has on each side an original pointed lancet of late twelfth century date. In the south wall is a shouldered piscina with two round drains, and north of the altar a square locker with grooves for a shelf. West of this is an inserted doorway into the vestry, which is a fifteenth century structure with a single light on the east and a two-light square-headed window on the north. The other bays of the chancel are pierced with two semicircular arches

part of it in 1603 from William Tuttie and of two orders carried by a round pillar and reThomasine his wife. ${ }^{83}$ Sir Nicholas Heighes' sponds with moulded capitals, all of late twelfth widow Martha was plaintiff in a suit as to the century work. The chancel arch is modern. The

\footnotetext{
To Feet of F. Hants, Mich. 4, Jas. I. and Hil. 7 Jas. I.

77 Chan. Proc. Jas. I. Hh. 22, 37, 42 . 78 Feet of F. Hants, Hil. II Geo. I. 79 Cur. Reg. R. 184 , roll 4

80 Inq. p.m. 35 Edw. III. pt. I, No. 101.

81 Add. Chart. 27,820.

82 Inq. p.m. Chan. ser. 2, vol. 250 , No, 16 .

\author{
83 \\ 84 Chan. Proc. Jas. I. Hh \\ 86 Feet of F. Hasts, East. I 3 Will. III. \\ 86 Add. Chart. 27,820 \\ 87 Ibid. \\ 88 Deeds enrolled, Com. Pleas Recor.
} R. Trin. 28 Eliz.
}

89 Ibid.

90 Ing. p.m. Misc. pt. 13, No. 92.

81 Feet of F. Hants, Hil. I Chas. I.

92 Ibid. Trin. 9 Chas. I.

93 Ibid. Div. Cos. Mich. 12 Wm. III. aod Add. Chart. 28,240, 28,293 .

94 Information given by Mr. Henry Wheeler of Wheatley. 


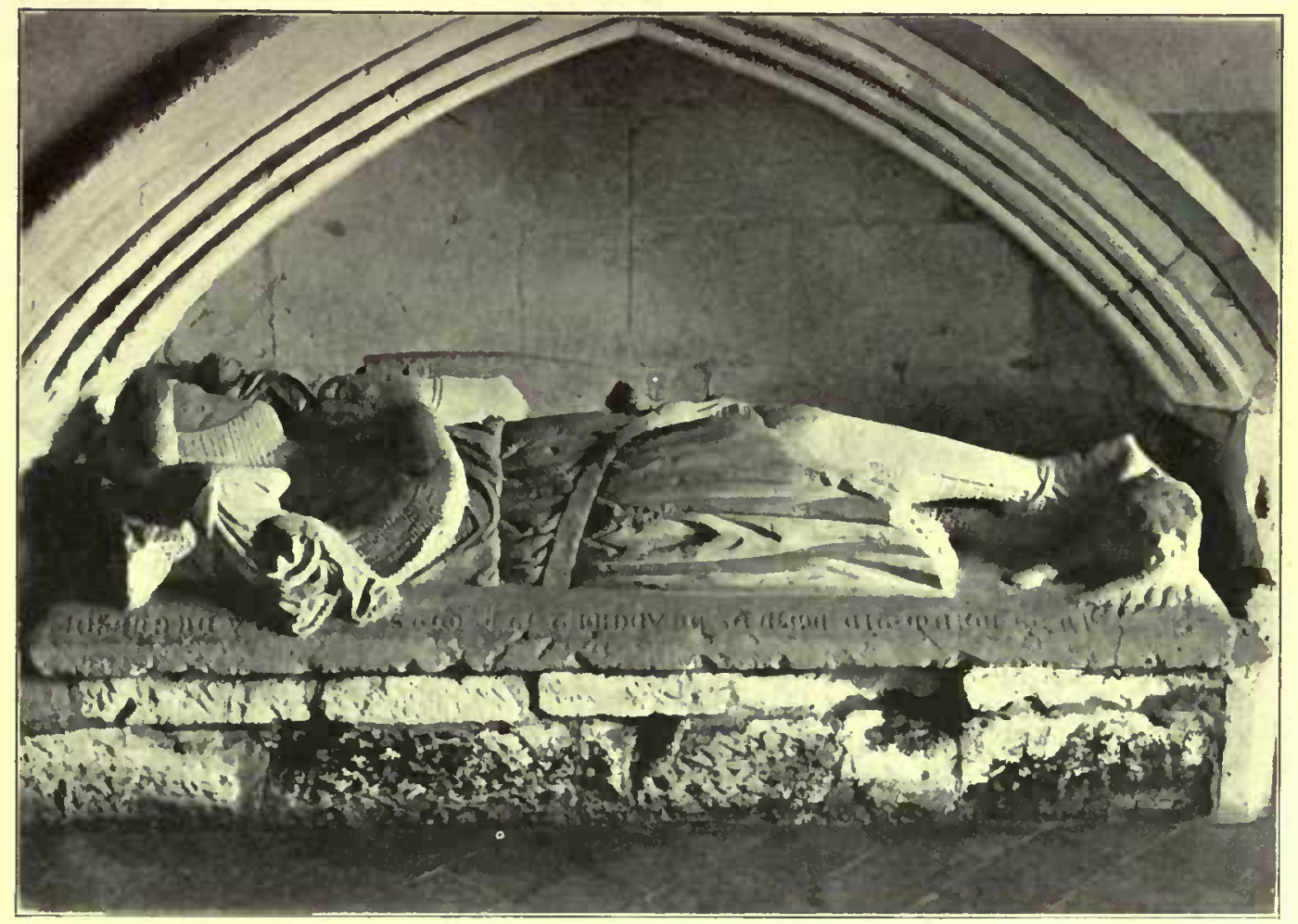

Monument of Richard de Westcote in Binsted Church.

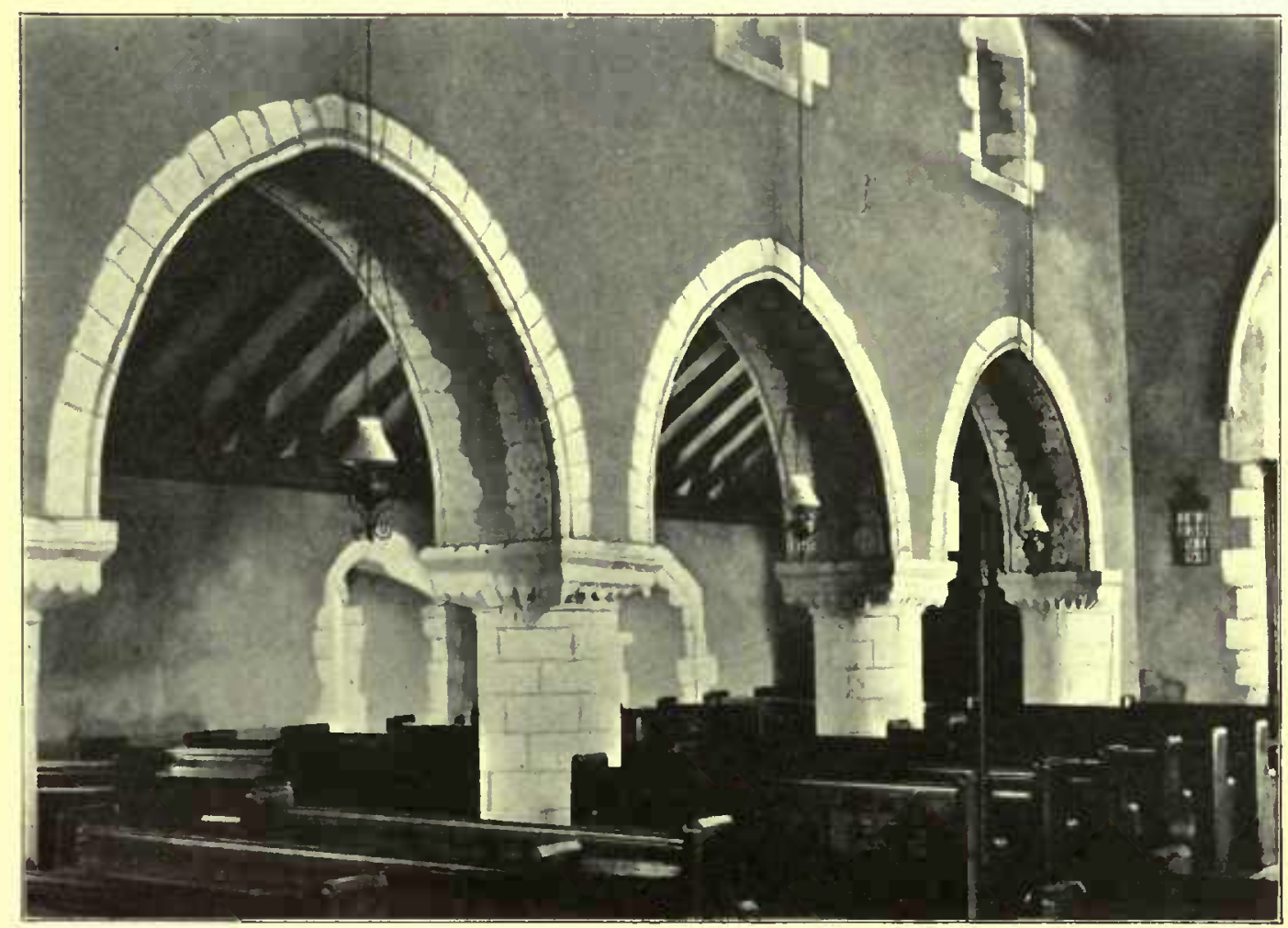

Arches in Binsted Church. 

south arcade opens into an aisle or chapel two bays long of the same date as the chancel. It has an inserted fifteenth century three-light window on the east, another of two lights on the south and a widely splayed cinquefoiled lancet beyond with a doorway between. On the west is a pointed arch from the nave aisle. In the east wall is a basin piscina, and in the south wall under the first window is a low pointed recess of the fourteenth century, within which lies a grave slab of the same period with incised cross. On the north of the chancel is a large chapel built transeptwise. It is two bays long and has in the east wall two windows each of two trefoiled lights with a cinquefoil in the head. Beside each window is a pointed piscina marking the place of an altar. The north wall has a three-light window of the same character as the others, and on the west are a pointed doorway from without and a like archway from the nave aisle. The northern half of the chapel is raised a step higher than the southern on account of a bonehole or charnel beneath.

In the western end of the north wall is a moulded and pointed recess in which lies a fine stone effigy of a knight. He is shown as clad in complete mail with long surcoar with a ridged bascinet on his head, which lies on a cushion supported by two angels. The hauberk reaches to the knees, which are capped, but shows the mail breeches covering the thighs. The shins are protected by plate or leather, and the mail-clad feet, which rest against a lion, have prick-spurs. The hands have mittens of mail, and the sword is slung by a belt on the left side. On the left arm is a shield carved with three covered cups in the chief. On the chamfer of the slab under the figure is inscribed :

\section{RICHARD : DE : WESTCOTE : GIST : ICI : DEU : DE : SA : ALME : EIT : MERCI : AMEN}

This Richard de Westcote is the same person as the Richard de la Bere of Westcote to whom the royal licence was granted on March 20, $1331-2$, for alienation in mortmain of certain lands in Kingsley and Binsted for a chaplain to celebrate daily in a chapel in Binsted church, newly built by the grantor. ${ }^{98}$ Both the chapel and the monument under notice are clearly of the date in question.

The nave is all of late twelfth century date, and of four bays, with arcades of low pointed arches carried by round pillars with square capitals and bases. The arches are of one order only, with a roll moulding on the edges. The capitals on the south are scolloped, but the first and second of the north arcade are partly carved. Above the arcades is an original clerestory with a single pointed lancet in every bay, and in the eastern gable two lancets with a quatrefoil above. The south aisle has been modernized, but has a good inserted fourteenth century doorway protected by a modern porch outside. The north aisle retains two of the original four lancet windows, but the others are modern, as is the west window.

The square western tower is contemporary with the nave, from which it is entered by a pointed

98 Pat. 6. Edw. III. pt. I, m. 13. arch of two orders. The interior contains a massive timber frame supported by heavy corner posts to carry the bells.

All the roofs, floors, and fittings of the church are modern, except the altar, which is a good Jacobean oak table with baluster legs. There is also a fine chest of the same period with three locks, now in the tower. The font is of alabaster of the date 1896 . The walls throughout seem to be of chalk rubble with clunch dressings,

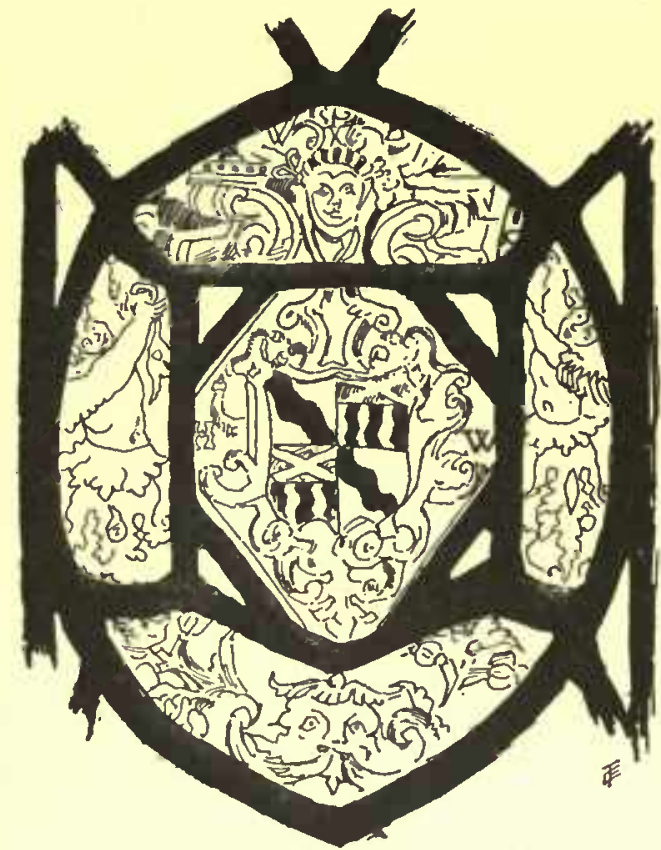

Glass in the Lancet Window of the Baptistery

plastered internally and roughcasted outside. The south aisle and porch have stone shingled roofs, but the other roofs are tiled. The tower has lately been refaced on the west and south sides. Beneath the north and east windows of the north chapel may be seen the blocked windows that formerly lighted the bonehole.

In the lancet window of the baptistery is a fragment of stained glass, dated 1578, with the arms of Sir Henry Wallop, silier a bend wavy sable with which are quartered the arms of Valoins.

There is a brass on the wall of the vestry to the memory of Henry, son of Richard Heighes, gentleman, who died in 1595 .

There are six bells, of which the tenor bears the inscription: 'In 1695 Nicholas Wheeler did contrive out of four bells to make them five.' The five bells weighed $44 \mathrm{cwt}$, and were

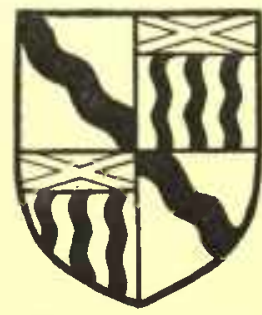

Wallop. The arms of WALLor, quartered with silver tbree pales gules witb a saltire gold, for VAloinis. wavy sable and a cbief recast and rehung in 1696 by Samuel Knight of Reading ${ }^{96}$ at a total cost of $£ 5^{\circ}$. The fourth bell was recast by $G$. Mears in 1864 . A sixth

$$
96 \text { Wheeler Papers. }
$$




\section{A HISTORY OF HAMPSHIRE}

bell was added and a chiming clock erected in 1887 as a Victoria Jubilee memorial.

The fommunion plate consists of a silver paten with inscription, recording its gift, in 1685 ; a silver flagon, the gift of Henry Christmas, gentleman, of Stubb, in 1703 ; a silver chalice (inscribed - Belonging to the parish of Binsted ') and a silver paten, both hall-marked 1790 .

The parish registers begin in 1653, and previous to 1812 consist of four volumes: i. $1653-78$; ii. $1678-1813$; iii. $1754-92$; iv. $1793-1812$. The first register includes marriages during the Commonwealth by Justice Heighes of people from all parts of the country between Odiham and Petersfield.

'The churchwardens' accounts begin in 1664 .

Binsted was a chapelry of Alton Church, with which it was granted by the Conqueror to Hyde Abbey, Winchester (vide Alton).

At the dissolution of the monasteries it was granted by Henry VIII. with the church of Alton to the Dean and Chapter of Winchester, ${ }^{97}$ who have ever since held the patronagc.

The tithcs of Binsted had been given to Waverley Abbey and were granted, ${ }^{98}$ on its dissolution, to $\operatorname{Sir}$ W. Fitzwilliam by Henry VIII. ; thcy were commuted in 1841 as follows: Rectorial, Binsted, $£_{761}$; Kingsley, $\complement_{262}$; Vicarial, Binsted, $\complement_{345}$; Kingsley, $\mathscr{L}^{1}$ 4. Neteham was declared by the award to be free by prescription from all vicarial tithe. In I 886 the hop tithe was commuted at a rent-charge of $£_{298}$ for Binstcd and $£ 38$ for Kingsley.

In 1854 Binsted and Kingsley were severed from Alton vicarage, and constituted a separate benefice under the patronage of the Dean and Chapter of Winchester.

In 1514 a lease of the rectory and glebe of Kingsley and Binsted was granted by Hyde Abbey to Ralph Heriet, vicar of Alton, and Walter Hubberd, and at the dissolution this part of the abbey's possessions was granted to the Dean and Chapter of Winchester 'excepting only the house and garden which from of old belong to the stipendiary chaplains in the chapel of Binsted.' 99

In 1649 the glebe house and buildings, with two gardens, a hop garden and an orchard, comprised $4 \frac{1}{2}$ acres; the house is described as built of timber and stonc covered with tile and worth $£^{6}$ 135. $4 d$. a year, and there was a meadow of 2 acres called Church Close, and a small mead of half an acre called the Chantry Close. ${ }^{100}$

In 1873,6 acres 1 rood 22 poles of rectorial glebe were given to the benefice as a site for a new vicarage house. The present vicarage is near the site of the older glebe house, the east gable of which had a stone bearing the date 1640 , but several parts of the building having fallen into ruins they were demolished with the consent of the patrons and under a faculty from the bishop in 1885 .

There is a district church at Rowledge, and there are Wesleyan, Primitive Methodist and unsectarian chapels in the parish.

97 Pat. 33 Hen. VIII. pt. 9. m. 5 .

98 Ibid. 28 Hen. VIII. pt. $2, \mathrm{~m}$. 9. The tithes were dealt wirh by fine from 1667-74. Feet of F. Div. Cos. Mich.
19 Chas. II.; Mich, 20 Chas. II. East. 23 Chas. II.; and Hil. 26, 27 Chas. II. II. Ibid. 33 Hen VIII. pt. 9, m. 5 .
The national school was built in 1874 , on a site given by the Ecclesiastical Commissioners, at a total cost of $£ \mathbf{I}, 178$, which was raised by subscription, and a house for the master was built in 1885. Binsted is entitled to send five free scholars to Holybourne Grammar School.

The charities for the relief of the poor consist of:-

(i.) Fielder's Dole, mentioned in $1685^{101}$ as being given by Alice Fielder 'unto the parishes of Faringdon and Bensted,' and consisting of $f_{2}$ to be paid to 'frendles pore widdows' of the said parish yearly out of a messuage in Stedam, county Sussex, called Croutch House. From 1709-99 reference is made to the distribution of Fielder's Dole of II $_{\text {I }}$ yearly at Lady Day in Binsted.

(ii.) Woodford's Charity. The iRev. Samuel Woodford, D.D., by his will dated 7 January, I 700 , having directed that land to the value of 40 s. yearly should be bought by his executrix and the income given to poor widows frequenting the parish church of Binsted, Ann Woodford, his daughter, in 1750 , granted to the minister, churchwardens and overscers of Binsted a rent-charge of 40 s. out of the enclosed ground called Rye Close, Binsted, to be distributed at Christmas, Easter and Whitsuntide.

(iii.) Schröder's Charity. This was a bequest of $\complement_{1}, 000$ to the minister and churchwardens for the time being of Binsted to be invested, and the dividends applied for the benefit of the poor of Binsted. In 1871 the vicar and churchwardens purchased 6976 18s. 8d. Consols, the income of which has bcen applied as directed.

The forest of $A L I C E H O L T$ (Alsiholt, xiii. cent. ; Aisholt, xiv. cent.; Ayles Holt, xviii. cent.) lies at the eastern end of the parish of Binsted. The soil is a strong loam and bears good turf and large trees, whilst the adjoining forest of Wolmer is 'a hungry, sandy, barren waste.' 102 'The keepership of Alice Holt was connected in early times with that of Wolmer Forest, and was generally held with the manor of East Worldham (q.v.). During the seventeenth and eighteenth centuries Alice Holt Forest supplied much timber for the navy. In 1608 it contained 13,031 trees fit for shipbuilding. After the seizure of Crown property during the Civil War, surveys were made of these forests of Alice Holt and Wolmer, from which we learn that there were three 'lodges' within the forest which were habitations for the foresters, who had enclosed to each lodge a park to the damage of the inhabitants; these parks were known as Great Lodge Park, near the middle of the north walk; Old Close Park, in the Old Close walk; and Goose Green Park in Goose Green walk. ${ }^{103}$

In 1777 three hundred loads of timber were felled in the forest for the use of the navy ; a thousand loads were felled in 1784 , and five hundred in 1788 . In 1783 it was found that 38,919 oaks were standing. The forest was stocked with deer until about sixty years ago, when it was disafforested. In 1857 forest land to the extent of 828 acres was enclosed.
100 Surv, of Ch. Liv, Commonwealth, Lamb. Lib. 101 Wheeler Papers. 102 White's Selborne, i. 25. 103 Parl. Surv. Hants, Nos. 14, 15. 


\section{BRAMSHOTT}

Brenbresete (xi. cent.); Bremesete (xii. cent.); Brembeshete (xiii. cent.); Brembelshete (xiv. cent.); Bremshote (xv. cent.); Bramshote (xvi. cent.).

Bramshott is a large agricultural and residential parish, containing 6,489 acres (349 of which are in Sussex), and situated, amidst undulating woodlands and picturesque valleys, on the eastern border

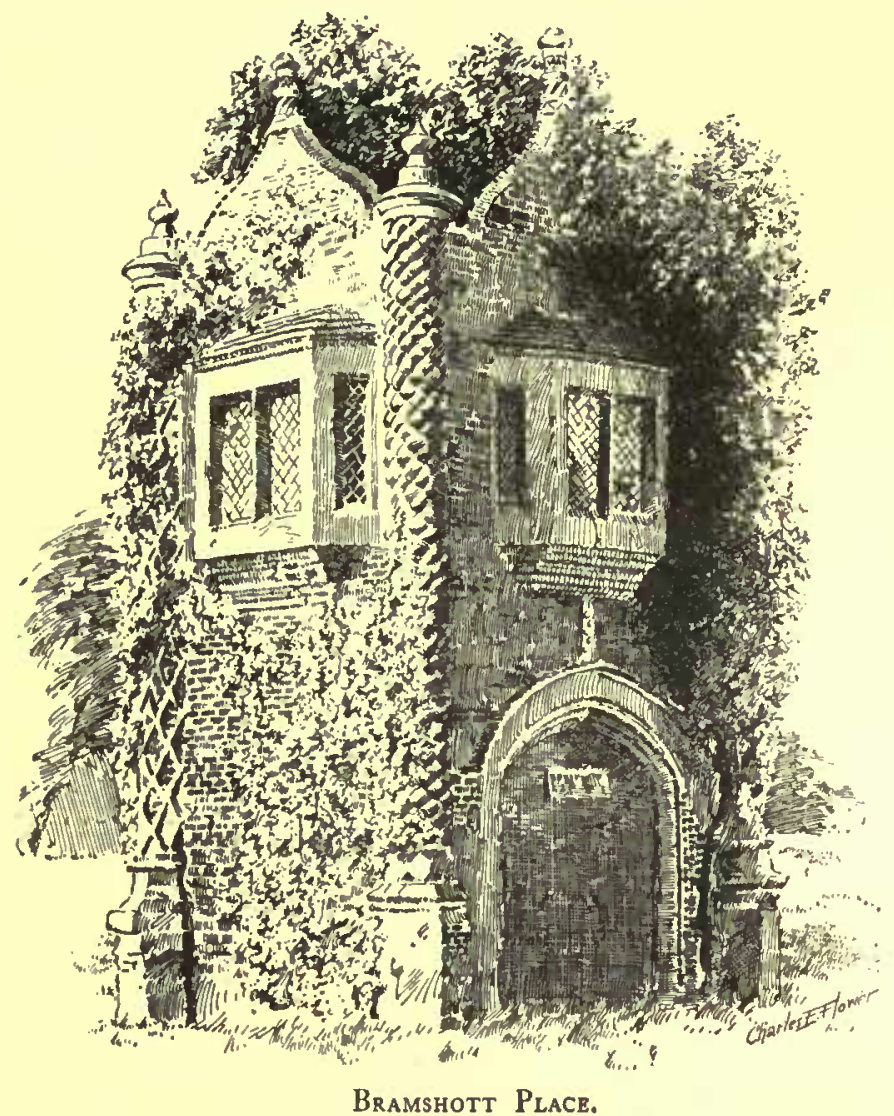

The parish also contains the hamlets of ConfordHolywater, Passfield and Hammer Vale, and in, cludes a large portion of unenclosed land belonging to Woolmer Forest and Wheatsheaf Common. Bohunt farm, Grigg's Green and Lowsley farm were formerly detached parts of Sussex, but in I 844 were added to the parish. ${ }^{1}$ In 1900 part of the parish was united with a portion of the parish of Headley and formed into the ecclesiastical parish of Greyshott, a rapidly increasing residential district three miles north of Liphook station.

The village of Bramshott lies to the north of Liphook between the road to Portsmouth and a road to Headley. Therc are residences of importance at Chiltley and Ludshott. Woolmer Lodge, the residence of Sir Archibald John Macdonald, bart, is erected on the sitc of an ancient farmhonse, and is surrounded with a wooded park of 200 acres. Downlands is an eightcenth century mansion belonging to the Butler family, approached by a long avenue of becch trees which form part of a park of 60 acres, and it is now the residence of E. H. Burrows. Folcy is a modern mansion situated in extensive grounds and is the property of Edward A. Lee. Bramshott Grange was built in 1850 by Sir William Erle ; it is situated near what remain of a sixteenth century residence of the lords of the manor of Bramshote which was called Bramshott Place, and is now the residence of $T$. W. Erle, J.P. The Royal Anchor Hotel is an ancient inn containing some good carving.

The hamlet of Hammer, on the

of the county. The main road from London to Portsmouth passes through its length from northeast to south-west, and the Portsmouth branch of the London and South Western railway skirts its southern side. There is a station at Liphook, a hamlet of the parish and now the chief centre of population, possessing a public reading room and library and a village hall. The southern tributary of the river Wey flows into the parish from Surrey at Hammer Bottom, and at Bramshott Mills receives a stream which descends from a succession of small lakes called Wakcners or Waggoners Wells (anciently called Downwater), and then flows through the parish to the north-west of Headley.

In 1853, when portions of the waste land on the borders of Woolmer Forest were enclosed, 2 new road was constructed across the forest to Greatham. It is this road which connects Liphook with the military camp at Longmoor. eastern side of Bramshott Manor, takes its name from ironworks formerly existing there. These, in the seventeenth century, were carried on at Hammer Iron Pond in Ludshott Manor, and the court rolls of that manor show that Henry Hooke, who developed the industry, made two lakes at Wakeners Wells to supply water power by flooding the waste between Ludshott and Bramshott Manors. The industry had died out in Bramshott by the middle of

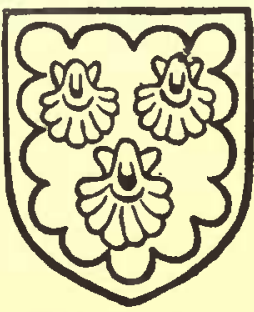

ERLc. Gules tbree escallops silver witb a border engrailed silver. the eighteenth century, but was then revived, by John Butler of Chiltley Manor, at Fernhurst, just over the Sussex border. There is a manufactory for edged tools at Conford and a paper mill at Bohunt farm. In 1795 grazing and gather- 


\section{A HISTORY OF HAMPSHIRE}

ing whortleberries and the making of brooms of the heath were the chief industries. ${ }^{2}$

$B R A M S H O T \mathcal{T}$ was held of Edward

MANORS the Confessor as an alod by two freemen, unnamed, and at the time of the

Domesday Survey was held of the Conqueror by Edward of Salisbury. William Maudit (Maldoit) of Hartley Mauditt (Harlege) claimed one hide of the land there. ${ }^{2}$ In I 194 mention is made of a John de Bremesete, ${ }^{4}$ and in the following century John de Brembilsite held a knight's fee in Bramshott by old enfeoffment of the Earl of Salisbury who held of the king in chief. ${ }^{5}$ The Earl of Lincoln -who was husband of the daughter and heir of the Earl of Salisbury-held the vill of Brambelshute in I $316 .^{6}$ William de Bramshott (Brembelshute) held one fee there (it is not stated of whom) in $1346 .^{7}$ John de Bremshott presented to the church in 1367,1379 and $1382 .^{8}$ William de Bramshott held there one fee (it is not stated of whom) in 1428 and $143 \mathrm{~J} ;{ }^{8}$ at the latter date he is described as ' of the Isle of Wight,' and his holding as the 'manor' of Bramshott.

In 1451 John Bramschote held the manor of Miles Windsor as of his manor of Stanwell in Middlesex. ${ }^{10}$ He married Katherine daughter of Sir John Pelham ${ }^{11}$ and left as his heirs two daughters, namely, Elizabeth, who in 1481 was wife of John Dudley, who died in 1498, and Margaret, who was the wife of Sir John Pakenham and died in $1485 . .^{12}$ These ladies inherited moieties of the manor, Elizabeth's passing to her son Edmund Dudley, who was attainted, and Margaret's to her son Edmund Pakenham, who inherited and who was six and more at his mother's death in 1485 . His moicty was held of Lady Worcester as of her manor of Alton. ${ }^{13}$ Edmund, who became Sir Edmund Pakenham, stated by his will, ${ }^{14}$ dated $9 \mathrm{July}, 1528$, that subject to a life interest of his wife Katherine, he had settled his Hampshire property on his daughter Elizabeth on her marriage with Sir Edmund Mervyn. In 550 the entire manor was in the possession of the latter and his wife, who settled it by fine on their son and heir Henry Mervyn on his marriage with Edith Windsor. ${ }^{15}$ Sir Edmund died in $1553,{ }^{16}$ and Henry Mervyn's son and heir Edmund dealt with the manor by fine in $1585 .{ }^{17}$ In 1605 he left it to his wife Anne, daughter of William Jephson of Froyle, and this lady held courts for the manor in 1605 and $1609 .{ }^{18}$ In 1610 Henry Mervyn conveyed the manor to John Hooke, ${ }^{19}$ who in $16 \mathrm{II}$ held a court for the manor. ${ }^{20} \mathrm{He}$ married Barbara Rous, a granddaughter of Sir Edmund Mervyn. Henry Hooke, their son and heir, ${ }^{21}$ held his first court there in $16 \times 6,{ }^{22}$ and was still in possession in $1625 .^{22}$ John Hooke his son, who died in 1685 , held a court in $1647 .^{24} \mathrm{He}$ was possibly succeeded by his son Henry, but in 1656 John Hooke appears to have conveyed the manor to Arthur Bold and John Bold. ${ }^{25}$ In 169 I the manor passed to John Whitehead, gent., who held his court there in $\mathbf{I} 7 \mathrm{II}^{26}$ and dealt with the manor by fine in 17 I $2,{ }^{27}$ as did Richard Whitehead, gent., in $1742,{ }^{28}$ and from him the manorial rights passed to Sarah, one of his co-heirs, who married the Rev. Jonathan Dennis, rector of Bramshott. Their son, Whitehead Dennis, sold the manorial rights in 1814 to Nicholas Kent, ${ }^{29}$ whose sister Sophia inherited them from him in 1826 . She married Thomas Butler of Downlands in Bramshott, and their grandson, Robert C. Butler, is the present lord of the manor.

The ancient manor house is now called Old Place, or Church farm, and is occupied as a farmhouse; it is situated to the south-west of the churchyard, and still preserves its fiftcenth century mullioned windows in the ground floor rooms and the oak timbers of the original hall in the roof. From the sixteenth century to the nineteenth Bramshott Place was the manor house. Since 1814 Downlands has been the residence of the manorial owners.

LUDSHOTT, Lidesette (xi. cent.); Ledessete (xiii. cent.); Ludeshote (xiv. cent.) ; Ludshute (xv. cent.), another manor in Bramshott parish, was held of the Confessor as an alod by Alwin, and, after the Conquest, by Hugh de Port. ${ }^{30}$ In 1312 Thomas Paynel acknowledged the manor to be the right of William de St. John, who granted it to the said Thomas for life. ${ }^{31}$ After this the descent of the manor followed that of Chawton (q.v.) till the sixteenth century. In August, I 577, Richard Knight, gentleman (who did not die seized of Chawton manor), died seized of the manor of Ludshott, leaving a son and heir Robert, then aged thirty-two. ${ }^{32}$ Robert settled the manor on his wife Constance and son Richard on I December, I 603. Richard died 6 January, I616-7, leaving an infant son Robert his heir, Robert the grandfather being then alive. ${ }^{33}$

In 1638 Andrew Wall acquired the manor of

\footnotetext{
Gents. Mag. 1795, pt. 11, 993-4.

V.C.H. Hanls. i. 487.

- Cur. Reg. R. 6 Rich. I. m. 16d.

- Testa de Nevill (Rec. Com.), i. 231.

Feud. Aids, ii. 315.7 Ibid. ii. 333

8 Hants Rec. Soc. Wykeham's Reg.

i. $5,104,133$.

Feud. Aids, ii. 357,363 .

10 Inq. p.m. 30 Hen, VI. No. 11. VI.

13 Inq. p.m. 21 Edw. IV. No. 54, and

Exch. ser, 2, File 962, No. 13 .

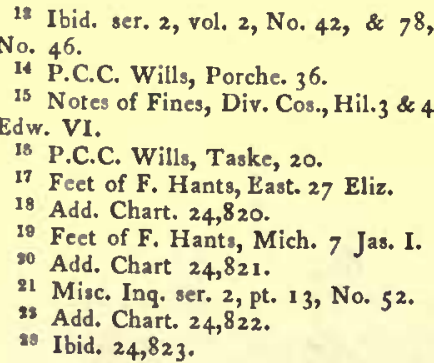

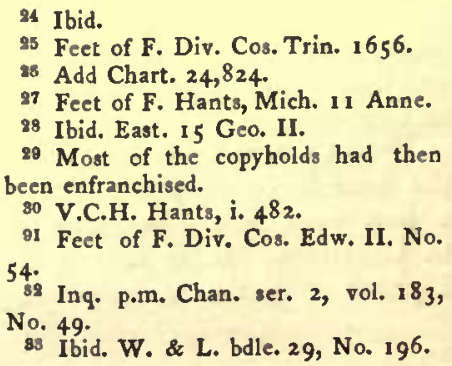

24 Ibid.

25 Feet of F. Div. Cos. Trin. 1656.

26 Add Chart. 24,824.

27 Feet of F. Hants, Mich. 11 Anne.

28 Ibid. East. 15 Geo. II.

29 Most of the copyholds had then been enfranchised.

go V.C.H. Hants, i. $4^{82}$.

פI Feet of F. Div. Cos. Edw. II. No. 54.

ss Ing. p.m. Chan. ser. 2, vol. 183 , No. 49:

83 Ibid. W. \& L. bdle. 29, No. 196. 
Robert Knight, ${ }^{34}$ who, according to the parish registers, resided on the estate in 1638 at a mansion called Fir Grove, ${ }^{36}$ of which the remains indicate that it was a considerable house. Later in the seventeenth century the manor was in the possession of Sir William Meux, bart., of Kingston, Isle of Wight, whose eldest daughter Elizabeth married Sir John Miller, bart., M.P. for Chichester, and their great-grandson, $\mathrm{Sir}$ Thomas Miller, bart., M.P. for Portsmouth, was in possession of Ludshott in $1792 .^{30}$ After Sir Thomas Miller's death the manor was purchased, about the year 1825 , by Sir Archibald Macdonald, bart., formerly chief-baron

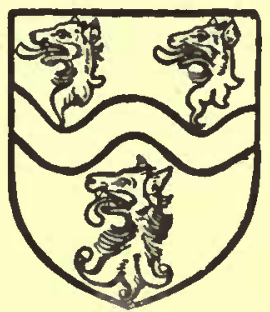

Mit,ler. Silver wave axure between ebree wolves' beads rased gules. of the Exchequer, who pulled down the old house
Confessor as an alod by Lanch, but at the time of the Domesday Survey it was in the possession of the Conqueror himself. ${ }^{37}$ A messuage and lands in Chilteleye were conveyed in $1296-7$ by John de Holtham to another person of the same name. ${ }^{38}$ 'The 'vill' was held in 1316 by Ralph de Camoys, ${ }^{39}$ who had holdings in the adjacent parts of Sussex. In 1346 William de Chiltele is returned as holding in Chiltley the eighteenth part of a knight's fee, formerly John de Chiltele's. ${ }^{40}$ John Weston

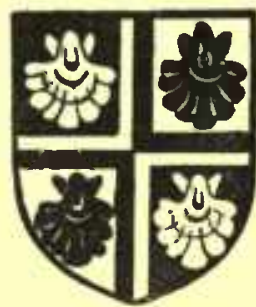

Hooke. Quarterly sable and silver witb a cross between four escallops all countercoloured. of Chiltley is mentioned in 1387,41 and the 'manor' of Chiltele was held in 1452 by John Weston, of Miles Windsor as of his manor of Stanwell in Middlesex. ${ }^{42}$ In 1562 John Carrill

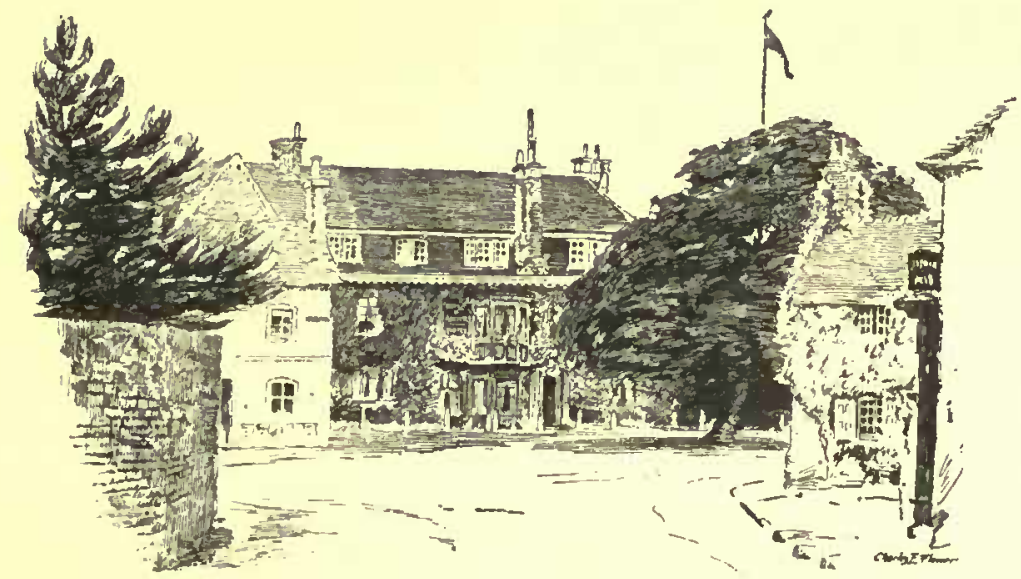

Royal Anchor Hotel, Liphook.

at Fir Grove and built Woolmer Lodge, which, with the manor of Ludshott, has since his death in 1826 remained with his descendants to the present time, his great-grandson, Sir Archibald John Macdonald, bart., being now lord of the manor. The court rolls, which are preserved at Queen's College, Oxford, commence in 1400.

CHILTLEY, Ciltlei (xi. cent.); Chilteleye (xiii. cent.); otherwise Liphook, La Lepe, La Leephok, Lepoke (xiv. cent.); Liephok (xv. cent.); Lippocke (xvii. cent.).

Chiltley was held of the

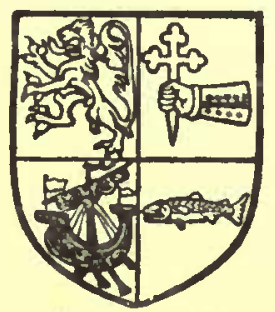

Macdonalo. Quarterly (i.) silver a lion gules; (ii.) gold an arm in armour cut off at the elbow, the band bolding a crosslet fitcby gules; (iii.) silver a galley sable, witb oars and furled sail ; (iv.) silver a salmon swimming. of Warnham, Sussex, dealt with the manor of Chiltley by fine, and in 1590 conveyed it to John Hooke, ${ }^{43}$ who (see above p. 492) was also lord of the manor of Bramshott. In 16 1 3 Chiltley is returned as held partly of Richard Tichborne, as of Alton Westbrook, and partly of Richard Knight, as of Ludshott. ${ }^{44}$ The descent of Bramshott and Chiltley seems to have been the same till the death of Richard Whitehead, when the latter manor passed to Whitehead's co-heir Anne, who married John Butler. Their grandson, James Butler, pulled down the existing manor house and rebuilt it on the same site. $^{\text {15 }}$ In 1830 he sold the property, and it came into the possession of T. P. Platt, and finally into that of Sir John Hawkshaw, whose son, John Clarke Hawkshaw of Hollycombe, is the present lord of the manor. The court rolls commence in $15 \mathbf{I} \mathbf{I}$.

The estate now known as FOLLEY (Folle, xiv. cent. ; Falleygh, xvi. cent.), was granted by John de Venuz in the thirteenth century to Sir Adam
4 Feet of F. Hants, Hil. I 3 Chas. I. a6 Caper' Rural Hampshire, p. 168. as Ibid. p. 275. In 1704 Samuel Diggle acquired the manor of John Goodyer (Feet of F. Hant,, Mich. 2 Anne). a7 V.C.H. Hants, i. $45 \mathrm{I}$.

38 Feet of F. Hants, 24 Edw. I. No.216.

39 Feud. Aids, ii. 31 5. 10 Ibid. p. 333.

11 Pat. 10 Rich. II. pt. r, m. 2.

12 Inq. p.m. 30 Hen. VI. No. II.

43 Feet of F. Div. Cos. East. 4 Eliz. and Hants, East., 32 Eliz, and Add. Chart. 8,961.

14 Misc. Inq. p.m. Chan. ser. 2, pt. 13 , No. 52.

16 Information from Walter Butler of Empshott. 


\section{A HISTORY OF HAMPSHIRE}

de Gurdon for life, and Sir Adam exchanged it for land in East Worldham with John de Venuz son of the grantee. ${ }^{40}$ In 1341 , on St. James's Day, it was found that Nicholas de Venuz held it at the time of his indictment for felony. ${ }^{47}$ In 1363 it was found that this Nicholas, called son of John de Venuz, died seized of it, held of the king in chief by the service of being chief forester of Woolmer Forest. He had the property by the gift of his said father, with successive remainders to Hugh his brother and

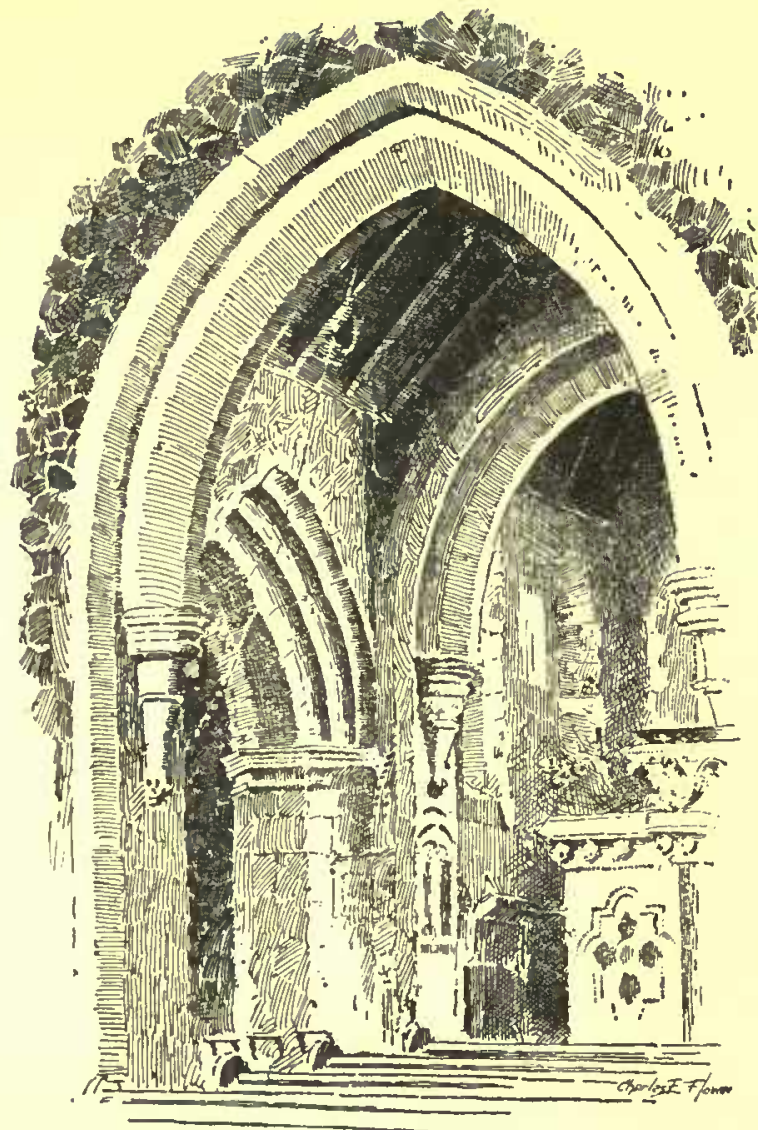

Chancel from South Transept.

his heirs, and Constance his sister, who was the wife of John Marshal, and her heirs. 'The said Nicholas and Hugh both died issucless and the property descended to John Marshal son of the said Constance, aged forty in $1363 .{ }^{48}$ In 1387 Folley, then described as a manor, was granted by the Crown to John Weston of Chiltley and Elizabeth his wife, who were at the same time pardoned for having previously acquired the property of Walter Marshal without obtaining the royal licence. ${ }^{49}$ Two years later, in 1389 , the same John Weston and Elizabeth his wife acquired the manor to themselves and their heirs of Walter Marshal of
Somerley..$^{00}$ In 1546 John Skullard acquired it of John Freeland. ${ }^{51}$ The subsequent descent of the property has not been ascertained.

The manor in $134 \mathrm{I}$ is described as consisting of a messuage, 60 acres of arable land, 128 acres of several pasture, a vivary, and as having two free tenants. ${ }^{62}$

Partially included in Bramshott parish, and adjoining to $i t$, are the manors of Rogate-Bohunt and Oakhanger. The former will be dealt with in the topography for Sussex, and the latter in that for Selborne Hundred.

The church of St. Mary stands on CHURCH rising ground on the east bank of a tributary of the Wey, a quarter of a mile from the main road from Portsmouth over Hindhead. The walls are of sandstone rubble, plastered, with ashlar dressings. The south transept walls are ashlar-faced externally. The roofs are red-tilcd.

The church is cruciform, with a chancel, north and south transepts, and central tower, and modern nave, aisles and western porch. The interest of the plan lies in the tower, which is narrower than either chancel or transepts, and suggests the following development : An early church with aisleless nave and square chancel, which was enlarged about 1220 by building, round the chancel, north and south transepts and a larger chancel to the east, the old chancel walls being pierced with arches on the east, north and south, and carried up as a central tower. ${ }^{53}$ The history of the nave has been destroyed by a complete rebuilding in 1872 . The transepts were rebuilt on the old plan in the fifteenth century. The chancel, measuring $22 \mathrm{ft} .3$ in. by $19 \mathrm{ft}$. 8 in., dates from about 1220 , and has three plain lancets on the east and two on the north, with a doorway in the middle of the south wall, of original date. On either side of the doorway are fifteenth century windows, squareheaded, of two lights with tracery; the main lights are remarkable, having eight cusps in the heads instead of the usual four. In the south wall, at the east end, is a piscina with a corbelled bowl under a plain arched recess. At both western angles of the chancel are fifteenth century squints from the transepts. The transepts are of equal size, $18 \mathrm{ft}$. 6 in. by $17 \mathrm{ft}$, high in proportion to their width. Both have fifteenth century details and plinths, and show no traces of earlier masonry, though their plan is probably of the date of the chancel. They open to the central tower by inserted arches of two orders with hollow chamfers, with octagonal caps, responds and bases, of a local type, which is not earlier than the end of the fourteenth century. The north transept has a three-light north window and a two-light east window, the sill of the latter having been carried down to form an altar-recess, now blocked. A piscina remains to the south in the cast wall. Originally there
46 Anct. D. (P.R.O.), A. 3,231

47 Inq. p.m. I $5 \mathrm{Edw}$. III. and nos. No. 46 .

18 Ibid. 37 Edw. III. Ist nos. No. 70.

19 Pat. 10 Rich. II. pt. I, m. 2.

50 Feet of $F$. Hants, case 28 , No. 50

51 Ibid. Mich. $3^{8}$ Hen. VIII.
32 Inq. p.m. 15 Edw. III. 2nd nos. No. 46 .

53 Compare Godalming Church, Surrey, for a parallel case. 
was a west window corresponding to the east window, showing by its position that the nave aisles in the fifteenth century were very narrow, if they existed at all; its north jamb only remains, the rest being destroyed by the arch into the north aisle of the nave. The south transept is like the north, but is ashlar-faced outside, and has under the sill of its south window a recess for a canopied tomb, now removed. The east window is squareheaded, of a fourteenth century type, but with label and details showing it to be of the fifteenth. A plain inserted doorway at the south end of the west wall suggests a widening of the south aisle of the nave in the sixteenth century.

The roofs of both transepts are of the fifteenth century, with cambered tiebeams and kingposts with struts, and collared rafters; the details in the south transept are better than those in the north.

The central tower, $17 \mathrm{ft}$. square at the base, has a low belfry stage with single light fourtecnth century windows and a wooden shingled spire. The walls are set back below the belfry stage. The tower opens to the nave and chancel with modern corbelled arches, and to the transepts as described above. The entrance to the ringing chamber is by a doorway in the south wall, above the south arch. The nave and aisles are of four bays with a western porch; they date from 1872 .

The font is of the fourteenth century, the bowl being modernized. It is octagonal, with deep sloping sides, and stem with large central and four small engaged shafts, round, with octagonal caps and bases.

On the north jamb of the east tower arch is a fifteenth century brass with figures of John Weston of Chiltey and Elizabeth his wife, with inscribed plate and scrolls. On the south jamb of the same arch is a brass plate with arms and inscription to John Hooke of Bramshott, 1613.

In 1795 there stood on the south side of the church a building divided into two stories, the lower open and entered by two Gothic doorways opposite to each other, which served as a porch. ${ }^{.4}$

There are six bells, which were rehung on an iron frame in 1901. The sixth bell is inscribed, "William Chalcraft \& John Neale, churchwardens'; the fifth bell has the inscription, 'Thomas Jannaway of Chelsea made us all 1784'; the third bell has the legend, 'Musica est mentis medicina'; the first bell was recast in 1893 , the original inscription, "When from the earth our notes rebound, the hills and valleys echo round,' being reproduced.

The parish registers, prior to 1813 , consist of four volumes: i., $1560-1728$ (omitting the years $1653-65$, for which a separate book is mentioned, but is not now with the registers); ii., 1729-1812; iii., 1754-93 ; iv., 1793-1812. There is a register of affidavits of burials in woollen from 1678 to 1730 , a churchwardens' book for the period between

1677 and 1704 , and several seventeenth century overseers' books.

The communion plate consists of: (i.) a silver chalice with date mark 1641 ; (ii.) a silver paten with date mark about 1630 and inscribed, 'Bramshott in Comt. South.; (iii.) a silver paten with date mark $1698 ;^{38}$ (iv.) a silver flagon with date mark 1 846 , given by T. P. Platt, esq., of Fowley; and (v.) silver chalice, altar paten and credence paten (Victorian).

In the middle of the thirteenth century Hugh de Arundel confirmed the grant of the tithes of Ludshott which his ancestors had made to Sherborne priory near Basingstoke; ${ }^{\text {b6 }}$ but thereupon the rector of Bramshott claimed them as belonging to the rectory. The decision of the priors of Wallingford and Eynsham going against the rector, he appealed to the Papal Court, and the dean and penitentiary of St. Paul's were directed to hear the pleadings. It was finally agreed that the rector should receive the tithes, paying I 3s. yearly to the convent. This payment was kept up until the priory, which was alien, was dissolved.

The advowson of Bramshott was sold in 1685 by Henry Hook to Queen's College, Oxford.

In the fourteenth century the rectory possessed 60 acres of glebe, ${ }^{57}$ but there are now only 40 acres; the difference may have arisen in the exchange of strips of land, scattered amongst other holdings, for a consolidated glebe. There is now a large rectory house in extensive grounds occupied by the rector.

Adjoining the churchyard is a building, belonging to the parish, in which persons attending church can stable their horses. The school-

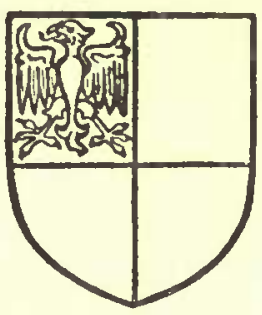

РАкеnнam. Quarterly gold and gules witb an eagle vert in the quarter. room at Liphook is used for services on Sunday evenings. The Bible Christians have a chapel at Liphook. At Woolmer is a Roman Catholic chapel dedicated to the Immaculate Conception and erected 1870 .

Sir Edmund Pakenham, lord of Bramshott manor, left by will in 1528 a yearly sum of $\ell_{6}^{6} 13 s .4 d$. for five years for an honest priest to pray within the parish of Bramshott for his soul and for those for whom he was bound to pray; he also gave to the parson of Bramshott a rent charge on his lands called Clerks to maintain a light before the high altar for twenty years to be continued after the good will and mind of his heirs and executors. ${ }^{88}$

There was a school at Bramshott as early as 1677, when 9s. 3d. was paid by the churchwardens for nails 'for the church and schoolhouse,' and in a woodcut of $1795^{89}$ a schoolroom is shown over the south transept of the church, where the jambs of a large square window can still be traced on 54 Geots. Magazine, I 795, pt. II, P
$993-4$.
65 With reference to this paten there
is 2 memorandum of the same date in the first volume of the registers, "For enlarging ye Paten 5 oz. $\frac{1}{2}$, for ye Altare with charges for carriage two journeys to Chichester fo 6 s.'

56 Archives of Queen's College, Oxford.

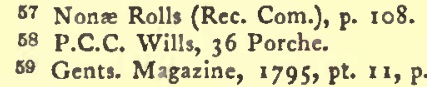




\section{A HISTORY OF HAMPSHIRE}

the inside of the west wall. In 1827 John Monkhouse, rector of Bramshott, left a considerable sum, representing nearly all he possessed, for the education of the children of respectable parents in the parish. The will was disputed by the next of kin, and probate was not granted until 1841 , when the trustees of the will, the provost and scholars of Queen's College, Oxford, purchased ground near the church, upon which school buildings, which bear the date 1845 , were erected, and children educated free of charge, an endowment of f73 $_{14}$ s. 9 d. being provided. A school was subsequently built at the hamlet of Conford out of the same trust. In 187 I Sir William Erle conveyed land on the London road adjoining Liphook for the erection of a school for that part of the parish, to be managed by the rector, churchwardens and subscribers.

Anthony Vallor, at his death in 1608 , left to the poor of Bramshott $\mathscr{E}$ I 2s. yearly out of his land at Kingsley for bread at Christmas. In response to the Government inquiry in 1786 the minister and churchwardens reported that even the memory of this bequest had died out in the parish. Another charity which has for long disappeared was a bequest of $f 10$ by Thomas Collins in 1627 , and there are now no parochial charities existing.

There are National Schools at Conford and Hammer, and a Roman Catholic school at Fairgrove, founded in 1871 .

\section{CHAWTON}

Celtone (xi. cent.), Chalvedone (xiii. cent.), Chauton (xiv. cent.).

The village is situated in a broad, wooded valley, one of the sources of the river Wey, and is watered by land springs called 'lavants.' These, in wet seasons, run at the foot of the churchyard. Hops are largely cultivated in the neighbourhood.

The road from London to Gosport passes through the parish and forms the western boundary of a park in which are situated, amidst elms and beeches, the parish church and Chawton House closely adjoining. The coach road from London to Winchester branches off from the Gosport road in the centre of the village. There is a working men's club, near the village pond, formed at a house once occupicd by Miss Jane Austen. In Chawton Park, to the north of the Winchester road, are banks of earth which apparently divided the two ancient parks. ${ }^{2}$ The whole of the parish is owned by Montagu George Knight, D.L., J.P., who is lord of the manor. There were formerly two roads leading from Chawton to Winchester, the upper adjoining the High Beeches in Chawton Park, along which there is still a right of way, and the lower, or Shrove Road, which forms the present main road. 'Four Marks' is a spot on the latter road where an old stone marks the junction of the boundaries of the parishes of Chawton, Faringdon, Medstead and Ropley.

The manor of Chawton, in the $M A N O R$ time of the Confessor, was held of the king as an alod by Oda, styled in the Sussex survey, Oda de Wincestre. Though apparently an Englishman he heads the list of Hampshire thanes of the Conqueror, who granted to him other lands in Hampshire, but took Chawton from him and granted it to Hugh de Port. $^{3}$ In 1167 John de Port was owner of Chawton."

The manor remained in the family of Port till the thirteenth century, when William son of Adam de Port and Mabel de Aureval, heiress, through her mother, of Roger de St. John, took the name of St. John. ${ }^{5}$ It continued in the St. John family ${ }^{8}$ until the year 1355, when Edmund, son

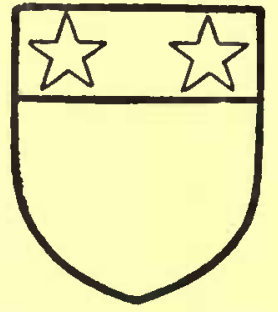

SAINT JоHN. Silver a cbief gules witb two moless gold upon tbe cbief. and heir of Hugh St. John, dying a minor, ${ }^{7}$ it passed as the portion of Margaret his sister, wife of John de St. Philibert ; she, two years later, giving it to her sister Isabel the wife of Luke de Poynings. ${ }^{9}$ It remained with the Poynings till the death of Thomas Poynings in 1429 , when it passed to his grandson John Bonville, son and heir of his daughter Joan, who married a Bonville. ${ }^{10}$ John Bonville died 24 August, 1494, to whose daughter and co-heir,

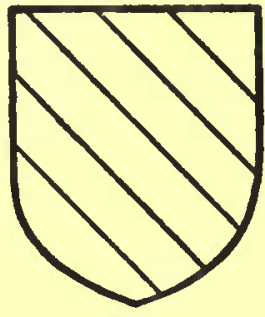

Saint Philimeat. Bendy silver and azure.
Florence, wife of Sir Humphrey Fulford, knight, Chawton was conveyed, with remainder to her sister Elizabeth. ${ }^{12}$ On Florence (who afterwards married Lord Fitzwarren) dying issueless, it passed to her sister Elizabeth, wife of Lord De la Warr. ${ }^{13}$
1 Selborne Priory Charters, Hants Record Soc. i. 3 .

2 Two parks are mentioned ia 1337. Inq. p.m. I 1 Edw. III. I st nos. No. 49.

3 V.C.H. Haat i. 482 . Chawton is placed in Neteham huadred in Domesday; before 1334 it formed part of Alton huadred (Lay Subsidy, 173-5).

4 Pipe Roll for 1167.
5 Paper by J. H. Round in the Genealogist, xiv. 1-13.

Inq. p.m, 3 Edw. I. No. 88 ; 30 Edw. I. No. 36 ; 3 Edw. III. I st nos. No. 67 ; I I Edw. III. I st nos. No. 49. 7 Inq. p.m. 29 Edw. III. 18t aos. No. 55 .

8 Ibid.

Ibid. $31 \mathrm{Edw}$. III. 2nd nos. No. 32.
10 Ibid, 7 Hea. VI. No. 69.

11 Ibid. Chan. ser. 2, vol. 10, No. 94. See also claim made by John Paulet ia I 503 setting out the descent ia more detail. De Banco Roll, Mich. 15 Hen. VII. roll 5 I 5 .

12 Ibid.

13 Inq. p.m. Chaa. ser. 2, vol. 41, No. 48 ; Feet of F. Hants, Mich. $16 \mathrm{Hen}$. VIII. 
In 1554 Lord de la Warr died and left it to his half-brother Leonard West, who sold it in 1555 to Thomas Arundel of Ewhurst. Thomas Arundel died seized of it in $1568,{ }^{14}$ and left his son and heir William, who sold it in 1578 to Nicholas Knight, ${ }^{15}$ whose family had been lessees of the manor house since 1524 , and owners of the site of the manor since $1571 .^{16}$

From 1578 the manor remained in the Knight and vert witb a baston family ${ }^{17}$ till 1679 , when Sir gules.

Richard Knight left it to Richard Martin, son of name of Knight. He was grandfather of $\mathrm{Mr}$. Montagu George Knight, the present owner..$^{18}$

In 1252 free warren was granted to Robert de St. John in his demesne of Chawton. ${ }^{19}$ Assize of bread and ale, and right of gallows, pillory and tumbrell were allowed to John de St. John, son of the said Robert, in $1280 .{ }^{20}$ It was then stated that the old gallows and pillory had fallen down and that the tumbrell was worn out, and that upon it being reported that St. John's an-

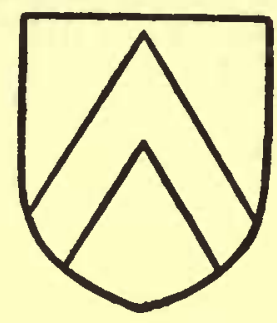

Fulfond. Silver cbeveron gules.

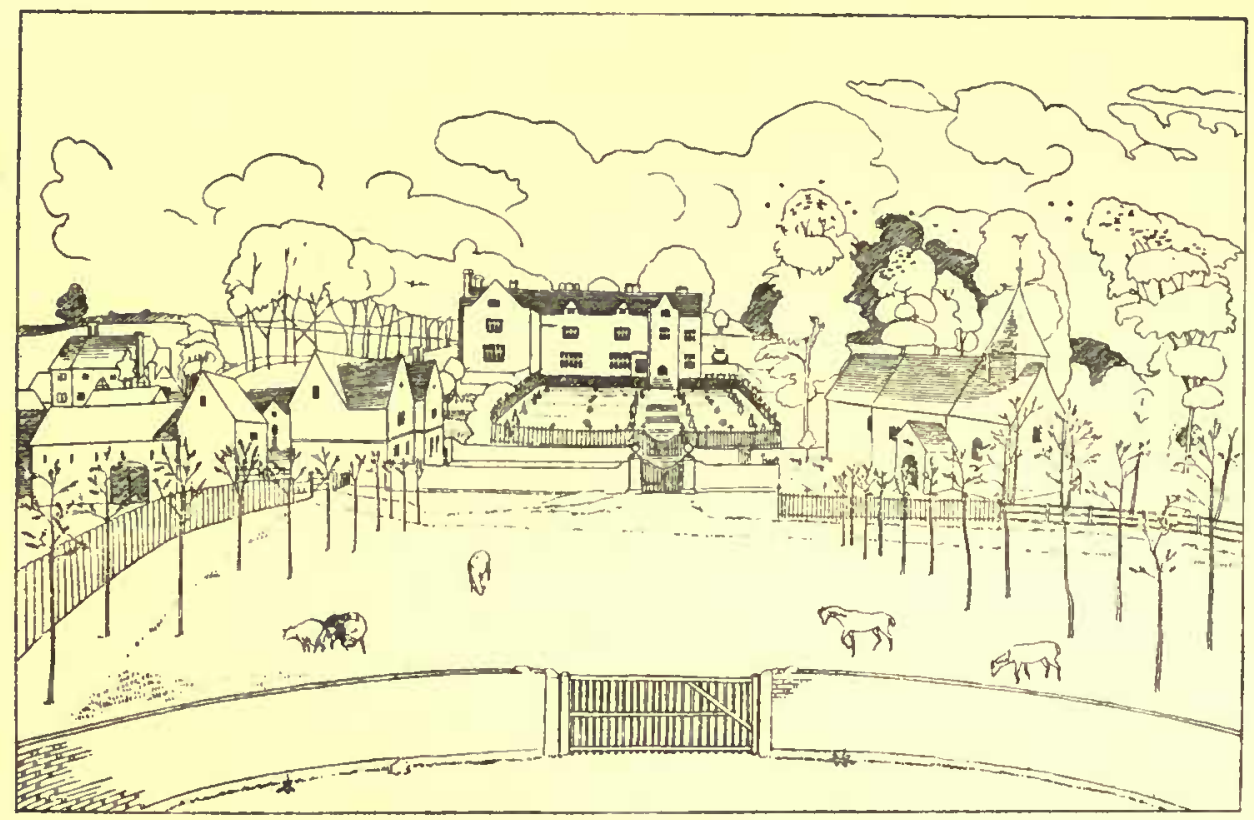

Chawton House.

(From an old picture in the possession of Montagu G. Knight, D.I.., J.P.)

his cousin Michael Martin. Richard Martin took the name of Knight on succeeding to the property, as did his brother Christopher on succeeding him. Christopher dying issueless the manor passed to his sister Elizabeth, who died in 1737 , also issueless, and left it to Thomas Brodnax, a cousin. He assumed the name of Knight and was succeeded by his son Thomas, who died issueless in 1794 , leaving it to

Edward Austen, a cousin, who thereupon took the the sheriff was ordered to allow him to replace them.

An extent of the manor in 1320 states that it consisted of a capital messuage with a garden and other easements of the court worth yearly ios.; four carucates of land each containing 100 acres; 95 acres ${ }^{21}$ of wood; 4 acres of meadow and a several pasture. There were eight free tenants, seven cus- sable. tomary tenants, each holding

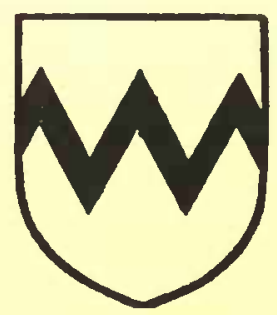

West. Silver a dance
16 acres of land and doing certain services in

14 Inq. p.m. 10 Eliz. No. 26.

15 Information furnished by the present lord of the manor. Feet of $\mathbf{F}$. Hant, Trin, 20 Eliz. and Close, 20 Eliz. pt. 12.

16 Information of the present lord of the manor from documents in his custody. 17 Set tlement in $x 59^{8}$ by John Knight

on his brothers and their issue (Common

Pleas Deeds enrolled East. 40 Eliz.m. I7).

16 Inq. p.m. Chan. ser. 2, vol, 204 , No. 113 ; ig Jas. I. ser. 2, vol. 33 , No. 86 ; 3 Chas. I. ser. 2 , pt. I, No. 108 ; 15 Chas. I. ser. 2, pt. 2, No. I 16 ; 18 Chas. I. ser. 2, pt. 2, No. 50 ; Feet of F. Div. Cos. Trin, 40 Eliz.; ibid. Hil. certain.

497
3 Chas. I. ; ibid. Trin. 12 Geo. I. : ibid. East. 30 Geo. II. ; and information supplied by present lord of the manor.

19 Vascon, Patent and Charter Roll, $37-38$, Hen. III. p. I, m. 18 .

20 Assize Roll, No. $78_{3}$, roll $36 d$.

21 The reading of the number is un- 


\section{A HISTORY OF HAMPSHIRE}

addition to their rent, five like tenants each holding 8 acres of land by rent and similar services, and 4 cottagers each holding 4 acres and paying rent and rendering in kind.22

The lord of the manor possesses court rolls from 1543 to the present time. Amongst the place - names mentioned in these rolls are 'Castle-land' and 'Arrow Croft'; on the death of the holder of the latter a relief of 61 pence, or 61 arrows, of 61 pence, or 61 arrows, engrailed gold with a
was payable. ${ }^{23}$ The site of cingfoil silver in the foor. 'the old gallows,' mentioned in $1560,{ }^{24}$ may be identified with the spot now known as 'The Gibbets,' which was formerly part of the common.

The Enclosure Act was passed in $1741 .^{25}$

In 1224 the king directed that two oaks from Alice Holt Forest should be delivered to William de St. John towards making a house in his manor of Chawton. ${ }^{26}$

Chawton House stands picturesquely on quickly rising ground, facing south and west, having the village of Chaw ton to the north, and the church immediately below it to the west. It is a late

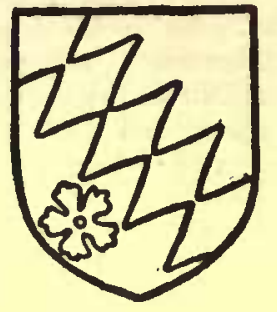

KNighr. Vert a bend engrailed gold witb a

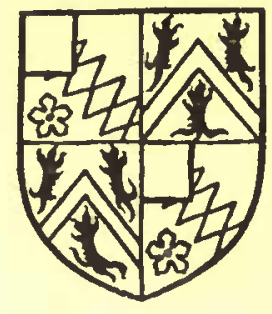

KNight. Vertabend engrailed gold witb a cinqfoil silver in tbe foot and a quarter gules (for Knigbi) quariered witb gold a cbeveron gules berween tbree lions' pawes erased sable (for Austen). sixteenth century building with large additions of the middle of the seventecnth century, and is of two storeys with an attic throughout. The older part was originally $Z$-shaped, and is built of flint rubble with dressings of stone and red brick, with square-headed mullioned windows and red tiled roofs. The appearance of the south and west fronts has been much injured by a coating of Roman cement which hides all the details of the walling, and by the renewal in wood of most of the window mullions. It seems probable that its builder was John Knight, who succeeded to the estate in 1580. The unusual shape of the plan is due to the nature of the site, but all the essential features of a house of this date, when the medixval arrangement was being modified to suit a higher standard of comfort, are to be found.

The central block standing north and south, contains the hall, built upon vaulted brick cellars, with the screens at the south end, and a fine open fireplace in the middle of the east side, with a four-centred arch of chalk ashlar, and iron fireback and dogs, the former bearing an anchor, with I.K. (for John Knight) and the date 1588 . Over the hall, which has a flat plaster ceiling, probably representing the original arrangement, though in itself of later date, are two rooms with good fireplaces with four-centred chalk arches and carved span- drils. To the north of the hall, and entered from its north-west angle, is the block containing the original main staircase and, in a wing projecting westwards, are the living and sleeping rooms of the family. South of the hall is a block divided from it by the passage through the screens, formerly containing the offices (buttery, kitchen, etc.) with living rooms over. The kitchen has been destroyed in later alterations and must have been on the east side of the block. The front entrance to the house was, and still is, by a porch of the full height of the rest of the building, placed towards the south end of the west front, not opening directly into the screens, but into a lobby adjoining them on the south.

The two usual defects in a house of this type, the planning of the staircase and the lack of communication between the wings at either end of the hall, are herewell illustrated. The staircase is ineffective and awkwardly arranged, and the rooms over the hall, taking up the full width of the block, in order to have fireplaces in the east wall and a good light from the west, left no room for a corridor connecting the wings, and had to be used as passage rooms.

In the middle of the seventeenth century (about 1655 , according to a date on a carved door-head) considerable additions in red brick were made on the east of the house, consisting of two gabled wings with mullioned windows, at either end of the hall, and a narrow connecting block, also facing east with two gables, built against the east wall of the hall, and giving the much needed means of access from one end of the house to the other. There may have been some building against the east wall of the hall before this time, but the evidence which remains is not conclusive. A courtyard was thus formed, facing eastwards up the slope on which the house is built, and closed on its eastern side by a low range of brick buildings connecting the east ends of the north and south wings. The offices were transferred from the south end of the hall to the new north wing, and in the south wing a new staircase was provided, with heavy oak newels, turned balusters, and moulded strings.

The only important addition to the plan after this date is a block built against the north wall of the sixteenth century north-west wing, containing a billiard room with bedrooms over; this is of comparatively modern date, with mullioned windows in imitation of the older work.

The house is rich in woodwork of the sixteenth and seventeenth centuries, the best specimens being the hall panelling and the doorheads and details of the south staircase. There is a long series of portraits in the hall and elsewhere, and of several pieces of tapestry the most important is a carpet of arms of the Lewknor family, dated 1564 .

In the windows of the south wing are a few roundels of old heraldic glass. There are several fine cast iron firebacks, besides that already mentioned in the hall, but, unlike it, they are not part
2 Ing. p.m. 30 Edw. I. No. 36.

23 Court Roll, 1 Eliz. 8 April.
24 Ibid. 2 Eliz, 20 Oct.

26 MS. index to Enclosure Acts, 1727 101812 (Pub. Rec. Off.).
26 Close, 8 Hen. III. pl. 1, m. 8. 


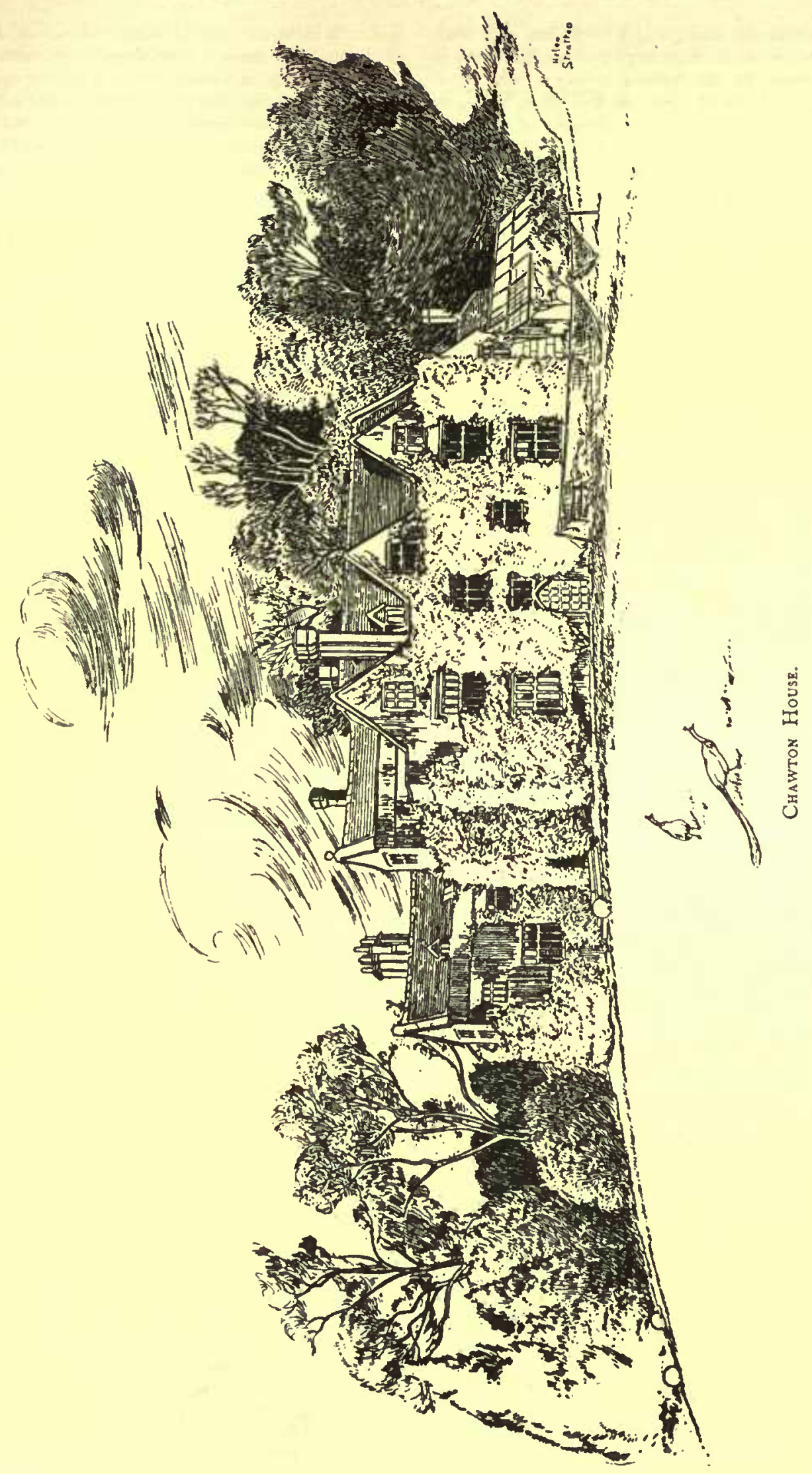




\section{A HISTORY OF HAMPSHIRE}

of the original fittings. A very fine and wellpreserved piece of thirteenth century ironwork, in the passage to the billiard room, is worthy of notice; it is an elaborate wrought-iron hinge, on a plain vak door which is probably of the samc date, removed a few years ago from Neatham manor house, formerly belonging to Waverley Abbey and afterwards to the Lords Montague of Cowdray.

The stables and outbuildings are to the northwest of the house, at a lower level, and are of considerable interest. The stables stand east and west, with projecting gables at either end of the south face. They arc built of brick and stone with stone dressings and mullioned windows, and

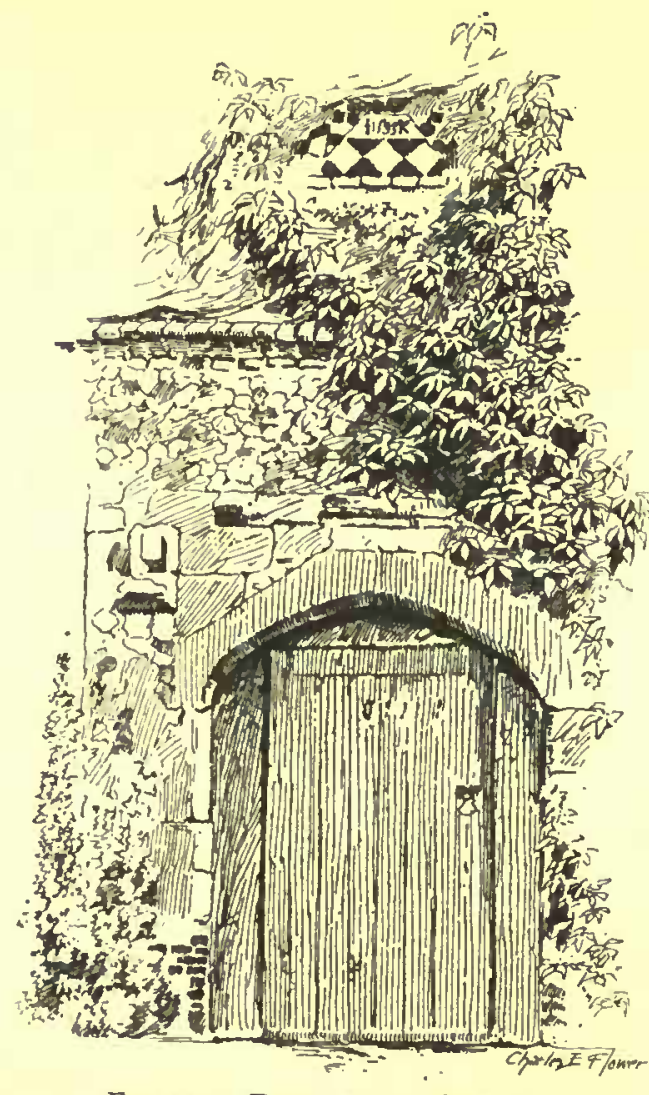

Entrance Doorway to Stables.

a cut brick string at half height. The entrance doorway is in the middle of the south side, with a plain arched hcad, and in the wall over it, in lead letters lct into a small stone, the initials and date I. $1593 \mathrm{~K}$, doubtless the same John Knight whose initials occur on the fireback in the hall. Northeast of the stables is a rectangular red brick pigcon house, now ruinous, and another rectangular gabled building with two narrow and deeply splayed window openings at either end, and above them in the gables small stone mullioned windows. A painting of the house, of the first half of the eighteenth century, shows the garden laid out in terraces with formal trees, but only slight traces of the old arrangement now exist.

In the village of Chawton stands a plain square brick house of two storcys, once the home of $\mathrm{M}$ iss Jane Austen, the famous novelist. It has no architectural interest, and retains beside its walls little which can claim to have existed in the time of her accupation. On its east side it abuts on the village street, having a little garden to the south. The south-east room on the ground floor is of some size, and must have been a pleasant room before it lost the projecting bay window at its east end. In the north-east room is a chimneypicce of 'Adam's' style.

The endowment of the rectory of Chawton, the patronage of which has always been held by the lord of the manor, is now commuted tithe of the nominal value of $£ 490$ with 60 acres of glebe and a rectory house.

The church of St. Nicholas, taxed CHURCH in 1291 at $81.135 .4 d .,{ }^{27}$ stands only about 70 yards from the manor house at the bottom of the valley. It consists of a chancel with north aisle or chapel, nave of four bays with north aisle, and tower at the south-west angle forming a porch entrance. The old church, which consisted of chancel and nave with low tower at the west end, was burnt down in 1871. The present building of flint and Bath stone was designed by Sir Arthur Blomfield. The altar is an oak table of the time of Archbishop Laud.

On the north side of the altar is a black and white marble monument with semi-recumbent effigy to Sir Richard Knight, ob. 1679. Also a tablet to Elizabeth Knight, ob. 1737. The roodscreen is surmounted by figures of the Rood and SS. Mary and John.

The parish registers begin in 1593 and previous to 1812 consist of five volumes: $i$. $1596-1658$; ii., $1662-1708$; iii., 1 708-1806; iv., 1757-1806; and v., 1806-1813. There are two volumes of churchwardens' accounts, from 1621 to 1812 , and from 1813 to the present time.

The communion plate includes a flagon dated 1641 , a large paten dated 1726 , and a chalice and small paten dated 1667 . Two of the six bells are pre-Reformation ; one is inscribed, 'S. Nicholas ora pro nobis,' and the other, 'Sancta Maria ora pro nobis.'

There is mention, in $\mathbf{3} 302$, of the free chapel of St. Laurence within the 'court' of the manor ; so that, as the church is so close to the manor house, we may presume this was a chapel of the church. In 1337 we have reference to a chantry in this chapel founded by Sir Robert St. John. ${ }^{28}$ The chantry certificate made in Henry the Eighth's reign does not mention either the chapel or the chantry therein, but refers to Thomas Womme, parson of Chawton, having, as his predecessors had, the chantry lands as parcel of his glebe. ${ }^{29}$ The chantry certificate of Edward VI. is also silent as to the chantry, but mentions an obit
27 Taxalion of Pope Nicholas (Rec. Com.), p. 210 ,
28 See Inq. p.m. 30 Edw. I. No. 36 , and also II Edw. III. I it nos. No. 49, and Pat. ro Edw. III. pt, $1, \mathrm{~m} .16$.
29 Chantry certif. No. $5 x$. 
celebrated in the church for some person unnamed, an obit of 'Thomas Moore,' and a light. ${ }^{30}$ In I 540 a lease of the 'Chantry House' was made (with the consent of the patrons of Chawton) by 'the chantry priest of the free chapel or chantry of Chawton' to Joane Raynolds and William Knight the younger of Chawton. ${ }^{31}$

The National Church of England school was built by Mr. Edward Knight in 1840 , and has undergone several enlargements, the last in 1897 by $\mathrm{Mr}$. Montagu Knight, and is his private property.

There are five charities connected with the parish :

(1) A sum of 6s. yearly paid by Mr. Montagu Knight to the parish clerk charged upon property formerly called church, or clerk's, land, near Chawton Pond, purchased by Mr. Edward Knight in 1838 from the guardians of Alton Union, subject to the above payment.

(2) Knight's charity, a charge of $£_{0} 2$ yearly, less land tax, on Amery farm, Alton, left by John Knight in 1617 to the minister and churchwardens for the relief of the poor in Chawton.

(3) Stent's charity, a charge of $£ z$ yearly, less land tax, 6s. $8 d$., on Wivelrode farm left by John Stent in 1592 , to be paid to the minister and churchwardens of Chawton to be by them distributed to the 'poor people' of that parish. ${ }^{32}$

(4) Harford's gift, the interest on $f_{1} 1075.2 \%$, 2 por cent Consols left by Mrs. Anne Harford, in 1773 , to the rector, to be divided between two, three or four industrious poor persons, not receiving parish allowance. This charity was transferred to the Official Trustees of Charitable Funds in 1858 .

(5) Poor's Money, the interest on $\oint_{23} 6$ s. $3 d$, 3 per cent Annuities, formerly received by the rector and given to the poor, but transferred in 1858 to the Official Trustees named above.

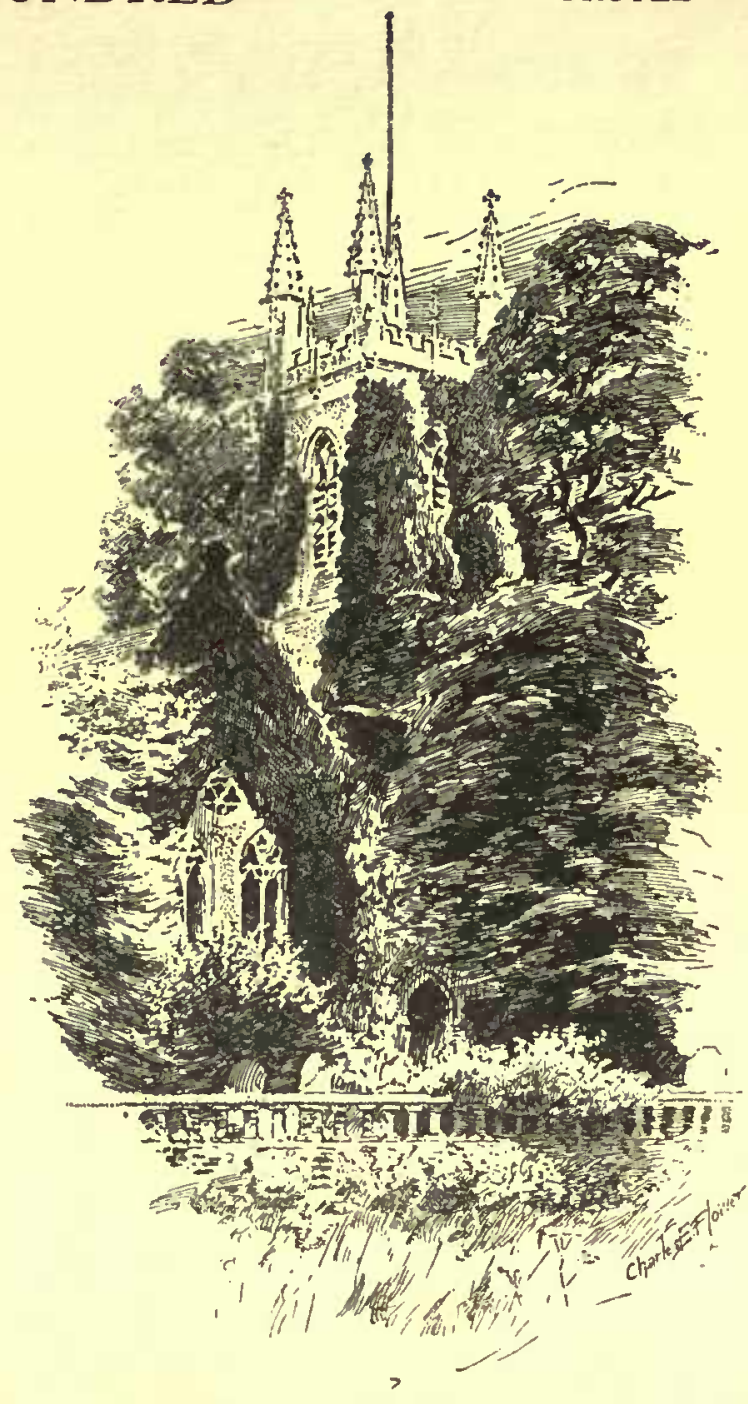

Church of St. Nicholas,

\section{FROYLE}

Froli (xi. cent.).

The parish of Froyle is situated on the northern side of the valley of the Alton branch of the river Wey. The village, called Upper Froyle, lies to the north-east of the London and Gosport road as it traverses the southern side of the parish, which is on that side bounded by the Wey. To the north of the village lies Lower Froyle. The parish of Long Sutton is the main boundary of Froyle parish on the north ; Bentley bounds it on the east and Holybourne on the west. Froyle Place (Captain E. H. Sawbridge) stands near the church in a wooded park of 150 acres, the property of Sir C. J. Hubert Miller, bart., lord of the manor. The house was entirely rebuilt in 1867 . Adjoin- ing the park is Froyle House, the residence of Walter T. E. Bentinck. The chief crops are hops and ccreals.

The following are some of the place-names that occur in a rental for the year 1415 : North Froyle, Burydonfield, Wykehill, Bownamesditche, 1 Spolicombe and Sonnebury. ${ }^{2}$ In 1539 occur : Bradenham, Brambleham, Motys, Berryfroyle, Church Froyle, Great battled gold between tbree ghurst and Coll- cocks' beads rased silver. ingbourne. ${ }^{3}$

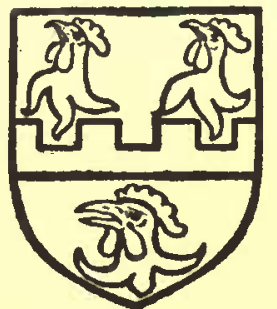

Jephson. Azure a fesse
30 Chantry certif. No. 52 .

31 In the custody of the lord of the manor.

32 Stent died in Nor, 1592. In 1602 the $K_{2}$ a year was in arrear to the amount of $\delta_{0} 20$. In 1655 a large sum was also in arrear. The Charity Commissioners on each occasion directed payment of the arrears to be made (Petty Bag Charity Inquisition, 1, 29 and 23,16 ).
1 Sic; perhaps a misrendering of Bowmansditche.

2 Add. Chart. 17,512.

3 Mins. Acct. 30-1 Hen. VIII. No. 139, m. 65 . 


\section{A HISTORY OF HAMPSHIRE}

MANORS Survey the manor of FROYLE Winchester, ${ }^{4}$ and it remained part of the possessions of that nunnery till its dissolution in $1539 .^{\circ}$ In 1541 the king, for the sum of $\{1,505$ 1 7 s. $4 d$., and an annual rent of $£_{4}$ 13s. 5d., granted the manor to William Jephson, ${ }^{6}$ in whose descendants the possession continued till 1652 .? Four ycars later John Fiennes was lord of the manor, ${ }^{8}$ and he, together with his brother Robert, sold it in 1666 , to Samuel Gauden of Lincoln's Inn. ${ }^{\circ}$ The descent from this time till the manor

At the time of the Domesday belonged to the abbey of St. Mary at

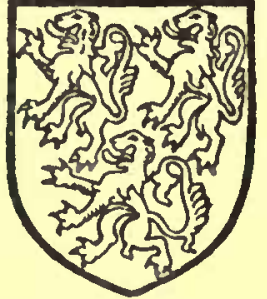

Fiennes. Azure tbrec lions gold. been ascertained, but the following persons presented to the living: William Salmon, in 1697 ; Gauden Draper, in 1706; Marian Draper, widow, and guardian of William Draper, her son, in 1719; William Draper, in 1733; Mary Nicholas, "this turn' in 1772 ; Johanna Logging, in 1773; and Sir Thomas Miller, in 1800.11

There was in the parish another manor of FROYLE, and it was held of the chief manor. This property belonged, in 1363 , to Sir John Brocas, ${ }^{12}$ and in 1378 was settled in trust by Sir John's

In 1415 the property is described as 6 virgates of land, and was in the tenure of William Brocas." In 1507 William Brocas died seized of the 'manor' of Froyle, described as held of the abbess of St. Mary's of Winchester, leaving two daughters as his co-heirs : Anne aged eleven and Edith aged nine. ${ }^{15}$ In 1583 a fraction of this manor belonged to Margery widow of Francis Cotton. She was a daughter and co-heir of Sir Richard Pexall, and had married, as her first husband, Oliver Becket. By him she left a son and heir John, under ten years of age at the time of her death. ${ }^{16}$

Considerable litigation followed as to the possession of this fraction, and the other property of Sir Richard Pexall, and Sir John Jephson, lord of the chief manor of Froyle, is mentioned in the proceedings as having purchased 2 fraction or fractions of the sub-manor. ${ }^{17}$ How correct this assertion may be it is difficult to say; but in 1631 , when, as we have seen, the Jephsons were lords of the chief manor, Sir Humphrey May died seized of the entire sub-manor, of whom held,

An Olo Timbered Cottage in the Village. the jurors did not know.
heir James, aged sixteen. ${ }^{18}$

the close of the eighteenth century, ${ }^{10}$ has not

He left a son and heir James, aged sixteen. ${ }^{18}$

1 V.C.H. Hants, i. 474 .

5 Mins. Accl. 30-1 Hen. VIII. No. 139, m. 65, elc.

- Pat. $33 \mathrm{Hen}$. VIII. pt. i. m. 35 ; and Particulars for Grants, No. 646. The origiaal grant, with portion of the great aeal attached, is amongst the Add. Chart. at the Brit. Mus, 17,601.

7 Inq. p.m. aer. x, Exch. File 990, No. 8 ; Feet of F. Haots, Easter, 41 Eliz. ; Ibid. Easter, 13 Chas. I.; Inq. p.m., ser. 2, Chan. 15 Chas. I. pt. 2, Burrows, p. 295, where the original deed No. 100 ; and Add. Chart. 17,557.

8 Add. Chart. 17,577.

R.), Trin. 18 Chas. II, roll $8 \mathrm{~d}$.

15 Ing. p.m. ser. 2, Exch. file 961, Hubert Miller given by Sir C. J. No. 9. 16 Ibid. Chan. vol. 200, No. 54 . Hubert Miller, bart. the present lord of 17 Chan. Proc. Eliz. SS. 15-55; and the manor.

11 P.R.O. Composition Books, Winchester Diocese.

13 The Family of Brocas, by Montagu
James I. M. bdle. 6 , No. 24 ; and bdle. 8, No. 15

18 Inq. p.m., ser. 2, Chan. vol. 457 , 
Coldrey House lies on the south-east of Froyle parish. The manor of COLDREY (Colreth, xiv. cent.), now a parish of itself and containing about 195 acres, was formerly an extra-parochial portion of Froyle; it was erected a parish about 1860 . The manor was, in 1253, the subject of an agreement between William and Philip de Sparsholt. ${ }^{19}$ In 1343 William de Castle Ralph was lord of the manor, ${ }^{20}$ and in 1351 mention is made of land in Coldrey held of Roger de Colrithe. ${ }^{21}$ Thomas Colrithe possessed the manor and left a daughter and heir Christine, who married Richard Holt, by whom she left a son, Richard Holt, who in 1458 , died seized of the property, described as held of the Bishop of Winchester. ${ }^{22}$ He left a daughter and co-heir Christine, who, in $146 z$, was wife of Edward Berkeley. ${ }^{2 a}$ Their daughter and heir heir. ${ }^{28}$ Richard, the grandson, in 1557 , conveyed the manor to Sir John Leigh. ${ }^{27}$

In 1567 Edward Fitzgarret, Agnes his wife, daughter and heir of Sir John Lcigh, and John Leigh conveyed the manor to John More and others, obviously in trust, ${ }^{28}$ as in 1575 John Leigh, nephew and heir male of the same Sir John, died seized of it. He left, as his heir, an infant son, ${ }^{29}$ who died seized of it in 1613 , leaving a son and heir, Thomas Leigh, aged six. ${ }^{30}$ This Thomas, in 1629 , sold the manor to Sir Humphrey May, ${ }^{31}$ who, during

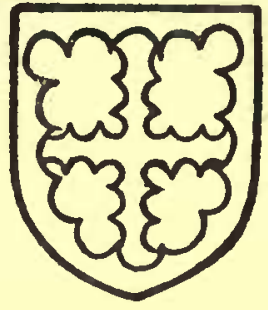

LrIGH. Gules a cross engrailed and a border engrailed silver.

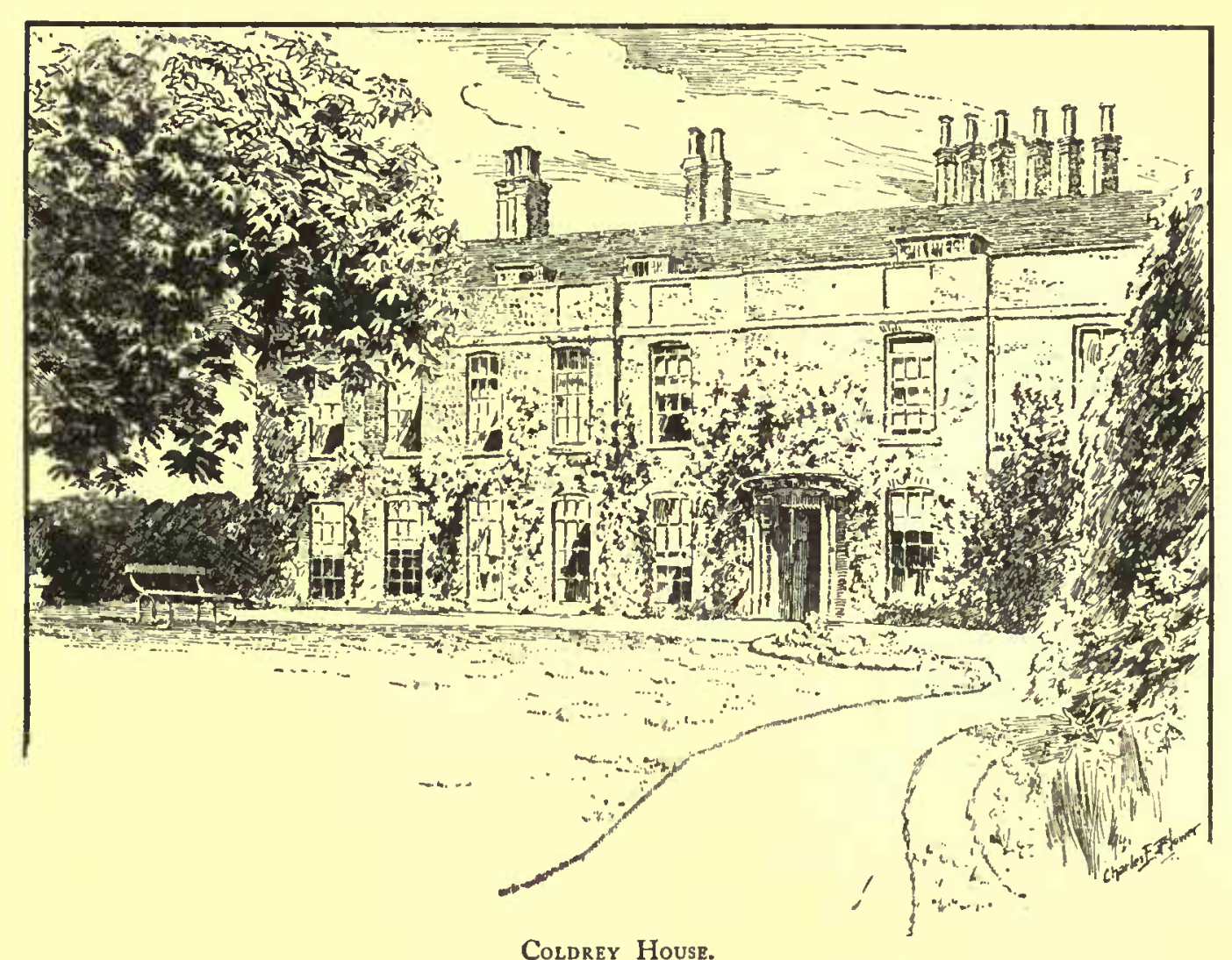

Laura, married William, Lord Mountjoy, whose son and heir William was aged twenty-six in $1506 .{ }^{24} \mathrm{He}$, in 1533, conveyed the manor to William Thorpe. ${ }^{25}$ Richard Lyster died seized of the manor in 1553, then held as before of the Bishop of Winchester, when his grandson Richard, three months under age, was found to be his

the following year, died seized of it, leaving a son and heir, James May, aged about fifteen. ${ }^{32}$

Hussey's farm lies to the east of the parish. The manor of HUSSEYS is mentioned as early as $126 z-3$; a tenement, consisting of a messuage, mill, and carucate of land, was then acquired by Walter Hussey (Heuse) of his brother William

19 Feet of F. Hants, Hen. III. No. 401 .

20 Add, Chart. 10,662.

21 Ibid. 17,4I3.

22 Inq. p.m. $36 \mathrm{Hen}$. VI. No. 32.

23 Add. Chart. I 7,600.

24 Inq. p.m. ser. 2, Chan. vol. I9, No. 8 g.
25 Feet of F. Hanls, Mich. 24 Hen. VIII.

26 Inq. p.m. ser. 2, vol. 124, No. 222, almost illegible.

27 Ibid. Hil. 3 \& 4 Phil. \& Mary. Sir John Leigh is said to have erected Coldrey House in $155^{8}$ (Woodward's Hants, iii. 236).
28 Notes of Fines, Div. Cos. Easter 9 Eliz.

29 Inq. p.m. ser. 2, Chan. vol. I75, No. 82 .

30 Ibid.Wards and Liveries, I 4, No.97.

a1 Feet of F. Hants, Mich. 5 Chas. I.

22 Inq. p.m. ser. 2, Chan. vol. 457, No. 107 . 


\section{A HISTORY OF HAMPSHIRE}

and Agnes his wife. ${ }^{33}$ Nicholas Hussey held land in Froyle in $1336,{ }^{34}$ and Nicholas Hussey and Christine his wife, in $1382 .^{35}$ In 1414 they conveyed to, amongst other persons, Richard Wyett, ${ }^{36}$ who, in 1416, acknowledged money received of Thomas Colrith for the 'manor' of Husseys. ${ }^{37}$ This is the earliest mention that has come to light of the holding as a 'manor.' Husseys probably descended as did Coldrey to Sir Richard Holt, and from him to Sir Edward Berkeley, who was a free suitor to the lady of the chief manor of Froyle in 1502. ${ }^{38}$ In 1539, at the time of the suppression of St. Mary's Abbey, Winchester, the rent for Husseys was paid by Sir Richard Lyster, chief baron of the Exchequer. ${ }^{39}$
A tenement in the parish called CATLEES is mentioned in the inquisition taken on the death of Miles Windsor in 1452.4 In 1367 Richard de Windsor had died seized of a virgate of land and a small pasture, held of the abbess of St. Mary's. He left a grandson and heir Miles, aged fourteen. ${ }^{45}$ In the rental of 1415 Richard de Windsor is returned as tenant of this virgate, mentioned as having been formerly in the tenure of Richard Catteley, ${ }^{t s}$ hence, no doubt, the name by which the holding was called in 1452 as mentioned above. Thomas Windsor died in 1485 seized of Catlees, leaving a son and heir Andrew, aged eighteen. ${ }^{47}$ The Windsors were entered as free suitors at the court of the chief manor of Froyle as late as I $550.0^{.9}$

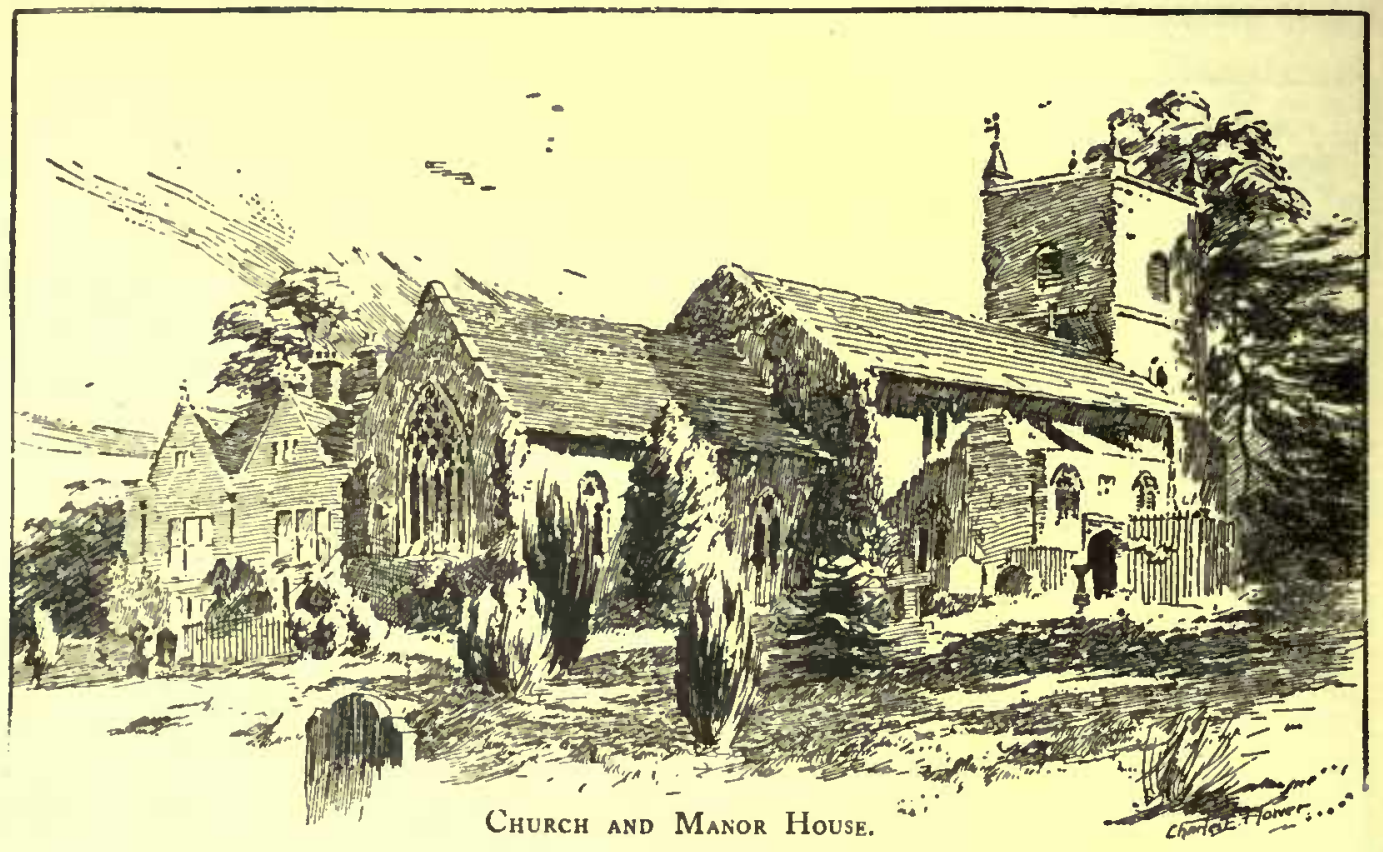

In 1557 Husseys was conveyed by John Gyffard and Susan his wife to John Fitzwilliam, ${ }^{40}$ who, in 1564 , died seized of it, leaving $a$ son and heir William, aged fifteen. ${ }^{41}$ The manor had, before 1639 , become the property of the Jephsons, owners of the chief manor of Froylc, ${ }^{42}$ and was sold by them in 1666 to Samuel Gauden, ${ }^{13}$ and the manorial rights have presumably remained in the subsequent owners of the manor of Froyle.

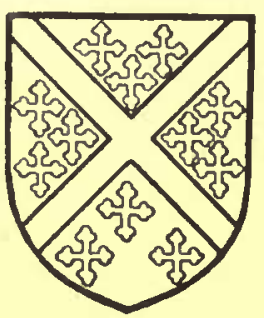

Winosor, Guler a ral tire silver berween rwelve crosslets gold. as Feel of F. Hanta, Hen. III. Nos. $55^{2}, 55^{8}$; and Add. Chart. $17,5^{82}$.

ad Ad. Chart. $7,5^{8} 3$.

35 Ibid. 17,585 .

ac Ibid, 17,597 .

I7 Ibid. 17,598. In the rental of 1415, Nicholas Hussey is returned as lenant, and the property described as ceven virgates of land and two mills and held at a rent of $6 \mathrm{ts}$.
There exists a fairly continuous series of court rolls of the chief manor of Froyle, from the fourtecnth to the sixteenth century, with one of the thirteenth and several of the seventeenth century. ${ }^{49}$ There is also a fine series of account rolls from 1235 to $1537 .^{\mathrm{BO}}$

The abbess, as lady of the manor, had a several fishery in the water next 'Parsonnysmede' in $1501^{81}$; and in 1587 the lord is stated to have the fishery of the whole 'water or river called Froyle River' from Millcourt Gooshatche to Isyngton Moor, and ' in Isyngton so far as the land of the lord extends.' Elsewhere within the bounds of the manor, he had the fishery to the mid-stream. He was bound to keep in repair the bridge over the
38 Ibid. 17,540

39 Mins. Accts. 30-t Hen. VIII. No. $139, \mathrm{~m} .65$.

10 Feet of F. Hants, Easter, 3 \& 4 Phil. \& Mary.

4I Inq. p.m. ser. 2, Chan. vol. 140 No. 179.

13 Ibid. 15 Chan, I. pt. 2, No. 100.

13 Com. Pleas, Deeds Enrolled (Recov. R.). Trin. 18 Chas. II. roll $8 \mathrm{~d}$
14 Inq. p.m. $30 \mathrm{Hen}$. VI. No. II.

45 Ibid. 4t Edw. IlI. ist nos. No.6

10 Add. Chart. 17,512 .

7 Ing. p.m. ser. 2, Chan, vol. 1, No. 14.

18 Add. Chart. 17,554

49 Ibid. 17,5:9-81.

so Ibid. $17,457-78: 13,33^{8}$ and $13,339: 17,479-511$ and $17,513-8$.

61 Ibid. 17,540 


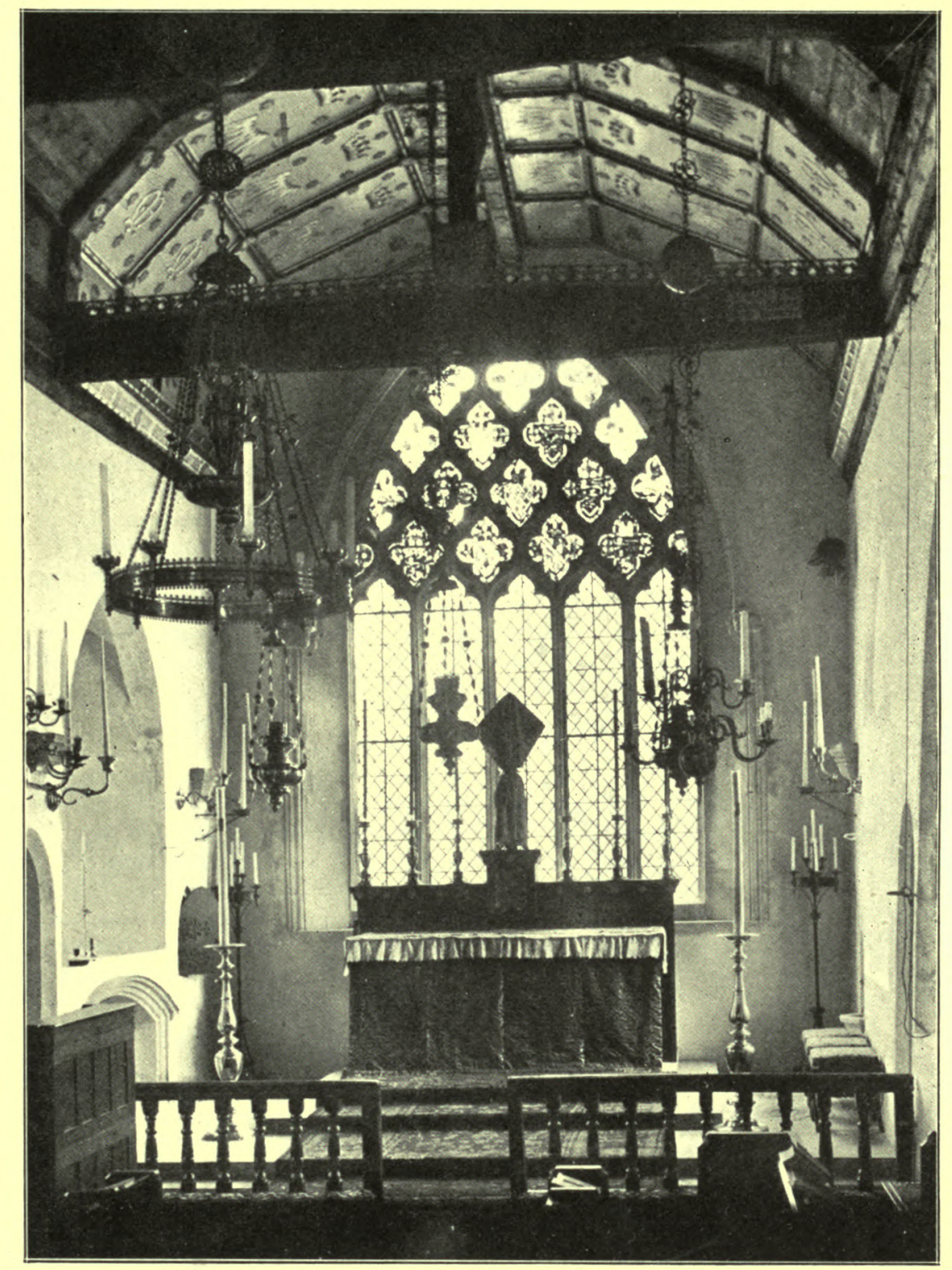

Window in Froyle Church. 

river in 'Le Commen Meade.' ${ }^{23}$ He also enjoyed free warren within the manor. ${ }^{53}$ Mention is made in 1539 of a rent called 'Oxfoldgable,' payable by the customary tenants at Michaelmas. ${ }^{54}$ In $16_{41} 1$ the customs of the manor, on various points including grazing, are set out, as is the rent payable by the various tenants in lieu of services formerly performed. ${ }^{35}$

The church, which is dedicated in CHURCH honour of the Assumption of the Blessed Virgin Mary, is prettily situated near the hall, and consists of a chancel, nave with north porch, gallery staircase and south vestry, and a square western tower. The nave and tower were rebuilt in brick in 1722 .

The chancel, which is of early fourteenth century date, is of three bays. The east end contains a fine five-light window, with delicatc reticulated tracery, retaining the whole of its original glazing. This is chiefly armorial, the arms being : (1) in the uppermost row, sable a lion passant and three crosslets silver, with an inseription round; ${ }^{56}$ in the second row (ii.) Warenne, and (iii.) England; in the third row (iv.) England with a silver label of five points, (v.) France, and (vi.) England; and in the fourth row, (vii.) England with an azure label of five points, (viii.) St. Edward the Confessor (only four martlets), (ix.) Bohun and (x.) England. Shields (vi.) and (v.) are apparently for Edward I. and Margaret of France, (vii.) for Edward of Carnarvon, as Prince of Wales, and (iv.) perhaps for Thomas de Brotherton the king's elder son by Queen Margaret. Shields (ix.) and (x.) are probably those of Humphrey de Bohun, Earl of Hereford and Essex, and his wife Elizabeth daughter of Edward I. and Eleanor of Castile, whom he married in 1302. Shield (ii.) may be that of John de Warenne, Earl of Surrey, who married, in 1306 , the king's grand-daughter Joan, daughter of Henry, Count de Bar. The date of the glass can hardly be later than 1307 .

The side windows contain some good modern glass; they have two trefoiled lights with a circle, and in one case a trefoil, in the head, containing the original glazing, but the easternmost window on the south was apparently enlarged in the fifteenth century and has now a modern head. Beside it is a small piscina of the same date with cinquefoiled arch, and groove for a shelf, but the basin is at present only I I inches above the floor. In the opposite wall is a pointed locker, and west of it, beneath the first window, a broad and low segmental tomb recess, within which is a modern slab. Beyond the window is a small doorway with semicircular rear arch, and there is a like doorway opposite, but now blocked.

The roof, which seems to be original, is of high pitch and heavy construction, with tie-beams and king-posts. The chancel arch is carried by semicircular responds of the fourteenth century. The nave is a broad room with flat ceiling and western gallery, and upper and lower ranges of plain window openings, but those on the north side have been 'Gothicized.' In several of them are placed some good pieces of carly fourteenth century painted glass. There is a north doorway, covered by a modern porch, alongside of which is the gallery staircase; and a south doorway, leading into a small brick porch used as a vestry.

Of the fittings, both the altar and altar rail are old and of late seventeenth century work. The font is described on a metal plate attached to it as an 'ancient' one 'restored' by the Rev. W. R. A. Cooper, 1864 . It is however too small in size for an old font, and its surface is entirely modern. The pews and other fittings are of no antiquity. There are some good ledger stoncs in the floor to members of the Draper ${ }^{57}$ family, and within the altar rails a brass to John Leigh, ob. $1575,^{58}$ and his wife Margaret. On the walls are a number of hatchments, and over the chancel arch the royal arms, etc. of George III.

Externally the chancel is of chalk rubble with a tiled roof, but the nave is covered with slate. By the south wall of the tower lies an old coffin lid of unusual thickness, now much mutilated; it is carved throughout with an engrailed cross.

Froyle church is mentioned in Domesday as belonging to St. Mary's Abbey at Winchester. ${ }^{50}$ In 1330 the Crown granted to the abbess licence to appropriate it, ${ }^{60}$ and the appropriation was carried out with 'apostolic authority' by the then Bishop of Winchester. His successor however and his provincial 'opposed themsclves' to the appropriation, the latter sequestring the income of the benefice. ${ }^{61}$ In 1346 the pope directed the appropriation to be carried out. ${ }^{62}$ Yearly payments to the vicar, always described as made by 'the grace" of the abbess, occur in the account rolls of the manor already mentioned. ${ }^{63}$ At the time of the suppression of the abbcy an annual payment of $6 s$. $8 d$. was made to the Bishop of Winchester out of the issues of the rectory: this payment is described as being for allowance of the appropriation. ${ }^{64}$

The rectory and advowson of the vicarage were granted to William Jephson with the chief manor in $154^{1}$ at an annual rent of $34^{s .},{ }^{65}$ but the limitations in regard to them were not precisely similar to those in regard to the manor, which were to William Jephson, Mary his wifc and their heirs and assigns for ever; those in regard to the rectory and advowson were to William Jephson and his heirs and assigns for ever.

As has been shown ${ }^{66}$ the descent of the adrowson was the same as that of the manor; but with regard to the rectory and great tithes it was
62 Add. MS. 27,949. (35).

3 Pat. 33 Hen. VIII. pt. 1, m. 8

54 Mins. Accts. 30-3I Hen. VIII.

No. 139, m. 65.

55 Add. Chart. 17,559, 17,572.
66 This piece is reversed, and probably later than the rest of the glass.

67 See p. 502. 58 Ibid. 503.

59 V.C.H. Hants, i. 47 a.

60 Pat. 4 Edw. III. pt. I. m. 39.

61 Cal. to Papal Petitions, i. Pp. 56 , 122.
62 Ibid.

63 See p. 504.

64 Mins. Accts. 30-3 I Hen. VIII.

No. $1.39, \mathrm{~m} .65$, etc.

65 See p. 502.

66 See above. 


\section{A HISTORY OF HAMPSHIRE}

apparently not so, for, towards the close of the eighteenth century, other persons than those presumably in possession of the manor dealt with them. ${ }^{67}$

The question of the vicarial tithes within the parish was dealt with by the Court of Exchequer in $17 \mathrm{~J}^{68}$

The parish register commences in 1690.

There is a temporary iron church at Lower
Froyle dedicated to the honour of St. Joseph, and served by the clergy of the parish church.

A Wesleyan meeting-house was built at Lower Froyle in 1841.69

The National Schools were built in 1867 at the cost of Sir C. H. Miller.

Three children from Froyle parish are entitled to be educated at the Endowed Free School at Holybourne. ${ }^{70}$

\section{GREATHAM}

Greteham (xi, cent.), Gratham (xiii. cent.).

Greatham is an agricultural parish, containing 2,030 acres, situated on the western side of Woolmer Forest, part of which forest is within the parish, ${ }^{1}$ near the Sussex border. The soil is extremely varied; hops are cultivated in some parts. The river Rother forms the boundary on the west, the parish of Selborne on the north, and that of Liss on the south and east. To the north the land is high and wooded. A considerable part of the parish is occupied by Greatham Moor or Long Moor, across which runs Little Dean Bottom; there is a rifle range on the moor. The road from Petersfield to Farnham runs through the parish, and near the church throws off a branch to the north in the direction of Alton. The War Office has recently established a military camp in the parish. Greatham Bridge is situated in the southwest corner, and carries the Petersfield and Farnham road over the river Rother. Greatham Mill stands on this river.

Amongst the ancient place-names may be mentioned 'Thele ${ }^{2}$ and Le Court or Lee Court. ${ }^{3}$

GREATHAM was a royal manor MANORS in the time of the Confessor, having been held by Queen Edith." At the time of the Domesday Survey it was in the hands of the Conqueror himself, being then in the hundred of Neatham.

In 1167 'Roger' held Greatham.s In 1223 the manor was possessed by Williain Aguillun. ${ }^{6}$ In 1286 Robert Aguillun died seized of it, held apparently of Alton. He left a daughter and heir, Isabel, wife of Hugh Bardolf. ${ }^{7}$ Robert's widow Margaret died six years later, holding the Aeur de lys silver. manor in dower. ${ }^{8}$ The reversion belonged to the abovesaid Hugh and Isabel.
Hugh died seized of the manor in 1304 leaving a son and heir Thomas, aged twenty-two. ${ }^{\circ}$ His mother Isabel survived till $13 \mathbf{z}_{4}$ and held the manor in dower. ${ }^{10}$

Thomas and Isabel's eldest son Thomas seems to have predeceased his mother, and at her death she was succeeded by William, another son, who was succeeded by his son Thomas. In 13z9, Thoinas died seized of this manor, leaving John Bardolf his son and heir. ${ }^{11}$ John died in 1371 , but he appears to have parted with a considerable portion of his property during his lifetime, and anongst others with the manor of Greatham, as Nicholas de Devenish of Winchester died in 1351 seized of the manor, jointly with his wife Edith, who is also apparently called Maud. ${ }^{12}$ He left a son and heir Thomas, aged seventeen, who died seized of the manor in 1374 , leaving a son and heir John, aged ten. ${ }^{13}$ Thomas's widow Elizabeth held the manor in dower and married William Marshal between 1376 and $1386,{ }^{14}$ at which latter date the manor was dealt with by a fine to which John Englefield and Nichole his wife were partics. ${ }^{15}$ Nichole was a daughter and eventually heir of Thomas Devenish mentioned above. ${ }^{16}$ In 1403 she, then being John Englefield's widow, was in possession of the manor as tenant for life. ${ }^{17}$ Before 1417 she had become the wife of John Golafre. The manor was then settled upon Philip Englefield and Ismania his wife and their issue, with a remainder to Philip's brother Robert, and an ultimate remainder to the right heirs of Nichole. ${ }^{18}$

The manor descended to John Skylling and Elizabeth wife of Richard Norton, who, about the year 1508 , appears to have conveyed it to Wil-

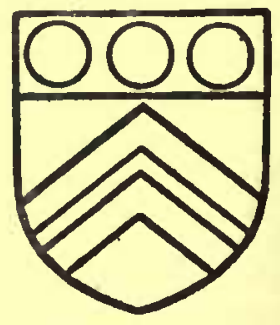

Sxyllyng. Silver two cbeverons gules and a cbief gules witb tbree besants. liam Faukener. ${ }^{19}$ Some seventy years later (in
2 See p. 507. $a$ Ibid.

- V.C.H. Hants, i. 450 . $\$$ Pipe R.

6 Feet of F. Hants, IIen. III. No. 79.

7 Inq. p.m. 14 Edw. I. No. 16.

9 Ibid. 20 Fdw. I. No. 20.

9 Ibid. 32 Edw. I. No. 64

10 Feet of F. Div. Cos. Edw. II. No.

67 ; and Fend. Aids, ii. 315.

11 Inq. p.m. 3 Edw. III. I st nos., No. 66. See also Inq. p.m. 9 Hen. IV. No. 31; aad 19 Ilen. VI. No. 20.

12 Feet of F. Martinmas, 16 Edw III. and Inq. p.m. 24 Edw. III. Ist nos. No. 61 .
13 Inq. p.m. 47 Edw. III. Ist nos. No. 10.

14 Bp. Wykeham's Reg. Hants Rec. Soc. pp. $63,180$.

is Feet of F. Hants, file 28 , No. 40. 10 De Banco R. Hil. 23 Hen. VII. roll 357 , and Mich. roll, 159.

17 Bp. Wykeham's Reg. Hants Rec. Soc. P. 240 , and Feet of F. Hants, file 31, No. 9.

18 Feet of F. Hants, file $31, \mathrm{No} .9$.

19 De Banco R. Hil. 23 Hen. VII. roll 357 . 
1577) it was in the possession of a William Faukener who then conveyed it to Richard Cooke and Nicholas Freeland. ${ }^{20}$

Richard Freeland died seized of it in 1608 , having settled it upon his wife Elizabeth for life, with remainder to their son John, then aged thirty..$^{21}$ John died in 1610 and left a daughter and heir Elizabeth, who married Sir Richard Caryll of Harting and died in $1632 .{ }^{22} A$ monument to her memory was erected by her kinsman, John Love, who in 1633 conveyed the manor to Thomas Cowper. ${ }^{23}$ This as 1286.25 A series of extents of the manor taken between this date and $1324^{26}$ show considerable changes in its condition: in 1286 there were sixtyeight acres of arable land; in 1292 , forty acres ; in 1304, fifty acres; and in 1324, sixty-two acres. The amount of meadow was two acres in $\mathrm{J} 286$, three in 1292 , two in 1304 and but one in 1324 ; in this last named year there was however 'a several pasture.' The amount of wood is described in $\mathbf{1 2 8 6}$ as three acres and in 1324 as scven acres. There were twenty-four free tenants in 1286 , sixteen in 1304 and thirty-two in 1324 . The grange and cattle shed were in 1304 described as covered with straw and in a decayed state.

LE COURT or LEE COURT (xvii. cent.), a modern residence, was built about 1865 , on the site of the ancient manor house of Greatham

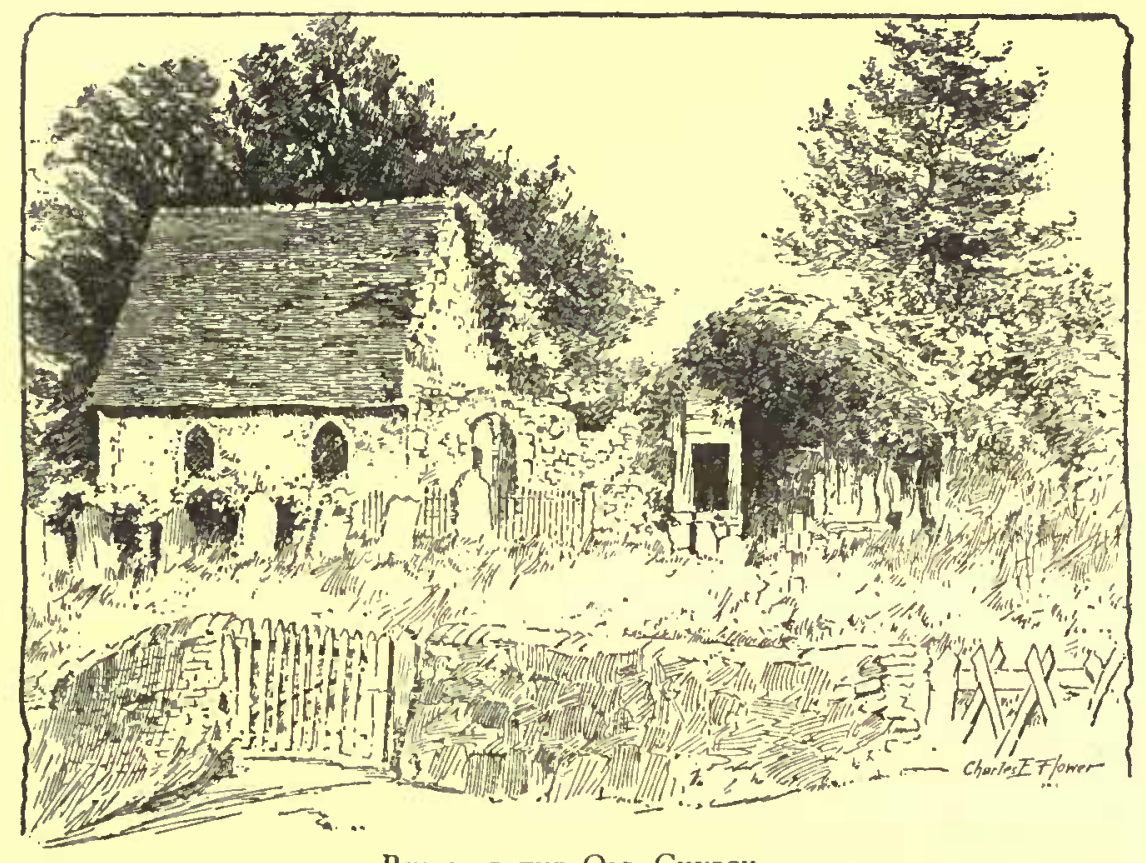

Ruins of the Old Church.

was probably for the purposes of a trust, for we find members of the Love family presenting to the living from 1661 to 1754 , when Susannah Love presented. In 1785 the presentation was made by $\mathrm{Su}$ sannah Beckford, widow. ${ }^{24}$

The subsequent descent of the manor has not been discovered. The present owner is F. Coryton, of Liss Place.

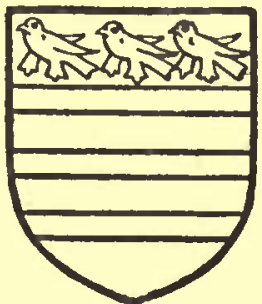

CARYLl. Silver tbree bars sable witb tbree martlets gules in the cbief.

$T$ be martlets are sometimes coloured sable.
Some time prior to 1610 the site, farm and demesne of this manor, called 'Le Court' had become separated from the manor and were then conveyed by Sir John Webb to James Percey, who in 1613 conveyed the property to William Chase and Thomas his son and heir. ${ }^{27}$ In 1638 it was dealt with by Thomas Chase, ${ }^{28}$ and in 1646 settled by him and Christine his wife upon their son Thomas. ${ }^{29}$

A holding called $T H E L E$ in Greatham is mentioned as the property of the Windsors as early as 1390, and Miles Windsor died seized of it (described as a messuage and 40 acres of land) in $1452^{30}$ By a fine levied in 1714 Spencer Cowper acquired the 'manor' of Thele of R. Kynnesman and his messuage is mentioned as early

20 Feet of F. Hants, Trin. 19 Eliz. 21 Inq. p.m. ser. 2. W. \& L. bdle. 2 , No. 217 .

22 Monumental inscription in Greatham Church.

${ }^{23}$ Feet of F. Hants, East. 9 Chas. I.
24 P.R.O. Composition Books. 25 Inq. P.m. 14 Edw. I. No, I6.

26 Ibid. 14 Edw. I. No. I6; 20 Edw. I. No. 20; 32 Edw. I. No. 64; and 17 Edw. II. No. 39.

27 Chan. Proc. Jas. I. C. 76, 3.
28 Feet of F. Hants, Hil, I4 Chas. I. 29 Ibid. Trin. 22 Chas. I.

30 Ing. p.m. 13 Rich. II. No. 32 ; 22 Rich. II. No. 52 ; and 30 Hen. VI. No. II. 


\section{A HISTORY OF HAMPSHIRE}

wife. ${ }^{\text {al }}$ The site cannot now be identified, but it should be noted that in a map of Hampshire, dated 1801 , Thele Bridge is the name given to the bridge which carries the Petersfield and Farnham road over the Rother, about half a mile north-east of the church.

There pertained to the manor of Greatham in 1292 a market, the profit of which yielded 12s. a year $^{32}$; no subsequent mention of this market has been found. A free fishery is mentioned in the conveyance of the manor from John Love to Thomas Cowper and his heirs in $1633 .^{\text {a3 }}$

The old church, now disused and CHURCH ruinous, lies at the south end of the village, at the junction of the main road from Petersfield to Farnham, with a side road. It is built of rubble composed of sandstone and ironstone with sandstone ashlar dressings. The chancel has a slate roof and the nave is roofless. The church is a small thirteenth century building, consisting of chancel, $20 \mathrm{ft}$. by $17 \frac{1}{2} \mathrm{ft}$., and nave $4^{\mathrm{j}} \mathrm{ft}$. by $23 \frac{1}{2} \mathrm{ft}$. (cxternal measurements), with north parch.

The chancel has a pseudo-Gothic two-light east window, and two plain lancets in the north and south walls, only those in the south wall showing any ancient ashlar. At the cast end of the south wall is a plain locker; the altar rails are cightecnth century balusters. The chancel arch, which is built up, with a door giving access to the chancel, is eighteenth century, three centred, with a projecting keystone and chamfercd strings at the springing ; thesc last seem to be twclfth century stones re-used. Part of the south jamb of a thirtcenth century chancel arch remains.

The nave was originally lighted by two small lancets on each side, with plastered splays. In the fourteenth century the castern pair were built up, and two-light windows with wide rear arches inserted further to the east, to light the nave altars. In the south wall the western lancet also was blocked, possibly at a later date, and two windows of a single light each inserted, one on each side of the south doorway. The nave was entered by north and south doorways, of which the north remains entire, with a pointed arch of a single chamfered order and segmental rear-arch. Of the original south doorway only part of the east jamb remains.

The west wall of the nave was rebuilt at a late date, with ashlar angle buttresses and a pseudoGothic two-light west window.

The north porch is ruinous and overgrown with ivy. It is of wood with low stone side walls and masonry benches. It retains some of its mediaval framing, though reconstructed at a late date.

In the chancel is a panelled altar tomb of alabaster with an alabaster effigy of Dame Margery Caryll, 1632, erected by her kinsman John Love. The covering slab is of black marble, and the inscription is on an alabaster tablet under an arched pediment carried by black marble columns with Corinthian capitals, and surmounted by strapwork, with a lozenge-shaped shield bearing the arms of Caryll impaled with Freeland.

The new church, dedicated to the honour of St. John the Baptist, stands about 200 yards away, and consists of chancel, nave and south-east tower with spire, and contains no ancient fittings. It was erected in 1875 partly at the expense of $\mathrm{Mr}$. W. F. Foster, and was completed in 1897 by $\mathrm{Mr}$. Harrison, who added the spire as a memorial of the jubilee of Qucen Victoria.

The advowson of Greatham church belonged to the Bardolfs in $1330^{34}$ and descended with the manor. ${ }^{35}$

The parish registers commence in 1571 .

The national schools (mixed) were built about 1850 .

\section{HARTLEY MAUDITT}

Herlegc (xi. cent.); Hertlegh, Hurtlcye, or $\mathrm{H}$ artley Maudit (xiii. cent.).

Hartley Mauditt is an agricultural parish of 1,403 acres situated on the upper greensand formation, which gradually rises to a considerable height eastward of the Alton branch of the river Wey, and terminates at Hartley Hanger in an abrupt escarpment of malm rock that slopes down, covered with wood, to Woolmer Forest below. The village, which is small and scattered, is on an old road from West Worldham to Oakhanger, which skirts Hartley Park and Candovers farm. ' The main road from Selborne to Alton lies a little to the west. To the north the parish closely adjoins the small village of West Worldham. The boundary of Woolmer Forest towards Hartlcy Mauditt was known, in the seventeenth century, as Mauditt Hatch. ${ }^{2}$

Amongst the place-names in the parish may be mentioned Mulcwellcroft and Candever (xiv. cent.), ${ }^{a}$ Pagles Green, Bindsworth, Week Common, Haukes Grove, Pillcroft, Barlie Bridge and Hallowell Close (xvi. cent.) ; ${ }^{\star}$ and Cooks Garden and Denham (xvii. cent.). ${ }^{5}$

Under the Confessor, the manor of MANORS HARTLEY was held by Guert as an alod, and at the time of the Domesday Survey by William Maudit (Malduith) of the Conqueror. ${ }^{6}$ The manor remained (with the exception of occasional forfeitures) in the possession
aI Feet of F. Hants, East, I Geo. 1. 22 Inq. p.m. 20 Edw. I. No. 20. 33 Feet of F. Hants, East. 9 Chas. I. as Inq. p.m. 3 Edw. III. 1 st nos. No. 66 .

25 Ibid. 47 Edw. III. I st. nos. No. 10 ; Feet of F. Hants, Trin. 19 Eliz.; Inq. p.m. ser. 2. W. and L. I0, No. 217 ; and

Feet of F. Hants, East. 9 Chas. I.

I See p. 510.

2 White's Selborne, i. 22.

Add. Chart. 16,195, and Inq. p.m.

3 Rich. II. No. 66.

4 Duchy of Lanc. Misc. Bks. 108, 116.
5 Add. Chart. I6, I rg and Misc. Inq. p.m. pt. 18, No. 26.

6 V.C.H. Hants, i. 488,492 . The hundred and shire testified that William Maudit also claimed one hide of the land of Bramshott manor which was in Hartley. 


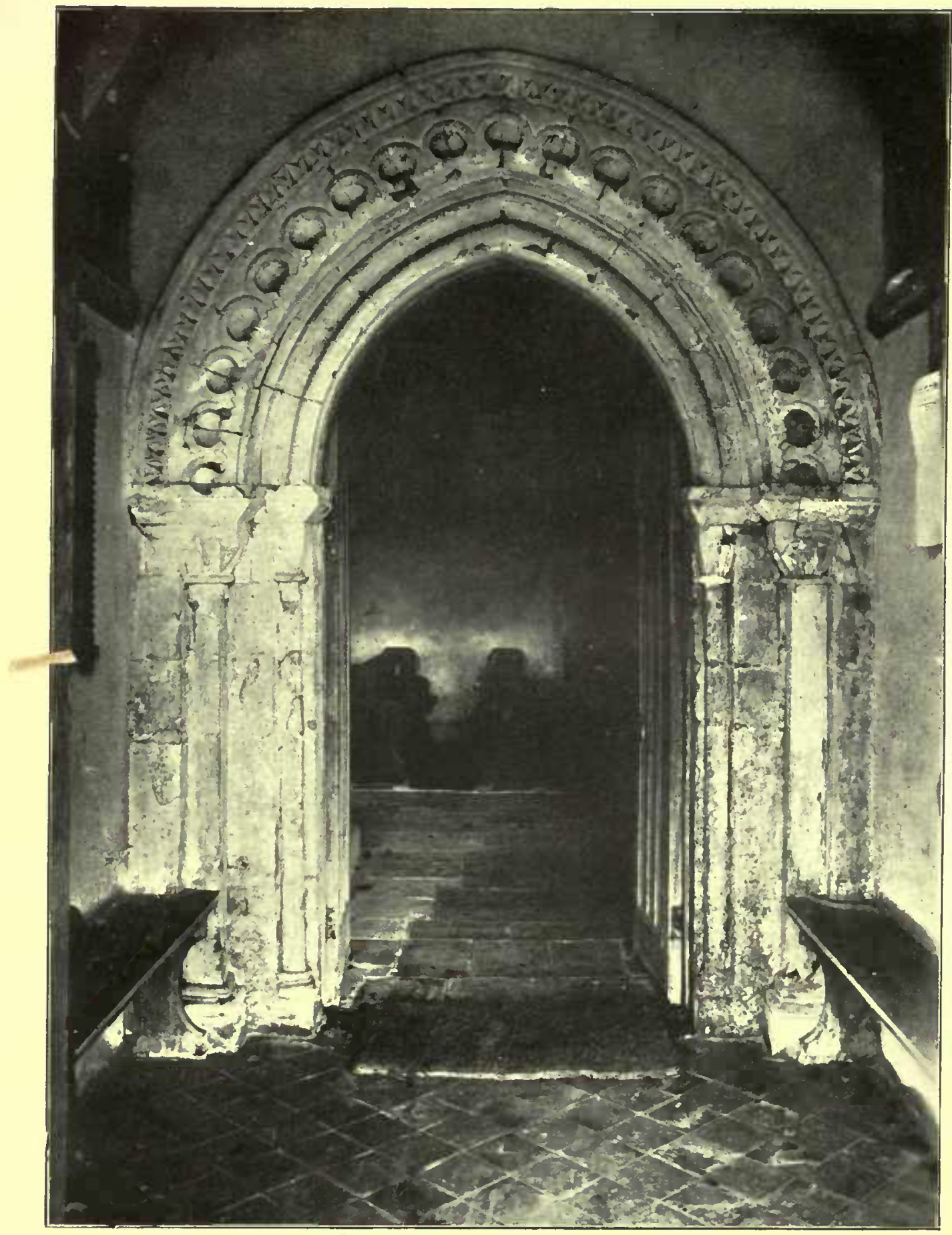

South Doorway of Harteey Mauditt Church. 

of the Maudits till the death, without issue, of William Maudit, Earl of Warwick, in 1267 , and was held of the Crown by the service of being Chamberlain of the Exchequer. In the year

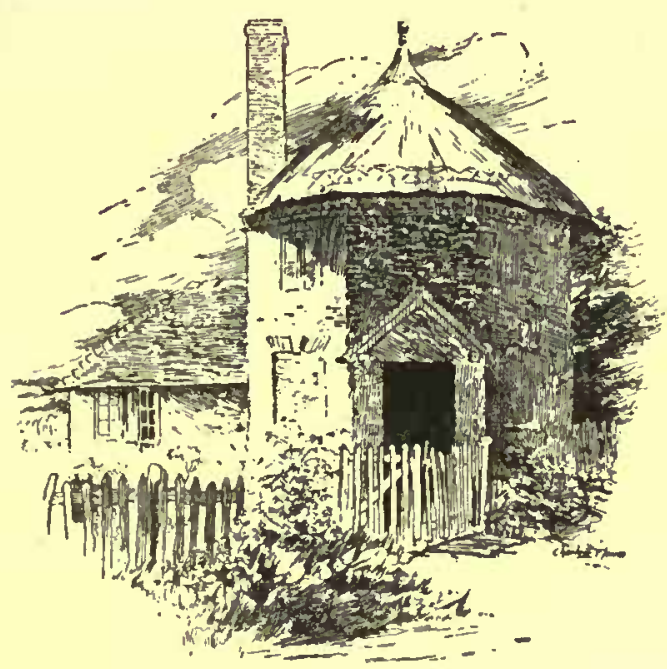

The Round House.

above mentioned the manor was inherited by William de Beauchamp, William Maudit's nephew, who became Earl of Warwick.

The manor was given by William de Beauchamp to his daughter Isabel on her marriage with Sir Patrick de Chaworth, who died seized of it in $\mathbf{1 2 8 3}$, then described as held of the Earl of Warwick in chief and by him of the king by the service of being Chamberlain of the Exchequer. Maud de Chaworth, then an infant, was found to be daughter and heir of Sir Patrick and Isabel. ${ }^{8}$ She, in 1298 , became the wife of Henry, Earl

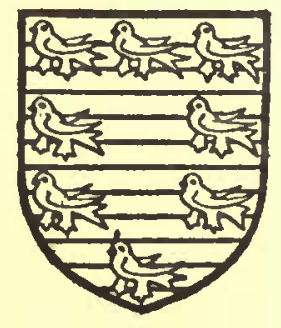

Chawarth. Burelly silver and gules witb an orle of martlets sable. of Lancaster, ${ }^{9}$ who died in $1345,{ }^{10}$ and who was suc-
ceeded by his son Henry, created Duke of Lancaster in 1351 . He died in 1361 seized of the manor of
Hartley Mauditt, and left as his co-heirs his daughters, Maud (who died the following year) and Blanche, wife of John of Gaunt, who became Duke of Lancaster. ${ }^{11} \mathrm{H}$ is son and heir ascended the throne as Henry IV. and the manor thereupon remained in the Crown as parcel of the Duchy of Lancaster till I $60_{3},{ }^{12}$ when the fee was granted to Sir Edward Blount and Joseph Earth, their heirs and assigns for ever. ${ }^{13}$

In 1614 Dr. Nicholas Styward had 'recently purchased' the manor-of whom it is not stated 14 -and in 1634 died seized thereof, leaving a grandson and heir, Nicholas, then in his sixteenth year. ${ }^{15} \mathrm{He}$, in 1645, compounded for his estates in Hampshire and elsewhere. ${ }^{16}$ On the restoration he was created a baronet.

The manor remained in his descendants (who appear to have spelled their name as Stuart) till the end of the eighteenth century, when it was sold by Sir Simeon Stuart. It then became the property of the Stawells and followed the descent of Alton Westbrook (q.v.) till it came to Henry Joln Dutton who is now lord of the manor. An extent of the manor, gules with a ragged baston made in 1283 , mentions a gold.

capital messuage and garden and a small vivary, 300 acres of arable land, 20 acres of meadow, a wood of which the pasturage was common, and a small grange. There were then nine free tenants, four customary, fourteen cottars, and certain other cottars qui frequenter remozentur. ${ }^{17}$

From a survey taken in 1552 we learn that there was within the manor a quarry of freestone, and that the common contained 100 acres 'well-set with fair oaks' of a hundred years' growth. ${ }^{18}$

In 1571 the site and demesnes of the manor were described as a house, with a barn, stable, 'and other necessary rooms' and a garden and orchard. ${ }^{19}$ The manor house was, according to tradition, pulled down at the end of the eighteenth century by Henry, last Lord Stawell. It has never been rebuilt, and only the foundations of it, near the church, now remain.
7 Pipe R. for 1130 and 1196 ; Close, 17 Joinn, pt. I, m. I6; Feet of F. Hants, 3 Hen. III. No. 34; Assize R. Nos. 775 , 778 , m. 43; and Ings. P.m. 41 Hen. III. No. 21 , and 52 Hen. III. No. 17. In 1273 the manor is described as held by the Earl of Warwick by the serjeanty of finding at the Exchequer one baron and one clerk (Assize R.780). See also article by $\mathrm{Mr}$. J. Horace Round on 'Mauduit of Hartley Mauduit' in the Ancestor of April, 1903, p. $20 \%$.

8 Inq. p.m. 11 Edw. I. No. 35.

8 Complete Peerage, จ. 6.

10 Ibid.

11 Inq. p.m. 35 Edw. III. pt. I, No. 122.

12 Whilat in the Ducby of Lancaster the manor was almost continually in lease (vide Duchy of Lanc. Registers of Grants and Enrolment of Leases).
13 Pat. I Jas. I. pt. 10, m. 12.

14 Chan. Proc. Jas. I. SS. 33, 52,

15 Inq. p.m. ser. 2, 9 Chas. I. pt. 3, No. 18.

10 Cal. to Papers of Committec for Compounding, p. 980 .

17 Inq. p.m. I I Edw. I. No. 35.

18 Duchy of Lanc. Misc. Bks. 108.

19 Ibid. 116. The boundaries of the manor, which are probably copied from an earlier survey, were then described as follows: "The boundary of the said manor beginneth on the north part there of at Worldham Oak and from thence east ward along the highway to an asb standing on Pagles Green which divideth this manor and the manor of Wardleham. There hence eastward as the watercourse or lake leadeth to the nether end of Pagles Green. From thence along as the ditch and water 509 leadeth to Maudit Gate. There thence south eastward as the same ditch and water leadeth to the corner of Bindsworth which divideth the said manor and the forest of Abistholt (sic). From thence as the same ditch and wate leadeth to Hatch Land's corner which divideth the manor and two parcels of ground, the one called Doggates on the east, and the other called Oakhanger, on the south east. From thence south along by another hedge overthwarting the highway to Longclose Hedge, and so leading southward by the same hedge to the brook or river which divideth the manor of Okehanger and the said manor. There thence following the same river south-westward to the south corner of Hartley Wood which divideth this manor from the priory of Selborne. From the said corner somewhat west- 


\section{A HISTORY OF HAMPSHIRE}

The customs of the manor of Hartley Mauditt are set out in the two surveys already mentioned. Hartley Wood is described as 'a common wood' containing by estimation 100 acres. There had, in 1591 , been great sales of wood by which the inhabitants had been impoverished in their supply of timber for repairs. The manorial court was kept at the "farmhouse," i.e. the house of the farmers of the manor. In the survey of 1591 it was presented that 'the common coroner and clerk of the market executes his office within this parish,' but whether 'rightfully' the jury did not know. The nearest market town was Alton, three miles distant. ${ }^{20}$

There are no manorial records in the possession of the present owner of the manor, nor do they occur amongst the Duchy of Lancaster documents.

CANDOVERS, now a farmhouse, lies to the south-east of the parish. At one time it possessed the additional name of Brians, and Isabel, widow of Walter atte Berghe, died seized, in 1369 , of a carucate of land in 'Hertele Candevere,' held of the Duchy of Lancaster, and left a son and heir, John, then aged eleven. Hugh Tyrell, Isabel's second husband, had, in 1380 , occupied these lands since her death. ${ }^{21}$ John's wife was Christine, and she died in 1396 seized of 'a messuage and divers lands in Hartley Mauditt,' leaving a son and heir, John atte Berghe, aged eighteen. ${ }^{22}$

The manor of Candovers and Brians was acquired in 1562 of Nicholas Lussher and Mary his wife by Thomas "Twyne of Shaldon as 'the manor' of Candovers and 13rians, ${ }^{23}$ and the following year the purchaser died seized of it, when it was held of the queen as of her manor of Hartley Mauditt. The property had been settled, on its acquisition by Thomas

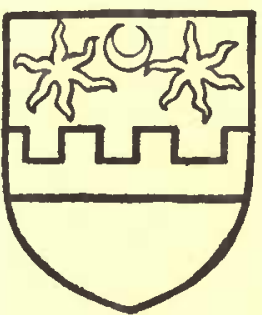

Twyne. Silver a fesse batled sable with two sars sable in the chief: a Twyne, upon one of his crescent gules for difference. younger children, Oliver. ${ }^{24}$

This Oliver, or a person of the same name, dealt with the manor on several occasions 25 between the date last mentioned and 1617 , when John Major acquired possession. ${ }^{26} \mathrm{He}$ died seized of it in 1630 described as a capital messuage' held of Dr. Nicholas Styward as of his manor of Hartley Mauditt. ${ }^{27}$ Richard Major was John's son and heir, then aged twenty-four, and he immediately disposed of the property to Thomas Burditt, ${ }^{28}$ who died seized thereof in 1633 , leaving a brother and heir, Richard, then aged nineteen. ${ }^{29}$ The subsequent history of the property has not been discovered.

The church of Hartley Mauditt CHURCH stands in the fields, away from any village or buildings. It consists of a small square-cnded chancel, which probably replaces one which was apsidal and attached to the existing Norman nave. The chancel is of early thirteenth century work, and retains its old highpitched roof and one of its lancet windows on the south side. The east window is a two-light traceried example of about 1350. That to the south of the altar is a little later, and also of two lights with the sill cut down to form a seat. East of it is a drain with deep square bowl. On the north side of the chancel is a small modern vestry. The chancel arch is plain and low, semicircular in form, with jamb shafts towards the nave. In the north wall of the nave, towards the east, is one of the old windows, a broad and squat Norman light with plain splay. The other window on this side of two lights is modern, as is also the west window, which is copied from the east window. The south wall has one of the original windows, with a two-light window of about 1320 on the east and a restored fourteenth century lancet on the west of it. The south doorway is a rich example of transitional Norman work of about 1190, having an ornate pointed arch of two orders with dog-toothed label carried by jamb shafts. The church contains no old fittings except the fine octagonal font which has traceried and flowered panels of early fifteenth century date. The nave roof is modern. In the chancel floor are some good early tiles, one of which has a pair of fishes, another a lion passant, and a third a two-headed eagle. There is also on the chancel walls an alabaster tablet, gorgeous with heraldry, to Frances Baker, 1633, another monu- ward as the ditch and hedge leadeth along by Week Common to Haukes Grove Corner, and so as the hedge leadeth to the west corner of Hallowell Close, which divideth this manor and the tithing of Norton. From the said corner north westward by another hedge to the northmost corner of Brodeclose to the highway which leadeth between the manor of Norton and the said manor, and so overthwart the highway westward by another hedge to the south corner of a close called Pillcroft, and so from thence northward to the south corner of a close called Ash Acre. There thence west ward by another hedge and ditch to the Greystone Corner and chere thence, southward by another hedge and highway, which leadeth from Som borne to Alton, to Connycroft Style. From thence westward by another hedge to the south corner of South Field.
From thence northward by another hedge unto Woodmead, parcel of the demesnes of the manor of Hartley. From thence westward to the west corner of Broadmead which divideth the aid manor and the tithing of Farringdon. There thence following the same hedge northward to Barlic Bridge and from thence to the same hedge northward to the west corner of Oxlease, dividing this manor and the tithing of Alton. There thence by the same hedge and ditch eastward to the north corner of Merriotts Grove which divideth the said manor and the manor of Woridham. From thence south eastward by another hedge and ditch overthwart the highway to the east corner of Candemers (Candevers ?) Field at a style there, and from thence eastward by the rame hedge and ditch to Worldham Oak where it first began.
20 The customs of the manor as to fines on admission, etc., were frequently in dispute in the Duchy Court; vide Calendar to Duchy of Lancaster Pleadings (Ducatus Lancastria), 3 vols. passim.

21 Inq. p.m. 3 Rich. II. No. 66.

22 Ibid. 20 Rich. II. No. 13

23 Feet of F. Hants, Trin. 4 Eliz.

24 Inq. p.m. ser. 2, Exchq. file 1,002, No. 9 .

23 Feet of F Hants, Trin, 25 Eliz. and Close, 31 Eliz. pt. 11 -deed Oliver Twyne to Robert Howland.

26 Notes of Fines, Hants, East. 14 James I.

27 Misc. Inq. p.m. ser. 2, pt. 18 , No. 26. Dr. Styward had acquired the chief manor before 1614 ; see p. 509 .

28 Feet of F. Hants, Mich. 5 Chas. I. 29 Inq. p.m. ser. 2, 9 Chas. I. pt. 2, No, 12 


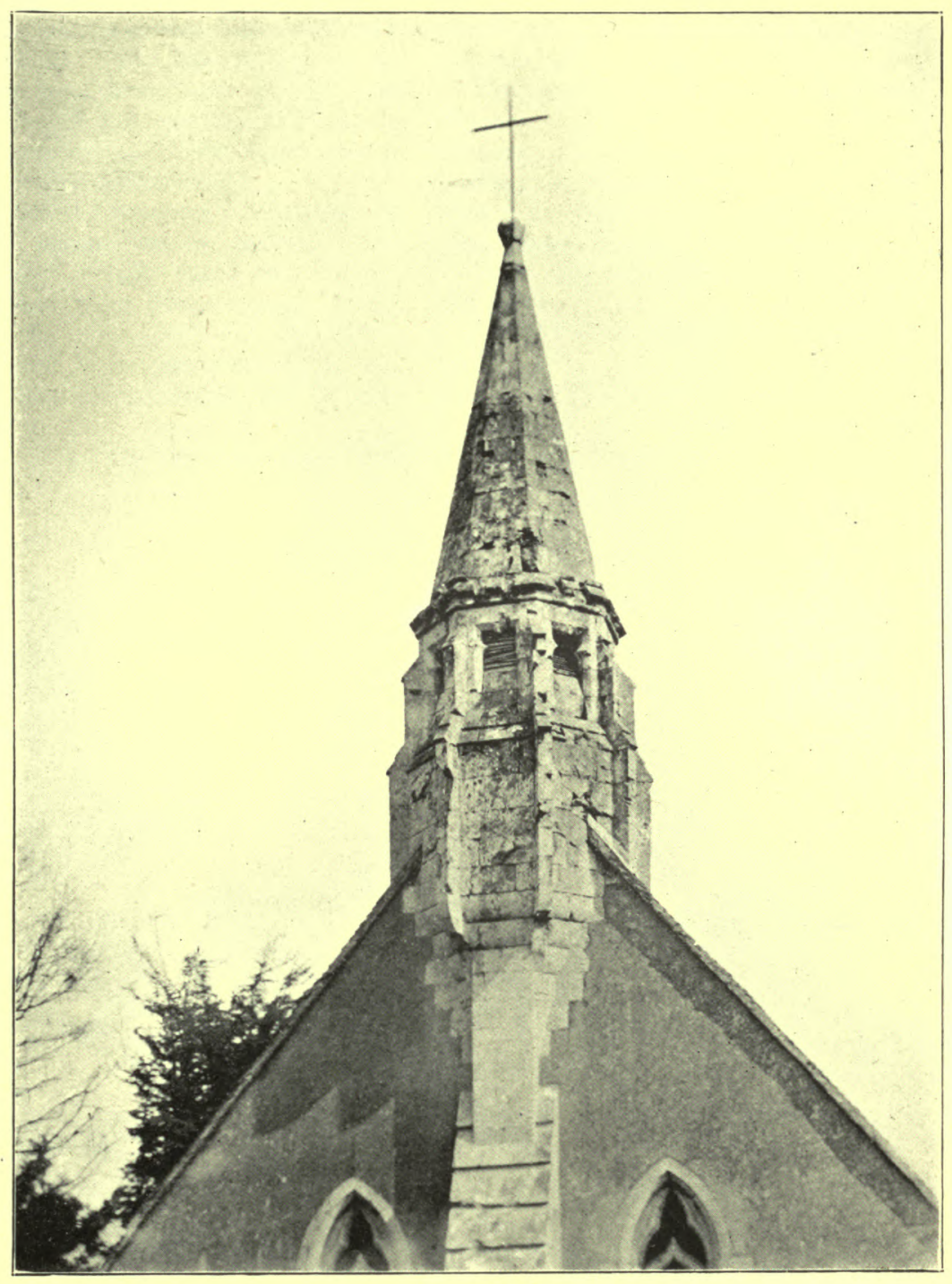

Bell Turret on Harteey Mauditt Church. 

ment to Elizabeth Ady, 1675, and another to Nicholas Stuart.

The walls throughout are plastered within and roughcast without, and the roofs are covered with tile. Externally the church is remarkable for the bell turret over the western gable, a beautiful octagonal structure surmounted with a spire of late fourteenth century work.

The advowson appears to have belonged to the owner of the manor from early times. Sir Patrick Chaworth was found to be patron of the 'chapel' in $1283,3^{30}$ and the patronage passed to the Crown in right of the duchy. The later history of the advowson has not been traced, but in 1805 the Rev. William Duke sold it to the Rev. Christopher Taylor, ${ }^{31}$ who together with Charles Arnold sold it in I $8 \mathrm{I}$ I to Isaac Samuel Clamptree. ${ }^{32}$

In 1567 the parson, answering a complaint by the farmer of the manor that he had cut wood growing in Hartley Wood, stated that he and his predecessors had, time out of mind, in the right of the church, taken necessary fuel in the said wood to be spent in the parsonage house, and timber for the repair of that house and its ontbuildings. ${ }^{33}$

In the survey of 1591 the parsonage was valued at $£ 50$ a year. The glebe then consisted of an orchard, garden, and certain closes of pasture land and 12 acres of arable. It was also presented 'that this parish hath a peculiar jurisdiction of itsclf, within which the probates of testaments of any dying, and the administrations also of any deceased, are to be performed by the parson there for the time, in as ample sort as the same might be performed before any spiritual judge in such causes.' 34

No mention has been found of a chantry within the parish, but an acre of land called 'the lamp acre,' in the surveys of 1553 and I 591 , suggests that this land had supported a light in the church. ${ }^{35}$

The parish registers prior to 1813 consist of two volumes: i. $1672-1812$, ii. 1804-1 I. There are no churchwardens' account books.

The church plate consists of a silver chalice, with dome-shaped cover, a silver paten and a large silver flagon, bearing the Stuart arms.

There is no Nonconformist place of worship in the parish.

The National Church of England School was built in 1869 (to replace a Dame School) by the Rev. J. T. Plummer, then rector.

There are no charities at present existing connected with the parish.

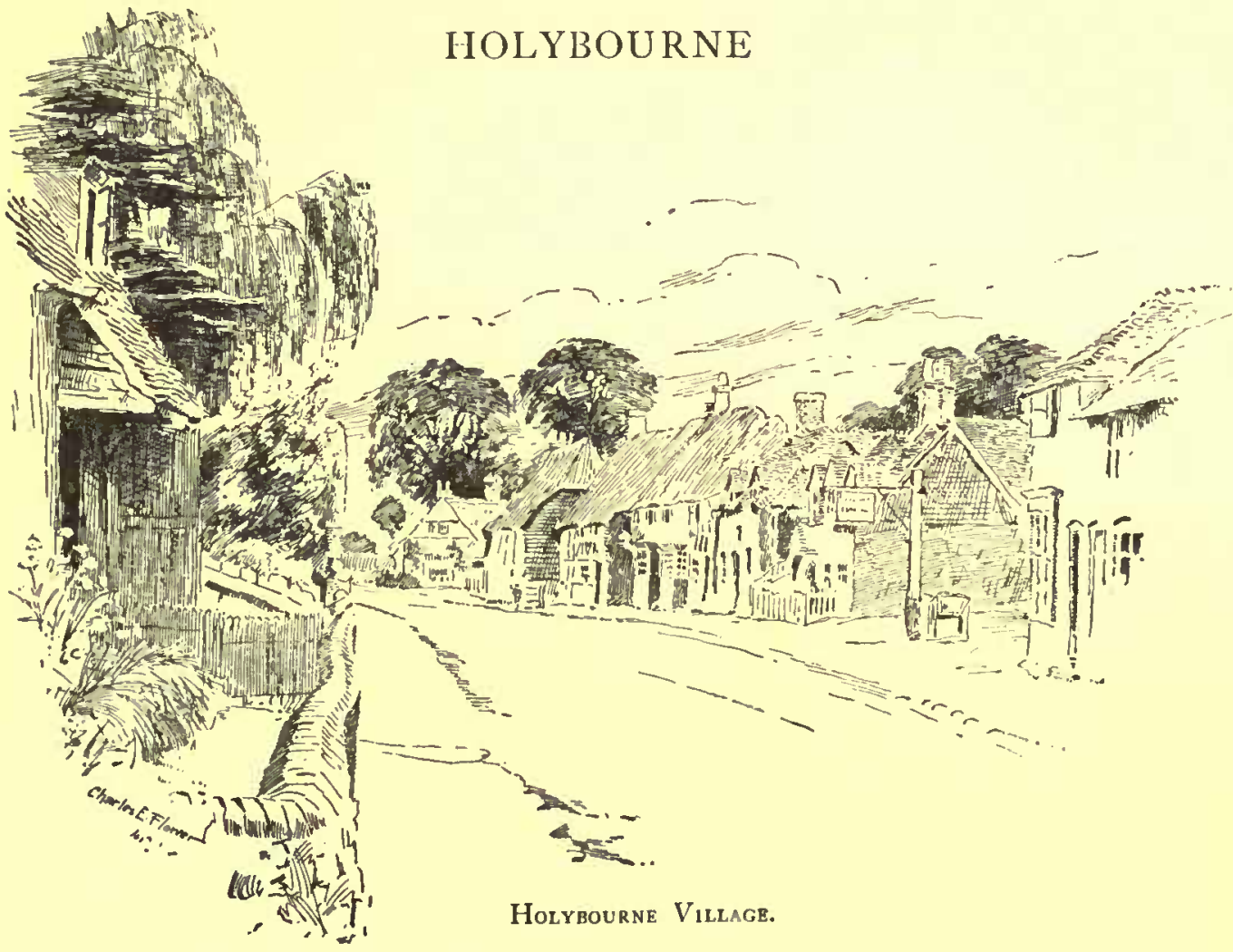

Haliborne (xi. cent.), Halibourne (xiv. cent.), Holybourne (xv. cent.), Holliborne (xvii. cent.).

This parish, which contains about 1,400 acres, is bounded on the north by Froyle, on the east by Binsted and on the south and west by Alton; the northern branch of the river Wey flows through it
30 Inq. p.m. II Edw. I. No. 35.

31 Com. Pleas, Recov, R. Mich, 46

Geo. III. Deeds Enrolled, m. 168.
32 Ibid. East. 52 Geo. III. m. 5 .

33 Duchy of Lanc. Plead. vol. 68 34 Ibid. Misc. Bks. I 16. M. 5 .
34 Ibid. Misc. Bk
35 Ibid. and 108. 


\section{A HISTORY OF HAMPSHIRE}

from south-east to north-west. A bourne-called the Holybourne-rises in the centre of the parish, and after a short course joins the Wey. This

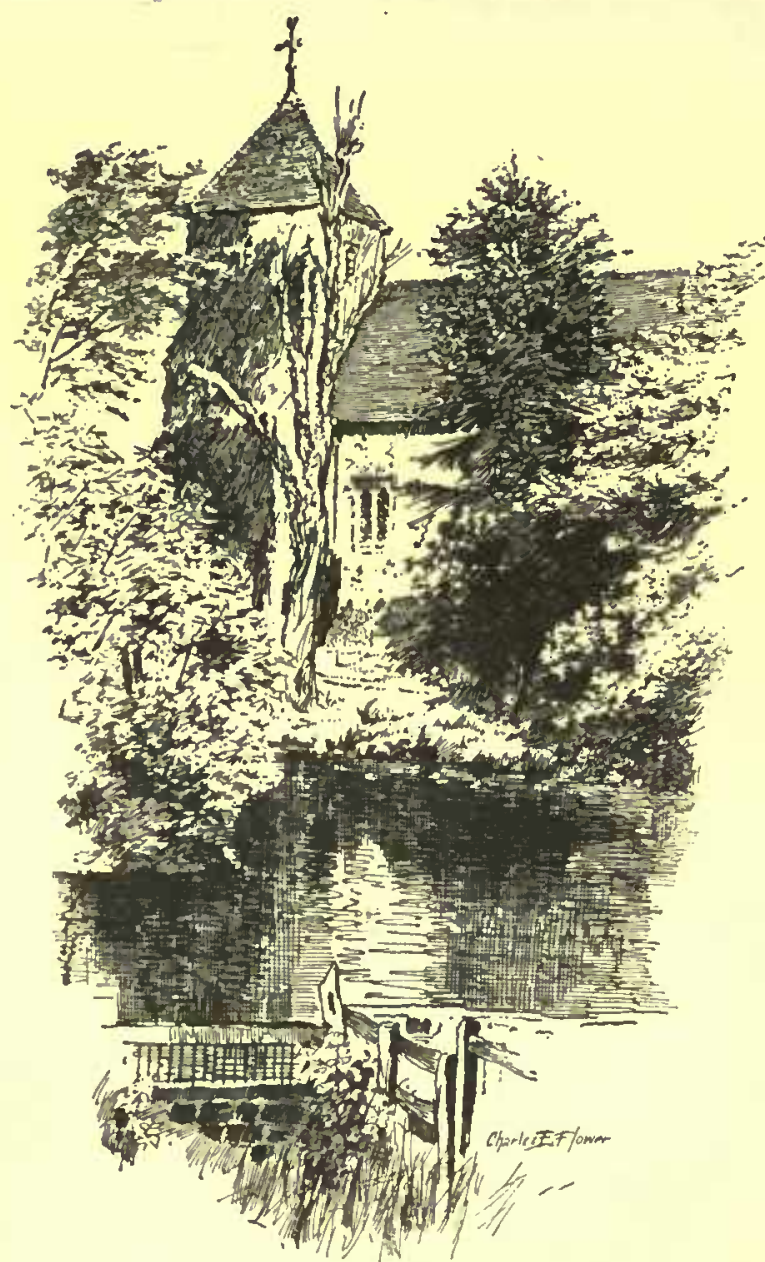

Source of the Holybourne.

division of the parish caused the name of Holybourne Eastbrook to be given, as early as $134^{6,1}$ to that portion lying on the right of the bourne, and Holybourne Westbrook to that on the left. The main road from London to Gosport passes through the parish, parallel with the river Wey ; and between the two is the railway from Farnham to Alton.

Neatham, a tithing containing about 1,100 acres, lies on the east side of the river Wey, about half a mile from Holybourne village. It was anciently a place of considerable importance. ${ }^{2}$ Waverley Abbey had a grange here and the name of Monk's Wood survives in connection with a finely wooded hill on the southern border of the parish. Neatham now only contains two farmhouses, two mills and a few scattered cottages, but it has a civil organization distinct from the parish of Holybourne, in which it is ecclesiastically included.
At the time of the Domesday Survey

MANORS HOLYBOURNE was in the king's hands; it had been held by Ulward of the Confessor, assessed at I hide; ${ }^{3}$ but it is added that Godwine held it of the Confessor and that it paid geld for 2 hides. In 1303 John de Westcote acquired a messuage, carucate of land and rents in Holybourne and La Holte of William Connyn." The "vill' is described as in the king's hands in $13160^{\circ}$

In 1333, Richard de la Bere of Westcote died seized of what was presumably the manor of Holybourne, as an extent is given setting out the services of tenants, etc., and it was then held of the Earl of Kent as of Alton. Thomas de la Bere was his son and heir, then aged thirty. ${ }^{\circ}$

A few years later, in 1337 , it was found that John son of John de Westcote, deceased, possessed two parts of the manor, and that these had been seized into the Crown's hands by reason of his idiocy ; the property was then held of John Dabernoun. The deceascd's four sisters were his co-heirs: Alice wife of William Colrich, Sibyl wife of Simon Bonyng, Alice wife of Laurence de Pagham, and Margaret wife of John de Fulguardby. ${ }^{7}$

In 1346 John Gask held the third part of a fee in Holybourne Eastbrook which was formerly of John de Westcote. ${ }^{8}$

Apparently the same property was held in 1428 by Gilbert Banbury. ${ }^{\circ}$ It was so held in 1431 , when it was decribed as 'the manor' of Holybourne Eastbrook. ${ }^{10}$

Joan daughter and heir of Gilbert Banbury, married Sir Bernard Brocas of Beaurepaire and retained posses-

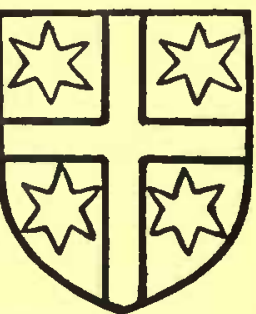

BANBURY. Silver a cross gules and four molets gules. sion of property in Holybourne Eastbrook and Westbrook until her death in 1429, when it was inherited by her younger son Bernard, described as of Horton, Bucks. ${ }^{11}$ Bernard died in 1459 , and a year and a half later, when the house of Lancastèr came to an end, his son, also named Bernard, placed his property in trust. ${ }^{12}$

In 1487 John Hayward, gent., died seized of the manors of Holybourne Eastbrook and Westbrook held of the manor of Alton. Thomas
1 Feud. Aids, ii. 333.

1 Sec p. 513 .

V.C.H. Hants, i. 510.

1 Feet of F. Hanis, file 15, No. 246.

- Feud. Aids, ii. 314.
- Inq. p.m. 6 Edw. III. Ist nos. No. 73 .

7 Ibid. 10 Edw. III. Ist nos. No. 46 , and Pat. 7 Edw. III. pt. 2, m. 2.

8 Feud. Aids, ii. 333 .
9 Ibid. P. 357

10 Ibid. p. 363

11 Brocas Family, by Prof. Burrows, p. I54.

12 Close, I Edw. IV. m. 12d. 
Hayward was his son and heir, then aged three years. ${ }^{13}$ In 1532 William Hayward conveyed the manors in trust to Lord Montagu and others. ${ }^{14}$ In 1553 Sir Richard Lyster died seized of the same property, held of the Earl of Arundel, as of his manor of Alton. Richard Lyster, grandson of Sir Richard (viz. son of his son Michael, deceased), was his heir, and then aged twenty years and nine months. ${ }^{15}$ In 1579 Michael Lyster and Elizabeth his wife sold the manors to Robert White and Mary his wife, ${ }^{16}$ and twenty years later Robert White of Aldershot died seized of them, leaving two daughters and co-heirs, Ellen, or Helen, wife parish, has however been sold, and is now owned by Sir C. J. Hubert Miller, bart., of Froyle.

NEATHAM, Neteham (xi. cent.), Nietham (xii. cent.), was before the Conquest held by the Confessor, and at the time of the Domesday Survey by the Conqueror. ${ }^{20}$ King Stephen gave it to Waverley Abbey in $1147 .^{21}$ The gift was confirmed in $\mathbf{2} 293$ by Henry III.

At the suppression of Waverley Abbey the manor of Neatham was granted on 28 July, I 536 , by Henry VIII. to Sir William Fitzwilliam,22 who was shortly after created Earl of Southampton. $\mathrm{He}$, in 1539 , settled it upon himself and his wife

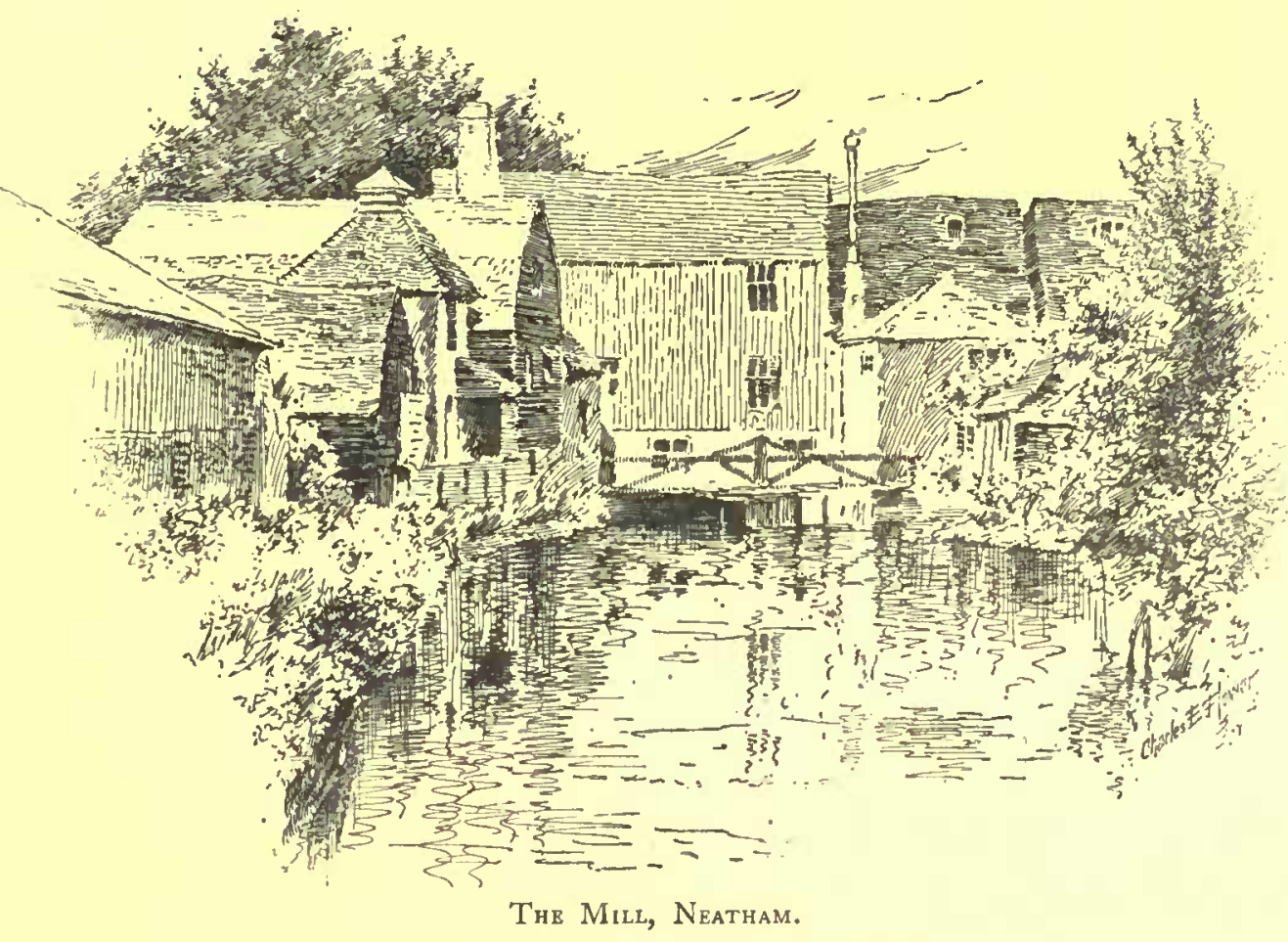

of Richard Tichborne and Mary wife of Walter Tichborne, ${ }^{17}$ who in 1604 conveyed them to Sir Richard Weston and William Brocke probably for the purpose of a settlement. ${ }^{18}$

Amphyllis, the only child of Richard Tichborne, married Laurence Hyde, son and heir of Sir Laurence Hyde, bart., and in 1632 died seized of the manors of Holybourne Eastbrook and Westbrook, Robert Hyde her son and heir being then aged two years and eight months. ${ }^{19}$ After this the descent of Holybourne followed that of Alton Westbrook (q.v.), and Henry John Dutton, J.P., of Hinton-Ampner is now lord of the manor. The manor farm, with the greater part of the for their lives, with remainder to his half-brother, Sir Anthony Browne, ${ }^{23}$ who died seized of the property in $155^{\circ},{ }^{24}$ and was succeeded by his son Anthony, who in 1554 was created Viscount Montagu. His grandson, in 1628 , mortgaged the manor to secure the payment of his debts before 24 April, $1629 .{ }^{25} \mathrm{He}$ died in that ycar seized of the manor, ${ }^{26}$ and his son Francis sold it in 1633 to Peter Giffard. ${ }^{27}$ John Giffard, his greatgrandson, left it by will in I 7 I 5 to his kinsman and heir-at-law, Thomas Hawkins, who in 1730 sold it to Sir Bulstrode Peachey, who died five years later, leaving it to his brother Sir John Peachey, whose son and namesake in 1745 ex-

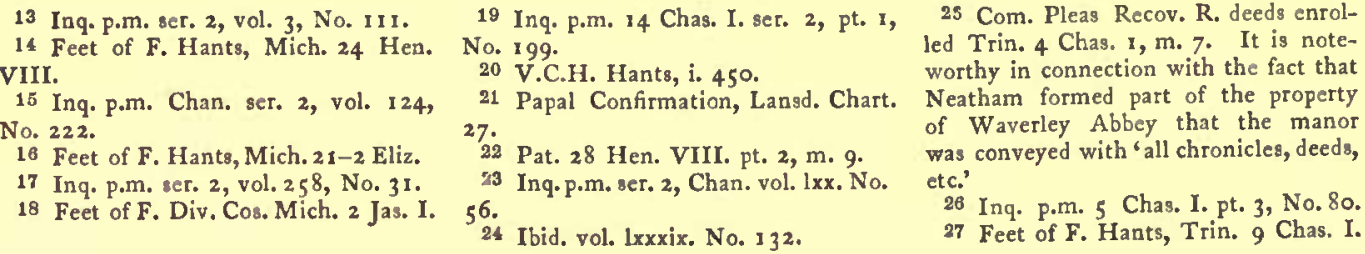




\section{A HISTORY OF HAMPSHIRE}

changed it for land in Sussex with Thomas Knight of Chawton, in whose family it has since remained. ${ }^{28}$

There was a market held in Neatham at the time of Domesday. ${ }^{29}$

The deponents in an Exchequer suit as to tithes, about $1627,{ }^{30}$ state that the demesnes of Neatham adjoin, on the east, the common fields of Binsted, on the south the common fields of Worldham, on the west the common fields of Alton, and on the north the common fields of Holybourne. Part of the land held of the manor of Neatham lay in the common fields of Holybourne, intermixed with land held of the manor of Alton. Some of the deponents doubted if any part of the manor of Neatham lay in Alton parish. 'The depositions seem to have been in a suit, brought very shortly before, by Viscount Montagu, lord of the manor of Neatham, against the vicar of the parish of Alton (with the chapelries of Binsted, Holybourne and Kingsley annexed), as to tithes from part of Neatham manor. ${ }^{31}$

Tithe is still paid on Bonham's farm to $\mathrm{Mr}$. Montagu G. Knight as successor of the original grantee of the possessions of Waverley Abbey in Neatham; the trustees of the Algebra Lecture at Cambridge also receive tithe from Neatham. ${ }^{32}$

Holybourne was a chapelry of Alton and was therefore included in the Conqueror's grant of the church of Alton to Hyde Abbey, Winchester (vide Alton).

In 1250 the Bishop of Winchester and Peter de Ryeval, rector of the church of Alton, gave permission for an oratory to be used to celebrate divine service at Neatham Grange without ringing of bells, but all the servants at the grange were to resort to the chapel of Holybourne for hearing divine service and receiving the sacraments. An indemnity to the mother church of Alton and the chapel of Holybourne was reserved. ${ }^{\text {as }}$ This appears to have been 10 marks paid yearly to the abbot of Hyde. ${ }^{34}$

After the dissolution of the monasteries, the chapelry of Holybourne was included in the grant of the rectory of Alton to the Dean and Chapter of Winchester by Henry VIII. ${ }^{35}$ It was served from Alton Church as late as 1830 , but since then it has been held as a separate vicarage under the patronage of the Dean and Chapter of Winchester.

In 1875 the Ecclesiastical Commissioners granted to the incumbent of Holybourne and his successors a yearly stipend of $£ 195$ out of their common fund and a capital sum of $£ 500$ towards defraying the cost of providing a parsonage house, which has not yet been done, and the sum remains in the hands of the Commissioners.

The church of the Holy Rood CHURCH stands on rising ground a quarter of a mile north of the main road. On the south boundary of the churchyard is a pool fed by the spring from which the village takes its name. The church is built of sandstone rubble with ashlar dressings, and has red-tiled roofs. It consists of a chancel of the thirteenth century with modern north chapel, a twelfth century nave with modern north aisle replacing one of the fifteenth century, and a twelfth century western tower with shingled wooden spire.

The chancel is as wide as the nave, ${ }^{36}$ and has a three-light fifteenth century east window flanked by two square-headed recesses for images. In the north wall are three windows: a two-light fourteenth century window nearest the east, a thirteenth century lancet in the middle, and a small lancet, also of the thirteenth century, low in the wall, at the west, having a groove for glass, and, in common with all the other windows of the chancel, a flat sill. In its western splay is a squint from the north aisle, in the head of which some twelfth century stones are inserted. In the centre of the south wall is a thirteenth century lancet; to the east a two-light fifteenth century window, its sill destroying the head and half the shafts of a thirteenth century piscina; the bowl remains, flanked by the circular moulded bases and stumps of the shafts; at the west end of this wall is a two-light fourteenth century window like that in the north wall. The chancel arch is of two chamfered orders with shallow octagonal responds without capitals : it is largely a modern restoration.

The nave walls are of the twelfth century, heightened in the fifteenth, when the north arcade was built and the present roof put on. The arcade is of two bays with octagonal pillars and arches of two chamfered orders. The north aisle is modern, having been rebuilt, not for the first time, in 1879 . In the south wall of the nave are three square-headed fifteenth century windows, and the lower part of the jambs of the original south doorway which has long been blocked. Some early thirteenth century detail (two stones of an arch with large dog-tooth ornaments) is worked into the blocking. At the east end of the south wall is a narrow trefoiled niche for an image in connection with the south nave altar. The fifteenth century nave roof has tie-beams with braces and jacklegs resting on well carved stone corbels; there are arched braces to the collars and the purlins are strutted.

The tower is of three stages, of plain and rather late twelfth century work, altered in the latter half of the fifteenth century. The east arch is of one square order, pointed, with no capital or string, and is not of the original date.

The western doorway is modern and over it is a twelfth century light, altered in the fifteenth century. The windows on the second stage are plain

\footnotetext{
28 The information as to the descent after $16_{33}$ is supplied by the present lord of the manor from documents in his possession.

29 V.C.H. Hants, i. 450.

30 Exch. Depos. 2 Chas. I. Mich. 25. 335 .

32 Information supplied by the present lord of the manor. The tithes of Holyboume and Neatham are dealt with by Feet of F. Div. Cos. Mich. 19 Chas. II.; Mich. 20 Chas. II. ; East. 23 Chas.
}

aa Annales Monastici (Rolls Series), ii. 342 .

34 Pat. 28 Hen. VIII. pt. 2, m. 9

as Pat. 33 Hen. VIII. pt. $9, m$. 5 .

at Having doubtless been built round the original twelfth century chancel in the usual way. 
round-headed lights, and the belfry windows retain their original rear arches, but have fifteenth century tracery.

Buttresses of the fifteenth century have been added at the north-west, south-west and south-east angles. A stone bench, into which a large circular thirteenth century base is worked, runs along the inner face of the north wall of the tower on the ground level.

The font is modern.

The bells, which are three in number, are reached by ladders. The treble is a fifteenth century bell from the Wokingham foundry, inscribed Ave Maria in black-letter smalls with Lombardic capitals; the second has in black-letter smalls, "Our hope is in the Lord, R. E. I600' (Richard Eldridge); the tenor is by Richard Phelps (of Whitechapel), 1728 .

The church plate consists of a silver chalice and paten and a flagon and two offertory plates of white metal.

There is one volume of the parish registers previous to 1812 , and it commences in the year $169:$. There are two volumes of overseers' and churchwardens' books : i. 1672-1722, ii. 1780-1817.
The parish contains a Presbyterian church erected in 1864 , and a Wesleyan chapel erected in 1867.

The Free School in Holybourne was the benefaction of Mr. Thomas Andrews, who in 1719 left f 100 per annum in fee farm rents for the erection and endowment of a free school for all the children in the parish of Holybourne, besides twelve from $\mathrm{Al}$ ton, five from Binstead and three from Froyle ; he also left the White Swan public house in Coleman Street, London, to provide an apprenticeship fund for some of the scholars. In 1721 it was decided by the trustees that $f 800$ income should be accumulated to purchase land and erect a schoolhouse, and this was completed in 1730 . There is a good house for the master, and a girls' school was added in 1872 . The school will accommodate 2 I 2 children, but the present average attendance is II 8 . The annual income amounts to about 6300 , of which $\mathcal{L} \mathrm{roo}$ is expended in teaching agriculture. There is also a technical education class, and $f_{20}$ is paid for apprenticing and f $_{2} \mathrm{O}$ for clothing the scholars. The management is under a body of eleven governors, who possess records containing a detailed account of the developinent of the school from the date of its foundation.

\section{KINGSLEY}

Kyngesle (xiv. cent.); Kingesley (xv. cent.).

The parish, which contains about I, 800 acres, lies in the valley of the river Slea or Slee (also called Oxney Stream), a tributary of the southern Wey ; the eastern part, which is narrow, lies between the forests of Alice Holt and Woolmer. The village is situated on the northern side of the river, and along a road which branches from the Farnham and Portsmouth road near Sleaford Bridgc, and traverses the parish westward towards East Worldham. The entire parish appears originally to have been within the forest of Woolmer.

The king had, from very early times, a park at Kingsley; the locality of this park is now called Lode farm. There is an open meadow of 37 acres, divided by ditches into twenty-seven divisions, which is called 'King's Meadow.' The grass of this meadow is used by the tenants for common feeding between 9 August and 31 December in each year, that is to say, it was Lammas land.

The occupation of the inhabitants is mainly agriculture. The crops chiefly grown are wheat and barley, but hops are also cultivated. The parish contains a manufactory of agricultural implements called the Park Ironworks.

The following, amongst other place-names, occur : Hommed and Oxeney or Oxene, thirteenth century ; ${ }^{1}$ Sandford, La Sandputte and North Longmead, in $1305 ;^{2}$ Okanger, then belonging to Selborne Priory, in 1398-9; ${ }^{\text {a }}$ Edwyns, Le Bough and Tylgale at the same date ; Averayesmead in $1410 ; 5$ Samfords, Stywards or Stewards, abutting on the river; Sekkyls, and a common called Kingsley Heath, in $1516,{ }^{6}$ Denes, Symes, Dolmans, Scots and Haremead in the sixteenth century. ${ }^{7}$

The bridge over the Slea was the subject of an inquiry in 1356. The king having heard that this bridge-called the bridge of 'Slayford'-was broken down, and that the passage of carriages was much impeded, to the great damage of the people in the neighbouring parts, commanded it to be ascertained who were customarily bound to maintain it, and that an estimate of the cost should be given. The jury found that the maintenance of the bridge belonged to the men of the tithing of Kingsley alone, and that from time immemorial they had been wont to keep it in repair, and that it might then be repaired for the sum of $26 \mathrm{~s} .8 d^{8}$

The manor of KINGSLEY is not MANORS mentioned in Domesday, and its history is obscure. In 1316 the "vill" was in the hands of the queen as part of the manor of Alton. ${ }^{9}$ It is not mentioned in the Feudal Aids of 1346,1428 and 1431 . In 1469 John White died seized of Kingsley, then first called a manor, but of whom it was held the jurors were ignorant. He left a son and heir Robert, aged fourteen and more. ${ }^{10}$ In 1561 Sir Thomas White of South Warnborough and Agnes his wife conveyed the manor-presumably in trust-to
1 Add. Chart. 27,958, and Feet of F. Hants, 8 \& 12 Hen. III.

2 Add. Chart. 27,957.

3 Ibid. 27,820 .
4 Ibid. Ibid. 26,141 .

6 Ibid, $27,97 \mathrm{I}$.

7 Ibid. 27,893 , and Close, 28 Eliz. p. 21 -deed, Holdway and Knight.
8 Inq. p.m. 29 Edw. III. 2nd nos. No. 49 .

9 Feud. Aids, ii. 314

10 Inq. p.m. $9 \mathrm{ddw}$. IV. No. 25. 


\section{A HISTORY OF HAMPSHIRE}

Chidiock Paulet." Sir Thomas died in 1566 seized of it, leaving Henry White his son and heir, aged thirty-four years and more. ${ }^{12}$ Sir Richard White died seized of it in $1613 . .^{13}$ By a fine in Hilary term I6 15-6 Samuel Backhouse and Elizabeth his wife conveyed the manor to Florence Henshaw, widow, Benjamin Henshaw and another, probably in settlement on marriage of John Backhouse their son with Florence daughter of Benjamin Henshaw. ${ }^{14}$
BАскиочвг. Party asure and gold saltirewise with a saltire ermine.

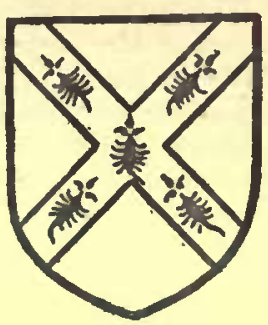

After this the property passed to the families of Hyde and Chaffin.

In 1713 George Chaffin was lord of the manor, ${ }^{16}$ and in 1746 an Act was obtained for the sale of his lands in Hants and Surrey to discharge his debts. The Kingsley property came into the posscssion of the Stawell family, and was held by Henry, the last Lord Staweli, who died in 1820 . Mary, his daughter and heir, married John, second Lord Sherborne, and, on a division of her property, Kingsley came

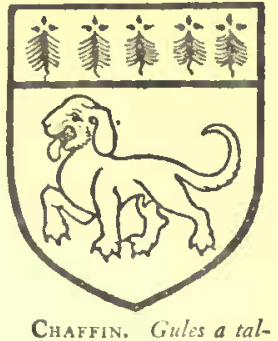

Chaffin. Gules a talbot passant gold and a cbicf ermine. to their son, John Thomas Dutton, ${ }^{10}$ whose son Henry John Dutton of Hinton Ampner is the present lord of the manor.

No details as to the manorial rights in Kingsley have been discovered. Queen Elizabeth granted -or intended to grant-to Samuel Backhouse, lord of the manor, free warren in his lands called Oxney, or Oxney grounds, abutting on Oxncy Moor. ${ }^{17}$ An Enclosure Act for Kingsley was passed in 1777 .

In Kingsley parish were two other manors or reputed manors - $L O D E P L A C E$, of which mention has been already made, and $M A R S H$ or MARSHES. Ivo de la Lode is mentioned as paying a rent to Kingsley in $1305,,^{18}$ and Peter atte Mersshe as doing the same in $1308 .^{10}$ It was probably of one of these holdings that Simon de Hcyes died seized in $1362 .{ }^{20}$ In a rental of Kingsley made in 1398-9 Richard Holt appears as tenant of le Mershe, and though Lode Place is not named, rent was paid by John atte Lode. ${ }^{21}$ A Richard Holt died seized of a messuage, etc., in Kingsley, probably Marshe, in 1458, leaving two daughters as his co-heirs: Christine, who married Sir Edward Berkeley, ${ }^{22}$ and Elizabeth. ${ }^{23}$ The Kingsley property was enjoyed by Richard's widow Joan, for her life, and it is not clear to which of her daughters it passed on her death, or if it was divided. Christine Berkeley had a daughter Lora, who became Countess of Ormond. Elizabeth Holt married John Pounde. Lora and Elizabeth were found to be heirs of Joan Holt (who, after Richard Holt's death, had married Constantine Darrell) at her death in $1495 .{ }^{24}$

Both Lode and Marsh are referred to in 1562 as having been held by John Fitzwilliam, who had purchased them of (or received them in exchange from) Thomas, Lord Sandys, Viscount Montagu, Lord Windsor and Sir Ralph Lyster. Fitzwilliam is stated to have sold them, on I June, I561, to Richard Springham. Fitzwilliam died in London on 17 June, 1562 , leaving a son and heir William, then aged fifteen. ${ }^{25}$ Notwithstanding this alleged sale, 'Fitzwilliams' (no Christian name is given) was-according to a rental of the end of the sixteenth century-tenant of Lode Place. Marsh Place is named in this rental, but its tenant is not mentioned. ${ }^{26}$ Despite the statement in the inquisition on Fitzwilliam above mentioned, Springham appears to have acquired the manor of Marsh of Richard Caryll in $1567,{ }^{27}$ and the following year Nicholas Backhouse acquired three parts of it of Richard Caryll and a fourth part of William Burd and his wife. ${ }^{28}$ In 1653 Sir John Backhouse paid a quit rent for the 'manor' of Lode, and Robert Harding for 'his manor house and lands called Marshes.' ${ }^{28}$ In 1775 Sir Simeon Stuart of Hartley Mauditt possessed Lode Place, and Peniston Fairmeadow was tenant of 'Marsh farm.' ${ }^{30}$

Lode manor house still stands, and is now a farmhouse. It is stated that Henry VIII., when Prince of Wales, was so often there that he earned for himself the title of 'Harry of Lode.' 31 Marshes manor house stood, within living memory, in the low ground at the bottom of Marsh Lane.

The parish church of All Saints',
consisting of a chancel, nave, south
porch and north vestry, is a modern structure built in 1876 on a commanding site to the east of the village. The old church, dedicated in honour of St. Nicholas, now used as a mortuary chapel, is some distance away to the west. It is little better than a brick barn with a tiled roof and south porch, and a shingled bell turret over the western gable. In the south wall is a tablet inscribed ' $w$. KING J. OSBORN Church Wardens 1778,' which probably gives the date of rebuilding. The east wall is all that is left of the older church. It is of clunch, plastered, and contains a window of two trefoiled lights with a cinquefoiled circle in the head, of a date
11 Feet of F. Hants, Trin. 3 Eliz.

12 Iaq. p.m. ser. 2, 9 Eliz. No. 9.

13 Ibid. 11 Jas. I. ser. 2, bdle. 18 , No. 221 .

14 Feet of F. Div. Cos. Hil. I 3 Jas. I.

15 Exch. Dep. 12 Anne, Trin. No. 3 or 13.

16 Information from the present owner.
17 Draft of letters fatent, undated; Add. Chart. 27,972.

18 Ibid. $27,957$.

20 Iog. P.m. 35 Edw. III. Iat pt. No. 101.

21 Add. Chart. 27,820.

22 See Weatcote in Binsted.

23 Ing. p.m. 38 Hen. VI. No. 32.

24 Ibid. ser. 2, vol. ii. No. 121 .

\author{
25 Ibid. ser. 2, vol. 140, No. 179. \\ 26 Add. Chart. 27,893. \\ 27 Feet of F. Hants, Mich. 9 \& 10 \\ Eliz. \\ 28 Ibid. Mich. 10 \& 11 Eliz. \\ 20 Documeat ia possession of the pre- \\ seat lord of the manor. \\ ao Ibid. \\ a1 Hants Field Club Papers, No. 2.
}


circa 1330. The west wall is built of coursed deep purple sandstone, but does not seem to be older than the nave and porch. The brickwork
Walter Hubberd, at a rent of $£_{0} 18$. In 1649 the rent was still $f_{1} 8$, though the value was estimated at $\{327$ 3s. $4 d$, and the Cromwellian Com-

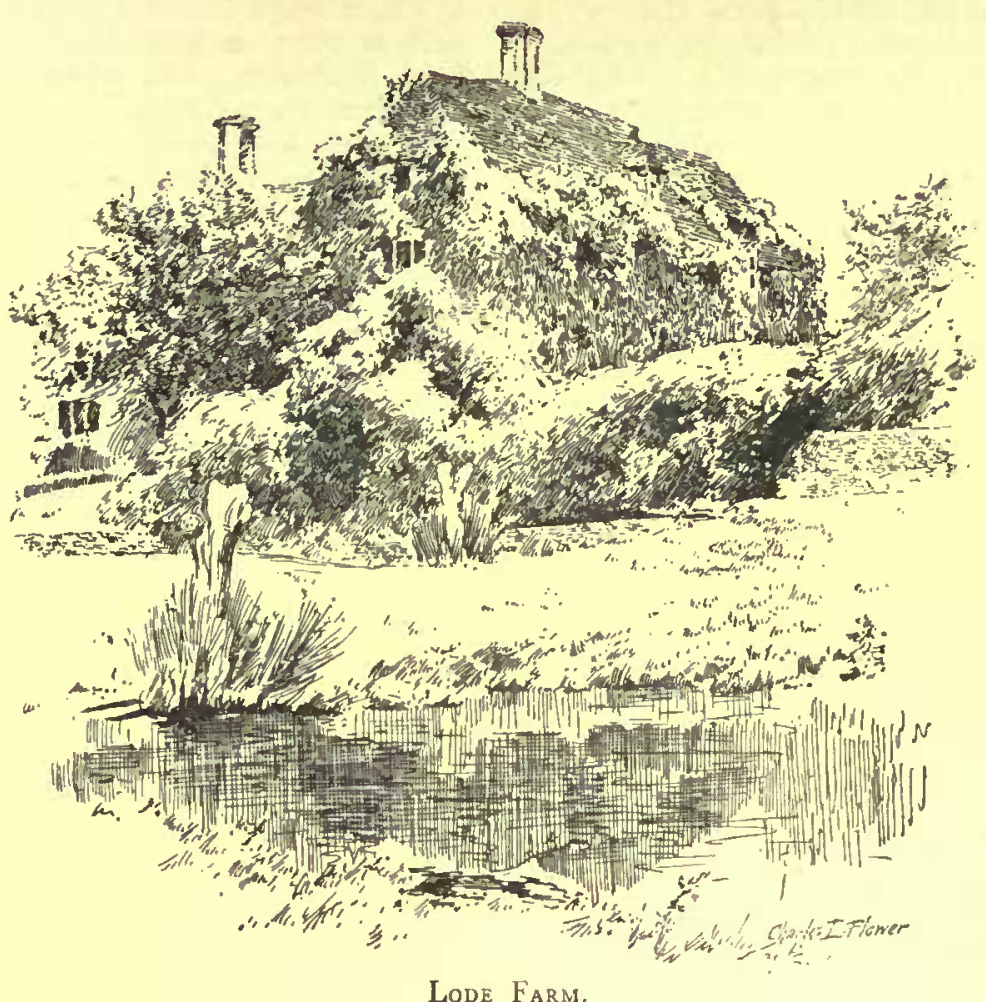

LOde Farm.

of the nave is noteworthy for its excellence. The pews are of the eighteenth century, as arc the fence-like altar rail and pulpit. The font is a plain cylindrical one standing on a round stcp, and may be of the twelfth century. The turret contains two bells.

The church of Kingsley is not mentioned in the Taxation of Pope Nicholas (A.D. I 291), but in 1362 the king is stated to have a chapel in boia sua de Kingesle. It was then found that the abbot of Hyde (to whom the church of Alton belonged) and the vicar of Alton ought to find a chaplain for the chapel, because they received the tithes of the place, and that mass ought to be celebrated three times a week. The church (ecclesia) of St. Nicholas is mentioned in 1492 ; bequests to the 'light of St. Nicholas' and to torches in the church were then made. ${ }^{32}$ The rectory and church of Binsted and Kingsley were granted, after the suppression of Hyde Abbey, to the dean and chapter of Winchester. ${ }^{33}$

The vicar of Alton provided a curate for Kingsley until it was separated from Alton and made a distinct parish with Binsted in 1854 .

When the rectory of Alton was granted by Henry VIII., out of the possessions of Hyde Abbey, to the dean and chapter of Winchester, ${ }^{34}$ the latter leased the rectory of Binsted and Kingsley to Ralph Heriet, the then vicar of Alton, and missioners directed that there should be a resident minister for Kingsley and Binsted. ${ }^{35}$

The parish registers begin in 1568 , and previous

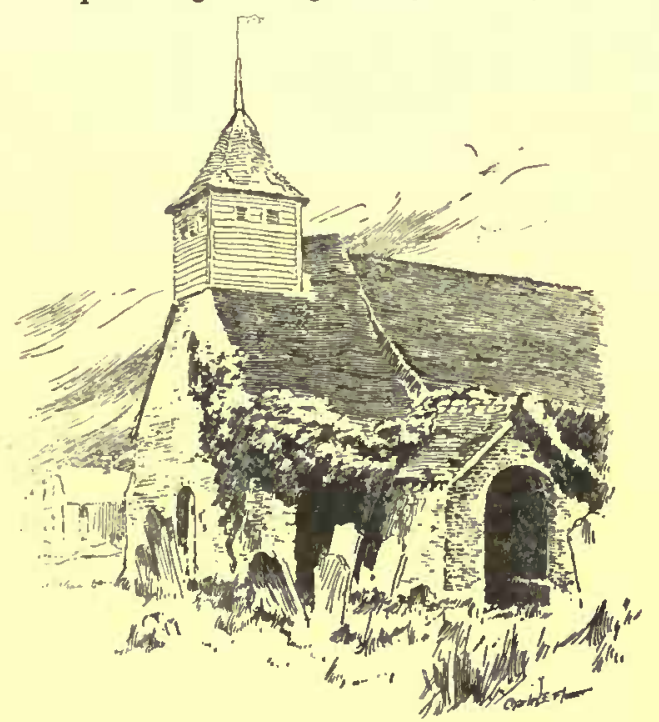

Old Church of St. Nicholas.

to 1812 consist of three volumes: i. I 568-1719, ii. 1683-1812, iii. 1719-1812. The first is a parchment-bound volume, in which it is stated on
22 Add. Chart. $27,970$.

a3 Pat. 33 Hen. VIII. pt. 9, m. 5 . a4 Ibid. pt. 9 , m. 5 .
35 Surveys of Church Livings, Lambeth Lib. 


\section{A HISTORY OF HAMPSHIRE}

a fly-leaf, "This Register Book was gathered out of certain old papers and herein new written for the great advantage of the parish by Henry Moss, Curate. Feb. 10, 1683.' From 1762 to 1845 Kingsley marriages were performed at Binsted.

The church plate consists of a silver chalice with hall mark of 1576 and a silver paten, apparently older, but which has the same date inscribed on it. There are also a silver paten inscribed 'Kingsley parish I $7 \mathbf{z}$,' a silver chalice and paten
(Victorian) inscribed as the gift of the Rev. Reginald Dutton, and a glass flagon with silver band, handle and top presented by the samedonor.

The National Church of England Schools were built in 1850 on land given and conveyed by Lord Sherborne. The school buildings, with master's house, cost $£ 354$. Since then they have been enlarged on two occasions. The Secondary Schools were built in 1876 at the expense of the Misses Lushington.

\section{EAST WORLDHAM}

Werildcham, Wardham (xi. cent.), Wirldham (xii. cent.), Vcrildham (xiii. cent.), Verilham and Werldham (xiv, cent.), Wardelham (xvi. cent.).

The village is situated at an elevation of 500 feet above the sea on the edge of a malm rock terrace which has the chalk of Alton on the west and slopes abruptly down to the gault adjoining Kingsley on the east. It lies in the centre of the parish where the road from Alton to Kingsley and a road from Binsted to Selborne intersect. The parish church of St. Nicholas stands a little to the east of the village. On the east side of the parish two brooks flow down into the Slea, and on the west two others flow down to the Caker' stream towards Alton.

Lodge Hill or King John's Hill, the traditional site of a hunting lodge of the king of that name, is an almost isolated eminence situated in the southeast of the parish, on the verge of Woolmer Forest, which formerly ' extended to the ditch of Wardelham park.' ' The Itinerary of King John shows that he was twice at Worldham in the year $1204 .^{2}$

Among other place names mentioned in records relating to the parish are Butlege in II $19 ;^{3}$ meadows called Reynaldesmor and Kenmede in the thirteenth century; ${ }^{4}$ and wood and pasture called Bynswood in $1625 .^{5}$

In Domesday WORLDHAM was

$M A N O R$ held as an alod by Alwin of the Confessor, and under the heading of the lands of the Conquerar's thegns ${ }^{6}$ it is described as held by Godwin in the time of King Edward. At the time of the survey it was held by Geoffrey the Marshal. He appears to have held it by serjeanty, ${ }^{7}$ and his successors in the property certainly held it by the service of bearing the marshal's rod in the king's household throughout the year.

Robert de Venuz, the heir and probably the son of Geoffrey the Marshal, ${ }^{8}$ whose family name was Venuz, claimed jointly with William de Hastings, the chief marshalship of the king's court, and we learn that Gilbert the marshal of Henry $\mathbf{I}$. recovered that office from him. ${ }^{\circ}$ In I I 90 William de Venuz owed to the Crown a large sum for the forestership of Alice Holt Forest and the marshalship, ${ }^{10}$ and in 1197 Robert de Venuz paid a fine for having his father's lands and forestership." Probably the same Robert ${ }^{12}$ is mentioned in I z I 9, whilst later in Henry III.'s reign a Robert de Venuz is mentioned as holding Worldham by being marshal, "which office William I. had given to Geoffrey the Marshal.' 13 Later again John de Venuz is named as holding Worldham by the same tenure. ${ }^{14}$ John de Venuz, probably grandson of Robert de Venuz last mentioned, ${ }^{15}$ died in I 260 holding Worldham of the king in chief by serjeanty, but the nature of the serjeanty is not stated. He left a son and heir John, then aged between six and seven. ${ }^{18}$ The manor is again described as held by the service of being marshal in 1306 when its possessor was John de Venuz, then aged over forty. ${ }^{17}$ This John de Venuz intended to settle the manar on his son Richard, but apparently the deed was never executed. In 1286 he conveyed it to Thomas le Marshal, who immediately reconveyed it to him and Margery his wife for life with reversion to the same Thomas and his heirs. ${ }^{18}$ This settlement was the cause of much litigation. In 1319 Richard Venuz died, when the jurors to the inquisition taken after his death returned that he held no lands of the king in chief. ${ }^{19}$ In 1326 however another inquisition was taken, by which it was stated that he died seized of the manor of East Worldham. ${ }^{20}$ Richard's father John died about 1325, when Margery his wife continued in possession. John son of John de Venuz ejected Margery from the manor, but she afterwards recovered it. At her death John le Marshal of Bovingdon, possibly son of Thomas le Marshal, and Constance his wife entered into possession until John de Venuz the son disseized them. ${ }^{21}$ This John de Venuz died seized of the manor in $13 z 7$, leaving, it is stated, his daughter Amice his heir, aged five years. ${ }^{22}$ 'The finding of this inquisition seems to have been inaccurate, for in July, 1327 , the escheator was ordered to assign
I White's Selborne, i. 22 John.

Hardy's Introd. to Pat. Rolls for

3 Feet of F. Hants, I John.

4 Anc. D. (P.R.O.) A 323 .

6 Exch. Dep. 22 Jas. I. East. 5.

- V.C.H. Hants, i. 510 and note.

7 Ibid. i. 430. 8 Ibid. 43 t.

- Charter R. I John, pt. ii. m. 13.
10 Pipe Roll. 11 Ibid.

12 Cur. Reg. R. No. 67 m. 4.

13 Testa de Nevill, p. 235.

14 Ibid. p. 236 , and Assize R. $778, \mathrm{~m}$. 43. John de Venuz held his land in Worldham and Notlee by the serjeanty of being marshal in the king's house ; now he pays for that serjeanty loos. a year at the Exchequer.
15 Close, 8 Edw. III. m. 8. 18 Inq. p.m. 44 Henry III. No. 7.

17 Ibid. 34 Edw. I. No. 175.

18 Close, 3 Edw. III. m. I5 \& 11.

18 Inq. p.m. 12 Edw. II. No. I.

20 Ibid. 19 Edw. II. No. 57

21 Close, 3 Edw. III. m. I5 \& II.

22 Inq. p.m. 20 Edw. II. No. 28. 
dower to Sibyl widow of John in the presence of Edward St. John, who had the custody of Thomas son and heir of the said John de Venuz. ${ }^{23}$ In I 329 John le Marshal and Constance brought an action against Edward St. John, as guardian of Thomas de Venuz, a minor, for the recovery of the manor of East Worldham. The litigation continued for some time, till in 1334 John le Marshal and Constance recovered seizin with damages against Thomas de $V$ enuz. ${ }^{21}$

In 1336 John le Mareschal, being established in his title, received the king's licence to settle the manor on the Burghersh family in fee, ${ }^{25}$ but in 1347 he granted it to Sir John de Burghersh to hold only for the life of the grantor; ${ }^{26}$ Thomas, son and heir of John de Venuz, relinquishing in 1349 all claim to the manor. ${ }^{27}$ Next year Sir John de Burghersh died seized of the property, still described as held by grand serjeanty, though the serjeanty is not specified. John de Burghersh ${ }^{28}$ was his son and heir, aged six. In 1374 this last named John conveyed the manor to the Crown. ${ }^{29}$ After this the custody of the manor was granted by the Crown to John Slegh. ${ }^{30}$

John de Burghersh left as his co-heirs two daughters, Maud and Margaret ; the former married Thomas Chaucer, son of the poet, and the latter Sir John Grenvyle. Despite the conveyance to the Crown made by their father in 1374 these co-heiresses and their husbands claimed the manor against the surviving Crown grantee. ${ }^{31}$ The result of the claim does not appear, but it seems to have been successful,

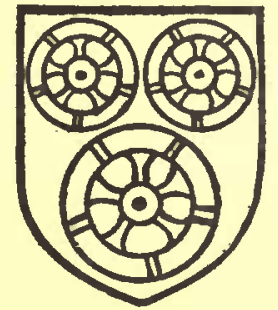

Chaucer. Gules tbree cartwbels gold. [The shield of RorT] since, in 1418 , after the death of Sir John Grenvyle, John Arundel and Margaret his wife (Grenvyle's widow) conveyed Margaret's moiety to her sister Mand, wife of Thomas Chaucer, ${ }^{32}$ both of whomthe latter in 1435 and the former in 1437 -died seized of the manor. Their daughter and heir was Alice wife of William de la Pole, Earl of Suffolk. ${ }^{33}$ In 1442 the Earl and Countess of Suffolk were still in possession of the manor, ${ }^{34}$ and the following year they-perhaps wisely, considering the extraordinary complications in the descent of the manor and the conflicting evidence concerning it- took from the Crown a fresh grant of it, to hold to them and their heirs by the annual rent of a rose to be paid on the feast of St. John Baptist. ${ }^{35}$ In 1445 they had licence to have view of frankpledge, assize of bread and ale, etc., in the manor. ${ }^{36}$ Presumably by the attainder of Edmund, Duke of Suffolk, in 1503 the manor came to the Crown, and in I 510 was, together with the lieutenancy of the park

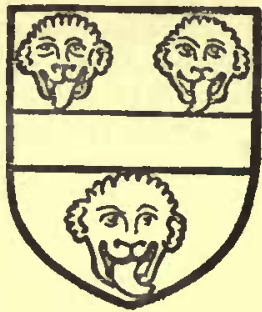

Polv. Azure a fesse between three leopards beads gold. and custody of the forests, granted to Thomas, Earl of Arundel, and William, Lord Maltravers, for their lives and the life of the longer liver. ${ }^{37}$ The custody of the forests was taken into the king's hands again in 1522 and granted to Sir William Sandys with the reversion (after the death of Lords Arundel and Maltravers) of the manor of East Worldham. ${ }^{38}$ It was howcver found, on the death of the Earl of Arundel in October, 1524, that he died seized of the manor, lieutenancy and wardenship of the forests for life with reversion to the Crown, ${ }^{39}$ a finding at variance with the grant to Sir William Sandys in 1522 . The Crown was still in possession of the manor of East and West Worldham (then referred to as one manor) in the reign of Elizabeth, and in 1576 it was leased to Henry Audley for twenty-one years from the death of John, Marquis of Winchester, who held the same for life. ${ }^{40}$ In 1623 the manor of 'Wordleham,' alias East and West Worldham, was granted by James $I$. to George Sheires and John Wells. ${ }^{41}$ Its subsequent history is very obscure. On the marriage, about $175^{\circ}$, of the Right Hon. Henry Bilson Legge with Mary Baroness Stawell, East Worldham appears to have been settled on the latter, and passed to their only son, Henry, the last Lord Stawell, who died in 1820 . Mary, his heir, married John, second Lord Sherborne, and on a division of her property East Worldham was taken by their son John Thomas Dutton, whose son, Henry John Dutton of Hinton Ampner, is the present lord of the manor.

With the possession of the manor of East Worldham went the keepership of Alice Holt and Woolmer forests (see account of Binsted), and John de Venuz who died in 1260 granted the same for life to the famous Adam de Gurdon, once an outlawed adherent of Simon de Montford (see Alton). Adam died before 1305, leaving as his heir his daughter Joan, then aged forty-five. Other references to the descent of the custody of the forest
23 Close, I Edw. III. pt. 2, m. I 9 ; and 3 Edward III. m. Is \& 11 .

24 Exemplification of proceedings taken in this suit. Co. Plac. Hants, No. 6; Coram Rege R. No. 262, rex roll $4 \mathrm{I}$; and Close, $8 \mathrm{Edw}$. III. m. 4 .

25 Pat. Io Edw. III. pl. 2, m. 34 .

26 Co. Plac. Hants, No. 41, and Ane. D. (R.R.O.) A. 3254 .

27 Co. Plac. No. 4I, and Anc. D. (P.R.O.) A. 3253 .
28 Inq. p.m. $24 \mathrm{Edw}$. III. I8t nos. No. 94 .

29 Co. Plac. Hants, No. 41, and Anc. D. (P.R.O.) A. 3249, 3250 and 325 . 30 Pat. I Rich. II. pt. 3, m. 37, and 7 Rich. II. pt. 2, m. 34 .

31 Co. Plac. Hants, No. 41.

32 Feet of F. Div. Cos. East. 6 Hen. V.

33 Inq. p.m. 2 Hen. VI. No. 29; I 3

Hen. VI. No. 35 ; and 15 Hen. VI.

No. 53.
34 Inq. a.q.d. $20 \mathrm{Hen}$. VI. No. 16.

35 Pat. 21 Hen. VI. m. 5.

38 Chart, R, 21-24 Hen. VI. No. 2 I.

37 Pat. I Hen. VIII. pt. 2, m. 5, and 2 Hen. VIII. pt. $\mathrm{r}, \mathrm{m}$. 18.

38 Pat. I 3 Hen. VIII. pt. 1. m. 26

39 Exch. Inq. p.m. ser, 2, file 978 ,

No. 19

40 Harl. Ch. 83, H. 16

41 Pat. 20 James I. 


\section{A HISTORY OF HAMPSHIRE}

will be found under the descent, given above, of the manor of East Worldham.

The advowson of the church of East Worldham was granted in 1254 by John de Venuz to the prior and canons of Selborne. Attached to the grant is an impression, in green wax, of the owner's seal, representing a figure on horseback holding a branched staff of office with the legend SIGILL' JOH'IS de VENZ MARESCALL' REGIS."2

In 1292 the Bishop of Winchester gave licence to the prior and convent to appropriate the church

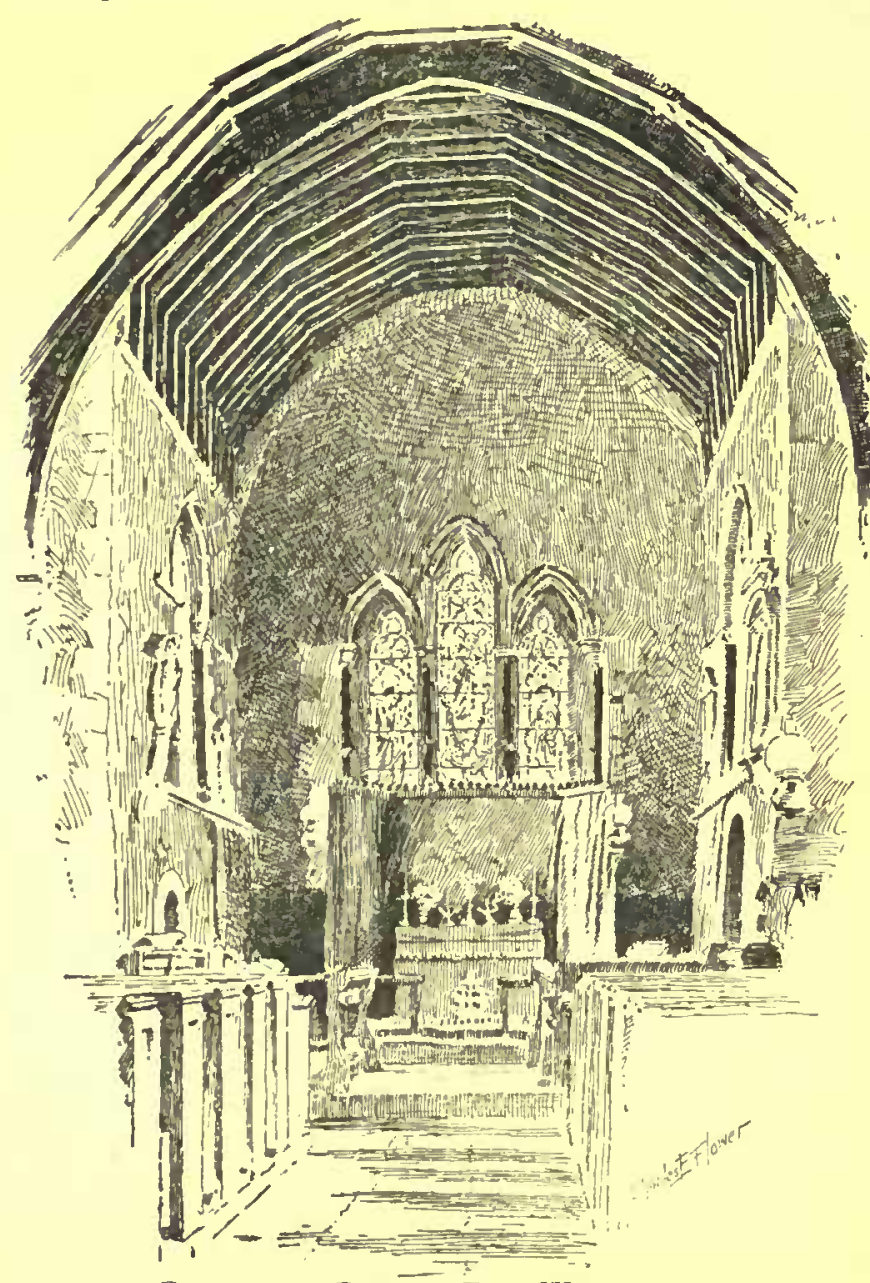

Chancel of Church, East Worldham.

when it fell vacant, reserving to himself the assignment of a sufficient provision for the vicar. ${ }^{43}$ Ten years later the bishop granted to them the appropriation of the vicarage on the cession or death of the existing vicar, the endowment being too small for the vicarage which was thereafter to be served by one of the canons. ${ }^{44}$

In 1305 the king confirmed to the prior and convent the advowson and appropriation. ${ }^{45}$

In 1484 Bishop Waynfleet of Winchester obtained the transfer of the rectory from Selborne Priory to Magdalen College which he had founded at Oxford; ${ }^{40}$ since then the advowson has remained in the hands of the College.

The rectory house is let by the patrons to the incumbent, as a vicarage, at a nominal rent.

The parish church of St. Mary CHURCH stands a little to the east of the village. It originally consisted of an apse, chancel and long nave, all of fine Transitional Norman work of the last quarter of the twelfth century. The apse has gone, but the tall pointed arch that opened into it may be seen over the present east wall, which contains a modern triplet of lancets. On each side of the chancel is a large lancet window, with moulded reararch carried by detached shafts, and hoodmould returned along the wall as a stringcourse. In the north wall is a low round-headed doorway into a modern vestry, but which probably opened anciently on to the stairs to the roodloft. There is also a south doorway. The chancel arch has been destroyed. The nave was for the most part rebuilt in 1865 , but with the old materials. It is of seven bays, the first, second, third, - sixth and seventh of which on each side contain pointed lancet windows with a roll moulding round the splay. A large doorway fills the intervening bays on either side. The west wall has an arcade of three pointed arches with nail-head ornament, carried by circular shafts with square carved capitals. Each arch is pierced with a window. The font and all the fittings are modern. In the south wall of the nave, under a modern arch, is an interesting semi-effigial slab of early fourteenth century date, with the bust of a lady in a wimple, and a cross paty below. This was discovered under the nave floor during the late restoration. There are also wall tablets to Henry Heighes, 1681 ; Elizabeth Heighes, wife of Samuel Metcalfe, 1680 ; and other members of the same family.

Externally the south doorway of the chancel is of one order, with jamb shafts, but much restored. Some of the ornamental details of the destroyed apse may be seen in the east wall. The north side is untouched by the restorer, and shows a broad projection at the junction with the nave, perhaps for the roodloft staircase. The north doorway of the nave is a very fine example, of two pointed orders, with hoodmould decorated with the dog-tooth ornament. The side shafts have square capitals worked into volutes. On the east jamb is a so-called 'consecration' cross. The west

\footnotetext{
12 Selborne Charters, i. 45, and $P_{a t}$ 33 Edw. I. m. 15.

43 Ibid. i. 76.
}

4 Ibid. i. 77 .

45 Pat. 33 Edw. I. pt. 1, m. I5, and Inq. p.m. 33 Edw. I. No. 259.
46 Selborne Charters, i. Itg. 


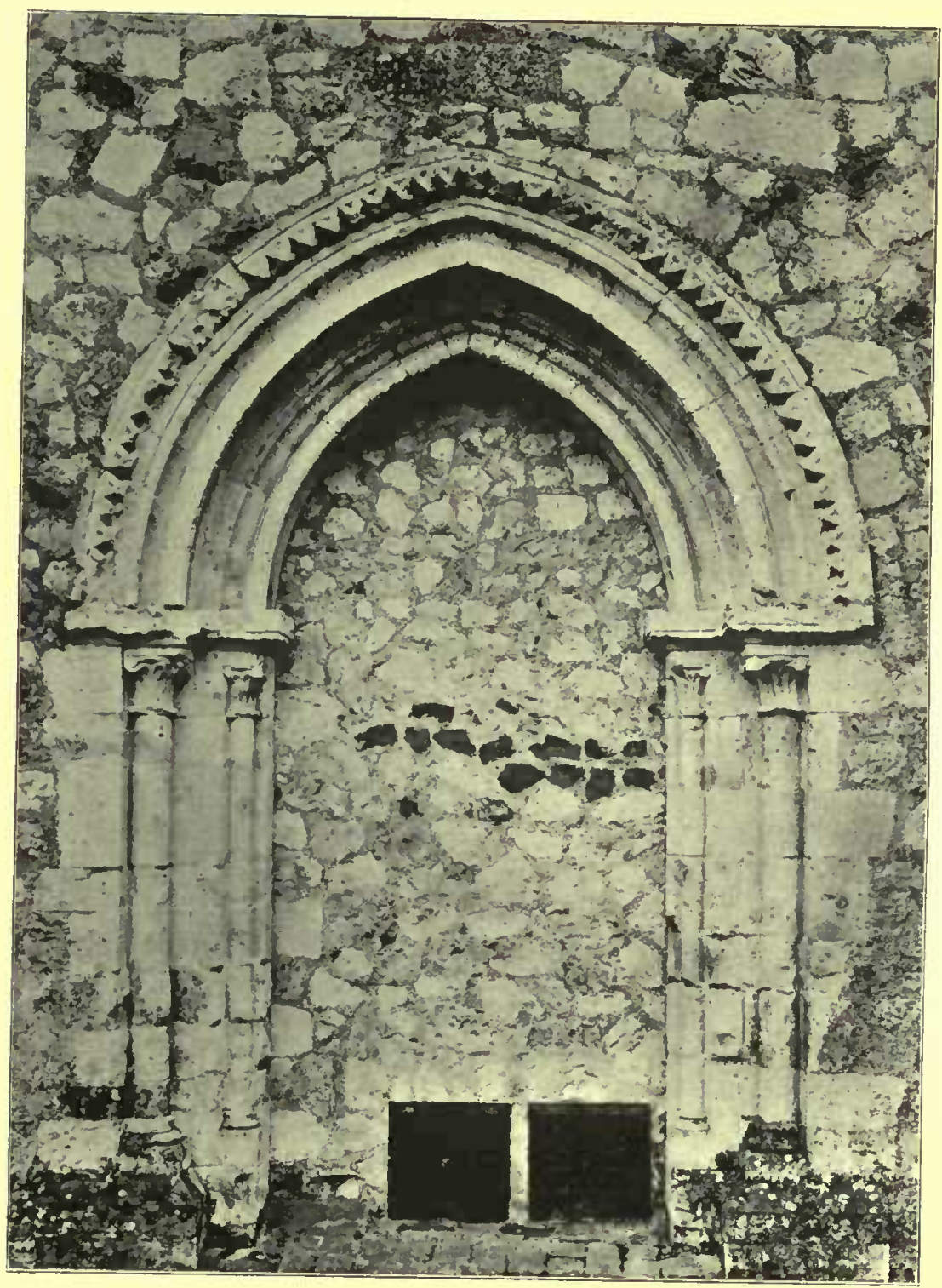

Doorway in East Worldham Church. 

windows have a square outer order, carried by nook shafts like those within. The south doorway resembles the north, but has been largely 'restored.' It has a large ' consecration ' cross cut in each jamb and several small crosses on the east jamb. This doorway is covered by a modern porch.

There are three bells in a wooden turret surmounting the west end of the nave.

The communion plate consists of a large silver flagon, with an inscription that it was given to East Worldham by Edward Heighes, gent. (whose arms it bears), who died 16 December, 1723 , and a silver chalice inscribed with the same date. There are also two silver patens, one inscribed as the ' gift of John Eggar, Gent., Io August, 1829,' and the other with the date I 843 .

The parish registers commence in 1690 and previous to 1812 consist of two volumes: i. $1690-$ I 8 I 1, ii. I 754-I 8 I 2.

The churchwarden's book, a parchment bound volume, commences 1623 , but is inscribed 'the Church Book of Account for the Parish of East Worldham, purchased by Henry Heighes (price $£_{6} 3$ ), 1663 .' It contains some interesting entries. In 1624 payment is made of 'smoke money' and 5s. 4d. was paid for the whole year for the maimed soldiers and
Marshalsea. In 1628 and after, two supervisors as well as two churchwardens are chosen, and in that year the churchwardens are summoned to Winchester and 'charged for reparations of our church.' Considerable repairs to the church are then mentioned, and $f_{1}$ os. Iod. is entered as provided by the rate of ' the Park'; 'King's Land' and 'Chantry Mead' are also mentioned. In I 654 the justices of the peace ordered that the sum which remained in the old churchwardens' hands should be employed towards the making of a whipping post and a pair of stocks.

There is a Wesleyan chapel in the parish.

A reading room was erected in 1893 at the cost of John Baigent.

The National Church of England Schools were built in 1864 , on land given by Lord Selborne, at a cost of about $£ 700$ for the school and schoolhouse, and an infants' class-room was added in 1897 at a cost of $f_{1} 85$.

There is a charity of $f_{1}$ a year charged on land in East Worldham and directed to be paid to the poor by the will of William Dunce, who died 20 December, 1761 ; and $£_{4}$ a year, for the same purpose, left to the parish in 1902 and called 'Christmas's.'

\section{WEST WORLDHAM}

West Worham (xiii. cent.), West Wordham (xiv. cent.), Parva Worldham or Worldham Minor (xv. cent.).

The parish of West Worldham, which contains a little over 400 acres, is now and, so far as we are able to judge, always has been, very thinly populated; in 1428 there were not ten 'domicilia tenentes' in 'Worldham Minor.' 1 The parish of East Worldham forms its northern and eastern boundaries, Hartley Mauditt its southern boundary and Alton its western. A road from Binsted to Faringdon passes through it, and on this the few cottages which form the village are built, about a mile after that road passes East Worldham. The ancient church of St. Nicholas stands a little to the east of the same point. West Worldham at the time of the Conquest appears to have had no separate existence from East Worldham, but when the parishes come to be separately mentioned they are found described as East and West, or Great and Little, Worldham. West Worldham was probably made a parish towards the end of the twelfth century, when Richard de Annecy endowed a church there. ${ }^{2}$ In I 29 I however the parish of West Worltham is not mentioned under the deanery of Alton, but it had then presumably acquired a distinctive name, because East Worldham appears as Worldham Major. ${ }^{3}$

MANOR In October, I 277, we have mention of a messuage, garden and rents in WEST WORLD$H A M$, formerly in the tenure of Godirey le Clerc and then in the hands of Thomas Paynel.4 In 1316 the vill of West Worldham was held by William Paynel.5 In 1317 John Paynel died seized of the manor which he held of Alton. Maud, the wife of Nicholas de Upton, was his daughter and heir, but Eve, William's widow, then the wife of Edward St. John, held a third of the manor in dower. ${ }^{6}$

In $134^{6}$ John Wace or Wasse held the fourth part of a fee in Little Worldham, which had belonged to Amice Shotesbroke and John Berwik. ${ }^{7}$ After this date the manor passed to Thomas Chaucer of Ewelme, who had married Maud, daughter and coheir of John de Burghersh, lord of the manor of East Worldham, as we find he was in possession in 1416 and $1431 .^{8}$ In the inquisition on the death of Thomas Chaucer in I 435 he is described as having acquired the manor conjointly with Maud his wife by gift of Henry Semer. It was held not of the king in chief, but of whom the jury knew not. ${ }^{9}$ Maud died in 1437 seized of the manor held as last described, leaving Alice, wife of William de la Pole, Earl of Suffolk, ${ }^{10}$ her daughter and heir, aged thirty. ${ }^{11}$ They had a grant of a court leet in this manor in 1445.12 The Earl of Suffolk was beheaded in 1450, and his wife died in $1475 .{ }^{13}$ The manor early in the next century
I Feud. Aids, ii. 342.

2 Hanti Noles and Queries, v. 15.

a Taxation of Pope Nicholaa (Rec. Com.), p. 210.

1 Inq. p.m. 5 Edw. I. No. 46 .

6 Feud. Aids, ii. 3 I 5 . V. and Feud. Aids, ii. 357,363 .

9 Inq. p.m. ${ }_{3}$ Hen. VI. No. 35 .
10 Alice had married, previously, (1) Sir John Philip and (2) Thomas, Earl of Salisbury.

11 Inq. p.m. 15 Hen. VI. No. 53. 12 Chart. R. 21-24 Hen. VI. No. 21.

13 Complete Peerage, vii. 306. 


\section{A HISTORY OF HAMPSHIRE}

was in the hands of the Crown, probably by the attainder of Edmund, Duke of Suffolk, grandson of the above-mentioned earl.

After this the two manors of East Worldham and West Worldham appear to have been treated

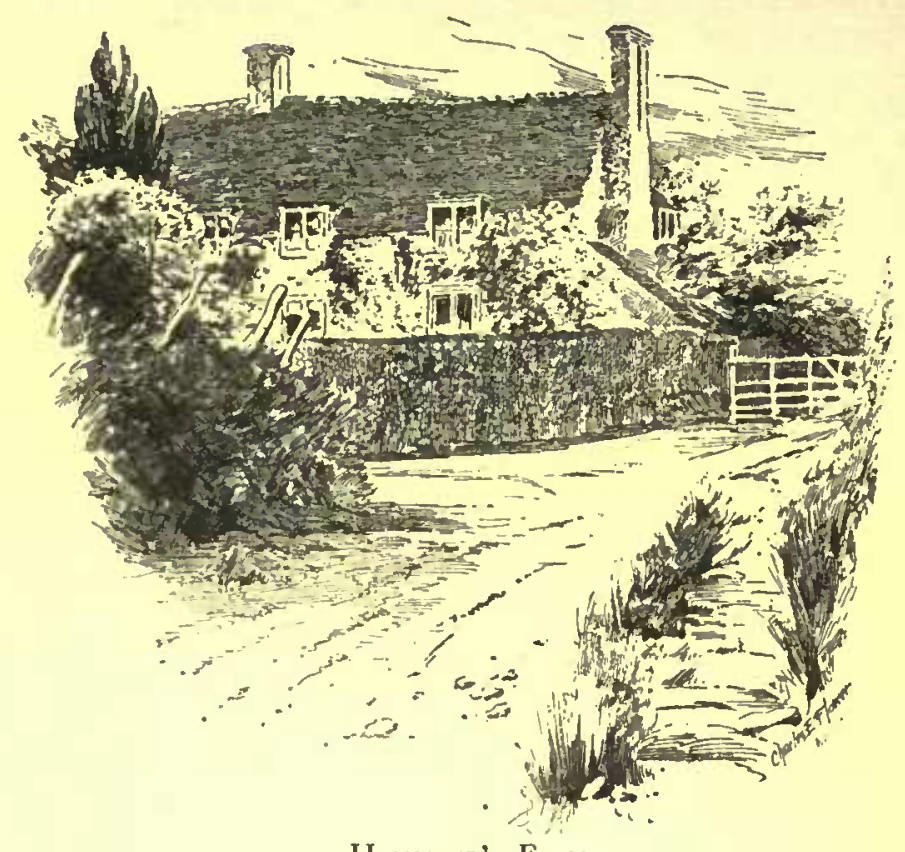

Hammond's Farm.

as one manor. We find they were so leased in 1576 to Henry Audicy. ${ }^{14}$ The descent of West Worldham from this date follows that of East Worldham (q.v.) through the Stawells and Legges to Henry John Dutton, J.P. of Hinton Ampner, who is the present lord of the manor and sole owner of the parish.

There are rent rolls but no court rolls of the manor in the possession of the lord of the manor.

The manor house, now called Hammond's farm, has the date 1652 cut on a stone tablet over the front doorway, and stands, a short distance from the church, on the right hand side of the road to Hartley Mauditt. On a barn belonging to the farm are two stone tablets inscribed 'W.H. 1768 ' and 'Rebuilt J.H. 1832,' which refer to the works of the Hammond family, who occupied the house for several generations, and to members of which there are several monumental tablets in the church.

At the end of the twelfth century CHURCH Richard de Annecy gave the church of St. Nicholas of Worldham to Hamble Priory, a cell of the Benedictine Abbey of Tiron near Chartres. After the dissolution of the alien priories in 1414 the church of West Worldham was purchased, with other possessions of Hamble Priory, by William of Wykeham, who added it to the endowment of Winchester College. ${ }^{15}$ In 1358 the glebe and tithe had been leased by the Prior of Hamble to Thomas Wayte, clerk, for ten years, the tenant being required to keep the fabric of the church in order and be responsible for the usual services. Subsequent leases were granted by Winchester College, a stipend of $£$ 10 being reserved for the incumbent, if he was not the lessee, up to 1588 , when a renewal of the lease to the Rev. Guy Dobbins, a fellow of the college, was the subject of legal proceedings by the incumbent, William Griffiths, in which it was stated that the fabric of the church was out of repair and the services not regularly performed. ${ }^{16}$ During the nineteenth century the church had again become ruinous and the services were interrupted, but the building was eventually restored in 1888 by the governors of Winchester College, the owners of the great tithes, in accordance with the terms of the original gift by Richard de Annecy to the Prior of Hamble. The advowson is still held by Winchester College, and the living is a perpetual curacy of the gross valuc of $£ 87$ with 3 acres of glebe. There is no vicarage, as the living, since the sixteenth century, has generally been held by the rector of Hartley Mauditt.

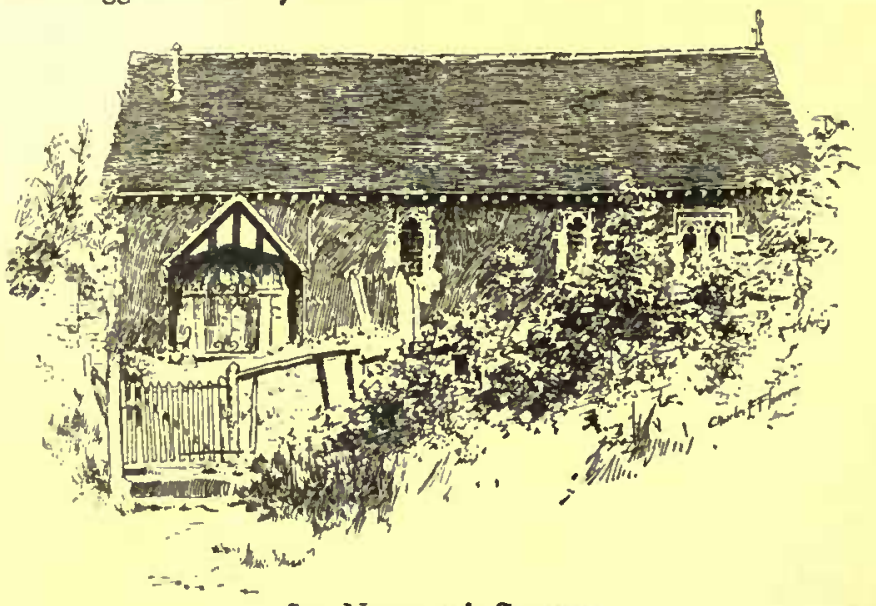

\section{St. Nichoras' ¿hurch.}

The church of St. Nicholas stands in plan a simple parallelogram about $44 \mathrm{ft}$. long and $18 \mathrm{ft}$. wide, of late Norman date. The east end contains a three-light fifteenth century window with tracery, but originally there was a triplet of lancets with a round window over in the gable. To the south of the altar is a two-light window, also of the fifteenth century, with drain under, and west of it a single cinquefoiled light. The corresponding windows on

\footnotetext{
14 Harl. Ch. 83 , H. 16.

16 Winchester College, by Kirby, p. 24.

10. Hants Notes and Queries, v. 15.
} 
the north are one of a cinquefoiled light, under which is a square locker, and another west of it, being an original pointed lancet. The division between chancel and nave was formerly marked by a screen, against which stood two altars. The place of these is shown by the piscine in the side walls, that on the north has a projecting basin and over it an original lancet window. The south window is a cinquefoiled light with a segmental rear arch, an insertion of the fifteenth century, like that east of it. The south doorway is contemporary with the church, and has a pointed arch of two orders. There is also a north door of the same date, of one order only, and now blocked. The west wall has a fifteenth century window, now filled with three modern round-headed lights, in which are inserted some pretty floral quarries of the seventeenth century. One of these has the motto: Conscientia mea mibi sufficit, and the date $16_{53}$. Another bears a shield of the arms of [BENNET ?]; gules a bezant between three demi-lions of silver.

All the fittings, including the font, together with the floor and roof, date from the reparation of 1888 . On the walls are tablets to William
Hammond, sen., I790 ; Elizabeth, daughter of John and Elizabeth Hammond, 1795, also Charlotte, ob. I 834 , and Margaret, ob. I 846 ; and to William Hammond, 1781 , his son John, 1787 , and wife Ann.

Externally the walls are roughcast with firestone dressings and the roof is tiled. The south doorway ${ }^{\mathbf{1 7}}$ is covered by an old wooden porch, perhaps of the fifteenth century. On the western wall is a modern bell gable containing one small bell.

The church is now used as a mortuary chapel and for occasional services.

There is only one parish register before 1813 , which begins in 1653 . There is no old churchwardens' book.

The church plate consists of a silver paten inscribed 'West Worldham I723,' a white metal chalice and a modern silver chalice of Italian make.

The population is not large enough to require a separate school for the children of the parish, and they attend the school at Hartley Mauditt.

There are no charities at the present time connected with the parish.

17 In the east jamb of this are incised several so-called 'consecration crosses.' 


\section{A HISTORY OF HAMPSHIRE}

\section{INDEX OF PARISHES IN TOPOGRAPHICAL MAPS OF HAMPSHIRE}

[The numbers refer to the sections of the map]

Abbots Ann, 1, 3

Abbots Barton, 4

Aldershot, 2

Allenford, 3

Alresford, New, 4

Alton, 2

"Old, 4

Alverstoke, 6

Ampfield, 3

Amport, 1

Andover, I

Andwell, 2

Appleshaw,

Arreton, North, 6 South, 6

Ashc, 1, 2

Ashey, I. of W., 6

Ashley, 3

Ashley Walk, 3, 5

Ashmansworth, I

Avington, 4

Baddesley, North, 3

Barton-Stacey, I, 3

Basing, 2

Basingstoke, 2

Baughurst, 1, 2

Beaulieu, 5, 6

Bcauworth, 4

Bedhampton, 4, 6

Bembridge, 6

Bentlcy, 2

Bentworth, 2

Bighton, 2, 4

Binstead, I. of W., 6

Binsted, 2

Bishopstoke, 4

Bishop's Sutton, 4 "Waltham, \&

Bitterne, 3, 4, 5

Blendworth, 4

Boarhunt, 4

Boldre, 5, 6

Bonchurch, 6

Bossington, 3

Botley, 4

Bournemouth, 5

Brading, 6

Bradley, 2

Bramdean, 4

Bramley, 2

Bramshaw, 3

Bramshill,

$$
\text { East, } 3
$$

Bramshott, 4
Breamore, 3

Brighstone, 5, 6

Brockenhurst, 5, 6

Brook, 5, 6

Broomey, 5

Broughton, 3

Brown Candover, I, 2

Buckholt, 3

Bullington, I

Burghclere, I

Buriton, 4

Burley, 5

Bursledon, 4

Calbourn, 5, 6

Candover, Brown, I, 2 " Chilton, 2

" Preston, 2

Carisbrook, 5, 6

Catherington, 4

Chale, 6

Chalton, 4

Chandlersford, 3,4

Charford, North, 3 , South, 3

Chawton, 2

Chcriton, 4

Chilbolton, 1, 3

Chilton Candover, 2

Chilworth, 3

Christchurch, 5 "East, 5

Church Oakley, 1, 2

Clanfield, 4

Clatford, Goodworth, I, 3

Upper, I,

Clidd csden, 2

Colbury, 3, 5

Coldrey, 2

Colemore, 4

Compton, 3, 4

Copythorne, 3, 5

Corhampton, 4

Cosham, 4, 6

Cove, 2

Cowes, 6

, East, 6

Crawley, 1, 3, 4

Crofton, 6

Crondall, 2

Crookham, 2

Crux Easton, I

Curdridge, 4

Damerham, South, 3
Dean, East, 3

" Priors, 4

"Vernhams, I

Deane, 1,2

Denny Lodge, 5, 6

Dibden, 5

Dogmersfield, 2

Droxford, 4

Dummer, 2

Dunwood, 3

Durley, 4

East Bramshaw. See Bramshaw

East Christchurch. See Christchurch

East Cowes. See Cowes

East Dean. See Dean

Eastleigh, 3, 4

East Meon. See Meon

Easton, 4

East Stratton. See Stratton

East Tisted. See Tisted

East Tytherley. See Tytherley

East Wellow. See Wellow

East Woodhay. See Woodhay

East Worldham. See Worldham

Ecchinswell, I, 2

Eldon, Upper, 3

Eling, 3, 5

Ellingham, 5

Ellisfield, 2

Elvetham, 2

Empshott, 4

Emsworth, 4

Eversley, 2

Ewhurst, I, 2

Exbury, 5, 6

Exton, 4

Faccombe, 1

Fairoak, 4

Fareham, 4, 6

Faringdon, 2, 4

Farleigh Wallop, 2

Farley Chamberlaync, 3

Farlington, 4, 6

Farnborough, 2

Fawley, 4, 5, 6

Fleet, 2

Fordingbridge, 3, 5

Foxcott, I

Freefolk, I

Frenchmoor, 3

Freshwater, 5, 6

Froxfield, 4 


\section{INDEX}

Froyle, 2

Fyfield, I

Gatcomb, 5, 6

Godsfield, 2

Godshill, 6

Goodworth Clatford, 1, 3

Gosport, 6

Grately, I

Greatham, 4

Greywell, 2

Hale, 3

Hambledon, 4

Hamble-en-le-Rice, 4,5

Hannington, 1, 2

Harbridge, 3,5

Hartley Mauditt, 2, 4

"Westpall, 2

"Wintncy, 2

Havant, 4, 6

Hawkley, 4

Hawley, 2

Hayling, North, 6

"South, 6

Headbourne Worthy, 4

Headley, 2, 4

Heckfield, 2

Hedge End, 4

Herne, 5

Herriard, 2

Highclere, I

Highcliff, 5

Hinton Ampner, 4

Holdenhurst, 5

Holybourne, 2

Hook with Warsish, 4, 6

Hordle, 5, 6

Houghton, 3

Hound, 4, 5

Hunton, 1,2

Hursley, 3, 4

Hurstbourne Priors, 1 " Tarrant, 1

Ibsley, 3, 5

Idsworth, 4

Itchin Abbas, I, 2, 4

", Stoke, 1, 2, 4

Kempshot, 2

Kilmeston, 4

Kimpton, 1

Kingsclere, 1, 2

Kingsley, 2

King's Somborne. SceSomborne

Kingston, 6

King's Worthy, I, 4

Knights Enham, 1

\section{Langrish, 4}

Lasham, 2

Laverstoke, I, 2

Leckford, I, 3

Linkenholt, 1

Liss, 4
Litchfield, I

Little Somborne. Sce Somborne

Littleton, 3, 4

Lockerley, 3

Long Parish, I

Longstock, I, 3

Long Sutton, 2

Lymington, 5, 6

Lyndhurst, 5

Maplederwell, 2

Marchwood, 3, 5

Martin, 3

Martyr Worthy, 1, 4

Mattingley, 2

Medsted, 2, 4

Melchet Park, 3

Meon, East, 4

"West, 4

Meonstoke, 4

Milford, 5,6

Millbrook, 3

Milton, 5

Minley, 2

Minstead, 3, 5

Mitcheldever, 1, 2

Mitchelmersh, 3

Monk Sherborne, 2

Monxton, 1

Morestead, 4

Mortimer, West End, 2

Mottisfont, 3

Mottistone, 5, 6

Nately Scures, 2

Neatham, 2

Nether Wallop. Sce Wallop

Netley Marsh, 3, 5

New Alresford. Sec Alresford

Newchurch, 6

New Forest, 5

Newnham, 2

Newport, 6

Newton Valence, 4

Newtown, 1

Niton, 6

North Arreton. See Arreton

North Baddesley. Sec Baddesley

North Charford. See Charford

North Hayling. See Hayling

Northington, 1, 2

North Stoneliam. See Stoneham

North Waltham. See Waltham

Northwood, 5, 6

Nursling, 3

Nutley, 2

Odiham, 2

Old Alresford. See Alresford

Otterbourne, 3, 4

Overton, 1, 2

Over Wallop. See Wallop

Ovington, 4

Owslebury, 4

Pamber, 2
Penton-Mewsey, I

Petersfield, 4

Plaitford, 3

Pokesdown, 5

Popham, I, 2

Porchester, 4, 6

Portsea, 6

Portsmouth, 6

Portswood, $3,4,5$

Preston Candover, 2

Prior's Dean. Sce Dean

Privett, 4

Quarley, I

Rhinefield, 5

Ringwood, 5

Rockbourne, 3

Romsey, Extra, 3

Ropley, 4

$$
\text { Infra, } 3
$$

Rotherwick, 2

Rowner, 6

Rownhams, 3

Ryde, 6

St. Helen's, 6

St. Lawrence, 6

St. Mary Bourne, 1

Sandown, 6

Sarisbury, 4

Selborne, 2, 4

Shalden, 2

Shalfleet, 5,6

Shanklin, 6

Shedfield, 4

Sheet, 4

Sherborn St. John, 2

" Monk, 2

Sherfield English, 3

" upon Lodon, 2

Shipton Bellinger, 1

Shirley, 3, 5

Sholing, 3-5

Shorwell, 5,6

Silchester, 2

Soberton, 4

Somborne, King's, 3

" Little, I, 3

Sopley, 5

Southampton, 4,5

$$
\begin{array}{ll}
" & \text { All Saints, 4, } 5 \\
" & \text { St. Mary, 3, 4, } 5 \\
\text { " St. Mary Extra, 3, 4, } 5
\end{array}
$$

South Arreton. See Arreton

Southbourne, 5

South Charford. Sce Charford

South Damerham. See Damerham

South Hayling. See Hayling

South Stoneham. See Stoneham

South Tidworth. See Tidworth

South Warnborough. See Warnborough

Southwick, 4

Sparsholt, 3, 4 


\section{A HISTORY OF HAMPSHIRE}

Steep, 4

Steventon, I, 2

Stockbridge, 1, 3

Stoke Charity, I

Stoke Park, 4

Stoneham, North, 3, 4

Stratfield Saye, 2 South, 3,4

" Turgis, 2

Stratton, East, 1, 2

Sutton, Bishop's, 4 " Long, 2

Swanmore, 4

Swarraton, I, 2

Sway, 5, 6

Sydmonton, I, 2

Tadley, 2

Tangley, 1

Thorley, 5, 6

Thruxton, I

Tidworth, South, I

Timsbury, 3

Tisted, East, 4 , West, 4

Titchborne, 4

Titchfield, 4, 6

Totland, 5,6

Toyd Farm and Allenford, 3

Tufton, I

Tunworth, 2

Twyford, 4
Tytherley, East, 3

, West, 3

Upham, 4

Up-Nately, 2

Upper Clatford. See Clatford

Upper Eldon. See Eldon

Upton Gray, 2

Ventnor, 6

Vernhams Dean. See Dean

Wallop, Nether, I, 3

" Over, 1, 3

Waltham, Bishop's, 4

"North, I,

Warblington, 4, 6

Warnborough, South, 2

Warnford, 4

Warsash. See Hook

Waterloo, 4

Wellow, East, 3

, West, 3

West End, 4

West Meon. See Meon

Weston-Corbett, 2

Weston-Patrick, 2

West Tisted. See Tisted

West Tytherley. See Tytherley

West Wellow. See Wellow

West Worldham. See Worldham

Weyhill, I

Wherwell, 1, 3
Whippingham, 6

Whitchurch, 1

Whitwell, 6

Wickham, 4

Wield, 2

Winchester, 4

" Chilcomb Without, 4

" St. Faith Within, 4

" St. Faith Without, 4

" Weeke Within, 4

Winchfield, 2

Weeke Without, 3, 4

Winnall, 4

Winslade, 2

Winton, 5

Wolverton, I, 2

Wonston, 1, 3

Woodcutt, I

Woodhay, East, I

Woodmancott, 1, 2

Wootton, 6

Wootton St. Lawrence, 2

Worldham, East, 2

, West, 2

Worthy, Headbourne, 4

" King's, I, 4

Worting, 2

Wroxall, 6

Yateley, 2

Yaverland, 6 


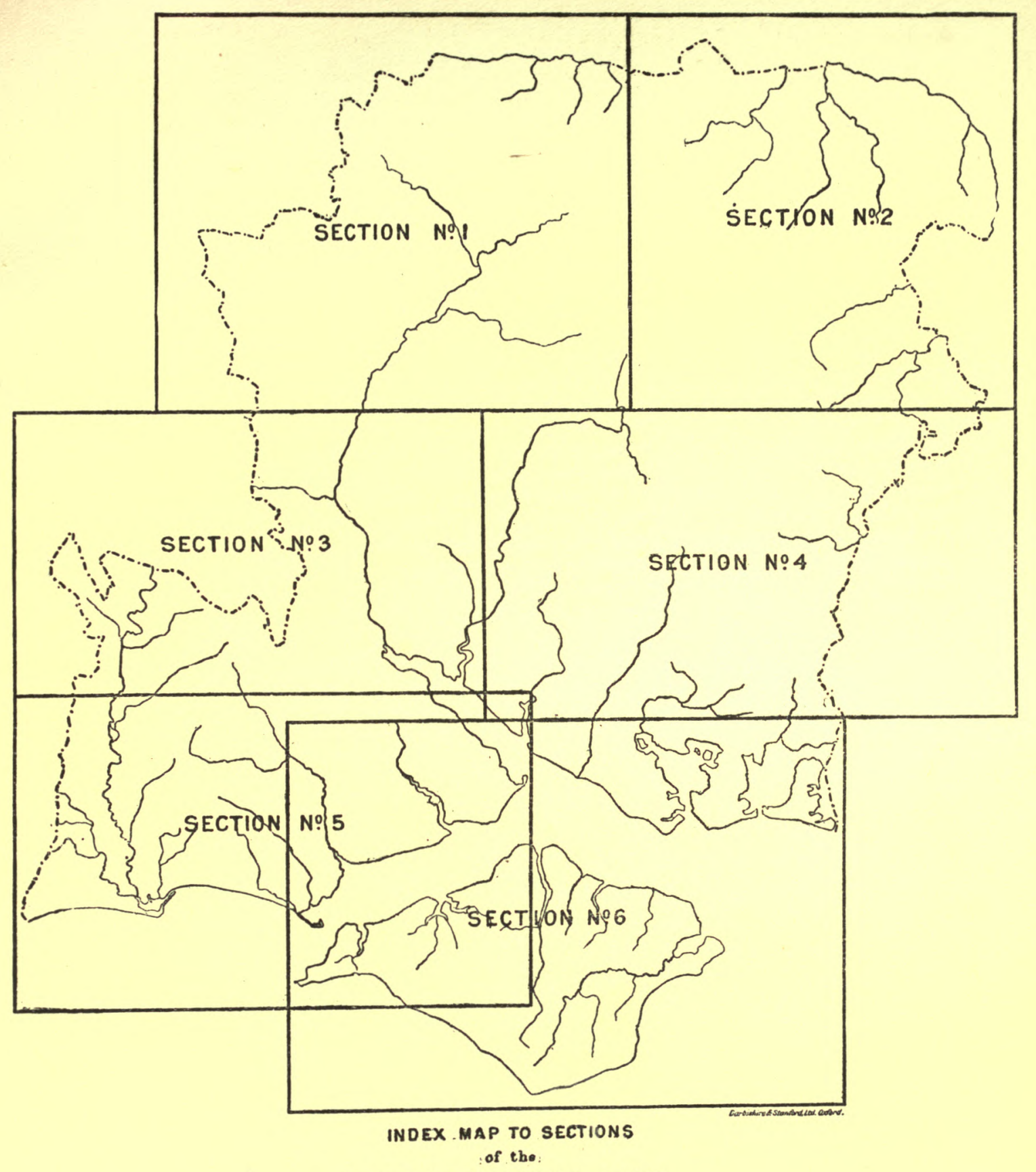

TOPOGRAPHICAL MAP.

Yictoria History of Bcmperine Vol.2 




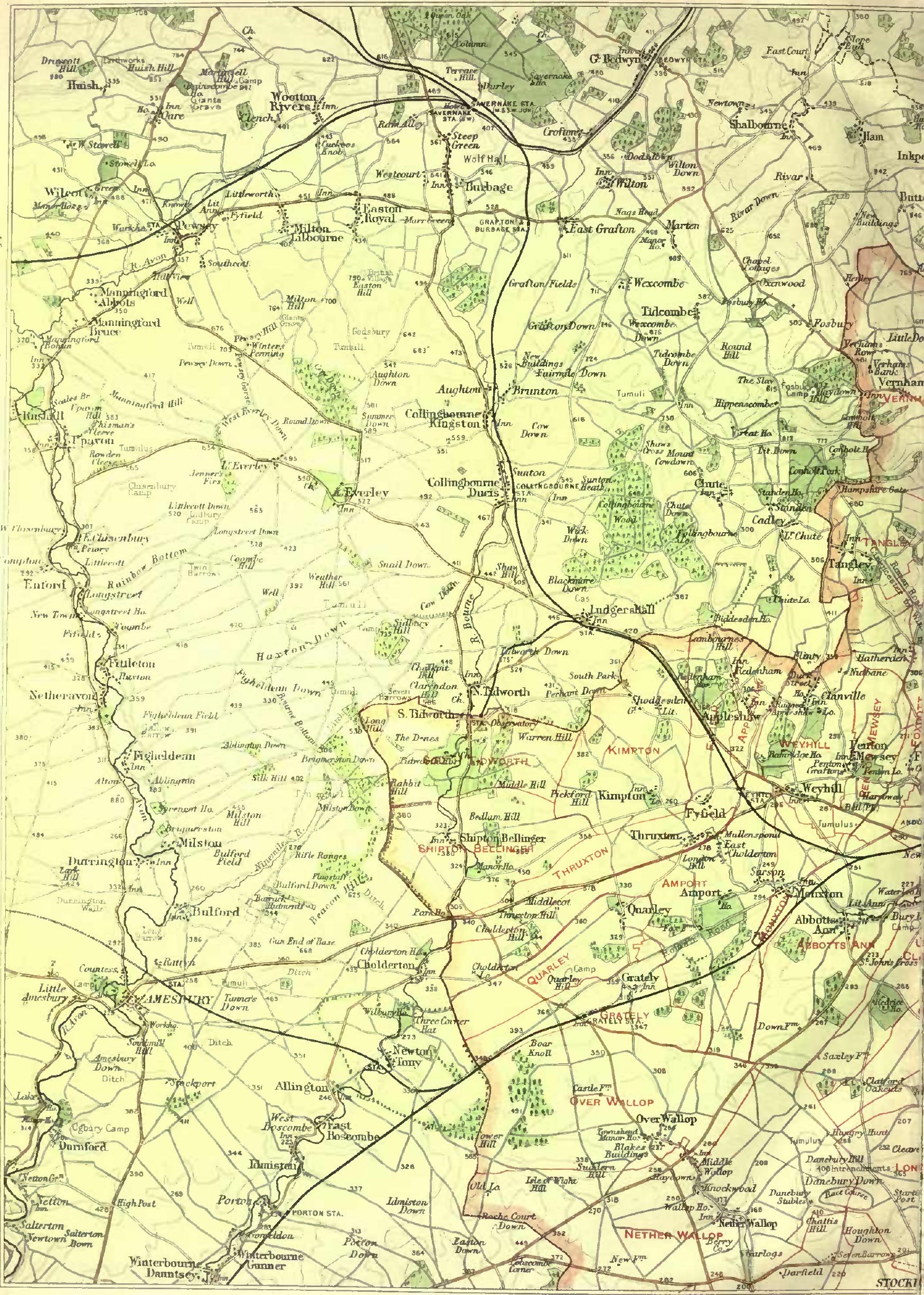




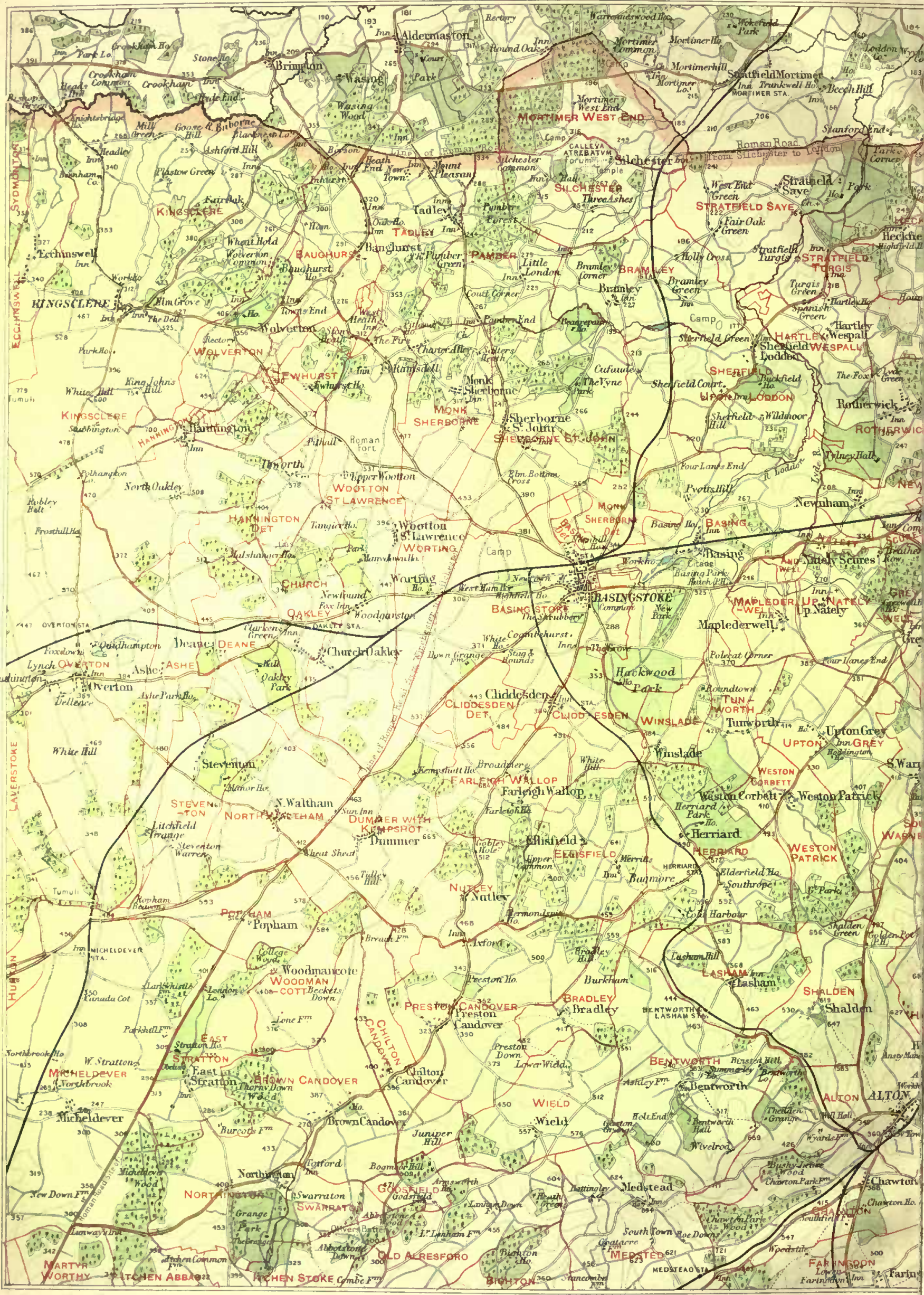




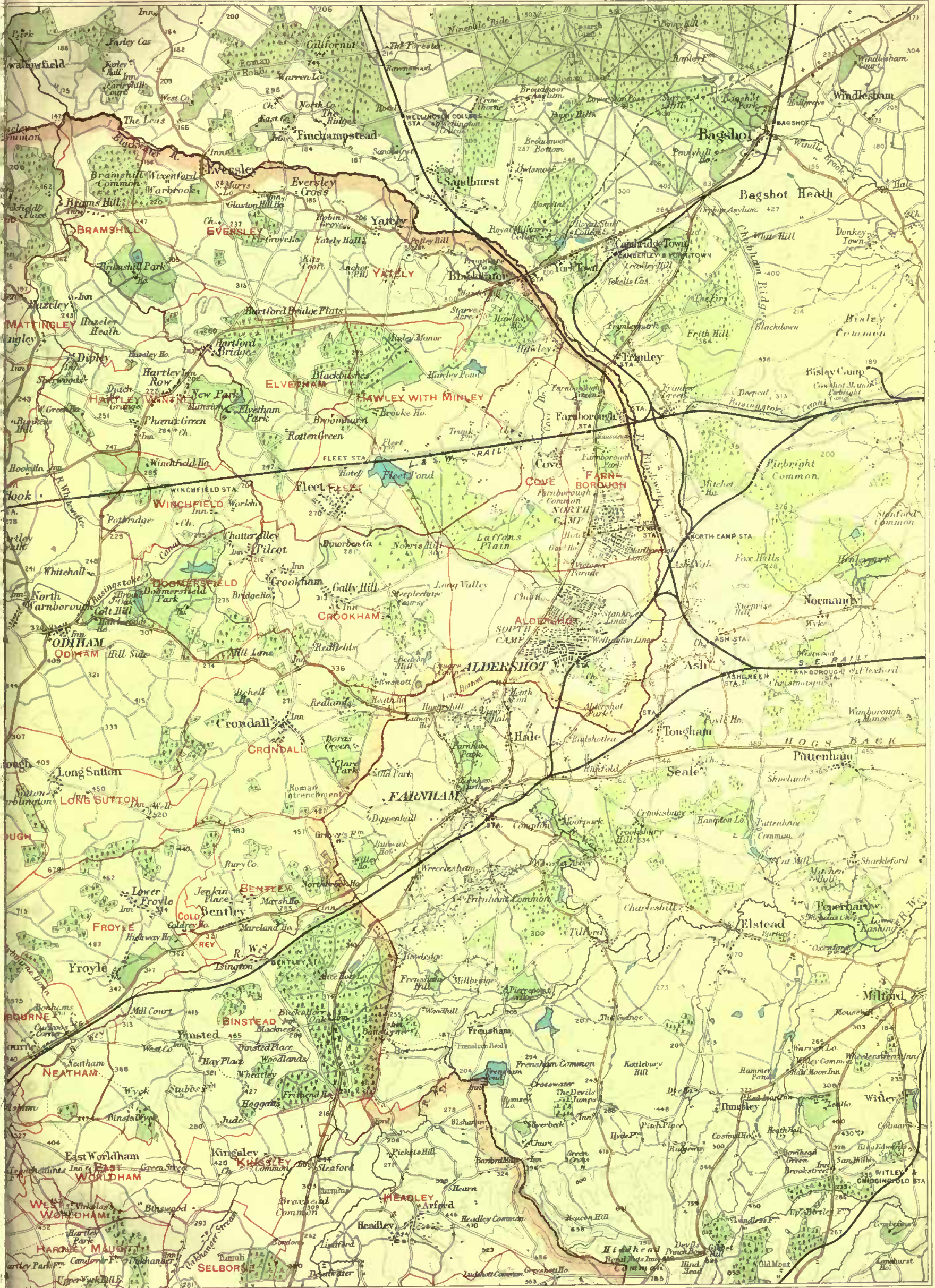


TOPOGRAPHICA

\section{I $R \quad E$}
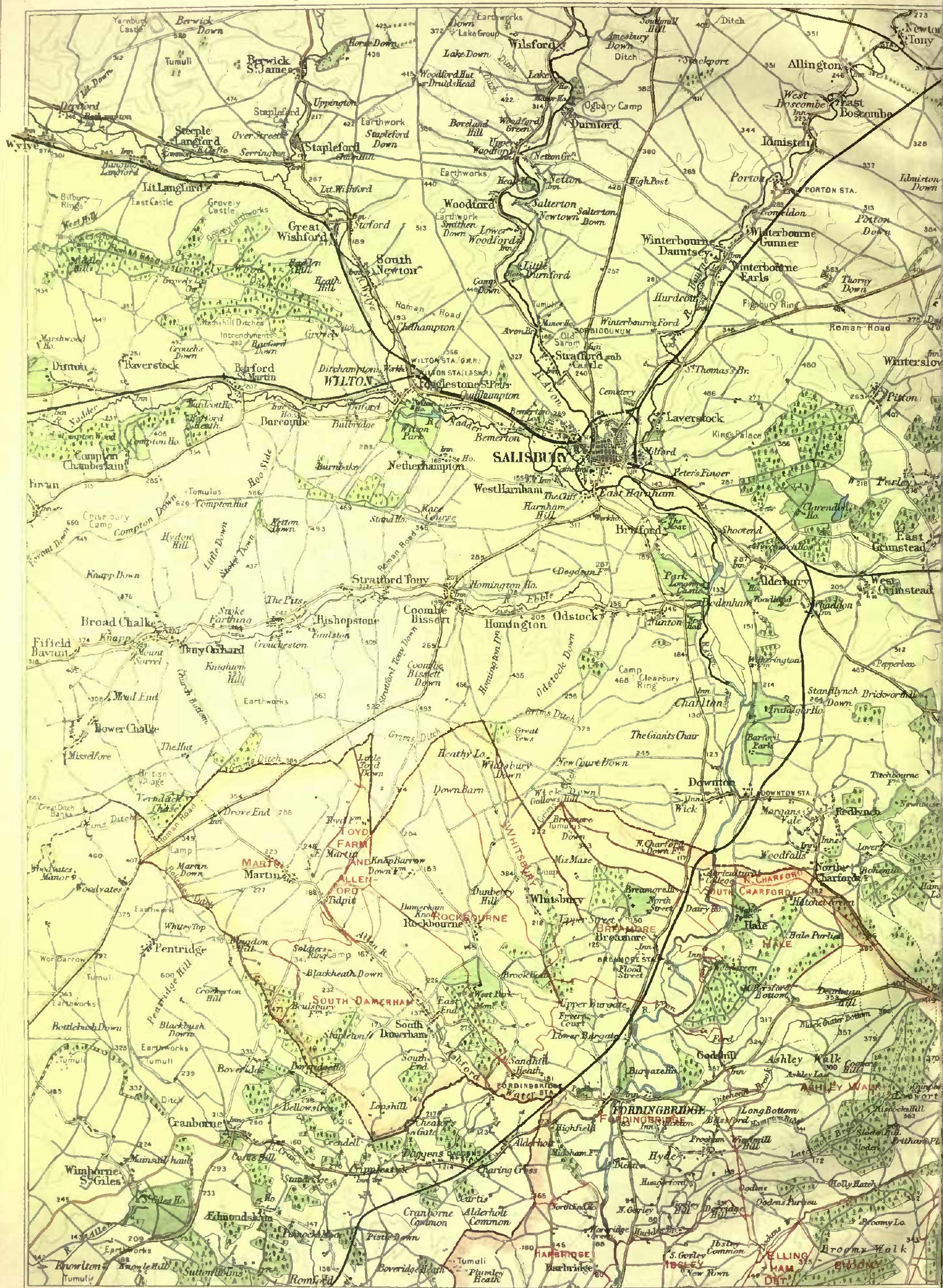
D

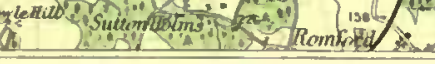




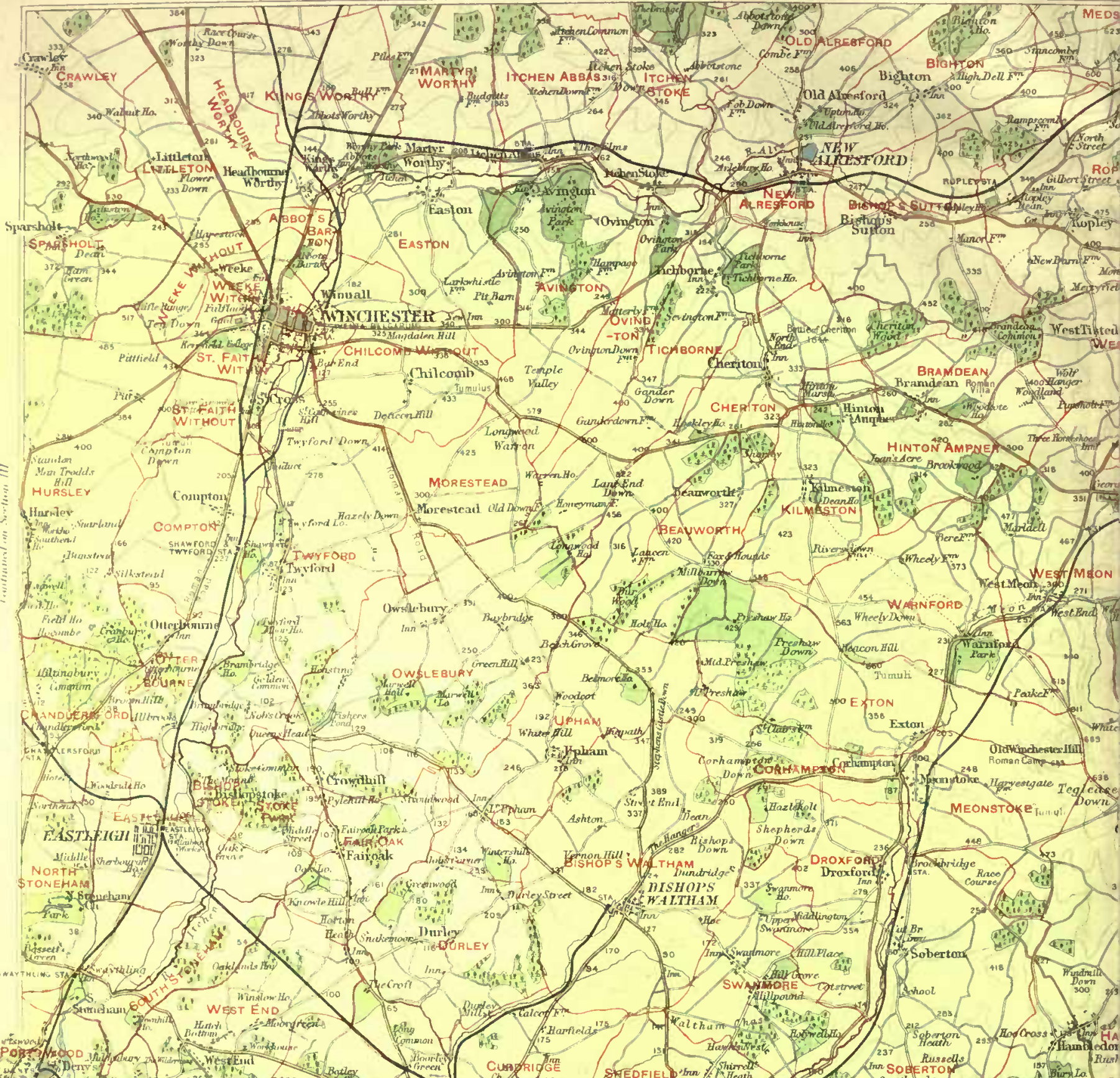

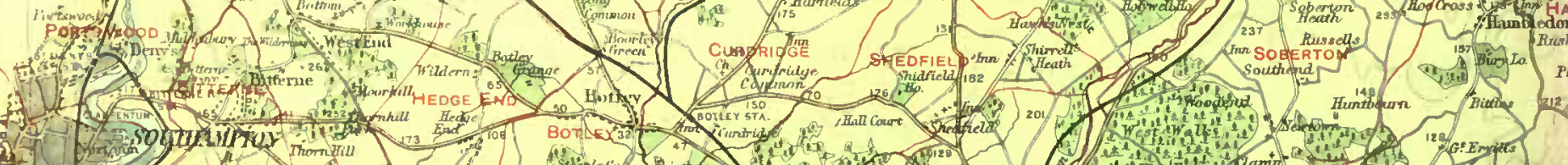

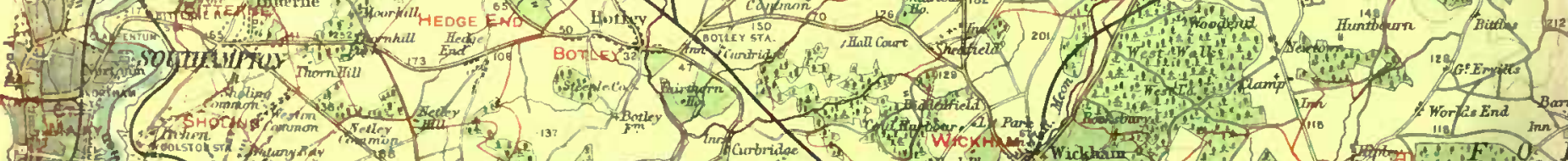

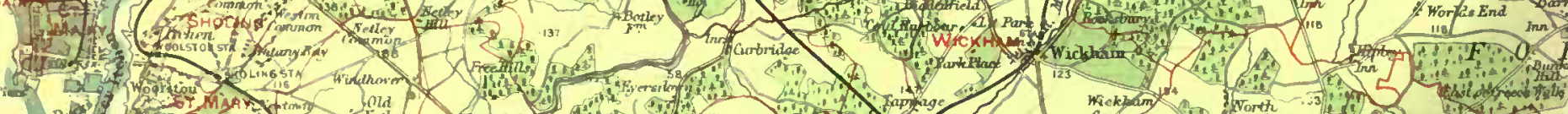

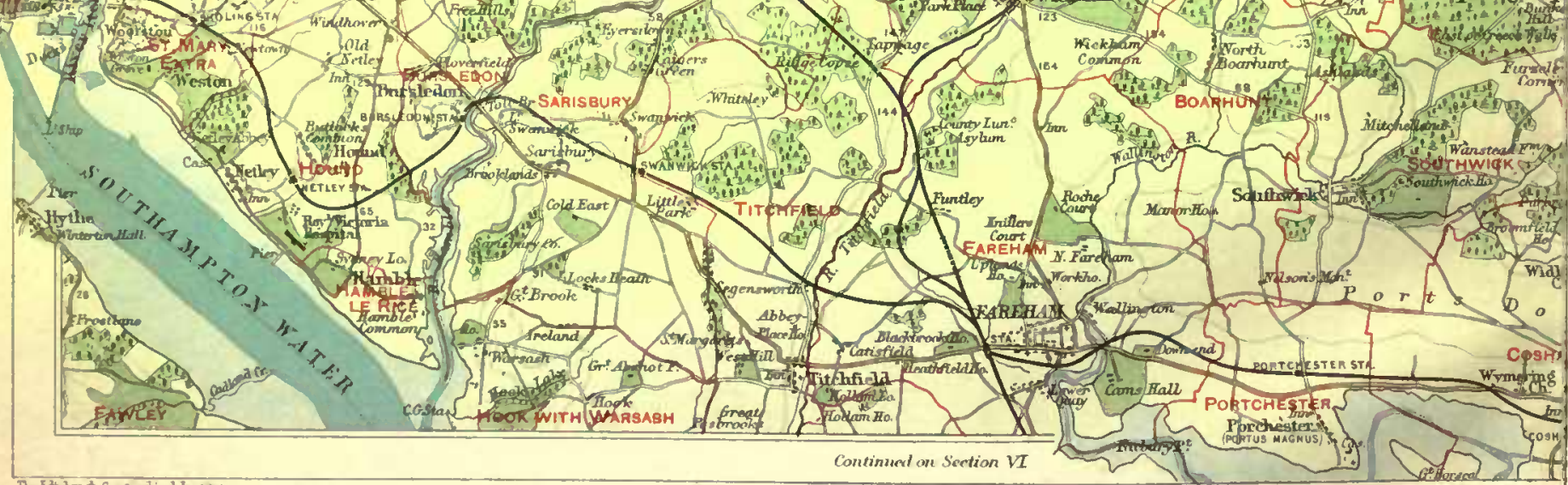




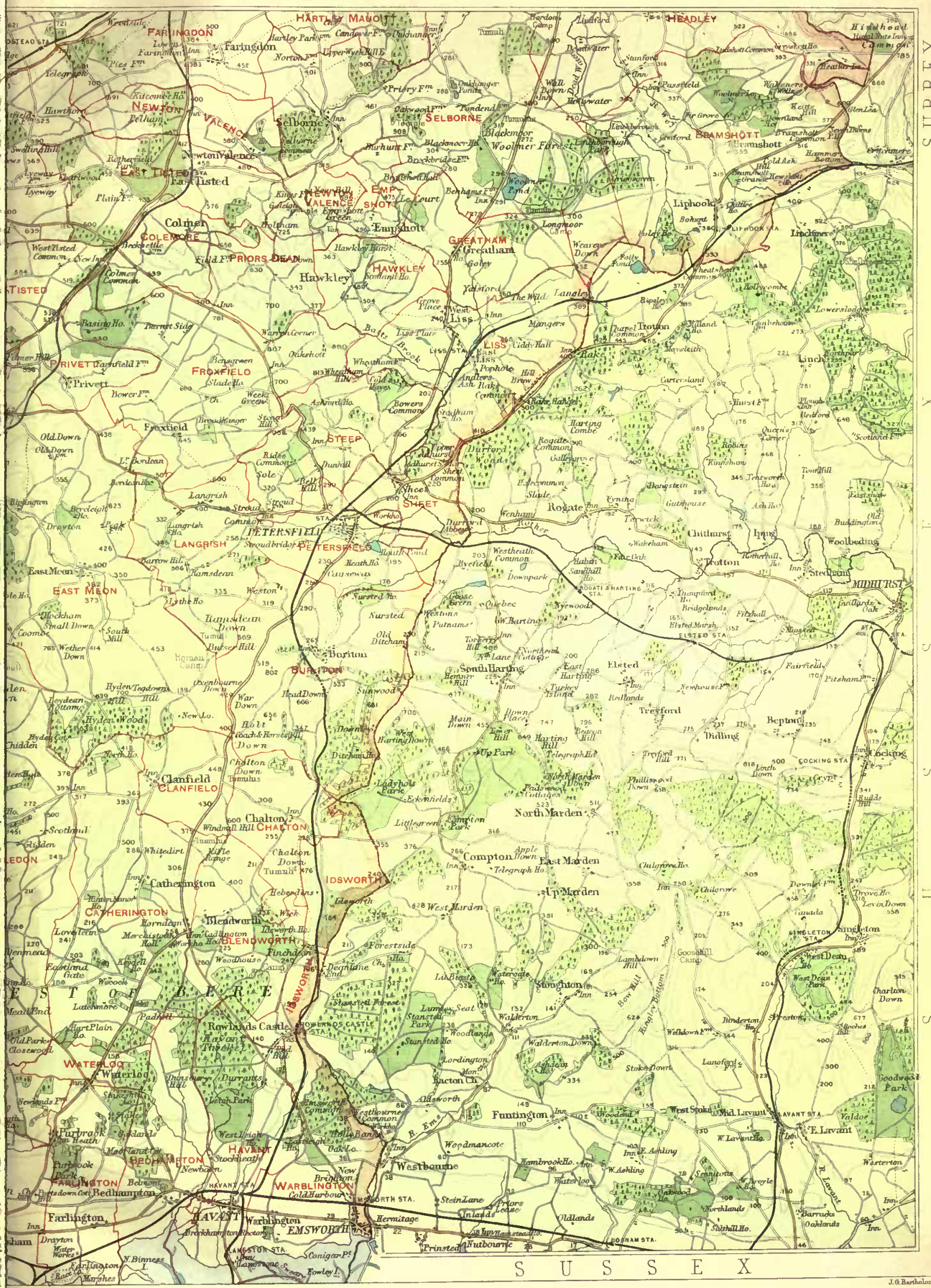




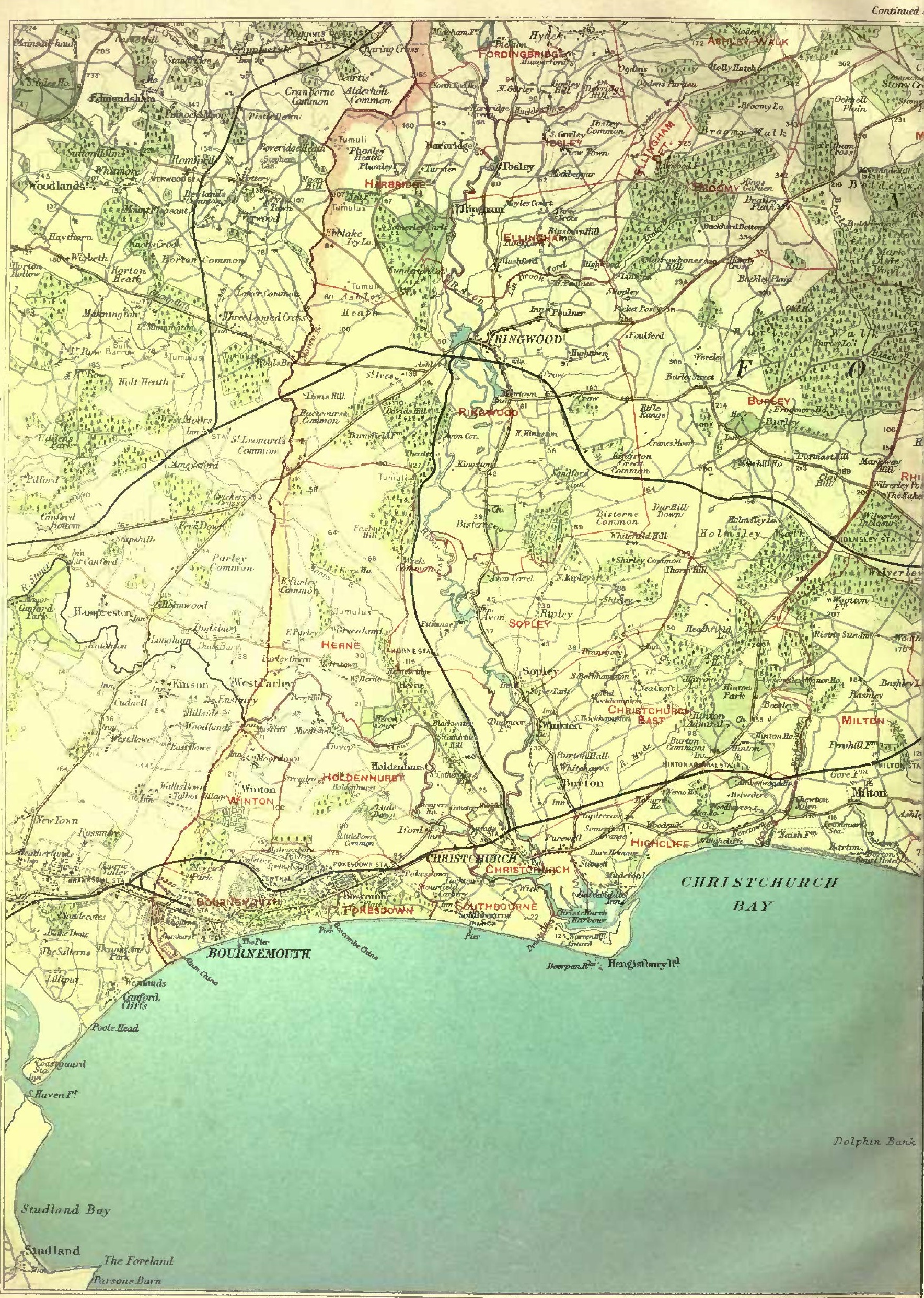




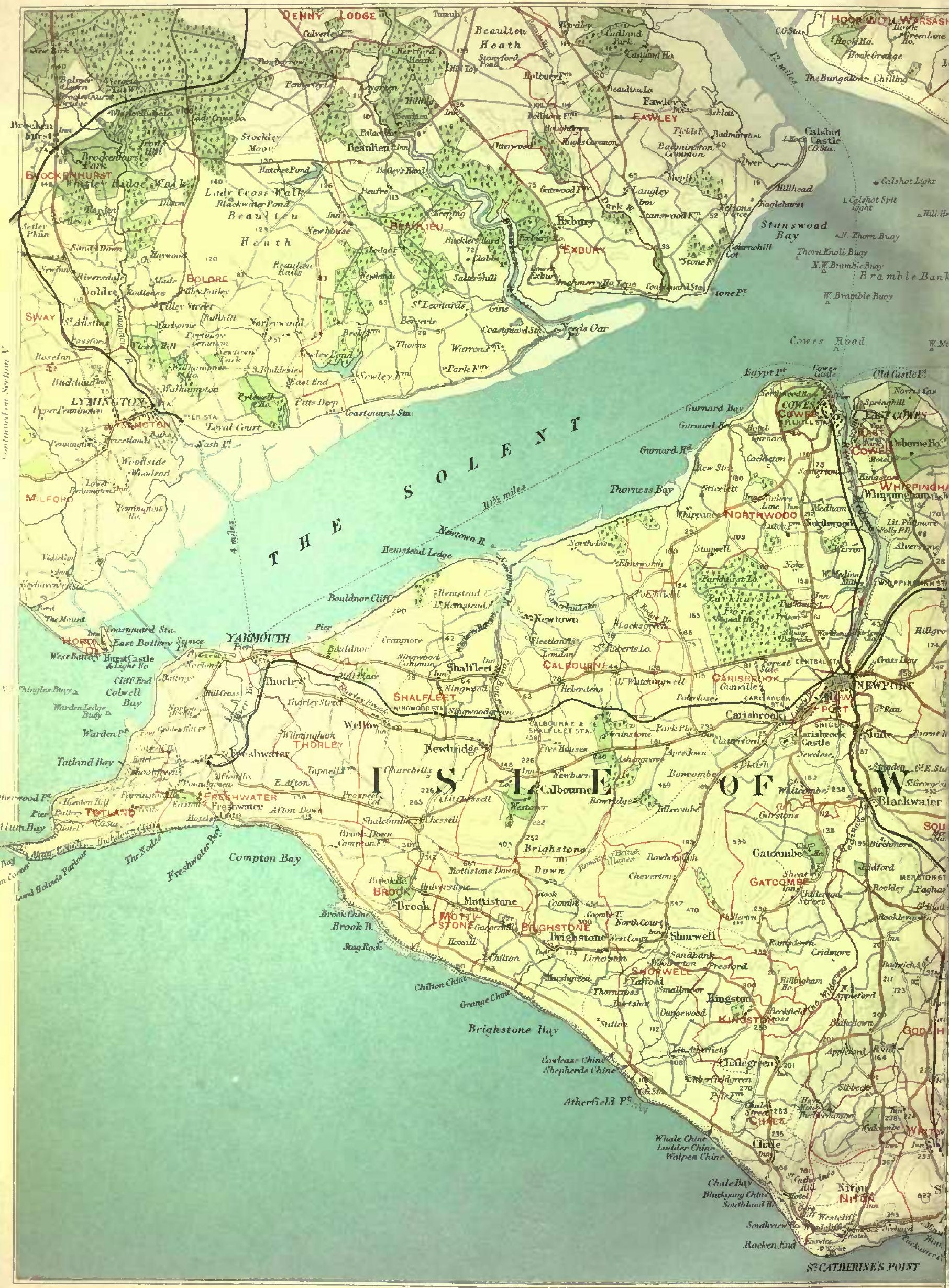



DA A history of Hampshire and

670 the Isle of Wight

$\mathrm{H} 2 \mathrm{H} 5$

v. 2

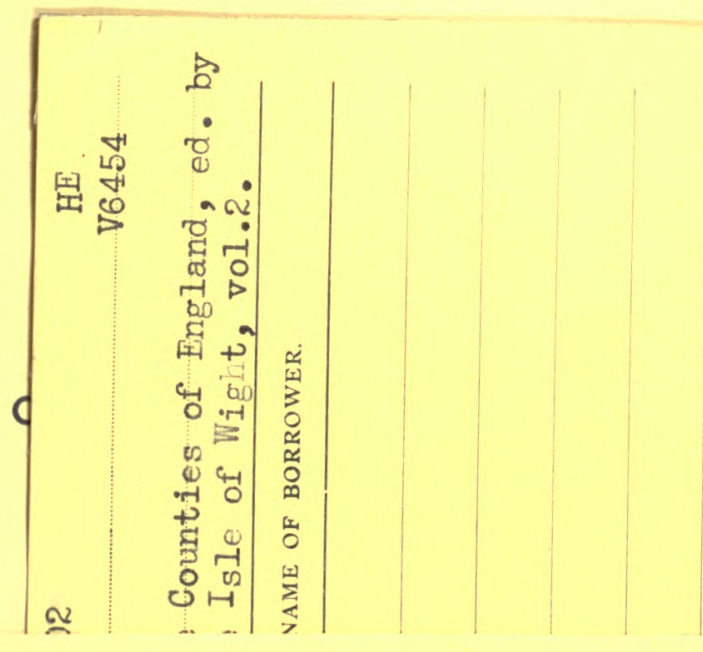




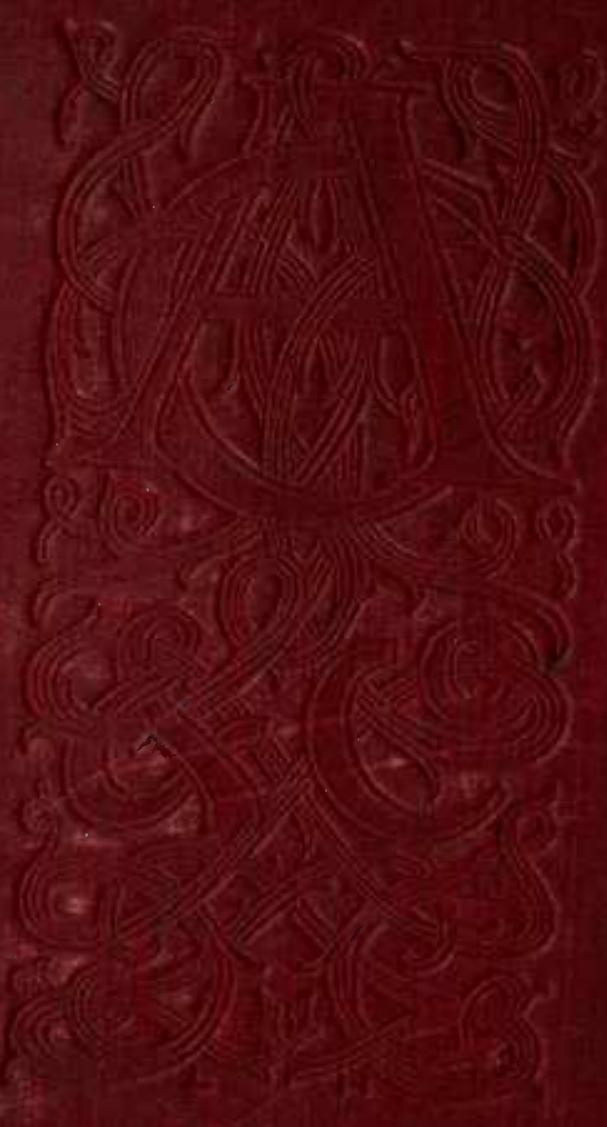

